UNIVERSIDADE DE SÃO PAULO

MUSEU DE ARQUEOLOGIA E ETNOLOGIA

PROGRAMA DE PÓS-GRADUAÇÃO EM ARQUEOLOGIA

SILVANA ZUSE

Variabilidade cerâmica e diversidade cultural no Alto rio

Madeira, Rondônia

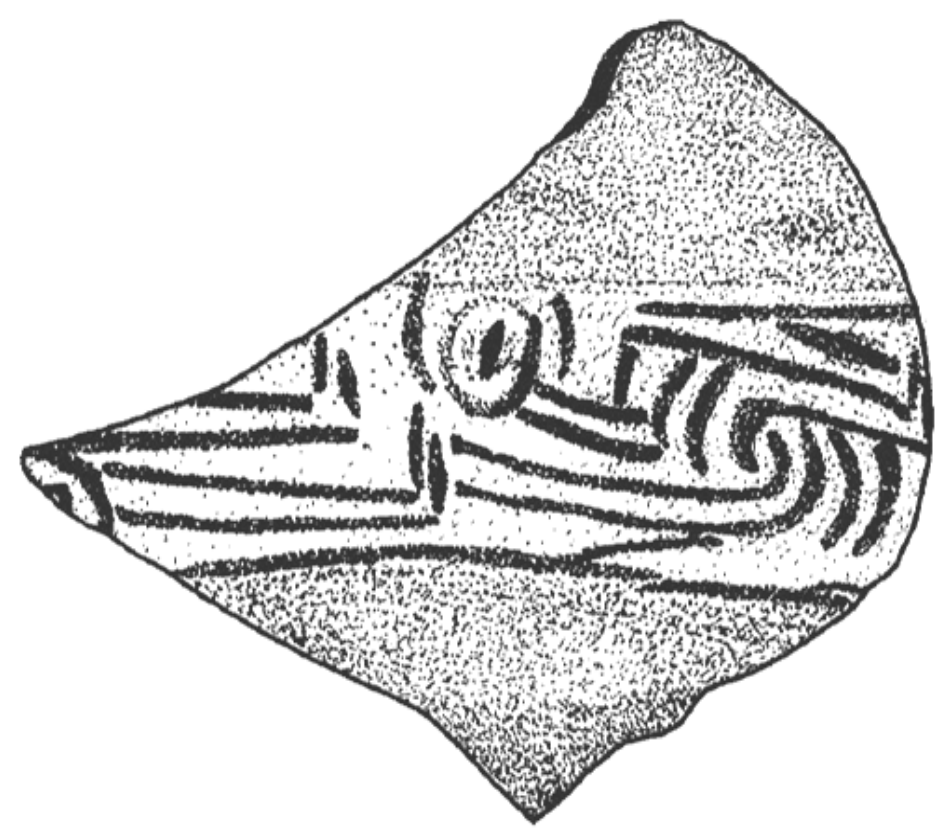

São Paulo 


\section{Variabilidade cerâmica e diversidade cultural no Alto rio Madeira, Rondônia}

Tese apresentada ao Programa de Pós-Graduação em Arqueologia do Museu de Arqueologia e Etnologia da Universidade de São Paulo para obtenção do título de Doutora em Arqueologia

Área de Concentração: Arqueologia

Orientadora: Prof ${ }^{a}$. Dra ${ }^{\mathrm{a}}$. Márcia Angelina Alves

Linha de Pesquisa: Cultura material e representações simbólicas em arqueologia

Versão corrigida*

(*) A versão original encontra-se disponível no MAE/USP

São Paulo 
Dedico este trabalho aos meus pais, Adão $e$ Renati, ao Fernando e ao Fabrício, com quem adquiri e compartilho os valores $e$ princípios que possuo.

Ao Eduardo, que reflete muitos deles. 


\section{AGRADECIMENTOS}

A necessária mudança de Santa Maria/RS e a escolha que contemplou Rondônia para o desenvolvimento desta tese gerou o afastamento inevitável e muita saudade de pessoas queridas, gostos e paisagens. Entretanto proporcionou muitos aprendizados no âmbito pessoal e profissional, ao conhecer um pouco a região do Alto rio Madeira e sua arqueologia e as pessoas que sempre foram receptivas e acolhedoras, muitas das quais tornaram-se grandes amigos (as). A finalização deste trabalho só foi possível graças à ajuda e apoio de muitos, que estiveram mais próximos ou distantes, aos quais agradeço.

Agradeço ao $\mathrm{CNPq}$ pelo apoio à pesquisa com a concessão de uma bolsa de doutorado.

À Profa. Dra. Márcia Angelina Alves pela orientação deste trabalho, confiança e apoio nas mudanças de rumo (projeto).

Ao Dr. Renato Kipnis pelo apoio e incentivo nesta trajetória de quase cinco anos em Porto Velho, e juntamente à Scientia Consultoria Científica, pela disponibilização de toda a estrutura do laboratório, materiais arqueológicos, dados de campo e datações.

Ao Prof. Dr. Eduardo Neves pelas orientações na qualificação e a cada ida a Porto Velho, que foram fundamentais para a conclusão desta tese.

A Profa. Dra. Fabíola Silva pelas sugestões e indagações na qualificação de doutorado.

A Helena Lima, pelos diálogos sobre a variabilidade cerâmica, nas visitas ao laboratório em Porto Velho, e por compor a banca de defesa.

Ao Arkley Bandeira por compor a banca de defesa e pela leitura cuidadosa da tese.

A Universidade de São Paulo e ao Museu de Arqueologia e Etnologia pelo acolhimento nestes oito anos na pós-graduação, e a todos os funcionários do MAE, especialmente da biblioteca e da Secretaria Acadêmica, que sempre estiveram prontos para ajudar.

Ao IPHAN Porto Velho e ao Ms. Danilo Curado pelo apoio.

Aos meus amigos e companheiros de pesquisa Cliverson Pessoa e Angislaine Costa, que desde 2010 me acompanham na triagem e análise do material cerâmico, bem como ao Francisco Chagas e Edileno Duram que posteriormente agregaram a equipe, assim como a 
Karleny Costa que chegou a tempo. Agradeço pelo apoio e parceria nesse período, e continuarei torcendo pelo envolvimento cada vez maior de vocês na Arqueologia de Rondônia e da Amazônia. Agradeço a Angislaine F. Costa pela organização das figuras com as fotos da cerâmica no corel draw.

A Mirtes, Adriana, Nazaré, Darci, Gelcinei, Júlio e Carlinhos que se dedicaram na curadoria de tantos fragmentos cerâmicos e líticos, pela recepção a Porto Velho e parceria durante esses anos. Também aos que me acompanharam em campo, em especial ao Geová pela sabedoria, ao Vanderlei, Ezequiel, Índio, Dedé, Teixeira, Pantanal, Adriano, Willian, Weliton, Lourival e muitos outros que não me recordo nesse instante.

A todos que participaram das escavações dos sítios abordados nesta tese e fizeram o registro cuidadoso das informações. Entre eles, convivi com Gil Bueno, Flávio Bonfim, Diogo Quirino, Diogo Borges, Fernando Cantelle, André Voto, Leonardo Napp, que lembro agora.

Um agradecimento especial a Michelle Tizuka, que me recebeu no laboratório em Porto Velho, me acompanhou na primeira vez que subi o rio Madeira de voadeira e relatou incansavelmente os sítios arqueológicos e as escavações. Por toda a ajuda na elaboração desta tese com os mapas, croquis e leituras, e principalmente pela amizade.

A Juliana Santi, parceira de pesquisa desde 2006, incialmente nos sítios Guarani da Depressão Central Gaúcha, e que motivada por objetivos semelhantes me acompanha nestes cinco anos de arqueologia no Madeira, atualmente colega do DARQ/UNIR. Obrigada pelo companheirismo nas escavações, pelas leituras da tese e elaboração dos croquis, pela tua amizade e chimarrões compartilhados em rodas pequenas e com gosto de saudade.

Ao Carlos Zimpel que reencontrei em Porto Velho, pelos tantos outros mates, churrascos e conversas sobre a Arqueologia de Rondônia, para a qual contribuiu muito com a atuação no DARQ/UNIR, onde atualmente somos colegas.

A Valéria Silva, que conheci em Porto Velho, colega no DARQ/UNIR, por compartilhar as experiências no ensino e os mais diversos sentimentos surgidos nesse meio e pelo apoio na finalização deste trabalho.

Ao colega André Penin (in memorian), com o qual infelizmente pude conviver pouco tempo, suficiente para aprender muito na UNIR. 
A Elisangela Oliveira, colega no DARQ/UNIR, companheira na maratona de provas do concurso.

Ao Klaus Hilbert pela visita ao laboratório em Porto Velho e discussão sobre a cerâmica policrômica antiga na Amazônia.

A Denise Schann pela leitura da qualificação e sugestões.

Ao Daniel Cruz, a Lilian Panachuck e a Lorena Garcia pela discussão da ficha de análise.

A Silvia Cunha Lima pelos ensinamentos sobre curadoria e conservação do material arqueológico.

Aos amigos de Porto Velho pela recepção na cidade e por me acompanharem nesse período, entre eles a Ednair Nascimento, querida amiga portovelhense, ao Ney Gomes, pelo convívio e parceria nestes anos, na república 'Panamá 2185' e no Marechal Rondon; ao Fernando Cantelle, Cássio Souza, Flávio Bomfim, Diogo Quirino, a Adriana Santos, Valzelice Souza, Daiane Hammes, Pepo, Luiz, Marconi, Iagê, Domingos, Marcondes, e tantos outros, que de uma forma ou de outra me ajudaram a prosseguir até o fim.

A Dona Neli e ao Caminho de Casa, que nos recebeu e ouviu nestes anos, com músicas de gostos variados na jukebox.

Aos colegas do MAE, especialmente aqueles com quem compartilhei experiências de campo em Rondônia, entre eles Fernando Almeida, Guilherme Mongeló, Rodrigo Suner, Thiago Trindade, Maurício Silva, e aqueles que compartilham as experiências da Arqueologia na Amazônia: Eduardo Kazuo, Márjorie Lima, Erêndida Oliveira, Jaqueline Beletti, Felippo Bassi, Marta Cavalline, Chico Pugliese, Anne Py-Daniel, Claide Moraes, Camila Jácome, Melian Gaspar, Chico Stuchi.

Aos que me hospedaram em São Paulo, especialmente ao Piero Tessaro e a Angela Artur, amigos de longa data, ao Bernardo Lacale, Jaqueline Gomes, a Dani, Francine, Guilherme Minoti, Carol, Júlia, Danilo, Luana.

A Grasiela Toledo pelo otimismo e companhia no fechamento da tese.

Ao mestre Marcelo Tenório e aos colegas da Elite Taekwondo, espaço de convivências e aprendizados fundamentais para perseverar nesta meta. 
Aos estudantes de arqueologia da Universidade Federal de Rondônia, por me fazerem continuar acreditando e me dedicando à pesquisa e ensino da arqueologia, entre eles a Cleiciane, Manu, Laura, Alyne, Odair, Brena, Eclésia, Renato, Igor, Robson, Ana.

A minha família pelo apoio a todas às decisões, pelo incentivo nas horas mais difíceis, pelos abraços calorosos nos reencontros e pela contenção das lágrimas nas despedidas. Obrigada aos meus pais, aos meus irmãos, a Tatiane e ao Miguel, e a todos os familiares que me apoiaram, pelas recepções ou despedidas nas rodoviárias e caronas após ou antecedendo as muitas horas de viagem.

A todos os amigos de longe pelo apoio a cada reencontro, especialmente a Taiara que veio me visitar em Porto Velho.

Ao Eduardo Bespalez por compartilhar comigo todos os sentimentos envolvidos na finalização de uma tese.

E a todos os que não foram contemplados nestas páginas, porém contribuíram para o andamento e conclusão do trabalho. Muito Obrigada! 


\section{RESUMO}

\section{Variabilidade cerâmica e diversidade cultural no Alto rio Madeira, Rondônia}

Este trabalho aborda o estudo dos significados históricos e culturais da variabilidade artefatual no Alto rio Madeira, estado de Rondônia, sudoeste Amazônico, através da análise da cerâmica e dos contextos evidenciados em quatorze sítios arqueológicos localizados entre a cachoeira de Santo Antônio, nas proximidades da cidade de Porto Velho, até a foz do rio Jaciparaná, próxima a cachoeira Caldeirão do Inferno. A caracterização das escolhas adotadas por ceramistas em todas as etapas de confecção dos artefatos cerâmicos, bem como em relação aos seus usos e descarte, permitiu identificar as ocupações em cada sítio, ao passo que a análise comparativa possibilitou diferenciar cinco conjuntos tecnológicos que representam, por um lado, diferentes identidades sociais e culturais e, por outro, a diversidade cultural existente na região em termos temporais, espaciais e tecnológicos. O diálogo com outros contextos da Amazônia e com os modelos para a ocupação da região, elaborados com dados da arqueologia, linguística histórica e história indígena, é salutar na construção de cenários da história cultural da região.

PALAVRAS-CHAVE: variabilidade artefatual; alto rio Madeira; história indígena; diversidade cultural. 


\begin{abstract}
Ceramic variability and cultural diversity in the Upper Madeira river, Rondônia

This work approaches the study of historical and cultural significance of artfactual variability in the Upper Madeira river, Rondonia state, southwestern Amazon, through the analysis of ceramics and contexts highlightedin fourteen archaeological sites located between the Santo Antonio's falls, nearPorto Velho city, to the mouth of Jaciparanáriver, next to Caldeirão do Inferno waterfall. The characterization of the choices adopted by potters in all stages of manufacture of ceramic artifacts as well as in relation to their use and disposal, identified the occupations at each site, while the comparative analysis allowed differentiating five sets of technologies that represent, for first, social and cultural identities and, secondly, the cultural diversity of the region in temporal, spatial and technological terms. Dialogue with other contexts of Amazon and models for the occupation of the region, made with data from archeology, historical linguistics and indigenous history, is beneficial in building scenarios of cultural history of the region.
\end{abstract}

KEY-WORDS: artifactual variability; upper Madeira river; indigenous history; cultural diversity. 


\section{LISTA DE FIGURAS}

Figura 1: esquema cronológico dos horizontes cerâmicos (MEGGERS e EVANS, 1961).....29

Figura 2: vasilhas da tradição Tupi-guarani em Rondônia (MILLER, 2009a, p. 125 e 127)...69

Figura 3: cerâmica da Subtradição Jatuarana (MILLER, 2013, p. 367).................................. 71

Figuras 4 e 5: cerâmicas escavadas na área de intervenção da UHE Jirau ................................75

Figuras 6 e 7: cerâmicas pintadas da área de intervenção da UHE Jirau. ................................ 75

Figura 8: pesca na cachoeira do Teotônio, rio Madeira (Gouldin, Smith \& Mahal, 2000)......87

Figura 9: modelo elaborado por Tizuka (2013) para o Alto rio Madeira. ............................... 90

Figura 10: sítios arqueológicos nas proximidades da cachoeira de Santo Antônio. ................96

Figura 11: croqui do sítio Ilha de Santo Antônio (Michelle Tizuka, 2012). ...........................97

Figura 12: perfil da unidade - Ilha de Santo Antônio N990 E849 ........................................99

Figura 13: Recipiente R1e feições F13, F14 E F15- Ilha de Santo Antônio ........................... 100

Figura 14: croqui esquemático das feições do setor do R1- Ilha de Santo Antônio................ 100

Figura 15: feições no perfil Oeste (N986 E848 a N993 E848)- Ilha de Santo Antônio.......... 101

Figura 16: perfil da unidade N979 E880 - Ilha de Santo Antônio......................................... 102

Figura 17: Perfil transversal da cachoeira de Santo Antônio (TIZUKA, 2013, p. 90)........... 104

Figura 18: croqui com densidades da cerâmica e lítico - sítio do Brejo.................................. 105

Figura 19: Croqui do sítio do Brejo (SCIENTIA, 2010)..................................................... 105

Figura 20: perfil da unidade N1040/1041 E957, sítio do Brejo. ........................................... 108

Figura 21: perfil da unidade N1021 E1059 e N1022 E1059 - sítio do Brejo. ....................... 110

Figura 22: estratigrafia do setor 1 do Brejo (TIZUKA, 2013: 101 e 102). ........................... 110

Figura 23: croqui do sítio Veneza (SCIENTIA, 2012)......................................................... 112

Figura 24: densidade cerâmica e lítica - sítio Veneza............................................................ 112

Figura 25: perfil da unidade N980 E937 -sítio Veneza. ....................................................... 114

Figura 26: feição F2 (N 1020 E 865) e F1 (N1020 E866)- sítio Veneza. ............................... 114

Figura 27: densidade cerâmica e posição dos montículos-Novo Engenho Velho ...................118

Figura 28: perfil das unidades N960 E980, N960 E981, N960 E982/ sítio Garbin ..............119

Figura 29:perfil da unidade N1000 E952- sítio Novo Engenho Velho .................................. 119

Figura 30: localização dos sítios arqueológicos junto à cachoeira do Teotônio. .................... 120

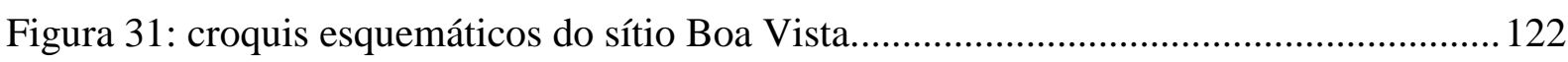

Figura 32: perfil norte da Unidade E0392900/N9022302- sítio Boa Vista............................ 123

Figura 33: croqui do sítio Vista Alegre (Michelle Tizuka, 2013)....................................... 126

Figura 34: perfil da unidade E387190 N9020490 - Vista Alegre (Michelle Tizuka, 2012).. 127

Figura 35: escavação das unidades N387190 E9020490 I, II, III e IV. 


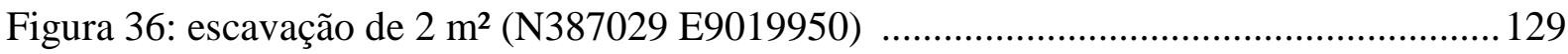

Figura 37: escavação de 2 x 1 m (E386970 N9019890)...................................................... 129

Figura 38: perfil norte das unidades N387029 E9019951 e N387030 E901995................... 130

Figura 39: perfil da escavação /Morro dos Macacos I.......................................................... 133

Figura 40: croquis do sítio Morro dos Macacos (Juliana Rossato Santi, 2014)............ ...132

Figura 41: Perfil das unidades 383934 e 383935/9022581-Foz do Jatuarana........................ 136

Figura 42: croquis do sítio Foz do Jatuarana (Juliana Rossato Santi, 2014) .......................... 138

Figura 43: perfil transversal da cachoeira Teotônio (TIZUKA, 2013:90). ........................... 137

Figura 44: croqui com localização dos sítios Teotônio e Santa Paula.................................... 139

Figura 45: perfil oeste da unidade 382631 - 9021469- sítio Santa Paula ............................. 140

Figura 46: escavação das vasilhas 1, 2 e 3 e zoomorfo encontrado- Teotônio........................ 143

Figura 47: sítios localizados entre as cachoeiras de Teotônio e Morrinhos ........................... 144

Figura 48: perfil norte da unidade E380600 N9013720 - Ilha de São Francisco. ................. 147

Figura 49: croquis do sítio Ilha de São Francisco (Juliana Rossato Santi, 2014)......... ...146

Figura 50: painéis, gravuras e feições de polimento - sítio Ilha das Cobras.......................... 149

Figura 51: Perfil da E376500 N9006380 - Ilha das Cobras.................................................. 151

Figura 52: gráficos com as concentrações de cerâmica por nível- sítio ilha das cobras ...152

Figura 53: croquis do sítio Ilha das Cobras (Juliana Rossato Santi, 2014)......................... 150

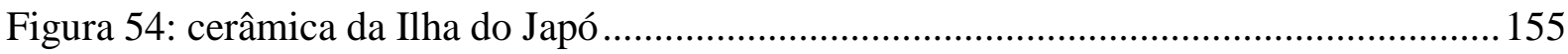

Figura 55: feições das unidades 368030/9001780 e 368029/9001780- Ilha do Japó .............. 156

Figura 56: croquis do sítio Ilha do Japó (Juliana Rossanto Santi, 2014) .............................. 157

Figura 57: materiais líticos da unidade E367980 N9001840- Ilha do Japó............................ 158

Figura 58: perfil sul da unidade E367981 N9001839 - Ilha do Japó .................................... 159

Figura 59: unidades contíguas (E367920 N9001860) e materiais- Ilha do Japó ..................... 160

Figura 60: sítios junto à foz do Jaciparaná e à montante...................................................... 163

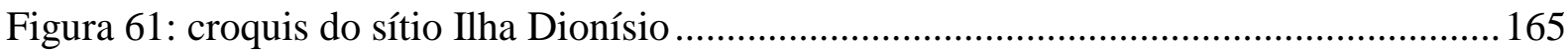

Figura 62: perfil norte da unidade E347805 N8983979 - Ilha Dionísio.............................. 168

Figura 63: croqui da área das vasilhas- setor sul, Ilha Dionísio (Diogo Quirino, 2010)....... 169

Figura 64: escavação do interior da vasilha 1 e 2 - Ilha Dionísio ......................................... 170

Figura 65: estrutura 1 (Unidade 347971/8983935) - Ilha Dionísio..................................... 171

Figura 66: fragmentos com engobo e pintura- Ilha de Santo Antônio ...................................211

Figura 67: tratamentos plásticos - Ilha de Santo Antônio. ……............................................212 
Figura 68: desenhos dos tratamentos plásticos - Ilha de Santo Antônio. 213

Figura 69: bordas extrovertidas - ilha de Santo Antônio.

Figura 70: bordas extrovertidas - Ilha de Santo Antônio. ...................................................218

Figura 71: bordas diretas inclinadas internamente- Ilha de Santo Antônio............................218

Figura 72: bordas diretas inclinadas externamente- Ilha de Santo Antônio ...........................219

Figura 73: bordas diretas verticais, introvertidas e de assadores- Ilha de Santo Antônio ......220

Figura 74: bases e marcas de fermentação- Ilha de Santo Antônio.

Figura 75: possíveis adornos/reciclagem, borda com sulco e fusos- Ilha de Santo Antônio. 222

Figura 76: vasilha R1, girando no sentido horário- Ilha de Santo Antônio. 224

Figura 77: Vasilha R4 - Ilha de Santo Antônio. 224

Figura 78: cerâmica dos níveis mais profundos da Ilha de Santo Antônio . 226

figura 79: bordas do material antigo da ilha de Santo Antônio 227

Figura 80: cerâmica com antiplástico mineral anguloso na pasta- Ilha de Santo Antônio

Figura 81: bordas selecionadas na triagem- Ilha de Santo Antônio 228

Figura 82: bordas selecionadas na triagem- Ilha de Santo Antônio 229

Figura 83: bases- Ilha de Santo Antônio 231

Figura 84: apêndices: asas, alças e trípode- Ilha de Santo Antônio. ......................................232

Figura 85: tratamentos plásticos- Ilha de Santo Antônio. .....................................................233

Figura 86: tratamentos plásticos - Ilha de Santo Antônio. ...................................................224

Figura 87: engobo vermelho; decoração vestigial e pintura- Ilha de Santo Antônio. ............235

Figura 88: adornos, fusos, representação zoomorfa independente; objetos tubulares ..........236

Figura 89: pasta com carvão e caraipé e caraipé - Veneza ..................................................239

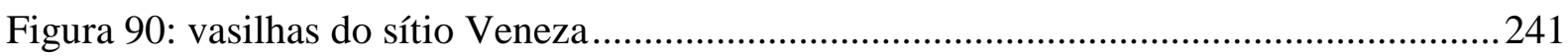

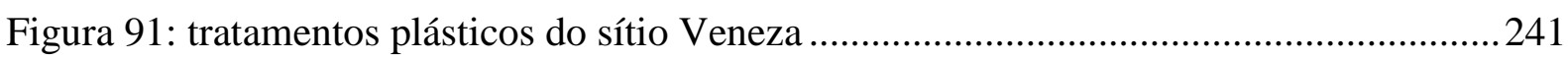

Figura 92: desenhos dos tratamentos plásticos- sítio veneza .............................................242

Figura 93: desenhos das bordas- sítio Veneza.....................................................................24

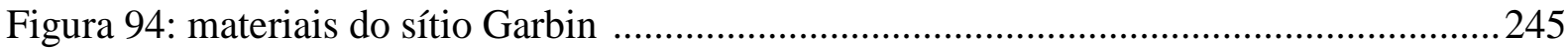

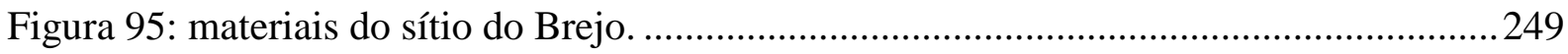

Figura 96: bordas extrovertidas - sítio do Brejo .................................................................251

Figura 97: bordas diretas inclinadas externamente - sítio do Brejo .....................................252

Figura 98: bordas diretas verticais - sítio do Brejo...........................................................253

Figura 99: bordas diretas inclinadas internamente, introvertidas e de assador - Brejo ..........254

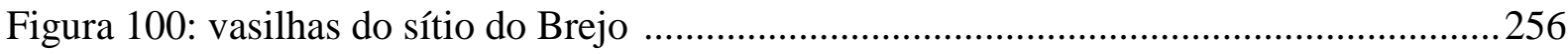

Figura 101: vasilhas cerâmicas - sítio Morro dos Macacos I ...............................................259 
Figura 102: vasilhas cerâmicas - sítio Morro dos Macacos I ..............................................260

Figura 103: bordas-Sítio Foz do Jatuarana (Desenhos: Angislaine F. Costa, 2012).............263

Figura 104: cerâmica do sítio Foz do Jatuarana. ..............................................................264

Figura 105: tratamento plástico - setor 1 do sítio Boa Vista .............................................267

Figura 106: desenhos das bordas- setor 1 do sítio Boa Vista ............................................268

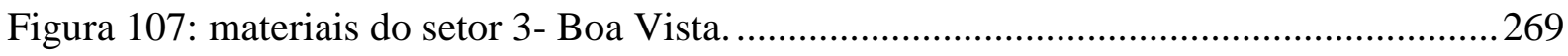

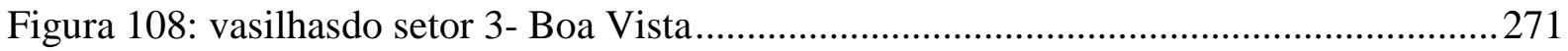

Figura 109: vasilha com fuligem (panela)- setor 3 do sítio Boa Vista ................................271

Figura 110: bordas- setor 3 do sítio Boa Vista (Angislaine F. Costa, 2012) ........................272

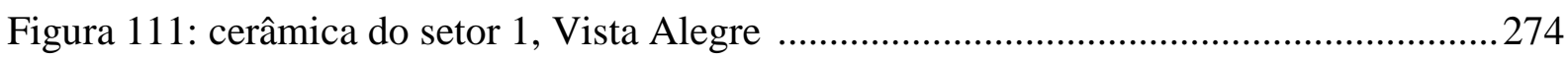

Figura 112: desenhos das bordas do setor 1 - Vista Alegre(Angislaine F. Costa, 2012)...... 275

Figura 113: bordas (40-50 cm e 70-80 cm), escavação de $2 \mathrm{~m}^{2}$ do setor 3- Vista Alegre ......281

Figura 114: desenhos das borda com incisões na face interna- sítio Vista Alegre.................282

Figura 115: possíveis zoomorfos em detalhe - Vista Alegre-sítio Vista Alegre....................281

Figura 116: cerâmica antiga $(40-50$ a $70-80 \mathrm{~cm}$ )/Vista Alegre.......................................... 281

Figura 117:cerâmica do segundo conjunto identificado- Vista Alegre. ................................284

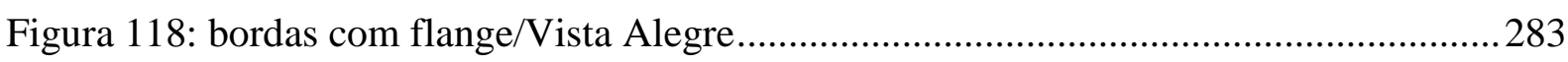

Figura 119: marcas de fermentação, engobo, incisões e polimento- Vista Alegre. ...............284

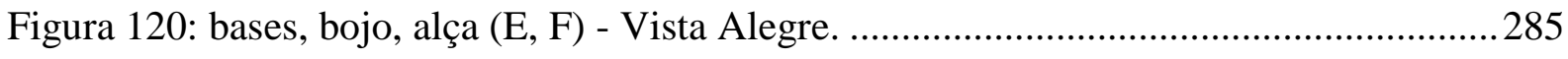

Figura 121: bordas do conjunto mais recente- Vista Alegre ...............................................285

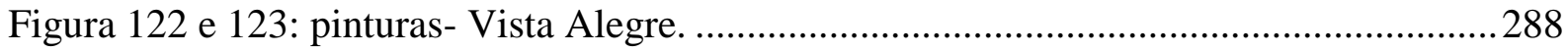

Figura 124: bordas e vasilha remontada do setor 3, Vista Alegre.......................................290

Figuras 125 e 126: cerâmica- Vista Alegre. ........................................................................291

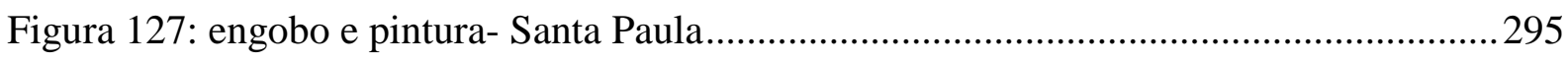

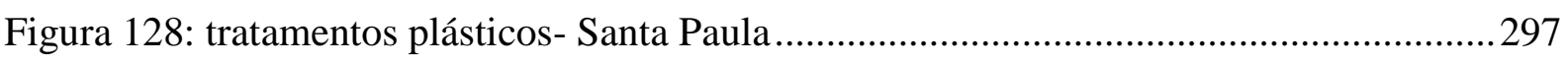

Figura 129: desenhos dos tratamentos plásticos - Santa Paula ............................................298

Figura 130: bordas diretas e introvertidas - Santa Paula ....................................................299

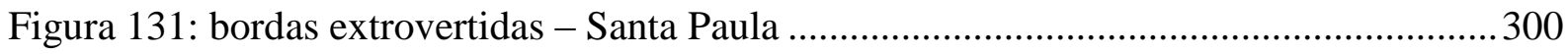

Figura 132: bordas diretas inclinadas externamente e diretas verticais- Santa Paula............301

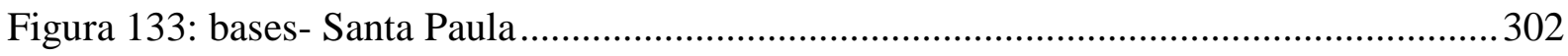

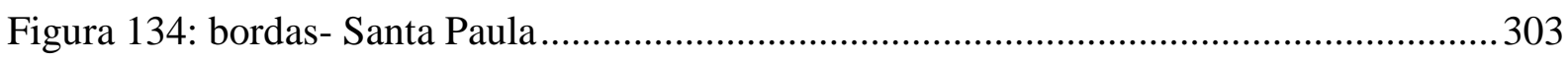

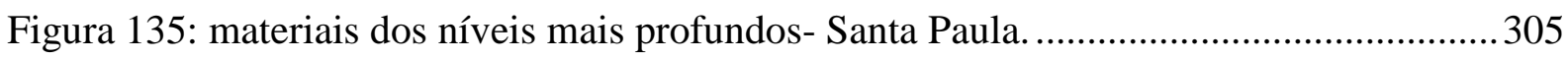

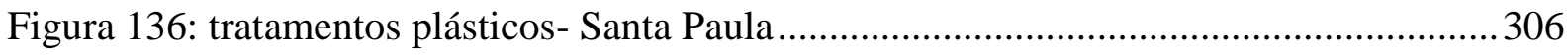

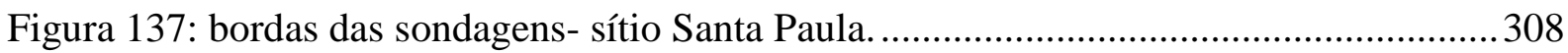


Figura 138: bordas das sondagens- sítio Santa Paula 309

Figura 139: bordas das sondagens- sítio Santa Paula 310

Figura 140: bordas de assador - sítio Santa Paula 310

Figura 141: cerâmica das sondagens - Santa Paula. 311

Figura 142: cerâmica antiga do sitio Santa Paula. 313

Figura 143: vasilhas do interior da vasilha 1- sítio Teotônio . 318

Figura 144: vasilhas V1, V2 e V3 e bordas encontradas no entorno- sítio Teotônio 319

Figura 145: desenho das bordas - ilha São Francisco (Algislaine F. Costa, 2013). 324

Figura 146: cerâmica da Ilha São Francisco. 325

Figura 147: gráficos com a distribuição das pastas nos níveis-Ilha das Cobras. 327

Figura 148: desenhos das bordas - sítio Ilha das Cobras (Angislaine F. Costa, 2013)......

Figura 149: materiais da ocupação mais antiga- Ilha das Cobras.

Figura 150: materiais da ocupação mais recente- Ilha das Cobras 331

Figura 151: vasilha com decoração incisa- Ilha do Japó 334

Figura 152: bordas do conjunto tecnológico mais recente- Ilha do Japó 336

Figura 153: bordas do conjunto tecnológico mais antigo- Ilha do Japó. 337

Figura 154: fragmentos da ocupação mais recente- Ilha do Japó. .338

Figura 155: fragmentos da ocupação mais antiga- Ilha do Japó. 339

Figura 156: vasilhas cerâmicas e conjuntos A, B, C e D- sítio Coração 344

Figura 157: fragmentos da camada A- sítio Ilha Dionísio. 346

Figura 158: brunidura - camada A- Ilha Dionísio 349

Figura 159: pintura da vasilha com forma de cálice- Ilha Dionísio 350

Figura 160: fragmentos da camada A- Ilha Dionísio 351

Figura 161: fragmentos da camada A- Ilha Dionísio 351

Figura 162: bordas extrovertidas - Camada A- Ilha Dionísio 355

Figura 163: bordas diretas inclinadas externamente - Camada A- Ilha Dionísio. 356

Figura 164: bordas diretas verticais-Camada A- Ilha Dionísio 356

Figura 162: bordas introvertidas e diretas inclinadas internamente- camada A- Dionísio..... 357

Figura 166: bases- Camada A- Ilha Dionísio (desenhos: Angislaine F. Costa, 2013)...........357

Figura 167: bordas da Camada C- Ilha Dionísio (desenhos: Angislaine F. Costa, 2013)......358

Figura 169: marcas de uso nos fragmentos da camada A- Ilha Dionísio 360

Figura 168: fragmentos de trempe e bolotas de argila - Camada A- Ilha Dionísio 360

Figura 170: cerâmica da Camada C- Ilha Dionísio 361

Figura 171: desenhos das vasilhas 1 e 2 e de fragmento da tampa - Ilha Dionísio. 362 


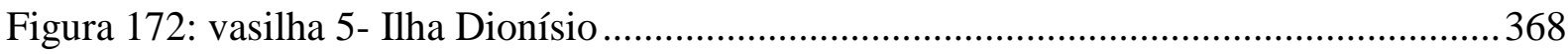

Figura 173: vasilha 1 e 2, 3, 4 e fragmentos de tampa e vasilhas 8 e 9- Ilha Dionísio ...........370

Figura 174: estrutura 2 (vasilha 5, 6 e 7 e bordas) e estrutura 3 - Ilha Dionísio..................... 371

Figura 175: vasilhas 16, 26, 18, 19 e da estrutura 21- Setor Norte- Ilha Dionísio.................373

Figura 176: motivo da vasilha da estrutura 21 - setor norte- Ilha Dionísio ............................373

Figura 177:vasilha cerâmica do sítio Bom Futuro.................................................................404

Figura 178: cerâmica do sítio Novo Engenho Velho . ........................................................... 404

Figura 179: cerâmica do sítio São Domingos e sítio Campelo. ..............................................405

\section{LISTA DE FOTOGRAFIAS}

Fotografias 1 e 2: moradia na Ilha São Francisco e plantação na ilha Dionísio........................ 87

Fotografias 3 e 4: escavações no setor do R1- Ilha de Santo Antônio ..................................... 101

Fotografia 5: perfil da unidade N870 E840- Ilha de Santo Antônio ....................................... 103

Fotografias 6, 7 e 8: líticos - Ilha de Santo Antônio ............................................................... 103

Fotografias 9, 10 e 11: artefatos polidos e adornos- Ilha de Santo Antônio............................. 104

Fotografias 12 e 13: estrutura e feição -N982 E981 e N983 E981- Sítio do Brejo................. 107

Fotografias 14 e 15: estruturas evidenciadas no setor 5 - sítio do Brejo .............................. 107

Fotografia 16: visibilidade para o rio Madeira a partir da área do topo -sítio Veneza.......... 113

Fotografia 17: perfil do barranco sítio Veneza ...................................................................... 116

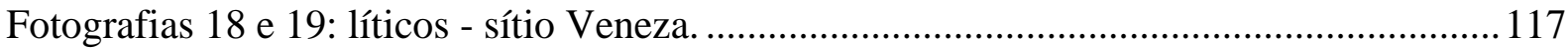

Fotografia 20: vista do rio Madeira a partir do setor III do sítio Boa Vista ........................... 121

Fotografias 21 e 22: perfil da unidade 20L E392511/N9021980 e cerâmica- Boa Vista........ 124

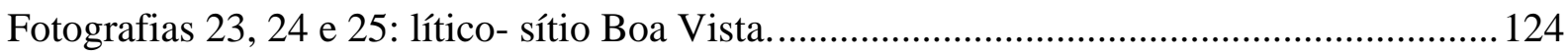

Fotografia 26: setor I do sítio Vista Alegre visto a partir do rio Madeira ............................. 125

Fotografias 27, 28 e 29: materiais líticos do sítio Vista Alegre . ......................................... 131

Fotografias 30 e 31: moradores com as vasilhas - Morro dos Macacos I............................. 134

Fotografias 32 e 33: escavação na área das vasilhas- Morro dos Macacos I ........................ 134

Fotografias 34, 35 e 36:líticos- sítio Santa Paula. ................................................................ 141

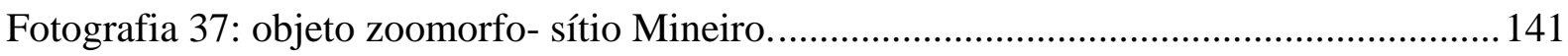

Fotografias 38 e 39: escavação do interior das vasilhas 1 e 3- sítio Teotônio ........................ 144

Fotografia 40: vista da Ilha do Japó a partir da margem direita. .......................................... 153

Fotografias 41, 42 e 43: adornos líticos e cerâmica da camada C- Ilha do Japó..................... 156

Fotografias 44 e 45: unidade E367980 N9001840 e expansões - Ilha do Japó. ..................... 158 
Fotografias 46 e 47: cerâmica com tratamento plástico roletado- Ilha do Japó 160

Fotografias 48, 49 e 50: adornos líticos- Ilha do Japó

Fotografias 51 e 52: fragmentos na superfície e escavação das duas bases - sítio Coração.. 162

Fotografias 53 e 54: estatueta antropomorfa e objeto zoomorfo - sítio Paraíso ...................... 163

Fotografias 55 e 56: moradiae escavação - Ilha Dionísio .................................................... 164

Fotografia 57 e 58: unidade 347800/8984160 e expansões com estrutura- Dionísio.............. 167

Fotografias 59 e 60: escavação da vasilha 1 e estruturas 1 e 2- Ilha Dionísio. ....................... 170

Fotografias 61 e 62: vasilha 3 e estrutura III - Ilha Dionísio................................................ 172

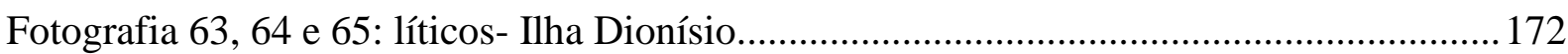

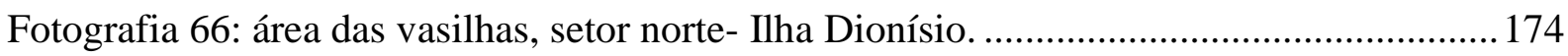

Fotografias 67, 68, 69: vasilhas 10 e 11 e vasilha 15 - setor Norte/Ilha Dionísio................. 174

Fotografias 70, 71 e 72: vasilha 16, 2618 e 19- setor Norte/ Ilha Dionísio........................... 175

Fotografias 73, 74 e 75: estrutura 20, vasilha 14 e estrutura de seixos- setor Norte/ Ilha

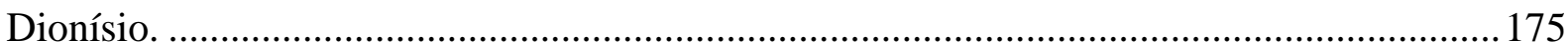

Fotografias 76, 77 e 78: possíveis adornos líticos - setor Norte/ Ilha Dionísio....................... 176

Fotografias 79, 80 e 81: líticos da área das vasilhas- setor Norte/ Ilha Dionísio. ...................176

Fotografias 82 e 83: pasta com caraipé; e caraipé e carvão-Ilha de Santo Antônio. ..............209

Fotografia 84, 85 e 86: vasilha R2 (FE) e vasilha R3 (FE e FI)- Ilha de Santo Antônio .......224

Fotografias 87 e 88: cerâmicas dos níveis datados (140-150 cm e 220-230cm)- Boa Vista. 266

Fotografias 89e 90: cerâmica do setor 1 do sítio Boa Vista ...............................................267

Fotografias 91 e 92: pinturas- Setor 1 do sítio Vista Alegre. ...............................................275

Fotografias 93 e 94: incisões e acanalado- setor 1 do Vista Alegre ......................................275

\section{LISTA DE GRÁFICOS}

Gráfico 1: distribuição da cerâmica - unidade E0392900/N9022302/Boa Vista. .................. 123

Gráfico 2: distribuição da cerâmica e lítico -unidade E367981 N9001840/ Ilha do Japó...... 158

Gráfico 3: distribuição da cerâmica e lítico - unidade E347820 N8983960/ Ilha Dionísio ... 168

Gráfico 4: escolha da pasta- sítio Ilha de Santo Antônio. ......................................................208

Gráfico 5: Variações da queima - sítio Ilha de Santo Antônio..............................................209

Gráfico 6: acabamentos de superfície dos fragmentos- sítio Ilha de Santo Antônio..............209

Gráfico 7: tratamentos plásticos - Ilha de Santo Antônio..................................................... 212

Gráfico 8:espessura dos fragmentos- Ilha de Santo Antônio. …..........................................214

Gráfico 9: forma e inclinação das bordas- sítio Ilha de Santo Antônio.................................215 
Gráfico 10: espessamento das bordas - sítio Ilha de Santo Antônio.

Gráfico 11: diâmetro de abertura das vasilhas cerâmicas- Ilha de Santo Antônio.

Gráfico 12: pasta dos fragmentos de vasilhas do sítio Veneza............................................239

Gráfico 13: Acabamentos de superfície - sítio Veneza. ......................................................239

Gráfico 14: Tratamentos plásticos- sítio Veneza..............................................................240

Gráfico 15: forma e inclinação das bordas - sítio Veneza. ....................................................243

Gráfico 16: espessamento das bordas- sítio Veneza.............................................................24

Gráfico 17: comparação entre as pastas dos diferentes setores do sítio do Brejo. .................247

Gráfico 18: comparação entre as pastas nas camadas do setor 1/ sítio do Brejo....................247

Gráfico 19: forma e inclinação das bordas- sítio do Brejo.................................................249

Gráfico 20: espessamento das bordas - sítio do Brejo. ....................................................250

Gráfico 21 e 22:frequência de cerâmicas analisadas por nível- sítio Foz do Jatuarana. ........261

Gráfico 23 e 24: distribuição da pasta nos níveis - sítio Foz do Jatuarana............................262

Gráfico 25: comparação da queima com a composição da pasta- sítio Foz do Jatuarana......263

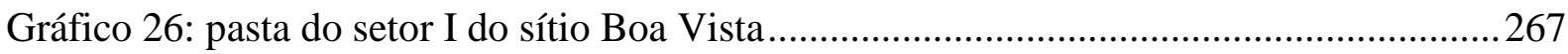

Gráfico 27: Acabamentos de superfície- setor 1 - sítio Boa Vista. ......................................267

Gráfico 28: pasta das cerâmicas do setor 3.- sítio Boa Vista ...............................................269

Gráfico 29: caracterização da pasta- setor 1 do sítio Vista Alegre........................................274

Gráfico 30: acabamentos de superfície - setor 1, Vista Alegre.............................................275

Gráficos 31 e 32: materiais nos níveis -setor 3/Vista Alegre ..............................................276

Gráfico 33: caracterização da pasta nos níveis- escavação de $2 \mathrm{~m}^{2}$ do setor 3/Vista Alegre.. 277

Gráfico 34: acabamentos de superfície- escavação de $2 \mathrm{~m}^{2}$ do setor 3/Vista Alegre..............278

Gráfico 35: acabamentos plásticos-escavação de $2 \mathrm{~m}^{2}$ do setor 3/Vista Alegre .....................279

Gráfico 36: forma e inclinação das bordas- -escavação de $2 \mathrm{~m}^{2}$ do setor 3/Vista Alegre....... 280

Gráfico 37: pasta das cerâmicas da escavação de 2 x $1 \mathrm{~m}$ - setor 3/Vista Alegre ..................286

Gráfico 38: forma e inclinação das bordas- escavação de 2 x 1 m/sítio Vista Alegre. ..........289

Gráfico 39: distribuição dos materiais diagnósticos nos niveis - unidade E382631

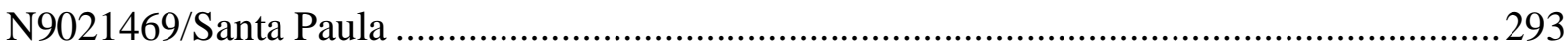

Gráfico 40: caracterização da pasta - unidade E382631 N9021469/ sítio Santa Paula..........294

Gráfico 41: acabamentos de superfície -unidade E382631 N9021469/ sítio Santa Paula......294

Gráfico 42: tratamentos plásticos - unidade E382631 N9021469/ Santa Paula....................296

Gráfico 43: quantidade de tratamentos plásticos nos niveis - unidade E382631 N9021469/

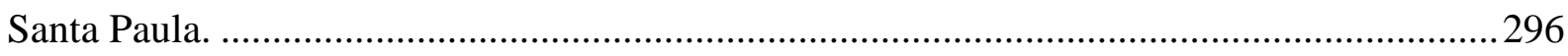

Gráfico 44: diâmetros de abertura das vasilhas- unidade E382631 N9021469/Santa Paula..301 
Gráfico 45: tratamentos plasticos - materiais das sondagens/ sítio Santa Paula. 307

Gráfico 46: diâmetro de abertura das vasilhas (cm)- sondagens do sítio Santa Paula. ..........308

Gráfico 47: acabamentos de superfície das vasilhas- Setor estrada do sitio Teotônio............317

Gráficos 48 e 49: espessamento e tipo de lábio- Setor estrada do sitio Teotônio ...................318

Gráfico 50: cerâmica do interior das vasilhas V1 e V3 e fora delas/Teotônio........................320

Gráfico 51: fragmentos analisados por nível- E380600 N9013720/Ilha São Francisco. ........321

Gráfico 52: tipos de antiplástico- sítio Ilha São Francisco....................................................322

Gráfico 53: acabamentos de superfície - Ilha São Francisco.................................................323

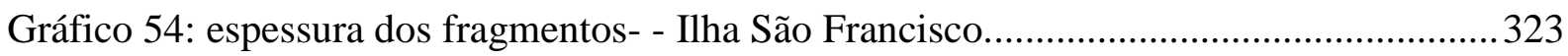

Gráfico 55: frequência de fragmentos por nível - E376500 N9006380/ Ilha das Cobras. ......326

Gráfico 56: acabamentos de superfície das vasilhas - Ilha das Cobras..................................328

Gráfico 57: espessura dos fragmentos cerâmicos- Ilha das Cobras..........................................328

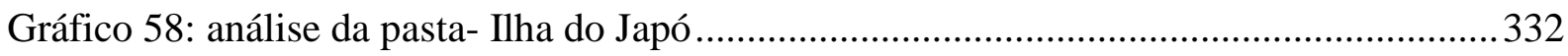

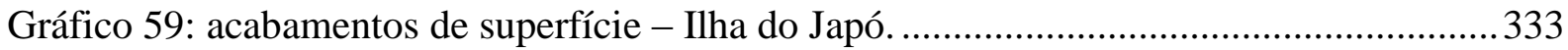

Gráfico 60: tratamentos plásticos nos níveis de escavação - Ilha do Japó..............................333

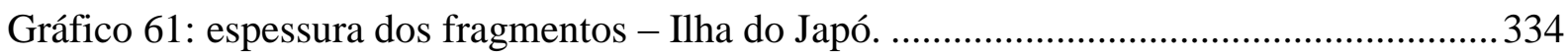

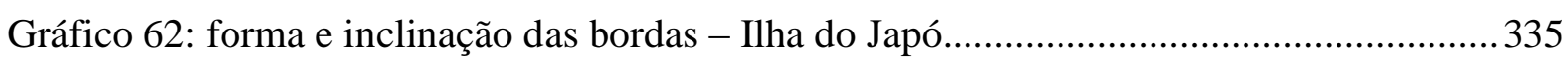

Gráfico 63: espessamento das bordas nos níveis de escavação - Ilha do Japó. ...................... 335

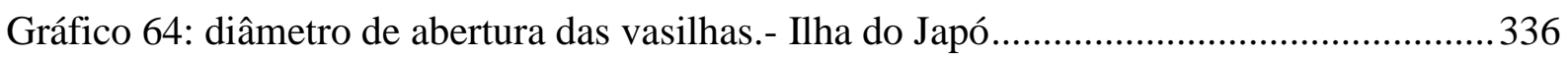

Gráfico 65: cerâmica nos níveis das quatro unidades analisadas- Ilha Dionísio.....................345

Gráfico 66: análise da pasta da camada A- Ilha Dionísio. .......................................................347

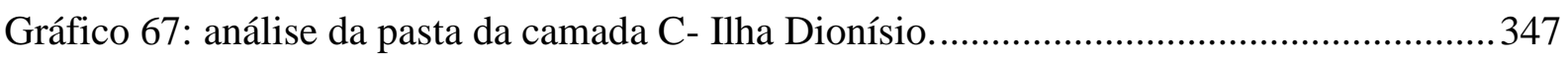

Gráfico 68: acabamentos de superfície - camada A- Ilha Dionísio.......................................348

Gráfico 69: acabamentos de superfície - camada C- Ilha Dionísio. .......................................348

Gráfico 70: ocorrência de pintura x tipo de pasta (Camada A)- Ilha Dionísio........................350

Gráfico 71: espessura dos fragmentos- camada A- Ilha Dionísio. .........................................352

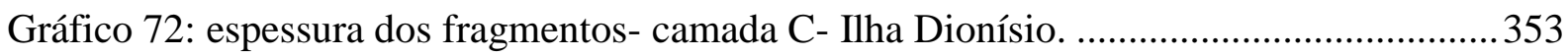

Gráfico 73: comparação do espessamento das bordas das camadas A e C/Dionísio..............353

Gráfico 74: comparação dos tipos de lábios das camadas A e C/Dionísio..............................354

Gráfico 75: diâmetros de abertura- camada A- Ilha Dionísio. .............................................. 354 


\section{LISTA DE MAPAS}

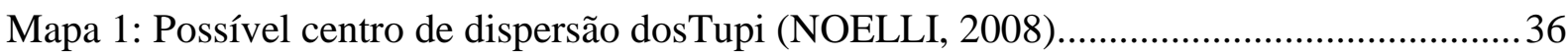

Mapa 2: sugestão da localização da língua Proto-Arawak (HECKENBERGER, 2002)......... 39

Mapa 3: grupos etno-linguisticos da Amazônia Meridional no período do contato (ERIKSEN, 2011) 42

Mapa 4: sistema regional Arawak na Amazônia em torno de 1000 AD (ERICKSEN, 2011). 44

Mapa 5:localização das fases arqueológicas no Alto Madeira (CRUZ , 2008)........................65

Mapa 6: localização da área de estudo, no Alto rio Madeira, Rondônia .................................. 86

Mapa 7: localização dos sítios arqueológicos no Alto rio Madeira, Rondônia .........................95

Mapa 8: Localização dos sítios arqueológicos e conjuntos tecnológicos identificados no trabalho 408

\section{LISTA DE TABELAS}

Tabela 1: Lista de sítios arqueológicos abordados na pesquisa............................................94

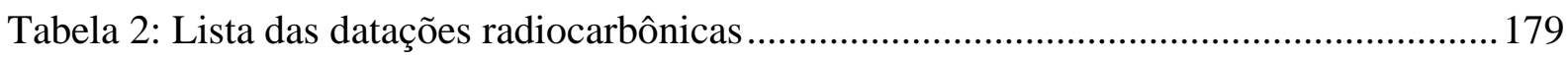

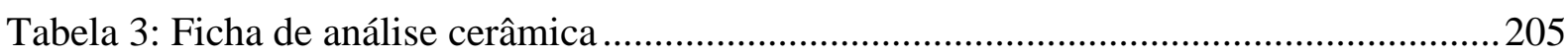

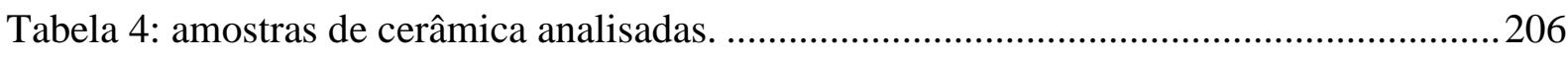

Tabela 5: comparação da cerâmica das camadas A e C- Ilha Dionísio..................................352 


\section{SUMÁRIO}

Introdução

Capítulo 1. Arqueologia na Amazônia e em Rondônia- os modelos sobre a ocupação précolonial na Floresta Tropical e as hipóteses para o Alto rio Madeira

1.1. Arqueologia na Amazônia e os modelos sobre a ocupação pré-colonial na Floresta Tropical.

1.2. Arqueologia no Alto rio Madeira e seus afluentes e as hipóteses sobre a ocupação da região 63

1.3. Diversidade cultural no Alto rio Madeira, Rondônia .82

Capítulo 2. Alto rio Madeira, Rondônia: a área de estudo e os sítios arqueológicos .84

2.1. A região do Alto rio Madeira 85

2.2. Nas ilhas e nas margens: os sítios arqueológicos no Alto rio Madeira 91

2.3. Considerações iniciais sobre as ocupações no alto rio Madeira 177

Capítulo 3. O estudo da tecnologia cerâmica: as escolhas tecnológicas e a variabilidade artefatual .183

3.1. O estudo da variabilidade artefatual: as escolhas técnológicas e a identificação de identidades e fronteiras culturais no registro arqueológico 183

3.2. A análise cerâmica: conceituação dos atributos 197

Capítulo 4- Análise da variabilidade cerâmica no Alto rio Madeira .206

4.1. Cerâmica do sítio Ilha de Santo Antônio. 206

4.2. Cerâmica do sítio Veneza .238

4.3. Cerâmica do sítio do Brejo .246

4.4. Cerâmica do sítio Morro dos Macacos I .257

4.5. Cerâmica do sítio Foz do Jatuarana 261

4.6. Cerâmica do sítio Boa Vista .265

4.7. Cerâmica do sítio Vista Alegre. 273

4.8. Cerâmica do sítio Santa Paula, 292 
4.9. Cerâmica do sítio Teotônio

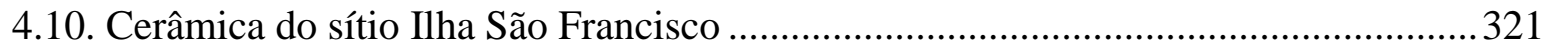

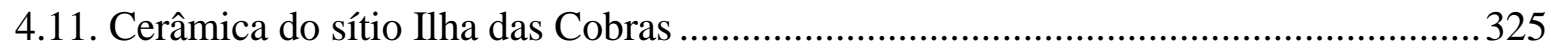

4.12. Cerâmica do sítio Ilha do Japó ...................................................................................331

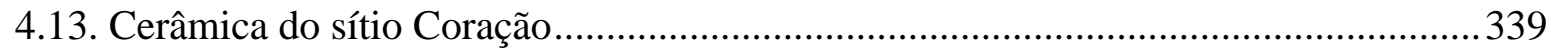

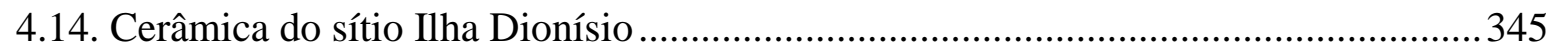

Capítulo 5- Cenários da história indígena no alto rio Madeira: variabilidade cerâmica e

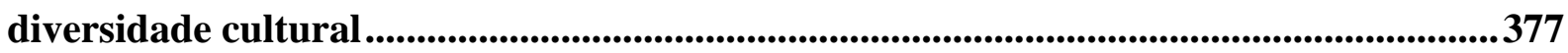

5.1. As ocupações ceramistas antigas no alto rio Madeira ............................................. 379

5.2. Ocupações ceramistas em 1.800 AP - sítios Morro dos Macacos I, Vista Alegre e Foz

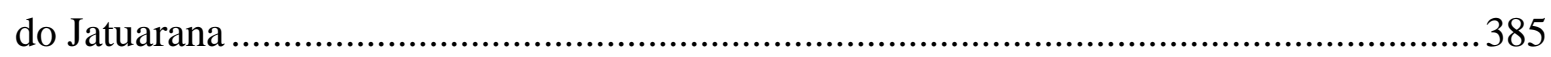

5.3. Ocupações dos portadores da cerâmica Barrancóide no Alto rio Madeira...................387

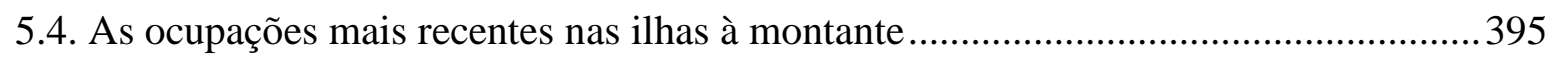

5.5. Ocupações dos portadores da Tradição Polícroma da Amazônia no Alto rio Madeira

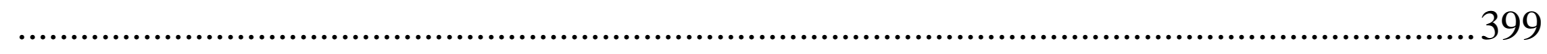

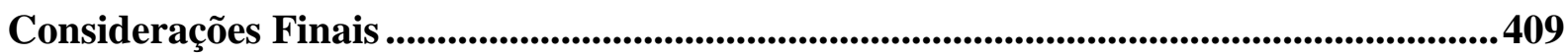

Referências bibliográficas.........................................................................................................4417 


\section{Introdução}

Os estudos lingüísticos, etnográficos e históricos caracterizam o sudoeste Amazônico como uma região de grande diversidade cultural, incluindo grupos indígenas de matriz cultural Tupi, Macro Jê, Arawak, Pano e outras línguas isoladas, considerada não somente como o local de origem e dispersão dos povos Tupi (RODRIGUES, 1958, 1964, 1984; NOELLI, 1996; NEVES, 2012), mas também como integrando um bloco quase contínuo de povos Arawak da chamada Periferia Meridional da Amazônia (HECKENBERGER, 2001), envolvendo uma possível esfera de interações com redes de comércio e comunicação (ERICKSEN, 2011).

As pesquisas arqueológicas, iniciadas na década de 1970 (MILLER 1983, 1992, 1999, 2009a, 2009b, 2013) demonstram que a bacia do rio Madeira possui uma longa sequência histórica, abrangendo o final do Pleistoceno e todo o Holoceno, com a formação das terras pretas mais antigas da Amazônia e evidências de manejo e domesticação de plantas. Entretanto, as ocupações dos povos ceramistas, presentes na região desde 5.000 anos, foram associadas a uma infinidade de fases e a cinco tradições distintas (Inciso Ponteado, Borda Incisa, Polícroma, Tupiguarani e Jamari), com base na análise de atributos isolados como a pasta e a decoração. Na área de estudo, a cerâmica foi atribuída a Subtradição Jatuarana da Tradição Polícroma da Amazônia, que estaria presente desde 2.700 anos até o período colonial, com maior popularidade das técnicas plásticas no início das seqüências e das técnicas crômicas no final. Além disso, a complexidade desta cerâmica no curso do rio Madeira foi estabelecida em oposição à simplicidade da cerâmica nos seus afluentes, como no Jamari (Tradição Jamari) e Jaciparaná (fase Jaciparaná) (MILLER, 1992).

Neste trabalho, partimos da hipótese de que a diversidade cultural presente no sudoeste Amazônico no período colonial possui raízes na história mais antiga da região. Porém, tal questão pode ser abordada, do ponto de vista arqueológico, somente através do estudo dos significados da variabilidade artefatual, com a análise das escolhas tecnológicas que perpassam o processo de confecção e uso dos artefatos. Tais escolhas são decisões tomadas por indivíduos em um contexto social e simbólico específico, de acordo com as trajetórias históricas e a tradição tecnológica e cultural do grupo (DIAS E SILVA, 2001; DAVID E KRAMER, 2001; SCHIFFER E SKIBO, 1992; LEMMONIER, 1992, 1993; 
DIETLER E HERBICH, 1998; GOSSELAIN, 1998; CHILION, 1998; PIKIRAYI, 2007; SILVA, 2007).

Analisamos a cerâmica de quatorze sítios arqueológicos, os quais se distribuem ao longo de $80 \mathrm{~km}$ no alto curso do rio Madeira, localizados entre a cachoeira de Santo Antônio, nas proximidades da cidade de Porto Velho, até a foz do rio Jaciparaná, próxima a cachoeira Caldeirão do Inferno, em planícies de inundação, terraços fluviais e superfícies de aplainamento. Nestes lugares, as ocupações ceramistas foram situadas entre aproximadamente 3.000 anos atrás e o período colonial, podendo ser ainda mais antigas. Todos os sítios foram escavados no âmbito do Projeto de Arqueologia Preventiva nas áreas de Interferência da UHE Santo Antônio/RO (SCIENTIA, 2008), cujos dados e acesso aos materiais arqueológicos foram disponibilizados por esta empresa para a realização desta pesquisa.

Analisamos atributos que caracterizam as escolhas tecnológicas na confecção dos artefatos cerâmicos, as quais indicam a variabilidade artefatual, e através da análise comparativa dos diferentes sítios identificamos cinco conjuntos tecnológicos que representam a diversidade e dinâmica cultural no passado. O diálogo com os dados arqueológicos de outras áreas da Amazônia e adjacências, bem como com os principais modelos de ocupação da região, construídos com base nos dados arqueológicos, linguísticos e etno-históricos, contribui para a construção de uma sequência histórica e cultural na região do Alto rio Madeira. A tese foi dividida em cinco capítulos e considerações finais.

No capítulo 1, apresentamos um panorama dos estudos arqueológicos realizados na Amazônia e as suas implicações teóricas e metodológicas, bem como uma síntese dos modelos sobre a ocupação e expansão dos povos nessa região, e das pesquisas realizadas no rio Madeira e seus afluentes, a fim de contextualizar as principais problemáticas e hipóteses deste trabalho.

No capítulo 2, caracterizamos a área de pesquisa, com destaque para aspectos da hidrologia, geologia e geomorfologia, e posteriormente a localização dos sítios ao longo do rio Madeira, ressaltando aspectos do seu tamanho, profundidade, estratigrafia, materiais associados, estruturas evidenciadas e datações.

No capítulo 3, sintetizamos alguns conceitos que guiam teoricamente esta pesquisa, focada no estudo da variabilidade artefatual através da análise das escolhas tecnológicas adotadas por ceramistas nas diferentes etapas da cadeia operatória de confecção dos artefatos 
cerâmicos. Através de exemplos de estudos arqueológicos e etnoarqueológicos problematizamos a questão da delimitação de identidades sociais e culturais no registro arqueológico, bem como a diversidade cultural e as fronteiras territoriais em escala regional. Também são descritos os atributos que caracterizam as escolhas tecnológicas que compõem a ficha de análise.

No capítulo 4, apresentamos os resultados da análise da cerâmica dos quatroze sítios arqueológicos, a partir da sistematização das variáveis (escolhas) e da relação entre os atributos, buscando identificar semelhanças e diferenças no decorrer da estratigrafia de cada sítio. Caracterizamos as escolhas da pasta, das técnicas de confecção, acabamentos de superfície, forma e queima das vasilhas, as quais refletem a variabilidade em termos temporais.

No capítulo 5 comparamos os resultados dos diferentes sítios, distinguindo os conjuntos tecnológicos que compõem as tradições tecnológicas e as ocupações indígenas no alto rio Madeira.

Nas considerações finais, apresentamos algumas reflexões sobre a arqueologia em Rondônia, as contribuições e os limites deste trabalho, bem como as expectativas e possibilidades de pesquisas futuras.

Com isso esperamos contribuir para a construção da história indígena de longa duração no Alto rio Madeira e com as questões teóricas que perpassam a prática arqueológica na região. 


\section{Capítulo 1. Arqueologia na Amazônia e em Rondônia- os modelos sobre a ocupação pré- colonial na Floresta Tropical e as hipóteses para o Alto rio Madeira}

Nesse capítulo, será apresentado um panorama das pesquisas arqueológicas realizadas na Amazônia e as suas implicações teóricas e metodológicas, bem como uma síntese dos modelos sobre a ocupação e expansão dos povos nessa região, construídos a partir da conjunção de dados da linguística histórica, arqueologia e etno-história. Posteriormente, será feita uma síntese das pesquisas arqueológicas realizadas no rio Madeira e seus afluentes e as implicações destes dados na discussão dos modelos acima referidos. Com isso, é possível contextualizar a região e as principais problemáticas e hipóteses de pesquisa.

\subsection{Arqueologia na Amazônia e os modelos sobre a ocupação pré-colonial na Floresta} Tropical

Ao passo que as pesquisas arqueológicas em algumas áreas da Amazônia podem ser consideradas as mais antigas do Brasil, no estado de Rondônia, e mais especificamente na região do Alto rio Madeira, o passado é ainda pouco conhecido do ponto de vista arqueológico. As expedições promovidas pelo Museu Nacional no século XIX concentraramse principalmente ao longo do rio Amazonas, com destaque para as regiões de Marajó, Santarém e Amapá. A partir das escavações feitas por Ladislau Netto (1985), João Barbosa Rodrigues, Domingos Soares Ferreira Penna (1987), Charles Hartt, Louis Agassiz entre outros, surgiram coleções de materiais arqueológicos e travaram-se discussões a respeito da ocupação da região amazônica. Nesse contexto, a monumentalidade dos sítios arqueológicos como dos tesos de Marajó, os sepultamentos em urnas funerárias e a aprimorada tecnologia dos artefatos cerâmicos e líticos eram avaliados sob um olhar colonialista e evolucionista que marcou profundamente a Arqueologia na Amazônia por muito tempo, acreditando-se que tais sítios só poderiam ter sido construídos por povos desenvolvidos vindos de fora que retrocederam à barbárie devido às condições encontradas aqui (MENDONÇA de SOUZA, 1991; FERREIRA, 1999, 2010; BARRETO, 1999/2000; NEVES 1999, 1999/2000; NOELLI e FERREIRA, 2007).

No início século XX, as pesquisas feitas por Erland Nordenskiold e Curt Nimuendajú, ao longo do rio Amazonas e na região de Llanos de Mojos, no caso do primeiro autor, 
forneceram importantes contribuições às discussões sobre a ocupação da Amazônia (NORDENSKIOLD, 1930; NIMUENDAJU, 1981, 2004). Já na passagem para a segunda metade deste século, o antropólogo Julian Steward juntamente com colaboradores publicou o Handbook of South American Indians. Sob a perspectiva da Ecologia Cultural norteamericana, com forte influência do determinismo ecológico e do neo-evolucionismo, as culturas da América do Sul foram classificadas de acordo com características da ecologia, modos de produção e modos de organização social e política, definindo áreas culturais (STEWARD, 1948). Dentre os quatro tipos de cultura- povos marginais, da Floresta Tropical, do Circun-Caribe e dos Andes ${ }^{1}$ - o conceito de Cultura da Floresta Tropical foi elaborado a partir de alguns traços comuns, como a agricultura incipiente com cultivo de tubérculos, especialmente a mandioca, o uso da cerâmica, de redes de dormir e da navegação fluvial, com populações linguisticamente pertencentes a três famílias linguísticas maiores: Arawak, Caribe e Tupi-Guarani (LOWIE, 1948). De acordo com esse modelo, as condições ecológicas da floresta tropical limitaram o desenvolvimento de sociedades sedentárias, com centralização política e religiosa e estratificação social. A Amazônia teria sido ocupada por grupos vindos das áreas andinas e subandinas, onde ocorriam os níveis culturais mais avançados e, como o ambiente tropical impossibilitava a manutenção de tal padrão cultural, passariam a adotar a Cultura de Floresta Tropical (STEWARD, 1948). Seriam, portanto, sociedades com baixa demografia e alta mobilidade, distribuídas em dois ecótonos principais: a várzea e a terra firme. Conforme salientou Neves (1999/2000, p. 89), essa perspectiva contrariava os conhecimentos sobre a arqueologia da região obtidos no inicio do século, colocando a Amazônia em um contexto periférico na História Pré-colonial da América do Sul. Esta visão foi dominante na Antropologia do continente americano até os anos 1970, com uma vulgarização da correlação entre área cultural e área ambiental (FAUSTO, 2005; NOELLI e FERREIRA, 2007).

Os arqueólogos Clifford Evans e Betty Meggers iniciaram suas pesquisas na Amazônia em 1948 (MEGGERS e EVANS, 1957), fortemente influenciados pelo modelo de Julian Steward, cujas premissas foram disseminadas através do Programa Nacional de Pesquisas Arqueológicas (PRONAPA) e do Programa Nacional de Pesquisas Arqueológicas na Bacia Amazônica (PRONAPABA). De forma semelhante ao modelo anteriormente proposto, Meggers (1954) define quatro tipos de ambientes com base na fertilidade do solo,

${ }^{1}$ Corresponde aos estágios de desenvolvimento sociopolítico de bando, tribo, cacicado e estado da tipologia de Service (1962). 
topografia, padrões de chuva e temperatura, sendo que o Tipo 2 correspondia ao padrão cultura de floresta tropical, caracterizado por áreas com limitado potencial agrícola devido à baixa fertilidade do solo. Segundo a autora, a introdução da agricultura de coivara permitiria o aumento da produção de alimentos, porém não seria suficientemente produtiva para suportar grandes concentrações de população ou assentamentos permanentes. Em Marajó, Meggers e Evans (1957) escavaram a cerâmica da fase Marajoara associada a montículos e enterramentos em urnas, características que indicavam a presença de uma população com alta densidade demográfica, estratificação social e centralização política, porém este contexto foi explicado como resultante de uma migração de povos exógenos com um nível cultural do tipo cacicado que, entretanto, teriam entrado em rápida decadência em função das condições ambientais, degenerando para o nível de floresta tropical. Segundo Meggers (1987, p. 64), apesar da várzea não ser um perfeito paraíso, apresenta maior potencial de subsistência para o homem do que a terra firme em função da renovação anual do potencial agrícola com a chegada de sedimentos andinos depositados pelos rios de águas brancas, porém, mesmo assim, não permitia o desenvolvimento de sociedades densas e sedentárias. De acordo com esta perspectiva, os espessos depósitos arqueológicos seriam resultantes da reocupação do mesmo local por grupos pequenos e com grande mobilidade, tendo como referência dados etnográficos do século XIX e sem levar em consideração o forte impacto que a colonização europeia teve sobre estas populações.

A diversidade linguística presente na Amazônia era entendida como uma colcha de retalhos com falantes da família Tupi-Guarani, Aruak e Karib, decorrente das oscilações climáticas ocorridas em 4.000-2.000 a.C., tendo em vista que o recuo da floresta teria facilitado a penetração de grupos de outras regiões nas terras baixas: alguns grupos teriam emigrado ou se adaptado às novas condições, outros permaneceram na floresta, e a separação das populações teria conduzido a uma diferenciação linguística e cultural (MEGGERS, 1987).

Noelli e Ferreira (2007) salientam que, apesar do conceito básico do difusionismo já estar presente nas interpretações sobre a origem das populações indígenas americanas desde o século XVIII, associado ao forte degeneracionismo típico de um pensamento colonialista, é no início do século XX que se perpetuou na teoria antropológica e arqueológica. O modelo de Julian Steward e as interpretações de Betty Meggers e Clifford Evans sobre as ocupações na Amazônia apresentam uma mistura de elementos evulocionistas e difusionistas (NEVES, 1999/2000), considerando a região como um receptáculo de povos e culturas das áreas andinas ou subandinas. 
Na década de 1950 surgiram as primeiras críticas às interpretações de Betty Meggers e Clifford Evans, feitas principalmente por Donald Lathrap (1970), cujo modelo ainda que não escape às premissas ecológicas, por preconizar os fatores ambientais da várzea como diretamente relacionados ao desenvolvimento das sociedades indígenas, traz contribuições teóricas importantes para a interpretação da ocupação humana na Amazônia. Através das pesquisas arqueológicas e etnográficas que desenvolveu no Ucayali Central, da comparação com outros contextos arqueológicos na Amazônia e da utilização dos dados linguísticos existentes na época, Lathrap (1970) elabora um modelo segundo o qual os grupos falantes de línguas Arawak e Tupi-Guarani teriam se dispersado da Amazônia Central a partir de 3.000 a.C. A agricultura praticada nas várzeas do Amazonas Central, complementada pela exploração da fauna aquática, teria fornecido as bases para o aumento e pressão populacional que impulsionaram as ondas migratórias destes povos, levando consigo a tecnologia cerâmica da tradição Inciso Modelada, ou Barrancóide, e da tradição Policrômica da Amazônia, respectivamente. Acreditava que teria ocorrido uma tradição cultural contínua nessa região, com a evolução gradual desde a tradição cerâmica Barrancóide até a Guarita (Tradição Polícroma da Amazônia).

Conforme veremos mais adiante, muitas das premissas elaboradas por Lathrap (1970) foram discutidas e contrariadas a partir da obtenção de novos dados resultantes das pesquisas realizadas nas ultimas décadas na Amazônia Central, porém cabe ressaltar algumas das principais contribuições teóricas do autor. Quando o modelo tipológico de Steward (1948) e as hipóteses desenvolvidas por Meggers (1954), Meggers e Evans (1957) e Meggers, Evans e Estrada (1965) estavam no seu auge, o autor apresentou visões alternativas para a compreensão da ocupação da Amazônia, a começar pela interpretação do conceito de Cultura de Floresta Tropical. Para Lathrap (2010, p 81), a Cultura de Floresta Tropical deveria ser definida em termos de elementos culturais comuns e não como um grau uniforme de evolução cultural. $O$ autor chamava a atenção para o fato de terem sido utilizados exemplos etnográficos recentes como referenciais para a criação do modelo de Julian Steward, sem levar em consideração os efeitos das doenças europeias, da catequização e do trafico de escravos. Segundo ele, os relatos do século XVI dos primeiros exploradores da bacia do Amazonas se referiam a densas populações e unidades políticas vastas com chefes, sacerdotes e templos, as quais deveriam ser tomadas como típicos representantes da cultura de Floresta Tropical. 
Para Lathrap (1970), a Amazônia Central seria uma fonte, mais que um receptáculo, de grande parte dos movimentos populacionais, portanto os grandes sítios seriam resultantes da ocupação contínua de populações grandes e hierarquizadas. Fortemente influenciado pelas ideias do geógrafo cultural Carl Sauer, acreditava que as populações indígenas têm condições de produzir uma vasta gama de cultivos mesmo em solos pouco férteis, de melhorar e recuperar o potencial agrícola e até mesmo de manter a fertilidade de solos durante um longo período de colheitas contínuas. Além disso, a agricultura teria surgido em vários pontos da Amazônia pela experiência de grupos dispersos, e pensava que não existiam grandes diferenças culturais entre os povos da Bacia do Amazonas e da costa do Pacífico, tampouco barreiras para o comércio e trocas de ideias entre estas duas regiões, bem como entre a Floresta Tropical e os Andes Centrais.

A cerâmica foi o vestígio arqueológico que forneceu a base para a elaboração dos horizontes, tradições e fases através da seriação (MEGGERS e EVANS, 1961; EVANS E MEGGERS, 1968), bem como para a elaboração de sequências regionais ou locais como a de Lathrap (1970) no Ucayali Central. No primeiro caso, a seriação fornecia elementos para identificar as diferenças no material cerâmico, as quais indicariam as reocupações dos sítios e as regularidades culturais de acordo com as condições ambientais (MEGGERS e EVANS, 1961), enquanto no segundo caso a análise das características de pasta, tratamentos de superfície e formas das vasilhas indicavam os estilos cerâmicos, as permanências e descontinuidades culturais, o comércio por longas distâncias e a expansão dos povos e das cerâmicas pela floresta tropical (LATHRAP, 1970).

Meggers e Evans (1961) definiram quatro horizontes estilísticos para a cerâmica da floresta tropical, apontando seus possíveis locais de origem e direções de dispersão, a partir da análise de vinte e dois complexos cerâmicos, em relação à presença ou ausência de alguns traços, especialmente os decorativos. A região teria recebido quatro distintas e sucessivas levas de influências: o horizonte Hachurado-Zonado e o Policromo teriam sido introduzidos a partir do oeste, e sua ocorrência se limitava a Bacia Amazônica, enquanto o Borda Incisa e o Inciso Ponteado teriam vindo do Orinoco para o Baixo Amazonas. O Zonado- Hachurado seria o horizonte mais antigo, representando a introdução da cerâmica na floresta tropical vinda dos Andes (cultura Chavín). Esta cerâmica apresenta decoração zonada com incisões (linhas largas delimitam campos a serem preenchidos com incisões finas paralelas ou hachuradas) e pintura, com ocorrência no Peru (Tutishcainyo), Equador (Yasuní), Baixo Amazonas (Jauarí) e Ilha de Marajó (Ananatuba). O horizonte Borda Incisa seria composto 
por três complexos cerâmicos do baixo Amazonas (Manacapuru, Boim, Mangueiras) e três do médio Orinoco (Cotua, Nericagua, Los Caros), cuja origem e dispersão não puderam ser postuladas devido às poucas datações. São características as bordas ampliadas (flanges) decoradas com incisões, além da aplicação de pigmento vermelho na face externa e/ou interna das vasilhas. O horizonte Polícromo representaria os sítios distribuídos desde o rio Napo, em direção a leste ao longo do Amazonas até a Ilha de Marajó, com as fases Napo, Coarí, Araçá, Guarita, Marajoara e Aristé. A característica diagnóstica é o engobo branco, associado ou não à pintura polícroma (vermelho e preto sobre branco), além de técnicas como a excisão e a incisão retocada de vermelho ou branco. O horizonte Inciso Ponteado está presente nos sítios distribuídos ao longo do Orinoco e do Amazonas, bem como nas Guianas inglesa e brasileira, representada pelas fases Arauquín, Mabaruma, Konduri, Itacoatiara, Santarém, Mazagão, e é caracterizado pelo uso de incisões, ponteados e modelados de diferentes formas, principalmente a combinação do inciso e do ponteado nas bordas das tigelas e no pescoço dos jarros, além dos adornos antropomórficos, zoomorfos e geométricos. Este último seria tardio, teria vindo da Colômbia e sobrevivido no baixo Amazonas até o contato com o europeu. No esquema abaixo os autores apresentam os horizontes estabelecidos, do mais antigo ao mais recente.

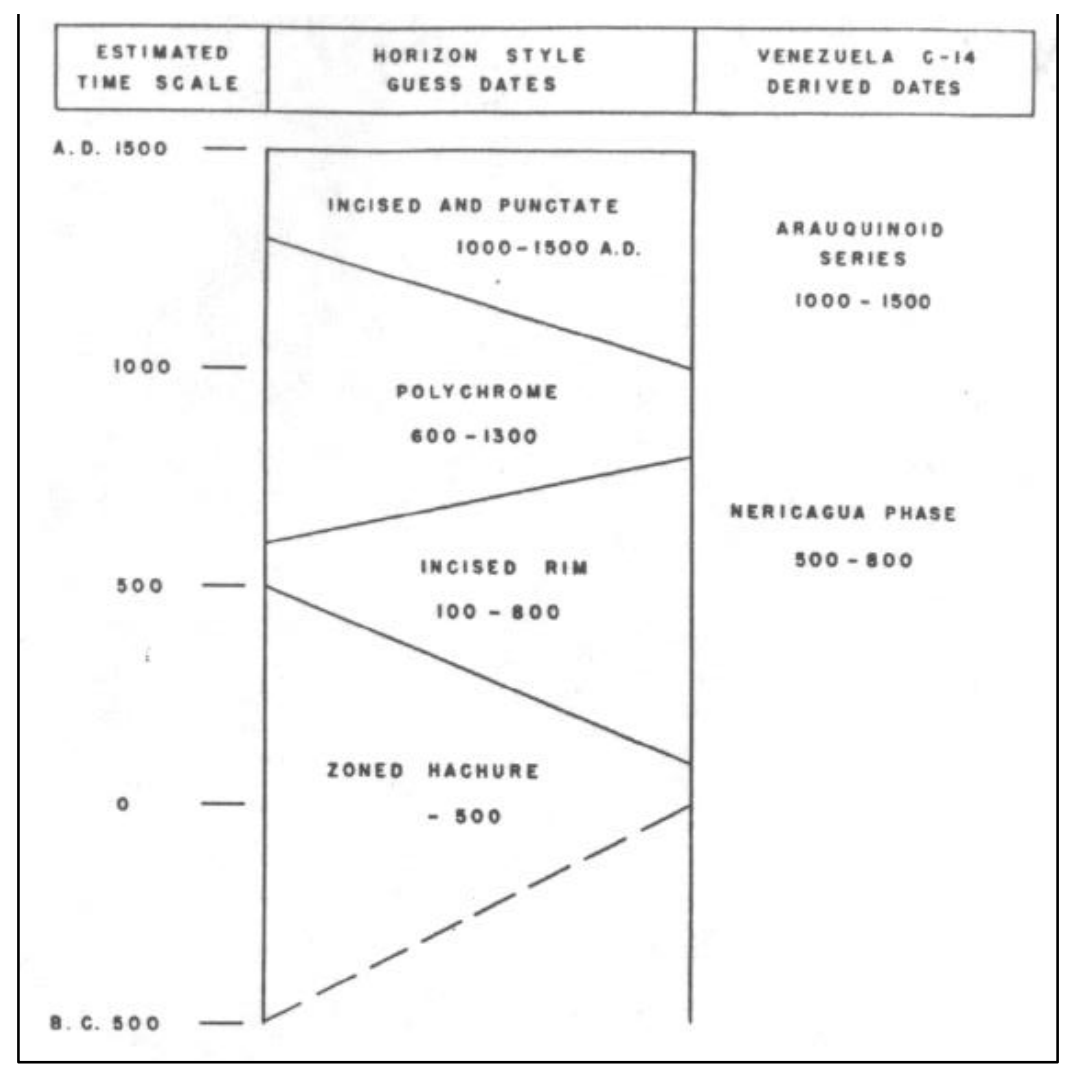

Figura 1: esquema cronológico dos horizontes cerâmicos (MEGGERS e EVANS, 1961). 
No Ucayali Central, Lathrap (1970) estabeleceu uma sequência das ocupações com base na análise cerâmica e na comparação com outros complexos da Amazônia, especialmente em relação às formas dos vasos, as quais o autor acredita terem maior persistência temporal que outras características como tratamentos de superfície e motivos decorativos, por isso poderiam ser consideradas os mais importantes testemunhos de relações históricas distantes. Uma cerâmica antiga, chamada Tutishcainyo Inferior foi encontrada no nível inferior das escavações, caracterizada por ângulos agudos em várias sessões dos recipientes, tanto próximos à base ou lateralmente com uma flange decorada, além de vasilhas abertas de paredes baixas e côncavas e raras vasilhas com duplo gargalo e ponte; quase todas eram decoradas com incisões e algumas possuem pintura vermelha pós-cocção. A cerâmica Tutishcainyo Superior seria derivada da anterior, porém com modificações estilísticas nas formas e decorações, com uso da decoração modelada e aplicada e entalhes nas bordas e nos ângulos e pontos salientes da vasilha. Neste complexo, o autor identificou uma cerâmica com pasta e decoração diferentes, indicando comércio de zonas distantes. Na mesma área, a cerâmica Shakimu Inferior, com uma data radiocarbônica de 650 a.C., seria resultado de um desenvolvimento gradual de Tutishcainyo Superior, porém também apresentaria elementos como bases planas e decoração excisa que indicavam uma influência externa à bacia do Ucayali, possivelmente dos Andes Centrais, com continuidade no Shakimu Superior. O autor estabelece comparações com outras cerâmicas antigas da Amazônia, como as da tradição Nazaratequi do Alto rio Pachitea, cujas datações radiocarbônicas estão entre 1.637 a.C. e 400 d.C., bem como de áreas mais distantes como o norte da América do Sul (costa da Venezuela, planícies alagadas do Baixo e Médio Orinoco e as Antilhas) cujas cerâmicas Saladóide seriam de 1.000 a.C., com elementos semelhantes que indicariam uma relação histórica válida. Assim, todas estas tradições cerâmicas antigas teriam origem na Amazônia central, possivelmente relacionadas aos falantes Arawak (LATHRAP, 1970).

Outra cerâmica evidenciada no Ucayali Central é a Hupa-Iya, caracterizada por vasos hemisféricos ou semicontraídos (carenados), com faces externas eventualmente convexas, geralmente com apêndices de suspensão abaixo da borda; as vasilhas são decoradas na face superior com incisões e esferas aplicadas, e algumas vezes com zoomorfos nas bordas dos vasos; na face externa as vasilhas são decoradas na parte inferior, cujo campo decorativo é delimitado por uma linha horizontal a $2 \mathrm{~cm}$ abaixo da borda; as incisões em linhas largas formam motivos espiralados simples; são frequentes os assadores, restos de argila e aparecem pela primeira vez em grandes quantidades os fusos cerâmicos. Esta seria pertencente à 
tradição Inciso-Modelada ou Barrancóide, encontrada pela primeira vez na planície inundável do Baixo Orenoco (estilo Los Barrancos), caracterizada pela decoração com incisões em linhas largas em superfícies alisadas e polidas, combinadas com a decoração aplicada e modelada (esferas aplicadas para realçar pontos chaves de um motivo); aplicação de linhas curvas e espirais separadas, e com maior frequência duas linhas paralelas na parte superior da vasilha, no "rebordo labial", algumas vezes interrompidas por pequenas bolas aplicadas. Com o tempo, as incisões tornam-se cada vez menos espaçadas e os motivos mais complexos; são mais frequentes as esferas aplicadas com pontos centrais, e os "rebordos labiais" contínuos e com decorações simples tornam-se orelhas assimétricas descontínuas com desenhos aplicados. Para Lathrap (1970) o estilo Barrancóide teria se originado na Amazônia Central, de onde teria se expandido com os grupos Maipure Arawak. Segundo o autor, foram as semelhanças entre a cerâmica Hupa-iya da Bacia no Ucayali com a de Los Barrancos, no Baixo Orenoco, que o levaram pela primeira vez a pensar no problema dos movimentos populacionais das planícies tropicais da América do Sul. As cerâmicas Barrancóide têm uma vasta distribuição na América do Sul, com um padrão estilístico característico e certas especificidades em alguns locais, como os suportes tetrápodes da cerâmica encontrada no rio Beni e Mamoré, Bolívia Oriental. No Alto Xingu, a cerâmica confeccionada pelos Maipure caracterizaria esta tradição na região, com redes de comércio típicas da cultura de floresta tropical, em uma área com falantes Maipure, Tupi, Caribe, e Gê, compartilhando uma cultura material comum e estabelecendo intercasamentos (LATHRAP, 1970).

Além destas, a cerâmica Cumancaya e a cerâmica Caimito teriam chegado à região do Ucayali no final do período pré-colombiano, a primeira caracterizada pela presença comum do corrugado, estrias múltiplas paralelas, pequenas esferas aplicadas, adornos zoomorfos, incisões em linhas finas (gregas e escalonados), às vezes associadas à pintura vermelha zonal, relacionada aos antepassados dos atuais grupos de língua Pano vindos do oriente boliviano. As ocupações Caimito (1.320 d. C. e 1.375 d. C.) são caracterizadas pela cerâmica complexa e variada, com grande repertório de formas, incisões largas com motivos variados; pintura preta e vermelha sobre branco ou branco sobre vermelho, às vezes associadas a incisões e excisões; decoração aplicada para indicar os traços da face humana; são comuns adornos com representações de espécies da fauna local, como a anaconda e a tartaruga; figuras de pequenas rãs aparecem como oferendas funerárias, e há cacos em que a base de um vaso em pedestal tomava a forma de uma rã; os fusos para fiação decorados são comuns, alguns ocos como os de Marajó. Segundo Lathrap (1970), esta apresenta semelhanças com uma vasta gama de 
outros estilos, desde o rio Napo no Equador até o rio Gurupy na costa do Brasil, que traduzem relações históricas da chamada Tradição Polícroma. Para o autor, a dispersão da Tradição Polícroma não seria oriunda do Planalto Colombiano, como haviam afirmado Meggers, Evans e Hilbert, mas teria um desenvolvimento local na Bacia do Médio e Baixo Amazonas, de onde teria ocorrido uma migração no sentido ascendente pelos antepassados dos Omáguas e dos Cocamas históricos. As subtradições Guarita e Miracanguera teriam se desenvolvido paralelamente, esta última no Baixo Amazonas. A Guarita teria se desenvolvido a partir da Barrancóide, sem descontinuidades significativas e sem sofrer influências externas importantes.

Brochado (1984, 1989), seguindo as hipóteses de Lathrap (1970) sobre a migração dos falantes Tupi a partir da Amazônia Central, elaborou um modelo baseado na distribuição geográfica histórica dos falantes Tupi, nos dados da classificação das línguas do Tronco Tupi, na distribuição geográfica das cerâmicas da Tradição Policrômica Amazônica e das respectivas datações radiocarbônicas. De acordo com sua hipótese, o Proto-Tupi teria resultado da separação dos povos produtores da cerâmica Guarita e, em função do aumento demográfico e das pressões populacionais, teriam partido para o sudoeste os produtores da cerâmica da subtradição Guarani e para o leste os da subtradição Tupinambá; a primeira, originária da subtradição Guarita e a segunda, da subtradição Miracanguera. Os Tupinambá e os Guarani teriam seguido por caminhos bastante diferentes, os primeiros descendo pela foz do Amazonas até a costa atlântica, enquanto os Guarani teriam descido do médio Amazonas através do Madeira e do Guaporé até atingir o Paraná, Paraguai e Uruguai. O autor chama a atenção para a antiguidade destas expansões, conforme demonstravam os dados obtidos por Rodrigues $(1958,1964,1984)$ de que a diferenciação do tronco Tupi teria ocorrido há 5.000 anos e a separação da família Tupi-Guarani há 2.500 anos, e com as datações radiocarbônicas existentes, indicando que em 100-200 AD a cerâmica da Subtradição Guarani já estava espalhada desde o Alto Paranapanema até o médio Jacuí e os Tupinambá teriam atingido o Nordeste em 500 AD (BROCHADO, 1984, 1989).

Perceber o desenvolvimento cultural na Amazônia como um processo interno e não como fruto de difusões de traços alóctones foi um grande avanço, porém com visões mais ou menos deterministas, os parâmetros da ecologia cultural permaneceram por um bom tempo na prática da arqueologia da região. Conforme ressalta Heckenberger (2005, p. 16), por muito tempo acreditou-se que o desenvolvimento de sociedades complexas ou cacicados na Amazônia seria decorrente de causas demográficas, econômicas e tecnológicas existentes 
apenas na várzea, diferente da terra firme onde as condições de subsistência seriam inexistentes e as sociedades seriam tribos pequenas, autônomas e igualitárias (CARNEIRO, 1970, 2007; LATHRAP, 1970; ROOSEVELT, 1980). Para o autor, as origens, distribuição e natureza das sociedades complexas permanecem mal resolvidas em função da falta de sequências sócio-históricas bem conhecidas nas diferentes partes da Amazônia, e não podem ser compreendidas simplesmente por parâmetros ecológicos, mas também através de fatores tais como escolha cultural, interação regional e histórias específicas (HECKENBERGER, 2005, p. 17). A pesquisa de Heckenberguer (2001, 2002, 2005) no Alto Xingu demonstra a importância de estudos que consideram a relação complexa entre ambiente, estruturas socioculturais e uma história específica, conforme enfatizado por Fausto (2005), que propõe a desconstrução da tipologia de Steward e dos modelos tradicionais esquemáticos e lineares de desenvolvimento sociopolítico para que seja possível reconstruir os processos históricos que conduziram a uma diversidade de formas de complexificação, em escala local e regional.

Novos dados fornecidos pelas pesquisas arqueológicas, linguísticas e etnográficas permitiram revisar muitas das discussões sobre a ocupação da Amazônia, em relação à antiguidade, à distribuição e expansão das populações e à diversidade de modos de vida refletidos nos diferentes contextos evidenciados a nível local ou regional. Nas suas escavações, no Sambaqui Taperinha e na Caverna da Pedra Pintada, no baixo Amazonas, Roosevelt (1995; ROOSEVELT et al, 1991) evidenciou ocupações na transição do Pleistoceno para o Holoceno (datas que chegam a 11.200 anos AP no sítio caverna da Pedra Pintada) e ocupações ceramistas com datas em torno do sétimo milênio antes do presente. A autora fez uma revisão das datações obtidas anteriormente para a cerâmica Mina no estuário e zona costeira do leste Amazônico (SIMÕES, 1981) e da cultura Alaka da Guiana Inglesa (WILLIAMS, 1997), bastante antigas, mas que não haviam sido publicadas. As datações do extrato cerâmico dos sítios Taperinha e Caverna da Pedra Pintada são de 1.000 a 1.500 anos mais antigas que as do norte da América do Sul e 3.500 anos mais antigas que as sequências da cerâmica dos Andes e Mesoamérica, o que inviabilizaria a teoria da origem e difusão única da cerâmica. Para Roosevelt et al (1991; ROOSEVELT, 1995), as diferenças nas cerâmicas das diversas regiões sugerem que teriam existido vários centros independentes de invenção da cerâmica. Além disso, os ceramistas de Taperinha e Pedra Pintada não baseavam sua subsistência na agricultura, mas na exploração de recursos ribeirinhos. Porém Meggers (1997) considera que o sítio Taperinha é um dos complexos problemáticos, e cronologicamente isolado, assim como Tutishcainyo (Peru) e La Gruta (Baixo Orinoco), defendendo que a 
cerâmica teria se difundido a partir dos complexos iniciais Valdívia (Equador - 5.600-4.300 A.P.) e San Jacinto (costa norte da Colômbia) para os complexos derivados Monagrillo (Sul do panamá - 4.500-3.200 a.P.), Barrancas (Baixo Orinoco na Venezuela - 2.900-?500 A.P.), Waira-jirca (serra Nordeste do Peru - 3.800-3.000 A.P.) e Ananatuba (na boca do Amazonas - 3.400-3.000 A.P.).

Os estudos de Schaan (2003, 2004, 2007) nos tesos do igarapé dos Camutins, na Ilha de Marajó, demonstraram que estes foram ocupados contemporaneamente durante 600 anos. $\mathrm{Na}$ comparação da cerâmica da fase Marajoara com a de 'fases' anteriores (Ananatuba, Mangueiras, Acauã, Formiga), a autora observou continuidades tecnológicas no preparo da argila e técnica de confecção das vasilhas, ao passo que as técnicas decorativas estão presentes desde o início da ocupação, passando a ser combinadas em um mesmo vasilhame com o passar do tempo, assim como as formas das vasilhas, que são semelhantes ou idênticas às de fases anteriores, surgindo novas formas mais complexas no período final. Assim, acredita que a cultura Marajoara teria um desenvolvimento autóctone a parir de 400 A.D. e que as diferenças estilísticas na cerâmica dos diferentes aterros seriam decorrentes de diferenciações sociais, identidades sociopolíticas e limites territoriais dentro do domínio da cultura Marajoara. Além disso, as mudanças tecnológicas na cerâmica da fase Marajoara indicariam a expressão de identidade grupal e individual e a necessidade de produção de objetos rituais para festas e cerimônias. A autora questiona a classificação dos conjuntos artefatuais em fases e tradições como entidades homogêneas e estáticas, por impedir a percepção de processos de mudança cultural, bem como a associação da categoria 'fase' a grupos etnolinguísticos como entidades homólogas (SCHAAN, 2007).

Os estudos feitos na perspectiva da Antropologia Ecológica ou Ecologia Histórica (BALÉE 1995, 2008; BALÉE e MOORE, 1994; DENEVAN, 1966, 1996; POLITIS, 1996; NEVES, 2006; NEVES e PETERSEN, 2006; NEVES, 2008; PETERSEN et al, 2001; KIPNIS et al, 2005; ERICKSON, 2008) demonstraram que a atual paisagem amazônica e a grande diversidade ecológica são resultantes de milênios de manejo humano, e que as terras pretas evidenciadas nos sítios arqueológicos são resultantes da acumulação de resíduos orgânicos de assentamentos grandes por grupos com técnicas de manejo ambiental e que possivelmente viviam em aldeias sedentárias por muito tempo. Estudos interdisciplinares nesta perspectiva teórica têm demonstrado a complexa relação do homem com o meio, especialmente aqueles focados no manejo e domesticação de plantas e na formação das terras pretas arqueológicas. Neves (2012, p. 109) sugere que devemos abandonar o discurso da 
escassez e se voltar para a abundância de recursos na Amazônia, e que ao contrário do litoral peruano, onde os recursos são abundantes e restritos, aqui são abundantes, porém irrestritos.

Além disso, os dados arqueológicos obtidos nos últimos anos possibilitaram retomar a discussão e reelaboração dos modelos anteriores (LATHRAP, 1970; LATHRAP e OLIVER, 1987; BROCHADO, 1984, 1989) sobre as migrações, expansões ou movimentos populacionais na Amazônia, principalmente quando discutidos em conjunto com os elementos da linguística histórica. Noelli (1996, p. 8) lembra-nos que somente a partir dos anos 1960 ocorreu a incorporação dos dados da arqueologia e da linguística na discussão sobre a origem e dispersão dos Tupi, período em que tornaram-se disponíveis métodos de ambas as áreas para determinar com maior precisão a temporalidade das expansões. Mesmo assim, as pesquisas feitas no âmbito do PRONAPA ignoram as informações históricas e linguísticas, utilizando apenas as arqueológicas, o que acabou no enquadramento de povos dentro de categorias artificiais, como no caso da tradição Tupiguarani. Para Noelli (1996), no caso dos Tupi, em que existem relações diretas entre os grupos pré-históricos e históricos, é possível considerar as relações entre língua, sociedade e vestígios materiais. $\mathrm{O}$ autor elabora duas hipóteses a serem testadas no decorrer das pesquisas e obtenção de novos dados: que as diferenciações materiais acompanham as derivações linguísticas; e que as diferenciações materiais e tecnológicas não aconteceram isoladamente. A única forma de avançar na discussão seria considerar as pesquisas arqueológicas e os dados regionais conjuntamente com os dados da linguística histórica (NOELLI, 1996).

Noelli $(1996,2008)$ apresentou um histórico das pesquisas sobre o centro e rotas de dispersão Tupi, e chamou a atenção para a necessidade do constante repensar dos modelos, hipóteses e problemas de pesquisa à luz dos novos dados obtidos a nível regional. Conforme o autor, os dados linguísticos obtidos por Aryon Rodrigues $(1964,1984)$ e as pesquisas arqueológicas da época possibilitam localizar o centro de origem dos Tupi em uma região delimitada ao norte pela margem direita do médio e baixo Amazonas, a leste pelo Tocantins, a oeste pelas bacias do Madeira e baixo-médio Guaporé e a sul por uma linha que vai do médio Guaporé até o Tocantins, próximo da foz do Araguaia (Mapa 1). 


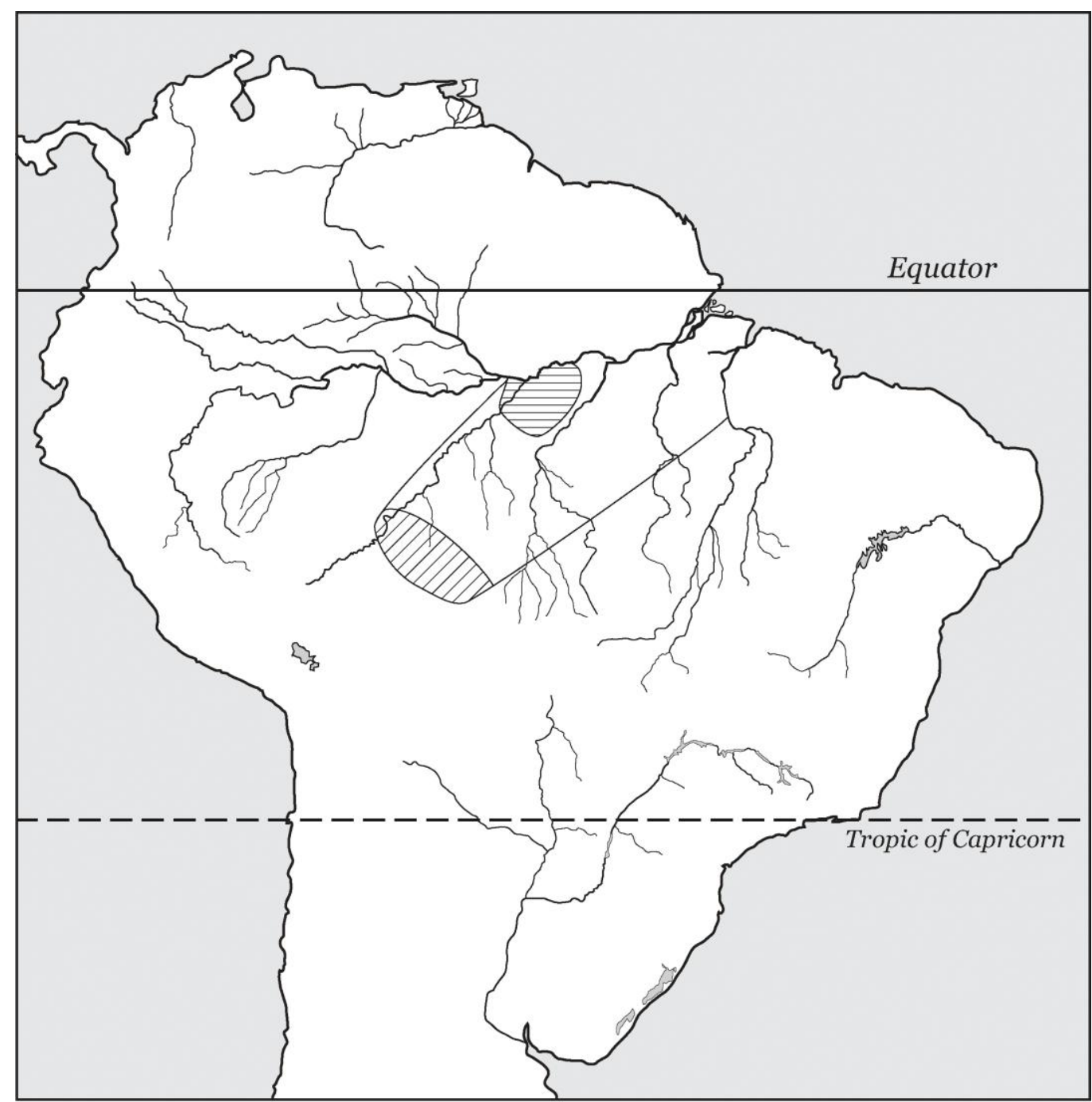

Homeland of the Tupi suggested by Brochado and Lathrap (1982) on the basis of archaeological evidence

Homeland of the Tupi suggested by Rodrigues (1964) on the basis of linguistic evidence

Mapa 1: Possível centro de dispersão dosTupi (NOELLI, 2008, p 667).

Heckenberger et al (1998) retomaram a discussão do modelo de Lathrap (1970), Brochado (1984) e Oliver (1989) a partir dos dados arqueológicos obtidos na área de confluência dos rios Negro e Solimões. As escavações, análises do material e as datações no sítio Açutuba permitiram a elaboração de uma detalhada sequência das ocupações da área. As ocupações da Tradição Inciso Modelada ou Barrancóide teriam predominado na Amazônia central até cerca de 900 D.C (datas entre 960 +- 70 A.C e $920 \pm 100$ D.C.), com continuidade nas formas cerâmicas e nas técnicas e campos decorativos (incisão, ponteado e decoração modelada lábios, bordas e a parte superior das paredes). Na superfície dos terraços do sítio 
Açutuba foram encontradas cerâmicas associadas à subtradição Guarita, datadas entre $970 \pm$ 60 D.C. e $1.260 \pm 40$ D.C., com inovações decorativas (policromia em vermelho e negro sobre engobo branco, decoração acanalada e o ponteado nas bordas) e nas formas (flanges mesiais com decoração na superfície dorsal) que indicam ruptura em relação às ocupações anteriores. Os dados demonstraram que não houve uma transição gradual entre as tradições Polícroma e Barrancóide, como havia sido sugerido por Lathrap (1970) e Brochado (1984, 1989), tampouco a Tradição Polícroma seria mais antiga nessa região que em outras partes da Amazônia, mas mais ou menos contemporânea a outros complexos desta tradição localizados no médio e alto Amazonas, com a possível exceção da fase Marajoara. Segundo os autores, o florescimento da Tradição Polícroma se deu em uma área ampla e em um período tardio, porém não era possível saber se seria ligada a uma expansão tardia e relativamente rápida de grupos Tupi-Guarani, tampouco existe uma ligação histórica e etnográfica entre esta tradição e os falantes de línguas da família Tupi-Guarani, diferente da tradição Tupiguarani (HECHENBERGER et al, 1998).

A antiguidade da expansão dos Tupi para o Sul e Sudeste do Brasil foi demonstrada pelos dados arqueológicos, sendo que os Guarani ocuparam a região sul há 2.000 anos e os Tupinambá já estavam no sudeste há 1.800 anos, em áreas bastante afastadas do centro de origem (NOELLI, 1993, 1996). As evidências arqueológicas dos Guaranis foram encontradas em uma área bastante ampla, incluindo os estados brasileiros do Mato Grosso do Sul, Paraná, Santa Catarina e São Paulo, e regiões da Argentina, Paraguai e Uruguai, com reprodução do estilo tecnológico por mais de 1.500 anos nesta vasta região, com assentamentos permanentes e formação de redes regionais que, mais do que a função defensiva e econômica, deveriam envolver a troca de pessoas, coisas, informações e conhecimentos (NOELLI, 2004). Segundo NOELLI (1993, 1996, 2004), estes movimentos populacionais dos Tupi não envolveriam migração, ou seja, a saída de um local para outro com abandono da região de origem, mas a conquista de novas áreas sem abandonar as antigas, melhor definidos pelo termo expansão, motivada por aumento demográfico, diversas modalidades sócio-políticas de fracionamento de aldeias e manejo agroflorestal, e necessariamente implicando complexas relações interétnicas na medida em que avançavam sobre territórios de outros povos, expulsando ou assimilando-os.

Datações antigas, a princípio associadas à Tradição Polícroma da Amazônia, haviam sido evidenciadas no Alto Rio Madeira nos sítios da Subtradição Jatuarana, com datas de 2.700 e 2.400 AP (MILLER, 1992), porém a recente retomada das pesquisas arqueológicas na 
região acrescentou novos elementos nas discussões sobre esta tradição e a expansão dos Tupi (CRUZ, 2008, ZIMPEL, 2009; MILLER 2009, 2013; NEVES, 2012, ALMEIDA, 2013; MORAES, 2013). Retomaremos esta questão após a apresentação dos dados arqueológicos da Bacia do Rio Madeira.

Por outro lado, a questão da expansão dos povos Arawak tem sido bastante discutida nos últimos anos, sendo fundamentais os dados obtidos por Heckenberger $(2001,2002,2005)$ no Alto Xingu. Através do estudo das evidências arqueológicas, linguísticas, etno-históricas e da história oral indígena, o autor construiu uma história cultural profunda, diferente da visão antropológica elaborada no século XIX, período de maior diminuição demográfica pelos efeitos da colonização europeia. Os dados demonstraram que os Arawak (Maipure) chegaram ao Alto Xingu por volta de 800-1.000 AD, dando início à primeira fase cultural chamada Ipavu (c.900-1.600), caracterizada por aldeias circulares em torno de uma praça central, presença de terra preta e cerâmica Barrancóide, com o surgimento de valas com função defensiva e aterros monumentais a partir de 1.400 AD. Durante esta primeira fase, destacamse os dois complexos de sítios na região: o complexo Oriental com aldeias menores compostas por uma ou várias casas circulares que não se distribuíam em torno de uma praça e presença de cerâmica distinta, pertencentes aos ancestrais das comunidades Karib do Alto Xingu, e o Complexo Ocidental com as aldeias fortificadas construídas pelos ancestrais dos Arawak contemporâneos do Alto Xingu. Os contatos iniciais com os europeus (c1.500-1.600) provocaram o despovoamento dos sistemas sociopolíticos macrorregionais e as aldeias fortificadas deixaram de ser construídas (fase Proto-Xinguana, 1.600-1.750). Porém, no século XVIII, as comunidades do Complexo Oriental migraram para esta área, cuja fusão formou a base da cultura regional multiétnica da fase Xinguana (c.1.700-presente). Da mesma forma que os Karib, alguns grupos Tupi (Kamayurá e os Aweti) também se incorporaram à cultura regional xinguana. A pesquisa, portanto, demonstrou que o sistema xinguano possui raízes pré-históricas, e apesar das mudanças ou descontinuidades dramáticas, há uma continuidade marcante das estruturas culturais ao longo do segundo milênio d.C. (HECKENBERGER, 2001).

As características como hierarquia social, regionalidade, sedentarismo, agricultura intensiva e cerâmica Barrancóide compõem o padrão cultural regional e foram associadas por Heckenberger (2001) aos Arawak. Segundo o autor, tais elementos estão presentes em uma área mais abrangente, a chamada Periferia Meridional da Amazônia, compreendida entre o Alto Xingu a leste e as terras baixas da Bolívia a oeste, situada entre as províncias 
fisioecológicas e macroculturais do sul da Amazônia e do Brasil Central, representadas pela floresta tropical e pelo cerrado, pelos falantes do tronco Tupi e os povos Jê, respectivamente. Para o autor, apesar desta região ser caracterizada como de grande diversidade cultural e de contato de povos, quando observada através de uma perspectiva histórica profunda, caracteriza-se como um bloco quase contínuo de povos Arawak, se estendendo do Alto Madeira e Montaña ao Alto Xingu, onde são identificadas evidências arqueológicas de construções de terra e grupos indígenas Arawak (Xinguano, Pareci, Bauré, Mojo, Terena/Guaná, Chané e Piro) (HECKENBERGER, 2001, 2002). A área de origem e dispersão dos Arawak foi atribuída à região entre o alto rio Negro e o alto rio Orinoco, na fronteira entre a Venezuela e o Brasil, de onde teriam partido para áreas bastante amplas, em direção a centros de dispersão secundários, entre eles o alto Rio Madeira, posteriormente se expandido para o oeste (Acre e Peru), sul (terras baixas da Bolívia) e leste (Periferia Meridional) (HECKENBERGER 2001, 2002) (mapa 2).

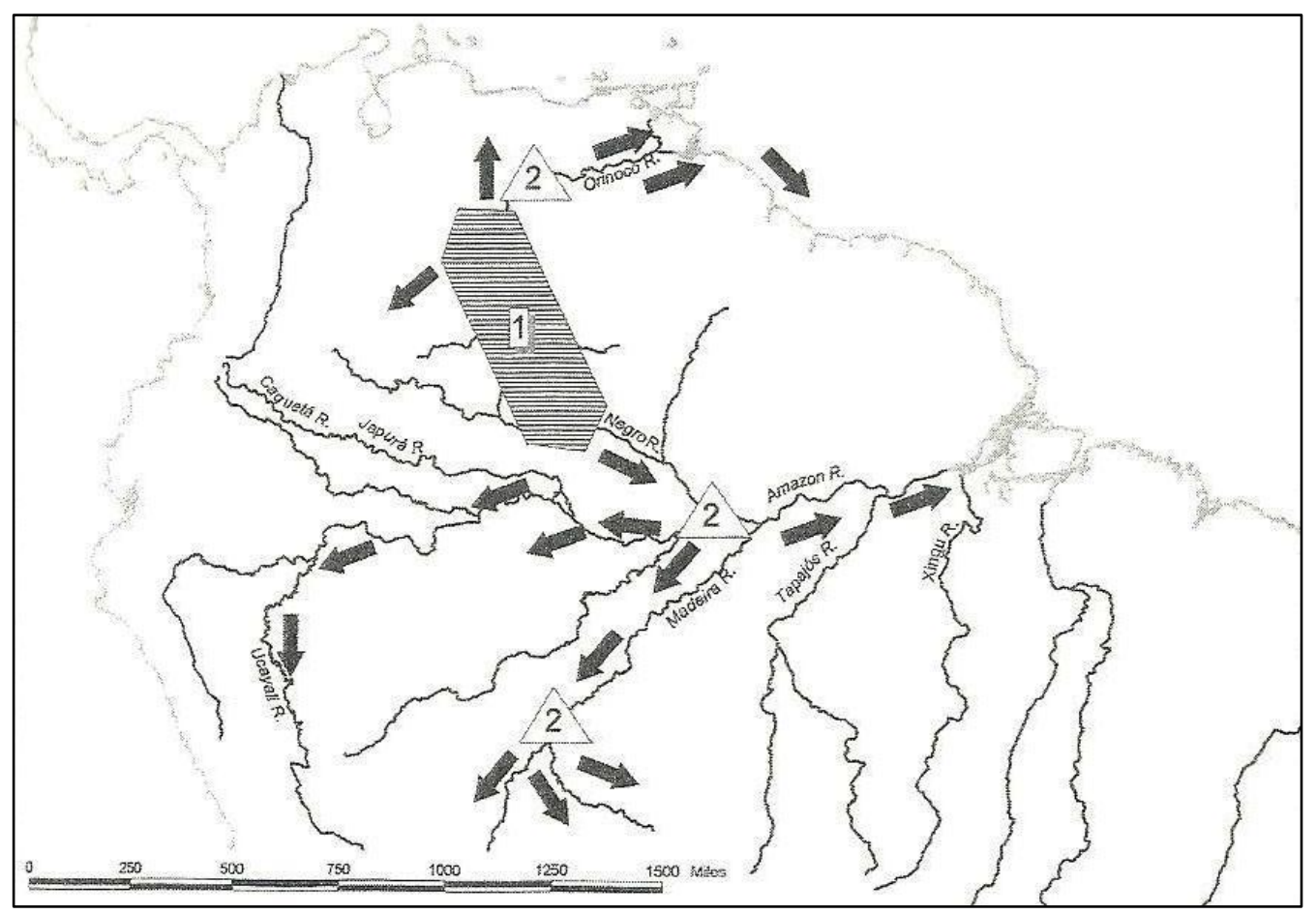

Mapa 2: sugestão da localização da língua Proto-Arawak no nordeste da Amazônia (caixa Hachurada) e centros secundários e dispersão no Médio Orinoco, Amazônia Central e Alto Madeira (triângulos); e rotas principais de dispersão (setas) (HECKENBERGER, 2002, p. 106).

Estudos regionais como o desenvolvido por Heckenberger (2001, 2002, 2005) com a utilização conjunta dos dados arqueológicos, históricos, etnográficos e da história oral, em locais onde há uma continuidade entre as ocupações do passado e do presente, não só permitem a construção de histórias culturais específicas, mas fornecem elementos para as 
discussões teóricas e metodológicas da associação de determinados contextos arqueológicos e cultura material a grupos linguísticos ou étnicos. Para Neves (1999), mesmo que o registro arqueológico condicione as possibilidades de construir história indígena, esta tarefa é o objetivo básico da arqueologia quando lida com processos de longa duração, sendo a associação com a linguística histórica inevitável. No alto rio Negro, as evidências linguísticas, combinadas com a Arqueologia e a tradição oral, permitiram ao autor identificar uma fronteira étnica diversificada no início do período colonial, com grupos falantes Tukano situados na bacia do Uaupés e presença de grupos Arawak, que chegaram à região no século XV d.C. vindos do norte, contrariando a suposta hegemonia Tukano da região, explicitada nos dados etnográficos e históricos (NEVES, 1999). Nessa região, a padronização tecnológica e estilística na cerâmica não corresponde a uma homogeneidade linguística e étnica, sendo os mesmos tipos de vasilhas produzidas e consumidas pelos mais de dez grupos que falam línguas da família Tukano Oriental e que compõem o sistema regional multiétnico e multilinguístico, possivelmente resultado das interações locais em uma das áreas de maior diversidade linguística da Amazônia. Segundo Neves (NEVES, 1999, p. 322), o exemplo do sistema regional do Alto rio Negro, bem como o do Alto Xingu, onde a cerâmica produzida nas comunidades Waurá é utilizada pelos falantes de línguas Arawak, Tupi, Karib e Trumai, demonstram que "o registro da cultura material não tem resolução fina o suficiente para apreender as sutilezas étnicas que compõe esses sistemas".

No caso do estudo das expansões Arawak, nos últimos anos, as abordagens multidisciplinares e comparativas têm priorizado a correlação de dados da geografia física, linguística, arqueologia, etnografia e etno-história da Amazônia (HILL e SANTOS GRANERO, 2002; HORNBORG e HILL, 2011; ERIKSEN, 2011; HORNBORG e ERICKSEN, 2011; HILL, 2013). A principal contribuição teórica destes trabalhos é a crítica feita aos conceitos essencialistas de migração e de etnicidade, segundo os quais os grupos etnolinguísticos são delimitados geneticamente e alcançam seus territórios através da migração sobre áreas vazias. Os autores entendem que na Amazônia existe uma relação mais fluída entre geografia, lingua, identidade étnica e genética, sendo as identidades e fronteiras etnolinguísticas continuamente geradas e transformadas por condições diversas, como a especialização econômica, rotas de comércio, guerras, alianças políticas e demografia.

Etnicidade, nesse sentido, pode ser entendida como um meio de comunicação de alteridade, envolvendo a construção de identidade étnica. Da mesma forma, etnogênese seria o processo de refazer autêntico de novas identidades sociais, com a recriação criativa dos 
componentes tradicionais, tais como as narrativas orais, textos escritos e artefatos materiais. Nos diferentes contextos, existem meios de expressão de distinção e identidade étnica, os marcadores étnicos, como a língua ou a cultura material, os quais podem ser transformados através dos processos de etnogênese. Nesse sentido, a etnicidade deve ter sido um fator importante na geração de diversidade cultural e linguística na Amazônia muito antes da chegada dos europeus. As conquistas e expansões no período pré-colonial certamente geraram novas fronteiras étnicas, bem como novos estímulos para transcender tais fronteiras através de etnogênese. Da mesma forma, situações de contato entre diferentes grupos são compreendidas como um enredamento de duas ou mais histórias distintas em uma única história, uma nova formação social (HORNBORG e HILL, 2011; ERIKSEN, 2011; HORNBORG e ERICKSEN, 2011; HILL, 2013).

As expansões dos falantes Arawak são entendidas como diásporas, através de uma série de ondas migratórias ao longo dos grandes rios da Amazônia em um período de cerca de dois milênios, envolvendo relações históricas entre estes povos com a maioria das famílias linguísticas, como os Carib, Tukano, Pano e Tupi, resultando em contextos multilinguísticos e culturais (HILL e SANTOS-GRANERO, 2002; HILL, 2013). Esta expansão deve ser entendida como um processo sociocultural contínuo de negociação interétnica, disputa e incorporação em uma vasta rede de intercâmbio com comércio, casamentos mistos e uma interação cerimonial elaborada (HORNBORG e ERICKSEN, 2011, ERIKSEN, 2011). A presença Arawak numa vasta região pode ser percebida através de características da cultura material e não material e da linguagem que conjuntamente definem o etos Arawak ou a matriz Arawak, entre elas: assentamentos geralmente ao longo dos principais rios, através dos quais estabelecem redes de intercâmbio; formações sociais regionais, inter-regionais ou macrorregionais, com estabelecimento de alianças amplas entre grupos locais e regionais; descendência e consanguinidade como a base da vida social e política; rituais incluindo um repertório de instrumentos musicais sagrados; práticas diversas de apropriação da paisagem, incluindo nomeação de lugares, petróglifos, arte verbal e ritual, construções de terra; sedentarismo e agricultura intensiva (campos elevados e montículos agrícolas, terra preta); supressão da guerra interna, com predomínio do poder ritual e das relações de troca e escambo cerimonial; confecção de cerâmicas (tradição Barrancóide ou Inciso Modelada) (HECKENBERGER, 2001, 2002, 2005; HILL e SANTOS GRANERO, 2002; HORNBORG e HILL, 2011; ERIKSEN, 2011; HORNBORG e ERICKSEN, 2011; HILL, 2013).

Eriksen (2011) reuniu dados da arqueologia, linguística, etno-história, etnografia e geografia em um Sistema de Informações Geográficas (GIS) das diferentes regiões da 
Amazônia pré-colombiana, principalmente do período entre 500 a.C. e 1.500 d.C., com foco no tema da dispersão linguística Arawak. O autor ressalta que o sul da Amazônia é uma das áreas de maior diversidade geográfica, ecológica, linguística e cultural, e conforme demonstram os dados da linguística histórica, no período do contato com os europeus, a região apresentava grande diversidade linguística, com uma concentração de famílias e línguas isoladas em torno do rio Guaporé, Llanos de Mojos e ao longo das encostas andinas, enquanto o Planalto Brasileiro foi ocupado pelos grupos Macro-Jê desde o período précolonial e a parte a leste do rio Madeira pelos falantes Tupi (Mapa 3).

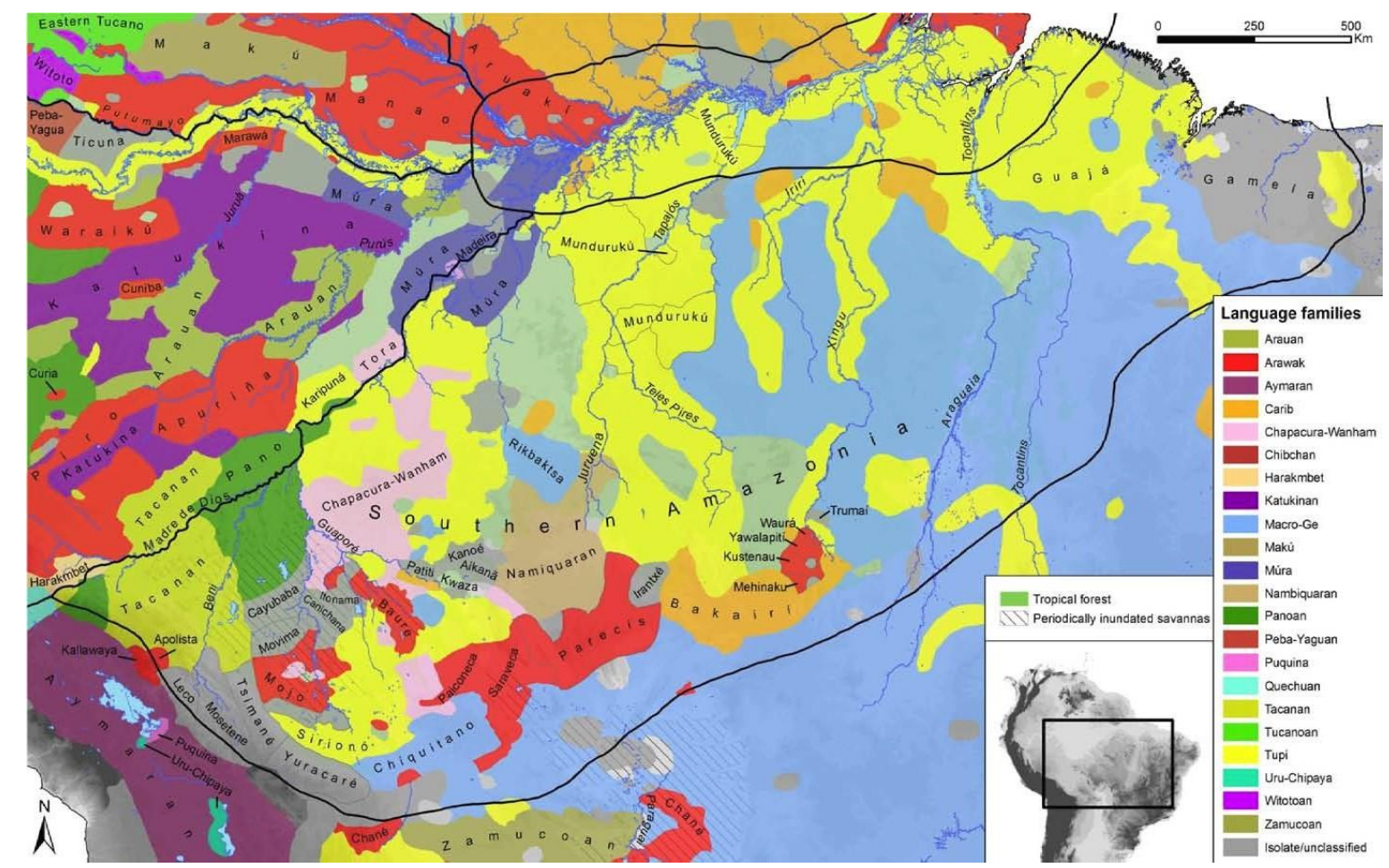

Mapa 3: grupos etno-linguisticos da Amazônia Meridional no período do contato (ERIKSEN, 2011, p 72).

Da mesma forma, os dados etno-históricos indicam um grande mosaico de grupos na região e apontam para a presença de redes de interação e comércio, tendo os rios Madeira, Tapajós, Xingu e Tocantins como importantes conectores entre o Amazonas e o interior. Para Eriksen (2011), os Llanos de Mojos, por possuírem conexões em todas as direções, teriam sido o ponto central desta extensa esfera de interações, há pelo menos 2.000 anos atrás até o período colonial, tendo o rio Madeira como uma das rotas. Os grupos Arawak de Mojos manteriam relações com os Arawak subandinos através do Guaporé e Madre de Dios e com os Arawak do Alto Xingu, onde o sistema de intercâmbio teria se desenvolvido desde a primeira metade do primeiro milênio d. C. Além disso, as línguas Pano formam dois grandes blocos no 
oeste e sul da Amazônia, um deles centrado no leste do rio Ucayali e o outro ao longo da parte inferior do Madre de Dios, separados pelos Arawak que estavam desde o Apurinã até o médio rio Purús (ERIKSEN, 2011).

Eriksen (2011) relaciona os geoglifos do Acre, bem como os campos elevados, canais, barragens, diques, montículos e caminhos nos Llanos de Mojos e as aldeias fortificadas do Alto Xingu à expansão dos Arawak na região. O autor acredita que um tipo de organização de assentamentos e tecnologia agrícola característica destes grupos se difundiu no sudoeste da Amazônia nos últimos séculos antes de cristo, apesar da cerâmica Barrancóide só ter aparecido na região a partir de 500 d.C, período em que a esfera de interações controlada por estes grupos abrangia grande parte da Amazônia. Por volta de 1.000 d.C., a esfera de influência Arawak abrangeria uma vasta região, envolvendo os cursos dos rios Madre de Dios, Ucayali, Amazonas, Madeira e Purús, sendo estes dois últimos corredores de comunicação no sistema de intercâmbio regional Arawak (Mapa 4). A partir de então o domínio Arawak no sul da Amazônia teria sido afetado pela expansão dos falantes Tupi a partir de Rondônia, principalmente entre AD 1.200 e o período do contato, cujas expansões eram caracterizadas por um etos mais predatório. Acrescenta ainda que, além da ampla distribuição dos falantes destas duas famílias linguísticas, outros grupos teriam propagado elementos culturais na Amazônia Meridional, porém ainda é impossível saber quando as línguas que compõe o mosaico etnolinguístico em 1.500 AD começaram a se dispersar na região (ERICKSEN, 2011). 


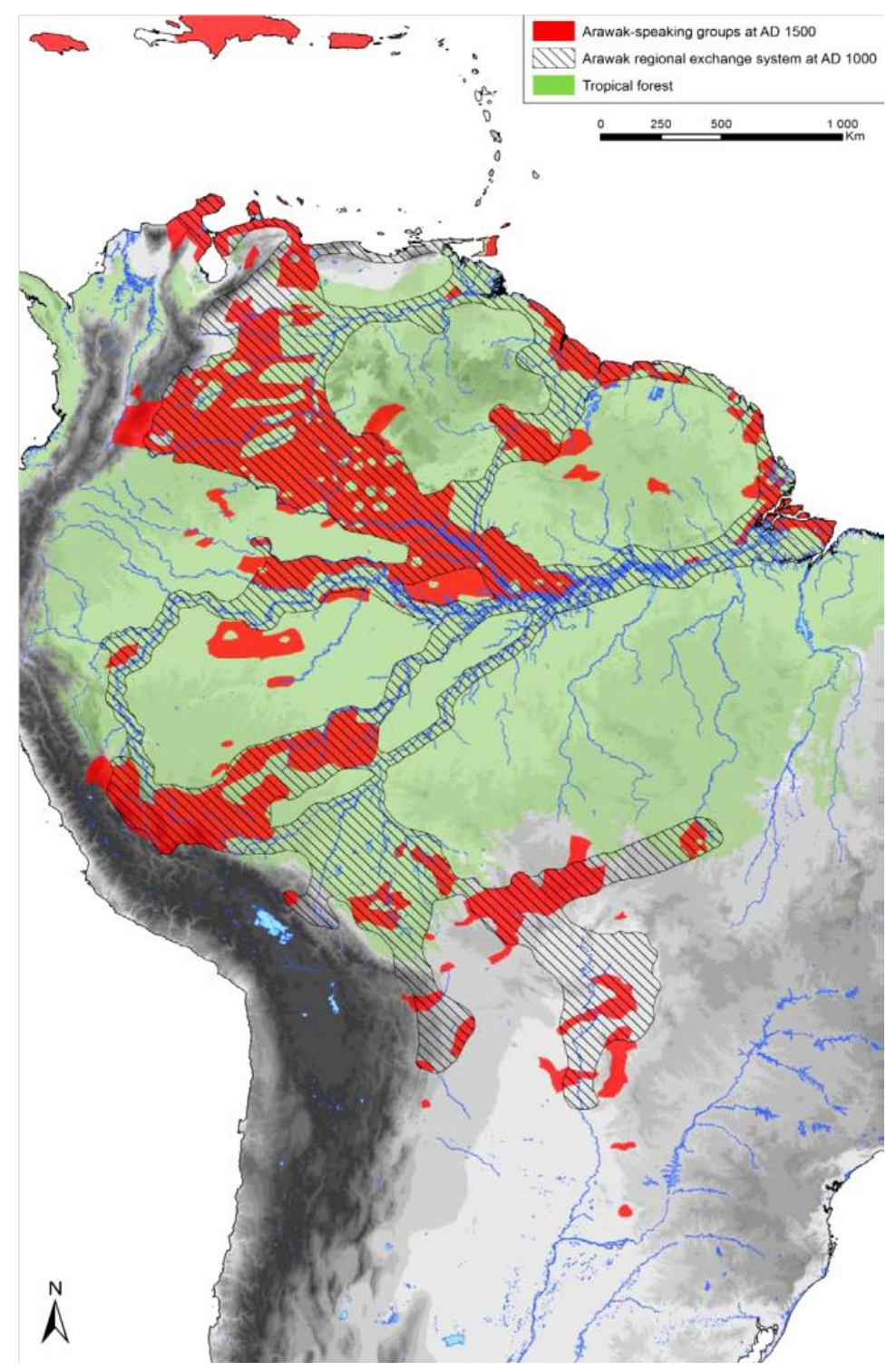

Mapa 4: sistema regional Arawak na Amazônia em torno de 1.000 AD (ERICKSEN, 2011, p. 222).

Antes de falar dos dados arqueológicos obtidos para a região do Alto rio Madeira e suas implicações nos modelos de ocupação e expansão dos falantes Tupi e Arawak, é importante apresentar um panorama sobre as ocupações em áreas relacionadas geograficamente ou culturalmente com o Alto rio Madeira, além dos trabalhos já citados no decorrer do texto. Segundo Neves (2006, 2012), há 10 mil anos, diferentes partes da Amazônia já eram ocupadas por grupos com economia diversificada, antes do advento da agricultura. Entretanto, devido às variações climáticas que ocorreram durante o Holoceno, poucos locais na Amazônia foram ocupados entre 6.000 AC e 1.000 AC, sendo um deles o curso do alto rio Madeira e seus afluentes, onde as ocupações foram contínuas durante todo o Holoceno, cujas evidências botânicas e genéticas demonstram que ocorreu a domesticação da mandioca e da pupunha nessa região. A partir do primeiro milênio DC, ocorreram mudanças 
sociais e políticas rápidas e sincrônicas em várias partes da Amazônia, quando o estabelecimento da vida sedentária e a criação de paisagens (estruturas monumentais) tornaram-se mais visíveis, bem como o estabelecimento de tradições cerâmicas distintas e em áreas geográficas bem definidas, que em alguns casos podem ser associadas a grupos linguísticos conhecidos etnográfica e historicamente (NEVES, 2012).

Na Amazônia Central, os dados obtidos através do Projeto Amazônia Central (PAC), iniciado em meados da década de 1990, permitiram a revisão da classificação anteriormente estabelecida por Peter Hilbert, constituída pelas fases Paredão e Manacapuru (Borda Incisa), Guarita (Tradição Polícroma da Amazônia) e Itacoatiara (Tradição Inciso e Ponteada), nessa ordem cronológica. Lima et al (2006) apresentaram uma cronologia para a região, eliminando a fase Itacoatiara e acrescentando uma nova fase cerâmica, a Açutuba, sendo a mais antiga da região com datas entre 300 a.C. a 360 D.C., seguida pela Manacapuru entre 600-1.000 DC. Essa cerâmica foi inicialmente identificada na base dos depósitos do sítio Açutuba e chamava a atenção por apresentar policromia (pintadas em vermelho, laranja ou roxo sobre branco) e incisões em linhas finas, porém era diferente dos materiais Guarita e da Tradição Borda Incisa (HECKENBERGER et al, 1998). Enquanto as cerâmicas Açutuba aparecem em matrizes sem modificações antrópicas visíveis (raramente estão associadas à terra preta) e com baixa densidade de fragmentos, sugerindo ocupações de curta duração e de proporções reduzidas, as cerâmicas Manacapuru aparecem com maior frequência e em camadas de terra preta, sugerindo um aumento da densidade demográfica na região com um apogeu em 1.000 DC (LIMA et al, 2006).

Lima (2008) volta-se para a caracterização das ocupações e materiais cerâmicos da Tradição Borda Incisa na Amazônia Central, pertencentes às fases Açutuba, Manacapuru e Paredão, comparando a cerâmica Açutuba (LIMA et al 2006) com contextos de cerâmicas antigas do médio Solimões e do Baixo Amazonas. Nas ocupações Açutuba são frequentes concentrações de materiais que podem ser lixeiras e feições com grande quantidade de material decorado. A Análise de uma amostra maior de cerâmica permitiu caracterizá-la melhor: apresenta pasta com composição variada, porém sempre leve e porosa, existindo um tipo de pasta branca associada a vasilhas de contorno complexo e pintura policrômica; possui variação formal muito grande, destacando-se flanges labiais e lábios expandidos, distando entre 2 e $5 \mathrm{~cm}$ do lábio; lábios planos e cortados; incisões, excisões e modelagens (figuras antropomorfas, zoomorfas e abstratas) na parte superior das flanges; presença de flanges mesiais, apliques, apêndices e estatuetas; as incisões finas ou largas, em linhas simples, são as mais recorrentes nestas coleções, com frequência associadas à modelagem ou pintura; é 
característica a incisão feita na superfície já seca ou queimada e com engobo vermelho; a decoração acanalada é feita na face externa, abaixo da flange labial ou no pescoço; a pintura, que ocorre em menor frequência que a decoração plástica, geralmente é feita sobre uma camada de engobo branco, na forma de linhas finas, faixas grossas ou cobrindo áreas, em diferentes tonalidades de alaranjado, vermelho, marrom e vinho (LIMA, 2008).

As ocupações Manacapuru ocorrem em um maior número de sítios grandes, circulares e com terra preta. Predomina a pasta com cauixí (raros fragmentos com caraipé), queima redutora de alta dureza, grande quantidade de fragmentos com polimento e enegrecimento, porém possui menor frequência de fragmentos com decoração plástica e menor variabilidade formal comparada com a fase Açutuba. As flanges labiais também são menos frequentes, substituídas pelas bordas extrovertidas. As decorações plásticas são aplicadas na parte superior das vasilhas, predominando incisões duplas ou múltiplas, em geral formando motivos retilíneos e geométricos, aplicadas nas flanges labiais ou na face externa de tigelas de contorno simples, de forma direta ou levemente expandida. Surgem as técnicas do ponteado, digitado e ungulado, geralmente nos lábios, e que são encontradas também na fase Paredão. Estão ausentes as flanges mesiais, a policromia e as decorações acanalada e excisa. Ocorrem vasos com gargalo carenado, com alguidares emborcados sobre eles (tampas), embora o contexto não seja funerário (não se observaram evidências de aparato funerário) (LIMA, 2008).

Os sítios Paredão são maiores, com aldeias circulares e presença de montículos em volta de uma praça central. Ao contrário das cerâmicas Açutuba e Manacapuru que possuem lábios espessos, na fase Paredão os lábios são afilados. A variabilidade formal diminui, sendo características as urnas piriformes com apliques antropomorfos duplos (cabecinhas) no ombro; destaca-se o uso de pedestais e alças; os vasos que diferenciam a fase Paredão das anteriores são as cestas com alças, os vasos com pescoço e potes com gargalo; as técnicas decorativas mais comuns são as incisões feitas com objeto pontiagudo fino, próximas à borda, com motivos geométricos ou espiralados; a pintura é feita diretamente sobre a superfície. Ocorrem contextos funerários e feições de estruturas de combustão com trempes (LIMA, 2008). Embora as ocupações Manacapuru e Paredão sejam contemporâneas em certo momento, a primeira é um pouco mais antiga na região, surgindo no século V d.C. e tornando-se mais visível no século VI, enquanto ocupações com cerâmicas da fase Paredão são mais comuns a partir do século VII d.C. (NEVES, 2012).

Lima (2008) comparou as cerâmicas antigas da Amazônia Central, do médio Solimões e do Baixo Amazonas, onde Hilbert e Hilbert (1980) estabeleceram a fase Pocó para a 
cerâmica dos estratos mais profundos dos sítios Pocó e Boa vista, localizados nos rios Nhamundá e Trombetas respectivamente, o primeiro com datas entre 65 e 205 d.C. e o segundo entre 1.330 e 1.000 a.C. A autora analisou uma amostra de material Pocó dos níveis mais profundos de uma unidade do sítio Pocó, escavada por Klaus Hilbert em 1992. A cerâmica é caracterizada pela presença de cauixí na pasta; são frequentes vasilhas de contorno composto ou complexo; alta incidência de flanges e inflexões; na superfície é comum a aplicação de resina que causa um brilho, além do escovado, uma gama variada de incisões, acanalados e excisões, modelagem e apliques zoomorfos e impressões de corda; as pinturas ocorrem em várias tonalidades de preto, vinho, alaranjado, amarelo e branco, além de engobos vermelhos e brancos e é comum a associação de pintura e tratamento plástico. A autora identificou similaridades tecnológicas e decorativas entre as cerâmicas antigas das três regiões, bem como nos contextos, com o início do processo de origem das terras pretas antrópicas e da própria agricultura nas três regiões.

Segundo Lima (2008), a cerâmica Açutuba possui semelhanças com outros complexos antigos: as vasilhas de contorno composto ou complexo com pintura policrômica são similares às da série Saladóide do Baixo Orinoco (Venezuela), ao passo que as formas e decorações plásticas são comparáveis às cerâmicas Barrancóides da mesma região. Segundo ela, Hilbert e Hilbert (1980) haviam observado semelhanças entre a cerâmica Pocó e a Barrancóide. Da mesma forma, na Amazônia Central, a autora identificou continuidades e transformações no material das três fases cerâmicas, o que indica um desenvolvimento gradual das cerâmicas Paredão a partir das fases Manacapuru e Açutuba. Percebeu ainda que quanto mais antigo é o conjunto, mais rebuscada é a decoração, menor é o esmero tecnológico e maior é a variabilidade formal. Com relação às decorações, ocorrem elementos estruturais comuns nas diferentes fases, e com correlatos em outras áreas, aplicadas sempre na parte superior do vaso. Seis tipos cerâmicos estabelecidos ocorrem nas três fases, sendo as cuias, assadores, alguidares, tigelas, vasos globulares e pratos. Os materiais Açutuba se parecem mais com os Manacapuru que com os Paredão, porém o que diferencia as duas fases é a presença de flanges mesiais e vasos com colo na mais antiga. As mudanças graduais no registro arqueológico em relação ao tamanho, densidade, quantidade e localização de sítios e formação de terras pretas na fase Manacapuru seriam decorrentes do aumento demográfico. Ainda, ocupações Manacapuru e Paredão possuem em comum a forma de aldeia circular, ocorrendo nesta última fase a construção de montículos. As padronizações encontradas nos materiais das três fases seriam indicativas de continuidade cultural dentro da Tradição Borda 
Incisa, ao longo de um intervalo de mais de mil anos, com influências de uma esfera de interações culturais, presente em uma área maior com partes da Bacia Amazônica e do Orinoco (LIMA, 2008).

Ainda de acordo com Lima (2008), a associação da cerâmica Manacapuru e, posteriormente, a Paredão a aldeias circulares confirmam o modelo que associa a dispersão das cerâmicas Barrancóide e aldeias circulares aos falantes de línguas Proto-Arawak, em uma ampla região no norte da América do Sul (LATHRAP, 1970; HECKENBERGER, 2002). Estas cerâmicas estão espalhadas por uma grande área que envolve a Colômbia, Venezuela, Amazônia Brasileira, as Antilhas e o Caribe, indicando um fenômeno regional com conexões em um sistema de interações. A autora elabora a hipótese de que as semelhanças nos materiais, datas e contextos das cerâmicas mais antigas da Amazônia Central, Médio Solimões, Baixo Amazonas e Baixo Orinoco podem indicar o início de uma esfera de interações, ao passo que a variabilidade interna poderia ser decorrente da necessidade de afirmação de identidade e status social (LIMA, 2008, p. 362). Na Amazônia Central, as mudanças no sistema tecnológico, social e econômico teriam resultado nos conjuntos materiais particulares das três fases; portanto, "apesar de compartilharem os elementos comuns à Tradição Borda Incisa, o acúmulo de mudanças históricas acaba por resultar em grupos culturais diferenciados, mas compartilhando de uma mesma estrutura" (LIMA, 2008, p. 380).

Costa (2012) relacionou a cerâmica do sítio Boa Esperança, localizado na reserva Amanã, Médio Solimões, a quatro fases cerâmicas, a Amanã, Pocó, Caiambé e Tefé. A cerâmica mais antiga (datas de $3.320 \pm 30$ AP e $2.800 \pm 30$ AP), identificada nas feições, é caracterizada pela presença predominante de caraipé na pasta, sendo recorrentes a pintura vermelha sobre engobo laranja e um amplo repertório de decorações plásticas, entre elas as incisões muito finas com motivos curvilíneos ou labirínticos, às vezes sobre engobo (vermelho), além das incisões em linhas paralelas e geométricos (losangos); as vasilhas possuem formas esféricas, com gargalo, sendo comuns as bordas triangulares e irregulares e as flanges labiais (ou logo abaixo do lábio). A cerâmica associada à fase Pocó ocorre nas camadas mais profundas de terra preta e em feições com solo mais claro que a terra preta, com datas de datas de $2.690 \pm 30 \mathrm{AP}, 2.500 \pm 40$ AP e $2.410 \pm 40$ AP, predominando o uso do caraipé na pasta, grande diversidade de motivos e técnicas decorativas feitas nas flanges (modelado, inciso, acanalado, ponteados), sendo comuns as incisões curvilíneas e em volutas ou que delimitam campos onde é aplicado o escovado, assim como o engobo e pintura 
polícroma em diferentes cores (vermelha e laranja predominam), em faixas de diferentes larguras, na superfície interna ou externa; os ponteados ocorrem isolados ou acompanham as incisões finas; são recorrentes as flanges mesiais e labiais e as formas de contorno complexo. A cerâmica da fase Caiambé (Tradição Borda Incisa/Barrancóide) ocorre nas camadas intermediárias dos perfis arqueológicos e associada à terra preta, com uma data de $1.080 \pm 30$ AP, com cauixí predominante na pasta, sendo características as incisões duplas e paralelas em motivos geométricos, geralmente na superfície externa dos vasilhames, ou em motivos curvilíneos e circulares, os apliques modelados (zoomorfos, antropomorfos ou abstratos), o engobo branco na face externa e a pintura vermelha. Finalmente, a cerâmica da fase Tefé (Tradição Polícroma da Amazônia) foi identificada nos níveis mais superficiais e na terra preta, com uma data de $1.220 \pm 30 \mathrm{AP}$, cuja pasta predominantemente possui caraipé, é frequente o alisamento e em menor quantidade aparece o polimento e o escovado, com presença de engobo branco, decoração acanalada em motivos geométricos e a pintura vermelha e branca. O reforço externo e as flanges mesiais são características. Para o autor, a cerâmica Caiambé marca um rompimento com a cerâmica Pocó e acredita que as diferenças marcantes nas ocupações Pocó indicam desenvolvimentos locais distintos (COSTA, 2012, p. 114).

Neves (2012) reitera que as primeiras datas das ocupações Manacapuru são contemporâneas às do final da fase Açutuba, observando-se um processo local de transição entre elas, sem rupturas marcantes nas formas de ocupação e nas cerâmicas. Segundo o autor, além das semelhanças nas características formais e decorativas da fase Açutuba com outras cerâmicas antigas da Amazônia, como as da fase Pocó no rio Trombetas, La Pedrera no rio Caquetá e as cerâmicas antigas do sítio Boa Esperança nas proximidades de Tefé, os contextos possuem outros aspectos em comum: são os primeiros sinais de ocupação humana após longos hiatos no Holoceno Médio; associação com o início das primeiras ocorrências de terra preta (sedentarismo); ocorrem nas proximidades de grandes rios ou lagos; amplo repertório decorativo; presença frequente de feições com concentrações de cerâmicas. Assim, a ampla dispersão destes contextos Pocó-Açutuba, a partir do primeiro milênio AC, permitiria denominá-los como uma tradição (Pocó) ou ao menos como um componente distinto da tradição Borda Incisa (NEVES, 2012, p. 147).

Moraes (2013) analisou os contextos do sítio Antônio Galo, localizado no município de Iranduba e de sítios do Baixo rio Madeira, especialmente o Vila Gomes no município de Borba, bem como dados inéditos das pesquisas de Eurico Miller e do PRONAPABA obtidos 
nessa região, buscando entender os limites da ocorrência da fase Paredão no rio Madeira, bem como a relação cronológica das ocupações da tradição Polícroma entre as duas regiões. No sítio Antônio Galo, Moraes (2013) mapeou trinta montículos, dos quais doze compõem uma disposição circular em torno de uma área central, na extremidade norte do sítio, construídos em uma área com sinais de antropização anterior, visível na ocorrência de uma camada escura de paleossolo com carvões, feições e esparsas ocorrências de fragmentos de cerâmica no latossolo, abaixo do paleossolo. Os nove montículos que escavou possuem um processo construtivo semelhante, utilizando o solo das imediações (latossolo mosqueado com solo mais rico em matéria orgânica), quando ainda não havia muita terra preta formada no local. Porém, enquanto alguns possuem pequena quantidade de cerâmica, outros apresentam pisos de fragmentos cerâmicos intencionalmente arranjados, com trempes e vasos inteiros quebrados (alguns intencionalmente) na base de construção, sobrepostos por solo dos arredores. A camada construtiva apresenta em média 40 a $60 \mathrm{~cm}$ de espessura, e após a construção dos montículos formou-se uma camada de terra preta de $20 \mathrm{~cm}$ com cerâmica. Em alguns deles, foram evidenciadas feições de buracos de esteios ou negativos deles e pedaços de laterita que eram utilizados para firmá-los, indicando a construção de malocas sobre os montículos. Feições de prováveis fogueiras com trempes inteiras, restos de fauna e carvões indicam que possivelmente atividades de preparo e consumo de alimentos ocorriam dentro das habitações. $\mathrm{Na}$ área central, entre os montículos, ocorre pouca cerâmica e terra preta, bem como nas suas imediações e na camada formada sobre eles após a construção, indicando que os fragmentos cerâmicos descartados eram reutilizados para a construção de novos montículos, e que o descarte das cerâmicas envolvia um cuidado na deposição para a preservação de fragmentos, assim como acontece com as urnas funerárias que geralmente têm uso secundário nos sepultamentos, algumas com pequenos furos causados pelo desgaste da base, podendo se tratar de vasos mortos (MORAES, 2013, p. 326). Portanto, os contextos evidenciados confirmaram a hipótese inicial do autor de que os montículos são plataformas para a construção de habitações. As novas datações obtidas para o sítio permitiram situar a construção do montículo 16 em 1.150 AP e o abandono do sítio em 850 AP. Datas de 1.360, 1.540 e 1.620 AP foram obtidas com carvão do paleossolo, abaixo dos montículos, e possivelmente correspondem a ocupações mais antigas relacionadas à fase Paredão, anteriores a sua construção. Foi ainda obtida uma data de 180 AP para a ocupação Guarita no local. Dessa forma, o autor conclui que o sítio Antônio Galo é do período do surgimento da fase Paredão na Amazônia Central, e possivelmente aqueles que compõem a aldeia circular da extremidade norte do sítio foram construídos ao mesmo tempo (MORAES, 2013, p. 284). 
Simões e Lopes (1987) haviam definido para a região do Baixo rio Madeira três fases arqueológicas: a fase Borba, atribuída a Tradição Polícroma da Amazônia, e as fases Axinim e Curralinho, associadas à tradição Inciso Ponteada. Moraes (2013) retomou os trabalhos na região, com levantamentos de sítios e escavação do sítio Vila Gomes, localizado na margem esquerda do rio Madeira. Nesse sítio, evidenciou duas urnas funerárias, contendo no seu interior restos de sepultamentos e fragmentos de possível tampa juntamente com a terra preta, tratando-se de dois vasos com forma restringida e base com um pequeno pedestal, um deles com dois apliques zoomorfos próximos à borda e o outro com um negativo de aplique. Em outro local do sítio, foi evidenciada uma terceira vasilha cerâmica enterrada abaixo da camada de terra preta, com um fragmento sobre ela que servia como tampa, e próximo a ela apareceu uma lamina de machado em miniatura (deve ter sido utilizada como pingente, apesar de não apresentar furo) e uma conta de colar, além de fragmentos de outras duas vasilhas, podendo ser uma área de cemitério. Também é interessante uma feição circular evidenciada no sítio, com fragmentos de diversas vasilhas, muitos deles decorados, juntamente com afiadores, fragmentos de arenito e material corante, que, segundo o autor, possivelmente faz parte da parafernália associada aos sepultamentos em urna, semelhante a contextos evidenciados nas ocupações mais antigas do sítio Hatahara e das ocupações Pocó da região do Trombetas (MORAES, 2013, p. 46). O sítio é unicomponencial com cerâmica da fase Axinim associada à terra preta em uma área de 40 hectares, com uma vala defensiva de $1 \mathrm{~km}$ cercando uma porção de 20 hectares do sítio, possivelmente construída em um curto espaço de tempo e mobilizando um grande número de pessoas. As datas obtidas pelo autor para o sítio situam a sua ocupação entre 1.250 AP e 800 AP e a construção da vala em 1.000 AP, período de maior densidade populacional na Amazônia Central e com maiores evidências de conflitos (MORAES, 2013, p. 241). Um material doado da Tradição Polícroma do Baixo rio Madeira foi datado em 660AP e 290AP, esta última bastante recente, assim como algumas datas obtidas por Eurico Miller na mesma região e aquela do sítio Antônio Galo, indicando que, provavelmente, grupos menores produtores da tradição Polícroma permaneceram na Amazônia Central até o século XVII (MORAES, 2013, p. 241). O autor analisa as datas obtidas por Simões e Lopes, sendo que possivelmente duas datas do século IX correspondem às ocupações Axinim e uma data do século XV à Tradição Polícroma. As datas inéditas fornecidas por Eurico Miller ao autor situam o início das ocupações ceramistas na região em 5.000 anos atrás, destacando-se o sítio Nova Olinda, que possui uma sequência de datas entre $4.965 \pm 65$ AP e $2.335 \pm 45$ AP para a cerâmica da fase Angelin (MORAES, 2013, p. 234). 
Moraes (2013) analisou a cerâmica dos sítios Antônio Galo e Vila Gomes e de uma pequena amostra de materiais doados dos sítios Borba e Traipu, priorizando os fragmentos grandes que permitem reconstruir a forma do vaso, bem como todos os fragmentos decorados, que, segundo o autor, seriam os melhores diagnósticos para classificar os diferentes conjuntos cerâmicos da região. Na fase Paredão os tipos mais recorrentes são as tigelas, seguidas pelos vasos globulares, sendo raros os vasos com colo e com flange mesial, que possivelmente começaram a ser produzidos por influência da ocupação Guarita. O volume das vasilhas varia entre 50 mililitros e 350 litros, e praticamente todos os tipos possuem miniaturas. A maioria das vasilhas possui espessura fina (entre 5 e $10 \mathrm{~mm}$ ) e são mais recorrentes diâmetros entre 12 e $36 \mathrm{~cm}$. Ocorrem assadores com diâmetro entre 35 e $106 \mathrm{~cm}$, a maioria com $90 \mathrm{~cm}$. Foi utilizado cauixí na pasta, frequentemente associado a carvão ou caco moído, não ocorrendo variações ao longo da estratigrafia, mas de acordo com a função das vasilhas. Os pigmentos (engobo e pintura) da cerâmica Paredão são bastante frágeis, possivelmente aplicados após a queima, e possivelmente grande parte das vasilhas, com exceção dos alguidares e assadores, possuíam pintura ou engobo. Os motivos decorativos das pinturas e incisões têm grande variação, aplicados predominantemente na borda e pescoço, mas também ocorrem no bojo, lábio, alça, ombro, flange e base. Os modelados, às vezes combinados com ponteados, formam olhos ou representações zoomorfas (MORAES, 2013).

A fase Axinim apresentou uma variação formal muito maior do que anteriormente estabelecida (SIMÕES E LOPES, 1987). Nesta cerâmica predomina o uso de cauixí como antiplástico, mas algumas vasilhas apresentam também caraipé, caco moído e caraipé B. É frequente o uso de engobo, e os motivos decorativos das técnicas plásticas e pintada variam bastante, mais que nas fases Paredão e Guarita, predominando as variações de campos zonados hachurados, bem como as incisões múltiplas que, às vezes, formam grandes campos incisos paralelos ou figuras geométricas, e os ponteados e modelados. Moraes (2013) entende que as características desta fase, identificadas no sítio Vila Gomes, remetem à cerâmica Borda Incisa, e não à tradição Inciso Ponteada, como havia sido proposto por Simões e Lopes. Conclui ainda que as ocupações Axinim e Paredão são contemporâneas, ocorrendo muitas semelhanças entre as cerâmicas, ambas com traços das cerâmicas mais antigas da região, das fases Açutuba e Manacapuru, o que reforça a hipótese de continuidade entre estas e as da fase Paredão (MORAES, 2006; LIMA, 2008).

Segundo Moraes (2013, p. 318), na Amazônia Central, os principais traços estilísticos e tecnológicos da cerâmica dos conjuntos mais recentes estão presentes nas cerâmicas mais antigas, sendo "os estilos mais tardios como ressignificações dos anteriores". A cerâmica do 
sítio Vila Gomes, associada à fase Axinim, apesar de possuir singularidades, representaria a pluralidade regional da ocupação da Amazônia, possuindo elementos de três tradições cerâmicas: a Borda Incisa, Inciso Ponteada e Hachurada Zonada. Além das semelhanças com a fase Paredão, ocorrem características Manacapuru como as bordas com dupla incisão, bem como elementos das fases Konduri e Tapajônica; também está presente o uso de incisões e excisões em superfícies engobadas que ocorrem na cerâmica Marajoara, e é frequente o motivo decorativo hachurado-zonado típico da cerâmica mais antiga da Amazônia. Assim, o autor entende que estas cerâmicas, bem como a Pocó, não se enquadram nas tradições anteriormente definidas por Meggers e Evans, e que estas provavelmente terão que ser inseridas em um novo complexo cerâmico (MORAES, 2013, p. 322). A cerâmica da Tradição polícroma também apresenta elementos da antiga cerâmica Açutuba (policromia, uso do caraipé, lábios reforçados, flanges mesiais), apesar de existirem diferenças nos padrões de assentamentos entre ocupações Manacapuru (que está cronologicamente entre as cerâmicas Açutuba e Guarita, tendo continuidade com a primeira) e Guarita, e estas semelhanças poderiam ser decorrentes da relação que estes grupos estabelecem com o material de ocupações anteriores. Apesar disso, o autor acredita que "as sociedades complexas da Amazônia antiga parecem ser o resultado de estruturas político-regionais multiétnicas e uma das características materiais dessas manifestações poderia ser a presença de elementos diversos das cerâmicas amazônicas contidos em um mesmo conjunto artefatual” (2013, p. 294). Para Moraes e Neves (2012), a pluralidade no conjunto cerâmico Axinim demonstraria que existe um coração cultural irradiando influências por toda a bacia Amazônica, não sendo possível descartar totalmente o modelo cardíaco de Lathrap (1970).

Neves (2012, p. 192) acredita que existiu na Amazônia Central um sistema regional multiétnico entre os séculos VII e IX d.C., quando sítios Manacapuru e Paredão, muito próximos, eram ocupados contemporaneamente, e com presença de quantidades pequenas de cerâmica Manacapuru em sítios Paredão ou vice-versa. Apesar da forma comum dos assentamentos circulares ou em forma de ferradura, as diferenças entre as cerâmicas Manacapuru e Paredão, que perduraram por dois séculos de ocupação, indicariam a presença de grupos étnicos distintos. Segundo o autor, possivelmente quando os produtores da cerâmica Paredão chegaram à região, em torno de meados do primeiro milênio DC, esta já era ocupada pelos grupos que produziam cerâmicas Manacapuru (os quais possuem uma continuidade histórica com as ocupações Açutuba), e a ausência de estruturas defensivas indica que estabeleceram relações horizontais e simétricas, incluindo a circulação de cerâmicas e o compartilhamento de uma mesma cosmologia baseada na ocupação de aldeias 
circulares. Enquanto as ocupações Manacapuru ocorrem até o século X d.C., as últimas ocupações Paredão são do século XIII d.C., possivelmente porque se passou a produzir apenas um tipo de cerâmica no sistema regional, ou em função das influências mútuas entre os dois conjuntos (NEVES, 2012, p. 199).

Moraes e Neves (2012) entendem que a vala artificial evidenciada no sítio Vila Gomes, Baixo rio Madeira, indica um sistema defensivo decorrente da emergência de conflitos na região, relacionados ao aparecimento de grupos produtores de cerâmica da Tradição Polícroma. As ocupações Paredão e Axinim são encontradas na ampla área que engloba o Médio/Baixo rio Madeira, o rio Amazonas e o baixo rio Negro por volta do ano mil da era Cristã, com estabilidade e continuidade na ocupação até o século IX, quando ocorre a expansão da ocupação Guarita e surgem as evidências de sistemas defensivos em diversos sítios. A expansão dos grupos portadores da Tradição Polícroma teria sido muito rápida, tendo em vista que os extratos são geralmente superficiais e ocorrem cerâmicas muito semelhantes desde o médio rio Madeira e o baixo rio Amazonas, nas proximidades da atual fronteira dos estados do Amazonas e Pará, até o rio Napo, no Equador (MORAES E NEVES, 2012). O aumento no número e tamanho dos sítios Paredão indicaria que houve um crescimento demográfico entre os séculos VII e XI d.C., com presença de montículos residenciais, cemitérios, paliçadas, valas, pátios circulares ou em forma de ferradura, caminhos e feições com diversas formas e conteúdos. Portanto, as estruturas defensivas de valas e paliçadas, que ocorrem no final das ocupações Paredão, na área de confluência entre o rio Negro e Solimões e no baixo Madeira, estariam relacionadas à chegada dos produtores da cerâmica Guarita (Tradição polícroma da Amazônia) a partir do século X d.C., que não parece ter sido muito pacífica (NEVES, 2012).

Na Amazônia central, a cerâmica Guarita ocorre em camadas superficiais ou pouco profundas e, embora geralmente associada à terra preta, não é possível saber se sua formação é decorrente destas ocupações ou das anteriores. A cerâmica Guarita é caracterizada pela decoração pintada em faixas grossas (vermelhas e negras sobre uma base branca), com motivos retilíneos, curvilíneos, geométricos, zoomorfos ou antropomorfos; decoração acanalada; decoração plástica antropomorfa em urnas; presença de flanges mesiais como suportes para a decoração; e grande variabilidade de formas (LIMA et al, 2006; LIMA, 2008; NEVES, 2012; TAMANAHA, 2012). A fase Guarita possui padrão de assentamento em formato linear (unidades habitacionais voltadas para o rio), diferente dos padrões Borda Incisa, circulares ou elipsoidais (MACHADO, 2005; LIMA, 2008; MORAES, 2006; MORAES e NEVES, 2012; TAMANAHA, 2012). 
Tamanaha (2012) estudou as ocupações da Tradição Polícroma de dois sítios da confluência dos rios Solimões e Negro e de cinco sítios do médio rio Solimões, no município de Coari. A análise da cerâmica destes sítios demonstrou que não há uma padronização tecnológica em relação ao preparo da pasta e tecnologia empregada, com excessão da morfologia dos vasos e dos aspectos decorativos (policromia e decoração acanalada são recorrentes), que são permanentes tanto numa escala espacial como temporal, apesar da grande variabilidade formal que caracteriza a cerâmica desta fase. A cronologia demonstra que as ocupações mais antigas da Tradição Polícroma da Amazônia ocorreram nos afluentes do rio Solimões, onde estão as datas mais antigas (763 d.C., 770 d.C. e 1.160 d.C.), seguidas pela presença ao longo do rio Solimões e baixo rio Negro, a partir de aproximadamente 1.000 d.C. (900 d.C. no rio Negro e 1.280 d.C no rio Solimões), sem entretanto abandonar os afluentes. $\mathrm{O}$ autor divide a história da ocupação pelos portadores da Tradição Polícroma em três momentos distintos: no século VIII, ocorrem as ocupações iniciais nos afluentes do rio Solimões com assentamentos pequenos e pouco permanentes; no século XI, o estabelecimento em toda a região e confronto com os habitantes da fase Paredão; e o século XVI com a chegada dos portugueses e espanhóis. A maior contribuição do trabalho de Tamanaha (2012) está em demonstrar que, embora tudo indique que a expansão da TPA tenha ocorrido no sentido leste-oeste, conforme demonstram as datas mais antigas da fase Marajoara do século V e mais recentes da fase Napo no século XII (NEVES, 2006), em uma escala regional, o processo não foi tão linear.

A tradição Polícroma da Amazônia ocorre em uma ampla região, incluindo a fase Marajoara na ilha de Marajó; fase Guarita na região de Manaus; Borba no baixo rio Madeira e Jatuarana no seu alto curso; Tefé na região de Tefé, Santa Luzia no alto rio Solimões, Zebu na região de Leticia (Colômbia); Napo, no rio Napo (Equador); Caimito no alto Amazonas e Ucayali (Peru), entre outras (NEVES, 2006, 2012; TAMANAHA, 2012). Segundo Neves (2012), a cronologia e distribuição geográfica dos sítios da Tradição Polícroma da Amazônia demonstram que as ocupações vão tornando-se cada vez mais recentes na medida em que subimos o rio Amazonas, desde a foz até os contrafortes dos Andes, tendo em vista que os sítios mais antigos ao longo deste rio foram encontrados na Ilha de Marajó no século V d.C.

Moraes (2013) acredita que os grupos Paredão teriam dominado uma área restrita em função da chegada dos produtores da cerâmica Polícroma, que no ano 1.000 AD ocupavam a calha do Solimões. Nesse período, a expansão Polícroma se estabeleceu na região do Baixo rio Madeira, gerando instabilidade política, o contato e a guerra. Para o autor, o predomínio e 
hegemonia das ocupações policromas, no Baixo rio Madeira e na Amazônia Central no século XII, bem como os sistemas defensivos identificados em sítios Paredão e Axinim, indicam que os últimos representantes de uma antiga expansão Arawak foram pressionados e empurrados para o Baixo Amazonas com a chegada das várias levas da expansão dos produtores da Tradição Polícroma que desceram o rio Madeira. Tal hipótese foi elaborada considerando as semelhanças entre as ocupações Paredão, Axinim, Konduri e Santarém. Nessa região, o material se difere do clássico Paredão, possivelmente em função da interação destes grupos com outros como os das fases Konduri e Santarém (MORAES, 2013, p. 22). Ainda, a falta de relações entre os estilos cerâmicos da Ilha de Marajó e da Amazônia Central, poderia ser explicada pela presença de conflitos com outros povos no baixo Amazonas (p. 322).

Voltemo-nos agora para a região a sul da área de pesquisa, rumo ao Brasil Central. Erig Lima (2012) abordou as ocupações da região do alto rio Guaporé, fronteira do estado do Mato Grosso com a Bolívia, nas proximidades da cidade de Vila Bela da Santíssima Trindade. A área teria sido ocupada pelos grupos produtores da cerâmica Córrego Banhado entre 500 e $1.400 \mathrm{AD}$, cujas características da cerâmica e de uma vala defensiva em um dos sítios permitiriam correlacioná-la as fases Corumbiara e Pimenteira (900-1.700 AD) definidas por Miller (1983) para o alto/médio Guaporé. Em torno de $800 \mathrm{AD}$, teriam chegado à região populações canoeiras produtoras da cerâmica Capão do Canga (800- 1.300 AD), cuja característica mais marcante seria a presença de decoração pela técnica plástica incisa ou pintada (vermelho) em motivos de linhas entrecruzadas. Estas ocupações seriam contemporâneas a outras da região, como as da Tradição Uru (800-1.700 AD), Tradição Una (500 AC-1.200 AD) e Tradição Tupiguarani (1.300/1.400-1.700 AD), sendo encontrados materiais intrusivos destas três tradições em sítios do alto Guaporé, a primeira delas nos sítios Capão do Canga e Córrego Banhado e as outras duas em sítios multicomponenciais, além da ocorrência de exemplares da cerâmica Capão do Canga nos sítios Córrego Banhado, o que indicaria a existência de antigas redes de trocas e de interdependência tecnológica entre as populações pré-coloniais da área, com períodos de integração ou de conflito interétnico. Em função de suas características e situação geográfica, a região do alto Guaporé seria estratégica na convergência e/ou passagem das populações indígenas pré-coloniais e etno-históricas oriundas de regiões vizinhas como o Planalto Central Brasileiro, a Amazônia central e ocidental, a bacia do alto rio Paraguai, o pantanal e as terras baixas orientais da Bolívia (ERIG LIMA, 2010, 2012). 
No sudeste do Mato Grosso, os primeiros ceramistas chegaram ao redor do início da era cristã, possuindo uma cerâmica semelhante à da tradição Una e, a partir de 900 d.C., surgiram as aldeias anulares dos ceramistas da tradição Uru, com um ou vários anéis concêntricos. Os portadores da tradição ceramista Tupiguarani chegaram à região no século XIII e permaneceram até o período histórico, assim como os portadores da tradição Uru (WUST, 1999). Nos sítios Bororo, grupo que pertence linguisticamente ao tronco Macro-Gê e se concebe como descendente de grupos locais distintos, Wust (1999) identificou elementos das tradições Uru e Tupiguarani, que indicariam não apenas redes de troca, mas um processo de fusão cultural e étnica. Enquanto nos sítios do período pré-contato e contato inicial a cerâmica é mais heterogênea com elementos das diferentes matrizes culturais, nos sítios mais recentes há uma homogeneização, o que poderia ser interpretado como uma imposição estética pelos portadores da tradição ceramista Bororo para fortalecer a identidade grupal ou como a adoção de um novo padrão estilístico para mascarar diferenças sociais, promover a comunicação, ou expressar o sentimento de uma nova etnicidade emergente (WUST, 1999). Entre o final do século XIII e início do XIV, o Brasil Central foi cenário de pressões demográficas internas e externas, estas provavelmente oriundas do Oeste e do Norte, conforme evidenciado nas estratégias defensivas, ocupação de áreas de difícil acesso e maior diversidade das tradições cerâmicas (WUST, 1999; WUST e BARRETO, 1999). O surgimento das aldeias anulares no Brasil Central, a partir de $800 \mathrm{AD}$, associadas às tradições ceramistas Uru e Aratu e a grupos etno-históricos como os Bororo, é interpretado como uma resposta local às pressões externas e regionais, em função do aumento demográfico, interação com grupos vizinhos como os Tupi, e necessidade de defesa. Pressões externas teriam causado uma variedade de alianças multiétnicas, integração inter-regional de diferentes grupos e aumento de complexidade entre sítios de um mesmo assentamento e entre assentamentos, diferente do modelo clássico de hierarquia vertical (cacicados) relacionados a algumas áreas da Amazônia (WUST e BARRETO, 1999).

No Alto rio Paraguai, os dados arqueológicos evidenciaram a presença de grupos ceramistas diferenciados, corroborando com os dados etno-históricos e etnográficos existentes para a região, que a caracterizam como fronteira cultural, representada por um mosaico de culturas composto por falantes Guaykuru, Tupi-Guarani, Macro-Jê e Aruak, entre outros. Devido à posição geográfica do Chaco, esta teria recebido influências culturais diversas, de origens pâmpida, amazônica e andina (MIGLIACIO, 2002, 2006). No pantanal de Cáceres, os estudos de Migliacio (2002, 2006) demonstram que a complexidade étnica, relatada pelos 
europeus no século XVI, teve início entre os séculos X e XI, quando grupos portadores de tradições ceramistas distintas ocuparam a mesma região, incluindo a planície alagável e áreas mais elevadas da Depressão do Alto Paraguai, mantendo contatos entre si. Nessa região, foram evidenciadas ocupações de duas populações ceramistas, da tradição Pantanal e da tradição Descalvados, distintas em relação à organização social, padrões de assentamento e subsistência, além de uma terceira cerâmica, presente nos estratos mais profundos dos aterros, que até o momento não foi caracterizada, e de alguns fragmentos com características distintas entre os conjuntos cerâmicos (intrusivos), que poderiam ter origem chaquenha, altoguaporeana ou andina (MIGLIACIO, 2002, 2006).

A tradição Pantanal é associada a grupos pescadores-caçadores-coletores que construíram os aterros na planície pantaneira. A cerâmica é composta predominantemente por vasilhas de pequenas dimensões, globulares e semiglobulares, apropriadas para cozinhar alimentos, possivelmente ensopados e cozidos, e poucas vasilhas abertas e com gargalo. Nesta cerâmica, está ausente o antiplástico de concha triturada, sendo esse um importante diferenciador desta em relação à Descalvados. A diversidade dos restos faunísticos sugere uma economia baseada predominantemente na pesca, na caça e na coleta, com uma organização social em pequenos grupos. O material lítico é composto pela alta frequência de corantes trabalhados e alguns quebra-cocos (MIGLIACIO, 2006).

Os grupos da tradição Descalvados ocuparam sítios a céu aberto em áreas mais elevadas, bem como os aterros anteriormente construídos pelos grupos da tradição Pantanal, nesse caso possivelmente em época um pouco mais recente, tendo em vista que as datações sugerem uma concomitância parcial das ocupações das duas tradições. Os aterros eram utilizados por estes grupos como habitações permanentes, acampamentos temporários ou para a realização de sepultamentos. Nos sítios Descalvados, foram evidenciadas diferentes áreas de atividades, como as oficinas líticas de confecção de adornos; estruturas de combustão com presença de blocos e fragmentos de arenito, cerâmica, cinzas, carvões e restos faunísticos, interpretadas como sendo áreas de cozinha; estruturas compostas por fragmentos de vasilhas grandes e espessas quebradas in situ, possíveis setores de armazenagem; e estruturas com fragmentos de vasilhas e blocos de arenito utilizados como bigornas, almofarizes e maceradores, interpretadas como setores de processamento (MIGLIACIO, 2006).

No contexto funerário, vasilhas restringidas são utilizadas como urnas funerárias, tigelas como tampas e vasilhas menores são depositadas como oferendas (às vezes contendo restos faunísticos), junto com outros itens como adornos líticos, materiais corantes, lâminas 
de machados, cerâmica decorada, restos ósseos de animais inteiros, e eventualmente outros líticos como almofariz, macerador, furador e raspador. Junto aos sepultamentos ocorrem fogueiras com cinzas e restos faunísticos próximos às urnas, às vezes iniciando no nível da base das urnas e permanecendo por vários níveis, sugerindo um ritual funerário de longa duração, assim como as oferendas funerárias que frequentemente são depositadas em diversos níveis. No interior das urnas, além dos ossos humanos, podem ser encontrados junto ao sedimento os carvões, restos faunísticos e florísticos, e oferendas de conchas de bivalves, líticos e fragmentos de outras vasilhas que podem ter sido utilizadas como tampas ou como recipientes de oferendas (MIGLIACIO, 2006).

A escavação destas áreas (de cozinha; de armazenagem e processamento; de sepultamentos) forneceu contextos que auxiliaram na análise da função das vasilhas cerâmicas. Foram identificadas duas classes de vasilhas, a de caráter doméstico e a de caráter ritual. Na primeira delas, as vasilhas possuem pasta com concha moída, a fuligem é frequente, algumas (restringidas de bordas diretas) apresentam apêndices de suspensão, o acabamento é grosseiro, raramente aparece engobo, ausência de pintura geométrica, bem como de formas complexas e vasilhas de grandes dimensões. Já a segunda classe possui vasilhas que não vão ao fogo, sendo encontradas em contexto doméstico com funções de armazenagem e de servir e no contexto funerário como urnas, recipientes de oferendas (vasilhas restringidas, grandes e pequenas, de armazenar) e tampas de urnas (vasilhas abertas, geralmente rasas, de servir). A pintura geométrica ocorre apenas em vasilhas com antiplástico de quartzo e caco moído, que não iam ao fogo, com padrões que incluem faixas, linhas e pequenos grafismos representados por pontos, cruzes e triângulos, que quando combinados formam barrados geométricos, às vezes intercalados por áreas preenchidas pelos grafismos. A pintura aparece em tigelas abertas, em vasilhas pequenas (restringidas de borda infletida) e no lábio de algumas vasilhas grandes de armazenagem, e é mais recorrente nas estruturas de sepultamento. O engobo aparece também como decoração, às vezes cobrindo apenas parte da vasilha, em associação com pintura geométrica. Pode ocorrer uma única linha incisa marcando o limite entre diferentes partes da vasilha, como o bojo e a borda ou a borda e o lábio. Estão presentes vasilhas de dimensões variadas, que sugerem preparo de alimentos tanto para grupo familiar pequeno quanto para grupo social extenso. Ocorrem fragmentos de borda com perfuração pósqueima. Além das vasilhas, ocorrem tortuais de fuso, adornos, cachimbos, instrumentos de sopro (flautas e possíveis apitos), ocasionais estatuetas antropomorfas e pisos de argila (MIGLIACIO, 2006). 
O material lítico é caracterizado pelos adornos, micropontas e eventuais raspadores feitos em rochas silicosas microcristalinas. Além de blocos e fragmentos de arenito utilizados como bigornas, almofarizes, amoladores e percutores de arenito, lâminas de machado em calcário e rochas ígneas, algumjas fragmentadas e reaproveitadas como bigornas, e chama atenção um bloco de arenito com pequenas depressões circulares e um disco lítico. O material lítico de silexito possui pequenas dimensões, e muitos adornos são feitos em caldedônia. As rochas microcristalinas e as rochas ígneas teriam origem exógena ou seriam de difícil obtenção (MIGLIACIO, 2002, 2006).

As ocupações da tradição Pantanal na região de Cáceres estão datadas entre $2.108 \pm$ 154 AP e 925+_ 100 AP, enquanto as ocupações Descalvados ocorrem entre $1.520 \pm 150$ AP e

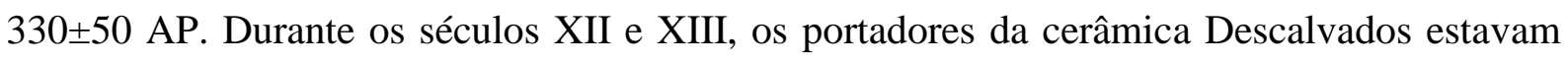
instalados em grandes aldeias, com espaços funerários especializados para determinadas classes de idade, gênero e possivelmente de descendência, e com variabilidade entre os assentamentos (sítios com diferentes funções) e possibilidade de hierarquia entre eles, características que indicam complexidade na organização social. A variabilidade apresentada pelo material cerâmico (aspectos tecnológicos, decoração, dimensões e morfologia) e lítico (obtenção de matérias primas, formas de produção, uso e reciclagem de artefatos) e os contextos evidenciados sugerem a ocorrência de grupos culturais distintos caracterizados pelas tradições Pantanal e Descalvado, sustentando a premissa de diversidade cultural no Pantanal de Cáceres. Alguns contextos com cerâmicas de ambas as tradições ocorrendo de forma concomitante na estratigrafia, bem como o provável sepultamento de indivíduos de ambos os grupos em cemitérios associados à ocupação Descalvados, sugerem contatos culturais, porém são necessárias escavações mais refinadas, realização de datações e análises de mudanças e permanências de padrões ao longo do tempo para confirmar essa hipótese. Migliacio (2006) associa os sítios da tradição Descalvados aos Xarayés, descritos nas fontes coloniais comopopulações concentradas em grandes aldeias próximas entre si e ligadas por caminhos largos, algumas delas fortificadas com paliçadas e fossos, compostas por habitações e espaços de celebrações sociais, com plantações extensas de milho, mandioca e outros tubérculos, com alguns principais (chefes cuja influência extrapolava o âmbito de uma aldeia), presença de tecelagem, cerâmica (grandes vasos para armazenamento), adornos líticos e conchíferos, arte plumária e instrumentos musicais como buzinas e tambores. Segundo a autora, esse conjunto de características registradas na crônica colonial (grandes e populosas aldeias, integração interaldeias, agricultura desenvolvida, hierarquias, construções de terra) 
permite considerar os Xarayés como Aruak, porém é necessário considerar que os grupos descritos pelos espanhóis como Xarayés podem representar uma diversidade de grupos de diferentes filiações étnica e/ou linguística, tendo em vista a diversidade cultural e a complexidade étnica que caracterizava o Chaco e o Alto Paraguai (MIGLIACIO 2002, 2006).

É importante também falar da pesquisa elaborada por James Betancourt (2010), que se constitui da análise da cerâmica de um montículo habitacional localizado nos Llanos de Mojos, Bolívia, a Loma Salvatierra, ocupado entre 600 e 1.400 d.C. As mudanças morfológicas e decorativas da cerâmica permitiram definir cinco fases que coincidem com eventos estratigráficos, correspondentes a momentos importantes de ocupação do montículo. As mudanças na cerâmica ocorreram de forma paulatina e constante durante 800 anos, portanto são decorrentes de mudanças no modo de fazer e talvez por influências de outras regiões, porém sem rupturas estilísticas radicais que pudessem indicar a reocupação do sítio por outros grupos culturais. A autora observou que se trata de uma história contínua, em que muitas ideias dos primeiros artesãos perduraram enquanto outras mudaram. As 39 datações radiocarbônicas situadas entre 600 e 1.400 d.C. apoiam a ideia de continuidade na ocupação do montículo. A autora também identificou mudanças nos rituais funerários ao longo do tempo, principalmente no tipo de vasilha e partes do corpo em que estavam associadas. O sítio possui áreas de atividades domésticas, de cultos festivos e de rituais funerários (JAMES BETANCOURT, 2010).

A cerâmica é caracterizada pela pasta bastante homogênea, com presença de quartzo e caco moído em diferentes tamanhos e proporções. Ocorrem os tratamentos de superfície escovado, alisado, brunido e polido, e também engobo de colorações claras (creme) e escuras (vermelho, marrom e preto), de acordo com a queima. Foram identificadas vasilhas abertas, fechadas e com pescoço, entre elas pratos, tigelas, garrafas, jarros, raladores (pratos raladores e tigelas raladores) e coadores. Ocorrem trípodes, asas (horizontais e verticais) e falsas asas (decorativas). Outros artefatos como tampas (algumas com asas ou com orifícios onde passaria um cordão), mãos de moer, rodas de fuso, estatuetas e adornos pessoais como tembetás, adornos auriculares e contas de colar. Entre as decorações, ocorre a pintada (cores preta, vermelha, marrom, marrom avermelhada e laranja, estas três últimas possivelmente decorrentes da queima) e a plástica com incisões e apliques. Há a combinação de diferentes decorações e uma grande variedade de motivos, a maioria sendo composições de figuras geométricas, elementos individuais como espirais, triângulos, círculos, volutas, etc., que, quando combinados, formam motivos complexos (JAMES BETANCOURT, 2010). 
Enquanto na fase 1 se combinam as técnicas pintada e incisa, na fase 2 se introduziu a técnica do aplicado (bandas delgadas horizontais ou curvilíneas no ombro das vasilhas globulares). $\mathrm{Na}$ fase 3 , motivos similares aos da fase anterior são feitos com incisões profundas, além da combinação de elementos criarem novos motivos, ocorrendo bandas aplicadas com ponteado ou digitado. $\mathrm{Na}$ fase 4, continuam sendo aplicadas bandas e os motivos incisos são similares aos da fase anterior, porém surge a técnica da pintura em negativo com desenhos complicados formados por espirais, círculos, retilíneos etc. $\mathrm{Na}$ fase 5 , as decorações incisas começam a desaparecer e a pintura em negativo é rara, porém torna-se comum a pintura em bandas horizontais, zigzag, motivos escalonados e em xadrez. Os rituais funerários também foram mudando com o passar do tempo. Segundo a autora, "La amplia variedad decorativa de la cerámica de la Loma Salvatierra es un reflejo de las constantes innovaciones, influencias y cambios de moda propiciados en un lapso de tiempo de casi mil años” (JAMES BETANCOURT, 2010, p. 62).

A comparação do material cerâmico da Loma Salvatierra com os materiais de outros sítios da região, sendo Lomas Velarde, Hernmarck, Masicito e Loma Alta de Casarabe, os três primeiros escavadas por Nordenskiöld e o último pela Misión Argentina, demonstrou que a cerâmica procedente destas escavações corresponde, ao menos, a uma das fases da sequência cerâmica proposta para Loma Salvatierra. Portanto, as ocupações dos montículos ocorreram de forma sincrônica. Já a cerâmica identificada como Velarde Inferior por Nordenskiöld na Loma Velarde apresentou elementos diferentes como a decoração modelada com representações zoomorfas e antropomorfas, associada por Lathrap (1970) ao estilo Barrancóide (JAMES BETANCOURT, 2010).

A apresentação de alguns contextos da Amazônia, do Brasil Central, do Pantanal de Cáceres e dos Llanos de Mojos, bem como dos principais modelos sobre as expansões dos povos na Amazônia, baseados em dados arqueológicos, etno-históricos, etnográficos e linguísticos, permite situar a região do Alto rio Madeira em relação às principais problemáticas da arqueologia. O rio Madeira, assim como o Guaporé, o Paraguai-Paraná, o Purús, Xingu e outros rios, certamente foi cenário de ocupações indígenas diversas ao longo da história pré-colonial da Amazônia e das terras baixas da América do Sul. 


\subsection{Arqueologia no Alto rio Madeira e seus afluentes e as hipóteses sobre a ocupação da região}

Em Rondônia, as pesquisas arqueológicas sistemáticas iniciam-se na década de 1970 através do Programa Paleoindígena (PROPA- MT-RO/1974-7), do Programa Nacional de Pesquisas Arqueológicas na Bacia Amazônica (PRONAPABA- RO-AM/ 1978-83), Programa Arqueológico de Rondônia (PAR/ SECEL-RO) e dos projetos de Arqueologia Preventiva da Usina Hidrelétrica de Samuel-RO, da UHE de Ji-Paraná-RO e da rodovia BR-429 Costa Marques/Presidente Médici-RO, todos coordenados pelo arqueólogo Eurico Miller. Este desenvolveu levantamentos ao longo do rio Madeira e seus principais afluentes, entre eles o rio Guaporé, um de seus formadores, o Ji-Paraná, Jamari, Jaciparaná, Aripuanã e Roosevelt, entre outros, realizando sondagens em alguns dos muitos sítios arqueológicos identificados, com datações do final do Pleistoceno até o período da colonização européia, elaborando as primeiras hipóteses de ocupação da região (MILLER 1983, 1992, 1999, 2009a, 2009b, 2013).

Desde as primeiras décadas do século XXI, tem aumentado o número de empreendimentos no estado de Rondônia, principalmente linhas de transmissão de energia e duas usinas hidrelétricas no rio Madeira, além de PCHs em rios do interior e uma ponte sobre o rio Madeira na cidade de Porto Velho. Em função dos projetos de arqueologia desenvolvidos no âmbito do licenciamento ambiental, aumentou muito o número de sítios encontrados nos últimos anos, apesar dos dados serem ainda pouco divulgados. Alguns sítios resgatados no Projeto de Arqueologia Preventiva na linha de transmissão Acre-Rondônia, foram abordados nas dissertações de Cruz (2008) e Zimpel (2009). Sítios arqueológicos escavados ao longo do rio Madeira no Projeto de Arqueologia Preventiva na área de intervenção da UHE Santo Antônio, Rondônia (SCIENTIA, 2008), foram abordados nas dissertações de Tizuka (2013) e Gomes (2013) e em projetos de mestrado em andamento como o de Pessoa (2014) e Costa (2013b), bem como em projetos de iniciação científica dos estudantes da Graduação de Arqueologia na Universidade Federal de Rondônia. Além disso, recentemente, o arqueólogo Eduardo Góes Neves iniciou pesquisas no estado de Rondônia ao longo do rio Madeira e seus afluentes, através do acadêmico denominado Projeto Alto Madeira (PALMA), cujos dados foram abordados na tese de Almeida (2013) e em projetos em andamento (SUÑER, 2010; SILVA, 2011; MONGELÓ, 2012; TRINDADE, 2012; ZIMPEL, 2013; PUGLIESE, 2013).

Uma síntese dos dados arqueológicos do estado de Rondônia presentes nos relatórios produzidos na década de 1980 foi elaborada por Cruz (2008) e Zimpel (2009). O primeiro 
autor sistematizou as fases, datas e características dos materiais em tabelas e as localizou em mapas (ver mapa 5), na ampla área que abrange a foz do Madeira com o Amazonas até o rio Guaporé. No Baixo rio Madeira e Aripuanã-Roosevelt, foram estabelecidas fases da tradição Inciso e Ponteada, Polícroma e Tupiguarani, além de fases não filiadas a tradições. No médio e alto curso do rio Madeira, entre a foz do Manicoré e a área do Beni-Mamoré, foram identificadas as fases Ribeirão (junto a Cachoeira do Ribeirão), Pederneiras (cachoeiras de Pederneiras, Paredão e Três Irmãos e no baixo rio Abunã), Curequetê (de contato, próximo à cachoeira das Pederneiras e da Cachoeira Três Irmãos), Jaciparaná (rio Jaciparaná) e a subtradição Jatuarana (no baixo, médio e alto Madeira). Ainda ocorre o sítio Serra da Muralha, a sudoeste da cachoeira de Pederneiras, a $9 \mathrm{~km}$ do rio Guaporé. Algumas fases foram definidas para o Ipixuna-Marmelos, sem tradição definida. Na bacia do rio Ji-Paraná, além das fases associadas à tradição Tupiguarani, ocorrem outras não filiadas a tradições. No rio Jamari foram estabelecidas fases pré-cerâmicas e as fases cerâmicas da Tradição Jamari. No rio Guaporé e seus tributários, foram identificas as fases cerâmicas Bacabal (no Pantanal do Guaporé), Poaia, Corumbiara e Pimenteiras. Sítios da fase Poaia ocorrem em abrigos sob rocha na cuesta do Chapadão do Parecis, baixo Guaporé, com datas entre 2.500 e 2.000 AP. Ainda, nos afluentes da margem direita do médio curso do Guaporé, foram identificadas as fases Machupo, Timbó, Tarioba, Boiuna e Xibói, sem muitas informações (CRUZ, 2008). Aqui, apresentaremos uma revisão dos artigos, dissertações e teses com dados sobre a região (MILLER 1983, 1992, 1999, 2009a, 2009b, 2013; CRUZ, 2008; ZIMPEL, 2009; NEVES, 2012; ALMEIDA, 2013), buscando contextualizar a área de pesquisa, com foco nas evidências das populações ceramistas.

A bacia do rio Madeira e seus afluentes foi ocupada desde a transição do Pleistoceno para o Holoceno por grupos de caçadores-coletores, sendo mais conhecidas as ocupações do complexo Dourado, em abrigos sob rocha como o MT-GU-01 Abrigo do Sol com datas de

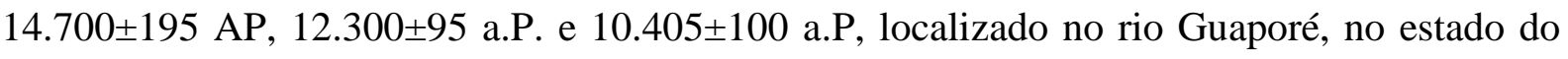
Mato Grosso próximo à divisa com Rondônia (MILLER, 1983; MEGGERS e MILLER, 2003). No estado de Rondônia, ocorrem ocupações durante todo o Holoceno, diferente de outras regiões da Amazônia onde há hiatos no Holoceno Médio. 


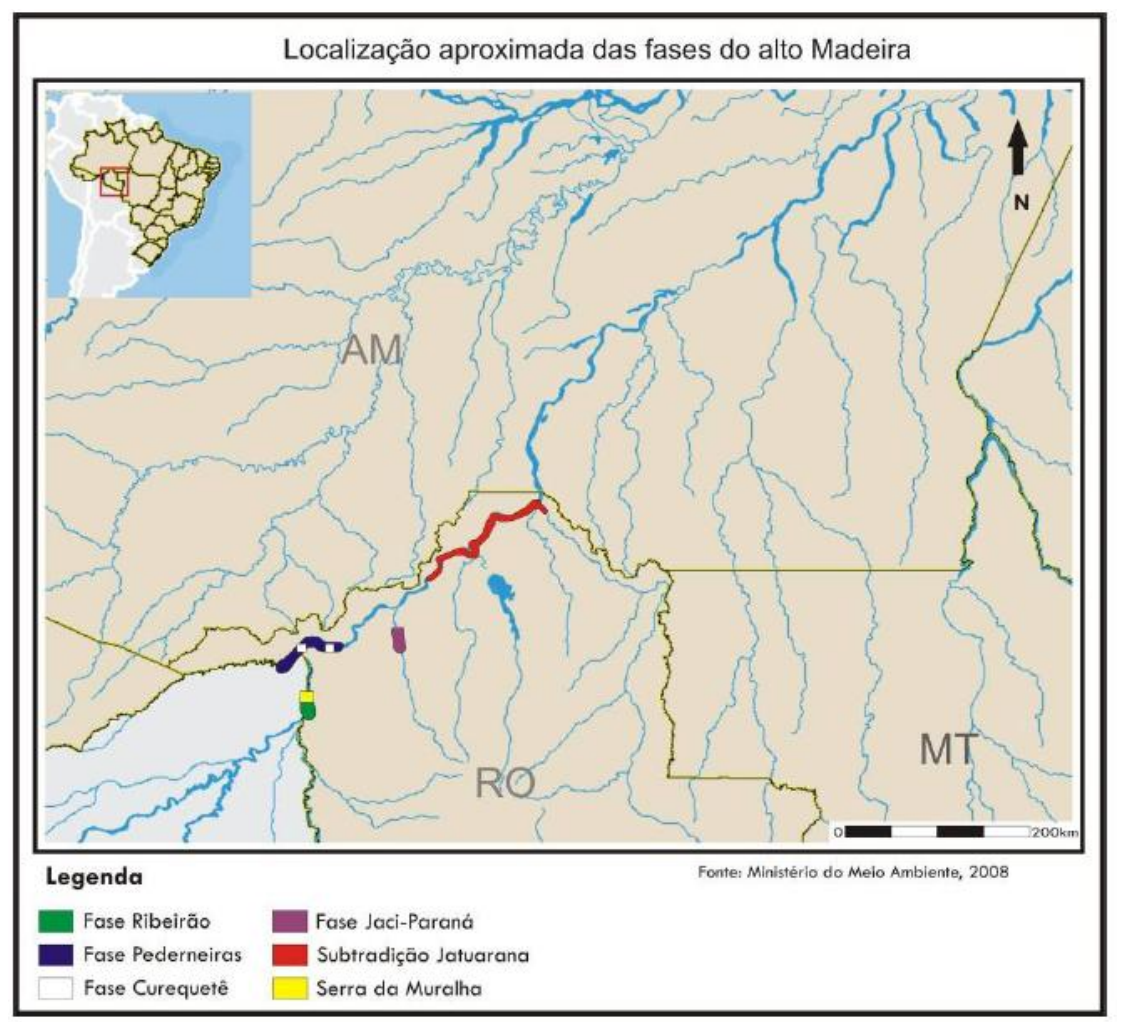

Mapa 5:localização das fases arqueológicas no Alto Madeira elaborado por Cruz (2008, p. 44).

No Pantanal do Guaporé, Miller (1983, 2009b, 2013) identificou ocupações das fases pré-cerâmicas Cupim e Sinimbu e a fase cerâmica Bacabal, enquanto no entorno noroeste ocorrem materiais das fases Pirizal (Tradição Borda Incisa), Tarioba e Muiratinga, e no Chapadão dos Parecis as fases Aguapé, Galera, Cajú, entre outras (MILLER, 2013). As ocupações da fase pré-ceramista Cupim foram identificadas nos sítios RO-PN-8 Monte Castelo e RO-PN-9, próximos ao rio Branco, no Pantanal do Guaporé, com datas entre 8.350 \pm 70 AP e $7.010 \pm 80$ AP (MILLER, 2009b). Os sambaquis do pantanal do Guaporé teriam sido construídos pelos pré-ceramistas da fase Sinimbu, e posteriormente pelos ceramistas da fase Bacabal. No sítio RO-PN-8 Monte Castelo, a ocupação Bacabal foi identificada nos últimos $220 \mathrm{~cm}$ do sambaqui, com presença de sedimentos com cerâmica, chão de casas e enterramento, sobre uma ocupação pré-ceramista Sinimbu, que, por sua vez, está sobre a ocupação da fase Cupim. No entorno do sambaqui, ocorre uma camada arqueológica de 10 a $25 \mathrm{~cm}$ com cerâmica da fase Bacabal. O Sambaqui é formado por conchas de moluscos gastrópodes de água doce acumulados pelas ocupações Sinimbu e Bacabal. Nesse sítio, foram evidenciadas vasilhas, suportes-de-panela, cachimbos e fragmentos modificados de cerâmica, e material lítico como lâminas-de-machado alisadas, plaquetas polidas com borda serrilhada, percutores, polidores, mãos-de-pilão alongadas e curtas, almofarizes, mós, núcleos, nódulos 
de laterita corante e artefatos em ossos e conchas bivalves. Foram obtidas dezoito datações radiocarbônicas para um corte feito no sambaqui (treze delas para a ocupação da fase cerâmica Bacabal) e quatro datações em três cortes na planície de inundação. As ocupações ceramistas Bacabal foram datadas entre ca. 4.055 a 700 AP., a fase Sinimbu entre 7.100 a 4.350 AP. e a fase Cupim com datas entre ca. 7.400 a 8.400 AP (MILLER, 2009b, 2013).

A cerâmica da fase Bacabal foi identificada não somente em sambaqui, mas também em planícies de inundação e em elevações ou ilhas florestadas. O sítio-habitação RO-PN-9 está localizado na ilha União, com forma elipsoide e uma ocupação da fase Bacabal entre 30 e $60 \mathrm{~cm}$ de profundidade e escassas evidências líticas pré-ceramistas da fase Cupim entre $90 \mathrm{e}$ $100 \mathrm{~cm}$. Além da cerâmica, foram evidenciados aglomerados de concha junto ao sedimento antropogênico e líticos como mão-de-pilão alongada, mó, almofariz, lasca, percutor e nódulo laterítico corante. O sítio RO-PN-12 é um pequeno sambaqui em ilha, e os sítios RO-PN-10, 11, 13, 14 e 15 seriam acampamentos de estiagem em planície de inundação. Foram obtidas duas datações radiocarbônicas para o sítio RO-PN-09, uma para o RO-PN-12 e outra para o RO-PN-13, situando suas ocupações entre 3.434 e $810 \pm 70$ a.P. (MILLER, 2009b).

Com a seriação de amostras cerâmicas de oito sítios (RO-PN-08 a RO-PN-15), Miller (2009b) apresentou algumas características deste material. Na pasta da cerâmica, ocorre cauixí, misturado a areia fina, concha moída ou caraipé e a técnica de confecção é a acordelada. Entre as decorações plásticas, ocorre o exciso em faixas horizontais em ziguezague, criando áreas triangulares rebaixadas por incisões finas paralelas; incisões largas, retas e paralelas; inciso hachurado; inciso reticulado; inciso e ponteado; e ponteado estampado dentado. Em alguns casos, as decorações plásticas estão associadas a banho vermelho e retoque preto. Em relação à forma das vasilhas, ocorrem bases do tipo convexa ou em calota, plana e côncava nas mesmas formas, arredondadas, plana carenada, côncava carenada e em pedestal incipiente. Foram identificadas 16 formas, algumas das quais tornam-se mais populares nos últimos períodos, como os assadores de beiju que sugerem a adoção do cultivo da mandioca. As culturas ceramistas mais recentes ocupam as margens do rio Guaporé, como as fases Pirizal, Corumbiara e Pimenteiras que aparecem a partir de 1.330 a.P. (Miller, 2009b). Em um primeiro momento, os ceramistas Bacabal possuiríam uma subsistência semelhante à da população Sinimbu, incluindo itens vegetais de raízes, frutos e sementes, gastrópodes, crustáceos, peixes e fauna terrestre; porém, por volta de 2.500 a.P., teriam adotado a agricultura incipiente da mandioca, indicada pela presença de terra preta em alguns sítios e fragmentos de alguns assadores de beiju, e interpretada pelo autor como uma 
influência das fases arqueológicas Pirizal e/ou Corumbiara do Guaporé ou da fase Massangana pré-cerâmica do rio Jamarí (MILLER, 2009b).

A cerâmica da fase Aguapé ocorre em sítios habitação a céu aberto e abrigo-sob-rocha, com presença de terra preta e assadores que indicariam a presença de agricultura de mandioca e semissedentarismo. Essa fase teria sido descoberta e registrada por Simões e Araujo-Costa (1978) e está presente em sítios do patamar superior do Chapadão dos Parecis, nos rios Guaritire ou Piolho (afluente do Guaporé), nas nascentes dos rios Camamarezinho e Buriti (afluentes do Juruena) e no rio Jaurú da Bacia do Paraguai. Possui data de 14C ca. 2.000 AP. (1.945 \$55 (SI-3744) no sítio MT-GU-8 Waioco), e também foi evidenciada no sítio MT-GU1: Abrigo do Sol. A decoração da cerâmica apresenta elementos como inciso lavrado ou raspado; raspado em baixo relevo (feito pós queima); grande variedade de setores combinando motivos em losangos, triângulos e retângulos, simples, ponteados, excisos, quadriculados, além de antropomórficos esquemáticos e naturalistas, com apliques, pernas e braços (MILLER, 2013).

A cerâmica da fase Galera ocorre em sítios habitação a céu aberto com cemitérios em abrigo-sob-rocha e canais ou túneis, ao longo do rio Galera e afluentes, no patamar superior e meia encosta do Chapadão dos Parecis, com uma data de 14C ca. 1.160 AP. [1.060 100 (SI3748) no sítio MT-GU-7 Galera 1. A presença de terra preta e ou assadores indicariam agricultura de mandioca e semissedentarismo. A decoração cerâmica apresenta incisões em linhas finas, com motivos horizontais e verticais em linhas retas; linhas inclinadas escalonadas; combinação de linhas retas e escalonadas em conjuntos espaçados entre si com gravados de aves ou arco raiado; losangos e meio-losangos alternados e contínuos com uma cruzeta puntiforme no centro; cruzeta simples e complexa; destaca-se o retoque branco sobre o inciso e os emblemas; ocorrem vasos antropomorfos, pesos-de-fuso e pendentes (MILLER, 2013).

No alto e médio Guaporé, foram identificados sítios das fases cerâmicas Corumbiara e Pimenteiras, ambas caracterizadas por sítios habitação e cemitério (presença de urnas funerárias), com aparentes trincheiras (taipas e valas). Segundo Miller (1983), as duas fases não possuem tradição determinada, por apresentarem elementos híbridos. Entretanto, “dentre as quatro tradições localizadas na Bacia Amazônica, as menores diferenças são quanto à tradição Incisa e Ponteada". As duas fases estendem-se aproximadamente entre A.D. 900 até 
1.746, ingressando nos tempos históricos até o deslocamento dos grupos indígenas devido à colonização (MILLER, 1983, p. 285).

No rio Jamari, afluente da margem direita do rio Madeira, foram identificados sítios acampamento de caçadores-coletores das fases Itapipoca e Pacatuba: a primeira com datas entre $8.320+-100$ e 6.970 +- 60 a.P. e a segunda entre 6.090 +-130 e 5.210 +-70 a.P. Acima dos sítios da fase Pacatuba, ocorrem os sítios-habitação da fase Massangana, com material lítico associado à terra preta, datados entre $4.780+-90$ e 2.640 +- 60 a.P. A terra preta associada a artefatos como pilões e mãos-de-pilão toscas, moedores impregnados de corante e pedras corante, lâminas de machado picotadas, lascadas, mal alisadas, pequenas, além das lascas de quartzo com microlascamentos do uso e raros raspadores, indica a existência de uma prática de agricultura e domesticação de plantas, em pleno Óptimum Climático (MILLER et al., 1992).

Sobre as ocupações da fase Massangana, ocorre a cerâmica da Tradição Jamari, com as fases Urucuri, Jamari, Cupuí e Matapi, datadas respectivamente em $2.500 \pm 90-2.230 \pm 50$; $2.130 \pm 140-420 \pm 50 ; 1.350 \pm 60$ AP; $420-230 \pm 80$. A cerâmica é caracterizada pela pasta pouco arenosa, com antiplástico de areia; caraipé; cauixí; cauixí e caraipé; o caraipé predomina na base da sequência, decrescendo e sendo suplantado no final pelo tempero de areia. A superfície não apresenta um acabamento esmerado e regular, e os tipos decorados são minoria, compostos pelo banho e engobo vermelho, e raros pintados em vermelho e preto sobre simples ou engobo branco. Os acabamentos plásticos são mais frequentes na porção antiga da sequência e compreendem o inciso, o ponteado, o roletado e o escovado, além de raros excisos e apliques zoo e antropomorfos. As formas das vasilhas mais abundantes são de contorno simples, como assadores, tigelas rasas em meia calota e hemisféricas profundas; vasos rasos, globulares, cônicos e carenados de pescoço e boca levemente constrita; ocorrem formas convexas como tigelas geminadas. Os lábios são arredondados e apontados (Miller, 1992). No rio Jamari, teria ocorrido uma sucessão cultural das ocupações dos caçadores coletores pré-ceramistas (fases Itapipoca e Pacatuba) aos pré-ceramistas agricultores incipientes (fase Massangana), aos ceramistas agrícolas (Tradição Jamari), aos neobrasileiros e aos históricos (MILLER et al, 1992; MILLER 1992, 1999).

No médio curso do Rio Aripuanã, estado do Mato Grosso e no alto e médio curso do rio Ji-Paraná, em pesquisas do PRONAPABA e do projeto de arqueologia da UHE Ji-Paraná, Eurico Miller identificou cerâmicas com características da tradição Tupiguarani, 
estabelecendo oito fases cerâmicas associadas a esta tradição (CRUZ, 2008). Miller (2009a) diz ter encontrado mais de uma centena de sítios, com terra preta e cerâmica corrugada e pintada, próximos ao rio Ji-Paraná, desde a jusante da cidade de Jiparaná, até os baixos cursos dos rios Pimenta Bueno e Comemoração, a maioria deles em terra firme e próximos aos rios na confluência com igarapés, com datações entre 5.000 anos e 400 anos antes do presente: o sítio RO-JI-15 Urupá possui duas datações recuadas, de 5.070 +-60 a.P. e 4.230 +-100 a.P.. O sítio RO-JI-23 Ipiranga apresentou datas de 3.760 +-70 a.P., 2.340 +- 70 a.P e 480 +- 60 a.P., e o sítio RO-JI-17 Nova Vida uma data de 3.990 +- 70 a.P. Nos rios Aripuanã, Roosevelt, Madeirinha e alto rio Marmelos, também ocorrem sítios com cerâmica corrugada e pintada, além de cerâmicas de tradições não determinadas. As decorações como corrugado complicado e pintura diretamente sobre a superfície ou sobre engobo branco e/ou vermelho e presença de urnas funerárias são os elementos que caracterizam o que o autor denominou tradição ProtoTupiguarani (figura 2) (MILLER, 2009, 2013).
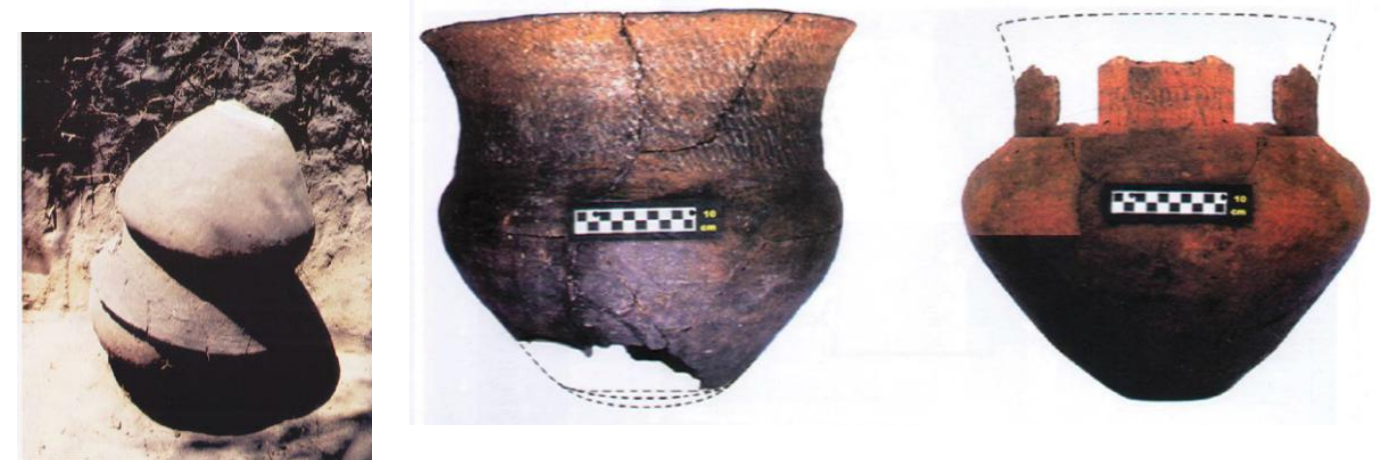

Figura 2: vasilhas da tradição Tupi-Guarani escavadas em Rondônia (MILLER, 2009a, p. 125 e 127).

Em ambas as margens do médio e alto rio Madeira, desde a confluência do rio Marmelos à jusante até as primeiras cachoeiras e corredeiras a montante, foram identificados mais de 32 sítios habitação da Subtradição Jatuarana, Tradição Polícroma da Amazônia, associados a sítios oficina lítica e um sítio cemitério. Os sítios habitação teriam forma elipsoide a retanguloide, indicada pela presença das palmeiras Attalea Excelsa (urucurí) e Pyrenoglyphis marajá (marajá), com terra preta da superfície até $210 \mathrm{~cm}$, estando os sítios maiores e mais complexos localizados próximos às cachoeiras, resultantes da concentração sazonal de populações humanas em decorrência da migração de peixes e quelônios, como na cachoeira de Teotônio (sítios RO JP 01 Teotônio e RO JP 03 Porto Seguro), e a jusante da Cachoeira de Santo Antônio na margem direita, o sítio RO-PV-19 Igapó 1. Foram obtidas as

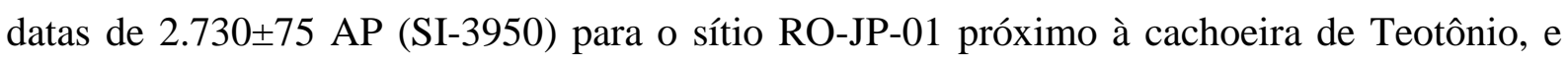

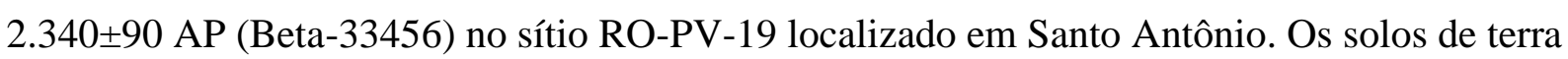


preta dos sítios habitação seriam decorrentes de reocupações contínuas, e de terra escura por reocupações esporádicas (MILLER, 1992, 1999). Miller diz que os sítios RO-JP-01 Teotônio e RO-PV-19 Igapó 1 não possuem evidências de pré-ceramistas nas camadas inferiores até o embasamento rochoso, e no sítio Teotônio a amostra datada foi coletada a $30 \mathrm{~cm}$ acima da base da Terra Preta (diretamente sobre rocha granito-laterítica) (MILLER, 1992, p. 224).

Na Subtradição Jatuarana, a cerâmica apresenta pasta pouco arenosa com temperos de caraipé e carvão, caraipé, caraipé e cauixí, cauixí, e areia fina. Apresenta tratamento de superfície bem elaborado, seja alisado, polido, brunido ou envernizado. $\mathrm{Na}$ decoração plástica, ocorre o exciso raspado, inciso dupla linha, ponteado, ponteado arrastado, ungulado, pinçado, serrungulado, acanalado fino, estampado e o carimbado, sendo estes isolados ou combinados entre si, com e sem engobo, monocromia, policromia, associados ou não a apliques zoomórficos, antropomórficos, flanges, alças, asas e outros. Ocorre monocromia em engobo vermelho, e policromias sobre engobo branco ou não, com as cores preta, marrom, magenta, vermelho, laranja, amarelo e creme, associadas ou não à decoração plástica. A decoração apresenta motivos em linhas, faixas e campos curvilíneos, geométricos, zoomórficos e antropomórficos, combinados ou não entre si. Ocorrem decorações plásticas como o inciso, exciso raspado e acanalado fino, retocadas ou preenchidas com branco, amarelo, laranja e vermelho (MILLER, 1992).

Entre as formas das vasilhas cerâmicas da Subtradição Jatuarana, ocorrem tigelas de planta simples circular ou curvilínea, rasas e profundas, com contorno simples a composto, com diâmetro entre 10 e $36 \mathrm{~cm}$, com bordas introvertidas, diretas, extrovertidas e dobradas tipo prato; assadores de beiju, de 30 a 45 cm de diâmetro; vasos rasos e profundos de planta circular, simples, globulares, hemisféricos, cilíndricos, carenados e compostos, de 9 a56 cm de diâmetro; além de urnas funerárias antropomórficas de até $69 \mathrm{~cm}$ de altura, com pescoço constrito; bordas expandidas e introvertidas a verticais, diretas e extrovertidas, lábios arredondados, planos, apontados e mistos, bases plana, arredondada, anelar e em pedestal. Além do vasilhame, ocorrem contas vazadas e arredondadas, torneadores sobre cacos com canaletas em meia-cana; porta-vaso com pedestal bicônico; e pesos-de-fuso arredondados de caco de cerâmica. O material lítico é composto por lâminas de machado, simétricas e polidas e de formas variadas. Foram encontrados ainda materiais em resina como adornos cilíndricos (MILLER, 1992). 
Miller (1992) identificou algumas mudanças significativas na cerâmica da Subtradição Jatuarana através do tempo: maior popularidade das técnicas plásticas no inicio da sequência e das técnicas crômicas no final e o aumento da popularidade das urnas funerárias antropomórficas. Evidenciou a maior popularidade das flanges e presença do acanalado tipo subtradição Guarita no inferior da sequência, substituído pelo acanalado fino típico desta subtradição na porção mediana-superior. Miller (2013) diz que quanto mais antiga é a cerâmica, mais é elaborada e diversificada. Segundo o autor, esta subtradição se estende desde o baixo rio Mamoré (sítio RO-GM-10 em Guajará Mirim-RO) até desembocadura do rio Madeira com o rio Amazonas e acredita que a origem desta cerâmica possa estar para além do Mamoré, especulativamente na bacia do alto Beni, ou do Madre de Dios. Além disso, acredita que, em toda esta extensão, a cerâmica já surge pronta, e deve haver variações que deveriam ser divididas em fases com trabalhos mais exaustivos (MILLER, 2013).

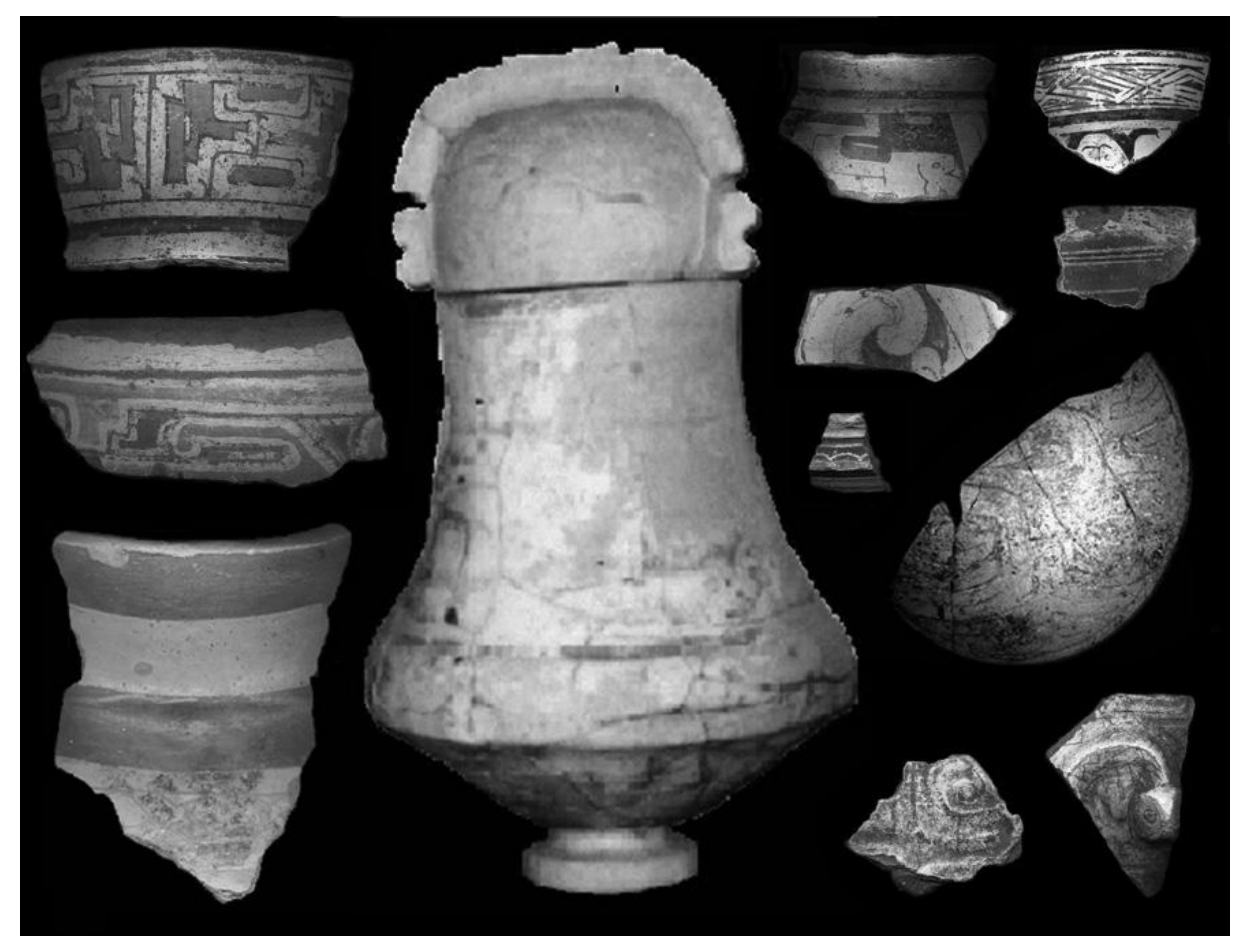

Figura 3: cerâmica da Subtradição Jatuarana, Tradição Polícroma (MILLER, 2013, p. 367).

Acima das cachoeiras de Teotônio e Morrinhos, no Alto rio Madeira, não há registro de sítios nas publicações do arqueólogo Eurico Miller. Entretanto, no baixo Jaciparaná, afluente da margem direita deste trecho do rio, o arqueólogo encontrou dois sítios-habitação, com terra escura de $30 \mathrm{~cm}$ de profundidade, com material cerâmico da fase Jaciparaná, de tradição desconhecida. A pasta da cerâmica é arenosa, com caraipé; as vasilhas não são decoradas, e possuem formas simples: tigelas rasas em meia calota (10 a 34 cm de diâmetro); 
tigelas e vasos profundos e globulares, de bordas inclinadas externamente e diretas a introvertidas, de lábio arredondado (15 a $53 \mathrm{~cm}$ de diâmetro), e os vasos carenados com pescoço constrito baixo e alto, bordas extrovertidas levemente reforçadas externamente e lábios apontados (16 a $31 \mathrm{~cm}$ de diâmetro). No Baixo Abunã, afluente da margem esquerda do Alto rio Madeira, foram localizados dois sítios-habitação com terra preta de $40 \mathrm{~cm}$ de profundidade, cuja cerâmica apresenta pasta com tempero de caraipé e areia fina, e as vasilhas possuem formas variadas, como as tigelas rasas em meia calota com bordas diretas e extrovertidas e lábios arredondados ( 8 a $36 \mathrm{~cm}$ de diâmetro) e os vasos rasos e profundos hemisféricos, globulares e carenados com pescoço constrito, bordas extrovertidas, lábios rredondados e fundos boleados (10 a $46 \mathrm{~cm}$ de diâmetro); algumas vasilhas são decoradas com incisões retilíneas e ponteado linear. Estes sítios, associados a sítios-oficina lítica e sítios com arte rupestre ou petróglifos, foram associados à fase Pederneiras (MILLER, 1992, p. 225226).

A identificação dos sítios arqueológicos e a seriação cerâmica embasaram não somente a definição de fases e de uma subtradição no rio Madeira e seus afluentes por Miller (1983, 1992, 1999, 2009a, 2009b, 2013), mas também a elaboração de algumas hipóteses sobre a ocupação da região que teria iniciado na transição do Pleistoceno para o Holoceno, conforme fica evidente no texto apresentado acima. Para Miller (1999), os sítios da fase Massangana identificados no rio Jamari representariam uma fase inicial do período Formativo no Sudoeste Amazônico, caracterizada pelo início do manejo de plantas e da agricultura pelos caçadores-coletores, antes de adquirirem a cerâmica, resultando nos pacotes arqueológicos com lítico em terra preta antropogênica, e introdução na região de palmeiras como o Urucuri. A introdução da cerâmica da fase Bacabal no pantanal do Guaporé representaria uma segunda fase cuja população, numerosa e semi sedentária, teria explorado a proteína de moluscos e praticado a agricultura. Uma terceira fase seria representada pelas populações da Subtradição Jatuarana, ocupando o rio Madeira e baixo curso de seus afluentes, até onde ocorriam a tartaruga, o pirarucu e o peixe boi. Ao longo do rio Madeira, a renovação dos solos pelas cheias anuais e a abundante fauna aquática das cachoeiras permitiriam uma intensa e constante reocupação de sítios-habitação, representados pelas espessas e densas camadas de terras pretas antropogênicas com cerâmica (MILLER, 1999).

Além disso, Miller (2009a, 2013) acredita que a cerâmica Bacabal não foi inventada localmente, mas teria se difundido do litoral da Colômbia e da Venezuela, pelos Llanos da Bolívia até o Pantanal do Guaporé, através do Ucayali, em função das semelhanças da 
decoração desta cerâmica com as da fase Valdívia (5.600 a.P.). Outras cerâmicas encontradas em Rondônia e Mato Grosso teriam origem a partir dessa difusão, como a tradição Jamarí no alto rio Madeira (2.500 a.P.) e as fases Aguapé e Galera no Guaporé (MILLER, 2009a, 2013). $\mathrm{Na}$ fase Bacabal, além das técnicas e motivos decorativos incisos e raspados semelhantes ao Hachurado Zonado da tradição Valdívia, ocorrem também as vasilhas em forma de bote, que

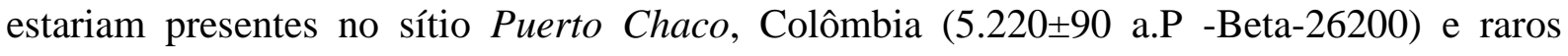
exemplares em Valdívia (MILLER, 2013). Já no Alto Ji-Paraná, região compreendida como a terra natal do Tronco Tupi (RODRIGUES 1958, 1964, 1986), os sítios da chamada tradição Proto-Tupiguarani possuiríam um desenvolvimento local (Período Formativo Antigo Independente do Proto-Tupiguarani), ocorrido em função das condições propiciadas pelo aquífero Parecis no período semiárido, sendo antecessor da Tradição Tupiguarani da faixa costeira (MILLER, 2013). O autor acredita que, da mesma forma que há uma correlação válida entre os dados etno-históricos, linguísticos e arqueológicos dos falantes Tupi-Guarani na costa atlântica do Brasil, no Alto Jí-Paraná, também existiria um vínculo entre os dados arqueológicos, da linguística histórica e as fontes etnográficas (MILLER, 2013).

Miller (1983, 1992, 1999, 2009a) buscou associar as cerâmicas encontradas às diferentes famílias do Tronco Tupi: inicialmente atribuiu à fase Pimenteiras a falantes da língua Pauserna, da família Tupi-Guarani; a fase Corumbiara a falantes da língua Guarátegaya (Amniape e Meken), da família linguística Tupari. Finalmente, afirma que a terra natal da cerâmica corrugada e pintada estaria na mesma área geográfica da terra natal do tronco linguístico Tupi, e que os grupos falantes das diferentes famílias linguísticas deste tronco teriam se dispersado a partir da área do Ji-Paraná devido ao adensamento populacional nos intervalos de semiaridez, a exemplo da que ocorreu para o sul e sudeste, onde são encontradas as cerâmicas da tradição Tupiguarani (MILLER, 2009). O pesquisador utilizou como suporte para tais associações as hipóteses sobre o centro de dispersão dos grupos falantes de línguas do tronco Tupi desenvolvidas por Aryon Rodrigues (1958 1964, 1984) e Migliazza (1982) e, sobretudo, nas fontes históricas dos séculos XVIII, XIX e XX, momento em que as dinâmicas populacionais eram impulsionadas também pelos fatores da colonização europeia.

Para Miller (1992) as culturas de nível complexo das cachoeiras do rio Madeira exerceriam influências sobre as culturas simples dos afluentes, como no caso do rio Jamari, onde a população Jatuarana penetrava nos períodos de estiagens sazonais ou ocasionais à procura da tartaruga na cachoeira de Samuel, deixando influências cerâmicas, como os tipos decorados plásticos (inciso e exciso) e pintados, e em formas de tigelas, bordas e lábio 
(apontado), e na morfologia e dimensões de algumas lâminas de machado, nos sítios RO-PV89 São Carlos e no RO-PV-11A Samuel. No caso da fase Pederneiras, no alto rio Madeira, esta teria recebido influência de alguma cultura mais complexa, ainda desconhecida (1992, p. 225). No rio Guaporé, as cerâmicas da fase Corumbiara e Pimenteiras teriam influências da área Moxo-Chiquitos, com a decoração cerâmica com fisionomias de Jaguar (e humana), traço mítico e característico do culto Moxo, tidos como de padrão subandino (MILLER, 1983).

Portanto, as interpretações de Miller (1983, 1992, 1999, 2009a, 2009b, 2013) para as ocupações do Sudoeste Amazônico corroboram com os modelos de Steward (1948), Meggers (1957, 1987) e Meggers e Evans (1954, 1961), carregadas de premissas difusionistas e deterministas ambientais. Da mesma forma, a definição de fases, a partir da distribuição dos tipos de antiplástico e de decorações cerâmicas no pacote arqueológico, não reflete a variação e variabilidade nos conjuntos artefatuais. Como vimos, estudos da Ecologia Histórica e da variabilidade artefatual fornecem novos elementos para uma visão alternativa da história indígena na Amazônia, destacando o papel dos agentes de diferentes identidades culturais no manejo e domesticação das paisagens, formação das terras pretas arqueológicas e na invenção, reprodução e ressignificação de tradições tecnológicas.

No Alto curso do rio Ji-Paraná, os trabalhos de Cruz (2008) e Zimpel (2009) trouxeram novos elementos para a discussão da expansão dos grupos Tupi. Cruz (2008) analisou o material arqueológico de alguns sítios do Alto rio Ji-Paraná e acredita ser possível que atributos da cerâmica Tupi da região, como o corrugado, policromia e morfologia (panela e caçarola), sejam atributos de uma cerâmica Proto- Tupiguarani que de lá teria partido para as áreas já conhecidas, tanto na Amazônia como fora dela. Entretanto, atributos clássicos desta tradição estão ausentes, como o tempero de caco moído, as bordas reforçadas e as formas pintadas, como o cambuchí, o que leva o autor a concluir que "ou estes atributos desapareceram quando as populações alcançaram o curso do Ji-Paraná, ou foram adquiridos em momento posterior ao desenvolvimento local, sendo a segunda hipótese mais provável" (CRUZ, 2008, p. 165). O autor lembra ainda que o contexto linguístico do sudoeste Amazônico vai além da problemática Tupi, estando presentes na região outras línguas como a Arawak, Pano, Takana e Nambikwara.

Zimpel (2009) apresenta dados em relação à cerâmica do sítio Encontro, na mesma região, para o qual foram obtidas datas radiocarbônicas entre $4.255 \pm 185$ e $4.425 \pm 200$ AP. As análises dos valores dos Isótopos do carbono (12C, 13C) obtidos no resultado da datação 
radiocarbônica (14C) da matéria orgânica do solo, indicam a ocorrência de floresta neste período (4.400- 4.200 anos AP), portanto com um clima úmido relacionado ao optimum climaticum, iniciado na área a partir de 5.500 anos AP. Na análise da cerâmica, observou características típicas da cerâmica Tupi-Guarani, como os vasos roletados, formas extrovertidas, recorrência de potes com 'ombros', carenas, policromia, engobo vermelho e decorações corrugadas predominantes entre as plásticas. Para o autor, a ocorrência desta cerâmica corrugada tão antiga no sudoeste Amazônico pode auxiliar na problemática da origem expansão dos grupos Tupi, tendo em vista que os dados linguísticos apontam as primeiras expansões Tupi a partir de um local próximo a Ji-Paraná, há aproximadamente 5.000 anos AP (ZIMPEL, 2009, p. 161).

No Alto rio Madeira, as pesquisas arqueológicas na área da UHE Jirau indicam a presença de, ao menos, três grupos ceramistas distintos, representados pela cerâmica pintada (figuras 6 e 7), com decoração plástica (figura 4) e não decorada (figura 5) (MOUTINHO E ROBHRAN-GONZALEZ, 2010). Segundo os autores, há pelo menos três mil anos o rio Madeira passou a ser ocupado por grupos indígenas essencialmente agricultores, com aldeias grandes e mais estáveis e presença de sepultamentos primários e secundários em grandes urnas funerárias decoradas com pintura. Além da cerâmica, ocorrem muitos artefatos líticos como as lâminas de machado de diferentes tamanhos e formatos (MOUTINHO e ROBHRAN-GONZALEZ, 2010).

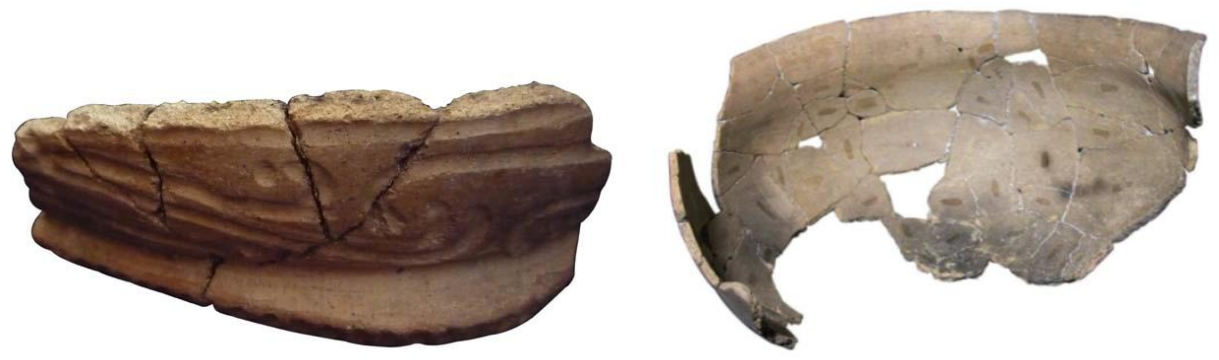

Figuras 4 e 5: cerâmicas escavadas na área de intervenção da UHE Jirau (MOUTINHO e ROBHRANGONZALEZ, 2010, p. 58 e 59).
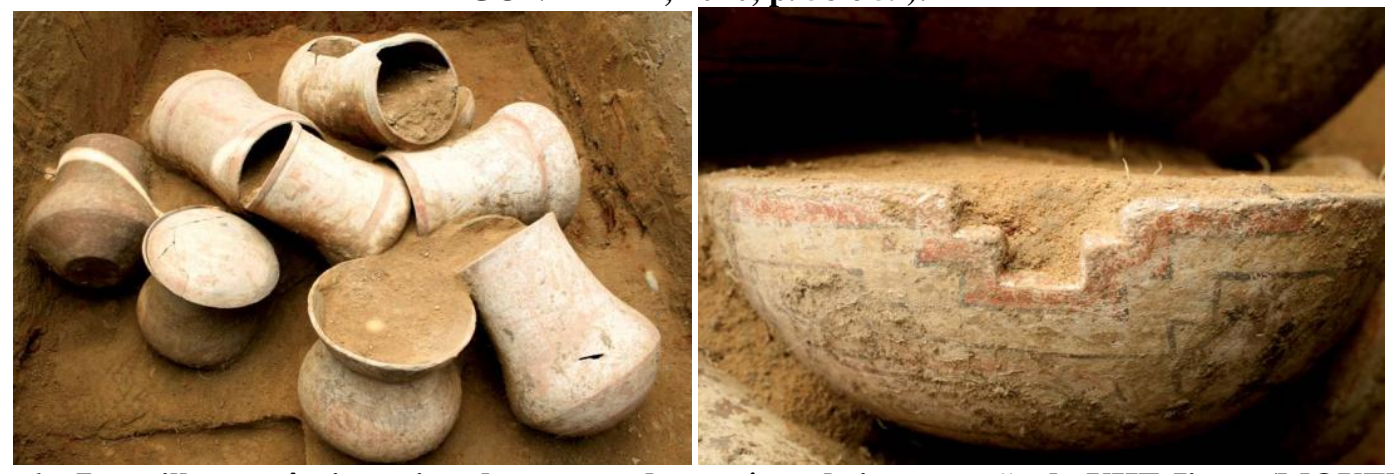

Figura 6 e 7: vasilhas cerâmicas pintadas, escavadas na área de intervenção da UHE Jirau. (MOUTINHO e ROBHRAN-GONZALEZ, 2010, p. 61 e 62) 
Almeida (2013) abordou cinco sítios arqueológicos na sua tese de doutorado, sendo dois deles próximos ao rio Madeira (sítio Itapirema em São Carlos e Teotônio junto à cachoeira homânima), dois no baixo rio Jamari (sítio Associação Calderita e Jacarezinho) e o sítio Nova Vida a poucos quilômetros do rio Madeira, em um meandro abandonado desse rio. Através da comparação das cerâmicas e dos contextos evidenciados nesses sítios, o autor concluiu que o sítio Jacarezinho (datações de $660 \pm 40$ AP, $860 \pm 40$ AP e $980 \pm 40$ AP), cujo material não apresenta pintura e raras incisões, pertence à Tradição Jamari, enquanto os sítios Associação Calderita e Itapirema (o primeiro com datações de $620 \pm 40$ AP, $940 \pm 40$ AP e

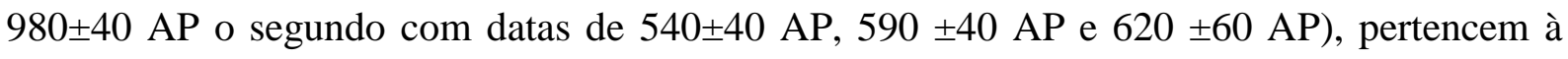
Subtradição Jatuarana da Tradição Polícroma da Amazônia. O sítio Nova Vida, que possui a

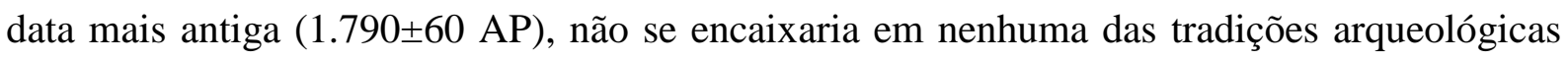
da região, possuindo baixa frequência de material cerâmico bastante erodido, e o sítio Teotônio apresentou uma ocupação pré-ceramista com terra preta datada em $3.170 \pm 30$ AP e ocupações ceramistas com datas de $1.550 \pm 30$ AP e $1.250 \pm 30$ AP, sendo a primeira relacionada a uma cerâmica mais antiga (pré-Jatuarana) e a segunda possivelmente a uma ocupação Jatuarana da Tradição Polícroma. O autor acredita que a datação obtida por Miller (1992) de 2.730 75 AP para esse sítio seja relacionada à ocupação pré-ceramista e não à Subtradição Jatuarana (ALMEIDA, 2013, p. 206).

Uma contribuição importante do trabalho de Almeida (2013) é a caracterização da cerâmica da Tradição Polícroma no rio Madeira. A cerâmica do sítio Itapirema, com uma densa ocupação desde o século XIII até o século XVII, seria a mais elaborada (em relação à forma e à decoração), sendo comuns as bordas com reforço (30\%), lábios arredondados (53\%) e planos (32\%) e algumas bordas recortadas; bases predominantemente côncavas, mas também ocorrem as planas; tratamentos plásticos em grande quantidade, porém com pequena variedade (predominam incisos finos e largos/acanalados, com exceção de um digitado e um filete aplicado), na face interna das bordas extrovertidas com ponto angular ou flanges (se diferenciam das incisões da cerâmica antiga por serem mais regulares); decoração pintada frequente, principalmente nas cores vermelha e branca ou somente vermelha; uma provável representação de uma cabeça zoomórfica com incisões e pintura vermelha e branca; e uma possível forma de cálice ou tigela com pedestal para o consumo de fermentados. No sítio Itapirema, predomina o antiplástico de cauixí (80\% dos fragmentos), enquanto no Associação Calderita o caraipé foi praticamente o único antiplástico identificado. No sítio Associação Calderita, ocupado duas vezes pelo mesmo grupo, chama atenção a grande quantidade de 
fragmentos com engobo vermelho, alguns deles com fuligem, e a presença de poucos fragmentos com pintura. Cabe ressaltar que ambos os sítios da Tradição Polícroma apresentam montículos (Itapirema e Associação Calderita), no primeiro deles possivelmente construídos para elevar as áreas de habitação em relação ao entorno alagável (ALMEIDA, 2013).

Já no sítio Jacarezinho, atribuído à Tradição Jamari, chama à atenção a presença de uma asa e duas peças arredondadas (recicladas), bem como o esmerado alisamento das vasilhas, ausência de decoração pintada e raros fragmentos com incisões, além da alta frequência de fuligem. Esse sítio também teria sido ocupado por um único grupo em duas ocasiões. No sítio Teotônio, foi identificada uma ocupação cerâmica mais antiga (préJatuarana), que se diferencia da Jatuarana pela presença de sequências de pequenos entalhados e decorações serrunguladas na face externa das vasilhas, às vezes delimitando ângulos na parede, pela espessura e alinhamento irregulares das incisões e acanalados, diferente das regulares e bem executadas da Jatuarana, além do predomínio de pasta apresentando apenas elementos minerais. Além disso, Almeida (2013) teve acesso ao material de uma unidade escavada por Eurico Miller nesse sítio, identificando, nos níveis mais profundos, elementos plásticos muito mais variados, incluindo corrugados, serrungulados, ungulados, escovados, ponteados, entalhados, filetes aplicados, associados a fragmentos com pintura policrômica e incisões na face interna da borda. No sítio Nova Vida, as incisões também são irregulares, assim como o material mais antigo do sítio Teotônio. No material decorado Jatuarana dos sítios Teotônio, Itapirema e Associação Calderita, os motivos incisos eram executados preferencialmente na face interna das bordas ou flanges enquanto os motivos pintados predominam na face externa das vasilhas. Observou-se ainda que, no sítio Itapirema, os motivos pintados e incisos eram mais finos que no Teotônio. Esses três sítios são os únicos que apresentam pintura vermelha e branca (vermelha sobre branca e branca sobre vermelha), intercalando linhas finas e espessas (faixas) e uso de pigmento mais escuro ou incisões para delimitar faixas. No sítio Teotônio, a anàlise da cerâmica evidenciou uma grande variabilidade (principalmente dos tratamentos de superfície), com uma mistura que representa uma heterogeneidade de cenários (ALMEIDA, 2013).

Segundo Almeida (2013, p. 316), a comparação entre todos os sítios evidenciou um quadro complexo, não havendo um sítio extremamente semelhante ao outro, indicando uma intensa mistura de populações, informações e estilos cerâmicos, possivelmente devido a um processo de redes de trocas. Tendo isso em vista, o autor elabora duas hipóteses para a 
história pré-colonial dos grupos ceramistas do Alto Madeira. De acordo com a primeira delas, o sítio Teotônio, por estar localizado em um lugar estratégico que é uma cachoeira, seria um núcleo ou entroncamento na rede de caminhos aquáticos e terrestres amazônicos, um lugar para a realização de trocas comerciais, rituais festivos de iniciação, troca de mulheres, alianças políticas ou festas com bebedeiras. A presença de determinados elementos estilísticos exógenos seria decorrente da troca de vasilhas cerâmicas como presentes, ou decorrentes do contato e troca verbal entre oleiras de diferentes grupos, caracterizada como uma transmissão horizontal de elementos cerâmicos. Assim, a ocupação no Alto Madeira seria caracterizada como um padrão multiétnico, hipótese que, segundo o autor, só poderá ser verificada com o refinamento da cronologia para outros sítios da região (ALMEIDA, 2013, p. 298).

A segunda hipótese aborda a diversidade do sítio Teotônio como decorrente de uma imensa variabilidade trazida de fora por um dos grupos que habitou o sítio, mais do que de trocas em redes de comércio. Esta hipótese explicaria o surgimento da Tradição Polícroma no alto Madeira: grupos ceramistas Arawak, portadores de uma cerâmica policrômica antiga (cerâmica Pocó), teriam subido o rio Madeira e ocupado a região; os grupos autóctones (falantes do tronco Tupi) teriam entrado em contato com estes grupos alóctones, do qual resultou a cerâmica da Tradição Polícroma mais antiga da Amazônia, que posteriormente teria descido o rio, com uma proposta mais bélica do que amistosa. Portanto, de acordo com esta segunda hipótese, a cerâmica policrômica antiga (Inciso Pintada) teria se transformado na Jatuarana (Polícroma) através da interação entre os grupos. A nova cerâmica seria mais simples (com menos atributos) do que o da antiga cerâmica policrômica (Pocó), porém mais sofisticada (com mais atributos) do que aquelas das antigas tradições ceramistas locais. Além disso, acredita que o surgimento de estilos a partir de outros também poderia ser resultado de processos envolvendo redes de trocas (econômicas e simbólicas) no alto Madeira, sendo esta uma região caracterizada por um grande mosaico cultural no período pré-colonial, tanto cronológica quanto espacialmente (ALMEIDA, 2013, p. 310-312).

Segundo o autor, independente de qual hipótese seja mais coerente, elas remetem a um padrão de ocupação de grupos de língua Arawak na região, representada pelas cerâmicas Inciso-Pintada do sítio Teotônio (semelhantes à Saladóide no Orinoco e Pocó na Amazônia Central), e Inciso-Modelada no Guaporé (semelhantes a Barrancóide do Orinoco e Manacapuru da Amazônia Central). Além disso, o duo Arawak no Alto Madeira poderia ser representado pela presença de cerâmica Inciso-Pintada nas cachoeiras de jusante e a IncisoModelada nas cachoeiras de montante. Os Arawak seriam, portanto, elementos-chave nestas 
redes de relações e trocas com os grupos do entorno, a exemplo dos contextos do alto rio Negro e do alto Xingu. No alto rio Madeira, os falantes do tronco Tupi teriam importante papel no núcleo regional, tendo em vista a histórica ocupação na região desde 3.000 a.C. Apesar de acreditar que as semelhanças entre as cerâmicas Tupi-Guarani e da Tradição Polícroma da Amazônia sejam resultado de contatos em diferentes locais e momentos, com uma vasta rede pan-amazônica, o autor não exclui a possibilidade da TPA estar relacionada a grupos de língua Tupi. E se houve uma dispersão de grupos da Tradição Polícroma a partir do Alto rio Madeira, ela teria sido extremamente rápida, em data próxima a 700 d.C., e não como uma expansão linear e gradativa decorrente de um grande e rápido crescimento populacional (ALMEIDA, 2013).

Ao fazer uma revisão das fases e tradições estabelecidas por Eurico Miller, Almeida (2013) chega a algumas conclusões sobre estas classificações, entre elas: 1) a Tradição Jamari foi corretamente desvencilhada da Subtradição Jatuarana, pois não possui um antecedente comum, mas apenas eventuais relações entre grupos geograficamente próximos com elementos Jatuarana em alguns sítios Jamari; 2) O termo Subtradição foi adequadamente utilizado por Miller na descrição da Subtradição Jatuarana do alto Madeira, pois foi identificada em sítios localizados a mais de $500 \mathrm{~km}$ ao longo do rio Madeira, e pertence à Tradição Polícroma da Amazônia que possui distribuição pan-Amazônica; 3) na área jusante das últimas cachoeiras do alto rio Madeira, o predomínio da Subtradição Jatuarana não ocorreu de forma homogênea, tendo em vista que o sítio Nova Vida não pode ser inserido nessa Tradição; 4) é recomendável não distinguir as fases da Tradição Jamari, anteriormente definidas em função de uma variabilidade cronológica. 5) no Guaporé, possivelmente a fase Pimenteira não existe, pois os elementos que a compõem pertencem à fase Corumbiara, e atributos da cerâmica desta última são semelhantes aos complexos cerâmicos do alto Guaporé; 6) a cerâmica do Guaporé apresenta decorações inciso modeladas tipicamente Arawak; 7) No rio Jiparaná, os dados apresentados até o momento são coerentes com a hipótese linguística da terra natal dos Tupi no sudoeste Amazônico, porém estão longe de indicar que de fato se trata de uma cerâmica Tupi-Guarani, além deste ser apenas um entre muitos outros estilos cerâmicos encontrados neste rio.

Os dados obtidos nos últimos anos no curso do rio Madeira, bem como em alguns de seus afluentes (CRUZ, 2008; ZIMPEL, 2009; ALMEIDA, 2013, MORAES, 2013), permitiram avançar na discussão sobre a expansão dos grupos produtores da cerâmica da Tradição Polícroma da Amazônia e da cerâmica Tupi-guarani na Amazônia. Primeiramente, em relação às ocupações Tupi registradas na Amazônia, Cruz (2008, p. 157) observa que 
estão em áreas distantes dos cursos mais volumosos, nos rios Tocantins, Xingu, Aripuanã e JiParaná. Porém, ressaltou o autor, se as cerâmicas antigas do rio Madeira (subtradição Jatuarana) estiverem relacionadas às ocupações Tupi, a ideia da preferência pelas cabeceiras seria errônea. Sendo assim, "não é possível chamar a cerâmica arqueológica, principalmente encontrada na Amazônia, onde existe um grande mosaico linguístico, de Tupi-Guarani (hifenizado), associando-a a apenas uma das nove famílias linguísticas" (CRUZ, 2008, p. 162).

Almeida (2008, 2013), a partir do estudo dos vestígios arqueológicos dos grupos que habitavam áreas de terra firme na região sudeste da Amazônia desde o início da era cristã e da comparação entre os atributos dessa cerâmica (fase Tauarí) com a descrição dos atributos das subtradições Tupinambá e Guarani, percebeu que as cerâmicas possuem muitas semelhanças, embora a variabilidade seja grande, e denominou esta de Subtradição Tupinambá da Amazônia. Essa subtradição estaria ligada aos grupos falantes de línguas Tupi-Guarani do sudeste Amazônico e à tradição arqueológica Tupi-Guarani. O autor entende que estes grupos Tupinambá não necessariamente se expandiram pelos grandes caminhos fluviais, como havia sido anteriormente proposto por Brochado (1984) e Lathrap (1970), mas por terra firme. Já em relação à associação da cerâmica corrugada do Alto Ji-Paraná com os Tupi-Guarani, assim como da Tradição Polícroma da Amazônia com estes grupos, o autor é mais pessimista. No primeiro caso, acredita que não existem elementos técnico-estilísticos ou etno-históricos suficientes para estabelecer uma ligação, podendo estar relacionada a outros grupos Tupi da região, como os Tupi-Maué. Já em relação à TPA, ressalta várias diferenças em relação à Tradição Tupi-Guarani, como a ausência de vasilhas específicas para fermentação, e entende que os elementos comuns seriam decorrentes de contatos em uma vasta rede dominada pelos grupos de língua Arawak, apesar de acreditar na relação desta tradição com grupos de língua Tupi.

Neves (2012) comparou os dados da vasta região onde a Tradição Polícroma da Amazônia está presente, incluindo toda a calha do rio Amazonas e em alguns de seus afluentes como o Madeira, o Negro, Japurá/Caquetá e Napo. As datas de meados do primeiro milênio DC obtidas por Almeida (2013) para o sítio Teotônio, no alto Madeira, para as ocupações da Subtradição Jatuarana, seriam as mais antigas obtidas para esta tradição (com exceção da fase Marajoara), tornando-se mais recentes no Baixo rio Madeira, Amazônia Central e Alto Amazonas respectivamente, o que caracterizaria uma expansão demográfica em meados do primeiro milênio DC na região do Alto Madeira pelos portadores desta 
tradição, que ocuparam o baixo curso desse rio, o rio Amazonas, e posteriormente o Solimões (NEVES, 2012, p. 229). Além disso, o processo de expansão dos grupos policromos não teria sido rápido, inicialmente ocupando os locais distantes das várzeas do Amazonas e Solimões, e apenas posteriormente partindo para a disputa das áreas próximas aos rios de águas brancas (NEVES, 2012).

Para Neves (2012) o processo de mudança lingüística evidenciado entre os Cocama e Omágua, falantes da família Tupi- Guarani do Alto Amazonas, teria ocorrido a partir do início do segundo milênio DC, decorrente da expansão dos grupos produtores das cerâmicas Polícromas a partir do alto rio Madeira, seguindo pelo alto e médio Amazonas. Para embasar sua hipótese, o autor compara a expansão Polícroma na Amazônia com a expansão Tupinambá no litoral Atlântico, encontrando alguns paralelos que indicariam uma mesma base cultural, entre eles: a presença da guerra, a rapidez das expansões e das ocupações dessas áreas, assentamentos relativamente pequenos ocupados por algumas décadas resultantes de um padrão de alta mobilidade, o uso de canoas e de caminhos fluviais como meios de transporte e comunicação, padronização formal e decorativa da cerâmica, ausência de um padrão de forma de aldeia e de duração dos assentamentos. Para Neves (2012, p. 265), tais evidências demonstram que "é plausível que os grupos associados à tradição policroma, que ocuparam o alto Amazonas no final do período pré-colonial, falassem alguma língua aparentada ao Tupinambá".

Sendo assim, a expansão demográfica polícroma pelo Madeira teria ocorrido no sentido inverso do anteriormente proposto por Lathrap (1970) e Brochado (1984, 1989). Além disso, esta expansão não ocorreu para o Baixo Amazonas, como anteriormente proposta pelos mesmos autores, tendo em vista que a região entre Itacoatiara e Parintins foi uma zona de fronteira nos séculos anteriores a colonização europeia, envolvendo os grupos da tradição Polícroma a oeste e os da tradição Inciso-Ponteada a leste. Nesse sentido, a fase Marajoara seria um fenômeno local e híbrido da foz do Amazonas, envolvendo diferentes complexos locais antigos, relacionado indiretamente à tradição polícroma (NEVES, 2012, p. 257).

Moraes (2013) concorda que a presença dos maiores assentamentos Paredão, na Amazônia Central em torno do ano 1000 da nossa era, concomitantes a ocupações Manacapuru, Guarita e Axinim, teriam envolvido relações multiétnicas, cujas evidências de conflito (estruturas defensivas em sítios Paredão e Axinim) indicam uma estratégia de defesa por parte destes grupos, provavelmente de origem Aruak, frente às várias levas de expansão dos produtores de cerâmicas policromas que desceram o rio Madeira, que seriam os ancestrais dos Cocama (MORAES, 2013, p. 320). 


\subsection{Diversidade cultural no Alto rio Madeira, Rondônia}

Conforme vimos anteriormente, os dados arqueológicos existentes para o Alto rio Madeira e seus afluentes (MILLER 1983, 1992, 1999, 2009a, 2009b, 2013; CRUZ, 2008, ZIMPEL, 2009; ALMEIDA, 2013) demonstram a grande variabilidade no registro arqueológico e na tecnologia cerâmica na região. Em um primeiro momento, foram determinadas fases e tradições a partir das frequências de atributos como a ocorrência de engobo vermelho, de decorações plásticas e crômicas e principalmente do tipo de antiplástico, evidenciadas na cerâmica de alguns cortes estratigráficos feitos nos sítios (MILLER 1983, 1992, 1999, 2009A, 2009b, 2013), o que acarreta uma série de problemas metodológicos amplamente discutidos na arqueologia brasileira (DIAS, 1995; DIAS e SILVA, 2001), apesar de tais pesquisas terem sido importantes para o levantamento dos diversos contextos da ocupação indígena no estado de Rondônia, desde o final do Pleistoceno e durante todo o Holoceno. É evidente que estudos mais aprofundados, que envolvem a escavação de áreas maiores dos sítios, análise espacial e da tecnologia cerâmica, permitem não apenas somar dados àqueles existentes, como também revisar algumas das hipóteses anteriormente construídas. Conforme vimos anteriormente, o estudo do sítio Vila Gomes no baixo Madeira por Moraes (2013), demonstrou que a cerâmica da fase Axinim não pertence à tradição Inciso Ponteada como anteriormente estabelecida, mas à Tradição Borda Incisa ou Barrancóide. Da mesma forma, as análises dos contextos e das cerâmicas no Alto rio Madeira por Almeida (2013) demonstraram que as ocupações relacionadas à Tradição Polícroma da Amazônia não são tão antigas quanto se supunha antes, e que existe uma variabilidade maior nos contextos de ocupação na região, com um possível sistema multiétnico. Certamente, o aprofundamento das pesquisas nas diferentes áreas ao longo do rio Madeira e seus afluentes permitirá ver um quadro muito mais complexo no passado.

Da mesma forma, os modelos e hipóteses elaborados sobre a ocupação da Amazônia (LATHRAP, 1970; BROCHADO, 1984, 1989; NOELLI, 1996; HECKENBERGER 2001, 2002; NEVES, 2012) apontam o alto rio Madeira como uma área importante do ponto de vista das expansões dos povos falantes Tupi e Arawak. Os dados da linguística histórica situam o estado de Rondônia como centro de dispersão dos povos falantes do tronco Tupi (RODRIGUES, 1958, 1964, 1984) e os estudos sobre a expansão Arawak (HECKENBERGER 2001, 2002; HILL e SANTOS GRANERO, 2002; HORNBORG e HILL, 2011; ERIKSEN, 2011; HORNBORG e ERICKSEN, 2011; HILL, 2013) consideram o rio Madeira, assim como o Purús, Xingu e Madre de Dios, importantes caminhos fluviais nas redes de interações nas quais estes povos estavam envolvidos. Os dados etno-históricos e 
etnográficos apontam para uma diversidade cultural e linguística no período colonial, incluindo falantes Tupi, Arawak, Pano e de línguas isoladas (KELLER, 1874; URBAN, 1992; RAMIREZ, 2006, 2010; AMOROSO, 1992; CREVELS \& VAN DER VOORT, 2008; HUGO, 1959; MENÉNDEZ, 1992; ROQUETTE-PINTO, 1935; FERREIRA, 2007, LEVISTRAUS, 2000; ERIKSEN, 2011; COSTA, 2013a; PESSOA e COSTA, 2014).

Essa grande diversidade cultural na região, mapeada no período pós-contato com o europeu, pode estar ao menos em partes representada no passado pré-colonial. Neste trabalho, buscamos averiguar tal hipótese através a análise da cerâmica de alguns sítios arqueológicos desta área. A escolha dos sítios ao longo de $80 \mathrm{~km}$ do rio Madeira, incluindo as proximidades das cachoeiras de Santo Antônio, Teotônio e Morrinhos, bem como um sítio junto à foz do rio Jaciparaná, é respaldada pelo objetivo do projeto, de verificar a variabilidade cerâmica em áreas onde as pesquisas anteriores já apontaram diferenças, como entre as cerâmicas e sítios da Subtradição Jatuarana junto às cachoeiras de jusante, e da fase Jaciparaná a montante. Esse trabalho não contemplou a revisão e utilização de dados históricos e etnográficos existentes para o Alto rio Madeira, apesar de considerarmos que o uso das diferentes fontes enriqueceria uma abordagem sobre a história das ocupações na região. Conforme diz Heckenberger:

\footnotetext{
Se a cultura, a história documental e o registro arqueológico são textos para serem lidos e interpretados, cada qual, à sua maneira, abertos a diversas leituras, o entendimento histórico é obviamente "intertextual". Adquirir tal entendimento ou síntese, entretanto, é tarefa mais facilmente enunciada do que executada, e, no tocante à Amazônia em geral, apenas começamos a aventar esse caminho (2001, p. 54-55).
}

Esse autor chama a atenção para um dos principais desafios dos arqueólogos que atuam na Amazônia, o de encontrar ordem na grande diversidade e pluralismo cultural cada vez mais evidente na região (HECKENBERGER, 2002, p 106). Esta diversidade nos padrões de ocupação humana na Amazônia parece ter aumentado a partir do início da era cristã (Neves, 2012), e certamente deve ser entendida a partir de fatores históricos, não somente ambientais como inicialmente proposto. A compreensão do complexo processo de ocupação no Alto rio Madeira só poderá ser alcançada através da análise tecnológica da cerâmica, do material lítico e dos demais vestígios evidenciados (como a terra preta) que, juntamente com os dados contextuais e cronológicos, permitirão ampliar o conhecimento da história indígena na região. Nesse trabalho, apresentaremos dados obtidos a partir da análise dos contextos evidenciados no alto rio Madeira e principalmente da análise da cerâmica. Apesar das limitações de diversos níveis que ficarão evidentes no decorrer do texto, certamente esses resultados contribuem para a construção de uma história indígena na região, ainda pouco conhecida. 


\section{Capítulo 2. Alto rio Madeira, Rondônia: a área de estudo e os sítios arqueológicos}

As paisagens resultam das relações históricas dos homens com os mundos natural e sobrenatural, envolvendo identidade individual e de grupo e memória, com uma trajetória que inclui a história natural da terra e seus recursos e a história social das pessoas que nela vivem e usam esses recursos (ZEDEÑO, 2008). As paisagens podem ser compreendidas a partir da identificação dos lugares que a compõem, os quais são resultado da modificação humana ao longo do tempo, portanto constituem-se em registros da cognição, percepção e comportamento humanos, são marcadores territoriais e podem se tornar âncoras para memórias individuais e coletivas, e seus significados geralmente derivam de suas posições dentro de uma rede de outros lugares articulados na paisagem (ZEDEÑO E BOSWER, 2009)

Quando os lugares são ocupados e experimentados por diferentes indivíduos ou grupos ao longo do tempo, podem adquirir sucessivos significados, e estes níveis ou camadas de significados podem ser descompactadas buscando a compreensão das biografias dos lugares, das causas e consequências das mudanças nos ocupantes ou nas atividades. Da mesma forma, a contextualização das relações entre os lugares auxilia no entendimento da paisagem (ZEDEÑO E BOSWER, 2009). Lugares acumulam histórias quando são construídos, ocupados, mantidos, modificados, desmantelados, realocados ou vão à ruína, e cada um destes eventos da sua história de vida carrega significados simbólicos (ASHMORE, 2009).

Este trabalho não se constitui em uma arqueologia da paisagem, tampouco lida com a diversidade de abordagens possíveis na descrição e caracterização dos lugares ao longo do tempo, mas somente com o estudo da cerâmica de alguns sítios arqueológicos. Mesmo assim, na medida em que buscamos entender os significados dos diferentes contextos e da variabilidade tecnológica, estamos contribuindo para a construção destas trajetórias históricas das pessoas que viveram junto ao rio Madeira, nas planícies de inundação, ilhas e terraços, mais próximos ou distantes das cachoeiras. Nosso esforço é no sentido de perceber as mudanças e continuidades no tempo, e na medida do possível buscar entender as conexões entre os diferentes sítios arqueológicos. Esta abordagem nos auxilia a pensar e fazer arqueologia como história indígena.

Mais de uma centena de sítios arqueológicos foram localizados no Alto rio Madeira (TIZUKA, 2013) com datações que recuam há aproximadamente 7.000 anos até o período 
recente, cujos remanescentes das ocupações constituem-se de artefatos líticos e cerâmicos, camadas de terra preta, gravuras rupestres, polidores e afiadores de ferramentas líticas, vegetação de palmáceas que indicam manejo florestal, estruturas de presídio, casas, ferrovia, seringais, antigos garimpos, entre outros. Ainda há aqueles lugares onde os vestígios da ocupação humana não são materialmente tão evidentes, mas que certamente foram ocupados e intensamente transformados, como as cachoeiras e ilhas, sendo difícil separar os elementos naturais e culturais que compõe a paisagem.

Os sítios arqueológicos abordados nesta pesquisa estão implantados nas ilhas fluviais e próximos as margens do rio Madeira, entre a cachoeira de Santo Antônio e a Foz do rio Jaciparaná, no município de Porto Velho, Rondônia. Inicialmente faremos uma breve caracterização da região do Alto rio Madeira, e posteriormente apresentaremos as pesquisas de campo e os contextos arqueológicos evidenciados nos diferentes sítios. Antes de prosseguir é preciso dizer que os lugares para os quais olhamos sofreram uma profunda transformação em função da construção da usina hidrelétrica de Santo Antônio. Ironicamente, grande parte da história destes lugares foi acessada e conhecida apenas pouco antes de sua transformação ou destruição, tendo em vista que as pesquisas arqueológicas na região, fundamentais para a construção da história indígena, são ainda incipientes. Todos estes lugares foram apropriados de diferentes maneiras até o período recente, e mesmo submersos, permanecem na memória de quem lá morava, frequentava ou conhecia através das histórias contadas. Conforme dizem Zedeno e Bowser (2009), lugares são ativos e podem influenciar relações sociais e mudança social, e sua destruição altera a trajetória histórica e a memória coletiva de um povo. As transformações na paisagem do alto Madeira alteraram a trajetória histórica da sociedade envolvente, entre eles ribeirinhos, indígenas e moradores das cidades próximas, ainda que a história possa ser reconstruída através de seus relatos, das fontes históricas e etnográficas, e dos vestígios arqueológicos.

\subsection{A região do Alto rio Madeira}

O rio Madeira é formado na confluência do rio Guaporé e dos rios bolivianos Beni e Mamoré, que nascem na Cordilheira dos Andes. Por transportar sedimentos dos Andes, é considerado um rio de aguas brancas, com aspecto barrento, sendo o maior afluente da bacia do Amazonas em descarga líquida e sólida. Seu curso abrange os estados de Rondônia e do Amazonas, sendo o trecho entre Abunã e Porto Velho chamado Alto rio Madeira. Na área de pesquisa (mapa 6), o maior afluente é o rio Jaciparaná, na margem direita, e são inúmeros os 
pequenos igarapés. Neste trecho o rio encontra-se num vale encaixado, marcado por corredeiras, travessões, saltos e planícies de inundação. Os meses de maiores cheias são os de março e abril e os de maiores vazões são agosto e setembro.

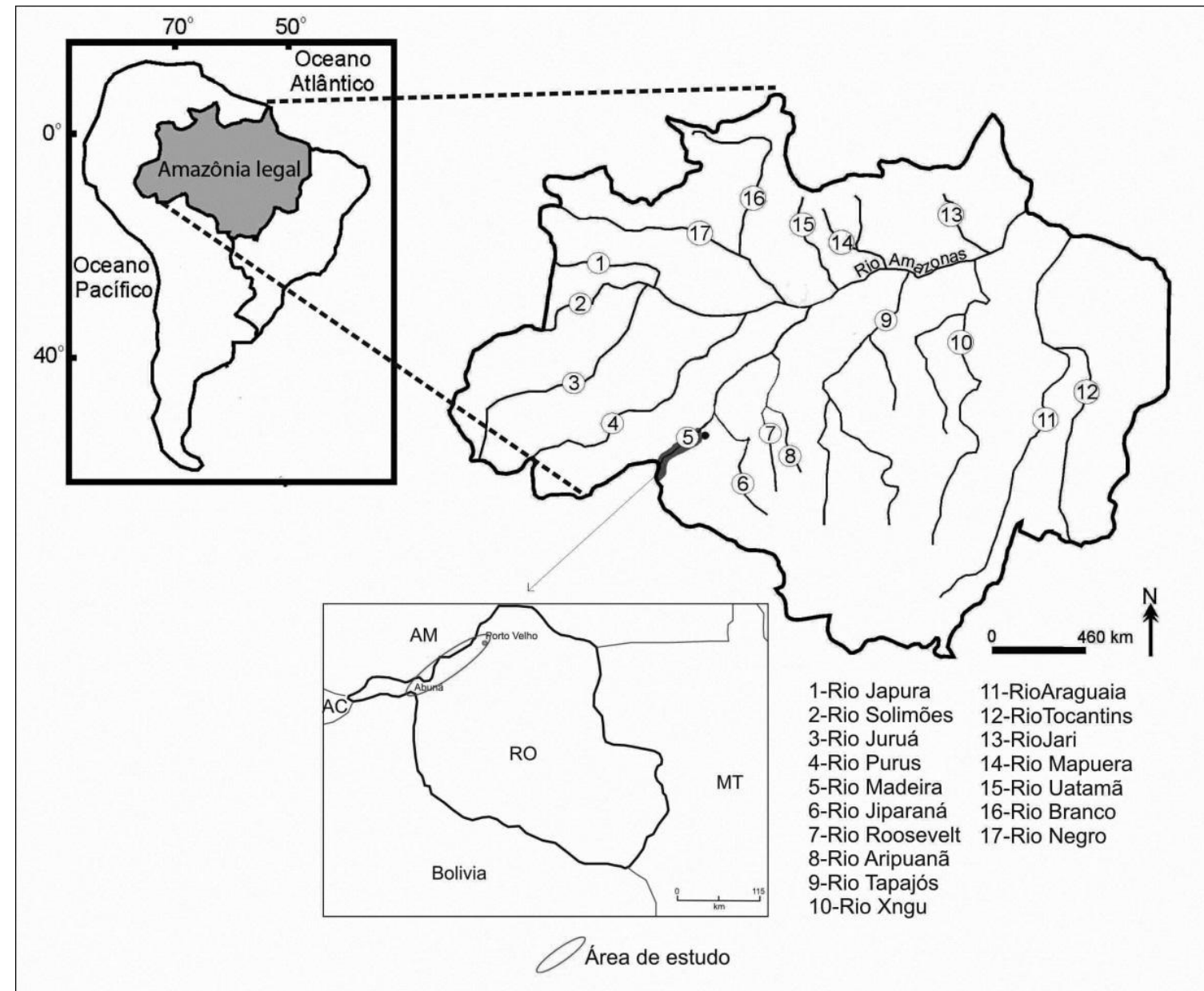

Mapa 6: localização da área de estudo, no Alto rio Madeira, Rondônia (Michelle Tizuka, 2013).

Ao encaixar-se nas falhas e fraturas das rochas metaígneas do Complexo Jamari, os desníveis estruturais formaram as cachoeiras e corredeiras, estando na área de estudo as corredeiras de Santo Antônio e Morrinhos e a cachoeira de Teotônio, esta última intransponível à navegação em qualquer época do ano até a recente construção de duas usinas hidrelétricas, de Santo Antônio e Jirau, cujos reservatórios as encobriram completamente (CPRM 2005; CPRM 2010; TIZUKA 2013). As cachoeiras marcavam a paisagem e nelas era praticada a pesca em grande escala. Junto a elas estão implantados sítios arqueológicos, em ambas as margens e junto às ilhas. As ilhas se formaram ao longo de vários ciclos sazonais a partir dos bancos de areias acumulados pelo rio, cujo padrão de sedimentação fluvial holocênico é caracterizado por depósitos de acreção lateral e de carga de fundo, destacando-se os depósitos de barras de canal formados pela emersão de acumulações arenosas em época de estiagem (TIZUKA, 2013). 
As ilhas fluviais são periodicamente inundadas, constituindo-se em típicas planícies de inundação com vegetação pioneira, herbáceo-arbustiva, e nas áreas mais altas uma floresta aluvial mais exuberante desenvolvida acima do nível das cheias sazonais (CPRM, 2005). Algumas ilhas foram ocupadas no passado e apresentam sítios arqueológicos, estando na área de pesquisa a Ilha Santo Antônio, Ilha São Francisco, Ilha das Cobras, Ilha do Japó e Ilha Dionísio, cujos sítios arqueológicos foram abordados neste trabalho. Nestas as ocupações concentraram-se principalmente nas áreas acima do nível das cheias, enquanto nas suas bordas, junto aos pedrais, ocorrem sulcos de polimento e/ou gravuras rupestres, que são sazonalmente inundadas. Estas ilhas foram habitadas até recentemente por moradores ribeirinhos com as casas construídas junto aos sítios arqueológicos, coincidindo a escolha do local de moradia no presente e no passado em função da topografia do local e da dinâmica do rio. Na época de máxima vazante do rio os ribeirinhos cultivavam nas áreas de aluvião em volta das ilhas o feijão, mandioca, melancia, melão entre outros, e nas proximidades das casas eram cultivados mamoeiros, bananeiras e outras árvores frutíferas.

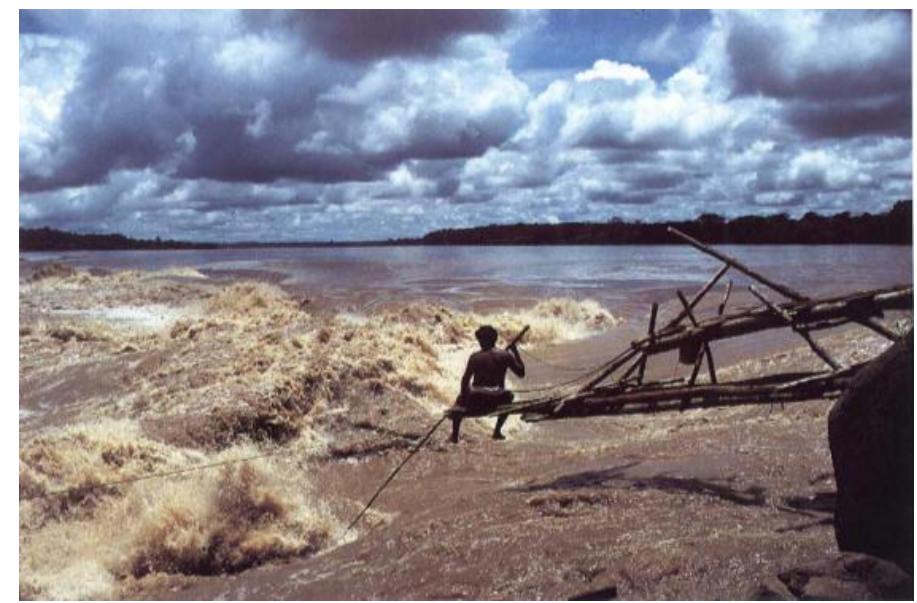

Figura 8: pesca na cachoeira do Teotônio, rio Madeira (Gouldin, Smith \& Mahal, 2000).

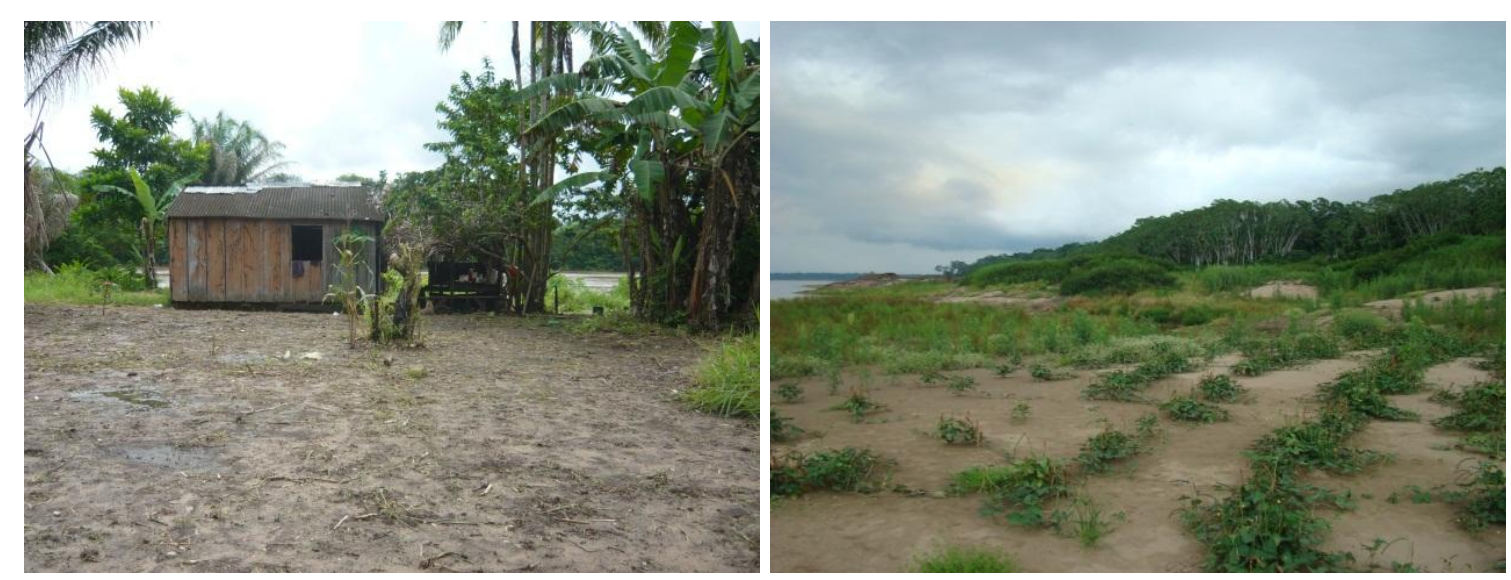

Fotografias 1 e 2: moradia na Ilha São Francisco e plantação de feijão no sedimento aluvial na ilha Dionísio (época de máxima vazante do rio) (SCIENTIA, 2010 E 2011). 
O clima predominante na área de estudo é o equatorial, que apresenta temperaturas elevadas aliadas a uma grande umidade, com somente três meses sem ocorrência de precipitação. Os meses mais secos são maio, junho e julho e os mais chuvosos outubro, novembro e dezembro. Nas áreas onde se inserem os sítios arqueológicos ocorre uma cobertura vegetal mista, com vegetação primária junto a áreas já impactadas pela ação antrópica, com cultivos diversos, evidências de queimadas e pastagens, não sendo verificados padrões específicos entre sítios arqueológicos e vegetação, como havia sido sugerido por Miller em relação à presença da palmeira urucuri (TIZUKA, 2013, p. 88). Estudos paleoambientais são raros para a região, porém Rossetti et al. (2005) acreditam que condições climáticas e ecológicas semelhantes às atuais se estabilizaram há cerca de 3.000 anos. Importante destacar que enquanto em outras regiões da Amazônia há uma ausência de sítios arqueológicos datados no Holoceno Médio, na bacia do rio Madeira ocorre uma longa sequencia de ocupações durante todo o Holoceno com formação de Terra Preta Arqueológica (NEVES, 2006, 2012; MILLER 1992, 1999).

O rio Madeira drena terrenos de constituição predominantemente sedimentar de idade quaternária e de granitos proterozóicos (CPRM 2005; CPRM 2010; TIZUKA 2013). O estado de Rondônia abrange a porção sul-ocidental do Cráton Amazônico, com registros de uma evolução geológica policíclica, cuja formação do substrato rochoso é resultante de sucessivos episódios de magmatismo, metamorfismo, sedimentação e deformação. A evolução geológica iniciou no Paleoproterozóico, há aproximadamente 1.700 milhões de anos, e são identificadas rochas pertencentes desde unidades paleoproterozóicas (embasamento cristalino que engloba o Complexo Jamari) até coberturas sedimentares cenozoicas que compreendem depósitos terciários e quaternários cuja deposição e formação são controladas por diversos fatores, entre eles os tectônicos, litológicos e paleoclimáticos, destacando-se para a região de estudo as Coberturas Detritolateríticas (perfil de intemperismo), Terraços Fluviais, as formações Rio Madeira e Jaciparaná, Coberturas Sedimentares Indiferenciadas, Depósitos Lacustres, Depósitos Argilosos e Depósitos Aluvionares (CPRM 2007; CPRM 2010, TIZUKA, 2013).

O arcabouço litológico regional é constituído por rochas pré-cambrianas, paleozóicas e mesozoicas: os gnaisses, granitos, quartzitos e rochas básicas diversas do Complexo Jamari (de idade Paleoproterozóica); granitos Rondonianos de idade Meso a Neoproterozóica que intrudiram o embasamento polimetamorfizado do Complexo Jamari e afloram esporadicamente na área de estudo, na margem direita entre as localidades de Jaci-Paraná e Teotônio; arenitos arcoseanos e conglomerados da Formação Palmeiral, de idade Mesoproterozóica ocorrem próximo ao rio Jaci-Paraná; e ainda os corpos e maciços de 
granitoides (texturas e estruturas variadas, com veios de quartzo preenchendo as fraturas) englobados nas suítes intrusivas Santo Antônio e Teotônio, a primeira junto à cachoeira homônima e a segunda junto à cachoeira do Teotônio e a Cachoeira de Morrinhos (CPRM 2005; CPRM 2010).

$\mathrm{Na}$ área estudada ocorrem três categorias de unidades geomorfológicas, consideradas como de agradação, de degradação e de intemperismo. Nas unidades de agradação estão englobadas as planícies aluviais, terraços fluviais, depressões, lagos e congêneres, enquanto que as unidades de degradação contemplam formas de relevo submetidas mais intensamente aos processos erosivos tais como alinhamentos de morrotes, superfícies de aplanamento, agrupamentos de morros e colinas com e sem controle estrutural, superfícies tabulares e cuestas. Os areais brancos com escoamento impedido foram classificados como unidades de Intemperismo. Baixos platôs lateríticos estendem-se, de forma espraiada, por toda a área de estudo (CPRM, 2005).

Ocorrem diferenças marcantes nas duas margens: enquanto na margem direita estão as exíguas planícies aluviais do rio Madeira, imprensadas contra as barrancas pelas superfícies aplanadas e baixos platôs lateríticos, na margem esquerda ocorrem os terraços fluviais, altos e não dissecados, com extensões de dezenas de quilômetros, e que constituem o divisor Madeira-Purus. Enquanto na margem direita a morfologia do relevo é plana ou pouco movimentada, com altitudes modestas, pontilhadas por relevos residuais constituídos de platôs lateríticos ou agrupamentos de colinas e morros dissecados ou tabulares e por hillocks e tors graníticos, na margem esquerda os terraços fluviais com dissecação baixa e/ou dissecação média ocorrem mais próximos ao leito do rio Madeira, e junto à sua calha desenvolvem planícies de inundação geralmente pouco extensas, que representam antigas planícies de inundação e canais fluviais semelhantes aos atuais, ativos durante períodos quentes do Pleistoceno. Tal configuração morfológica sugere uma migração gradual do leito do rio Madeira em direção a sul-sudeste ao longo do Quaternário, condicionado por basculamentos neotectônicos de blocos (CPRM, 2005, 2007).

Tizuka (2013) fez um estudo geoarqueológico na mesma área, com foco nos sítios précoloniais identificados em terraços e planícies aluviais (margens e ilhas) entre as cachoeiras de Teotônio e Santo Antônio, pertencentes aos seguintes períodos: anterior a 8000AP; 80003000AP; 3000-2000AP; 2000-1000AP e a partir de 1000AP. A autora ressalta que o entendimento da evolução das planícies aluviais (onde se incluem as ilhas e regiões de entorno de cachoeiras) com os sítios arqueológicos torna-se essencial para se entender padrões de assentamento locais. Através de pesquisas de campo e consulta dos relatórios 
técnicos de pesquisas anteriores na região, Tizuka levantou 139 sítios arqueológicos précoloniais com material cerâmico e/ou lítico e/ou gravuras rupestres no Alto rio Madeira, porém o foco de sua pesquisa foi a área entre as cachoeiras do Teotônio e Santo Antônio. A autora não identificou padrões de ocupações em locais específicos na paisagem, com ocorrência de sítios em planícies aluvionares de rios principais, terraços fluviais altos e baixos, em superfícies de aplainamento e em platôs lateríticos, portanto em compartimentos topográficos variados em ambas as margens do rio. Em áreas mais afastadas do rio não foram localizados muitos sítios até o momento porque as prospecções arqueológicas realizadas recentemente nos empreendimentos hidrelétricos abrangeram apenas a área de influência direta do reservatório, o que se constitui em um viés amostral (TIZUKA, 2013, p. 85). Na figura 9 está o modelo proposto pela autora para o Alto Rio Madeira.

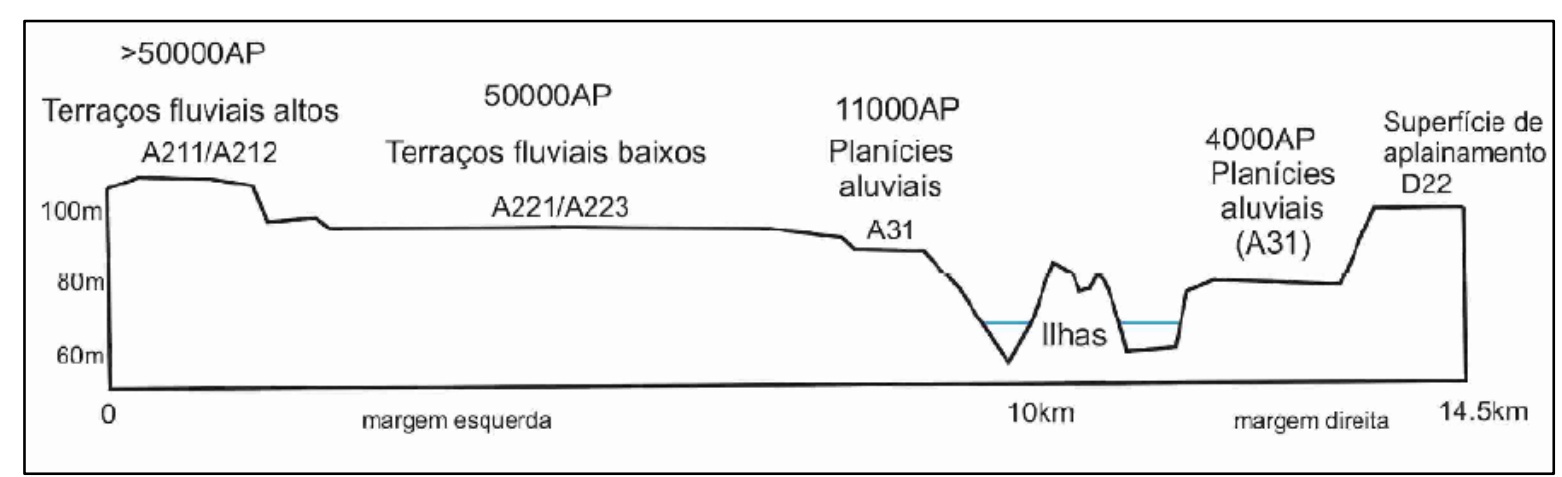

Figura 9: modelo elaborado por Tizuka (2013) para o Alto rio Madeira.

Ao contrário do que foi sugerido recentemente, de que as características do rio Madeira são consideradas como limitadoras para a ocupação humana e deslocamento, em função da erosão fluvial (desbarrancamentos) na planície de inundação e das corredeiras e cachoeiras, algumas instransponíveis em qualquer época do ano (CPRM, 2010), nos períodos mais recuados todas as áreas foram ocupadas por diferentes populações indígenas, sejam elas planícies de inundação (nas margens e ilhas), terraços fluviais ou platôs lateríticos. Até recentemente estas áreas eram ocupadas pelas populações ribeirinhas, muitas vezes coincidindo com os locais ocupados no passado.

Os contextos evidenciados até o momento corroboram com o que vem sendo estabelecido pelos estudos da Ecologia Histórica no restante da Amazônia, de que no passado ocorreram grandes e longas ocupações, cujas transformações empreendidas ao meio são visíveis nos espessos pacotes de terra preta, na variedade de plantas manejadas ou domesticadas e na diversidade ecológica existente. 


\subsection{Nas ilhas e nas margens: os sítios arqueológicos no Alto rio Madeira}

Foram escolhidos quatorze sítios arqueológicos para a realização da pesquisa, sendo cinco deles implantados em ilhas (sítios Ilha de Santo Antônio, Ilha São Francisco, Ilha das Cobras, Ilha do Japó e Ilha Dionísio), cinco na margem direita (sítio do Brejo, Boa Vista, Vista Alegre, Teotônio e Coração) e quatro na margem esquerda (Veneza, Morro dos Macacos I, Foz do Jatuarana e Santa Paula), em um trecho de $80 \mathrm{Km}$ ao longo do rio Madeira, entre a cachoeira de Santo Antônio e a foz do rio Jaciparaná. Os sítios Veneza, Teotônio e Santa Paula foram identificados por Eurico Miller na década de 1970, e os demais através das prospecções realizadas onde se situa hoje o reservatório da Usina de Santo Antônio (SCIENTIA, 2011a), implantados em planícies de inundação, terraços fluviais e superfícies de aplainamento, entre as cotas 60 e 110m. Serão apresentados os contextos arqueológicos dos sítios acima citados, dos quais foram analisadas amostras de cerâmica, porém serão mencionados outros sítios ao longo do texto que fornecem informações contextuais e cronológicas importantes para o entendimento das ocupações ceramistas na região.

Optamos por caracterizar os sítios na medida em que se implantam rio acima, de jusante a montante. Convido os leitores a embarcar numa viagem de voadeira rio acima, partindo da cidade de Porto Velho e chegando à Foz do rio Jaciparaná ao longo deste trecho de $80 \mathrm{Km}$. Teremos paradas obrigatórias, como na cachoeira do Teotônio, intransponível durante o ano todo. Todos os sítios estudados podem ser vistos a partir do rio, em função da sua proximidade nas planícies aluviais, terraços e superfícies de aplainamento em ambas as margens, bem como nas ilhas, e nestes locais as paradas serão mais demoradas. Embarcamos em uma descrição da paisagem e dos sítios arqueológicos, através de relatórios, fichas de campo, fotos, desenhos e resultados de análises (incluindo datações radiocarbônicas), fornecidos pela empresa Scientia Consultoria Científica, os quais foram elaborados por diferentes pesquisadores que localizaram ou escavaram sítios na região, e através da própria experiência em alguns lugares deste trecho ao longo dos últimos quatro anos. Também foram consultados os artigos de Miller (1992, 1999, 2009) e os trabalhos recentes de Tizuka (2013) e Almeida (2013). A viagem é uma metáfora e um convite a conhecer um pouco da Arqueologia do rio Madeira e das transformações empreendidas na paisagem ao longo dos milhares de anos de ocupação da região pelas populações indígenas, e necessariamente seria realizada em 2008, antes da construção da usina, sendo o cenário hoje bem diferente.

Todos os sítios estudados nesta pesquisa foram localizados no âmbito do Projeto de Arqueologia Preventiva nas áreas de Intervenção da UHE Santo Antônio-RO (SCIENTIA, 2008), através das prospecções feitas na área do canteiro de obras e no reservatório da usina 
em duas etapas: o levantamento abrangente extensivo, que consiste na vistoria da área e conversas com os moradores das áreas percorridas, e a prospecção sistemática ${ }^{2}$, que consiste na realização de furos de cavadeira (sondagens pequenas, cilíndricas, com $30 \mathrm{~cm}$ de diâmetro, feitas com cavadeira "boca de lobo") de acordo com uma malha ortogonal regular de linhas lineares distando $100 \mathrm{~m}$ entre si, seguindo níveis artificiais de $20 \mathrm{~cm}$ a partir da superfície, até $1 \mathrm{~m}$ de profundidade (5 níveis artificiais), com peneiramento do sedimento de cada nível. A prospecção sistemática foi realizada na área do canteiro de obras, nas proximidades da cachoeira de Santo Antônio, bem como na área entre esta e a cachoeira do Teotônio, enquanto à montante foram selecionadas áreas amostrais. Como o lago da usina atingiu a cota de 71,3 $\mathrm{m}$, a prospecção foi feita até a cota $100 \mathrm{~m}$, portanto todos os sítios trabalhados estão inseridos em área muito próxima ao rio. Foram localizados quarenta e três sítios arqueológicos com ocupação pré-colonial, sendo que alguns deles foram totalmente atingidos pelo reservatório ou pelas obras, outros foram parcialmente alagados e alguns estão acima da cota de alagamento (SCIENTIA, 2008, 2010).

Após a localização dos sítios, foi realizada a delimitação que visou verificar as suas dimensões horizontais e verticais, através da realização de furos-testes feitos em uma malha regular de 20 em $20 \mathrm{~m}$, em níveis artificiais de $20 \mathrm{~cm}$, com peneiramento do sedimento e descrição das suas características e dos materiais encontrados. Este procedimento forneceu informações para a escolha das áreas a serem escavadas.

As escavações foram realizadas em unidades de $1 \mathrm{~m}^{2}$, em níveis artificiais de $10 \mathrm{~cm}$ e controle das camadas arqueológicas, com registro da quantidade de material, características do sedimento e desenho dos perfis. No caso de estruturas e vasilhas inteiras, foram feitas escavações em áreas amplas. As camadas identificadas no perfil foram descritas de acordo com a cor, textura e compactação do sedimento, com a quantificação dos materiais arqueológicos quando presentes. Nos sítios Ilha de Santo Antônio, Brejo, Veneza e Santa Paula as unidades foram localizadas em um grid e nomeadas convencionalmente de acordo com a distância de um ponto referencial (N1000 E1000), tendo como referência para a nomeação da unidade o seu canto nordeste, e as camadas foram nomeadas por números romanos (Camada "I", “II”, "III”, etc.), da mais profunda para a mais superficial. Já nos sítios Boa Vista, Morro dos Macacos I, Foz do Jatuarana, Vista Alegre, Teotônio, Ilha São Francisco, Ilha das Cobras, Ilha do Japó, Coração e Ilha Dionísio, as unidades foram

\footnotetext{
${ }^{2}$ Tais conceitos são abordados em Araújo (2001).
} 
nomeadas de acordo com a coordenada GPS do canto sudoeste, e as camadas foram nomeadas por letras sequenciais (Camada "A", “B”, “C”, "D”, "E”, etc), da mais superficial para a mais profunda.

Entre os sítios estudados, os sítios Ilha de Santo Antônio, Brejo, Veneza e Garbin foram impactados pela construção do canteiro de obras; os sítios Boa Vista, Vista Alegre, Foz do Jatuarana, Morro dos Macacos I, Ilha São Francisco, Ilha das Cobras, Ilha do Japó e Ilha Dionísio foram parcialmente alagados; e os sítios Teotônio, Santa Paula e Coração não foram atingidos por estarem em cotas mais altas. Os sítios diretamente atingidos pelas obras e pelo alague do reservatório passaram pelos procedimentos de delimitação e resgate. Já os sítios que estão acima da cota de inundação do reservatório foram somente delimitados (SCIENTIA, 2011).

Partiremos agora para a descrição dos contextos arqueológicos evidenciados nas pesquisas de campo realizadas nos quatorze sítios arqueológicos, porém mencionaremos outros sítios e vestígios materiais encontrados ao longo deste trecho, buscando construir um quadro das ocupações ceramistas no rio Madeira (verificar a localização dos sítios no Mapa 2). Subindo o rio $6 \mathrm{~km}$ a partir da cidade de Porto Velho, nos deparamos com a cachoeira de Santo Antônio, sendo a primeira corredeira do rio Madeira encontrada por quem sobe o rio desde a sua foz, transponível em qualquer época do ano. Sempre presente no relato dos viajantes, esta cachoeira constituiu-se em um marco na paisagem local. Sítios arqueológicos foram identificados por Eurico Miller nesta área, como o sítio RO-PV-19 Igapó 1 na margem direita acima desta cachoeira, para o qual obteve a datação de 2.340 990 AP (Beta-33456) (Miller, 1992), e o sítio RO-PV-13 Veneza na margem esquerda a montante da cachoeira, ambos com cerâmica da Subtradição Jatuarana da Tradição Polícroma da Amazônia. Na margem direita também está o sítio arqueológico Vila de Santo Antônio, patrimônio cultural de Porto Velho, remanescente da vila do final do século XIX e início do século XX, no contexto da construção da estrada de ferro Madeira Mamoré. Recentemente foram identificados outros sítios arqueológicos (SCIENTIA, 2010, 2011) pré-coloniais nas proximidades desta cachoeira, sendo o sítio Ilha de Santo Antônio na ilha homônima; sítio do Brejo na margem direita; sítios Garbin, São Domingos, Catitu, Campelo, Igarapé do Engenho e Novo Engenho Velho na margem esquerda, este último quase em frente à cidade de Porto Velho. 
Tabela 1: Lista de sítios arqueológicos abordados na pesquisa

\begin{tabular}{|c|c|c|c|c|c|c|c|c|}
\hline & Sítio & Coordenada (UTM) & $\operatorname{Cotas}(\mathbf{m})$ & Implantação & Pesquisas de campo & $\begin{array}{c}\text { Tamanho } \\
(\mathrm{m})\end{array}$ & Lítico & Cerâmica \\
\hline 1 & $\begin{array}{l}\text { Ilha de Santo } \\
\text { Antônio }\end{array}$ & E395600 N9026400 & $60 \mathrm{~m}$ a $75 \mathrm{~m}$ & Planície de inundação & $\begin{array}{l}\text { Prospecção, delimitação e } \\
\text { escavação. }\end{array}$ & $300 \times 320$ & 50.939 & 58.909 \\
\hline 2 & Veneza & N9027398 E395116 & 60 a 90 m & Planície de inundação & $\begin{array}{l}\text { Prospecção, delimitação, } \\
\text { coletas de superfície e } \\
\text { escavação. }\end{array}$ & $204 \times 340$ & 2.257 & 4.703 \\
\hline 3 & Brejo & E 3952289 N 9026219 & $60 \mathrm{~m}$ a $65 \mathrm{~m}$ & Planície de inundação & $\begin{array}{l}\text { Prospecção, delimitação e } \\
\text { escavação. }\end{array}$ & $150 \times 300$ & 2.282 & 42.009 \\
\hline 4 & $\begin{array}{l}\text { Morro dos Macacos } \\
1\end{array}$ & E388285 N9022787 & 60 e 98 m. & $\begin{array}{l}\text { Planície de inundação e } \\
\text { superfície de } \\
\text { aplainamento }\end{array}$ & $\begin{array}{l}\text { Prospecção, delimitação, } \\
\text { coletas de superfície e } \\
\text { escavação pontual }\end{array}$ & $300 \times 250$ & 10 & 1.107 \\
\hline 5 & Foz do Jatuarana & E383900 N9022550 & $60 m-62 m$ & Planície de inundação & $\begin{array}{l}\text { Prospecção, delimitação e } \\
\text { escavação. }\end{array}$ & $300 \times 250$ & 5 & 738 \\
\hline 6 & Boa Vista & E392600 N9022200 & 70 a $100 \mathrm{~m}$ & $\begin{array}{l}\text { Planície de inundação e } \\
\text { superfície de } \\
\text { aplainamento }\end{array}$ & $\begin{array}{l}\text { Prospecção, delimitação, } \\
\text { coletas de superfície e } \\
\text { escavação. }\end{array}$ & $640 \times 520$ & 35 & 1.594 \\
\hline 7 & Vista Alegre & E387190 N9020490 & $62 \mathrm{~m}$ a $80 \mathrm{~m}$ & $\begin{array}{c}\text { Planície de inundação e } \\
\text { terraço }\end{array}$ & $\begin{array}{l}\text { Prospecção, delimitação, } \\
\text { coletas de superfície e } \\
\text { escavação. }\end{array}$ & $800 \times 500$ & 830 & 22.135 \\
\hline 8 & Santa Paula & E382736 N9021440 & $\begin{array}{l}95 \mathrm{~m} \mathrm{a} \\
100 \mathrm{~m}\end{array}$ & Terraço fluvial & $\begin{array}{l}\text { Prospecção, delimitação e } \\
\text { escavação pontual }\end{array}$ & $500 \times 310$ & 203 & 19.692 \\
\hline 9 & Teotônio & E 383376 N9019700 & $\begin{array}{l}95 \mathrm{~m} \mathrm{a} \\
100 \mathrm{~m}\end{array}$ & $\begin{array}{l}\text { Superfície de } \\
\text { aplainamento }\end{array}$ & $\begin{array}{l}\text { Prospecção, delimitação e } \\
\text { escavação pontual. }\end{array}$ & $400 \times 600$ & 308 & 8.847 \\
\hline 10 & Ilha São Francisco & E380600 N9013700 & 69 a 83 m & Planície de inundação & $\begin{array}{c}\text { Prospecção, delimitação e } \\
\text { escavação. }\end{array}$ & $200 \times 180$ & 286 & 2184 \\
\hline 11 & Ilha das Cobras & E376500 N9006380 & 64 a $91 m$ & Planície de inundação & $\begin{array}{c}\text { Prospecção, delimitação e } \\
\text { escavação. }\end{array}$ & $400 \times 100$ & 223 & 1.629 \\
\hline 12 & Ilha do Japó & E367980 N9001840 & 59 e $92 \mathrm{~m}$ & Planície de inundação & $\begin{array}{l}\text { Prospecção, delimitação, } \\
\text { coletas de superfície e } \\
\text { escavação. }\end{array}$ & $230 \times 140$ & 8.848 & 59.638 \\
\hline 13 & Coração & E370623 N9002138 & $\begin{array}{c}104 \text { a } 128 \\
\mathrm{~m}\end{array}$ & $\begin{array}{l}\text { Superfície de } \\
\text { aplainamento }\end{array}$ & $\begin{array}{l}\text { Prospecção, delimitação e } \\
\text { escavação pontual. }\end{array}$ & $300 \times 300$ & 1 & 2.951 \\
\hline 14 & Ilha Dionísio & E347800 N8984160 & & Planície de inundação & $\begin{array}{l}\text { Prospecção, delimitação e } \\
\text { escavação. }\end{array}$ & $350 \times 550$ & 10.682 & 41.345 \\
\hline
\end{tabular}




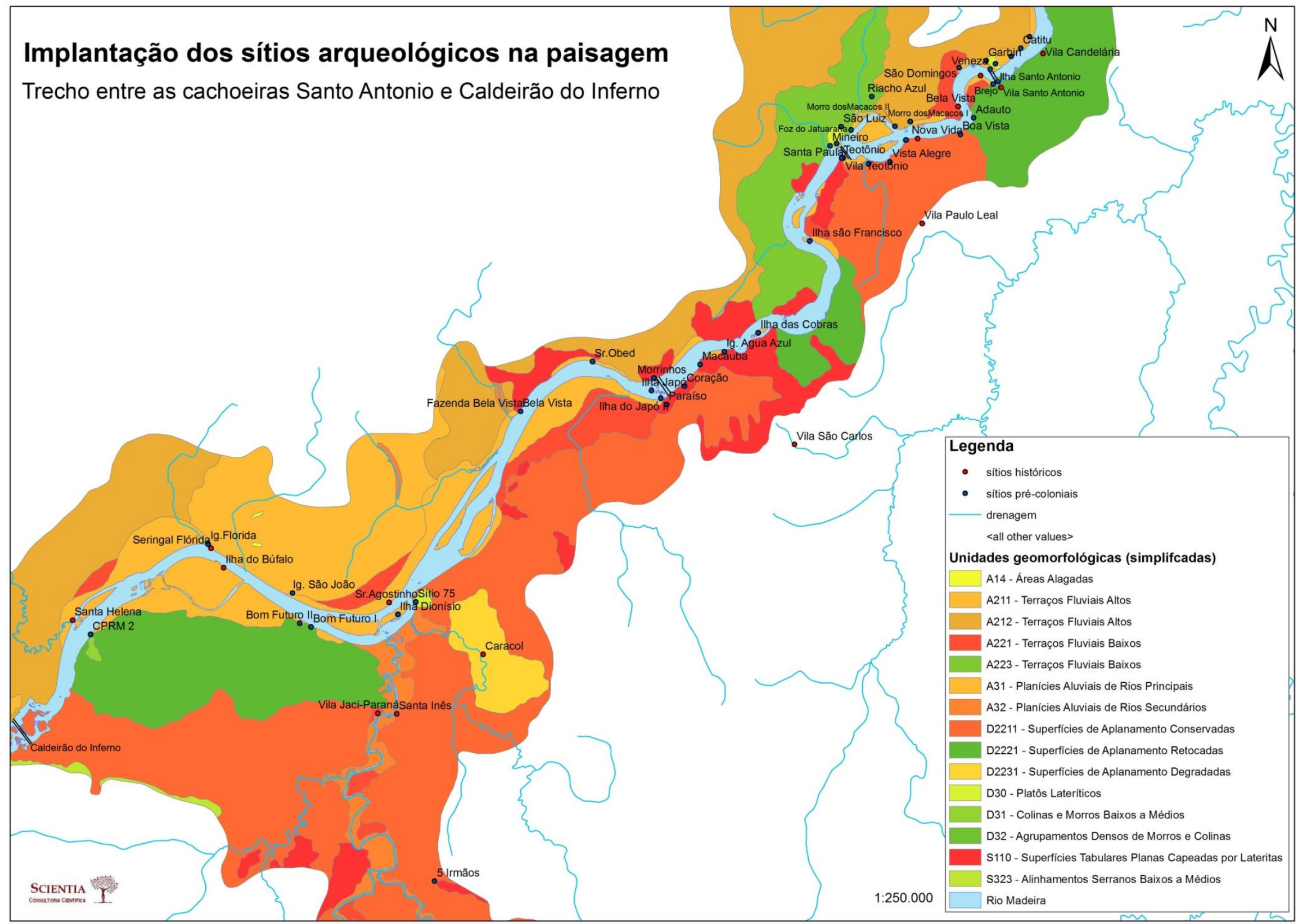

Mapa 7: localização dos sítios arqueológicos no Alto rio Madeira, Rondônia (Michelle Tizuka, 2012). 


\subsubsection{Sítio Ilha de Santo Antônio}

A Ilha de Santo Antônio, separada da margem esquerda pela cachoeira de Santo Antônio e da margem direita por um pequeno braço do rio Madeira, transponível a pé em épocas de estiagem, possuía na sua porção noroeste as estruturas de um presídio do Território Federal de Rondônia construído na década de 1970 e desativado no início de 1980, sobre o qual existem poucos documentos em função de um incêndio (MENEZES \& GUSMÃO, 2005, p. 8). No ano de 2008 ainda existiam na ilha moradias, roçados, plantações e caminhos diversos utilizados pela população local que ia pescar na cachoeira e realizar atividades de lazer. A vegetação era mesclada entre áreas de roçado recente e capoeira, e ocorriam incêndios anualmente. As áreas de roça, onde eram cultivados mamão, banana, e principalmente mandioca estavam na porção oeste-sudoeste, junto a uma mancha de terra preta, que se diferenciava dos sedimentos álicos e silto-argilosos nas demais áreas da ilha. Junto à mancha de terra preta foi localizado o sítio arqueológico pré-colonial Ilha de Santo Antônio.

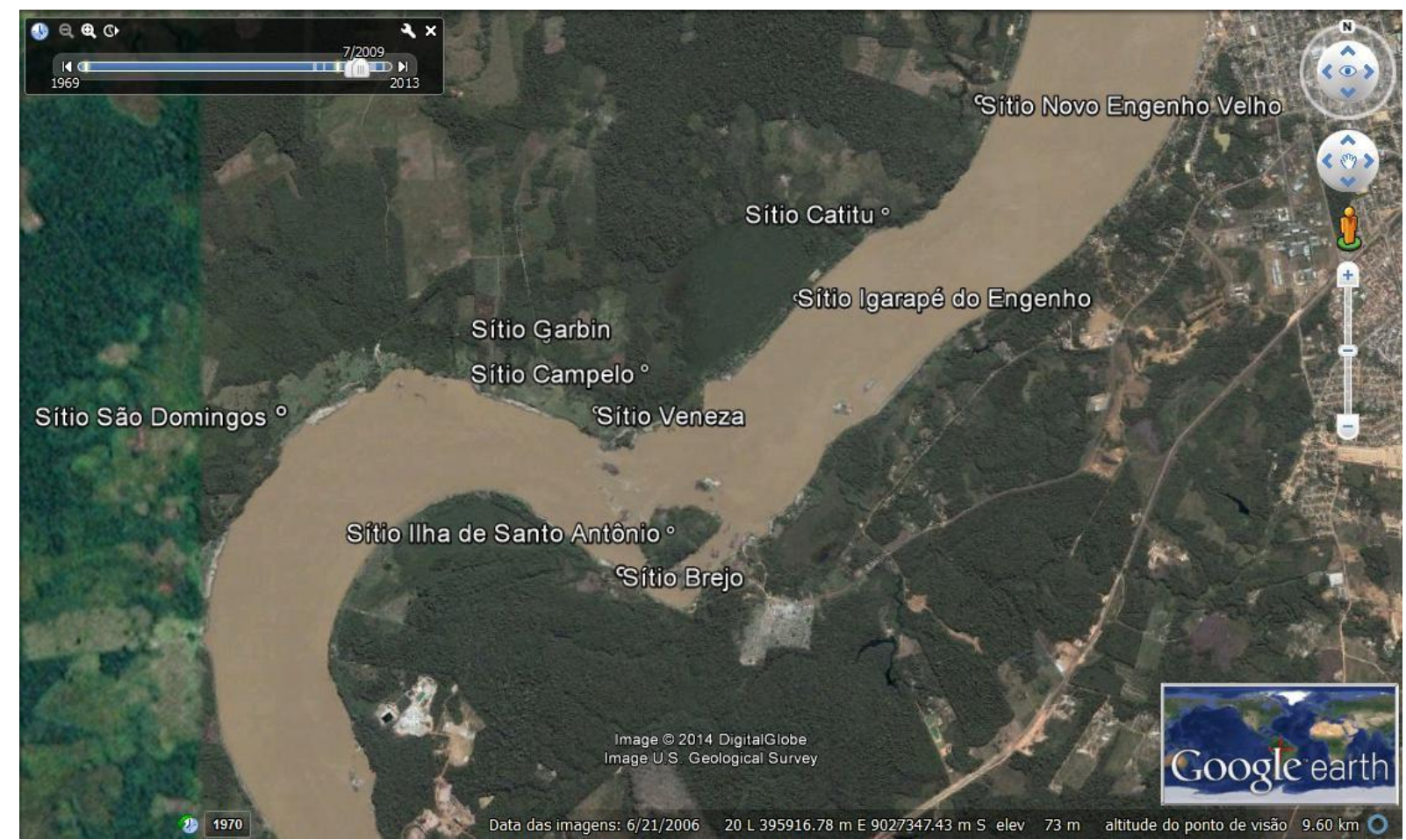

Figura 10: sítios arqueológicos nas proximidades da cachoeira de Santo Antônio. Imagem: Google Earth.

O sítio possui $300 \mathrm{~m}$ Leste-Oeste e $320 \mathrm{~m}$ Norte-Sul de extensão (ver croqui abaixo), sendo que a cerâmica estava mais concentrada a noroeste onde a camada de terra preta era mais espessa e o lítico na porção sudeste do sítio (área central da ilha). Nos afloramentos de granito em volta da ilha é possível visualizar os polidores em quatro áreas (noroeste, leste, sul e sudeste da ilha). Foram realizadas escavações principalmente na área de terra preta 
arqueológica, porém também nos seus limites e fora dela, totalizando 26 unidades de $1 \mathrm{~m}^{2}$, sendo algumas contíguas (Croqui do sítio na figura 11). As escavações revelaram dois contextos distintos: um relacionado à ocupação por grupos pré-cerâmistas e um contexto de ocupação por grupos ceramistas.

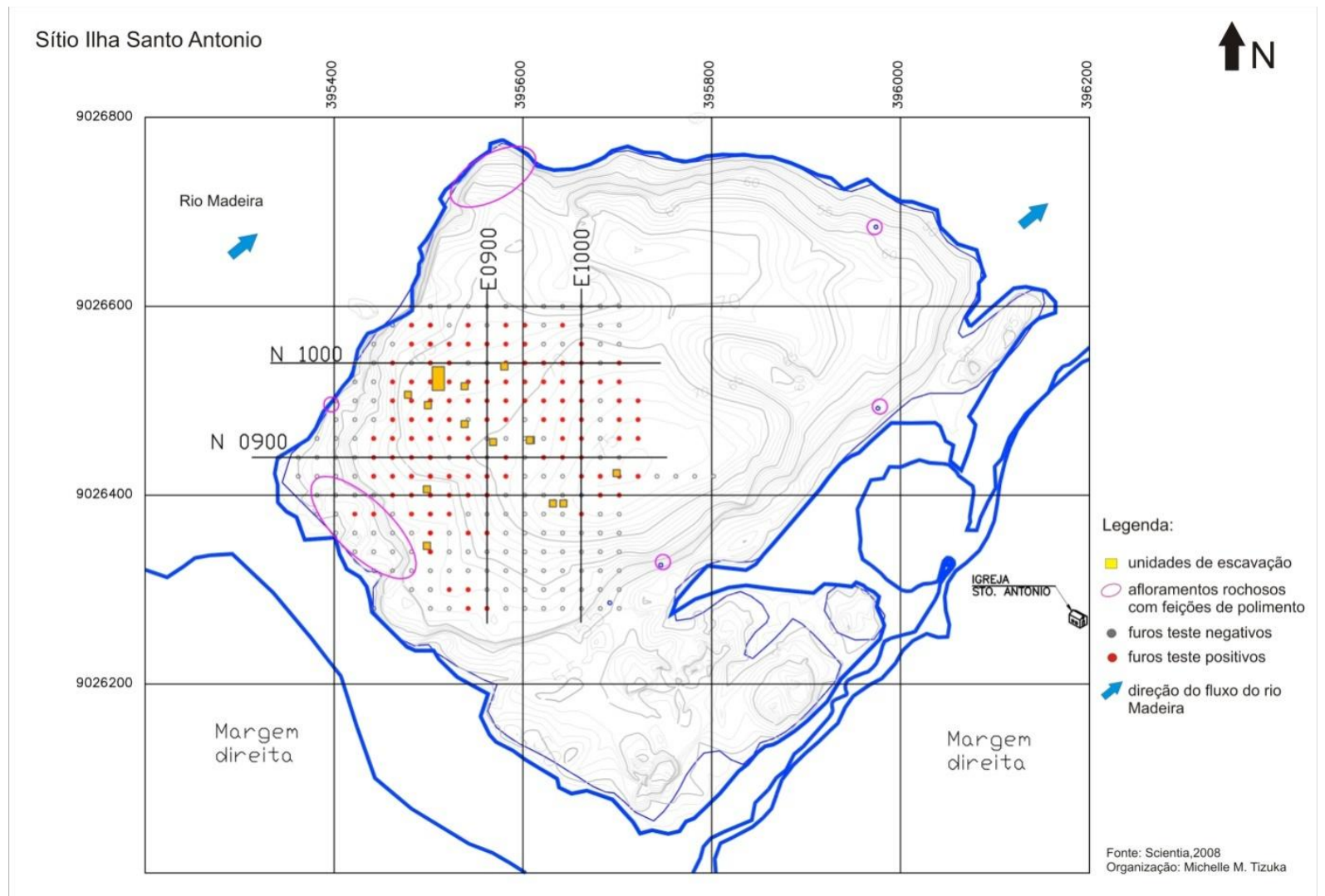

Figura 11: croqui do sítio Ilha de Santo Antônio (Michelle Tizuka, 2012).

A porção mais alta da ilha (leste do sítio) foi ocupada por grupos pré-ceramistas (unidades N922 E949; N922 E950 e N 887 E 1041), cujo material lítico é caracterizado por lascas e blocos fragmentados de quartzo leitoso, algumas lascas de quartzo hialino e lateritas com marcas de ação abrasiva. Nas unidades N922 E949 e N922 E950, escavadas no limite sul da terra preta ocorreu pouca cerâmica associada ao lítico até o nível 60-70 cm, enquanto este continuou aparecendo até $220-230 \mathrm{~cm}$, com maior concentração no nível $70-80 \mathrm{~cm}$. Na unidade N887 E1041, escavada fora da mancha de terra preta, foram encontrados apenas materiais líticos até o nível 140-150 cm. Na unidade N959 E841 o lítico lascado continua aparecendo abaixo da camada com cerâmica, com a possibilidade desta ocupação se estender até essa área. Foi obtida a data de $7760 \pm 50 \mathrm{AP}^{3}$ para amostra de carvão coletada a $163 \mathrm{~cm}$ de profundidade na unidade N922 E949 (SCIENTIA, 2011b).

\footnotetext{
${ }^{3}$ Datação inédita fornecida pela Scientia Consultoria Científica.
} 
$\mathrm{Na}$ área ocupada pelos grupos ceramistas foi evidenciada uma mancha de terra preta com coloração bruno escuro (10 YR 3/3) ou Bruno acinzentado muito escuro (10 YR 3/2), textura silto-argilosa, macia e pouco compacta, com presença de cerâmica, lítico lascado e polido, blocos de granito, lateritas, seixos, bolotas de argila e carvão. A terra preta estava assentada sobre uma camada sedimentar de latossolo álico, bruno-amarelado, compacto, argiloso a argilo-siltoso, com ou sem cascalho laterítico (SCIENTIA, 2011b). Foi escavada uma área com treze unidades contíguas (N990 E850, N990 E851, N990 E849, N989 E849, N991 E849, N992 E849, N993 E849, N989 E850, N989 E851, N988 E849, N988 E850, N988 E851, N987 E849), onde a terra preta apresenta aproximadamente $50 \mathrm{~cm}$ de profundidade (com mergulhos nas bioturbações e feições), sendo evidenciada uma vasilha cerâmica denominada Recipiente 1 (R1), enterrada no latossolo e na terra preta, entre 40 e 90 cm de profundidade nas unidades N990 E849 e N990 E850. Também apareceram feições no latossolo, de tamanhos e formas variadas. Foi escavado um assador emborcado junto a bolotas de argila queimadas e a um fragmento de carvão no nível 20-30 cm da unidade N988 E 849, possível contexto doméstico. Nesta área de escavação também foram encontrados líticos polidos (possíveis lâminas), dois adornos polidos (um pingente no interior do R1), fusos de cerâmica e fragmentos de vasilhas com decoração variada: engobo vermelho e branco, apliques (um deles zoomorfo), incisos, ponteados, etc. As bioturbações ocorrem em grande quantidade, causadas principalmente por cupins, formigueiros e raízes (SCIENTIA, 2011b).

Nesta área a estratigrafia apresenta três camadas bem definidas, denominadas em ordem crescente da base para o topo: camada I é caracterizada pelo latossolo amarelo, argiloso e de compactação alta, com material arqueológico nos primeiros níveis associados às bioturbações (esta camada ocorre até $170 \mathrm{~cm}$ da superfície, sobre solo vermelho argiloso muito compacto e estéril arqueologicamente de coloração vermelha 2.5 YR 4/8); a camada II é a camada arqueológica, com coloração bruno muito escuro (10YR 2/2) e preto (10YR 2/1), argilo-arenoso e de compactação média, com grande quantidade de material arqueológico, e estende-se até $50 \mathrm{~cm}$ de profundidade, com mergulhos resultantes das bioturbações e das feições identificadas; a camada III é húmica, de coloração bruno escuro (10YR3/3), arenoargilosa e de baixa compactação, com presença de muitas raízes e radículas, e pouca quantidade de material arqueológico. Foi obtida uma datação 14C $990 \pm 40 \mathrm{AP}^{4}$ para uma amostra de carvão coletado a $42 \mathrm{~cm}$ da unidade N990 E849 (SCIENTIA, 2011b).

\footnotetext{
${ }^{4}$ Datação inédita fornecida pela Scientia Consultoria Científica.
} 
A vasilha R1 estava enterrada parcialmente no latossolo, cuja feição de enterramento foi denominada F17, seccionada por três outras menores (F13, F14 e F15). No seu interior, associados à terra preta, foram encontrados fragmentos cerâmicos, líticos, pequenas bolotas de argila, carvões, destacando-se um pingente de hematita com furo, escavado a $20 \mathrm{~cm}$ de profundidade em relação à borda da vasilha (SCIENTIA, 2011b). Apesar de não terem sido evidenciados fragmentos ósseos, possivelmente trata-se de uma urna funerária. Outras vasilhas semelhantes foram identificadas nesta área do sítio ( $\mathrm{R} 2$ e R3), conforme mencionaremos em seguida.

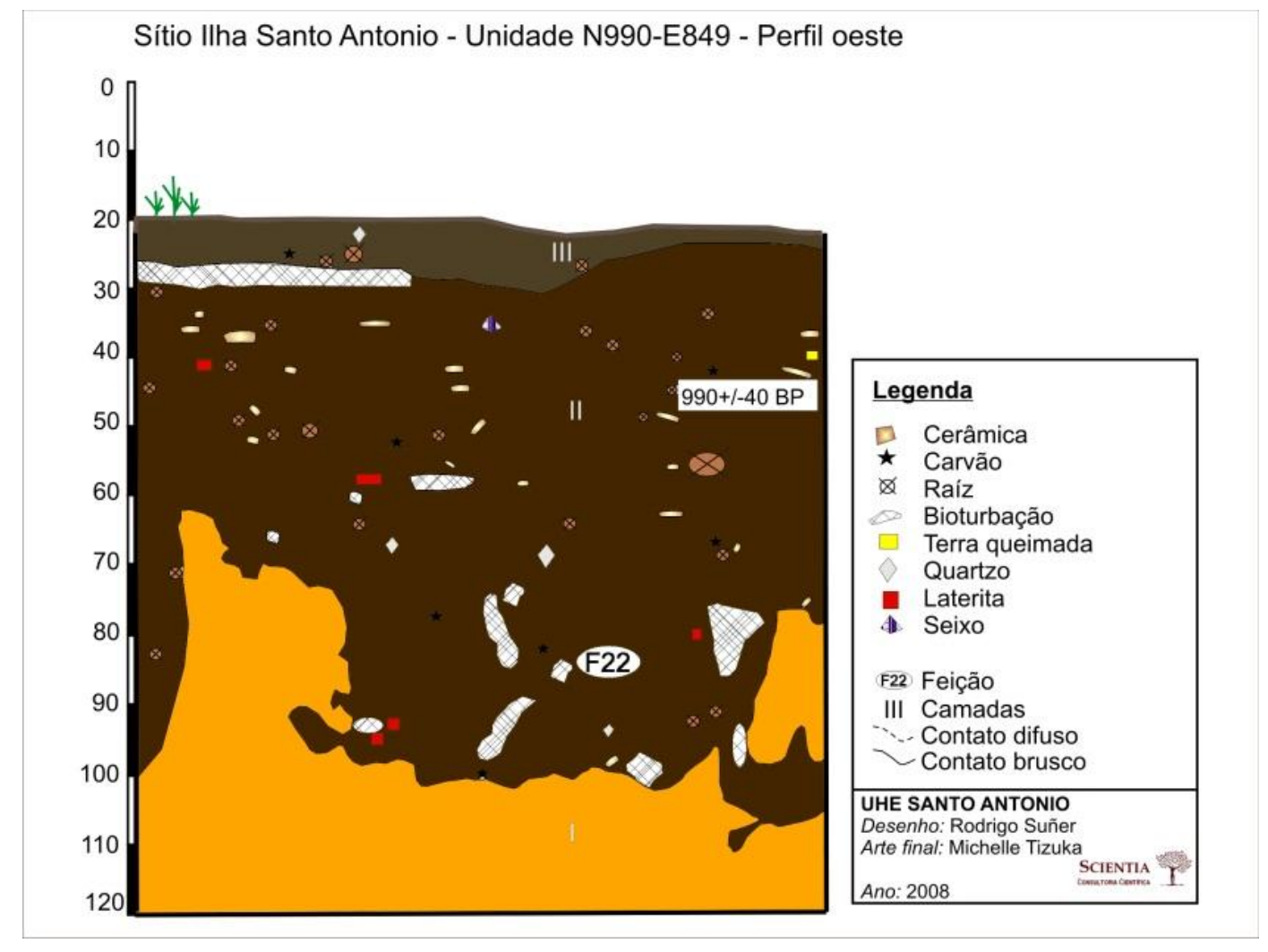

Figura 12: perfil da unidade N990 E849 - sítio Ilha de Santo Antônio (SCIENTIA, 2008).

Outras nove feições foram identificadas nesta área. Ao analisar os dados de campo relativos à localização, tamanho e forma das feições, percebemos que existem dois tipos: aquelas que apresentam sessão circular, com o mesmo diâmetro até a base ou diminuição dele obtendo-se a forma de um cone invertido (feições F5, F16, F19, F9 e F23), que possivelmente são buracos de estaca; e as feições que são mais largas do que profundas (F3, F6, F22 e possivelmente a F21 e a F23) com a base arredondada (ver croqui). 

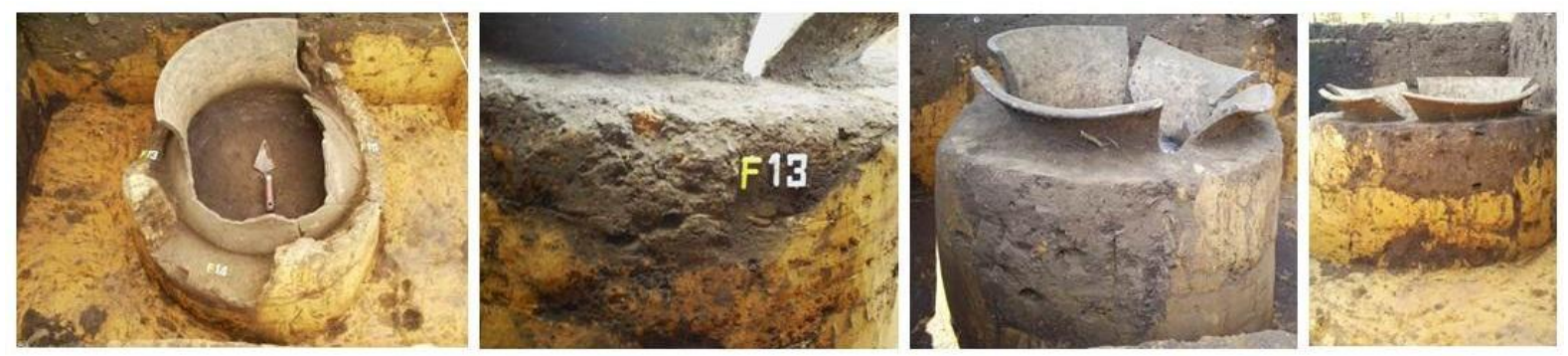

Figura 13: Fotos do recipiente 1 e feições F13, F14 E F15, respectivamente (SCIENTIA, 2008).

\section{Sítio llha Santo Antonio}

Croqui de feições - Setor do Recipiente 1

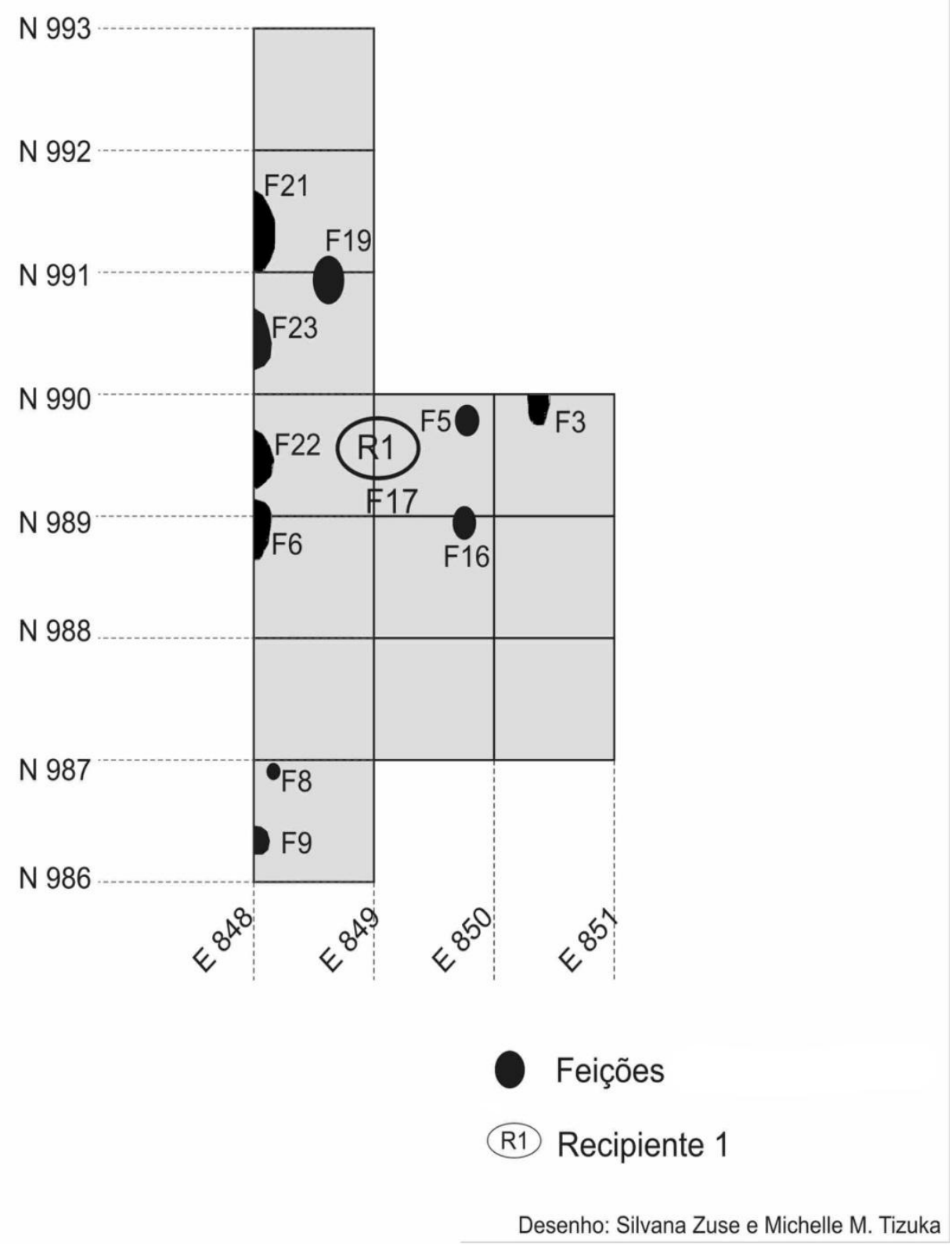

Figura 14: croqui esquemático das feições evidenciadas no setor do R1 (Michelle Tizuka, 2013). 

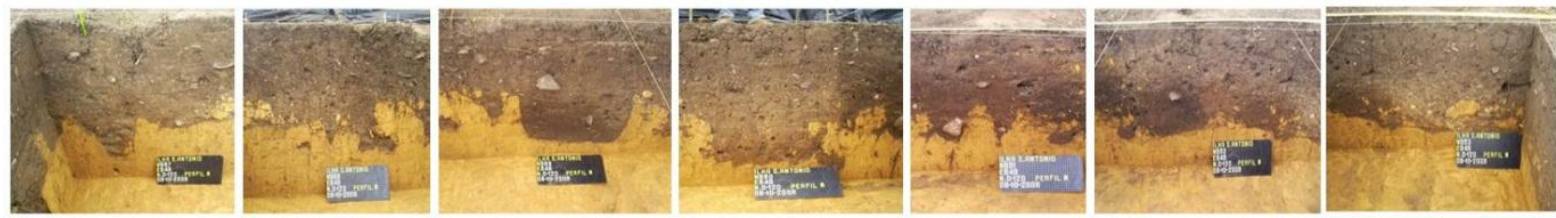

Figura 15: feições no perfil Oeste (N986 E848 a N993 E848) (Fotos: SCIENTIA, 2008).

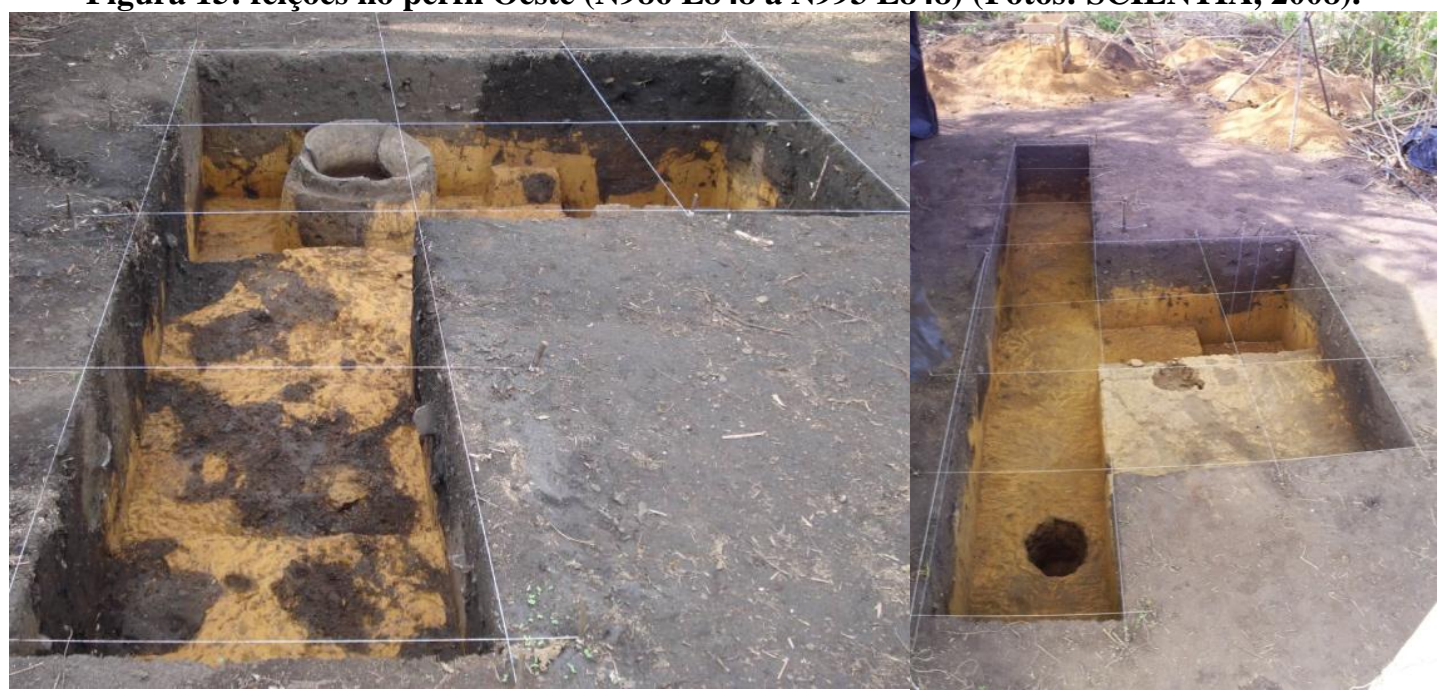

Fotografias 3 e 4: escavações no setor do R1 - sítio Ilha de Santo Antônio (SCIENTIA, 2008).

$\mathrm{Na}$ parte leste deste setor foi realizada uma escavação com retroescavadeira, sendo encontrados fragmentos de duas vasilhas muito semelhantes ao R1, denominadas R2 e R3, além de uma vasilha com fuligem e depósito de carbono (R4) e dez feições com forma predominantemente circular. O R3 apresentava apenas uma parte da base enterrada no latossolo, e o R2 estava emborcado na terra preta (SCIENTIA, 2011b). Ambas possuem pintura vermelha e branca na face externa e motivos semelhantes ao R1.

Em outras áreas do sítio (unidades N959 E841, N974 E849, N979 E880, N980 E849 e N939 E880) também ocorreu uma camada de terra preta (60 cm de espessura em média) com material arqueológico. Uma estrutura (E1) com cerâmicas e rochas dispostas em formato vertical (possível lixeira) foi escavada na unidade N959 E841 (20-30 e 30-40 cm) e uma segunda estrutura (E2) com cerâmicas e rochas foi escavada no nível $50-60 \mathrm{~cm}$ da mesma unidade. Na unidade N974 E849, que apresenta uma camada de terra preta com cerâmica, lítico lascado, seixos e rochas até o nível $50-60 \mathrm{~cm}$, foi evidenciada a feição F12 na metade norte da unidade, entre os níveis 90-100 e 110-120 com presença de terra preta, lítico, carvão, bolotas de argila e seixos de laterita. 


\section{UHE Santo Antônio Sítio Illha Santo Antônio Unidade: N979 E880 \\ Perfil Norte \\ Data: 26/08/08 \\ Profundidade: $0-150 \mathrm{~cm}$}

Legenda:

Camada A: arqueológica principal $(\mathrm{Cr}+\mathrm{Lt}) 80$ presença de radiculas.

Camada B: bioturbada $(\mathrm{Cr}+\mathrm{Lt})$ 10YR 4/4; textura argilosa, presença de raizes e radiculas

Camada C $(\mathrm{Cr}+\mathrm{Lt})$

10YR 3/3; textura argilosa,

presença de poucas radiculas, compacto

Camada D $(\mathrm{Cr}+\mathrm{Lt})$

10YR 6/6; textura argilosa,
mosqueada, predominio de latossolo amareld 120

Cerâmica

Bioturbação

contato difuso entre camadas

contato brusco entre camadas

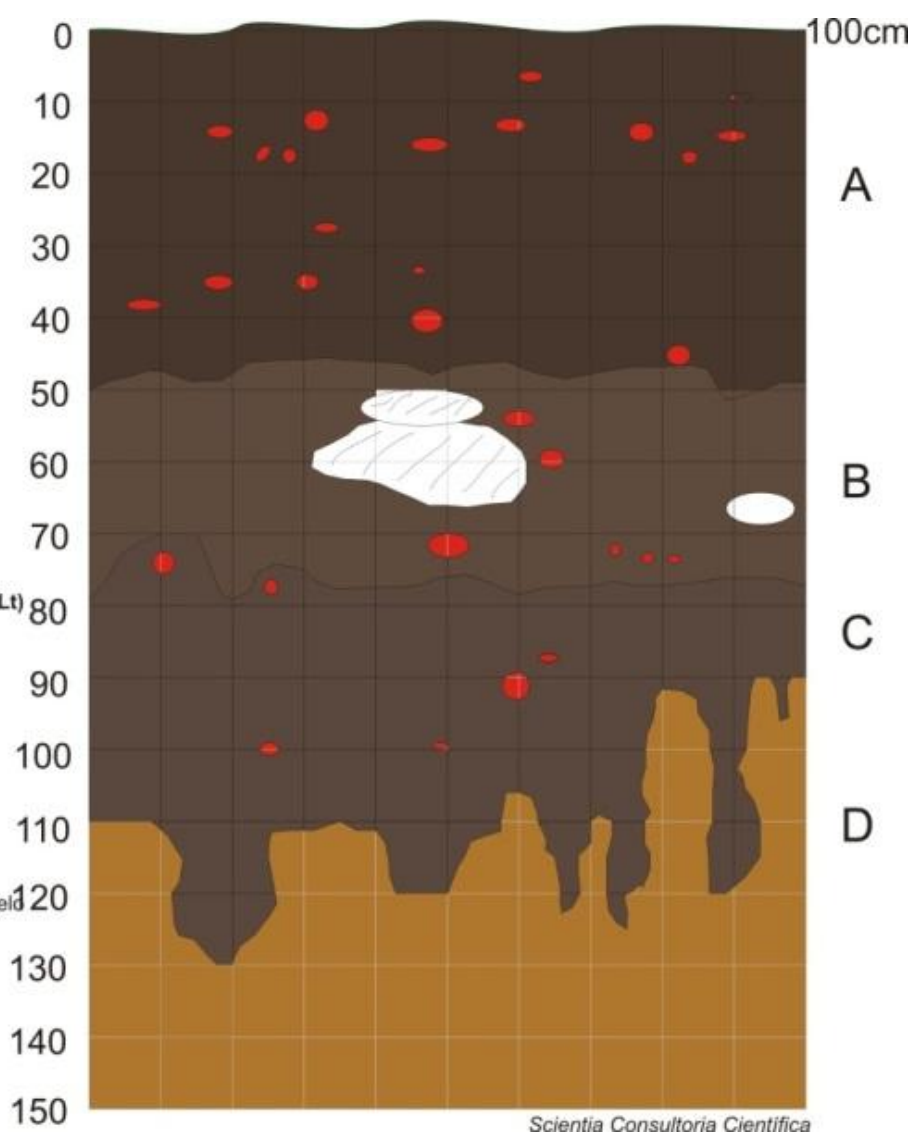

Scientia Consultoria Cientifica

Figura 16: perfil da unidade N979 E880 - sítio Ilha de Santo Antônio (SCIENTIA, 2008).

$\mathrm{Na}$ periferia (limites) da mancha de terra preta foram feitas algumas escavações (N1000 E922 a norte; N970 E820 a oeste; N920 E910 a sudeste; e as unidades N870 E840 e N810 N840 a sudoeste). Uma feição (F1) foi escavada na unidade N1000 E922 (100-110 a 130-140 cm), com forma de cone invertido (40 cm de diâmetro no topo e $26 \mathrm{~cm}$ de altura), com um bloco de granito de $13 \mathrm{~cm}$ de comprimento máximo colocado no fundo da feição, caracterizada como um buraco de estaca. A feição F2 foi escavada na unidade N970 E820, caracterizando-se como um prolongamento da terra preta no canto noroeste a partir de $50 \mathrm{~cm}$ até o nível $110-120 \mathrm{~cm}$. Na unidade N920 E910 a camada de terra preta possui apenas $30 \mathrm{~cm}$ de espessura, seguida por uma camada de coloração mais clara, pouca cerâmica e presença de muitos blocos de granito. As unidades N870 E840 e N810 N840 foram escavadas em área com maior declividade em um patamar inferior próximo ao rio, destacando-se o contexto da primeira por apresentar uma camada arqueológica enterrada (camada III) entre 20 e $50 \mathrm{~cm}$ de profundidade, com cerâmica e carvão, entre duas camadas praticamente estéreis (fotografia 5). Nesta o pacote arqueológico teria sido enterrado pela ação do rio em cheias no passado (SCIENTIA, 2011b). 


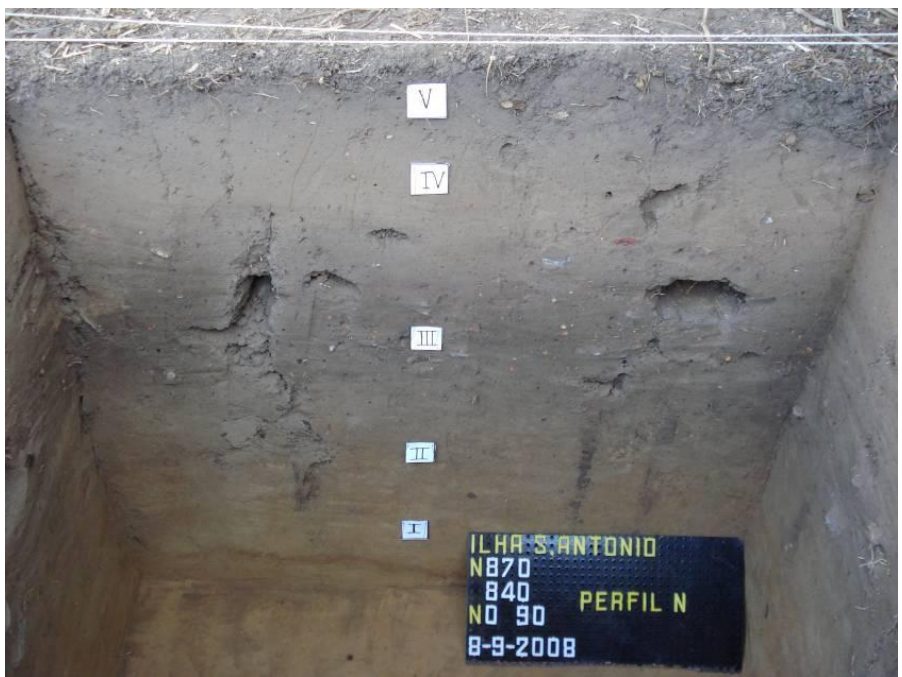

Fotografia 5: Perfil da unidade N870 E840 - sítio Ilha de Santo Antônio (SCIENTIA, 2008)

O material lítico do sítio é composto predominantemente por lascas e núcleos de tamanho pequeno, predominantemente de quartzo leitoso e menor quantidade de quartzo hialino, algumas lascas apresentando marcas de estilhaçamento no gume, que podem ser decorrentes do uso, e são frequentes pequenos nódulos e veios de quartzo cuja retirada de lascas corticais produzem um gume denticulado e cortante, possíveis instrumentos (fotografias 6 a 11). Ao todo ocorrem oito percutores no sítio, de quartzo, quartzito e granito. Entre os materiais polidos, ocorrem três artefatos quase inteiros que podem ser lâminas, com fragmentação apenas no gume ou no talão, além de fragmentos de líticos polidos, todos elaborados em rocha ígnea, e cinco adornos, um deles em laterita e os demais de matéria prima não identificada, sendo um com furo (encontrado no interior do recipiente R1). Ocorrem ainda nódulos e plaquetas de laterita com as faces polidas (possíveis fontes de pigmento ou adornos) e blocos de granito, um deles com uma face polida e uma cavidade (sulco) de sessão arredondada, possível calibrador sobre lasca retirada de um lítico polido. Destaca-se um lítico polido (nível 50-60 cm da unidade N980 E849), confeccionado em laterita, com forma triangular produzida pelo polimento nos bordos, que formou gumes.

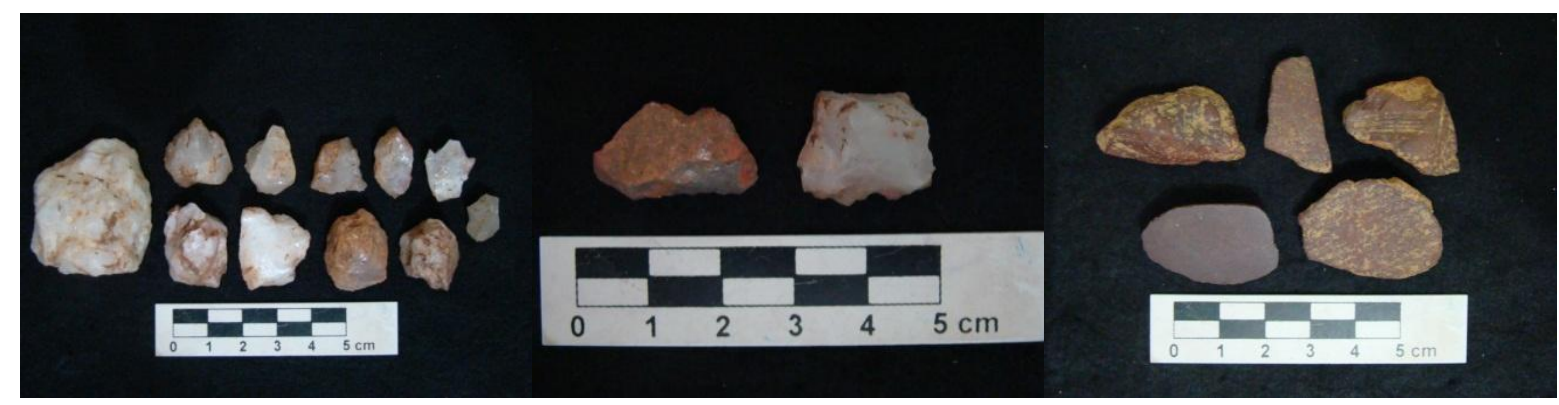

Fotografias 6, 7 e 8: líticos lascados (quartzo) e lateritas com marcas de polimento (SCIENTIA, 2012). 


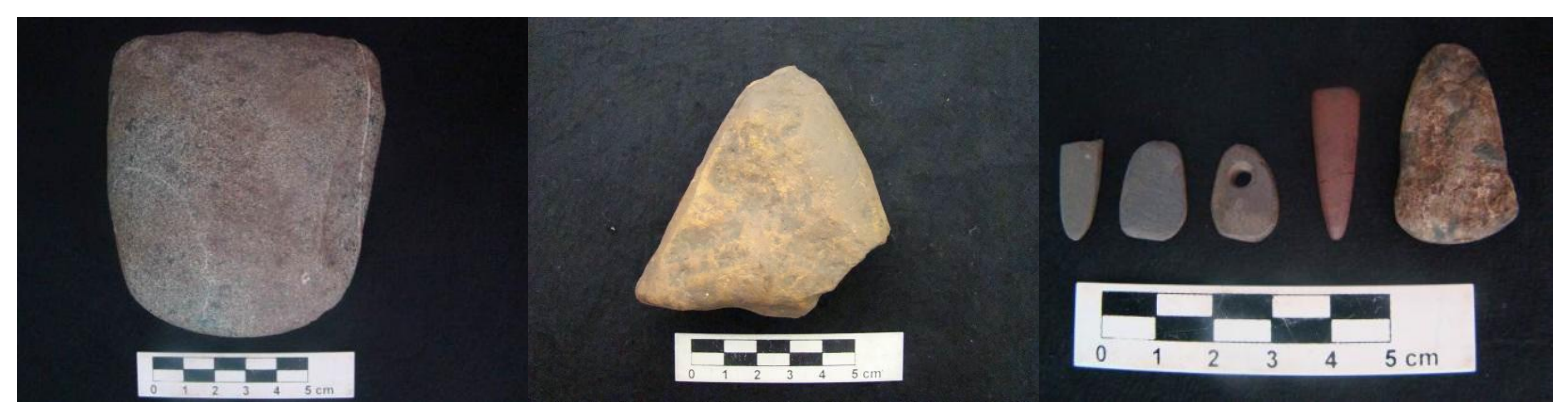

Fotografias 9, 10 e 11: artefatos e adornos polidos - sítio Ilha de Santo Antônio (SCIENTIA, 2012).

A principal questão levantada pelos trabalhos de campo é em relação à continuidade ou hiato entre as ocupações pré-ceramistas e ceramistas. As datas sugerem descontinuidade (14C $7760 \pm 50$ AP para a ocupação pré-ceramista e 950 40 AP para a ocupação ceramista), porém somente a análise do material lítico trará novos dados. Este sítio vem sendo estudado em projetos de iniciação científica e monografias de conclusão de curso (PESSOA, 2012; OLIVEIRA, 2013) e no projeto de mestrado de Pessoa (2013) em andamento. Neste trabalho buscamos entender a variabilidade cerâmica no sítio da ilha, com a análise de amostras de seis unidades (N990 E849, N990 E850, N990 E851, N959 E841, N939 E880 e N870 E840) incluindo a vasilha R1 escavada na N990 E851, além das vasilhas R2, R3 e R4, buscando comparar a cerâmica em termos espaciais (diferentes áreas do sítio: centro da mancha de terra preta, área periférica e área externa à mancha com camada enterrada pela ação do rio), e em termos temporais (se corresponde uma única ou mais de uma ocupação ceramista).

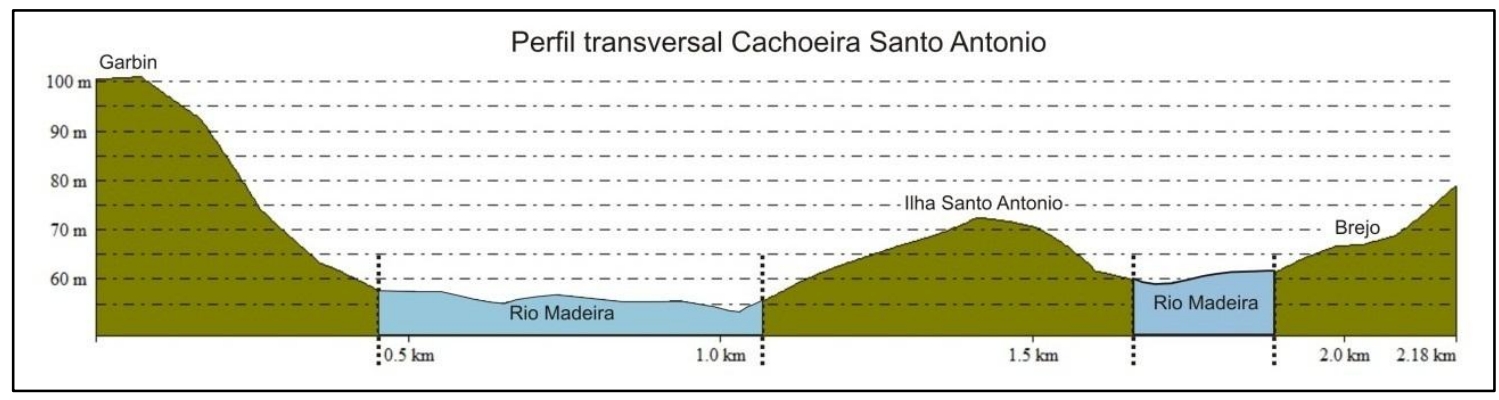

Figura 17: Perfil transversal da cachoeira de Santo Antônio (TIZUKA, 2013, p. 90).

\subsubsection{Sítio do Brejo}

Na margem direita do rio Madeira, em frente à Ilha de Santo Antônio, está o sítio do Brejo, em planície de inundação e com vegetação secundária, capoeira e árvores frutíferas próximas a antigas moradias. É delimitado ao sul e leste por um pântano (“brejo") e a norte pelo rio Madeira. O procedimento de delimitação do sítio evidenciou as áreas com maior 
concentração de material: a cerâmica apresentou alta densidade nas diversas áreas do sítio, enquanto o lítico estava mais concentrado na parte mais elevada, a sul (SCIENTIA, 2010).

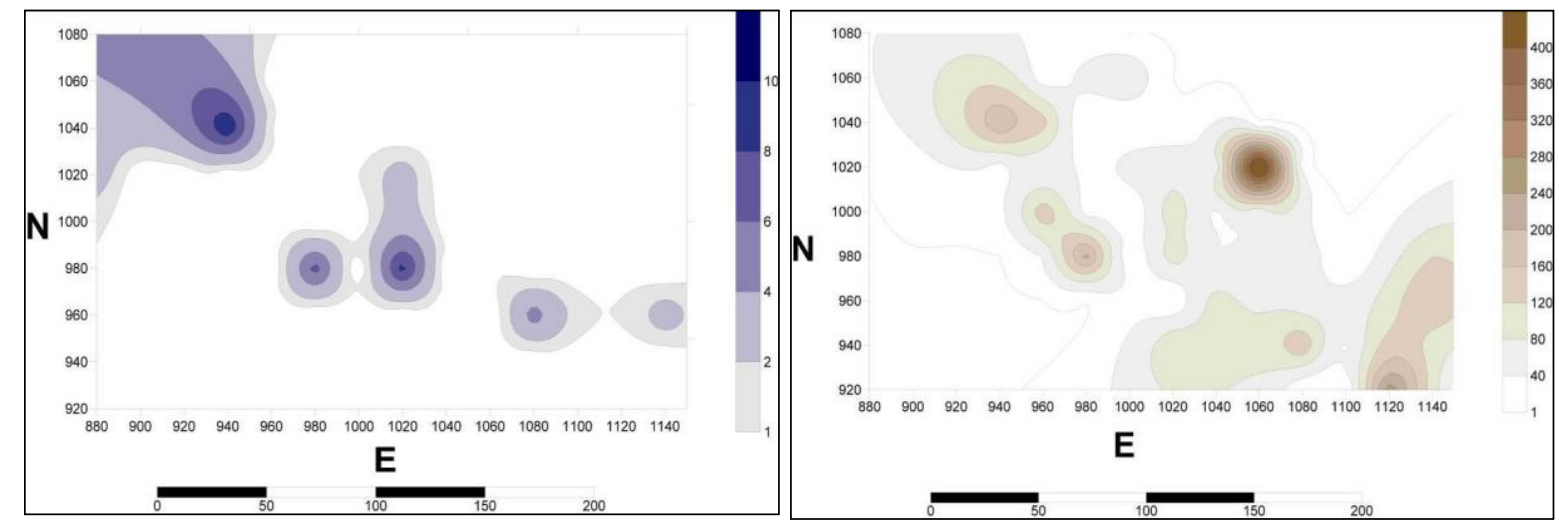

Figura 18: croquis com as densidades da cerâmica e lítico, respectivamente - Brejo (SCIENTIA, 2009).

A partir da delimitação das concentrações de material arqueológico, foram escolhidos seis "setores de escavação" com duas unidades contíguas de $1 \mathrm{~m}^{2}$ em cada um deles (figura 19). Os setores 2, 3 e 4 estão na porção mais elevada do sítio, a sul, enquanto os setores 5 e 6 são intermediários e o setor 1 está em área de altitude inferior, próxima ao rio na porção norte do sítio. Além destas escavações, foram também evidenciados alguns perfis.

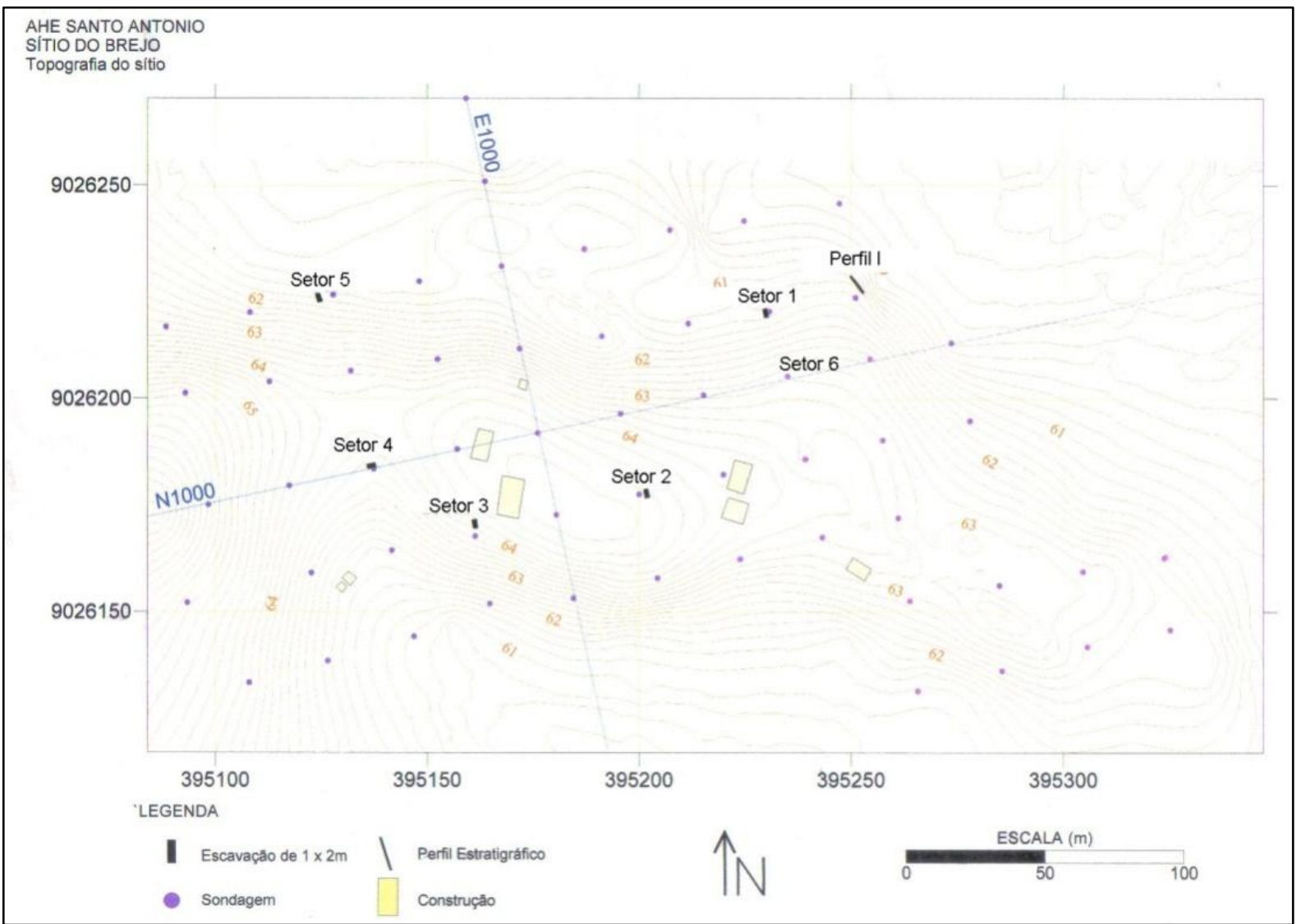

Figura 19: Croqui do sítio do Brejo (SCIENTIA, 2010). 
Tizuka (2013: 98) sintetizou as características da estratigrafia do sítio do Brejo da seguinte maneira: nos seis setores de escavação identificou-se nas camadas arqueológicas um sedimento bruno-escuro a bruno-escuro acinzentado, caracterizado com "terra preta". Nos setores II, III, IV e VI, a estratigrafia apresenta mudanças de textura e coloração a partir da superfície, com quatro camadas de limites difusos entre si: uma camada orgânica silte-arenosa (menos de $10 \mathrm{~cm}$ ), uma camada bruno a bruno escuro silte-arenoso a silte-argiloso arqueológica (de $20-40 \mathrm{~cm}$ ), seguida por camada bruno escuro acinzentado silte-argiloso (40$60 \mathrm{~cm}$ ), até atingir os níveis arqueologicamente estéreis, mosqueados, silte-argilosos a argilosos, compactos, que variam de $60 \mathrm{~cm}$ a $290 \mathrm{~cm}$. Já o setor 1 apresenta uma estratigrafia diferenciada e complexa, com treze camadas identificadas, distintas quanto a textura, composição e processos de formação.

Na parte mais elevada, mais distante do rio e bastante impactada por estar próxima a uma moradia, foram feitas as escavações dos denominados setores 2, 3 e 4 . No setor 2 (N980 E 1022 e N981 E 1022) (cota 64m) a camada arqueológica apresentou $60 \mathrm{~cm}$, coloração bruno escuro e presença de cerâmica, lítico e seixos. O setor 4 (N1001 E959 e N1001 E960) foi escavado na parte do sítio onde foi identificada grande concentração de lítico na delimitação. Neste setor a frequência de material se sobressai em dois momentos: até o nível $80-90 \mathrm{~cm}$ predomina a cerâmica, com poucos líticos associados, enquanto entre os níveis 110-120 e 160-170 cm ocorrem apenas líticos, podendo se tratar de uma ocupação pré-ceramista. $\mathrm{O}$ lítico se apresenta em quartzo leitoso, quartzo hialino, seixos, conglomerados e lateritas.

No setor 3 (N982 E981 e N983 E981) a cerâmica associada a lítico, seixos, blocos e argila, aparece até o nível 90-100 cm, enquanto o lítico continua aparecendo até o nível 110$120 \mathrm{~cm}$. Uma estrutura de combustão (chamada de feição F2) foi escavada na unidade N982 E981 (60-70 a 90-100 cm) composta por sedimento mais escuro, três rochas nas extremidades, cerâmicas queimadas e uma grande quantidade de tições de carvão. Carvões desta fogueira foram datados (nível $70 \mathrm{~cm}$ ), em 14C 1.390 440 AP. Bolotas de argila e rochas apareceram também no nível 40-50 cm desta unidade, não estruturadas. Já na unidade N983 E981 ocorreu uma concentração de material lítico lascado de quartzo no nível 50-60 cm, que pode estar associado à fogueira F2. Nesta unidade foi evidenciada a feição F3 (70-80 a 90100), sendo um possível buraco de estaca. 


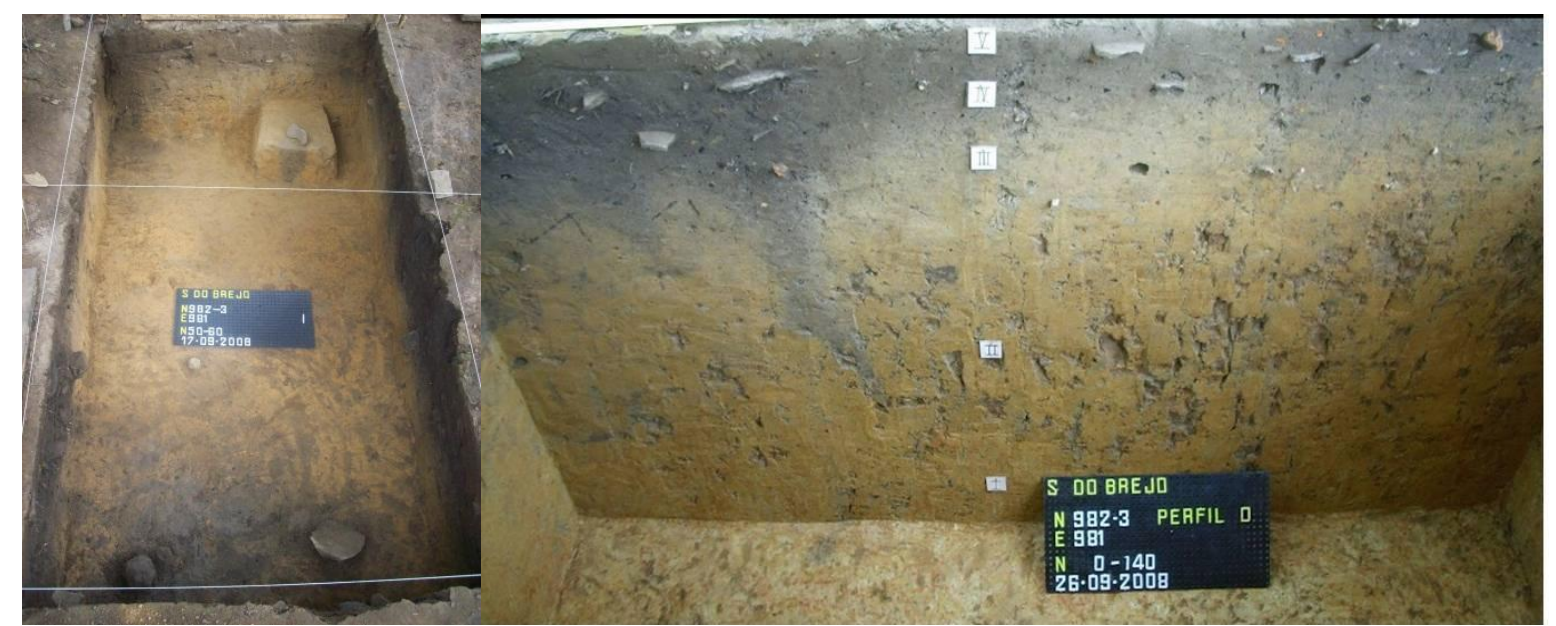

Fotografias 12 e 13: unidades N982 E981 e N983 E981 (estrutura de combustão F2 e buraco de estaca F3), e perfil (SCIENTIA, 2008).

Os setores 5 e 6 foram escavados em área inclinada sul-norte, em cotas de elevação intermediárias (62 e $63 \mathrm{~m}$ ), numa distancia de cerca de 50 e $70 \mathrm{~m}$ do rio Madeira, respectivamente. No setor 5 (N1040 E957 e N1041 E957) a cerâmica ocorreu desde a superfície até o nível 130-140 cm, enquanto o lítico continuou aparecendo até $2 \mathrm{~m}$ de profundidade. Em uma camada de terra preta enterrada, com grande densidade de material arqueológico, foram evidenciadas duas fogueiras, a E1 (N1040 E957) e E2 (N1041 E957), ambas compostas por blocos de granito, cerâmica e carvão (na E2 aparecem também bolotas de argila queimada e alguns fragmentos remontam a base e parede de uma vasilha). Seixos de rio foram coletados ao longo da escavação, bem como lateritas e blocos de granito. Foi obtida a datação de 940 $30 \mathrm{AP}^{5}$ para uma amostra do nível 60-70 cm da unidade N1040 E957.

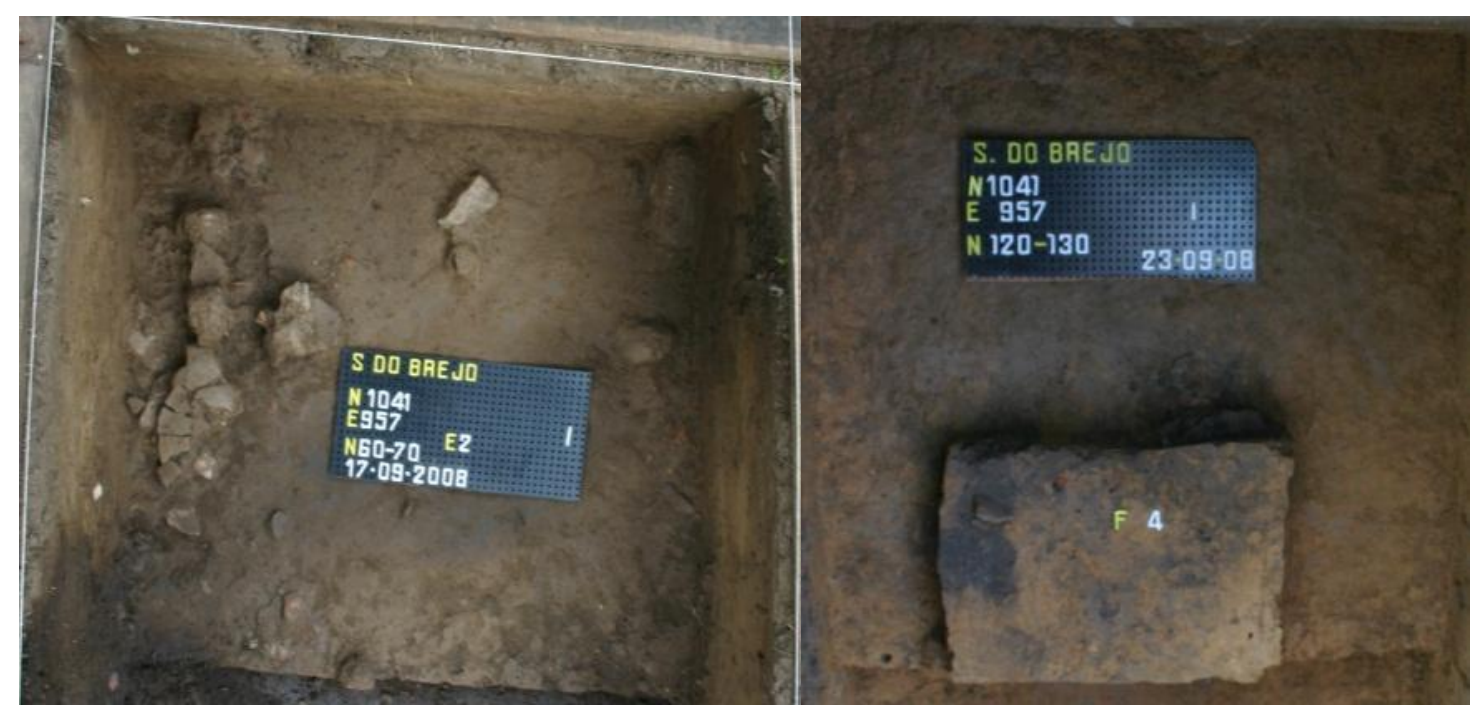

Fotografias 14 e 15: estruturas evidenciadas no setor 5 - sítio do Brejo (SCIENTIA, 2008)

\footnotetext{
${ }^{5}$ Datação inédita fornecida pela Scientia Consultoria Científica.
} 


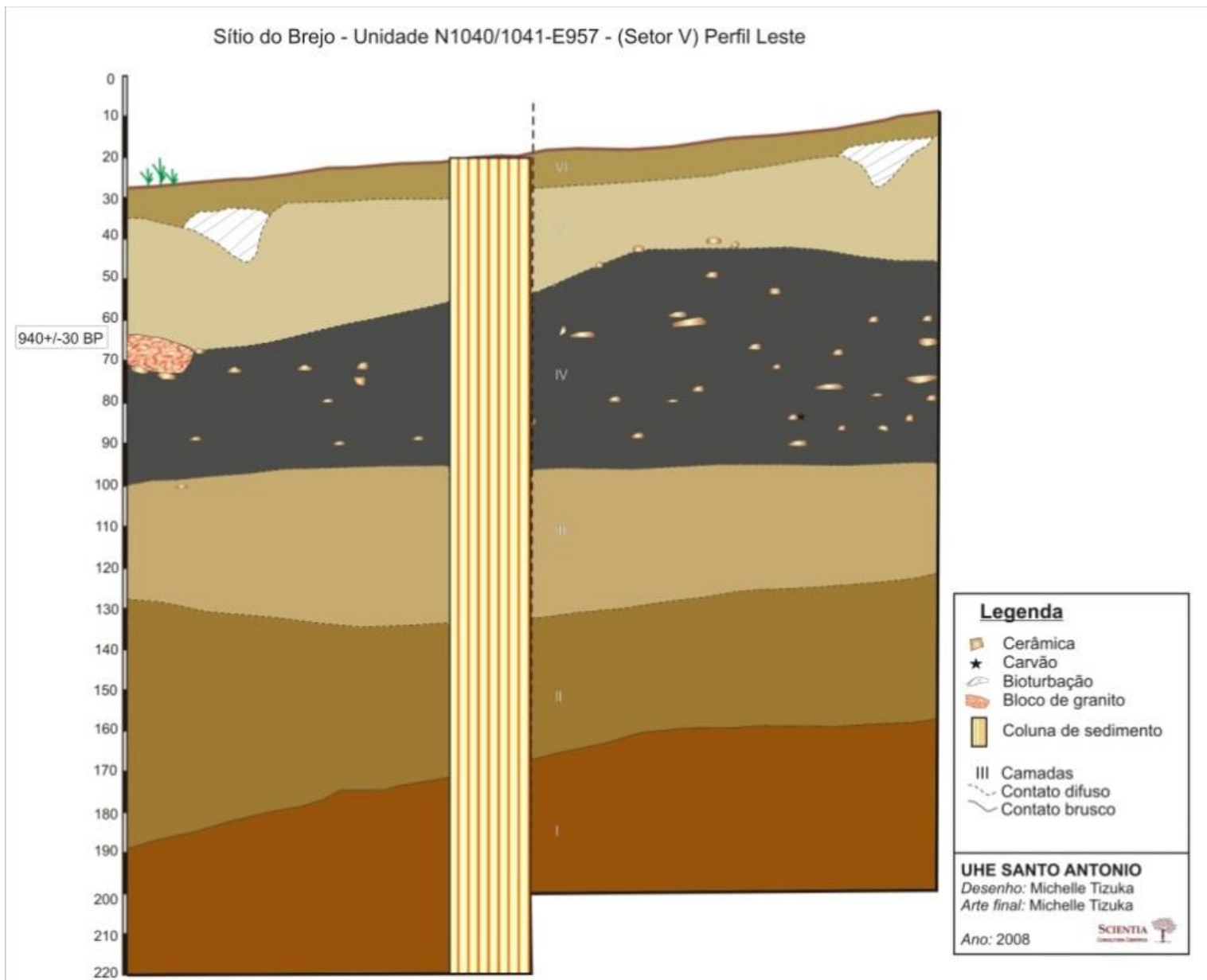

Figura 20: perfil da unidade N1040/1041 E957, sítio do Brejo (SCIENTIA, 2008).

No setor 6 (N1003 E1059 e N1004-E1059), a aproximadamente 70 m do rio Madeira, foi encontrada cerâmica, lítico, argila e rochas, destacando-se uma vasilha no perfil norte da unidade N1004 E1059, na posição inclinada, com fragmentos dela ao redor e até $130 \mathrm{~cm}$, alguns queimados. Ocorreram muitas bioturbações, e um prego foi encontrado a $2 \mathrm{~m}$ de profundidade na unidade N1003 E1059. Neste mesmo setor também foi aberta uma trincheira de $6 \times 1 \mathrm{~m}$ (perfil 2), sendo evidenciada uma camada arqueológica de terra preta enterrada com sedimento de coloração mais clara sobreposto, possivelmente acumulado pelo morador antigo ao construir um canal de escoamento.

No setor 1, situado na porção mais baixa (elevação de 61,157m) próxima ao rio (porção norte do sítio), foram escavadas as unidades N1020 E1059, N1021 E1059, N1022 E059 e N1019 E1059 e ampliado um perfil, totalizandoquatorze metros evidenciados. Neste setor a profundidade das escavações atingiu $4,40 \mathrm{~m}$, com a identificação de treze camadas com características de textura e cor diferenciadas, formadas por processos antrópicos (terra preta) associadas a camadas originadas por processos naturais (depósito fluvial) (TIZUKA, 
2013). Cinco delas são camadas arqueológicas, com presença de material lítico e cerâmico juntamente a carvão, e variam em termos de espessura e quantidade de material, sendo a camada $\mathrm{X}$ a mais espessa e com maior quantidade de fragmentos cerâmicos e carvões. Foram obtidas seis datações radiocarbônicas para as diferentes camadas arqueológicas da unidade N1022 E1059: $1.120 \pm 40$ AP $(620-630 \mathrm{~cm}), 1.040 \pm 60$ AP $(590-600 \mathrm{~cm}) ; 1.160 \pm 40$ AP $(470-480), 1.040 \pm 40$ AP $(350-360 \mathrm{~cm}), 890 \pm 40$ AP $(150-160), 760 \pm 40$ AP $(80-90)^{6}$. As datas nas camadas arqueológicas que são do mesmo período indicam que poderia se tratar de uma mesma ocupação, porém as cheias do Madeira atingiram esta área do sítio depositando sedimento arenoso. Em área próxima ao setor foi evidenciado o perfil I com 4,50m x 2,20m, onde foi visualizada uma camada arqueológica de terra preta enterrada (coloração brunoescuro, siltoso) e abundância de material cerâmico, carvões, seixos de lateritas, granitos friáveis e argila queimada.

Após a expansão das unidades, percebeu-se que a camada IV e VI descritas nos primeiros perfis das unidades N1020-1021 E1059 seriam uma única camada arqueológica que está sobre a camada I, acompanha o desnível de sul para norte e apresenta uma camada arenosiltosa (Camada V) que deve ter sido um evento de cheia do rio. Tizuka (2013) analisa este sítio, mais especificamente a estratigrafia deste setor, buscando entender a dinâmica do rio Madeira e das populações que habitaram a área. Segundo a autora, evidenciou-se neste setor um paleossolo e paleotopografia diferentes da paisagem atual: na época da ocupação humana existia um barranco íngreme com aproximadamente $45^{\circ}$, argiloso, sendo que em 400 anos de ocupação humana foram depositados $7 \mathrm{~m}$ de sedimento, uma deposição rápida em relação ao tempo de ocupação humana no local. Verificou também que todas as camadas arqueológicas profundas (camadas II, IV e VI) são do mesmo período, e que as camadas intermediárias são eventos de cheias do rio Madeira, portanto na medida em que o dique marginal ia se formando, as populações avançavam sobre ele, ocupando áreas cada vez mais próximas ao rio.

Nas proximidades do setor 1 também foram evidenciadas vasilhas cerâmicas, cujo contexto ficou comprometido porque as obras da usina já estavam em andamento no local. Mesmo assim, uma vasilha ainda estava no in situ (R1), contendo no seu interior fragmentos que inicialmente pareciam de três outras vasilhas, porém em laboratório percebeu-se que se tratava de um recipiente quebrado que estava emborcado dentro do R1. Também foram evidenciados fragmentos de outro recipiente (R2) com pintura vermelha e branca e incisões.

\footnotetext{
${ }^{6}$ Datações inéditas fornecida pela Scientia Consultoria Científica.
} 
Foram ainda visualizadas duas feições de enterramento de recipientes, uma possivelmente do R2 (feição F2).
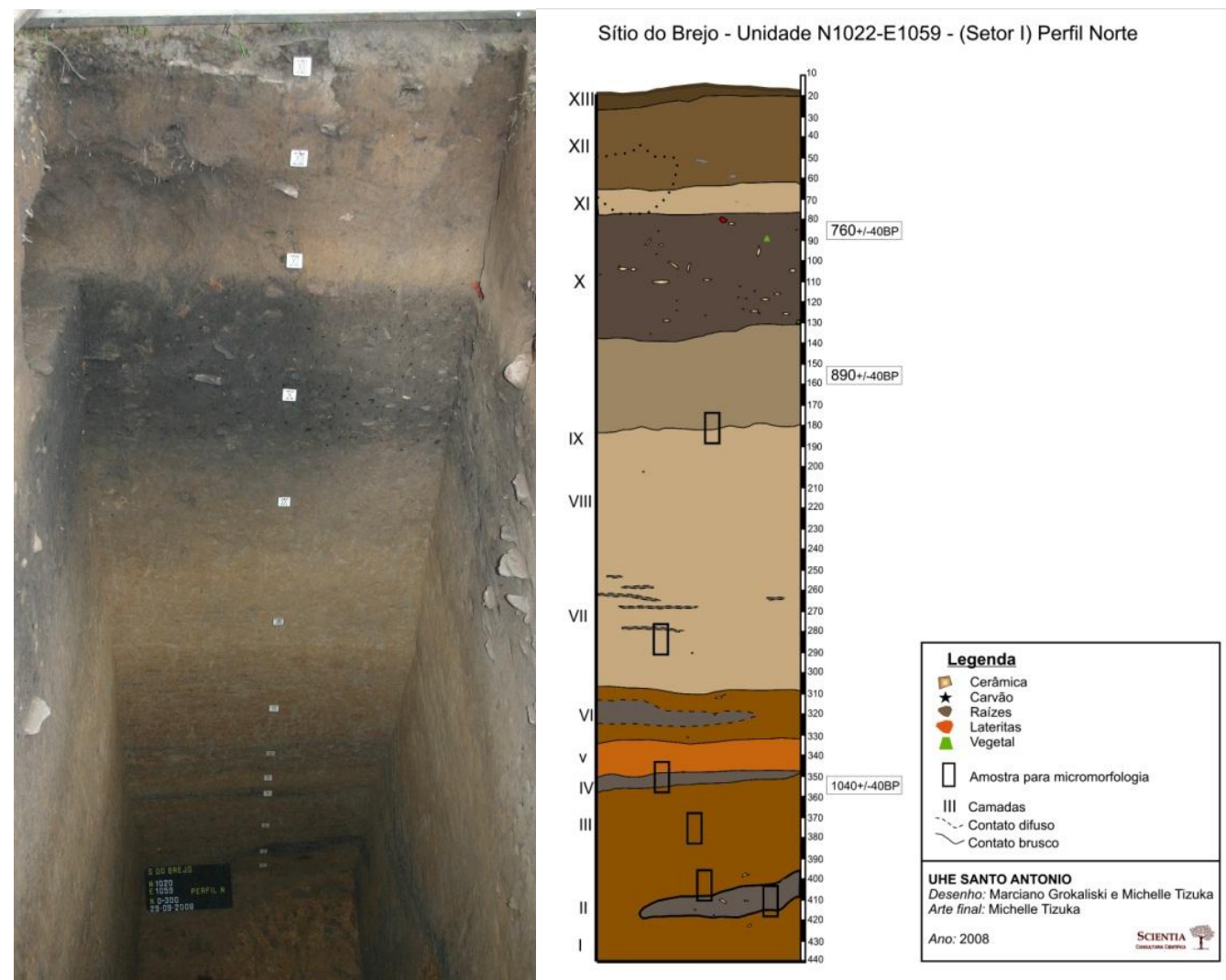

Figura 21: perfil Norte da unidade N1021 E1059, com as 13 camadas identificadas, e perfil da unidade N1022 E1059, respectivamente (SCIENTIA, 2008).
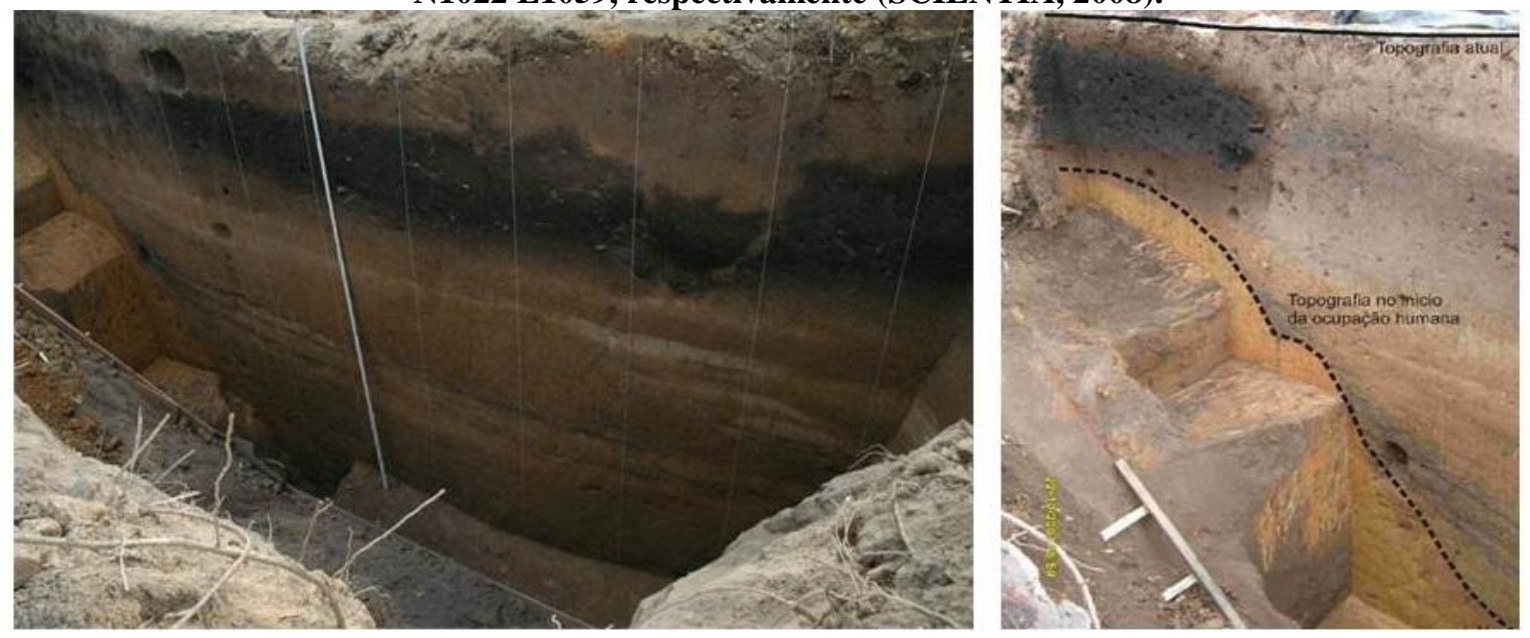

Figura 22: estratigrafia do setor 1 do Brejo e desnível de aproximadamente 45 graus evidenciando uma paleotopografia diferenciada da atual (TIZUKA, 2013: 101 e 102).

Entre as principais problemáticas desenvolvidas a partir dos trabalhos de campo, uma delas é referente à possibilidade de haver uma ocupação pré-ceramista no sítio, tendo em vista que nos setores 4,5 e 6 houve uma transição gradual para o aparecimento dos líticos, saindo do sedimento escuro, para o latossolo. A outra é relacionada à ocorrência de diversas camadas arqueológicas de terra preta enterrada no sítio, algumas intercaladas por camadas naturais de 
deposição fluvial, se elas correspondem a uma única ocupação ou por ocupações distintas. Com a análise da cerâmica dos setores 1, 3 e 5 buscamos entender a ocupação do sítio pelos grupos ceramistas, cujos resultados contribuem para a compreensão da complexa estratigrafia do setor 1, relacionada a ação fluvial, temática abordada por Tizuka (2013). Buscamos comparar o contexto do sítio do Brejo com o sítio Ilha de Santo Antônio, localizado em frente, separados apenas por um pequeno braço do rio Madeira, que em épocas de máxima vazante era transponível a pé.

\subsubsection{Sítio RO-PV-13 Veneza}

Na margem esquerda do rio Madeira, em frente à cachoeira de Santo Antônio, Eurico Miller encontrou o sítio RO-PV-13 Veneza, no ano de 1978 no âmbito do PRONAPABA. Conforme consta na ficha de registro no IPHAN, o sítio possuía na época uma área de $300 \mathrm{~m}$ x $65 \mathrm{~m}$ e um pacote arqueológico com $15 \mathrm{~cm}$ de espessura, com lítico e cerâmica da Subtradição Jatuarana (Tradição Polícroma da Amazônia), já sendo na época pouco conservado devido a erosão, roças e cheias. Em 2008 o sítio foi delimitado (SCIENTIA, 2011b), apresentando forma elipsoidal e extensão de $204 \mathrm{~m}$ de largura e $340 \mathrm{~m}$ de comprimento, com coordenada central E0395116 N9027398. Apresentava-se bastante comprometido, conforme já havia sido registrado por Eurico Miller, ocorrendo perturbações e presença de material recente na camada arqueológica. O local serviu para criação de gado e cultivo de subsistência dos moradores e também sofreu a ação fluvial do rio Madeira, que periodicamente erodia a sua porção sul, conforme pôde ser diagnosticado pela abundância de material arqueológico no pedral em frente ao sítio. A vegetação era predominante rasteira, composta por pastagem, árvores de pequeno e médio porte, além de goiabeiras, mangueiras e palmeiras urucurí (SCIENTIA, 2011b).

O sítio está implantado em planície de inundação. Na sua porção sul adjacente aos pedrais e ao rio possui $60 \mathrm{~m}$ de altitude, elevando-se para o norte na medida em que se distancia do rio, com uma pequena elevação com $90 \mathrm{~m}$ de altitude (chamada área do topo), onde se concentram afloramentos do embasamento granítico, por vezes com veios de quartzo, blocos e matacões. Na porção nordeste o sítio é delimitado por um igarapé com área alagadiça (pantanosa); feições de polimento ocorrem nos pedrais próximos ao rio (figura 23). Na parte mais alta, junto aos afloramentos de granito, ocorreu maior concentração de lítico, enquanto a cerâmica estava dispersa por toda a área do sítio (figura 24). Em superfície os materiais afloraram no topo, junto aos matacões de granito, no setor sul em área próxima ao barranco 
(junto às mangueiras), bem como no barranco e nos pedrais. Nas duas primeiras áreas foram feitas coletas sistemáticas e na área do barranco e pedrais uma coleta não sistemática.

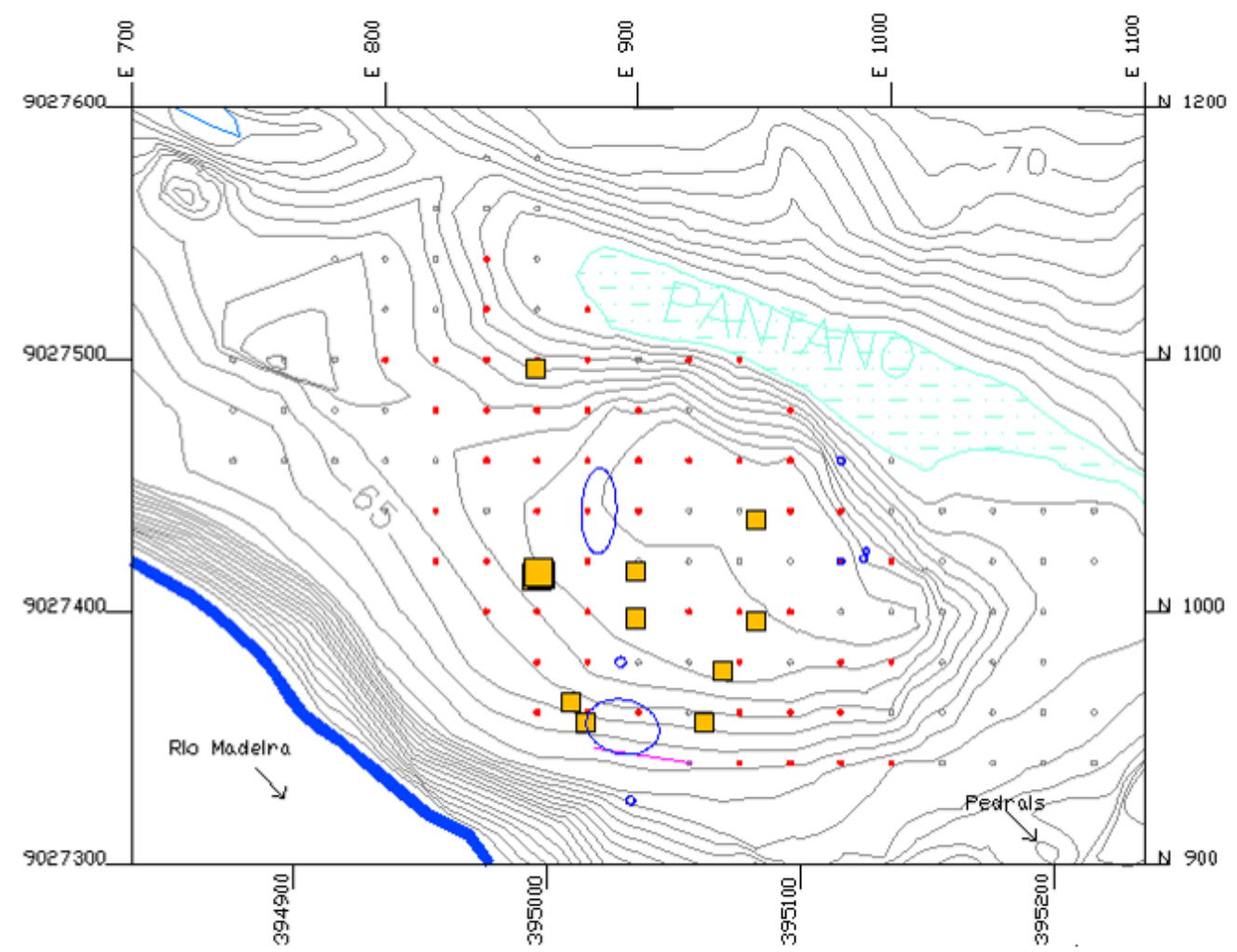

Figura 23: croqui do sítio Veneza. Pontos vermelhos são os furos positivos (delimitação); quadrados amarelos representam as unidades escavadas, círculos azuis as coletas de superfície e traço rosa perfil do barranco (SCIENTIA, 2012).

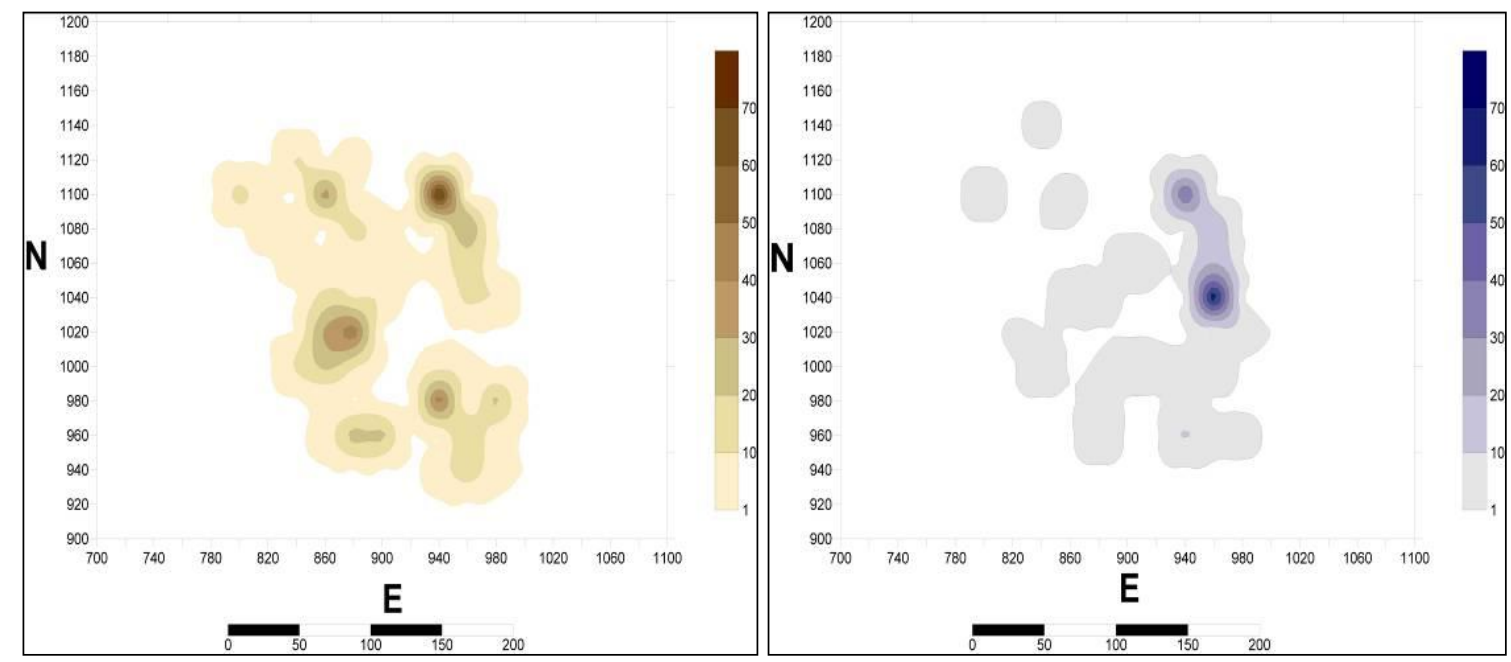

Figura 24: densidade cerâmica e lítica, respectivamente (escala em metros) - sítio Veneza. (SCIENTIA, 2008) 


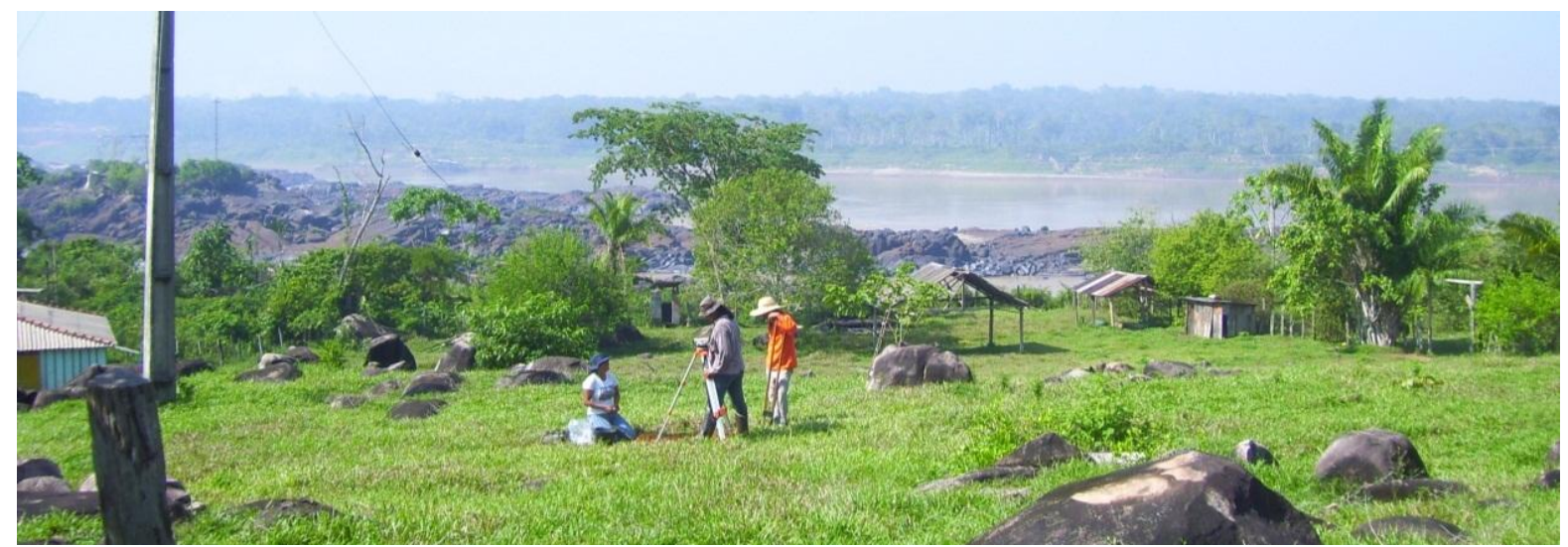

Fotografia 16: visibilidade para o rio Madeira a partir da área do topo- sítio Veneza (SCIENTIA, 2008).

As escavações de 15 unidades de $1 \mathrm{~m}^{2}$ e de um perfil junto ao barranco $(3 \times 8 \mathrm{~m})$ permitiram obter mais informações sobre o sítio. Na parte mais alta (área do topo), além da coleta de superfície mencionada anteriormente, em que predominaram os materiais líticos, foram feitas escavações (unidades N1040 E950, N1020 E903 e N1000 E950), com características semelhantes entre si: camada arqueológica assentada sobre a camada de latossolo com baixa frequência de material arqueológico. Na unidade N1040 E950 a cerâmica ocorreu até $90 \mathrm{~cm}$ e o lítico até $110 \mathrm{~cm}$ de profundidade, nas camadas III, IV e V, de coloração bruno forte (7.5YR 5/8), bruno (10YR3/4) e bruno escuro (10YR 3/3) respectivamente, sendo que na camada III foi identificada a feição F1, possível lixeira, entre $70 \mathrm{~cm}$ e $110 \mathrm{~cm}$. Na unidade N1020 E903 o pacote arqueológico apresentou $50 \mathrm{~cm}$ de espessura e na unidade N1000 E950 $80 \mathrm{~cm}$ (SCIENTIA, 2011b).

Algumas escavações revelaram uma camada arqueológica diretamente sobre o embasamento granítico. Uma delas (N1001 E903) foi escavada na área mais elevada (topo) cuja camada arqueológica (coloração bruno muito escuro - 10YR2/2) apresentou $60 \mathrm{~cm}$ de profundidade e grande quantidade de rochas graníticas a partir de $40 \mathrm{~cm}$. A unidade N980 E837, em área de declive, apresentou uma camada arqueológica de $100 \mathrm{~cm}$ de espessura (coloração variando de bruno 10YR 4/3 nos primeiros $10 \mathrm{~cm}$ a bruno muito escuro 10YR2/2 nos demais níveis), com predominância de material lítico lascado (quartzo), polido (laterita), e seixos de granito a partir de $30 \mathrm{~cm}$ de profundidade ${ }^{7}$.

As unidades contíguas N1020 E865, N1021 E865, N1020 E866, N1021 E866, N1020 E867, N1019 E865, em um patamar intermediário, apresentaram uma camada arqueológica que varia entre 60 e $90 \mathrm{~cm}$, cinzento muito escuro (10YR 3/1), diretamente sobre o piso de granito, sendo que em algumas delas ocorrem placas nos últimos níveis, e em algumas partes

\footnotetext{
${ }^{7}$ Foi feita uma datação C14 de amostra coletada no nível 50-60 cm desta unidade, porém estava contaminada e obteve-se uma data recente
} 
ocorre um sedimento mosqueado amarelo sobre o embasamento. Foi identificada a feição F2, forma arredondada, entre 50 e $90 \mathrm{~cm}$ das unidades N1020 E865, N1021 E865 e N1021 E866 com sedimento bruno muito escuro (10YR 2/2) e presença de cerâmica. No perfil da unidade N1021 E866 foi identificada a estrutura E1 com placas de granito, a $70 \mathrm{~cm}$ de profundidade (SCIENTIA, 2011b).

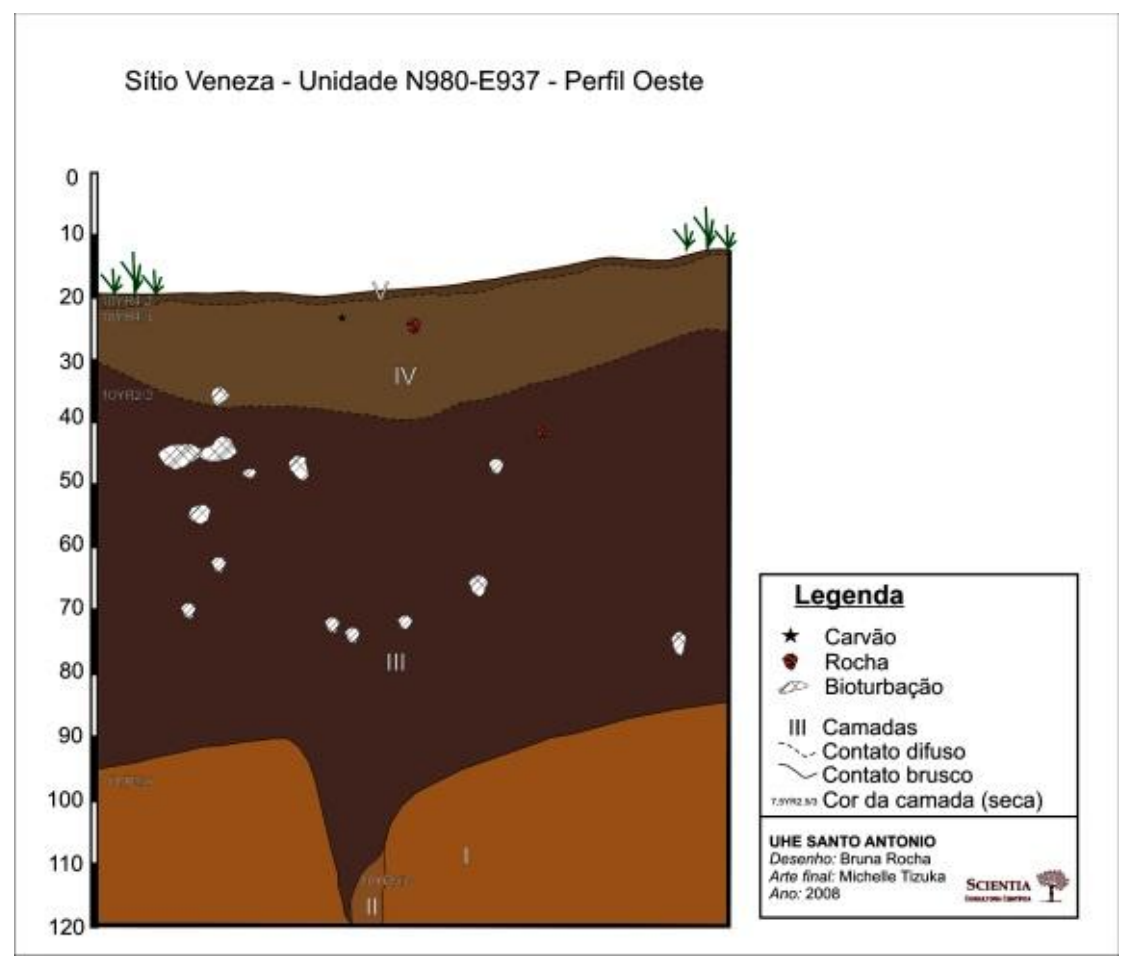

Figura 25: perfil da unidade N980 E937- sítio Veneza (SCIENTIA, 2008).
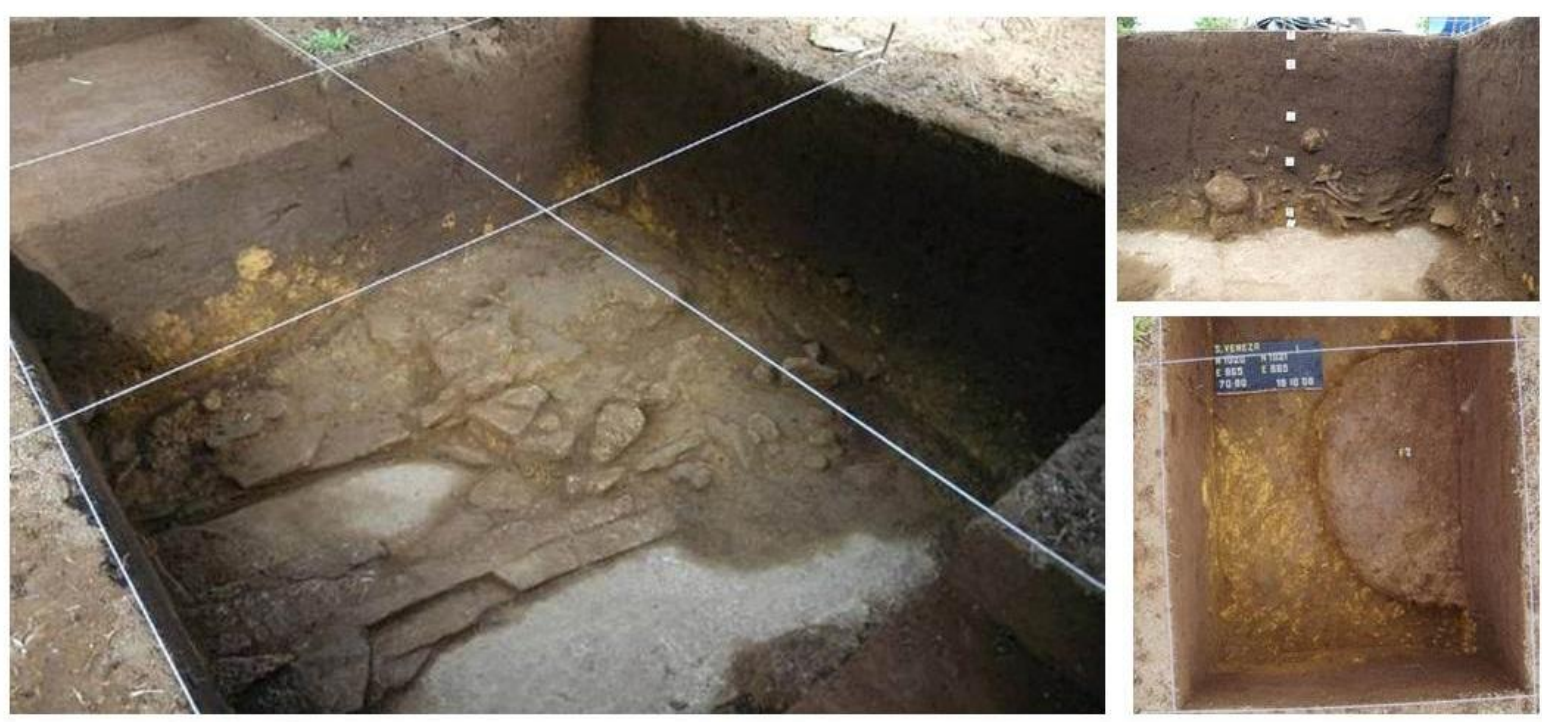

Figura 26: base das unidades, feição F2 (N 1020 E 865) e F1 no perfil leste da unidade N1020 E866 (Fotos: SCIENTIA, 2008). 
Na parte noroeste do sítio, em local com vista para o igarapé (pântano), foi escavada a unidade N1100 E863 que apresentou características peculiares: a camada arqueológica, que atingiu $90 \mathrm{~cm}$ de profundidade não apresentou terra preta. A camada mais superficial (húmica) possui sedimento bruno escuro (10YR3/3), porém na camada III (níveis 10-20 e 2030) o sedimento é mosqueado (cinzento escuro10YR4/1 e amarelo brunado10 YR6/8), e na camada II (20-30 a 90-100) o sedimento é bruno (7.5YR5/4).

O setor sul do sítio é a parte mais baixa e mais próxima ao rio, onde parte do sítio deve ter sido erodida pelo rio, conforme sugere o grande numero de vestígios visíveis no barranco e nos pedrais. Nesta área foi realizada a coleta de superfície sistemática e escavadas as unidades N960 E930, N960 E 883 e N968 E887, o perfil no barranco e uma coleta de superfície não sistemática no barranco e nos pedrais. Essa área apresenta características específicas: uma camada arqueológica mais espessa e na estratigrafia observam-se duas densidades de materiais arqueológicos em duas unidades, o que poderia sugerir dois eventos de ocupação, pelo mesmo grupo ou grupos diferentes.

A unidade N960 E883 apresentou cerâmica associada ao lítico até $110 \mathrm{~cm}$ de profundidade enquanto o lítico apareceu até $130 \mathrm{~cm}$, e nos níveis abaixo o material estava associado à bioturbações. Foram identificadas sete camadas, sendo que os materiais arqueológicos ocorrem nas camadas III, IV, V, VI e VII, sendo a ultima mais superficial e húmica. As camadas I e II são de latossolo; a camada III entre 120 e 160 cm, de transição (bruno - 7.5YR 4/3) com baixa densidade de material arqueológico; a camada IV (bruno escuro 7.5YR3/4), entre 80-90 e 120-130 com presença de rochas graníticas; camada V (bruno muito escuro - 10YR2/2) entre 60-70 cm e 90-100 cm; e camada VI de sedimento bruno escuro (10YR3/3) entre os níveis $0-10 \mathrm{~cm}$ e $60-70 \mathrm{~cm}$. Verificamos que ocorrem duas concentrações de material: uma entre 0-10 e 40-50 cm e outra entre 50-60 e 110-120 cm, o que poderia sugerir dois eventos de ocupação, porém na descrição de campo e desenho do perfil não foi mencionada tal característica, apesar de serem visualizadas na foto do perfil duas camadas mais escuras de sedimento. Na unidade N960 E930 o contexto é muito semelhante, com duas concentrações de material: uma entre 0-10 e 40-50 cm e outra entre 5060 e 120-130 cm. Porém a coloração e características do sedimento não mudam (uma só camada de terra preta). Os materiais arqueológicos estão nas camadas III, IV e V. A camada $\mathrm{V}$, mais superficial (0-10 a 30-40 cm) possui sedimento bruno acinzentado escuro (10YR4/2), com pouco material; a Camada IV $(10-20 \mathrm{~m}$ a $90-100 \mathrm{~cm})$ possui sedimento bruno escuro (10YR3/3), com material arqueológico e rochas; a camada III apresentava sedimento 
mosqueado (bruno escuro 10YR3/3 e bruno forte $7.5 \mathrm{YR} 5 / 8$ ), de transição e com pouco material arqueológico; as camadas I e II são estéreis. Na unidade N968 E887 o pacote arqueológico alcança o nível 100-120 cm, e a estratigrafia é semelhante a N960 E883, porém não ocorrem as duas concentrações de fragmentos de cerâmica.

Foi escavado um perfil no barranco próximo ao rio, com $3 \mathrm{~m}$ de altura e $8 \mathrm{~m}$ de comprimento, e presença de material arqueológico nas camadas IV, V, VI, VII e VIII, esta ultima superficial, todas com textura siltosa, e colorações de 10YR 4/2 e 10YR 4/4. As camadas I, II e III são arenosas e estéreis, ocorrendo carvão na camada III (Fotografia 17).

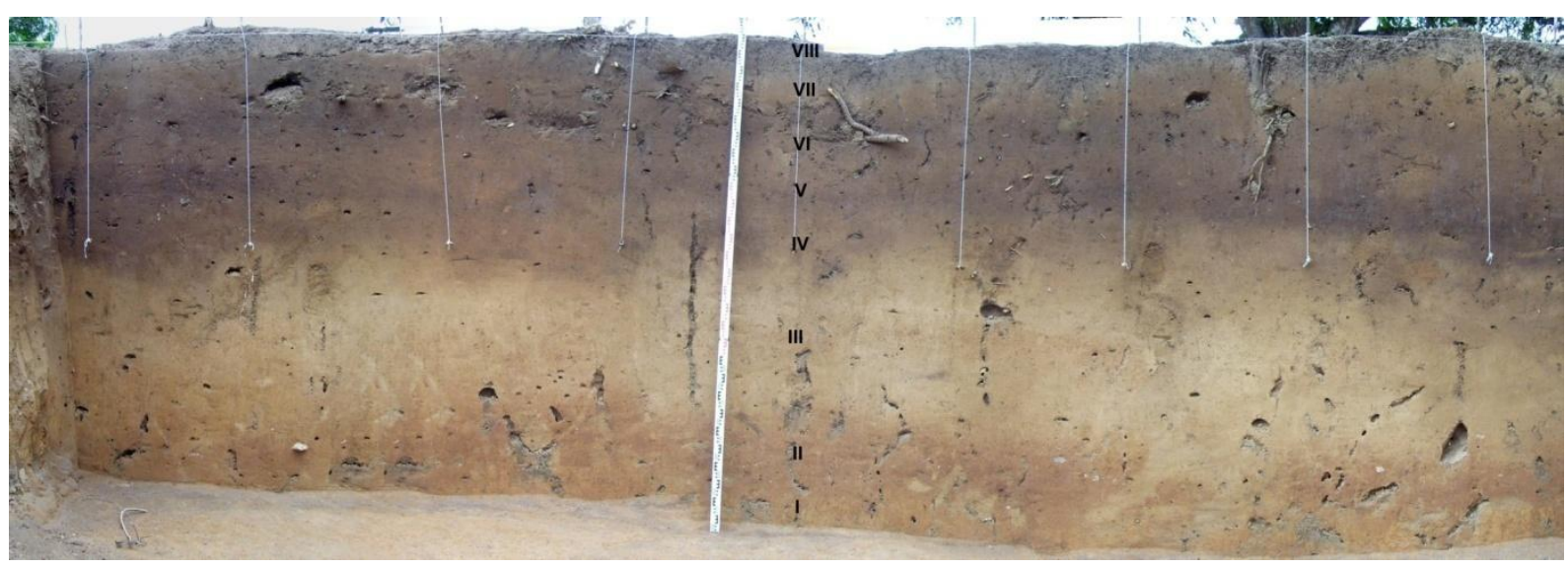

Fotografia 17: perfil do barranco (SCIENTIA, 2008).

A estratigrafia do barranco se parece muito com a da unidade N960 E930, sendo visíveis em algumas partes duas camadas mais escuras de sedimento, porém em outras se apresenta como uma única camada. No setor sul do sítio Veneza apareceu maior quantidade de cerâmica, enquanto na área do topo o lítico foi mais frequente.

O material lítico do Veneza é constituído principalmente por lascas unipolares e bipolares e núcleos de quartzo leitoso e translúcido e poucos hialinos, além de pequenos nódulos de argilitos, "laterita", os quais estão polidos ou lascados em mais de uma face, levantado dúvidas sobre a sua utilização apenas para retirada de corante, ou se seriam adornos, assim como as lascas de quartzo leitoso que poderiam ser "pré-formas" de adornos. São encontradas outras matérias primas como hematitas, silexitos, poucos arenitos e granitos (fotografias 18 e 19) (NISINGA, 2014).

Neste trabalho foram analisados os fragmentos cerâmicos da delimitação, coletas de superfícies e escavações realizadas no ano de 2008. A amostra datada por radiocarbono estava contaminada, e em todo o sítio são frequentes as bioturbações. 

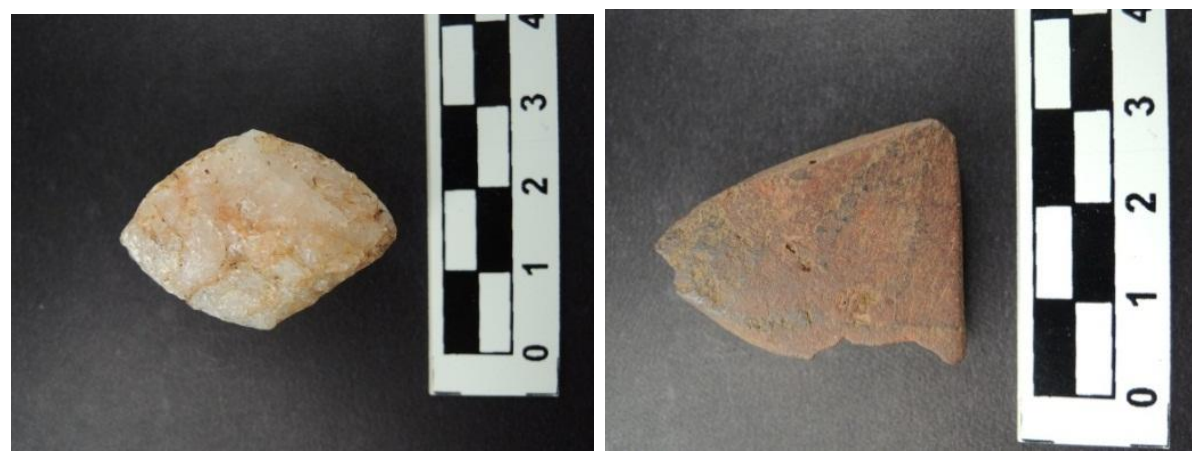

Fotografias 18 e 19: líticos (quartzo e argilito)- sítio Veneza (NISINGA, 2014).

\subsubsection{Outros sítios nas proximidades da cachoeira de Santo Antônio}

Outros locais próximos à cachoeira de Santo Antônio foram ocupados por grupos ceramistas, sendo o sítio Garbin, Campelo, São Domingos, Catitu, Igarapé do Engenho e Novo Engenho Velho na margem esquerda e sítio Igapó I na margem direita. Não foram analisadas amostras de materiais destes sítios (com exceção da análise de algumas vasilhas e triagem dos fragmentos), porém os contextos arqueológicos identificados são importantes para entender a história indígena na região.

No sítio Garbin foram identificadas duas camadas arqueológicas bem definidas na estratigrafia, sendo uma com material cerâmico e lítico junto à terra preta, mais recente e com maior densidade de cerâmica entre 30 e $40 \mathrm{~cm}$ (Camada IV), e uma com material lítico em terra preta, mais antiga, com maior densidade entre 80-90 cm (Camada III) (figura 28). Para a ocupação ceramista foram obtidas as datações 14C $1.710 \pm 40$ AP (N981 E941), $1.300 \pm 30$ AP (Expansão 2010), $990 \pm 30$ AP (Expansão 2010) e $480 \pm 40$ AP (N981 E988), portanto o sítio foi ocupado por um longo período.

O sítio Novo Engenho Velho pode ser visualizado do cais na Praça da Estrada de Ferro Madeira Mamoré, a pouco mais de $1 \mathrm{~km}$ de distancia subindo o rio. Foi identificado em julho de 2008, implantado em terraço fluvial na margem esquerda do rio Madeira (E398125 N9029925). A delimitação permitiu visualizar sua forma circular, uma área central com poucos vestígios arqueológicos, e muita cerâmica no entorno e bordas do terraço. Foram escavadas ao todo dezoito unidades de $1 \mathrm{~m}^{2}$ que confirmaram a presença de quatro montículos circulares (SCIENTIA, 2011b). Nos croquis (figura 27) visualiza-se a distribuição deles e a localização das áreas escavadas. A estrutura de combustão E1 foi evidenciada no montículo I, de forma elipsoidal com fragmentos cerâmicos, blocos lateríticos, carvão, trempes de argila, nódulos de argila avermelhada queimadas, líticos fragmentados e semente queimada. Esta 
estrutura estava inserida em uma camada mais escura e com muito carvão, de coloração bruno (10 YR 4/3). Já o contexto evidenciado no montículo II o caracteriza como um local de descarte de uma unidade habitacional, e os materiais arqueológicos ocorreram em uma camada arqueológica enterrada ao longo de todo o montículo, com textura argilo-arenosa e coloração que varia entre bruno amarelado escuro (10 YR 4/4) e bruno (10 YR 4/3). O montículo III apresentou menor quantidade de vestígios arqueológicos (cerâmicos e líticos), distribuídos na camada de coloração bruno amarelado claro (10 YR 6/4) para o solo seco e bruno amarelado escuro (10 YR 4/4), com o solo úmido, com 30 a $35 \mathrm{~cm}$ de espessura. $\mathrm{O}$ montículo IV a quantidade de vestígios foi ainda menor, dispersos em uma camada arqueológica de coloração diferenciada. Portanto trata-se de um sítio unicomponencial com montículos, possivelmente unidades habitacionais distribuídas em torno de uma parte central onde ocorreu pouco material cerâmico (SCIENTIA, 2011b). Foi obtida a datação 14C $490 \pm$ $50 \mathrm{AP}^{8}$ para este sítio.
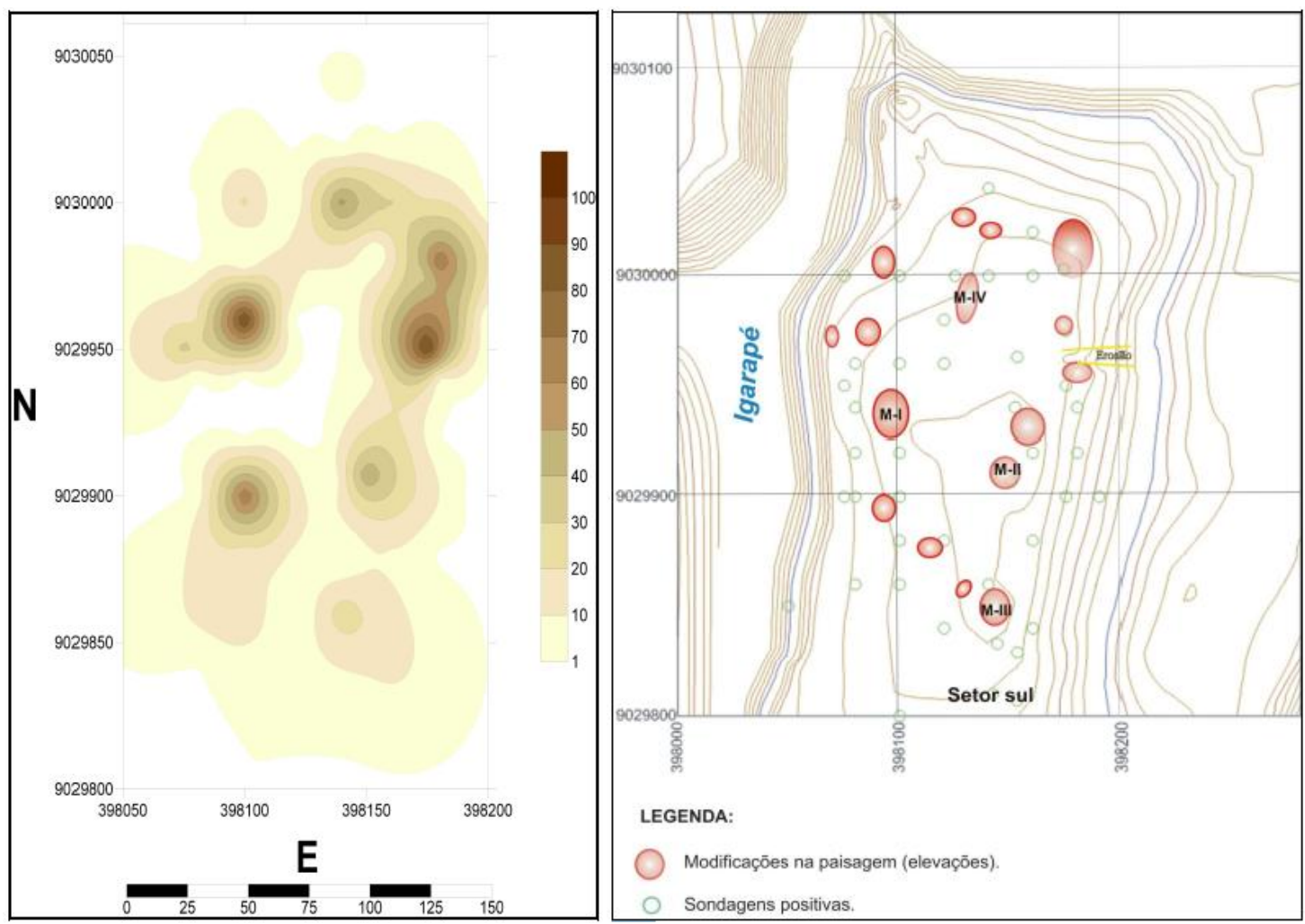

Figura 27: densidade cerâmica (João Paulo Atuí, 2008); e posição dos montículos e das sondagens positivas (Vinícius Honorato, 2008) - sítio Novo Engenho Velho (SCIENTIA, 2011b).

\footnotetext{
${ }^{8}$ Datação inédita fornecida pela Scientia Consultoria Científica.
} 
UHE Santo Antônio - Sítio Garbin

N 960 / E 980-981-982 - Perfil Sul

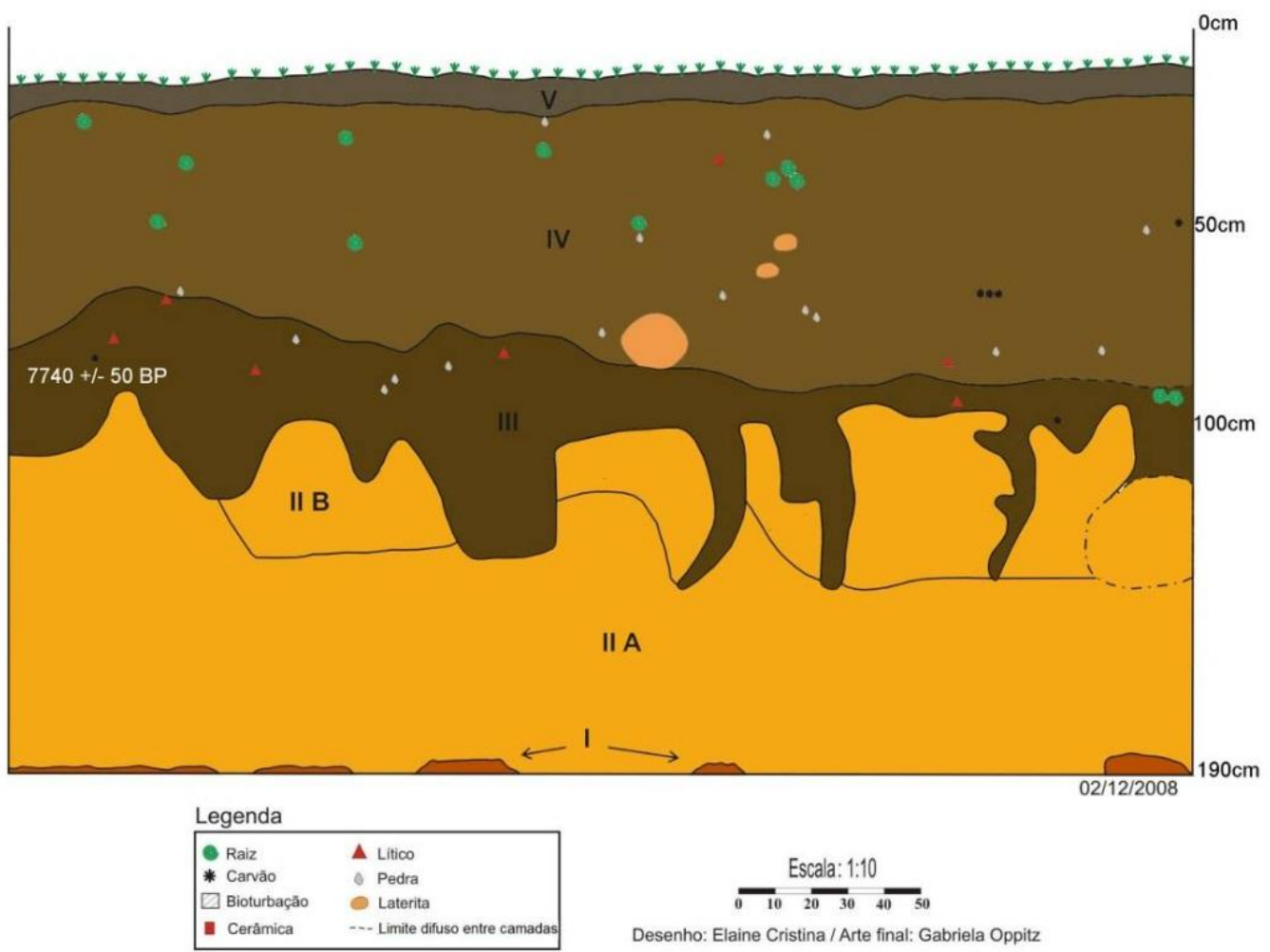

Figura 28: perfil sul das unidades N960 E980, N960 E981 e N960 E982/ sítio Garbin (SCIENTIA, 2008).

Sítio Novo Engenho Velho - Unidade N1000-E952 - Perfil Norte

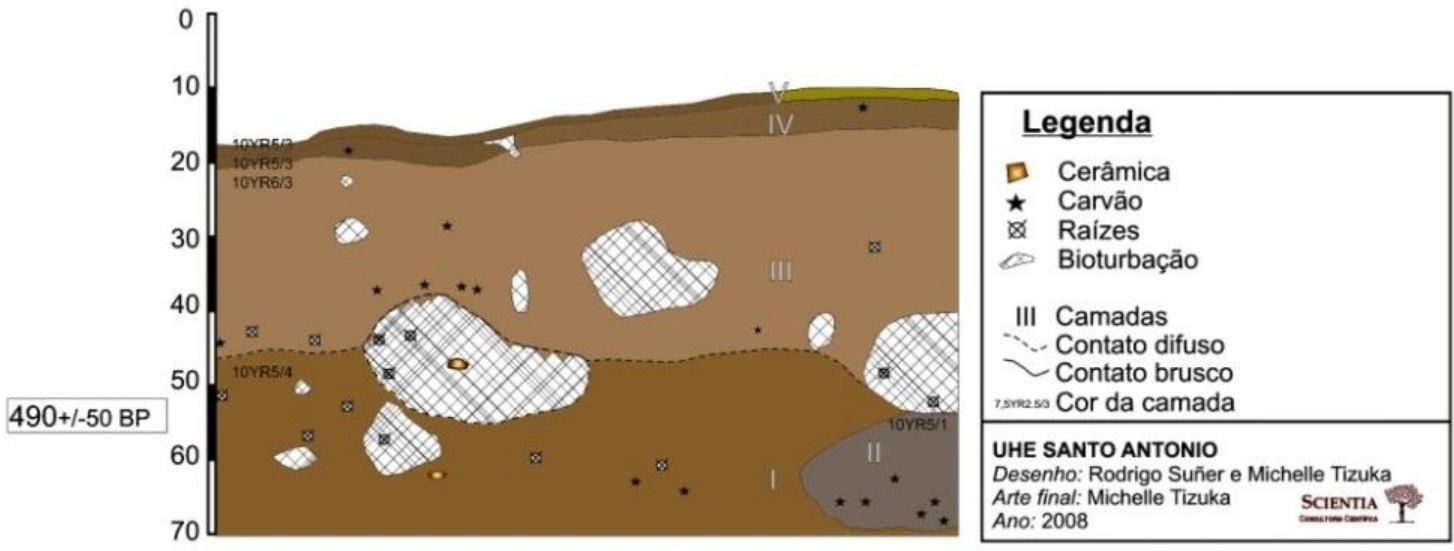

Figura 29: perfil da unidade N1000 E952, sítio Novo Engenho Velho (SCIENTIA, 2008).

O sítio Igarapé do Engenho, localizado em planície de inundação da margem esquerda,

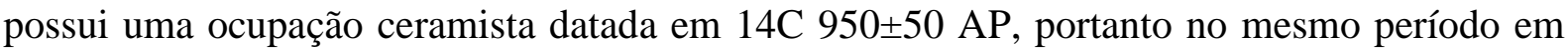
que os sítios da ilha, Brejo e Garbin foram ocupados. Já os sítios São Domingos, Campelo e Catitu possuem ocupações mais recentes. O sítio Campelo, implantado em terraço elevado, 
apresentou um montículo com material cerâmico, incluindo fragmentos com pintura vermelha sobre engobo branco, incisões e bordas com reforço externo, cuja ocupação foi datada em 14C $370 \pm 40 \mathrm{AP}^{9}$, data relativamente próxima daquela obtida para o sítio Novo Engenho velho. O sítio São Domingos possui uma ocupação ceramista datada em 14C 500 30 AP, com material cerâmico semelhante ao do sítio Campelo e Novo Engenho Velho (pinturas, bordas reforçadas). Em outro terraço fluvial alto da margem esquerda do rio Madeira situavase o sítio Catitu, que apresentou pequena quantidade de material cerâmico em superfície e até no máximo $60 \mathrm{~cm}$ de profundidade, e datação de $14 \mathrm{C} 160 \pm 40 \mathrm{AP}^{10}$.

Subindo o rio Madeira, antes de chegar à cachoeira do Teotônio, estão os sítios Boa Vista e Vista Alegre na margem direita, e os sítios Morro dos Macacos I e II e Foz do Jatuarana na margem esquerda (Figura 30). Estes locais foram ocupados por populações ceramistas em um período mais recuado.

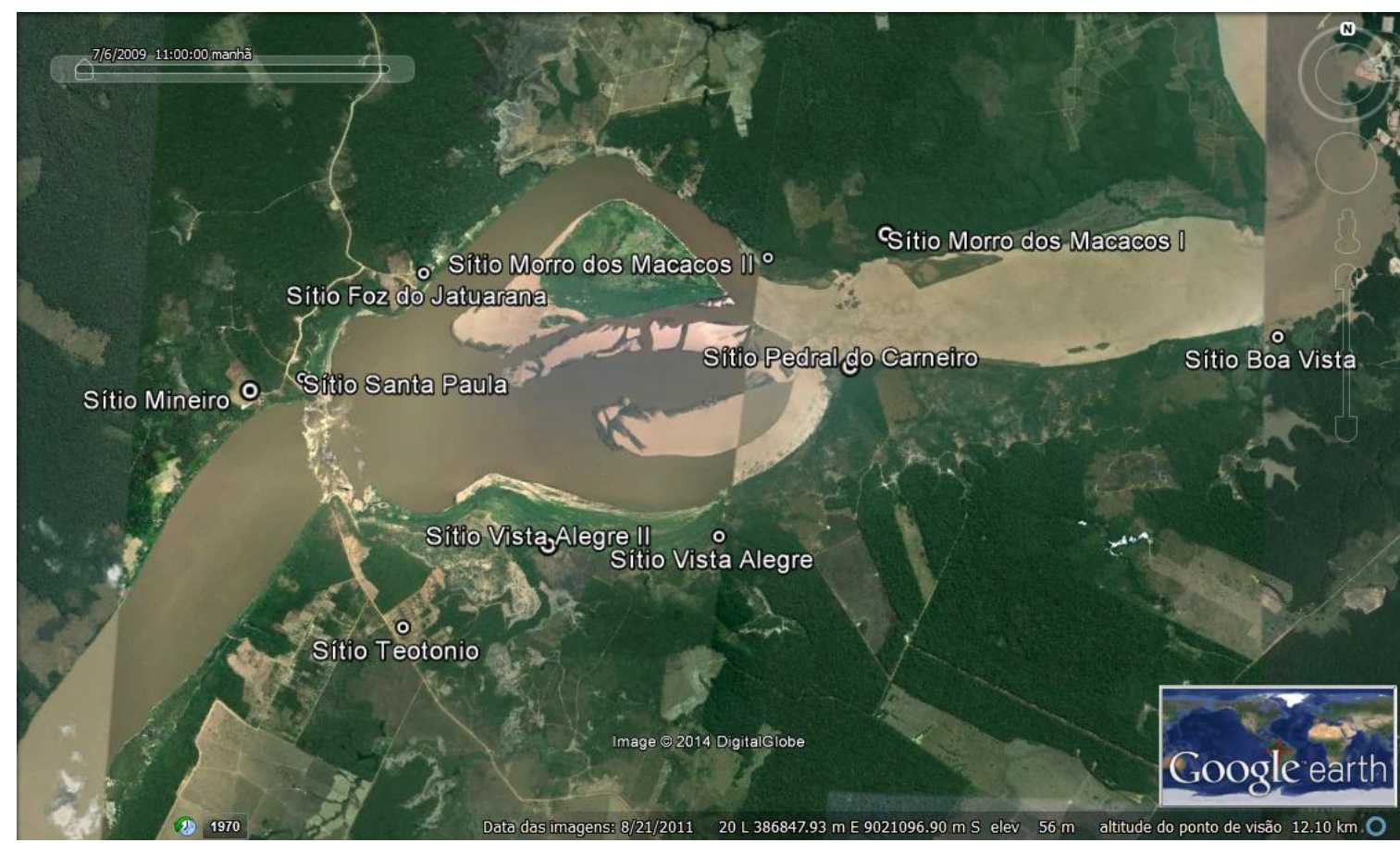

Figura 30: localização dos sítios arqueológicos junto à cachoeira do Teotônio e abaixo dela. Imagem: Google Earth.

\subsubsection{Sítio Boa Vista}

Ha meio caminho entre as cachoeiras de Santo Antônio e Teotônio, na margem direita, localiza-se o sítio Boa Vista (E392600 N9022200), identificado através das prospecções realizadas no ano de 2009 (SCIENTIA, 2011a), sendo delimitado e escavado no mesmo ano. Está implantando parcialmente em uma planície (setor I a nordeste do sítio) e em dois

\footnotetext{
${ }^{9}$ Datação inédita fornecida pela Scientia Consultoria Científica.

${ }^{10}$ Datação inédita fornecida pela Scientia Consultoria Científica.
} 
patamares de um platô (setores II e III a noroeste e sudoeste do sítio, respectivamente). A oeste é limitado pelo Igarapé do Rumão e a leste por um topo de alta vertente, a sul por uma pastagem em vertente suave, com palmeiras esparsas e capoeira baixa, e a norte pelo rio Madeira. Os setores I e II estão em cota inferior a $70 \mathrm{~m}$, enquanto o setor III atinge cotas de 90 e 100 m, com acentuado declive. Em todo o sítio predomina a vegetação de gramínea (pastagem), com presença de palmeiras (tucumã e urucuri) e castanheiras nos setores I e II. No setor II ocorrem também árvores frutíferas (cajá, cupuaçu, coco, açaí, laranjeira) e seringueiras nas proximidades das casas e outras construções como cercas, currais, barracões e um açude.

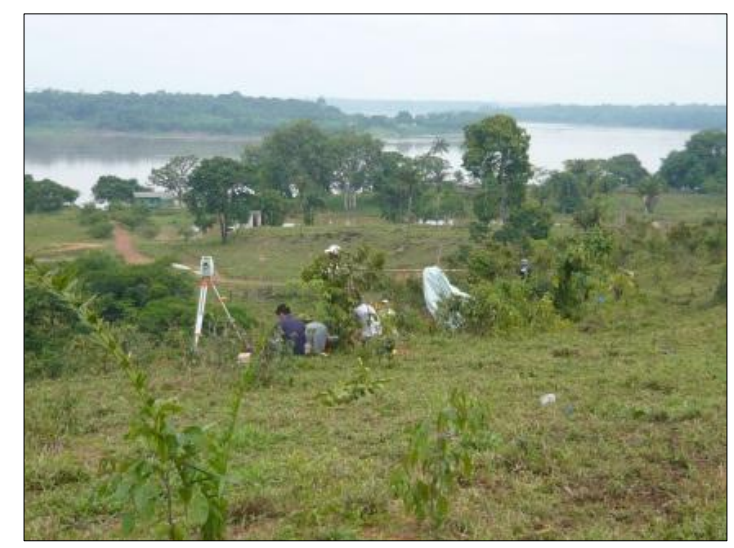

Fotografia 20: vista do rio Madeira a partir do setor III do sítio Boa Vista (SCIENTIA, 2009)

No setor I, entre as 12 unidades de $1 \mathrm{~m}^{2}$ escavadas, apenas cinco apresentaram material arqueológico (cerâmica e raros líticos lascados) em baixa frequência. A unidade E0392900 N9022302 foi escavada até a profundidade de $260 \mathrm{~cm}$, com material arqueológico até $230 \mathrm{~cm}$, distribuído em cinco camadas, conforme pode ser visualizado no perfil norte (figura 32). Foram obtidas duas datações 14C $4.470 \pm 40$ AP para a Camada E (nível 220-230 cm), que pode corresponder à base da ocupação, e de $2.010 \pm 30 \mathrm{AP}^{11}$ para a camada $\mathrm{D}(140-150 \mathrm{~cm})$. O material cerâmico é bastante erodido e fragmentado em todos os níveis escavados (gráfico 1). Nas outras unidades onde ocorreu material arqueológico, neste setor, ocorre pouca cerâmica (mínimo de 3 fragmentos e máximo de 20) e raras lateritas, entre 20-30 cm e 60-70 cm de profundidade máxima (E0392900 N9022340; E0392940 N9022220; E0392940 N9022300; e E0392940 N9022389 onde apareceu apenas um quartzo e nenhuma cerâmica). A ocupação se restringe a uma área pequena, de 40 x 170 m). O carvão apareceu isolado em outras unidades escavadas.

\footnotetext{
${ }^{11}$ Datação inédita fornecida pela Scientia Consultoria Científica.
} 

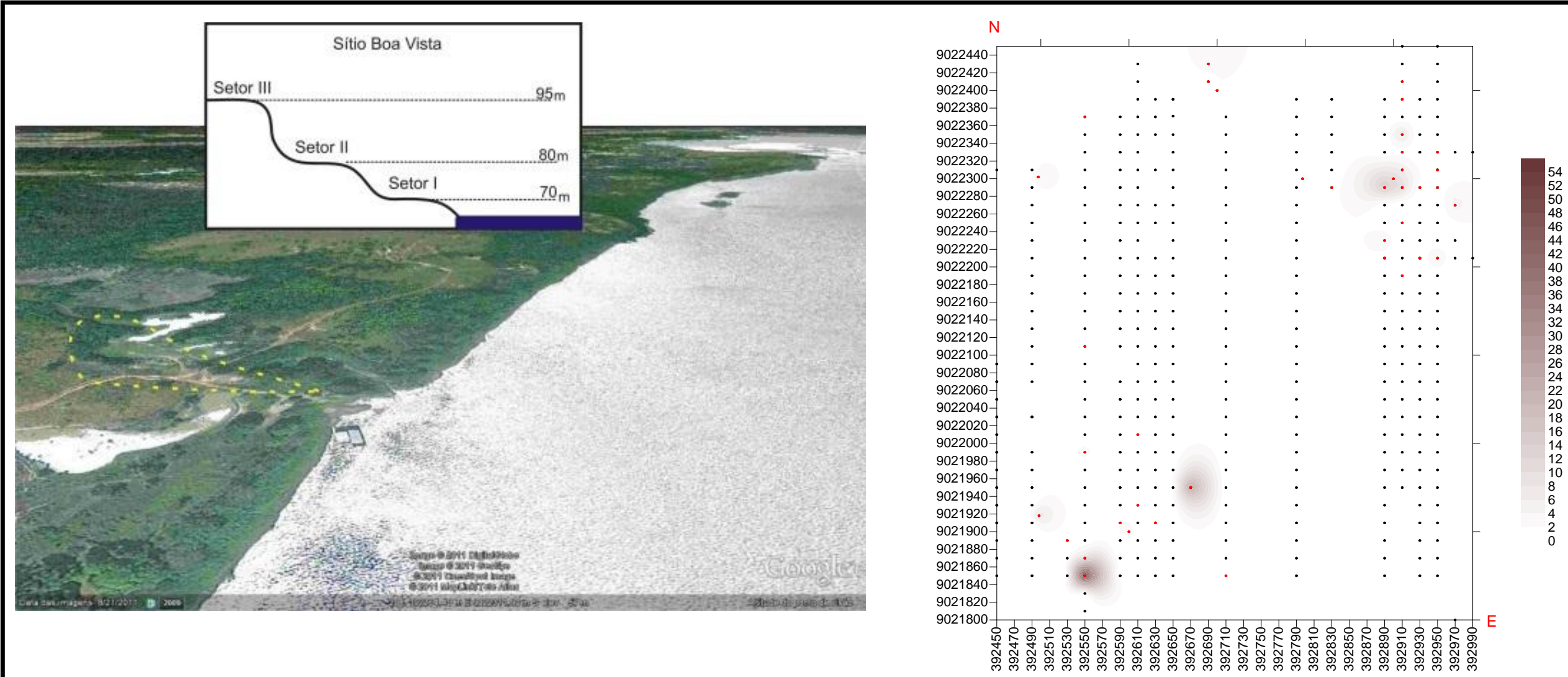

\section{Sítio Arqueológico Boa Vista}

Imagem 1 - Localização do Sítio Boa Vista, imagem Google Earth.

Imagem 2 - Frequência de material arqueológico, a partir da delimitação.

\section{LEGENDA}

Furos testes com ausência de material arqueológico.

Furos testes com presença de material arqueológico

$\square$ Frequência de material arqueológico

Figura 31: Croquis esquemáticos do sítio Boa Vista (Michelle Tizuka, 2012 e Juliana Rossato Santi, 2014, respectivamente). 

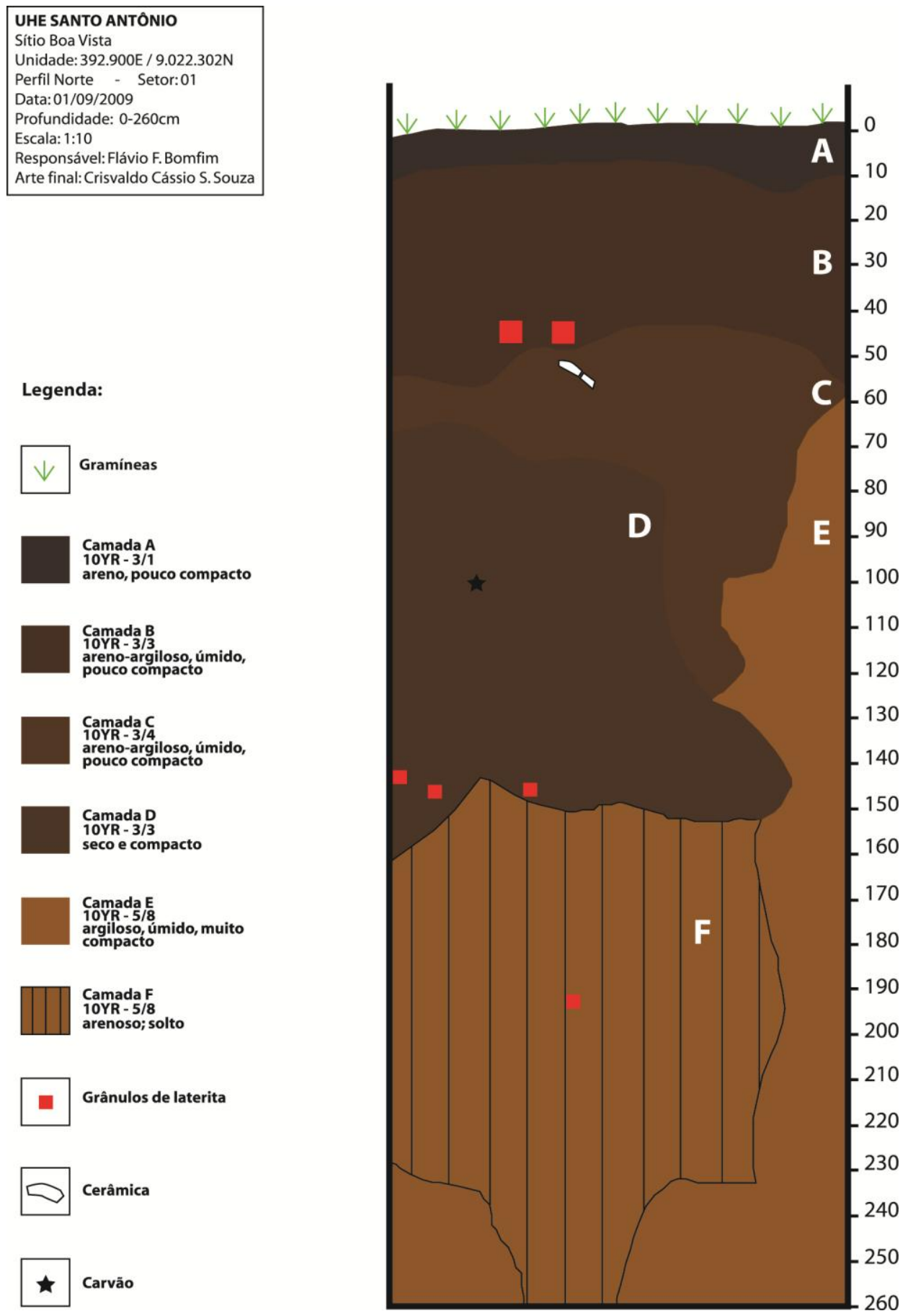

Figura 32: perfil norte da Unidade E0392900/N9022302, sítio Boa Vista (SCIENTIA, 2009).

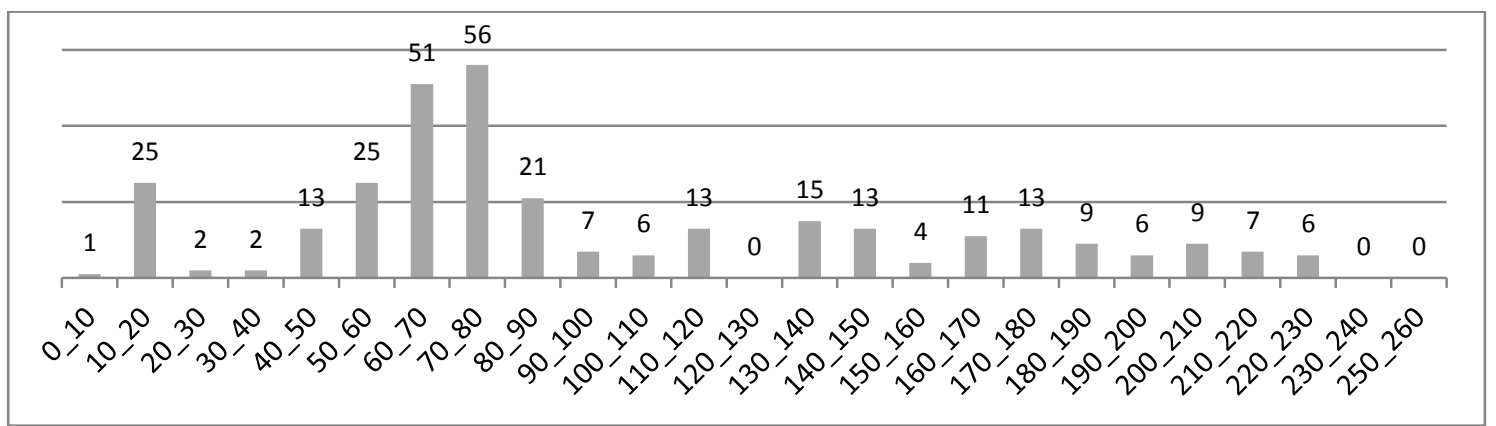

Gráfico 1: distribuição da cerâmica ao longo da escavação da unidade E0392900/N9022302. 
No setor II a escavação de duas unidades revelou a presença de poucos fragmentos cerâmicos nos primeiros níveis. Já na parte mais alta do sítio (setor III), a escavação de onze unidades de $1 \mathrm{~m}^{2}$ revelou uma camada arqueológica pouco espessa sobre o cascalho laterítico, com baixa frequência de cerâmica e raros líticos em dez unidades entre as onze escavadas.A unidade E392540 N9021860 apresentou material arqueológico (26 cerâmicas e poucos líticos) desde a superfície e até $50 \mathrm{~cm}$ e carvão até $60 \mathrm{~cm}$ de profundidade, sobre uma camada argiloarenosa laterítica, consistência friável e média compactação datada em 14C 8.120 $\pm 50 \mathrm{AP}^{12}$. Nesse mesmo setor, as unidades contíguas E0392510/N9021980 e E0392511/N9021980 apresentaram material cerâmico com decoração plástica e pintura e também material lítico polido. Nas proximidades destas duas unidades foi realizada uma coleta de superfície, com fragmentos decorados com incisões sobre engobo branco, além de um lítico polido quebrado e reaproveitado. Muitos fragmentos cerâmicos de superfície no setor III apresentam pintura.Entre os poucos líticos encontrados na camada arqueológica, ocorrem lascas (unipolar, bipolar ou fragmentada), um núcleo de quartzo e nódulos de laterita com marcas de alisamento (possivelmente fontes de pigmentos). No setor III ocorrem blocos sem marcas de uso de rochas ígneas, granito e óxido de ferro, que podem ter sido utilizados de alguma forma.
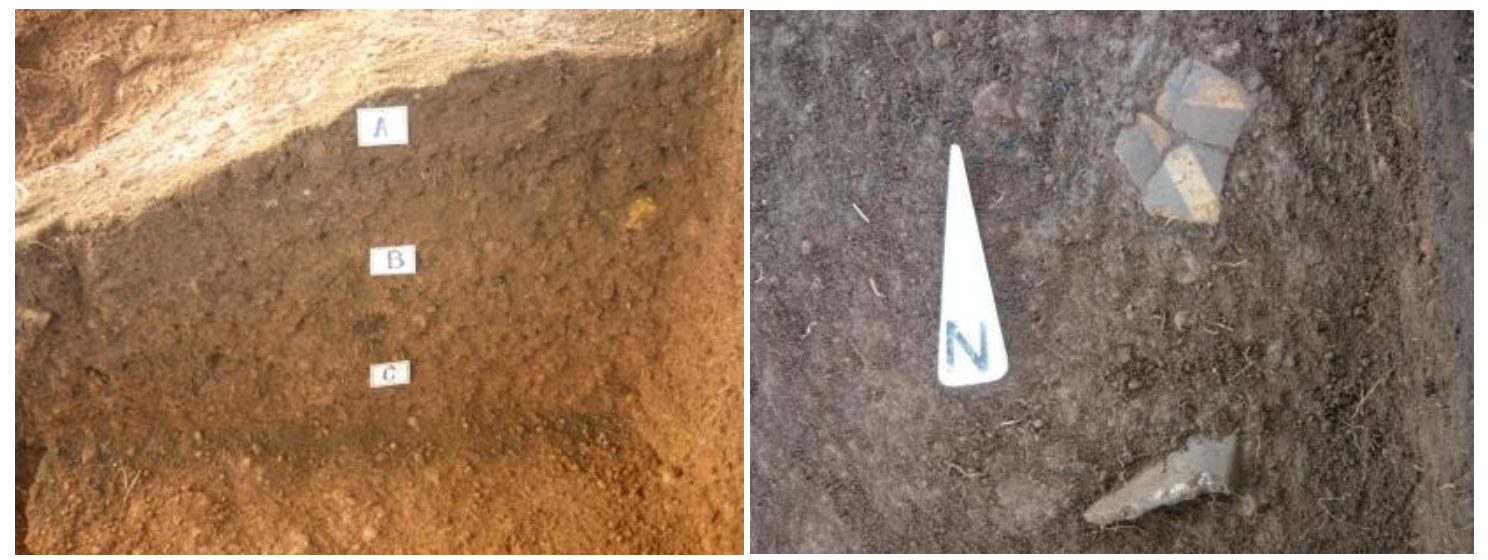

Fotografias 21 e22: Perfil norte da unidade 20L E392511/N9021980; e fragmentos cerâmicos com pintura preta e branca da unidade E392510/N9021980 (SCIENTIA, 2009).

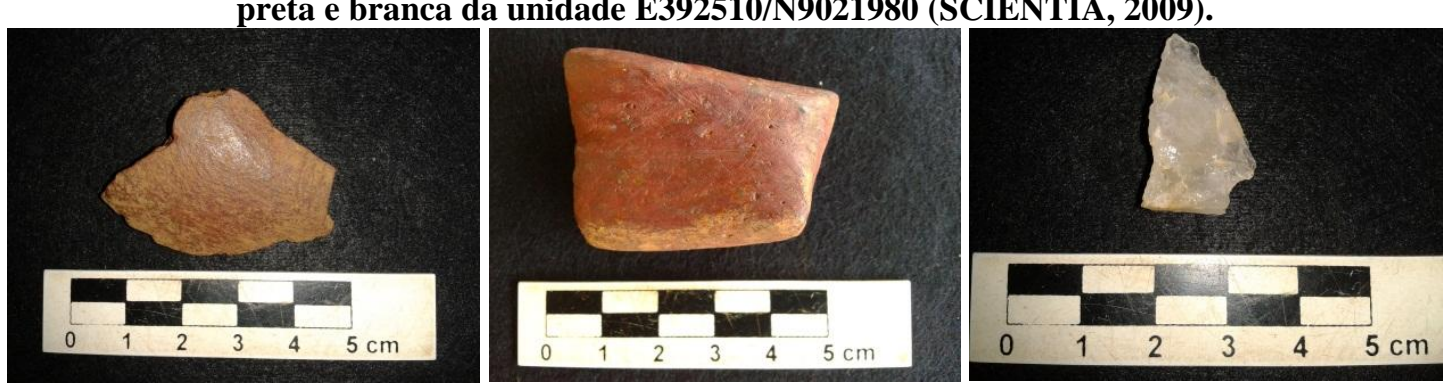

Fotografia 23, 24 e 25: nódulo e possível artefato de laterita, com as faces polidas; e lasca de quartzo (SCIENTIA, 2012).

\footnotetext{
${ }^{12}$ Esta data possivelmente é de um período anterior à ocupação do sítio, e precisa ser investigada.
} 
Analisamos os materiais cerâmicos das unidades E0392900 N9022302 (setor I), E0392540/N9021860, E0392510/N9021980 e E0392511/N9021980 (Setor III), e os resultados apontam para diferenças tecnológicas entre os setores I e III, portanto possivelmente foram ocupados em momentos distintos, porém estes resultados serão apresentados nos capítulos posteriores.

\subsubsection{Sítio Vista Alegre}

A apenas $4 \mathrm{Km}$ antes de chegar na cachoeira do Teotônio, avista-se o sítio Vista Alegre na margem direita, localizado em uma vertente do Igarapé Teotônio. Apresenta três setores com concentrações de material (setores I, II e III), delimitados em partes pelas declividades do terreno (uma vala separa os setores I e II), pelo Igarapé Teotônio que separa os setores II e III, e pelos barrancos adjacentes ao rio Madeira a noroeste (Figura 33). É um sítio extenso, e implantando em cotas que variam de $62 \mathrm{~m}$ a $80 \mathrm{~m}$, em diferentes compartimentos na paisagem: enquanto o setor I está na planície de inundação, sobre sedimentos arenosos de depósitos aluviais, o setor III, em área mais alta, apresenta solos avermelhados ou cascalho laterítico na base da ocupação. O sítio possivelmente foi erodido pela ação do rio Madeira e é habitado por moradores ribeirinhos nos três setores, com árvores frutíferas diversas no entorno das casas.

As escavações (91 unidades de $1 \mathrm{~m}^{2}$ ) revelaram pacotes arqueológicos variando entre 30 e $130 \mathrm{~cm}$ de espessura, com cerâmica, carvão, lítico, blocos de granito, e algumas estruturas de combustão. Não ocorreu terra preta em nenhum dos setores, mas somente um sedimento de coloração escura, areno-siltoso ou areno-argiloso com maior densidade de material arqueológico. Ocorria material em superfície, coletado de forma sistemática em algumas áreas (SCIENTIA, 2011c).

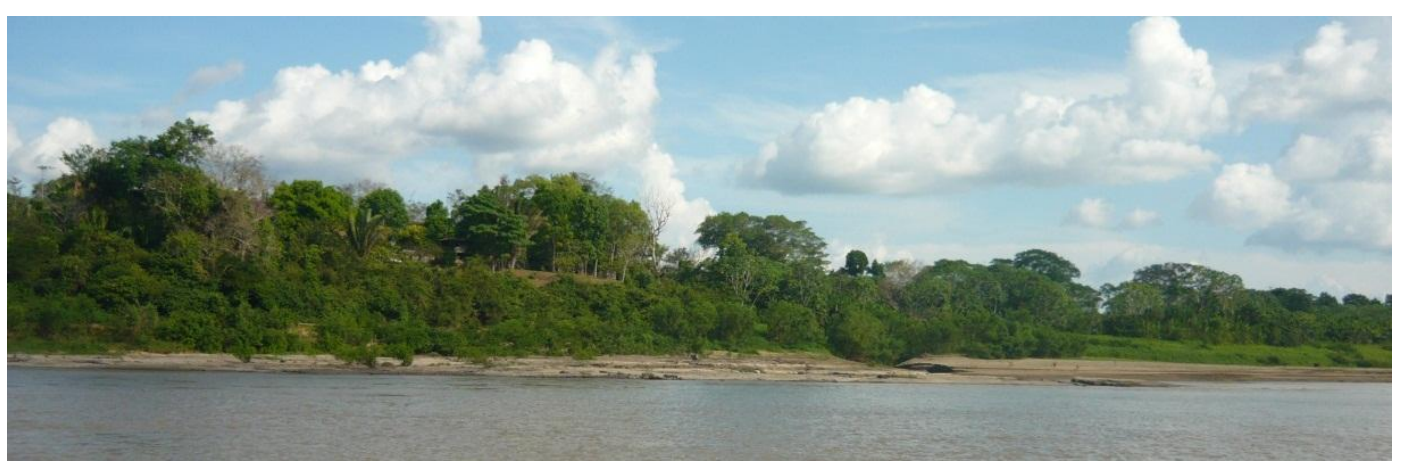

Fotografia 26: setor I do sítio Vista Alegre visto a partir do rio Madeira (SCIENTIA, 2009). 


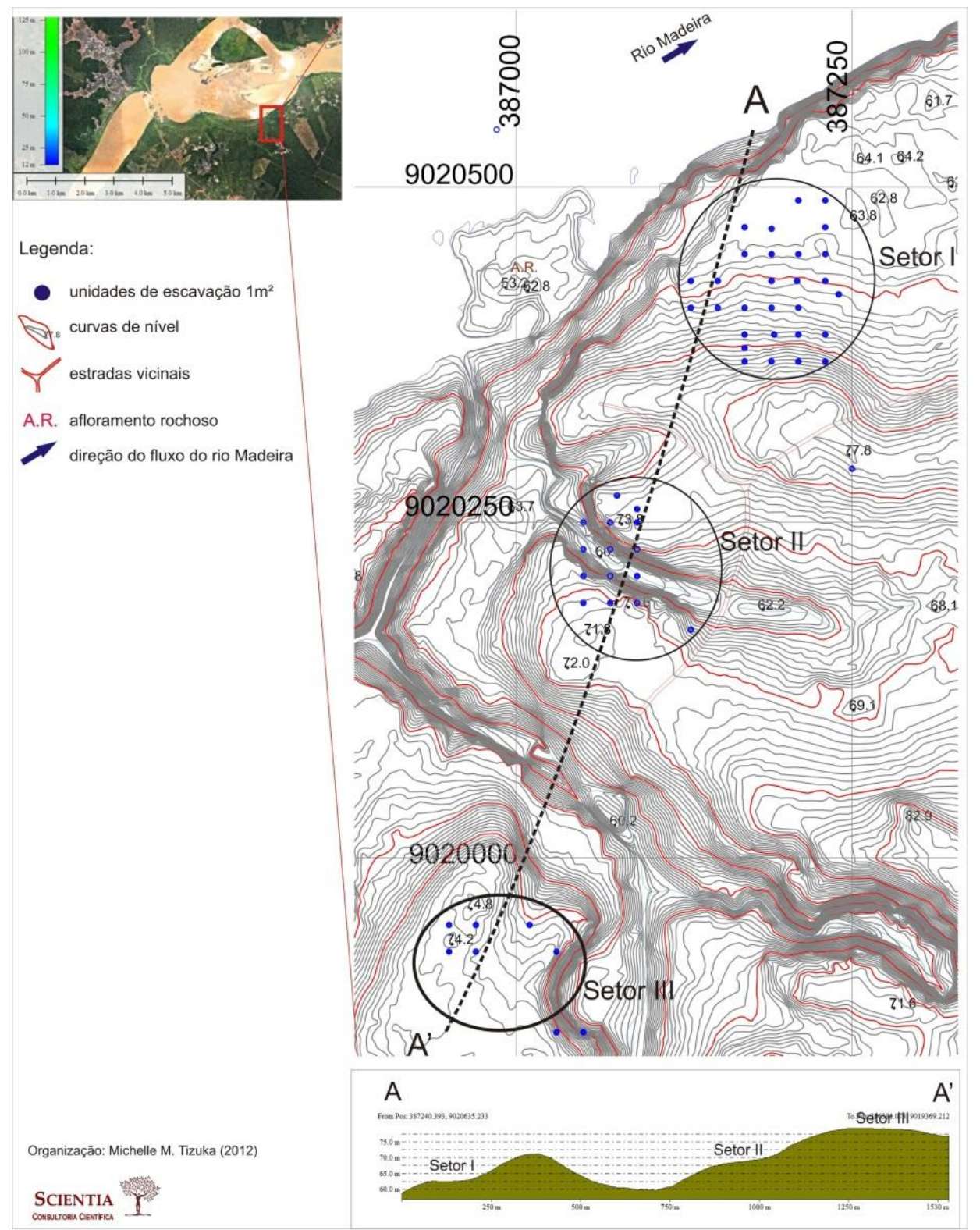

Figura 33: croqui do sítio Vista Alegre (Michelle Tizuka, 2013).

No setor I foram escavadas três estruturas de combustão, sendo uma delas précolonial, datada em $1.240 \pm 30 \mathrm{AP}^{13}$. Esta estrutura $(\mathrm{C} 1)$ foi evidenciada a $60 \mathrm{~cm}$ da escavação de 2 m² $^{2}$ (unidades E387190 N9020490 I, II, III e IV), e é composta por argila queimada, grande quantidade de carvão e blocos lateríticos associados. Ocorreram ainda concentrações de blocos de rochas (granito e laterita) estruturados e alinhados e fragmentos cerâmicos nos níveis 60-70 e 70-80 cm, próximos a estrutura de combustão, além de duas possíveis feições de buraco de estaca, uma delas nos níveis 60-70 e 70-80 da unidade III, e a outra entre 64 e $78 \mathrm{~cm}$ na unidade II, ambas com $25 \mathrm{~cm}$ de diâmetro e sedimento mais solto; por não apresentar grande diferenciação na cor do sedimento encontrado no seu interior, não

\footnotetext{
${ }^{13}$ Datação inédita fornecida pela Scientia Consultoria Científica.
} 
pôde ser confirmado se realmente tratam-se de buracos de estaca, porém o contexto evidenciado sugere que sim.

Nestas unidades ocorreu material arqueológico até $130 \mathrm{~cm}$, porém a maior densidade de cerâmica ocorre entre 20 e $70 \mathrm{~cm}$ e o material lítico entre 60 e $90 \mathrm{~cm}$, sendo que aqueles materiais encontrados em níveis mais profundos podem ter descido com as bioturbações muito frequentes nesta área. Foram definidas três camadas no perfil: camada "A", de sedimento bruno amarelado (10YR 5/8), textura areno-siltosa e solto; a camada "B" de mesma coloração e textura, bastante compactada; e a camada $\mathrm{C}$, com sedimento compacto, úmido, amarelo avermelhado (7.5YR 6/8) e textura areno-argilosa, estéril (Figura 34). Foi obtida a datação $14 \mathrm{C} 1.240 \pm 30 \mathrm{AP}^{14}(60-70 \mathrm{~cm})$ e $3.140 \pm 40 \mathrm{AP}(130-40 \mathrm{~cm})$ para a camada C, onde não ocorreram vestígios cerâmicos e líticos, podendo ser a base da ocupação. Em muitas unidades do sítio Vista Alegre o carvão aparece até dois níveis abaixo do ultimo nível com material cerâmico e lítico. Outra possível estrutura de combustão foi identificada no setor 1 (níveis 40-50 e 60-70 cm das unidades N387210 E9020470 e N387211 E9020470), com fragmentos de uma mesma vasilha cerâmica e muitos carvões associados.

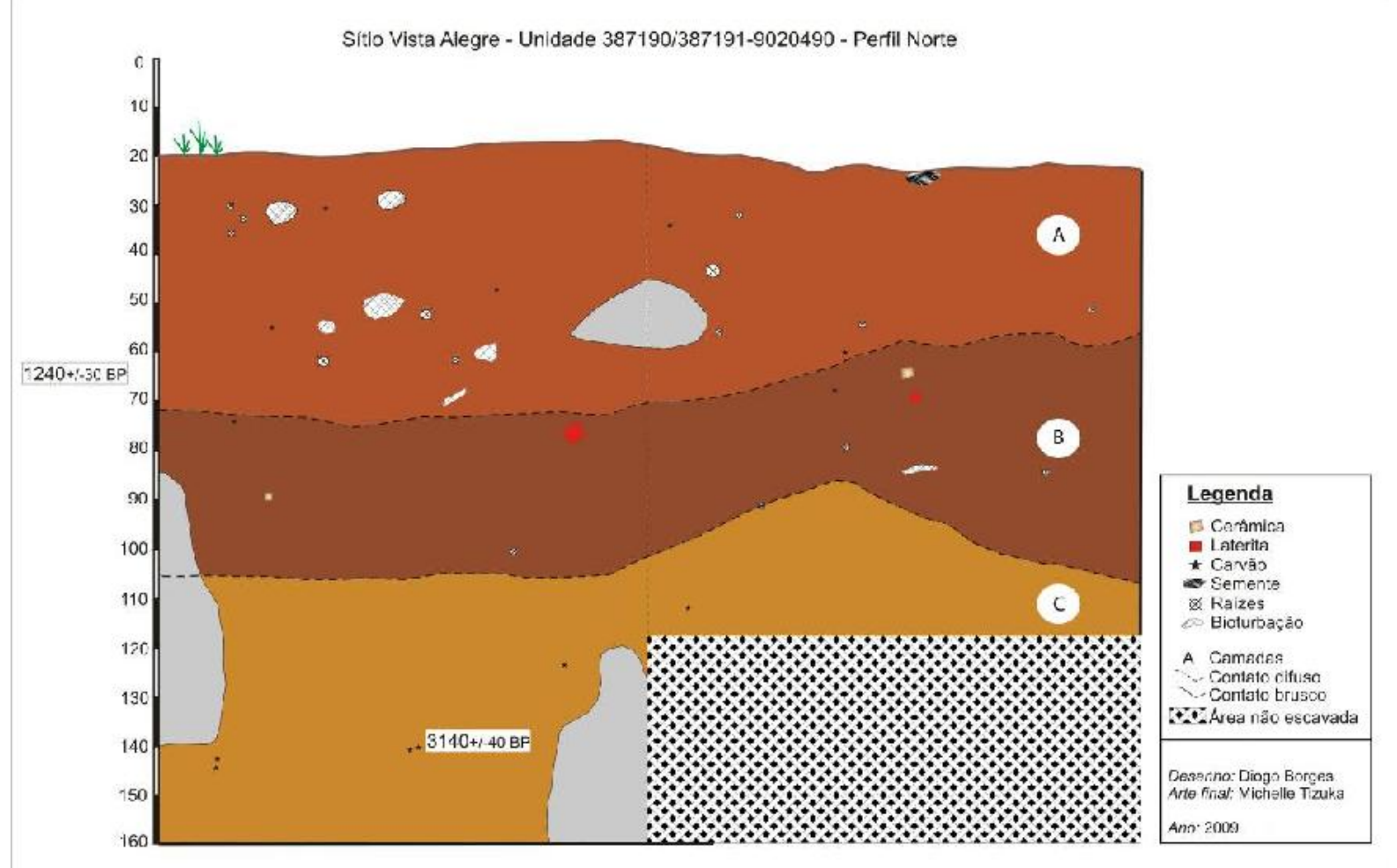

Figura 34: perfil da unidade E387190 N9020490 I (Michelle Tizuka, 2012)

\footnotetext{
${ }^{14}$ Datação inédita fornecida pela Scientia Consultoria Científica.
} 


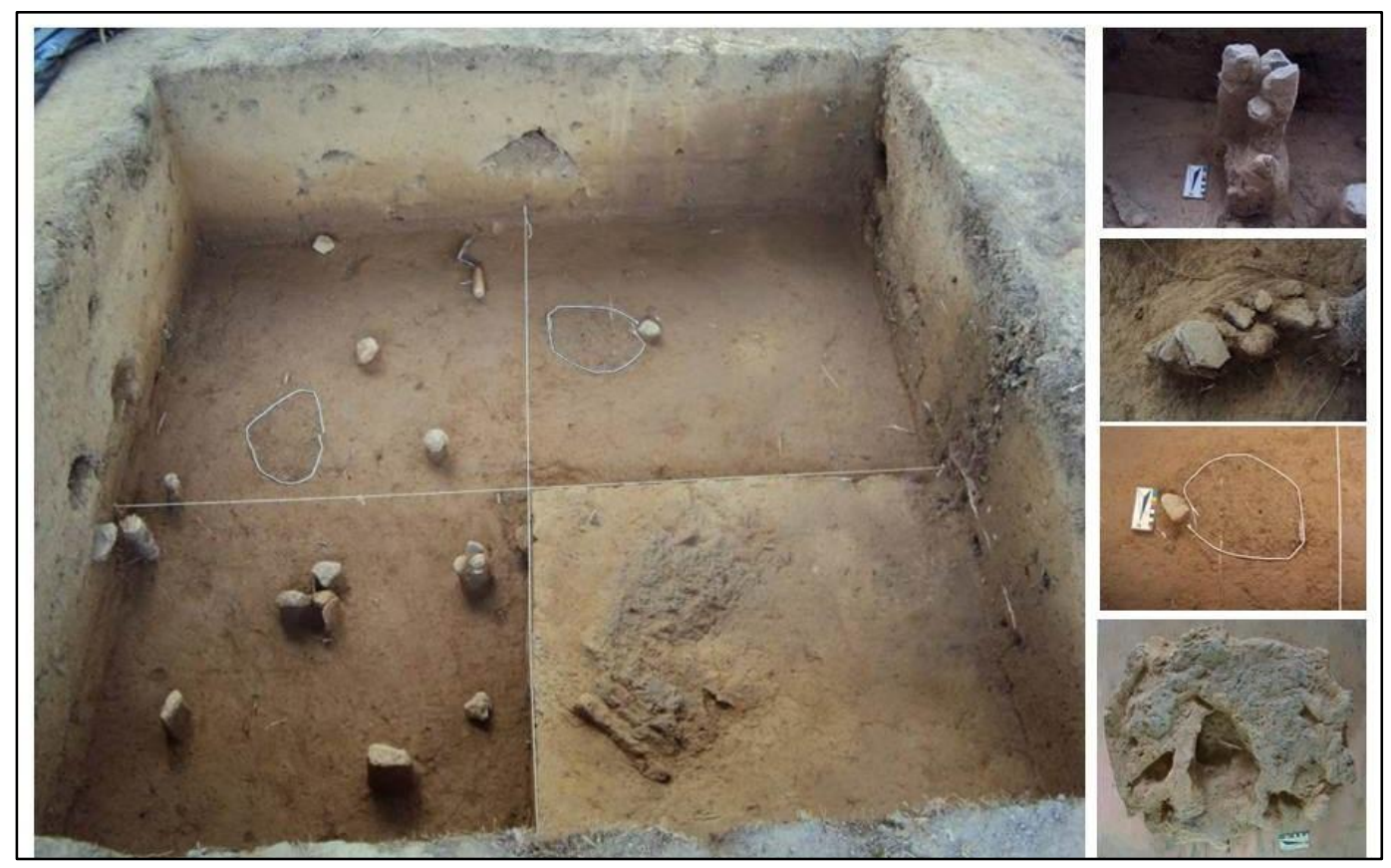

Figura 35: à esquerda escavação das unidades N387190 E9020490 I, II, III e IV; a direita, de cima para baixo: estrutura com blocos de granito; concentração de fragmentos cerâmicos; possível feição de buraco de estaca; e estrutura de combustão (possível forno) (SCIENTIA, 2009).

No setor II o pacote arqueológico se apresentou menos espesso, e não foram evidenciadas estruturas, com muitas bioturbações nas unidades escavadas. No setor III do sítio foi escavada uma estrutura de combustão no nível 60-70 cm de uma escavação de $2 \mathrm{~m}^{2}$ (unidades N387029 E9019950, N387029 E9019951, N387030 E9019950 e N387030 E9019951), caracterizada pela presença de carvão e sementes carbonizadas (Figura 36). Nestas unidades o material arqueológico estava presente nas camadas A, B e C, todas com sedimento areno-siltoso, bruno (10 YR 4/3 e 10 YR 5/3), assentada sobre a camada " $D$ ", arqueologicamente estéril e argilosa. A datação de 14C 2.080 \pm 30 AP (40-50 cm) foi obtida para o final da camada A, e a 14C $8.740 \pm 50$ AP $(70-80 \mathrm{~cm})$ para a transição da camada B para a C (Figura 38). Conforme Tizuka (2013), esta datação antiga pode ser atribuída à formação do solo ou a uma evidência de queimada, entretanto, são necessárias análises palinológicas e/ou datação da fração húmica do próprio sedimento para confirmar alguma destas hipóteses.

Nesse mesmo setor, uma escavação de 2 x 1 m (E386970 N9019890 e E386971 N9019890) apresentou material arqueológico entre os níveis 0-10 e 80-90 cm, e uma estrutura com fragmentos cerâmicos de uma mesma vasilha, alguns deles inclinados e alinhados no perfil sul da unidade E386970 N9019890 (Figura 37). 


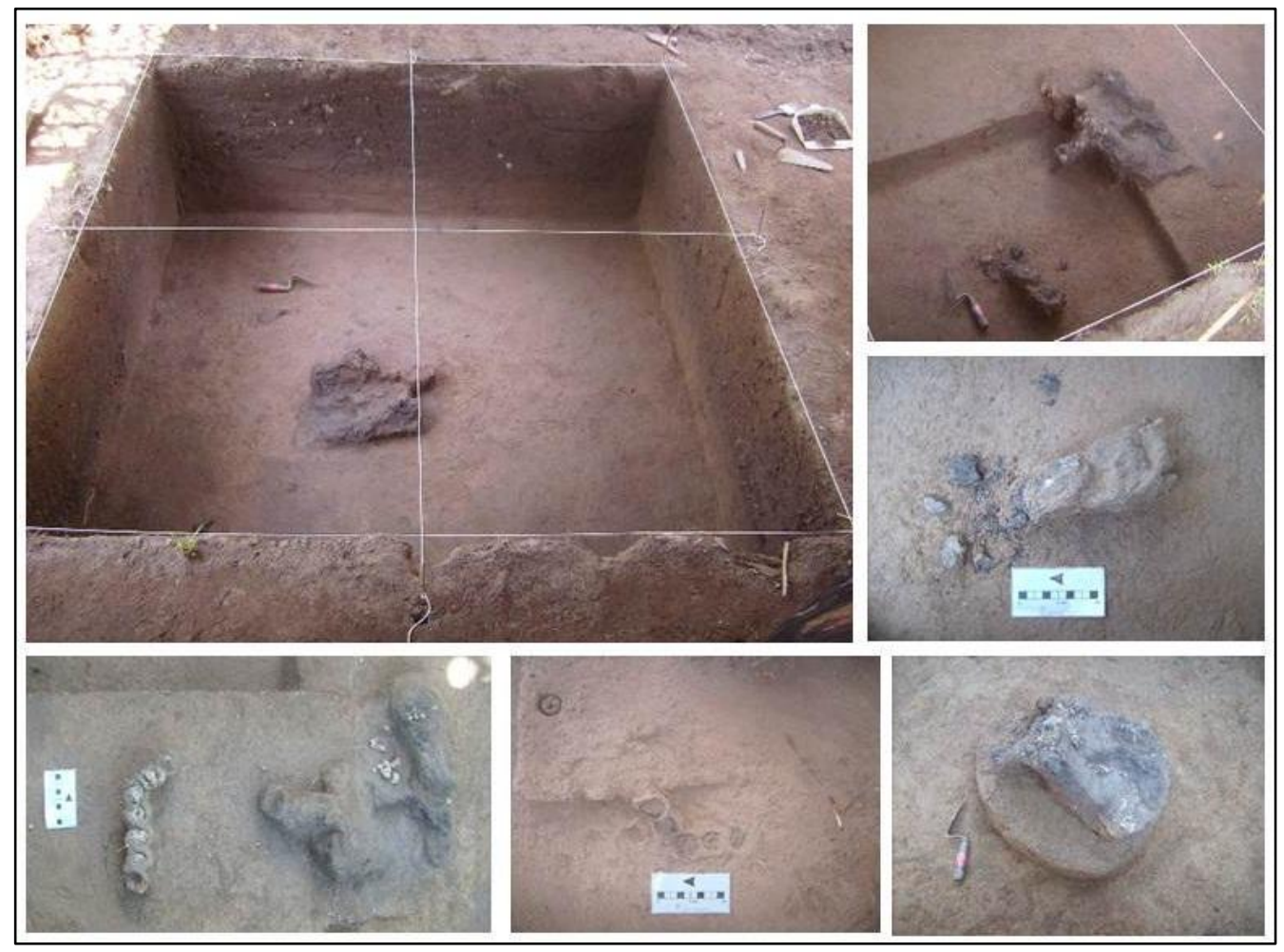

Figura 36: escavação de $2 \mathrm{~m}^{2}$ (N387029 E9019950); a direita detalhes da estrutura de combustão (carvões e sementes evidenciadas) (Fotos: SCIENTIA, 2009)

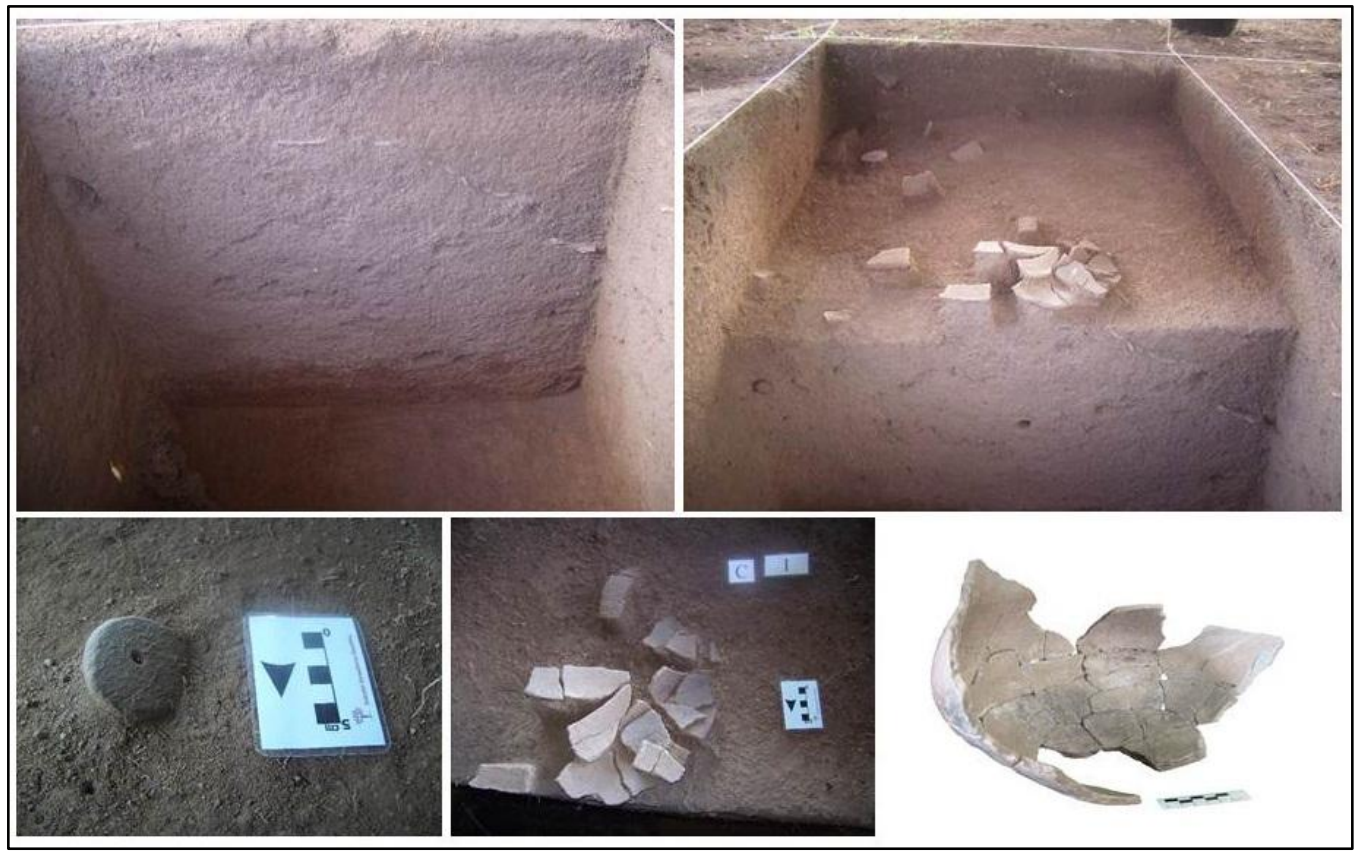

Figura 37: escavação de 2 x 1 m (E386970 N9019890), com evidenciação de fragmentos de uma mesma vasilha e um fuso (Fotos: SCIENTIA, 2009). 


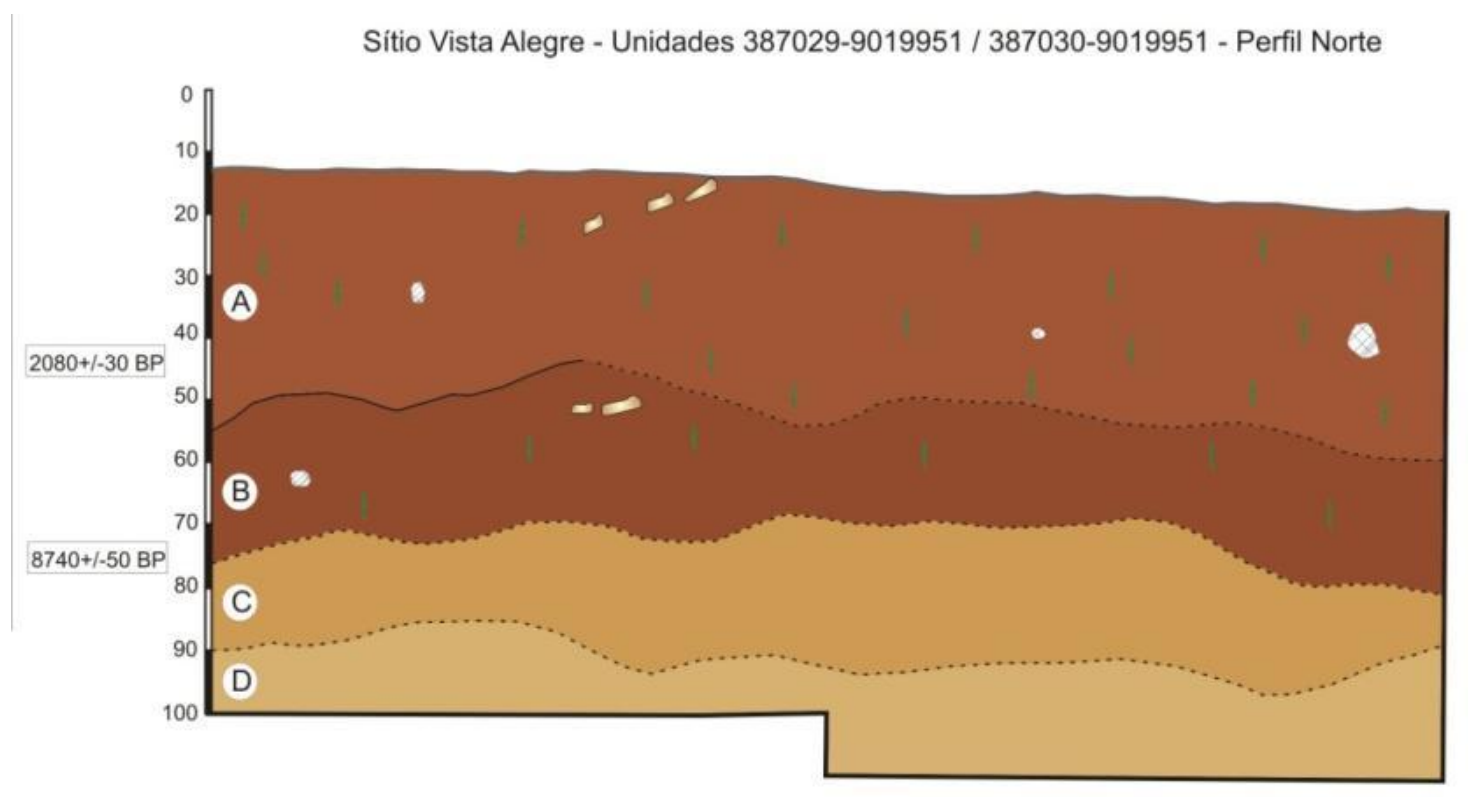

Descrição das camadas

A- Camada espessa, entre 30 e $40 \mathrm{~cm}$, sedimento coloração bruno (10 YR 4/3),

textura areno-siltoso, consistência ligeiramente friável (úmido), alta atividade biótica, com muitas raizes, radiculas, sendo esta camada com média frequência de material arqueológico, sendo em geral fragmentos cerâmicos.

B- sedimento coloração pouco mais escuro bruno (10 YR 5/3) e com alta frequência de material arqueológico, textura areno-siltoso, consistência ligeiramente friável (úmido), alta atividade biótica, com muitas raizes, radiculas,

C- camada arqueológica com boa freqüência de material, sendo de transição a lato-solo, onde ocorreu estrutura de combustăo. Sedimentos friável, coloraçăo mais escura, em consistência ligeiramente friável. Menor atividade biótica.

D- arqueologicamente estéril, com sedimento argilosa, coloração mais clara, havendo intrusōes bióticas, sendo ultima camada evidenciada.

\begin{tabular}{|l|}
\hline Legenda \\
C Cerâmica \\
(Bioturbação \\
A Camadas \\
Contato difuso \\
Contato brusco \\
\hline UHE SANTO ANTONIO \\
Desenho: Diogo Quirino \\
Arte final: Michelle Tizuka \\
Ano: 2009 SCIENTI I \\
\hline
\end{tabular}

Figura 38: perfil norte das unidades N387029 E9019951 e N387030 E901995 (SCIENTIA, 2009).

Nesse sítio, o material lítico polido e lascado é elaborado principalmente em granito ou quartzo. Foram encontradas algumas lâminas polidas, adornos (na unidade N387150 E9020430 um adorno/conta de colar com orifício central), núcleos, lascas e percutores (Fotografias 27 a 29). A cerâmica apresenta-se em geral bastante erodida, porém desde o processo de higienização em laboratório percebeu-se a grande variedade de decorações, como pinturas, incisões, modelados; vários tipos de pasta (somente mineral; com caraipé; com cauixí) e formas (flanges; alças). Os resultados da análise demonstrarão que o sítio possivelmente não apresenta apenas uma ocupação ceramista, conforme indicaram as escavações. 

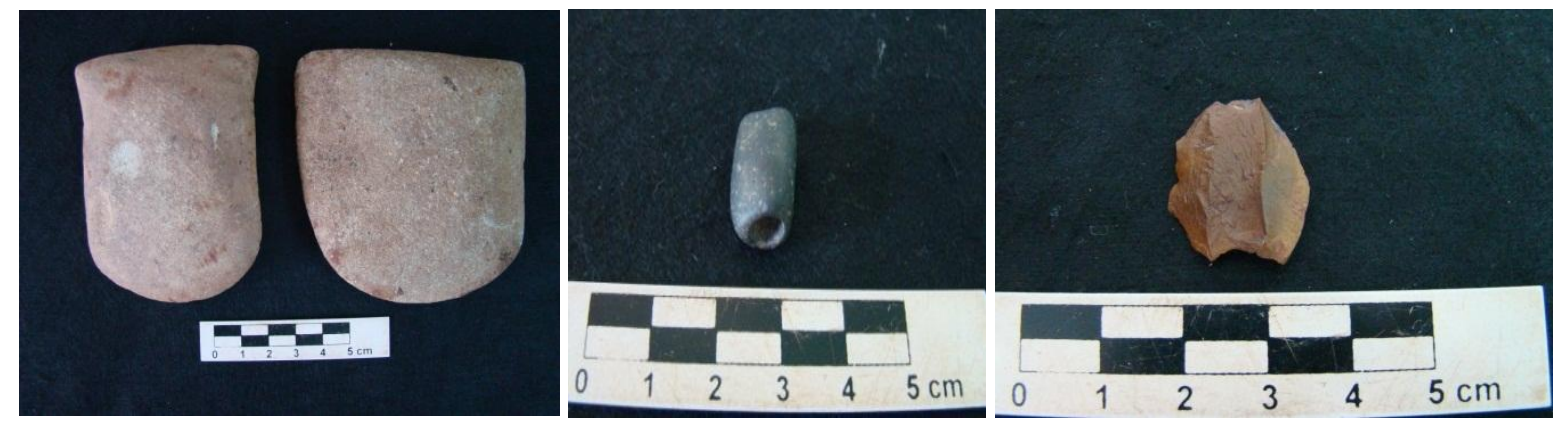

Fotografias 27, 28 e 29: materiais líticos do sítio Vista Alegre (SCIENTIA, 2012).

Foram analisadas as cerâmicas das unidades N387190 E9020490 (I, II, III e IV), N387029 E9019950, N387029 E9019951, N387030 E9019950 e N387030 E9019951, E386970 N9019890 e E386971 N9019890, cujos resultados serão apresentados no próximo capítulo.

\subsubsection{Sítio Morro dos Macacos I}

O sítio Morro dos Macacos I está parcialmente implantado em terraço conhecido como Morro dos Macacos, e parcialmente em planície de inundação do rio Madeira, em frente à Ilha Grande, em cotas entre 75 e 98 m (Figura 40). A área do sítio apresenta diversas palmeiras, como anajá, babaçu e tucumã, além de embaúbas e outras árvores. As casas dos moradores localizavam-se nas proximidades do rio (SCIENTIA, 2011a).

Foi encontrado material em superfície, onde foi feita uma coleta, e até $60 \mathrm{~cm}$ de profundidade, com a hipótese de o sítio ser unicomponencial. Inicialmente o sítio foi apenas delimitado na parte mais alta do terreno, em cotas entre 86 e $98 \mathrm{~m}$. Porém, no ano de 2010, moradores do local ao remover uma casa na parte mais baixa do terreno (cota de $75 \mathrm{~m}$ ), junto à planície de inundação, encontraram e retiraram algumas vasilhas cerâmicas. Segundo eles, todas estavam próximas, sendo que em uma delas havia ossos e outra servia de tampa. Tendo estas vasilhas sido doadas pelos moradores, procedeu-se ao peneiramento do sedimento que haviam retirado do local, encontrando-se fragmentos das respectivas vasilhas, e a escavação de uma área de $2 \mathrm{~m}^{2}$ na área de retirada delas. Esta área é relativamente plana, em um patamar delimitado pelo Rio Madeira a sul e pelo morro dos macacos a norte, e parte do sítio foi erodido pelo rio.

Nesta escavação, abaixo do buraco onde as vasilhas foram retiradas, evidenciaram-se fragmentos cerâmicos associados a carvão e a um pequeno bloco de granito, no nível 130-140 
cm (camada C). O perfil apresentou cinco camadas: a camada "A", de 0 a $70 \mathrm{~cm}$, é arenosa, de coloração bruno amarelado, com poucos fragmentos cerâmicos (entretanto o contexto foi alterado pela retirada das vasilhas); a camada "B", de 70 a $120 \mathrm{~cm}$ possui a coloração e textura da camada anterior, porém mais compacta, e corresponde a camada de onde os recipientes haviam sido retirados; a camada "C", entre 120 e $145 \mathrm{~cm}$, com sedimento arenoargiloso, de coloração bruno amarelado claro e compactação média, apresentando uma lente de coloração diferenciada, onde foram evidenciadas as concentrações de fragmentos cerâmicos, dispostos horizontalmente no nível 130-140 cm. A camada D (140-160) consiste em uma camada arqueologicamente estéril, com solo de textura arenosa, coloração bruno amarelado; e a camada "E” se estende de 160 - 290 de profundidade, estéril, com coloração bruno avermelhada e textura argilosa, compacta (Figura 39). Possivelmente as camadas A e B correspondem a deposição de areia em eventos de cheia.

Sitio Morro dos Macacos I - Unidade 388285/9022787 - Perfil Norte

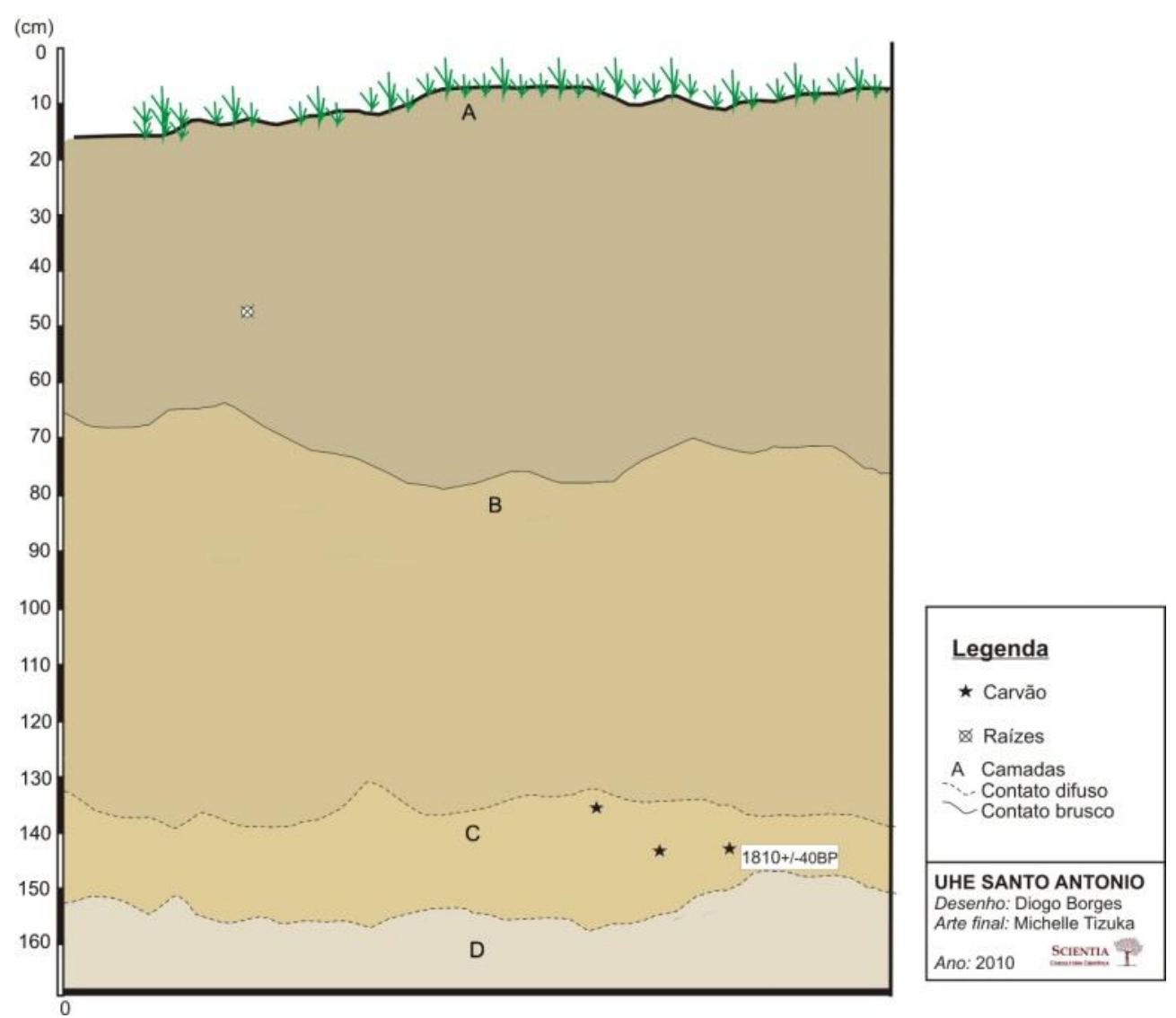

Figura 39: perfil da escavação com a indicação das camadas/Morro dos Macacos I (SCIENTIA, 2009) 

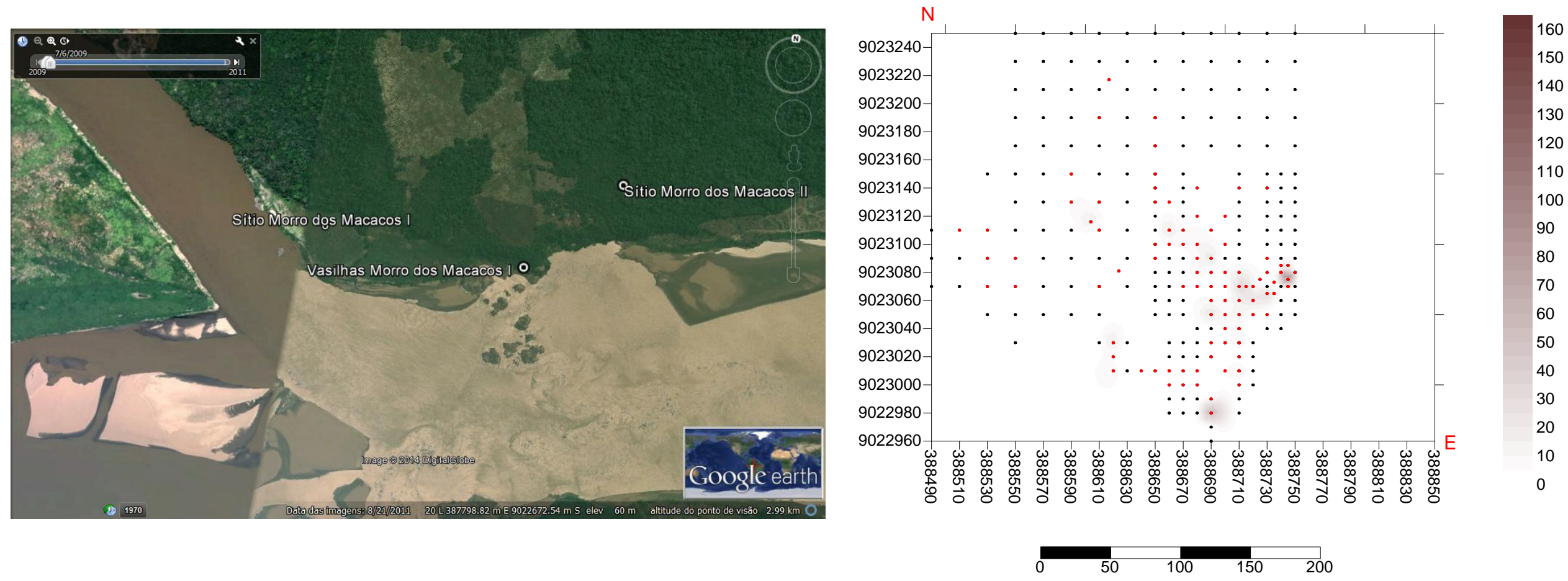

\section{Sítio Arqueológico Morro dos Macacos I}

\begin{tabular}{|l|l}
\hline Imagem 1 - Localização do sítio Morro dos Macacos I, imagem Google Earth. & Imagem 2 - Frequência de material arqueológico, a partir da delimitação.
\end{tabular} LEGENDA

- Furos testes com ausência de material arqueológico.

- Furos testes com presença de material arqueológico

$\square$ Frequência de material arqueológico 


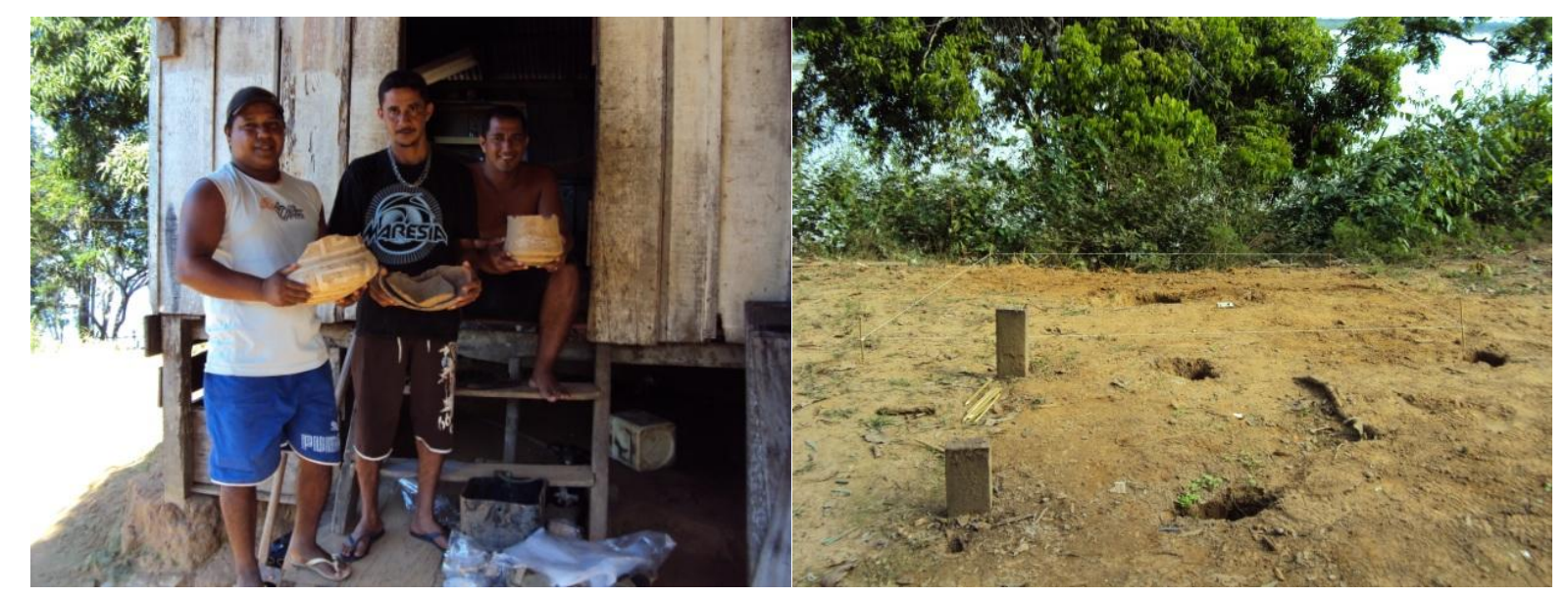

Fotografias 30 e 31: moradores com as vasilhas e área de onde foram retiradas (Scientia, 2009).

Os fragmentos doados pelo morador ou encontrados no sedimento peneirado (camadas A e B) remontaram cinco vasilhas. Já os fragmentos escavados na camada C remontaram 3 vasilhas cerâmicas (fotografias 32 e 33). Um dos carvões associados aos fragmentos cerâmicos da camada $\mathrm{C}$ foi datado em $1.810 \pm 40 \mathrm{AP}^{15}$, sendo uma datação bastante antiga para as ocupações ceramistas da região. O sítio não apresenta terra preta antropogênica. Analisamos apenas as vasilhas cerâmicas deste setor, porém já foi suficiente para expandir as interpretações em relação às ocupações desta área, pois os resultados apontaram que o sítio não é unicomponencial como fora inicialmente sugerido.
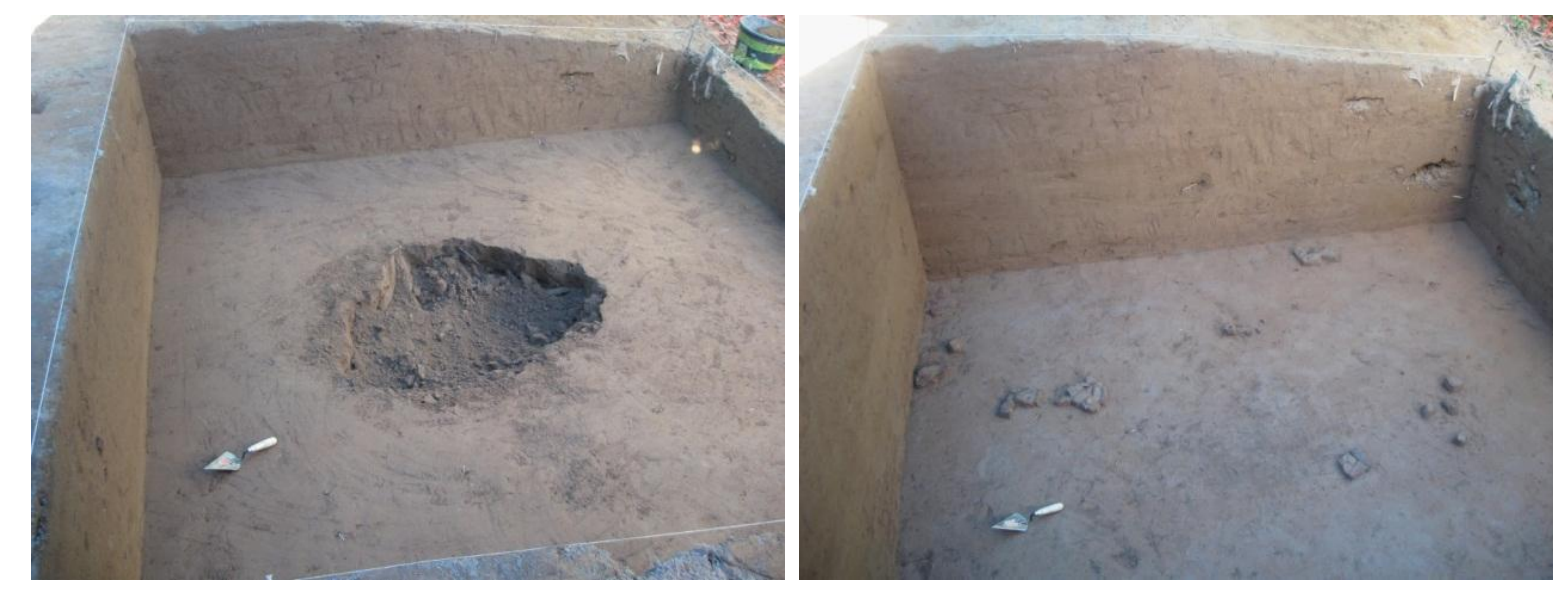

Fotografias 32 e 33: escavação na área das vasilhas: buraco de onde foram retiradas e fragmentos nos níveis mais profundos- Morro dos Macacos I (SCIENTIA, 2009).

O sítio Morro dos Macacos II localiza-se na margem esquerda, próximo ao Morro dos Macacos I, podendo se tratar de um único sítio. Este está implantado em terraço (cotas entre

\footnotetext{
${ }^{15}$ Datação inédita cedida pela Scientia consultoria científica.
} 
65 a85 m), em frente à Corredeira dos Macacos, e apresentou material arqueológico (cerâmico e lítico) em superfície e sub-superfície, além de feições de polimento nos pedrais que dão acesso a ele. Possui uma área 250m x 120m, com material arqueológico até $60 \mathrm{~cm}$ de profundidade. A área é contornada a oeste e ao sul pelo rio Madeira e a norte pelo Morro dos Macacos. Apesar de a área ter sido utilizada para o plantio de mandioca, macaxeira, mamão e banana, e ocupada por residências e uma casa de farinha, foi possível verificar duas áreas com maior concentração de material arqueológico, cujas escavações de 10 unidades de $1 \mathrm{~m}^{2}$ revelaram um pacote arqueológico pouco espesso, com baixa densidade de material cerâmico, e baixíssima densidade de material lítico (SCIENTIA, 2011c), obtendo-se as datações de $1.940 \pm 30 \mathrm{AP}^{16}$, para o nível 80-90 cm da unidade E387440 N9022780 e de $920 \pm 30 \mathrm{AP}^{17}$ para o nível 60-70 cm da unidade E387450 N 9022760. Não foram analisadas as cerâmicas deste sítio, porém seu contexto arqueológico e cronológico assemelha-se bastante aos sítios Morro dos Macocos 1, Boa Vista, Vista Alegre e Foz do Jatuarana, do qual falaremos a seguir. Possivelmente os sítios Morro dos Macacos I e Morro dos Macacos II, bastante próximos, estejam relacionados.

\subsubsection{Sítio Foz do Jatuarana}

O sítio arqueológico Foz do Jatuarana localiza-se na margem esquerda do rio Madeira, próximo à cachoeira do Teotônio e à confluência do Igarapé Jatuarana com o rio Madeira, na planície de inundação (60m-62m), com coordenada central E383900 N9022550. Inserido paralelamente ao rio Madeira, possui $300 \mathrm{~m}$ de extensão por $250 \mathrm{~m}$ de largura (Figura 42). Em área bastante impactada pela presença de moradias, cultivo de milho, cana, pastagem e árvores frutíferas (coqueiros, bananeiras, mamoeiros, mangueiras, cajuzeiro, laranjeira e outros), gramíneas e uma área de mata secundária.Apresentou baixa densidade de material cerâmico bastante erodido. É um sítio multicomponencial por apresentar uma ocupação précolonial e uma ocupação colonial (estruturas de uma serraria de período recente) (SCIENTIA, 2011a, 2011c).

As escavações foram realizadas nas diferentes partes do sítio (23 unidades de $1 \mathrm{~m}^{2}$ e áreas de decapagens nas estruturas históricas). As unidades contíguas E383934 N9022581 e E383935 N9022581 apresentaram uma camada arqueológica com maior frequência de

\footnotetext{
${ }^{16}$ Datação inédita cedida pela Scientia consultoria científica.

${ }^{17}$ Datação inédita cedida pela Scientia consultoria científica.
} 
material nos níveis de 10-20 até 30-40 cm, sendo que nos primeiros níveis de escavação os fragmentos cerâmicos apresentam uma coloração de núcleo escuro e com espessura relativamente fina (até $10 \mathrm{~mm}$ ), enquanto nos níveis inferiores possuem núcleo avermelhado e espessuras maiores (Figura 41) (SCIENTIA, 2011c). Foi obtida uma datação 14C $1.890 \pm 30$ AP para o nível 30-40 cm. Já na unidade E383857 N9022428 as cerâmicas ocorreram até 70 cm de profundidade e carvão até o nível $90 \mathrm{~cm}$. Foi obtida uma data 14C $2.780 \pm 40$ AP para o nível 70-80 cm, portanto pode ser a base das ocupações. A análise do material cerâmico das unidades E383934 N9022581, E383935 N9022581 e E383857 N9022428 será apresentada no próximo capítulo.

Deixando o sítio Foz do Jatuarana e subindo o rio logo chegamos à cachoeira do Teotônio, que foi até recentemente um dos pontos turísticos mais visitados pelos moradores de Porto Velho, sendo também importante ponto de pescaria no rio Madeira. Segundo Costa (2013), a cachoeira recebeu este nome porque o bacharel Teotônio da Silva de Gusmão tentou fundar uma povoação no local em 1757, quando já fazia parte da capitania de Mato Grosso, com o objetivo de estabelecer um comércio entre as capitanias, porém não obteve sucesso principalmente em decorrência do ataque dos Mura, conforme indicado na obra de Alexandre Rodrigues Ferreira (2007 v. III, p.16).

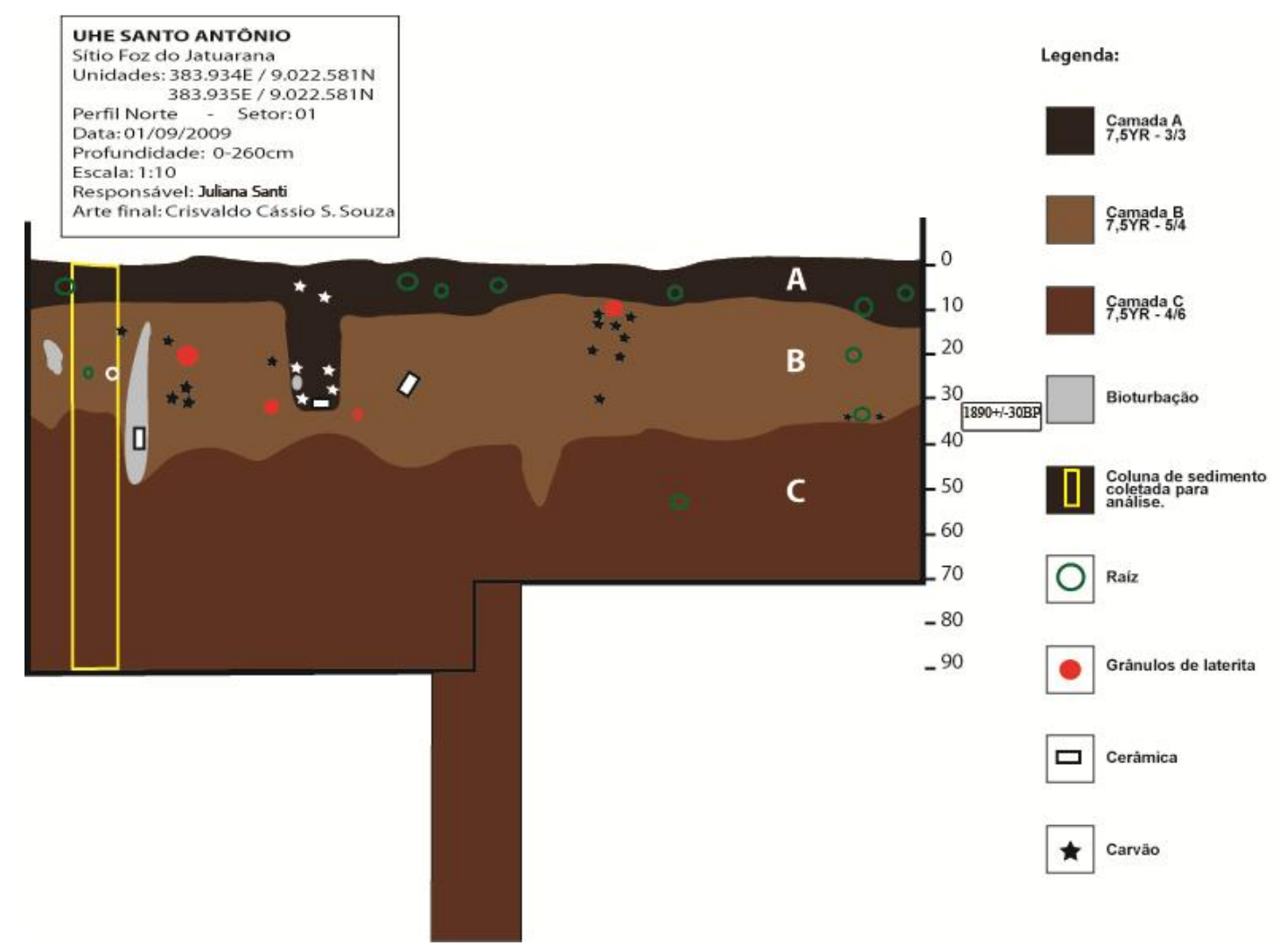

Figura 41: Perfil das unidades 383934/9022581 e 383935/9022581 -Foz do Jatuarana (SCIENTIA, 2009). 


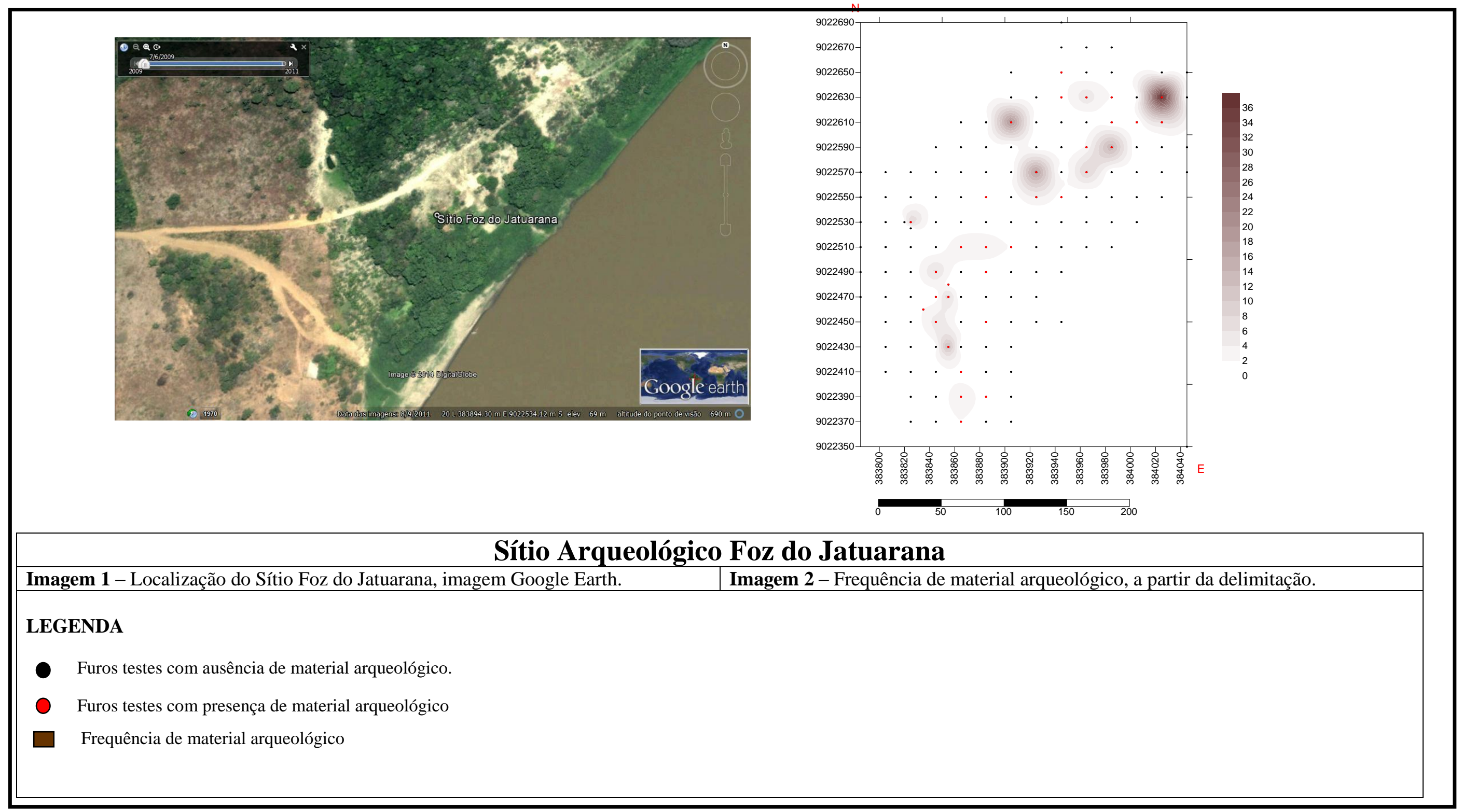

Figura 42: Croquis do sítio Foz do Jatuarana (Juliana Rossato Santi, 2014). 
No alto das duas margens do Madeira, junto a esta cachoeira, Eurico Miller encontrou sítios arqueológicos: o sítio RO-JP-01 Teotônio na margem direita e o sítio RO-JP-03 Porto Seguro na margem esquerda, posteriormente denominado Santa Paula (RO-JP-26) no relatório do EIAA RIMA referente à área de implantação da usina de Santo Antônio (Furnas et al., 2005, p. 338).

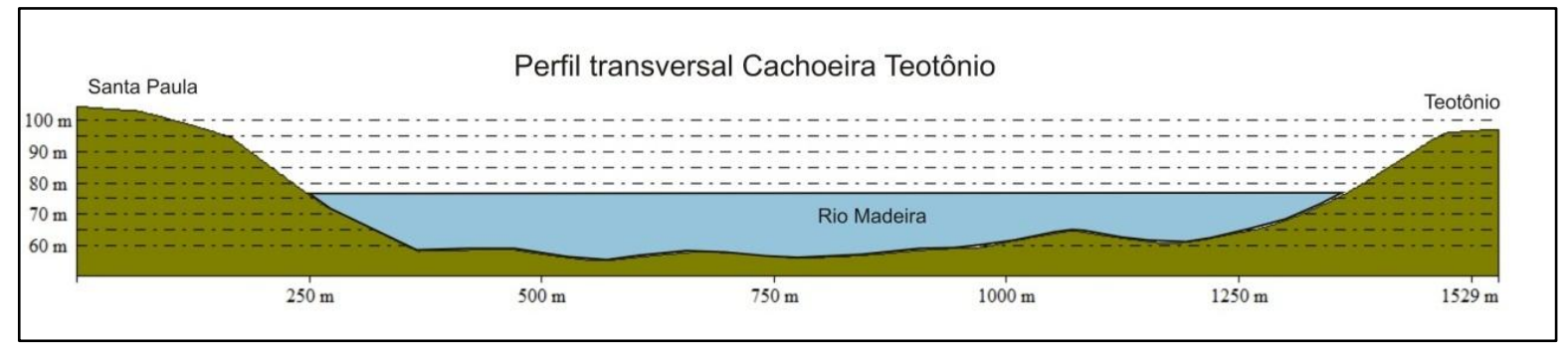

Figura 43: perfil transversal da cachoeira Teotônio (TIZUKA, 2013:90)

\subsubsection{Sítio Santa Paula (RO-JP-26) ou RO-JP-03 Porto Seguro}

O sítio Santa Paula (E382736 N9021440) está implantado em terraço fluvial (cota $100 \mathrm{~m})$, sendo feitas até o momento apenas a sua delimitação e escavação de duas unidades de $1 \mathrm{~m}^{2}$ cada uma, a E382631 N9021469 na parte central do sítio e a E382670 N9021310 na porção sul, próxima ao barranco (figura 44) (SCIENTIA, 2011c). Possui uma vegetação composta por árvores frutíferas diversificadas, áreas de roça e de capoeira. Apresenta um espesso pacote de terra preta de 2,3m com cerâmica, lítico lascado e polido, fragmentos ósseos, carvões e sementes, e a topografia parece indicar a presença de montículos.

A unidade E382631 N9021469 apresentou material até $230 \mathrm{~cm}$, e foi obtida uma sequência três datações da camada arqueológica: 14C $1.550 \pm 30 \mathrm{AP}(103 \mathrm{~cm}$ de profundidade), $1.530 \pm 30$ AP $(181 \mathrm{~cm})$ e $1.520 \pm 40$ AP $(203 \mathrm{~cm})$. Portanto, representa uma densa ocupação, e nesta área do sítio o depósito se formou em um curto período de tempo (cujos $110 \mathrm{~cm}$ de solo antropogênico e material arqueológico foram acumulados entre $40 \mathrm{e}$ 100 anos). Foi escavada até 2,50 m, e ao final da escavação foram identificadas sete camadas sedimentares no perfil oeste, denominadas de I a VII, da base para o topo, caracterizadas no perfil da figura 45.

A unidade E382670 N9021310, localizada próxima ao barranco, também apresentou material até $230 \mathrm{~cm}$, com presença de uma camada de terra preta, dividida em IIB (primeiros $50 \mathrm{~cm}$, mais escura) e IIA (Abaixo de $50 \mathrm{~cm}$ ) em função da coloração. Segundo observações 
de campo, nos primeiros níveis $(20$ e $40 \mathrm{~cm}$ ) sobressaiu a cerâmica pintada, enquanto entre 60 a $80 \mathrm{~cm}$ ocorreram fragmentos com motivos estilísticos diferenciados, destacando-se lábio expandido e flanges mesiais. Não foi analisado o material desta unidade, porém tal informação pode ser levada em consideração na interpretação da variabilidade cerâmica do sítio. Além da cerâmica, ocorrem líticos lascados e polidos, sementes queimadas, carvões e ossos. Entre os níveis 130-140 e 200-210 cm teria ocorrido uma feição (F1) com terra preta, cerâmica, ossos e sementes queimadas, no quadrante noroeste da unidade. No perfil abaixo é possível observar as camadas definidas.

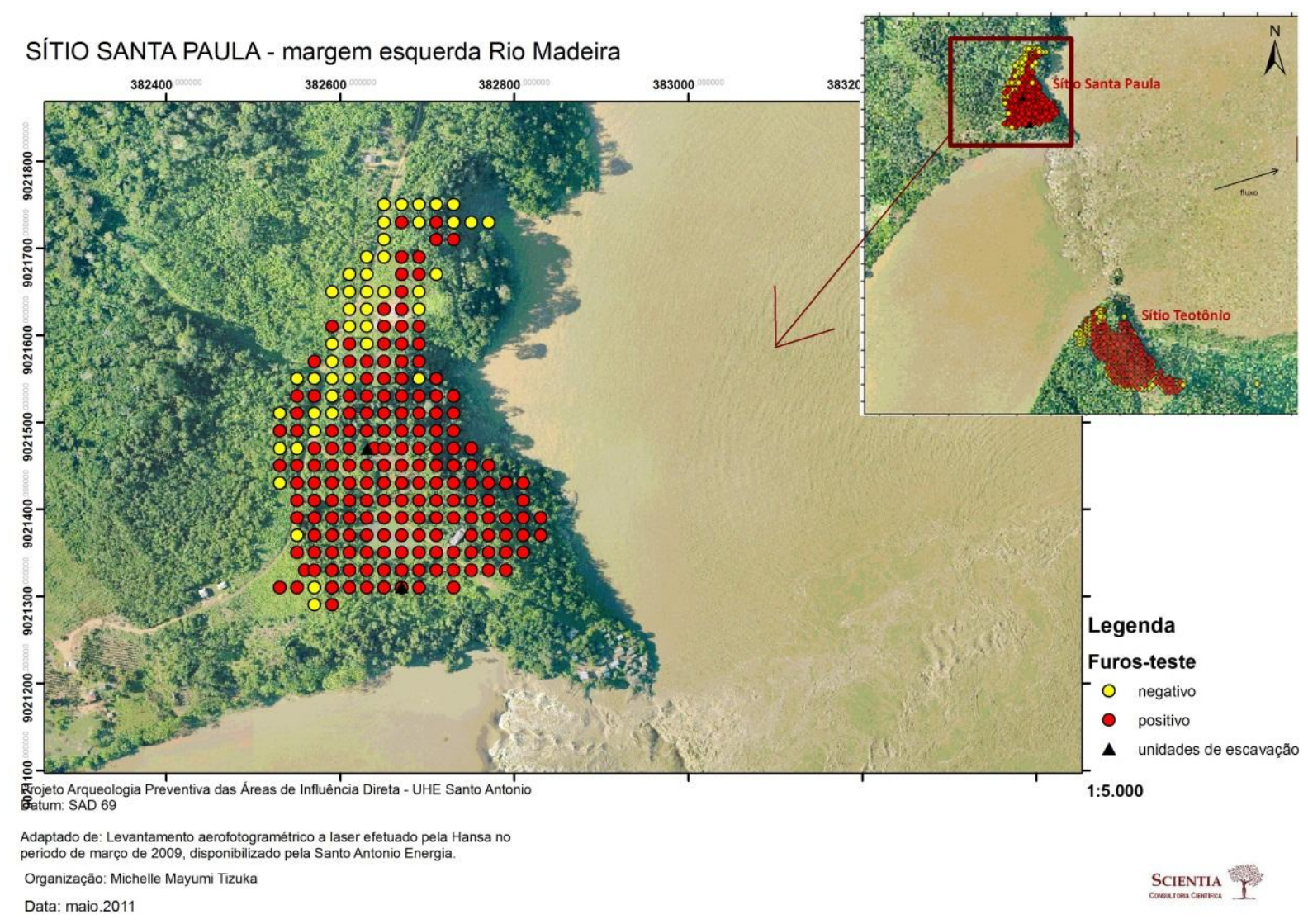

Figura 44: croqui com localização dos dois sítios, com os furos da delimitação e as unidades escavadas (SCIENTIA, 2012). 


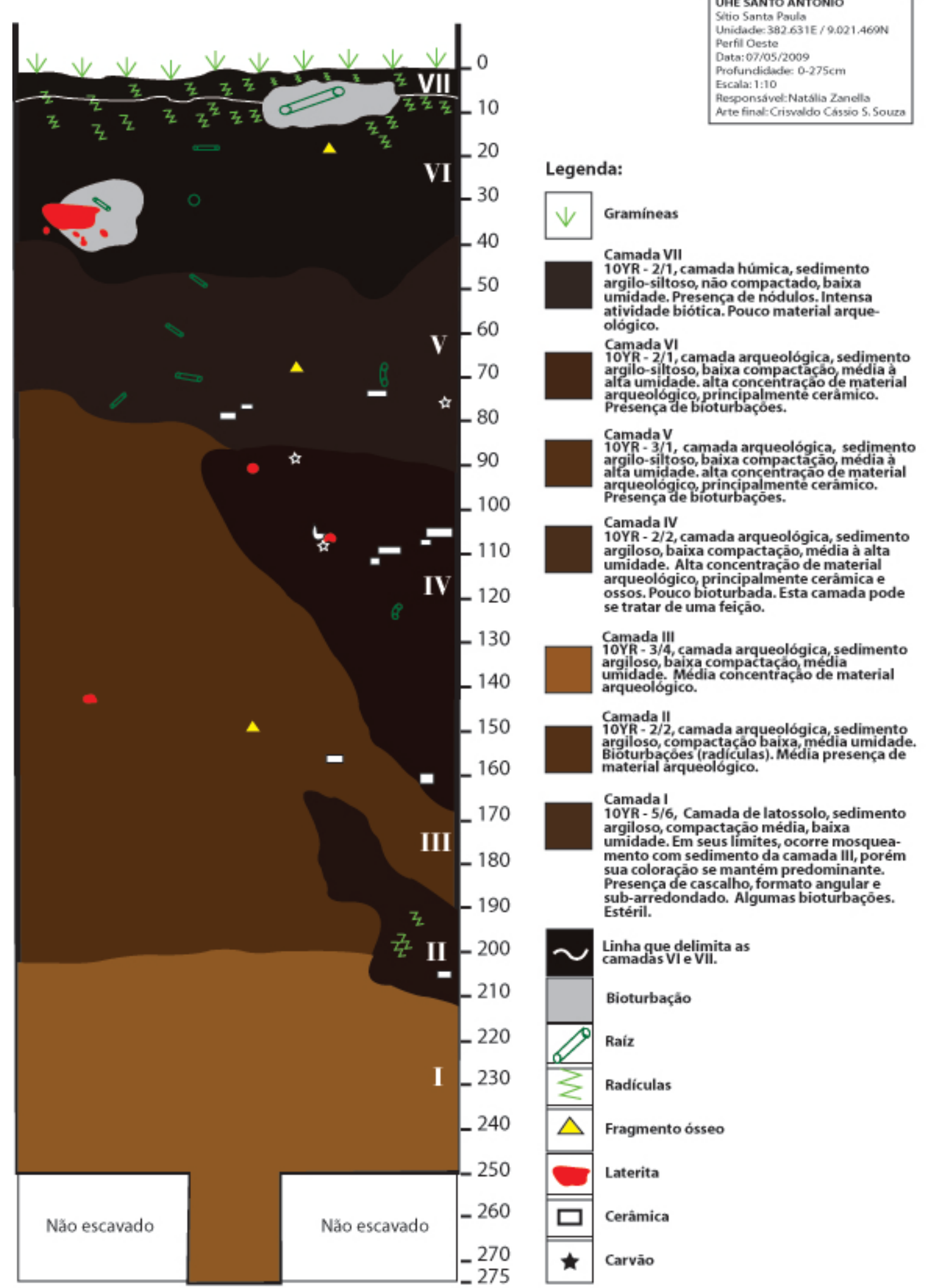

UHE SANTO ANTONNIO

Sitio Santa Paula

Defundiduste= $0.275 \mathrm{~cm}$

Escala: 1:10

Arte final:Crisvaldo Cássio S. Souza

Legenda:

Camada VII

CYR-2/1, camada húmica, sedimento

argilo-siltoso, não compactado, baixa

umidade Presenç de nódulos. Intensa tividade biótica. Pouco material arque

ada arqueológica, sedimento ta concentraçao de materia

OYR - 3/1, camada arqueológica, sedimento ailo-syy roso, baixa compactaçao media a . giloso, baixa compactação, média à alt elogico.

. Eterial arqueológico.

Camada I

o, sedimento cous coloracá se mantém predominante. . stéril.

inha que delimita as

Bioturbaçẫo

Raiz

Radiculas

Fragmento ósseo

Laterita

Carvào

Figura 45: croqui do Perfil oeste da unidade 382631 - 9021469- sítio Santa Paula (SCIENTIA, 2009). 
O material lítico do sítio Santa Paula é constituído predominantemente por blocos de granito sem marcas de lascamento, detritos e seixos sem marcas de uso, mas também estão presentes lascas de quartzo leitoso e hialino e de granito, percutores, duas lâminas polidas (rocha ígnea), seis fragmentos de artefatos polidos (rocha ígnea), três adornos polidos, uma lasca com as facetas polidas e nódulos de laterita com estrias. Destaca-se um artefato polido que apresenta um sulco de encabamento e marcas na parte distal indicam que foi utilizada como batedor ou mão de pilão, podendo tratar-se do reaproveitamento de um artefato polido fragmentado como batedor (Fotografias 34 a 36).

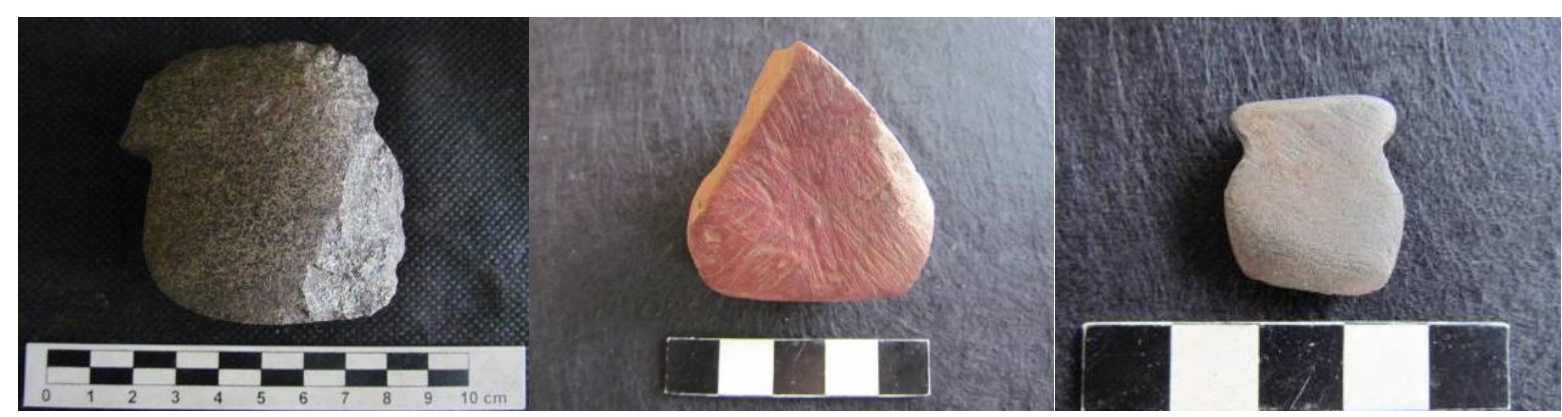

Fotografias 34, 35 e 36: lâmina polida, laterita com estrias e adorno (SCIENTIA, 2012).

Próximo ao sítio Santa Paula, na mesma margem, a apenas $410 \mathrm{~m}$ a sudoeste, identificou-se o sítio Mineiro, sob as coordenadas E382250 N9021281 (elevação em torno de $70 \mathrm{~m})$, sem terra preta antrópica e com baixo índice de material cerâmico, que pode ser uma área periférica do sítio Santa Paula. O morador do sítio, seu Mineiro, doou uma peça coletada no local, que constitui-se de um objeto zoomorfo (cobra), com representação de duas cabeças com olhos e incisões finas no corpo, pedestalizada em quatro partes sobre uma placa (tampa ou objeto independente zoomorfo) (Fotografia 37).

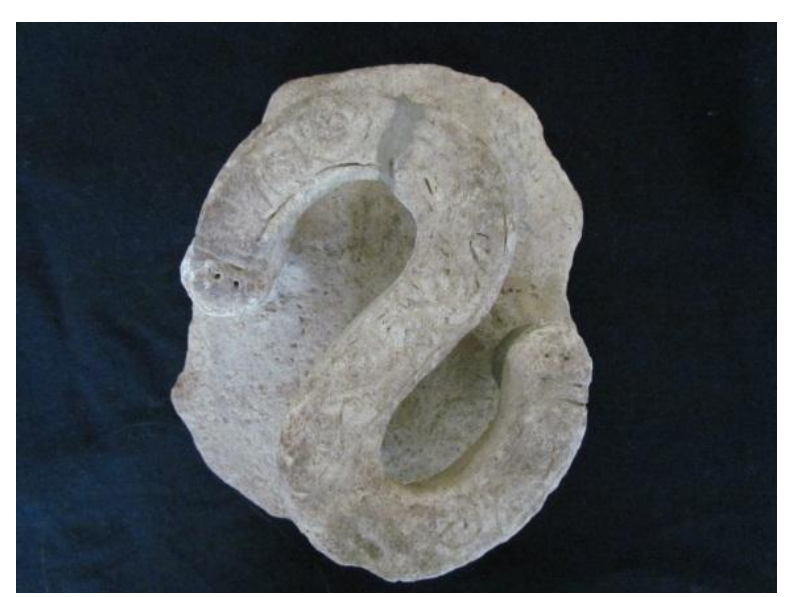

Fotografia 37: objeto zoomorfo- sítio Mineiro. 


\subsubsection{Sítio RO JP 01 Teotônio}

O sítio RO JP 01 Teotônio (cota de 100-103 m) foi escavado e registrado por Eurico Miller na década de 1970, quando foi evidenciada uma espessa camada de terra preta com

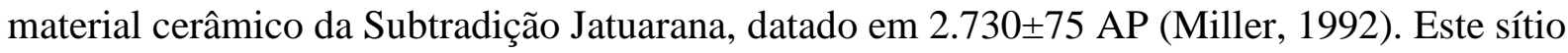
foi alvo de estudo de Félix (2012), Duran Silva (2013) e Almeida (2013) e está sendo abordado no trabalho de Mongeló (2012). Anualmente o sítio é escavado nas etapas do sítio escola promovido pelo Departamento de Arqueologia (DARQ) da UNIR, em parceria com a equipe do Projeto Alto Madeira (PALMA), coordenado pelo Professor Eduardo Góes Neves (MAE/USP). Apesar de estar bastante impactado pela presença de moradias, de plantio e da extração ilegal de terra preta para fins comerciais, o sítio Teotônio tem grande potencial de pesquisa, conforme vem sendo demonstrado nas ultimas etapas de campo desenvolvidas pelo DARQ e PALMA. Almeida (2013) obteve outras datas para a ocupação ceramista no sítio Teotônio, uma de 500 d.C para um conjunto cerâmico distinto da Subtradição Jatuarana e uma de 700 d.C para a base do nível Jatuarana, além de uma ocupação pré-ceramista datada em 1200 a.C. Neste trabalho analisamos apenas o material cerâmico proveniente do Setor Estrada, por considerar que o estudo deste contexto contribui para a compreensão da ocupação deste local.

$\mathrm{Na}$ estrada de acesso para a cachoeira foi visualizada a circunferência de duas vasilhas cerâmicas pelos moradores que contataram a equipe de arqueologia, onde foi aberto um setor de escavação de 2 x 2,6 m denominado Setor Estrada (SCIENTIA, 2011 c). O Setor estrada foi escavado em níveis artificiais de $20 \mathrm{~cm}$, evidenciando-se três vasilhas cerâmicas em um pacote de terra preta que ocorreu até a profundidade máxima de $60 \mathrm{~cm}$ com cerâmica, materiais líticos em quartzo e carvões. O pacote de terra preta estava sobre uma crosta laterítica que se constitui no embasamento nesta área do sítio. As vasilhas 1 e 3 são maiores e foram enterradas sobre a crosta laterítica, sendo que blocos desta crosta aparecem ao redor das vasilhas junto com a terra preta, podendo ter servido de suporte no seu enterramento. A vasilha 1 estava levemente inclinada devido ao tombamento sobre a base laterítica que era irregular, e sua base encontrava-se deslocada do corpo. Ambas apresentavam a borda cortada pela estrada, restando apenas a base e parte do corpo, com as seguintes medidas: vasilha 1 com $68 \mathrm{~cm}$ de diâmetro na parte superior e $30 \mathrm{~cm}$ de altura, e vasilha $3 \mathrm{com} 58 \mathrm{~cm}$ de diâmetro na parte superior e $45 \mathrm{~cm}$ altura. As duas vasilhas apresentam paredes espessas, base convexa côncava e paredes diretas verticais, pasta laranja com pouca frequência de grãos finos de quartzo e grande quantidade de cauixí, e ambas possuem um furo na base, feito após 
a queima da vasilha. Já a vasilha 2 estava depositada lateralmente entre as vasilhas 1 e 3, com a base para sul e a borda para norte. Esta possui forma e pasta diferentes: base plano-côncava, parede e borda direta inclinada externamente e pasta com alta inclusão de grãos minerais grossos. A nordeste da vasilha 1 ocorreu uma estrutura (E 17) de fragmentos cerâmicos, pequenos fragmentos de carvão e argila queimada $(x=1,90 \mathrm{~m} ; \mathrm{y}=0,60 \mathrm{~m} ; \mathrm{z}=0,17 \mathrm{~m} ;)$, estando os fragmentos na posição vertical. Destaca-se ainda um aplique zoomorfo coletado na peneira. Foram identificadas duas camadas: camada A, sedimento bruno amarelado (10YR 5/6), argilo-siltoso, muito compacto, com uma alta concentração de raízes e presença de material arqueológico; e camada B, sedimento bruno amarelado (10YR 5/8), argilo-siltoso e alta compactação, presença de grânulos, seixos e blocos lateríticos.

As vasilhas 1 e 3 foram removidas com o sedimento, e escavadas em laboratório. Na vasilha 1 ocorreu uma mistura de terra preta e sedimento argiloso compacto e amarelado somente nos primeiros $10 \mathrm{~cm}$, sendo que nos demais níveis apareceu somente terra preta fragmentos de tamanho grande, em posição horizontal em relação a borda cortada da vasilha, associados a carvão, além de fragmentos da própria vasilha, minerais e microlascas de quartzo. Possíveis farelos de ossos foram encontrados, porém o mais evidente foi um fragmento de dentina próximo à base. Já na vasilha 3 verifica-se uma mistura dos dois sedimentos desde a base até borda, bastante compactado, com menor quantidade de fragmentos cerâmicos, pequenos. No capítulo 4 apresentaremos a análise das vasilhas e dos fragmentos encontrados no interior e fora delas.

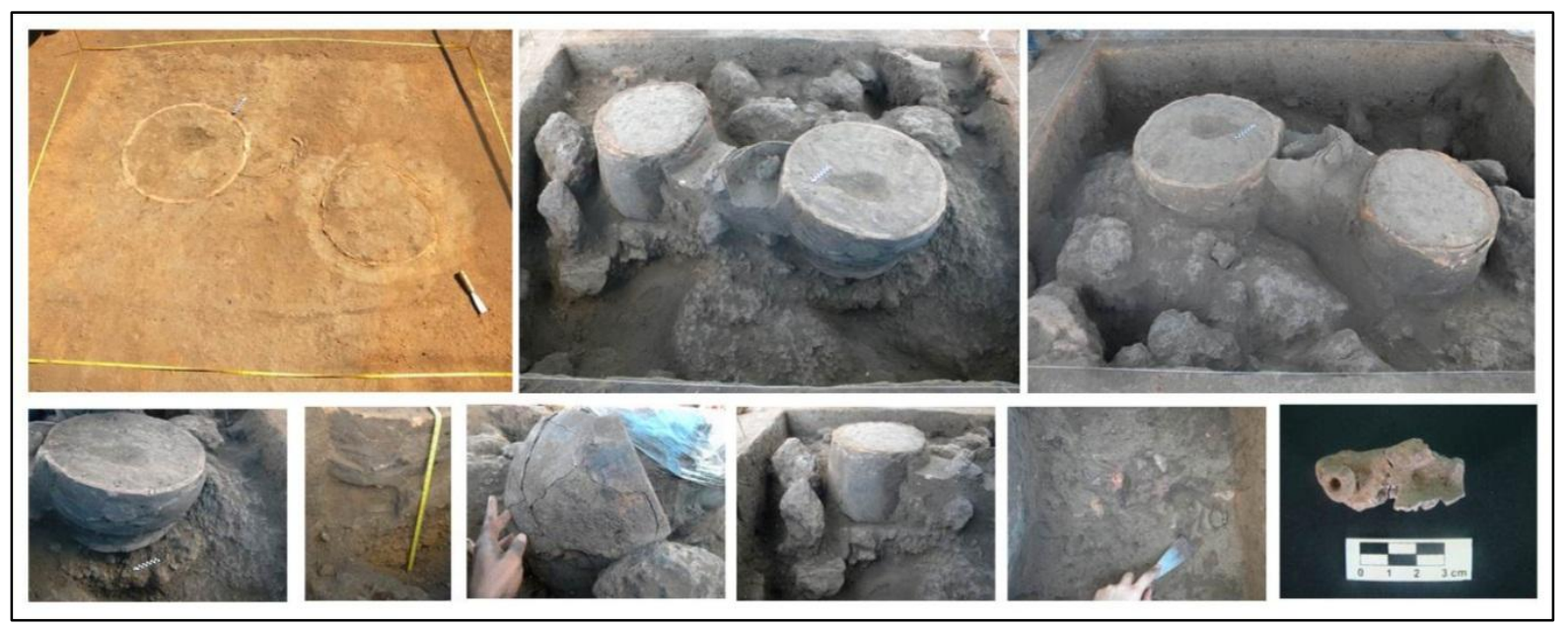

Figura 46: escavação das vasilhas 1, 2 e 3 e zoomorfo encontrado. 

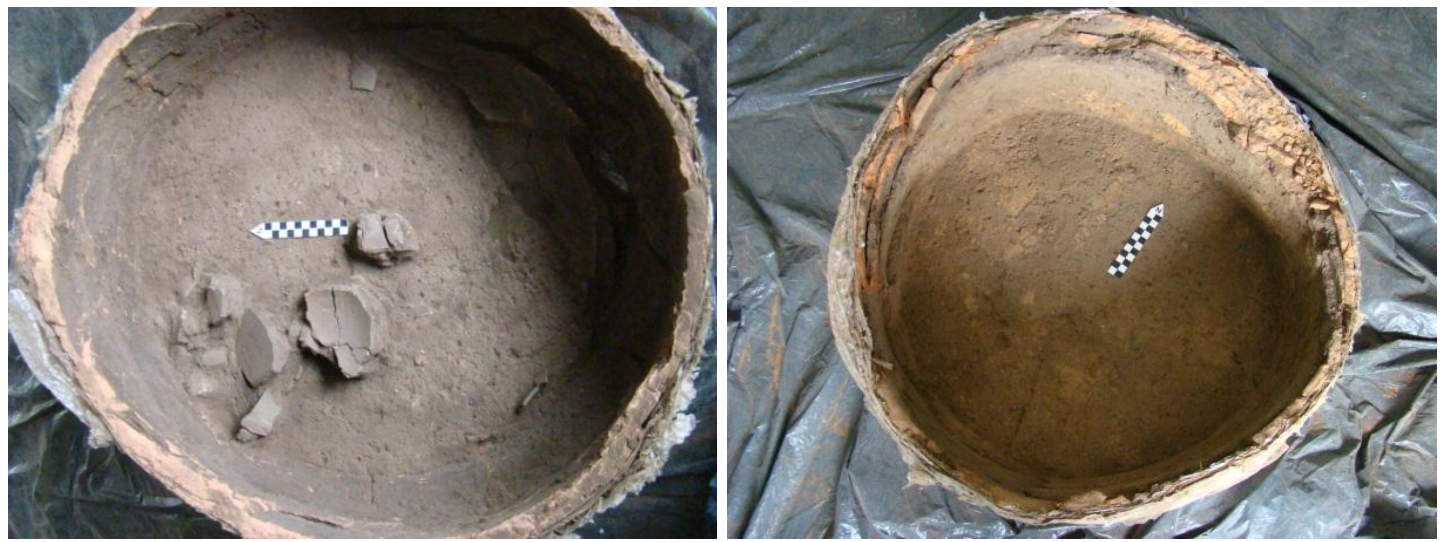

Fotografias 38 e 39: escavação do interior das vasilhas 1 e 3- sítio Teotônio (SCIENTIA, 2010).

Deixemos a cachoeira do Teotônio e vamos subir o rio. Na área compreendida entre as cachoeiras do Teotônio e o Caldeirão do Inferno, foram feitas prospecções assistemáticas e sistemáticas (SCIENTIA, 2011a), sendo encontrados sítios arqueológicos nas margens e ilhas. Daremos maior atenção aos sítios das ilhas porque analisamos uma amostra de cerâmica de cada um deles (Ilha São Francisco, Ilha das Cobras e Ilha do Japó), porém também falaremos dos demais sítios encontrados no caminho (Figura 47).

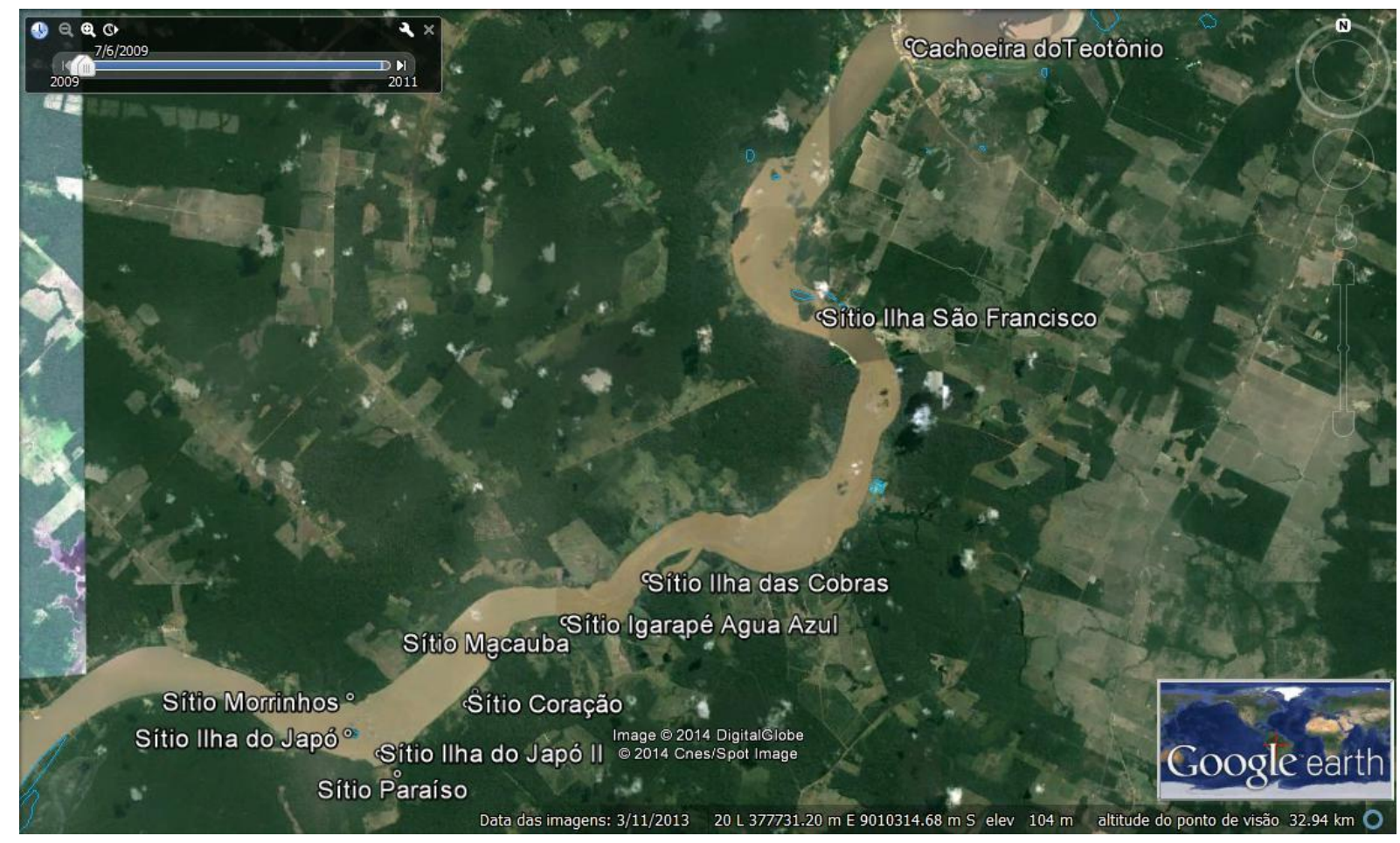

Figura 47: sítios localizados entre as cachoeiras de Teotônio e Morrinhos. Imagem: Google Earth.

\subsubsection{Sítio Ilha São Francisco}

Subindo o rio, $9 \mathrm{~km}$ a montante da cachoeira do Teotônio encontramos a ilha São Francisco. Está mais próxima da margem direita, e possui vegetação variada composta por 
partes de mata secundária, capoeiras densas e árvores frutíferas nas proximidades da moradia (mamoeiros, bananeira). Nos períodos de cheia do rio Madeira a área não alagada da ilha fica reduzida, enquanto na época de vazante uma maior parte fica visível, aparecendo os pedrais a sudeste, onde ocorrem feições de polimento e gravuras rupestres (SCIENTIA, 2011a).

O sítio arqueológico está implantado entre cotas de 69 a $83 \mathrm{~m}$, na porção sudeste da ilha (E380600 N9013700), a montante do curso do rio, onde também havia uma moradia, e de fácil acesso aos pedrais da ilha e à margem direita do rio. $\mathrm{O}$ material arqueológico apareceu em superfície e subsuperfície até $100 \mathrm{~cm}$ de profundidade, com maior quantidade nos níveis 20-40 e 40-60 cm (Figura 49).

Dentre as oito unidades de $1 \mathrm{~m}^{2}$ escavadas nesse sítio, cinco delas (E380560 N9013690, E380560 N9013710, E380600 9013720, E380600 N9013745 e E380600 N9013780) apresentaram maior densidade de material arqueológico, enquanto a unidade E380500 N9013800 apresentou pouco material. A E380580 N9013840 apresentou uma camada arqueológica enterrada, entre 40 e $100 \mathrm{~cm}$, possivelmente pela ação fluvial, e a E380400 N9013800 foi escavada em área externa ao sítio (SCIENTIA, 2011c).

O material apareceu entre a superfície e o nível 110-120 cm, com maior quantidade nos níveis 20-30 e 30-40 cm, que corresponde à camada $\mathrm{C}$ com sedimento mais escuro, composto por cerâmica, lítico lascado (em quartzo) e polido (uma lâmina de machado no nível 30-40 da unidade E380560 N9013690), e blocos de granito em algumas delas. No perfil sul da unidade E380600 N9013745 foi evidenciado um buraco de estaca. Nas unidades E380560 N9013710 e E380600 9013720 a maior quantidade de cerâmica ocorreu na camada C, enquanto a maior concentração de lítico está na camada D, o que poderia sugerir uma ocupação pré-ceramista.

Analisamos a cerâmica da unidade E380600 N9013720 por apresentar material diagnóstico (apliques). Esta foi escavada na parte sudoeste do sítio Ilha São Francisco, próximo à área de inundação do rio. Foram escavados 20 níveis artificiais, que resultou na identificação de cinco camadas de sedimento com presença de material (cerâmico e lítico) em quase todos os níveis, com uma maior concentração de cerâmica nos níveis de 30-40 cm (156 fragmentos), e baixa quantidade de lascas de quartzo a partir dos $80-90 \mathrm{~cm}$ ate o último nível. A camada "A" (níveis 0-10 cm e 10-20 cm) apresentou sedimento bruno escuro (10YR 3/3), argiloso- arenoso (fino) e consistência friável, com muitas de radículas e raízes, apresentando cerâmica erodida. A Camada "B" (10-20 e 20-30 cm), com sedimento bruno (10YR 3/4) areno- 
argiloso, com presença frequente a presença de radículas e poucas raízes e fragmentos cerâmicos erodidos, porém maiores. A Camada "C" (30-40 a 70-80 cm), bruno-acinzentado muito escuro (10YR 3/2), areno - argiloso e friável, e poucas radículas e raízes; apresenta alta frequência de fragmentos de cerâmica e algumas lascas. A camada "D" esta localizado entre os níveis de 70-80 a 90-100 cm com coloração bruno forte (7.5YR 4/6), com textura argiloarenosa pouco compactada com baixíssima presença de finas raízes, e presença de cerâmica e lítico. A camada "E", coloração vermelha amarelada (5YR 4/6) com textura argilosa, com 1 fragmento de cerâmica e 49 lascas apontado uma aumento dos vestígios em lítico nas camadas mais profundas. A unidade foi encerrada aos $200 \mathrm{~cm}$ por atingir uma rocha que tomava toda a base da unidade, impendido a continuidade da escavação mesmo o último nível escavado sendo positivo (figura 48).

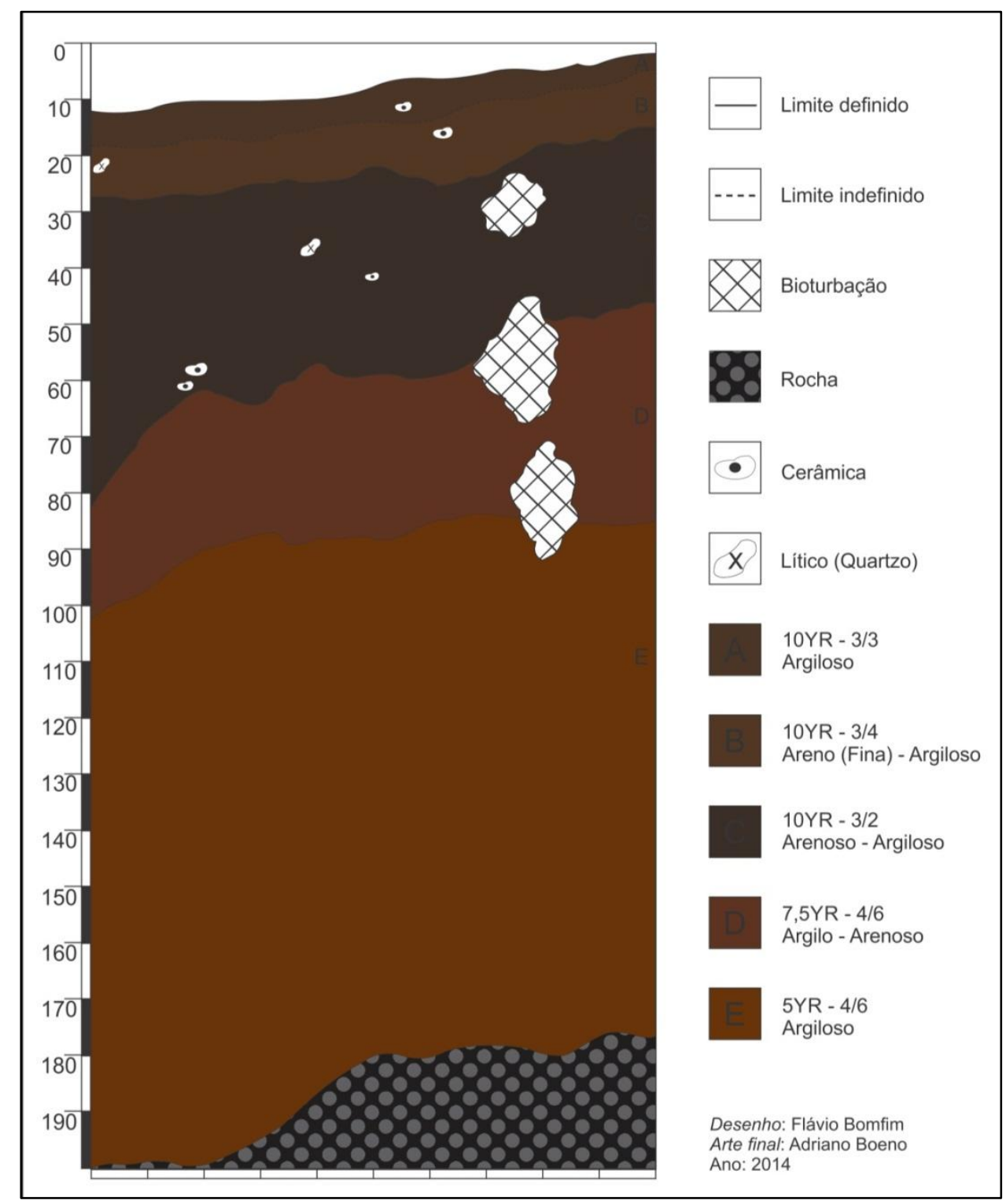

Figura 48: perfil norte da unidade E380600 N9013720 (SCIENTIA, 2010). 

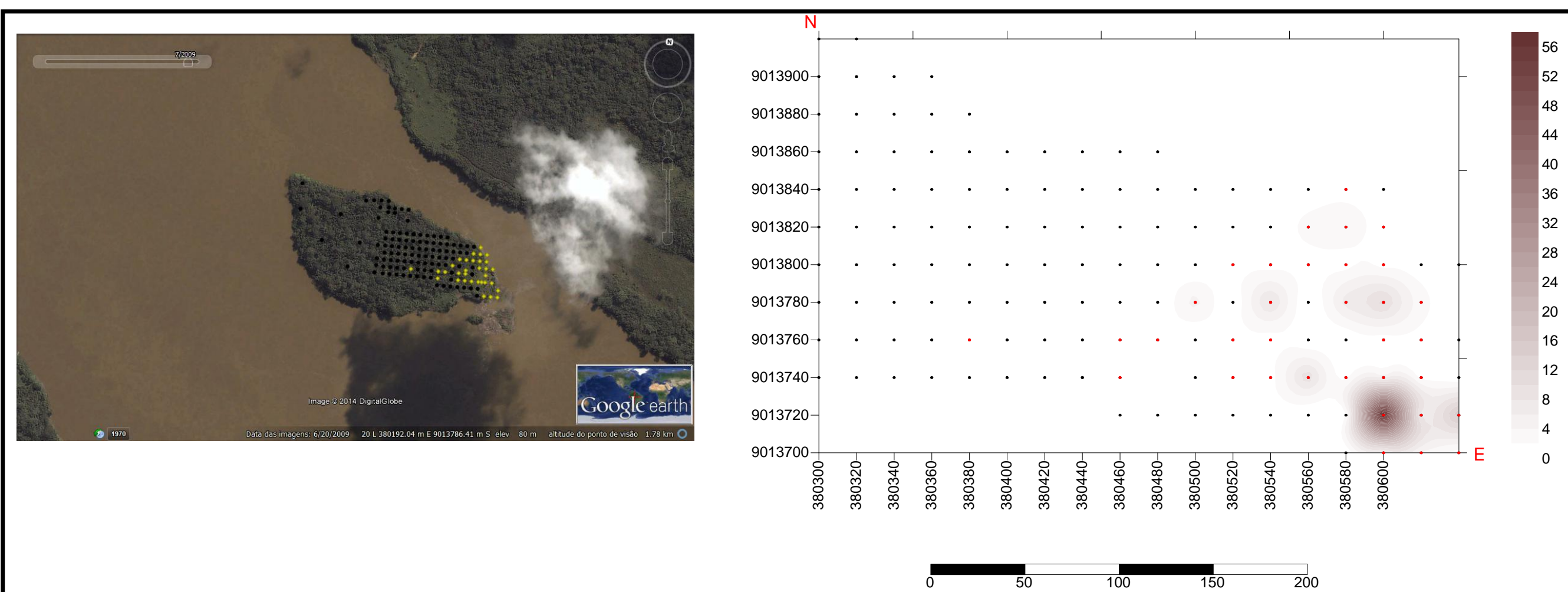

\section{Sítio Arqueológico Ilha São Francisco}

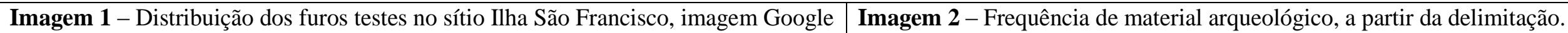
Earth.

\section{LEGENDA}

Furos testes com ausência de material arqueológico.

Furos testes com presença de material arqueológico.

\section{LEGENDA}

- Furos testes com ausência de material arqueológico.

Furos testes com presença de material arqueológico

$\square \quad$ Frequência de material arqueológico 


\subsubsection{Sítio Ilha das Cobras}

Saindo da Ilha São Francisco e navegando $12 \mathrm{~km}$ rio acima, avistamos a Ilha das Cobras, que possui formato alongado de acordo com o curso do rio, uma vegetação variada com partes de mata secundária, palmeiras esparsas, capoeiras densas, e presença de bananeiras e mamoeiros nas proximidades de uma moradia, na parte sudoeste da ilha (a montante), onde foi localizado o sítio arqueológico. O sítio está implantado em uma área mais plana e mais alta, em unidade geomorfológica constituída por planície aluvial, compartimento topográfico de regime deposicional (cotas de 64 a 91m), com vestígios cerâmicos e líticos em superfície e subsuperfície até $120 \mathrm{~cm}$ de profundidade, com maior quantidade entre os níveis artificiais 20-40 e 40-60 cm (Figura 53). Nos pedrais próximos a esta área, que ficam visíveis na época de vazante do rio, ocorrem gravuras rupestres (SCIENTIA 2011b).

Não aparece terra preta neste sítio, porém na camada $\mathrm{C}$ da maioria das unidades ocorre um sedimento de coloração mais escura do que nas demais camadas (sedimentobruno 10 Y3/4, cinzento escuro 10YR4/1, bruno 10YR5/3 e bruno amarelado 10 YR 5/4) (SCIENTIA, 2011c). Analisamos os dados de campo relativos à quantidade de materiais por nível para as nove unidades escavadas no sítio e observamos que em algumas delas (E376480 N9006360, E376500 N9006380, E376545 N9006480) ocorrem três concentrações de cerâmica, o que poderia sugerir a ocorrência de três ocupações no sítio. Em outras (E376500 N9006340 e E376530 N9006380) a cerâmica apresenta-se em duas concentrações, e em algumas (E376520 N9006400, E376480 N9006340 e E376460 N9006400) apenas uma concentração. A unidade E376700 N9006600 apresentou três fragmentos, sendo uma área periférica do sítio. Quando observamos a distribuição do material lítico (incluindo blocos e seixos) de algumas unidades, as concentrações acompanham aquelas da cerâmica (Figura 52).

Foi analisado o material cerâmico da unidade E376500 N9006380, escavada no quintal da moradia, onde ocorria maior quantidade de material em superfície, atingindo a profundidade de $160 \mathrm{~cm}$, sendo identificadas quatro camadas (A, B, C e D). A camada A é húmica, com sedimento bruno (10 YR 3/4), areno-siltoso, consistência ligeiramente friável (úmido), alta atividade biótica, com muitas raízes e radículas, e baixa frequência de material arqueológico. A camada B possui sedimento com textura arenosa, bruno amarelado (10 YR 4/4), consistência ligeiramente friável e alta atividade biótica, com baixa frequência de material arqueológico no nível 30-40 cm (o nível $20-30 \mathrm{~cm}$ é estéril). A camada C possui sedimento de textura arenosa, consistência ligeiramente friável e coloração mais escura, sendo 
pouco mais úmida que camadas anteriores, com material arqueológico. A Camada D possui lentes de coloração avermelhada de possível lençol freático, com baixa frequência de material arqueológico (Figura 51).

Esta é uma das unidades onde ocorreram três concentrações de cerâmica: superfície e 0-10 cm; nos níveis 20-30 a 40-50 cm; e uma maior entre 50-60 e 100-110 cm. Apesar de o sítio ter sido caracterizado como unicomponencial através dos trabalhos de campo (SCIENTIA, 2011c), o resultado da analise cerâmica poderá trazer novos elementos que corroborem com a hipótese de diferentes ocupações elaborada a partir dos gráficos e distribuição de material.

Entre a ilha e a margem direita, alguns pedrais ficavam visíveis nas épocas de máxima vazante do rio, onde foram identificadas feições de polimento e gravuras rupestres. O suporte é o granito da Suíte Intrusiva Teotônio, de coloração cinza médio a escuro. A técnica de elaboração das gravuras é o picoteamento, e os motivos são variados: formas zoomórficas ("lagartos"), círculos concêntricos às vezes espiralados, e compostos por círculo e linha (Figura 50). Foram realizados decalques das gravuras, bem como o escaneamento 3D, nos meses de agosto, setembro e outubro de 2009, 2010 e 2012 (SCIENTIA, 2011d; KIPNIS et al, 2013). Não comparamos os motivos das gravuras com os da cerâmica, e este é um trabalho que pode ser feito futuramente.

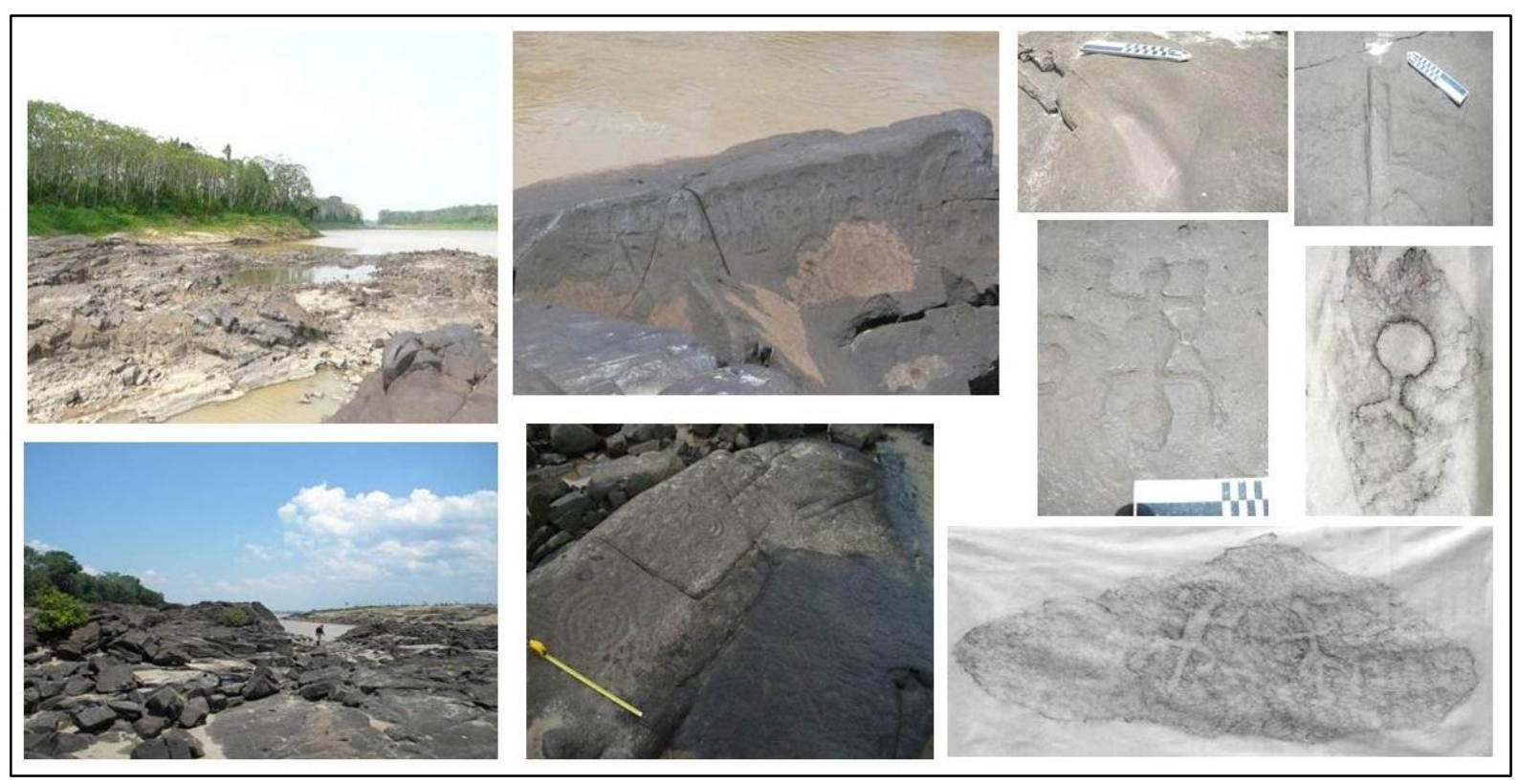

Figura 50: exemplos de painéis, gravuras e feições de polimento - sítio Ilha das Cobras (SCIENTIA, 2012). 
Ao subir o rio por mais $10 \mathrm{~km}$ encontramos a cachoeira de Morrinhos, transponível em qualquer época do ano. Percebemos que aqui o rio corre imprensado pelas colinas e baixos platôs lateríticos, estando os terraços fluviais na margem esquerda e as superfícies aplainadas na margem direita, que caracteriza a migração progressiva da calha do rio Madeira para sulsudeste até ser forçado a atravessar um terreno pontilhado pelos remanescentes de uma superfície de um antigo e vasto platô laterítico, característica observada no trecho entre a Cachoeira do Teotônio e Morrinhos (CPRM, 2005).

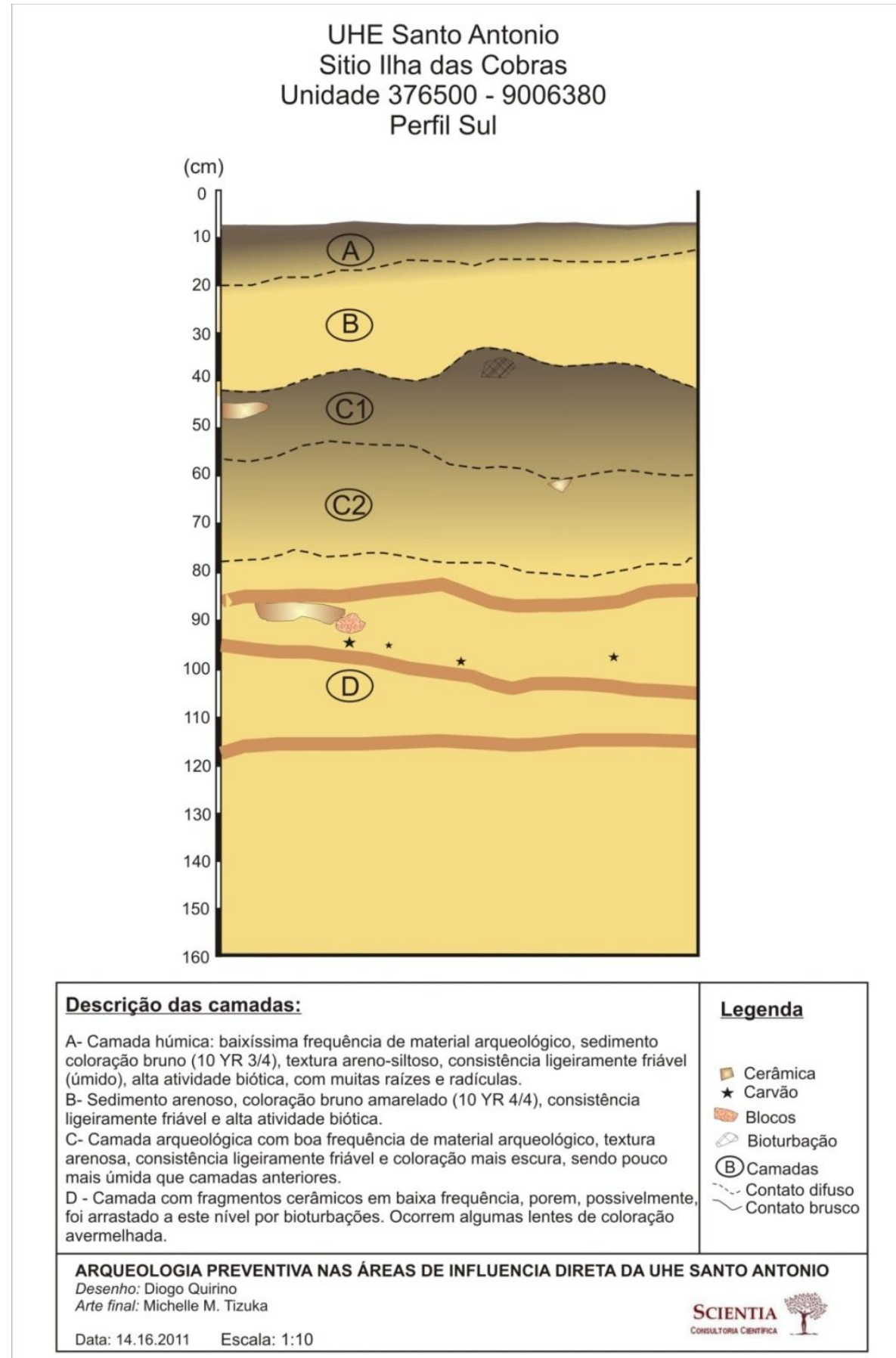

Figura 51: Perfil da E376500 N9006380 com indicação das camadas e lentes (Michelle Tizuka, 2013). 
Cerâmica- Unidade E0376480 N9006360

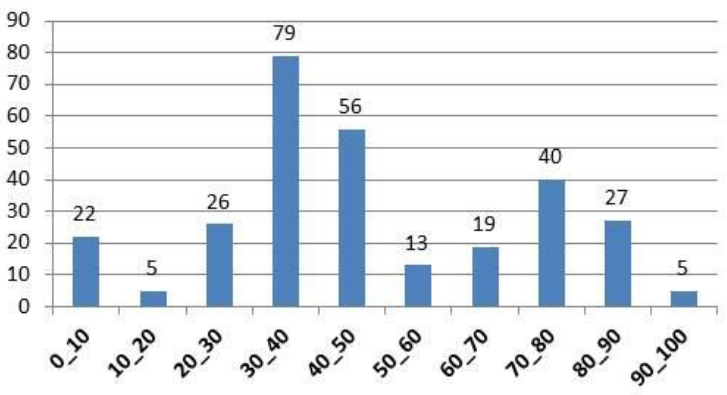

Cerâmica-Unidade E0376500 N9006380

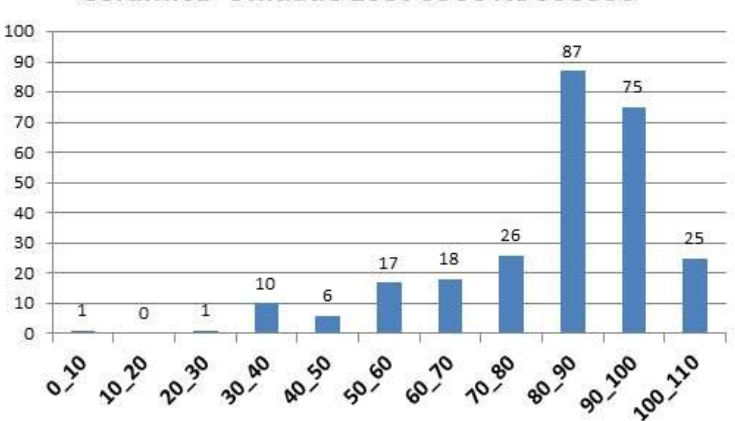

Cerâmica- Unidade E0376545 N9006480

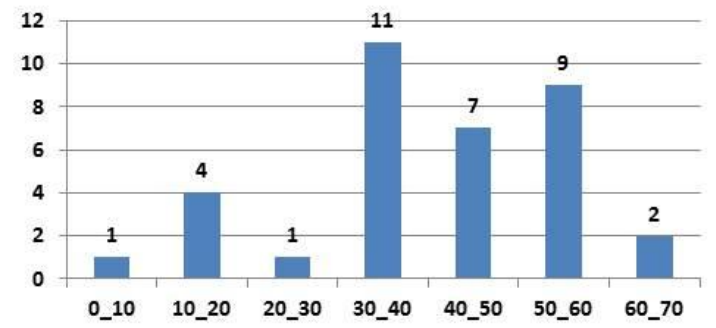

Cerâmica-Unidade E0376500 N9006340

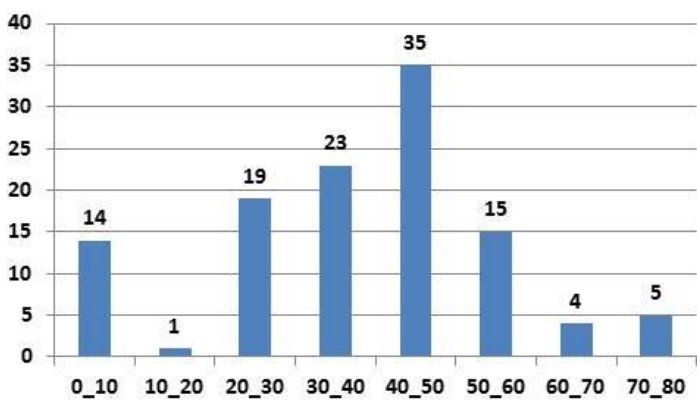

Cerâmica- Unidade E0376530 N9006380

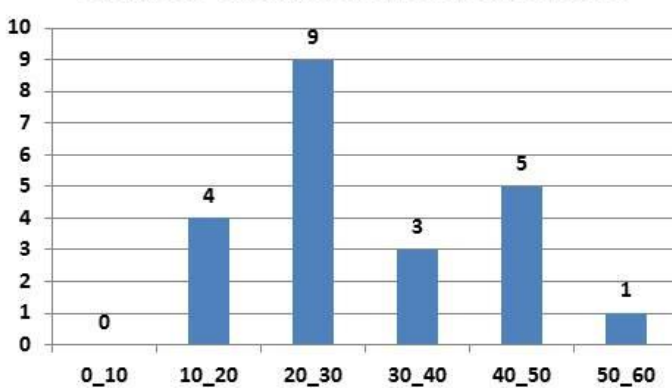

\section{Cerâmica- Unidade E0376700 N9006600}

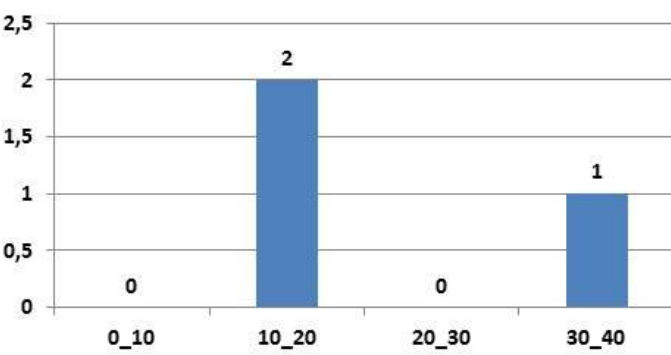

Cerâmica- Unidade E0376520 N9006400

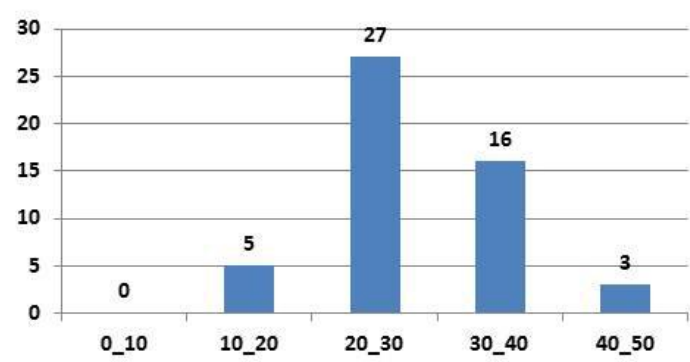

Cerâmica- Unidade E0376480 N9006340

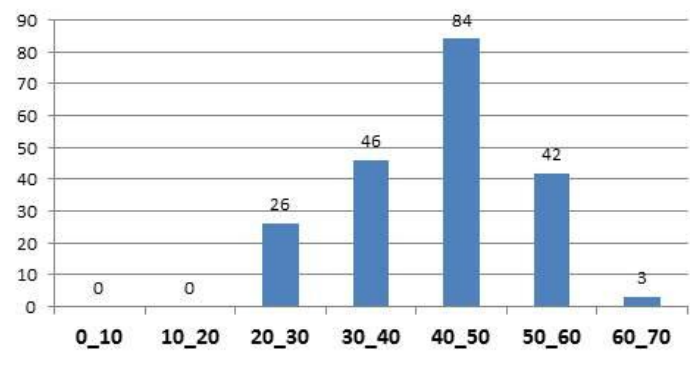

Cerâmica-Unidade E0376460 N9006400

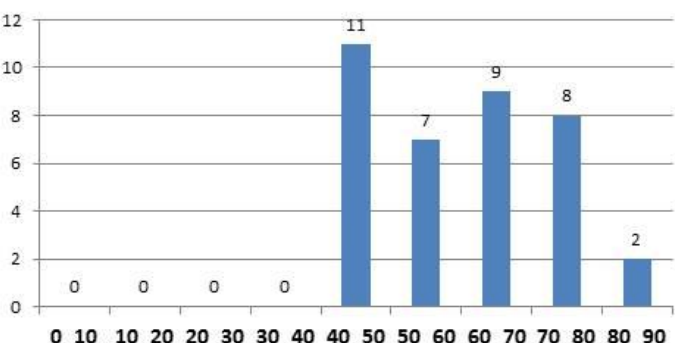

Figura 52: gráficos com as concentrações de cerâmica por nível- sítio ilha das cobras. 


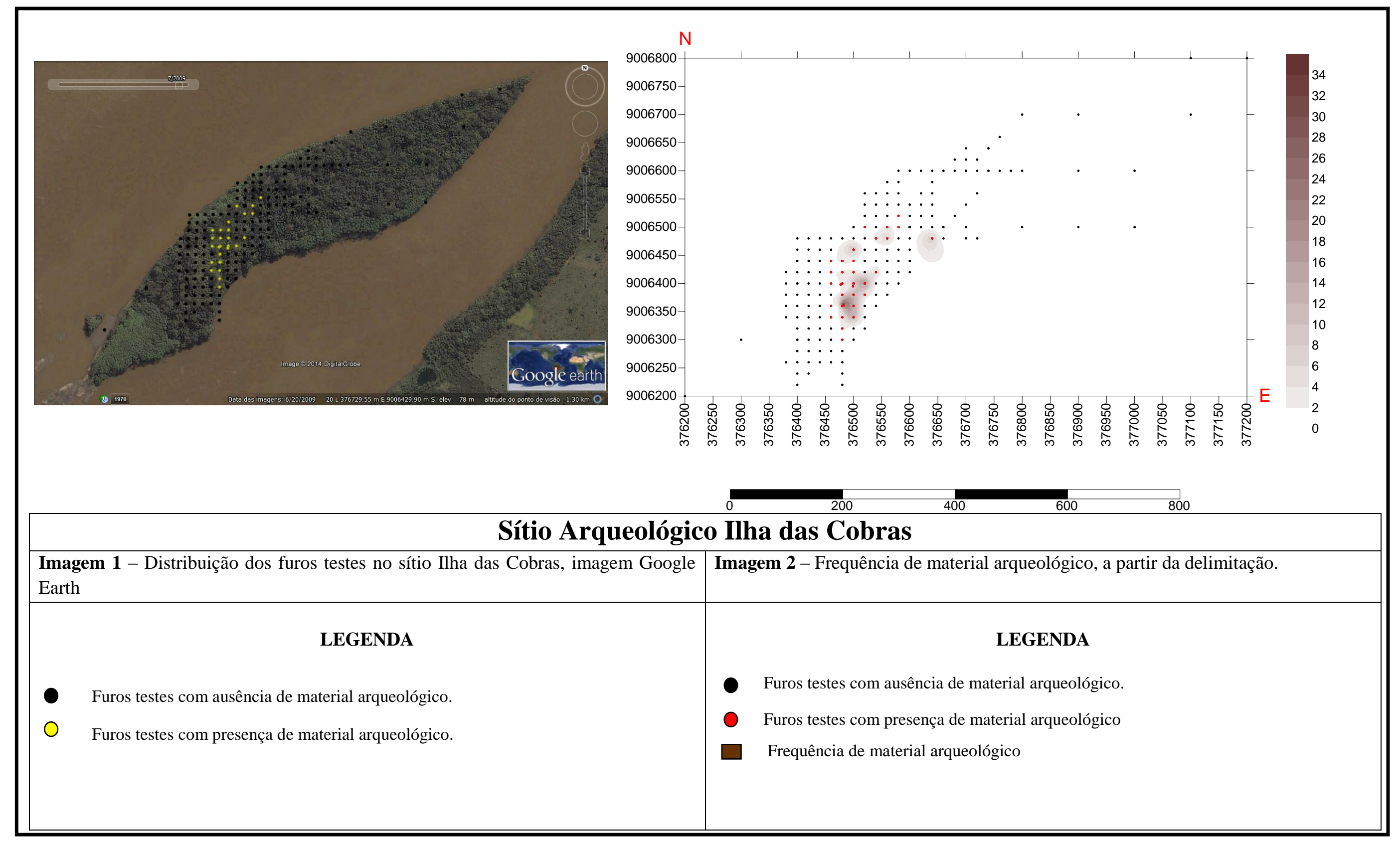

Figura 53: croquis do sítio Ilha das Cobras (Juliana Rossato Santi, 2014). 
Os grupos humanos ocuparam todos os compartimentos geomorfológicos nesta área, em locais com visibilidade privilegiada. Antes mesmo de chegar na cachoeira de Morrinhos, avista-se na margem direita os sítios Igarapé Agua Azul, Macaúba e Coração. Junto à cachoeira estão duas ilhas, uma grande denominada Ilha do Japó onde foi identificado um sítio arqueológico homônimo, e uma ilha menor onde foram identificados poucos materiais arqueológicos (sítio Ilha do Japó II). Nas margens direita e esquerda estão localizados os sítios Paraíso e Morrinhos, respectivamente. Os sítios Coração (RO-JP-24) e Paraíso (RO-JP23) foram localizados durante o EIA/RIMA e os demais pelas prospecções realizadas em 2010 (SCIENTIA, 2011a).

Destes sítios citados, abordaremos apenas o sítio Ilha do Japó, através da analise da cerâmica de uma das unidades escavadas. Mesmo assim, vamos salientar algumas características destes contextos evidenciados, buscando entender as ocupações no entorno da cachoeira de Morrinhos, a terceira que encontramos ao subir o rio Madeira. Vale ressaltar que existe uma ótima visibilidade entre os sítios Paraíso, Macaúba, Coração, Morrinhos e a Ilha do Japó.

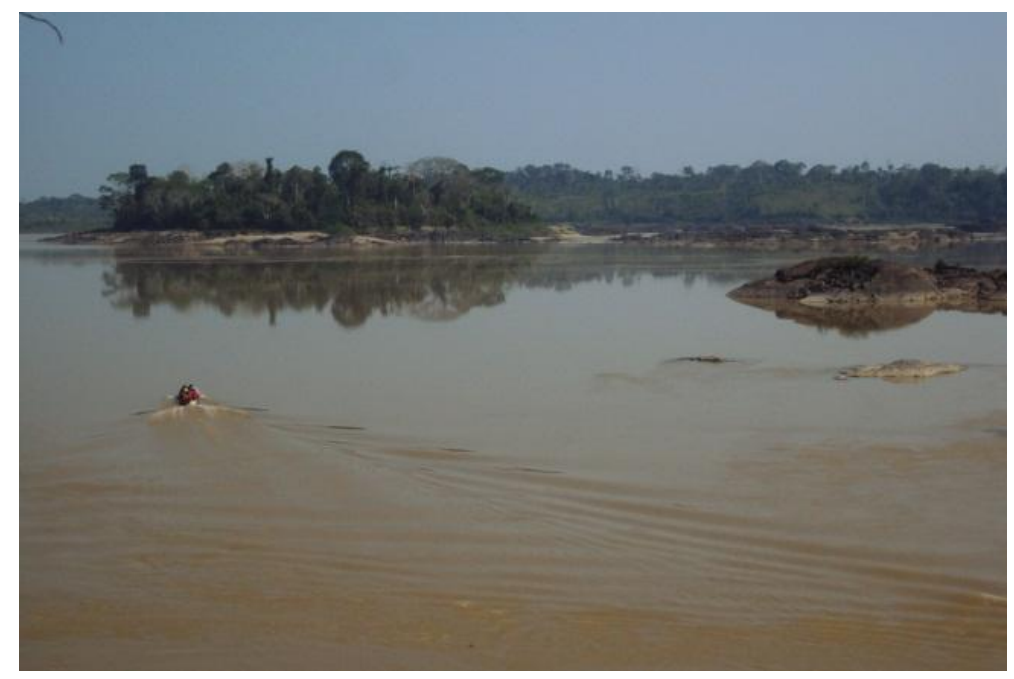

Fotografia 40: equipe indo em direção a Ilha do Japó a partir da margem direita (SCIENTIA, 2010).

\subsubsection{Sítio Ilha do Japó}

A Ilha do Japó apresenta uma porção mais alta que não alaga na época das cheias, enquanto a parte leste sofre inundações. O terreno é formado por suaves ondulações, as quais terminavam nas barrancas arenosas e, posteriormente encontravam a rocha sobre a qual a ilha está embasada (granito da Suíte Intrusiva Teotônio). Uma antiga roça na parte central da ilha demonstra que ela foi habitada apesar de não existirem mais construções, porém na parte sul 
está uma pequena estrutura de um acampamento de pescadores, o qual foi utilizado muito recentemente. A vegetação, conforme relatório de levantamento florístico realizado pela equipe de arqueologia em 2010, ocorre sob a forma de Floresta Secundária com espécies pioneiras e perenes, com uma flora arbórea diversificada composta por uma área de capoeirão e uma antiga roça em uma tapera onde estão presentes os mamoeiros e bananeiras. Entre as de grande porte destacam-se o axixá (Sterculia chicha), sumaúma (Ceiba pentandra), pinhocuiabano, e a figueira. Há espécies de palmeiras como urucuri (Attalea phalerata), tucumã (Astrocaryum aculeatum) e babaçu (Orbignya phalerata) (Scientia, 2011c).

No sítio Ilha do Japó o material ocorria em superfície e subsuperfície na parte mais elevada da ilha (porção oeste), com cotas entre 59 e 92 m, em área aproximada de $230 \mathrm{~m}$ (leste-oeste) x $140 \mathrm{~m}$ (norte-sul), mas também foram encontrados alguns achados isolados em superfície na porção leste e feições de polimento nos pedrais das encostas sul, norte e oeste, indicando que toda a ilha foi ocupada. Os pedrais ficam expostos nas épocas de máxima vazante do rio, com feições de polimento e gravuras rupestres (figura 56).

Ocorreu material arqueológico em superfície, sendo feitas coletas em cinco áreas. As escavações feitas no sítio (26 unidades de $1 \mathrm{~m}^{2}$ e um perfil no barranco) revelaram um possível contexto pré-cerâmico em uma área onde ocorreram majoritariamente materiais líticos e desprovidos de materiais cerâmicos a partir do nível 130-140 cm (unidades E367950 N9001800, E367970 N9001800, E367970 N9001820, E367923 N9001800 e E367924 N9001800). A cerâmica ocorreu junto à terra preta em toda a dispersão do sítio (verificada em vinte e três unidades escavadas). Em campo foram evidenciados pelo menos dois conjuntos tecnológicos cerâmicos: um mais recente, entre a superfície e o nível $60-70 \mathrm{~cm}$ com pasta homogênea e núcleo claro, laranja e amarelo, sugerindo queima completa; fragmentos com dimensões avantajadas e espessos, indicando vasilhame diversificado; fragmentos de base de assador e base em pedestal; decorações com engobo e faixa vermelha; e presença de apêndices de suspensão. E um segundo conjunto, mais antigo, evidenciado a partir do nível 40-50 cm, com pasta homogênea e núcleo escuro, subentendendo queima incompleta; fragmentos com dimensões e espessuras menores que o outro conjunto; fragmentos de vasilhas fechadas com pescoço e flanges labiais e mesiais; decoração incisa, excisa, aplicada e engobo vermelho (Figura 54). Ainda poderia haver mais duas ocupações ceramistas distintas, sendo uma mais recente, inferida a partir de certos fragmentos diagnósticos achados apenas em superfície, como o roletado, e uma mais antiga, em subsuperfície, abaixo do segundo conjunto observado. Além disso, ocorrem duas concentrações de materiais na escavação, uma 
no nível 20-30 cm e outra no nível 60-70 cm (os níveis variam nas unidades) (SCIENTIA, 2011c). Com a análise do material da unidade E367981 N9001840 averiguamos esta hipótese levantada em campo.

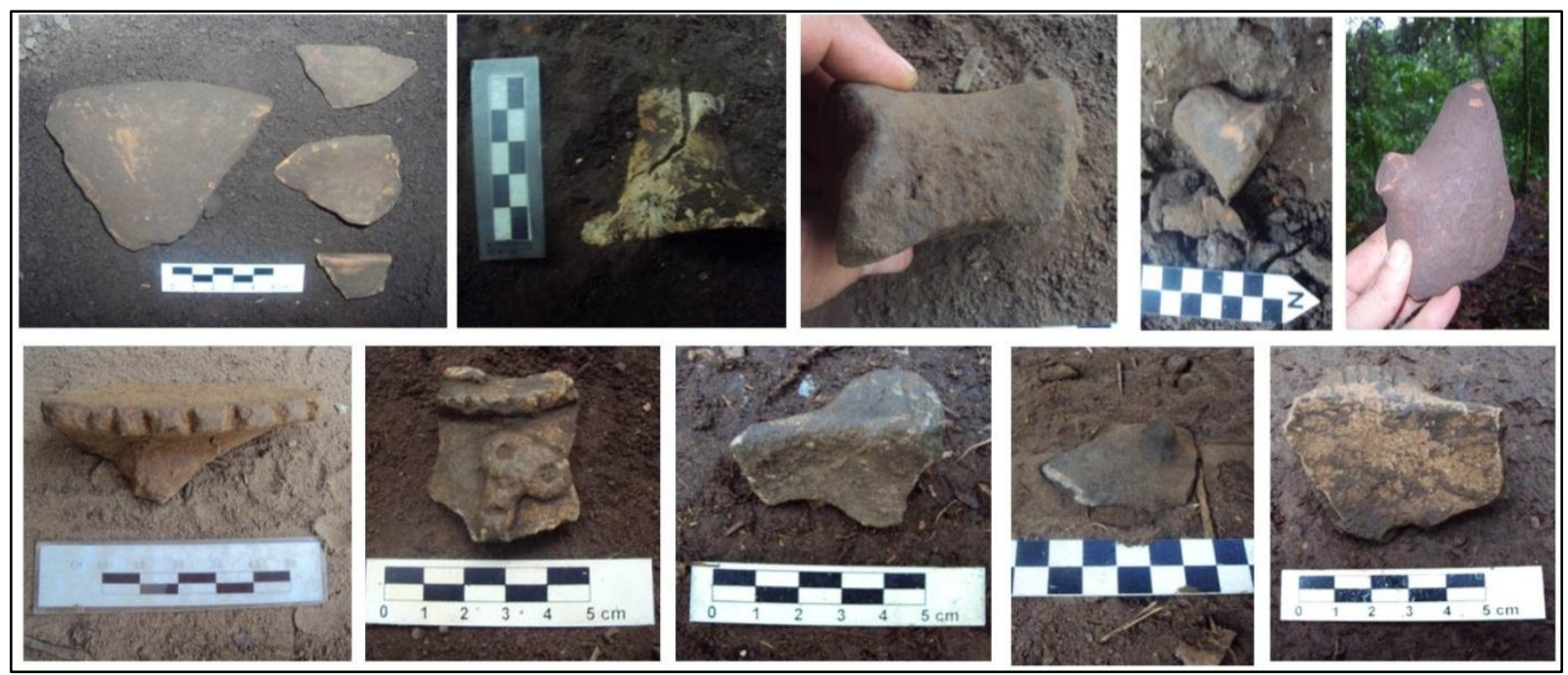

Figura 54: cerâmica da Ilha do Japó- acima fragmentos do conjunto mais recente; abaixo do conjunto mais antigo (fotos: SCIENTIA, 2010).

Como analisamos a cerâmica de apenas uma unidade deste sítio, recorremos aos dados de campo que são bastante numerosos (fichas, fotos, descrições, perfis), para caracterizar alguns contextos e materiais que nos auxiliam a interpretar as ocupações no sítio. Nas unidades contíguas E368030 N9001780 e E368029 N9001780, escavadas na área da roça antiga, foram evidenciadas sete feições na camada D, nos níveis 50-60 a 70-80 cm, com formas arredondadas ou subarredondadas e elípticas, entre 20 e $40 \mathrm{~cm}$ de profundidade, contendo e seu interior sedimento escuro da camada acima com cerâmica, carvão, argila e seixos (Figura 55). A feição F4 apresenta maior diâmetro e seu perfil pode ser visualizado na parede oeste da unidade E368030 N9001780, apresentando base circular; já a feição F7, visualizada no perfil oeste da unidade E368029 N9001780 apresenta forma característica de um possível buraco de estaca. Nestas duas unidades foi verificada a presença dos dois conjuntos tecnológicos citados acima, o mais recente nas camadas A e B (mais superficiais), e o outro nas camadas C e D (a partir de $20 \mathrm{~cm}$ de profundidade). Na camada B foi evidenciada uma estrutura com 186 seixos, próxima ao perfil sul da unidade E368030 N9001780. Destacase ainda um adorno polido fragmentado $(20-30 \mathrm{~cm}$ ), um lítico polido fragmentado (nível 30$40 \mathrm{~cm}$ ), e cerâmicas com decoração incisa e ponteada na camada D. Na transição das camadas B e C ocorrem muitas bolotas de argila, que se tornam mais numerosas a partir do nível 40-50 cm, bem como blocos, seixos e cerâmicas com incisões. 


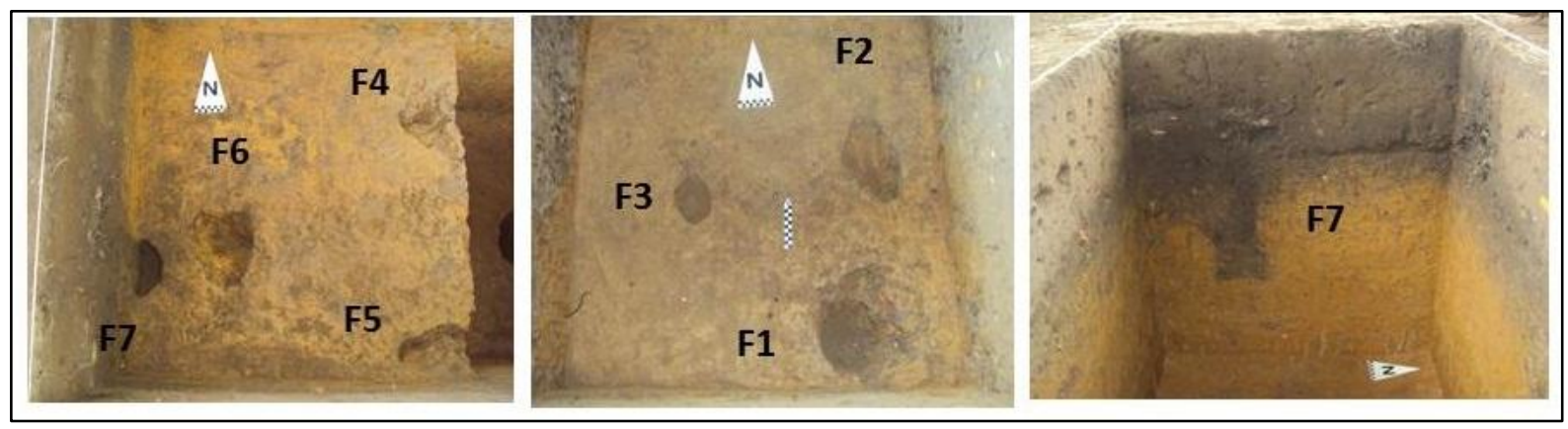

Figura 55: feições evidenciadas nas unidades 368030/9001780 e 368029/9001780 (Fotos: SCIENTIA, 2010).

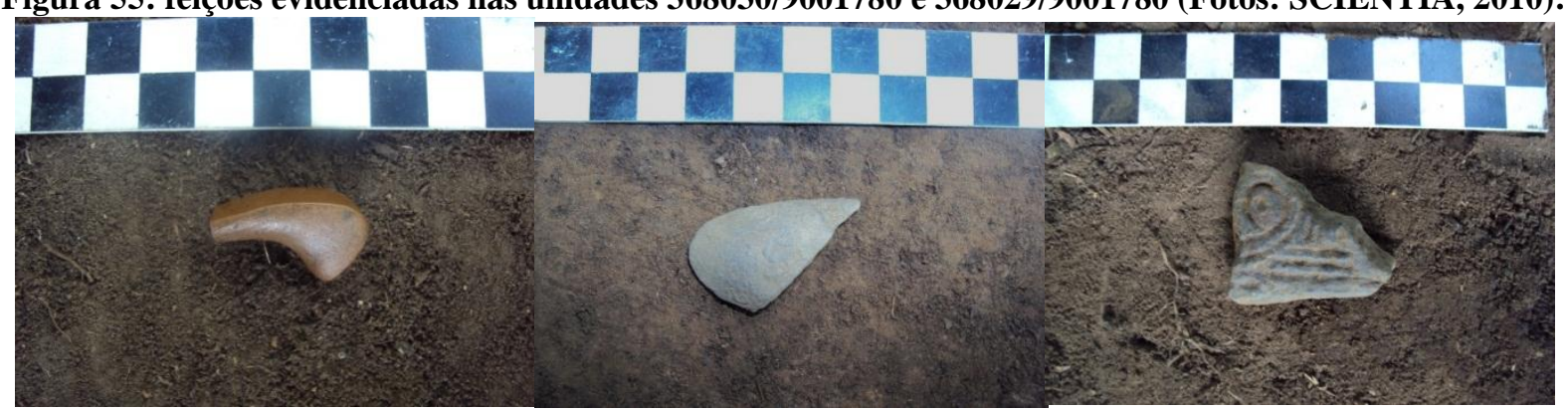

Fotografias 41, 42 e 43: adornos líticos $(20-40 \mathrm{~cm})$; cerâmica com incisões da camada C (SCIENTIA,2010).

Nas unidades contíguas E367980 N9001840, E367980 N9001840, E367981 N9001840, E376982 N9001840 e E367981 N9001839, a cerâmica da ocupação mais recente aparece até o nível 30-40 cm (no nível 40-50 há uma mistura das duas cerâmicas, com exceção da estrutura evidenciada), associada a blocos líticos, polidores, lascas e estilhas em silexito e quartzo, fragmentos de lâminas de machado e um batedor/bigorna. Já a cerâmica da ocupação mais antiga apresenta atributos como decoração incisa (motivos triangulares e oblíquos), apliques, apêndices de suspensão (asas); ocorrem ainda dois fragmentos de fuso (nível 50-60 e 70-80 da unidade 367981/9001839). Observa-se o aumento das bolotas de argila a partir do nível $60-70 \mathrm{~cm}$, relacionadas a esta ocupação.

No nível 30-40 cm ocorreu uma feição na unidade E367981 N9001840, sendo uma mancha arredondada de coloração mais escura, com presença de carvão. No nível seguinte $(40-50 \mathrm{~cm})$ foi identificada uma grande estrutura nas unidades E367980 N9001840 e E367981 N9001840, composta por fragmentos grandes de cerâmica da ocupação mais recente, líticos lascados e polidos e carvão. Os fragmentos estavam sobrepostos, em geral na posição horizontal, e na sua parte central tem continuidade até o nível 50-60 cm (fotografia 45). Ocorrem duas densidades de material (gráfico 2) na unidade E367981 N9001840, associadas a possíveis duas ocupações, cujo material diagnóstico foi analisado. 

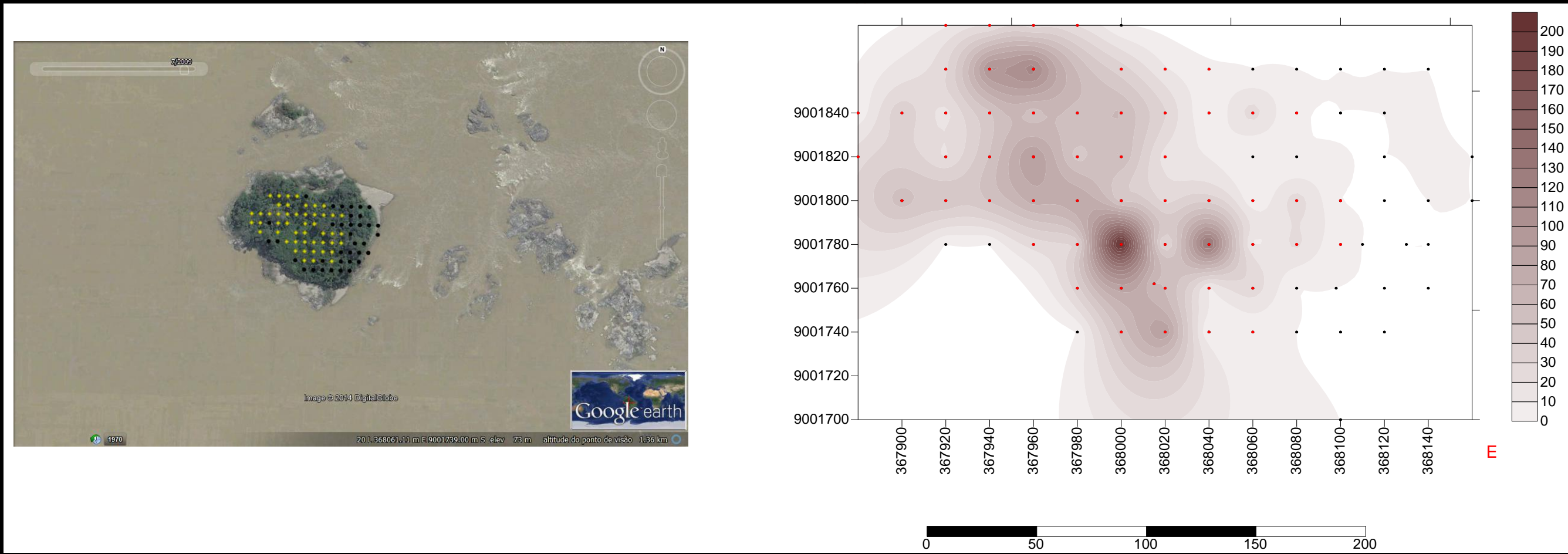

Sítio Arqueológico Ilha Japó

Imagem 1 - Distribuição dos furos testes no sítio Ilha do Japó, imagem Imagem 2 - Frequência de material arqueológico, a partir da delimitação. Google Earth.

\section{LEGENDA}

- Furos testes com ausência de material arqueológico.

Furos testes com presença de material arqueológico.

\section{LEGENDA}

- Furos testes com ausência de material arqueológico.

- Furos testes com presença de material arqueológico

$\square \quad$ Frequência de material arqueológico

Figura 56: croquis do sítio Ilha do Japó (Juliana Rossanto Santi, 2014) 


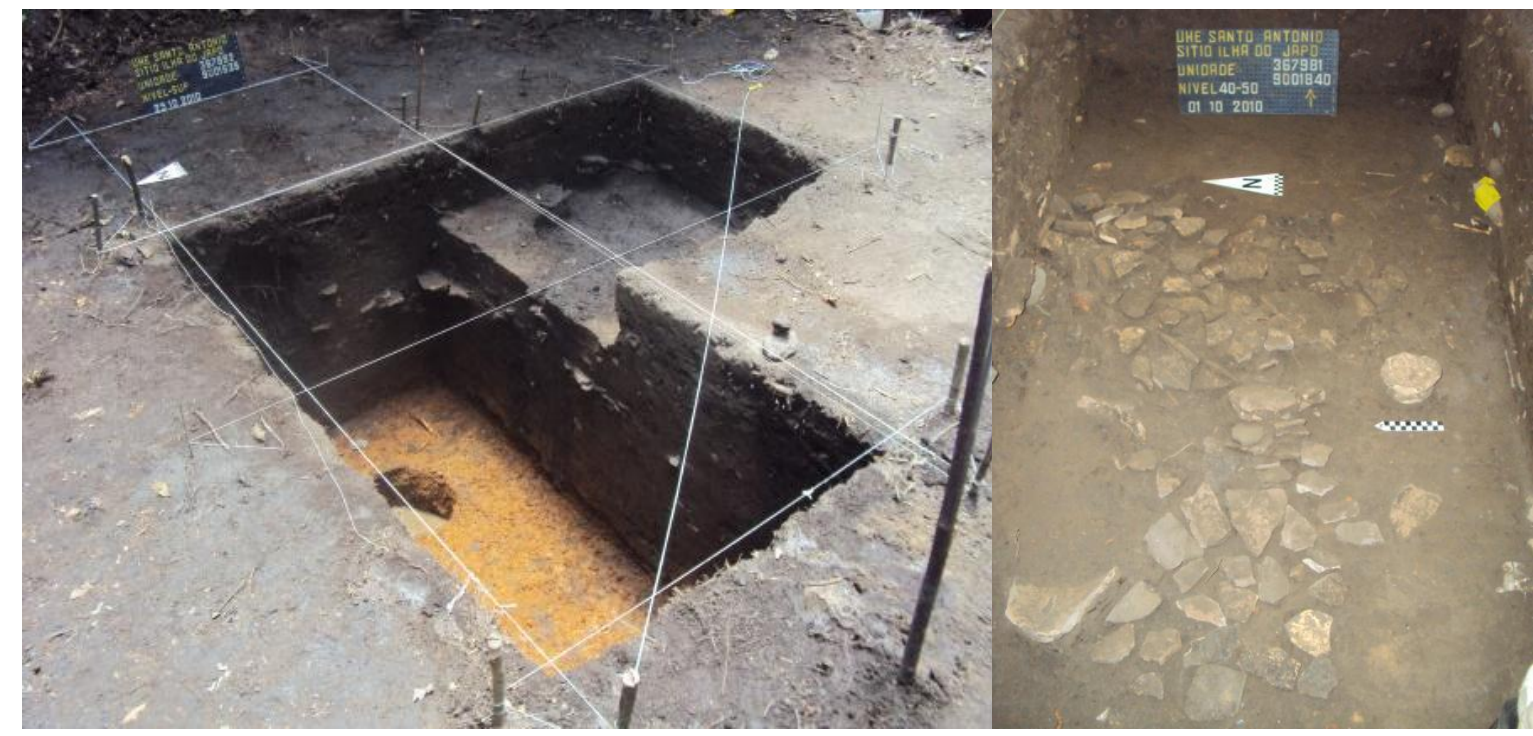

Fotografias 44 e 45: escavação da unidade E367980 N9001840 e expansões e estrutura de fragmentos evidenciada entre 30-40 e50-60 cm (SCIENTIA, 2010).

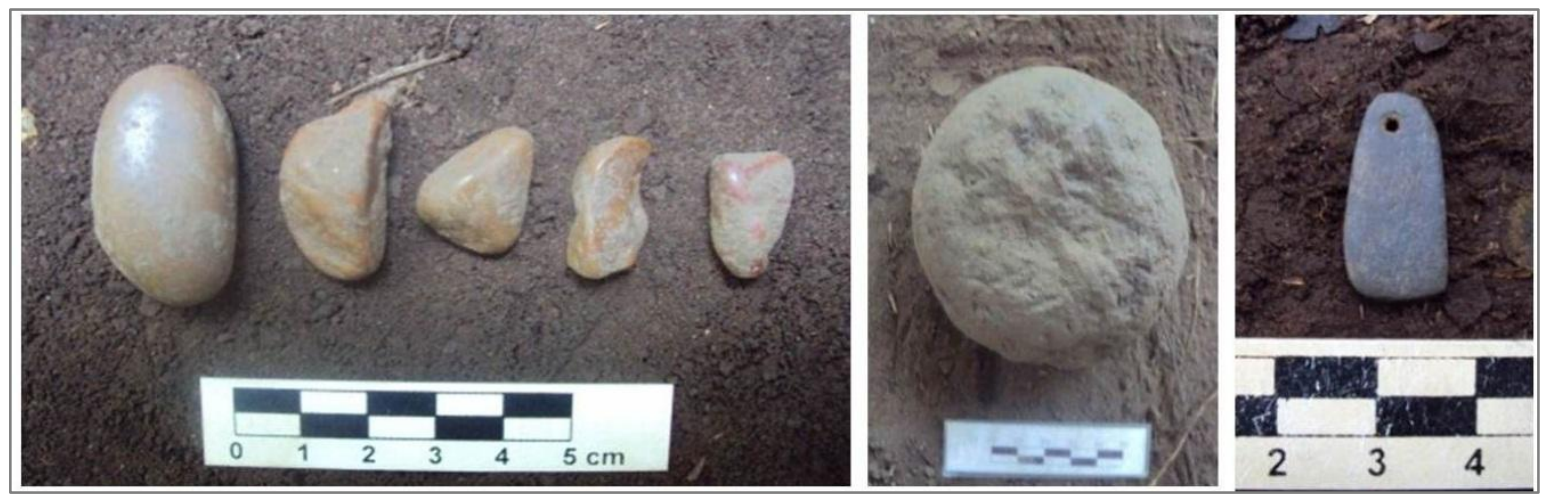

Figura 57: materiais líticos encontrados na unidade E367980 N9001840 (SCIENTIA, 2010).

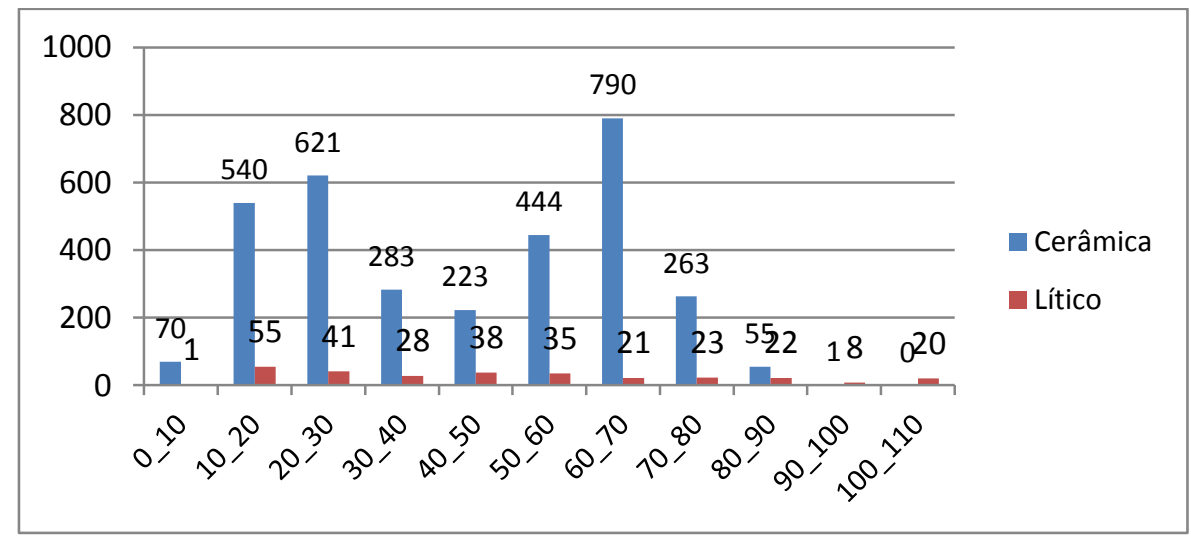

Gráfico 2: distribuição da cerâmica e lítico nos níveis da unidade E367981 N9001840- Ilha do Japó. 
UHE Santo Antônio

Sítio llha do Japó

Croqui do Perfil Sul

Coordenada UTM: 20L 367981-9001839

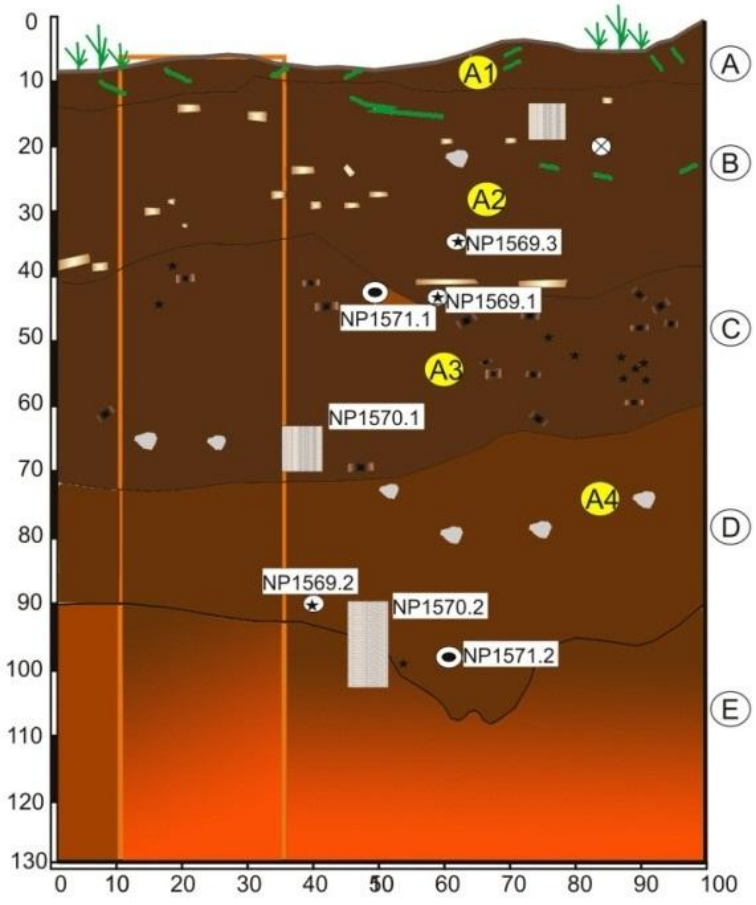

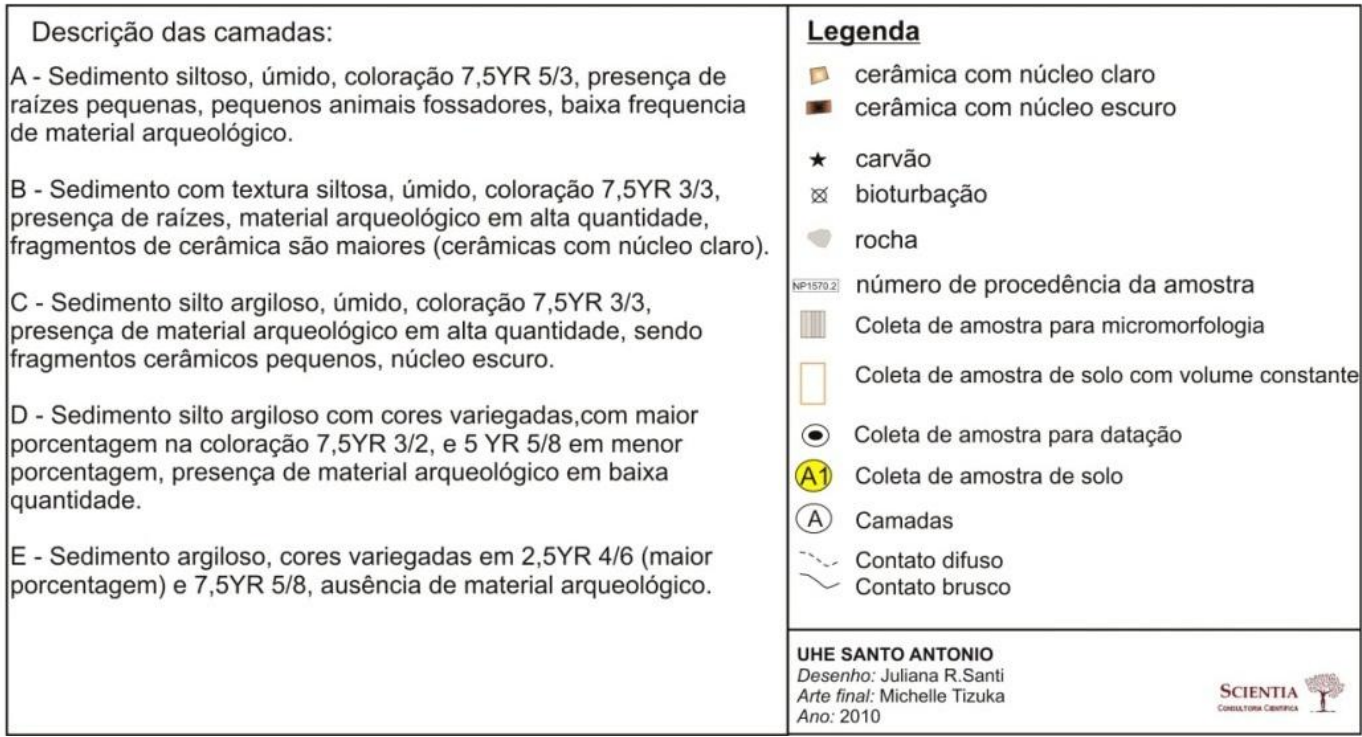

Figura 58: perfil sul da unidade E367981 N9001839 (SCIENTIA, 2010)

Nas unidades contíguas com coordenada de referência E367920 N9001860 também ocorreu uma estrutura de fragmentos cerâmicos, e como foi escavada em área inclinada na borda oeste da ilha, estes encontravam-se inclinados. Além de fragmentos grandes e de um fuso de cerâmica, destacam-se nesta unidade uma lâmina fragmentada com duas partes (nível 20-30 cm), um lítico polido que parece ter sido reaproveitado e um adorno de quartzo 
fragmentado. Em algumas unidades (E367981 N9001839 e E368010 N9001760), ocorre maior quantidade de bolotas de argila na camada mais antiga, bem de carvões, que juntamente com a coloração cinza da cerâmica, confere uma coloração mais escura a camada. Na ultima ocorrem fragmentos da ocupação mais antiga com tratamento roletado na borda.
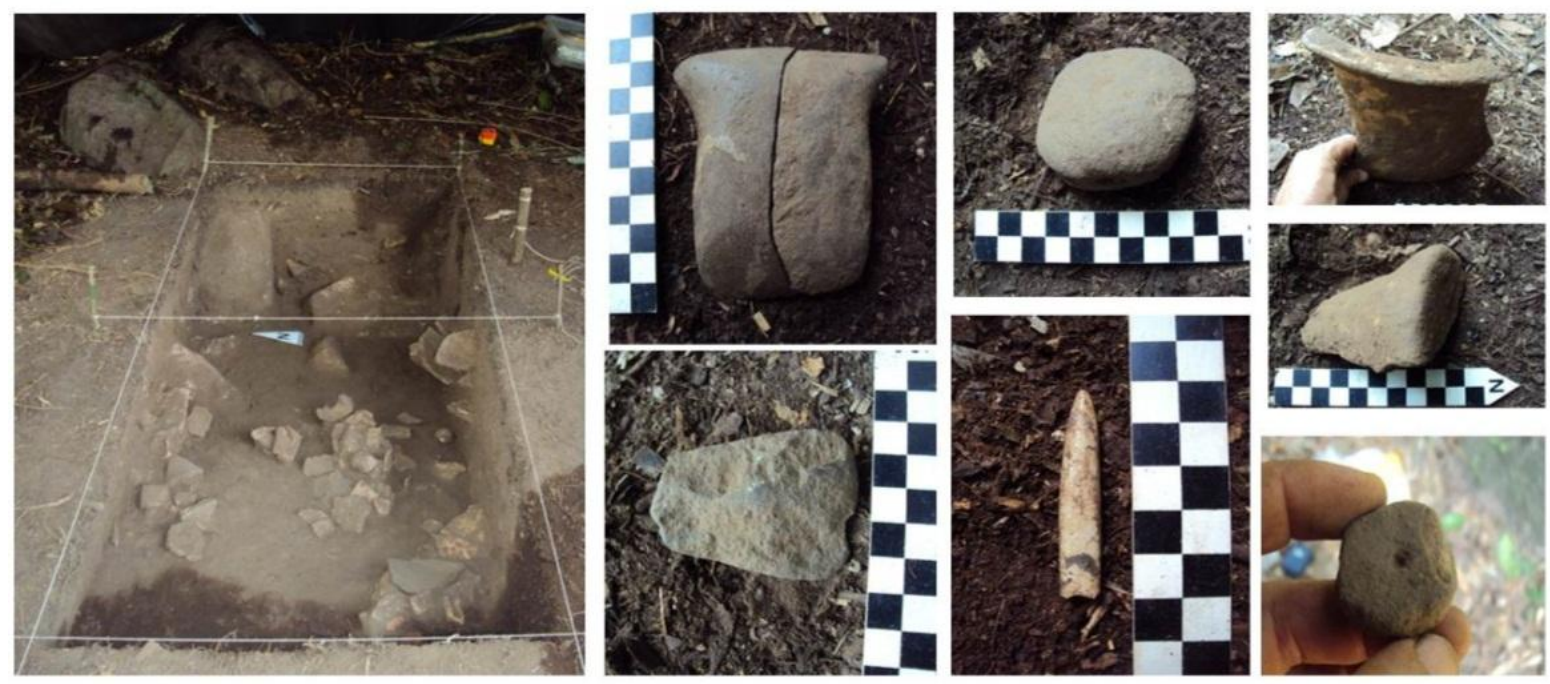

Figura 59: unidades contíguas (E367920 N9001860) e materiais encontrados (Fotos: SCIENTIA, 2010)
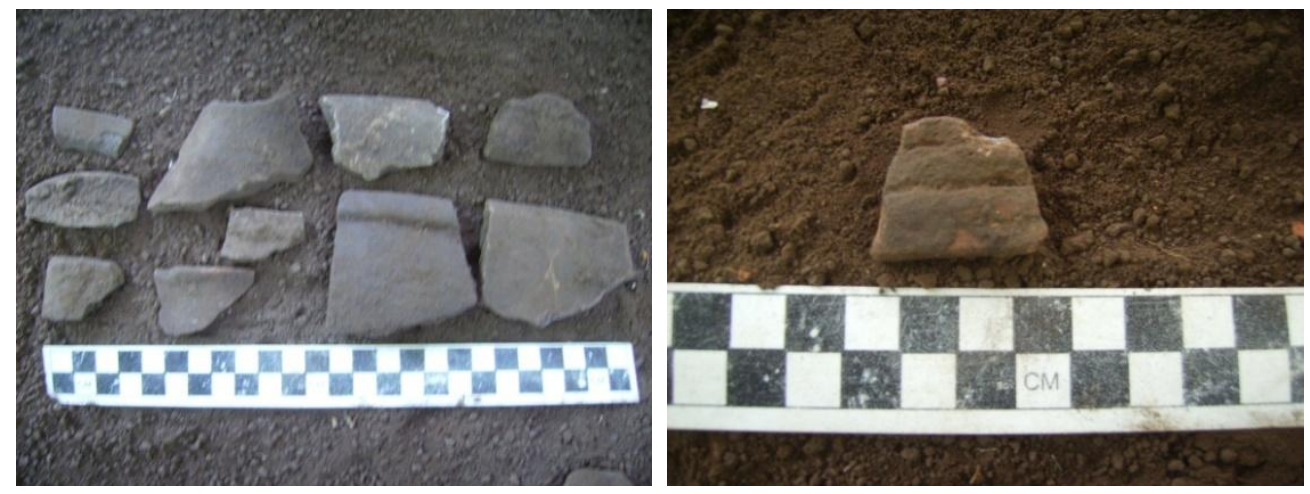

Fotografias 46 e 47: cerâmica com tratamento plástico roletado, camada D da unidade E368010 N9001760 (SCIENTIA, 2010).

Além dos adornos das unidades E368030 N9001780, E367980 N9001840 e E367920 N9001860, foram encontrados outros no sítio, como um evidenciado no nível 10-20 cm da unidade E367970 N9001820, que é confeccionado sobre seixo de silexito e possivelmente é auricular; um possível adorno confeccionado com seixo polido apresentando marca mesial da unidade E368010 N9001780 (essa unidade apresentou apenas material da ocupação mais recente, até 40-50 cm); e um possível adorno na unidade E368040 N9001820.

Outras lâminas fragmentadas e inteiras apareceram em diferentes partes do sítio, além daquelas provenientes da superfície e das unidades E367980 N9001840 e E367920 
N9001860. Na unidade E367990 N9001780 ocorreu um fragmento de lâmina no nível 30-40 cm e duas lâminas inteiras no nível 80-90 cm (estas associadas à cerâmica mais antiga). No nível 90-100 cm da unidade E367970 N9001820 apareceu uma lâmina fragmentada, bem como na camada D da unidade E367970 N9001840, ambas relacionadas ao conjunto cerâmico mais antigo. É provável que os ocupantes da ilha estavam fazendo lâminas nos pedrais do seu entorno, conforme indicam as muitas feições e bacias de polimento, e que estavam utilizando e descartando no sítio. Um estudo mais aprofundado poderá relacionar diferentes tipos de lâminas às diferentes ocupações ceramistas.
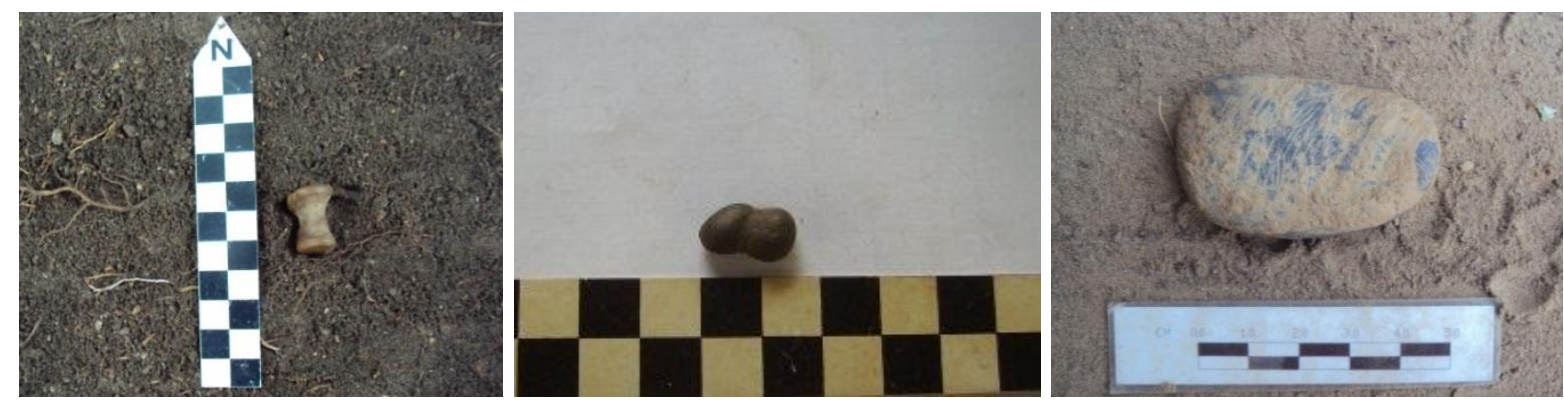

Fotografias 48, 49 e 50: adornos das unidades E367970 N9001820; E368010 N9001780 e E368040 N9001820 (SCIENTIA, 2010).

\subsubsection{Sítio Coração}

O sítio Coração- RO-JP-24 (E370623 N9002138) localiza-se em superfície de aplainamento na margem direita do rio Madeira (104 a $128 \mathrm{~m}$ ), pouco abaixo das corredeiras de Morrinhos, com material arqueológico (principalmente cerâmica) até $80 \mathrm{~cm}$ de profundidade, e ausência de terra preta. Na parte central do sítio ocorre baixa frequência de material cerâmico, enquanto nas extremidades a quantidade de vestígios foi significativa (SCIENTIA, 2011a). Em área adjacente a uma estrada, junto a uma cascalheira, foram localizadas vasilhas cerâmicas durante a retirada de cascalho, cujo contexto foi impactado pela máquina. Foi realizada uma coleta de superfície e aberta uma unidade de escavação para a retirada de parte de duas vasilhas que ainda estavam in situ. Verificou-se que estas foram enterradas no depósito laterítico, e não foram identificados vestígios ósseos no seu interior (SCIENTIA, 2011c). Na margem direita está implantado o sítio Macaúba, em planície de inundação (E371875 N8003875) nas cotas entre 73 e 83 m, com cerâmica bastante erodida e lítico em superfície e até $40 \mathrm{~cm}$ de profundidade. Neste destaca-se o contexto evidenciado junto aos pedrais de granito, onde foram encontradas lâminas de machado, possivelmente confeccionadas no local. 


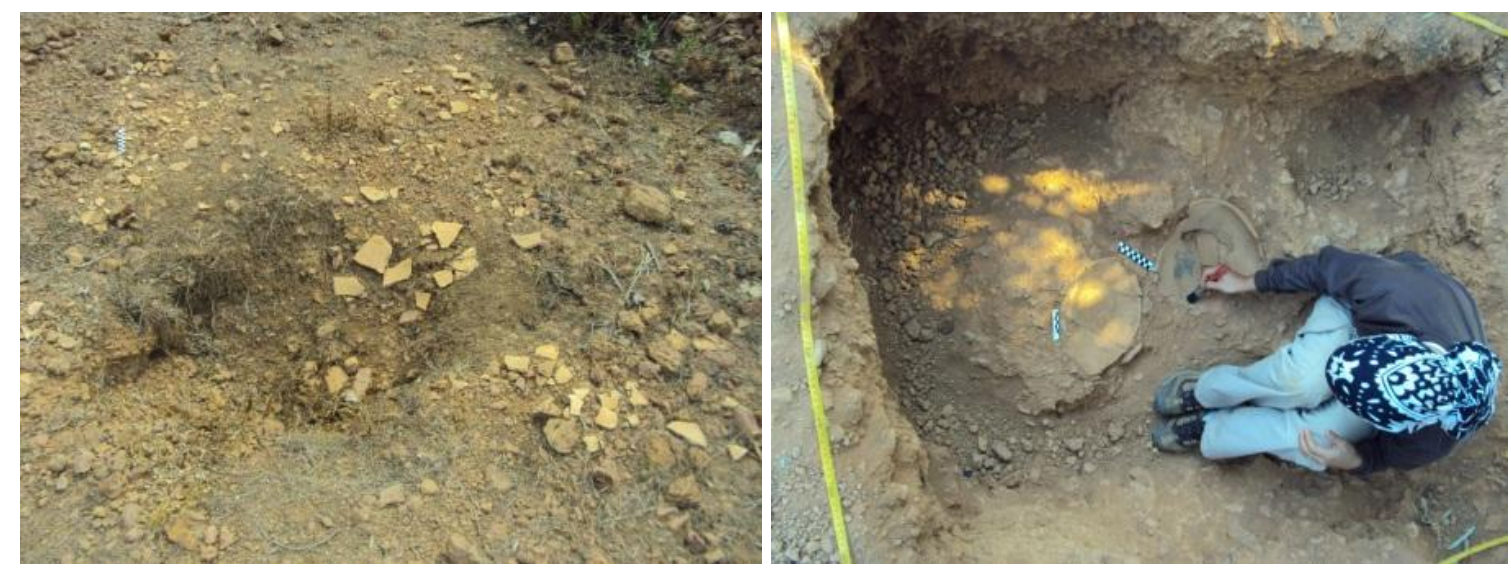

Fotografias 51 e 52: fragmentos na superfície e escavação das duas bases in situ (SCIENTIA, 2010).

\subsubsection{Outros sítios nas proximidades da cachoeira de Morrinhos}

Os sítios localizados no entorno da cachoeira de Morrinhos estão muito próximos e são visualizados uns em relação aos outros. No sítio Ilha do Japó II, ocorreu cerâmica em pequena quantidade e ausência de terra preta, assim como nos sítios Igarapé Agua Azul e Goiano Branco. Já no sítio Morrinhos (E368100 N9002800), implantado em terraço (cotas entre 90 e 110 m) na margem esquerda do rio, em frente à cachoeira de Morrinhos e à Ilha do Japó, foi evidenciada terra preta com material cerâmico e lítico. O sítio Paraíso- RO-JP-24 (E369200 N9000692), localizado na margem direita em grandes altitudes (78 a $139 \mathrm{~m}$ ) e visibilidade privilegiada, não apresentou terra preta, porém o material arqueológico que ocorre em superfície e até $80 \mathrm{~cm}$ de profundidade se estende por uma área extensa. Entre o material evidenciado (cerâmica, lítico lascado e polido e feições de polimento portáteis), destaca-se uma estatueta antropomorfa cerâmica encontrada em superfície, junto a um buraco feito por tatus. Os fragmentos remontaram duas partes, uma da cabeça, com a representação da boca, nariz e olhos, além de um orifício e outra parte que poderia ser a parte oposta (base). Trata-se de um objeto com espessura fina, e com a representação em apenas uma das faces (fotografia 53). Um dos proprietários da área, Sr. Braz, doou à equipe de arqueologia um objeto zoomorfo (fotografia 54), que relatou ter encontrado durante atividades de corte de barranco, nas proximidades de sua residência (E369314 N9000085). Além desta peça identificada por ele como "pescoço de pato", teria encontrado "pedras de raio". Este local foi verificado pela equipe e não foram encontrado outros vestígios. A peça, cuja pasta apresenta caraipé, apresenta uma abertura na boca, representação dos olhos e um orifício na cabeça. $\mathrm{O}$ pescoço está fragmentado. Poderia fazer parte de uma vasilha cerâmica, não sendo possível afirmar se trata-se de um vestígio pré-colonial ou colonial (cerâmica local/regional). 

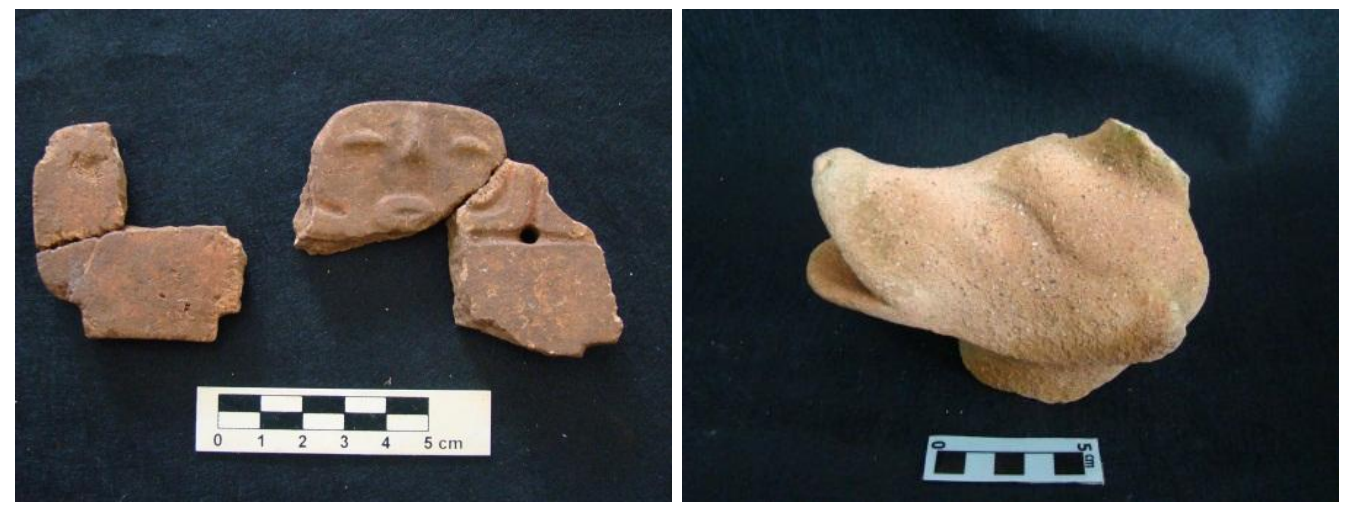

Fotografias 53 e 54: estatueta antropomorfa e objeto zoomorfo - sítio Paraíso (SCIENTIA, 2010).

Analisamos uma amostra pequena do sítio Ilha do Japó e as vasilhas do sítio Coração. Subindo o rio passaremos por ilhas onde não ocorrem sítios arqueológicos, porém ao chegar na confluência com o rio Jaciparaná, um dos maiores afluentes da margem direita neste trecho do rio, encontramos a Ilha Dionísio, distante $31 \mathrm{~km}$ da Ilha do Japó (figura 60). Esta ilha apresenta áreas inundáveis na época das cheias onde predomina uma vegetação típica de igapó e partes que não são atingidas pelas águas, onde predomina vegetação secundária com árvores de grande porte e duas áreas de urucuris. Na margem direita, sobre uma superfície de aplainamento, está implantado o Sítio 75 onde atualmente está a sede de uma fazenda e logo a montante está o sítio Bom Futuro.

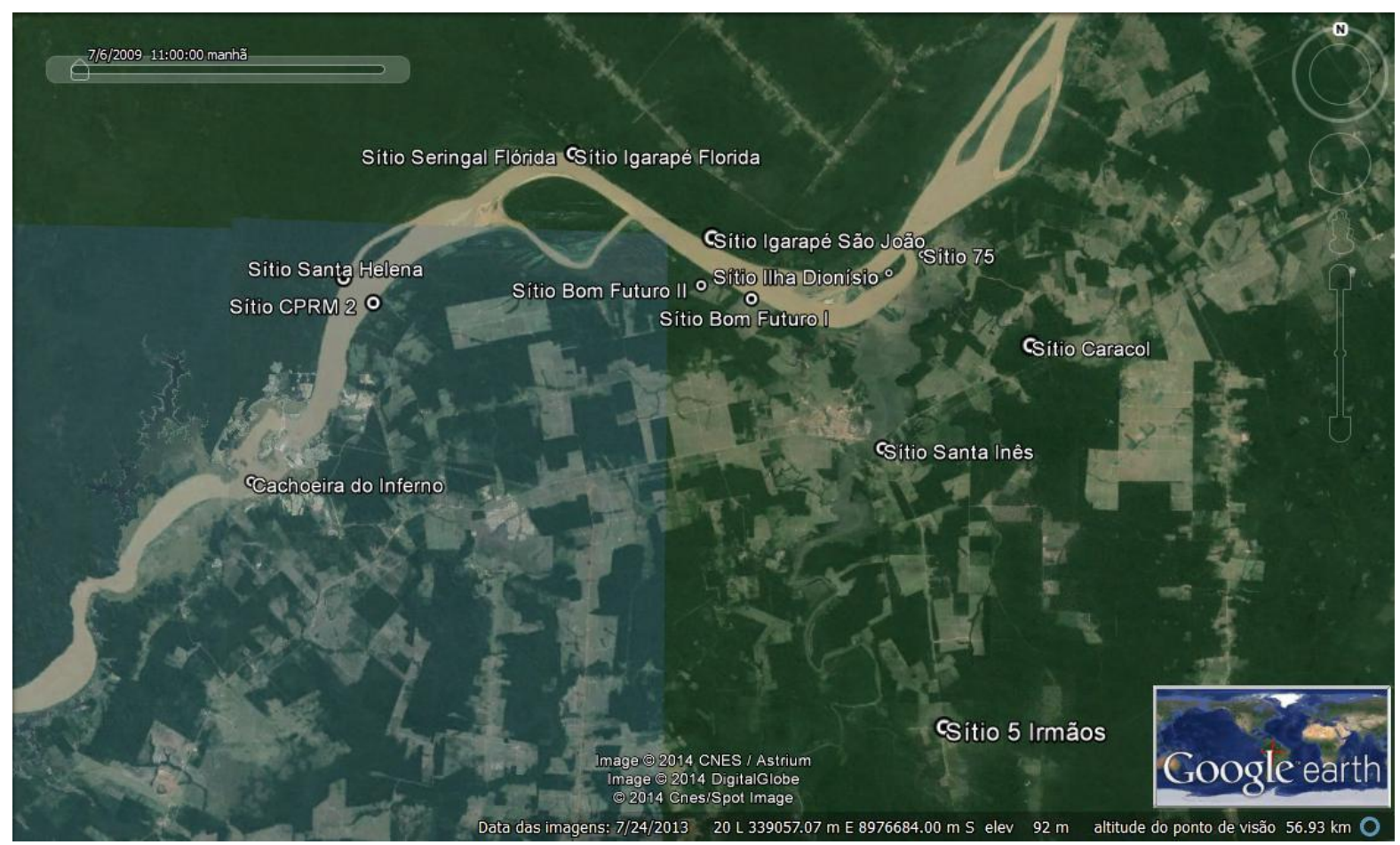

Figura 60: sítios junto à foz do Jaciparaná e à montante. 


\subsubsection{Sítio Ilha Dionísio}

Na parte central da Ilha Dionísio foi localizado um sítio arqueológico em duas áreas, separadas por uma parte rebaixada alagável na época das cheias, denominadas "Setor Norte" e "Setor Sul". Como nas demais ilhas, existem estruturas de casas justamente na área do sítio (área não alagável da ilha) em ambos os setores, sendo comum nos arredores das casas a presença de bananeiras, macaxeira e mamoeiros, e nas margens da ilha são plantados macaxeira e feijão na época de máxima vazante do rio, quando ficavam expostos os sedimentos aluviais junto aos pedrais do entorno da ilha. Áreas alagadas se formavam nesta época no entorno da ilha, atraindo animais para caça. Ao sul do sítio foram visualizadas gravuras rupestres nos pedrais.

O "Setor Sul" apresenta forma semicircular, delimitada a oeste por um declive para uma área alagada, a sul por um barranco erodido pela ação do rio, a leste parcialmente por áreas alagadas e a norte pela área rebaixada alagável sazonalmente que separa este do "Setor Norte". No setor Sul ocorre uma longa faixa semicircular de sedimento escuro com vestígios cerâmicos e líticos em grande quantidade. No centro do semicírculo ocorreram poucos vestígios cerâmicos e líticos em sedimento de coloração clara, e junto ao barranco foi identificada uma área com vasilhas e estruturas enterradas. Este setor apresenta uma vegetação fechada de urucuris em quase toda sua extensão, com transição para vegetação secundária na medida em que se aproxima do barranco, onde esta predomina. A presença de urucuris não coincide com a área de presença de terra preta. No "Setor Norte" os vestígios aparecem junto à terra preta em área delimitada pela declividade do terreno para as áreas alagáveis a sul e oeste e pelo barranco do rio a norte. Neste setor também foram evidenciadas vasilhas e estruturas cerâmicas e líticas enterradas. A vegetação é constituída por mata secundária.
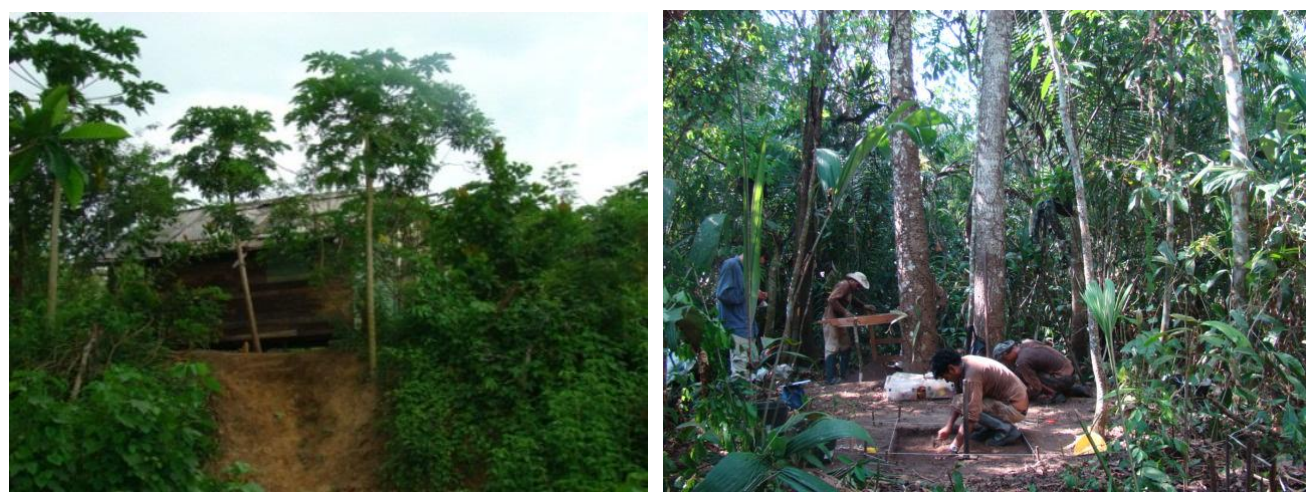

Fotografias 55 e 56: moradia sobre o barranco do setor Sul; e escavação em área de mata secundária, com urucurís ao fundo - Ilha Dionísio (SCIENTIA, 2010) 


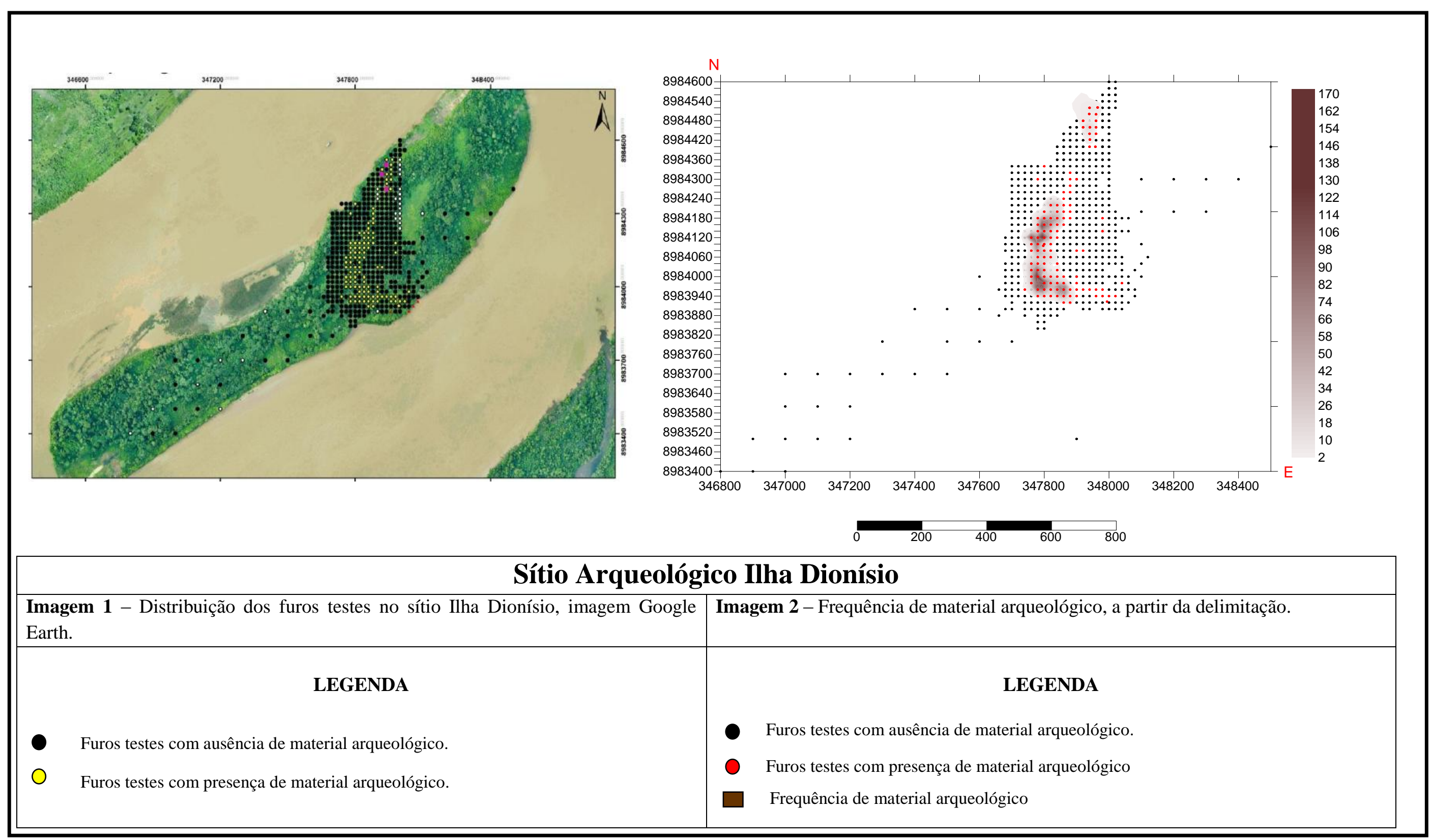

Figura 61: Croquis do sítio Ilha Dionísio (Michelle Tizuka, 2013 e Juliana Rossato Santi, 2014) 
As escavações no Setor Sul evidenciaram duas camadas arqueológicas. A mais profunda é caracterizada pela alta frequência de fragmentos de vasilhas cerâmicas com queima predominante oxidante, fragmentos de trempe, grande quantidade de bolotas de argila, seixos de rio lascados ou inteiros (silexito ou quartzo), lascas de quartzo e silexito, placas de laterita e fragmentos de granito. Essa camada possui espessura variável nas diversas partes do sítio, sendo mais espessa nas unidades contíguas E347800 N8984160, E347800 N8984161 e E347799 N8984161; e E347800 N8984120 e E347800 N984121. Foi ainda identificada uma ocupação mais antiga, separada desta por uma camada estéril, caracterizada por baixa densidade de cerâmica com queima predominantemente redutora, presença de franges, ausência de trempes e poucas bolotas de argila, e presença de poucos seixos e lascas de quartzo e silexito.

A escavação das unidades contíguas E347800 N8984160, E347800 N8984161 e E347799 N8984161 (Fotografia 57) evidenciou cinco camadas de sedimento, sem uma camada húmica superficial. A camada A (da superfície até $60 \mathrm{~cm}$ ) é caracterizada por um sedimento de coloração escura, textura areno-siltosa e compactação média com presença de fragmentos cerâmicos, blocos de granito, plaquetas de óxido de ferro, seixos inteiros e lascados, fragmentos de quartzo e bolotas de argila em grande quantidade. No nível $40-50 \mathrm{~cm}$ das unidades 347800/8984160 e 347799/8984161 foi evidenciada uma estrutura com fragmentos cerâmicos dispostos horizontalmente e um possível adorno em rocha com marcas de polimento (Fotografia 58). A camada B (entre 60-110 cm) possui sedimento mais claro, bruno amarelado e textura areno-siltosa com menor quantidade de material arqueológico (em campo observou-se mudanças na espessura dos fragmentos, na queima, no antiplástico e na forma de tratamento da superfície, em relação aos fragmentos da camada A). A camada C (110-250) possui sedimento mesclado (bruno amarelado e branco), textura areno-siltoso e compacto, com material até $200 \mathrm{~cm}$, baixa frequência de vestígios arqueológicos, com um aumento na presença de rochas como granito e óxido de ferro. As camadas D e E se apresentaram arqueologicamente estéreis, a primeira com sedimento de alta compactação, com coloração mesclada entre bruno amarelado avermelhado e textura areno-argilosa e a ultima com de compactação alta, coloração amarronzada e argilo-siltosa. 

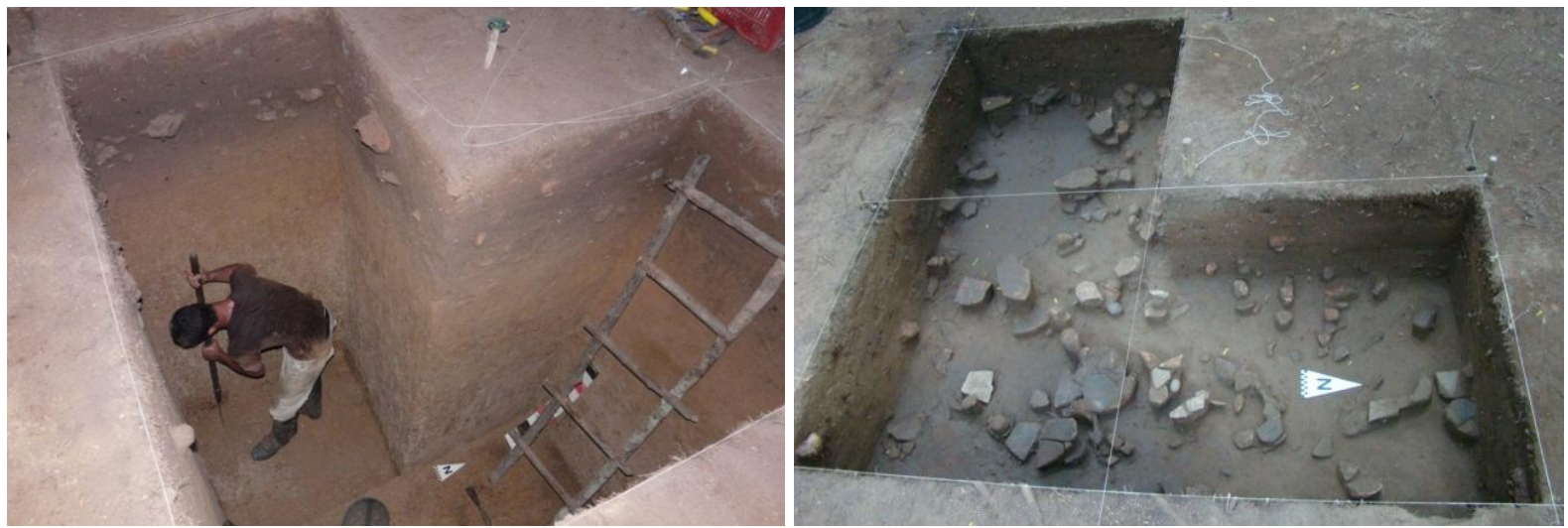

Fotografia 57 e 58: unidades 347800/8984160, 347800/8984161 e 347799/8984161 e estrutura no nível 40-50 cm (SCIENTIA, 2010).

Em área próxima foi escavada a unidade E347800 N8984120, posteriormente expandida para norte (E347800 N8984121). Nestas também ocorreram duas camadas arqueológicas: a primeira está presente da superfície até $80 \mathrm{~cm}$ (sedimento bruno acinzentado escuro - 10YR4/2), com grande quantidade de fragmentos cerâmicos de tamanho grande, que se encontram estruturados no nível 0-10 e 10-20 da E347800 N8984121, bem como nos níveis 50-60 e 60-70 da unidade E347800 N8984120. Apareceram líticos lascados, muitas bolotas de argila, carvão e alguns fragmentos de trempe, além de um possível adorno confeccionado sobre seixo. Após $20 \mathrm{~cm}$ de sedimento estéril, apareceu a segunda camada de ocupação, entre 100 e 150 cm, com cerâmica, lítico lascado, carvão e poucas bolotas de argila.Na unidade E347760 N8984040, na borda oeste do setor sul, ocorrem duas concentrações de densidade de material cerâmico, e apesar de não existirem níveis estéreis pode-se dizer que ocorrem as duas ocupações, evidenciadas nas demais unidades. Nesta destaca-se dois fragmentos de uma lâmina polida que remonta.

$\mathrm{Na}$ área de mata secundária, no setor Sul, foram escavadas as unidades E347805 N8983979, e E347798 N8983975, E347804 N8983955, E347820 N8983960 e E347859 N8983960. Nesta área ocorreu material histórico nos níveis mais superficiais (metal, loucas, vidro), possivelmente das ocupações na ilha pelos ribeirinhos. Todas as unidades apresentaram duas camadas arqueológicas: a primeira (camada A) com coloração mais escura (bruno escuro 10 YR 3/3 ou bruno avermelhado escuro 2.5 YR 2/4) desde a superfície até 50 ou $80 \mathrm{~cm}$, com cerâmica, líticos, placas de laterita, bolotas de argila, seixos e carvões; a segunda (camada C) com 40 ou $50 \mathrm{~cm}$ de espessura e cerâmica em menor quantidade que ocorre depois de três a seis níveis estéreis (camada de transição B) (Figura 62). 
Sítio Ilha Dionísio - Unidade 347805-8983979 - Perfil Norte

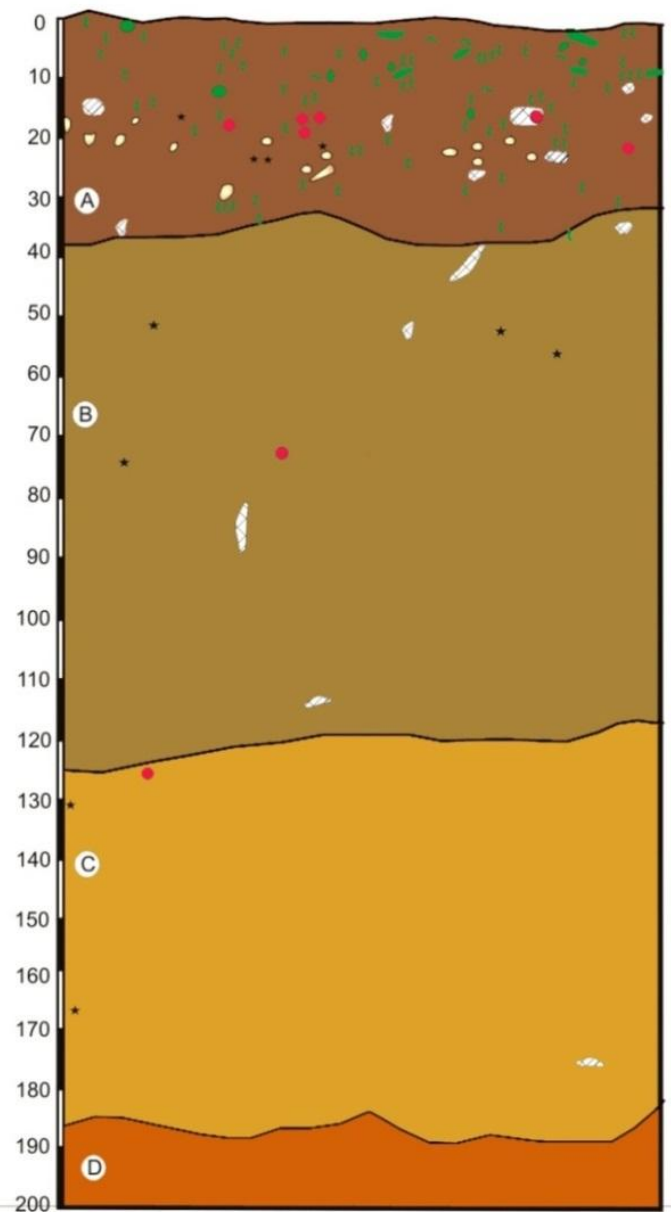

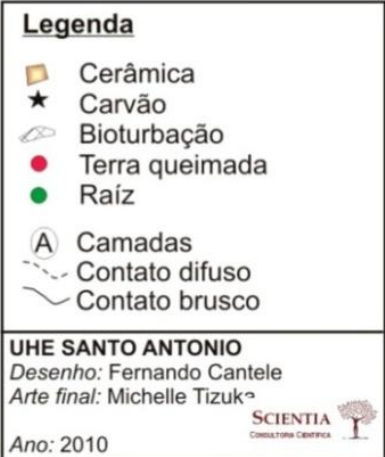

Figura 62: perfil norte da unidade E347805 N8983979 (SCIENTIA, 2010).

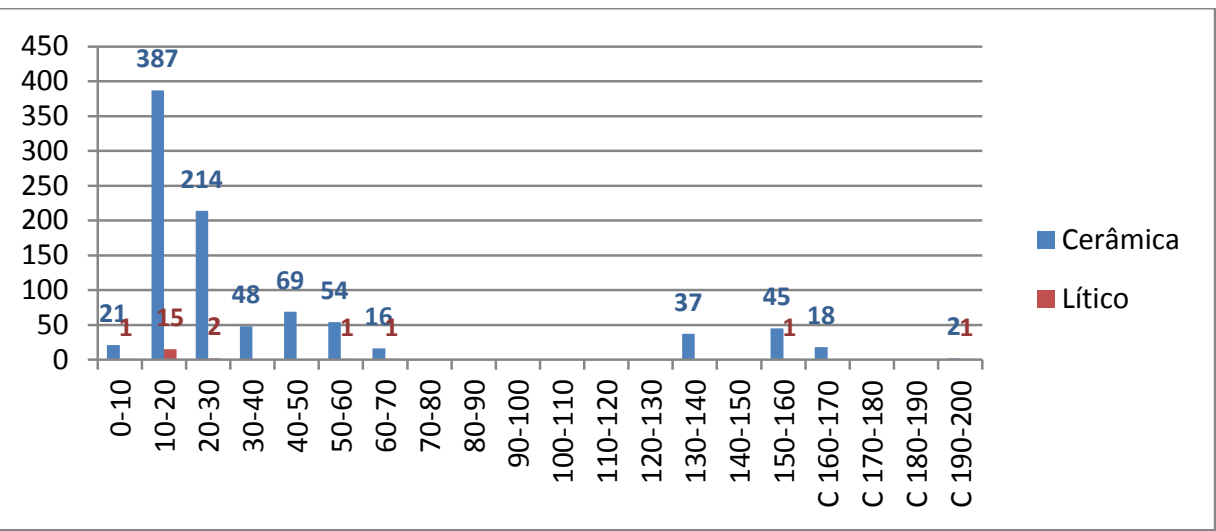

Gráfico 3: distribuição da cerâmica e lítico nos níveis da unidade E347820 N8983960- Ilha Dionísio

$\mathrm{Na}$ área contígua ao barranco que delimita o sítio a sul, após a visualização da borda de uma vasilha enterrada, foram escavadas oito unidades de $1 \mathrm{~m}^{2}$ (níveis artificiais de $10 \mathrm{~cm}$ ) e nove unidades de $2 \mathrm{~m}^{2}$ denominadas “A, B, C, D, E, F, G, H e I" (níveis de $30 \mathrm{~cm}$ ) e feita a limpeza de uma grande extensão do barranco. Foram evidenciadas ao todo três estruturas com 
vasilhas inteiras, duas estruturas com fragmentos de vasilhas, uma estrutura de seixo, e em superfície no barranco fragmentos que remontaram parcialmente duas vasilhas (Figura 63). Esta é uma área periférica do sítio, onde foram evidenciadas as duas camadas arqueológicas, porém com menor quantidade de material e sedimento mais claro.

A estratigrafia desta área foi verificada nas unidades E347972 N8983936 e E347973 N8983936 que foram escavadas até o nível 120-130 cm, com a identificação das duas camadas arqueológicas, uma primeira com maior quantidade de material no nível $30-40 \mathrm{~cm}$, com fragmentos cerâmicos, lítico lascado, bolotas de argila e blocos, carvões (Camada B) e a segunda na camada D (confirmando o que foi visto em um perfil feito no barranco em área adjacente). As demais unidades foram escavadas até o nível $70-80 \mathrm{~cm}$, profundidade suficiente para evidenciar as vasilhas e estruturas.
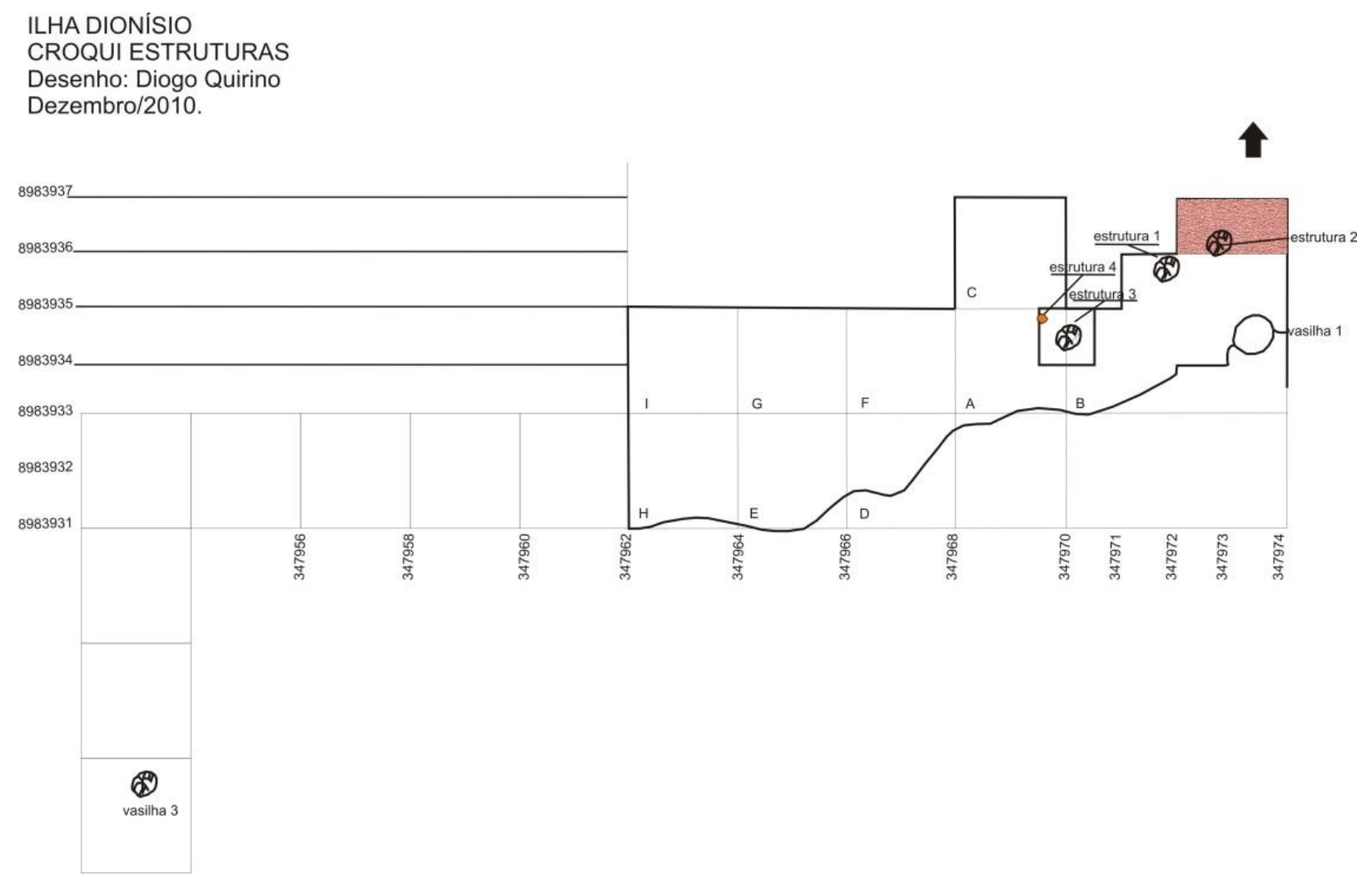

Figura 63: croqui da área das vasilhas, no setor sul (Diogo Quirino, 2010).

A vasilha 1 foi escavada na unidade E347973 N8983934 (fotografia 59). No seu interior foi evidenciado sedimento com fragmentos cerâmicos e líticos (micro lascas, seixos alisados) e carvões, e algumas bolotas de argila nos primeiros $20 \mathrm{~cm}$, quando foi evidenciada uma segunda vasilha (Vasilha 2), composta por borda, gargalo e bojo, emborcada dentro da vasilha 1, e com fragmentos estruturados no seu interior, que serviam como tampa; estes fragmentos pertencem a 5 vasilhas, conforme analise em laboratório. A vasilha 2 estava 
levemente inclinada, evidenciada entre 11 e $25 \mathrm{~cm}$ abaixo da borda da vasilha 1 . Entre os fragmentos da tampa ocorria uma pequena lente de sedimento com carvão. Um fragmento de osso foi coletado entre 30-40 cm, entre as paredes da vasilha 1 e 2 (Figura 64).

Na unidade E347971 N8983935, escavada até 69 cm, com material cerâmico e lítico em todos os níveis, foi evidenciada a estrutura 1 (figura 65) composta por uma vasilha cerâmica (vasilha 4) tapada com fragmentos grandes de duas vasilhas diferentes (Fotografia 60). Na base do nível 30-40 observou-se duas manchas (feições) mais escuras no canto noroeste, onde ocorreu maior quantidade de carvões, enquanto em volta da estrutura o sedimento apresenta-se mais claro, o que poderia indicar o negativo de retirada de sedimento para o seu enterramento. Foram removidos os fragmentos que serviam de tampa e no interior da vasilha ocorreu sedimento com fragmentos cerâmicos e líticos. Na base ocorre um furo de $10 \mathrm{~cm}$ de diâmetro, feito após a queima. Nenhum fragmento de osso foi evidenciado.

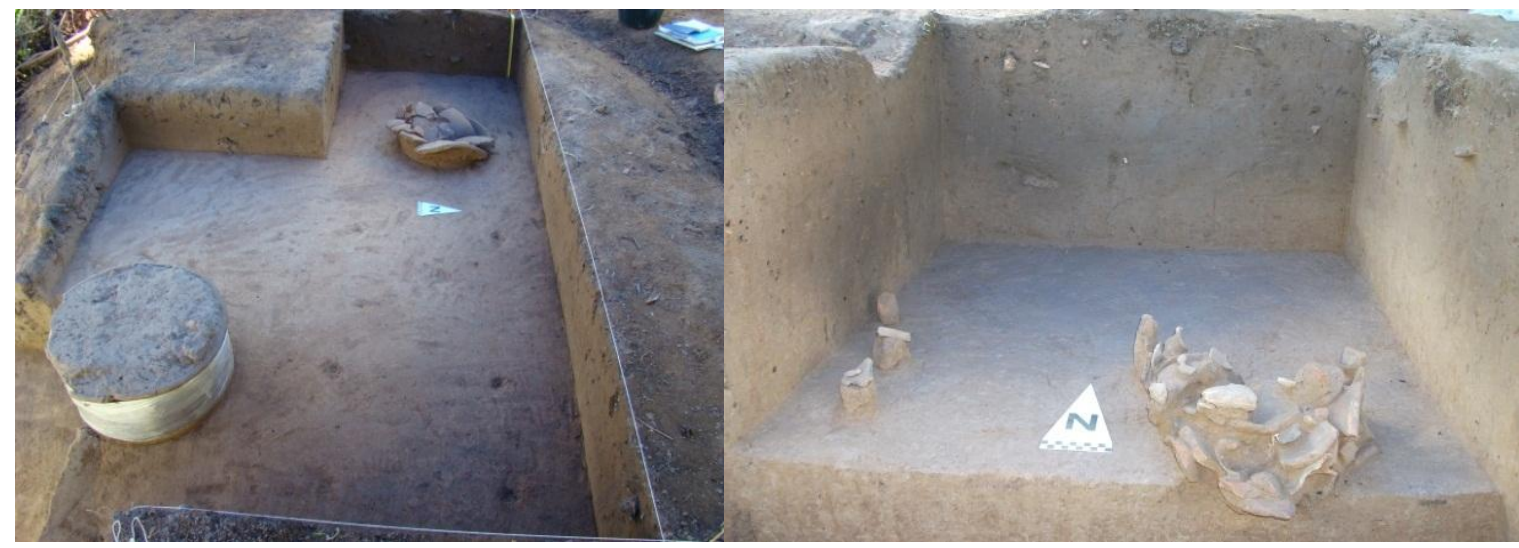

Fotografias 59 e 60: escavação da vasilha 1 e estruturas 1 e 2 (SCIENTIA, 2010).

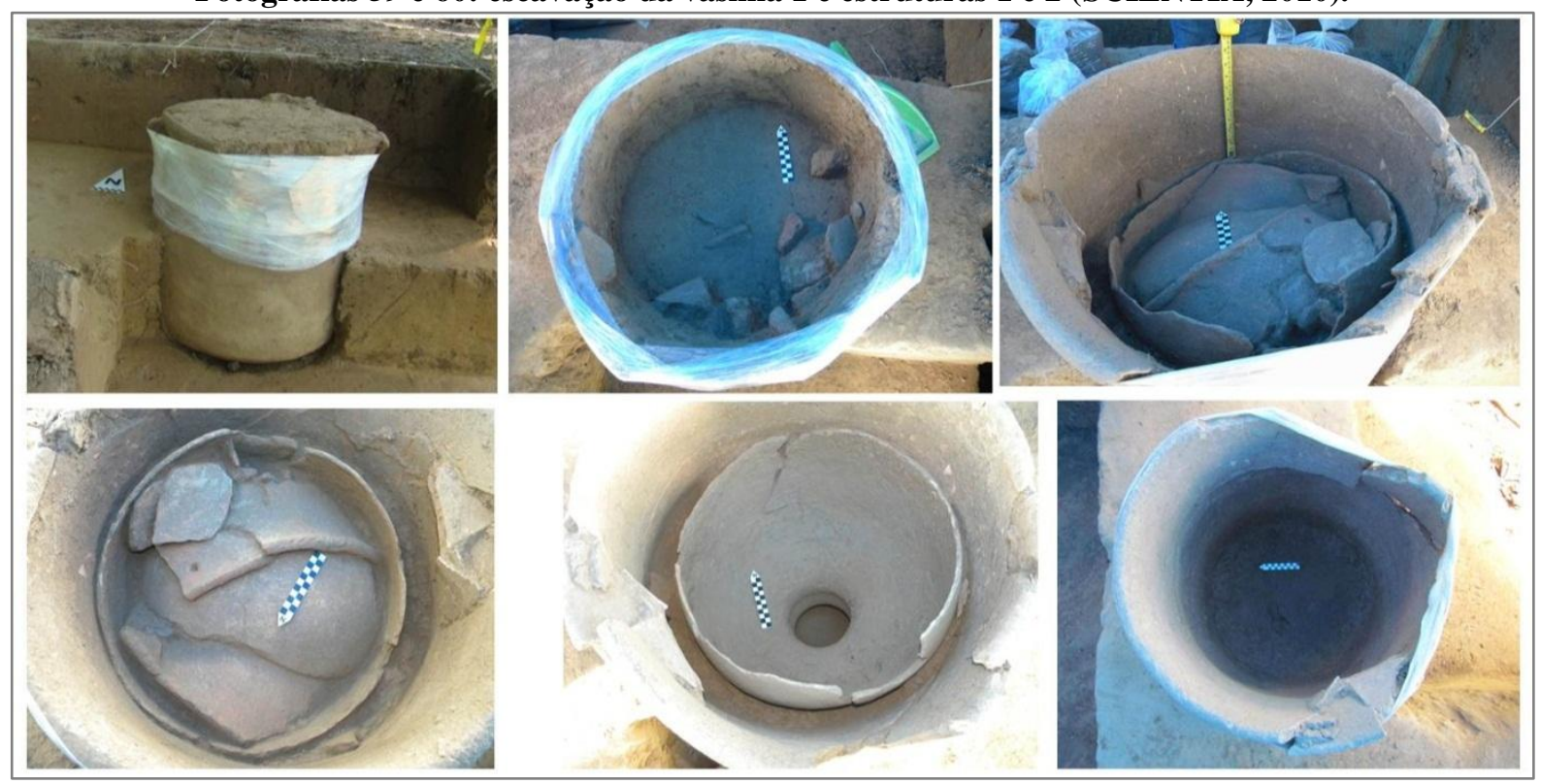

Figura 64: escavação do interior da vasilha 1 e 2 (SCIENTIA, 2010) 


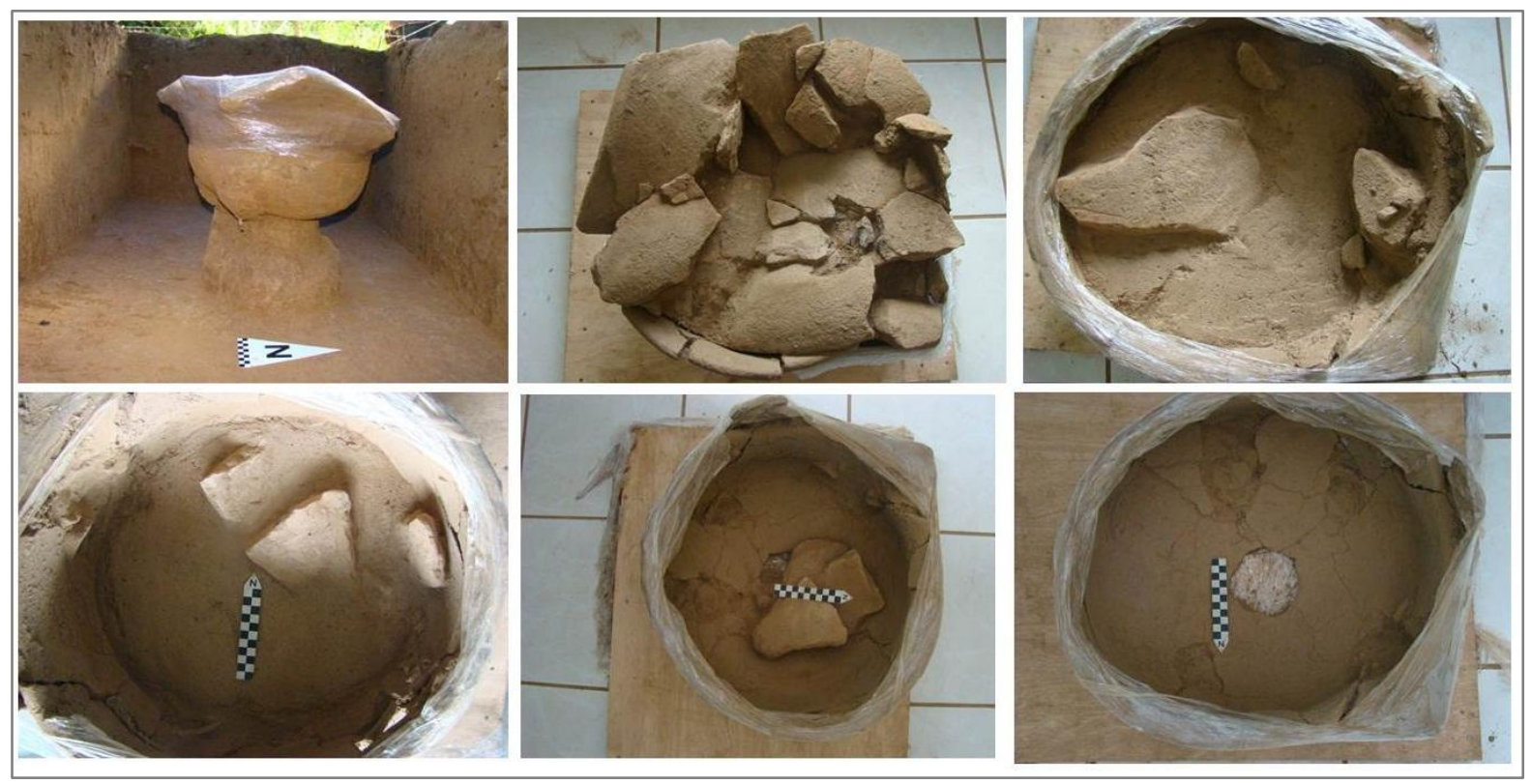

Figura 65: estrutura 1 (Unidade 347971/8983935) (SCIENTIA, 2010, 2011).

A estrutura 2 foi escavada nos níveis 40-50 e 50-60 cm da unidade E347972 N8983936 (fotografia 60). A estrutura é composta por fragmentos cerâmicos, carvões, bolotas de argila, líticos e um possível pingente (conta). No lado oeste da unidade foi evidenciada a Feição F2 no nível 40-50 cm, sendo uma mancha acinzentada de forma irregular, porém sem material arqueológico. Na estrutura ocorrem fragmentos de diversas vasilhas de espessuras e queimas diferenciados. A analise permitiu a remontagem parcial de três delas (vasilhas 5, 6 e 7) e reconstituição da forma, porém ocorrem outras bordas, bases e paredes.

Com a limpeza de uma vasta extensão do barranco forame encontrados fragmentos que remontam duas vasilhas (8 e 9) na coordenada E348020 N8983924 em superfície. Já na coordenada E347952 N8983925 foram visualizados fragmentos de uma vasilha (vasilha 3), sendo realizada uma escavação de $1 \mathrm{~m}^{2}$ até $60 \mathrm{~cm}$ de profundidade. A vasilha 3 (fotografia 61) estava com a borda quebrada, e alguns fragmentos de outra vasilha serviam com tampa. Ao lado da tampa estava um fragmento de borda, e abaixo da tampa ocorriam muitas bioturbações (cupim, raízes). No seu interior, junto com o sedimento foram encontrados carvões e farelos de ossos, além e fragmentos cerâmicos que possivelmente eram da tampa. Nos limites das unidades A e B ( $2 \mathrm{~m}^{2}$ cada uma) foram escavadas duas estruturas próximas entre si, uma caracterizada por fragmentos cerâmicos sobrepostos (estrutura 3) e a outra por uma concentração de seixos de silexito (Estrutura 4). 


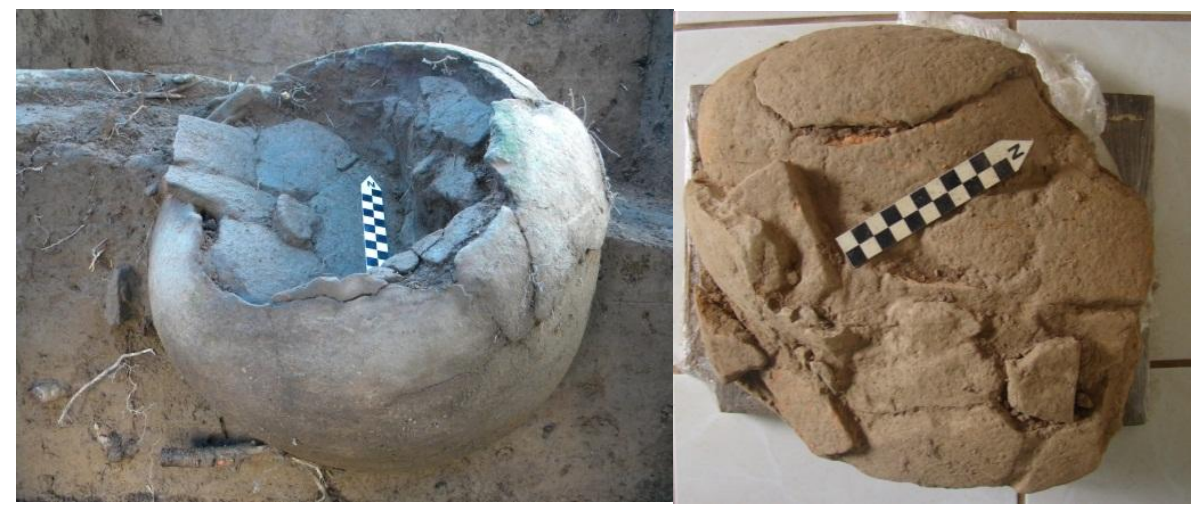

Fotografias 61 e 62: vasilha 3 (E347952 N8983925) e estrutura 3 (unidades A e B) (SCIENTIA, 2010).

A estrutura 3 (Fotografia 62) possuía duas camadas de fragmentos, e abaixo alguns farelos de ossos/dentes com carvão; os fragmentos pertencem a duas ou três vasilhas. A estrutura IV apresentou 77 seixos (a maioria de silexito; três de quartzo) e carvões dispersos. Os seixos foram selecionados por tamanho e forma antes de serem agrupados: são subangulosos a sub-arredondados.Outros materiais foram encontrados nas escavações das unidades A, B, C, D, E, F, G, H e I. Chama a atenção uma peça lítica com concavidades em ambas as faces mais planas e nas extremidades (fotografia 63), que pode ter a função de quebra coquinho, porém também pode apresentar uma função simbólica, tendo em vista a área do sítio onde foi encontrada. Outra peça lítica apresenta um sulco contínuo nas extremidades e concavidades nas partes mais planas (fotografia 64), semelhantes ao da peça citada anteriormente. Foi também encontrado um adorno com perfuração (fotografia 65), de matéria prima não identificada (possivelmente vegetal). No barranco adjacente foram ainda coletados fragmentos que remontaram duas vasilhas (vasilha 8 e vasilha 9).

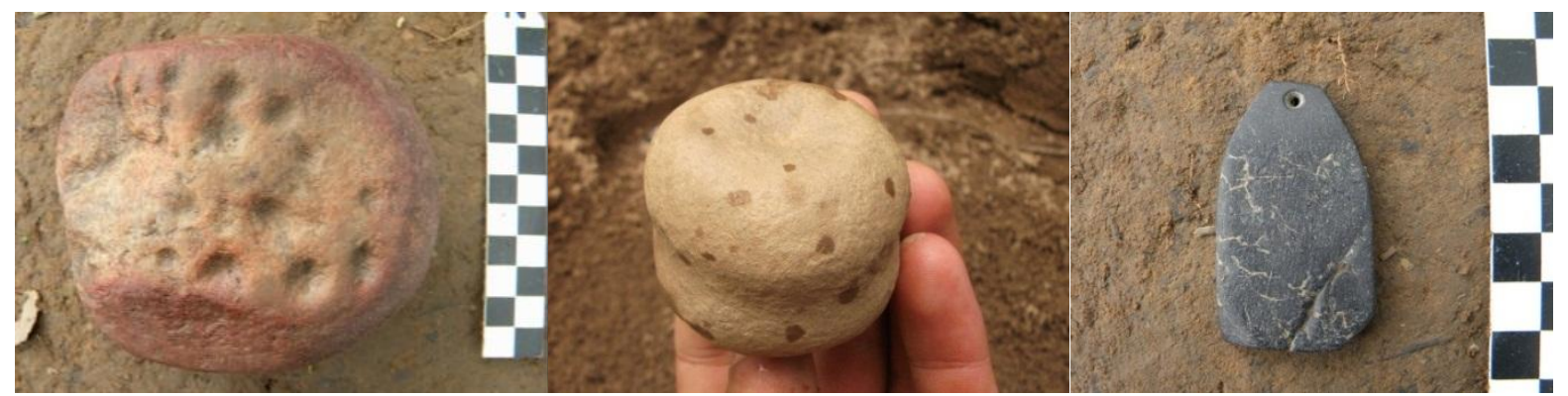

Fotografia 63, 64 e 65: lítico com cavidades em todas as faces; lítico com sulco; e adorno (SCIENTIA, 2010)

No Setor Norte, foram escavadas inicialmente as unidades E347940 N8984460, E347940 N8984400, E347940 N8984500 e E347920 N8984460, sendo em todas elas interrompida a escavação devido ao acúmulo de água das chuvas, não sendo possível verificar se ocorriam duas camadas arqueológicas como no Setor Sul. A unidade E347940 N8984460 
foi escavada até $160 \mathrm{~cm}$ e apresentou material cerâmico e lítico até $130 \mathrm{~cm}$, evidenciando-se uma camada arqueológica semelhante a mais recente do setor sul (cerâmica semelhante, presença de uma trempe). Analisamos os dados de quantidade de material por nível escavado e percebemos que na unidade E347940 N8984500, escavada até o nível 180-190 cm, ocorreram materiais nos níveis 140-150 e 170-180 que podem ser de uma segunda camada arqueológica.

Foi feita a escavação de uma área ampla (fotografia 66), onde haviam sido identificadas bordas de vasilhas cerâmicas, com 16 unidades de $2 \mathrm{~m}^{2}$ contíguas (níveis artificiais de $30 \mathrm{~cm}$ ) escavadas até $100 \mathrm{~cm}$ de profundidade (com exceção de duas que foram aprofundadas), resultando na evidenciação de doze vasilhas in situ, cinco estruturas com fragmentos cerâmicos, três estruturas de seixos e lâminas de machado em contexto. Estas estavam junto a uma camada mais escura (C), com presença de fragmentos cerâmicos, bolotas de argila, muitas lascas, seixos de rio, placas de laterita, rochas sem marcas de uso, algumas lâminas e líticos polidos e carvões. Nessa área foram identificadas quatro camadas $(\mathrm{A}, \mathrm{B}, \mathrm{C}$, D): a camada A, superficial, é húmica com cerca de $4 \mathrm{~cm}$ e baixa frequência de material arqueológico; a camada B possui em torno de $30 \mathrm{~cm}$ de espessura, com sedimento de coloração bruno amarelado, textura areno-siltoso, e média frequência de material arqueológico; a camada $\mathrm{C}$ possui espessura de $20 \mathrm{~cm}$, com sedimento mais escuro (bruno amarelado escuro, textura areno-siltosa e alta frequência de material arqueológico, onde ocorre a maioria das vasilhas depositadas; a camada D possui sedimento de coloração bruno amarelado, e apresenta algumas vasilhas enterradas. Ocorrem, nesta camada, lentes (finas camadas) de sedimento com coloração avermelhada. Apesar do local ser uma planície aluvial com regime deposicional, ocorreu um processo de erosão recente provocando uma inclinação leste-oeste, que acabou causando a fragmentação da parte superfor de algumas vasilhas e o arraste de seus fragmentos.

As vasilhas 10 e 11 (fotografias 67 e 68) foram e evidenciadas na unidade 1 (N347917 E894461), estando com a sua parte superior bastante fragmentada. A vasilha 12 foi escavada em contexto semelhante, na unidade 2 (E347917 N8984463), com uma estrutura de fragmentos próxima a sua borda, coletada conjuntamente. Na unidade 7 (E347919 N8984459) foi escavada a vasilha 15 (fotografia 69), com forma semelhante a 12, e na unidade 10 (E347919 N8984457) as vasilhas 22 e 23. Todas apresentaram cerâmica, lítico e carvão no interior, estando com a parte superior bastante fragmentada e a base preservada. 


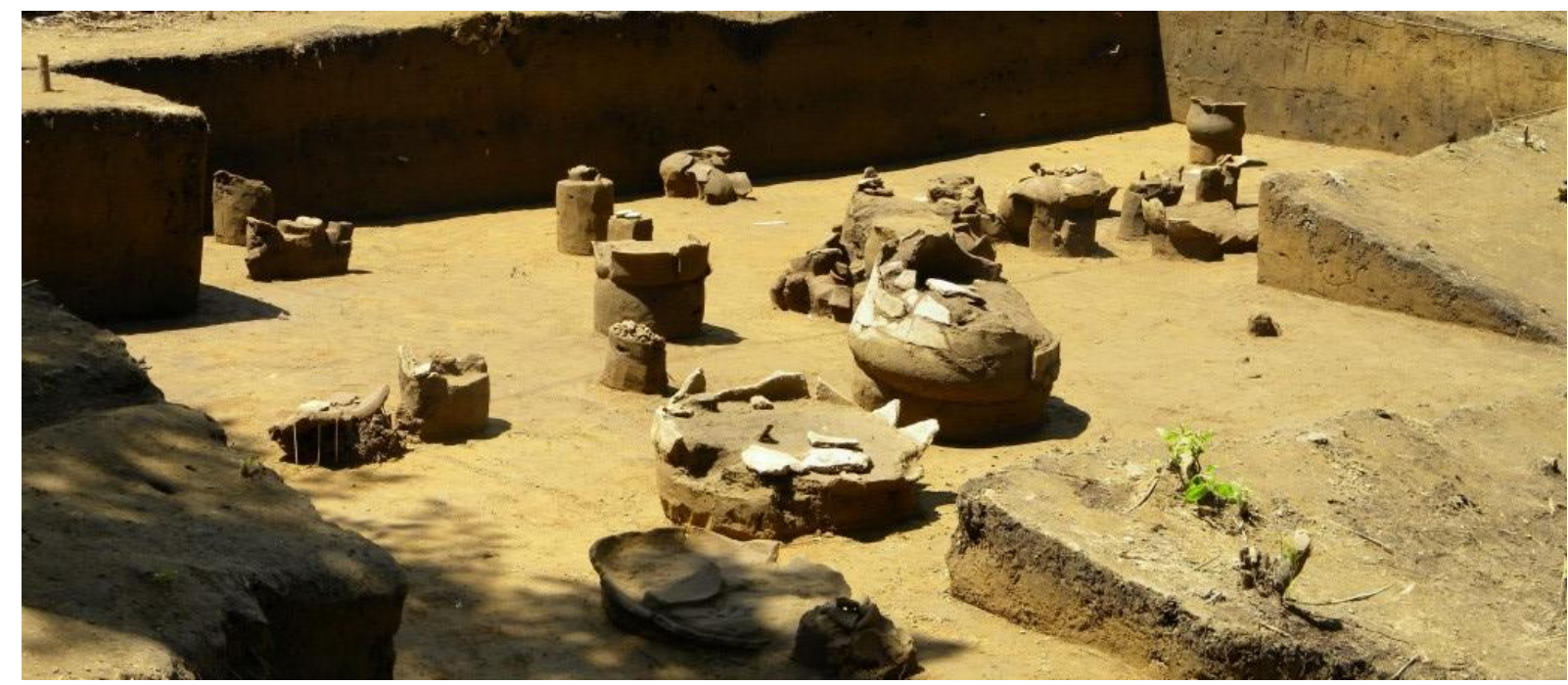

Fotografia 66: área das vasilhas, setor norte (SCIENTIA, 2011).

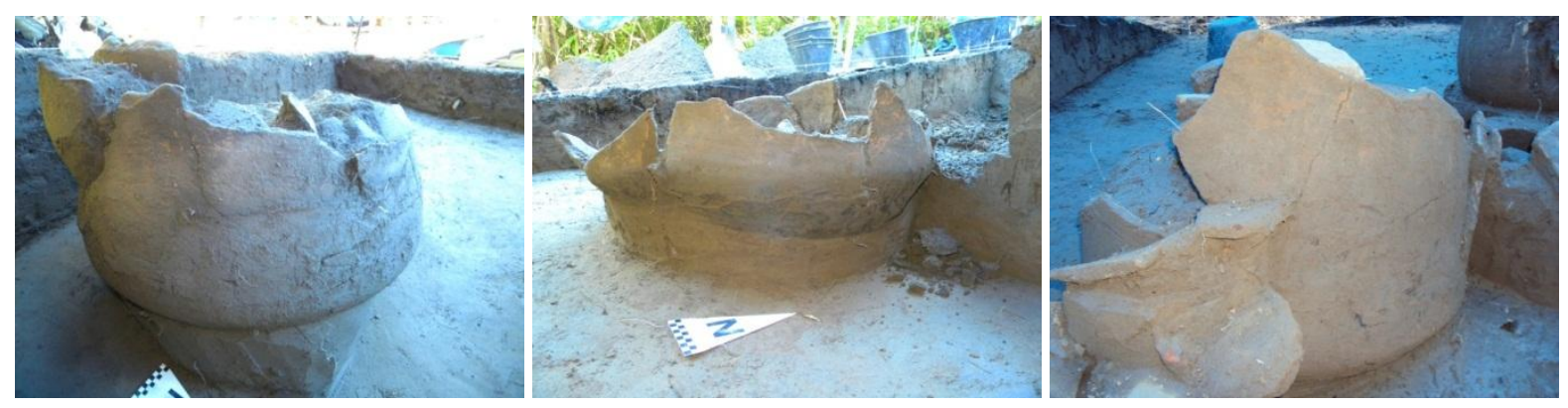

Fotografias 67, 68, 69: vasilhas 10 e 11 (unidade 1) e vasilha 15 (unidade 7)- (SCIENTIA, 2011)

Na unidade 7 (E347919 N8984459), além da vasilha 15, foram escavadas as vasilhas $16,17,18$ e 19 e as estruturas 20 e 21 . A vasilha 16 estava conservada e é muito semelhante à vasilha 26, escavada na unidade 13 (E347921 N8984455). A vasilha 17 estava com a parte superior fragmentada, e possuía uma vasilha emborcada sobre ela (possivelmente tampa). As vasilhas 18 e 19 são pequenas, possivelmente miniaturas, sendo que uma delas se assemelha a uma pequena vasilha com pintura vermelha escavada na unidade 6 (E347919 N8984461). A estrutura 20 é composta por carvões associados a uma argila queimada, interpretada como estrutura de combustão, enquanto a estrutura 21 é composta por fragmentos cerâmicos e material lítico, e está ao lado da vasilha 15 (semelhante ao contexto da vasilha 12).

Na unidade 6 (E347919 N8984461), além da vasilha em miniatura citada acima, foi evidenciada a vasilha 14 (nível $30-60 \mathrm{~cm}$ ) e uma estrutura com 110 seixos, 04 fragmentos cerâmicos e 09 líticos lascados (nível 60-90 cm). No interior da vasilha 21, que possui $21 \mathrm{~cm}$ de altura, ocorreram fragmentos de cerâmica (que podem ser dela mesma), lascas e carvões. Na unidade 5 (E347917 N8984459) também foi encontrada uma estrutura com 67 seixos e 07 
líticos lascados, no nível 40-70 cm, bem como na unidade 9 (E347921 N8984459) uma estrutura com 37 líticos brutos (seixos), 03 fragmentos cerâmicos e 09 líticos lascados (nível $30-60 \mathrm{~cm})$.

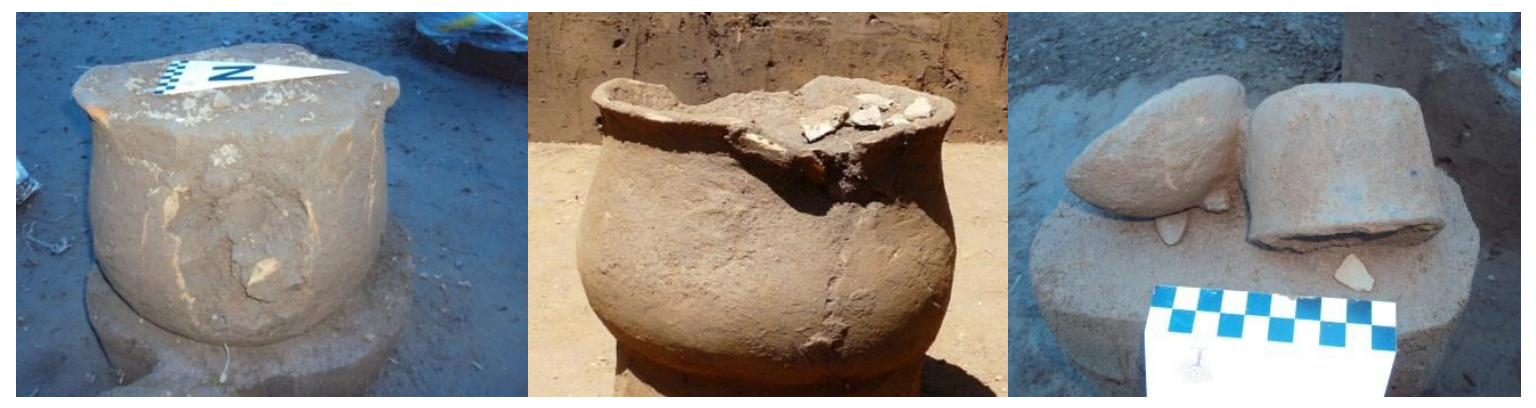

Fotografias 70, 71 e 72: vasilha 16 (unidade 7), vasilha 26 (unidade 13) e Vasilhas 18 e 19 (unidade 7) (SCIENTIA, 2011).

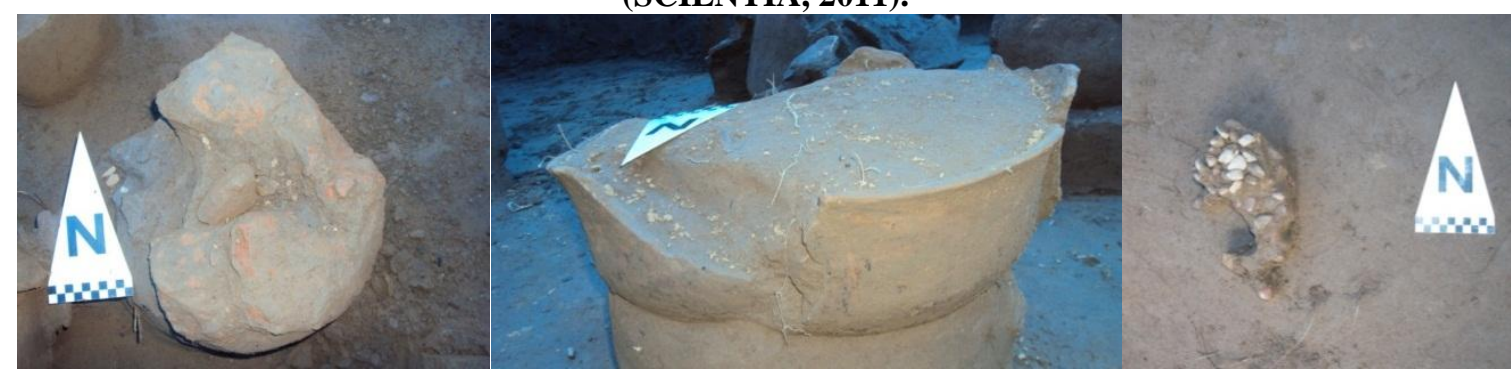

Fotografias 73, 74 e 75: estrutura 20 (unidade 7); vasilha 14 (unidade 6) e estrutura de seixos (unidades 5) (SCIENTIA, 2013).

Na unidade 9 foi escavada também a vasilha 25, que se encontrava em posição horizontal, com a boca voltada para sul. Foram ainda encontrados dois líticos polidos no nível 60-100 cm, com forma semelhante (triangular) e lascas muito pequenas em silexito. $\mathrm{Na}$ unidade 4 (E347919 N8984463) foi evidenciada a estrutura 13, com fragmentos cerâmicos e material lítico. Na unidade 10 (N347919 E8984457) foi encontrada uma estrutura semelhante (estrutura 24), e na unidade 8 (E347921 N8984461) a estrutura 27. Lâminas polidas e outros líticos polidos (alguns podem ser adornos) foram encontrados neste setor. Também estão presentes líticos com concavidades, semelhantes aquele encontrado no setor sul, e uma das lâminas apresenta estas concavidades. O material lítico relacionado a segunda camada arqueológica do sítio Ilha Dionísio é variado, com alta frequência de seixos, lascas pequenas e núcleos silexito, o qual é encontrado em períodos de seca nas margens do rio Madeira. 

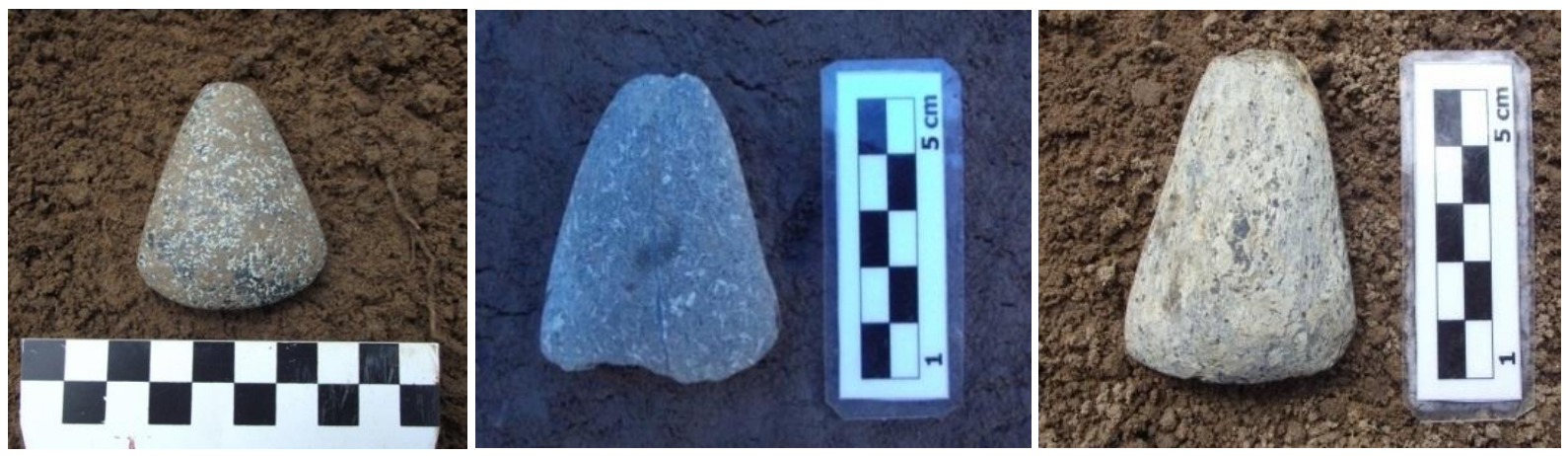

Fotografias 76, 77 e 78: possíveis adornos líticos - área das vasilhas, setor norte (SCIENTIA, 2011).
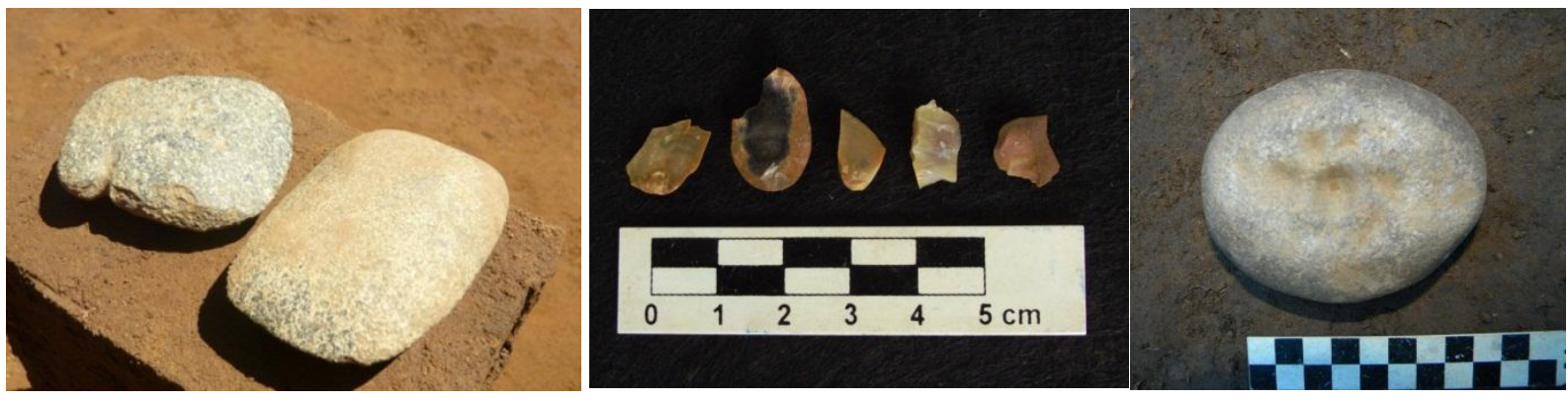

Fotografias 79, 80 e 81: líticos da área das vasilhas, setor norte: lâminas polidas; lascas e seixos de silexito e lítico com concavidades (SCIENTIA, 2011).

Analisamos a cerâmica das unidades E347799 N8984160, E347800 N8984160, E347800 N8984161 e 3478058983979 , do setor sul, bem como todas as vasilhas e estruturas escavadas na área do barranco no setor sul, e algumas vasilhas do setor norte (vasilhas 16, 26, 18, 19). São necessárias datações para o sítio Ilha Dionísio para entender os contextos das duas camadas arqueológicas e relacioná-las com os outros sítios da região. Nossa última paragem foi no Sítio 75 (RO-JP-19), localizado em frente à Ilha Dionísio na margem direita (88 a 113m), com coordenada central E349168 N8984936. Possui uma camada arqueológica com 40 a $80 \mathrm{~cm}$ de espessura, ausência de terra preta e fragmentos cerâmicos estruturados associados a lítico lascado e polido (SCIENTIA, 2011c). Sabemos da existência de sítios à montante, porém não fomos até eles. Trata-se do sítio Bom Futuro (RO-JP-17) e Bom Futuro II (RO-JP-18), registrados pelo arqueólogo Eurico Miller em 1978, e delimitado recentemente como sendo apenas um sítio (SCIENTIA, 2011c), localizado na margem direita $9 \mathrm{~km}$ acima da Ilha Dionísio. Ocorrem sítios à montante, abaixo da cachoeira Caldeirão do Inferno (SCIENTIA, 2011c), bem como junto à cachoeira (na Ilha do Padre) e acima dela (TIZUKA, 2013; SILVA ET AL, 2010; MOUTINHO \& ROBRANH - GONZALEZ, 2010). Nossa viagem se encerra aqui. A seguir apresentamos uma síntese dos contextos abordados neste 
trabalho e as principais problemáticas, e no próximo capítulo a análise da variabilidade cerâmica dos quatorze sítios mencionados no início do texto.

\subsection{Considerações iniciais sobre as ocupações no alto rio Madeira}

A Arqueologia e a história indígena no Alto rio Madeira são ainda pouco conhecidas, seja do ponto de vista da arqueologia, da etnografia, linguística ou da etno-história. Alguns sítios arqueológicos foram localizados e escavados por Eurico Miller na década de 1970 (MILLER, 1992, 2009), fornecendo as primeiras datações de 14C 2.730 75 AP para o sítio RO-JP-01 Teotônio e 14C 2.340ะ90 AP para o RO-PV-19, atribuídos a Subtradição Jatuarana da Tradição Polícroma, caracterizados como sítios habitação de forma elipsoide a retangulóide e presença de terra preta desde a superfície até $210 \mathrm{~cm}$ de profundidade, associados a sítios oficina lítica e um sítio cemitério. Segundo o autor, os sítios maiores e mais complexos estariam próximos às cachoeiras. No baixo curso do rio Jaciparaná, o qual desagua em frente à Ilha Dionísio, os sítios identificados por Eurico Miller possuíam terra escura de $30 \mathrm{~cm}$ de profundidade, com material cerâmico da fase Jaciparaná, de tradição desconhecida, e a montante, no baixo Abunã, identificou sítios habitação, associados a sítiosoficina lítica e sítios com arte rupestre ou petróglifos, com terra preta de $40 \mathrm{~cm}$ de profundidade e cerâmica da fase Pederneiras.

O estudo das ocupações ceramistas no alto rio Madeira foram retomados recentemente, a exemplo do trabalho de Almeida (2013) que apresenta novos elementos para a ocupação na região. Os dois sítios da Subtradição Jatuarana estudados pelo autor (Associação Calderita no baixo Jamari e Itapirema no rio Madeira) apresentam terra preta com cerâmica em camadas de $50 \mathrm{~cm}$ no primeiro deles e $90 \mathrm{~cm}$ no segundo, ambos com montículos. O sítio Associação Calderita apresentou dois episódios de ocupação pelo mesmo grupo, inicialmente em $980 \pm 40$ AP e $940 \pm 40$ AP $(30-50 \mathrm{~cm})$ e a mais recente em $620 \pm 40$ AP (20-30 cm). O sítio Itapirema está implantado em uma barra de sedimento, com forma alongada. O sítio da Tradição Jamari (Jacarezinho) possui uma área estimada entre 8,3 há e 10 ha, com uma camada de $55 \mathrm{~cm}$ de terra preta e material arqueológico na área central e sedimento mais claro na periferia, com duas ocupações ceramistas pelo mesmo grupo, uma em torno de $860 \pm 40 \mathrm{AP}$ e a outra em $660 \pm 40 \mathrm{AP}$, a primeira em uma área de 2 ha e o mais recente todo o sítio (8 ha). Já o sítio Nova Vida, com ocupação ceramista mais antiga

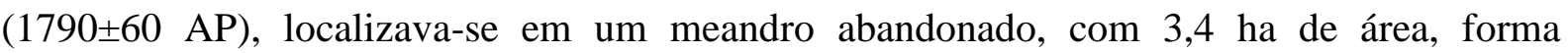


irregular e baixa densidade de material arqueológico até $70 \mathrm{~cm}$ de profundidade junto a um sedimento escuro (Almeida, 2013).

Esta pesquisa constitui-se em mais uma contribuição para o estudo da história indígena no alto rio Madeira por se dedicar ao estudo da variabilidade cerâmica nesta região. Optamos por estudar amostras de diferentes sítios ao longo deste trecho de $80 \mathrm{~km}$ ao longo do rio buscando fornecer um panorama ampliado das ocupações em uma região ainda pouco conhecida, a ser aprofundado com pesquisas futuras. Para os sítios localizados entre as cachoeiras de Santo Antônio e Teotônio tivemos acesso a datações (tabela 2), em cuja área foi possível avançar na interpretação da variabilidade cultural.

As ocupações ceramistas mais antigas foram identificadas nos sítios Foz do Jatuarana (14 C $2.780 \pm 40$ AP e $1.890 \pm 30$ AP), Morro dos Macacos II (14C $1.940 \pm 30$ AP), Boa Vista $(14 \mathrm{C} 4470 \pm 40$ AP e $2.010 \pm 30$ AP), Vista Alegre (14C $3.140 \pm 40$ AP e $2.080 \pm 30$ AP) e Morro dos Macacos I (14C 1.810 \40 AP). Estes sítios estão implantados (ou parcialmente implantados) em planície de inundação, são menores em termos de densidade de material e espessura da camada arqueológica e não apresentam terra preta antropogênica, mas um sedimento escuro com material arqueológico. A cerâmica é mais friável, fragmentada e erodida. Os dados de campo indicaram que estes sítios possuem uma única ocupação précolonial, em alguns deles possivelmente temporária e sazonal (SCIENTIA, 2011c), porém a análise dos materiais cerâmicos aponta para contextos mais complexos nestes sítios, conforme será demonstrado no capítulo 4. Analisamos uma amostra de cada sítio (as unidades datadas) a fim de comparar os materiais destas ocupações mais antigas. No caso do sítio Vista Alegre procuramos compreender se existe uma continuidade na ocupação do período mais antigo (14C $3.140 \pm 40$ AP e $2.080 \pm 30$ AP) ao período mais recente (14C $1.240 \pm 30$ AP), e no sítio Boa Vista se a ocupação mais antiga presente na planície adjacente ao rio se estende até a área mais alta do sítio no platô. 
Tabela 2: Lista das datações radiocarbônicas (SCIENTIA CONSULTORIA CIENTÍFICA)

\begin{tabular}{|c|c|c|c|c|c|}
\hline Sítio & Unidade & $\begin{array}{l}\text { Nível }(\mathrm{cm}) \text { ou } \\
\text { estrutura }\end{array}$ & $\begin{array}{c}\text { Datação } \\
\text { Convencional (AP) }\end{array}$ & $\begin{array}{c}\text { Data calibrada } 2 \text { sigma AC- } \\
\text { DC/AP }\end{array}$ & Código do laboratório \\
\hline \multirow[t]{2}{*}{ Ilha de Santo Antônio } & N922E949 & 163 & $7.760 \pm 50$ & 6670 a $6470 / 8620$ a 8420 & Beta - 260331 \\
\hline & N990 - E849 & 42 & $990 \pm 40$ & 980 a $1160 / 960$ a 800 & Beta -260332 \\
\hline \multirow[t]{8}{*}{ Sítio Garbin } & N981 - E988 & 17 & $480 \pm 40$ & 1400 a $1460 / 550$ a 490 & Beta - 260336 \\
\hline & Quadra 3 x 3m (2010) & 50 & $990 \pm 30$ & $\begin{array}{c}1000 \text { a } 1050 / 950 \text { a } 900, \\
1090 \text { a } 1130 / 860 \text { to } 820 \\
\text { e } 1140 \text { a } 1140 / 810 \text { a } 810\end{array}$ & Beta - 294086 \\
\hline & Quadra 3 x 3m (2010) & 90 & $1.280 \pm 30$ & 660 a $780 / 1280$ a 1170 & Beta - 294087 \\
\hline & N981 - E941 & 75 & $1.710 \pm 40$ & 240 a $420 / 1710$ a 1530 & Beta -260335 \\
\hline & N900 - E1017 & $50-60$ & $4.910 \pm 100$ & 3950 a $3510 / 5900$ a 5460 & Beta -260333 \\
\hline & Quadra 3 x 3m (2010) & 100 & $6.050 \pm 40$ & 5050 a $4840 / 7000$ a 6.790 & Beta -294088 \\
\hline & Quadra 3 x 3m (2010) & 105 & $6.050 \pm 40$ & 5050 a $4840 / 7000$ a 6.790 & Beta - 294089 \\
\hline & N960 - E982 & 85 & $7.740 \pm 50$ & 6650 a $6470 / 8600$ a 8420$)$ & Beta - 260334 \\
\hline $\begin{array}{c}\text { Veneza* } \\
\text { *amostra contaminada }\end{array}$ & N980 - E937 & $50-60$ & $60 \pm 40$ & $\begin{array}{c}1690 \text { a } 1730 / 260 \text { a } 220 \\
1810 \text { a } 1930 / 140 \text { to } 20 \\
\text { e } 1950 \text { a } 1960\end{array}$ & Beta - 260341 \\
\hline Sítio 5 irmãos & $350674 / 8962507$ & $40-50$ & $2.450 \pm 30$ & $\begin{array}{l}760 \text { a } 680 / 2.710 \text { a } 2630 \\
\text { e } 670 \text { a } 410 / 2620 \text { a } 2360\end{array}$ & Beta - 294078 \\
\hline \multirow[t]{3}{*}{ Boa Vista } & $392900 / 9022302$ & $140-150$ & $2.010 \pm 30$ & 60 a 60/ 2010 a 1890 & Beta - 294079 \\
\hline & & $220-230$ & $4.470 \pm 40$ & 3.350 a $3020 / 5.300$ a 4.960 & Beta -294080 \\
\hline & $392540 / 9021860$ & $50-60$ & $8.120 \pm 50$ & $\begin{array}{l}7250 \text { a } 7230 / 9200 \text { a } 9180, \\
7190 \text { a } 7040 / 9140 \text { a } 8990\end{array}$ & Beta - 294081 \\
\hline \multirow[t]{2}{*}{ Foz do Jatuarana } & E383857/N1022428 & $70-80$ & $2.780 \pm 40$ & 1010 a $830 / 2960$ a 2780 & Beta - 294084 \\
\hline & $383934 / 902281$ & $30-40$ & $1.890 \pm 30$ & 60 a $210 / 1890$ a 1740 & Beta - 294085 \\
\hline Morro dos Macacos I & $388285 / 9022787$ & 140 & $1.810 \pm 40$ & $\begin{array}{c}120 \text { 260/ } 1830 \text { to } 1680 \\
\text { E } 280 \text { a } 330 / 1670 \text { a } 1620\end{array}$ & Beta -294090 \\
\hline \multirow[t]{2}{*}{ Morro dos Macacos II } & $387450 / 9022760$ & $60-70$ & $920 \pm 30$ & 1030 a $1200 / 920$ a 750 & Beta - 294091 \\
\hline & $387440 / 9022780$ & $80-90$ & $1.940 \pm 30$ & 10 a $120 / 1940$ a 1830 & Beta - 294092 \\
\hline Sítio do Brejo & N1022 - E1059 & $80-90$ & $760 \pm 40$ & 1210 a $1290 / 740$ a 660 & Beta - 260321 \\
\hline
\end{tabular}




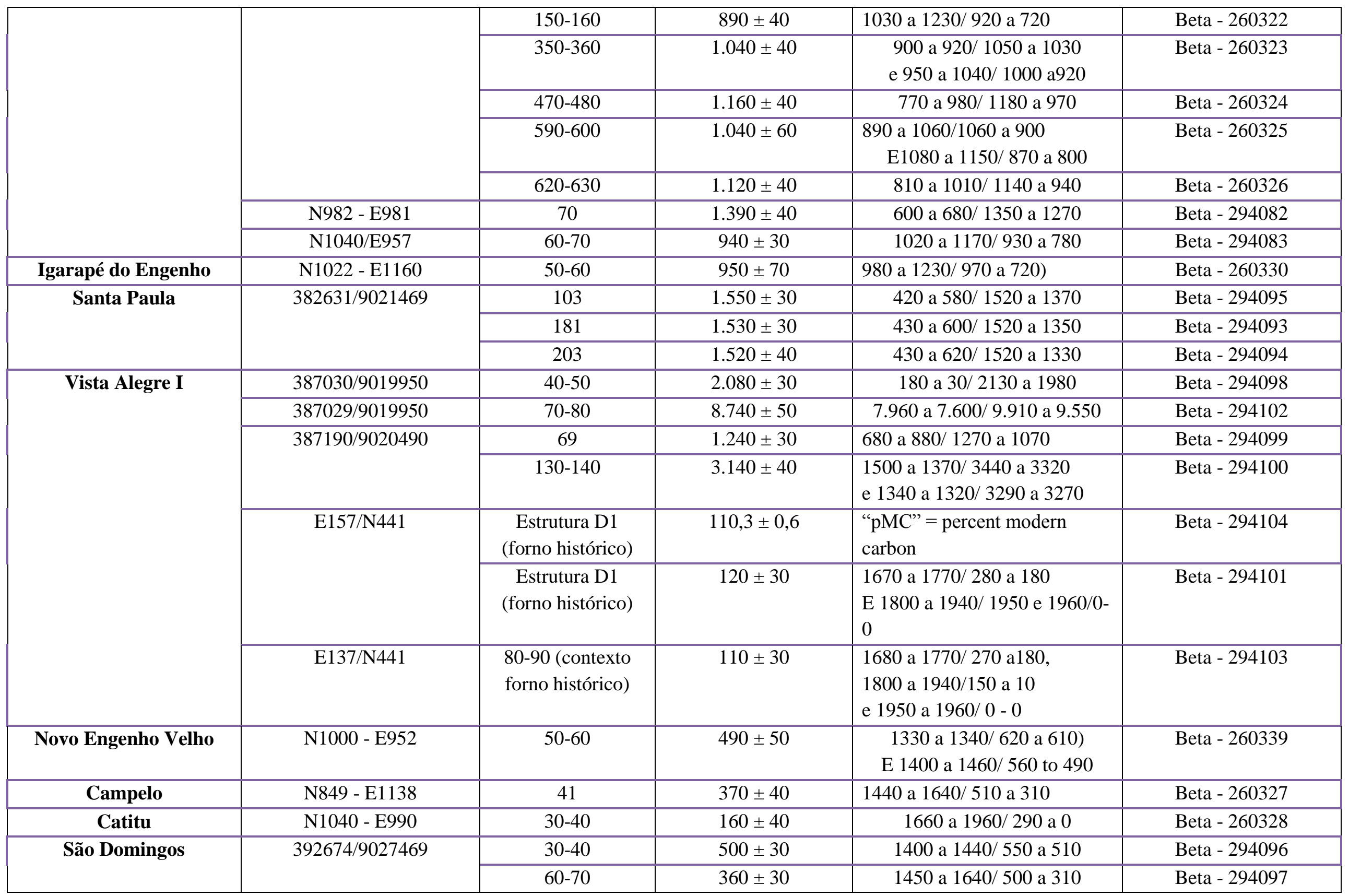


Próximo às cachoeiras de Santo Antônio e Teotônio estão sítios com espessos pacotes de terra preta e grande quantidade de material arqueológico, resultado de ocupações densas e duradouras. Junto à cachoeira de Santo Antônio a ocupação ceramista mais antiga foi evidenciada no sítio Garbin (14C $1.710 \pm 40$ AP e $1.300 \pm 30$ AP) que teria sido ocupado até o período recente $(14 \mathrm{C} 990 \pm 30 \mathrm{AP}$ e $480 \pm 40 \mathrm{AP})$, sendo a data de $4910 \pm 100 \mathrm{AP}$ possivelmente de transição entre a ocupação pré-ceramista com terra preta e a ceramista. Já na cachoeira do Teotônio a ocupação do sítio Santa Paula foi datada em 14C $1.550 \pm 30$ AP, $1.530 \pm 30 \mathrm{AP}$ e $1.520 \pm 40 \mathrm{AP}$, enquanto a ocupação ceramista do sítio Teotônio possui uma data de 2.730 \pm 75 AP (MILLER, 1992), porém pode ser mais recente, conforme aponta

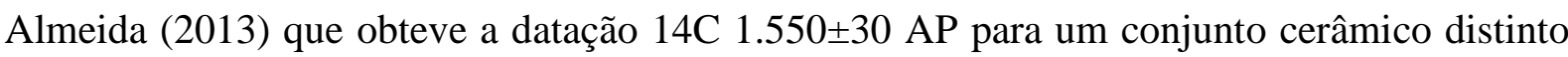
da Subtradição Jatuarana e 1.250 30 AP para a base da ocupação Jatuarana, enquanto a data de 3.170 \30 AP seria de uma ocupação pré-ceramista no sítio (Almeida, 2013: 206).

Na cachoeira de Santo Antônio o sítio do Brejo apresentou uma sequencia de datações entre 14C $1.390 \pm 40$ AP e $760 \pm 40$ AP, mesmo período que a Ilha de Santo Antônio teria sido ocupada (14C $990 \pm 40$ AP) e o sítio Igarapé do Engenho (14C $950 \pm 70$ AP). Analisamos o material de seis unidades do sítio da ilha e três unidades do sítio do Brejo buscando caracterizar as ocupações desse período e perceber as continuidades e mudanças na tecnologia cerâmica. O estudo das ocupações mais recentes desta área, como no sítio Novo Engenho Velho (14C $490 \pm 50$ AP), Campelo (14C $370 \pm 40$ AP), São Domingos (14C 500 $\pm 30 \mathrm{AP}$ e $360 \pm 30 \mathrm{AP})$ e Catitu (14C $160 \pm 40 \mathrm{AP})$, não foi abordada neste trabalho, sendo feita apenas a triagem da cerâmica do sítio Novo Engenho Velho e de uma unidade do sítio São Domingos.

Os dados analisados têm demonstrado que os sítios maiores e mais complexos estão nas cachoeiras, conforme sugeriu Miller (1992), indicando ocupações densas e duradouras, com espessos pacotes de terra preta e datações de um longo período. As cachoeiras constituem-se em lugares que se destacam na paisagem local, em função da pesca abundante e do valor simbólico atribuído (até recentemente pela população de Porto velho), e no passado estes locais foram intensamente transformados. A análise do material dos sítios Santa Paula e de uma pequena amostra do sítio Teotônio, e a comparação com elementos da cerâmica do sítio Garbin (que foi apenas triada), trará novos dados sobre as ocupações ceramistas nestas cachoeiras da jusante, com a expectativa de evidenciar características tecnológicas diferentes, além daquelas atribuídas à Subtradição Jatuarana, em um quadro de diversidade cultural sugerida para a região do Alto rio Madeira. 
Foram também analisadas amostras de materiais cerâmicos dos sítios arqueológicos das ilhas localizadas acima da cachoeira do Teotônio, que apesar de não terem sido datados até o momento, possuem alguns contextos diferentes daqueles localizados a jusante, a exemplo da cerâmica com queima oxidante, pasta laranja e presença de cauixí e da presença de gravuras rupestres e feições de polimento. A análise de uma amostra do sítio Ilha do Japó objetiva testar as hipóteses de campo de que existem ao menos duas ocupações ceramistas no local. Já o sítio Ilha Dionísio apresenta duas camadas arqueológicas, cujas cerâmicas serão comparadas, sendo a mais recente característica pela forma semi-circular do sítio e pela presença de áreas com vasilhas e estruturas enterradas. Buscaremos comparar os materiais destes dois sítios, a princípio multicomponenciais, com os sítios Ilha das Cobras e Ilha São Francisco cujos dados de campo apontam para uma única ocupação. O sítio Ilha Dionísio está em uma área próxima de onde Eurico Miller identificou uma cerâmica com características diferentes da Subtradição Jatuarana, a qual denominou fase Jaciparaná (MILLER, 1992).

Com a análise cerâmica destes sítios arqueológicos pretendemos avançar na discussão dos dados estabelecidos anteriormente para a região. As escavações evidenciaram sítios com forma circular e elíptica, com exceção do sítio Ilha Dionísio que possui formato semi-circular, porém estes dados espaciais precisam ser aprofundados com a análise dos materiais cerâmicos, líticos e dos sedimentos. $\mathrm{Na}$ maioria dos sítios ocorre um único pacote arqueológico, com variações sutis nas frequências nos diferentes níveis, na coloração e textura do sedimento, sendo difícil distinguir as diferentes ocupações. Tais variações e variabilidades poderão ser alcançadas com a análise tecnológica dos materiais arqueológicos e a realização de uma cronologia detalhada. Sítios inicialmente considerados unicomponenciais podem conter vestígios materiais de diferentes ocupações indígenas. 


\section{Capítulo 3. O estudo da tecnologia cerâmica: as escolhas tecnológicas e a variabilidade artefatual}

As pesquisas arqueológicas na Amazônia e, mais especificamente, na porção sudoeste onde está o alto curso do rio Madeira, estão preocupadas com questões importantes tais como: a expansão dos povos falantes do Tronco Tupi a partir desta região, a dispersão de falantes Arawak, com possível formação de contextos etnogênicos e redes de interações, bem como na origem da diversidade cultural identificada desde o início do período colonial. Entendemos que tais questões podem ser abordadas com o estudo da variabilidade na cultura material, através da análise das escolhas que perpassam a confecção e uso dos artefatos, e que são decisões tomadas por indivíduos em um contexto social e simbólico específico. Neste capítulo, apresentaremos brevemente os conceitos teóricos que embasam a pesquisa, bem como os métodos utilizados na análise da cerâmica.

\subsection{O estudo da variabilidade artefatual: as escolhas técnológicas e a identificação de identidades e fronteiras culturais no registro arqueológico}

O modo como os arqueólogos lidam com a cultura material e o contexto arqueológico mudou bastante no decorrer do século XX e início do século XXI, apesar das questões básicas continuarem latentes até o presente. Inicialmente, os estudos voltaram-se para a identificação de culturas arqueológicas através da caracterização de alguns traços dos artefatos, sendo criados tipos a partir da sua quantificação e classificação, em um espaço e tempo específicos, e interpretados como reflexo direto de etnicidade. Porém, a determinação de unidades histórico-culturais, a partir de similaridades e diferenças na forma dos artefatos, apesar de ter sido útil na sistematização das informações e na construção de histórias culturais, tornou-se cada vez mais insustentável, principalmente pela falta de relação com o contexto funcional, social e simbólico. Seguiu-se uma ampla discussão na arqueologia sobre a variabilidade e o conceito de estilo, principalmente entre Binford $(1962,1965,1989)$ e Sackett $(1977$, 1991), e entre este último autor e Wiessner (1991), sobre a dicotomia entre estilo e função, a característica passiva ou ativa do estilo, onde o estilo reside e a intencionalidade ou não do estilo na identificação de etnicidade. Há uma infinidade de 
concepções sobre o estilo, as quais não serão abordadas aqui, sendo mais comumente definido como o modo que as pessoas fazem as coisas, incluindo as escolhas em relação aos materiais e técnicas de produção, próprio de um determinado tempo e lugar (DIAS e SILVA, 2001; DAVID e KRAMER, 2001).

A mudança do foco na forma ou decoração dos artefatos como indicadores de estilo e etnicidade para a abordagem de todo o seu processo de confecção, uso e descarte foi um dos principais avanços, porém algumas abordagens passaram a definir os sistemas tecnológicos e os estilos em termos de estratégias adaptativas e dos constrangimentos econômicos, ambientais e funcionais, com pontos de vista deterministas, evolucionistas e estáticos. Somente nas últimas décadas tem sido mais frequente uma abordagem da tecnologia como produção social e compondo sistemas culturais e simbólicos.

O estudo das técnicas e da tecnologia foi inicialmente abordado por etnólogos na análise e descrição das técnicas tradicionais e, com o passar do tempo, passou a ser amplamente discutido na arqueologia. Para os arqueólogos, o conceito de cadeia operatória tornou-se uma ferramenta indispensável no estudo da cultura material, servindo como base para a identificação de tradições e sistemas tecnológicos, sociais e culturais. A técnica foi definida por Mauss (2003) como material e social, na medida em que é mediadora entre natureza e cultura, socialmente apreendida e transmitida através da tradição. Para esse autor, a técnica pode ser entendida como um encadeamento de etapas de transformação da matéria, em diferentes momentos de fabricação de um artefato, e pode ser abordada através do objeto em si, em relação às pessoas e em relação à totalidade do sistema. A abordagem de Marcel Mauss envolvia a dimensão sociológica ou sincrônica, a histórica ou diacrônica e a física-psicológica, conforme ressaltou Lévi-Strauss (2003, p.24) ao analisar a obra do etnógrafo.

Leroi-Gourhan (1985) formalizou o uso da noção de cadeia operatória nas análises tecnológicas, entendendo que não é possível estudar e descrever o instrumento isoladamente, mas em relação aos gestos que são aprendidos e que dão forma e utilidade a ele. O comportamento técnico do homem é abordado pelo autor em três níveis, o específico, o sócio-étnico e o individual, envolvendo laços genéticos, aprendizagem e decisões individuais. 
Balfet (1991) definiu a cadeia operatória como o encadeamento das operações mentais e dos gestos técnicos, visando a satisfazer uma necessidade imediata ou não, segundo um projeto pré-existente. Tais operações são efetuadas dentro de um tempo e de um espaço, em vista de um determinado resultado, por um ou vários atores, em um processo dinâmico de tomada de decisões, abrangendo, portanto, uma realidade complexa: é gesto, é instrumento, mas também ator, com seu saber técnico, ligado à sua posição social. No caso da confecção da cerâmica, esta envolve um encadeamento obrigatório de etapas, que vão desde a aquisição da argila até as vasilhas estarem prontas ao uso.

Para Schiffer e Skibo (1992), a tecnologia é um conjunto de artefatos, comportamentos e conhecimentos para criar produtos, transmitida através das gerações por estruturas de aprendizado, por meio da imitação, instrução verbal, demonstração prática e tentativa e erro. O processo tecnológico, que vai desde a aquisição da matériaprima, seu processamento até a finalização do artefato, envolve escolhas técnicas, entendidas como decisões tomadas durante a manufatura, que determinam as propriedades formais dos artefatos, que por sua vez afetam as suas características de performance, ou seja, a sua capacidade de desempenhar de maneira eficiente a função nas atividades específicas pretendidas. Inovações surgem quando artesãos experimentam e suas criações são aceitas e adotadas pelo grupo, e consequentemente as estruturas de aprendizado são alteradas. Como arqueólogos estudam as propriedades formais (ou atributos) dos artefatos, que são consequências de escolhas técnicas, então podem perceber as mudanças tecnológicas no tempo (SCHIFFER e SKIBO, 1992, 1997; SKIBO e SCHIFFER, 2001).

Schiffer e Skibo (1992) entendem que a variabilidade artefatual - as diferenças e as similaridades em um determinado tempo e espaço - pode ser abordada através das dimensões formal, espacial, quantitativa e relacional dos artefatos. Os autores formularam a teoria do desing, entendida através de quatro componentes: a história de vida ou cadeia comportamental, atividades e interações, escolhas técnicas e características de performance dos artefatos. A história de vida dos artefatos compõe uma série de etapas, não somente relacionadas à sua manufatura, mas também ao uso, reutilização e descarte, sendo que cada uma delas abrange interações pessoa-pessoa, pessoa-artefato e artefato-artefato (SCHIFFER e SKIBO, 1992). Além disso, a variabilidade não pode ser entendida sem o estudo simultâneo da formação do registro 
arqueológico, que envolve processos do contexto sistêmico e do contexto arqueológico, ou seja, a história de vida dos artefatos de acordo com os comportamentos de quem os produziu, utilizou e descartou (SCHIFFER, 1995).

Lemmonier $(1992,1993)$ define as escolhas tecnológicas como representações sociais, componentes do grande sistema simbólico e indicadores de significados e símbolos. São opções adotadas pelos artesãos, de maneira consciente ou inconsciente, em como usar ou não certos materiais disponíveis, os instrumentos e as ações. Como o sistema tecnológico está relacionado a outros fenômenos sociais, ao estudá-lo é necessário se perguntar por que as sociedades adotam certas características tecnológicas e rejeitam outras e como essas escolhas são compatíveis com outras escolhas sociais. Os conhecimentos são adquiridos através da tradição que compõe o sistema simbólico.

A reconstrução de grupos e fronteiras culturais no passado continua sendo um importante objetivo da pesquisa arqueológica, especialmente para aqueles interessados em compreender a diversidade regional. Para Dietler e Herbich (1998), isso só pode ser atingido com a identificação de padrões na cultura material e fronteiras no registro arqueológico. É necessário, porém, buscar estratégias apropriadas para identificar tais padrões e, mais do que isso, explorar a gama de processos sociais que possam ter produzido tais padrões e fronteiras, levando em consideração a natureza complexa e fluída das identidades sociais e culturais e o caráter contextual de negociação de fronteiras de vários tipos. Estudos etnográficos e etnoarqueológicos têm contribuído muito na abordagem destas questões, de como a cultura material é produzida em seu contexto social e cultural, sobre seu papel na formação e reprodução de identidade e seu potencial na identificação de grupos e fronteiras culturais no passado.

Com relação à primeira questão, a da estratégia ou metodologia mais adequada para identificar os padrões, ou melhor, a variabilidade na cultura material ou suas variações estilísticas, a maioria dos estudos demonstra que não é possível focar na análise de apenas um traço do artefato, como a forma ou a decoração, ou uma etapa do processo de confecção, mas em toda a sequência e contexto de manufatura, uso e descarte. Isso é em parte fruto da superação da concepção que separava estilo, função, tecnologia e significado, em que o estilo era visto como compondo apenas os atributos dos objetos que não afetavam a sua função e que não resultavam de constrangimentos técnicos, como algo adicionado no artefato para expressar identidade estilística. 
Para Gosselain (1998), o estilo técnico é decorrente das escolhas que os artesãos fazem de acordo com o contexto social onde aprendem e praticam o artesanato, podendo a expressão estilística ser muito estável no tempo e no espaço, diferente do estilo formal ou decorativo que pode ser facilmente manipulado, imitado ou rejeitado. Este autor entende que o estilo técnico permite explorar os aspectos mais profundos da identidade social e, apesar de todas as etapas da cadeia operatória serem um lócus para a expressão estilística, nem todas possuem a mesma significância estilística, por isso a importância da análise conjunta dos diferentes aspectos (GOSSELAIN, 1998).

Da mesma forma, Chilion (1998) chama a atenção para o fato de que, quando isolamos um aspecto da cultura material a ser analisado, determinamos os padrões de comportamento que teremos condições de identificar. Além disso, em muitos contextos, a decoração pode ser menos indicativa de identidades sociais que outros aspectos da cultura material, porém não é o caso de simplesmente transferir a ênfase da decoração para a tecnologia ou a função, mas dar atenção para a maneira como os artefatos são feitos e usados, tanto quanto para como são decorados. Essa autora entende que o estilo é permeado por todos os aspectos da variação na cultura material, focando na relação das técnicas com a sociedade e não nas técnicas em si, a fim de entender a sua dimensão social. Ressalta que as escolhas feitas pelos agentes sociais, mais do que os materiais ou ferramentas, são fundamentais na confecção de um artefato, as quais envolvem não apenas aspectos materiais e tecnológicos, mas também informacionais ou simbólicos (CHILION, 1998).

Dietler e Herbich (1998) consideram importante a distinção entre coisas e técnicas: as primeiras são entidades físicas que ocupam espaço, as quais os arqueólogos recuperam como evidências, enquanto as técnicas são as ações humanas que resultam na confecção e uso das coisas. Sendo as técnicas mediadoras entre os artefatos e a sociedade, precisamos compreender como as coisas foram feitas e usadas na prática diária, ou seja, como os estilos foram criados. Esses autores defendem uma visão holística de estilo material, englobando os aspectos formais, decorativos e tecnológicos, baseada na abordagem da cadeia operatória, das técnicas como fato social e da cultura material como produto social. Além disso, se as coisas são feitas, usadas e descartadas como parte de uma atividade social, coisas e técnicas compõem e são condicionadas por relações sociais e práticas culturais, e a compreensão desta complexa relação fornece informações sobre a sociedade e a cultura (DIETLER e HERBICH, 1998). 
Para David e Kramer (2001), as características formais dos artefatos são resultado das escolhas dos artesãos no seu processo de manufatura, por isso padrões de escolhas culturais podem evidenciar as diferenças entre os conjuntos de cultura material. Entretanto, entendem que, antes de tentarmos explicar padrões de variação formal relevantes a nível sociocultural, precisamos entender como eles foram produzidos. Para estes autores, estilos estão relacionados a dinâmicas sociais, e por isso fornecem informações importantes sobre a esfera social e simbólica, e são meios de troca de informações, mesmo que nem sempre de maneira intencional. David e Kramer (2001) recorrem ao conceito de reservatório simbólico para abordar a cultura material, entendido nesse caso como um reservatório de símbolos, mitos e crenças, ao qual as pessoas recorrem para extrair e exibir uma tradição que serve aos seus próprios interesses. Este seria equivalente a uma representação social comum, e é uma abordagem que busca ligar tradição cultural à agência humana.

A questão da agência é também retomada nestes trabalhos. Ao passo que as visões são contraditórias sobre a intencionalidade ou não da comunicação de identidade através da cultura material, a maioria dos autores concorda que esta se constitui em uma importante forma de significação, e que artesãos não são passivos aos constrangimentos ambientais e técnicos, mas tomam decisões ao longo de suas atuações (HEGMON E KULOW, 2005).

Gosselain (1998) faz uma crítica aos estudos clássicos de cerâmica ${ }^{18}$, que em geral ressaltam os efeitos negativos do meio (disponibilidade de matéria-prima, técnicas de queima limitadas, condições climáticas pobres, do processo técnico, acidentes, encadeamento estático das etapas de produção) e a função (performance) que os artefatos deverão desempenhar (propriedades físicas como condutividade térmica, força de flexão, impermeabilização). Conforme o autor, a explicação do comportamento humano em termos universais e a ênfase nos constrangimentos não dá espaço para a compreensão das expressões de identidade dos ceramistas ou suas preocupações não técnicas ou não funcionais.

Para Dietler e Herbich (1998), as concepções de estilo passivo e ativo são fruto da dicotomia paradigmática das ciências sociais entre estrutura e agência. Nesse sentido, a teoria da prática de Pierre Bordieu e seu conceito de hábitus têm grande potencial para

\footnotetext{
${ }^{18} \mathrm{O}$ autor se refere às abordagens da chamada "Ecologia Cerâmica" e da "Função" e "Uso".
} 
situar a cultura material, a cadeia operatória e os atores sociais responsáveis pela sua produção e transformação dentro de uma abordagem que media estrutura e agência.

Bourdieu (1977, 2006) elaborou os conceitos de campo e de habitus objetivando dar coerência para as relações dos indivíduos enquanto agentes no seu espaço social, o campo. O habitus é uma noção mediadora que ajuda a romper a dualidade entre indivíduo e sociedade, sendo os indivíduos tanto portadores de disposições autônomas, aprendidas e geridas pelo habitus, quanto produtos do meio social onde atuam, o campo. Ao mesmo tempo em que os indivíduos interiorizam as disposições da sociedade nas suas práticas diárias, sendo coagidos a agir de determinadas maneiras nas diferentes circunstâncias, são também portadores de diretrizes geradoras de suas práticas e ações, dando respostas criativas aos constrangimentos e solicitações do meio social, forjando e reproduzindo tais estruturas (BOURDIEU, 1977, 2006; WACQUANT, 2004, SOUZA, 2007).

Dietler e Herbich (1998) entendem que é através do hábitus que o sentido de identidade de grupo é formado e transformado nas trajetórias históricas específicas. Nesse sentido, técnicas são como disposições que geram ação em todos os domínios da vida social, e para compreender as mudanças nas técnicas e na cultura material é necessário entender o hábitus que estrutura as respostas para os problemas técnicos e sociais, bem como as condições materiais e as demandas que surgem desde a escala das relações interpessoais até a economia política supralocal.

A superação das dicotomias entre indivíduo e norma, estrutura e processo, o ideal e o material, o sujeito e o objeto entre outras foi também proposta por Hodder (1994), com uma forte crítica às abordagens que minimizam a capacidade do indivíduo de gerar a mudança e criar sua própria cultura como um processo social ativo. Para esse autor, a variabilidade individual tem grande importância em relação à mudança social e cultural. Dessa forma, para que a mudança, a inovação e o individuo ativo sejam possíveis, é necessário analisar as relações entre as normas, regras e indivíduos, já que na vida cotidiana os fatores variam e torna-se necessário improvisar dentro das normas e regras, transformando-as nesse processo (HODDER, 1994).

A maioria dos autores acredita que a variabilidade na cultura material pode ser entendida através da análise das escolhas tecnológicas feitas pelos artesãos em todas as etapas de produção e uso dos artefatos, e que por tais escolhas constituírem sistemas 
culturais e simbólicos, sua análise permite diferenciar grupos culturais. Entretanto, a identificação de tais identidades e fronteiras é uma tarefa um pouco mais complexa, conforme indicam muitos estudos etnoarqueógicos e arqueológicos.

David e Kramer (2001), através da sua pesquisa entre grupos falantes de línguas do tronco Biu-Mandara e da família Chadic no norte das montanhas Mandara do Camarões, buscaram entender os fatores responsáveis pela geração da variabilidade na cultura material, o que a variabilidade representa e como pode ser relacionada à identidade de grupo. Estes identificaram uma grande diversidade nas expressões estilísticas em muitas comunidades diferentes, considerada como um conjunto politético com derivação comum a partir de um reservatório simbólico compartilhado, ou seja, uma representação social comum. As pressões internas e externas teriam levado a um jogo de estilos conduzido de acordo com normas do reservatório simbólico, sendo as próprias regras modificadas ao longo do tempo. Nesse caso, ao passo que a coerência dos conjuntos de cultura material derivaria dos reservatórios simbólicos, existem produtos diversificados em função da interação de conjuntos simbólicos internamente coerentes, porém diferenciados (DAVID e KRAMER, 2001).

Dietler e Herbich (1998), ao analisarem a produção cerâmica dos falantes Luo, ao redor do Golfo Winam, na África Oriental, perceberam a existência de micro estilos locais nas diferentes comunidades ceramistas, caracterizados por mudanças padronizadas nos atributos técnicos, formais e decorativos. Apesar de compartilhar um conjunto similar de ferramentas e técnicas, os ceramistas criaram estilos distintivos, através das suas escolhas, tidas como respostas às demandas, indicando trajetórias históricas separadas. No entanto, a análise da distribuição espacial dos potes demonstrou que, no contexto de consumo, o estilo cerâmico desempenha um papel pequeno na expressão da identidade de grupo, pois as cerâmicas atravessam fronteiras importantes para as pessoas, incluindo as fronteiras dos subgrupos Luo e a fronteira entre os Luo e seus vizinhos falantes Bantu do Luhyia. Além disso, os limites das zonas de estilo abrangem áreas que não são de importância cultural e social. Nesse caso, a expressão de identidade individual e de grupo tem um papel importante na criação do estilo cerâmico somente no contexto de produção, sendo pouco significativa fora destas redes de relações pessoais, e, por isso, os autores chamam a atenção para a observação de ambos os contextos de produção e consumo. Portanto, quando analisamos a variabilidade na cultura material de uma determinada região, precisamos estar atentos 
para o fato de que nem sempre a distribuição espacial dos estilos de cerâmica são bons indicadores de identidade de grupo, pois, em alguns casos, zonas de estilos homogêneas podem atravessar fronteiras tradicionalmente hostis, assim como as fronteiras destas zonas de estilo podem dividir grupos com um forte sentido de identidade mútua. Os autores também chamam a atenção para uma definição de fronteiras e limites que leve em consideração as dimensões político-econômicas do processo de interação entre os grupos, pois a própria natureza da definição de grupo, as estratégias para demarcar exclusão e pertencimento e as mudanças nos diferentes elementos culturais dessas estratégias variam muito (DIETLER e HERBICH, 1998).

Gosselain (1998) observou diferentes contextos de produção cerâmica entre as populações do Camarões Meridional, comparando as técnicas usadas pelos ceramistas nas etapas da cadeia operatória, buscando entender as razões subjacentes às escolhas técnicas e as relações entre estas escolhas e a identidade social. O autor observou uma grande variabilidade do comportamento técnico, tanto nas técnicas de processamento da matéria-prima, na confecção dos vasos, queima e tratamentos de superfície pósqueima. Portanto, nesse caso, os objetivos técnicos e funcionais permitem uma grande flexibilidade nas escolhas, com alta adaptabilidade aos constrangimentos ambientais e contextos sociais, sendo todas as opções funcionalmente equivalentes. Também existe uma grande flexibilidade entre os estágios do processo de manufatura, ou seja, uma escolha feita em um nível não condiciona automaticamente as escolhas feitas nos próximos níveis, sendo possível fazer várias combinações. Além disso, as preocupações simbólicas são tão determinantes quanto às econômicas na manufatura e uso da cerâmica, visível na comparação dos vasos com as pessoas, da associação metafórica do processo de manufatura a outros tipos de processos de transformação como a gestação, germinação, iniciação e casamento, das proibições que os ceramistas devem respeitar nesse processo, do uso de plantas medicinais para impermeabilizar as superfícies. Já as relações entre identidade técnica e social são complexas, e nem todos os estágios do processo de manufatura têm a mesma significância estilística. Gosselain (1998) observou que o único estágio do processo de manufatura fortemente relacionado com identidade social é o processo de confecção, cuja distribuição coincide com as fronteiras linguísticas, enquanto os outros estágios como o processamento da argila, a queima e os tratamentos de superfície pós-queima são marcadores culturais fracos, atravessando ou sobrepondo fronteiras geoculturais, sendo 
mais relacionados a indivíduos, localidades ou territórios. Populações que falam a mesma língua e possuem uma historia comum tendem a confeccionar seus vasos da mesma maneira, ou a usar técnicas semelhantes que se diferem significantemente daquelas dos seus vizinhos, em função do contexto de aprendizagem na família nuclear. A identidade linguística do aprendiz e do professor são geralmente coincidentes, e os movimentos pós-aprendizado alcançam pequenas distâncias, não ultrapassando as fronteiras culturais. Interações pós-aprendizado levam alguns ceramistas a abandonar uma parte de sua identidade técnica inicial, porém as técnicas de confecção são mais resistentes a mudanças, possivelmente porque elas são essencialmente dependentes de hábitos motores e envolvem um longo período de aprendizagem (GOSSELAIN, 1998).

Gosselain (1998) conclui que as variações na maneira de confeccionar os vasos podem ser relacionadas a unidades espaciais maiores ou menores que as fronteiras linguísticas. No Camarões meridional, as redes de aprendizagem se propagam por áreas que incluem várias aldeias, contudo continuam menores que os territórios linguísticos. Em outros contextos, as tradições cerâmicas são distribuídas por territórios grandes, que atravessam as fronteiras linguísticas, e esses diferentes padrões de distribuição social e técnica são mais complicados quando ocorre mistura de populações ou diferenças espaciais ou sociais nos contextos de produção e consumo, sendo problemático, portanto, fazer associações simplistas entre identidade social e padrões de cultura material. $\mathrm{O}$ autor acredita que a reconstrução de comportamentos técnicos antigos possui um grande potencial na arqueologia, entretanto chama a atenção para os limites inerentes às inferências que podemos fazer. Segundo ele, a análise dos dados arqueológicos de grandes áreas e longos períodos de tempo, permite reconhecer padrões contrastantes de variação estilística, e pode fornecer evidências de redes de interação social e movimentos de populações, porém é difícil entender a relação destas variantes às facetas particulares de identidade social, em função da natureza imprevisível do comportamento cultural (GOSSELAIN, 1998).

Pikirayi (2007), que estuda a cerâmica da Idade do Ferro na África Meridional, foca a pesquisa no papel da cerâmica como meio de comunicação. Para a autora, se a cerâmica é parte integrante da organização social humana do passado, pode contribuir para a construção de narrativas sociais. Acredita que, se a identidade é definida e criada através da interação de grupo, seria mais interessante relacionar correlatos 
materiais a este processo do que a etnicidade, que geralmente é definida como sendo estática, através das diferenças de parentesco, língua, cultura e sentido de identidade em grupos autônomos e independentes. Assim, se a maneira de fazer e usar a cerâmica é uma expressão de significados sociais, a análise deve buscar entender o seu significado para além das funções utilitárias e da definição de etnia. A decoração cerâmica seria um meio de transmissão de mensagens para destinatários, incluindo o próprio autor, outros indivíduos, grupos, objetos da cultura material ou estruturas. Mensagens são aprendidas, relembradas e transmitidas através de paisagens geográficas, não necessariamente envolvendo migração, mas também através da propagação de idéias e objetos em situações de interação social (PIKIRAYI, 2007).

Silva (2007) discute a relação da variabilidade artefatual com as noções de identidade étnica e social, ao analisar a variabilidade formal dos vasilhames cerâmicos Assurini do Xingu, no estado do Pará. Verificou que a cerâmica possui uma variedade de formas, tamanhos e motivos decorativos, resultante da funcionalidade das vasilhas, das estruturas de ensino aprendizagem, da organização social e das contingências históricas. Nesse caso existe uma variabilidade entre os conjuntos de vasilhas dos diferentes grupos domésticos, onde acontece a aprendizagem, porém são quase imperceptíveis em relação ao conjunto total de vasilhas da aldeia. Além disso, ocorrem variações individuais, especialmente no acabamento da borda, do fundo e do corpo das vasilhas e nos motivos decorativos. Portanto, alguns atributos são melhor definidores de tradições tecnológicas em termos culturais, e indicadores de identidade étnica, social e individual. Já as inovações no contorno formal e tamanho das vasilhas são decorrentes das relações interculturais dos Assurini, seja pela observação das formas dos artefatos da sociedade envolvente ou pela adequação ao comércio. Silva (2013) entende que as inovações tecnológicas, que incluem a incorporação de matérias-primas, técnicas ocidentais e bens industrializados, correspondem a um processo de expressão estética e criativa e de (re) criação cultural, sendo uma forma de afirmação da identidade em relação ao outro. Ainda, esta dinâmica entre a tradição e a inovação está presente em vários aspectos da vida dos Asurini, sendo as permanências e mudanças resultantes de diversos fatores, tais como os sociais, econômicos, políticos e culturais (SILVA, 2013).

Estudos etnoarqueológicos preocupados com a questão da variabilidade artefatual e sua relação com identidades sociais e fronteiras culturais fornecem as bases para pensarmos no registro arqueológico que estudamos e nos conjuntos de artefatos 
que identificamos. Alguns trabalhos arqueológicos também fornecem uma base teórica e metodológica interessante para pensar esta questão. Gostaríamos de citar o estudo feito por Chilion (1998) com a variabilidade cerâmica de três sítios arqueológicos do período Woodland tardio do nordeste dos EUA, com o objetivo de verificar a relação entre as escolhas técnicas, o contexto histórico e a sociedade. Dois sítios são do vale do rio Connecticut, historicamente habitado por falantes da família linguística Algonquian, e um sítio do vale do rio Mohawk, ocupado pelos falantes Iroquoian, com distinções culturais marcadas: a primeira por maior flexibilidade e mobilidade de grupos pequenos e a segunda por assentamentos grandes e sedentários. Existem evidências de interações entre os grupos dos dois vales desde o período pré-histórico. A autora analisou os atributos, que nesse caso representam as escolhas técnicas, tais como o tipo, tamanho e densidade de inclusão (antiplástico), tratamento de superfície, a localização do caco no pote, a forma da borda, entre outros. Um atributo nesse caso é considerado um aspecto ou variável, cada um tendo um número considerável de possibilidades ou opções técnicas. Foram comparadas as características específicas dos artefatos, visando identificar a variação através de objetos, tendo os vasos como unidades de análise. Chilion (1998) identificou diferenças técnicas e decorativas nas cerâmicas dos sítios das duas regiões: as vasilhas do vale do Connecticut apresentaram maior diversidade de materiais de inclusão na pasta, paredes mais espessas e uma diversidade maior de tipos de tratamentos de superfície em relação à cerâmica do vale do rio Mohawk. Estas diferenças foram interpretadas como decorrentes de escolhas, que são relacionadas à subsistência, assentamento e estrutura social, mais do que a fatores ecológicos ou evolutivos. O vale do Connecticut era habitado pelos grupos falantes Algonquians que são muito móveis e com fronteiras sociais relativamente fluídas, sendo por isso também fluídos os contextos social e ambiental de produção cerâmica, diferente dos Iroquiois do vale do rio Mohawk, sedentários e vivendo em comunidades estruturadas que refletem na maior estabilidade e continuidade na tradição cerâmica, sendo a cerâmica, nesse caso, um bom marcador cronológico e geográfico. As diferenças não se restringem ao meio social e ao contexto de produção, mas também à escala de produção: enquanto entre os Algonquians a produção é doméstica e desenvolvida por um número menor de pessoas, entre os Iroquians a produção se dá em uma escala maior, visível na maior densidade de fragmentos nos sítios arqueológicos, principalmente no período final quando reflete o aumento populacional e consequente aumento pela demanda de cerâmica e maior especialização. Portanto, apesar da interação e acesso a tipos similares 
de informação tecnológica, as escolhas técnicas semelhantes adotadas nas diferentes sociedades possivelmente não possuíam o mesmo significado. Este estudo demonstra que devemos nos voltar para as explicações históricas dos significados da cultura material a fim de entender a complexidade da escolha técnica, pois nem sempre existem vantagens sociais e técnicas lógicas ou óbvias para escolhas específicas (CHILION, 1998).

Ao analisar a aplicabilidade dos conceitos de sistema tecnológico e estilo nas indústrias líticas no sul do Brasil, Dias e Silva (2001, p. 101) chegam a alguns consensos: que a variabilidade dos conjuntos de artefatos líticos é resultante de escolhas tecnológicas determinadas culturalmente; que estas escolhas refletem estilos tecnológicos, os quais residem na escolha dos materiais, técnicas, sequências de produção e nos resultados materiais destas escolhas; e que os estilos tecnológicos podem indicar identidades sociais e culturais na medida em que são o produto de uma tradição cultural. Sendo assim, é possível verificar a diferenciação de grupos culturais através da comparação contextual de conjuntos tecnológicos de uma região, delimitados através das escolhas técnicas que definem os estilos tecnológicos, estes compondo sistemas tecnológicos, que, por sua vez, compõem um sistema cultural mais amplo, desde que sejam utilizados padrões comparativos uniformes focados na variabilidade (entre os conjuntos artefatuais) e na variação (nos conjuntos artefatuais), e com o estabelecimento de cronologias sólidas.

No sul do Brasil, a determinação de unidades histórico-culturais (tradições líticas) através da associação a artefatos-guia, subentendia a existência de unidades sociais distintas, ou seja, de que existiam dois grupos de caçadores-coletores diferenciados associados às tradições Umbu e Humaitá. A continuidade das pesquisas (DIAS, 2003, 2007), através da análise das cadeias operatórias de confecção dos artefatos líticos de diferentes sítios no alto vale do rio dos Sinos, região nordeste do estado do Rio Grande do Sul, permitiu verificar distinções tecnológicas sinalizando fronteiras territoriais entre os grupos que ocuparam a região, entre eles os caçadorescoletores da tradição Umbu e os grupos horticultores, das tradições Taquara e Guarani. Sítios, que anteriormente tinham sido associados à tradição Humaitá, em função da presença dos talhadores, na verdade são áreas de atividade específicas nos sistemas de assentamento dos ceramistas. Vale lembrar que Dias $(1995,2007)$ foi uma das maiores críticas à forma como os conceitos de fase e tradição foram utilizados na arqueologia 
brasileira durante o PRONAPA, cujas pesquisas não incorporaram a discussão teórica destes conceitos que foram sistematizados por Willey e Phillips (1958), principalmente os seus aspectos tecnológicos e contextuais.

Conforme vimos no primeiro capítulo, no alto rio Negro e no alto Xingu, a padronização tecnológica e estilística na cerâmica, e em outros domínios da cultura material, não corresponde a uma homogeneidade linguística e étnica, mas a distribuição de um mesmo tipo de cerâmica entre todos os grupos que compõem estes sistemas regionais, como resultado das interações locais (NEVES, 1999; HECKENBERGER, 2001, 2002, 2005). Entretanto, entendemos que apesar de ser problemática a associação da distribuição da variabilidade na cultura material a fronteiras culturais, é possível relacionar conjuntos artefatuais a identidades sociais e culturais, quando abordadas as escolhas tecnológicas adotadas durante o processo de confecção dos artefatos nos contextos arqueológicos e históricos específicos. Em alguns casos, a utilização conjunta das informações históricas, linguísticas e arqueológicas permite estabelecer relações claras entre conjuntos artefatuais e grupos específicos, como no caso da associação da cerâmica Guarani aos grupos desta matriz cultural. Na Amazônia, esta discussão é mais complexa, apesar dos modelos existentes associarem a cerâmica da tradição Barrancóide aos falantes Arawak e, bem como a cerâmica da tradição Polícroma a falantes do Tronco Tupi. Como diz Heckenberger (2002, p. 107),

Pots may not be people, but they are of people, just like language, and although material culture not naturally or even commonly change in tandem with language, particularly over broad stretches of time and space, we are on solid empirical and theorical ground to say that sometimes it does.

Além disso, o conceito de etnogênese anteriormente apresentado, utilizado para explicar os contextos relacionados às expansões Arawak, compreende etnicidade como em fenômeno dinâmico em que identidades sociais e fronteiras etno-linguísticas seriam continuamente geradas e transformadas. Sendo o rio Madeira indicado como possível rota de expansão de grupos Arawak e Tupi no período pré-colonial (LATHRAP, 1970; BROCHADO, 1984, 1989; NOELLI, 1996; HECKENBERGER 2002; ERIKSEN, 2011; NEVES, 2012), e esta região considerada como sendo de grande diversidade linguística e cultural desde o início do período colonial, temos a hipótese de que a história mais antiga da região é muito mais dinâmica do que inicialmente se imaginou, e buscaremos delimitar tais identidades culturais através da análise da variabilidade 
cerâmica, focada nas escolhas tecnológicas envolvidas em todo o processo de confecção das vasilhas. A seguir, apresentaremos as definições dos atributos analisados.

\subsection{A análise cerâmica: conceituação dos atributos}

Para a compreensão das escolhas tecnológicas foi elaborada uma ficha de análise que contempla atributos que caracterizam a pasta (tipos de antiplástico; tipos de minerais; tamanho, forma e inclusão dos grãos de quartzo), os acabamentos de superfície (barbotina; alisamento fino, médio e grosseiro; polimento; brunidura); tratamentos cromáticos (engobo e pintura); tratamentos plásticos (inciso, roletado, exciso, aplique, modelado etc), queima (coloração da pasta); vestígios de uso (fuligem, depósito de carbono e fermentação são os mais frequentes); estado de conservação (bem conservado; erodido; desgaste de pinturas; etc.) e forma da vasilha através da análise da forma, inclinação e espessamento da borda, forma do lábio, forma e diâmetro da base, diâmetro de abertura da vasilha e quando possível sua estrutura (aberta ou fechada), contorno e altura. A ficha de análise foi formulada a partir dos textos de Shepard (1995), Rice (1987), Orton et al (1997), Chymz (1976), La Salvia e Brochado (1989), Brochado, Monticelli e Neumann (1990), Brochado e Monticelli (1994), Silva (2000), Cerezer (2009), Lima (2008), Machado (2005), Garcia (2010, 2012), Panachuk e Cruz (2010), Dantas e Lima (2006), Neumann (2008, 2010), Zuse (2009), entre outros. ${ }^{19}$ Muitas destas características são melhor identificadas através das técnicas arqueométricas (ALVES, 1998, 2009; GOULART, 2004; APPOLONI et al, 1997, 2004; MUNITA, 2005; CUNHA LIMA, 2010; RIZUTTO, 2009) que não puderam ser contempladas nesta pesquisa.

A curadoria e a análise do material arqueológico foram realizadas no laboratório da Scientia Consultoria Científica, na cidade de Porto Velho, Rondônia, contando com uma equipe de técnicos e de acadêmicos dos cursos de arqueologia e de história da Universidade Federal de Rondônia (UNIR). Inicialmente, os materiais foram triados, separando-se os fragmentos diagnósticos, que são todos aqueles que dão informação sobre as formas (bordas, bases, ombros, carenas, bojo, além de peças modeladas e apêndices), de acabamentos de superfície (superfícies polidas, brunidas, engobos,

\footnotetext{
${ }^{19}$ A ficha foi elaborada a partir da leitura da bibliografia citada e das discussões com Lorena Garcia, Daniel Cruz e Lilian Panachuk, 2010.
} 
acabamentos plásticos e pinturas) e marcas de uso (fuligens, depósito carbônico). Para a maioria dos sítios foram analisados somente os materiais diagnósticos, porém no caso de algumas amostras a erosão intensa dos fragmentos permitiu separar um número muito reduzido de diagnósticos, e nestes casos optou-se por analisar todos os fragmentos (somente as unidades do setor 1 dos sítios Boa Vista e Vista Alegre; e as amostras analisadas dos sítios Foz do Jatuarana e Ilha das Cobras). Os dados da análise foram processados em planilhas e gráficos Excel, a partir de um número mínimo de fragmentos, ou seja, no caso de fragmentos remontados ou que compõem uma mesma vasilha, foram considerados conjuntamente. Para a análise das vasilhas cerâmicas inteiras e semi-inteiras foi elaborada uma ficha individual que permitiu a descrição mais detalhada, porém com os mesmos atributos.

Além das análises das amostras de quatorze sítios arqueológicos, foi realizada uma "triagem qualitativa" do material das unidades não analisadas do sítio Ilha de Santo Antônio. Esta consiste na caracterização dos fragmentos que dão informação da forma das vasilhas (bases inteiras, bordas maiores, franges, apêndices de suspensão) ou decorações (pinturas, incisões, ponteados, apliques), bem como os fusos e demais artefatos, buscando informações adicionais em relação aos conjuntos cerâmicos identificados na análise.

$\mathrm{Na}$ análise dos diferentes tipos de materiais (bolotas de argila, fragmentos de vasilhas, trempes, fusos ou artefatos não identificados), foram verificados atributos que caracterizam a pasta, técnicas de confecção, queima, acabamentos de superfície, formas, vestígios de utilização e estado de conservação. Em alguns fragmentos, não foi possível visualizar a característica referente a algum dos atributos, sendo utilizada a expressão "não identificado" (sigla NI). Foi utilizada a sigla FE para se referir à face externa e FI para a face interna. Os atributos analisados foram os seguintes:

\section{Escolha da pasta}

A escolha da pasta constitui-se em uma etapa importante na cadeia operatória de confecção dos artefatos cerâmicos, influenciando nos demais estágios de sua confecção e utilização (performance). Junto com a argila coletada pelas ceramistas, estão presentes grânulos e grãos de minerais (quartzo, feldspato, mica, óxido de Ferro etc.), os quais podem ser mantidos na pasta, ou parcialmente retirados buscando obter as características desejadas. O cauixí (espícula de esponja de água doce) também pode 
estar misturado com a argila na fonte, porém são necessários estudos sobre este elemento em cada região onde ocorre. O caraipé é uma casca de árvore queimada e adicionada na pasta, portanto é um tempero. O tipo de pasta é uma escolha da ceramista, independente da adição dos elementos (tempero) ou inclusão na argila na fonte. Pode ocorrer a mistura de argilas de fontes diferentes.

Denominamos os elementos não plásticos de "antiplástico" por ser um termo consagrado na arqueologia brasileira, independente da sua adição intencional ou não. Além de verificar os tipos de antiplástico em cada fragmento (alguns apresentam somente mineral, outros mineral e caraipé, mineral e cauixí e outras associações), foram analisados separadamente os tipos de minerais (quartzo, feldspato e óxido de ferro são os mais comuns), bem como o tamanho, forma e quantidade de grãos de quartzo na pasta. No entanto, esta última variável foi considerada com ressalvas por não terem sido feitas lâminas microscópicas.

\section{Queima:}

Vários fatores influenciam no tipo de queima, entre eles a temperatura, o combustível utilizado, o tipo de forno, a atmosfera que circunda o vasilhame, a quantidade de ar disponível. Analisamos a queima através da coloração dos fragmentos: quanto mais oxidante é a queima (quantidade suficiente de oxigênio ao combustível), mais claras são as cerâmicas, enquanto ambientes redutores (quantidade insuficiente de oxigênio) produzem cerâmicas com tonalidades escuras, geralmente cinza a preta.

Além da queima oxidante (núcleos claros) e reduzida (núcleos escuros), são encontradas variações intermediárias: oxidante interna/ reduzida externa; oxidante externa/ redutora interna; oxidante com núcleo reduzido; reduzida com núcleo reverso (núcleo oxidante). Nas queimas a céu aberto, comuns entre as comunidades indígenas, podem ocorrer microambientes, com ambientes oxidantes e redutores em uma mesma queima, produzindo variações na coloração da pasta de uma mesma vasilha. A coloração da pasta é também alterada por diversos fatores como a composição da argila, a qualidade e quantidade do antiplástico, o posicionamento do pote na fogueira, entre outros.

\section{Técnicas de confeccão:}

Nos conjuntos analisados, as vasilhas são confeccionadas com as técnicas acordelada, modelada e raramente em placas. Em geral, apenas alguns tipos de bases 
(anelares, em pedestal, plano côncavas), flanges e apêndices (alças, asas, trípodes) são confeccionados com a técnica modelada, enquanto o corpo da vasilha é elaborado com a técnica acordelada. $\mathrm{O}$ acordelado consiste na sobreposição de cordões (roletes) de argila (a partir de uma base modelada ou não), produzindo fragmentos com formato retangular, quadrangular, triangular e losangular quando a quebra coincide com as terminações dos roletes. Quando a peça é confeccionada a partir da manipulação de uma porção de argila com os dedos, e a quebra produz fragmentos disformes no corpo e borda, ou regulares no caso de uma base modelada, que terá forma circular compacta, chamamos a técnica de modelada. Na confecção por placas, são utilizadas porções retangulares ou quadradas de argila, e as quebras geralmente possuem o formato original da placa. Em alguns casos, as placas são utilizadas como reforço e aplicadas sobre a superfície (interna ou externa) da vasilha. Algumas vasilhas, que não são necessariamente confeccionadas com placas, quando possuem paredes espessas e são mal queimadas, apresentam "desplacamento" de porções de argila. A técnica de radiografia por raios- $X$ pode ser utilizada no estudo da estrutura interna das peças, especialmente as inteiras, porém não foi utilizada neste trabalho.

\section{Acabamentos de superfície (face interna e face externa):}

O processo de acabamento das superfícies de uma vasilha começa durante o alisamento para a junção dos roletes, placas ou na modelagem. Após esse procesimento, pode ser feito um alisamento mais elaborado, a aplicação da barbotina, engobo, polimento, brunidura, pintura ou tratamentos plásticos. Não faremos a distinção entre acabamentos decorativos e funcionais, pois alguns como o polimento, engobo e brunidura, podem ter apelo tanto decorativo como funcional.

Alguns acabamentos envolvem a passagem ou fricção de algum instrumento na superfície. O alisamento pode ser grosseiro (presença de rugosidades, porosidade e irregularidade da superfície), médio (superfície porosa, porém regular) e fino (textura lisa e homogênea, sem poros visíveis). Quando a ceramista pretende deixar a superfície brilhosa, utiliza um instrumento (seixo ou semente), produzindo superfícies polidas (técnica de polimento). Em algumas vasilhas, são produzidas superfícies escuras (pretas) através da impregnação de fuligem seguida de polimento (brunidura). Quando não é aplicado o polimento sobre a fuligem (ausência de brilho), alguns arqueólogos denominam de esfumarado. Porém, nesse trabalho, utilizamos o termo brunidura para 
denominar a técnica de escurecimento das superfícies, com ou sem a aplicação de polimento. A queima e o uso da vasilha podem produzir manchas e superfícies escurecidas, sendo necessário distingui-las da brunidura, na medida do possível.

A barbotina consiste na aplicação de uma camada de uma pasta refinada na superfície da vasilha, conferindo maior resistência à peça e a diminuição da porosidade. Portanto, possui um caráter funcional, não decorativo. Entretanto, apesar de não ser aplicada com a intenção de dar cor à peça (como no caso do engobo), algumas barbotinas contêm elementos minerais que a deixam com uma coloração vermelha ou laranja. $\mathrm{O}$ que a diferencia do engobo é a espessura da camada, por ser uma pasta com argila.

Denominamos engobo a aplicação de pigmentos em toda a superfície da vasilha, e geralmente ocorre nas cores vermelha ou branca e, muitas vezes, são utilizados como base para aplicação das pinturas. A pintura é a aplicação de pigmentos diretamente sobre a superfície ou sobre o engobo, e diferencia-se deste por formar motivos e padrões, possuir contorno ou preencher áreas delimitadas, enquanto o engobo recobre toda a superfície. Ambos podem ser aplicados antes ou depois da queima.

Os tratamentos plásticos causam a modificação tridimensional da superfície da vasilha, antes da queima. Os mais comuns nas coleções analisadas são o inciso (fino ou largo), ponteado (tem como expressão decorativa "o ponto", podendo ser de várias formas e tamanhos, de acordo com o instrumento utilizado), exciso (diferencia-se do inciso por produzir um efeito de baixo e alto relevo), acanalado (sulcos alongados ou canais, contínuos e de fundo côncavo), entalhado (entalhes feitos com instrumento cortante, geralmente nos lábios ou pontos angulares do corpo das vasilhas), escovado (utilização de um instrumento com pontas múltiplas), roletado (presença de rolete, mantido do processo de confecção da vasilha, ou elaborado com a retirada de uma parte da argila com um instrumento de corte, geralmente na face externa da borda, junto ao lábio). Ocorrem também apliques (formas geométricas ou figurativas modeladas e posteriormente aplicadas à superfície da vasilha), modelados (porções de argila da própria vasilha modeladas de modo a produzir saliências com diferentes formatos, geralmente nos lábios e flanges). Nos conjuntos analisados, são raros os ungulados (sessão semicircular produzida com a unha ou outro instrumento com formato semelhante) e serrungulados (ação de dois dedos em forma de pinça). 
As pinturas e alguns tratamentos plásticos (inciso, exciso, acanalado, apliques) formam motivos e padrões. Os motivos são formados por elementos ou traços decorativos (traços, esferas, escadas, triângulos, retângulos, pontos, círculos, semicírculos, linhas sinuosas etc.). Quando os motivos se repetem, formam padrões decorativos. Os motivos podem ser geométricos ou figurativos (naturalistas). Os motivos podem ser simples (retilíneos ou curvilíneos), compostos (dois elementos retilíneos, dois elementos curvilíneos, ou um elemento curvilíneo e um retilíneo) ou complexos (abrangem vários elementos e motivos decorativos); os motivos complexos figurativos representam a forma humana ou animal.

Nas coleções analisadas, são comuns as linhas horizontais (paralelas à borda da vasilha, de forma isolada ou sequencial), as linhas transversais oblíquas (em posição transversal em relação à borda da vasilha, isolada ou sequencial) e o motivo escalonado (representado pela forma de escada). Ocorrem também as linhas verticais (em posição vertical em relação à borda, geralmente sequenciais), as linhas retas entrecruzadas, o motivo triangular (duas linhas transversalmente opostas formando um ângulo agudo), angular ou grega (linhas que formam ângulos), ondular (linhas levemente onduladas), curvilíneo (forma circular ou elíptica, isolados ou concêntricos), em espiral, em ziguezague e o trançado ou cestaria (combinação de linhas verticais e transversais não sobrepostas). São comuns motivos compostos por mais de um elemento geométrico (combinação de motivos geométricos curvilíneos e retilíneos horizontais e/ou verticais) e complexos (motivo composto por diversos elementos geométricos e/ou desenhos figurativos, que podem estar associados à forma humana ou animal).

\section{Forma das vasilhas:}

A forma da vasilha foi analisada através da identificação das suas partes (bordas, bojos, carenas, pescoços, bases) e da caracterização das bordas e bases. As bordas foram analisadas em relação à forma e inclinação (extrovertida, introvertida, direta vertical, direta inclinada externamente, direta inclinada internamente, extrovertida com ponto angular), espessamento (linear, contraída, expandida, reforçada externamente, reforçada internamente), tipo de lábio (arredondado, plano, biselado ou irregular no caso de não ser definida a forma) e diâmetro de abertura (foram medidas bordas com mais de $7 \%$ da boca da vasilha, e raramente com porcentagens menores). As bases foram analisadas em relação à forma que apresenta na face externa e interna (convexa côncava; planocôncava; côncava convexa; bi-plana; convexa plana; côncava plana, anelar e em 
pedestal) e da medida do diâmetro, quando o tamanho e forma permitem. Em geral, as vasilhas apresentam boca circular, com exceção de algumas com boca oval, irregular ou não identificada em função da fragmentação (possibilidade de ser retangular ou quadrangular). Foram desenhadas as formas das vasilhas inteiras e as bordas com a inclinação e diâmetro, porém não foram reconstituídas as formas das vasilhas a partir dos fragmentos de borda, em função da grande fragmentação e da falta de uma coleção de referência para a região. Além disso, há uma grande variação nos tipos de bases o que dificulta a reconstituição total da forma. Por isso, o contorno da vasilha apenas pôde ser inferido quando apresentou um fragmento indicando todo o seu perfil (o contorno da vasilha pode ser simples, composto, infletido ou complexo), bem como a estrutura (vasilhas abertas ou não restringidas com o diâmetro da boca igual ou maior que o diâmetro máximo da vasilha e vasilhas fechadas, restringidas ou de boca ampliada quando o diâmetro da boca igual ou maior que o diâmetro máximo da vasilha).

\section{Parte da vasilha:}

A análise da parte da vasilha fornece informações importantes com relação à sua forma. Além das bordas, paredes e bases, presentes em todos os conjuntos, em alguns ocorreram bojos, pescoços ou gargalos, flanges labiais ou mesiais, trípode e apêndices de suspensão (asas e alças) ou partes não identificadas (NI). Fragmentos do corpo/parede da vasilha com dobras, curvas e inclinações (pontos de tangência, pontos de inflexão e pontos angulares reentrantes), para os quais não foi possível afirmar o tipo (bojo, pescoço, carena) foram chamados genericamente de inflexões.

\section{Vestígios de utilizacão:}

Os vestígios de utilização mais recorrentes estão presentes em vasilhas utilizadas diretamente sobre o fogo (panelas), sendo a fuligem (acúmulo de fuligem na face externa, geralmente no bojo e na borda), o depósito de carbono (acúmulo no fundo da vasilha) e a redução ou oxidação da base. Também ocorreram marcas de fermentação na face interna (pincipalmente no pescoço) e reciclagem ou reutilização de fragmentos cerâmicos (possíveis adornos e fusos).

\section{Estado de conservação:}

O estado de conservação dos fragmentos depende das características do registro arqueológico (tipo de sedimento, umidade etc), antiguidade (em geral cerâmicas de 
ocupações mais antigas encontram-se mais erodidas) e do modo e local como foram descartados pelos grupos. Fragmentos com as superfícies bem conservadas possibilitam a observação dos acabamentos de superfície, técnicas de confecção, vestígios de utilização e formas das vasilhas, enquanto fragmentos erodidos e fragmentados fornecem informações sobre a escolha da pasta e queima. A conservação dos fragmentos foi analisada com as seguintes categorias: bem conservados, erodidos, com uma das superfícies ausentes, com decoração vestigial (desgaste de pinturas), com crosta de sedimento, marcas de raízes ou rolados pelo rio.

Foi elaborada uma ficha de análise (tabela 3) com os atributos descritos acima. Após a análise, os dados foram digitados em planilhas Excel e, posteriormente, sistematizados na forma de tabelas e gráficos, sendo feitas correlações entre os atributos (forma, acabamentos de superfície, pasta e vestígios de utilização). Posteriormente, foi realizada a comparação entre os conjuntos dos diferentes sítios, buscando estabelecer as semelhanças e diferenças entre as cerâmicas e suas possíveis relações. Dessa forma, foi possível avançar na interpretação das ocupações de cada sítio (sendo detectados conjuntos diferentes no caso de sítios multicomponenciais e mudanças tecnológicas em sítios unicomponenciais), bem como relacionar as cerâmicas e contextos dos diferentes sítios. Tendo em vista a dificuldade na interpretação dos contextos evidenciados em campo, em função da dificuldade de diferenciar as ocupações em pacotes aparentemente homogêneos, optamos por analisar as coleções sem estabelecer critérios prévios de diferenciação de conjuntos tecnológicos, que, entretanto, foram delimitados a partir do processamento dos dados da análise. No capítulo 4, serão apresentadas as análises cerâmicas de cada sítio, e no capítulo 5 serão feitas as correlações entre os conjuntos, as tradições e as fases definidas para a Amazônia e para a região de Rondônia, a fim de verificar se os dados obtidos corroboram ou não com as pesquisas anteriores e com a hipótese desta pesquisa, de que a variabilidade nos conjuntos expressa à diversidade cultural presente na região no período pré-colonial. 
Tabela 3: Ficha de análise com as variáveis analisadas para cada fragmento ou conjunto de fragmentos de um memso artefato (frente e verso)

\begin{tabular}{|c|c|c|c|c|c|c|c|c|c|c|c|c|c|c|c|c|c|c|c|c|c|}
\hline Sítio & NP & 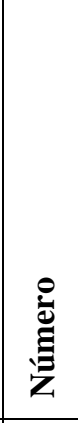 & Sondagem & 离 & 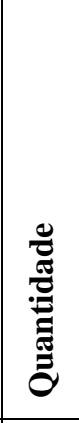 & 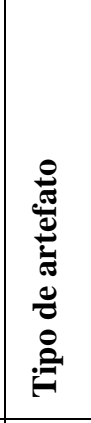 & 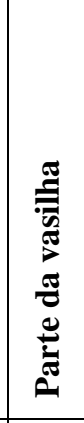 & 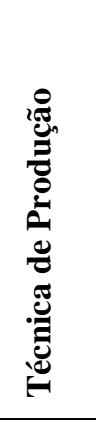 & 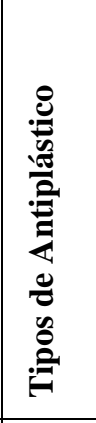 & 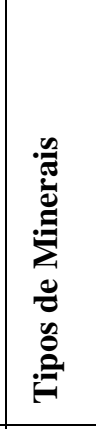 & 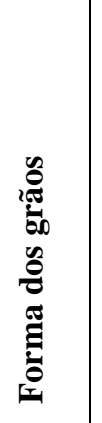 & 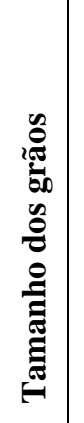 & 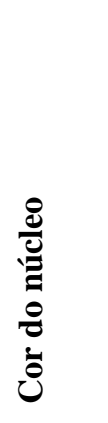 & $\begin{array}{l}\frac{\pi}{\underline{m}} \\
\frac{\bar{z}}{\partial}\end{array}$ & 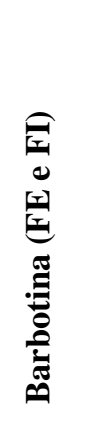 & 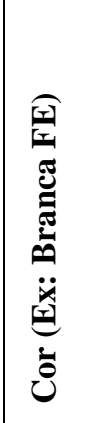 & 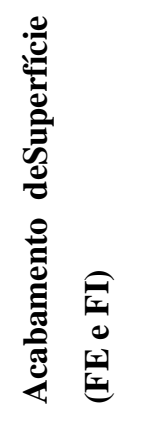 & 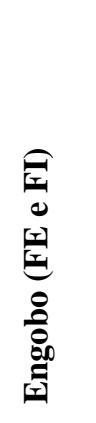 & 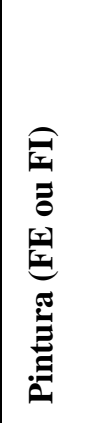 & 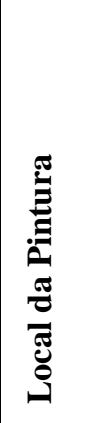 & 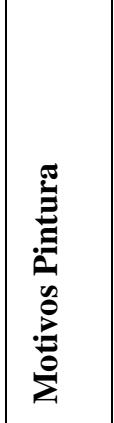 \\
\hline & & & & & & & & & & & & & & & & & & & & & \\
\hline & & & & & & & & & & & & & & & & & & & & & \\
\hline
\end{tabular}

\begin{tabular}{|c|c|c|c|c|c|c|c|c|c|c|c|c|c|c|c|c|c|c|}
\hline 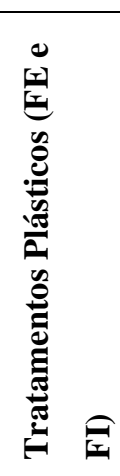 & 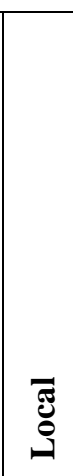 & 总 & 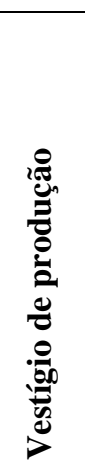 & 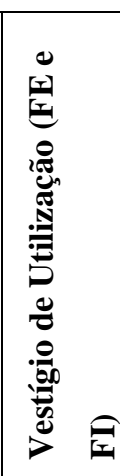 & 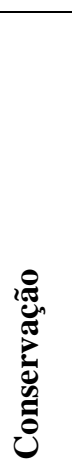 & 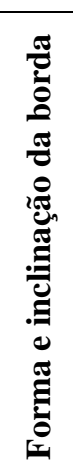 & 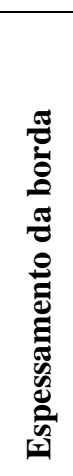 & 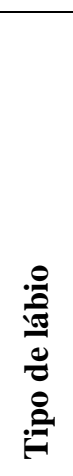 & 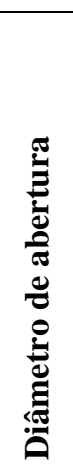 & 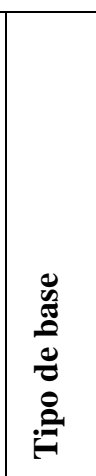 & 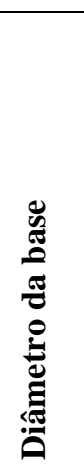 & 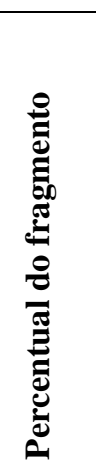 & 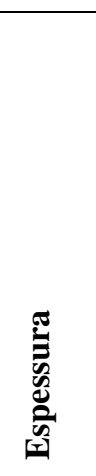 & 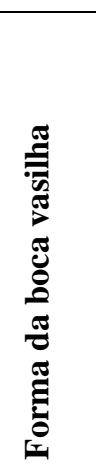 & 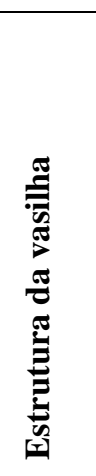 & 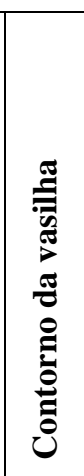 & 吾 & Observaç̄es \\
\hline & & & & & & & & & & & & & & & & & & \\
\hline & & & & & & & & & & & & & & & & & & \\
\hline
\end{tabular}




\section{Capítulo 4- Análise da variabilidade cerâmica no Alto rio Madeira}

Neste capítulo apresentamos o estudo da variabilidade cerâmica na região do alto rio Madeira. Através da análise de amostras de cerâmica de quatorze sítios arqueológicos, buscamos estabelecer as semelhanças e diferenças tecnológicas entre os conjuntos cerâmicos e dessa forma pensar nos significados históricos e culturais das ocupações na área. Foram selecionadas amostras de tamanhos variados para os diferentes sítios, permitindo-nos aprofundar na interpretação de contextos intra-sítio quando os dados são mais abundantes, ou apenas elaborar comparações entre os diferentes sítios no caso das amostras menores.

Tabela 4: amostras de cerâmica analisadas.

\begin{tabular}{|c|c|c|c|}
\hline \multicolumn{2}{|r|}{ Sítio } & \multicolumn{2}{|c|}{ Cerâmica analisada } \\
\hline & & Fragmentos & Vasilhas inteiras e semi-inteiras \\
\hline 1. & Ilha de Santo Antônio & 3.077 & 4 \\
\hline 2. & Sítio Veneza & 1.137 & - \\
\hline 3. & Brejo & 1.235 & 3 \\
\hline 4. & Morro dos Macacos I & - & 8 \\
\hline 5. & Foz do Jatuarana & 148 & - \\
\hline 6. & Boa Vista & 360 & - \\
\hline 7. & Vista Alegre & 1.720 & - \\
\hline 8. & Santa Paula & 3.305 & - \\
\hline 9. & Teotônio & 465 & 3 \\
\hline 10. & Ilha São Francisco & 196 & - \\
\hline 11. & Ilha das Cobras & 351 & - \\
\hline 12. & Ilha do Japó & 572 & - \\
\hline 13. & Coração & - & 10 \\
\hline \multirow[t]{2}{*}{14.} & Ilha Dionísio & 2.881 & 13 \\
\hline & TOTAL & 15.447 & 41 \\
\hline
\end{tabular}

\subsection{Cerâmica do sítio Ilha de Santo Antônio}

Foram triados 56.556 fragmentos cerâmicos do sítio Ilha de Santo Antônio, sendo selecionados 10.221 diagnósticos, dos quais foram analisados 3.077 fragmentos, das unidades N970 E840, N939 E880, N990 E850, N990 E849, N990 E851 e N959 E84, além de três vasilhas remontadas parcialmente $(\mathrm{R} 2, \mathrm{R} 3, \mathrm{R} 4)$, provenientes do setor amplo de escavação 
com máquina. Nas unidades contíguas N990 E849, N990 E850 e N990 E851 foi evidenciada a vasilha R1; a unidade N959 E841 foi escavada no centro da mancha de terra preta; a N939 E880 mais a sul da mancha de terra preta onde o pacote é menos espesso; e a N870 E840 no local onde a camada arqueológica encontrava-se enterrada pela ação fluvial. Além da análise desta amostra, fizemos uma triagem qualitativa dos fragmentos das demais unidades escavadas no sítio, caracterizando-os em relação às características da forma das vasilhas (fragmentos maiores), tratamentos de superfície (principalmente pintura e tratamento plástico) e marcas de uso. Neste procedimento foram selecionados 647 fragmentos, sendo 59 bordas, 160 bases, 7 franges, 365 decorados e 56 outros com características variadas (carenas, fusos, apêndices de suspensão, cerâmica com furo, reciclagem, engobo e outros), os quais foram fotografados e alguns desenhados. Com isso obtivemos resultados qualitativos que permitiram entender a distribuição dos materiais nas diferentes áreas do sítio e na estratigrafia.

Desde o início da análise da cerâmica deste sítio, intrigava-nos a ocorrência de vasilhas pintadas em vermelho e branco, que possivelmente estariam associadas à Tradição Polícroma da Amazônia, conjuntamente com fragmentos com incisões e modelados que destoam das características desta tradição, ao passo que os trabalhos de campo não identificaram diferenças na estratigrafia e nas áreas do sítio que pudessem sugerir mais de uma ocupação, mas somente uma camada de terra preta sobre o latossolo amarelo. A análise dos dados buscará entender os processos de permanências e mudanças tecnológicas neste sítio ou mesmo diferenças que caracterizem conjuntos tecnológicos distintos, no caso do sítio ser multicomponencial. Em algumas unidades do sítio o material está distribuído em duas concentrações maiores ao longo da estratigrafia (unidades analisadas N990 E849 e N870 E840 e unidades triadas N100 E922, N922 E849, N922 E850, N979 E880, N980 E849, N987 E849 e N988 E849), enquanto em outras (N959 E841, N990 E850 e N990 E851 e demais unidades triadas) estão distribuídos em apenas uma concentração. Portanto, na área nordeste do sítio as duas concentrações na estratigrafia poderiam indicar duas ocupações.

\subsubsection{Análise da cerâmica das unidades N870 E840, N939 E880, N990 E850, N990 E849, N990 E851 e N959 E841}

Analisamos 3.072 fragmentos de vasilhas e cinco fusos das seis unidades do sítio Ilha de Santo Antônio. Em função dos das remontagens de fragmentos e de conjuntos de uma mesma vasilha, trabalhamos com um número de 2.855 fragmentos, a maioria deles bem conservada, com exceção da pintura e engobo que em muitos deles estão desgastados 
(decoração vestigial). As ceramistas da ilha de Santo Antônio escolheram preferencialmente uma argila com poucos grãos minerais de tamanho fino, ou retiraram os grãos maiores para obter uma pasta com estas características, adicionando o caraipé na maioria das vasilhas. Predominam pastas com grãos de quartzo arredondados e subangulosos, e apenas 181 fragmentos possuem grãos angulosos. Em 1.709 fragmentos $(59,86 \%)$ foi identificado mineral e caraipé e em 1.063 (37,23\%) ocorre mineral, caraipé e carvão, ao passo que o mineral aparece isolado em apenas 55 fragmentos (1,93\%) e o cauixí está presente em apenas 15 fragmentos (gráfico 4). O quartzo geralmente está associado ao óxido de Ferro e ao Feldspato, e apenas 20 fragmentos possuem mica na pasta. Foi verificada uma continuidade no uso de todos os tipos de pasta nos níveis das unidades e nas diferentes partes do sítio e não foram identificadas recorrências entre tipos de vasilhas e tipos de pastas.

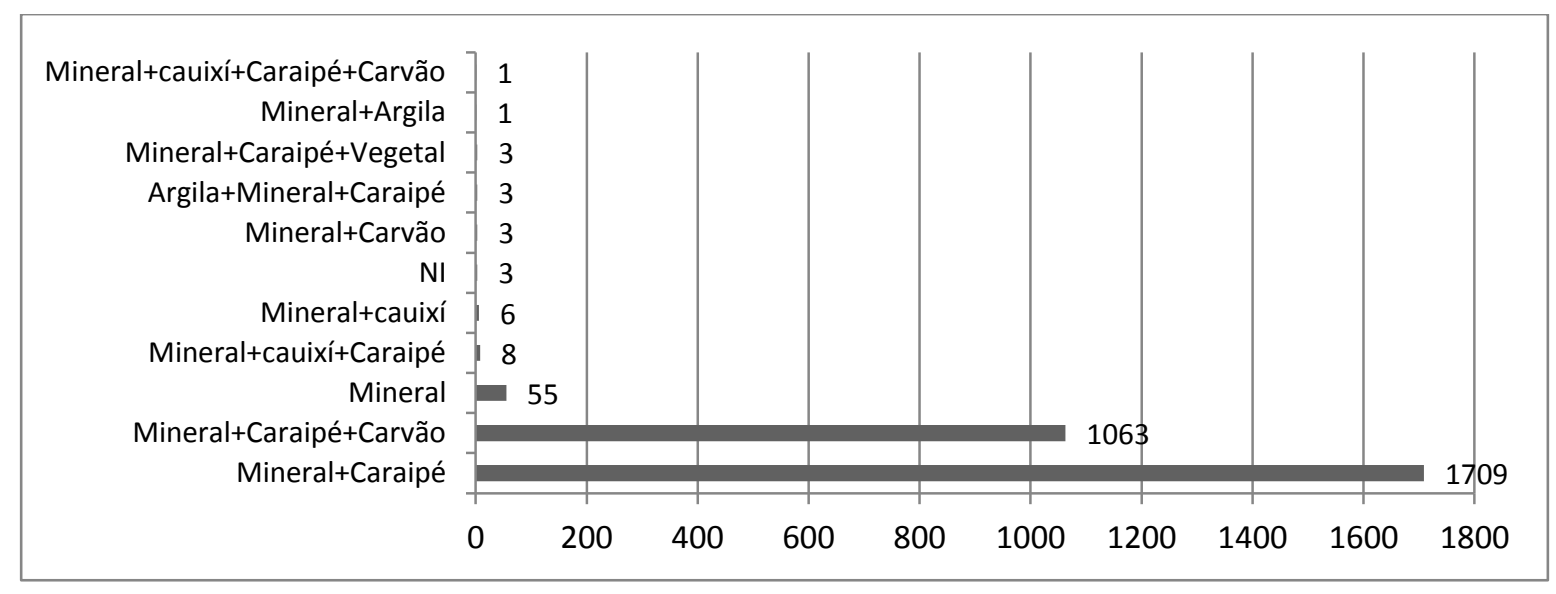

Gráfico 4: escolha da pasta- sítio Ilha de Santo Antônio.

Ocorrem tanto núcleos escuros (queima reduzida) quanto claros (queima oxidante) em proporções semelhantes, e poucos fragmentos com variações (gráfico 5). As vasilhas eram confeccionadas com a sobreposição de roletes de argila (2.595 fragmentos), com exceção de algumas bases, flanges e apêndices de suspensão que foram modelados (122 fragmentos), e em 181 fragmentos a técnica não foi identificada. 


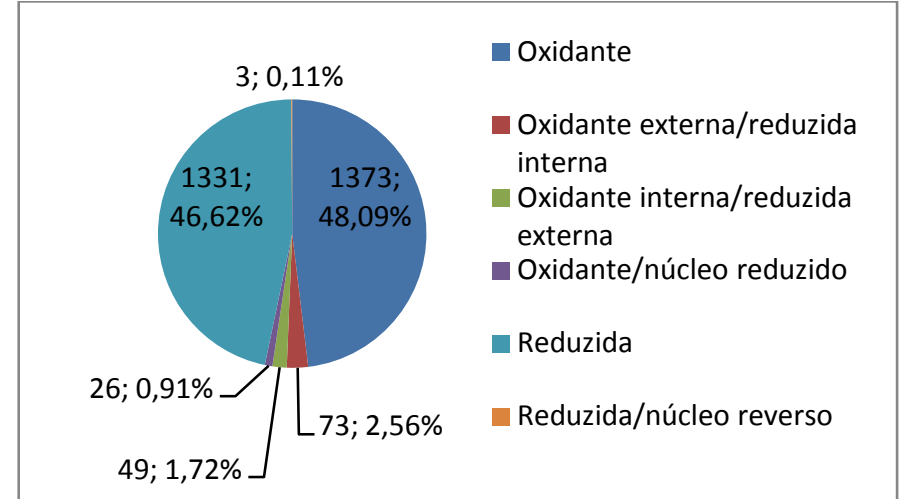

Gráfico 5: Variações da queima - sítio Ilha de Santo Antônio.
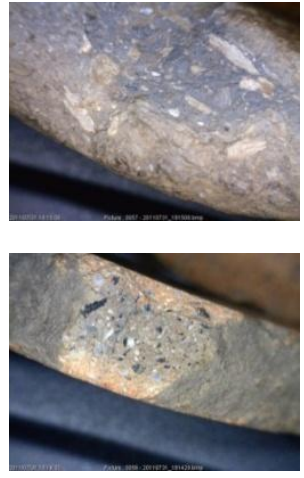

Fotografias 82 e 83: pasta caraipé; e caraipé e carvão (SCIENTIA, 2011).

As superfícies da maioria das vasilhas são polidas ou bem alisadas em ambas as faces, ocorrendo também a brunidura e raramente os alisamentos grosseiros e médios. $\mathrm{O}$ alisamento fino e/ou polimento é uma característica importante na coleção, podendo ter um objetivo prático/funcional (deixar a superfície regular; omitir marcas de roletes; deixar a vasilha menos porosa) ou artístico (proporcionar brilho) (gráfico 6). Observa-se que muitas vasilhas possuem as paredes irregulares, porém polidas.

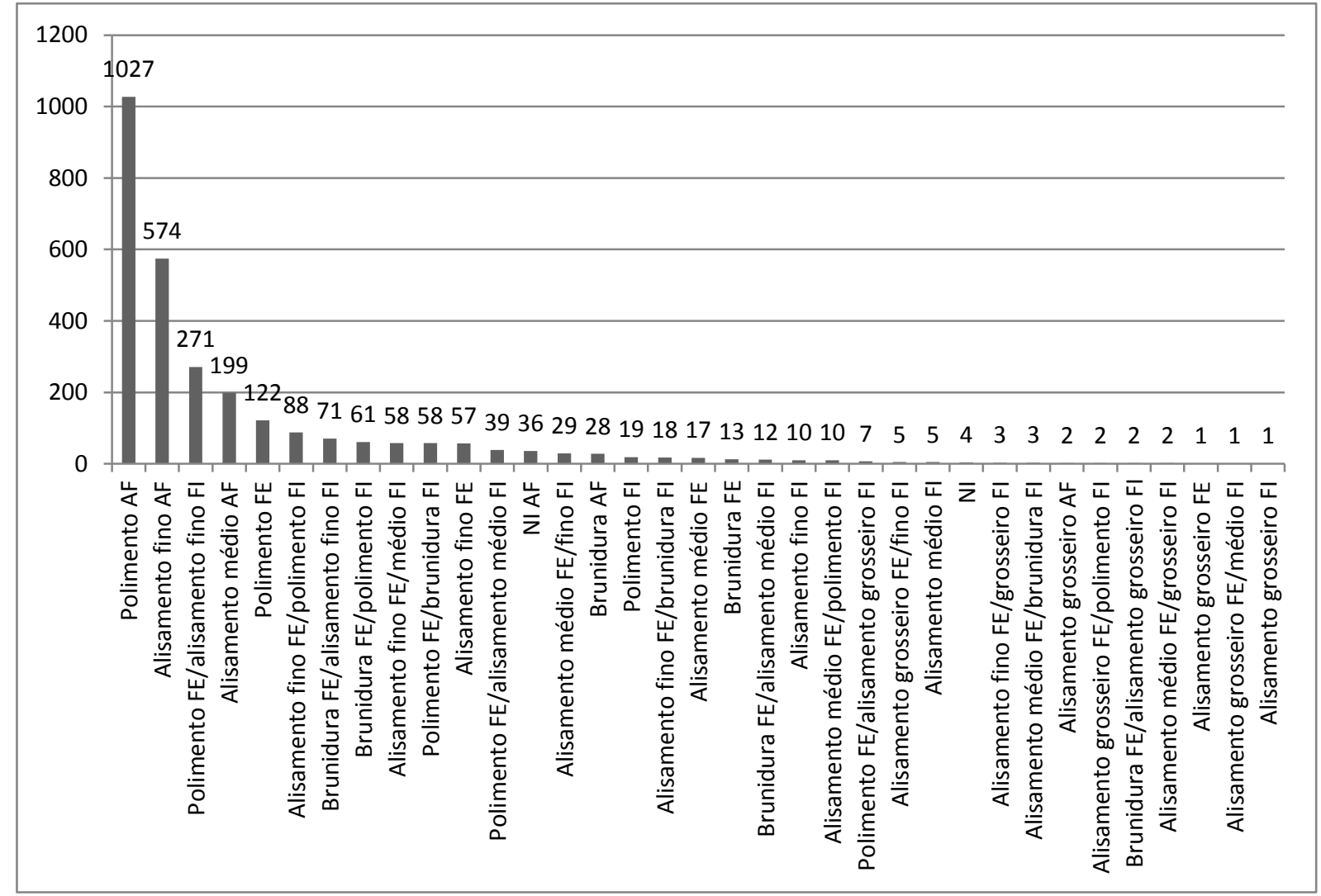

Gráfico 6: acabamentos de superfície dos fragmentos- sítio Ilha de Santo Antônio. 
O engobo está presente em 522 fragmentos (18,28\%), não pôde ser identificado em 103 fragmentos $(3,61 \%)$ devido ao desgaste das peças e nos demais está ausente (2.230; $78,11 \%$ ). No material desse sítio encontramos dificuldade em distinguir o engobo (camada fina de pigmento) da barbotina (camada fina de argila). As colorações do engobo são as seguintes: vermelho FE (201); vermelho FI (134); vermelho AF (139), vinho FE (9); vinho FI (2); vinho FE e vermelho FI (1), vinho AF (1), vermelho Fe e laranja FI (1), laranja FE (13), laranja FI (9), laranja AF (4), branco FE (7) e branco FI (1). Já a barbotina está presente em $1.738(60,87 \%)$ fragmentos, enquanto nos demais não foi identificada $(714 ; 25,1 \%)$ ou está ausente $(403 ; 14,12 \%)$. As cores mais frequentes são a marrom, laranja e bege, mas também ocorre nas cores rosada, vermelha e cinza. Observamos que nas vasilhas com muito caraipé na pasta a barbotina pode ter uma função importante de tornar a superfície mais apta ao alisamento ou polimento (evitando a pulverização do elemento vegetal), e menos porosa e suscetível à abrasão durante o uso.

Entre os fragmentos analisados a pintura ocorre em apenas 20 fragmentos $(0,70 \%)$, enquanto em 58 (2,03\%) não pôde ser identificada e em 2277 (92,27\%) está ausente. Ocorrem na parede (13), inflexão (4) e borda (3), nas seguintes cores: vermelha FE (9); vermelha em ambas as faces (1); branca e vermelha FE (7); branca e vermelha AF (1); branca sobre vermelho FE (1) e branca FE (1). Os motivos na maioria dos casos não puderam ser identificados, com exceção de quatro deles que são linhas horizontais (possivelmente não correspondem à totalidade do motivo). Os fragmentos com pintura ocorrem entre os níveis 010 e 60-70 cm, e como estão muito erodidas, não é possível distinguir aquelas dos níveis mais profundos e dos níveis mais superficiais, mas são frequentes as faixas largas (Figura 66). 


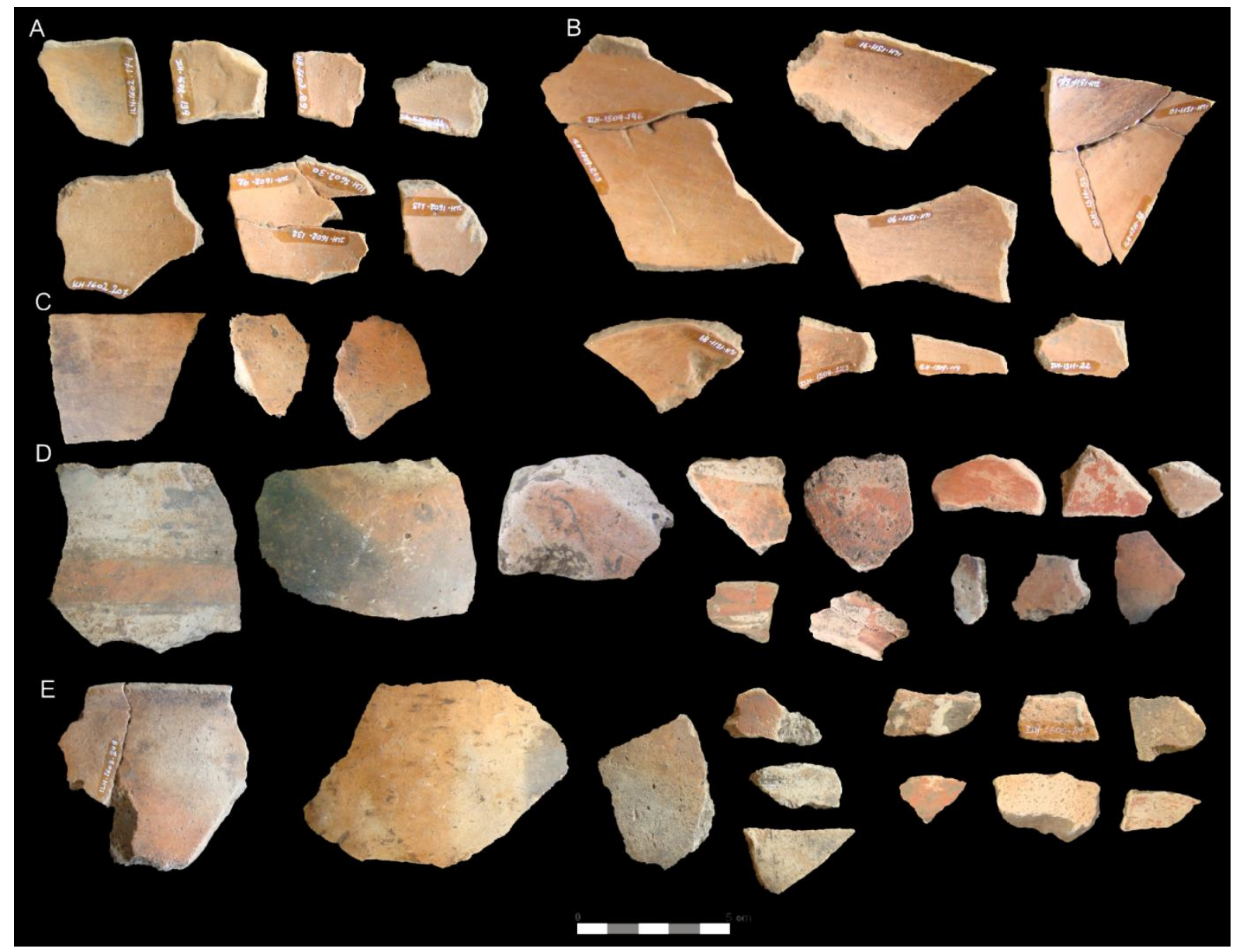

Figura 66: Fragmentos com engobo e pintura- Ilha de Santo Antônio (Fotos: SCIENTIA, 2011, 2012).

Os tratamentos plásticos são mais frequentes que as pinturas, estão presentes em 151 fragmentos $(5,39 \%)$. Predominam os incisos, roletados e modelados, mas também ocorrem apliques, escovados, ponteados, acanalado, inciso e ponteado, exciso, entalhado, serrungulado (gráfico 7). Foram feitos predominantemente nas bordas e paredes das vasilhas, possivelmente no bojo superior conforme pôde ser observado em alguns fragmentos maiores. As incisões ocorrem predominantemente nas paredes e nas bordas, o roletado na face externa das bordas junto ao lábio e o modelado no lábio (bicos ou formas retangulares e onduladas). Aparecem entre os níveis $0-10 \mathrm{~cm}$ e $70-80 \mathrm{~cm}$, e não foi possível perceber recorrências de tratamentos plásticos em níveis específicos. Em relação aos motivos, no caso dos incisos e acanalados predominam as linhas horizontais paralelas, mas também ocorrem alguns fragmentos com linhas curvilíneas, entrecruzadas ou em zigue-zague e motivos compostos ou complexos. Os modelados ocorrem junto ao lábio formando uma saliência alongada (bico) ou arredondada, com exceção de um deles em filete na face externa da parede (pode ser um aplique) e um com forma escalonada. Os apliques são arredondados (esfera), em alguns casos com incisões que os delimitam e um ponteado no centro. Quando ocorrem aos pares podem ser interpretados 
como olhos (representação figurativa zoomorfa). Ocorrem diferentes técnicas na elaboração das incisões, com instrumentos pontiagudos e finos ou de sessões maiores, quadrangulares e arredondadas, que produzem linhas finas e largas (assemelhando-se a uma excisão), feitas com a pasta mais mole ou mais seca (Figuras 67 e 68).

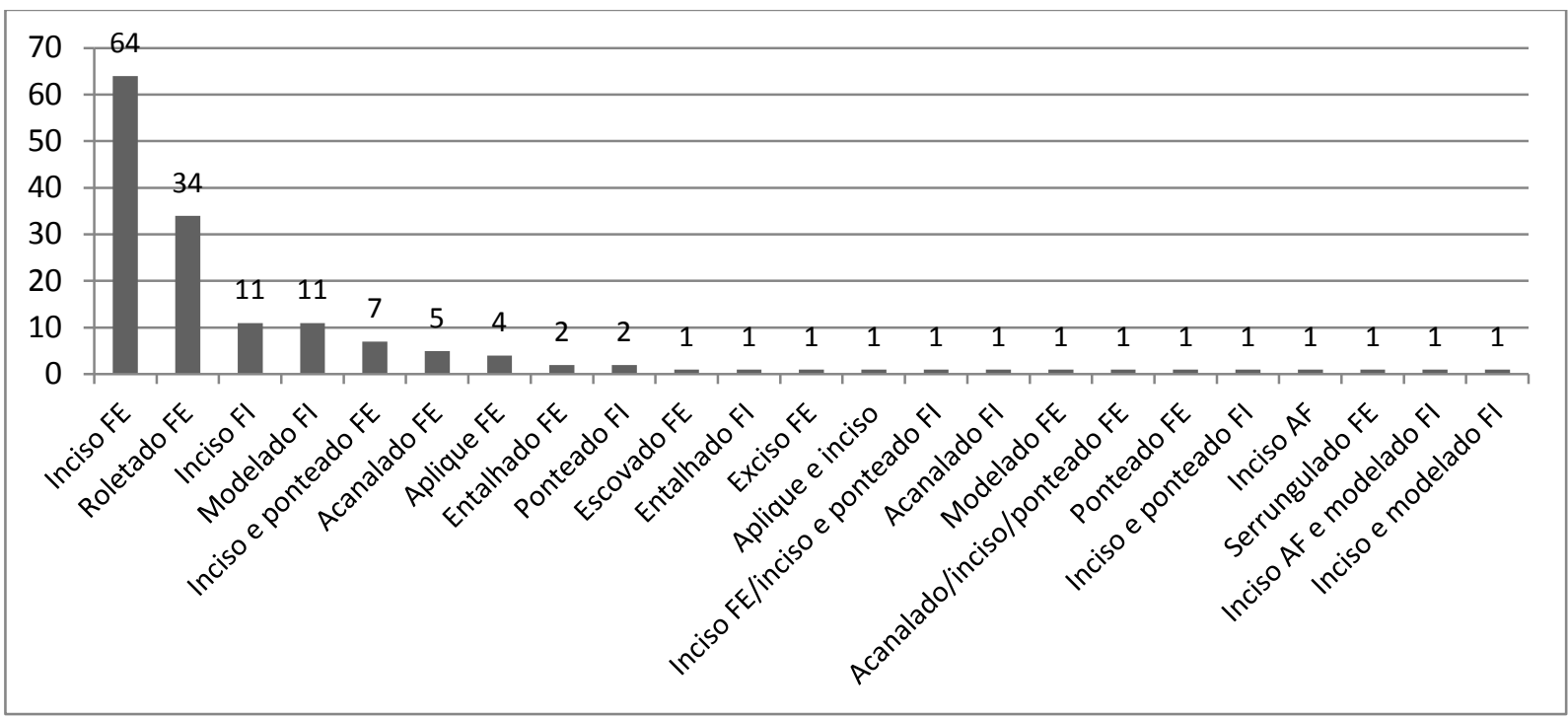

Gráfico 7: tratamentos plásticos - Ilha de Santo Antônio.

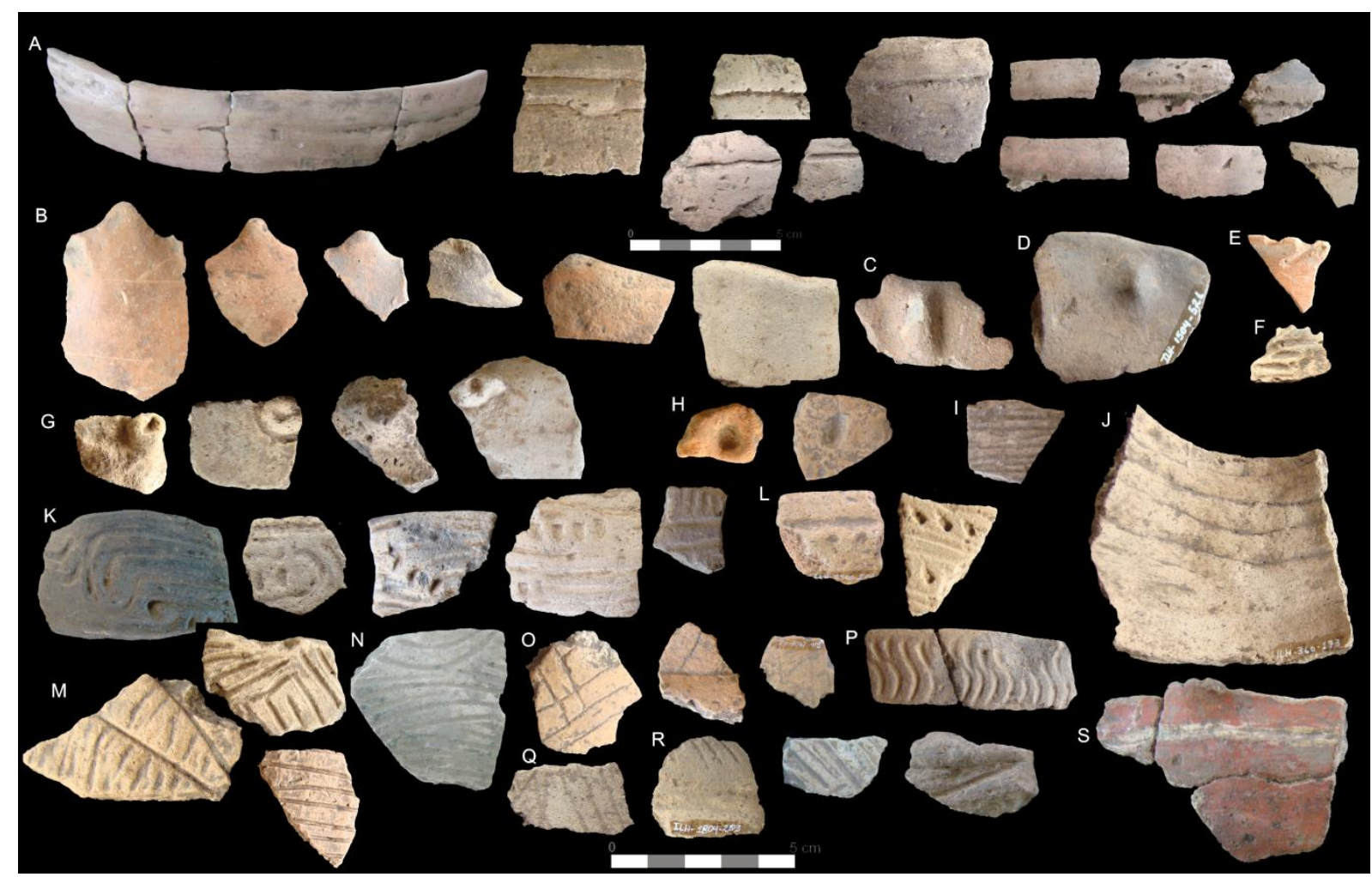

Figura 67: tratamentos plásticos: roletado (A, J)), modelado (B-D), entalhado (E), modelado e inciso (F), aplique (G), NI (H),inciso (I, M, N, O, P, Q), inciso e ponteado (K, L), inciso e pintado (S) - Ilha de Santo Antônio (Fotos: SCIENTIA, 2011, 2012). 


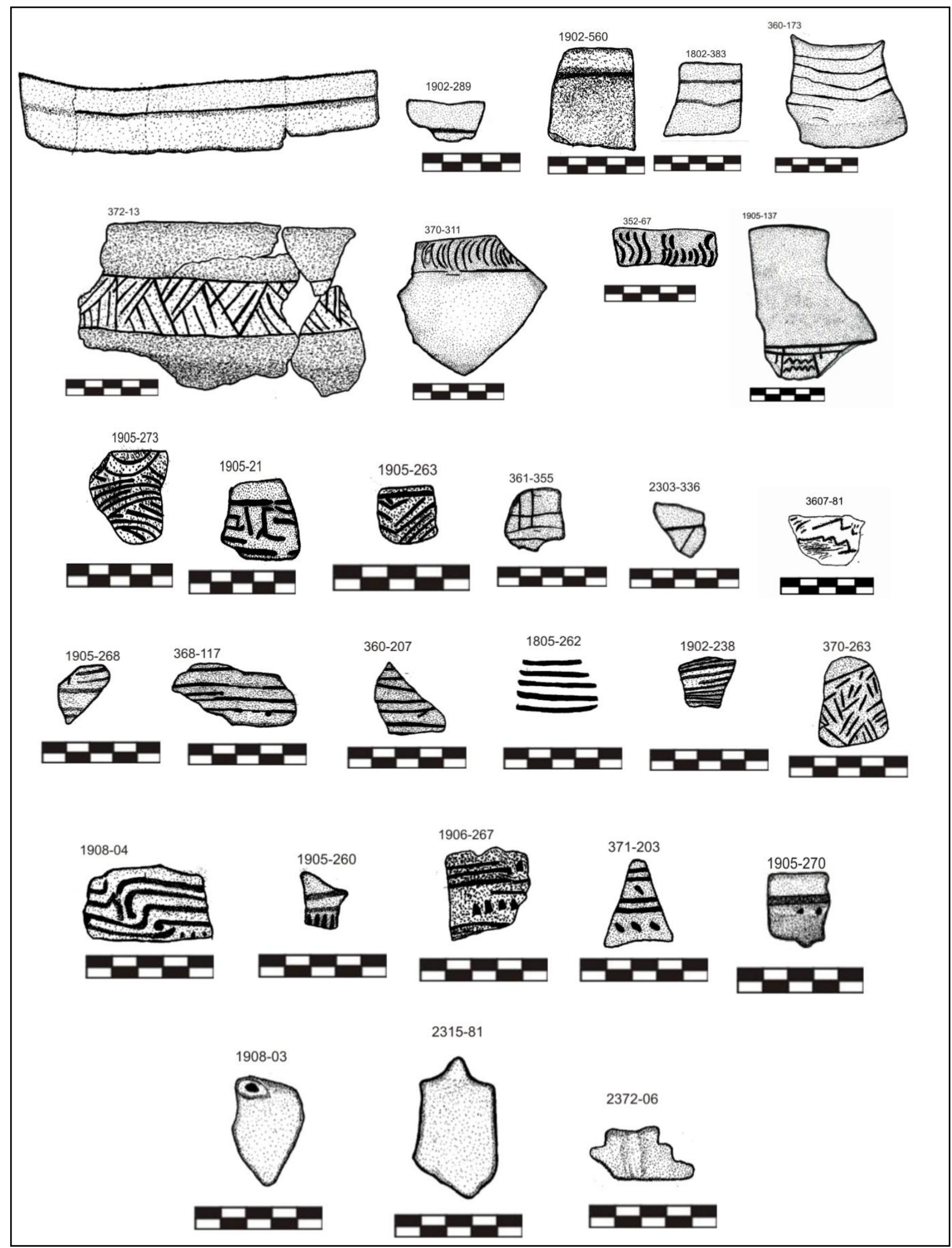

Figura 68: Desenhos dos tratamentos plásticos - Ilha de Santo Antônio (Angislaine F. Costa, 2012, 2013)

Ocorrem fragmentos de parede (1.370), borda (826), inflexão (408), base (186), bojo (17), pescoço (8), borda e bojo (5), borda e pescoço (1), borda com flange labial (2), base e parede (1), uma alça, uma vasilha com perfil completo e 29 fragmentos não identificados. A 
análise das forma das vasilhas conjuntamente com as características de tratamento de superfície e marcas de uso possibilita fazer inferências sobre a utilização das vasilhas, especialmente na à cocção e fermentação, porém as vasilhas deste sítio são bastante fragmentadas e existe uma diversidade de tipos de bases e bordas com diferentes inclinações, o que torna a projeção das formas das vasilhas e a inferência dos usos muito complicada. A espessura dos fragmentos varia entre 1 e $28 \mathrm{~mm}$ de espessura, sendo mais frequentes fragmentos entre 4 e $10 \mathrm{~mm}$ (gráfico 8).

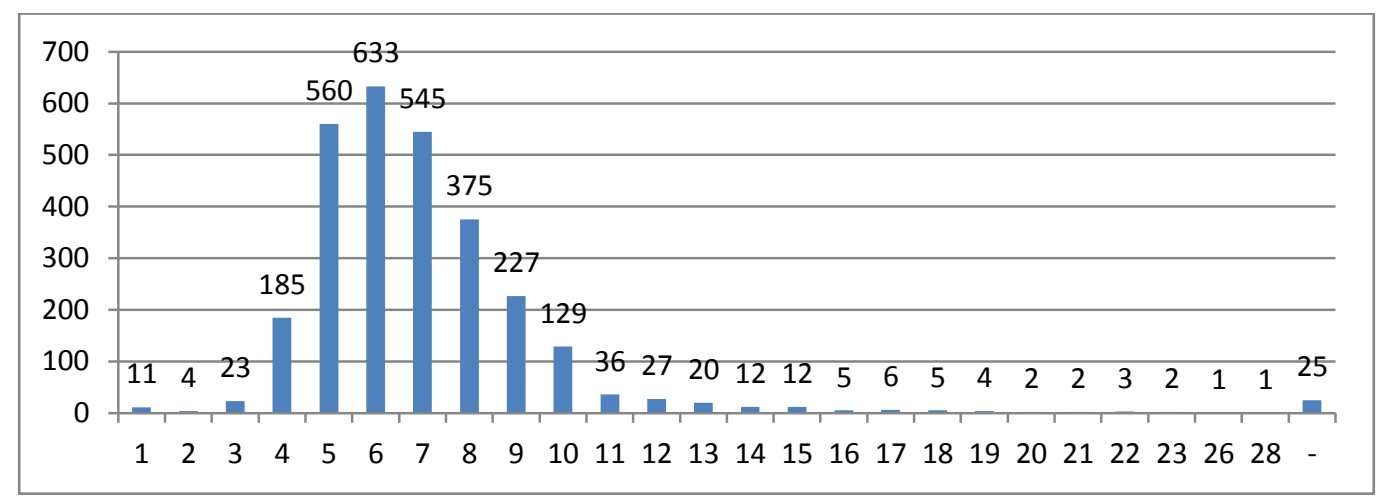

Gráfico 8:espessura dos fragmentos- Ilha de Santo Antônio.

Entre as 835 bordas (algumas com pescoço, flange, bojo e um perfil completo), predomianm as diretas inclinadas externamente, diretas verticais e extrovertidas (gráfico 9). Já em relação ao espessamento, predominam as lineares e contraídas, com poucas expandidas e reforçadas (gráfico 10). Os lábios são na maioria arredondados (535; 64,07\%), mas também ocorrem os planos $(156 ; 18,68 \%)$, apontados $(80 ; 9,58 \%)$, irregulares $(16 ; 1,92 \%)$ e biselados (2; $0,24 \%)$, e em $46(5,51 \%)$ bordas não foi possível caracterizá-los. Em muitas vasilhas do sítio Ilha de Santo Antônio os lábios são irregulares, ou seja, em partes da borda o lábio é arredondado, em outras é plano e em outras apontado, por isso parte dos lábios caracterizados como planos não necessariamente foram intencionalmente feitos desta forma. O diâmetro de abertura das vasilhas varia entre $6 \mathrm{~cm}$ e $34 \mathrm{~cm}$, com percentuais entre 5 e $75 \%$ da borda (gráfico 11). 

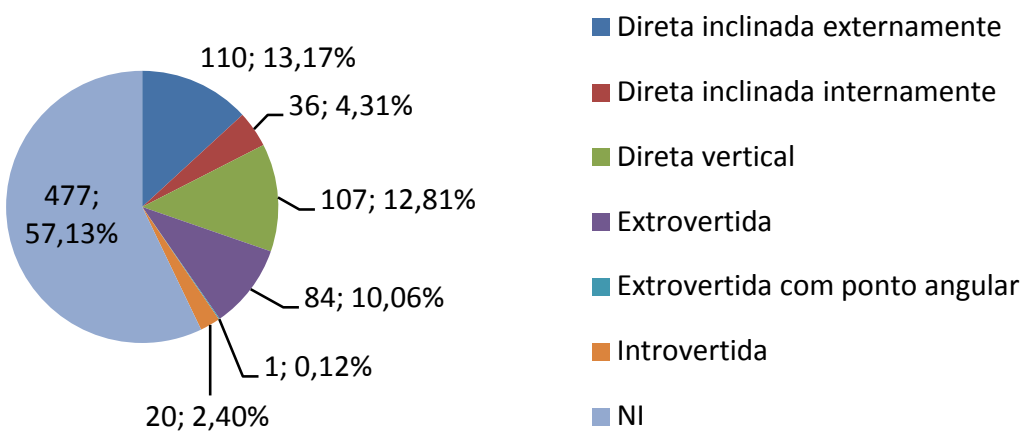

Gráfico 9: forma e inclinação das bordas- sítio Ilha de Santo Antônio.
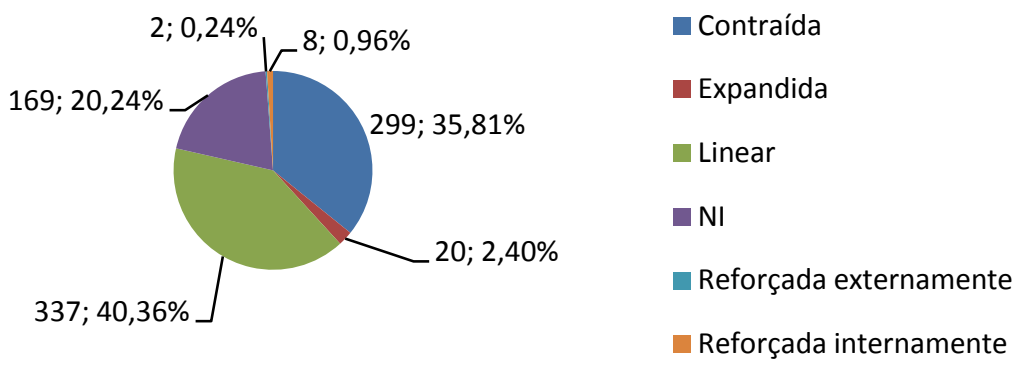

Gráfico 10: espessamento das bordas - sítio Ilha de Santo Antônio.

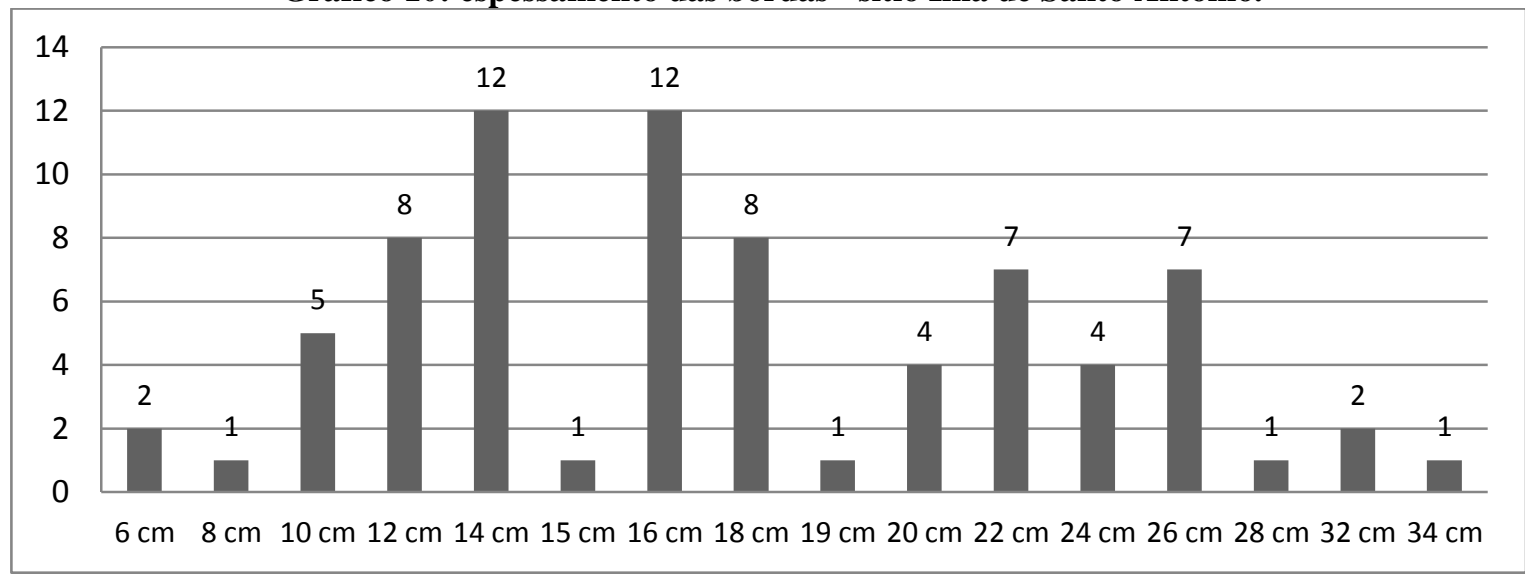

Gráfico 11: diâmetro de abertura das vasilhas cerâmicas- Ilha de Santo Antônio.

Entre as bordas analisadas, as extrovertidas possuem diâmetro variando entre 8 e 26 $\mathrm{cm}$. Entre elas, duas apresentam fuligem; duas possuem pintura e em quatro ocorrem vestígios de pigmentos; cinco apresentam incisões na face externa; algumas estão erodidas na face interna, e apesar das erosões não terem sido identificadas como fermentação, é possível que sejam decorrentes deste uso. Tudo indica que vasilhas com borda extrovertida eram utilizadas em diferentes atividades (cozinhar, servir, armazenar, fermentar bebidas). As bordas possuem tamanho pequeno e por isso não foi possível reconstituir as formas das vasilhas, que possivelmente apresentam contorno infletido e estrutura fechada. 
As bordas diretas inclinadas externamente possuem diâmetro variando entre 6 e 32 $\mathrm{cm}$. Quatro apresentam fuligem na face externa e duas possuem marcas de fermentação na face interna. Não apresentaram pintura, porém os tratamentos plásticos estão presentes em quatorze delas, sendo que na face externa ocorre o roletado (6), acanalado (1), inciso e ponteado (1) e inciso (2), enquanto na face interna também ocorrrem incisões (1) e inciso e ponteado (1); uma borda apresenta o lábio modelado, uma apresenta incisões em ambas as faces e outra incisões na face externa e inciso e ponteado na face interna. Portanto, possivelmente vasilhas com bordas diretas inclinadas externamente eram utilizadas em diferentes atividades, entre elas cozinhar alimentos, fermentar bebidas e servir. Algumas vasilhas apresentam uma parte consideravel da borda e parede, indicando formas simples (cuias), possivelmente utilizadas para servir e consumir alimentos.

As bordas diretas verticais possuem diâmetro variando entre 10 e $34 \mathrm{~cm}$. Duas apresentam fuligem na face externa, uma possui pintura vermelha na face externa e algumas possuem tratamentos plásticos: entalhado no lábio (1), inciso FE (2) e roletado FE (5). Tudo indica que estas vasilhas foram utlizadas para cozinhar e para servir e consumir alimentos. As bordas introvertidas possuem diametro variando entre 12 e $26 \mathrm{~cm}$ de diâmetro. Duas apresentam fuligem na face extrerna, as pinturas estão ausentes e apenas uma possui tratamento ponteado na face externa. A maioria destas vasilhas deve ter sido utilizada no consumo de alimentos. Já as bordas diretas inclinadas internamente possuem diâmetro variando entre 14 e $32 \mathrm{~cm}$, porém são bastante fragmentadas, sendo possível desenhar apenas uma delas, com $18 \mathrm{~cm}$ de diâmetro.

Das 188 bases analisadas, foi possível identificar a forma de apenas 147 delas: 94 biplanas, 20 convexas concavas, 14 plano côncavas, 14 anelares, 3 em pedestal, uma côncava plana e uma convexa plana. Os diâmetros variam entre 3 e $18 \mathrm{~cm}$, porém as menores podem estar fragmentadas e o diâmetro não corresponder a todo o seu tamanho. São recorrentes bases de $4 \mathrm{~cm}, 6 \mathrm{~cm}$ e $8 \mathrm{~cm}$ de diâmetro. As bases anelareas variam entre 6 e $12 \mathrm{~cm}$, as biplanas entre 4 e $18 \mathrm{~cm}$; convexas concavas entre 4 e $8 \mathrm{~cm}$; em pedestal $8 \mathrm{~cm}$; e plano concava entre 3 e $10 \mathrm{~cm}$. 


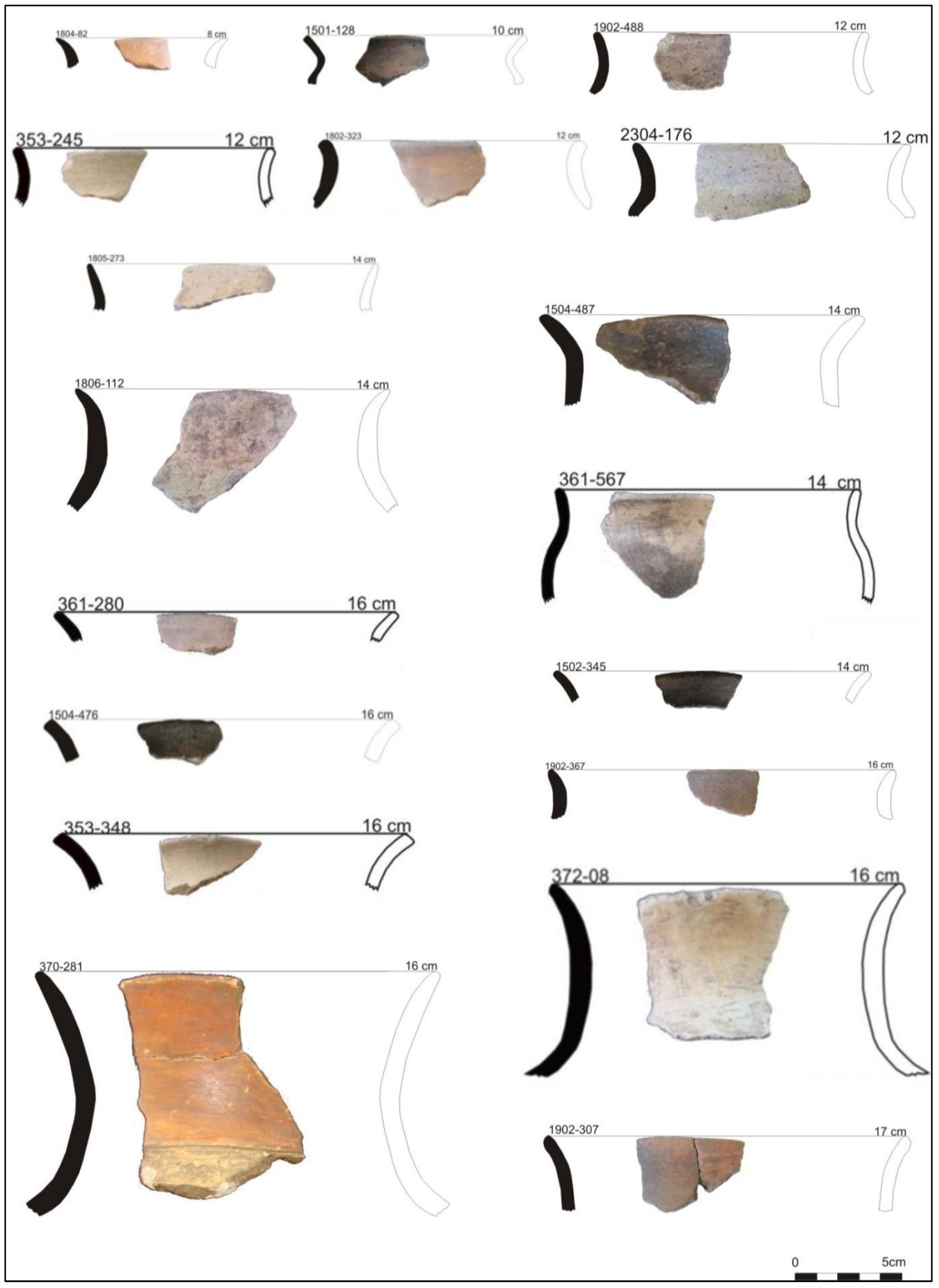

Figura 69: bordas extrovertidas - ilha de Santo Antônio (Desenhos de Angislaine F. Costa, 2011). 


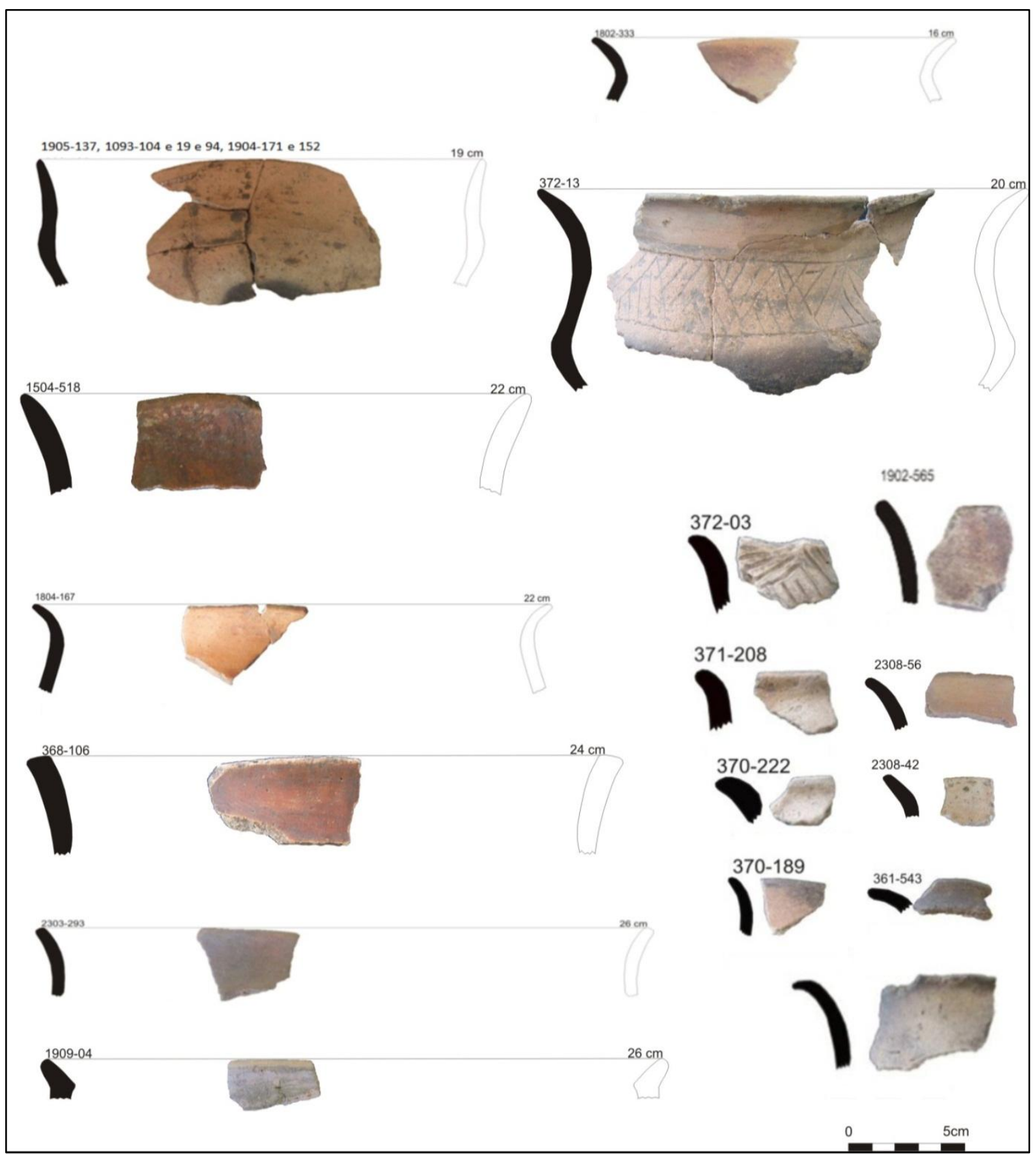

Figura 70: bordas extrovertidas - Ilha de Santo Antônio.

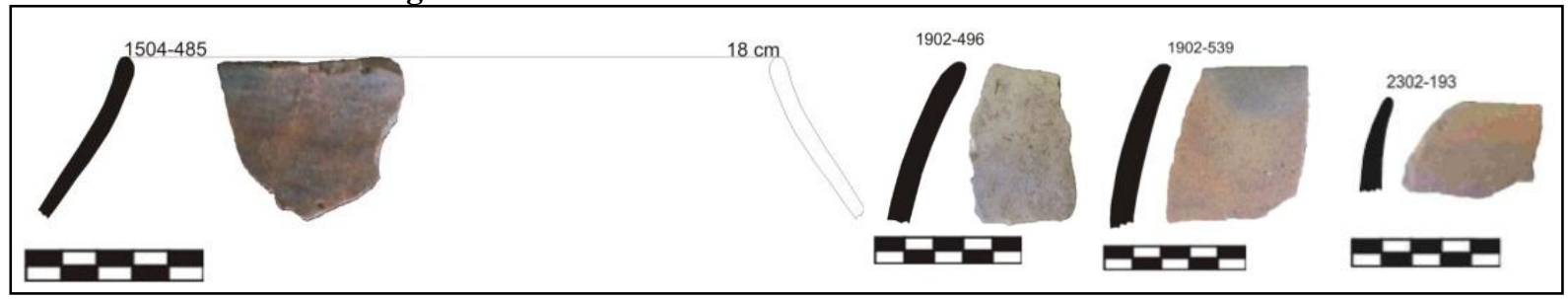

Figura 71: Bordas diretas inclinadas internamente- Ilha de Santo Antônio (Angislaine F. Costa, 2011) 


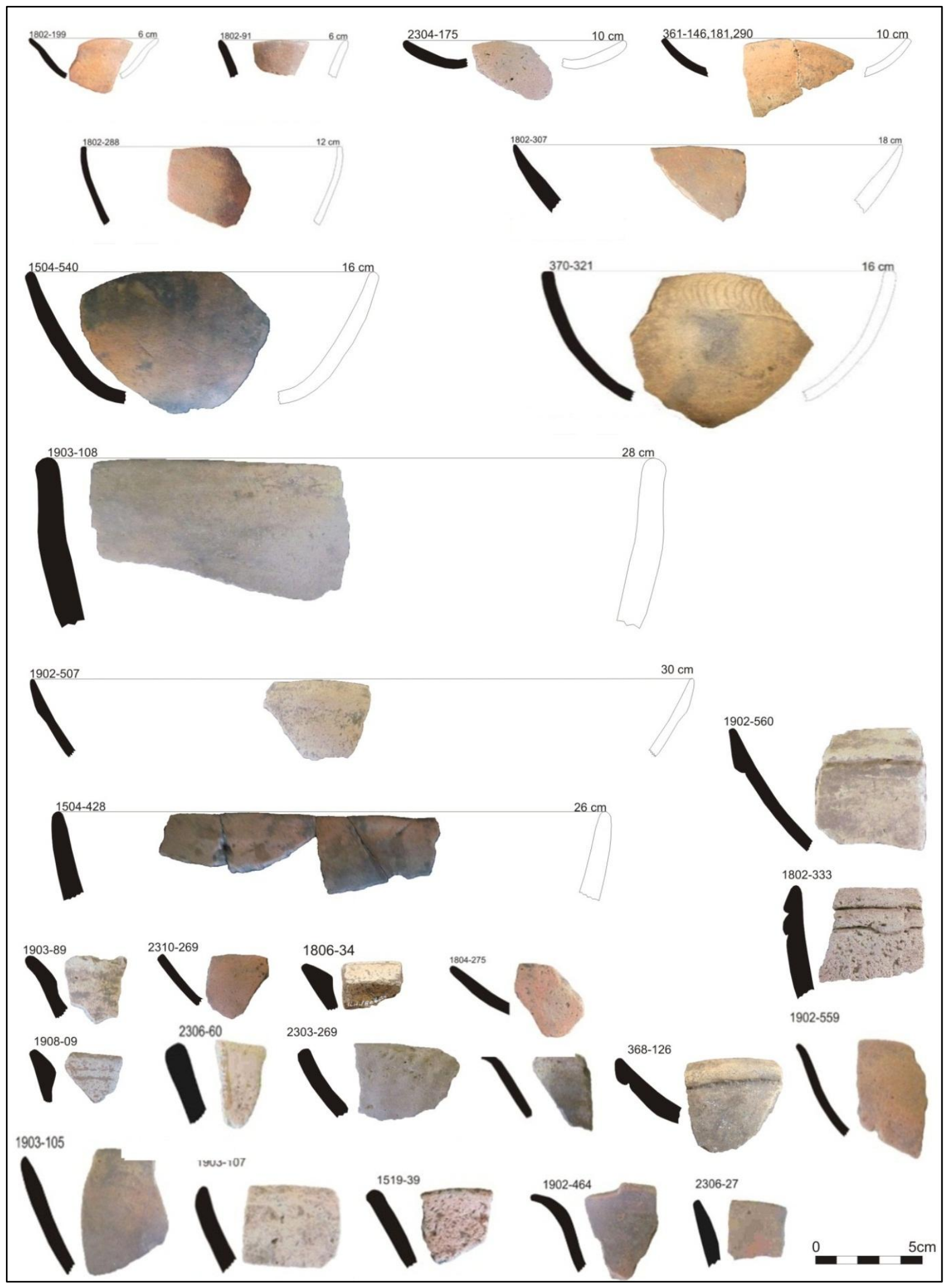

Figura 72: Bordas diretas inclinadas externamente- Ilha de Santo Antônio (Angislaine F. Costa, 2011) 


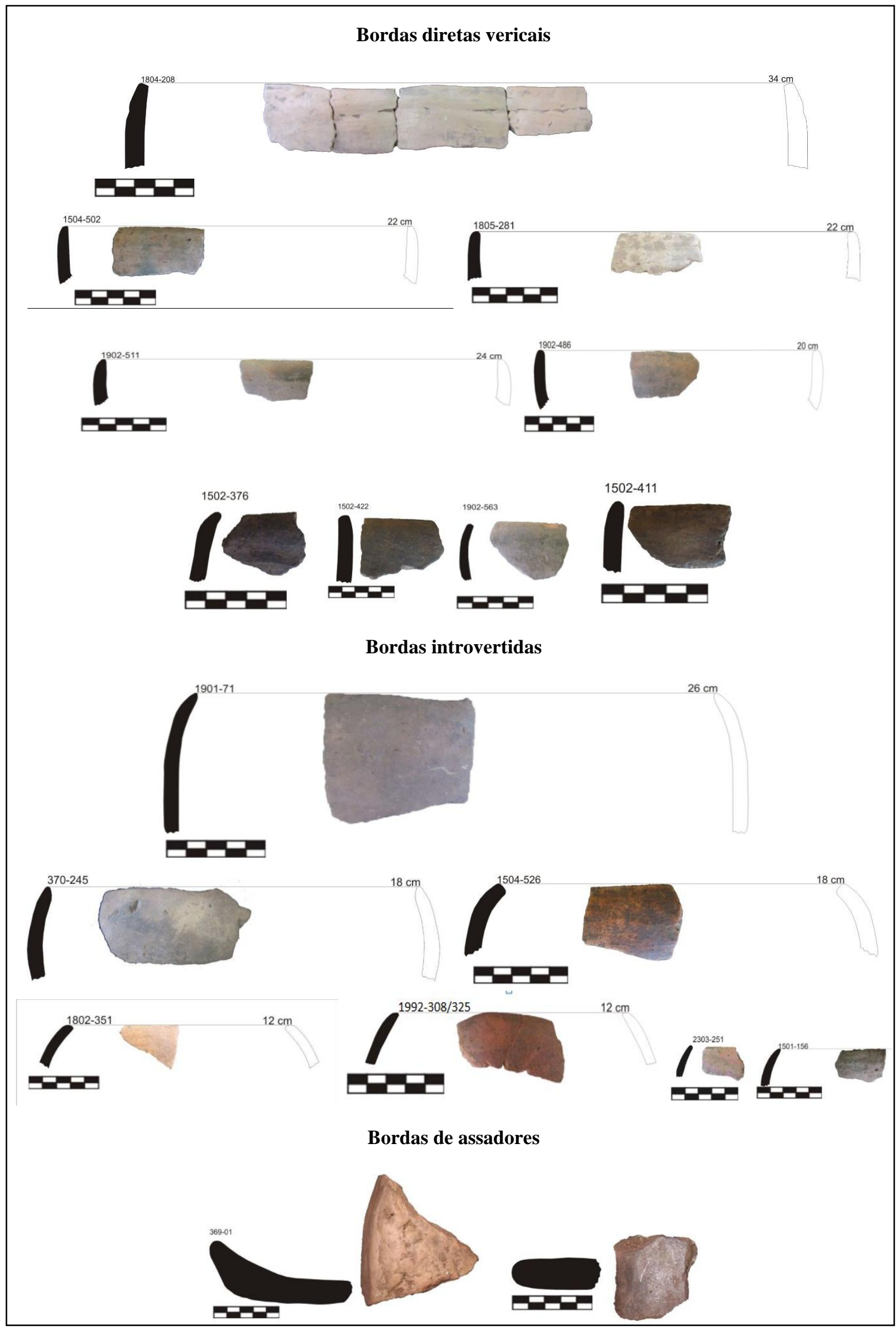

Figura 73: bordas diretas verticais, introvertidas e de assadores- Ilha de Santo Antônio (Angislaine F. Costa, 2011). 
Em relação as marcas de uso, estas foram identificadas em 222 fragmentos, sendo mais recorrente a fuligem na face externa (107), fermentação na face interna (65), depósito de carbono na FI (32), reciclagem (10), depósito de carbono e fuligem no mesmo fragmento (5) e fuligem e fermentação no mesmo fragmento (3). A fuligem ocorre em fragmentos de todas as partes da vasilha, com maior recorrência na parede, inflexão e borda (4 diretas inclinadas externamente; 2 diretas verticais; 2 introvertidas; 1 direta inclinada internamente e 1 extrovertida) e base (bi-plana, anelar e convexa côncava), sendo que quatro fragmentos apresentam tratamento plástico (inciso, inciso e ponteado e roletado). A fermentação ocorre em fragmentos de todas as partes da vasilha, destacando-se as bordas extrovertidas (4), diretas inclinadas externamente (2), inflexões (7) e bases bi-planas (6); oito destes fragmentos apresentam pintura e quatro com tratamento plástico (inciso, inciso ponteado e roletado). $\mathrm{O}$ depósito de carbono predomina nas bases, a maioria bi-plana, mas também ocorre nas convexas côncavas e plano-côncavas. Outros fragmentos estão erodidos na face interna, porém não foi possível afirmar se é decorrente do uso (figura 74). A reciclagem foi evidenciada em fragmentos com as quebras polidas, que produzem peças com forma circular ou alongada (possíveis adornos). Uma borda apresenta desgaste (possível calibrador). Marcas de produção também estão presentes em alguns fragmentos, entre elas algumas perfurações e fragmentos com marcas de folhas (assadores) e manchas de queima.

As vinte bolotas de argila possuem apenas mineral na pasta (ausência de caraipé) e podem ser restos de argila da produção cerâmica, ou utilizada em fogueiras, na confecção das casas ou demais estruturas. Não foram analisadas todas as bolotas de argila destas unidades, e elas são frequentes no sítio. Ocorreram cinco fusos nos níveis superiores das seguintes unidades: N990 E849 (20-30 cm); N990 E850 (10-20 cm), N990 E851 (30-40 cm); N870 E840 $(30-40 \mathrm{~cm})$ e N959 E841 $(30-40 \mathrm{~cm})$. Os fusos parecem ter sido feitos com fragmentos de vasilhas (em geral curvos) (figura 75). 


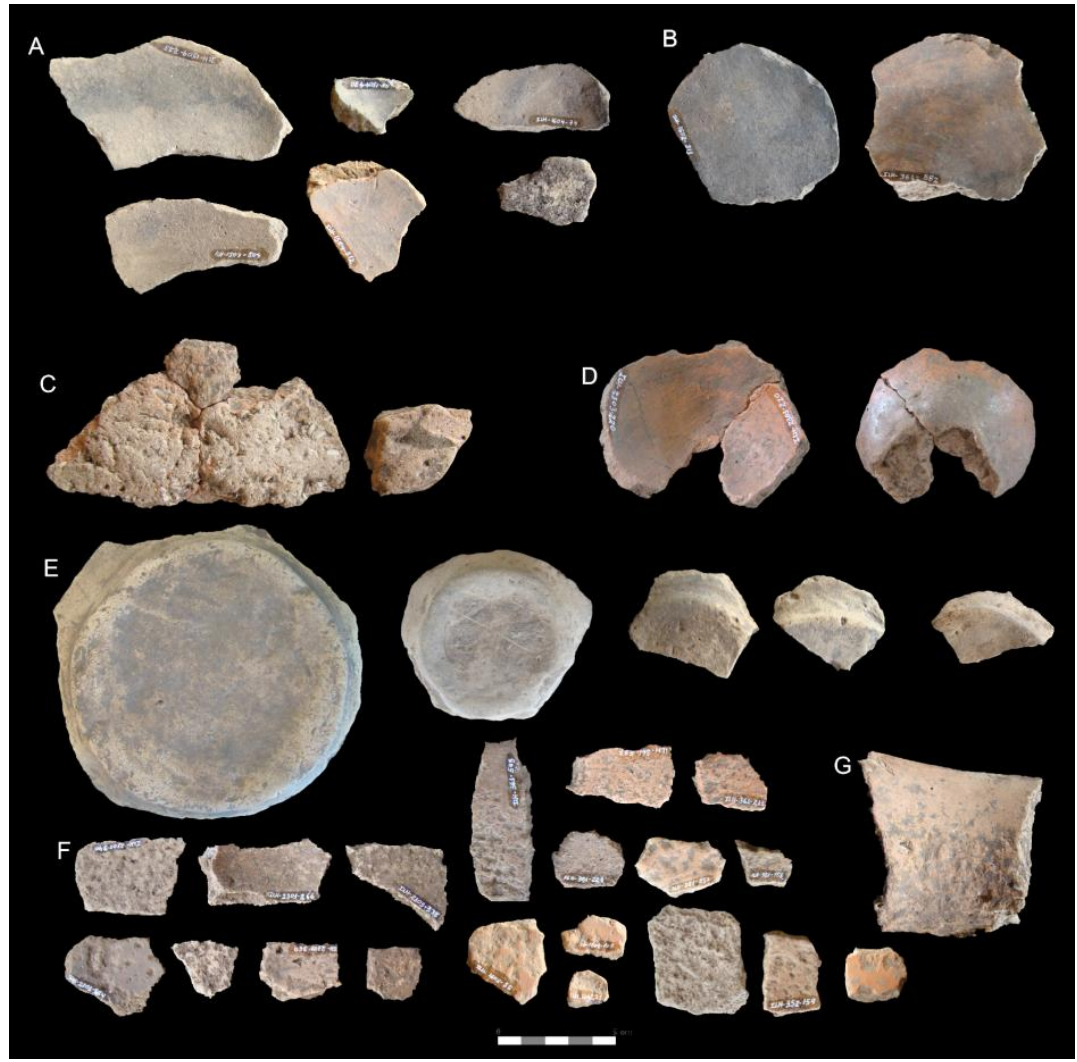

Figura 74: bases convexas côncavas (A, D); bi-planas (B); de assador (C); anelares (E); e marcas de fermentação em fragmentos de parede (F) e borda (G) (Fotos: SCIENTIA, 2011, 2012, 2013).

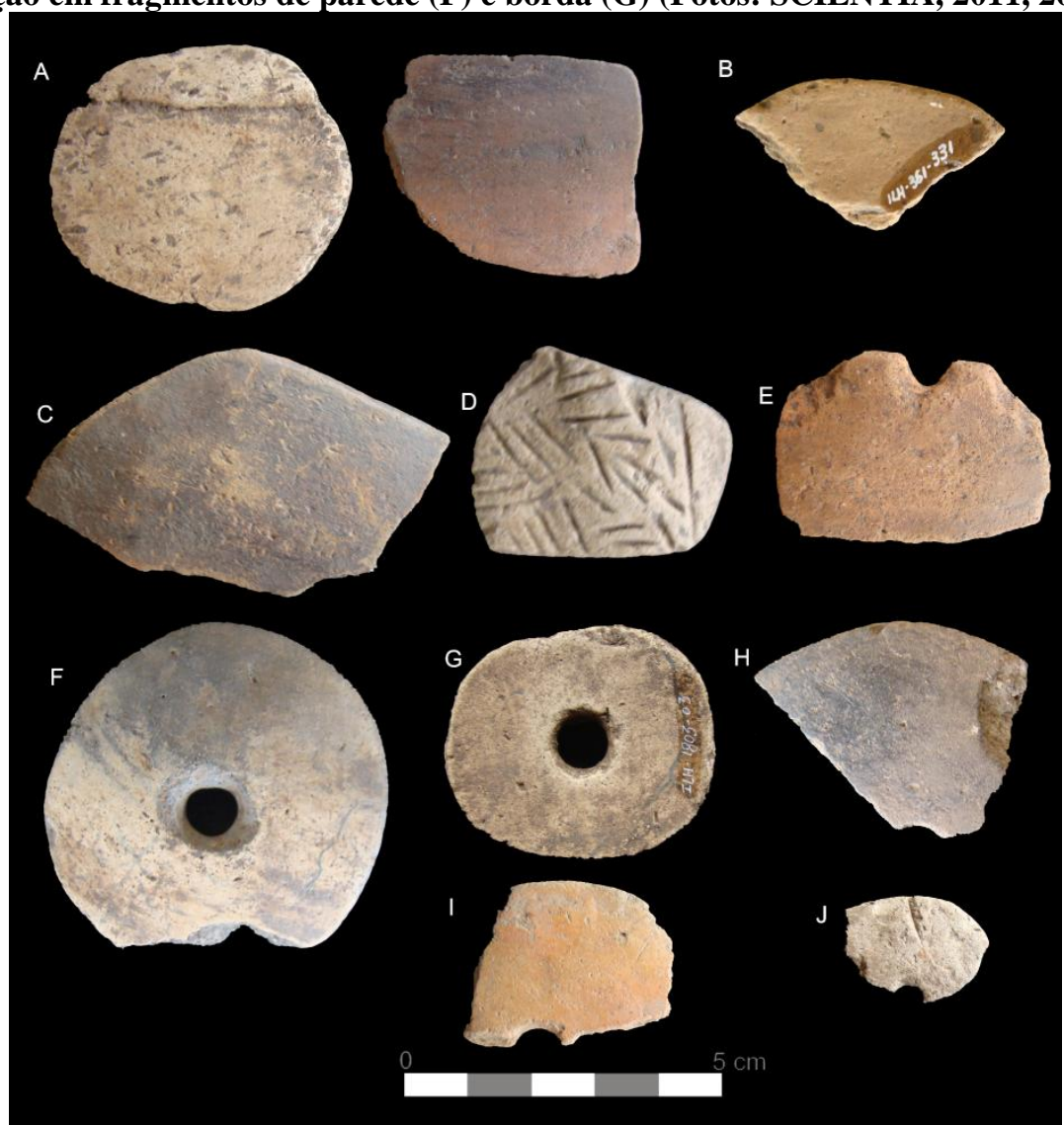

Figura 75: possíveis adornos/reciclagem (A, B, C, D); borda com sulco (E); fusos (F-J) (Fotos: SCIENTIA, 2011, 2012, 2013). 


\subsubsection{Análise das vasilhas R1, R2, R3 e R4}

A vasilha R1, escavada na unidade N990 E850, possui $63 \mathrm{~cm}$ de altura e $61 \mathrm{~cm}$ de diâmetro, borda extrovertida, lábio plano, base convexa plana, contorno infletido e estrutura fechada. A pasta apresenta grãos de quartzo, óxido de $\mathrm{Fe}$ e feldspato, caraipé e carvão, coloração clara em todas as partes da vasilha com queima oxidante. A base possivelmente foi modelada, porém o corpo foi feito com a técnica acordelada. Ambas as superfícies apresentam uma camada de barbotina e são polidas. Na face externa foi aplicada pintura vermelha e branca em dois campos, sendo no pescoço e no bojo inferior, com motivos complexos. A vasilha apresenta perfurações em lados opostos (20 furos em um lado e 22 no outro), aos pares em fragmentos que remontam, indicando quebra e posterior amarração dos fragmentos a fim de que pudesse continuar sendo utilizada. Na base ocorre um furo feito após a queima da vasilha. Observou-se que a pintura vermelha foi aplicada antes da pintura branca, porém a primeira não recobriu toda a superfície, mas delimitou os espaços que receberam a pintura branca. A camada de pigmento branco é mais espessa que a do vermelho, e bastante saliente. Ocorrem dois campos de pintura, um deles na borda e pescoço, delimitado pelo lábio e por uma faixa branca pintada na porção superior do bojo, e o outro em todo o bojo, delimitado pela faixa branca na sua parte superior e por outra faixa branca na base. Os motivos são complexos e podem ser observados na imagem abaixo. Desgastes ocorrem na face interna indicando seu uso na fermentação de bebidas antes da quebra. Também ocorrem sulcos rasos e finos, provocados por um instrumento pontiagudo, na posição horizontal no bojo, possivelmente causados por um instrumento utilizado para mexer o conteúdo durante o uso. Os furos na parede do R1 possivelmente foram feitos de fora para dentro, pois não causaram nenhuma alteração na face externa da vasilha, apenas pequenos lascamentos na face interna ao redor deles. Já o furo na base possui $26 \mathrm{~mm}$ de diâmetro na face interna e $21 \mathrm{~mm}$ na externa, e ocorrem marcas da sua execução feitas a partir da superfície interna, que parecem ser interrompidas próximas à superfície externa, momento em que o gesto muda de direção, da superfície externa para a interna, na finalização do furo. A espessura da base é de $2 \mathrm{~cm}$. A vasilha foi restaurada em 2011 pela Dra. Silvia Cunha Lima (figura 76).

Os recipientes R2 e R3 (fotografias 84 a 86), encontrados na área escavada com máquinas possuem as mesmas características de pasta, acabamentos de superfície, técnicas de confecção, forma e queima. O R2 é composto por fragmentos de base e bojo que remontam e de borda extrovertida que não remonta ao restante da vasilha, com espessura regular de $8 \mathrm{~mm}$. A base é convexa côncava e alguns fragmentos curvos indicam a presença de pescoço. $\mathrm{Na}$ 
face externa a pintura vermelha e branca apresenta motivos geométricos e escalonados semelhantes aos do Recipiente 1. O Recipiente 3 é composto por fragmentos de base, parede e bojo, com espessura variando entre 1,2 cm (base) e $1 \mathrm{~cm}$ (bojo). Apresenta um furo na base de $1 \mathrm{~cm}$ de diâmetro. O R2 estava enterrado emborcado integralmente na terra preta, e o R3 estava enterrado parcialmente no latossolo amarelo. Nesta mesma área foi escavado outro recipiente, que denominamos no laboratório de Recipiente R4 (figura 77), com contexto desconhecido. Este possui $58 \mathrm{~cm}$ de diâmetro, pasta com presença de mineral, fuligem na face externa e redução na base que indicam seu uso primário como panela.

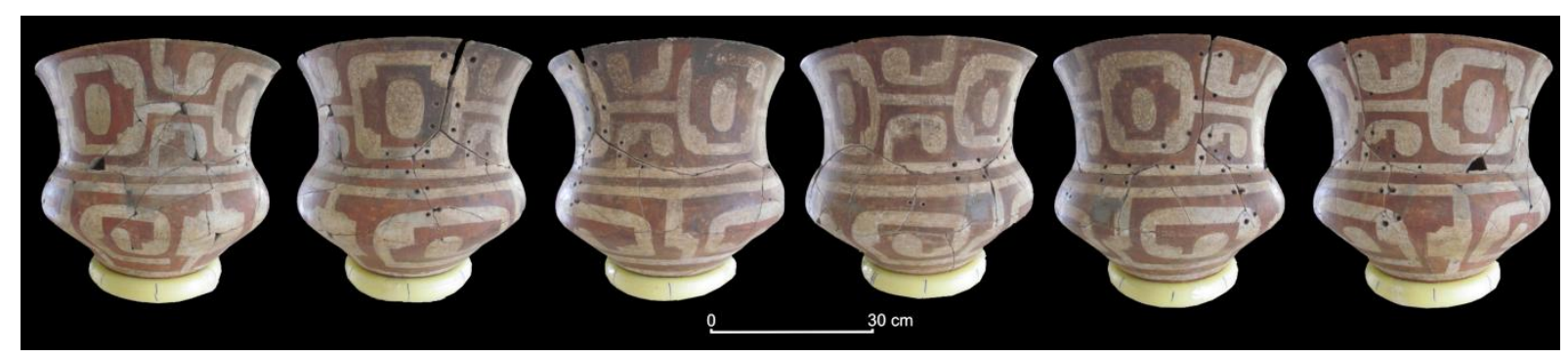

Figura 76: vasilha R1, girando no sentido horário (Fotos: Silvia Cunha Lima, 2012).
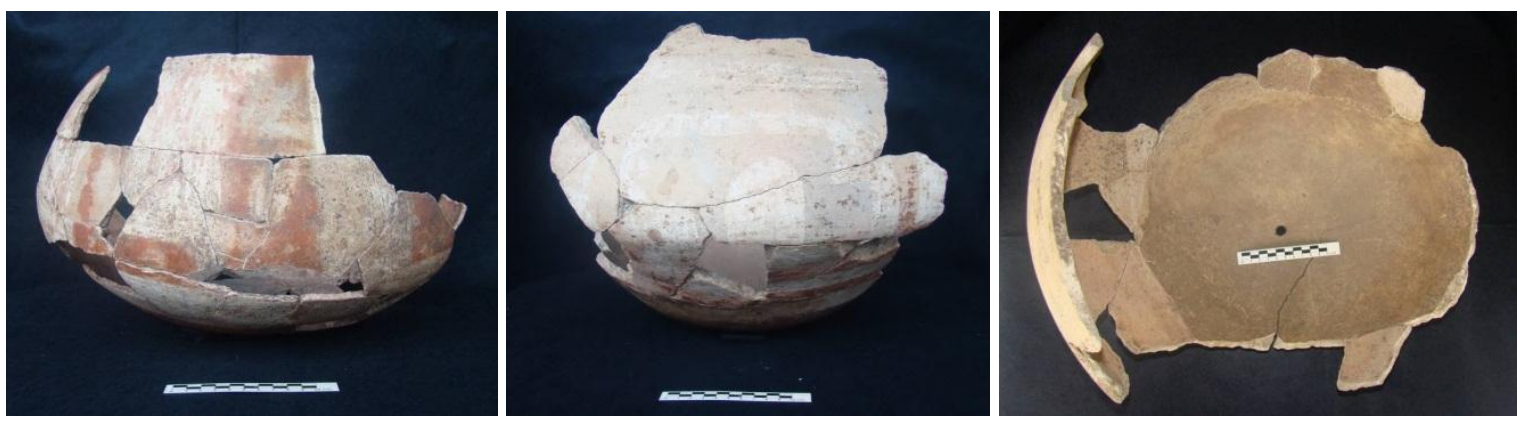

Fotografias 84, 85 e 86: vasilha R2 (FE) e vasilha R3 (FE e FI)- Ilha de Santo Antônio (SCIENTIA, 2010).

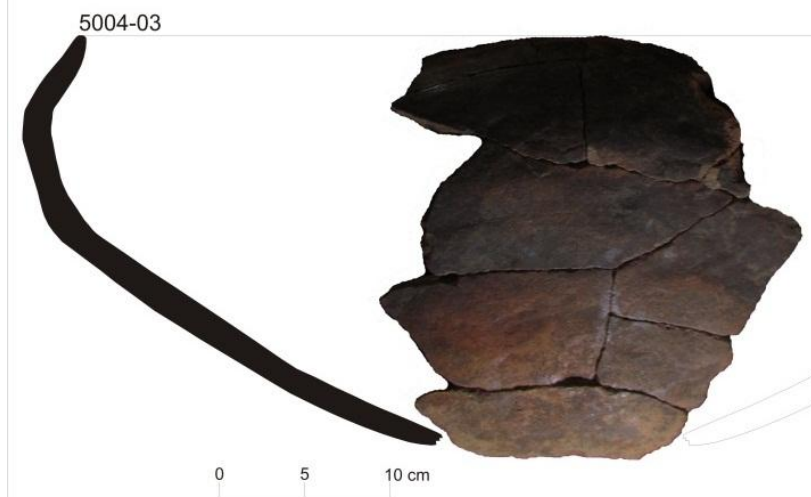

$58 \mathrm{~cm}$

Figura 77: Vasilha R4 (desenho: Angislaine F. Costa, 2012).

O contexto em que as vasilhas foram encontradas, enterradas na terra preta, ou parcialmente no latossolo, precisa ser discutido em conjunto com os dados obtidos na análise 
destes recipientes. Tudo indica que estas vasilhas foram utilizadas inicialmente na fermentação de bebidas (R1, R2, R3) e para cozinhar alimentos (R4), e posteriormente foram intencionalmente enterradas nesta área do sítio, no centro da mancha de terra preta. As duas vasilhas com furo na base (R1 e R3) estavam enterradas com a borda para cima, enquanto o R3 estava emborcado. Apesar de não terem sido evidenciados restos de sepultamentos, elas podem ter tido um uso secundário como urnas funerárias, tampas ou anexos. Os furos na base parecem estar relacionados a este momento de sua utilização.

\subsubsection{Triagem qualitativa da cerâmica das demais unidades do sítio Ilha de Santo Antônio}

A triagem qualitativa dos materiais das demais unidades, voltada para a caracterização dos atributos de forma das vasilhas dos fragmentos maiores, bem como os acabamentos pintados e plásticos, foi realizada com o intuito de esclarecer algumas hipóteses decorrentes dos resultados da análise apresentada anteriormente, que não puderam ser resolvidas em função do tamanho da amostra. Apesar da camada arqueológica ser homogênea, com um grande pacote de terra preta sobre o latossolo amarelo (principalmente no centro da mancha) sendo o sítio caracterizado como unicomponencial a partir dos dados de campo, acreditamos que o sítio pode ser multicomponencial com cerâmicas pertencentes a mais de um conjunto tecnológico. A cerâmica que predomina no sítio é caracterizadapor apresentar superfícies bem alisadas, polidas ou brunidas, formas simples ou infletidas erecorrência de decorações plásticas, principalmente incisões, roletados, modelados e apliques. Porém ocorrem também três vasilhas cerâmicas pintadas (R1, R2 e R3) e poucos fragmentos com pinturas em traços largos nas unidades, misturados aos demais fragmentos, que poderia caracterizar um segundo conjunto tecnológico relacionado a um episódio de ocupação posterior e menos duradouro. Ainda ocorrem bordas expandidas e fragmentos com flanges, com associação de pintura e incisões, que poderiam caracterizar um conjunto tecnológico diferenciado, mais antigo que estes dois. Entretanto, a predominânciado material do primeiro conjunto citado e baixa frequência de fragmentos dos possíveis conjuntos mais recente e mais antigo do sítio (possivelmente ocupações menos duradoras), bem como a continuidade em algumas nas escolhas técnicas, como é o caso da pasta (uso do caraipé) dificultam esta diferenciação, por isso optamos por fazer uma triagem dos materiais das demais unidades que dão informações consistentes relacionadas à forma das vasilhas e decorações, atributos que são mais 
diferenciadores neste sítio. Cabe ainda esclarecer que tais hipóteses não foram estabelecidas apenas com a análise do material deste sítio, mas na comparação com os materiais dos sítios próximos, como o Veneza, Garbin e Brejo.

Foram selecionados 647 fragmentos (59 bordas, 160 bases, 7 franges, 365 decorados e 56 outros com características variadas (carena, fusos, apêndices de suspensão, cerâmica com furo, reciclagem, engobo e outros), os quais foram fotografados e alguns desenhados e descritos. Os dados foram analisados de acordo com os níveis de escavação com o objetivo de perceber se existem diferenças entre os materiais na camada arqueológica, e nas diferentes áreas do sítio, sendo aqui sintetizados os principais resultados obtidos.

Nos níveis mais profundos identificamos fragmentos que possuem características diferenciadas da maioria da cerâmica da Ilha de Santo Antônio: uma pasta porosa e com grande quantidade de carvão associado ao caraipé, barbotina laranja, presença frequente de bordas expandidas, incisões na face interna da borda, em uma parte plana que lembra uma flange labial (são comuns as incisões duplas paralelas); além da presença de flanges labiais e mesiais e pontos angulares nas paredes (figuras 78 e 79). Estes materiais assemelham-se muito aos encontrados no sítio Veneza, situado na margem esquerda, e podem corresponder a uma ocupação mais antiga no sítio Ilha de Santo Antônio. A presença deste material é sutil, podendo representar uma ocupação rápida.

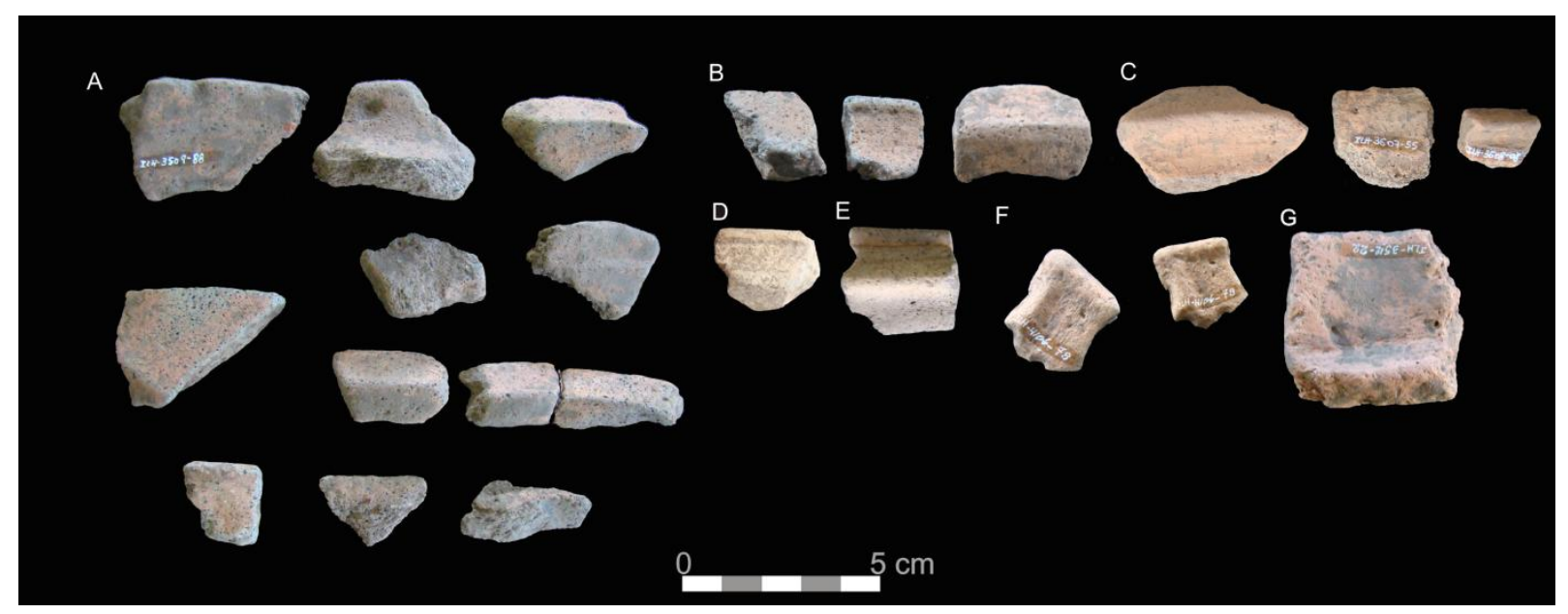

Figura 78: materiais semelhantes ao do sítio Veneza, nos níveis mais profundos da Ilha de Santo Antônio (Fotos: SCIENTIA, 2012). 


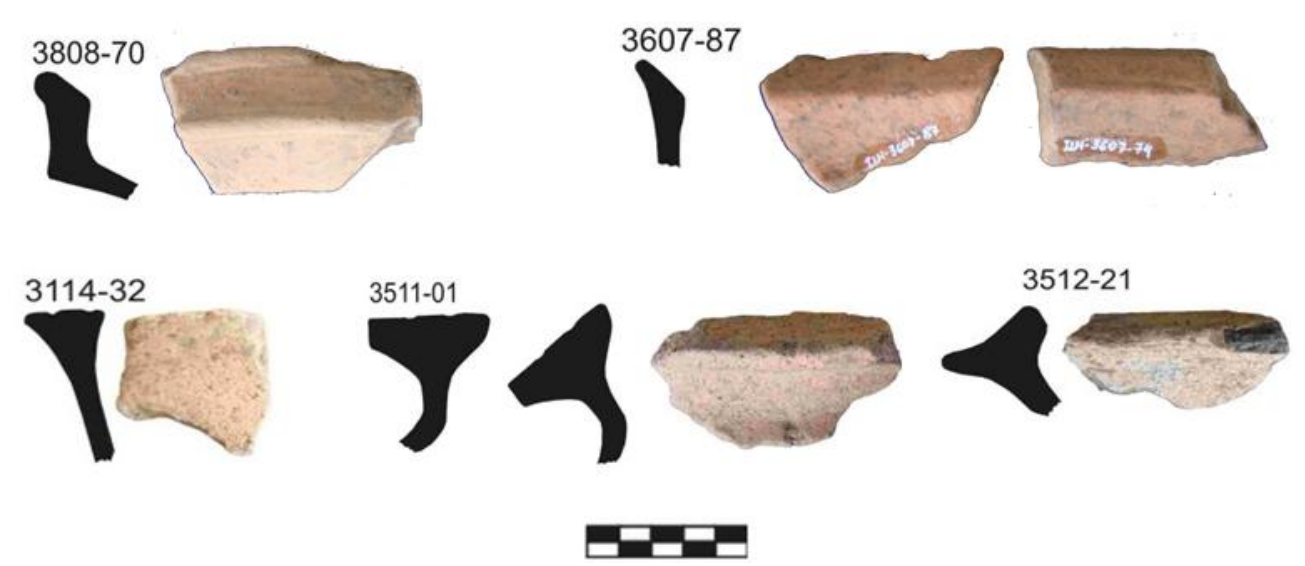

Figura 79: bordas e possíveis inclinações do material antigo da ilha de Santo Antônio (Desenhos: Angislaine F. Costa, 2012)

Outros fragmentos apresentam na pasta grãos grossos e angulosos de quartzo, os quais são pouco frequentes, não sendo possível afirmar se compõem este conjunto mais antigo (figura 80). Como veremos no decorrer, estes materiais estão presentes em outros sítios como Vista Alegre, Morro dos Macacos I e Foz do Jatuarana.

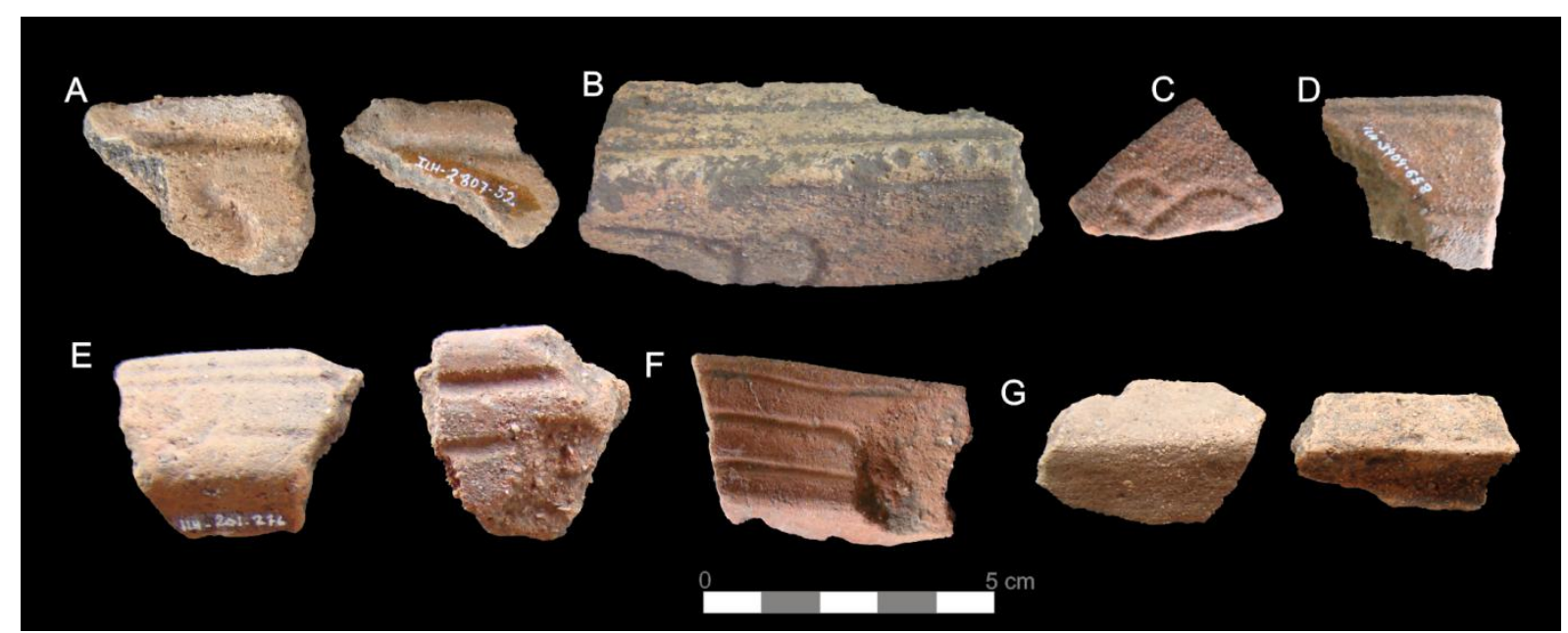

Figura 80: cerâmica com antiplástico mineral anguloso na pasta: bordas diretas com incisões (A, C, D, E, F); borda; borda com tratamento inciso e ponteados $(B)$; fragmentos de inflexão $(G)$.

A triagem também permitiu caracterizar melhor o conjunto tecnológico predominante no sítio, associado à terra preta. Foram desenhadas bordas extrovertidas, diretas inclinadas externamente, diretas verticais, introvertidas e diretas inclinadas internamente. Entre as extrovertidas, destacam-se duas vasilhas fechadas com gargalo, de 6 e $10 \mathrm{~cm}$ de diâmetro de abertura (2909-349, 225 e 2909-305), uma de contorno infletido e a outra de contorno composto. Entre as diretas inclinadas externamente foi possível reconstituir a forma de três vasilhas rasas, de 8cm, $10 \mathrm{~cm}$ e $18 \mathrm{~cm}$ de diâmetro (2701-181; 3805-466; 2703-255), duas com a bases bi-plana e uma com a base convexa côncava, possivelmente utilizadas para 
servir. O tratamento plástico roletado aparece tanto em bordas diretas verticais, diretas inclinadas externamente e diretas inclinadas internamente. Foi possível reconstituir a forma de um assador de $50 \mathrm{~cm}$ de diâmetro, encontrado na unidadeN988 E849, remontado em duas partes (borda e base) a partir de 26 fragmentos, que apresenta duas placas sobrepostas, possivelmente em função da sua confecção em placas ou em decorrência da queima, o qual foi denominado recipiente R2 na escavação.

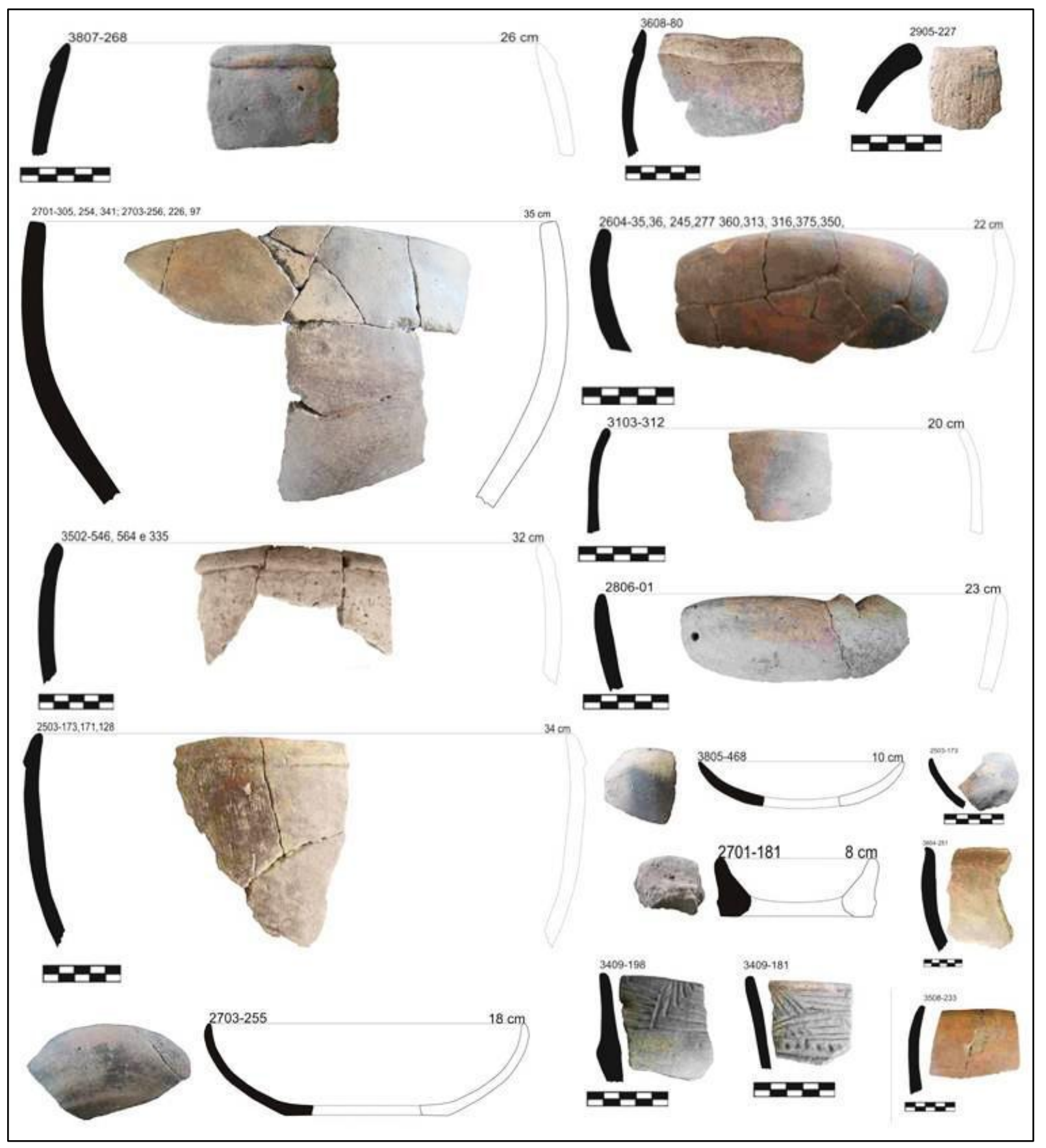

Figura 81: Bordas selecionadas na triagem- Ilha de Santo Antônio (Desenhos: Angislaine F. Costa, 2012). 


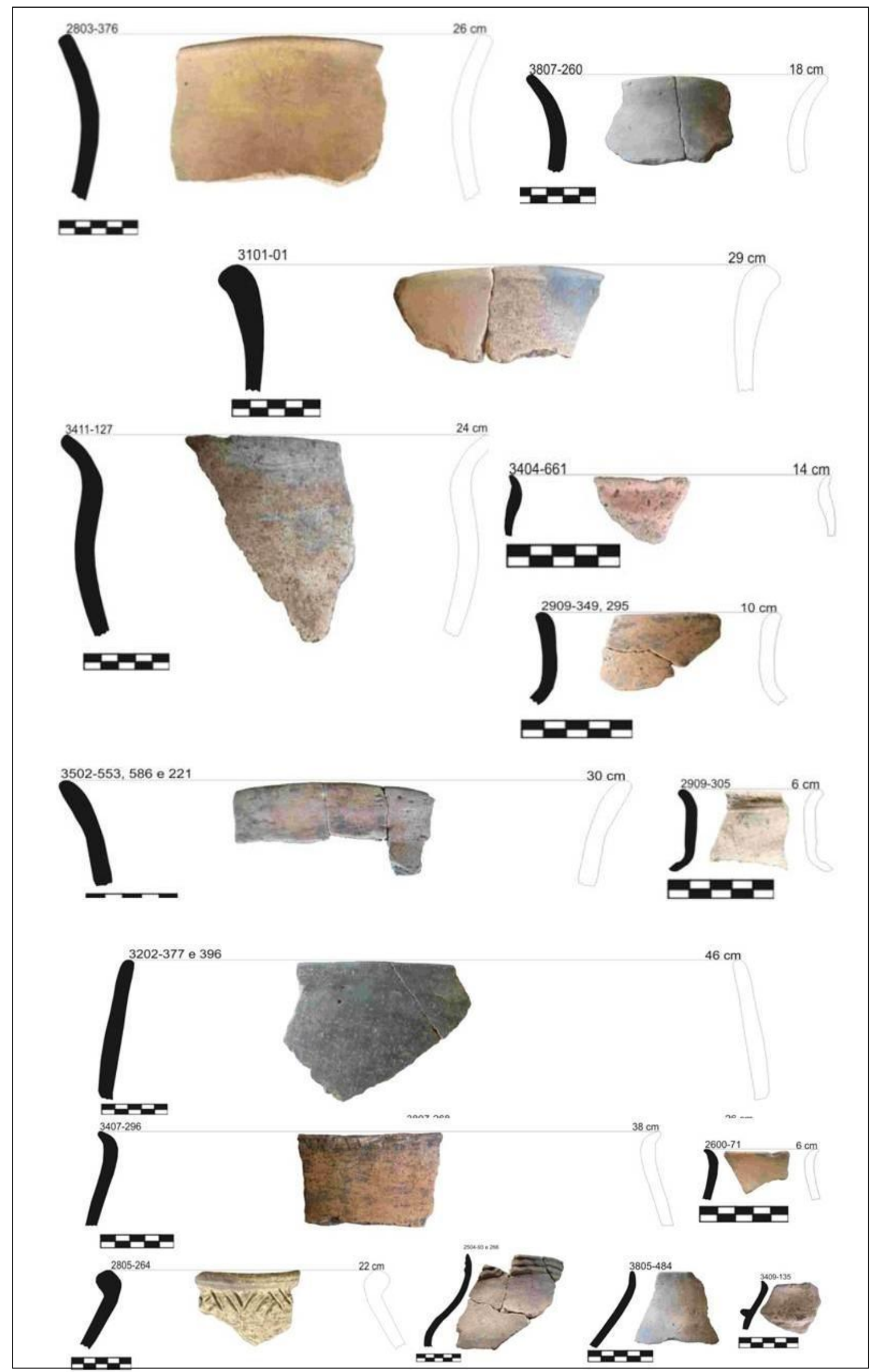

Figura 82: Bordas selecionadas na triagem- Ilha de Santo Antônio (Desenhos: Angislaine F. Costa, 2012). 
Entre os fragmentos de base destacam-se as de assadores, muitas delas com impressão de folha na face externa, presentes entre os níveis 20-30 a 60-70 cm ( unidades N989 E850; N988 E851, N988 E850, N988 E849, N989 E851, N980 E849). São frequentes no sítio bases anelares e bi-planas, entre os níveis 20-30 e 50-60 cm (unidades N988 E849, N989 E851, N991 E849, N989 E849, N988 E851, N988 E850, N989 E850, N979 E880,N980 E849,N920 E910), sendo nas bases anelares o diâmetro varia entre 4 e $16 \mathrm{~cm}$, sendo mais frequentes as de 8 e $10 \mathrm{~cm}$. As bi-planas variam entre 6 e $10 \mathrm{~cm}$ (apenas uma possui $20 \mathrm{~cm}$ ), sendo mais frequentes as de $9 \mathrm{~cm}$ de diâmetro. Entre as anelares duas possuem depósito de carbono (10 e $16 \mathrm{~cm}$ ), portanto seriam de panela, e três estão erodidas na face interna (duas de $8 \mathrm{~cm}$ e uma de $12 \mathrm{~cm}$ ), possivelmente pela fermentação de bebidas. Já entre as bi-planas apenas uma possui fuligem na face externa $(7 \mathrm{~cm})$. Portanto vasilhas com bases anelares e bi-planas parecem ter tido diferentes funcionalidades, algumas delas no processamento de alimentos sobre o fogo e outras no armazenamento e consumo de alimentos, incluindo fermentados. Três bases em pedestal foram identificadas no setor escavado com máquina, com $8 \mathrm{~cm}$ e $9 \mathrm{~cm}$ (duas) de diâmetro, apresentando desgaste na face interna, portanto possivelmente são de vasilhas utilizadas para consumir e armazenar fermentados.

Bases plano-côncavas ocorreram nas unidades N980 E849, N974 E880 e no setor escavado com máquina, com diâmetro variando entre 6 e $10 \mathrm{~cm}$ de diâmetro, duas delas com a face interna reduzida e uma com depósito de carbono, indicando uso sobre o fogo. Entre as bases convexas côncavas destaca-se uma da unidade N991 E849, remontada a partir de oito fragmentos, com polimento e engobo vermelho na face externa, $15 \mathrm{~cm}$ de diâmetro e depósito carbônico no seu interior, portanto de uma vasilha utilizada no processamento de alimento sobre o fogo. Esta remontagem permite observar que a quebra deste tipo de base prejudica sua identificação, sendo alguns fragmentos facilmente confundidos com bojos em função da curvatura (inflexão), enquanto bases anelares, bi-planas e em pedestal conservam sua forma ao fragmentarem-se. Outras bases convexas côncavas foram encontradas nas unidades N987 E849, N974 E880, N920 E910 e na área escavada com máquina. 


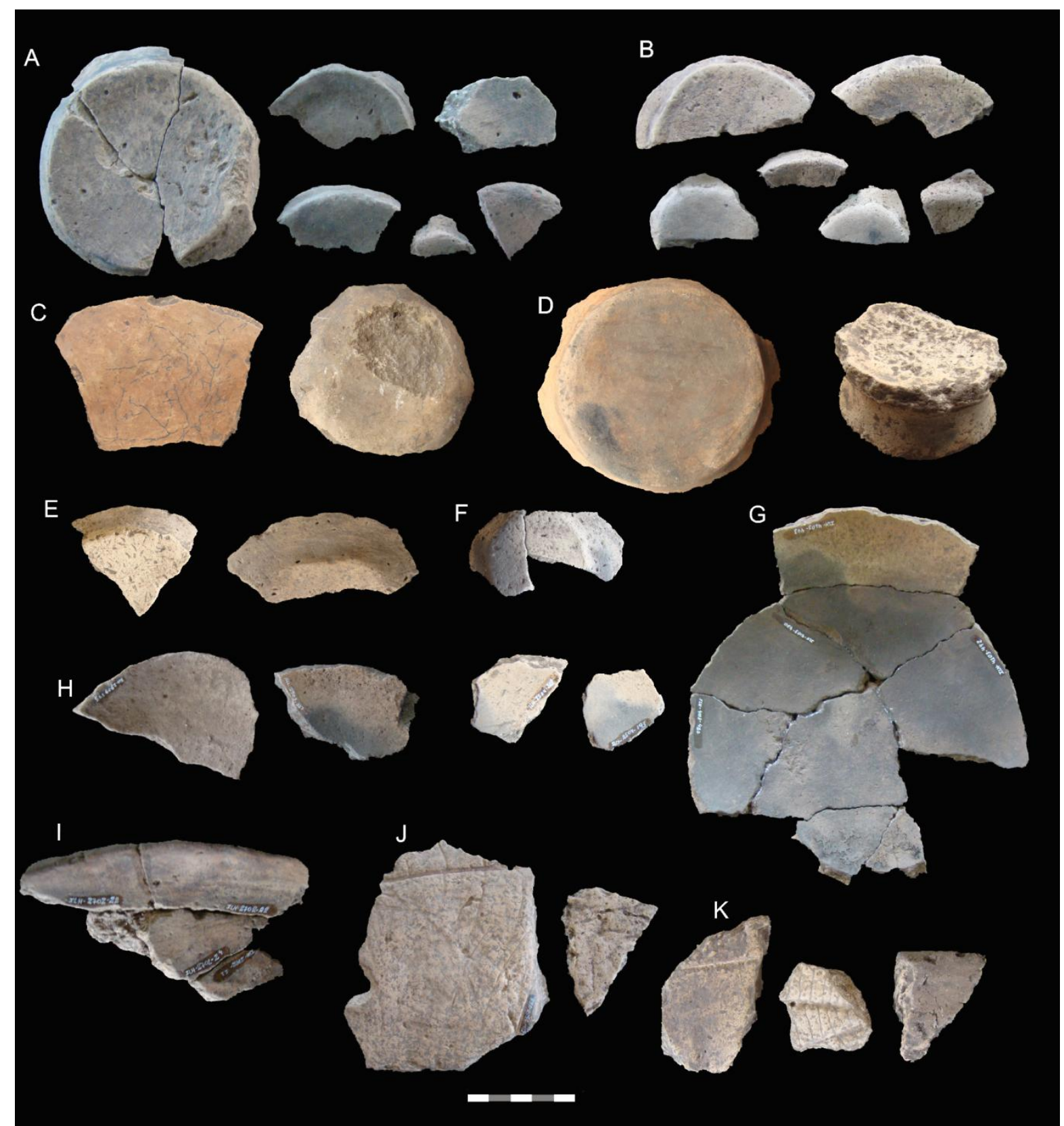

Figura 83: bases anelares (A, B, E, F); bi-planas (C); em pedestal (D); convexas côncavas (G, H); bases de assadores (I, J, K) (Fotos: SCIENTIA, 2012).

Entre os apêndices de suspensão foram encontradas cinco possíveis asas e duas alças. Uma das asas está fixada à borda $(40-50$ cm/N980 E849), duas estão associadas à fragmentos de parede com decoração incisa, e outras duas estão quebradas, sendo estas últimos decoradas: incisões largas no apêndice encontrado na unidade N988 E850 $(50-60 \mathrm{~cm})$ e entalhes no da N988 E950 (30-40 cm). Na unidade N993 E849 ocorre um fragmento de bojo com uma faixa de argila aplicada, que pode ser um apêndice de suspensão ou flange mesial. Dois fragmentos de alça foram encontrados nas unidades N979 E880 e N1000 E922, assim 
como uma trípode na unidade N989 E849, com decoração ponteada em um dos lados e na ponta (figura 84).

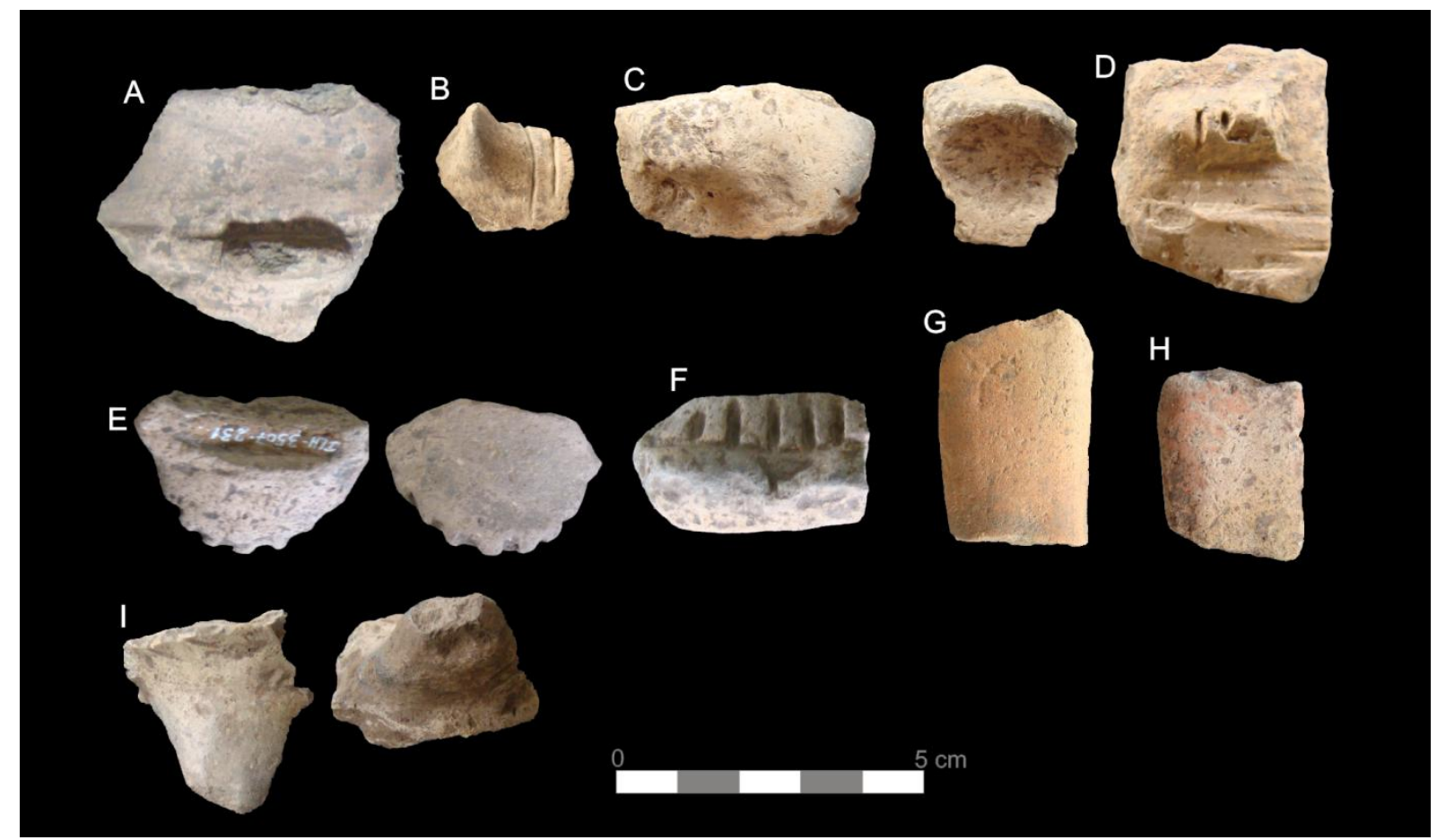

Figura 84: apêndices: asas entre 30-40 e 50-60 cm (A, B, C, D, E, F), alças dos níveis 10-20 e 40-50 cm (G, H) e trípode do nível 30-40 cm (I) (Fotos: SCIENTIA, 2012).

Com relação aos tratamentos plásticos, são recorrentes no sítio os roletados na face externa das bordas, e apesar da predominarem nos níveis mais superficiais, em algumas unidades ocorrem também nos mais profundos. Geralmente são simples, mas em algumas bordas são duplos e triplos. Foram identificados nas seguintes unidades triadas: N988 E849, N988 E850, N988 E951, N989 E849, N989 E850, N 989 E851, N987 E849, N974 E880, N979 E880 e área escavada com máquina.

Foram identificados apliques, dois deles da unidade N989 E850, ambos possivelmente representações figurativas zoomorfas (membro inferior ou superior e olhos). Na N989 E851 uma borda remontada a partir de três fragmentos apresenta apliques em alinhamento vertical que parecem representar pares de olhos (zoomorfos), associados a incisões. Na unidade N974 E880 foram encontrados dois fragmentos com apliques, um deles também zoomorfo (olhos) e o outro fragmentado também poderia representar um zoomorfo. Outros dois apliques foram encontrados nas unidades N980 E849 $(50-60 \mathrm{~cm})$ e N1000 E922 $(40-50 \mathrm{~cm})$, e constituem-se de esferas aplicadas. Um último foi encontrado no setor escavado com máquina, e ocorre na borda. Os apliques zoomorfos caracterizam-se pela aplicação de duas semi-esferas com um ponteado no centro, representando olhos. 
Fragmentos de borda com tratamento modelado junto ao lábio também ocorrem em algumas unidades do sítio (entre os níveis 20-30 e 70-80 cm das unidades N980 E849, N979 E880, N987 E849, N988 E849, N988 E851, N989 E849 e N992 E850). Possuem formas pontiagudas (bicos), onduladas, arredondadas e uma quadrangular, isolados ou em dupla, e uma borda com este tratamento plástico apresenta um furo feito antes da queima. Um fragmento de parede possui um elemento modelado (ou aplique) de forma alongada, na face externa, associado a engobo branco.

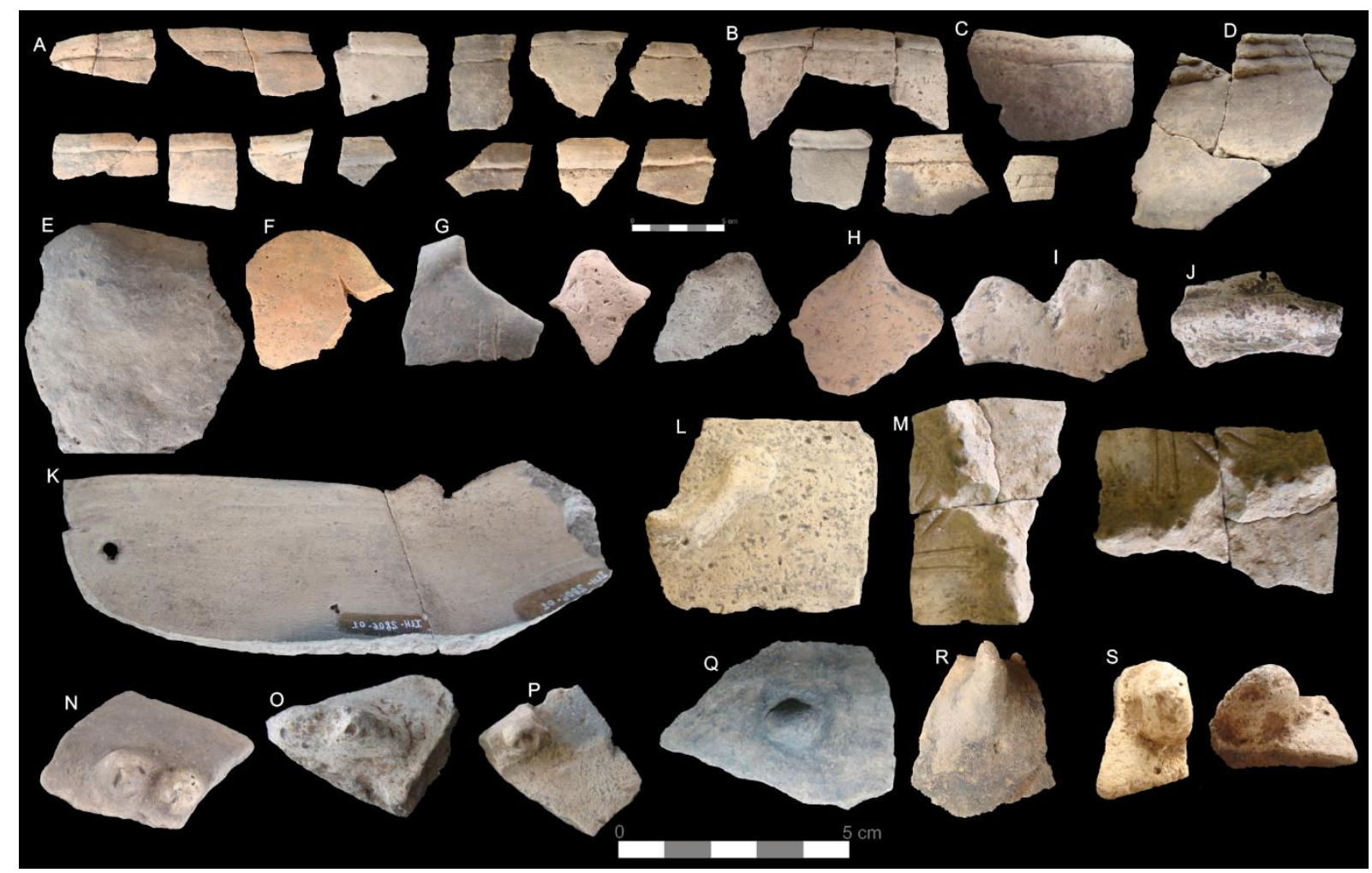

Figura 85: tratamentos plásticos: roletado (A, B, C, D); modelado (E a K); apliques zoomorfos (L, M, N, O, P); esperas aplicadas (Q, R, S) e aplique alongado (J) (Fotos: SCIENTIA, 2012).

Entre os tratamentos plásticos, os mais recorrentes são os incisos e incisos e ponteados, tanto na face interna (borda) quanto na face externa (borda e bojo superior), entre os níveis 20-30 e 70-80 cm das escavações. As incisões são feitas com instrumentos com seções de diferentes formas e tamanhos. Entre incisos os motivos são variados, incluindo linhas paralelas horizontais, verticais, triangulares, curvilíneos, em zigue-zague, linhas perpendiculares que se entrecruzam (xadrez), linhas oblíquas entre si que não se cruzam, entre outros, sendo comuns os compostos e complexos. Já no tratamento inciso e ponteado predominam as incisões paralelas interrompidas por uma sequência de três ponteados. Destacam-se dois fragmentos com motivos escalonados em linhas finas (níveis 30-40 e 50-60 cm da unidade N988 E851) que parecem ser da mesma vasilha, e um fragmento com incisos 
em zigue-zague (espinha de peixe) do nível 60-70 cm desta mesma unidade. Na unidade N988 E850 chama a atenção uma borda com incisões na face externa em motivo complexo associado à pintura branca, e vestígios de pigmentos vermelhos na face interna. Na unidade N989 E851 destacam-se algumas incisões finas e profundas duplas, com motivos escalonados. Na unidade N980 E849 ocorrem 26 fragmentos com tratamento plástico inciso, inciso e ponteado e entalhado na face externa, nas bordas e no bojo superior; em outros fragmentos estes tratamentos estão na face interna, na borda onde é mais visível. Destaca-se ainda uma flange labial modelada e recortada, com decoração incisa na face interna e três fragmentos de borda apresentam tratamento entalhado no lábio. Na unidade N974 E880 ocorrem muitos fragmentos com tratamento inciso, inciso e ponteado e escovado na FE, destacando-se um motivo quadrangular formado por linhas entrecruzadas e motivos em linhas curvilíneas, que em uma das peças parecem representar uma figura zoomorfa. Tratamentos incisos e incisos e ponteados ocorrem também nas unidades N920 E910, N979 E880, N 1000 E922, N989 E850 e no setor escavado com máquina.

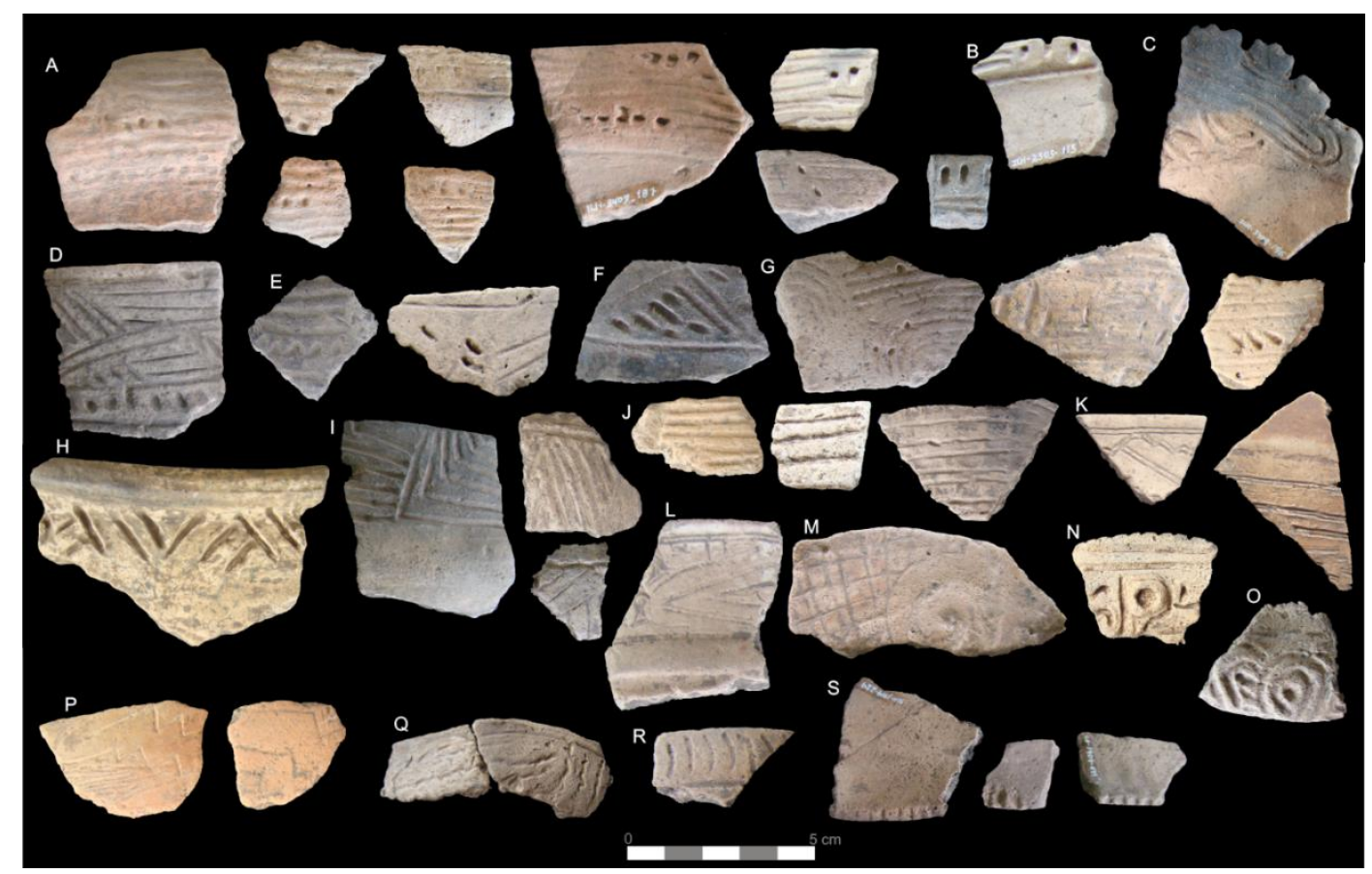

Figura 86: tratamentos plásticos: inciso e ponteado (A, B, D, E, F, G); borda recortada/modelada com incisões (C); inciso (H, I, J, K, Q, R); incisões associadas a engobo branco $(L)$; inciso, exciso e engobo vermelho (M); excisões (N, O); incisões escalonadas (P); entalhes no lábio (S) (Fotos: SCIENTIA, 2012).

Fragmentos com pintura ocorrem nas unidades N991 E849, N992 E850, N993 E849, N987 E849, N980 E849, N920 E910, N979 E880, N1000 E922 e N974 E880, porém todos bastante fragmentados e com a pintura desgastada. Ocorrem entre os níveis 20-30 cm e 80-90 
$\mathrm{cm}$, porém tudo indica que existam diferenças entre aquelas mais profundas e as mais superficiais: estas últimas apresentam motivos com faixas largas. Em quase todos os fragmentos com pintura ocorre desgaste na superfície interna, possivelmente devido ao uso destas vasilhas na fermentação de bebidas. Não foi possível identificar os motivos das pinturas, e elas ocorrem nas cores vermelha, branca ou vermelha e branca associadas.

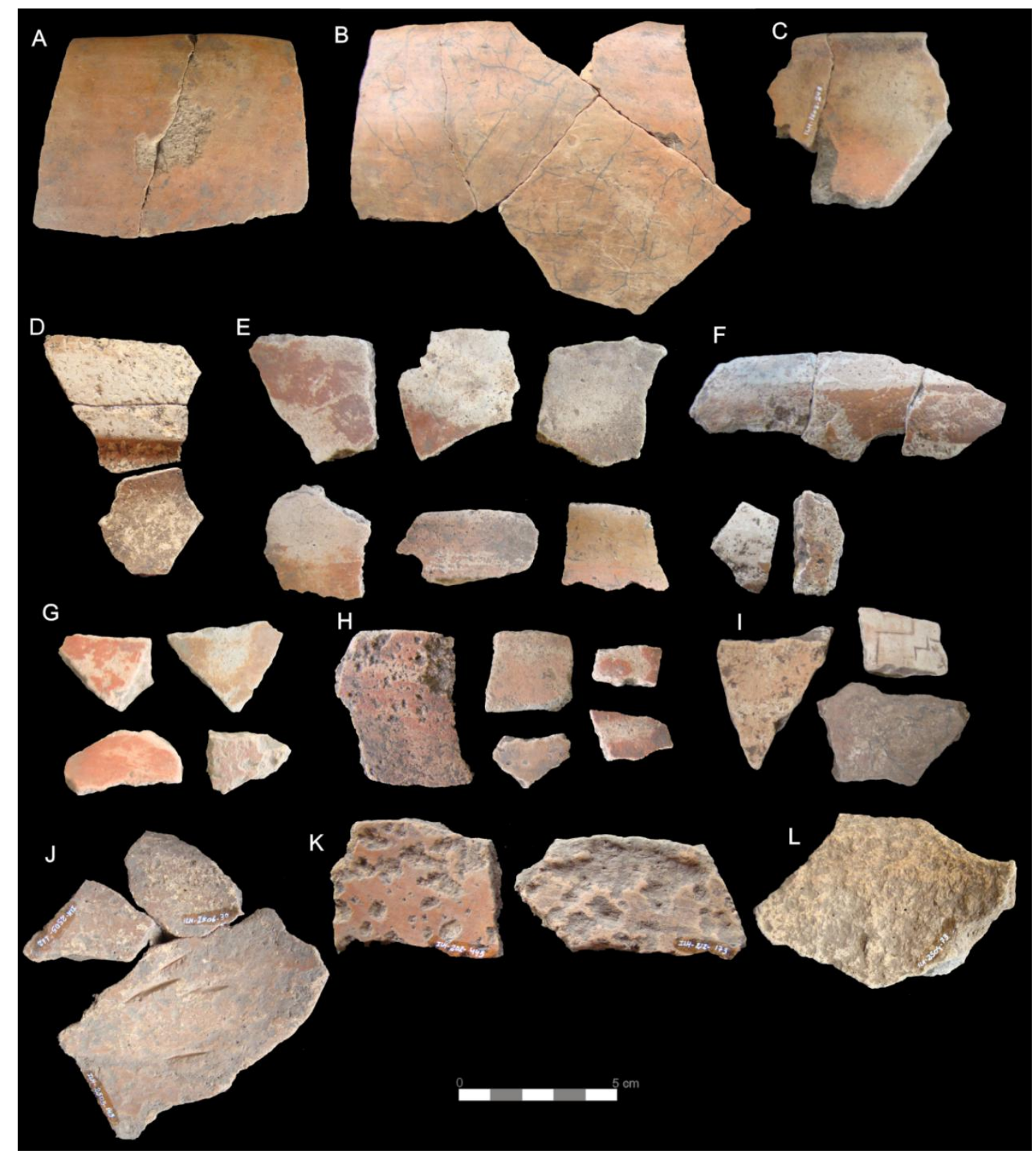

Figura 87: engobo vermelho $(A, B, G)$; decoração vestigial $(C)$; pintura vermelha e branca $(D, E, F)$; engobo e pintura vermelha $(G)$; engobo branco $(L)$; e marcas de fermentação na face interna $(J, K, L)$ (Fotos: SCIENTIA, 2012).

Foram identificados fragmentos de outros artefatos no sítio Ilha de Santo Antônio. Uma peça da unidade N989 E850 $(30-40 \mathrm{~cm})$ é modelada e está quebrada junto a dois furos, 
possivelmente tratando-se de um adorno. Na unidade N1000 E922 ocorre uma representação zoomorfa (objeto figurativo independente) no nível 50-60 $\mathrm{cm}$. Ocorrem também peças arredondadas ou subarredondadas, algumas delas sendo confeccionadas com a reciclagem de fragmentos cerâmicos, uma com incisões em uma das faces (possíveis adornos auriculares). Estas estão presentes nas unidades N988 E850, N988 E851, N989 E851, N 920 E910, N1000 E922, N993 E849, N987 E849, N991 E849 e 979 E880, entre os níveis 20-30 e 40-50 cm, com predominância no $20-30 \mathrm{~cm}$. Também foram encontrados ao todo quatro fragmentos de fuso nos níveis mais superficiais das unidades N988 E851, N989 E851 e N980 E849. Finalmente, cabe chamar a atenção para duas peças com formato tubular encontradas nas unidades N989 E851 e N987 E849, com 4 cm de diâmetro.

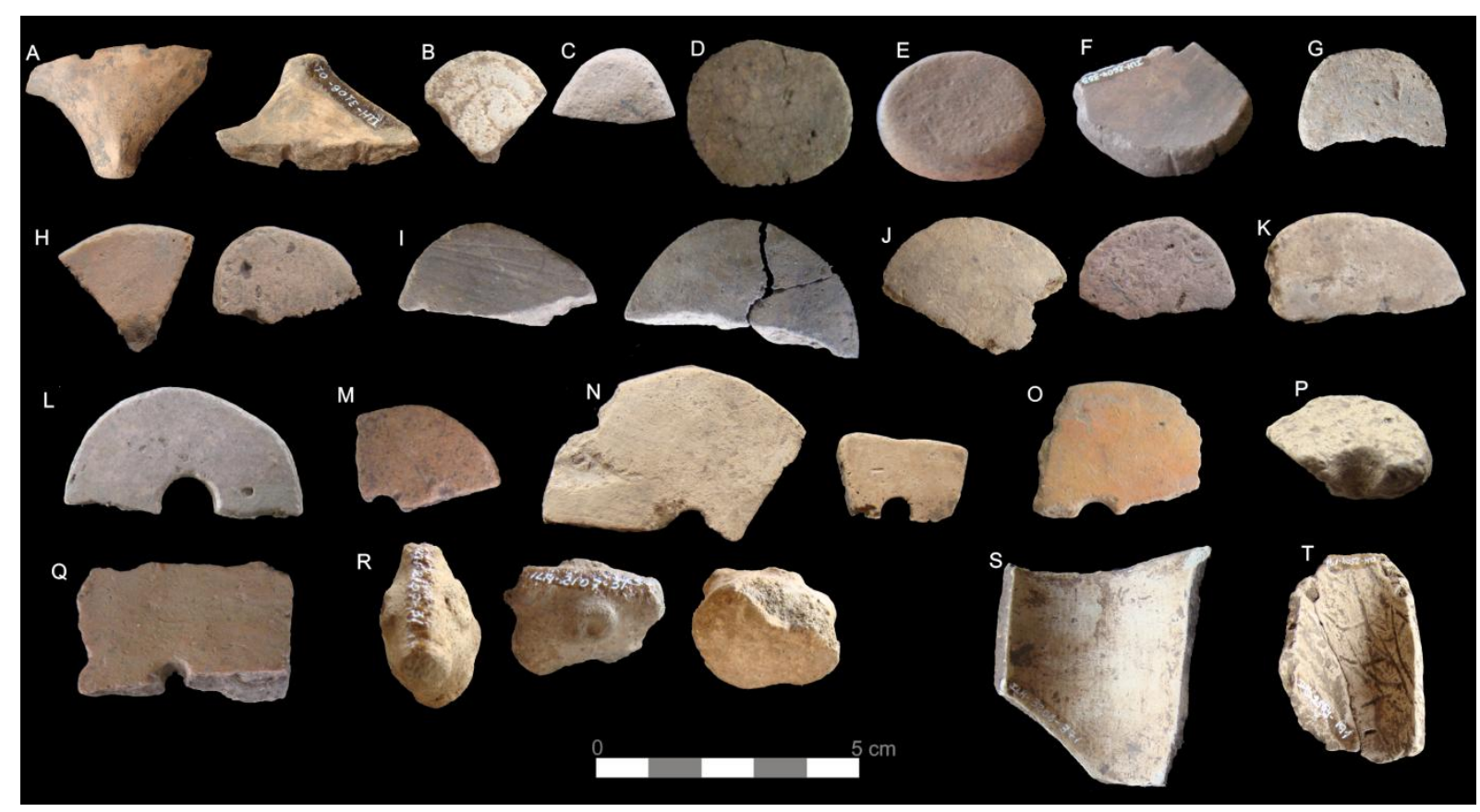

Figura 88: adorno com furos (A); adorno circular com incisões (B); possíveis adornos circulares (C - L); fragmentos de fusos (L-Q); representação zoomorfa independente (R); fragmentos de objetos tubulares (C, L) (Fotos: SCIENTIA, 2012).

\subsubsection{Considerações o material cerâmico do sítio Ilha de Santo Antônio}

A análise do material das seis unidades e das vasilhas cerâmicas, bem como a triagem qualitativa dos materiais das demais unidades e da área ampla escavada com máquina, possibilitou a caracterização da coleção cerâmica do sítio Ilha de Santo Antônio. Maiores considerações serão feitas no próximo capítulo, quando faremos a comparação entre os materiais dos sítios analisados, porém aqui já é possível fazer algumas considerações sobre a tecnologia cerâmica deste sítio. 
Predomina no sítio Ilha de Santo Antônio um conjunto tecnológico caracterizado pela adição de caraipé na pasta, superfícies das vasilhas bem alisadas, polidas ou brunidas, presença considerável de tratamentos plásticos incisos, incisos e ponteados, modelados (bicos nos lábios), aplicados (zoomorfos) e roletados e frequência considerável de engobo vermelho. vasilhas com diferentes formas sendo utilizadas no preparo de alimentos sobre o fogo; vasilhas com gargalos ou pescoço sendo utilizadas para a fermentação de bebidas; vasilhas pequenas (formas de cuia) sendo utilizadas para servir e consumir os alimentos líquidos e sólidos; possíveis vasilhas com boca não circular (bordas com bicos poderiam ser de vasilhas naniformes/ forma de navio); presença de erosão na face interna de muitos fragmentos contrastando com a face externa bem conservada, alguns mais visíveis enquanto marcas de fermentação; presença de fusos e peças circulares feitas com a reciclagem de fragmentos nos níveis superiores. Tais características podem ser atribuídas ao conjunto tecnológico predominante neste sítio, as quais destoam daquelas atribuídas à Tradição Polícroma da Amazônia, anteriormente definida para a região (Miller, 1987, 1992), e se aproximam mais da Tradição Barrancóide ou Borda Incisa. Este foi datado em 14C $990 \pm 40$ AP.

Além deste conjunto, buscamos delimitar um mais antigo, com a presença de bordas com flanges labiais e mesiais, pontos angulares nas paredes, bordas expandidas, incisões paralelas duplas na face interna das bordas, pasta porosa com grande quantidade de carvão ou com elementos minerais angulosos, barbotina laranja entre outros elementos, encontrado nos níveis mais profundos do sítio da Ilha. Não foi possível avançar nesta hipótese apesar de ser bastante pertinente, tendo em vista que materiais com estas características ocorrem em sítios como o Garbin e Veneza na margem direita. Este não foi datado no sítio da Ilha de Santo Antônio.

Entendemos que as vasilhas cerâmicas (R1, R2 e R3) podem ser associadas à Tradição Polícroma da Amazônia, e que os grupos portadores desta tradição tecnológica poderiam ter ocupado o sítio em um período mais recente. Apesar da presença de fragmentos cerâmicos com pintura vermelha e branca em traços largos, semelhante à dos recipientes 1, 2 e 3, não foi possível delimitar tal ocupação neste local. Existe a possibilidade da ocupação ter sido pouco duradoura, resultando em uma quantidade de fragmentos não muito significativa nos níveis superficiais, como ocorre em sítio do baixo Madeira e Amazônia Central. Retomaremos esta discussão na comparação com outros sítios arqueológicos, sendo a interpretação dos contextos balizada em uma perspectiva regional. É necessário também refinar a cronologia do sítio Ilha de Santo Antônio e aumentar o número de amostras analisadas. 
O material deste sítio foi abordado no projeto de iniciação científica (PIBIC/UNIR) e trabalho de conclusão de curso de Pessoa (2012), bem como no seu projeto de mestrado em andamento (PESSOA, 2014), no qual compara esta cerâmica com a do sítio Novo Engenho Velho, localizado na margem esquerda do rio Madeira, a jusante da cachoeira.

\subsection{Cerâmica do sítio Veneza}

Foram triados 4.703 fragmentos cerâmicos do sítio Veneza, sendo 640 provenientes da delimitação do sítio, 1.019 das coletas de superfície sistemáticas e não sistemáticas, 310 do perfil do barrando e 2.734 das unidades de escavação ${ }^{20}$. Na triagem de toda a coleção foram separados 1.137 fragmentos diagnósticos, os quais foram analisados, sendo 1.046 de vasilhas, cinco de artefato não identificado (NI) e 86 bolotas de argila. Como muitos fragmentos remontaram ou formam conjuntos de uma mesma vasilha, trabalhamos com um número de 768 fragmentos de vasilhas e cinco não identificados. A maioria dos fragmentos apresenta-se bem conservada apesar de bastante fragmentados, decorrente dos processos antrópicos pósdeposicionais, ficando em parte comprometida a análise das características morfológicas e decorativas das peças.

Predominou a escolha de uma pasta homogênea, com baixa inclusão de grãos finos de quartzo, subangulosos e arredondados, associado a óxido de ferro ou feldspato, e adição de caraipé na grande maioria associado ao carvão, sendo raros os fragmentos com cauixí ou apenas com mineral na pasta (gráfico 12$)$. A queima redutora é mais frequente $(419 ; 54,56 \%)$, seguida pela oxidante $(331 ; 43,10 \%)$, oxidante externa e reduzida interna $(11 ; 1,43 \%)$, oxidante interna e reduzida externa (5 fragmentos) e oxidante com nucleo reduzido (2 fragmentos). As bases e as flanges foram confeccionadas com a técnica modelada $(27 ; 3,51 \%)$ e o corpo da vasilha com a sobreposição de roletes $(658 ; 85,68 \%)$, e nos demais fragmentos $(83 ; 10,81 \%)$ não foi possível identificar a técnica de confecção. Na maioria dos fragmentos analisados ocorreu a aplicação da barbotina $(621 ; 80,86 \%)$ em uma ou em ambas as faces, em $119(15,49 \%)$ não foi identificada e em $28(3,65 \%)$ está ausente.

\footnotetext{
${ }^{20}$ A cerâmica deste sítio foi abordada no projeto de iniciação científica de Costa (2010).
} 


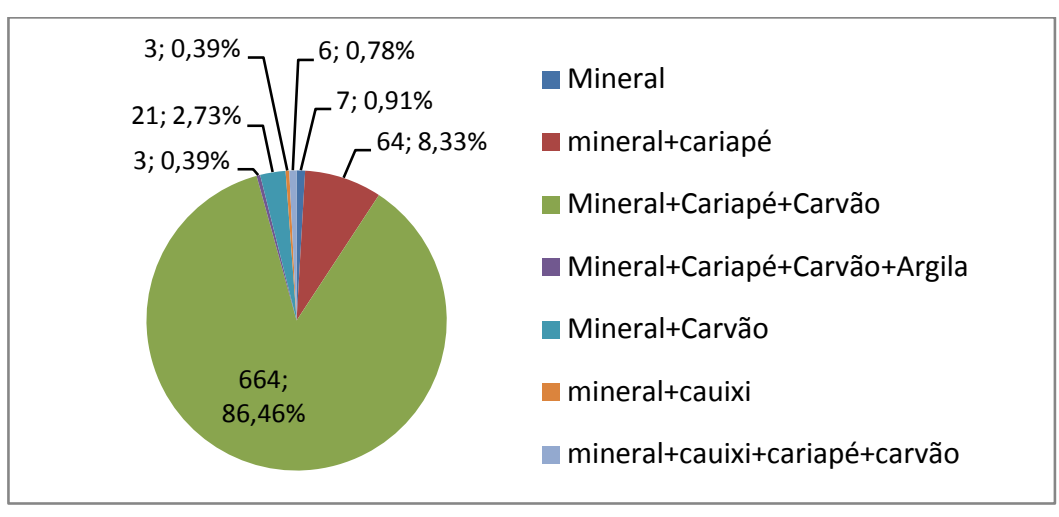

Gráfico 12: pasta dos fragmentos de vasilhas do sítio Veneza.

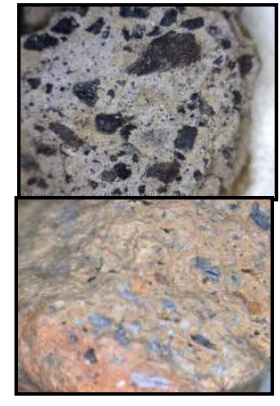

Figura 89: pasta com carvão e caraipé e caraipé - Veneza (Fotos: SCIENTIA, 2011)

A barbotina ocorre nas cores marrom clara, bege, marrom escura, vermelha, rosada, cinza clara e laranja, esta última podendo ser decorrente de um engobo vermelho desgastado aplicado sobre ela. Na superfície das vasilhas predominam os alisamentos médios e finos, mas ocorre também o alisamento grosseiro, o polimento e raramente a brunidura (gráfico 13). São visíveis em alguns fragmentos as marcas deixadas pelo instrumento utilizado para alisar ou polir, decorrente da aplicação deste tratamento com a pasta mais seca, as vezes confundindose com o tratamento plástico escovado.

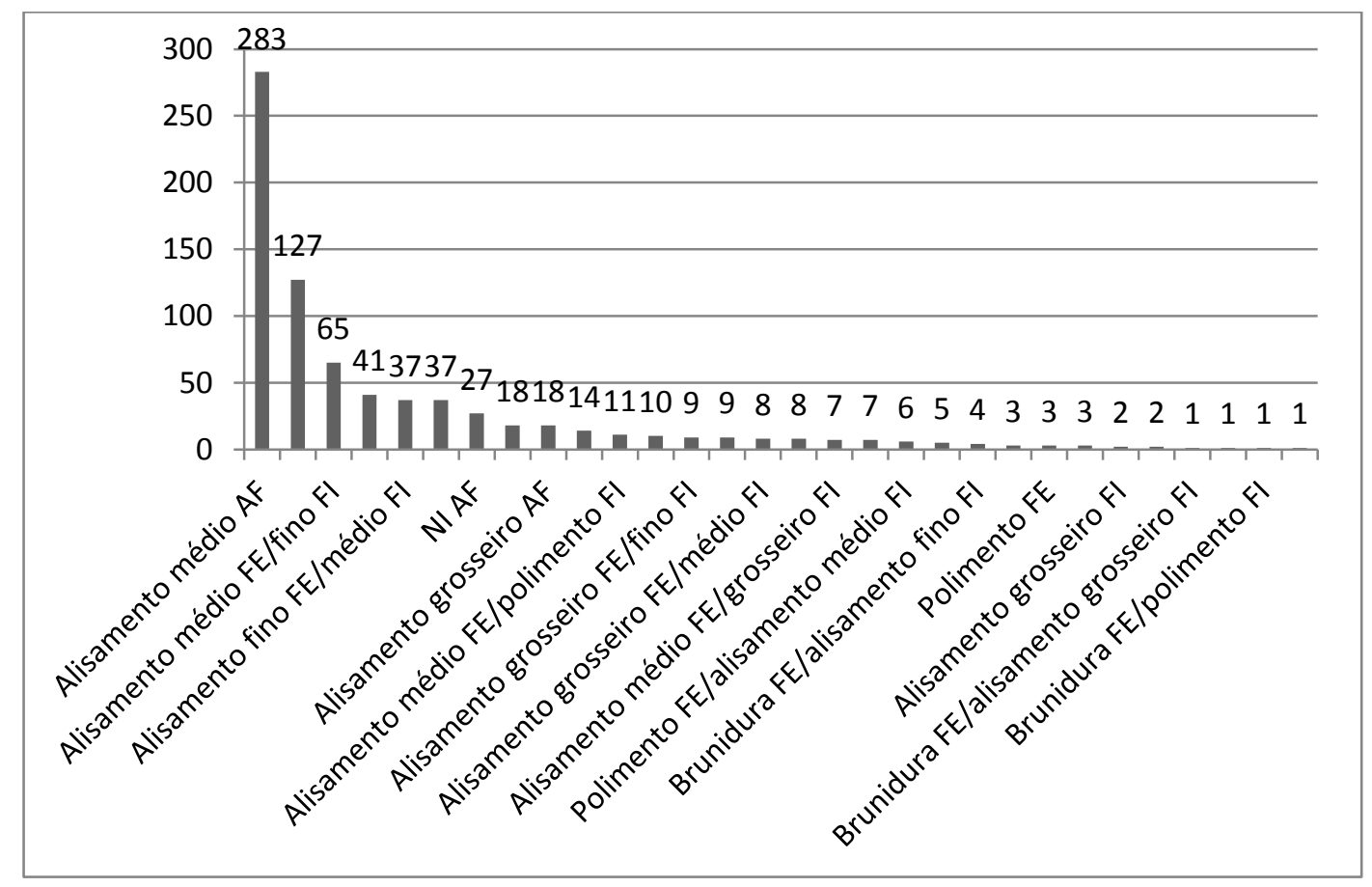

Gráfico 13: Acabamentos de superfície - sítio Veneza.

Ocorre engobo em 267 (34,76\%) fragmentos analisados, nas seguintes cores: vermelho AF (91 fragmentos), vermelho FE (83), vermelho FI (90), branco FE (2) e vinho FE(1). Nos 
demais está ausente $(475 ; 61,85 \%)$ ou não foi identificado $(26 ; 3,39 \%)$. A pintura ocorre em 39 fragmentos (5,07\%), enquanto em 25 não foi identificada e em 704 está ausente. Predomina a pintura vermelha e branca FE (17), vermelha FI (11) e vermelha FE (6), mas também ocorre a a pintura vermelha e branca FI (2), branca FE (1), vermelha e branca FE e vermelha FI (1) e vermelha FE e branca FI (1). Enquanto na face interna foi aplicada nos lábios e em apenas uma borda, na face externa ocorre nas bordas, inflexões, paredes ou no perfil completo da vasilha. Com relação aos motivos, apenas 12 foram descritos como linhas horizontais e os demais não foram identificados. Raramente o vermelho sobrepõe o branco ou vice-versa. É recorrente a aplicação da pintura concomitante aos acabamentos plásticos incisos.

Ocorre tratamento plástico em 172 fragmentos (22,39\%), predominando os incisos e escovados, porém ocorre uma grande variação de outras técnicas em menor quantidade (gráfico 14). A maioria ocorre na borda, especialmente aqueles aplicados na face interna, na parte mais visível. Ocorrem linhas horizontais em 107 fragmentos, e os demais são curvilíneos, linhas verticais, angulares, entrecruzadas, triangulares, composto ou complexo. Observa-se que em duas peças ocorre um motivo semelhante à letra "J"; além de incisões interrompidas por incisos menores no sentido oposto. Destaca-se um aplique no lábio, possivelmente zoomorfo.

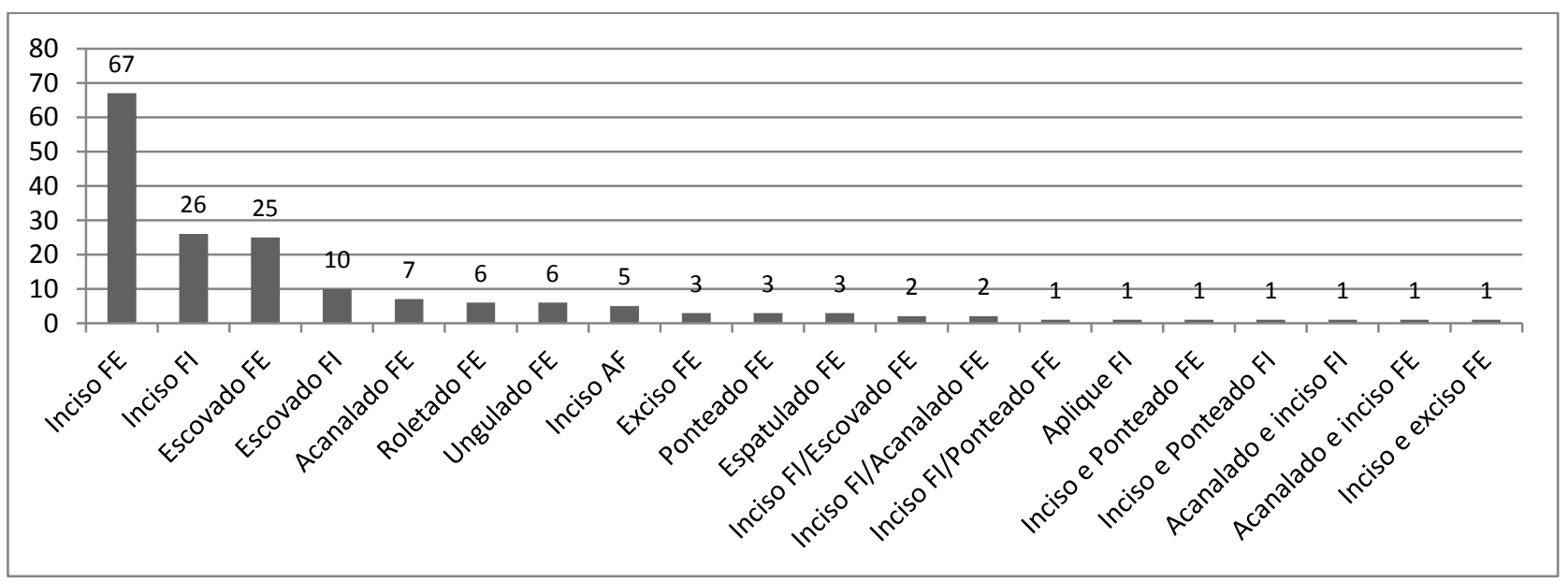

Gráfico 14: Tratamentos plásticos- sítio Veneza. 


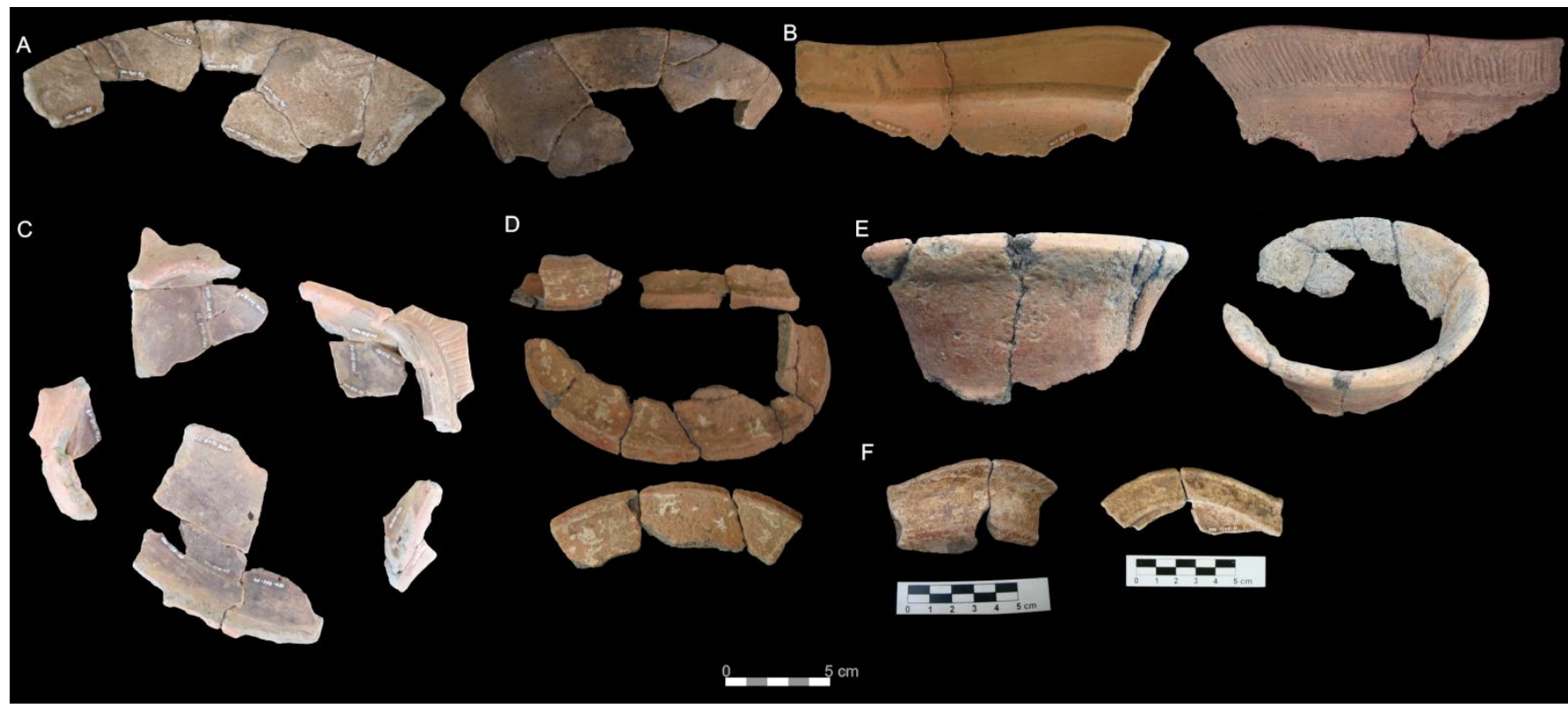

Figura 90: vasilha com incisões curvilíneas na borda (FI) e fuligem FE (A); borda com inciso FI e escovado FE (B); vasilha com flange mesial modelada com incisões FE e (C); vasilha com contorno complexo, pintura branca e vermelha e incisões na $F E * D)$; gargalo com engobo vermelho (E) e vasilha com pintura vermelha e branca $F E$ e incisões na flange labial (F).

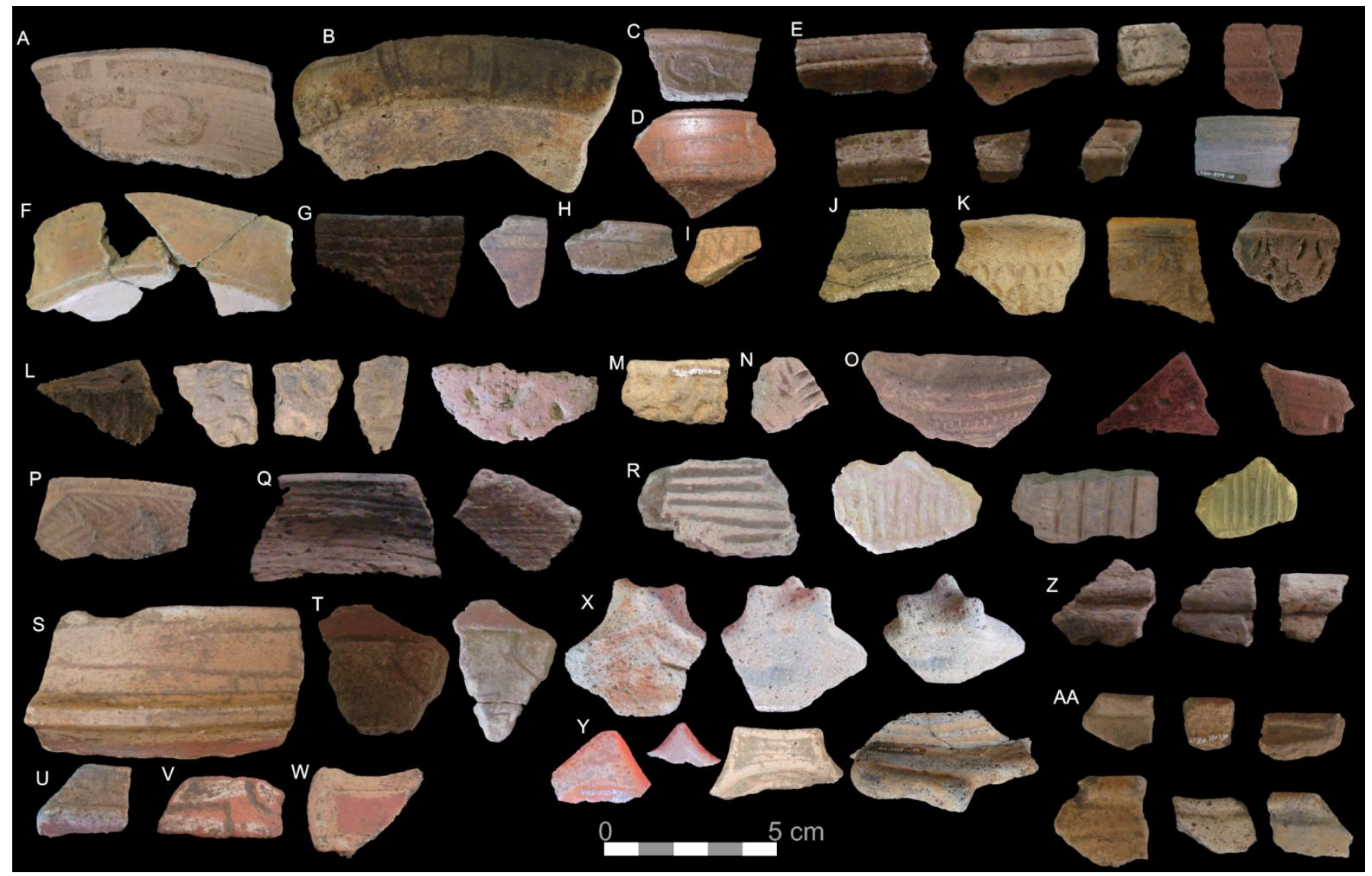

Figura 91: tratamentos plásticos: inciso e exciso (A); inciso em linhas curvilíneas (B, C); inciso em linhas paralelas (E, F, G); inciso composto $(H, J)$ e em linhas entrecruzadas $(H)$, serrungulado $(K, L)$, ponteado (M), inciso triangular (N), inciso e ponteado $(\mathbf{O})$; inciso triangular $(P)$, escovado $(Q)$, inciso em linhas horizontais e verticais $(R)$, inciso e pintado (S, T, U, V, W, D), aplique zoomorfo $(\mathrm{X})$; roletado $(\mathrm{Z})$, flanges ou bordas modeladas e aplique ou asa (Y); acanalado (AA) (Fotos: SCIENTIA, 2011). 


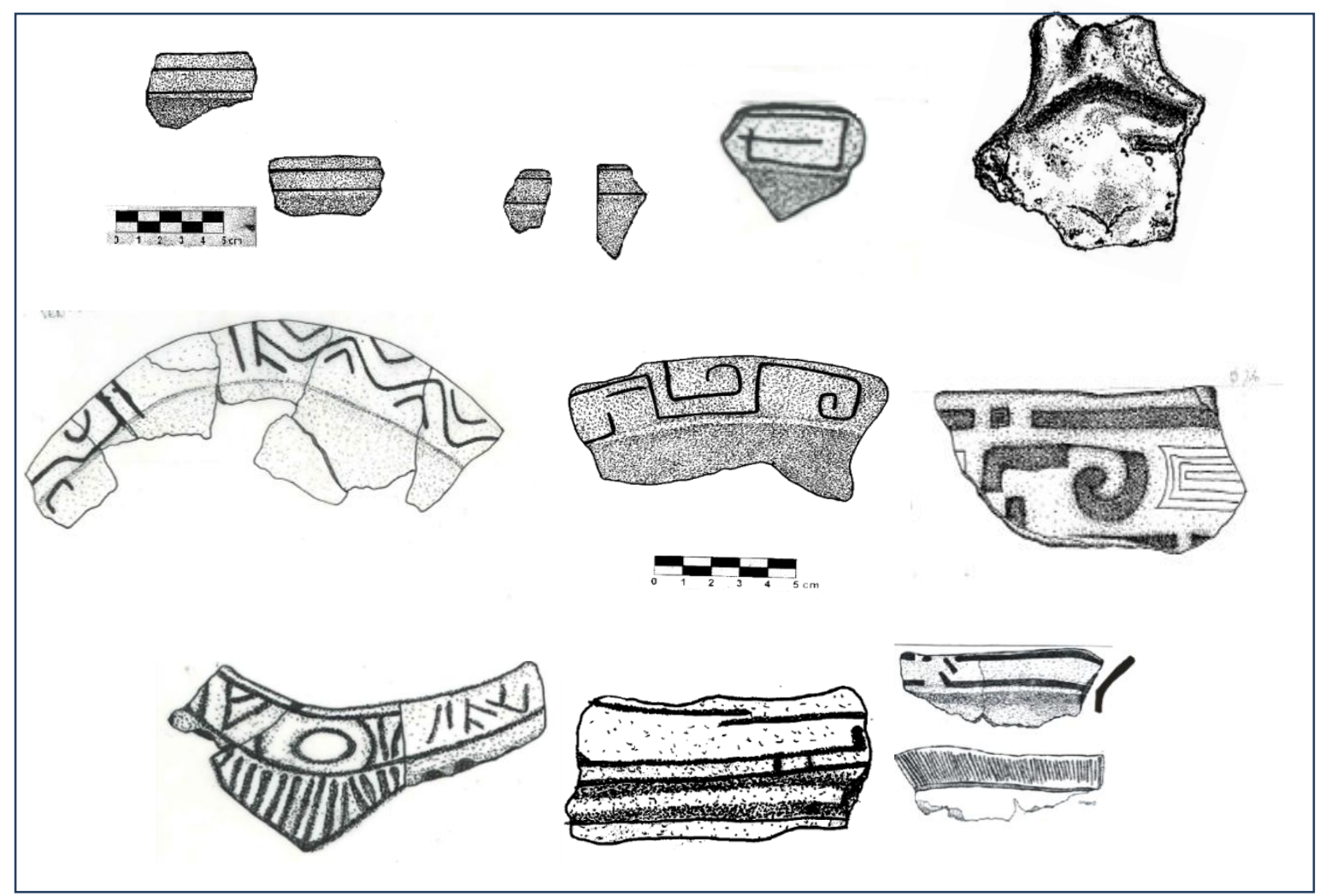

Figura 92: desenhos dos tratamentos plásticos- sítio veneza (Desenhos: Angislaine F. Costa, 2011).

Foram analisados fragmentos de borda (324), parede (266), inflexão (76), base (35), bordas com flange (6), flanges (7), borda e parede (10), borda e bojo (2), borda e carena (1), borda e pescoço (1), bojo (1), carena (1), além de conjuntos de fragmentos de três vasilhas, quatro vasilhas com o perfil completo e fragmentos não identificados (31).A espessura dos fragmentos varia entre 2 e $40 \mathrm{~mm}$, com maior frequência entre 5 e $9 \mathrm{~mm}$. Predominam as bordas diretas verticais, inclinadas externamente, inclinadas internemente e extrovertidas (gráfico 15). Quanto ao espessamento, além das lineares destacam-se as expandidadas e reforçadas (gráfico 16). Os lábios são arredondados (177; 50,86\%), planos (119; 34,20\%), apontados $(48 ; 13,79 \%)$ ou não identificados $(4 ; 1,15 \%)$. As bordas expandidas e com reforço geralmente possuem os lábios planos, muitos deles com decorações incisas, e são características desse sítio. 


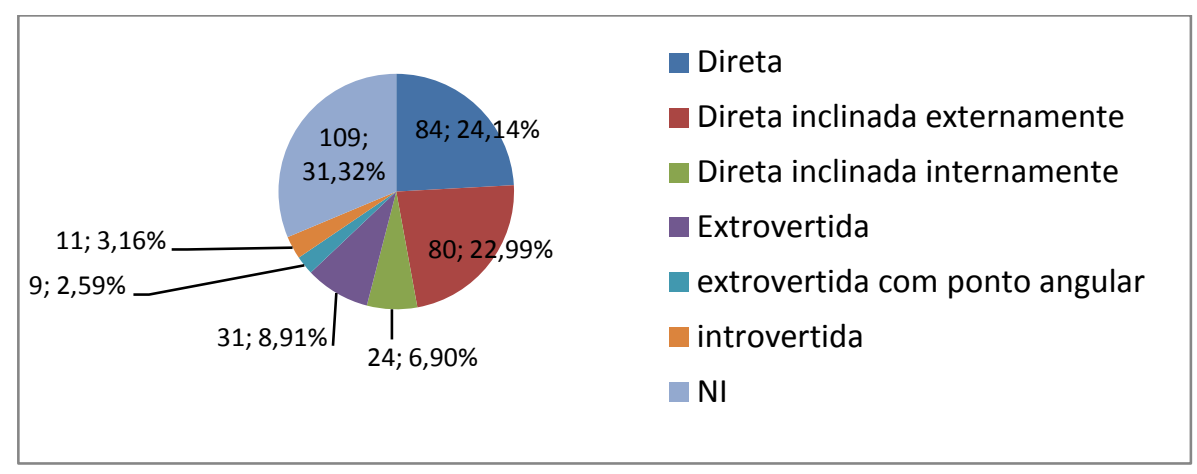

Gráfico 15: forma e inclinação das bordas - sítio Veneza.

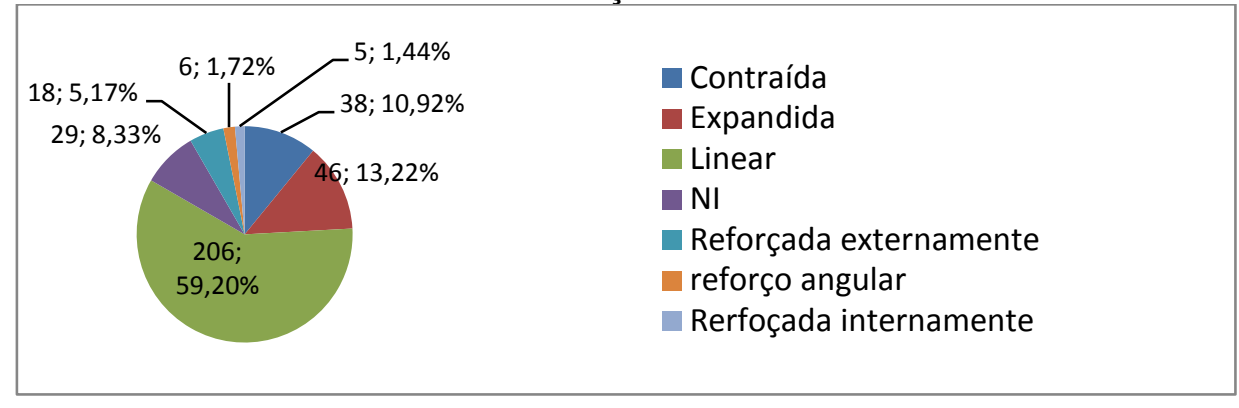

Gráfico 16: e espessamento das bordas- sítio Veneza.

Devido à grande fragmentação foi possível medir o diâmetro de apenas 48 bordas, que variam entre 8 e $76 \mathrm{~cm}$, com maior quantidade entre 14 e $26 \mathrm{~cm}$. Portanto são vasilhas pequenas, com excessão de dois assadores (54 e $76 \mathrm{~cm}$ ). Algumas bordas de vasilhas de tamanho grande são irregulares (onduladas), por isso não foi possível medir o seu diâmetro. Os 35 fragmentos de base identificados possuem a forma plano-côncava (21), bi-plana (10) e convexa-côncava (1), e nas demais não foi possível identificar (3). Ocorreram inflexões angulares que podem compor fragmentos de base, carena ou de flange labial. Ocorre apenas um bojo na coleção, porém são frequentes fragmentos com pontos angulares, denominados de inflexões na analise.Ocorre fuligem em apenas 26 fragmentos e depósito de carbono em 16, sendo que nos demais não foi possível identificar ou está ausente. A fuligem está presente em cinco bordas diretas inclinadas externamente, cinco extrovertidas, duas diretas verticais e uma extrovertida com ponto angular.

Na figura 93 são apresentados alguns tipos de bordas identificados no sítio Veneza, e que representam a variabilidade formal presente no sítio, algumas delas com hipóteses sobre o uso. Ocorrem somente quatro vasilhas com o perfil completo, sendo três assadores e uma tigela rasa decorada com pintura na superfície externa e incisões na flange labial. Importante ressaltar que neste sítio verificou-se a presença de vasilhas com boca não circular, e não foi possível vizualizar a forma, se são retangulares, quadrangulares ou irregulares. 

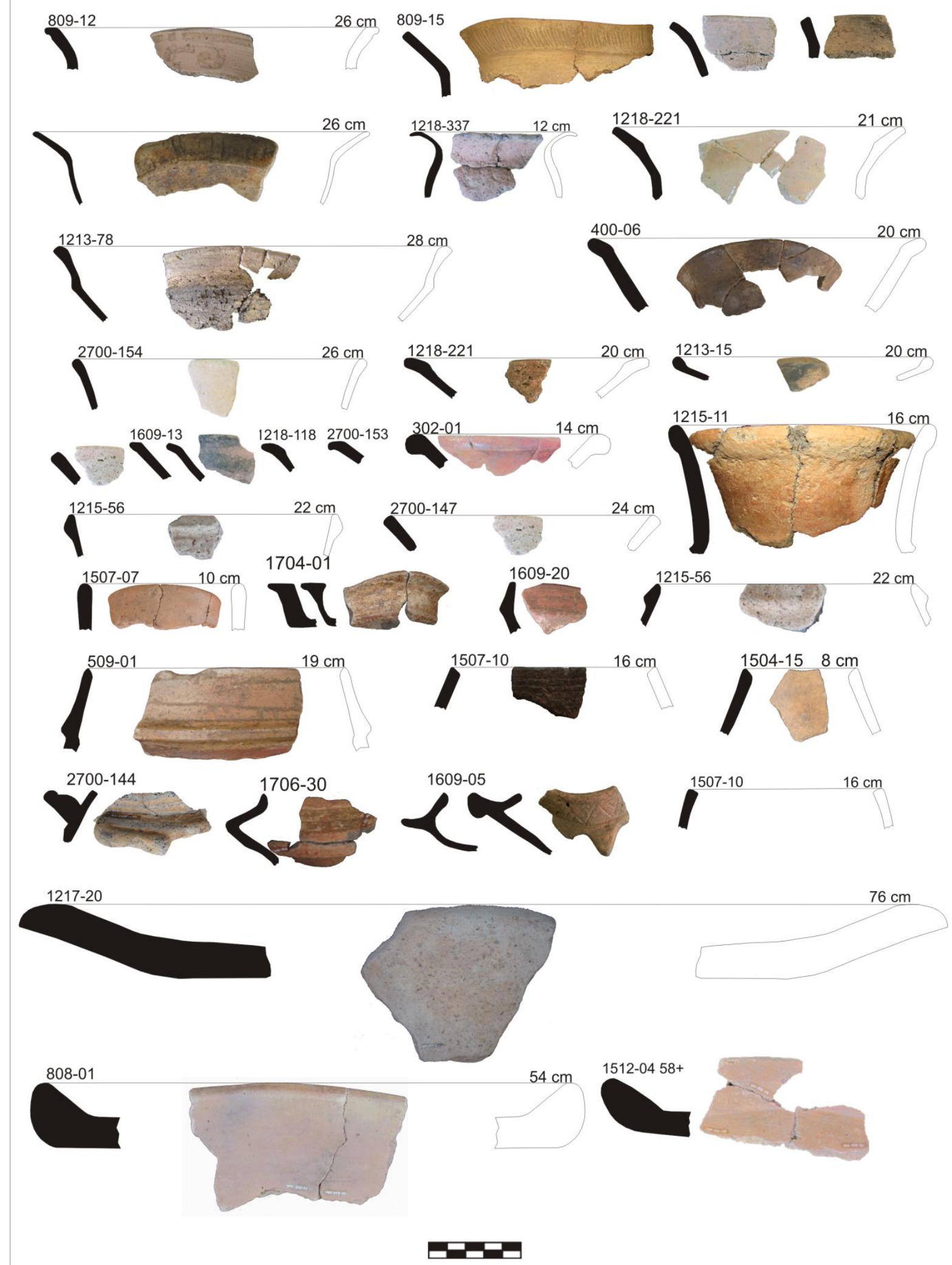

Figura 93: desenhos das bordas- sítio Veneza 
A análise do material cerâmico do sítio Veneza permitiu caracterizar a coleção que possui uma diversidade de formas de vasilhas, entre elas aquelas cuja boca não é circular, vasilhas com flange labial e mesial, bordas extrovertidas e introvertidas com ângulos, vasilhas com pescoço (fechadas), vasilhas rasas com a borda bastante inclinada (pratos), bordas e lábios com diferentes espessamentos e formas. Também ocorre alta frequência e diversidade de tratamentos plásticos aplicados preferencialmente na borda, incisões com motivos variados, alta frequência de engobo vermelho e pintura vermelha (frequente nos lábios) e associação de pintura e incisões. A amostra de carvão datada para este sítio estava contaminada. Temos a hipótese de que este material seja mais antigo do que aquele que associamos a tradição Barrancóide do sítio Ilha de Santo Antônio datado em 14C $990 \pm 40$ AP, e que o possível conjunto mais antigo do sítio Ilha de Santo Antônio apresenta características tecnológicas semelhantes e este do sítio Veneza. Se essa hipótese se confirmar a ocupação do sítio Veneza será uma das mais antigas pelos povos ceramistas nas proximidades da cachoeira de Santo Antônio.

No sítio Garbin, cuja ocupação ceramista possui datas 14C $1.710 \pm 40 \mathrm{AP}, 1.300 \pm 30$ AP, $990 \pm 30$ AP e $480 \pm 40$ AP, ocorre uma cerâmica semelhante a do sítio Veneza. Apesar de não terem sido analisadas, fizemos uma "triagem qualitativa" que permitiu observar a presença de flanges labiais decoradas com incisões, bordas extrovertidas com ponto angular igualmente decoradas; bordas expandidas e lábios planos, alguns com decoração incisa; poucos fragmentos de bojo que indicariam formas globulares; inflexões angulares (carenas, flanges ou bases muito fragmentadas), algumas delas com decoração ponteada ou incisa, e poucos fragmentos com pintura. As incisões duplas paralelas são as mais frequentes, e destaca-se um possibel aplique zoomorfo (Figura 94).

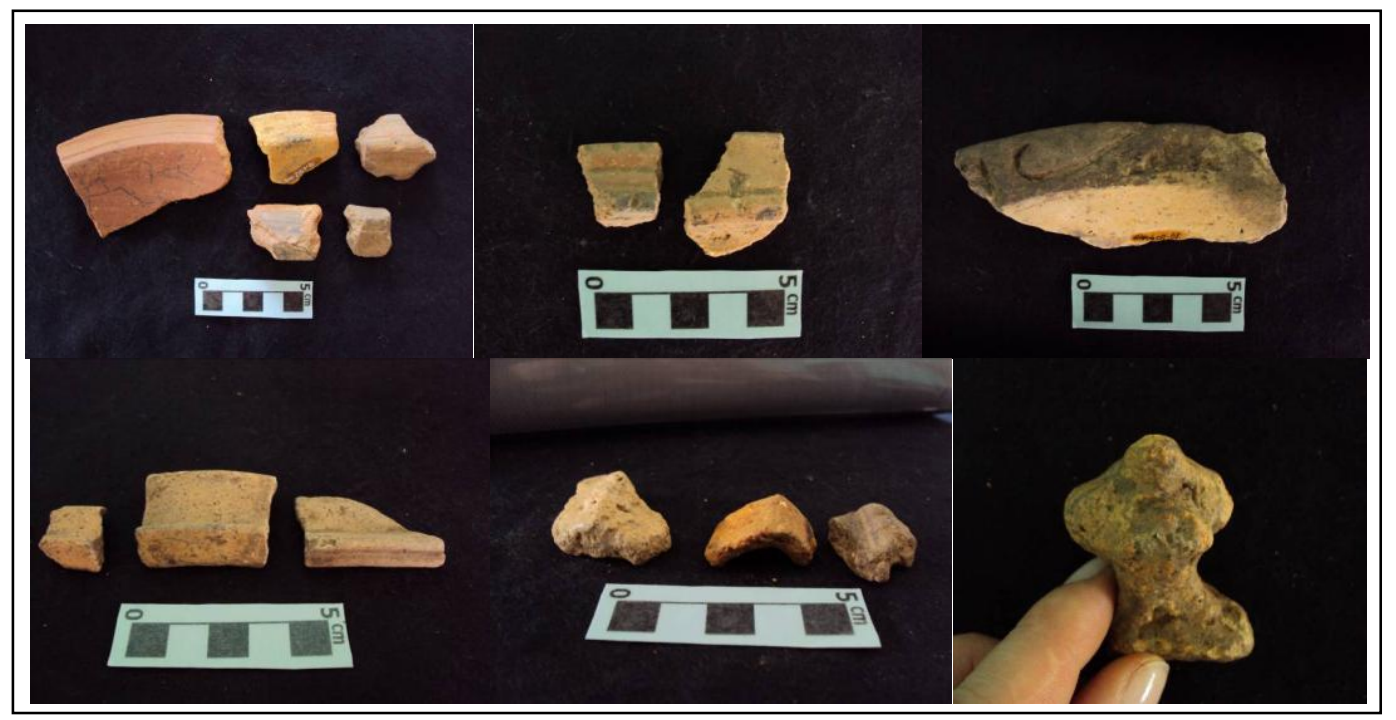

Figura 94: materiais do sítio Garbin (fotos: SCIENTIA, 2010) 


\subsection{Cerâmica do sítio do Brejo}

Foram analisados 1.235 fragmentos diagnósticos, sendo 489 da unidade N1022 E1059 (setor 1), 580 da N1040 E957 (setor 5) e 166 da N982 E981 (setor 3). Com as remontagens e conjuntos de fragmentos da mesma vasilha, o número diminuiu para 1.200 fragmentos de vasilhas. Também foram analisadas as vasilhas R1, R2 e R3 deste sítio. O setor 1 está mais próximo ao rio e apresentou cinco camadas arqueológicas com datações de 14C $1.120 \pm 40$ AP $(620-630 \mathrm{~cm}), 1.040 \pm 60$ AP $(590-600 \mathrm{~cm}), 1.160 \pm 40$ AP $(470-480), 1.040 \pm 40$ AP (350-360 cm), $890 \pm 40$ AP (150-160) e $760 \pm 40$ AP (80-90); o setor 5 está a $50 \mathrm{~m}$ do rio em elevação intermediária e datação de 14C 940 30 AP (60-70 cm/N1040 E957) e o setor 3 mais distante do rio na parte mais alta com datação 14C $1.390 \pm 40$ AP (70 cm/ N982 - E981). Este sítio está localizado muito próximo a Ilha de Santo Antônio.

\subsubsection{Análise dos materiais das unidades N1022 E1059 (setor 1), N1040 E957 (setor 5) e N982 E981 (setor 3)}

A maioria dos fragmentos está bem conservada (1.123), e entre os demais 65 estão erodidos (53 na face interna e 12 na face externa), sete possuem decoração vestigial e cinco com uma das superfícies ausentes. Na pasta predomina a presença de mineral e caraipé (730; 60,83\%), seguido por mineral, caraipé e carvão (421; 35,08\%); 42 fragmentos com mineral $(3,50 \%)$; e apenas sete fragmentos com cauixí, em dois deles associado ao caraipé. Comparando as pastas dos diferentes setores (gráfico 17), observa-se que todos os fragmentos com cauixí são do setor 5 , bem como a maioria das peças que apresentam somente mineral na pasta: 29 fragmentos do setor 5, um fragmento do setor 3 e dozedo setor 1 . A frequência de fragmentos com presença de carvão associado ao caraipé também varia: $75,78 \%$ dos fragmentos do setor 1 possuem caraipé e mineral na pasta e $21,77 \%$ apresentam carvão associado ao caraipé e mineral, enquanto nos outros dois setores as quantidades destas duas pastas são mais equilibradas $(57,86 \%$ e $41,5 \%$ no setor $3 ; 49,29 \%$ e $44,36 \%$ no setor 5 , repectivamente). Todos os fragmentos com cauixí são dos níveis $50-60 \mathrm{~cm}$ a $80-90 \mathrm{~cm}$, e os fragmentos com mineral estão entre 30-40 e 110-120 cm de profundidade. Quando comparamos as pastas dos fragmentos do setor 1 (gráfico 18), considerando os pacotes arqueológicos separados por camadas arenosas estéreis (eventos de cheia), verificamos que o elemento mineral aparece isolado apenas em fragmentos entre 20 e $180 \mathrm{~cm}$, além da grande maioria apresentar mineral e caraipé e apenas uma pequena quantidade possuir carvão. Nas camadas entre 300 e $420 \mathrm{~cm}$ e $660-580 \mathrm{~cm}$ deste setor ocorrem tanto fragmentos com caraipé 
quanto com caraipé e carvão, porém está ausente o mineral isolado. Portanto, no período mais antigo de ocupação do sítio era mais recorrente a presença de carvão na pasta das vasilhas, enquanto no período posterior a940 \pm 30 AP aparecem poucas vasilhas cuja pasta possui somente mineral ou com cauixí (setor 5) e a frequência de carvão na pasta diminui. Buscaremos verificar se ocorrem mudanças em relação aos demais atributos nos diferentes períodos e setores.

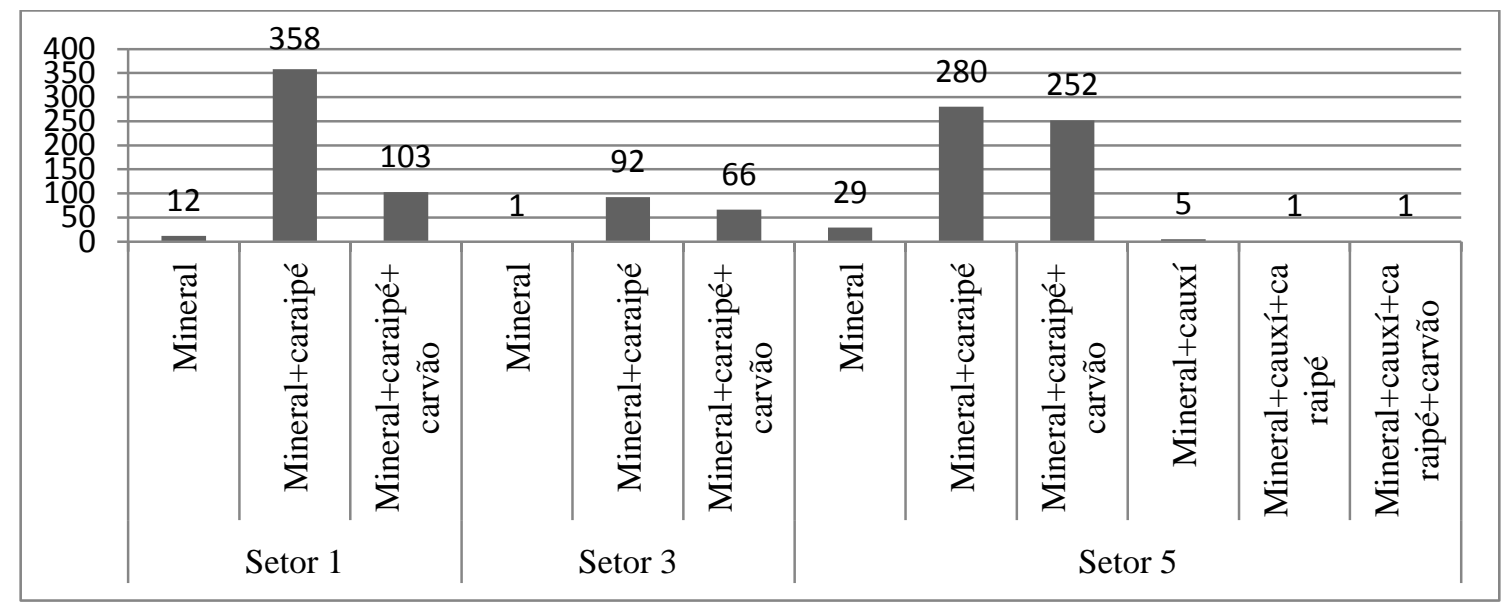

Gráfico 17: comparação entre as pastas dos diferentes setores do sítio do Brejo.

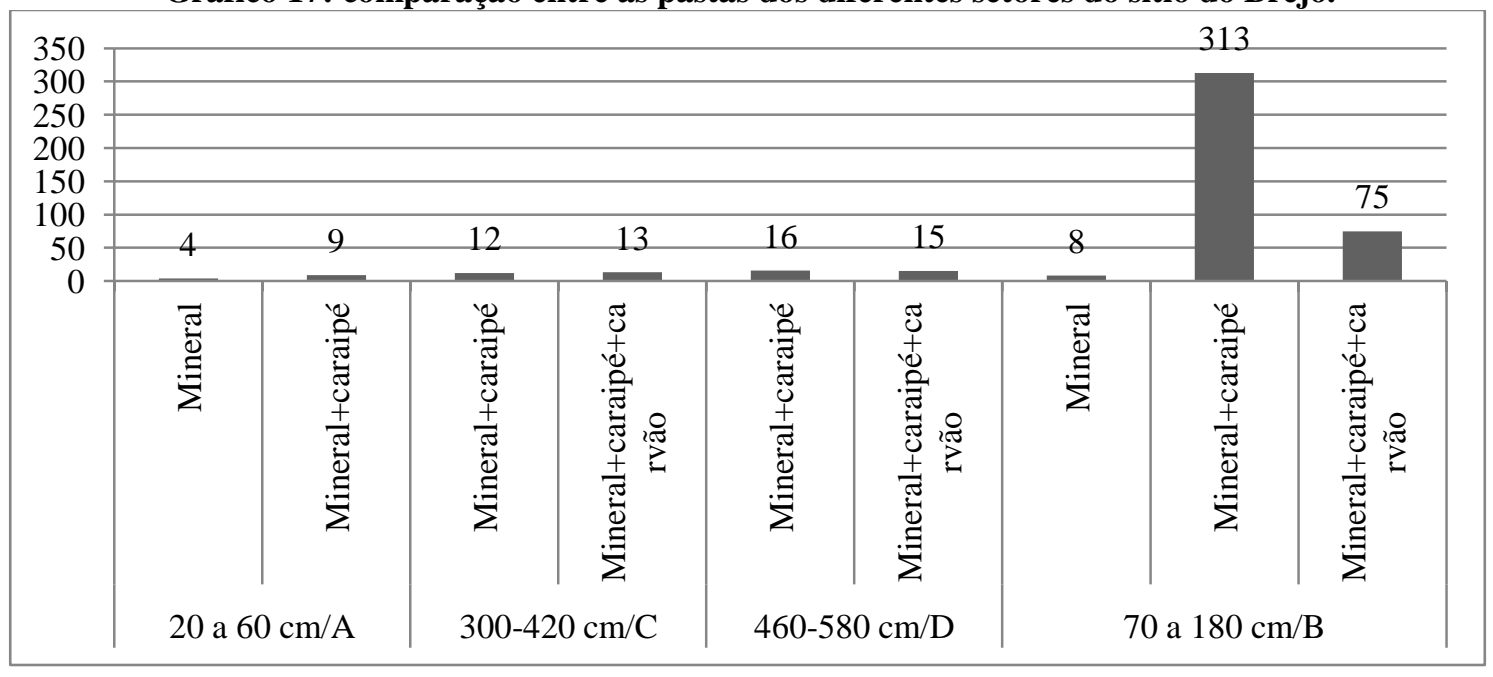

Gráfico 18: comparação entre as pastas dos pacotes com material evidenciados no setor 1- do sítio do Brejo.

Predomina a queima reduzida $(66,25 \%)$, mas também ocorre queima oxidante $(24,92 \%)$, oxidante externa e reduzida interna $(3,83 \%)$, oxidante interna e reduzida externa $(2,92 \%)$ e oxidante com núcleo reduzido (2,08\%), não sendo verificadas diferenças significativas nos diferentes setores e períodos. Com relação à técnica de confecção, apenas algumas bases foram confeccionadas com a técnica modelada (17), porém para as demais bases e o corpo das vasilhas utilizou-se a técnica acordelada. 
A barbotina está presente em $576(48 \%)$ fragmentos, enquanto nos demais não foi identificada $(197 ; 16,41 \%)$ ou está ausente $(427 ; 35,58 \%)$. As vasilhas são bem alisadas ou polidas (muitas foram identificadas como alisamento fino e médio porque as superfícies são irregulares, porém apresentam brilho característico do polimento). O engobo está presente em 100 fragmentos $(8,33 \%)$, não foi identificado em sete e nos demais está ausente. As colorações do engobo são as seguintes: vermelho FE (41), vermelho FI (30), vermelho AF (21), laranja FE (4), branco FE (2), laranja AF (1) e vinho FE (1). A pintura foi identificada em apenas 15 fragmentos: branca e vermelha FE (6); branca FE (2); vermelha FE (5), sendo que onze são do setor 5, três do setor 1 e um fragmento do setor 3. No setor 1 os fragmentos com pintura estão entre 70 e $120 \mathrm{~cm}$, ou seja, na camada mais espessa de terra preta (camada $\mathrm{X}$ ), no setor 3 o único fragmento é do nível $30-40 \mathrm{~cm}$ e no setor 5 os fragmentos estão entre 40-50 e 70-80 cm. Chama a atenção um fragmento com decoração que chamamos "em negativo", que possui ausência de pigmento em pontos circulares.

Os tratamentos plásticos ocorrem em apenas 46 fragmentos $(3,83 \%)$ e são os seguintes: roletado FE (17), inciso FE (16), modelado no lábio (5), inciso FI (4), ponteado FI (2), entalhado FE (1), acanalado FE (1), distribuídos nos três setores (13 no setor 1; 8 no setor 3 e 25 no setor 5). O tratamento roletado ocorre entre $70-180 \mathrm{~cm}, 300-420 \mathrm{~cm} \mathrm{e} 460-580 \mathrm{~cm}$ no setor 1, portanto existe uma continuidade; os incisos estão entre 20-60 cm, 70-180 cm e $300-420 \mathrm{~cm}$ neste setor, e os demais ocorrem entre $70-180 \mathrm{~cm}$, camada com maior quantidade de fragmentos. No setor 3 ocorrem entre $20-30$ e $40-50 \mathrm{~cm}$ e no setor 5 entre 40-50 e 70-80 $\mathrm{cm}$. Estes tratamentos foram aplicados nas bordas, paredes e inflexões.

Entre os fragmentos analisados, 459 são de parede, 479 bordas, 214 inflexões, 36 bases, 7 bojos, 1 borda com pescoço, 1 vasilha com perfil completo e dois fragmentos não identificados (NI). A espessura dos fragmentos varia entre 2 e $21 \mathrm{~mm}$, com maior frequência entre 4 e $10 \mathrm{~mm}$ e predominância de $6 \mathrm{~mm}$. Entre as bordas, predominam as diretas verticais, diretas inclinadas externamente, diretas inclinadas internamente e extrovertidas (gráfico 19), com espessamento contraído ou linear (gráfico 20). Os lábios são arredondados (317; $65,90 \%)$, planos $(73 ; 15,18 \%)$, apontados $(58 ; 12,06 \%)$, irregulares $(13 ; 2,70 \%)$, biselado (2; $0,42 \%)$ ou não identificados NI $(18 ; 3,74 \%)$. Assim como na ilha de Santo Antônio, no sítio do Brejo as vasilhas não receberam um tratamento cuidadoso no lábio, ficando algumas partes mais planas e outras mais arredondadas ou apontadas, o que nem sempre pode ser percebido na análise por serem as bordas muito fragmentadas. As vasilhas possuem diâmetros de abertura variando entre 8 e $42 \mathrm{~cm}$. Abaixo são colocados os desenhos das bordas. 


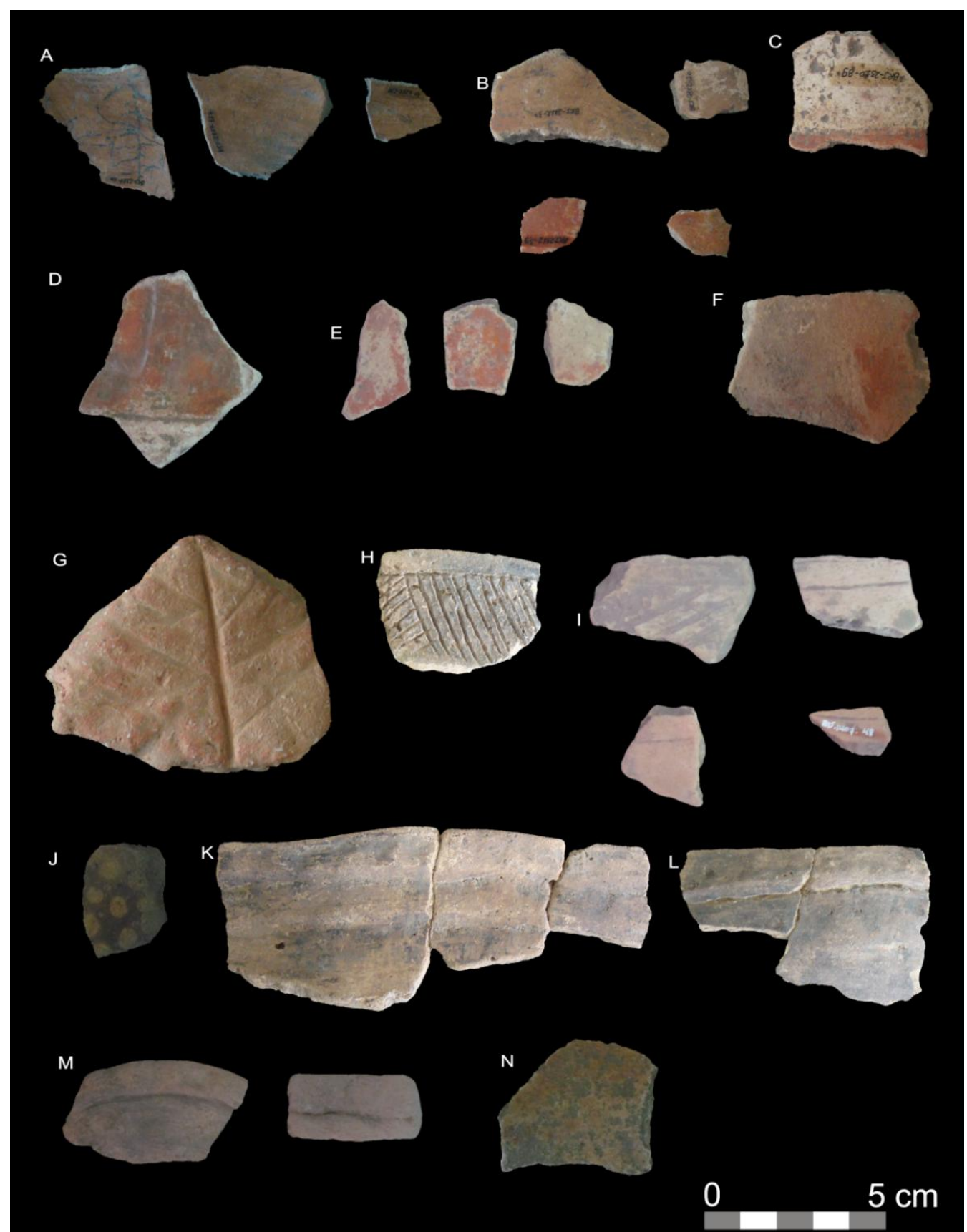

Figura 95: polimento (a, b), engobo vermelho (a, c, e, f), pintura vermelha e branca (c, d), incisões (h, i), tratamento plástico roletado $(\mathrm{k}, \mathrm{l}, \mathrm{m})$, pintura em negativo $(\mathbf{j})$, marca de folha $(\mathrm{g})$ e fermentação (n) (Fotos: SCIENTIA, 2011).

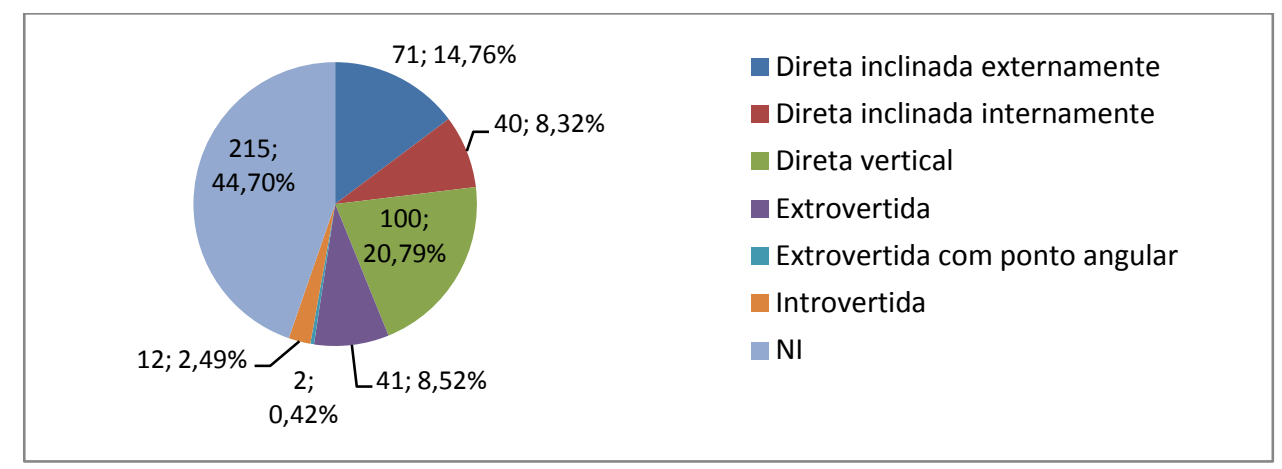

Gráfico 19: forma e inclinação das bordas- sítio do Brejo. 


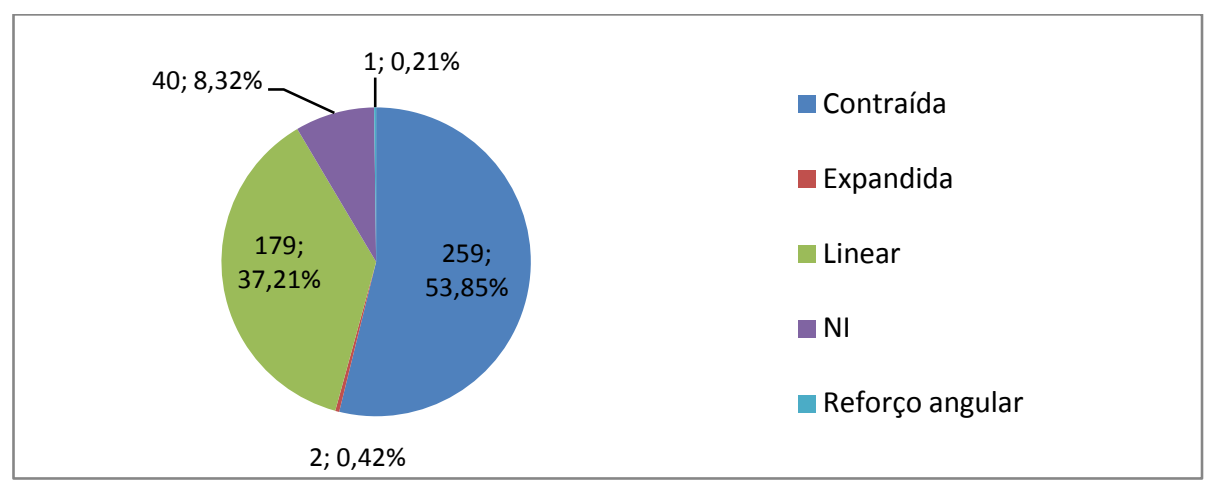

Gráfico 20: espessamento das bordas - sítio do Brejo.

As bases são anelares (9), bi-planas (9), convexas côncavas (5), em pedestal (2), plano côncava (1), côncava convexa (1) e não identificada (6). Foi possível medir o diâmetro de quinze bases, variando entre $3 \mathrm{~cm}$ e $16 \mathrm{~cm}$, sendo mais recorrentes as de 6 e de $10 \mathrm{~cm}$. Não foram encontradas carenas no sítio do Brejo, e as inflexões possivelmente correspondem a bojos ou pescoços. Apesar de não ter sido feita a reconstituição das vasilhas por não ser possível associar os tipos de base com as bordas, acredita-se que a maioria delas deve possuir contorno infletido e simples.

Entre as marcas de uso ocorre a fuligem (259 fragmentos), depósito de carbono (10), fermentação (9) e sulcos (1). A presença de fuligem em grande quantidade de fragmentos (incluindo bordas de diversas formas e inclinações) e poucos fragmentos com marcas de fermentação, além da baixa frequência de fragmentos com tratamentos plásticos e pinturas neste sítio poderia indicar que se trata de uma área onde predominam atividades de preparo e consumo de alimentos, diferente de outras, como o sítio Ilha de Santo Antônio, onde são muito mais recorrentes as marcas de fermentação, pinturas e tratamentos plásticos. Em ambos os sítios as vasilhas são polidas, bem alisadas ou brunidas, o tratamento plástico roletado e modelado são característicos, e as formas das vasilhas são semelhantes (tipos de borda, bojos, pescoço, bases), permitindo associar os conjuntos cerâmicos a uma mesma tradição tecnológica. As datações do sítio do Brejo coincidem com a única data existente para o sítio da Ilha. A pouca frequência de material decorado com incisões e modelados e a ausência de fusos no sítio do Brejo o diferenciam do sítio Ilha de Santo Antônio, e também da Tradição Barrancóide à qual o conjunto cerâmico predominante na ilha foi associado, entretanto o polimento também é uma das características da cerâmica desta tradição, e possivelmente estas variações podem estar relacionadas a diferentes áreas de atividades. Entretanto entendemos que uma amostra maior do sítio precisa ser analisada para avançar em tais hipóteses. 


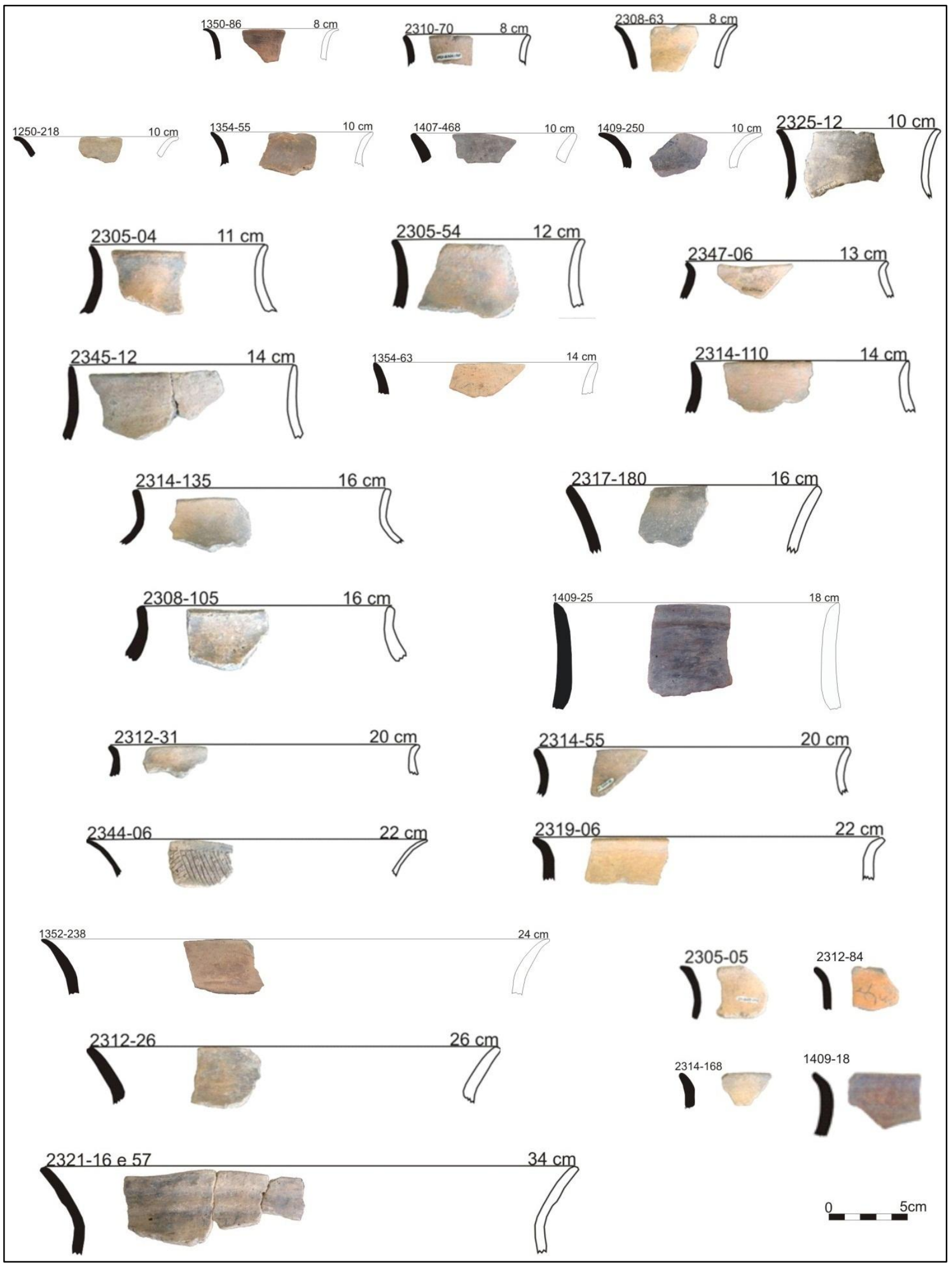

Figura 96: Bordas extrovertidas - sítio do Brejo (Desenhos: Angislaine F. Costa, 2011). 


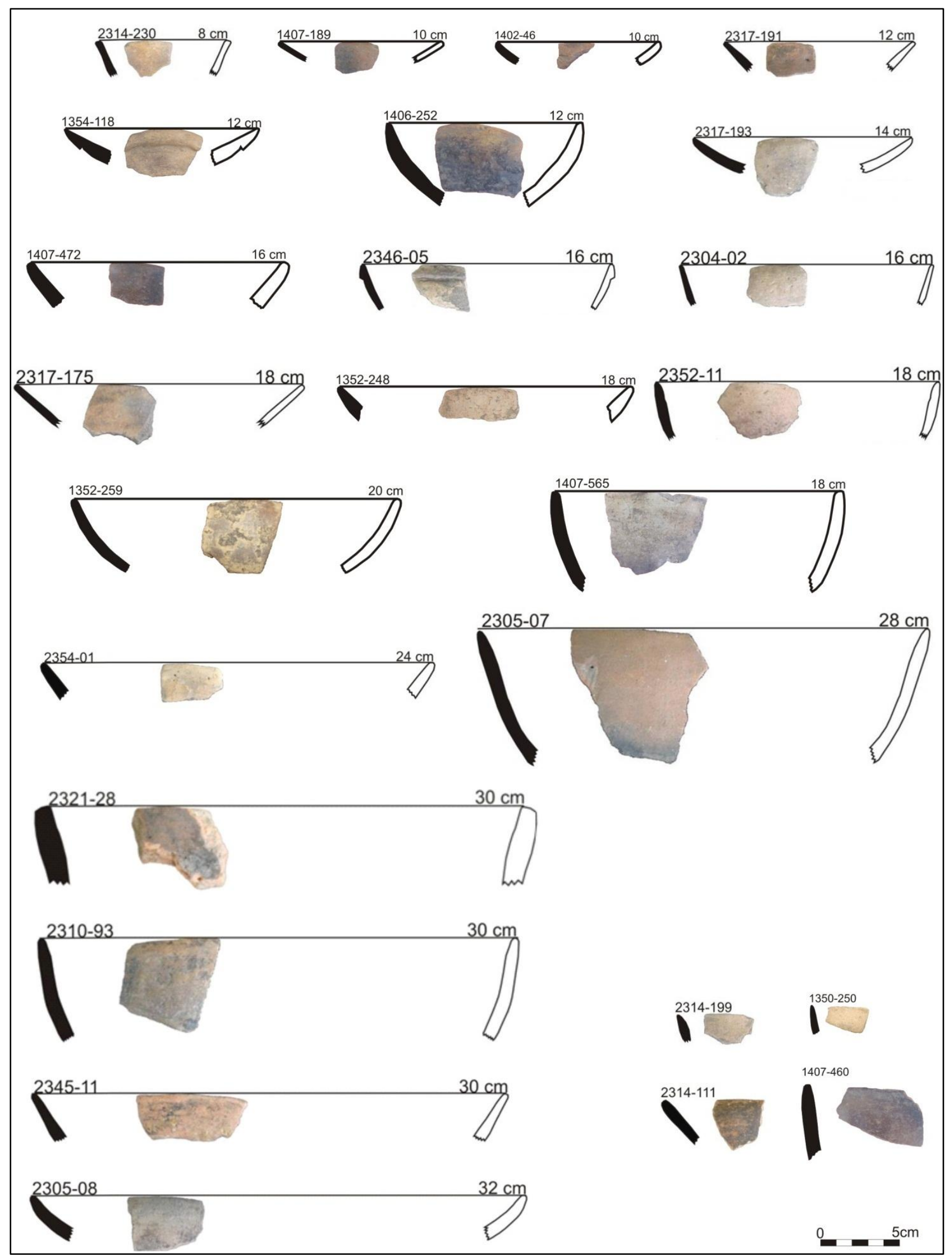

Figura 97: bordas diretas inclinadas externamente - sítio do Brejo (Desenhos: Angislaine Freitas, 2011). 

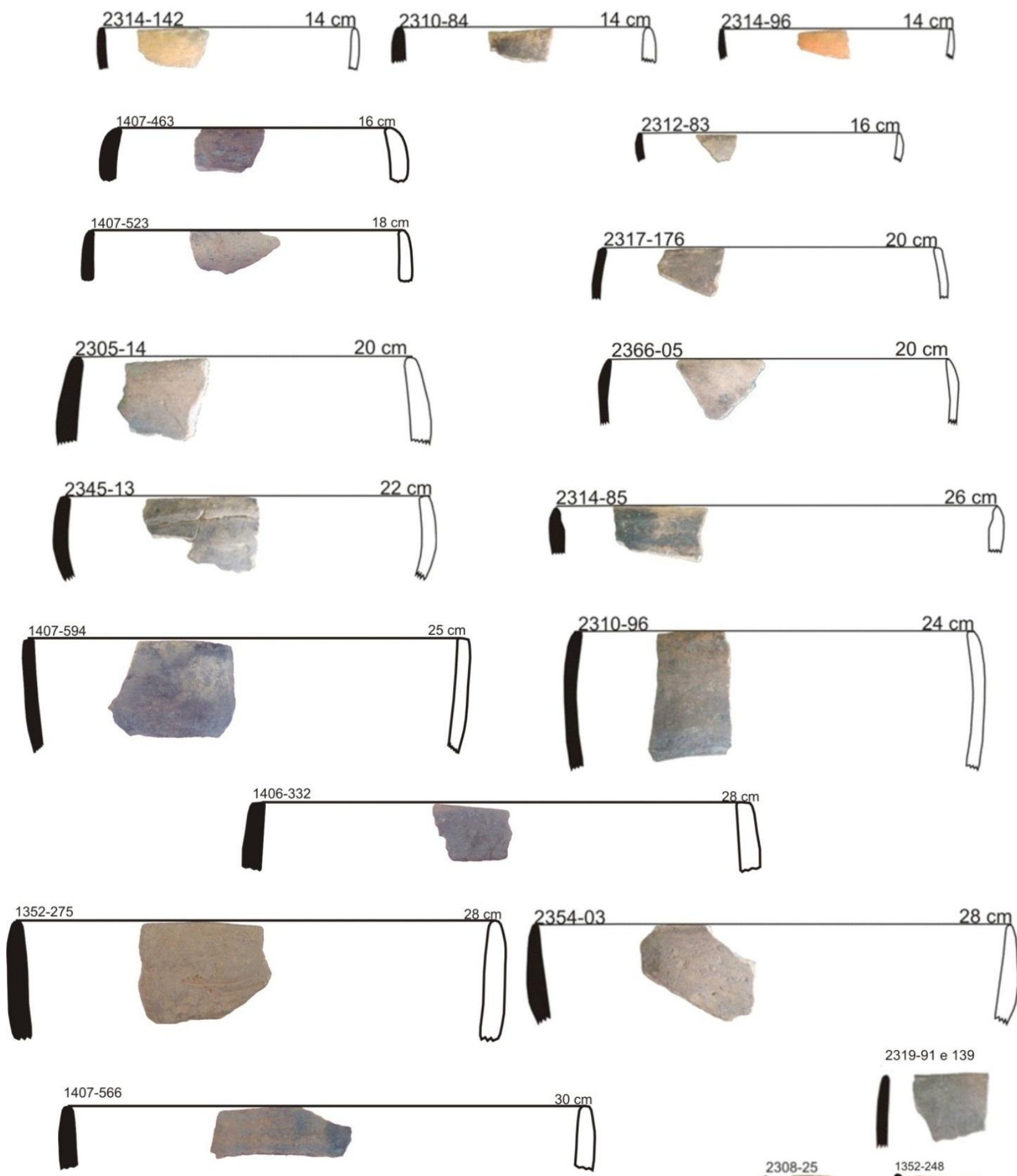

2319-91 e 139
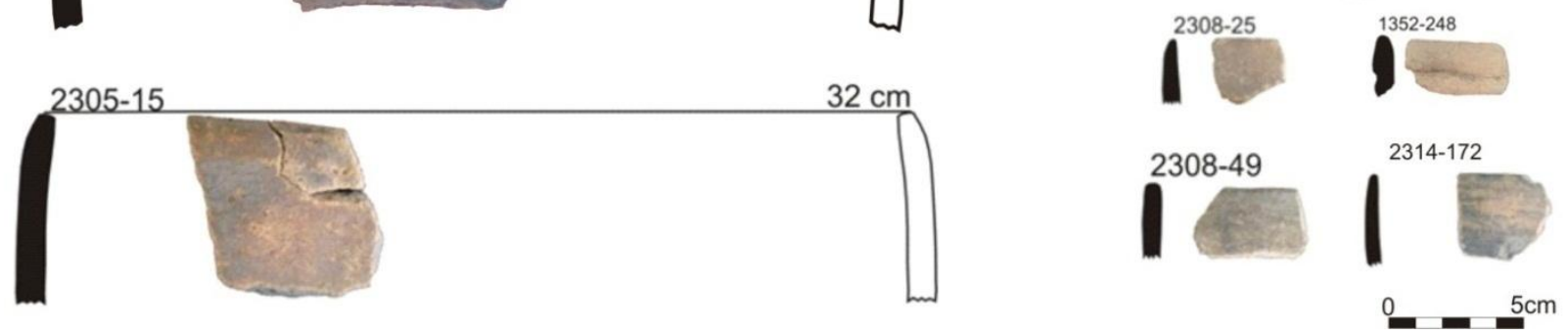

Figura 98: Bordas diretas verticais - sítio do Brejo (Desenhos: Angislaine Freitas, 2011). 


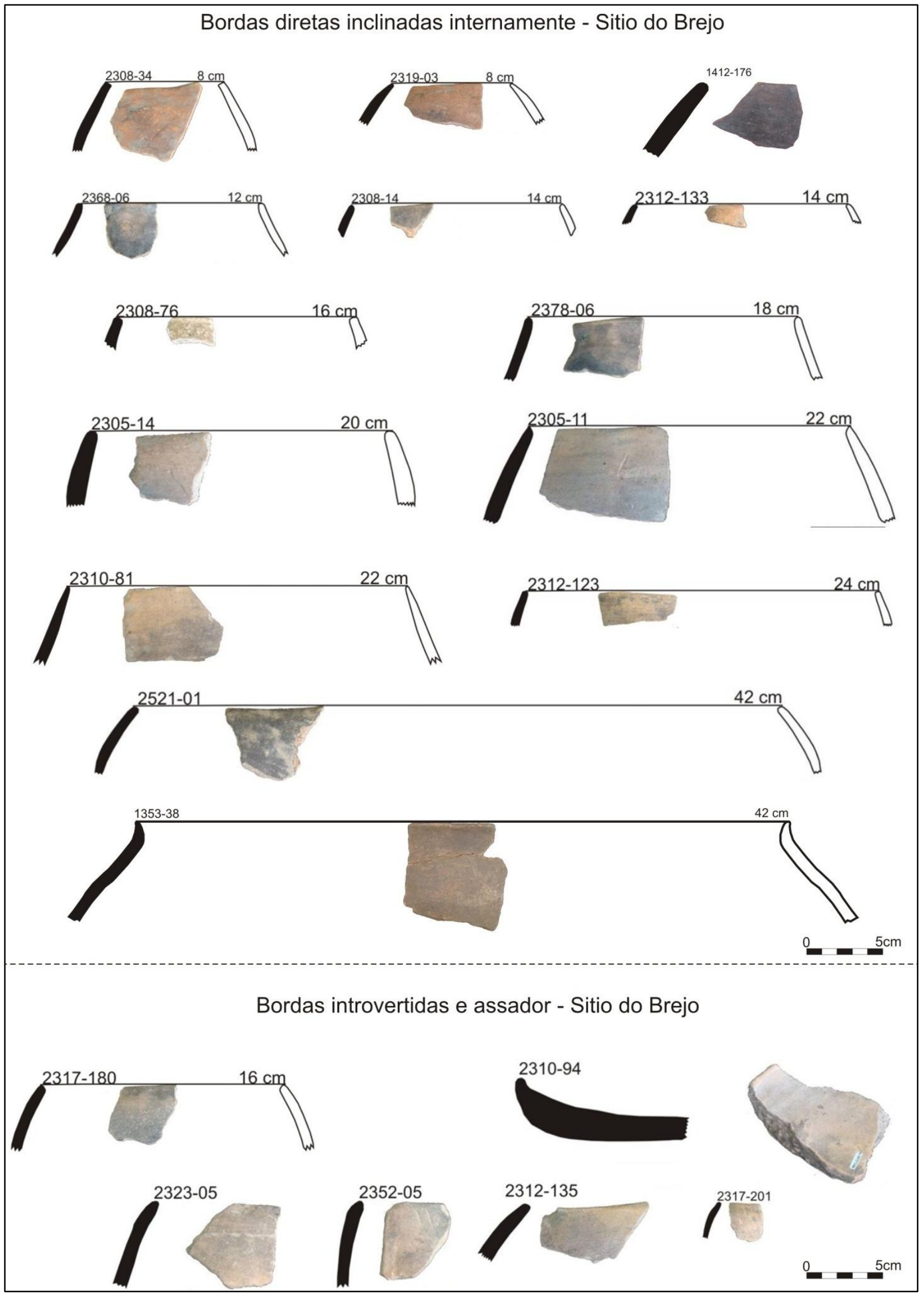

Figura 99: Bordas diretas inclinadas internamente, introvertidas e de assador (Desenhos: Angislaine F. Costa, 2011). 


\subsubsection{Análise dos recipientes $\mathrm{R} 1, \mathrm{R} 2$ e $\mathrm{R3}$}

Foram também analisadas as vasilhas encontradas no monitoramento do sítio (R1, R2 e R3). O R1 estava emborcado centro do R3, e os fragmentos do R2 estavam próximos a estes e à sua feição de enterramento. A vasilha R1 foi parcialmente remontada em laboratório, com base convexa côncava e bojo, porém sem a borda. Possui pasta com mineral e cauixí, foi confeccionada coma técnica acordelada, é polida em ambas as faces e apresenta pintura vermelha na face externa em linhas finas horizontais (apenas uma pequena porção preservada, portanto o motivo poderia ser complexo) feitas diretamente sobre a superfície. Na face interna apresenta uma mancha escura que parece ser do uso. Na base ocorre um furo que parece ter sido feito intencionalmente, após a queima, característica presente nas vasilhas de outros sítios.

Os fragmentos que compõe o R2 remontam parcialmente a base de uma vasilha, cuja pasta apresenta carvão, caraipé e quartzo. Foi confeccionada por acordelamento, com barbotina em ambas as faces, e na face externa possui pintura associada a incisões. A pintura vermelha e branca não se sobrepõe, e as incisões, aplicadas somente sobre o pigmento branco, apresentam motivos complexos destacando-se os escalonados. Apresenta manchas escuras na face interna e um furo na base de $5 \mathrm{~cm}$ de diâmetro feito após a queima da vasilha. Já a vasilha R3 é composta por 63 fragmentos que remontam uma base, possui pasta com cauixi, técnica de confecção acordelada e ambas as superfícies estão muito erodidas.

A vasilha R2 do Brejo é semelhante às vasilhas R1, R2 e R3 do sítio Ilha de Santo Antônio em relação à pasta, acabamentos de superfície e pintura, porém as vasilhas R1 e R3 do sítio do Brejo se diferenciam das cerâmicas encontradas nos sítios próximos: ambas apresentam pasta com cauixí, que não é recorrente no sítio e o R1 possui pintura com linhas muito finas diretamente sobre a superfície. Existem poucas informações sobre o contexto destas vasilhas, porém parecem ter sido intencionalmente enterradas, e podem estar relacionadas a um contexto simbólico, possivelmente funerário, apesar de não terem sido encontrados restos ósseos. 


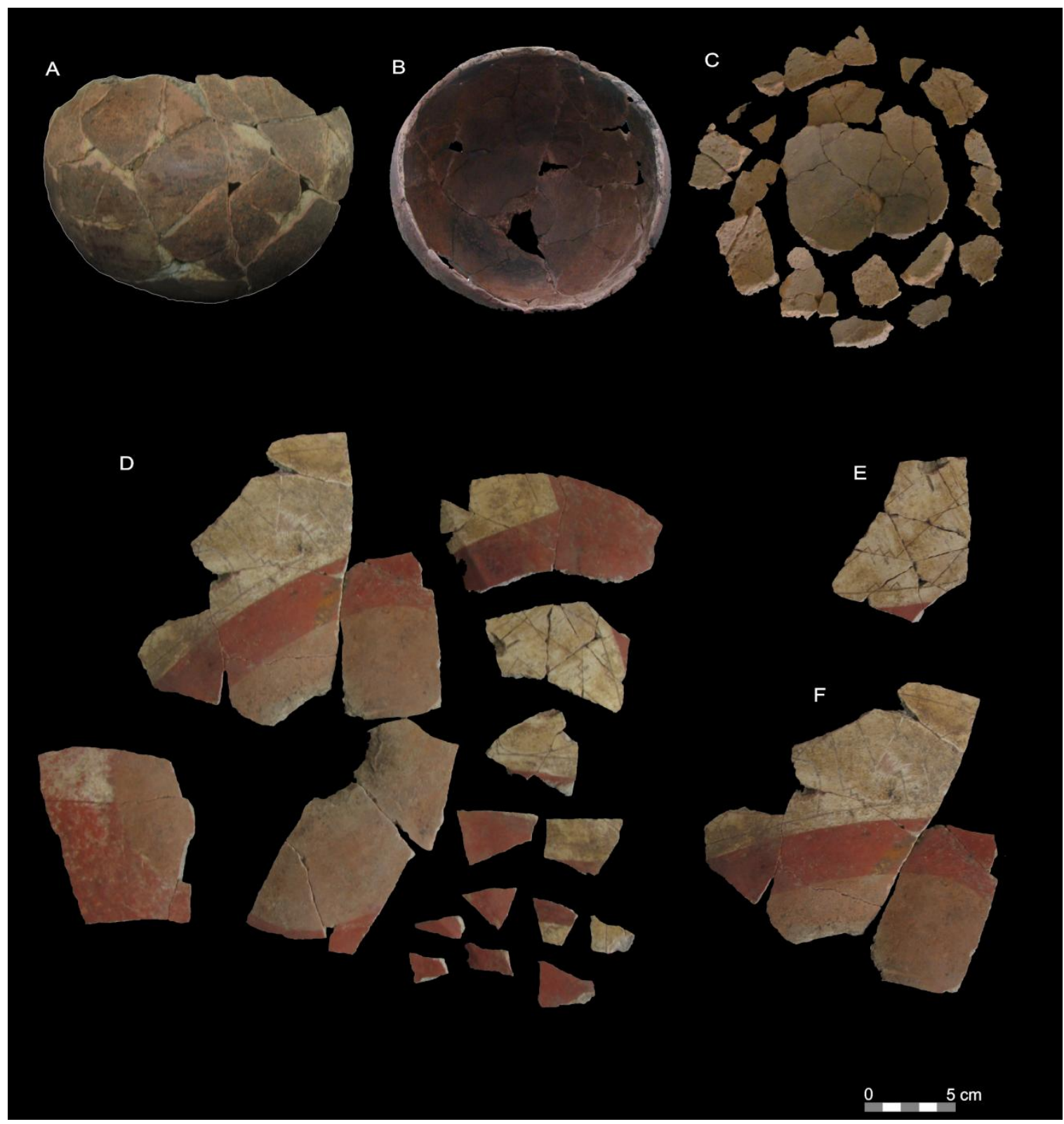

Figura 100: Vasilha 1 (A, B); vasilha 2 (D, E, F) e vasilha 3 (C)- sítio do Brejo (Fotos: SCIENTIA, 2012).

Com estes dados é possível esboçar algumas hipóteses em relação à ocupação do sítio do Brejo. Primeiramente, quando comparamos as cerâmicas dos períodos mais antigos (setor 3 e dois pacotes mais profundos do setor 1) e aquelas do período mais recente (setor 5 e camadas arqueológicas mais superficiais do setor 1), percebemos que no período mais recente

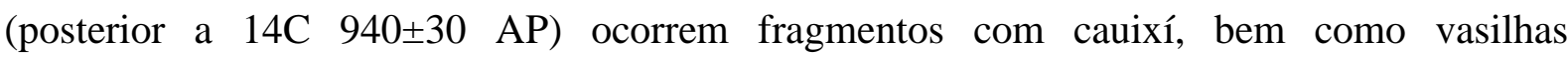
confeccionadas com pasta contendo apenas mineral, diferente do período mais antigo, quando as ceramistas misturavam caraipé na pasta de todas as vasilhas. Não foram verificadas diferenças nos demais atributos como forma e acabamentos de superfície, porém consideramos a amostra analisada muito pequena, especialmente aquela do período mais antigo do setor 1. De qualquer forma, tais mudanças podem indicar a adoção de novas 
características técnicas nesse período mais recente pelo grupo que ocupava o local, relacionado à maior diversidade cultural presente na região nesta época. O material do sítio do Brejo possui características tecnológicas semelhantes ao conjunto predominante no sítio Ilha de Santo Antônio (formas infletidas e simples; presença de bojos e pescoços, porém sem ângulos no corpo das vasilhas; ausência de flanges; tratamento roletado junto ao lábio, polimento e brunidura, engobo vermelho) e a comparação entre ambos permite avançar em questões mais abrangentes do uso dos espaços nas proximidades da cachoeira de Santo Antônio. A ausência de carenas e ângulos no corpo das vasilhas diferencia o material desse sítio daquele do Veneza, bem como do possível conjunto mais antigo do sítio Ilha de Santo Antônio. Além disso, a presença de vasilhas (R1, R2 e R3) no sítio do Brejo com características tecnológicas diferenciadas (pasta, forma e acabamento de superfície) fornece subsídios que reforçam a hipótese de diversidade cultural no rio Madeira e possíveis redes de trocas de objetos ou conhecimentos, principalmente no período mais recente. Voltaremos a discutir tais questões no próximo capítulo.

O sítio do Brejo foi abordado no projeto de iniciação científica (PIBIC/UNIR) de Francisco das Chagas dos Santos, que buscou entender a variabilidade tecnológica ao longo das 5 camadas arqueológicas evidenciadas no setor 1, e está sendo abordado no projeto de trabalho de conclusão de curso onde as análises intra-sítio serão aprofundadas (SANTOS, 2014).

\subsection{Cerâmica do sítio Morro dos Macacos I}

Analisamos oito vasilhas cerâmicas, inteiras e semi-inteiras, do sítio Morro dos Macacos I. Cinco delas (figura 101) foram retiradas por moradores em um buraco com profundidade máxima de 1m, na planície de inundação do rio Madeira. Escavações realizadas nesse mesmo local pela equipe de arqueologia evidenciaram uma segunda camada arqueológica a $140 \mathrm{~cm}$ de profundidade, cujos fragmentos cerâmicos compõem três vasilhas cerâmicas (figura 102), com datação 14C $1.810 \pm 40$ AP.

Entre as vasilhas doadas pelos moradores do sítio quatro apresentam pasta com caraipé (vasilhas 1, 2, 3 e 4) e uma com cauixí e caraipé B (vasilha 5). A vasilha 1 (123 fragmentos) é infletida com pescoço, forma aberta, com $27 \mathrm{~cm}$ de altura e $31 \mathrm{~cm}$ de diâmetro de abertura e espessura variando entre $10 \mathrm{~mm}$ (borda e corpo) e $16 \mathrm{~mm}$ (base). Possui borda extrovertida e linear, lábio biselado e base convexa côncava. A pasta, com minerais (pouco quartzo e óxido 
de Fe), caraipé e carvão, possui coloração cinza escura e queima reduzida em toda a vasilha. É polida e na face externa apresenta pintura preta e branca: os motivos complexos pintados com uma camada espessa de pigmento branco não sobrepõe a pintura preta, cuja camada é bastante fina. A pintura ocorre em dois campos, um no bojo e outro no pescoço, e os motivos são diferentes nos dois campos apesar de apresentarem semelhanças em relação a largura e presença de escalonado nos ângulos. Na face interna ocorre uma mancha escura brilhosa na base.

A vasilha 2 possui contorno composto e base convexa côncava. Possui $17 \mathrm{~cm}$ de altura, $18 \mathrm{~cm}$ de diâmetro de abertura e $10 \mathrm{~mm}$ de espessura. A borda é direta vertical e o lábio é biselado. A pasta apresenta mineral (pequena quantidade de quartzo e oxido de ferro) e caraipé, e a queima é oxidante na borda. Apresenta pintura preta e branca na face externa, em dois campos: abaixo da carena ocorrem duas faixas brancas e entre elas pigmento preto, um não sobrepondo o outro. Acima da carena ocorre também pintura branca e preta, entretanto devido ao desgaste não fica clara a delimitação dos espaços de ambas, mas aparentemente a branca sobrepõe a preta. Ocorrem seis motivos grandes pintados em branco, delimitados pela pintura preta, três próximos a carena e três próximos a borda, intercalados entre si. Sobre o motivo pintado de brancoforam feitas incisões finas com motivos complexos.

A vasilha 3 (33 fragmentos) possui contorno simples, estrutura aberta, $6 \mathrm{~cm}$ de altura, $18 \mathrm{~cm}$ de diâmetro de abertura e espessura variando entre $12 \mathrm{~mm}$ (base) e $6 \mathrm{~mm}$ (borda). A borda é direta inclinada externamente, lábio biselado e base convexa côncava. A pasta apresenta as mesmas características da vasilha 2 e a queima é oxidante na borda e oxidante com núcleo reduzido na base. A barbotina ocorre apenas na superfície interna, que é polida. $\mathrm{Na}$ face externa ocorre pintura branca e preta diretamente sobre a superfície da vasilha, que aparentemente não se sobrepõem. Os motivos são largos e de difícil visualização devido ao desgaste. Tudo indica que esta seja a tampa da vasilha 2.

A vasilha 4 (41 fragmentos) possui contorno infletido, estrutura aberta, borda extrovertida e lábio plano, com $21 \mathrm{~cm}$ de diâmetro de abertura. A espessura varia entre $5 \mathrm{~mm}$ (borda) e $12 \mathrm{~mm}$ (base). A pasta apresenta mineral, caraipé e carvão, e a queima é reduzida. É bem alisada em ambas as faces, e apresenta marcas de uso: fuligem na face externa e depósito de carbono na face interna, portanto foi utilizada sobre o fogo.

A vasilha 5 (49 fragmentos) possui contorno infletido, estrutura fechada, borda extrovertida, lábio arredondado e base anelar. Possui $17 \mathrm{~cm}$ de altura, $12 \mathrm{~cm}$ de diâmetro de 
abertura e base com $8 \mathrm{~cm}$ de diâmetro. A espessura varia nas diferentes partes da vasilha: 12 $\mathrm{mm}$ na borda; $10 \mathrm{~mm}$ no bojo e $14 \mathrm{~mm}$ na base. Na pasta ocorre minerais (quartzo subanguloso e oxido de Fe), cauixí e caraipé B, e a queima é oxidante na borda e reduzida no bojo e base. Ambas as faces são bem alisadas e estão ausentes marcas de uso.

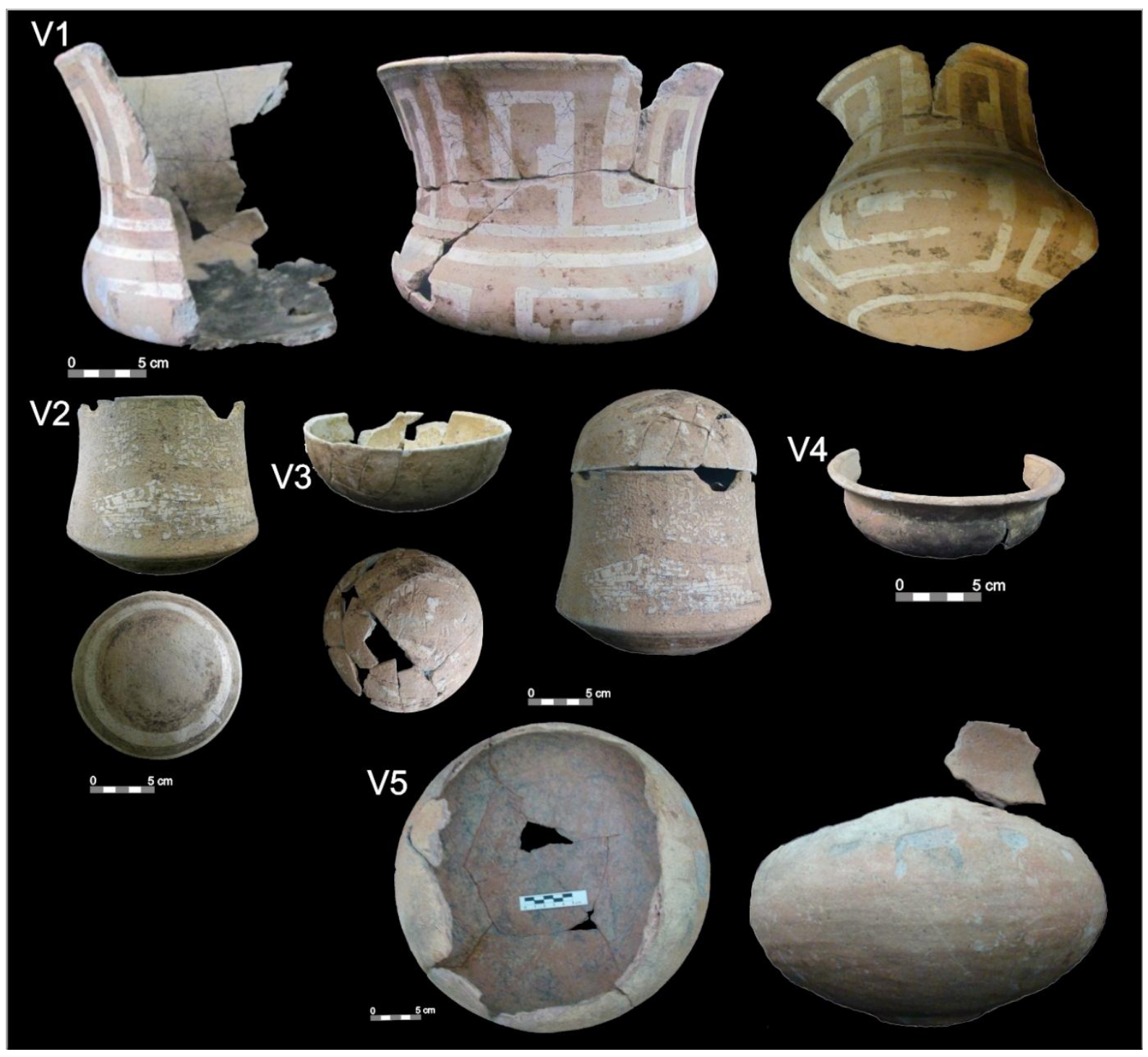

Figura 101: vasilhas cerâmicas 1 a 5 - sítio Morro dos Macacos I (Fotos: SCIENTIA, 2012)

Na escavação foram evidenciados na camada C (14C $1810 \pm 40$ AP), fragmentos que remontam três vasilhas com pasta, coloração, forma e decorações semelhantes. A vasilha 6 (75 fragmentos ) é rasa, com estrutura aberta, contorno simples e flange labial. Possui espessura variável entre $7 \mathrm{~mm}$ (borda) e $11 \mathrm{~mm}$ (base convexa côncava). Não foi possível verificar se a boca da vasilha é circular. Na pasta ocorre mineral (grãos de quartzo arredondados, óxido de ferro e mica) e pouco caraipé. Apresenta barbotina em ambas as faces 
e polimento, e na flange ocorrem incisões. A vasilha 7 (46 fragmentos) é também rasa, com estrutura aberta, flange labial e boca de forma oval. A espessura varia entre $5 \mathrm{~mm}$ (flange) e 7 mm (base). A pasta apresenta apenas elementos minerais em grande quantidade (grãos de quartzo angulosos, óxido de $\mathrm{Fe}$ e feldspato). Apresenta barbotina em ambas as faces e polimento, e na flange labial ocorrem incisões. A vasilha 8 apresenta borda direta inclinada externamente, e não foi possível medir seu diâmetro e observar sua forma. A espessura varia entre $6 \mathrm{~mm}$ (borda) e $8 \mathrm{~mm}$ (parede). A pasta é semelhante a da vasilha 7, e junto ao lábio ocorre decoração incisa e ponteada.

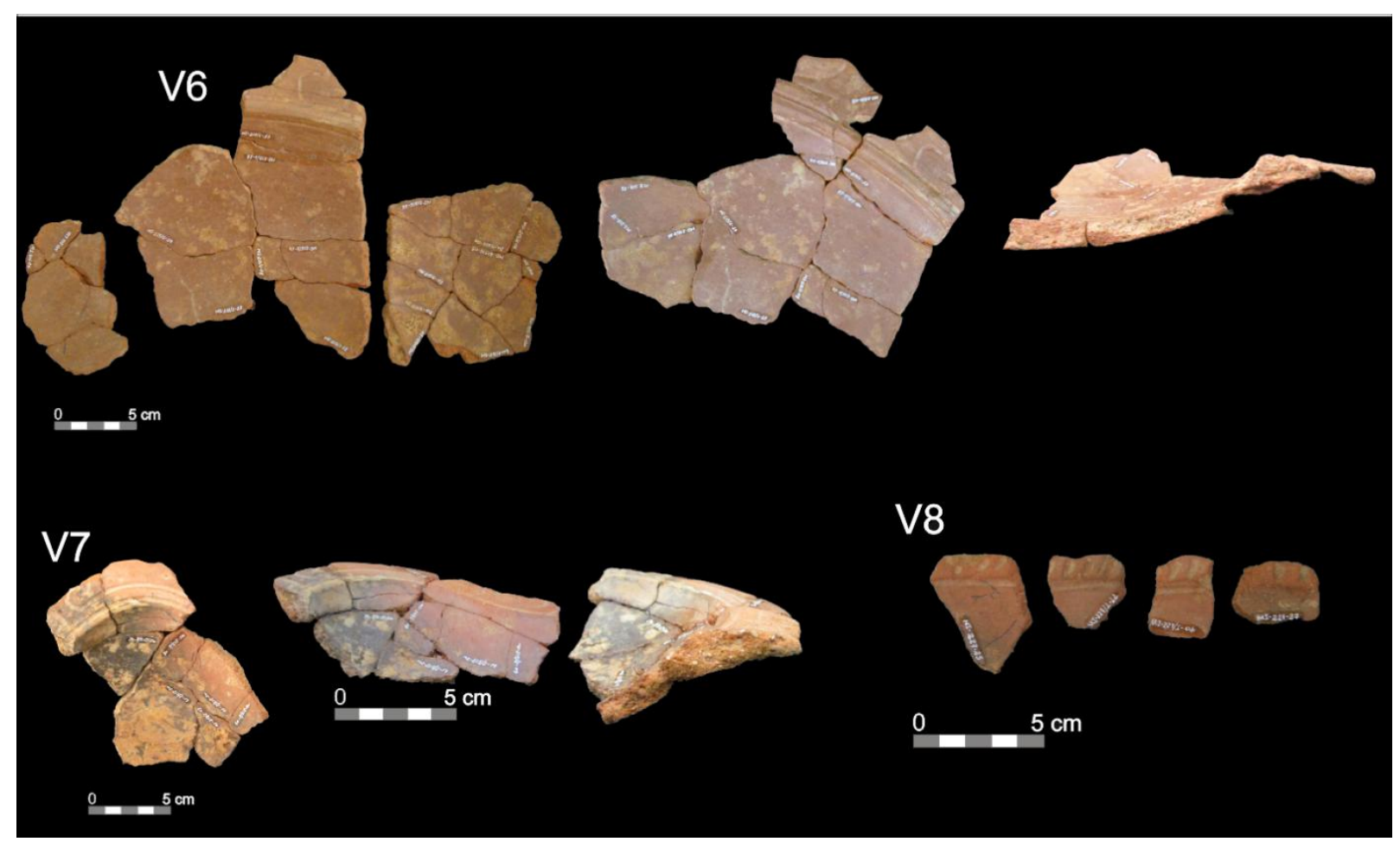

Figura 102: Vasilhas cerâmicas 6, 7 e 8- sítio Morro dos Macacos I (Fotos: SCIENTIA, 2012)

Apesar da amostra analisada ser pequena foi possível chegar a conclusões interessantes sobre a ocupação deste sítio. O local foi ocupado em um período antigo (14C $1810 \pm 40 \mathrm{AP}$ ) por grupos que possuíam uma tecnologia cerâmica caracterizada por uso de pasta com elementos minerais, preferencialmente angulosos, confecção de vasilhas rasas, algumas com flanges labiais, e aplicação de incisões na parte mais visível da borda ou flange. Possivelmente estas vasilhas (6, 7 e 8) não resumem o arcabouço tecnológico do grupo, afinal a área abordada á muito pequena, porém este contexto forneceu uma cronologia que remete a ocupações antigas e será comparado com a de outros sítios próximos com datas recuadas, como o Foz do Jatuarana, Boa Vista e Vista Alegre. De qualquer forma, as vasilhas doadas pelos moradores, escavadas no mesmo local, porém em uma camada superior, portanto de um 
período mais recente, possuem características tecnológicas destoantes damais antiga. A descrição do morador de que existiriam farelos de ossos associados a estes materiais, reforçam a ideia de que trata-se de um contexto funerário. As vasilhas 1, 2 e 3 possuem características tecnológicas típicas da Tradição Polícroma da Amazônia, e a vasilha 4 poderia tambem ser associada a esta tradição, porém a vasilha 5 se diferencia bastante, não só em relação à pasta, mas principalmente na forma e ausência de pintura. Mais uma vez ocorrem vasilhas com características tecnológicas diferenciadas associadas em um contexto específico, possivelmente funerário, assim como no sítio do Brejo. Voltaremos a discutir tais questões no próximo capítulo, porém antes de prosseguir é preciso dizer que a contribuição maior da análise deste material é no sentido de demonstrar que o sítio Morro dos Macacos I é multicomponencial, com ao menos duas ocupações.

\subsection{Cerâmica do sítio Foz do Jatuarana}

Do sítio Foz do Jatuarana foram analisados os materiais das unidades E383857 N9022428, E383934 N9022581 e E383935 N9022581. Este sítio está bastante impactado pela ação antrópica recente, porém obtiveram-se datações bastante antigas para as ocupações ceramistas. Na unidade E383857 N9022428 o material apareceu entre 30-40 cm e 70-80 cm, e nos níveis superiores foi escavada uma estrutura do período histórico; foi obtida a data de $2.780 \pm 40$ AP para uma amostra de carvão do nível 70-80 cm desta unidade. Nas unidades E383934 N9022581 e E383935 N9022581 o material arqueológico ocorre entre 0-10 cm e 70$80 \mathrm{~cm}$, sendo obtida a data de $1890 \pm 30$ AP para um carvão do nível 30-40 cm desta escavação. Foram analisados todos os fragmentos maiores de $2 \mathrm{~cm}$, diagnósticos e não diagnósticos, em função da baixa frequência de fragmentos diagnósticos nestas unidades.

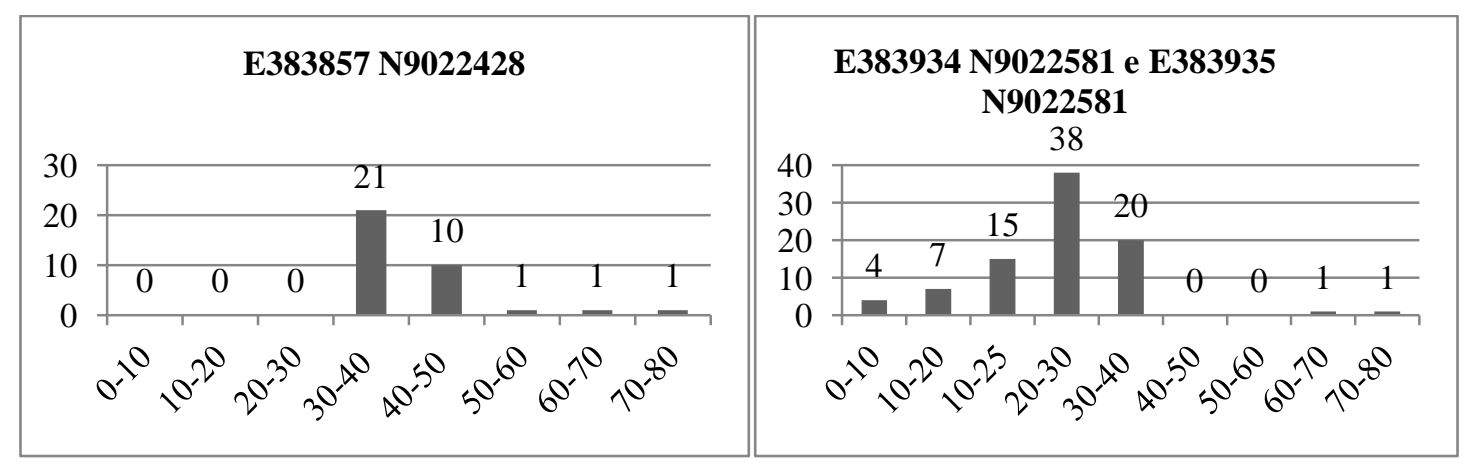

Gráficos 21 e 22:frequência de cerâmicas analisadas por nível- sítio Foz do Jatuarana. 
Foram analisados 148 fragmentos de vasilhas cerâmicas, sendo 38 da unidade E383857 N9022428 e 110 das E383934 N9022581 e E383935 N9022581, e com as remontagens totalizam 119 fragmentos. A cerâmica deste sítio está bastante fragmentada e erodida (apenas 14,29\% dos fragmentos estão bem conservados em ambas as faces). A pasta é caracterizada pela presença de mineral, caraipé e carvão (54 fragmentos; 48,65\%), mineral e caraipé(18; 16,22\%) e somente mineral $(39 ; 35,14 \%)$. Analisamos a presença das diferentes pastas nos níveis artificiais das duas escavações separadamente, e observamos que a pasta com mineral está presente principalmente em fragmentos dos níveis 20-30, 30-40 e 40-50 cm, sendo que nos mais superficiais e nos mais profundos esta pasta praticamente não aparece, porém deve-se considerar que o material está bastante misturado pelo grande impacto que sofreu este sítio e que a amostra analisada é pequena (gráficos 23 e 24).

Com relação a queima, predominou a reduzida em 63 fragmentos $(52,94 \%)$, seguida pela oxidante $(50 ; 42,02 \%)$, oxidante externa e reduzida interna $(4 ; 3,36 \%)$ e oxidante interna e reduzida interna em 2 fragmentos $(1,68 \%)$. Em geral as pastas que apresentam colorações claras possuem apenas mineral na pasta, enquanto aquelas com núcleo escuro apresentam caraipé e carvão (gráfico 25).

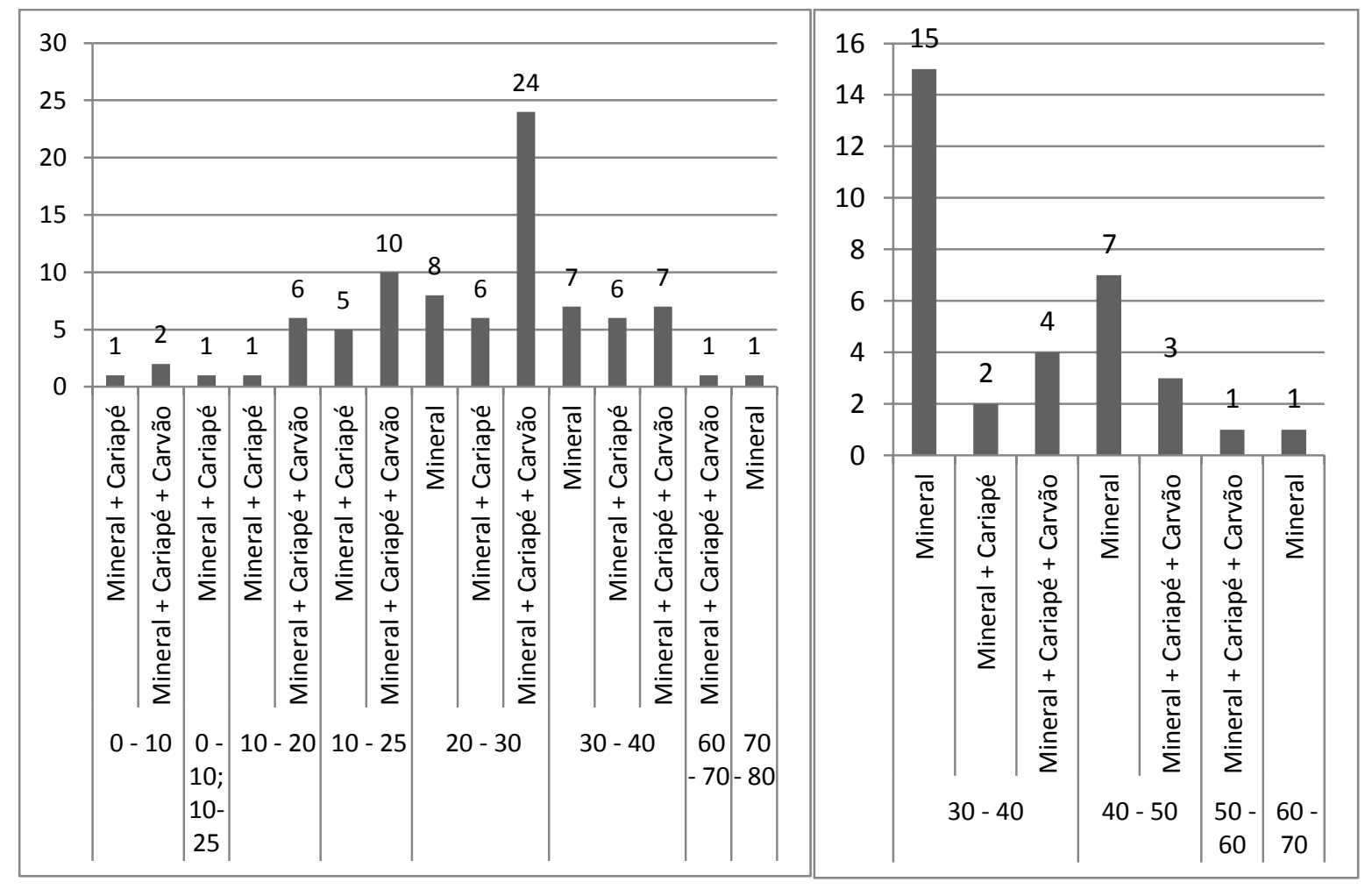

Gráficos 23 e 24: distribuição da pasta no decorrer dos níveis das unidades E383934 N9022581 e E383935 N9022581; e da E383857 N9022428, respectivamente - sítio Foz do Jatuarana. 


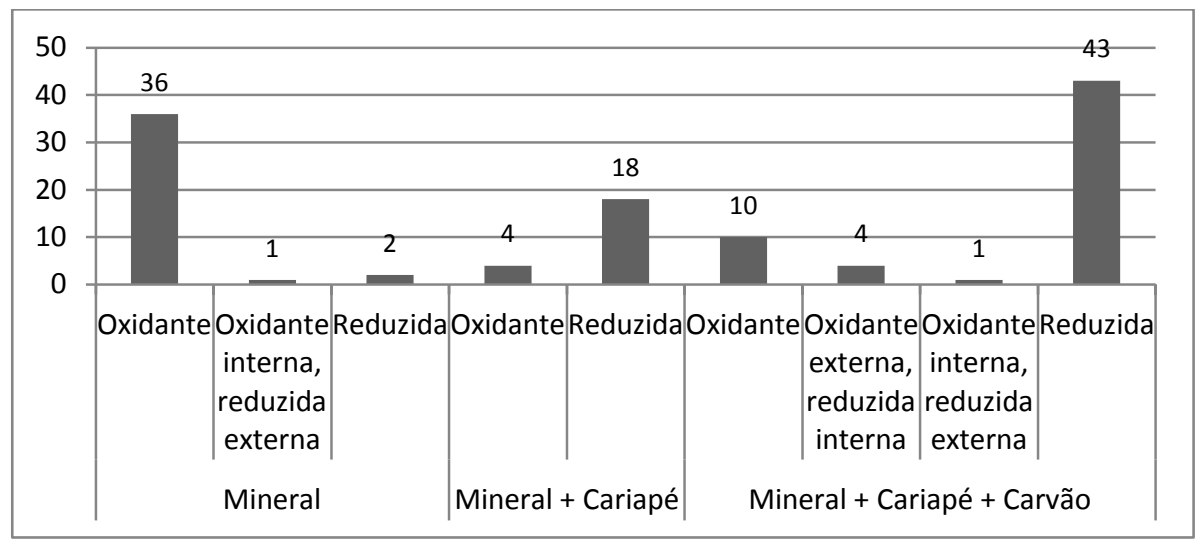

Gráfico 25: comparação do tipo de queima com a composição da pasta- sítio Foz do Jatuarana.

Houve dificuldade na identificação de acababamentos de superfície, barbotina, engobo e pinturas em funçao do estado de conservação dos fragmentos. Em apenas 44 fragmentos foi possível definir o acabamento de superfície, predominando o polimento e alisamento fino, com excessão de um fragmento com alisamento médio e um com brunidura. A barbotina foi identificada em apenas três fragmentos. Não ocorrem engobos e pinturas, e apenas doispossuem tratamento plástico inciso, um na face interna e o outro na face externa.

Ocorrem 72 paredes, 25 inflexões, 7 bordas, 5 bases e 2 não identificados (NI). Entre as bordas duas são extrovertidas, duas diretas inclinadas externamente e em três delas a inclinação não foi identificada. Três possuem espessamento linear, duas contraídas, uma expandida e uma reforçada externamente. Ocorrem 4 lábios arredondados, dois planos e um não identificado. Foi possível medir o diâmetro de apenas uma borda de $16 \mathrm{~cm}$ (figura 103). Entre as cinco bases, duas são anelares, uma plano côncava, uma bi-plana e uma não identificada.

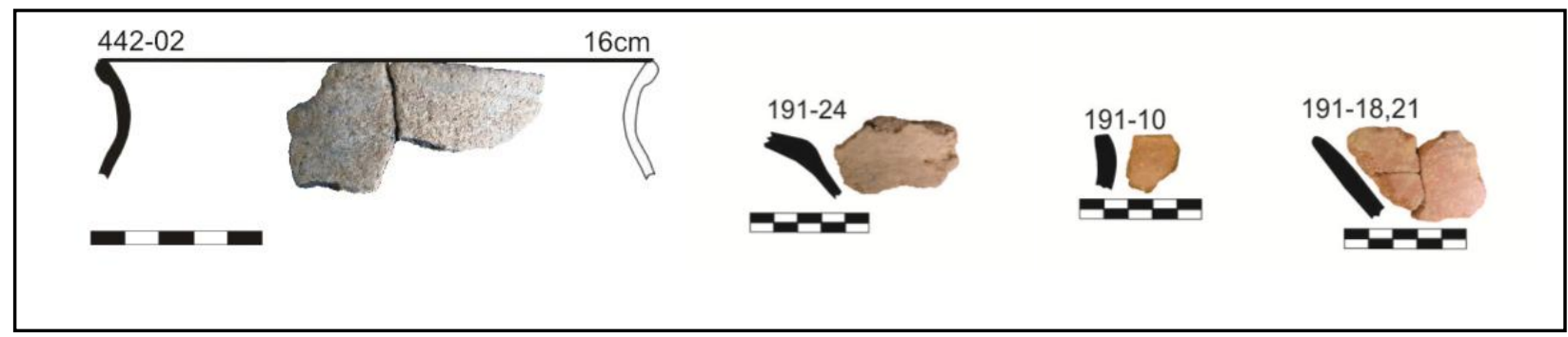

Figura 103: borda remontada dos níveis 0-10 e 10-20 cm (caraipé); e bordas do nível 30-40 cm (mineral). Sítio Foz do Jatuarana (Desenhos: Angislaine F. Costa, 2012). 


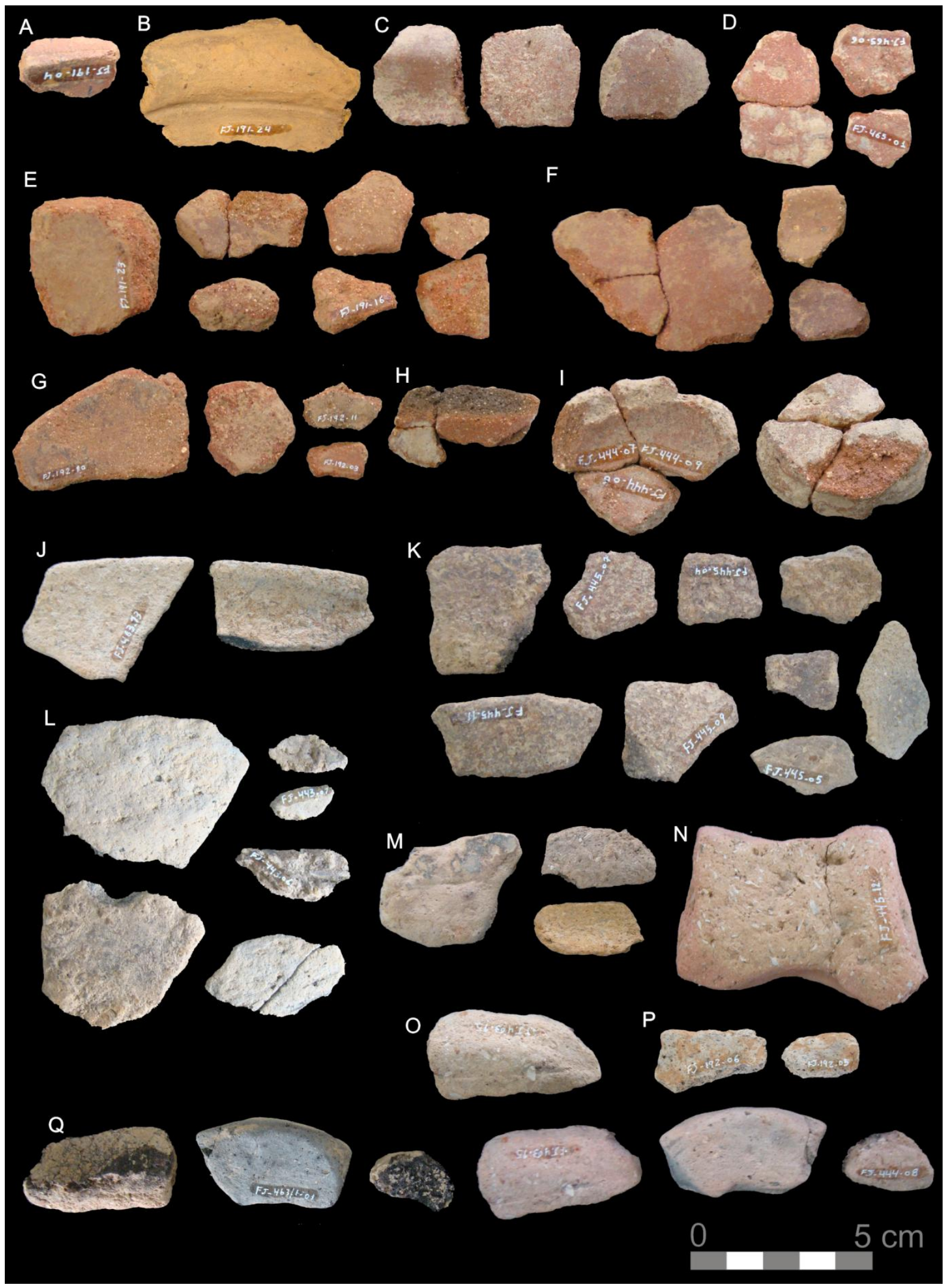

Figura 104: pasta com mineral (A - I): fragmentos com incisões (A, B), inflexões (C), paredes (D, E, G, H), bordas $(\mathrm{F})$ e bases $(\mathrm{L})$; pasta com caraipé $(\mathrm{J}-\mathrm{P})$ : paredes $(\mathrm{K}, \mathrm{L}, \mathrm{M}, \mathrm{P})$, bordas $(\mathrm{J})$, possível assador $(\mathrm{N})$, bases (O, Q)- sítio Foz do Jatuarana (Fotos: SCIENTIA, 2012). 
Analisamos os materiais destas três unidades do sítio Foz do Jatuarana por apresentarem datações bastante recuadas para a ocupação dos grupos ceramistas no rio Madeira. Com a análise verificou-se que cerâmicas de núcleos avermelhados possuem apenas mineral na pasta, diferente daquelas de núcleo escuro que possuem caraipé e carvão, portanto a coloração está relacionada à escolha da pasta e ao tipo de queima. As cerâmicas cujas pastas apresentam apenas mineral predominam nos níveis 30-40 e 40-50 da unidade E383857 N9022428 e nos níveis 20-30 e 30-40 cm das unidades E383934 N9022581 e E383935 N9022581, e parece que tanto nos níveis mais superficiais quanto nos mais profundos das duas unidades predomina a pasta com caraipé. A data de $2.780 \pm 40$ AP foi obtida para o nível 70-80 cm da unidade E383857 N9022428 e a de 1.890 \pm 30 AP para o nível 30-40 cm das outras duas unidades contíguas, e poderíamos sugerir que esta ultima está relacionada ao material com mineral na pasta e queima oxidante, comparando com o contexto evidenciado no sítio Morro dos Macacos I (com data de 14C $1810 \pm 40$ AP) e no sítio Vista Alegre, cujas ocupações caracterizaremos na sequencia. A data de $2.780 \pm 40$ AP pode estar relacionada com uma ocupação mais antiga, relacionada ao material de núcleo escuro e com caraipé na pasta. Como veremos na sequencia, no sítio Vista Alegre caracterizamos um conjunto cerâmico cuja pasta possui caraipé e carvão, mais antigo que aquele apenas com mineral na pasta. Nesse sítio, diferente do Foz do Jatuarana, foi possível observar atributos das formas das vasilhas. É possível que ocorram duas ou mais ocupações distintas no sítio Foz do Jatuarana, afinal as duas datas estão afastadas em mais de mil anos.

\subsection{Cerâmica do sítio Boa Vista}

Foram triados 788 fragmentos cerâmicos do sítio Boa Vista, sendo 383 da unidade E392900 N9022302 (setor 1) e os demais das unidades E392510 N9021980, E392540 N9021860 e E392670 N9021950 (setor 3). Analisamos 360 fragmentos, sendo 175 da unidade E392900 N9022302, para a qual optou-se por analisar todos os fragmentos maiores de $2 \mathrm{~cm}$, em função do número reduzido de diagnósticos (material erodido). Do setor 3 analisamos 134 fragmentos da uniudade E392510 N9021980, 23 da E392540 N9021860 e 28 da unidade E392670 N9021950. Foram obtidas datações bastante antigas de 14C $4.470 \pm 40$ AP para a camada E $(220-230 \mathrm{~cm})$ e $14 \mathrm{C} 2.010 \pm 30$ AP para a camada D $(140-150 \mathrm{~cm})$ da unidade E392900 N9022302. No setor 3 a única datação obtida parece corresponder a um período anterior à ocupação do sítio. 


\subsubsection{Análise da cerâmica do setor 1}

A cerâmica da unidade E392900 N9022302, escavada no Setor 1 do sítio, é bastante fragmentada, erodida e com as extremidades arredondadas. Desta unidade foram analisados 175 fragmentos, que com as remontagens totalizam 136 fragmentos, além de 12 bolotas de argila. A maioria dos fragmentos (90\%) está erodida em ambas as faces, e os demias ao menos em uma face, sendo apenas 4 bem conservados.

A pasta é caracterizada pela presença de mineral, caraipé e carvão (106 fragmentos), mineral e caraipé (19), dois fragmentos apenas com mineral (níveis 50-60 cm e 220-230 cm), um com mineral e carvão $(70-80 \mathrm{~cm})$ e sete fragmentos de parede com cauixí $(70-80 \mathrm{~cm}, 90$ $100 \mathrm{~cm}, 100-110 \mathrm{~cm}$ e 200-210 cm), sendo um deles associado ao caraipé (gráfico 26). A maioria da amostra possui alta inclusão de grãos finos de quartzo subangulosos e arredondados, associados a óxido de Ferro e feldspato. A queima é reduzida na maioria dos fragmentos $(110 ; 80,15 \%)$, enquanto outros possuem queima oxidante $(25 ; 18,38 \%)$ e apenas um fragmento com queima oxidante externa e reduzida interna. As cores predominantes são cinza escura e preta, mas também ocorrem marrom claro e escuro, cinza clara, laranja e rosada.

Devido ao desgaste das peças, foi identificada barbotina em poucos fragmentos: $19 \mathrm{em}$ ambas as faces; 14 na face externa e 6 na face interna. $O$ acabamento de superfície também é difícil identificar, predominando o alisamento fino e o polimento (gráfico 27). Em apenas cinco fragmentos ocorre engobo vermelho, sendo três na face externa e um na face interna. Ocorrem apenas três fragmentos com incisão, muito erodidos, dois na face interna e um na face externa, e um ponteado na FI.

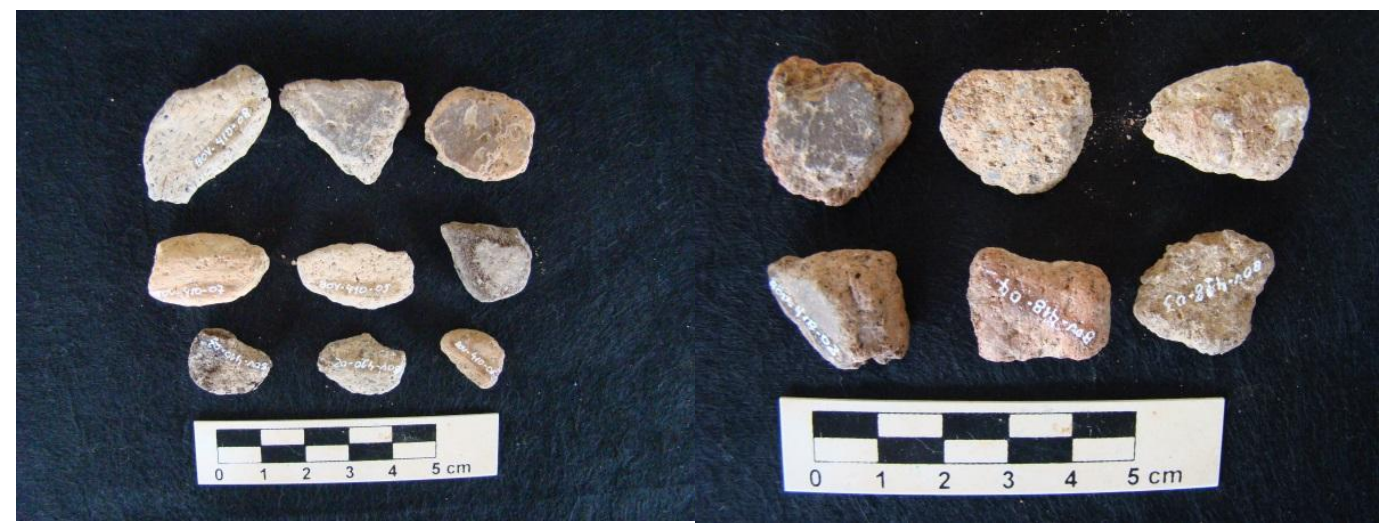

Fotografias 87 e 88: cerâmicas dos níveis datados: 140-150 cm e 220-230 cm (SCIENTIA, 2012). 


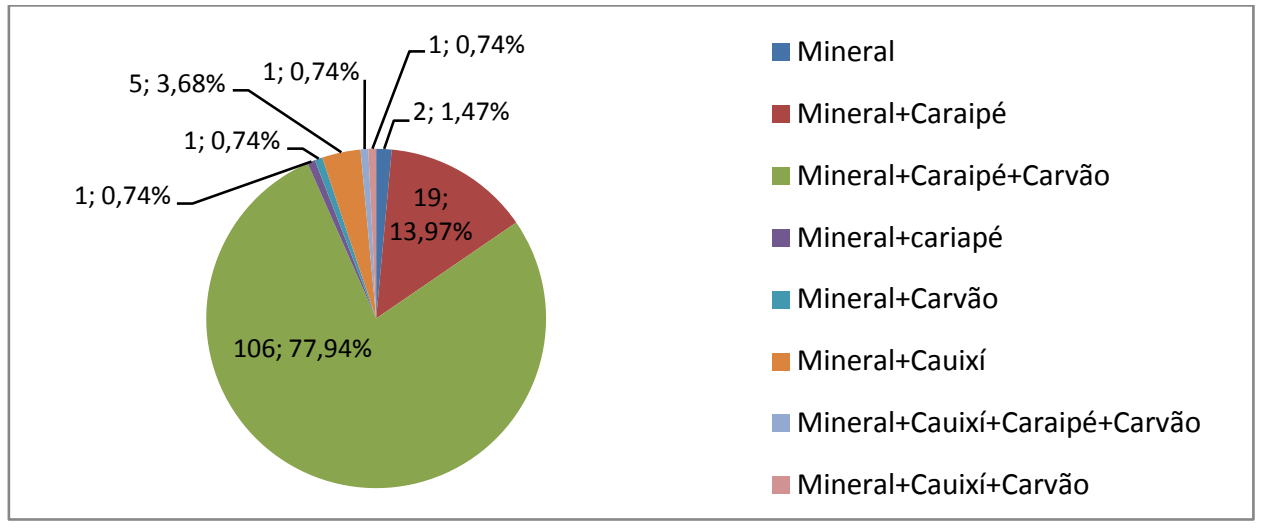

Gráfico 26: pasta do setor I do sítio Boa Vista

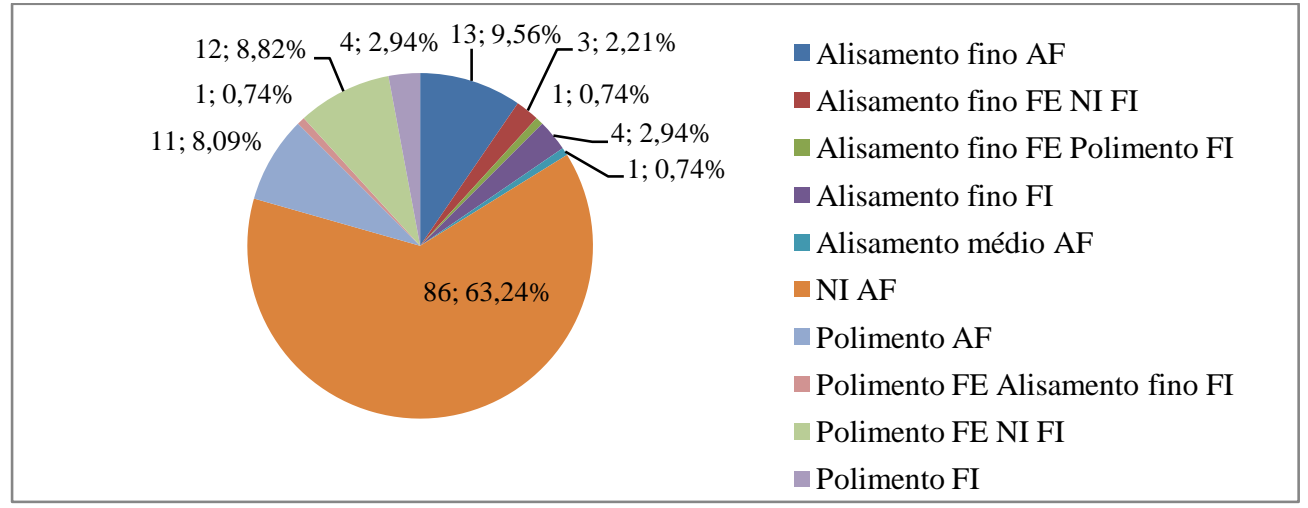

Gráfico 27: Acabamentos de superfície- setor 1 - sítio Boa Vista.

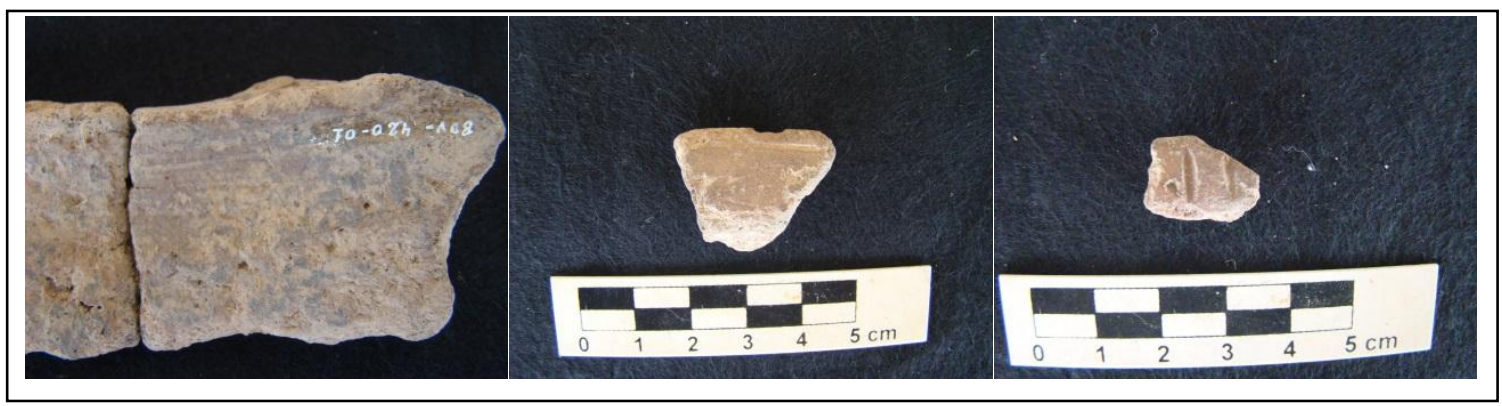

Figura 105: fragmentos com tratamento plástico - setor 1 do sítio Boa Vista (Fotos: SCIENTIA, 2012).

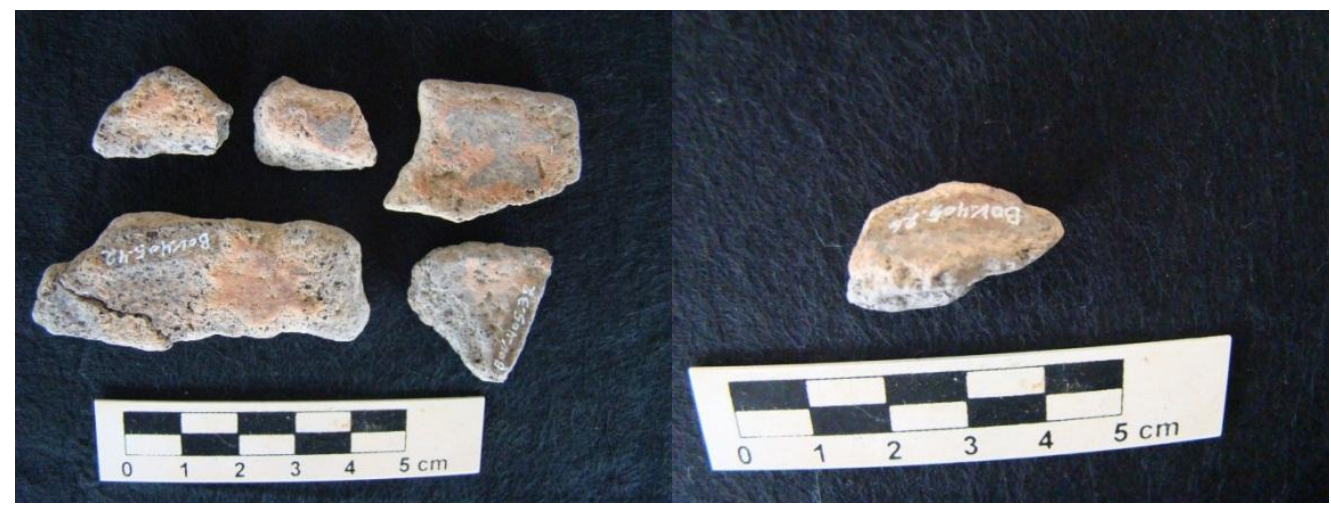

Fotografias 89 e 90: engobo vermelho e possível apêndice de suspensão ou aplique - setor 1 do sítio Boa Vista (Fotos: SCIENTIA, 2012). 
As vasilhas foram confeccionadas com a técnica acordelada (81 fragmentos), apenas três fragmentos indicam a técnica modelada e nos demais não foi identificada (52). Foi possível identificar apenas sete bordas, uma borda com flange labial, uma flange labial e uma base, sendo os demais de parede (104), inflexão (14) ou não identificados (8). Foi possível desenhar o perfil de apenas duas bordas diretas inclinadas externamente, sendo uma com flange, porém não foi possível medir o diâmetro (Figura 106). Também foi identificada apenas uma base na coleção (convexa côncava). Em apenas um fragmento foi identificado depósito carbônico na face interna e em cinco ocorre fuligem na face externa.

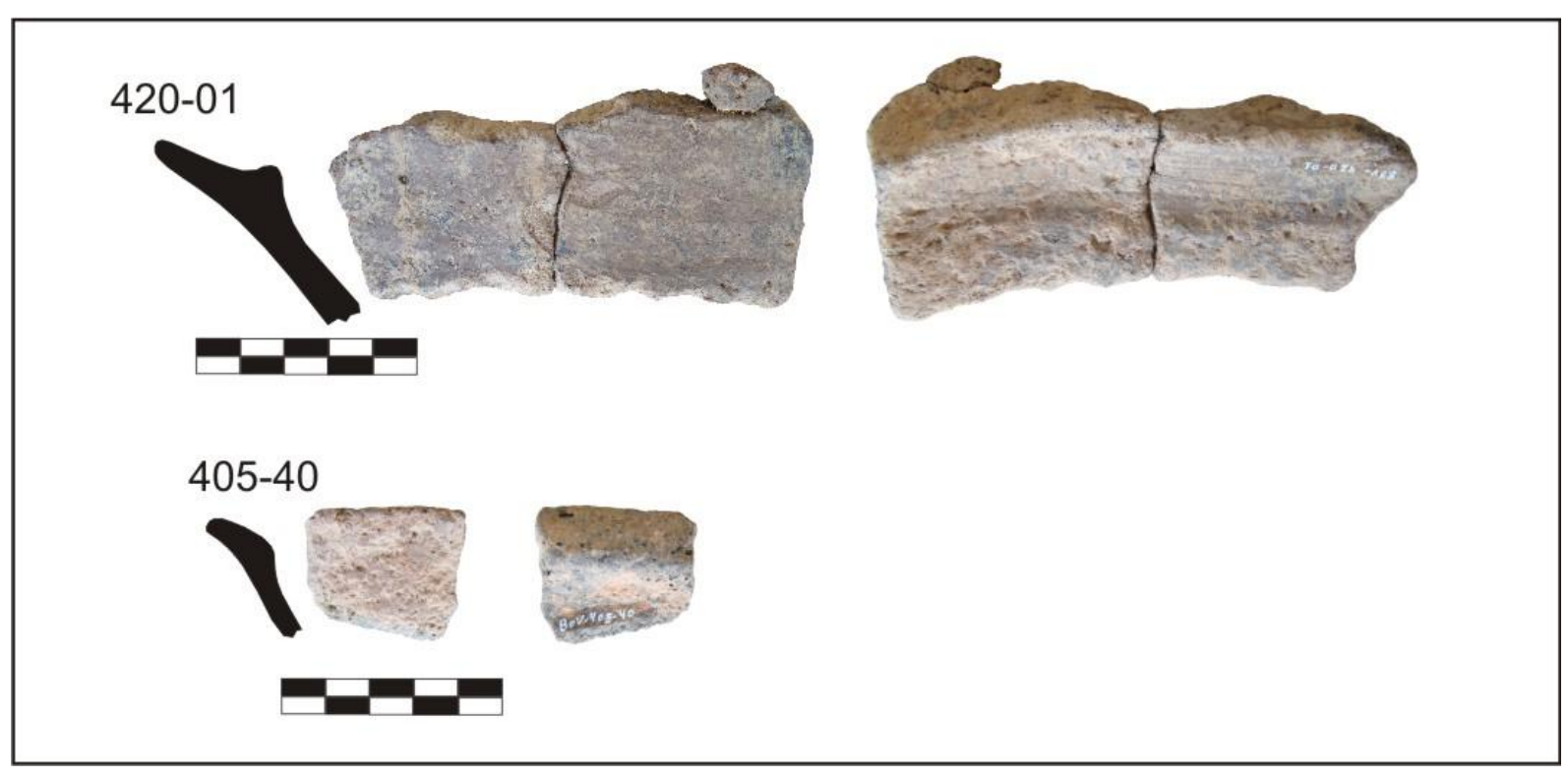

Figura 106: desenhos das bordas- setor 1 do sítio Boa Vista (Angislaine F. Costa, 2012).

\subsubsection{Análise da cerâmica do setor 3}

Do setor 3 foram analisados 185 fragmentos cerâmicos, que com as remontagens totaliza 71 fragmentos de vasilhas, além de uma bolota de argila e um fragmento de objeto não identificado (NI). O material está concentrado entre 0 e $70 \mathrm{~cm}$. Da unidade E392510 N9021980 foram analisados 134 fragmentos diagnósticos (compõe um número mínimo de 64), destacando-se duas vasilhas parcialmente remontadas (vasilhas 2 e 3), além de 23 fragmentos (8 vasilhas) da unidade E392540 N9021860, e 28 fragmentos de uma mesma vasilha (vasilha 1) da unidade E392670 N9021950. Os fragmentos apresentam bom estado de conservação.

Neste setor a pasta da maioria das vasilhas apresenta mineral e caraipé $(33 ; 46,48 \%)$ e mineral caraipé e carvão (23;32,39\%), além da presença de cauixí (14; 19,72\%), em quatro deles associado ao caraipé, e apenas mineral em um fragmento (gráfico 28). Entre os minerais 
ocorre quartzo, feldspato e óxido de Ferro. Predomina baixa inclusão de grãos finos e média inclusão de grãos finos e médios de quartzo. Portanto, neste setor ocorre menor quantidade de vasilhas com carvão na pasta, além de uma maior quantidade de peças com cauixí. Também ocorre maior frequência de feldspato e de óxido de ferro associado ao quartzo, e maior frequência de grãos arredondados de quartzo.

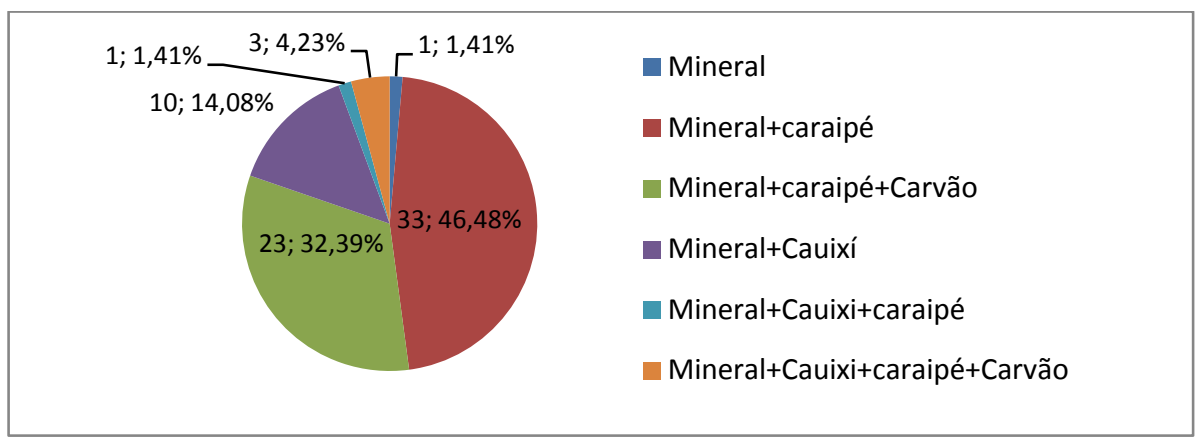

Gráfico 28: pasta das cerâmicas do setor 3.

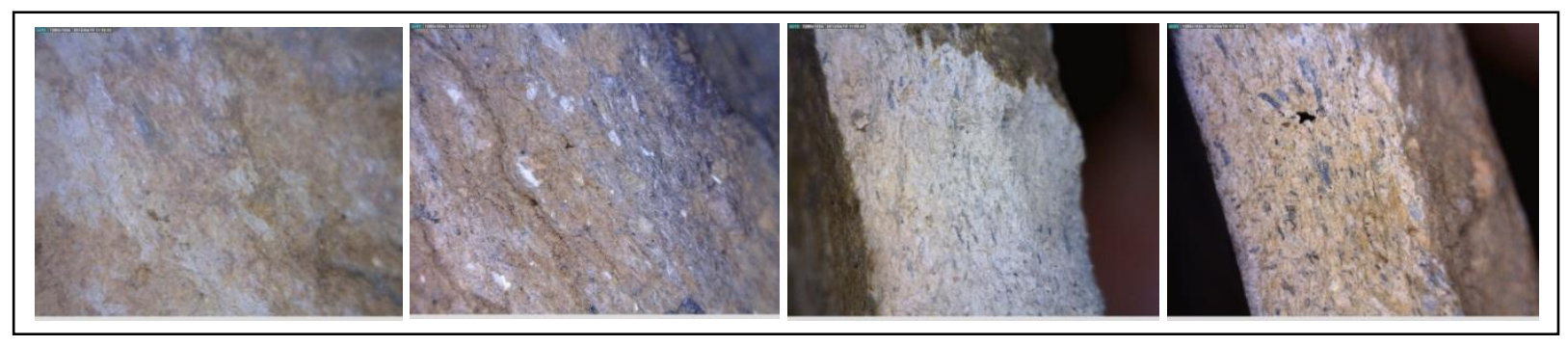

Figura 107:pastas com cauixi; cauixí e caraipé; caraipé; e caraipé e carvão (fotos: SCIENTIA, 2012).

Em relação à queima, predomina a reduzida (41 fragmentos; 57,75\%), seguida pela oxidante $(28 ; 39,44 \%)$, oxidante com núcleo reduzido (1) e oxidante interna e reduzida externa (1). As vasilhas foram confeccionadas com a técnica acordelada (92\%), com exceção de uma flange que é modelada eem cinco fragmentos a técnica não identificada. A barbotina está presente em 33 fragmentos (46,47\%), em uma ou em ambas as faces. A maioria dos fragmentos apresenta polimento em ambas as faces $(41 ; 57,75 \%)$ ou somente na face externa (16 fragmentos), enquanto as demais são bem alisadas ou o acabamento não foi identificado.

A pintura esta presente em fragmentos de cinco vasilhas. A vasilha 1 (28 fragmentos da Unidade N392670 E9021950) possui pasta com minerais (feldspato e quartzo), cauixí, carvão e caraipé, coloração cinza escura no bojo superior e preta no bojo inferior, portanto possui queima reduzida (V1, figura 128). Foi confeccionada com a técnica acordelada, possui contorno composto e estrutura aberta, borda extrovertida com lábio plano, $21 \mathrm{~cm}$ de diâmetro de abertura e $8 \mathrm{~cm}$ de altura. Apresenta uma carena cujo prolongamento na face externa 
constitui-se em uma flange mesial; a base é convexa-côncava com $11 \mathrm{~cm}$ de diâmetro; a espessura varia entre 6 e $11 \mathrm{~mm}$, sendo mais espessa na base. Ambas as faces são polidas, e a face externa apresenta pintura, apliques e incisões. Na parte superior (acima da carena) apresenta pintura preta e branca associada a incisões: uma faixa preta foi pintada acima da carena, e uma faixa larga branca até o lábio sobre a qual foram feitas incisões com motivos complexos, bem finos. A parte inferior (abaixo da carena) foi decorada com apliques, posteriormente pintada de branco, e neste pigmento foram feitas as incisões finas em algumas partes. Parte do aplique se desprendeu da peça, restando seu negativo, porém a parte conservada permite visualizar um motivo complexo. Na face externa ocorre fuligem abaixo da carena e desgaste na base possivelmente pelo atrito com a superfície, indicando utilização intensa desta vasilha. $\mathrm{Na}$ face interna, abaixo da carena a peça está totalmente erodida, possivelmente decorrente do uso.

A vasilha 2 (24 fragmentos entre 0 e $50 \mathrm{~cm} / \mathrm{E} 392510$ N9021980) possui pasta com mineral (óxido de Fe e quartzo), carvão e caraipé, queima oxidante e foi confeccionada com a técnica acordelada. A vasilha é polida em ambas as faces. A espessura varia entre 6 e $10 \mathrm{~mm}$, sendo a borda expandida e o lábio arredondado. Possui pintura branca e preta em ambas as faces, tanto na borda quanto nos fragmentos de parede. A pintura branca é mais espessa e compõem os motivos geométricos, e a preta, cuja camada é fina, compõe o fundo, estando sob a pintura branca em algumas partes. As faixas brancas que compõe os motivos geométricos variam em largura entre 10 e $17 \mathrm{~mm}$, sendo mais finas na borda, em ambas as faces, e mais grossas na parede (figura 128, letra A).

Em oito fragmentos de uma mesma vasilha (E392510 N9021980), cuja pasta contém elementos minerais, caraipé e carvão, ocorre pintura preta e branca na face externa, enquanto a face interna encontra-se bastante desgastada possivelmente pelo uso para fermentação de bebidas (B e C da figura 128). Nestes fragmentos a pintura preta, bastante desgastada e fina, forma motivos geométricos largos, e na pintura branca foram feitas incisões finas com motivos complexos. Ocorre pintura vermelha sobre engobo branco em um fragmento (E na figura abaixo) e branca em outros três de uma mesma vasilha (figura 128, letra D). 


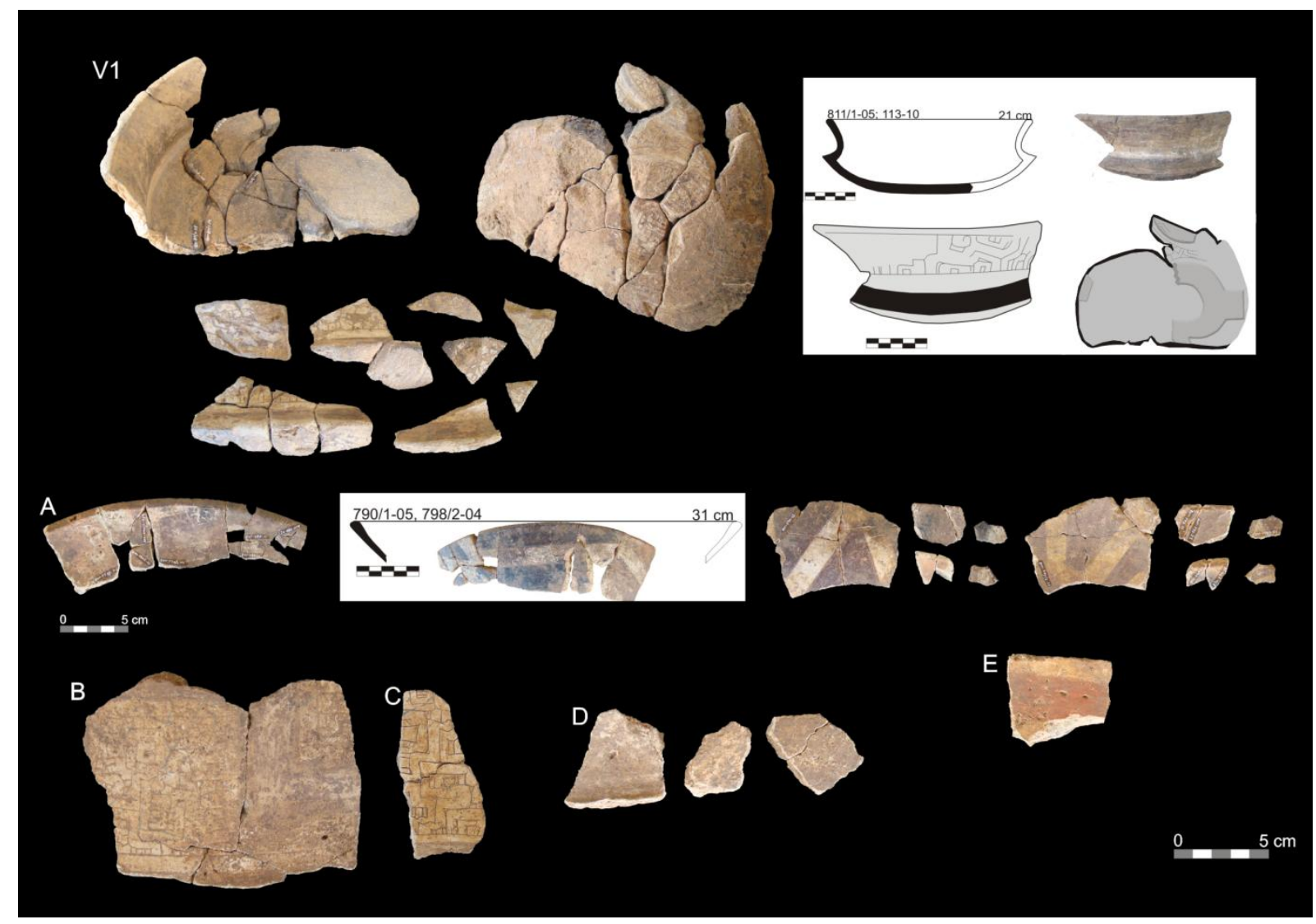

Figura 108: Vasilhas 1 (V1) e 2(A); fragmentos com pintura branca e incisões (B, C); pintura branca (D) e pintura vermelha e branca (E) (Fotos: SCIENTIA, 2012).

Fragmentos de borda e bojo (evidenciados entre 15 e $40 \mathrm{~cm}$ da unidade E392510 N9021980) compõem a vasilha 3, cuja pasta contém minerais (óxido de Fe e quartzo) e caraipé, e a queima é oxidante. Confeccionada com a técnica acordelada, possui contorno infletido e estrutura fechada, $20 \mathrm{~cm}$ de diâmetro de abertura, lábio arredondado, borda extrovertida e espessura de $7 \mathrm{~mm}$. Apresenta polimento em ambas as faces, fuligem na face externa do bojo e desgaste na face interna no pescoço. Possivelmente trata-se de uma vasilha utilizada sobre o fogo (panela) (figura 129).

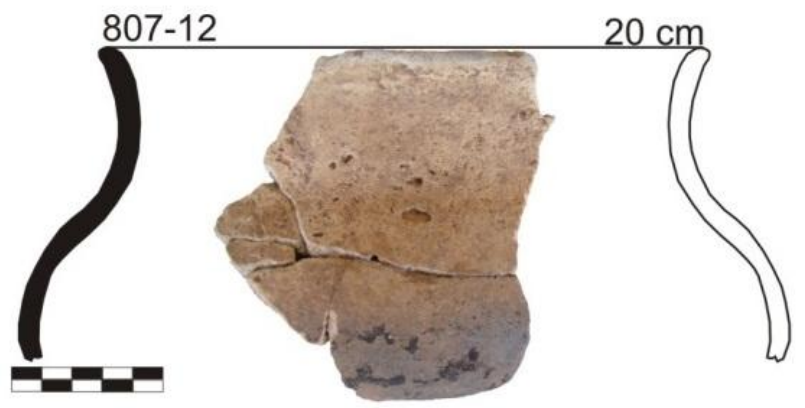

Figura 109: vasilha com fuligem (panela)- Setor 3 do sítio Boa Vista (SCIENTIA, 2012). 
Nesta mesma unidade ocorrem fragmentos de duas outras vasilhas com borda extrovertida (807-07 e 792/1-07), polidas em ambas as faces, e uma possível borda extrovertida (possui as duas extremidades bem alisadas podendo também ser uma vasilha vazada) com $32 \mathrm{~cm}$ de diâmetro de abertura (798/1-01). Outras duas bordas desta unidade são diretas inclinadas externamente, uma de $31 \mathrm{~cm}$ outra de $8 \mathrm{~cm}$.

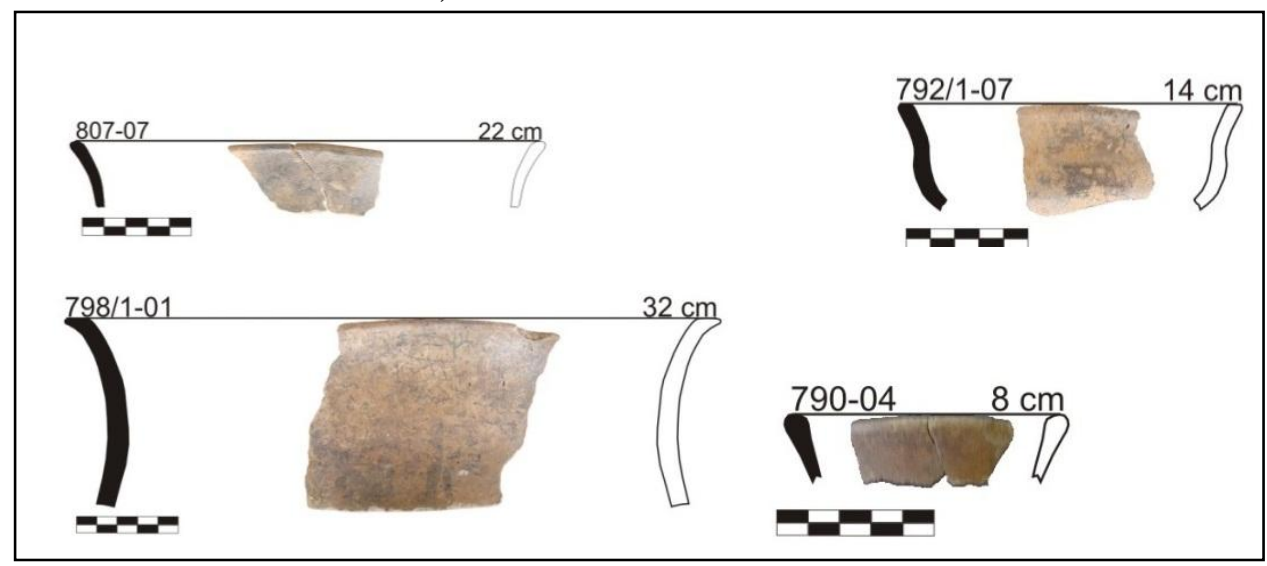

Figura 110: Bordas- setor 3 do sítio Boa Vista (Angislaine F. Costa, 2012)

Foram identificados apenas 3 fragmentos de base, sendo dois de uma mesma vasilha, todos da unidade E392510 N9021980. As bases são convexas côncavas (diâmetros não identificados), e apresentam depósito de carbono na face interna. Ocorre um único fragmento que pode ser de flange (30-40 cm da unidade E392510 N9021980), porém está bastante desgastado, com cauixí na pasta.

Comparando os resultados obtidos para os dois setores, o primeiro na planície de inundação do rio Madeira com uma datação recuada entre as obtidas para as ocupações ceramistas da região, e o segundo mais distante do rio e com uma camada arqueológica menos profunda, percebemos diferenças principalmente na composição da pasta (maior quantidade de carvão no setor 1, que caracteriza as cerâmicas mais antigas no alto Madeira), queima (no setor 3 a queima oxidante é mais recorrente que no 1), conservação dos fragmentos e forma das vasilhas (as duas bordas do setor 1 se diferenciam daquelas do setor 3). Entendemos que tais características permitem caracterizar o sítio como multicomponencial, com uma ocupação mais antiga na planície (setor 1) e uma mais recente no platô (setor 3). A cerâmica do setor 3 apresenta elementos tecnológicos da Tradição Polícroma da Amazônia, e é interessante que esta área do sítio parece ser unicomponencial, com fragmentos cerâmicos de vasilhas com diferentes funções: vasilha 1 e outros fragmentos com pintura e desgaste na face interna, possivelmente utilizadas na fermentação de bebidas; vasilha com fuligem e fragmentos de base com depósito de carbono indicando uso como panelas; e vasilhas pequenas utilizadas 
para servir; as bases são convexas côncavas (estando ausentes as anelares e em pedestal, características de outros conjuntos tecnológicos associados a Tradição Barrancóide). Esse contexto do setor 3 do sítio Boa Vista serve de referência para a compreensão das ocupações na região pelos portadores da Tradição Polícroma, apesar de não termos datações disponíveis para esta ocupação do sítio.

\subsection{Cerâmica do sítio Vista Alegre}

Foram triados 5.311 fragmentos do sítio Vista Alegre, sendo 566 das unidades E387190 N9020490 I, II, III e IV (setor 1), 1.963 das unidades N386970 E9019890 e N386971 E9019890 (setor 3) e 2.782 das unidades N387029 E9019950, N387029 E9019951, N387030 E9019950 e N387030 E9019951 (setor 3). Foram analisados no total 1.720 fragmentos, sendo 302 do setor 1 e 1.417 do setor 3. Os fragmentos das unidades E387190 N9020490 I, II, III e IV (setor 1) apresentam-se muito erodidos, por isso foram analisados os maiores de $2 \mathrm{~cm}$, e não somente os diagnósticos que são raros.

Das unidades do setor 3, cujos fragmentos são melhor conservados, foram analisados os fragmentos diagnósticos. No setor 1, nas quatro unidades contíguas com coordenada de referência E387190 N9020490 (I, II, III e IV), foi escavada uma estrutura de combustão e foram obtidas duas datações $14 \mathrm{C} 3.140 \pm 40$ AP e $1.240 \pm 30$ AP. Esta apresenta material arqueológico entre 0-10 e 70-80 cm e apenas um fragmento no nível 110-120 cm. No setor 3, nas quatro unidades contíguas com coordenada de referência N387030 E9019950, foi escavada uma estrutura de combustão na camada B, datada em 14C2.080 \pm 30 AP (40-50 $\mathrm{cm}$ ).

\subsubsection{Análise da cerâmica do setor 1- unidades E387190 N9020490 (I, II, III e IV)}

Das quatro unidades do setor 1 foram analisados 302 fragmentos cerâmicos (em função das remontagens, trabalhamos com o número de 273 fragmentos de vasilhas) e uma bolota de argila. Os fragmentos apresentam-se bastante desgastados: 157 (57, 51\%) estão erodidos em ambas as faces, $68(24,91 \%)$ bem conservados em ambas as faces e os demais apresentam ao menos uma das faces erodidas, ausentes ou com decoração vestigial. Verificou-se que a maioria dos fragmentos erodidos está nos níveis 40-50 a 70-80 cm, portanto o material mais antigo. 
Na pasta da maioria das vasilhas foi adicionado caraipé e carvão ou somente caraipé, em outras ocorre apenas mineral ou mineral e cauixí (gráfico 29). Entre os minerais, ocorre quartzo, óxido de Fe, feldspato e mica (esta última em apenas dois fragmentos). Nas pastas que somente com minerais predominam os grãos de quarto angulosos e subangulosos, enquanto nas demais predominam grãos subangulosos. Todos os tipos de pastas estão distribuídos ao longo de todos os níveis de escavação, não sendo possível isolar nenhuma diferença na estratigrafia.

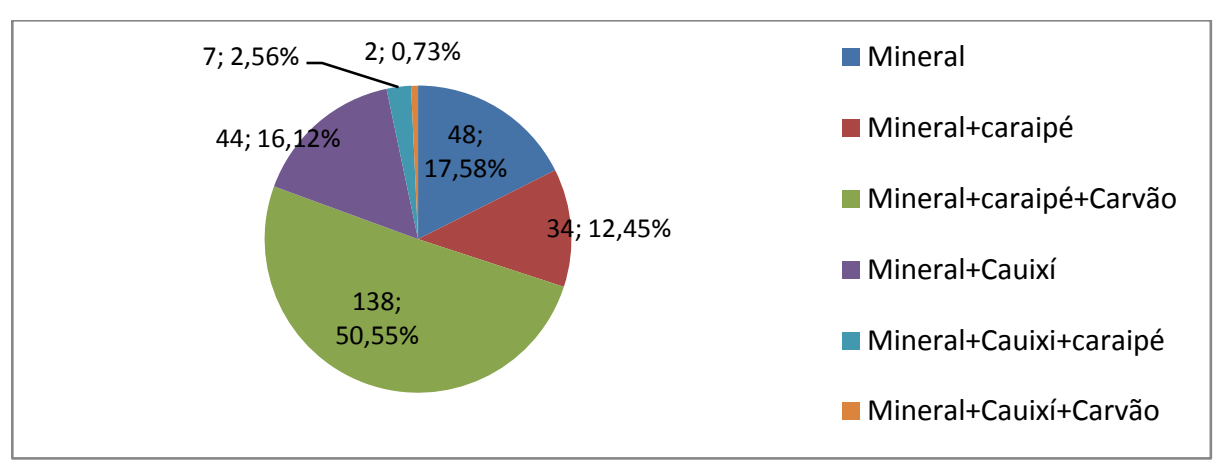

Gráfico 29: caracterização da pasta- setor 1 do sítio Vista Alegre.

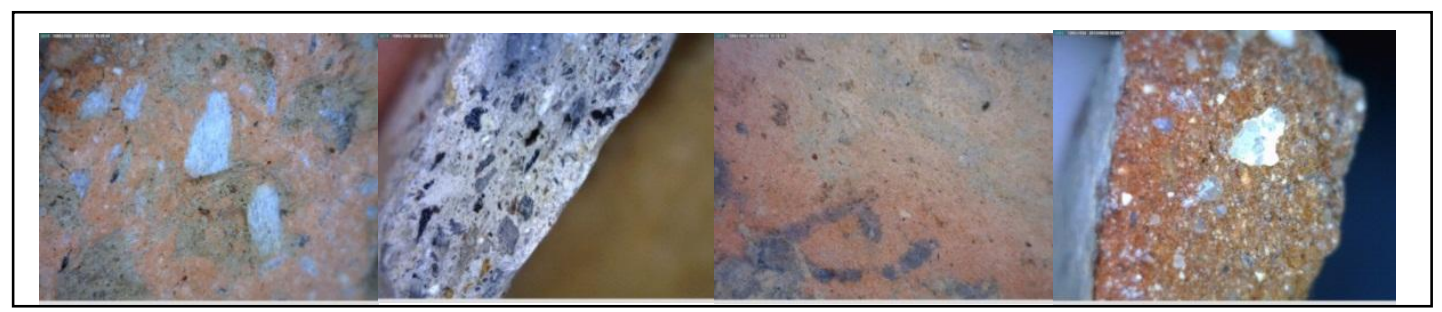

Figura 111: pastas com caraipé; caraipé e carvão; cauixí; e mineral - setor 1, Vista Alegre (Fotos: SCIENTIA, 2012)

Predomina a queima reduzida $(188 ; 68,86 \%)$, seguida pela oxidante $(73 ; 26,74 \%)$, oxidante externa e reduzida interna (6) e oxidante interna e reduzida externa (6). Entre os fragmentos com caraipé e carvão na pasta predomina a queima reduzida e entre os fragmentos com cauixí a oxidante. Na maioria dos fragmentos não foi possível identificar o acabamento de superfície devido ao desgaste, porém nos demais predomina o alisamento fino e polimento, além de aparecer brunidura e alisamento médio ou grosseiro em pequena quantidade (gráfico 30). Com a barbotina houve a mesma dificuldade, sendo identificada em apenas 33 fragmentos. Não foi identificado engobo, e a pintura está presente na face externa de apenas oito fragmentos, sendo dois com pintura vermelha e branca e seis com pintura vermelha (Fotografias 91 e 92). Tratamentos plásticos estão presentes em 4 fragmentos: inciso FI (2), inciso FE (1) e acanalado FE (1) (fotografias 93 e 94). 

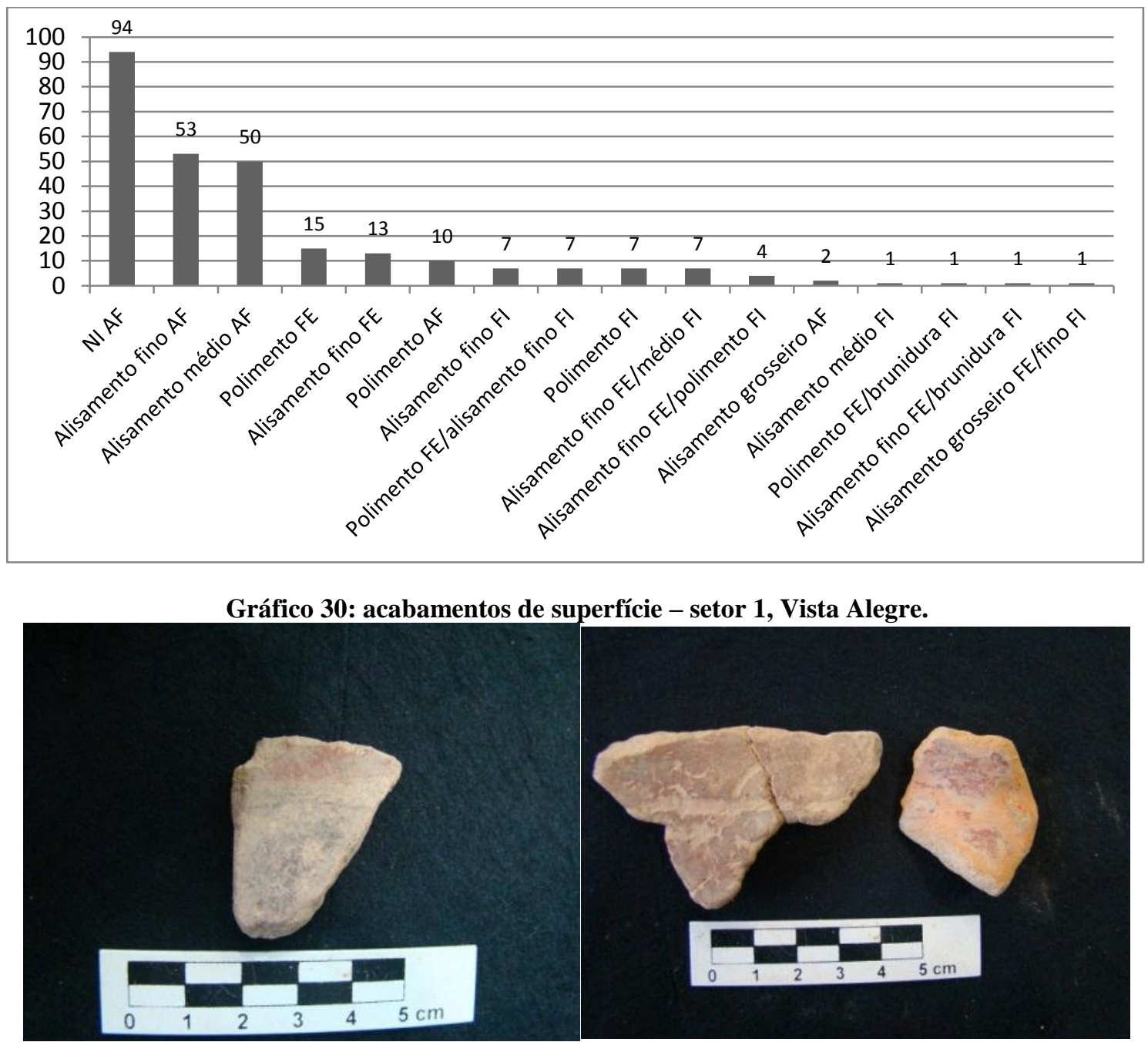

Fotografias 91 e 92: pintura vermelha e branca (pasta com caraipé) e vermelha (cauixí) (SCIENTIA, 2012).

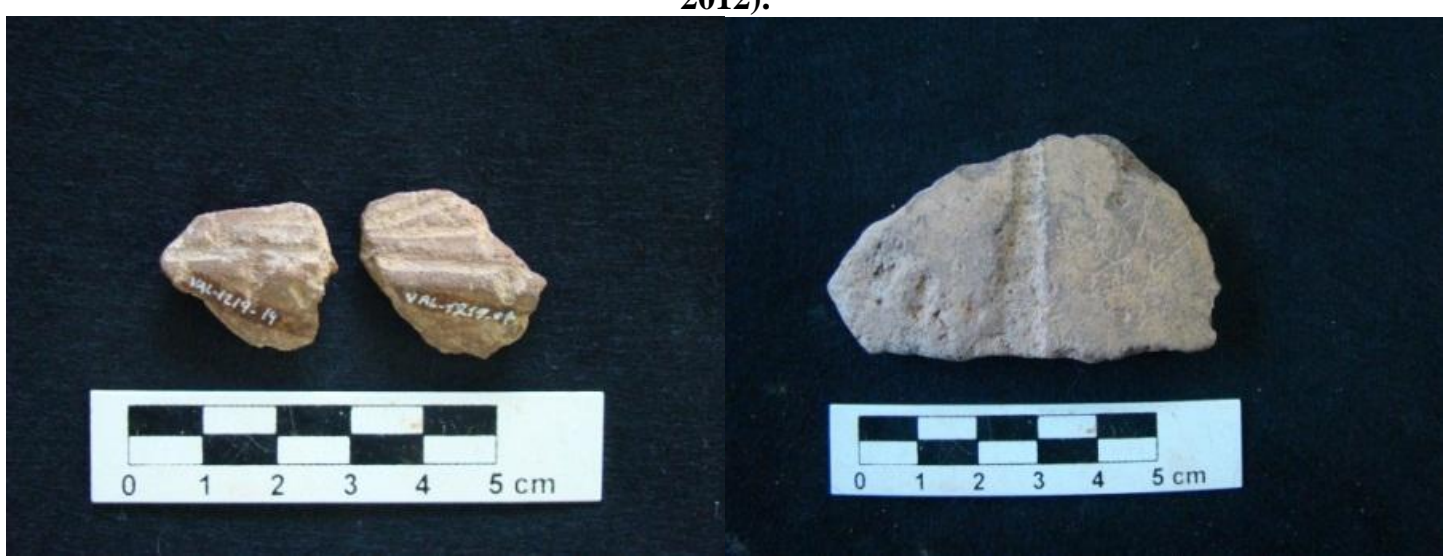

Fotografias 93 e 94: incisões e acanalado- setor 1 do Vista Alegre (SCIENTIA, 2012)

Ocorrem fragmentos de parede (221), inflexão (31), borda (12), borda com flange (2), pescoço (2), bojo (1) e não identificado (4). As duas bordas com flange são do nível 50-60 $\mathrm{cm}$. Os fragmentos possuem espessura variando entre 3 e $18 \mathrm{~mm}$, predominando 5 a $7 \mathrm{~mm}$. 
As bordas (uma com flange) são extrovertidas (3), diretas inclinadas externamente (2) e diretas inclinadas internamente (2); apresentam espessamento linear (4), contraído (2) e expandido (1); nas demais (7) não foi possível visualizar a inclinação e espessamento. Possuem lábio arredondado (9), plano (1) ou não identificado (4). Foi possível medir o diâmetro de apenas uma borda de $30 \mathrm{~cm}$ (. Nenhuma base foi identificada na coleção. Ocorre fuligem (11 fragmentos), depósito de carbono (2) e fermentação (1).
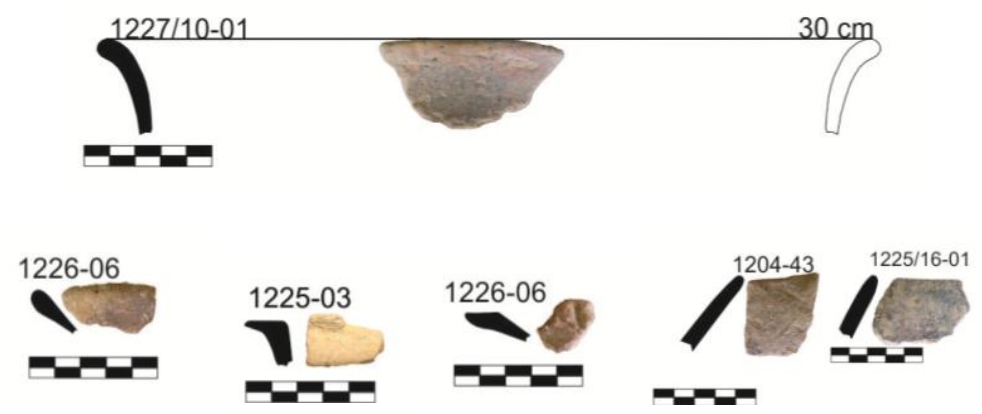

Figura 112: bordas das unidades do setor 1- Vista Alegre (Desenhos: Angislaine F. Costa, 2012)

\subsubsection{Análise da cerâmica do setor 3}

No setor 3 a escavação de 2 m² (unidades N387029 E9019950, N387029 E9019951, N387030 E9019950 e N387030 E9019951) apresentou material até o nível 70-80 cm enquanto as unidades E386970 N9019890 e E386971 N9019890 até 110 cm (gráficos 31 e 32). Analisamos separadamente os resultados destas duas unidades, buscando evidenciar as semelhanças e diferenças na estratigrafia.
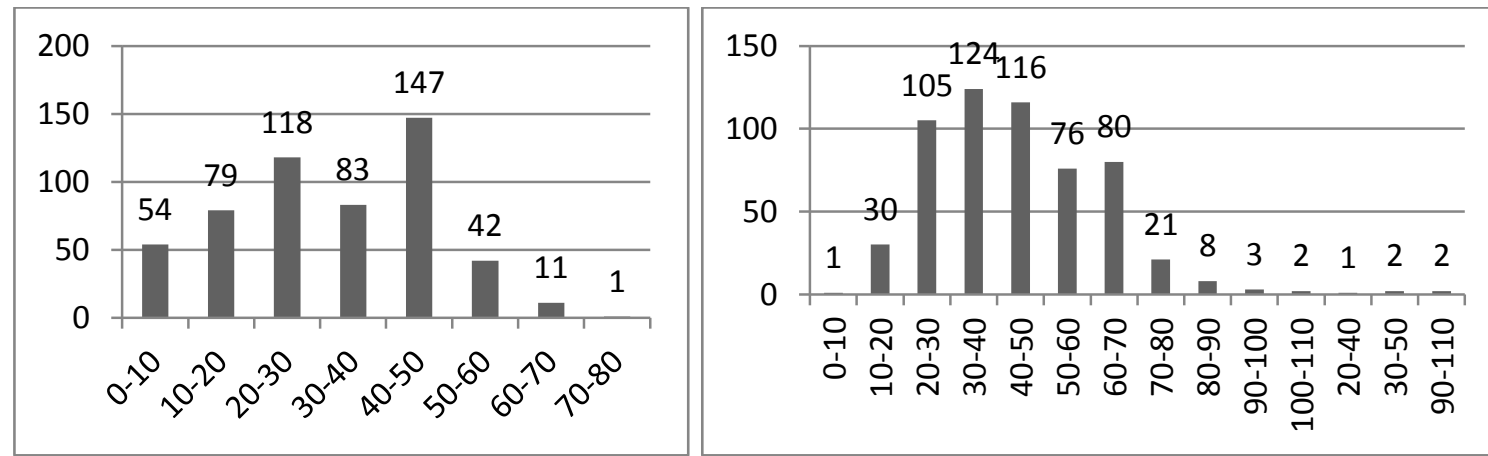

Gráficos 31 e 32: materiais nos níveis das escavações de 2 x 2 m e 2 x 1 m no setor 3 do sítio.

\subsubsection{Cerâmica da escavação de 2 m²$^{2}$ - unidade N387029 E9019950 e expansões}

Foi obtida a datação de 14C 2.080 \30 AP para o nível 40-50 cm da escavação de $2 \mathrm{~m}^{2}$, onde foi evidenciada uma estrutura de combustão. Foram analisadas 97 bolotas de argila e todas apresentaram mineral. Também ocorreu um fuso no nível 30-40 cm com mineral, 
caraipé e carvão na pasta. Foram analisados 690 fragmentos de vasilhas e 2 fragmentos de artefatos não identificados (que possivelmente são de decoração modelada ou aplicada de vasilhas), e como muitos foram remontados ou associados à mesma vasilha trabalhamos com um número de 535 fragmentos.

$\mathrm{Na}$ pasta predomina a presença de mineral, caraipé e carvão (291 fragmentos; $54,39 \%)$, mineral e caraipé $(109 ; 20,56 \%)$, somente mineral $(96 ; 17,94 \%)$, mineral e carvão (35; 6,54\%), e cauixí em apenas três fragmentos. A pasta com mineral é mais recorrente nos níveis $20-30$ e 30-40 cm (89,58\% dos fragmentos com mineral estão entre 0-10 cm e 30-40 cm e apenas 10,42\% deles ocorrem nos níveis 40-50 e 50-60 cm) com um pico no nível 20-30 cm. A pasta com mineral e carvão predomina entre os níveis 40-50 cm e 70-80 cm (74,29\% dos fragmentos com esta pasta estão entre 40-50 e 70-80 cm, enquanto 25,71\% ocorrem entre 10-20 e 30-40 cm). A pasta com mineral, caraipé e carvão aumenta consideravelmente em relação às outras abaixo do nível 30-40 cm, quase predominante no nível 40-50 cm, enquanto a pasta com mineral e caraipé predomina nos níveis superiores $(80 \%$ dos fragmentos com esta pasta estão entre 0-10 e 30-40 cm e apenas $20 \%$ entre $40-50$ e 60-70 cm). Os três fragmentos com cauixí estão no nível 0-10 e 10-20 cm (gráfico 33). Acreditamos que a pasta com mineral e carvão dos níveis mais profundos corresponda a uma adição de caraipé carbonizado, que em função da queima reduzida não transformou-se um uma estrutura mais clara, típica do caraipé.

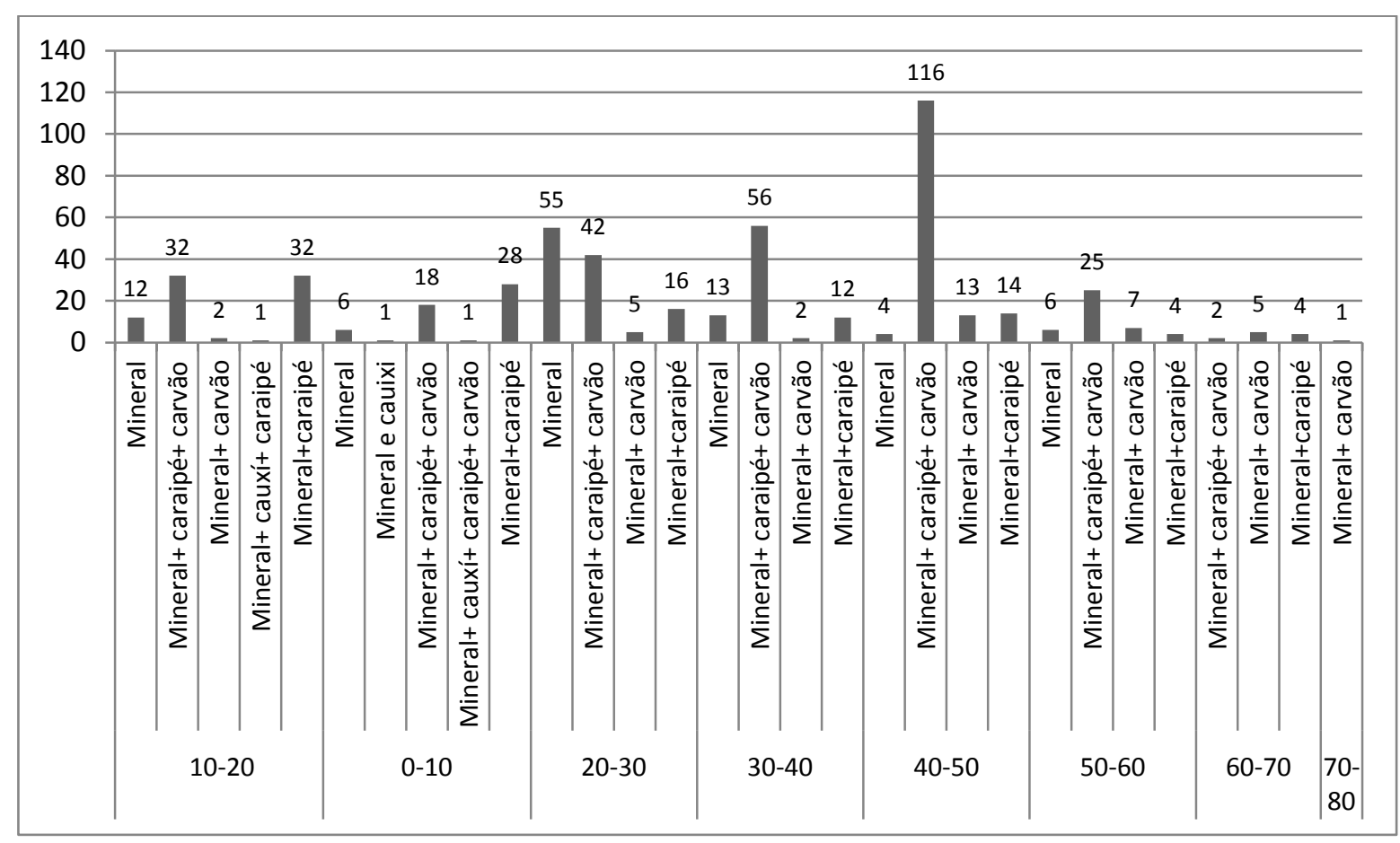

Gráfico 33: caracterização da pasta nos diferentes níveis- escavação de $2 \mathrm{~m}^{2}$ do setor 3 
A técnica de confecção utilizada foi a acordelada (464 fragmentos) e modelada (41 fragmentos), não sendo identificada em trinta fragmentos. Predomina a queima reduzida (330; $61,68 \%)$, seguida pela oxidante $(180 ; 33,64 \%)$, oxidante externa e reduzida interna (15; $2,80 \%)$, oxidante interna e reduzida externa $(8 ; 1,50 \%)$ e oxidante com núcleo reduzido (2). Vasilhas com apenas mineral na pasta possuem em grande parte queima oxidante, enquanto as vasilhas com caraipé e carvão, assim como aquelas com mineral e carvão, possuem na maioria queima reduzida. Entre as vasilhas com mineral e caraipé (sem carvão), ocorrem os dois tipos, apesar de predominar a reduzida. Portanto, verificou-se que a presença de carvão na pasta pode estar associada ao processo de queima e que as vasilhas somente com mineral na pasta são claras (geralmente avermelhadas).

$\mathrm{Na}$ maioria dos fragmentos não foi possível observar os acabamentos se superfície, porém nos demais predomina o polimento e o alisamento fino, além de poucos fragmentos com brunidura, alisamento médio ou grosseiro (gráfico 34). A barbotina ocorre em ambas as faces (180 fragmentos), na face interna (34) e na face externa (50), e nos demais não foi identificada (163) ou está ausente (108).

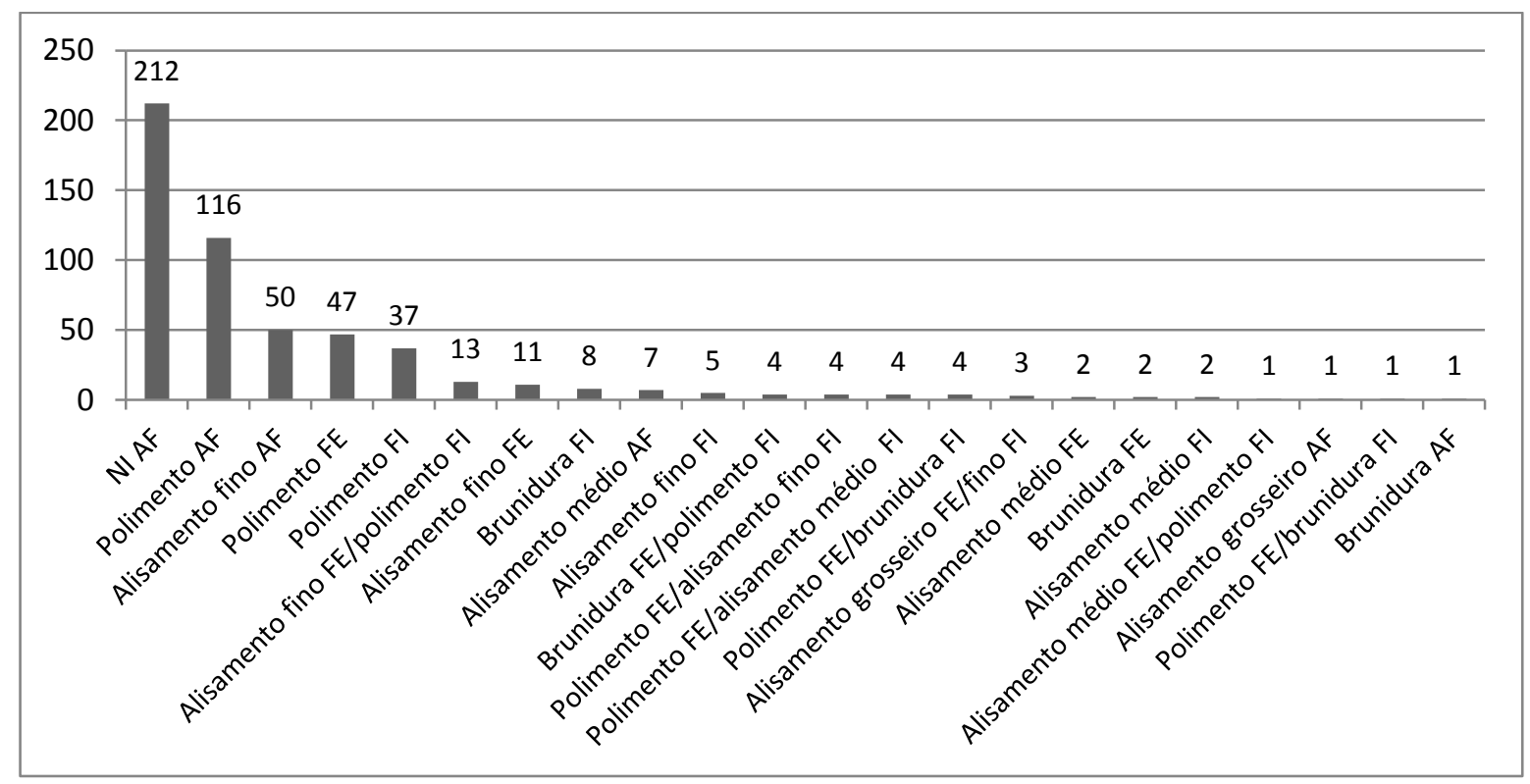

Gráfico 34: acabamentos de superfície- escavação de $2 \mathrm{~m}^{2}$ do setor 3.

O engobo ocorre em 61 fragmentos $(11,40 \%)$, em uma ou em ambas as faces, nas cores vermelha, laranja, vinho e branca, e nos demais está ausente (431 fragmentos) ou não foi identificado (43 possuem vestígios de pigmento). O engobo foi aplicado quase exclusivamente em vasilhas com caraipé na pasta, com exceção de alguns fragmentos com 
mineral carvão. A pintura (vermelha) foi identificada na face externa de três fragmentos $(0,56 \%)$ e em outros 13 não foi possível visualizá-la com segurança. Os tratamentos plásticos ocorrem em 63 fragmentos, predominando as incisões, modelados e ponteados, além de um fragmento escovado e um acanalado (gráfico 35). Enquanto nas vasilhas com pasta somente com mineral predominam os tratamentos plásticos na face interna, na parte superior das vasilhas (incisões, modelados, ponteados), naquelas com mineral e caraipé predomina na face externa, e nas com mineral, caraipé e carvão ocorrem igualmente em ambas às faces.

Comparamos o atributo tratamento plástico com o tipo de pasta, porém não encontramos nenhuma recorrência, ou seja, estão presentes em vasilhas com diferentes pastas, porém chama a atenção o grande número de vasilhas cuja pasta apresenta somente mineral com incisões e modelados, considerando a relação percentual destas vasilhas no sítio. Da mesma forma, os tratamentos plásticos estão presentes em todos os níveis, apesar de serem mais recorrentes no $20-30 \mathrm{~cm}$ e $40-50 \mathrm{~cm}$, justamente os níveis com maior concentração de material analisado, e com os picos dos materiais com mineral na pasta e com mineral, caraipé e carvão, respectivamente.

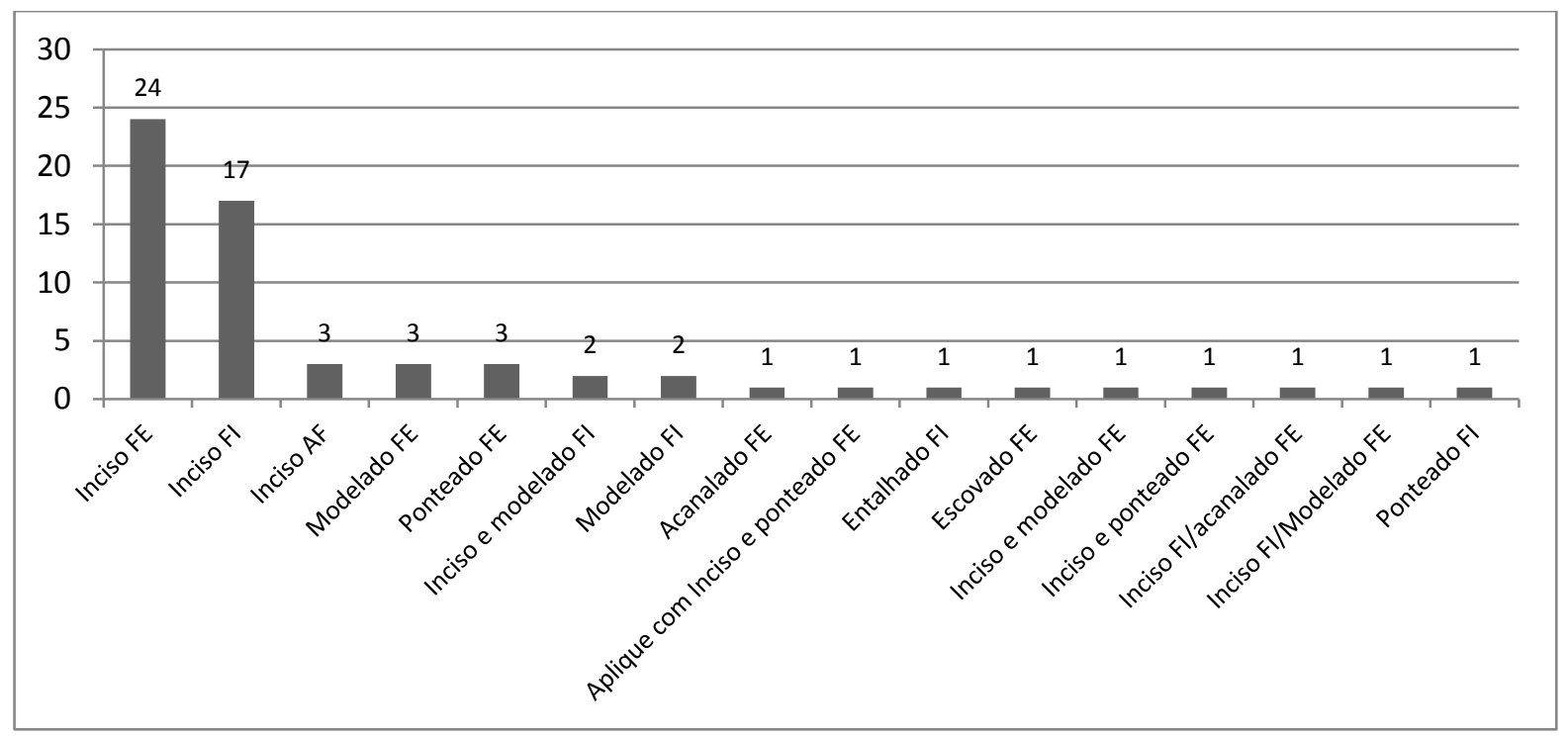

Gráfico 35: tratamentos plásticos-escavação de $2 \mathrm{~m}^{2}$ do setor 3

Estão presentes fragmentos de parede (187), borda (124) inflexão (133), base (39), borda com flange (11), flange (6), carena (4), pescoço (3), bojo (2), alça (1), e aplique (1) e não identificado (22). A espessura varia entre 4 e $21 \mathrm{~mm}$, predominando fragmentos com espessura entre 5 e $8 \mathrm{~mm}$. Para a maioria das bordas não foi possível visualizar a inclinação, e entre as demais predominam as diretas inclinadas externamente e extrovertidas (gráfico 36). 
Já em relação ao espessamento, a maioria é linear $(60 ; 44,44 \%)$, seguida pelas contraídas (19; $14,47 \%)$, expandidas $(11 ; 8,85 \%)$, reforçadas internamente $(2 ; 1,48 \%)$ e reforçada externamente $(1 ; 0,74 \%)$, e nas demais não foi possível visualizar $(42 ; 31,11 \%)$. Os lábios são arredondados $(51 ; 37,38 \%)$, planos $(16 ; 11,85 \%)$, apontados $(12 ; 8,89 \%)$, biselado $(1 ; 0,74 \%)$ e irregular (1), e em 54 bordas não foi identificado (40\%). Foi possível medir o diâmetro de abertura de apenas seis bordas $(8,10,16,18,24 \mathrm{~cm})$. Entre as bases, 9 são bi-planas, 6 convexas côncavas, duas plano côncavas e 22 não identificadas. As bases possuem diâmetro variando entre 4 e $14 \mathrm{~cm}$. Dentre os materiais desta escavação ocorre fuligem em 16 fragmentos, fermentação em sete, depósito de carbono em três, redução em quatro, em um ocorre fuligem FE e depósito de carbono FI e em outro fuligem FE e fermentação FI.

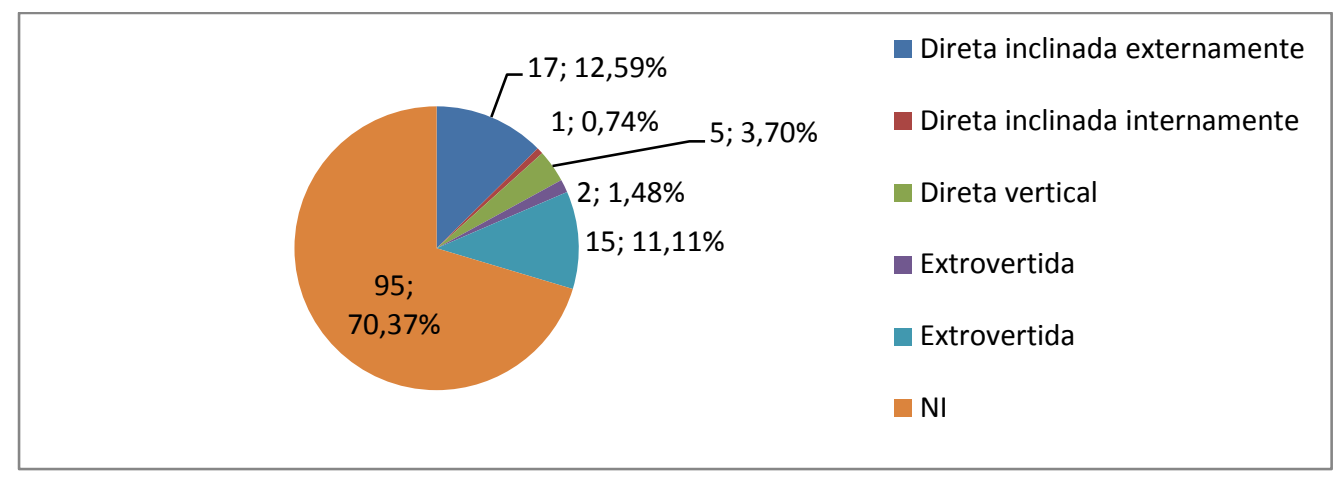

Gráfico 36: forma e inclinação das bordas- -escavação de $2 \mathbf{m}^{2}$ do setor 3, sítio Vista Alegre.

Os desenhos das bordas e características da pasta, tratamentos plásticos e pinturas permitiram evidenciar três conjuntos de materiais nesta escavação. No primeiro deles estão vasilhas com ângulos próximos as bordas (1365-84,88; 1376- 72,66), bordas expandidas (1376-69) ou com flange labial (1357-18; 1038-105), cuja pasta predominantemente apresenta mineral, caraipé e carvão ou mineral e carvão, porosa, queima reduzida, presença de decoração plástica na parte superior das vasilhas, como incisões na parte interna das bordas e flanges labiais, incisões na face externa ou um alisamento que deixa estrias (semelhante a escovado) e modelados, alguns deles como bicos que podem ser fragmentos de flanges, e outros que possivelmente são elementos zoomorfos. Ocorre ainda engobo branco ou vermelho em cores vivas (figuras 113 a 116). Estes materiais ocorrem predominantemente nos níveis mais profundos, associados à datação de $14 \mathrm{C} 2.080 \pm 30 \mathrm{AP}(40-50 \mathrm{~cm})$ e se parecem com aqueles do sítio Veneza e Garbin. 


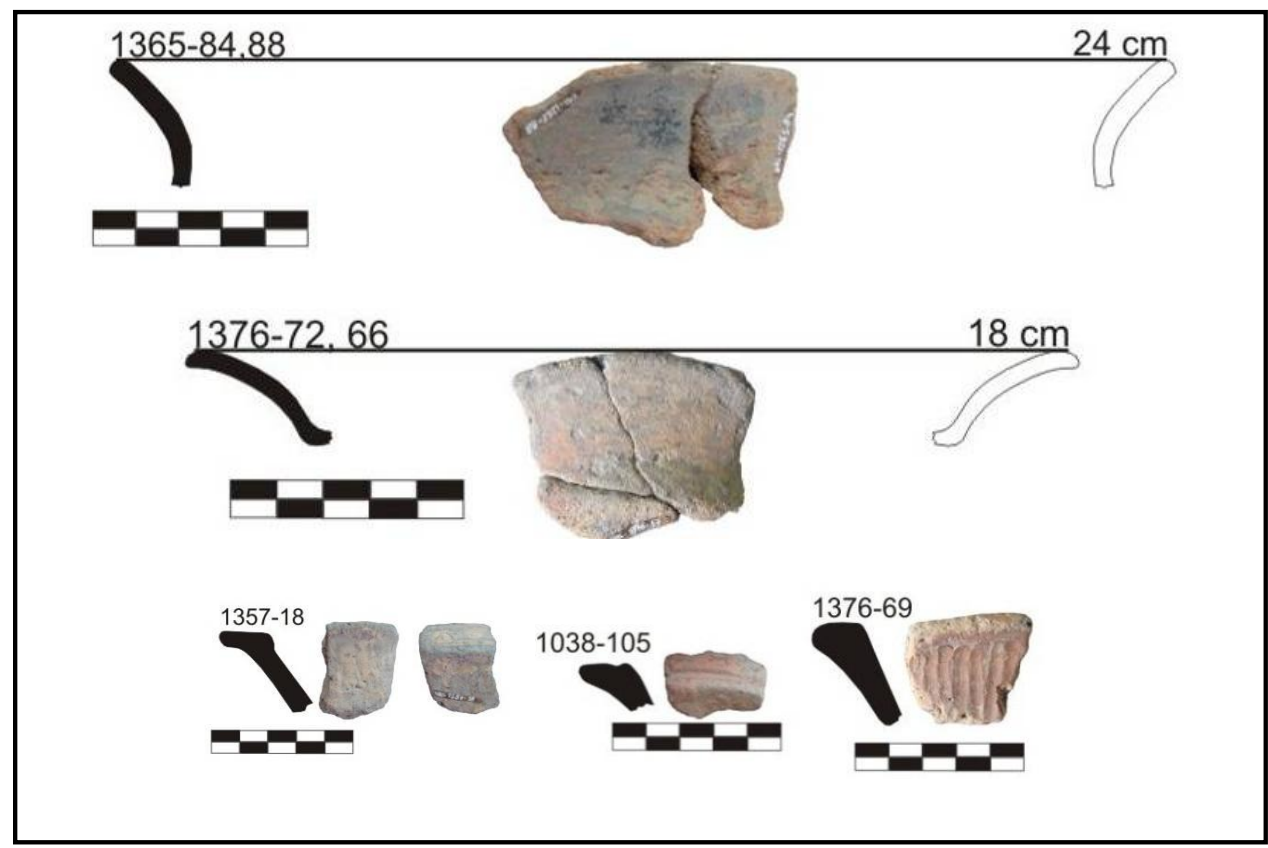

Figura 113: bordas do conjunto predominante entre $40-50 \mathrm{~cm}$ e $70-80 \mathrm{~cm}$ escavação de $2 \mathrm{~m}^{2}$ do setor 3, sítio Vista Alegre (Angislaine F. Costa, 2012)

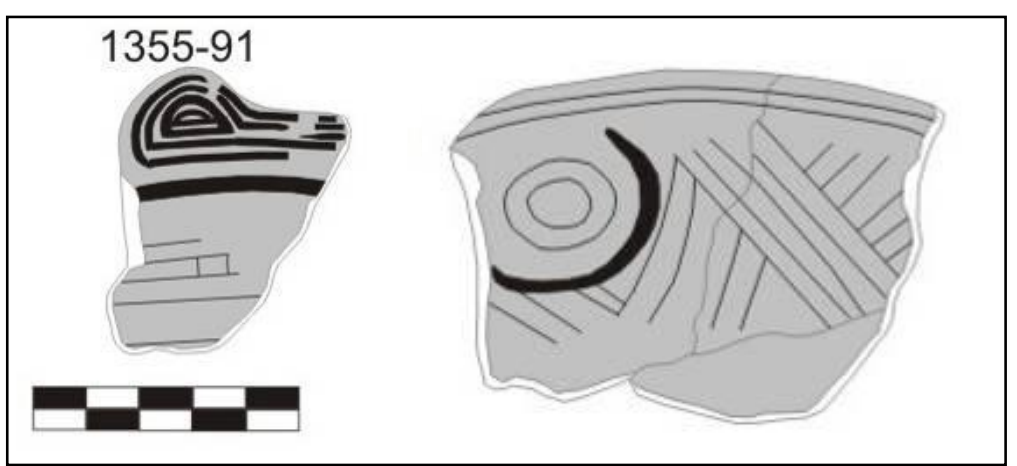

Figura 114: Bordas com incisões na face interna (40-50 cm). Desenhos: Angislaine F. Costa, 2012.
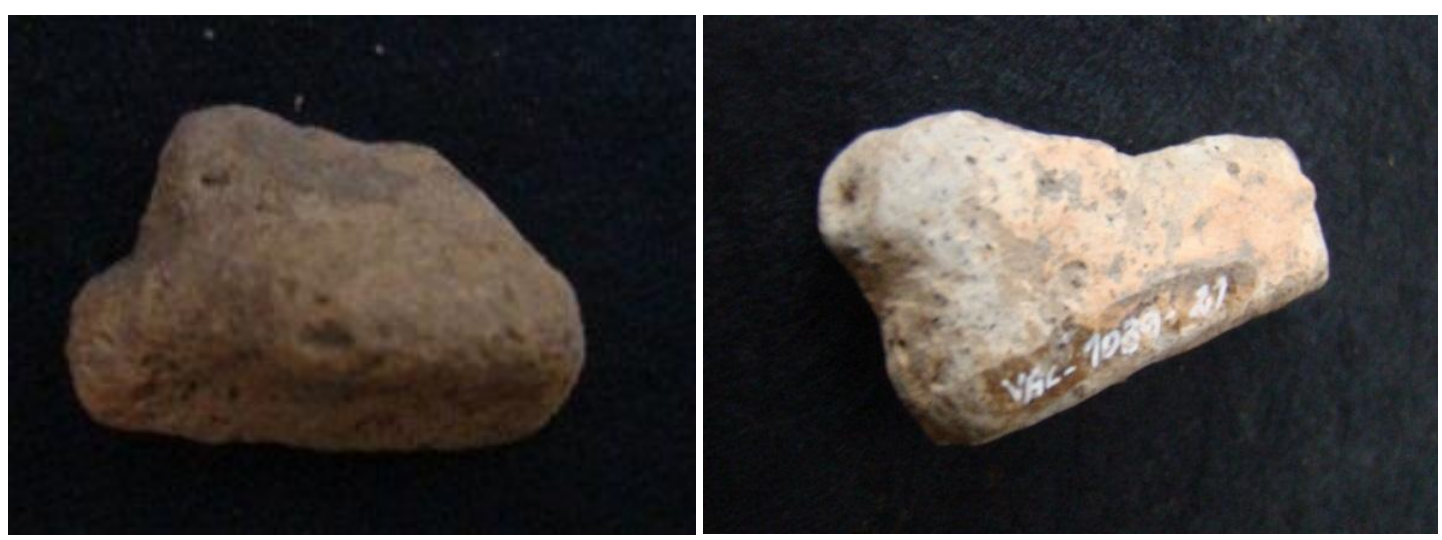

Figura 115: possíveis zoomorfos em detalhe - tamanho: 3 e 5 cm (Fotos: SCIENTIA, 2012). 


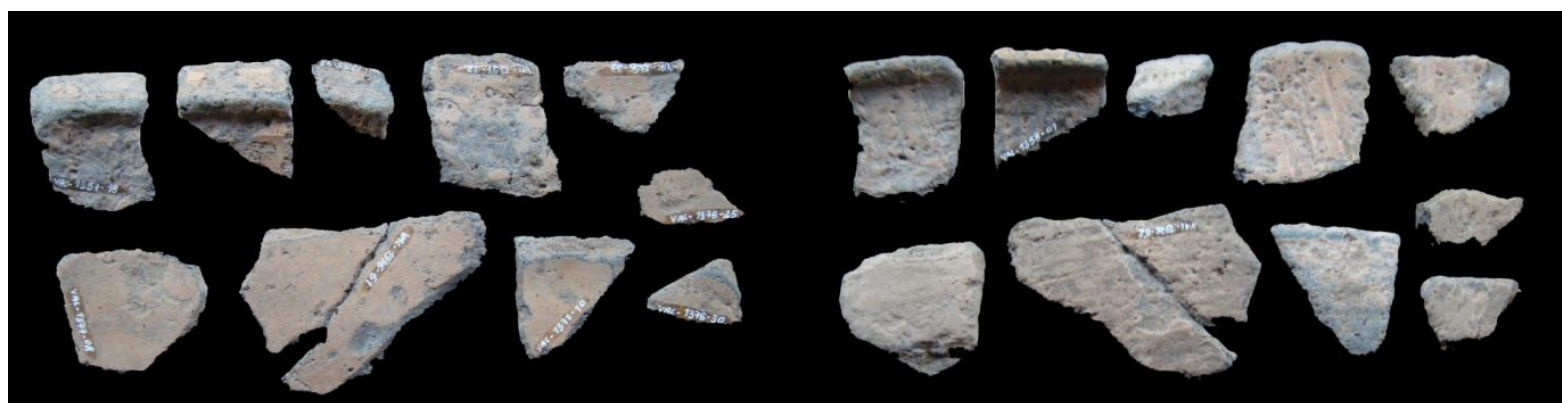

?
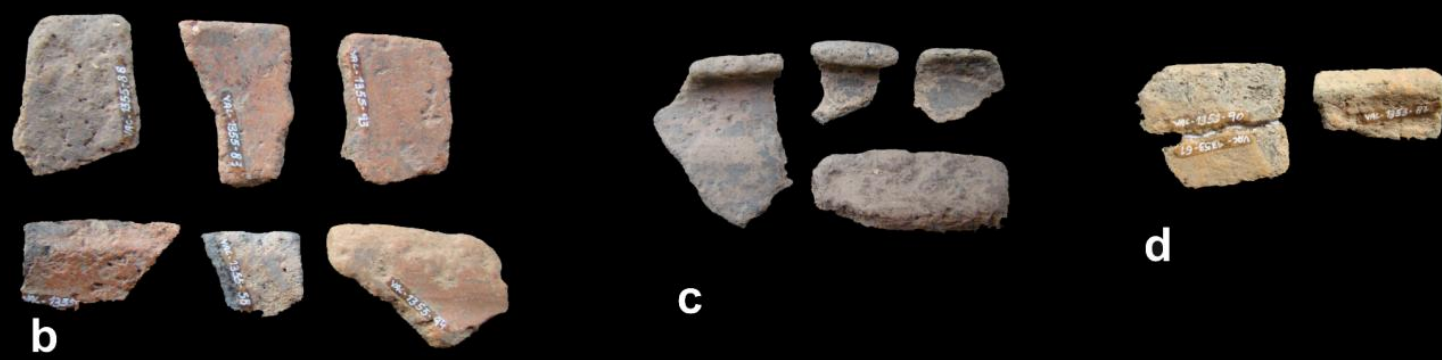

d

C

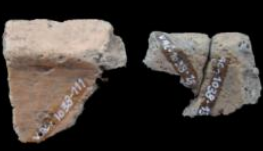

e

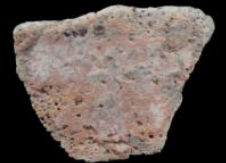

f

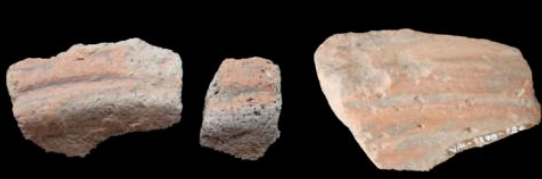

h
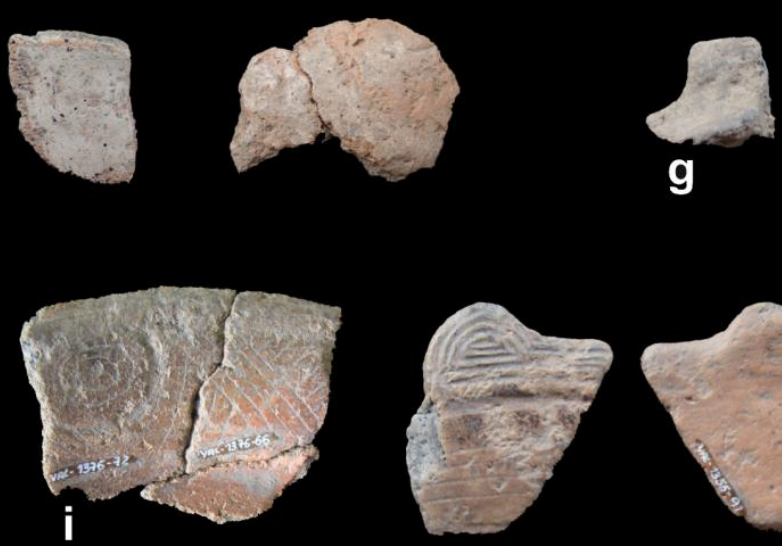

g
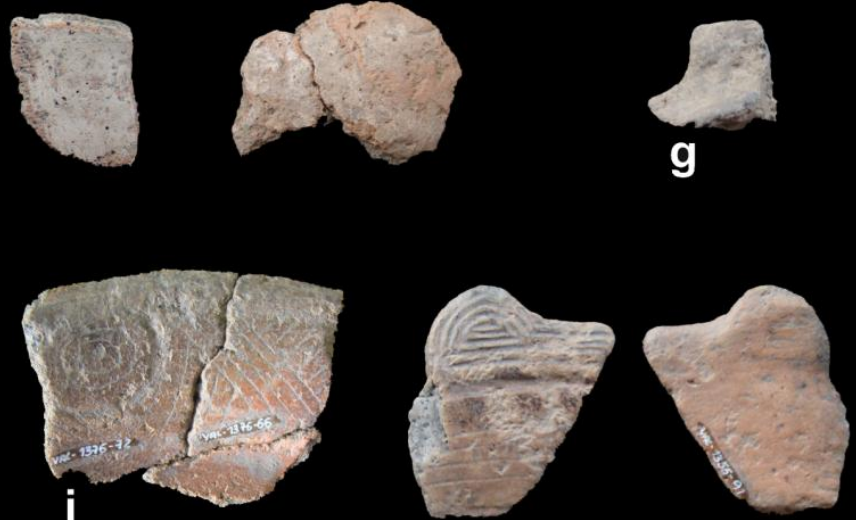
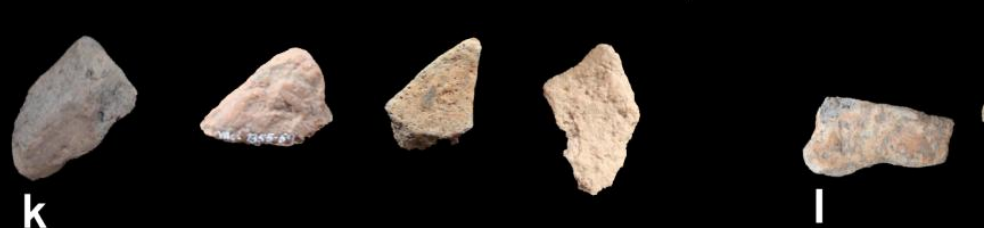

k
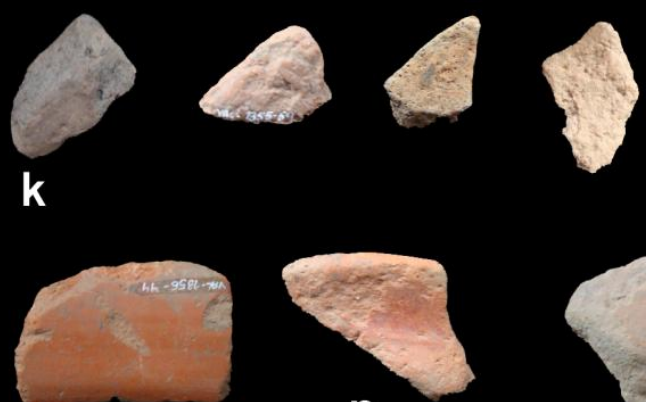

○

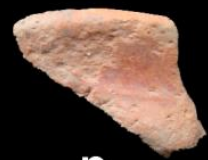

$p$
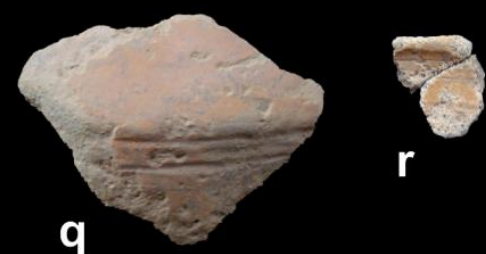

r
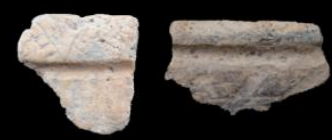

X

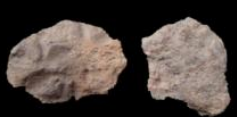

$\mathbf{u}$

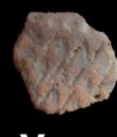

v j
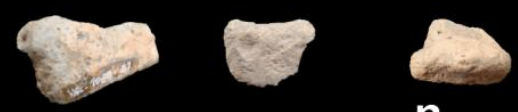

m

n

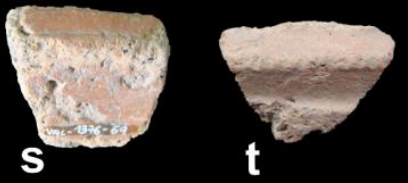

0 $5 \mathrm{~cm}$

Figura 116: Cerâmica antiga do sítio Vista Alegre $(40-50$ a $70-80 \mathrm{~cm})$ : fragmentos com incisões FI e na face interna e escovado FE (a); bordas (b, c, d, e); engobo branco sobre barbotina laranja (f); possível asa (g); bordas com flange e expandida, com incisões paralelas (h); borda com incisões complexas na face interna (i), borda modelada com incisões na face interna (j); fragmentos modelados, possíveis bordas ou flanges (k); modelado zoomorfo $(l, m, n)$; engobo vermelho $(0, p)$; engobo e incisões $(q, r, s)$; ponteado (t, $\mathrm{u}, \mathrm{v})$; acanalado e inciso (x) (Fotos: SCIENTIA, 2012). 
Outro conjunto cerâmico é caracterizado por vasilhas com presença de flange labial (frequentemente $2 \mathrm{~cm}$ abaixo da borda) cuja pasta apresenta predominantemente mineral (anguloso), queima oxidante, alisamento fino ou polimento e presença frequente de incisões nas flanges, as vezes associadas a modelados. Estão bastante fragmentadas e não foi possível reconstituir a forma das vasilhas, apenas sua inclinação (figuras 117 e 118). Estas vasilhas predominam entre 20-30 e 30-40 cm, e se parece com as vasilhas da ocupação mais antiga do sítio Morro dos Macacos I, datada em 14C 1.810 440 AP naquele sítio.

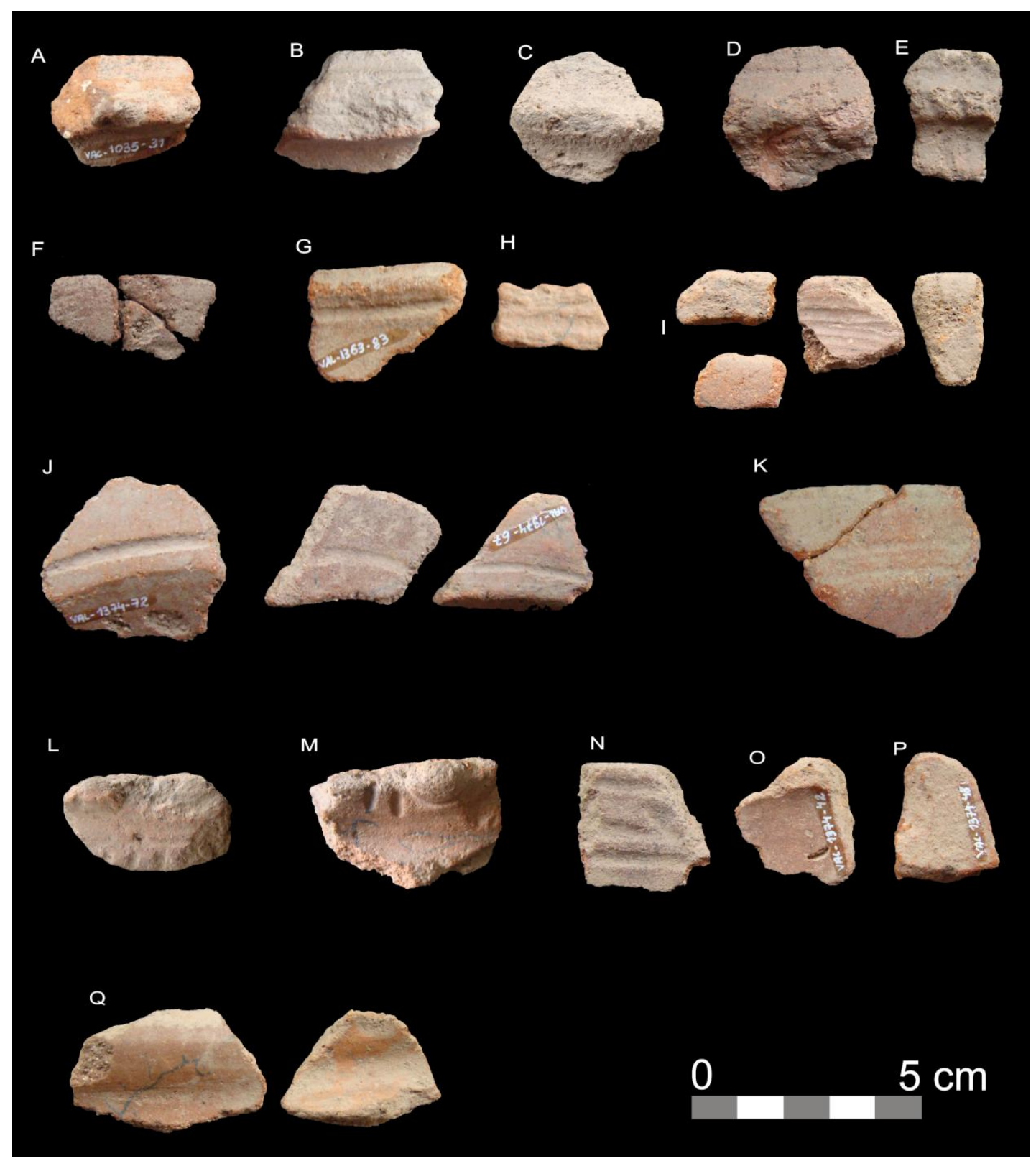

Figura 117: materiais do segundo conjunto identificado- bordas com flange a $2 \mathrm{~m}$ do lábio, com incisões (A, B) e com ponteados (C, D, E); fragmentos de borda (F, G, H, I, N); flanges labiais com incisões na face interna $(J, K)$; flanges com tratamentos modelados, incisos e ponteados $(L, M)$; possíveis bases $(O, P)$ e inflexões (Q). (Fotos: SCIENTIA, 2012). 


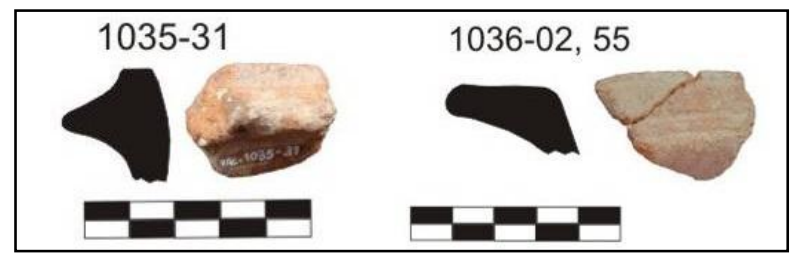

Figura 118: Bordas com flange (Desenhos: Angislaine F. Costa, 2012).

Um terceiro conjunto apresenta bordas predominantemente extrovertidas (algumas com fuligem), bojos com presença de fuligem, desgaste interno (possível fermentação), bases convexas côncavas com depósito de carbono, alisamento fino ou polimento e incisões sobre o engobo branco em dois fragmentos; destaca-se ainda uma alça. Estes materiais ocorrem predominantemente entre $0-10$ e $30-40 \mathrm{~cm}$, portanto nos níveis mais superficiais, e assemelham-se aos do setor 3 do sítio Boa Vista, associados a Tradição Polícroma da Amazônia (figuras 119 a 121). Os três fragmentos com cauixí estão no nível 0-10 e 10-20 cm, e parecem ter surgido no sítio em um período mais recente, possivelmente concomitante a TPA.

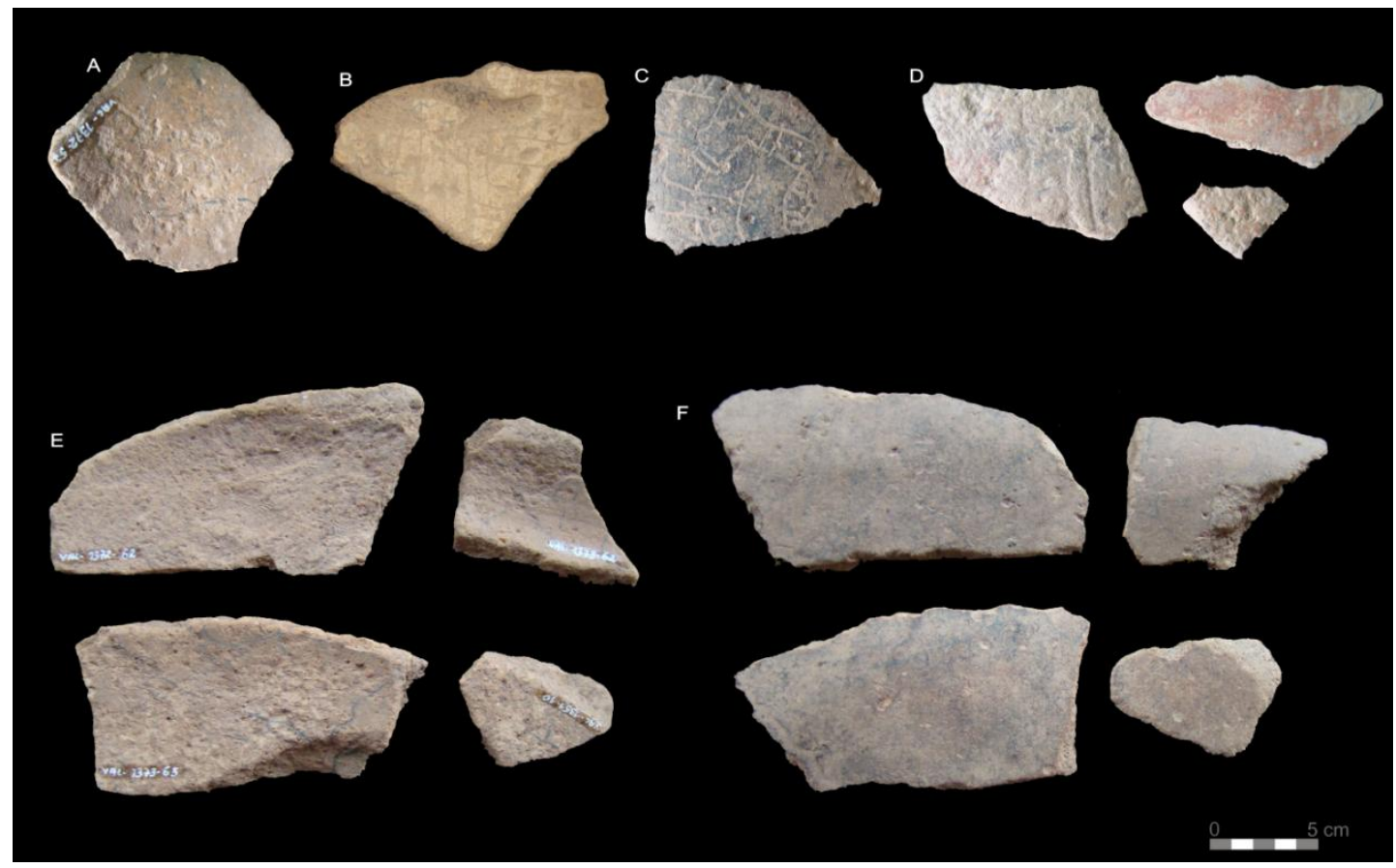

Figura 119: marcas de fermentação (A), engobo branco e incisões(B, C), engobo vermelho (D); polimento na face externa e desgaste na interna (E, F) (Fotos: SCIENTIA, 2012). 


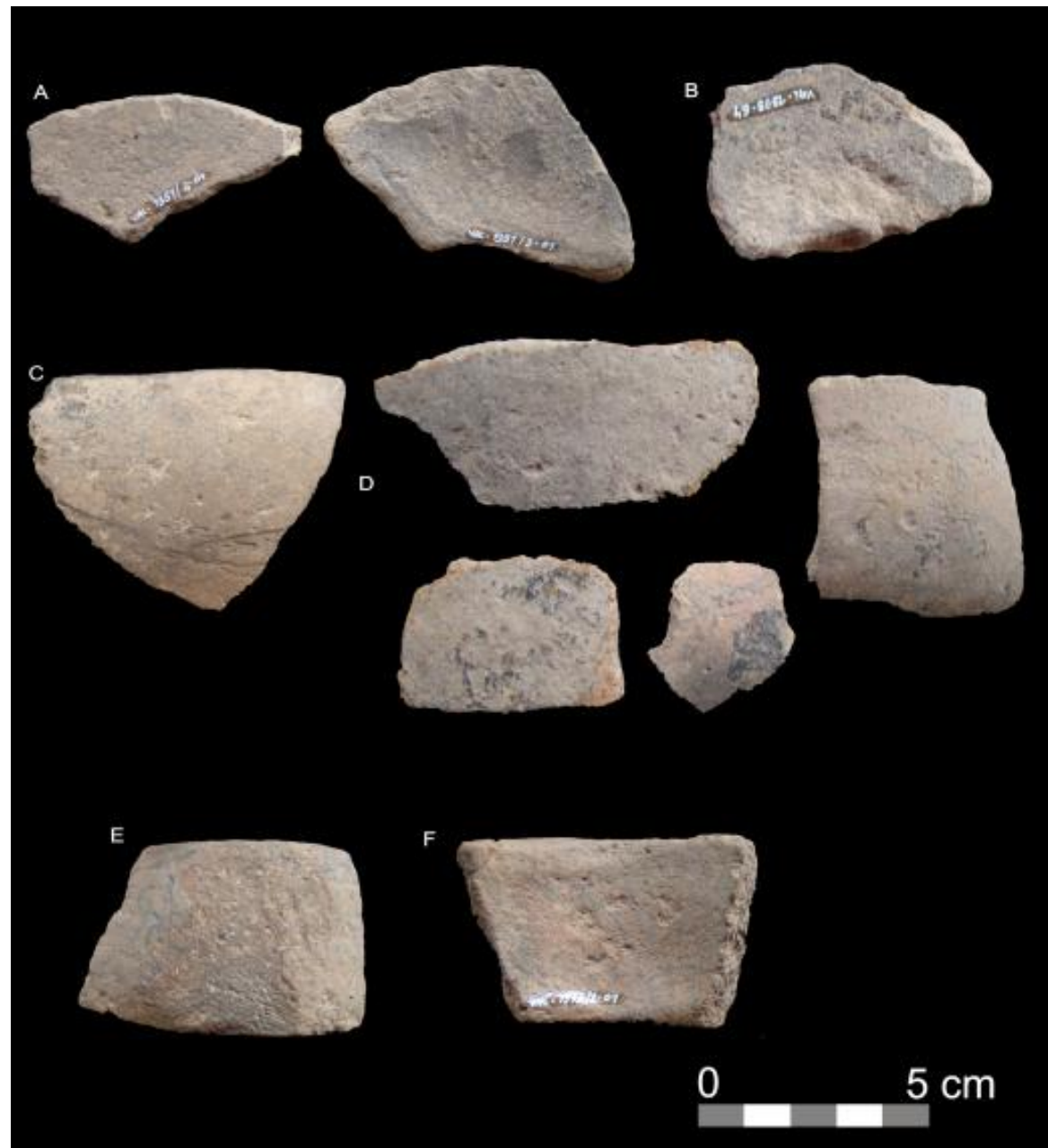

Figura 120: fragmentos de bases convexas côncavas (A); fragmentos de bojo (C, D); alça (E, F) (Fotos: SCIENTIA, 2012)

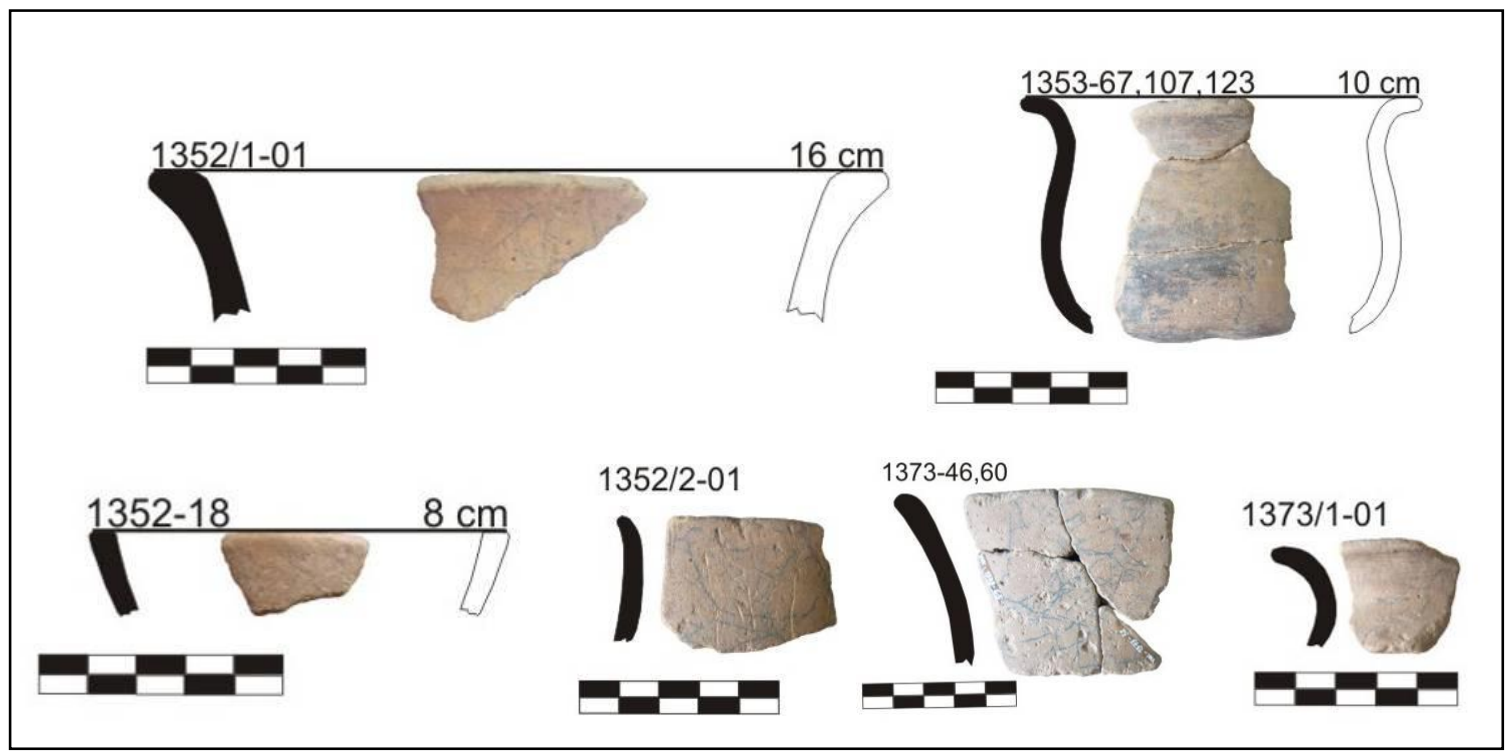

Figura 121: bordas do conjunto mais recente- Tradição Polícroma da Amazônia (Desenhos: Angislaine F. Costa, 2012). 


\subsubsection{Cerâmica da escavação de 2 x 1 m- unidades E386970 N9019890 e E386971 N9019890}

Nas unidades E386970 N9019890 e E386971 N9019890 (2x1m) ocorreram 12 bolotas de argila, todas com mineral na pasta, 1 fuso com mineral e caraipé na pasta $(30-40 \mathrm{~cm}), 709$ fragmentos de vasilha e três não identificados (NI). Os fragmentos de vasilha e NI foram analisados conjuntamente, e como houve remontagens e formação de conjuntos trabalhamos com um número de 567 fragmentos, a maioria deles bem conservada, o que facilita a visualização dos atributos. Em relação à pasta, nestas unidades também predominam fragmentos com mineral, caraipé e carvão, porém a frequência de fragmentos com mineral e com mineral e carvão na pasta é menor que nas outras unidades deste setor, e a frequência de materiais com cauixí na pasta é maior (gráfico 37). A pasta somente com mineral ou com presença de cauixí aparece entre os níveis 20-30 a 80-90 cm, enquanto as pastas com caraipé ocorrem até $110 \mathrm{~cm}$. Fragmentos com mineral na pasta ocorrem em proporções semelhantes no decorrer dos níveis, porém aqueles com mineral e caraipé são mais frequentes nos níveis superiores (assim como aqueles com cauixí), enquanto os com mineral, caraipé e carvão nos níveis inferiores.

A queima é reduzida na maioria dos fragmentos $(344 ; 60,67 \%)$, seguida pela oxidante $(175 ; 30,86 \%)$, oxidante interna e reduzida externa $(11 ; 1,94 \%)$, oxidante externa e reduzida interna $(24 ; 4,23 \%)$ e oxidante com núcleo reduzido $(13 ; 2,29 \%)$. Vasilhas cuja pasta apresenta apenas mineral, ou cauixí, possuem a queima predominantemente oxidante, apesar de também apresentarem as outras variações. Já as pastas com caraipé possuem queima predominantemente reduzida em relação às outras variações, principalmente aquelas com carvão.

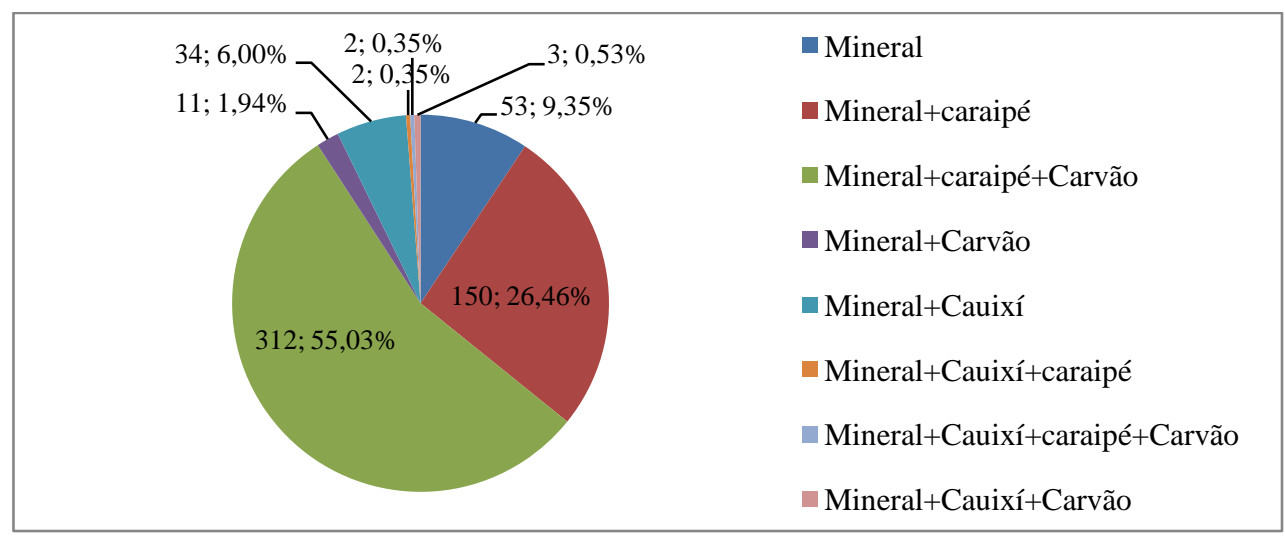

Gráfico 37: pasta das cerâmicas da escavação de 2 x 1 m - setor 3 
A barbotina foi identificada em 238 fragmentos, e nas superfícies predomina o polimento e o alisamento fino, além de poucos fragmentos com brunidura e alisamento médio e grosseiro. O engobo está presente em apenas 33 fragmentos (5,82\%), predominando a cor vermelha na FE (18), vermelho FI (6), vermelho AF (3); ocorre ainda o branco FE (3), laranja FE (2) e vinho FE (1), e em 12 fragmentos não foi identificado. Tratamentos plásticos ocorrem em 31 fragmentos (5,46\%), entre eles: inciso FE (21), inciso FI (2), modelado no lábio (2), ponteado FE (2), acanalado FE (1), aplique $\mathrm{FE}$ (1), entalhado no lábio (1) e decoração figurativa (1). Alguns incisos da face externa estão associados a pintura.

A pintura ocorre em 48 fragmentos $(8,47 \%)$ e em 12 não foi identificada (apenas vestígios de pigmentos), nas cores branca, vermelha e preta e suas associações: branca e vermelha FE (22), vermelha FE (16), branca FE (4), vermelha AF (1); vermelha e preta FE (1), preta FE (1), vermelha FI (2), branca e preta FE (1). Fragmentos com pintura aparecem entre 0-10 cm e 60-70 cm, com maior frequência entre 20-30 e 40-50 cm. Enquanto a pintura vermelha e branca é mais recorrente nos níveis mais superficiais (em relação aos demais tipos), a vermelha é mais frequente nos níveis profundos. Entre os fragmentos com pintura, apenas três apresentam cauixí na pasta (pintura vermelha), enquanto todos os outros possuem caraipé. Em relação aos motivos, alguns foram caracterizados como linhas horizontais e outros como complexos, porém a fragmentação das peças prejudicou esta análise. De qualquer forma, existem motivos geométricos com traços largos em vermelho bem como incisões em motivos complexos sobre a pintura branca, características semelhantes à cerâmica pintada do setor 3 do sítio Boa Vista, associado à tradição Policroma, assim como do sítio Morro dos Macacos I, porém nestes dois sítios as cores predominantes são o branco e o preto utilizadas conjuntamente, enquanto no Vista Alegre é comum a associação das cores vermelha e branca. Também ocorre uma vasilha com pintura vermelha e traços brancos mais estreitos, diferente dos traços largos comumente identificados nos materiais relacionados à Tradição Polícroma de outros sítios no Madeira, e com uma camada espessa e resistente de pigmento vermelho e branco, diferente dos demais. Além desta, um fragmento com pintura em traços largos diretamente sobre a superfície (não associada a pigmento branco) chama a atenção, porém estes materiais ocorrem misturados aos demais (figuras 122 e 123). Nos fragmentos com cauixí a pintura é vermelha com uma tonalidade mais escura, e diretamente sobre a superfície, assim como os de sítios a montante, como o Ilha São Francisco, Ilha das Cobras, Ilha do Japó e Ilha Dionísio, o que poderia indicar relações de trocas de coisas, pessoas ou 
conhecimentos, apesar de ser muito cedo para fazer tal afirmação, tendo em vista o tamanho das amostras analisadas e as datações disponíveis até o momento.

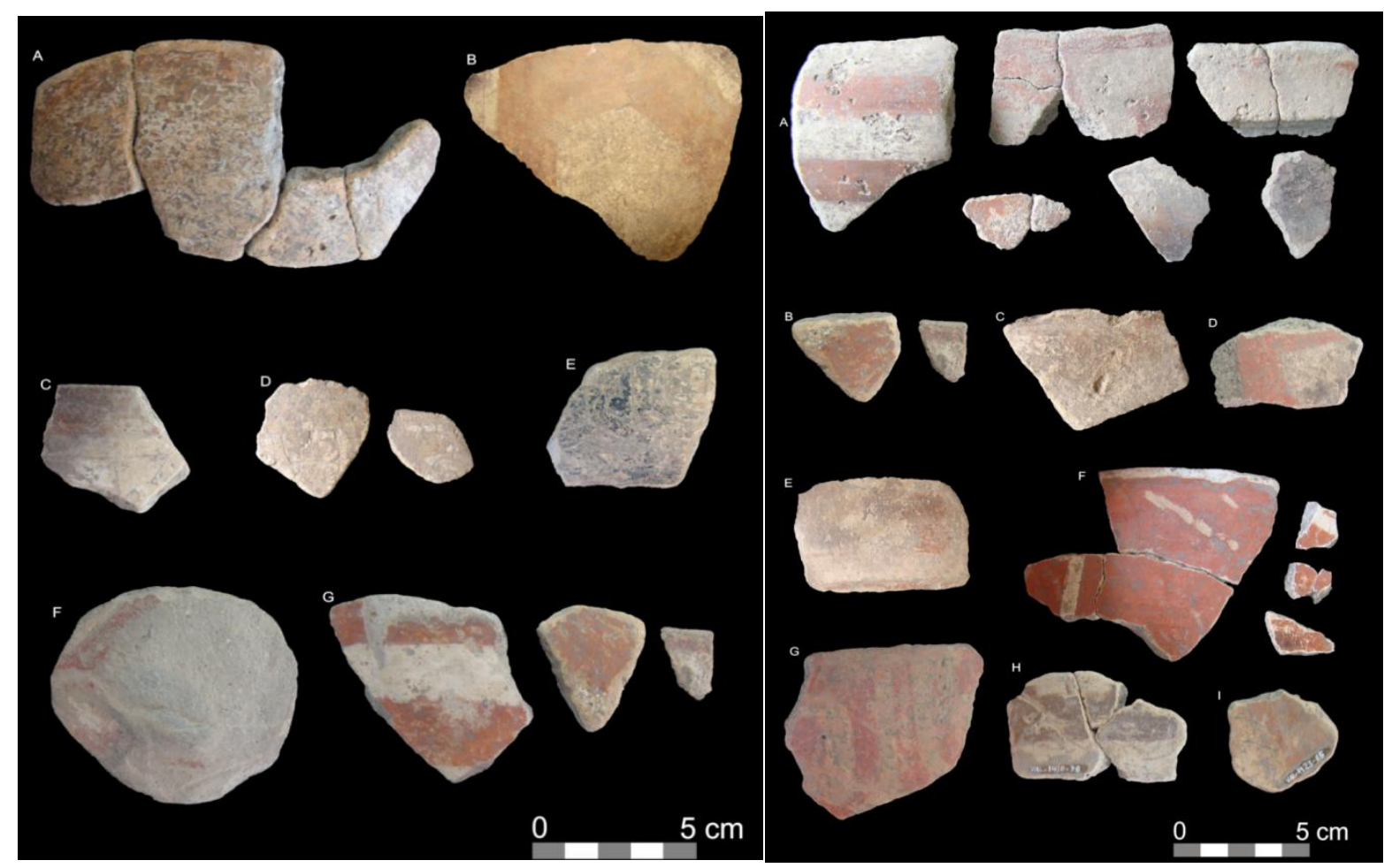

Figuras 122 e 123: Primeira: tigela com pintura vermelha e branca (A); pintura vermelha e branca e incisões (B); incisões associadas a pintura branca $(\mathrm{C}, \mathrm{D}, \mathrm{E})$; base com pintura vermelha e branca $(\mathrm{F})$; pintura vermelha e branca $(G)$. Segunda: pintura vermelha e branca $(A, B, C, D)$; vestígios de pigmento vermelho $(E)$; tigela com pintura vermelha e branca $(F)$; pintura vermelha diretamente sobre a superfície (G); pintura vermelha sobre a superfície e pasta com cauixí (H, I)(Fotos: SCIENTIA, 2013).

Ocorrem fragmentos de parede (299), inflexão (122), borda (71), bases (33), bojo (15), pescoço (6), alça (1), borda com flange (1), uma vasilha com perfil completo e três conjuntos de fragmentos de diferentes partes de três vasilhas cerâmicas, os demias não sendo identificados (15). A espessura dos fragmentos varia entre 1 e $26 \mathrm{~mm}$, com predominância entre 4 e $9 \mathrm{~mm}$. Entre as bordas, predominam as extrovertidas e diretas inclinadas externamente (gráfico 38). Na maioria são lineares (43; 57,33\%), seguidas pelas contraídas $(11 ; 14,67 \%)$ e expandidas $(4,5,33 \%)$, e nas demais $(17 ; 22,67 \%)$ não foi possível visualizar o espessamento. Os lábios são arredondados (37; 49,33\%), planos (18; 24\%), apontados (6; $8 \%)$, irregulares $(2 ; 2,67 \%)$, biselado $(1 ; 1,33 \%)$ e NI $(11 ; 14,67 \%)$. Foi possível medir o diâmetro de 9 bordas: $5 \mathrm{~cm}$ (1), $8 \mathrm{~cm}$ (1), $12 \mathrm{~cm}$ (1), $13 \mathrm{~cm}$ (1), $14 \mathrm{~cm}$ (2), $15 \mathrm{~cm}$ (1), $16 \mathrm{~cm}$ (1) e $28 \mathrm{~cm}$ (1). Uma vasilha foi parcialmente remontada, com forma infletida, estrutura fechada, borda extrovertida e base convexa côncava, com polimento em ambas as faces e fuligem na face externa.As bases são na maioria convexas côncavas (17), bi-planas (9), côncava plana (2) e plano côncava (1), não sendo possível visualizar a forma de cinco delas, e 
possuem diâmetros entre 5 e $18 \mathrm{~cm}$. Nesta unidade ainda ocorre uma peça não identificada, com formato cilíndrico (possível apêndice) e um fuso fragmentado.

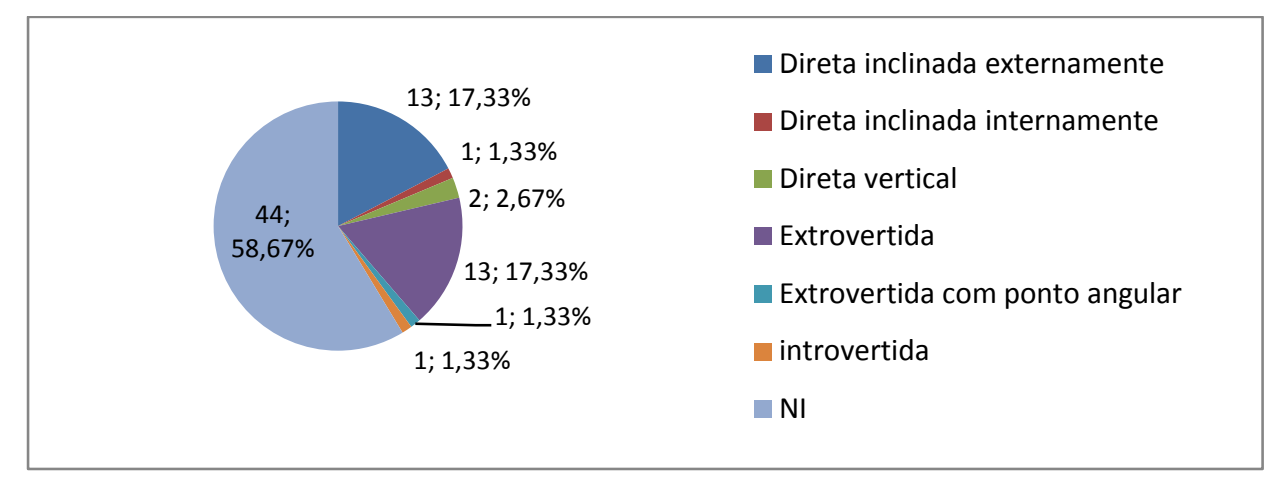

Gráfico 38: forma e inclinação das bordas- escavação de 2 x 1 m- sítio Vista Alegre.

Nos aspectos morfológicos as vasilhas destas unidades diferenciam-se das outras analisadas nesse setor do sítio: ocorre apenas uma borda com flange labial decorada, e são mais frequentes fragmentos de bojo e pescoço, bem como bases convexas côncavas, e poucos fragmentos com ângulos de parede. Com relação à distribuição do material nos diferentes níveis, não houve maiores concentrações de tipos de pastas, formas das vasilhas e tratamentos de superfície, estando bastante misturados (figuras 124 a 126). Como vimos anteriormente, nesta unidade foram encontrados fragmentos de uma mesma vasilha alinhados na estratigrafia ao longo de diferentes níveis, porém o contexto não ficou claro se é decorrente de uma bioturbação ou da própria deposição no contexto sistêmico. Alguns fragmentos de bojo e inflexão encontrados nos níveis 50-60 e 60-90 cm parecem desta mesma vasilha, porém não puderam ser remontados. Acreditamos que o material predominante nestas unidades pode ser atribuído a uma ocupação mais recente, relacionada à Tradição Polícroma da Amazônia. Nesta escavação $8,47 \%$ do material analisado apresenta pintura, possivelmente a maior porcentagem evidenciada entre as amostras de todos os sítios que analisamos. Ao passo que nesta escavação do setor 3 a pintura é bastante frequente, o engobo ocorre em apenas 5,82\% dos fragmentos, diferente do material da escavação de $2 \mathrm{~m}^{2}$, em que o engobo ocorre em $11,40 \%$ dos fragmentos e a pintura é rara, semelhante ao que ocorre no sítio Veneza, ao qual estamos comparando este material mais antigo do Vista Alegre. 


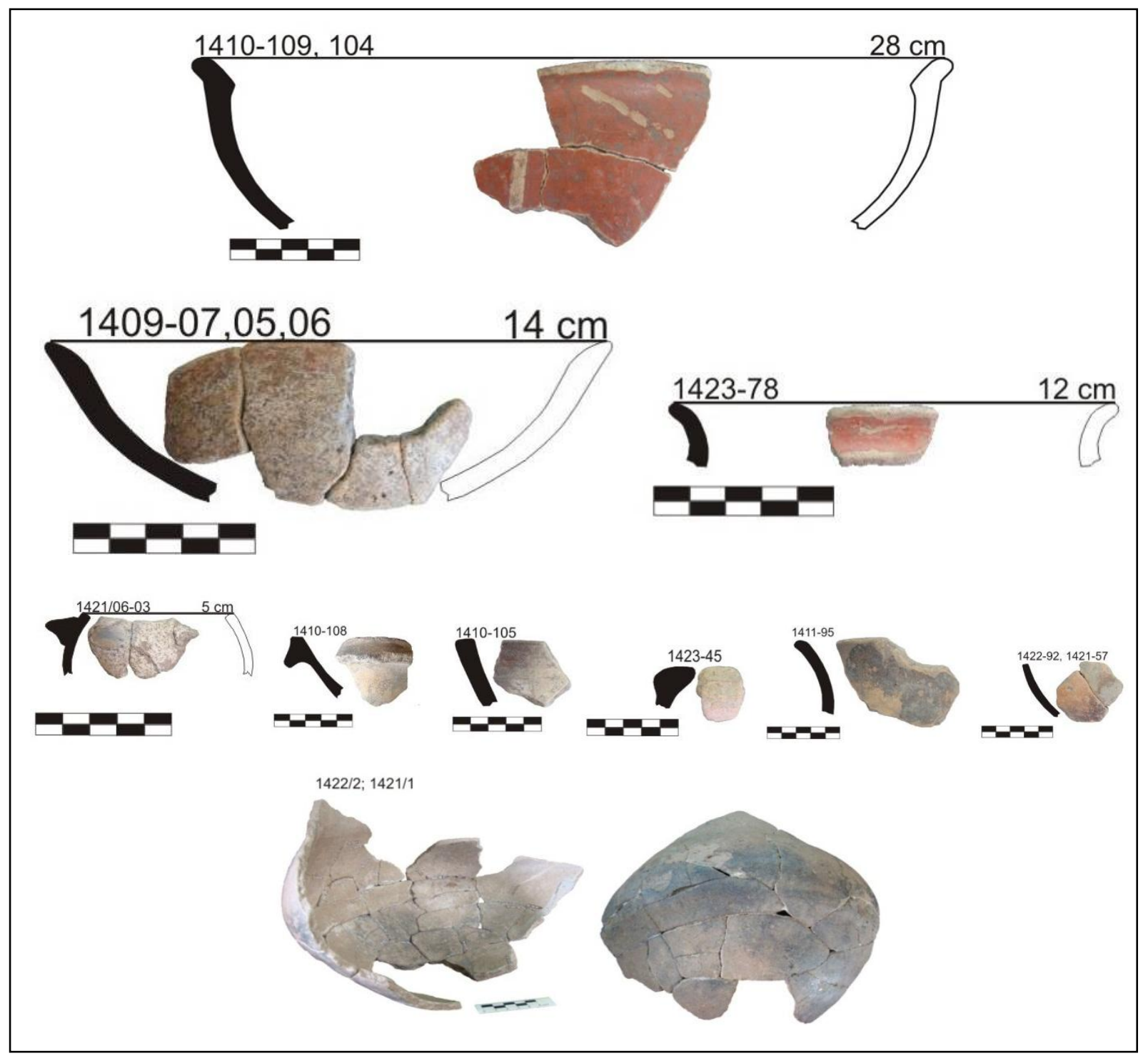

Figura 124: Bordas e vasilha remontada da escavação de 2 x 1 m do setor 3, Vista Alegre. 

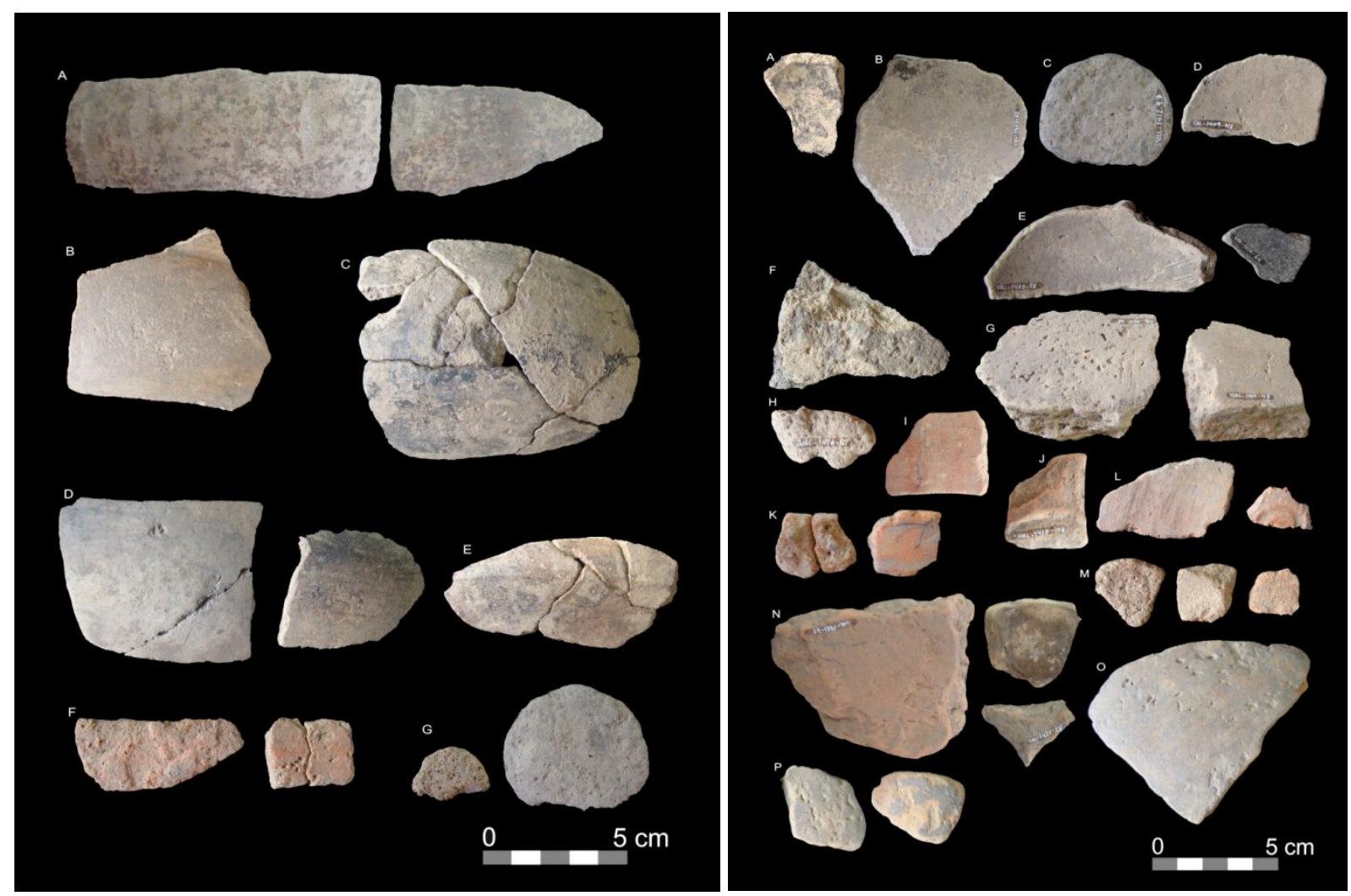

Figuras 125 e 126: Primeira- bojo com com pintura (A), bojo com polimento (B, D, E) e bojo com fuligem (C), todos com caraipé na pasta; fragmentos com caraipé e carvão na pasta porosa e barbotina laranja ( $F$, G). Segunda- base plano côncava com depósito de carbono (A); base convexa côncava com depósito de carbono(B); bases convexas concavas $(\mathrm{C}, \mathrm{D}, \mathrm{E})$; fragmentos de assadores (f, g); fragmento de fuso (H); alça com pintura vermelha e branca na $\mathrm{FE}(\mathrm{I}, \mathrm{J})$; fragmentos com pasta de mineral $(\mathrm{K}, \mathrm{L}, \mathrm{M})$; fragmentos com cauixí na pasta $(\mathrm{N}, \mathrm{O}, \mathrm{P})$. Os fragmentos de A a J possuem caraipé na pasta (Fotos: SCIENTIA, 2013).

Ainda é necessário refinar a análise destes dados do sítio Vista Alegre, principalmente na comparação das diferentes áreas de escavação, porém até o momento foi possível chegar a algumas conclusões ao comparar todos os dados. Como no sítio Foz do Jatuarana e Morro dos Macacos I ocorrem vasilhas pequenas com flanges labiais decoradas com incisões, cuja pasta contém apenas mineral e queima oxidante, sobre um material com mineral, caraipé e carvão na pasta e queima reduzida, que predomina na escavação de $2 \mathrm{~m}^{2}$ do setor 3 (datada em 14C $2.080 \pm 30$ AP), mas também ocorre na escavação de 2 x 1 deste mesmo setor e na escavação do setor 1. São recorrentes também materiais com pintura (vermelha, preta, branca, vermelha e branca, vermelha e preta), com motivos em faixas largas, algumas associadas a incisões, que se assemelham as vasilhas pintadas encontradas na ocupação mais recente do sítio Morro dos Macacos I e aos materiais do setor 3 do sítio Boa Vista, portanto parecem representar uma outra ocupação no sítio Vista Alegre pelos portadores da Tradição Polícroma. Acreditamos que a cronologia desta ocupação não foi estabelecida para o sítio Vista Alegre, e que a datação de $1.240 \pm 30$ AP obtida no setor 1 corresponda ainda as ocupações mais antigas. 
Ocorrem materiais com cauixí na pasta, que não são frequentes nos sítios a jusante da cachoeira do Teotônio, porém são recorrentes nos sítios a montante (Ilha São Francisco, Ilha das Cobras, Ilha do Japó e Ilha Dionísio). Como a quantidade é relativamente grande, principalmente na unidade de $2 \times 1 \mathrm{~m}$ do setor 3 , acreditamos que esta pasta tenha sido utilizada concomitantemente aquela com caraipé pelo mesmo grupo. Porém é interessante não descartar a possibilidade da existência de redes de trocas com os grupos da montante, sejam elas de pessoas, conhecimentos ou coisas, ou mesmo uma ocupação deste sítio por outro grupo.

Apesar das dificuldades em delimitar as ocupações no sítio Vista Alegre, os dados demonstram que ele possui ao menos duas ocupações, e possivelmente três, portanto é multicomponencial. O conjunto tecnológico mais antigo apresenta semelhanças com o do sítio Veneza; um segundo conjunto possui semelhanças com o material mais antigo do Morro dos Macacos e mais recente do Foz do Jatuarana; e um terceiro conjunto pode ser associado a Tradição Polícroma da Amazônia.

\subsection{Cerâmica do sítio Santa Paula,}

Conforme vimos anteriormente, o sítio Santa Paula foi delimitado e foram escavadas apenas duas unidades de $1 \mathrm{~m}^{2}$, uma delas localizada próxima ao barranco e a outra na parte central do sítio, sendo realizadas três datações radiocarbônicas (14C $1.550 \pm 30$ AP (103 cm de profundidade), $1530 \pm 30$ AP $(181 \mathrm{~cm})$ e $1520 \pm 40$ AP $(203 \mathrm{~cm})$ para esta última (E382631 N9021469). Analisamos os materiais diagnósticos desta unidade (668 fragmentos) bem como parte da cerâmica das sondagens da delimitação (2.637 fragmentos). O sítio foi abordado no projeto de iniciação científica de Duran da Silva (2013) e na sua monografia de conclusão de curso, em andamento. Aqui analisamos os dados obtidos para a unidade E382631 N9021469, comparando a distribuição dos atributos nos diferentes níveis de escavação, buscando entender as permanências e mudanças tecnológicas. Além disso, analisamos dados obtidos com os materiais das sondagens, priorizando alguns atributos como forma e tratamentos de superfície, com o objetivo de alcançar um olhar mais abrangente em relação ao restante do sítio e elaborar algumas hipóteses sobre sua ocupação, a serem investigadas em trabalhos futuros. 


\subsubsection{Análise da cerâmica da unidade E382631 N9021469}

Entre os 668 fragmentos diagnósticos analisados ocorreram algumas remontagens e formação de conjuntos, totalizando 578 fragmentos, distribuidos entre a superfície e $230 \mathrm{~cm}$ (gráfico 39). Destaca-se uma remontagem de 10 fragmentos de uma vasilha, distribuidos nos níveis 50-60, 60-70 e 110-120 cm.

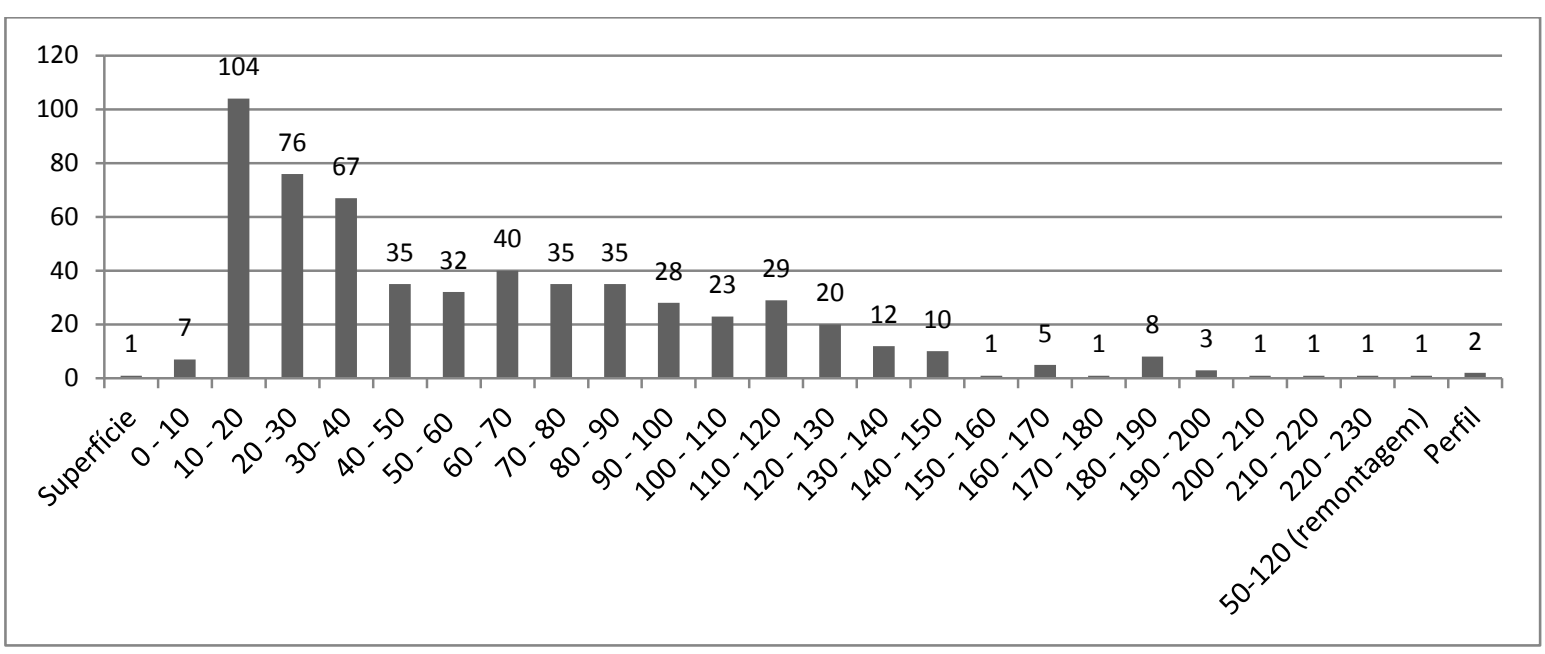

Gráfico 39: distribuição dos materiais diagnósticos nos níveis de escavação da unidade E382631 N9021469

Em relação a escolha da pasta, verificou-se que foi adicionado caraipé em grande parte das vasilhas, ocorrendo poucos fragmentos com cauixí ou somente com mineral (gráfico 40). A pasta com caraipé e carvão ocorre entre a superficie e $230 \mathrm{~cm}$, enquanto a com mineral e caraipé ocorre entre 10-20 e 190-200 cm, a pasta com mineral entre 20-30 e 180-190 cm e com caiuixi entre 30-40 cm e 130-140. Portanto, no periodo incial de ocupação do sítio a ocorrencia de caraipé e carvão na pasta é mais frequente, e o cauixí aparece somente na parte superiro da estratigrafia.

A queima reduzida é predominante $(387 ; 66,96 \%)$, seguida pela oxidante (157; $27,16 \%)$, oxidante externa e reduzida interna $(22 ; 3,81 \%)$, oxidante interna e reduzida interna (5) e oxidante com nucleo reduzido (7). Foi utilizada a técnica acordelada na confecção das vasilhas (571 fragmentos), sendo algumas bases modeladas (4) e os demais não identificada (3). A barbotina está presente na face externa de 65 fragmentos $(11,25 \%)$, na face interna de $25(4,33 \%)$ e em ambas as faces de 160 fragmentos $(27,68 \%)$, estando ausente em 134 e não foi identificada em 194. Com relação ao acabamento de superfície predomina o alisamento fino e polimento, mas também ocorre o alisamento médio e grosseiro em uma ou ambas as faces e brunidura (gráfico 41). 


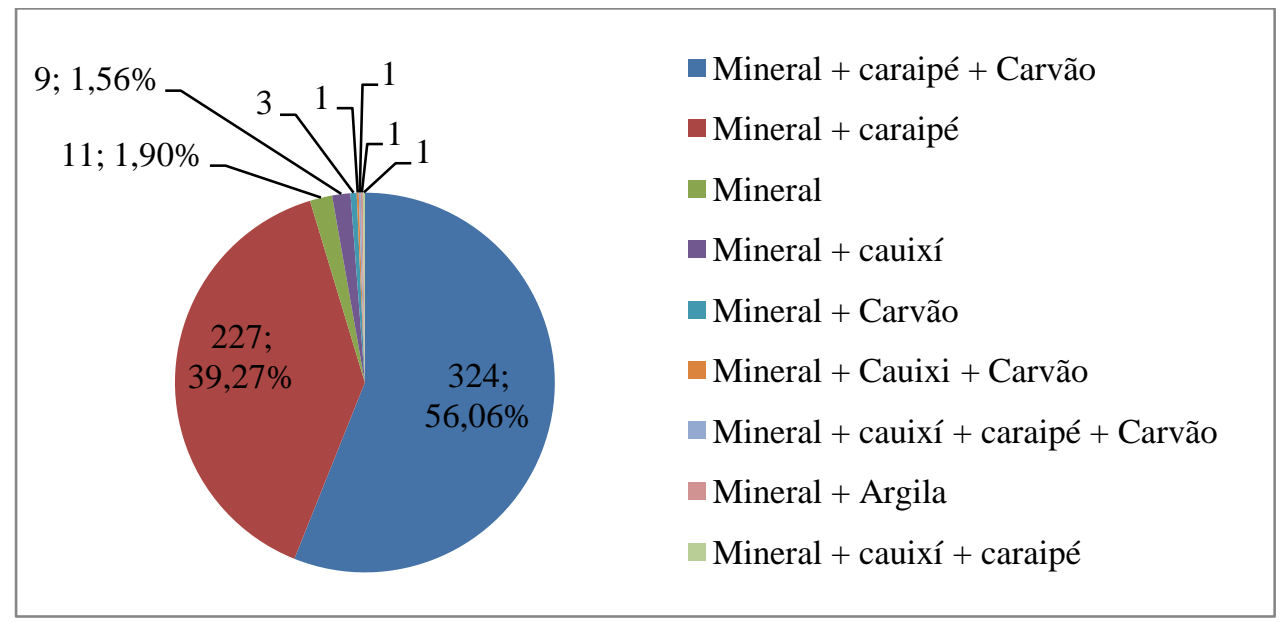

Gráfico 40: caracterização da pasta dos materiais da unidade E382631 N9021469, sítio Santa Paula.

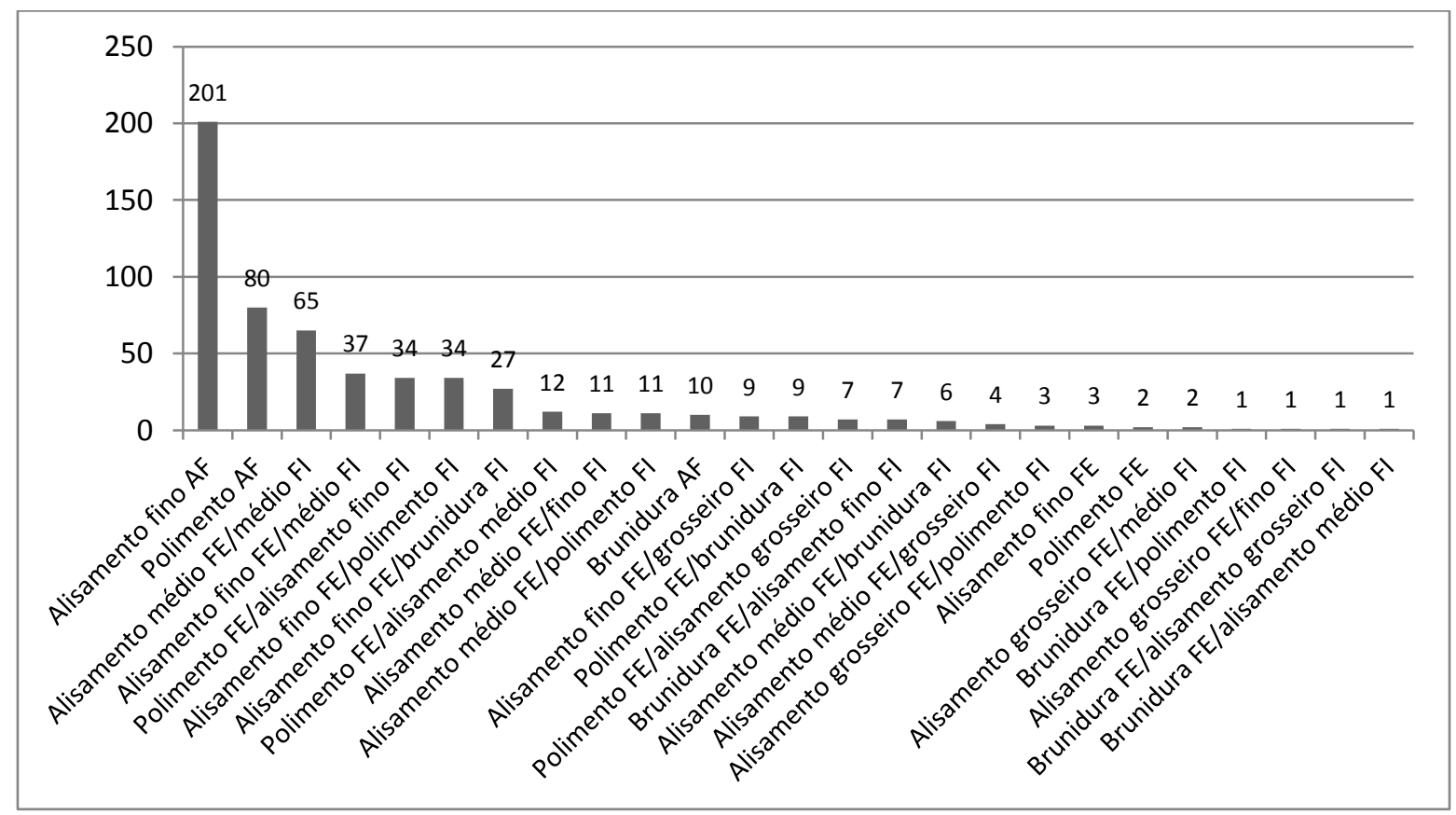

Gráfico 41: acabamentos de superfície dos fragmentos da unidade E382631 N9021469, sítio Santa Paula.

O engobo foi identificado em 75 fragmentos (12, 97\%), em 16 não pode ser identificado (apenas vestífios de pigmentos) e em 487 está ausente. Ocorre nas seguintes cores: vermelho FE (44), vermelho AF (5), laranja FE (13), laranja AF (5), laranja FI (2), branco FE (6). O engobo branco foi identificado nos níveis 0-10 e 10-20 cm e deve compor vasilhas pintadas; o engobo vermelho e laranja ocorre entre 10-20 cm e 160-170 cm, o primeiro mais frequente no nível $20-30 \mathrm{~cm}$ e o laranja no $120-130 \mathrm{~cm}$. A pintura ocorre em apenas 11 fragmentos, nas sequintes cores: branca sobre vermelho FE (2), branca e vermelha FE (7) e vermelha FE (2), dez deles entre 0 e $30 \mathrm{~cm}$ e apenas um com pintura vermelha no 
nível 190-200 cm (figura 127). Em outros onze fragmentos foram encontrados apenas vestígios de pigmentos.

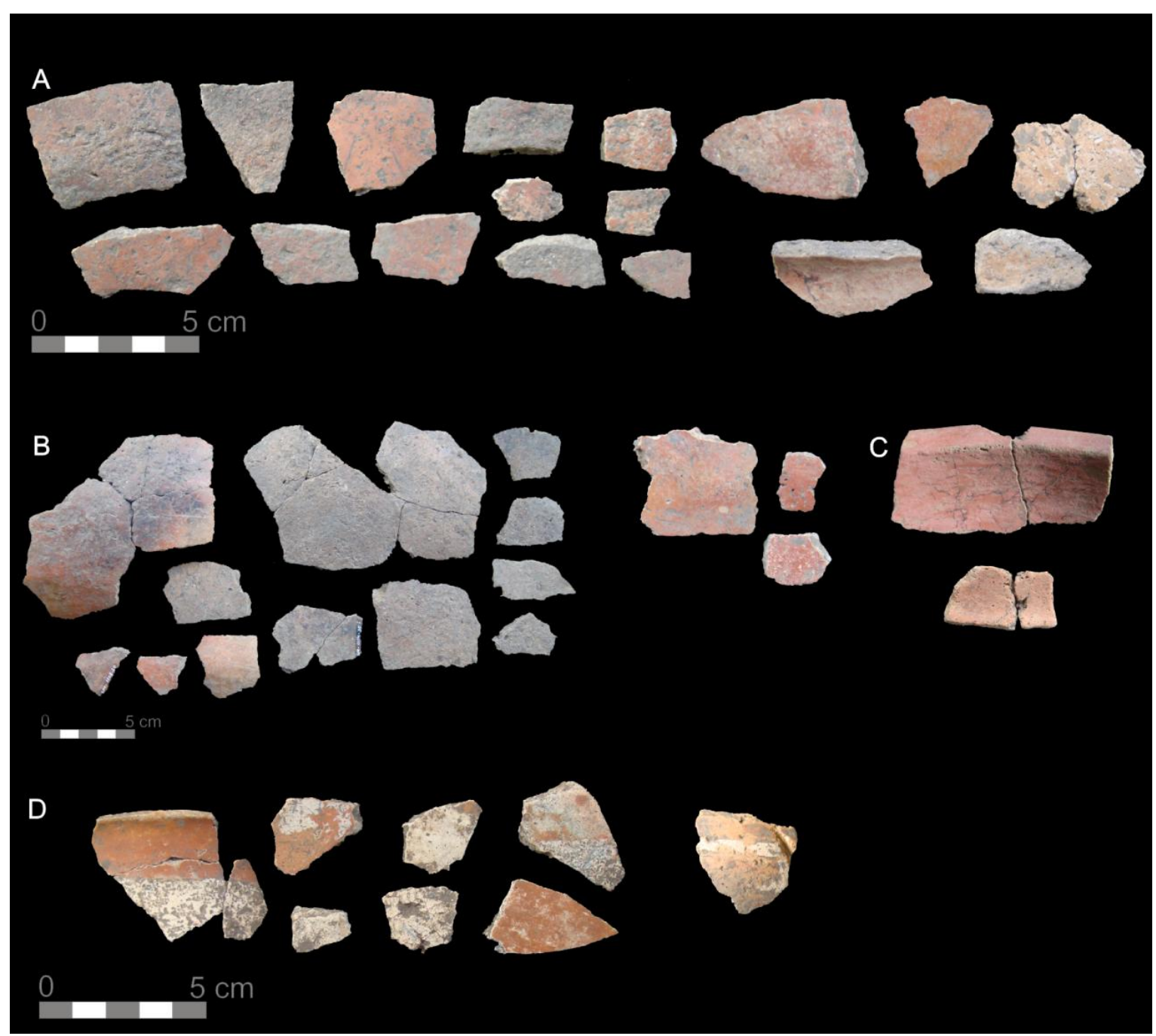

Figura 127: engobo vermelho (A, B) e rosado (C); pintura vermelha e branca (D) (Fotos: SCIENTIA, 2011)

Tratamentos plásticos estão presentes em 87 fragmentos (15,05\%), predominando as incisões e incisos e ponteados, porém tambem ocorrem modelados e apliques, as vezes combinados com incisões e ponteados, além do exciso, escovado e roletado (gráfico 42). Estes são aplicados principalmente na parte superior das vasilhas (borda, lábio, bojo). Entre os motivos das incisões, predomina as linhas horizontais e os compostos por dois elementos, além de algumas linhas verticais, motivos complexos, curvilíneos, linhas transversais, triangulares e algulares. Entre os modelados, destaca-se o lábio ondulado. Um aplique no lábio da vasilha parece ser uma representação zoomorfa e o outro em uma parte infletida da vasilha (formato mamilonar) possui uma esfera aplicada com um ponteado no centro, envolto por incisões. Em alguns fragmentos as incisões estão associadas a pigmentos laranja ou 
branco. Na maioria dos fragmentos as incisões foram feitas quando a vasilha já estava mais seca. Possivelmente entre todos os sítios estudados este é o que apresenta maior quantidade de fragmentos com tratamentos plásticos, com ampla variação dos motivos (figuras 128 e 129). Há maior concentração de fragmentos com tratamentos plásticos nos níveis 10-20 a 50-60 cm e entre 90-100 e 120-130 cm (gráfico 43). Entre 130-140 e 190-200 ocorrem 7 fragmentos com incisões, um inciso e ponteado e um aplique.

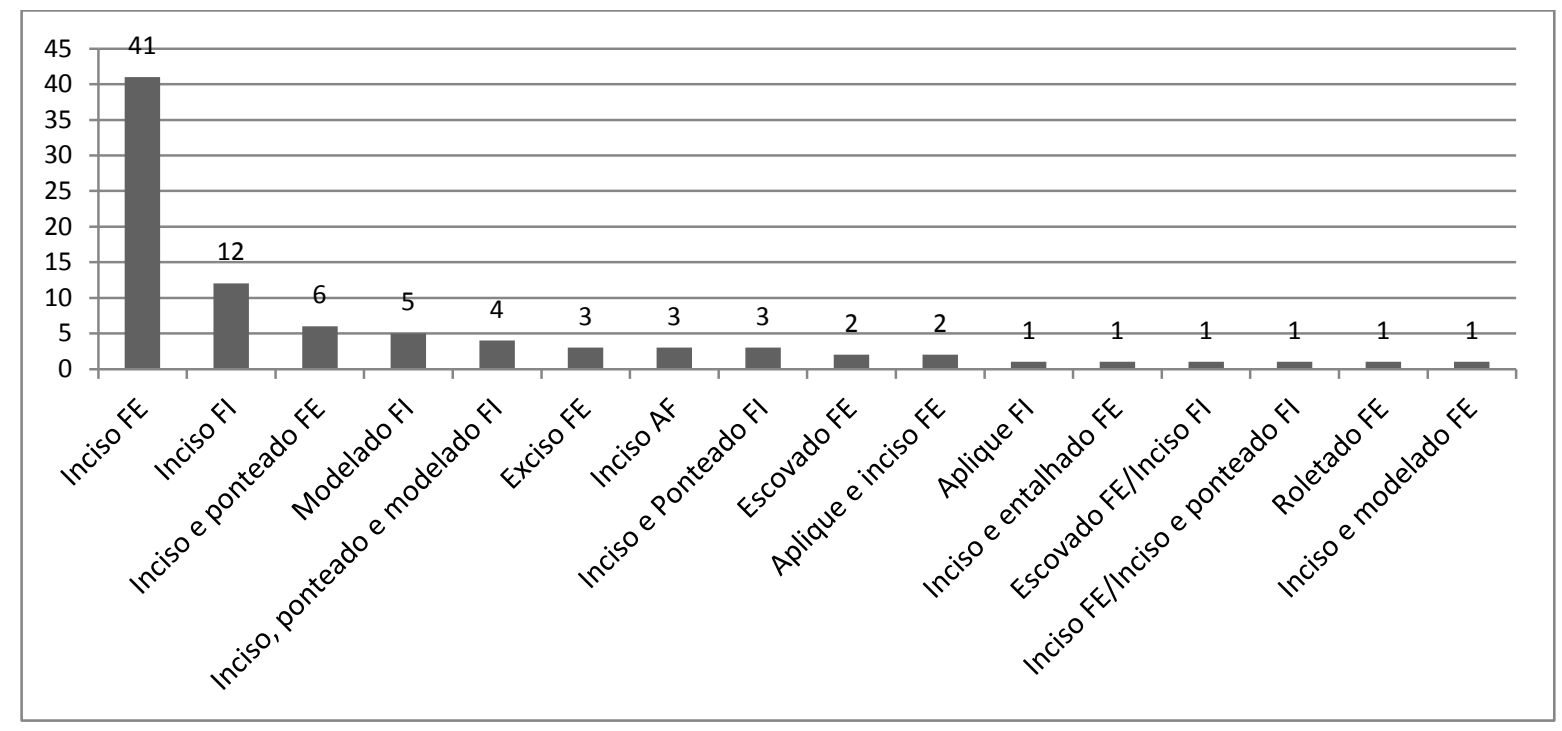

Gráfico 42: tratamentos plásticos nos materiais da unidade E382631 N9021469, sítio Santa Paula.

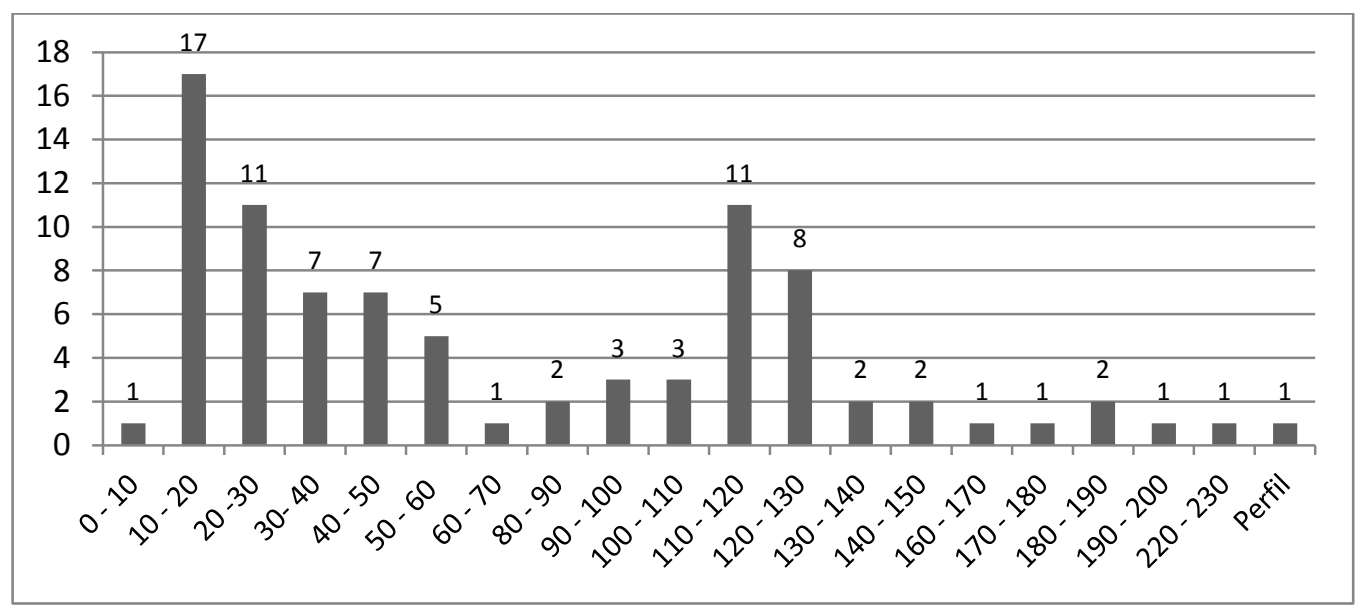

Gráfico 43: quantidade de tratamentos plásticos nos níveis de escavação da unidade E382631 N9021469, sítio Santa Paula. 


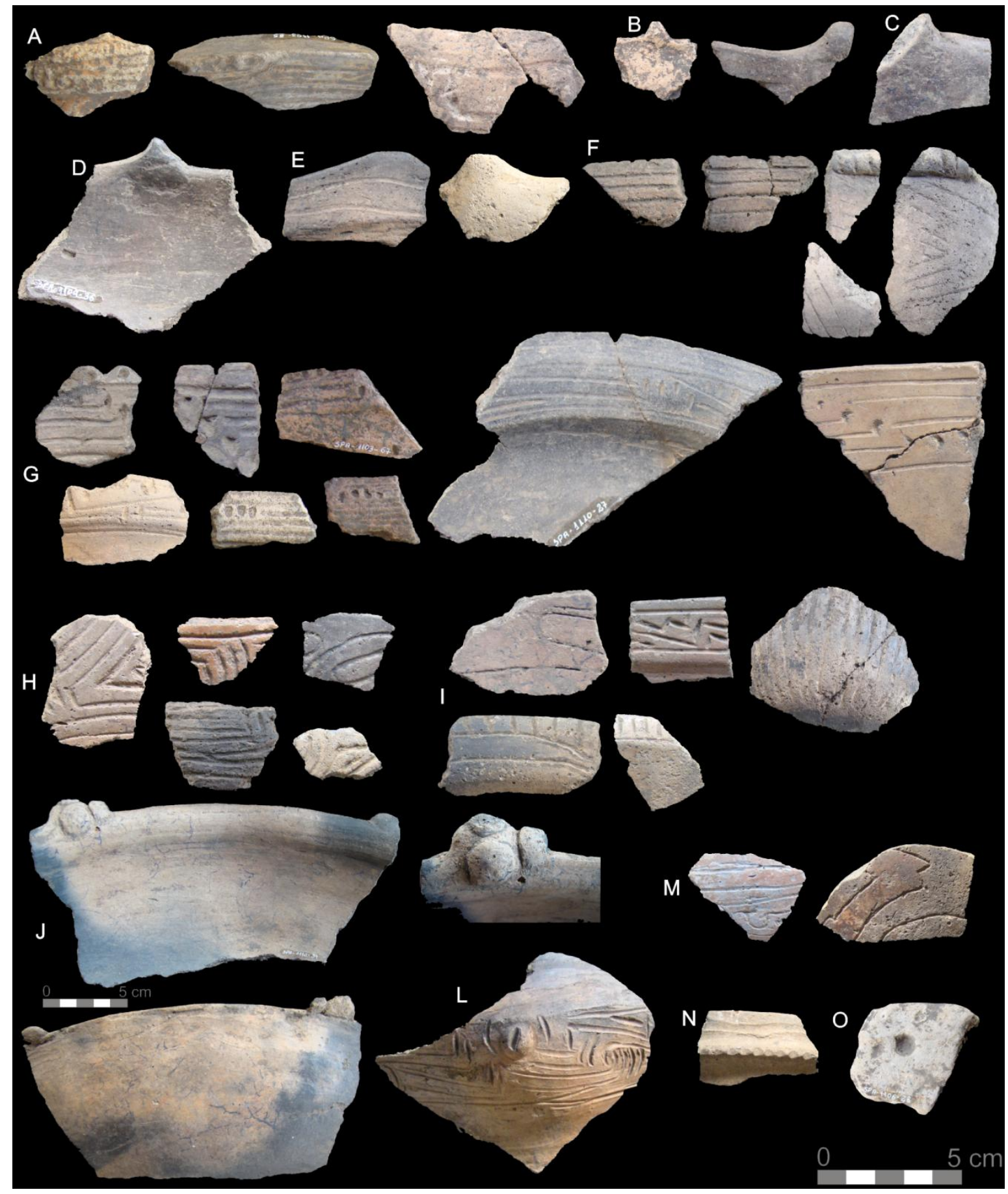

Figura 128: tratamentos plásticos: com incisões e engobo entre 0-30 cm (A); lábio modelado entre 10-20 e $110-120 \mathrm{~cm}(\mathrm{~B}, \mathrm{C}, \mathrm{D}, \mathrm{E})$; incisos e entalhados do nível $40-50 \mathrm{~cm}(\mathrm{~F})$; inciso e ponteado entre 30-40 e 110$120 \mathrm{~cm}(\mathrm{G})$; incisões entre $30-40$ e $120-130 \mathrm{~cm}(\mathrm{H}, \mathrm{I})$; incisos do nível 140-150 e 190-200 cm; apliques dos níveis 90-100 e 170-180 cm $(\mathrm{J}, \mathrm{L})$; e ponteado/110-120 cm $(\mathrm{N}, \mathrm{O})$ (Fotos: SCIENTIA, 2011) 


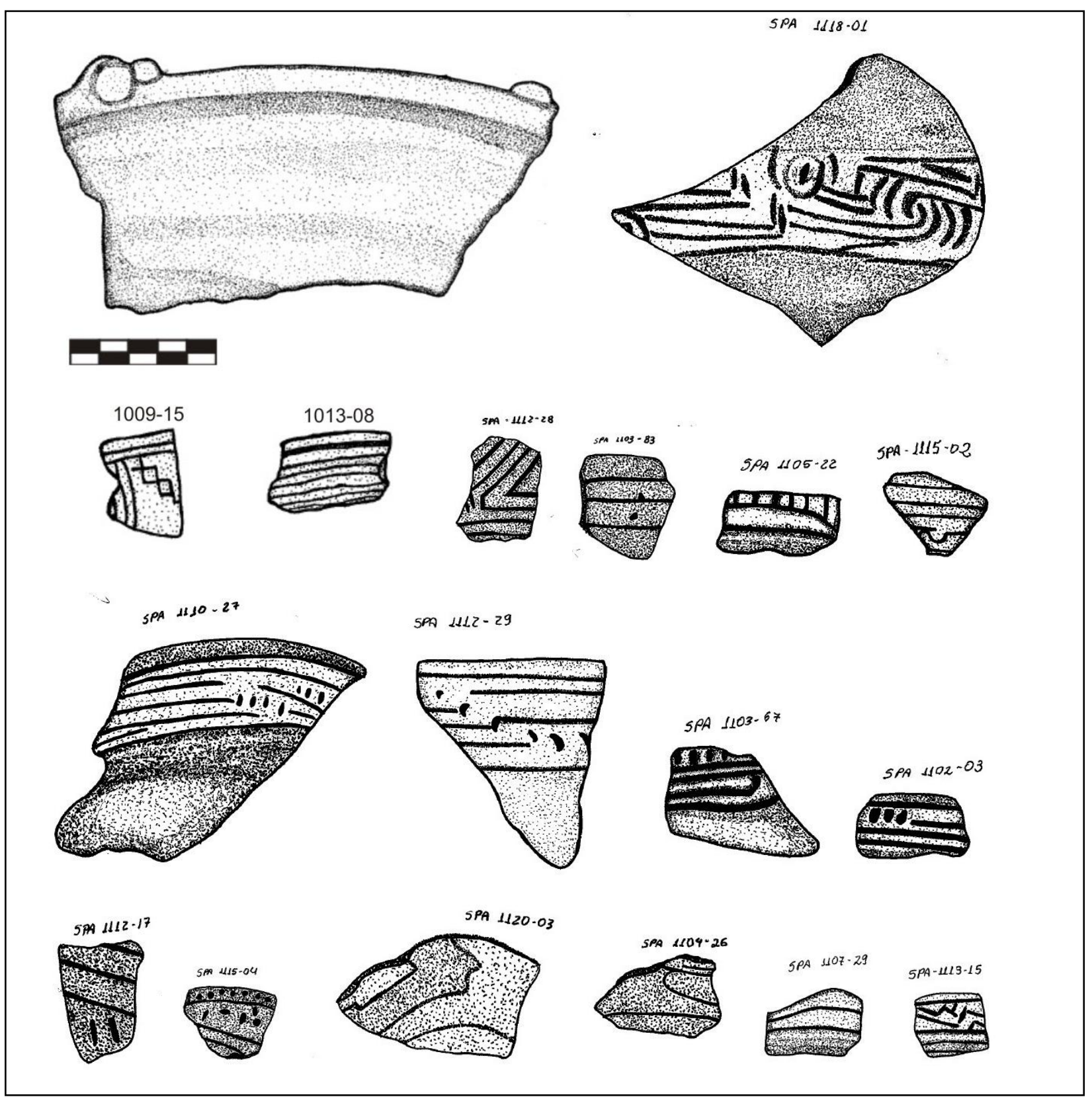

Figura 129: desenhos dos tratamentos plásticos (Angislaine F. Costa, 2012)

Além dos fragmentos de parede (230), ocorrem bordas (186), inflexões (137), bases (11), bojos (4), flanges (3), borda com flange (1), carena (1) e não identificados (5). Muitos fragmentos analisados como inflexões são curvos ou angulares, porém não foi possível caracterizar como bojo, pescoço ou carena. A espessura varia entre 1 e $19 \mathrm{~mm}$, com maior frequencia entre 4 e $10 \mathrm{~mm}$. Ocorrem fragmentos espessos e grandes que são de vasilhas com grandes volumes, porém de muitos não foi possível medir o diâmentro.

Entre as bordas ocorrem as diretas inclinadas externamente (42), diretas verticais (24), extrovertidas (23), diretas inclinadas internamente (9), introvertidas (4), extrovertidas com 
ponto angular (3) ou não identificadas (82). Com relação ao espessamento, predominam as contraidas (92), seguido pelas lineares (69), expandidas (14), reforçadas internamente (4) ou não identificadas (4). Os lábios são arredondados (119), planos (30), apontados (20), irregulares (9), biselados (2) ou não identificados (7). O diâmetro de abertura varia entre $8 \mathrm{~cm}$ e $52 \mathrm{~cm}$ (gráfico 44). Entre as bases (apenas 11) predominam as convexas-côncavas e biplanas, apenas uma anelar e uma plano-côncava, com diametros entre 9 e $20 \mathrm{~cm}$, portanto são grandes (figura 133). Em 57 fragmentos ocorre fuligem (9,86\%), em 17 depósito de carbono $(2,94 \%)$ e dois fragmenttos com fuligem e depósito. Não foram evidenciadas marcas de fermentação, porém acreditamos que a erosão (30) ou ausência da superfície interna (3) é decorrente do uso. A fuligem está presente em apenas 10 bordas, sendo 7 extrovertidas (32 $\mathrm{cm}, 14 \mathrm{~cm}$ e NI) e 3 diretas inclinadas externamente $(14 \mathrm{~cm}, 18 \mathrm{~cm}$ e NI).

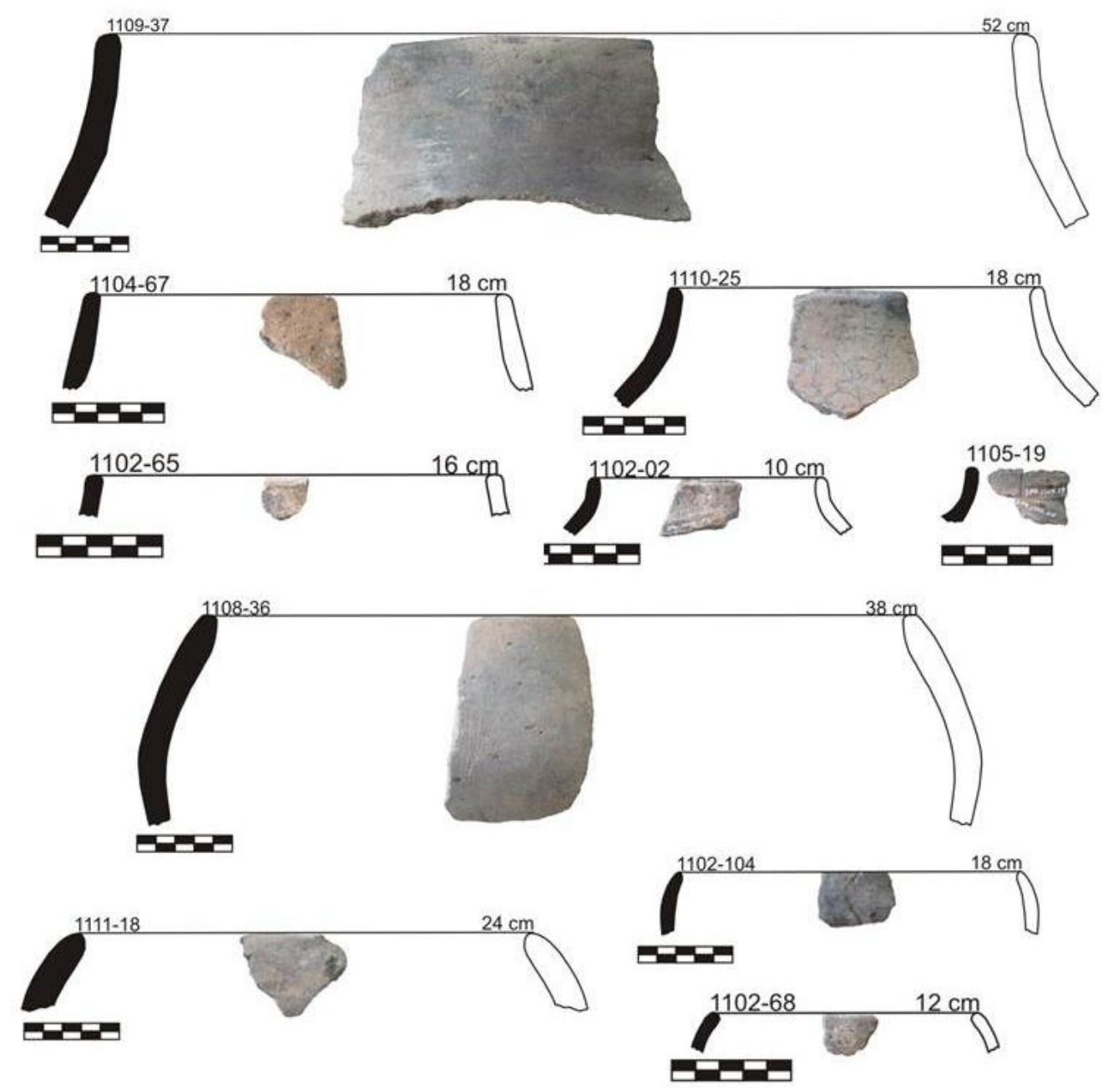

Figura 130: bordas diretas e introvertidas - Santa Paula (Desenhos: Angislaine F. Costa, 2012) 

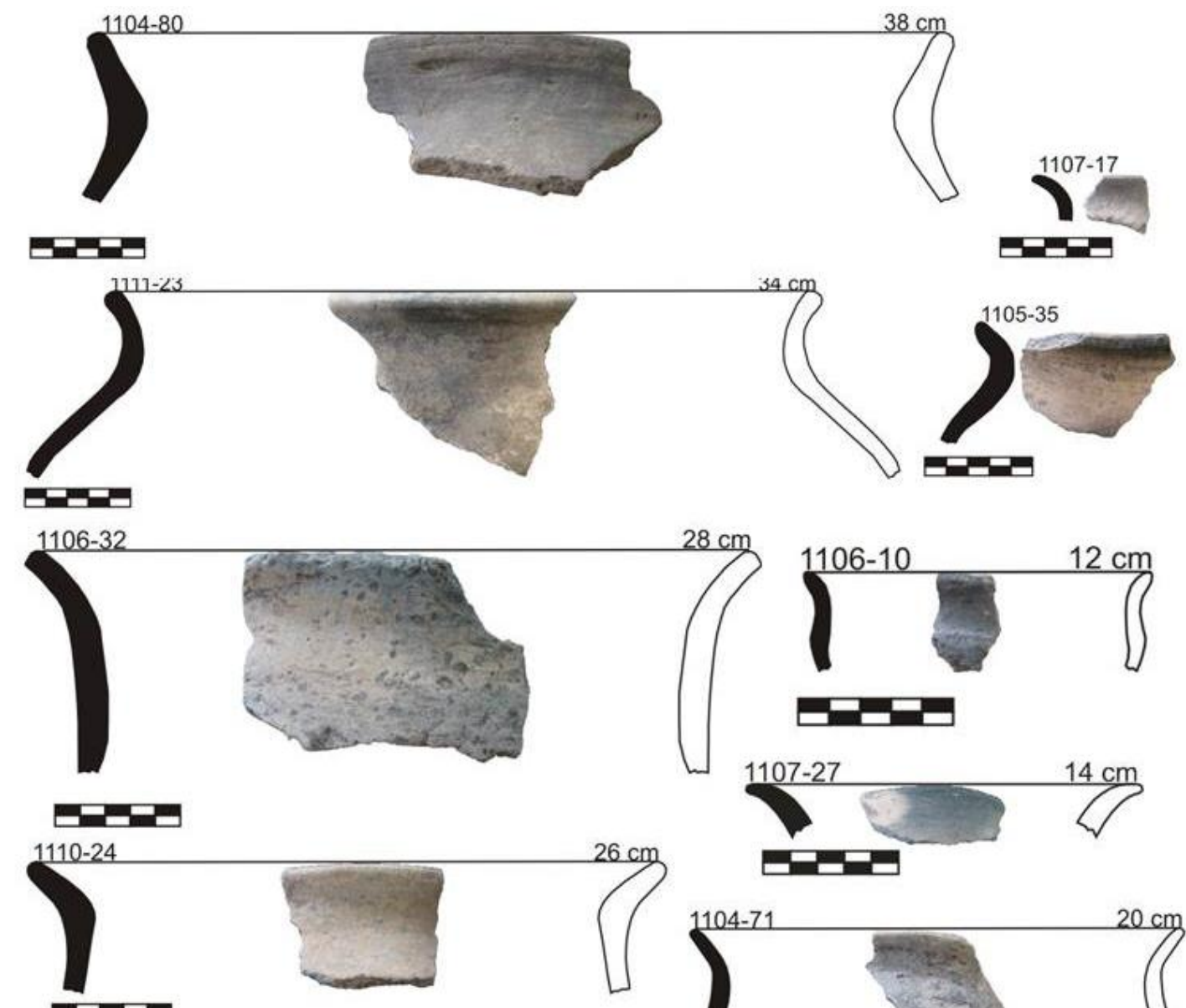

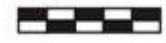

1104-77

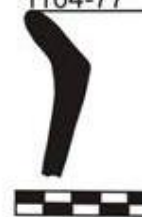

1103-71

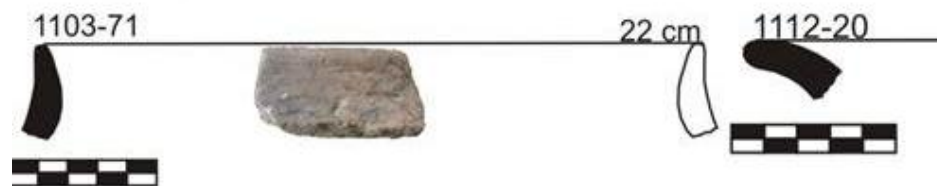

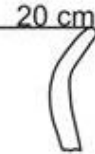

$20 \mathrm{~cm}$

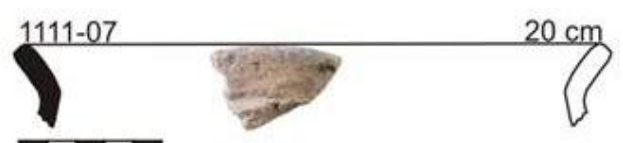

$20 \mathrm{~cm}$

Figura 131: bordas extrovertidas - Santa Paula (Desenhos: Angislaine F. Costa, 2012). 

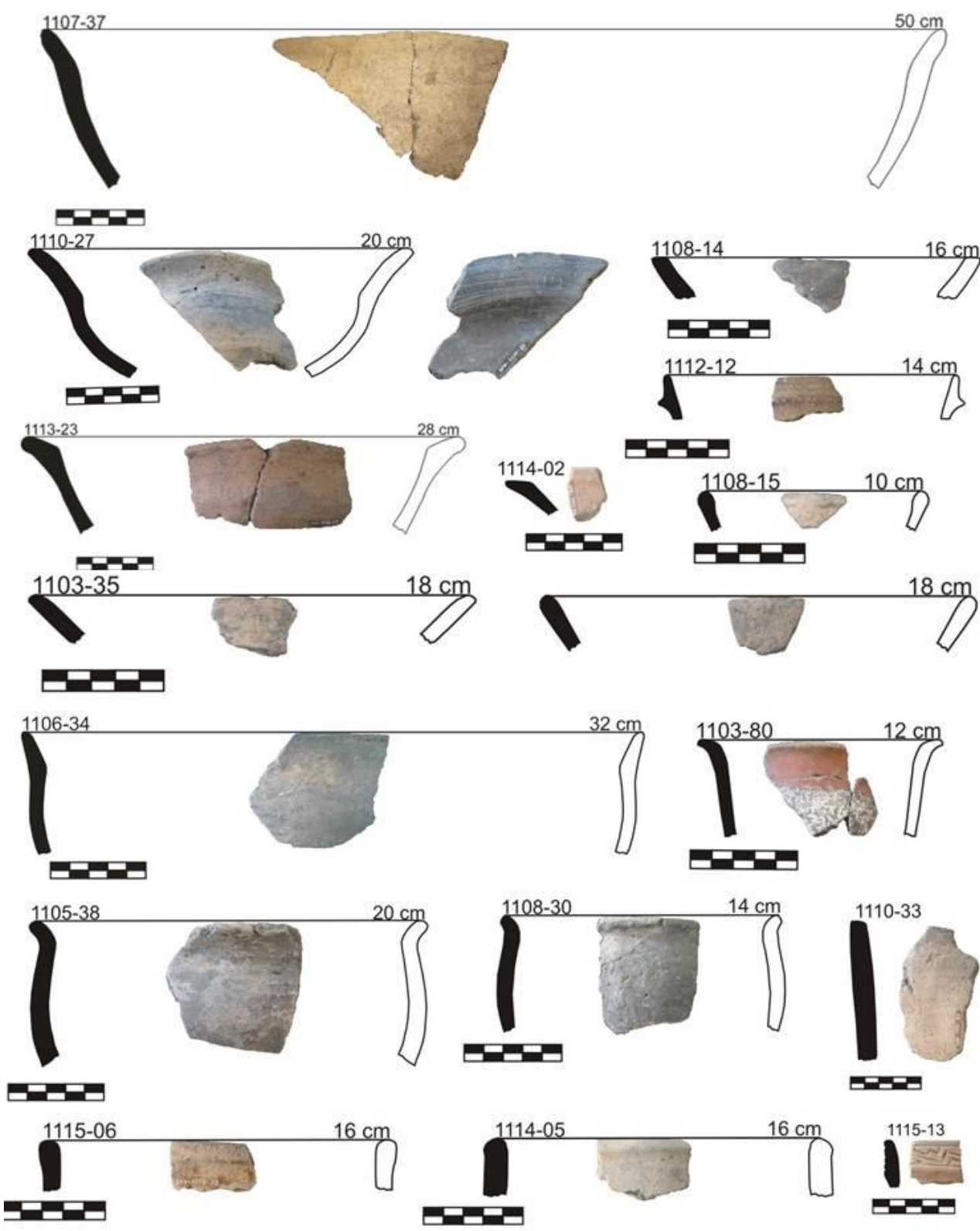

Figura 132: bordas diretas inclinadas externamente e diretas verticais- Santa Paula (Desenhos: Angislaine F. Costa, 2012).

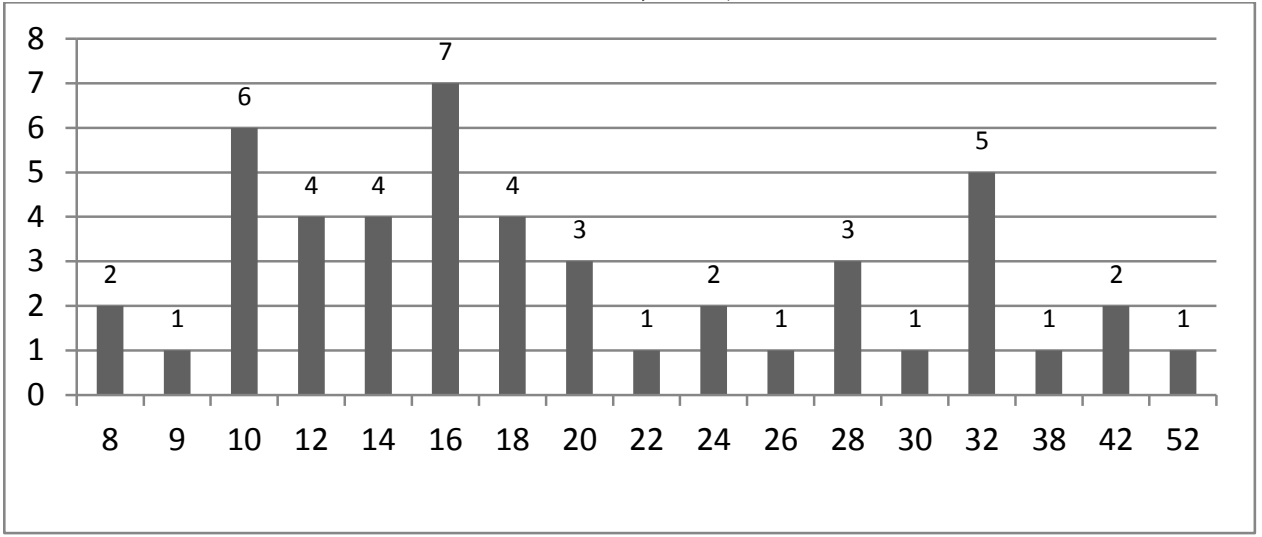

Gráfico 44: diâmetros de abertura das vasilhas da unidade E382631 N9021469, sítio Santa Paula. 


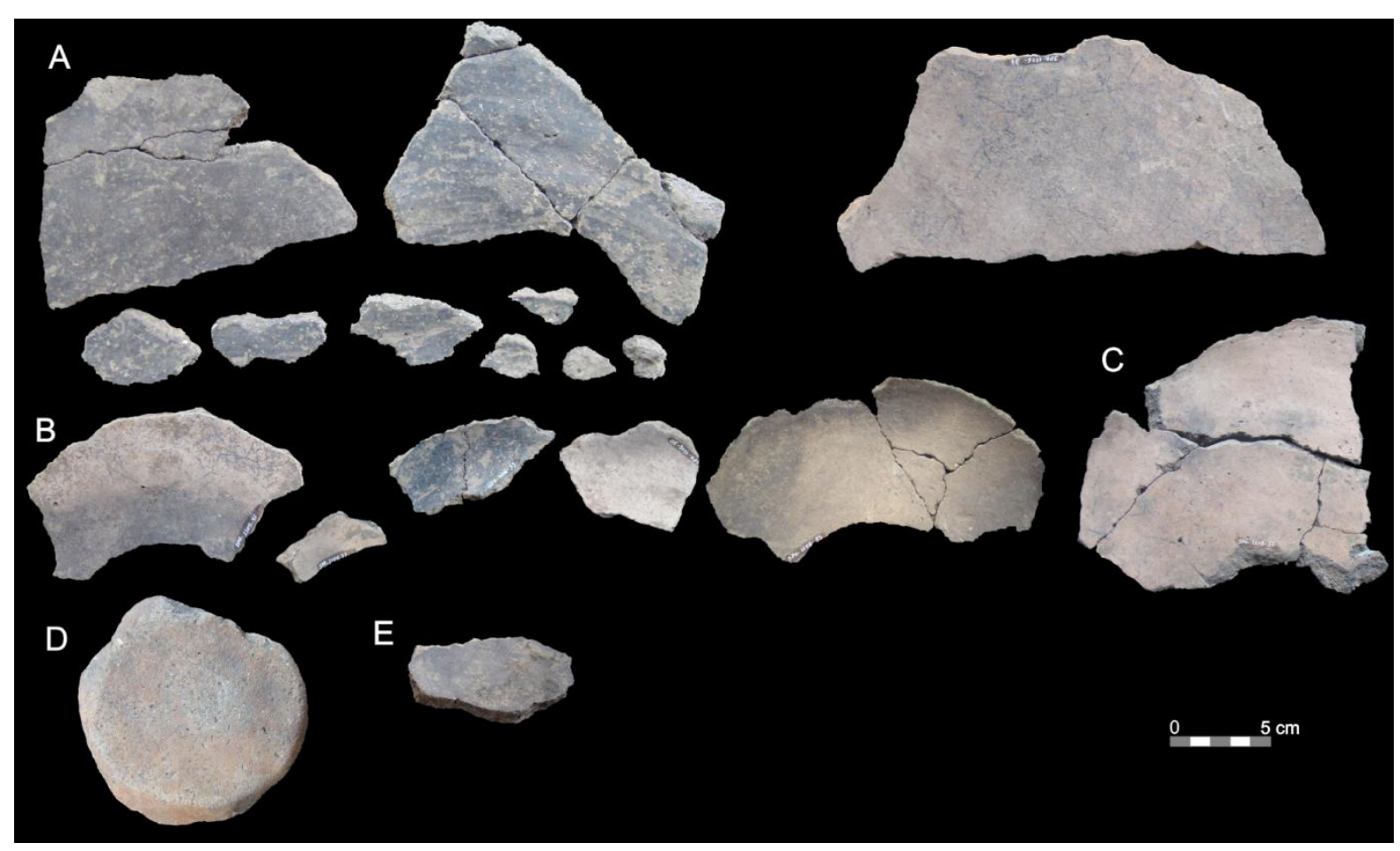

Figura 133: possíveis bases biplanas (A); bases convexas concavas (B) ; base bi-plana (C); base anelar (D) e base com depósito de carbono (E) (Fotos: SCIENTIA, 2012)

Analisando os atributos da pasta, acabamentos de superficie e forma conjuntamente percebemos que trata-se de um conjunto bastante homogêneo, caracterizado principalmente por vasilhas de contorno simples (pratos e tigelas e servir) e infletido (vasilhas com bojo, abertas ou fechadas), com bases na maioria convexas-côncavas e anelares, decoradas predominantemente com incisos, incisos e ponteados e modelados na parte superior, cuja pasta predominantemente apresenta caraipé e é bastante dura. Este material é predominante entre a superfície e 110-120 cm, apesar de aparecer também nos níveis mais profundos, e apresenta muitas semelhanças com o conjunto predominate no sítio Ilha de Santo Antônio.

Entretanto, no sítio Santa Paula a maioria das bordas desenhadas foram encontradas nos níveis superiores (superfície a 110-120 cm, com PN 1101 a 1112) e apenas cinco bordas desenhadas são dos níveis mais profundos (120-130 a 140-150 cm, com PN 1113, 1114 e 1115). Buscamos averiguar se as outras bordas dos níveis mais profundos possuem diferenças em relação as dos mais superficiais, comparando os atributos espessamento, tipo de lábio e forma e inclinação nos diferentes níveis, assim como os atributos de decoração, porém não constatamos diferenças por meio da elaboração de gráficos. Tendo em vista que a frequência de material (diagnóstico) nos níveis mais profundos é menor e são mais fragmentados e desgastados, resolvemos dar mais atenção a estes fragmentos dos níveis mais profundos que 
têm menor visibilidade nos gráficos e desenhos. Observamos que, as bordas desenhadas dos níveis mais profundos (120-130 a 140-150 cm, com PN 1113, 1114 e 1115) são diretas inclinadas externamente com lábios planos ou partes aplanadas próximas ao lábio (1114-02 e 1113-23) e bordas diretas verticais com lábios expandidos (1114-05 e 1115-06), características dos materiais dos sítios Veneza e Garbin e que aparecem nos níveis mais profundos do sítio Ilha de Santo Antônio. Além destas bordas, ocorrem outras não desenhadas (figura 134) com estas características, entre elas duas com flanges labiais (uma flange quebrada, $2 \mathrm{~cm}$ abaixo da borda). A pasta de alguns fragmentos é porosa e destaca-se a barbotina ou engobo laranja ou rosado ( a borda 1113-23 possui um engobo com uma cor muito viva rosada).

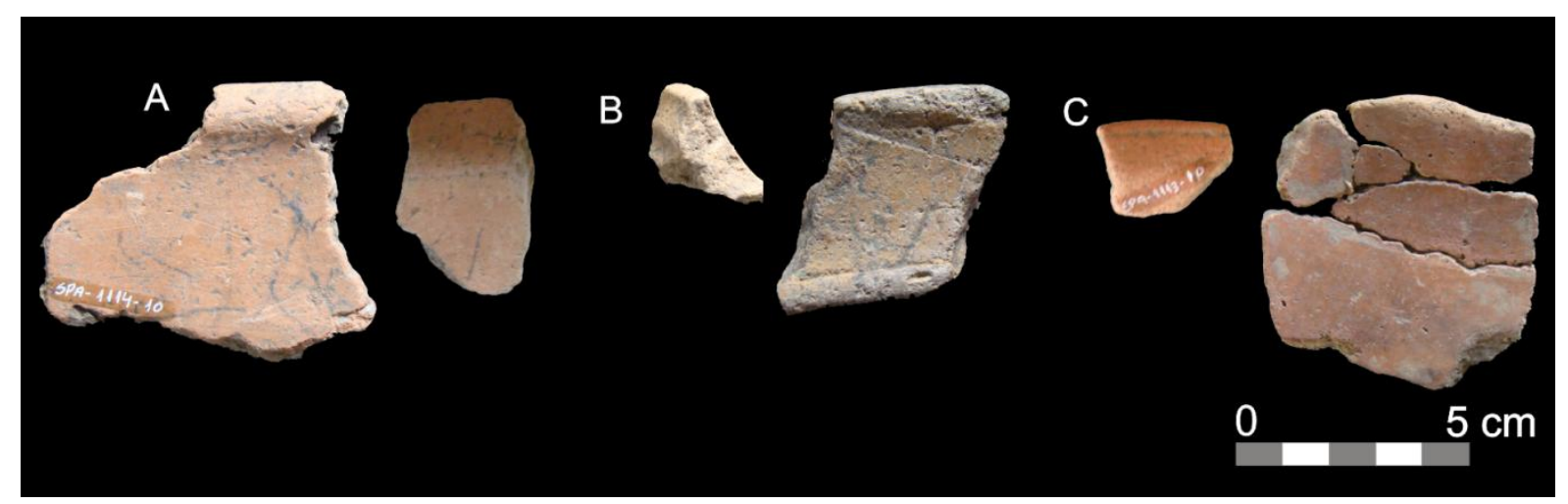

Figura 134: bordas diretas inclinadas externamente/130-140 cm (A); Borda com flange labial e incisões/110-120 cm (B); bordas dos níveis 120-130 e 160-170 cm (C) (Fotos: SCIENTIA, 2012).

Além disso, constatamos que alguns fragmentos com pintura vermelha e branca e marcas de fermentação na face interna encontrados nos níveis superiores (como a vasilha 1103-80) poderiam corresponder a uma ocupação posterior, relacionada a Tradição Polícroma da Amazônia, porém mais uma vez, a amostra analisada é muito pequena.

Com a amostra desta unidade não foi possível avançar nestas questões, por isso analisamos alguns atributos dos materiais das sondagens (especialmente forma e decorações), buscando caracterizar a variabilidade tecnológica nos demais espaços do sítio, ao menos para propor hipóteses a serem aprofundadas nos trabalhos futuros. Antes disso porém, é necessário analisar as datações desta unidade de escavação. A datação obtida para o nível 100-110 cm $(1.550 \pm 30$ AP) parece representar a transição para uma ocupação mais densa no sítio, representada por vasilhas de tamanho grande e alta variação de decorações plásticas. Este é um nível de transição dos materiais sugeridos como semelhantes ao sítio Veneza (mais profundos) e os materiais dos níveis superiores, semelhantes aos do sítio Ilha de Santo 
Antônio, e conjuntamente com as outras duas datas obtidas nos níveis mais profundos

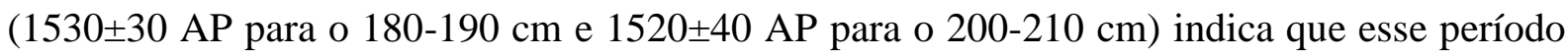
corresponde a ocupação mais antiga no sítio sendo provavelmente ainda mais recuada), e que a ocupação mais densa dos níveis superiores $(0-10 \mathrm{~cm}$ a $90-100)$ não foi datada, podendo ter

perdurado por algumas centenas de anos, tendo em vista a datação obtida para a ocupação do sítio Ilha de Santo Antônio de $990 \pm 40$ AP. Analisaremos alguns atributos dos materiais das sondagens de delimitação do sítio, buscando esclarecer tais hipóteses, tendo em vista que no sítio Ilha de Santo Antônio obtivemos informações importantes ao olhar para os materiais de uma área mais abrangente do sítio.

\subsubsection{Cerâmica das sondagens da delimitação do sítio Santa Paula}

Foram analisados os materiais diagnósticos de apenas uma parte das sondagens do sítio Santa Paula (2.637 fragmentos), dos quais daremos mais atenção aos dados relacionados aos atributos que caracterizam os tratamentos de superfície e forma das vasilhas, que permitam ampliar nossas hipóteses sobre a ocupação do sítio. Com as remontagens totalizou 2.279 fragmentos, escavados entre a superfície e o nível 120-140 cm. Verificou-se que nesse sítio a adição de caraipé na pasta é uma escolha importante, pois na cerâmica das sondagens está presente em 97,37\% dos fragmentos, sendo raros os com cauixí ou somente mineral.

O engobo está presente em 201 fragmentos $(8,82 \%)$, predominando a cor vermelha, mas tambem ocorre nas cores laranja, vinho, preta e branca. A pintura ocorre em 47 fragmentos e em 25 não pode ser identificada (apenas vestigios de pigmentos). Predomina a associação das cores branca e vermelha nos materiais dos níveis mais superficiais $(0-40 \mathrm{~cm})$, com traços mais largos, e laranja e branca nos níveis mais profundos $(40-120 \mathrm{~cm})$, algumas com incisões associadas (figura 135). 


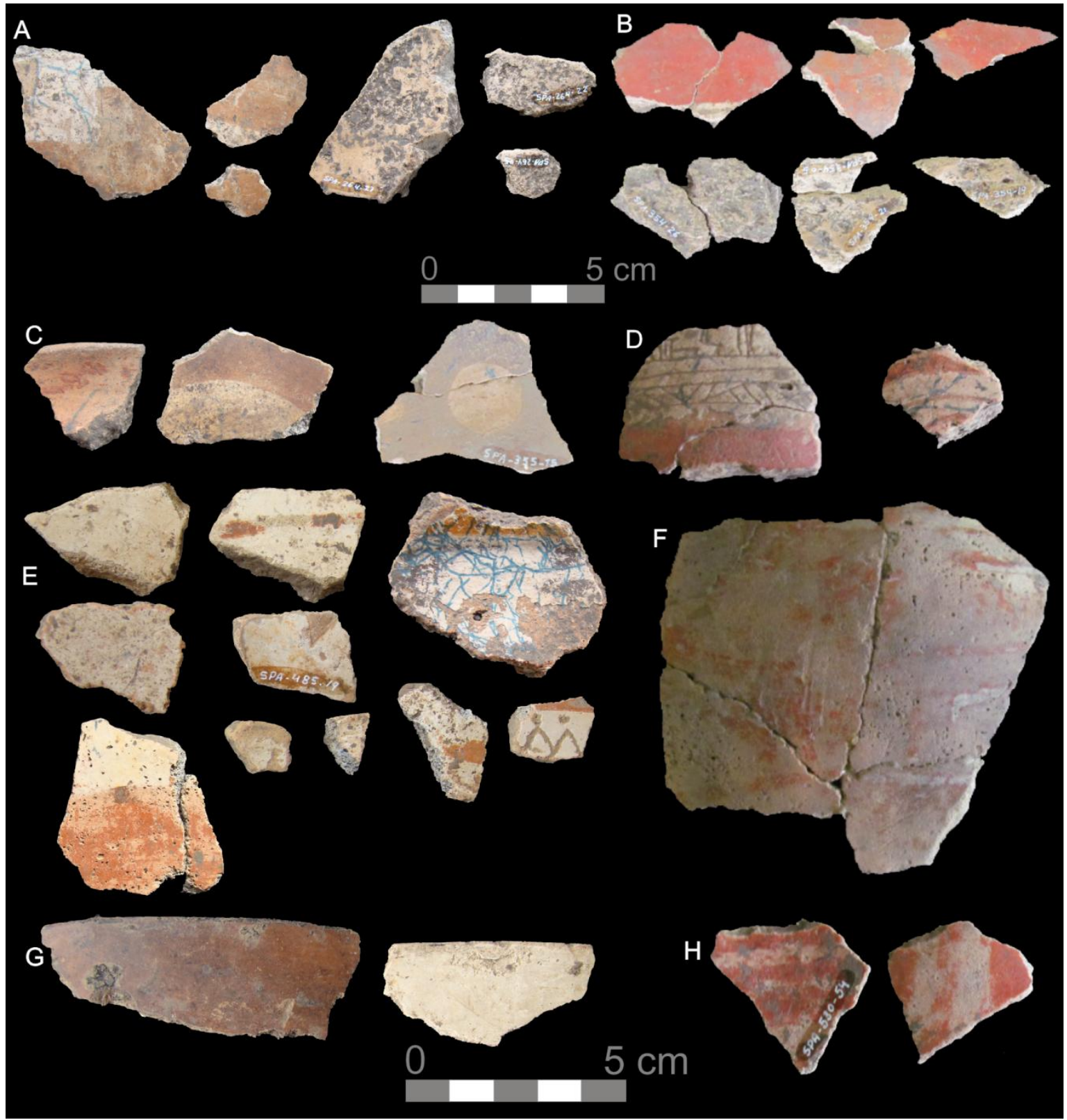

Figura 135: pintura, engobo e marcas de fermentação na face interna. materiais entre 0 e $40 \mathrm{~cm}(\mathrm{~A}, \mathrm{~B}, \mathrm{C}$, G); materiais dos níveis mais profundos (D, E, F, H) (Fotos: SCIENTIA, 2012).

Os tratamentos plásticos ocorrem em 218 fragmentos (9, 57 \%). São mais comuns as incisões, porém também aparece o roletado, ponteado, escovado, acanalado, modelado, aplique e combinações entre eles (gráfico 45 e figura 136). São feitos principalmente na borda (85), parede (76) e inflexão (36), mas tambem em alguns lábios (7), flanges (5), bases (3), borda e flange (1), flange e lábio (1), bojo (1), pescoço (1), carena (1) e no aplique (1), portanto predominantemente na parte superior das vasilhas. Entre os motivos, são mais comuns as linhas horizontais (67), linhas verticais (4), zigue-zague (3), curvilíneos (2), linhas retas entrecruzadas (2), linhas transversais ou obliquas (2), escalonado (1), triangular (1), 
composto por dois elementos (14) e complexo (7) que consiste na associação de mais de dois elementos.

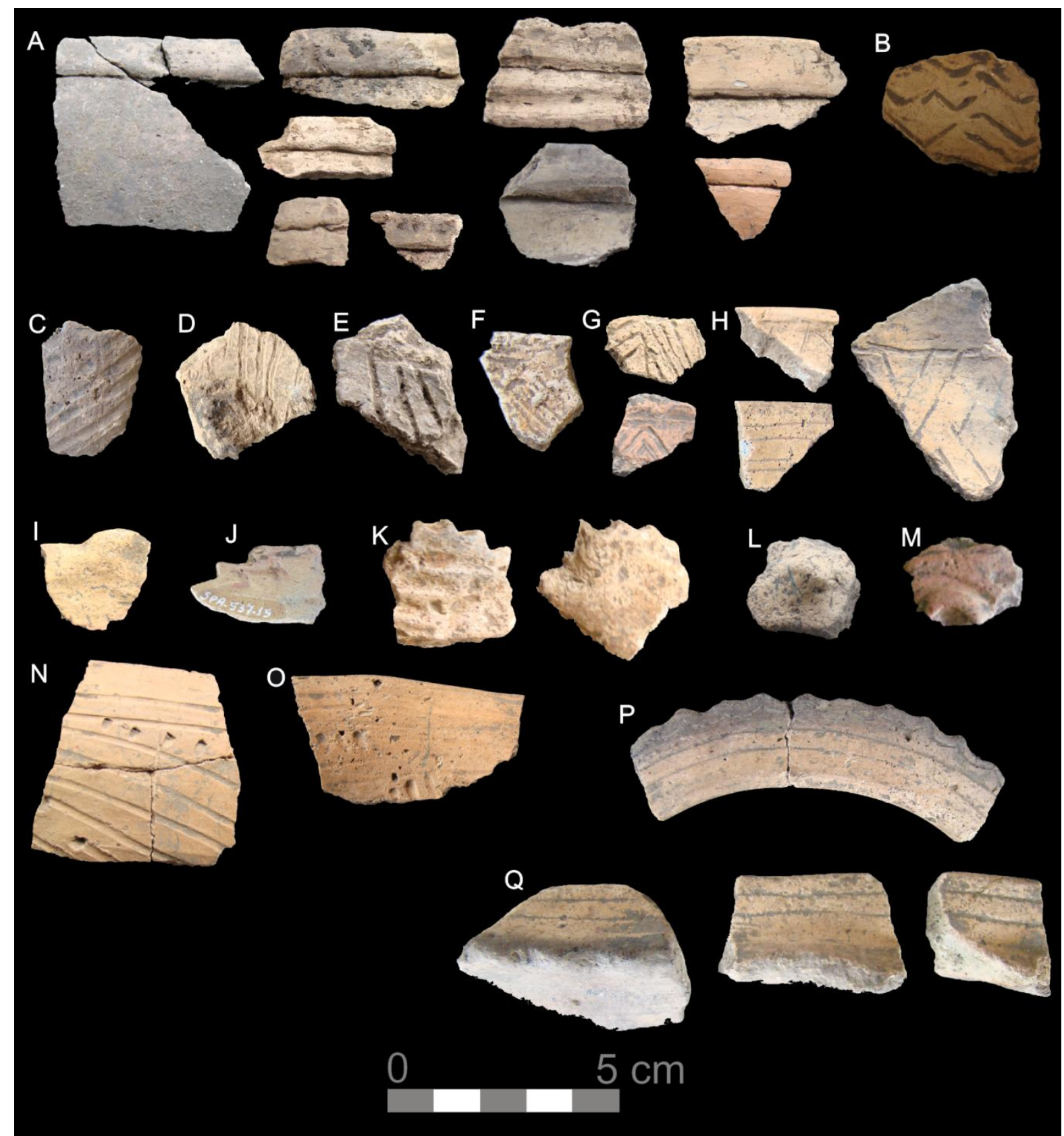

Figura 136: tratamentos plásticos: roletado (A); inciso (B, C, E, F, G, H); inciso e negativo de aplique (D); modelados (I a M); inciso e ponteado (N, $\mathbf{O}$ ); frange labial com incisões (P) e borda com incisões (Q). (Fotos:SCIENTIA, 2012). 


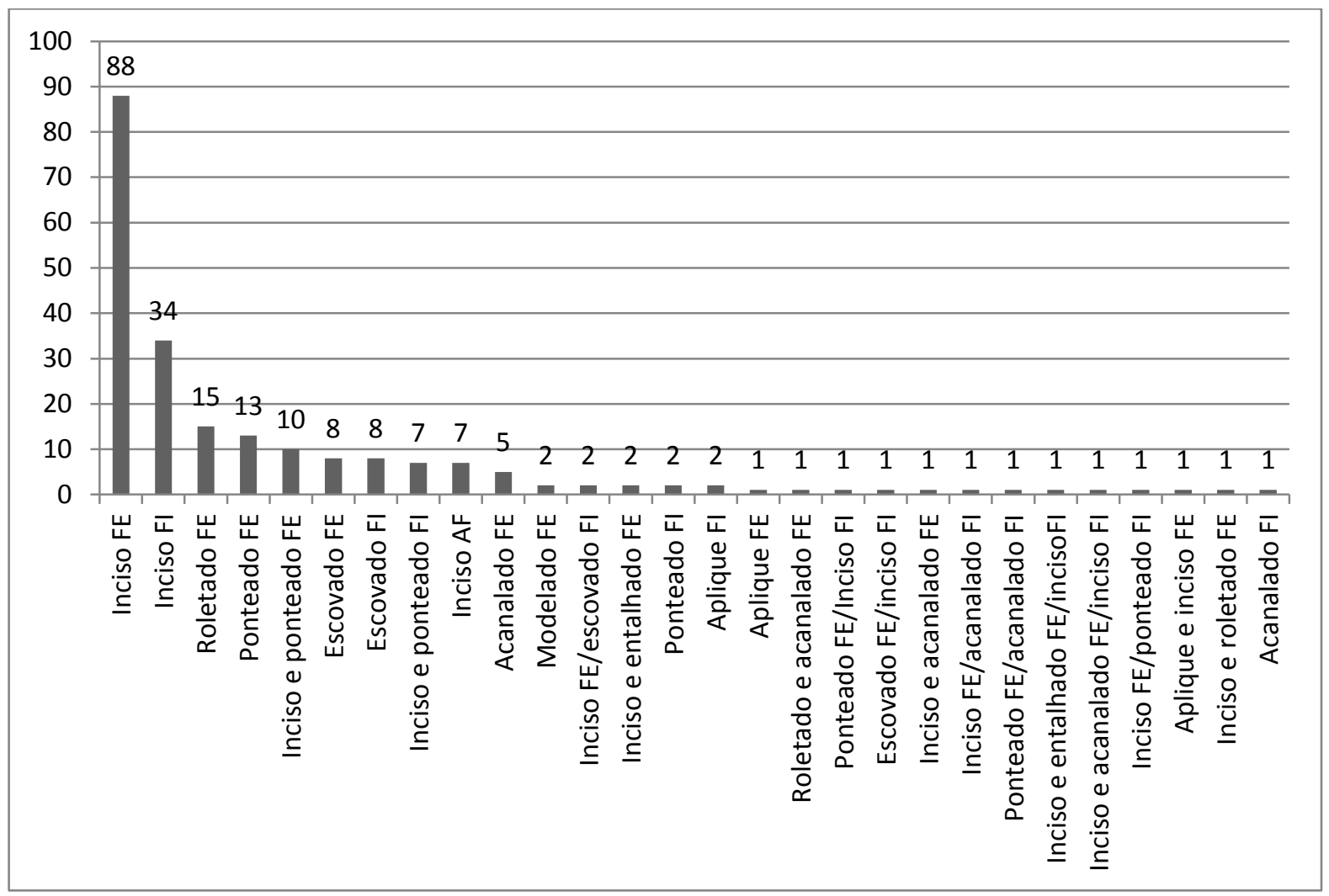

Gráfico 45: tratamentos plásticos identificados nos materiais das sondagens do sítio Santa Paula.

Entre os fragmentos analisados das sondagens ocorrem fragmentos de parede (1.136), bordas (646) e inflexões (392), bases (51), bojos (10), pescoços (10), flanges (7), carenas (6), borda com parede (5), borda com flange (5), borda e bojo (3), borda com carena (3), base com parede (1), base e inflexão (1), aplique (1) e vasilhas com perfil completo (3). Entre as bordas, foi possível observar a forma e inclinação de 273 delas, predominando as diretas inclinadas externamente (108), extrovertidas (69), diretas verticais (44), diretas inclinadas internamente (34), introvertidas (9), extrovertida com ponto angular (8) e introvertida com ponto angular (1). Em relação ao espessamento, foi possível verificar em 594 delas, sendo 307 com espessamento linear, 251 contraídas, 25 expandidas, 6 reforçadas externamente e 5 reforçadas internamente. Os labios arredondados são mais comuns (368), bem como os apontados (111) e planos (77), mas tambem ocorrem os irregulares (25) e biselados (13). O diâmetro de abertura foi identificado em 40 bordas, variando entre 6 e $34 \mathrm{~cm}$ (gráfico 46). Entre as bases predominam as bi-planas (20), anelares (9), convexa-côncava (4), plano- concava (3), em pedestal (1) e as demais não foram identificadas em relação a forma (16) (figura 141). O diâmetro varia entre 6 e 14 cm, porém não foi possível medir da grande maioria. 


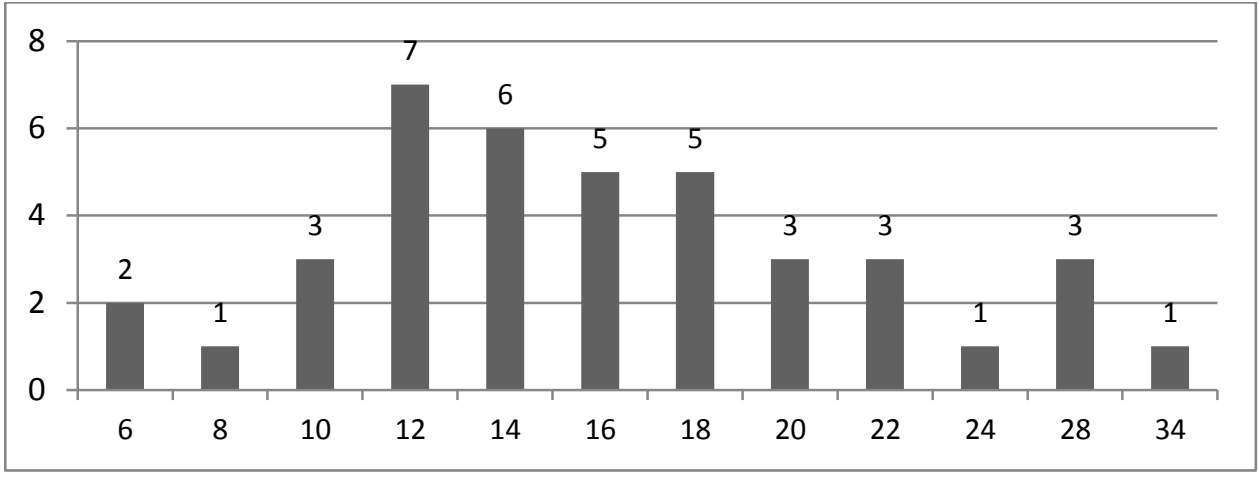

Gráfico 46: diâmetro de abertura das vasilhas (cm)- sondagens do sítio Santa Paula.

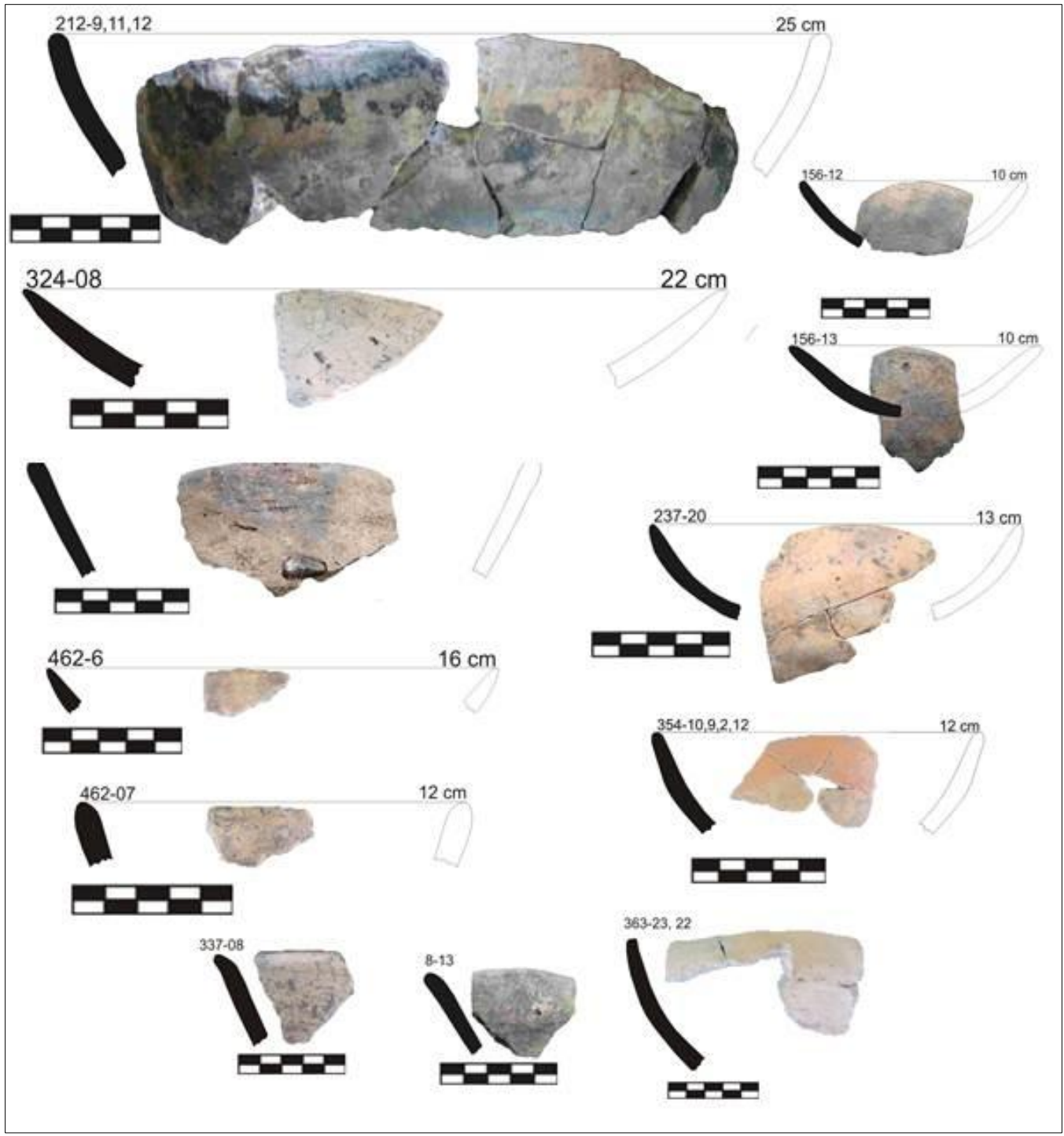

Figura 137: Bordas das sondagens- sítio Santa Paula (Desenhos: Angislaine F. Costa, 2012). 


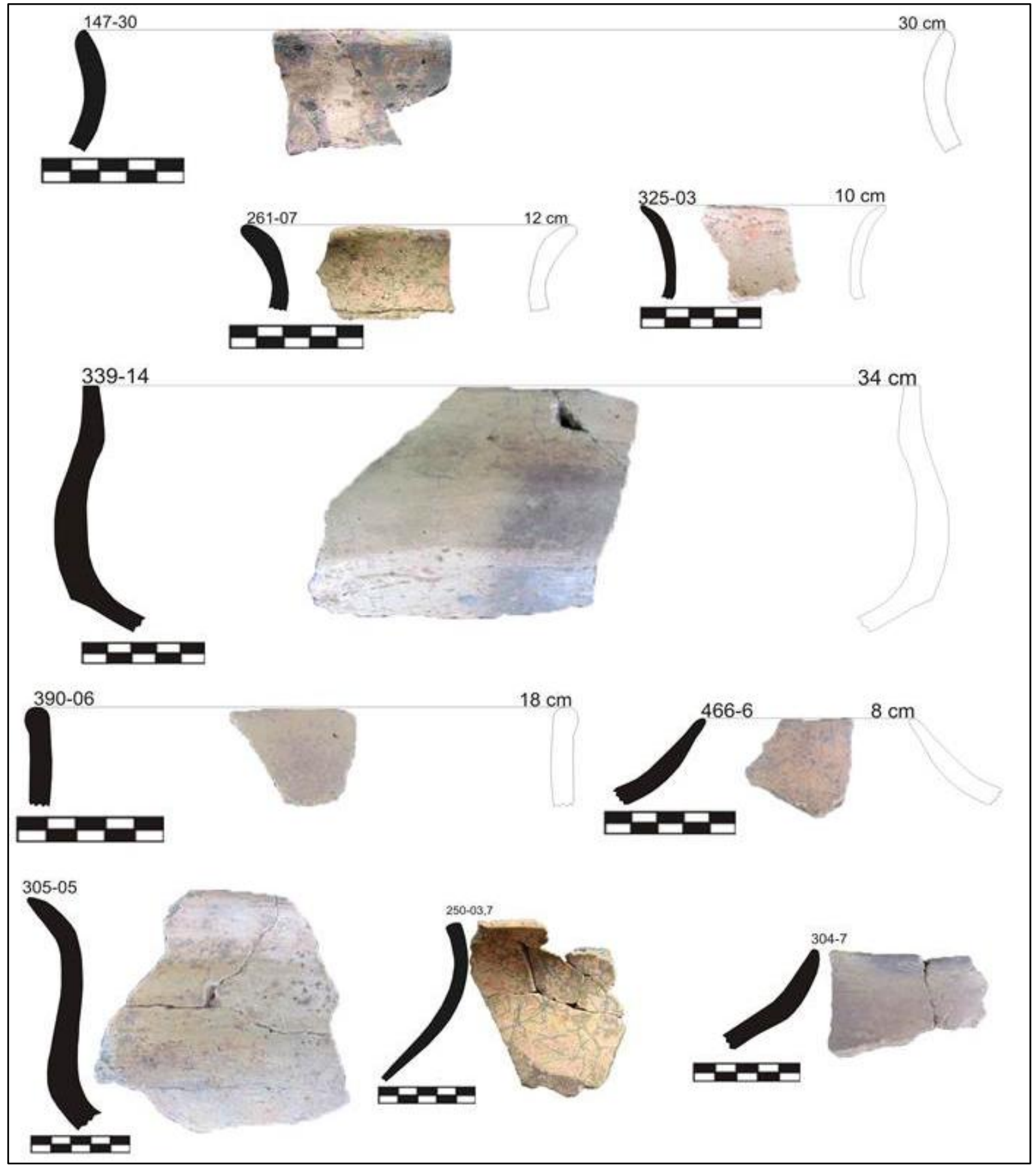

Figura 138: bordas das sondagens- sítio Santa Paula (Desenhos: Angislaine F. Costa, 2012). 


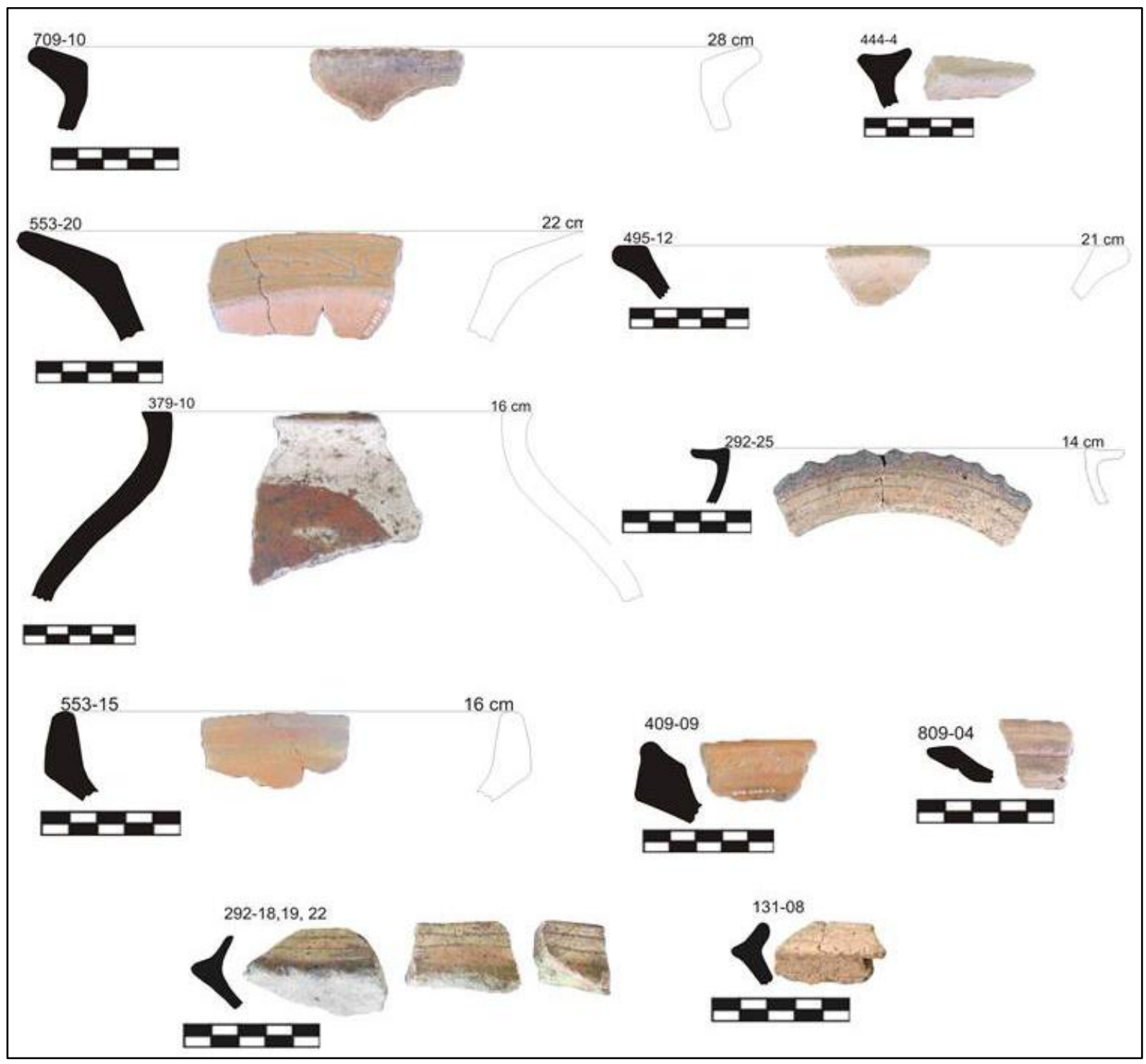

Figura 139: Bordas das sondagens- sítio Santa Paula (Desenhos: Angislaine F. Costa, 2012).
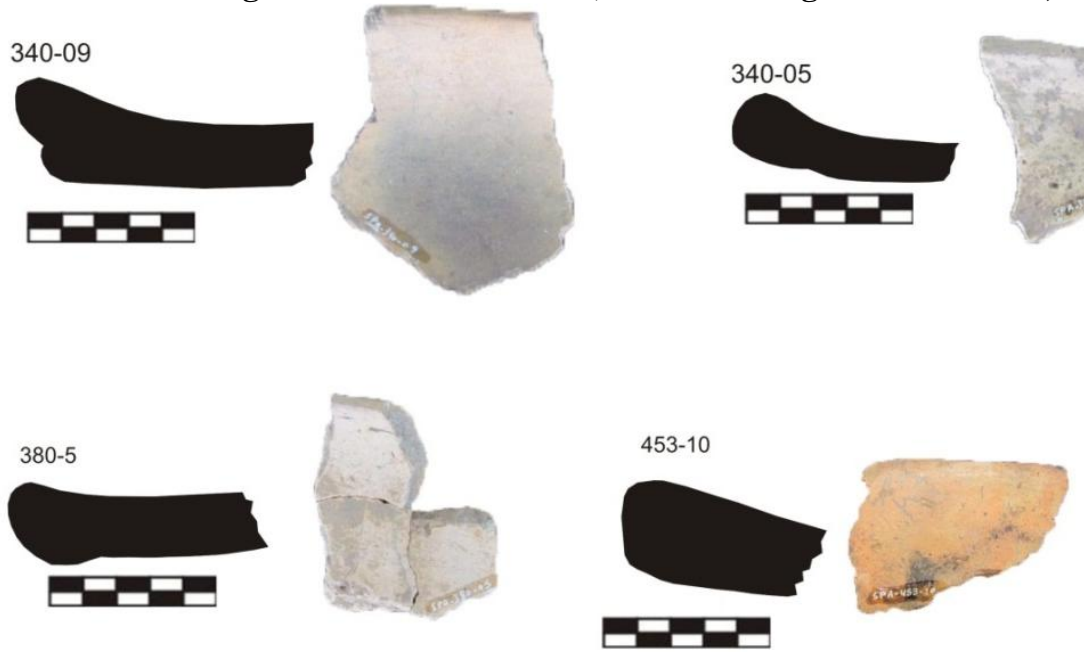

Figura 140: Bordas de assador - sítio Santa Paula (Desenhos: Angislaine F. Costa, 2012). 


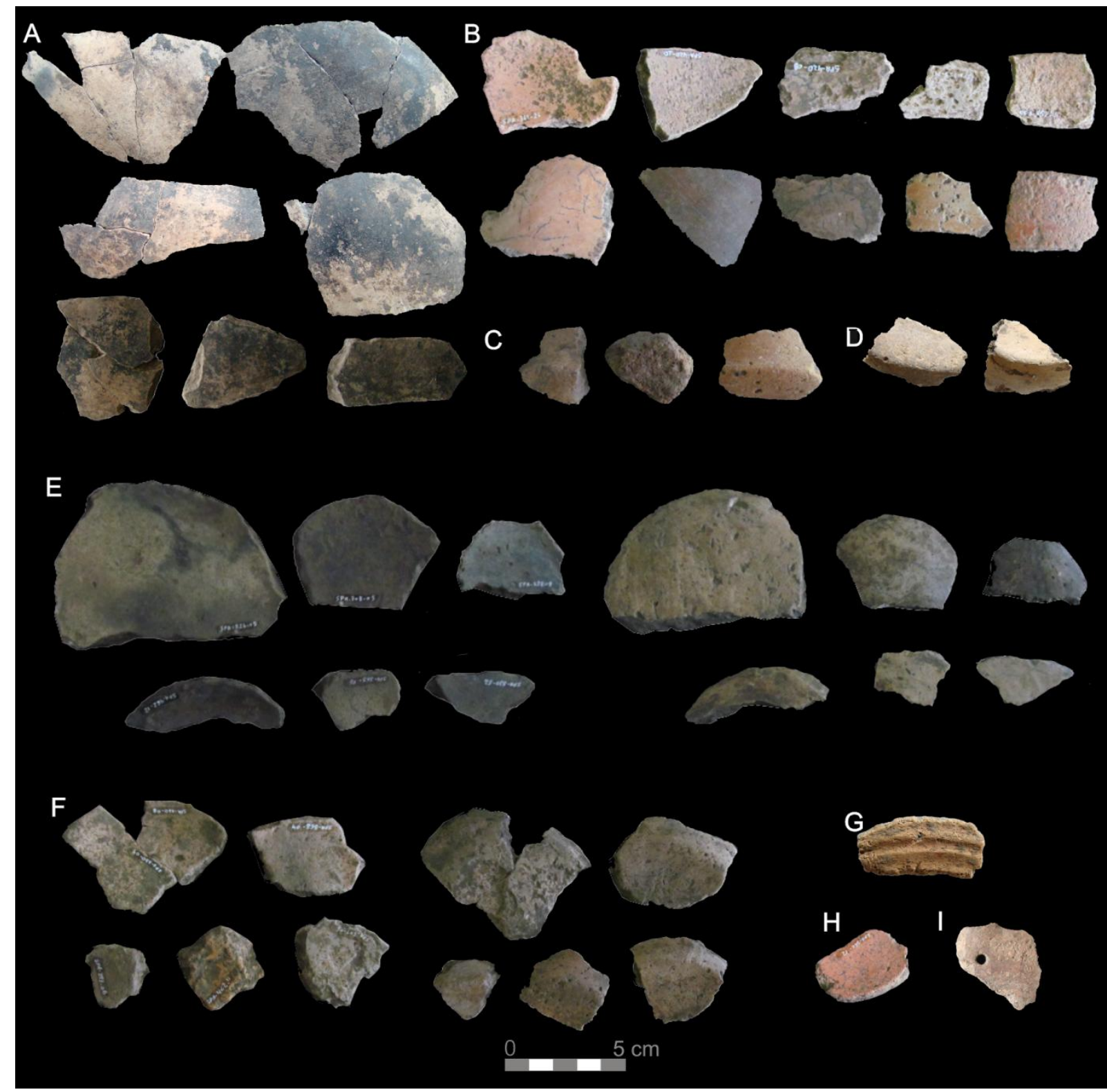

Figura 141: fragmentos de inflexão com fuligem (A); fragmentos com marca de fermentação FI e polimento ou engobo FE (B); bases convexas côncavas FI e FE (E); bases anelares FI e FE (F); bases em pedestal $(\mathrm{C})$; bases anelares $(\mathrm{D})$, base plano côncava com incisões largas $(\mathrm{G})$; reciclagem/ possível adorno (H); fragmento com furo (I) (Fotos: SCIENTIA, 2012).

Procuramos separar os conjuntos cerâmicos do sítio Santa Paula através das semelhanças e diferenças nos atributos cerâmicos, de acordo com as hipóteses estabelecidas com a análise dos materiais da unidade E382631 N9021469, buscando relacionar as características de pasta, decoração e forma com os materiais do sítio Veneza e da Ilha de Santo Antônio, tendo em vista que são sítios com uma boa amostra analisada e que servem de parâmetro para pensarmos nas ocupações desta área. Com a análise dos materiais das sondagens, conseguimos caracterizar melhor o conjunto predominante na parte superior da estratigrafia da unidade E382631 N9021469, com cerâmicas bem alisadas ou polidas, 
tratamento plástico roletado, inciso (motivos triangulares e linhas obliquas entrecruzadas são típicas), inciso e ponteado e modelado, vasilhas com formas infletidas (fechadas) e simples (formas de cuia, tigelas), sendo que algumas vasilhas com o tratamento roletado no lábio apresentam fuligem. As bases que apresentam depósito de carbono são as convexas-côncavas, mas também ocorrem as anelares e outros tipos, e são frequentes fragmentos com fuligem e com marcas fermentação. Estas cerâmicas possuem características semelhantes com aquelas do conjunto predominante no sítio Ilha de Santo Antônio.

Além disso, identificamos vasilhas muito semelhantes a do sítio Veneza: bordas expandidas, lábios planos ou uma parte da borda aplanada para aplicação de decoração incisa, flanges labiais e mesiais (próximas à borda), bases plano côncavas (uma com decoração incisa larga), paredes escovadas (possivelmente do alisamento com a pasta mais seca), pintura com uma gama variada de cores (laranja, branco, vinho e vermelho) e raras carenas. Além das bordas 409-09, 495-6, 444-04; 131-08; 292-18,19,20; 292-25; 553-15; 553-20; 495-12 e talvez a 379-10, cujos desenhos foram apresentados acima, ocorrem outras com características semelhantes (figura 142). Destaca-se também a porosidade da pasta, a barbotina ou engobo laranja e fragmentos de uma vasilha com decoração serrungulada. Plotamos estas peças no croqui do sítio, e estas se concentram em uma área circular, passando a sul na área próxima ao barranco, onde foi escavada a unidade E382670 N9021310, da qual não analisamos o material, mas segundo as observações de campo ocorriam diferenças nos materiais ao longo da estratigrafia desta unidade: nos primeiros níveis $(20$ e $40 \mathrm{~cm})$ sobressaiu a cerâmica pintada, enquanto entre 60 a $80 \mathrm{~cm}$ ocorreram fragmentos com motivos estilísticos diferenciados, destacando-se lábio expandido e flanges mesiais. Quanto à distribuição dos fragmentos em uma área circular, não avançamos nas interpretações em relação à forma do sítio, porém esta é uma tarefa interessante a ser desenvolvida em pesquisas futuras. 


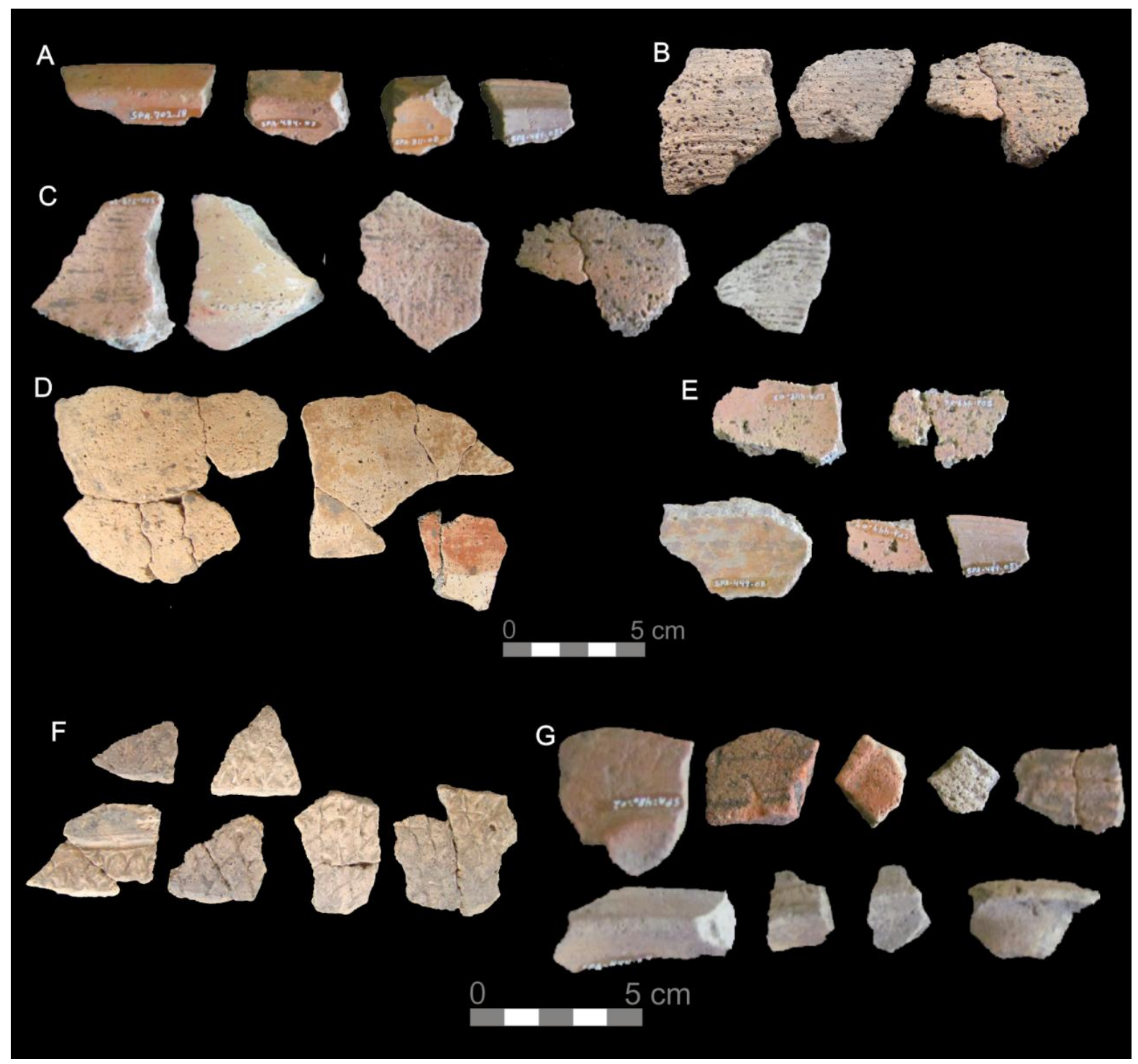

Figura 142: cerâmica antiga do sítio Santa Paula: bordas expandidas (A); tratamento escovado (B, C); pintura laranja e branca (D); engobo e barbotina laranja (E); tratamento serrungulado (F); bordas e flanges com tratamento inciso (G) (Fotos: SCIENTIA, 2012).

Com relação a um possível terceiro conjunto, caracterizado por vasilhas com pintura vermelha e branca em traços largos na face externa e marcas de fermentação na face interna, típicas da Tradição Polícroma da Amazônia, a amostra analisada nos forneceu poucos fragmentos, não sendo possível avançar nesta hipótese, mesmo que seja bastante pertinente. Voltemos a discussão das datações. Tendo como base a análise dos materiais da unidade E382631 N9021469 e das sondagens, reforçamos a hipótese de que as datações obtidas de 14C $1.550 \pm 30 \mathrm{AP}(103 \mathrm{~cm}$ de profundidade $), 1530 \pm 30 \mathrm{AP}(181 \mathrm{~cm})$ e $1520 \pm 40 \mathrm{AP}(203$ $\mathrm{cm}$ ) correspondem a um período mais antigo de ocupação do sítio, caracterizado pela presença do material semelhante ao do sítio Veneza. Acreditamos que logo após esse período o sítio foi ocupado por uma população mais densa, tendo em vista o aumento no número e 
tamanho das vasilhas, semelhantes aquelas do conjunto predominante no sítio Ilha de Santo

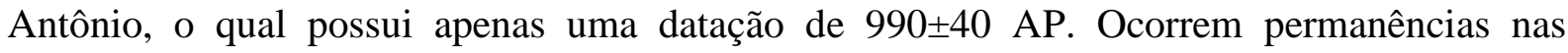
escolhas tecnológicas no período mais antigo e mais recente, como no emprego da pasta, no uso do engobo (apesar de diminuir a gama de cores), nas decorações incisas e local de sua aplicação (parte superior da vasilha) e em algumas formas das vasilhas, o que poderia indicar uma continuidade com mudanças tecnológicas em função do aumento populacional. As mudanças mais perceptíveis são no tamanho das vasilhas, ausência de flanges labiais e mesiais, aumento no número de vasilhas decoradas com tratamentos plásticos, sendo estes mais variados (o modelado torna-se mais comum; surge o roletado), assim como uma maior variedade de motivos das incisões; e ausência ou raridade de fragmentos pintados. É necessário aprofundar esta questão das permanências e mudanças tecnológicas, tendo este sítio um grande potencial para essa problemática. Outra hipótese possível é que povos diferentes, porém com uma representação social comum ocuparam o sítio. O sítio Santa Paula está implantado sobre o barranco alto na margem esquerda do rio Madeira, em frente à cachoeira do Teotônio, portanto não foi atingido pelo reservatório da usina e seu estudo poderá ser aprofundado.

\subsection{Cerâmica do sítio Teotônio}

Conforme vimos no capítulo 2, na estrada de acesso a cachoeira do Teotônio foi escavada uma área ( 2 x 2,6 m denominada Setor Estrada), onde foram evidenciadas três vasilhas cerâmicas em um pacote de terra preta que ocorreu até a profundidade máxima de 60 cm com cerâmica, materiais líticos em quartzo e carvões. As vasilhas 1 e 2 estavam com a parte superior cortada, enquanto a vasilha 2 apresentava-se inclinada entre as duas outras, e por ser menor não foi afetada, sendo possível reconstituir sua forma inteira. Além das três vasilhas, foram analisados os fragmentos cerâmicos que apareceram na sua volta e no interior das vasilhas 2 e 3 .

A vasilha 1 apresenta pasta com mineral (alta inclusão de grãos pequenos de quartzo, arredondados e sub-angulosos, e hematita) e cauixí. A superfície interna está bastante erodida, mas foi possível perceber em alguns pontos a brunidura. A superfície externa foi polida, e parece ocorrer uma fina camada de banho ou engobo vermelho. Em ambas as faces ocorre uma impregnação de sedimento, removido apenas parcialmente por estar muito aderido à peça. A técnica de confecção aparentemente é a acordelada. A queima é oxidante em toda a 
vasilha, predominando a coloração laranja nas paredes e marrom na base. A borda da vasilha foi cortada, restando apenas a base e parte da parede. A base possui a forma convexa côncava, com aproximadamente $52 \mathrm{~cm}$ de diâmetro e ocorre um furo de $4 \mathrm{~cm}$ de diâmetro no seu centro, feito após a queima. A parede apresenta $30 \mathrm{~cm}$ de altura na parte maior. A base possui $25 \mathrm{~mm}$ de espessura e a parede aproximadamente $21 \mathrm{~mm}$. Na parte superior da parede o diâmetro é de $68 \mathrm{~cm}$, o que corresponde aproximadamente ao bojo da vasilha (V1, figura 144).

A vasilha 2 apresenta apenas elementos minerais na pasta, sendo identificados o quartzo (alta inclusão de grãos grossos, angulosos, subangulosos e subarredondados), feldspato e óxido de Fe, além de um conglomerado de difícil visualização, que aparentemente é um pedaço de granito. Possivelmente foi adicionado mineral moído na pasta, e pela forma prismática do feldspato pode ter sido um granito moído e adicionado. Ocorre uma camada de barbotina em ambas as faces, de coloração marrom clara a avermelhada. Na superfície externa a vasilha é polida, e na interna apresenta alisamento fino. A pasta possui a coloração marrom escura, com queima reduzida. A técnica de confecção aparentemente é a modelada em toda a vasilha. Ocorre fuligem na face externa, próximo à borda. Possui forma simples, aberta, base plano-côncava com $14 \mathrm{~cm}$ de diâmetro, parede e borda direta inclinada externamente e espessamento contraído, com lábio apontado, $48 \mathrm{~cm}$ de diâmetro de abertura e $27 \mathrm{~cm}$ de altura. A base mede $11 \mathrm{~cm}$ de espessura no centro e $17 \mathrm{~cm}$ nas extremidades, enquanto a parede mede entre 10 e $11 \mathrm{~mm}$ de espessura, e próximo ao lábio a espessura da borda diminui para $8 \mathrm{~mm}$. A vasilha foi parcialmente remontada, tudo indica que apenas parte dela foi depositada no local, pois estão faltando fragmentos. Assim como as vasilhas 1 e 3, esta também apresenta uma incrustação de ferro, do contexto pós-deposicional (V2, figura 144).

A vasilha 3 possui características semelhantes a vasilha 1, de pasta, acabamentos de superfície e queima, diferenciando-se na forma. A pasta é apresenta mineral (baixa inclusão de grãos finos de quartzo e grãos de óxido de Fe) e cauixí, possui coloração laranja e queima oxidante. Na face externa ocorre polimento e na interna brunidura. $\mathrm{Na}$ face interna a base apresenta-se bastante desgastada, enquanto as paredes estão bem conservadas. Em ambas as faces ocorrem impregnação de sedimento. A borda foi cortada, restando apenas à base e a parede. A base é convexa côncava aplanada com $56 \mathrm{~cm}$ de diâmetro na junção com a parede, e possui um furo de 17 x $30 \mathrm{~mm}$ feito após a queima. A vasilha foi parcialmente restaurada por Silvia Cunha Lima em 2012. A fragmentação impede a análise da forma, porém percebese que logo acima da junção da base com o corpo possui $58 \mathrm{~cm}$ de diâmetro, enquanto na 
parte superior do corpo (próximo à borda) é menor, sendo a vasilha levemente fechada. A parede possui $15 \mathrm{~mm}$ de espessura e a base é mais espessa. A parte da vasilha que restou possui $45 \mathrm{~cm}$ de altura (V3, figura 144).

Foram ainda analisados 465 fragmentos do setor estrada, que com as remontagens e associações totalizaram 402. Destes, 142 estavam no interior da vasilha 1, 57 no interior da vasilha 2 e os outros 203 no entorno das vasilhas. A maior parte dos fragmentos apresenta-se bem conservada em ambas as faces $(305 ; 75,87 \%)$, porém os demais estão erodidos ao menos em uma das faces ou com a superfície ausente. Na pasta das vasilhas, predomina a presença de caraipé e carvão $(205 ; 51 \%)$ e de caraipé $(156 ; 38,81 \%)$, mas também ocorrem fragmentos com cauixí $(17 ; 4,23 \%)$ ou somente com mineral $(23 ; 5,72 \%)$, além de um fragmento com caraipé e cauixí associados. Predomina a queima reduzida (243;60,45\%), porém também ocorre a oxidante $(139 ; 34,58 \%)$, oxidante externa e reduzida interna $(7 ; 1,74 \%)$, oxidante interna e reduzida externa $(6 ; 1,49 \%)$ e oxidante com núcleo reduzido $(7 ; 1,74 \%)$.

As vasilhas foram confeccionadas com a técnica acordelada (395 fragmentos), com exceção das flanges e bases que são modeladas (7 fragmentos). As superfícies da maioria das vasilhas são polidas ou bem alisadas, apesar de também ocorrer alisamento médio e grosseiro e brunidura em uma ou ambas as faces (gráfico 47). A barbotina está ausente em 196 fragmentos (48,76\%), ocorrem em ambas as faces de 34 (8,46\%), na face interna de 30 (76\%), na face externa de $34(8,46 \%)$ e não foi identificada em 18 (4,48\%). O engobo ocorre em 18 fragmentos (4, 47\%) nas seguintes cores: vermelho FE (7), vermelho AF (3), laranja FE (3), laranja AF (3), branco FE (1), e preto FI (1). A pintura ocorre em apenas 5 fragmentos, sendo vermelha e branca FE em dois e vermelha FE em três (figura 144, letra E).

Os tratamentos plásticos são mais frequentes, ocorrendo em 28 fragmentos $(6,96 \%)$, entre eles o inciso (10 FE e 9FI), ponteado FE (4), inciso e ponteado FE (2), acanalado (1 FE e 1FI) e aplique (1). Entre os motivos ocorrem os seguintes: linhas horizontais (10), composto por dois elementos (2), complexo (1), linhas verticais (1) e NI (10). Foram aplicados na borda (7), lábio e borda (1), flange, lábio e borda (1), inflexão (6) e parede (13). Um aplique zoomorfo foi encontrado na escavação ao redor das vasilhas (figura 144, letra D). 


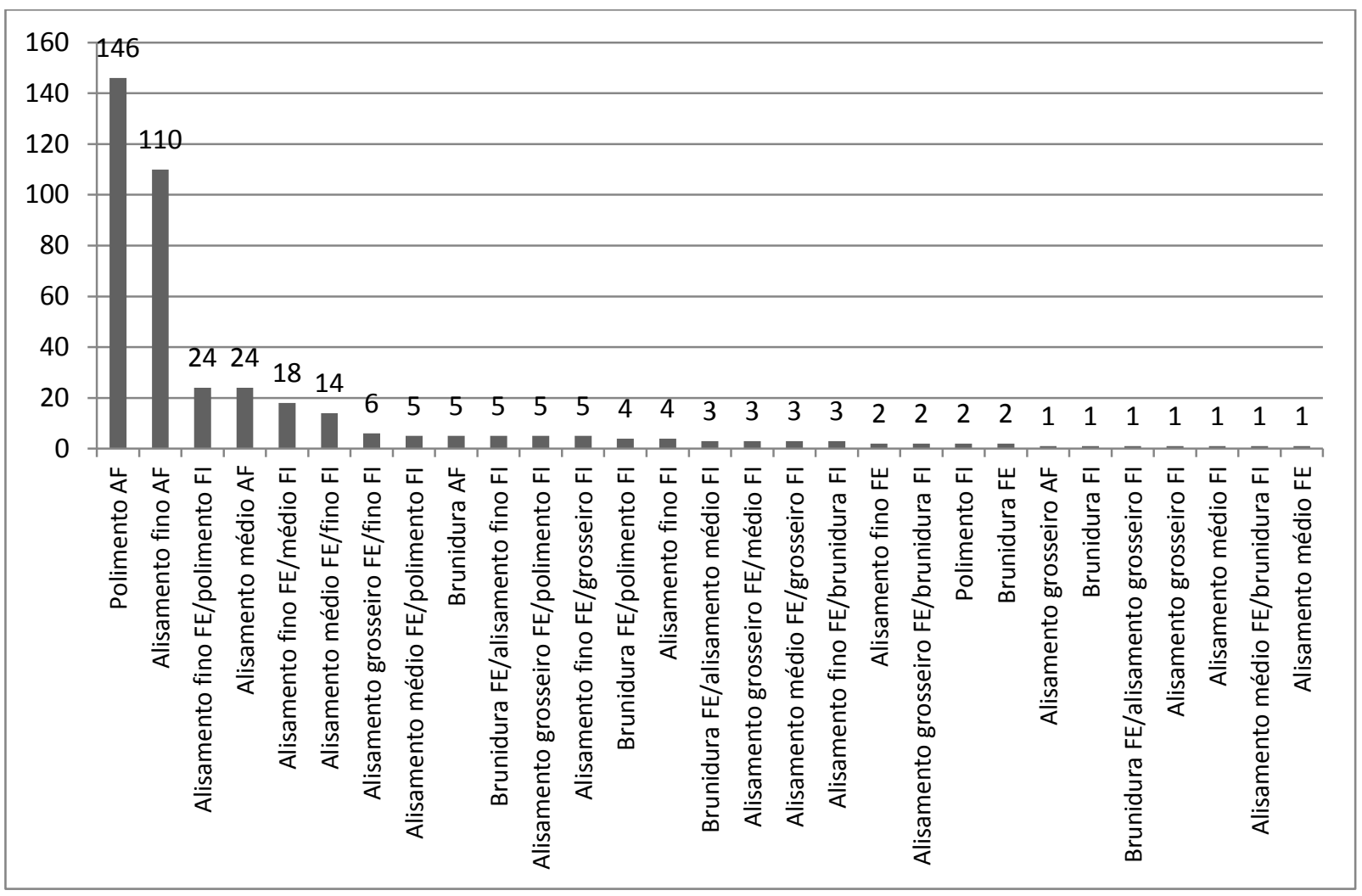

Gráfico 47: acabamentos de superfície das vasilhas- - Setor estrada do sítio Teotônio.

Em relação à parte das vasilhas, estão presentes os fragmentos de parede (249; $61,94 \%)$, bordas $(82 ; 20,40 \%)$, inflexões $(60 ; 14,93 \%)$, bases $(5 ; 1,24 \%)$, além de duas bordas com flange, uma base com parede, um bojo, uma flange e uma vasilha com perfil completo. A espessura dos fragmentos varia entre 3 e $21 \mathrm{~mm}$, com maior recorrência entre 5 e $10 \mathrm{~mm}$. Entre as bordas, foi possível ver a forma e inclinação de apenas 17 entre as 85 analisadas, sendo as seguintes: extrovertida (7), direta inclinada externamente (6), direta vertical (3) e direta inclinada internamente (1). Em relação ao espessamento predominam as lineares e contraídas, seguido pelas expandidas (gráfico 48). Os lábios são na maioria arredondados, mas também ocorrem os apontados e planos (gráfico 49). Foi possível ver o diâmetro de abertura de apenas duas bordas, de 18 e $22 \mathrm{~cm}$ (figura 143). Entre as bases (6), duas são biplanas e as demais não foram identificadas em relação à forma. Uma delas possui $14 \mathrm{~cm}$ de diâmetro. 


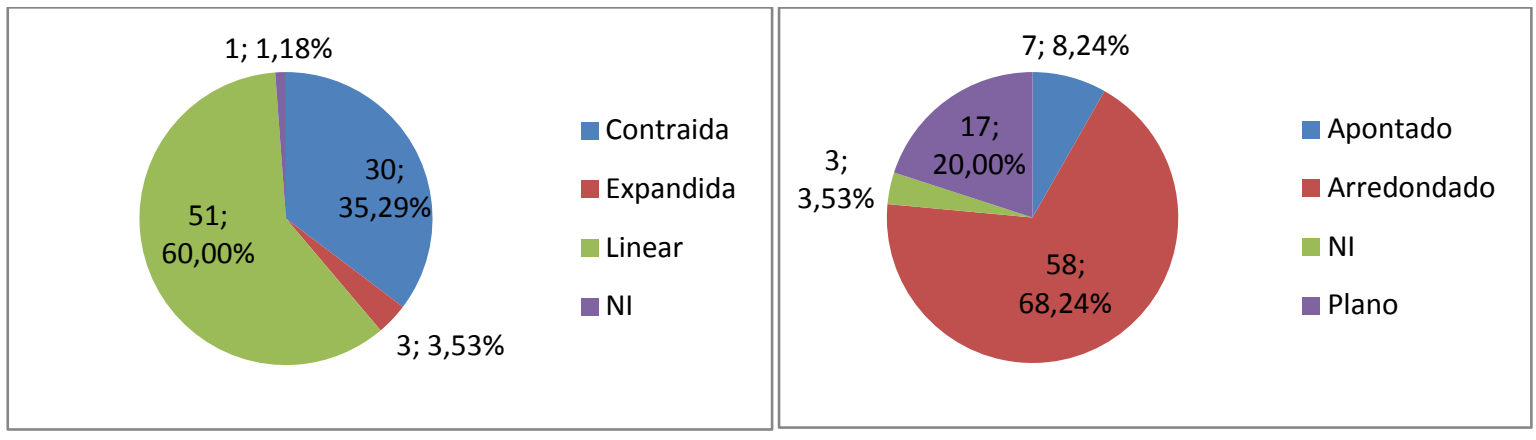

Gráficos 48 e 49: espessamento e tipo de lábio- Setor estrada do sítio Teotônio

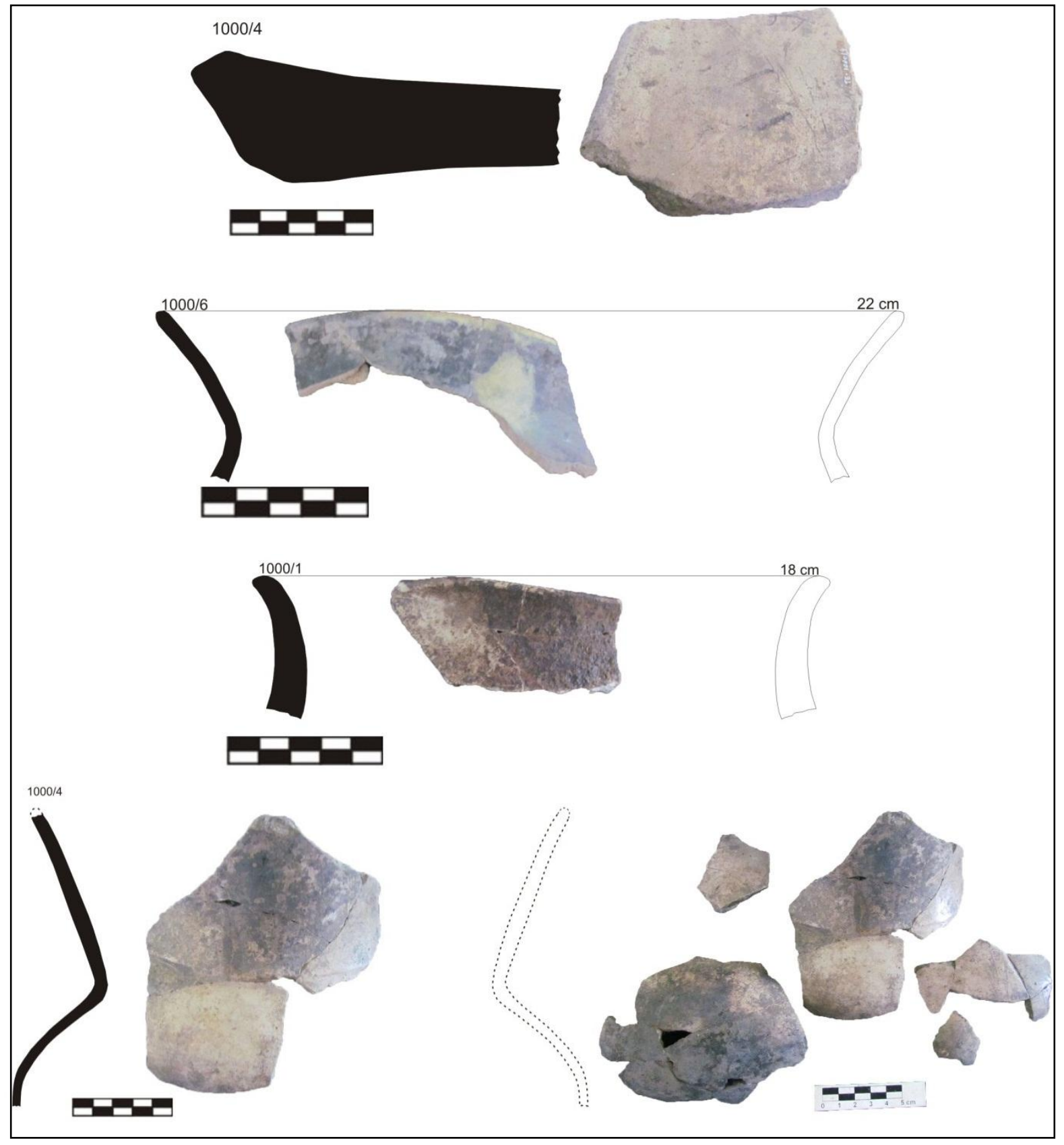

Figura 143: vasilhas do interior da vasilha 1- sítio Teotônio (Desenhos: Angislaine F. Costa, 2012) 

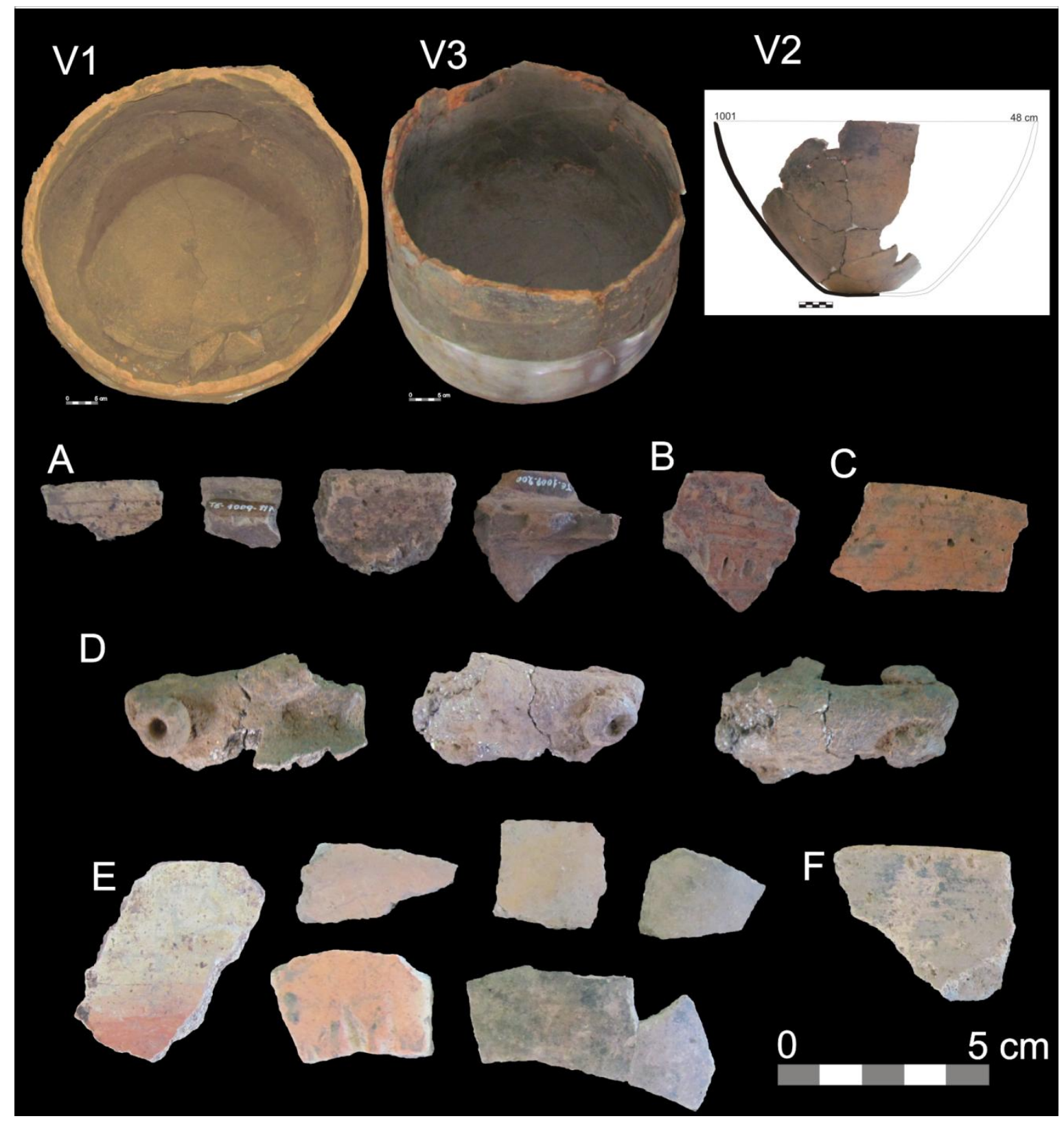

Figura 144: Acima vasilhas V1, V2 e V3; bordas encontradas no entorno das vasilhas (A, B, C e F), algumas expandidas ou com flange e presença de tratamento inciso e inciso e ponteado; modelado zoomorfo (D); e fragmentos encontrados no interior da vasilha V3 (E) (Fotos: SCIENTIA, 2012)

Todas as bordas desenhadas são do interior da vasilha 1, onde estavam mais inteiras (figura 144). Percebemos que a cerâmica do interior das vasilhas 1 e 3 se diferencia da encontrada fora das vasilhas em alguns aspectos: somente no entorno ocorrem flanges e bordas expandidas (gráfico 50), enquanto as bordas do interior são lineares ou contraídas; predomínio de tratamentos plásticos no entorno (somente 5 fragmentos com incisões na V1 e um fragmento com ponteado na V3); fragmentos com pastas com mineral ou mineral e cauixí são mais frequentes no exterior das vasilhas que no interior; no interior foram encontrados os 
dois fragmentos com pintura vermelha e branca e um com pintura vermelha, enquanto no exterior foram encontrados apenas dois com pintura vermelha.

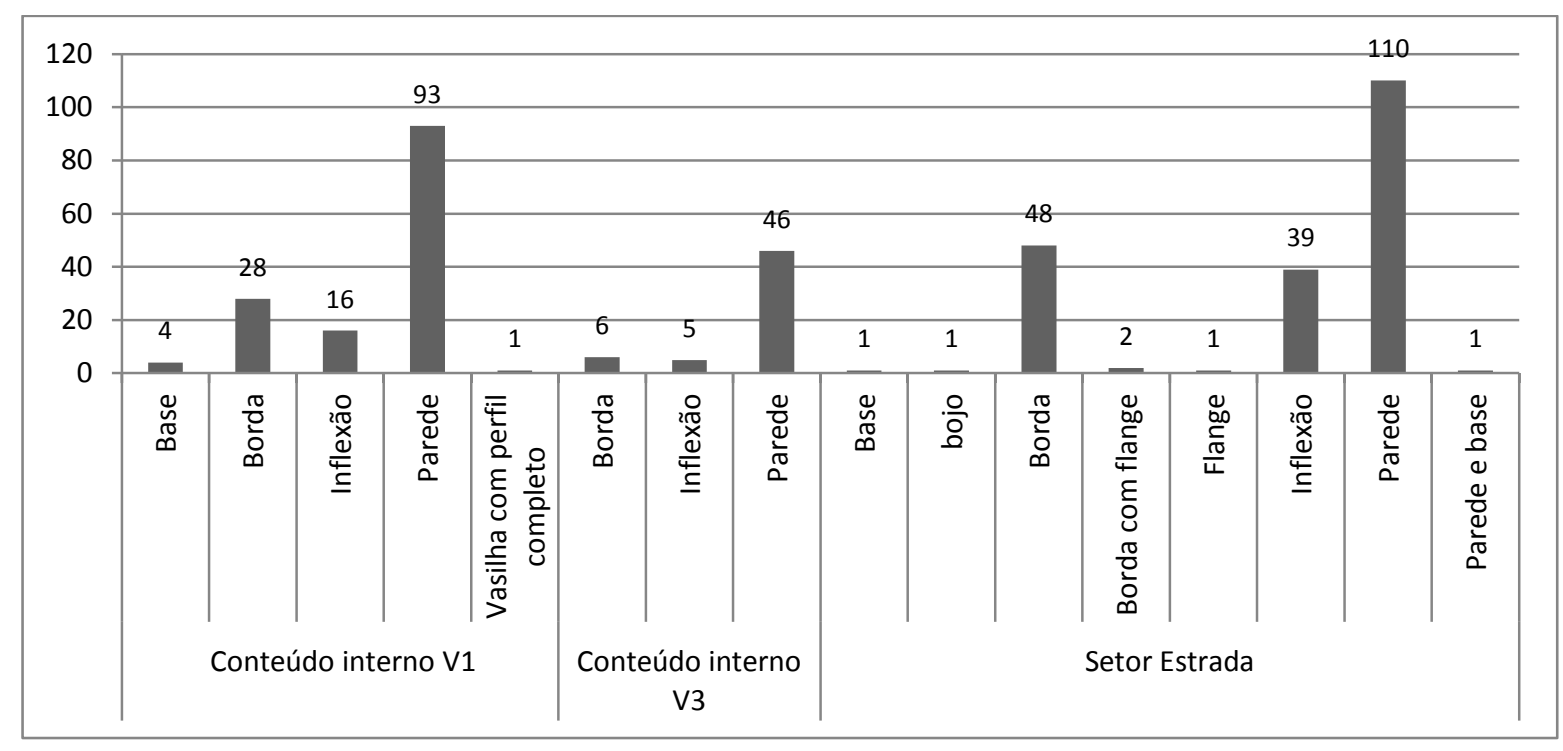

Gráfico 50: Fragmentos encontrados no interior das vasilhas V1 e V3 e fora delas.

A amostra é muito pequena para ampliar as interpretações, porém é possível formular algumas hipóteses. Possivelmente as vasilhas foram enterradas no local quando o sítio já tinha sido ocupado, na camada com material arqueológico, sobre uma crosta laterítica. As três vasilhas se diferenciam tecnologicamente dos fragmentos encontrados no seu entorno e no seu interior, principalmente as vasilhas 2 e 3 que são grandes, com a pasta porosa e frágil, possivelmente confeccionadas para um fim específico. Por apresentarem furos na base, feitos após a queima, presentes também em outras vasilhas da região (sítios Ilha de Santo Antônio, sítio do Brejo) em contextos específicos, e em função do pequeno fragmento de dentina encontrado no interior da vasilha 1 , acreditamos tratar-se de um contexto funerário. A vasilha 2 parece ter sido intencionalmente depositada entre as duas outras na posição inclinada (base para sul e borda para norte), sendo que não se encontrava inteira, e poderia estar cobrindo algo. No interior das vasilhas 1 e 3 foram encontrados fragmentos diversos, que se diferenciam daqueles do entorno, e possivelmente correspondem a fragmentos da ocupação posterior do sítio que caíram para dentro das vasilhas, juntamente com sedimento. Uma borda de assador, bordas extrovertidas com fuligem (panelas), fragmentos com bojo e pescoço, polimento em ambas as faces, pintura vermelha e branca, e um conjunto de fragmentos de uma panela infletida com fuligem na face externa do bojo destacam-se entre estes. Os fragmentos do entorno das vasilhas possuem características semelhantes aos das ocupações mais antigas da região, enquanto os fragmentos do interior possuem características mais 
semelhantes aos das ocupações mais recentes, da Tradição Polícroma da Amazônia. Já as vasilhas V1 e V3 possuem características de pasta e forma semelhantes a algumas do sítio Ilha Dionísio, localizado a montante, e a vasilhas encontradas no rio Guaporé (acervo do Museu Estadual de Rondônia), que também apresentam um furo na base. A vasilha V2 possui também características tecnológicas semelhantes às encontradas na ocupação mais recente do sítio Ilha Dionísio. Portanto, estes dados reforçam a hipótese de Almeida (2013) de que o sítio é multicomponencial, diferente do que havia sido proposto por Miller (1992), e que a ocupação da Tradição Polícroma nesse local é muito mais recente do que este autor havia proposto. O aplique zoomorfo encontrado nesse sítio nitidamente se diferencia das características desta tradição, e parece bastante característico da tradição Borda Incisa ou Barrancóide. Voltaremos a tratar destas associações no próximo capítulo.

\subsection{Cerâmica do sítio Ilha São Francisco}

Foram triados 489 fragmentos da unidade E380600 N9013720 do sítio Ilha de São Francisco, dos quais foram analisados 196 diagnósticos, e em função das remontagens totalizam 162 fragmentos (gráfico 51). Apenas 70 fragmentos $(43,21 \%)$ da coleção estão bem conservados, sendo que nos demais ao menos uma das faces apresenta-se erodida ou com superfície ausente. Os materiais estão distribuídos entre a superfície e $100 \mathrm{~cm}$ de profundidade.

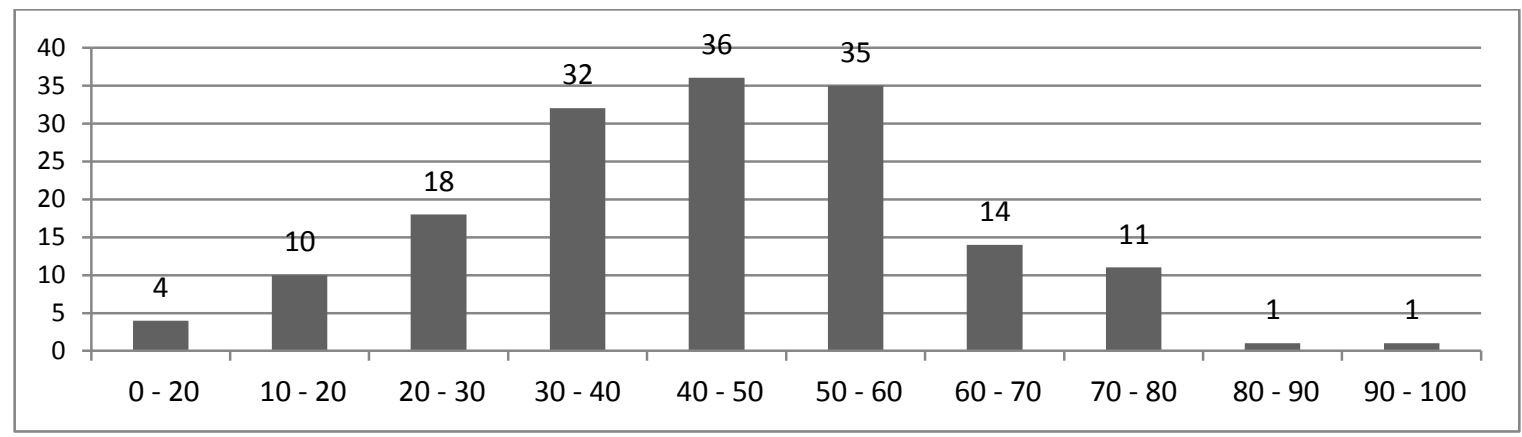

Gráfico 51: fragmentos analisados distribuídos nos níveis da unidade E380600 N9013720- Ilha São Francisco.

A pasta da maioria dos fragmentos apresenta mineral, caraipé e carvão, mas também ocorre o caraipé associado ao mineral, o cauixí, o mineral isolado e raramente outras associações (gráfico 52). Entre os minerais ocorre quartzo, óxido de Ferro e Feldspato. Todos os tipos de pasta ocorrem tanto nos níveis mais profundos quanto nos mais superficiais, com 
exceção da pasta com cauixí que aparece entre a superfície e o nível 40-50 cm (apenas um fragmento abaixo deste nível).

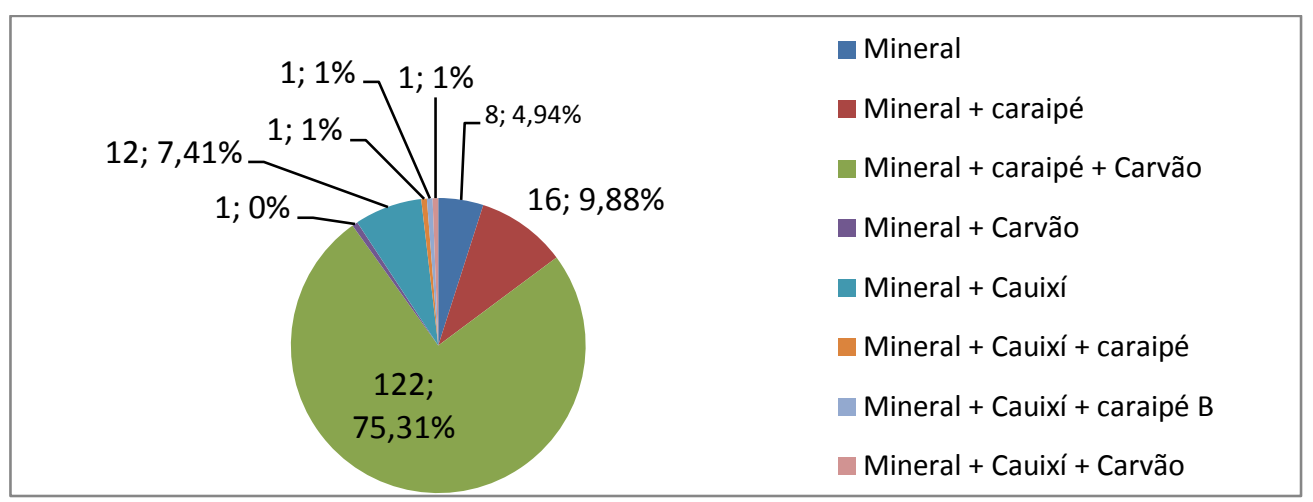

Gráfico 52: tipos de antiplástico- sítio Ilha São Francisco.

Predomina a técnica de confecção acordelada (148 fragmentos) e poucos fragmentos com a técnica modelada (8) ou não identificada (6). Predomina a queima reduzida (118; $72,84 \%)$, porém também ocorre queima oxidante $(21 ; 12,96 \%)$, oxidante externa e reduzida interna $(15 ; 9,26 \%)$; oxidante interna e reduzida externa $(4 ; 2,47 \%)$; oxidante com núcleo reduzido $(3 ; 1,85 \%)$ e reduzida com núcleo reverso $(1 ; 0,62 \%)$. A queima oxidante é mais frequente entre 0-10 e 40-50 cm, enquanto a queima reduzida ocorre em maior quantidade abaixo de 30-40 cm, apesar de ambas estarem presentes em toda estratigrafia.

As superfícies das vasilhas são bem alisadas ao menos em uma das faces (alisamento fino), além de ocorrer o alisamento médio e polimento e raramente a brunidura e o alisamento grosseiro (gráfico 53). A barbotina foi identificada em 82 fragmentos, sendo em 37 (22,84\%) em ambas as faces, $24(14,81 \%)$ na face externa e $21(12,96 \%)$ na face interna; em 46 fragmentos (28,40\%) não foi identificada e em 34 (20,99\%) está ausente. O engobo ocorre em 10 fragmentos nas seguintes cores: Vermelho FE (5); Vermelho AF (2); vermelho FI (2), laranja AF (1) e não identificado ou com decoração vestigial (2) (figura 146).

Ocorre pintura branca e vermelha em apenas um fragmento de parede do nível 20-30 cm (pasta com cauixí). Já os tratamentos plásticos são mais frequentes: inciso FE (3 fragmentos/ 20-30 a 40-50 cm), inciso FI (2 fragmentos/ 40-50 e 60-70 cm), apliques FE (2 fragmentos/30-40 e 50-60 cm) e modelado FI (1 fragmento/30-40 cm). Os apliques são representações zoomorfas, ao menos um deles que está mais preservado (figura 146). 


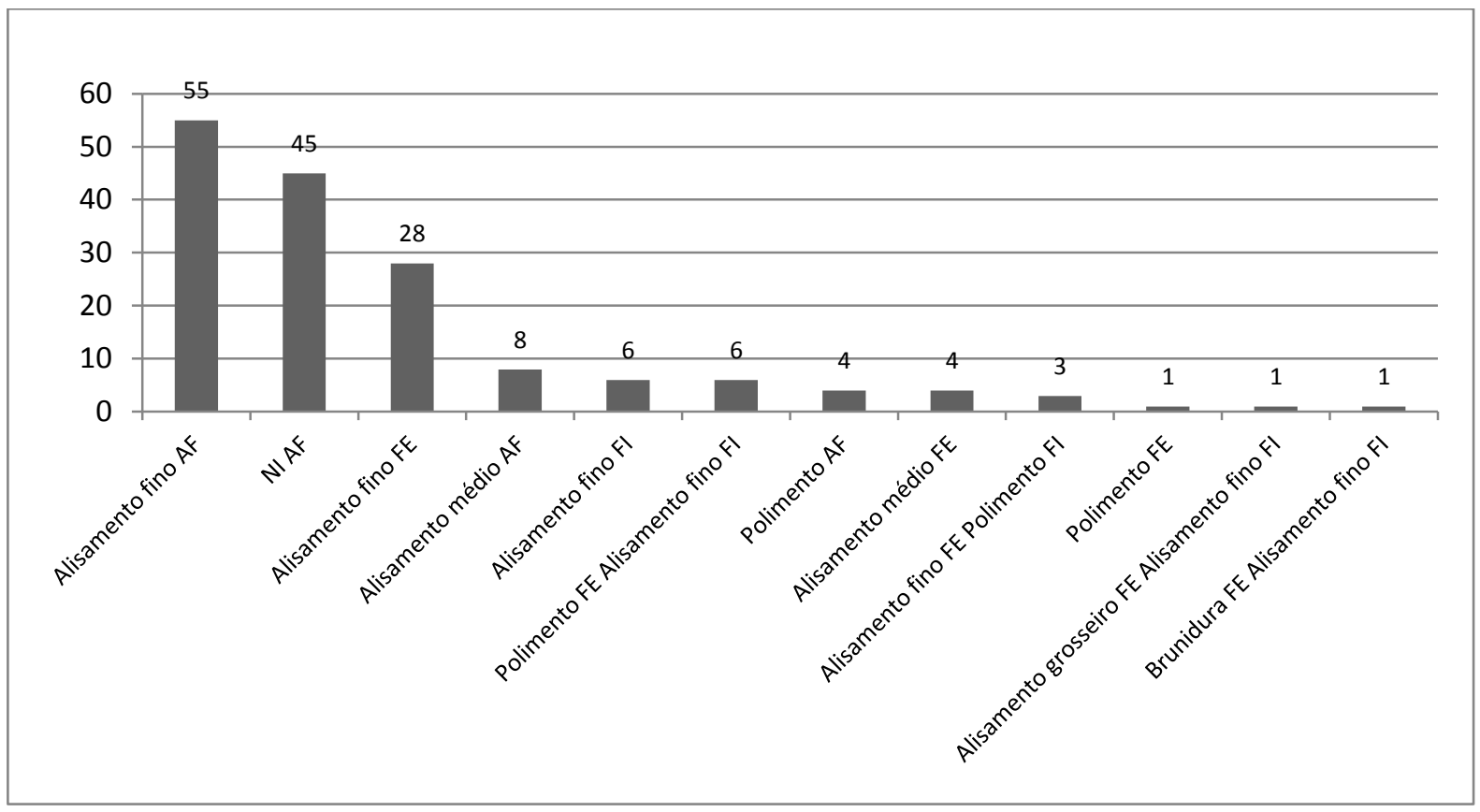

Gráfico 53: acabamentos de superfície - Ilha São Francisco

Entre as partes da vasilha, ocorrem inflexões (84), parede (33), bordas (27), base (16), bojo (1) e um fragmento não identificado. A espessura dos fragmentos varia entre 4 e $20 \mathrm{~mm}$, predominando aqueles entre 5 e $11 \mathrm{~cm}$ (gráfico 54). Todos os fragmentos mais espessos (mais de $12 \mathrm{~mm}$ de espessura) estão entre a superfície e 40-50 cm, apenas um sendo de 5 nível 50$60 \mathrm{~cm})$.

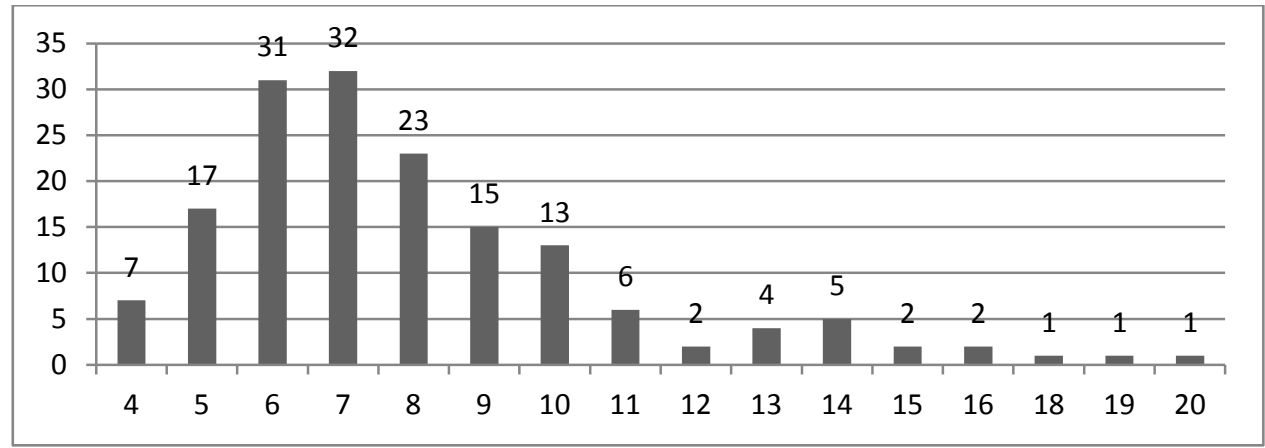

Gráfico 54: espessura dos fragmentos- - Ilha São Francisco.

Entre as bordas 5 são extrovertidas, 3 diretas inclinadas externamente e duas diretas verticais; das outras (17) não foi possível aferir a forma e inclinação. Com relação ao espessamento, são lineares (13), contraídas (8) e expandidas (3), não sendo identificado em três. Os lábios são arredondados (17), apontados (6), biselado (1) e não identificado (1). Foi possível medir o diâmetro de apenas três bordas de 10, 14 e $30 \mathrm{~cm}$ (figura 145). As bordas 
expandidas são dos níveis 20-30 e 30-40 cm, as contraídas do 30-40, 40-50 e 60-70 cm, e as lineares ocorrem entre $10-20$ e $80-90 \mathrm{~cm}$.

As bases são convexas côncavas (6), bi-planas (3), anelares (2), plano côncava (1) ou não identificada (4). Foi possível medir o diâmetro de sete delas, sendo $5 \mathrm{~cm}$ (1), $8 \mathrm{~cm}$ (4), 10 cm (1), $12 \mathrm{~cm}$ (1). As anelares e bi-planas medem $8 \mathrm{~cm}$ enquanto as convexas côncavas tem maior variação.Foi evidenciado depósito de carbono em um fragmento e fuligem em 11 fragmentos, todos com pasta de mineral, caraipé e carvão.

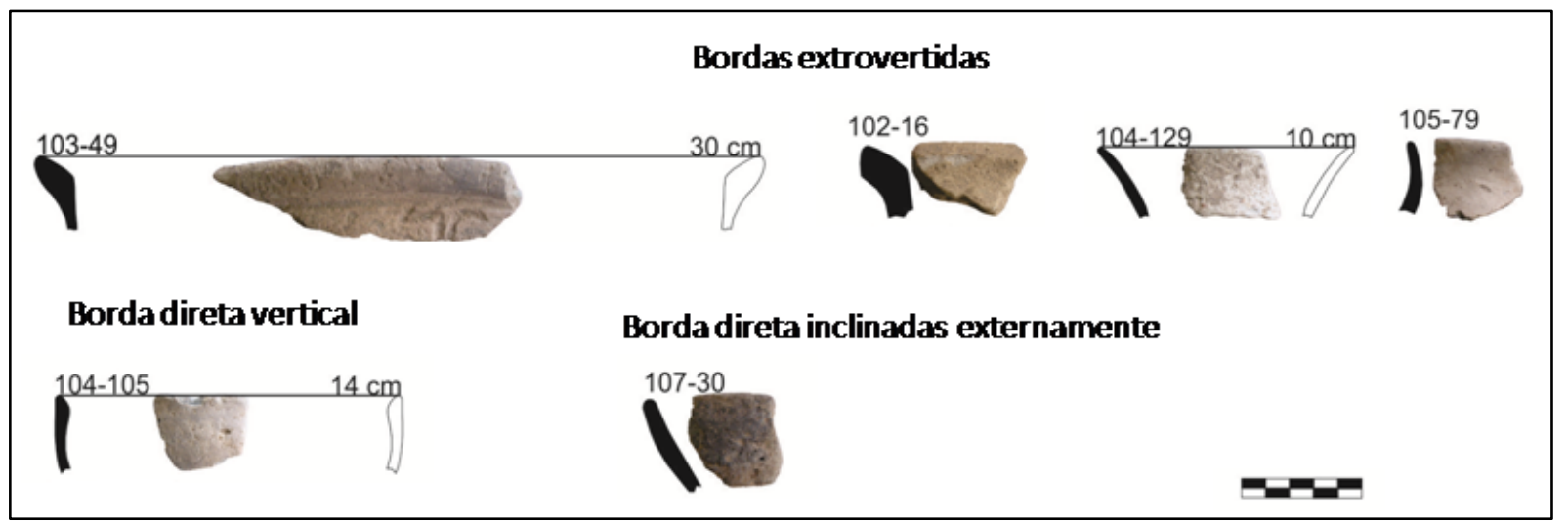

Figura 145: desenho das bordas - Ilha São Francisco (Algislaine F. Costa, 2013).

O tamanho da amostra, somado a fragmentação do material (poucas bordas desenhadas) e a falta de datações, dificulta a interpretação da variabilidade cerâmica nesse sítio. A cerâmica predominante nesta unidade é constituída por vasilhas confeccionadas com adição de caraipé na pasta, queima predominante reduzida, com alisamento fino ou polimento (mesmo que as superfícies sejam mais ou menos irregulares), paredes finas (entre 4 e $12 \mathrm{~mm}$ ), presença de engobo vermelho, decoração incisa na face interna da borda, lábio modelado (ondulado), apliques zoomorfos, vasilhas infletidas (ausência de carenas e de flanges), bordas contraídas e lineares, bases convexas côncavas, plano côncavas e anelares. Esta cerâmica é predominante nos níveis mais profundos $(40-50 \mathrm{~cm}$ a $90-100 \mathrm{~cm})$. Já nos níveis mais superficiais ocorrem fragmentos de vasilhas predominantemente com cauixí na pasta, queima oxidante mais frequente, paredes mais espessas (13 a $20 \mathrm{~mm}$ ), menor frequência de decorações plásticas e engobo vermelho e presença de bordas com espessamento linear e expandido. A diferenciação destas duas cerâmicas torna-se mais evidente se compararmos os dados de análise dos sítios Ilha das Cobras e Ilha do Japó, dos quais falaremos a seguir, semelhantes ao do sítio da Ilha São Francisco. 


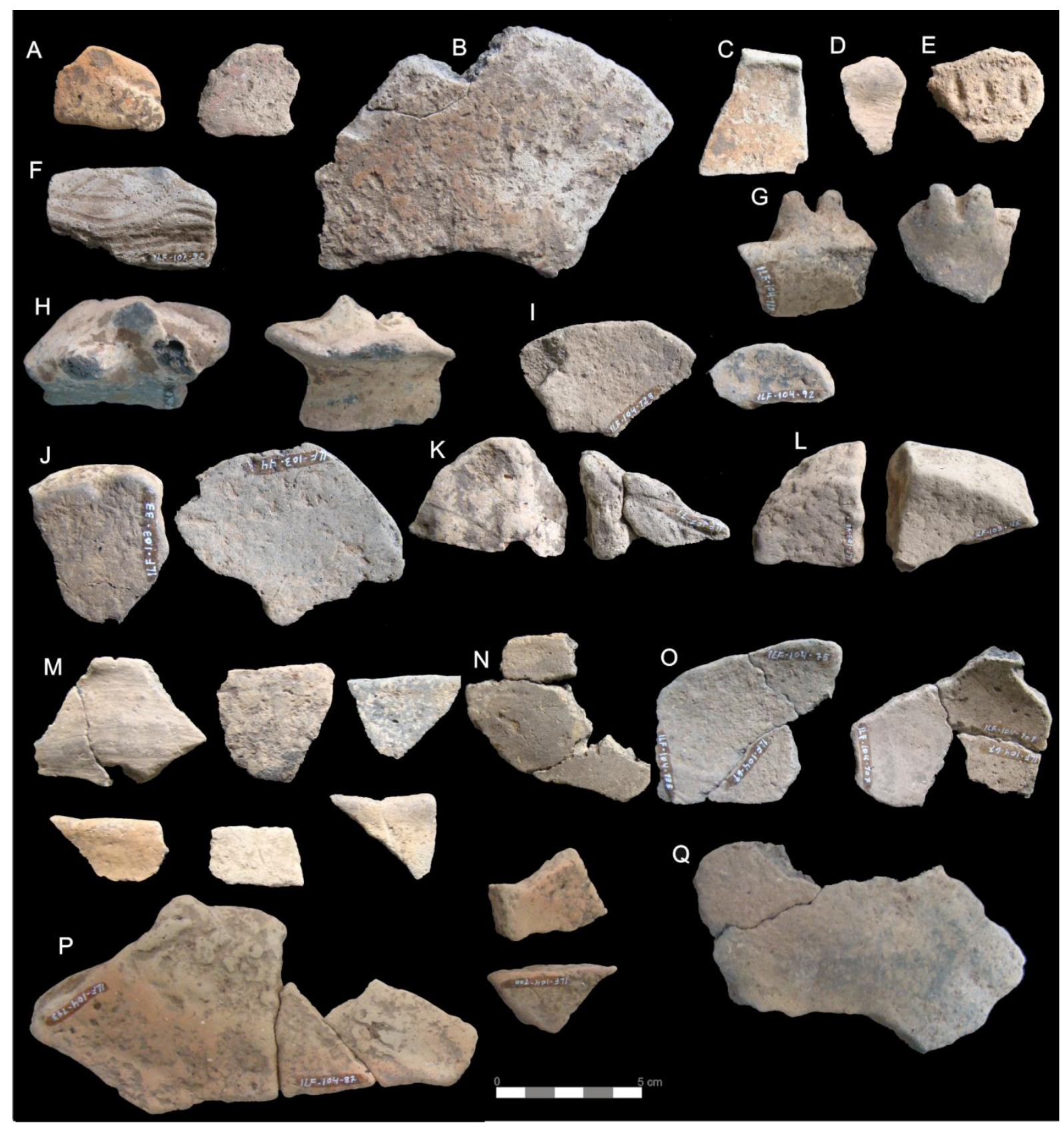

Figura 146: pintura e engobo vermelho (A, B, C); lábio modelado (D); ponteado (E); inciso (F); apliques zoomorfos $(G, H)$; bases com caraipé na pasta $(I, J)$; bases com cauixí $(L)$; possíveis bases de assador (K); bordas e bojo com caraipé (M, N, O, Q); inflexão com cauixí (P) (Fotos: SCIENTIA, 2013).

\subsection{Cerâmica do sítio Ilha das Cobras}

Foram analisados todos os fragmentos (não somente os diagnósticos) coletados na unidade E376500 N9006380, porque muitos fragmentos de níveis diferentes remontaram, e também pela baixa frequência de cerâmica nesta unidade, totalizando 351 fragmentos cerâmicos, e com as remontagens esse númetro diminui para 238 fragmentos de vasilhas, além de dois fragmentos de artefato não identificado (um deles pode ser uma trempe), distribuídos entre os níveis 0-10 e 100-110 cm (gráfico 55). 


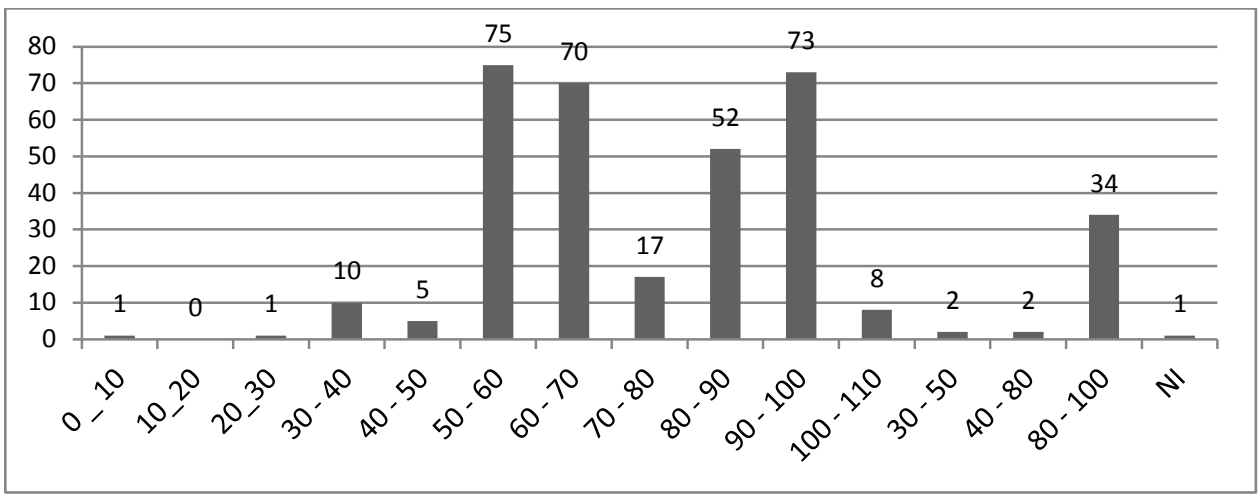

Gráfico 55: frequência de fragmentos por nível - unidade E376500 N9006380, Ilha das Cobras.

De acordo com o gráfico acima e com as informações de campo, sugerimos que poderia haver uma ocupação mais recente representada pelo material encontrado em superfície, e outras duas ocupações representadas pela alta frequência de material em duas profundidades da estratigrafia: entre $30-40 \mathrm{~cm}$ e $70-80 \mathrm{~cm}$; e entre $80-90 \mathrm{~cm}$ e $100-110 \mathrm{~cm}$. Com relação ao material de superfície, não será possível explorar neste trabalho, mas buscaremos verificar se o sítio possui mais de uma ocupação, representadas por diferentes tecnologias cerâmicas. A maior parte dos fragmentos encontra-se bem conservada.

Na pasta dos 351 fragmentos analisados predomina a ocorrência de mineral, caraipé e carvão $(151 ; 63,45 \%)$, mineral e caraipé $(46 ; 19,33 \%)$, mineral e cauixí $(26 ; 10,92 \%)$, mineral (13; 5,46\%), além de um fragmento com mineral, cauixí e carvão e um fragmento com mineral e carvão. Entre os minerais são recorrentes os minerais quartzo, óxido de Ferro e feldspato, associados de diversas maneiras. Enquanto as cerâmicas cuja pasta apresenta mineral, caraipé e carvão estão presentes em todos os níveis, em proporções semelhantes, o cauixí ocorre somente entre 0-10 e 60-70 cm. Já o antiplástico mineral e o mineral e caraipé (sem carvão), ocorre apenas em fragmentos com maior profundidade, entre 50-60 e 100-110 $\mathrm{cm}$ (figura 147). 


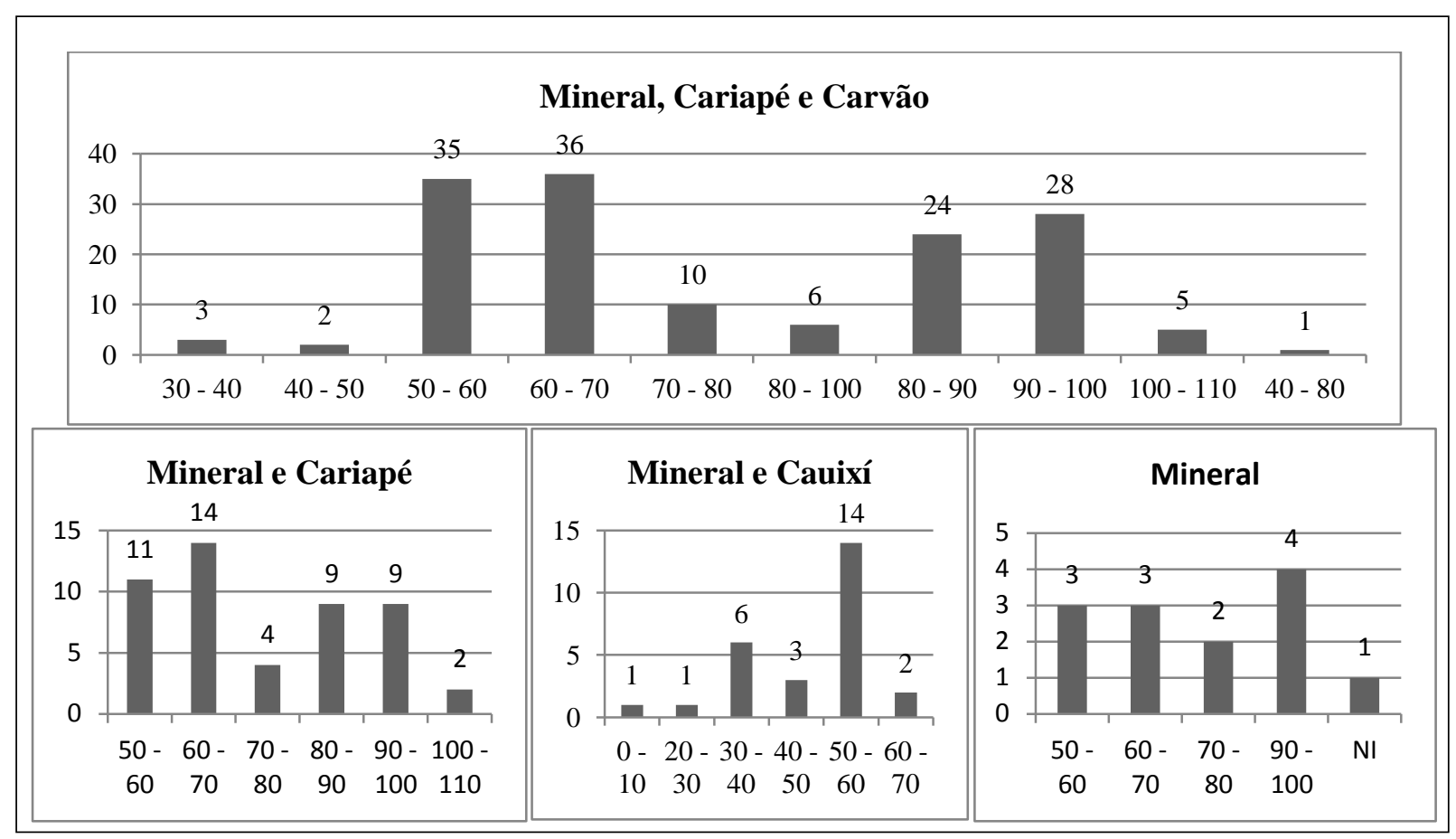

Figura 147: gráficos com a distribuição das pastas nos níveis-Ilha das Cobras.

As vasilhas eram confeccionadas com a técnica acordelada (228), sendo apenas dois fragmentos de base modelados e em oito não foi identificada. A queima reduzida é predominante $(154 ; 64,71 \%)$, seguida pela oxidante $(52 ; 21,85 \%)$, oxidante externa e reduzida interna $(14 ; 5,88 \%)$, oxidante interna e reduzida externa $(12 ; 5,04 \%)$ e oxidante com núcleo reduzido $(6 ; 2,52 \%)$. A queima oxidante é mais frequente entre os fragmentos com cauixí na pasta, e a reduzida nas pastas com caraipé.

As ceramistas alisavam cuidadosamente ou poliam as vasilhas, sendo poucos os fragmentos que apresentam alisamento médio ou grosseiro (gráfico 56). Ocorre engobo em apenas seis fragmentos, sendo laranja na face externa (3), vermelho em ambas as faces (1) e vermelho na face externa (2). Já pintura está presente em apenas um fragmento de borda com antiplástico de cauixí, feita em uma parte rebaixada e polida da peça.

Ocorre tratamento plástico em nove fragmentos: roletado em um fragmento de borda (nível 60-70 cm); um fragmento com ponteado $(70-80 \mathrm{~cm}$ ) que parece representar uma figura (dois ponteados menores representam olhos); duas vasilhas com aplique figurativo zoomorfo e incisões (níveis 90-100 e 80-100); um aplique na FE, cuja fragmentação prejudica a visualização, mas poderia se tratar de um aplique figurativo (olhos); e um fragmento com incisões $(50-60 \mathrm{~cm})$, que poderia compor a vasilha com aplique e inciso associado. Todos os fragmentos com tratamentos plásticos estavam nos níveis mais profundos (entre 60 e $100 \mathrm{~cm}$ ). 


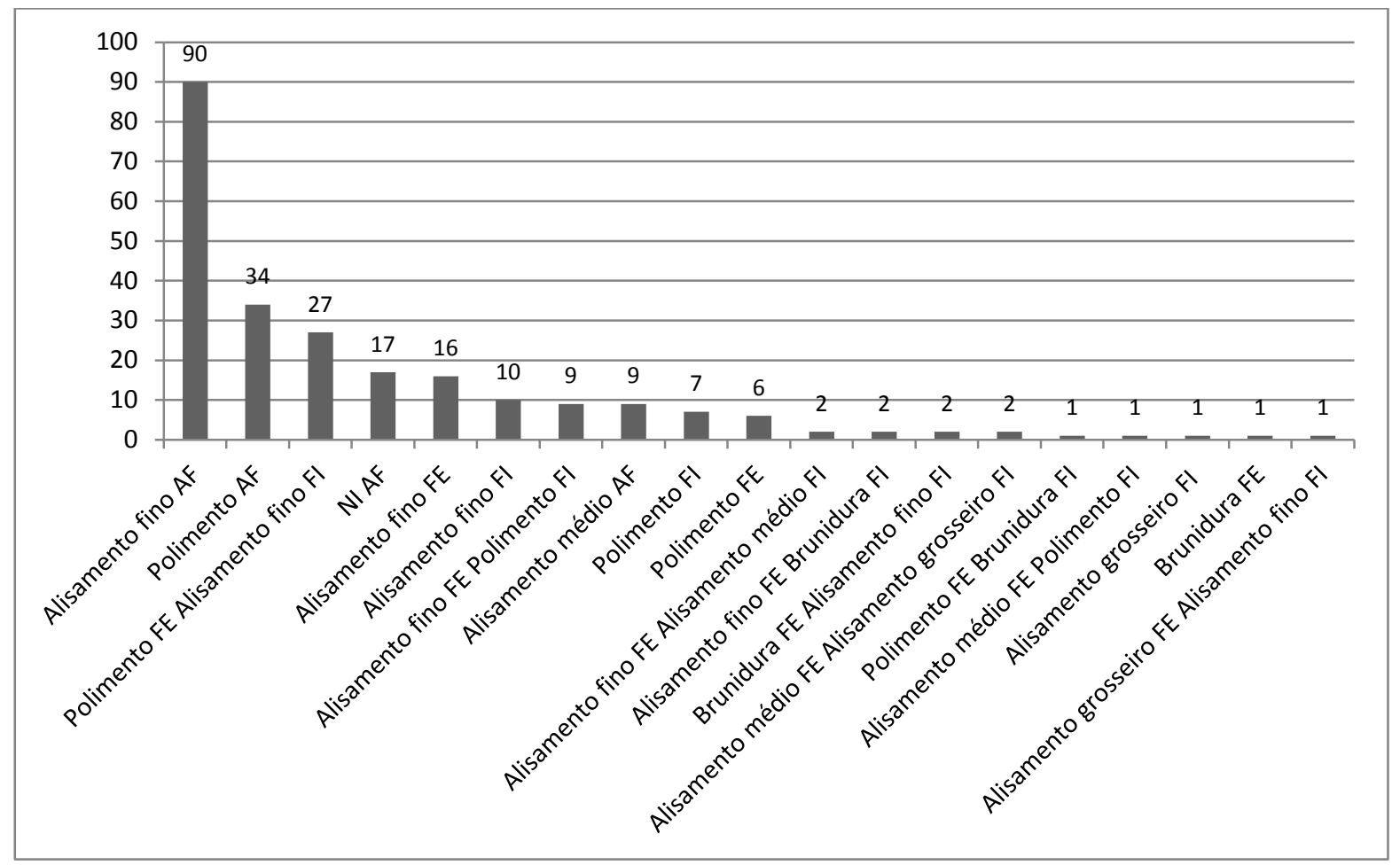

Gráfico 56: acabamentos de superfície das vasilhas -Ilha das Cobras.

Predominam os fragmentos de parede (143), seguidos pelos de inflexão (57), borda (23), base (6) e bojo (3). Uma vasilha foi remontada parcialmente, possuindo a borda e o bojo, e alguns fragmentos não foram identificados em relação à parte da vasilha (5). Neste sítio estão ausentes as flanges. A espessura varia entre 2 e $17 \mathrm{~cm}$, porém predominam fragmentos com espessura entre 5 e $10 \mathrm{~cm}$ (gráfico 57).

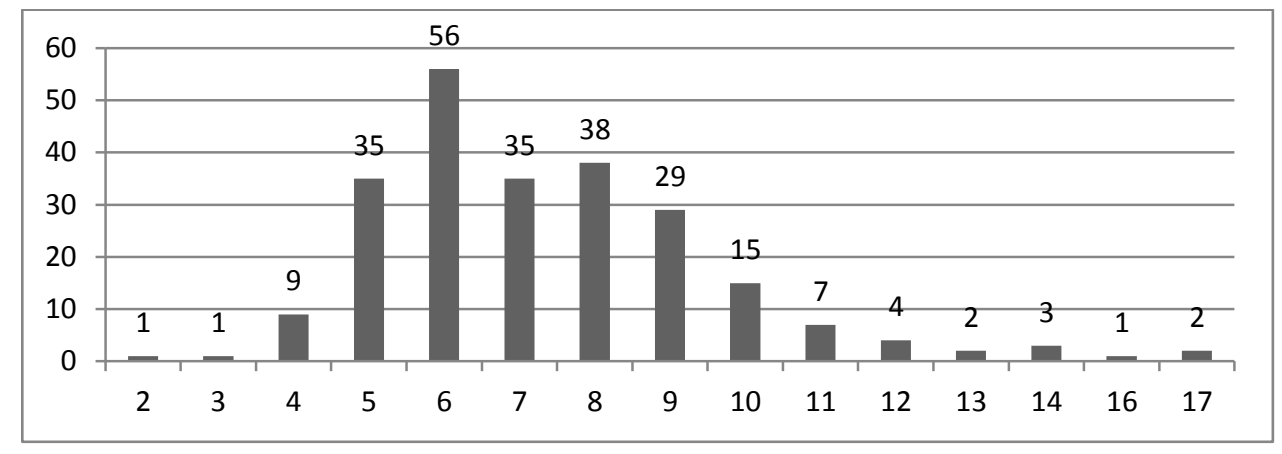

Gráfico 57: espessura dos fragmentos cerâmicos.

Entre as bordas, predominam as extrovertidas (11), apenas duas são diretas inclinadas externamente e duas inclinadas internamente e nas demais não foi possível visualizar a inclinação (9). Em relação ao espessamento, ocorrem as lineares (11), contraídas (5), expandida (4) e não identificada (4). A maioria possui lábio arredondado (11) e apontado (3), 
sendo um não identificado. Foi possível medir o diâmetro de cinco bordas, sendo duas de 12 $\mathrm{cm}$, uma de $13 \mathrm{~cm}$, uma de $16 \mathrm{~cm}$ e uma de $28 \mathrm{~cm}$. Entre as seis bases identificadas, duas são convexas côncavas ( $8 \mathrm{~cm}$ e $12 \mathrm{~cm}$ de diâmetro) e das demais não foram identificadas a forma e o diâmetro (figura 148). O depósito de carbono está presente em cinco bases e uma parede que também possui fuligem na FE. A fermentação foi identificada um bojo e em uma inflexão. As bases com fuligem e depósito de carbono são convexas côncavas ou de forma não identificada, e uma borda com fuligem é extrovertida. Entre os fragmentos de artefato não identificados, ocorre uma possível trempe no nível 30-40 cm.

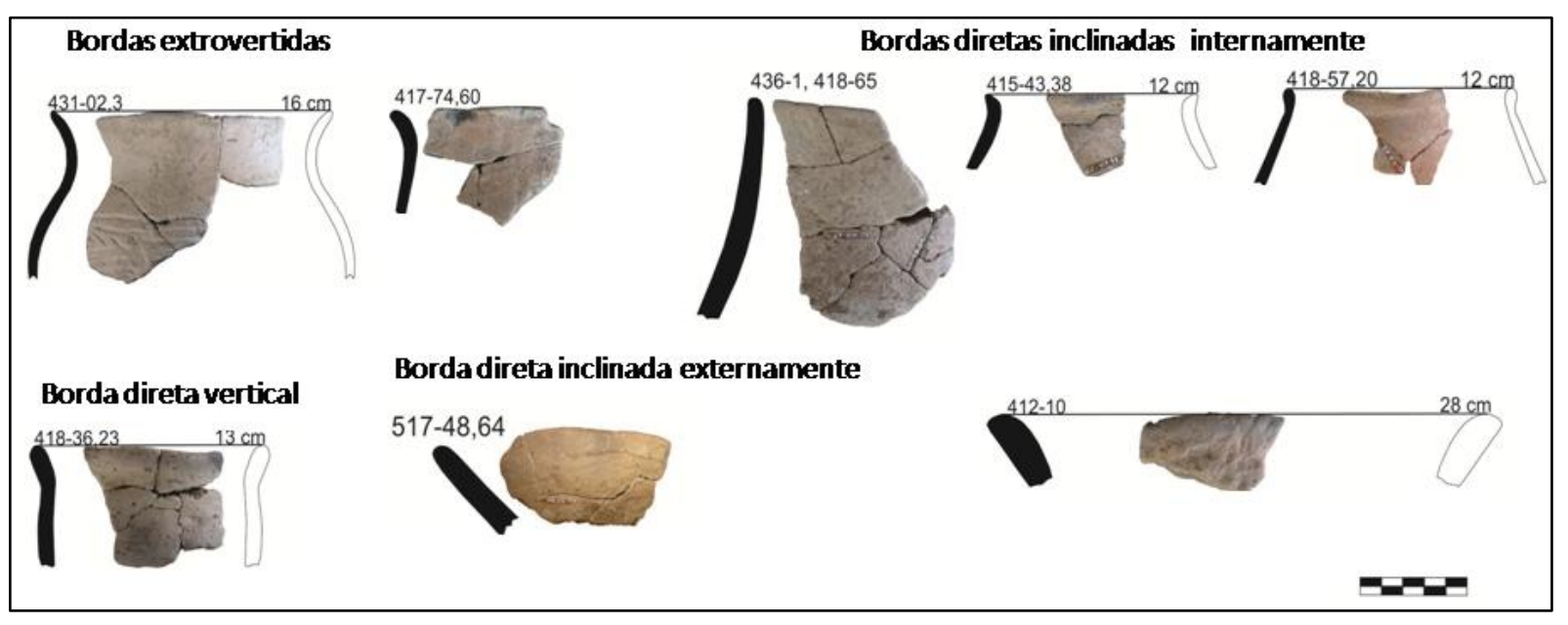

Figura 148: desenhos das bordas - sítio Ilha das Cobras (Angislaine F. Costa, 2013)

A análise dos atributos confirmou a hipótese inicial, de que o sítio teve ao menos duas ocupações ceramistas, representadas por conjuntos tecnológicos distintos. Entre as bordas desenhadas, a maioria é da camada de ocupação mais profunda, com exceção da 412-10 que é do nível 30-40 cm, com cauixí na pasta. Observou-se que o conjunto mais antigo é caracterizado pela pasta com adição de caraipé, queima reduzida mais frequente, predomínio de vasilhas bem alisadas ou polidas, acabamentos plásticos ponteados (possivelmente figurativos), roletado, apliques figurativos zoomorfos, associados a incisões, e presença de engobo vermelho (figura 149). O conjunto tecnológico mais recente, evidenciado nos níveis mais superficiais possui vasilhas com cauixí na pasta (o caraipé parece ter sido utilizado concomitantemente), queima predominantemente oxidante, ausência de tratamentos plásticos e presença de trempes (figura 150). Tais características do contexto arqueológico e da cerâmica se assemelham muito ao sítio Ilha São Francisco e Ilha do Japó, o qual será abordado na sequência. 


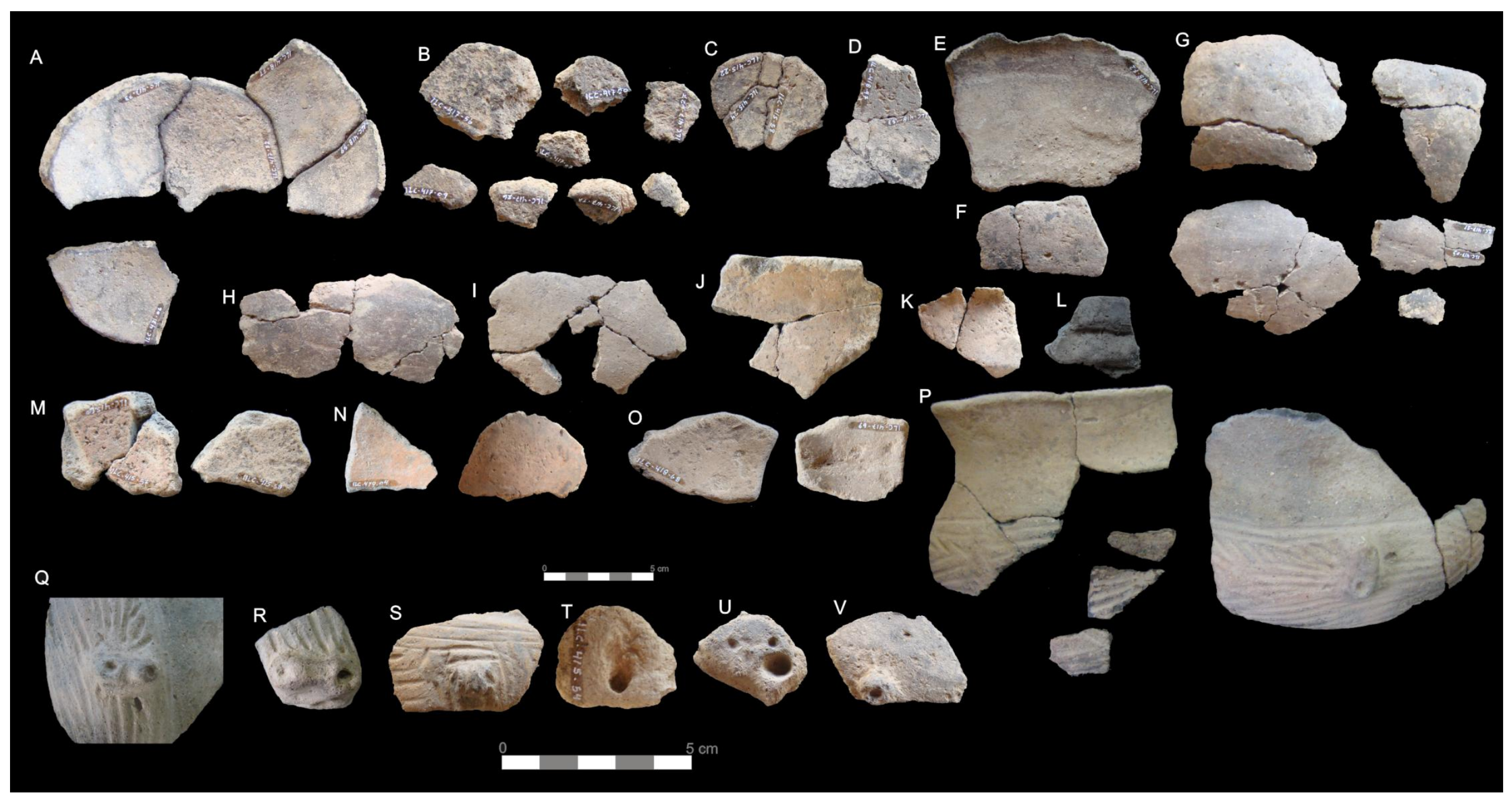

Figura 149: fragmentos da ocupação mais antiga: bases (A- E); bojos (G, H, I); bordas (J, K); engobo vermelho (M, N); inflexões (O), tratamento roletado (L); fragmentos de vasilha infletida com dois apliques zoomorfos e incisos $(\mathbf{P})$ e detalhes dos apliques $(\mathbf{Q}, \mathbf{R})$; aplique zoomorfo (S); aplique (V) e possíveis representações zoomorfas (T, $U$ ). 


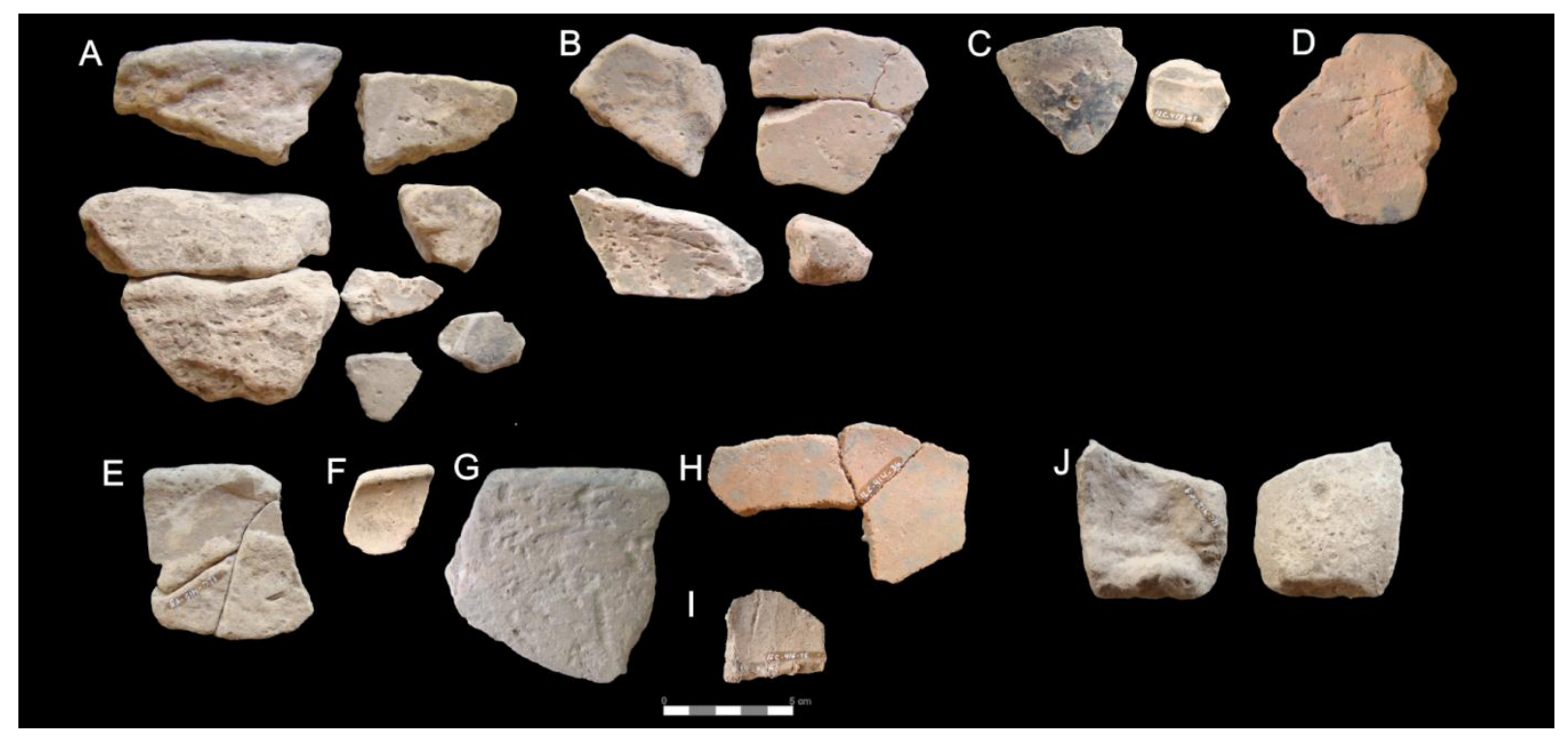

Figura 150: materiais da ocupação mais recente: pasta com cauixí (A-D e G); pintura vermelha (E); fragmentos com mineral (F, H); fragmento de trempe (J) (Fotos: SCIENTIA, 2013).

\subsection{Cerâmica do sítio Ilha do Japó}

Foram analisados 572 fragmentos diagnósticos da unidade E 367981 N 9001840, sendo uma trempe, dois não identificados que podem ser trempes e 469 de vasilha, que com as remontagens totalizam 439 fragmentos. Conforme mencionamos no capítulo 3, as escavações revelaram um contexto multicomponencial com ao menos dois conjuntos tecnológicos cerâmicos: um mais recente, entre a superfície e o nível $60-70 \mathrm{~cm}$ com fragmentos grandes e espessos, núcleo claro, bases de assador e em pedestal, engobo e pintura em faixa vermelha e presença de apêndices de suspensão. Um segundo conjunto, mais antigo, evidenciado a partir do nível $40-50 \mathrm{~cm}$, cujos fragmentos são menores e menos espessos, núcleo escuro, vasilhas fechadas com pescoço, flanges labiais e mesiais, decoração incisa, excisa, aplicada e engobo vermelho. Na unidade E367981 N9001840 ocorrem duas densidades de materiais, uma entre 0-10 e 40-50 cm e outra entre 50-60 e 90-100 cm. Algumas remontagens foram feitas com fragmentos de diferentes níveis. Nos níveis 40-50 e 50-60 cm foi escavada uma estrutura com fragmentos relacionados a ocupação mais recente no sítio.

Os fragmentos estão na maioria bem conservados em ambas as faces (332), porém alguns estão erodidos na face interna (46), em ambas as faces (29), na face externa (14) e outros estão com uma das superfícies ausentes (8) ou com decoração vestigial (10). Na pasta predomina a adição de caraipé e carvão, porém também ocorrem vasilhas com cauixí ou somente com mineral (gráfico 58). Vasilhas com mineral na pasta ou com mineral e cauixí 
predominam entre os níveis 0-10 cm e 50-60 cm, enquanto pastas com mineral e caraipé (e carvão) são mais frequentes nos níveis mais profundos, principalmente no $60-70$ e 70-80 cm.

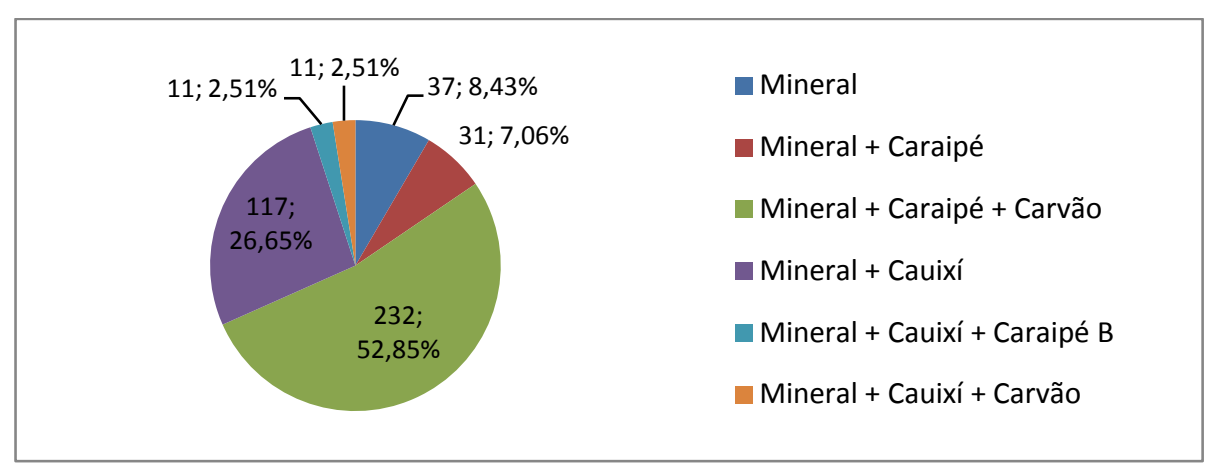

Gráfico 58: análise da pasta- Ilha do Japó

A queima reduzida é mais frequente $(228 ; 51,94 \%)$, seguida pela oxidante (157; $35,76 \%)$, oxidante externa e reduzida interna $(31 ; 7,06 \%)$, oxidante com núcleo reduzido (13; $2,96 \%)$, oxidante interna e reduzida externa $(9 ; 2,05 \%)$ e um fragmento com queima reduzida e núcleo reverso. A queima reduzida predomina entre os níveis $60-70$ e $80-90 \mathrm{~cm}$, enquanto a oxidante é mais frequente entre $0-10 \mathrm{~cm}$ e $50-60 \mathrm{~cm}$, assim como a oxidante externa e reduzida interna, oxidante interna e reduzida externa e oxidante com núcleo reduzido que também são mais frequentes nos níveis superiores. As vasilhas foram confeccionadas com a técnica acordelada $(400 ; 91,12 \%)$, com exceção de algumas bases que são modeladas $(25 ; 5$, $69 \%$ ), e em 14 fragmentos (3,19\%) não foi identificada. A barbotina ocorre em 191 fragmentos e está ausente em 248. Observamos que a barbotina ocorre predominantemente em vasilhas cuja pasta apresenta somente mineral ou com adição de caraipé, e raramente nas com cauixí.

As superfícies das vasilhas são em geral bem alisadas ou polidas, mas ocorrem poucos fragmentos com brunidura e alisamento médio (gráfico 59). O engobo está presente em apenas 27 fragmentos (6\%), em 405 (92\%) está ausente e em 7 (2\%) não foi identificado. Ocorre nas seguintes cores: vermelho FE (13), vermelho FI (3), branco FE (7), branco FI (1), laranja FE (2) e laranja FI (1). A maior parte dos fragmentos com engobo concentram-se nos níveis mais superficiais. A pintura está presente em apenas 13 fragmentos, somente na face externa, nas cores branca e vermelha (6), branca (2) e vermelha (5). A pintura branca e vermelha aparece nos níveis $10-20 \mathrm{~cm}$ a $30-40 \mathrm{~cm}$, a branca no $20-30$ e 70-80 cm e a vermelha entre os níveis $20-30$ e $80-90 \mathrm{~cm}$. 


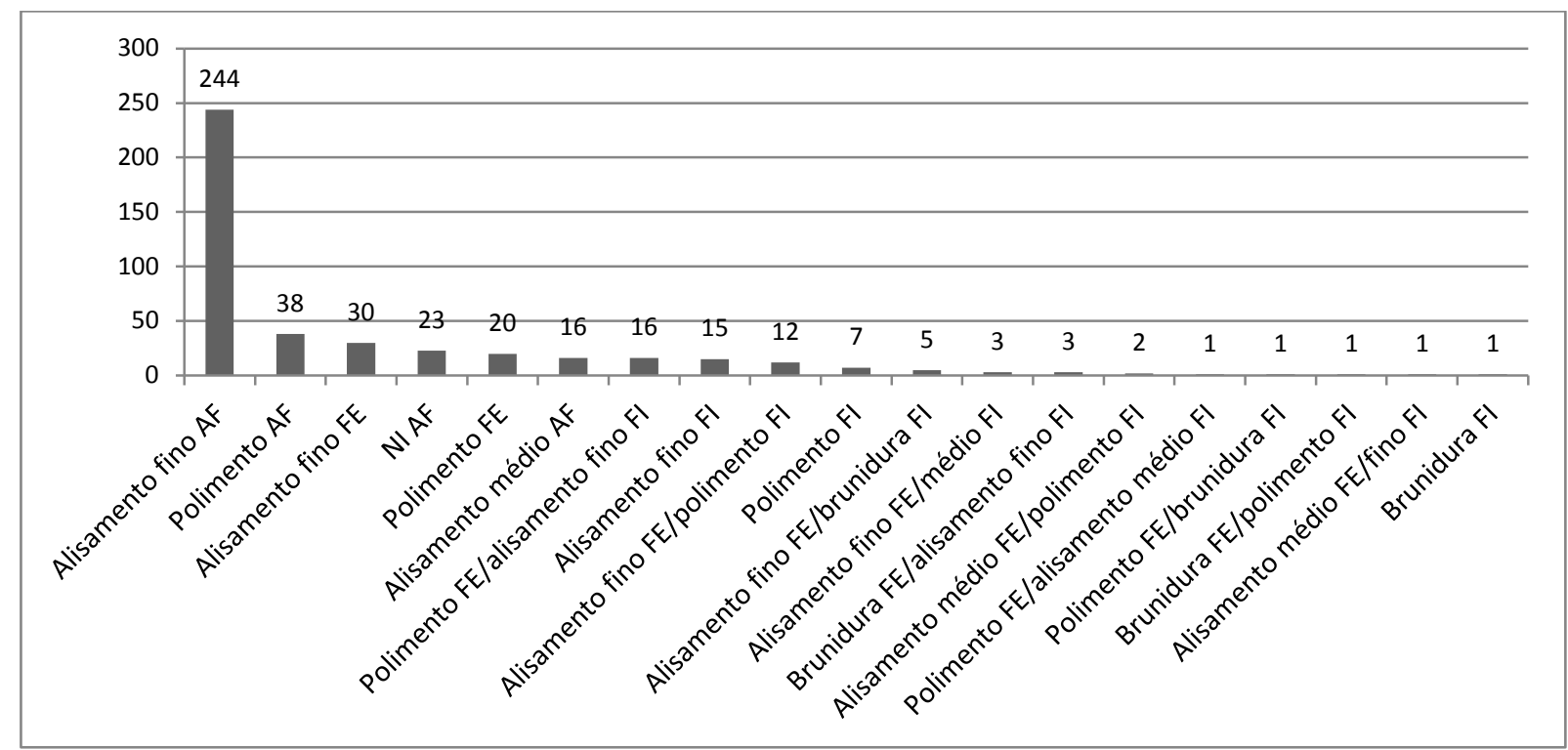

Gráfico 59: acabamentos de superfície -Ilha do Japó.

Apenas 23 fragmentos $(5,24 \%)$ apresentam tratamento plástico, sendo o inciso $\mathrm{FE}$ (14), inciso FI (1), inciso e ponteado FE (1), ponteado FE (1), roletado FE (2), acanalado FI (1), aplique FE (2) e modelado FI (1). As decorações plásticas são mais frequentes nos níveis mais profundos, entre 50-60 e 80-90 cm: incisões ocorrem entre o nível 20-30 e 80-90 cm, com maior frequência nos níveis mais profundos; os dois apliques são do nível $50-60 \mathrm{~cm}$ e 70-80 cm e o modelado é do nível 70-80 cm, assim como o inciso e ponteado e o acanalado; o roletado aparece no $20-30 \mathrm{~cm}$ e $50-60 \mathrm{~cm}$ (gráfico 60). Entre os motivos os mais comuns são as linhas horizontais (11), composto (5), angular (1) e figurativo (1), feitos na borda, inflexão, bojo, lábio e parede das vasilhas.

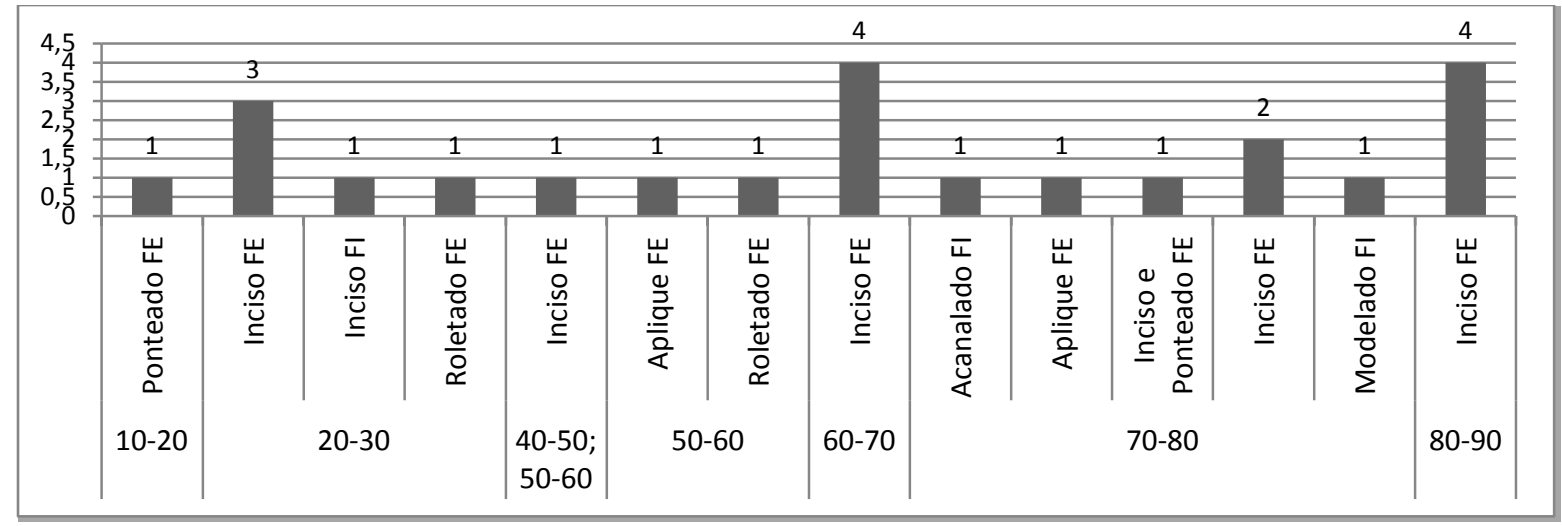

Gráfico 60: tratamentos plásticos nos níveis de escavação -Ilha do Japó. 


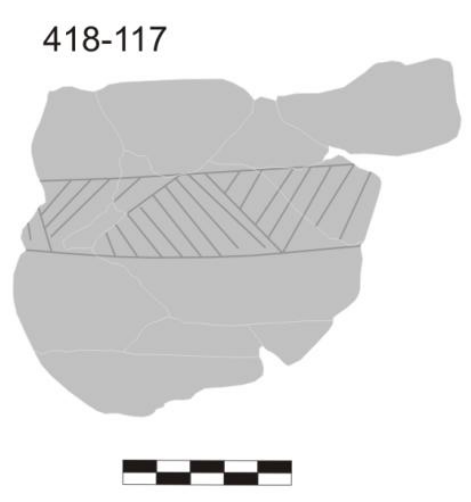

Figura 151: vasilha com decoração incisa (desenho: Angislaine F. Costa, 2013).

Foram analisados fragmentos de borda (157), inflexão (140), parede (84), base (40), bojo (9), pescoço (3), borda e bojo (2), borda e parede (1) e borda e inflexão (1). A espessura variou entre 4 e $29 \mathrm{~mm}$, com maior frequência entre 5 e $10 \mathrm{~mm}$ (gráfico 61). Todos os fragmentos com espessura igual e maior que $14 \mathrm{~mm}$ são dos níveis superiores (entre 0-10 e 60-70 cm), portanto esta é uma característica do material mais recente.

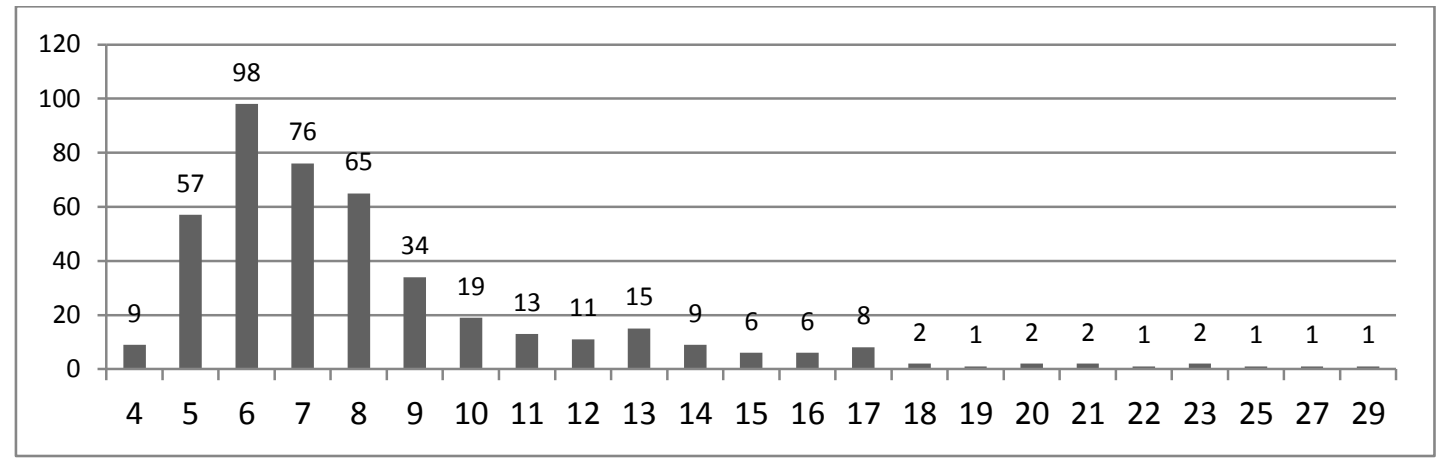

Gráfico 61: espessura dos fragmentos -Ilha do Japó.

Foi possível ver a forma e inclinação de 90 bordas $(55,9 \%)$, sendo mais frequentes as extrovertidas e diretas inclinadas externamente (gráfico 62). As bordas introvertidas e extrovertidas com ponto angular aparecem entre os níveis 10-20 e 40-50 cm, enquanto as diretas inclinadas externamente são do nível $60-70 \mathrm{~cm}$. As bordas extrovertidas e diretas inclinadas externamente ocorrem em todo o pacote arqueológico, sendo o primeiro tipo mais frequente no nível 20-30 cm e o segundo no nível 60-70 cm. Em relação ao espessamento, a maioria das bordas é linear $(72 ; 44,72 \%)$, seguidas pelas contraídas $(47 ; 29,19 \%)$, expandidas (26; 16,15\%), reforçadas internamente (2) ou não foi identificado (15;9,32\%). Bordas contraídas são mais frequentes nos níveis mais profundos e as expandidas nos níveis mais superficiais (gráfico 63). Os lábios são arredondados (120; 74,53\%), apontados $(24 ; 14,91 \%)$, planos $(12 ; 7,45 \%)$, irregulares $(4 ; 2,48 \%)$ e não identificado (1). Os lábios apontados e 
irregulares são mais frequentes nos níveis mais profundos, os planos nos níveis mais superficiais e os arredondados ocorrem em toda estratigrafia.

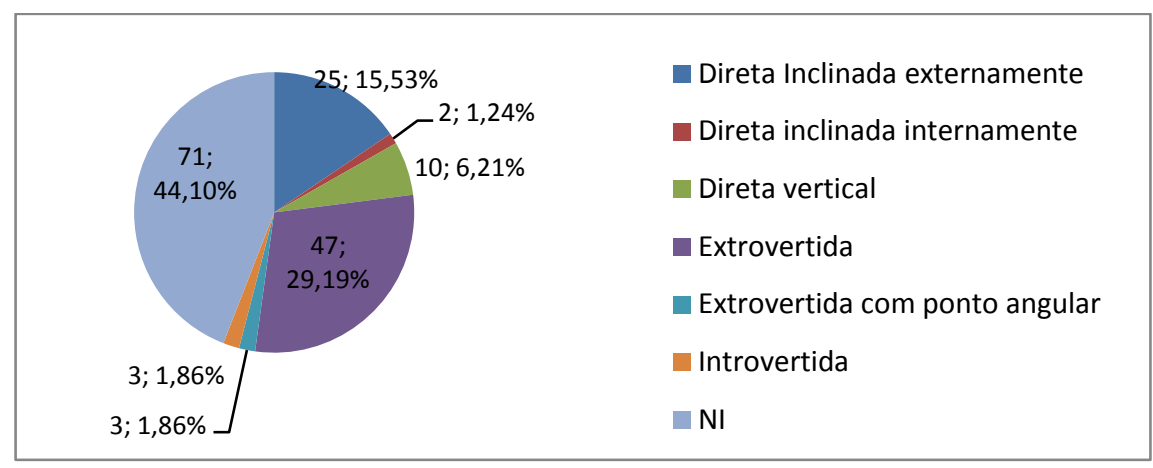

Gráfico 62: forma e inclinação das bordas - Ilha do Japó.

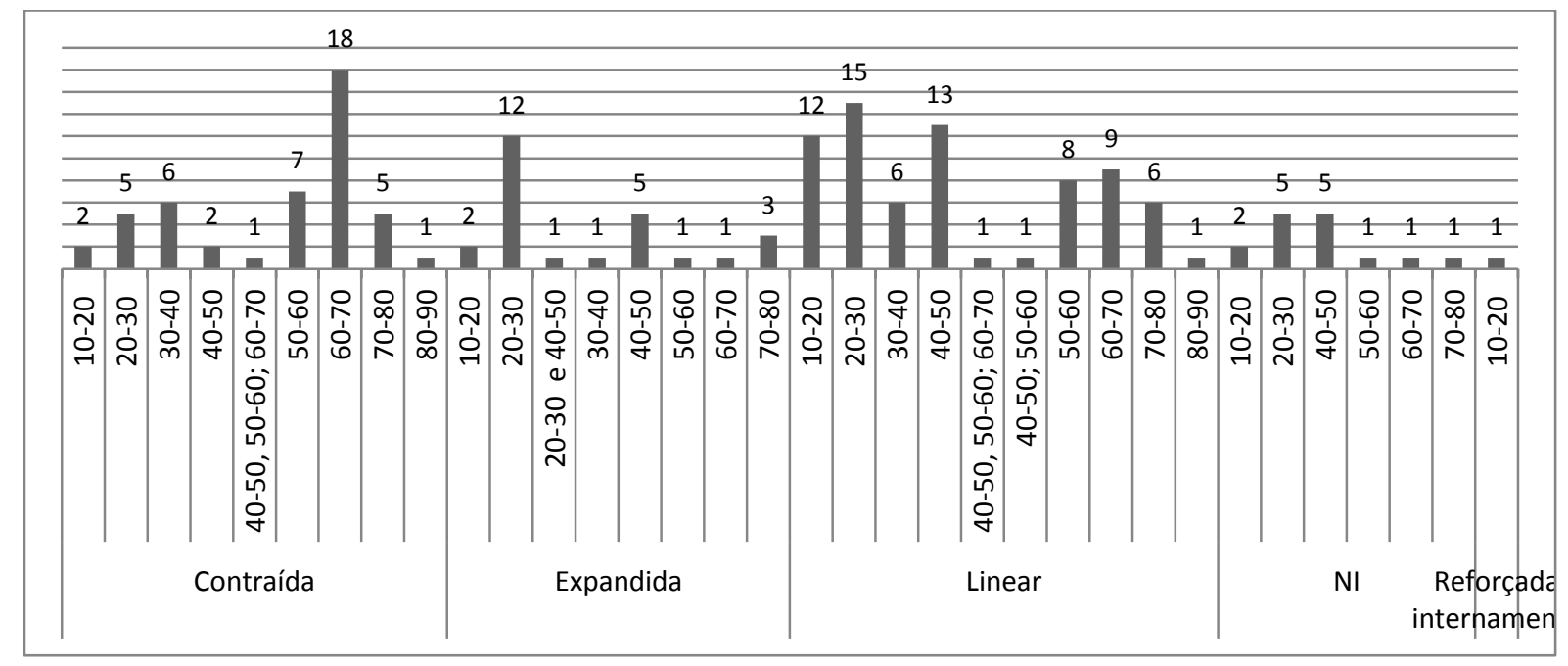

Gráfico 63: espessamento das bordas nos níveis de escavação -Ilha do Japó.

Foi possível medir o diâmetro de abertura de apenas 24 bordas, que varia entre $8 \mathrm{~cm}$ e $28 \mathrm{~cm}$ (gráfico 64). Porém, ocorrem vasilhas maiores no sítio, de paredes espessas, das quais não foi possível medir o diâmetro de abertura. Entre as bases, 16 (40\%) são convexas côncavas, $9(22,50 \%)$ são plano-côncavas, 9 (22,50\%) são bi-planas, 1 (2,50\%) é convexa côncava e 5 (12,50\%) não foram identificadas. O diâmetro varia entre $4 \mathrm{~cm}$ (2 bases), $6 \mathrm{~cm}$ (4), $8 \mathrm{~cm}$ (3), $10 \mathrm{~cm}$ (5) e $12 \mathrm{~cm}$ (2 bases). Nos níveis mais superficiais predominam bases convexas côncavas, enquanto nos níveis mais profundos predominam as plano-côncavas e biplanas. Marcas de uso foram identificadas em apenas 26 fragmentos, sendo três com depósitos de carbono, 4 com fermentação e 19 com fuligem. Além dos fragmentos de vasilha, foi analisada uma trempe e duas peças não identificadas, que possivelmente são fragmentos de trempe. 


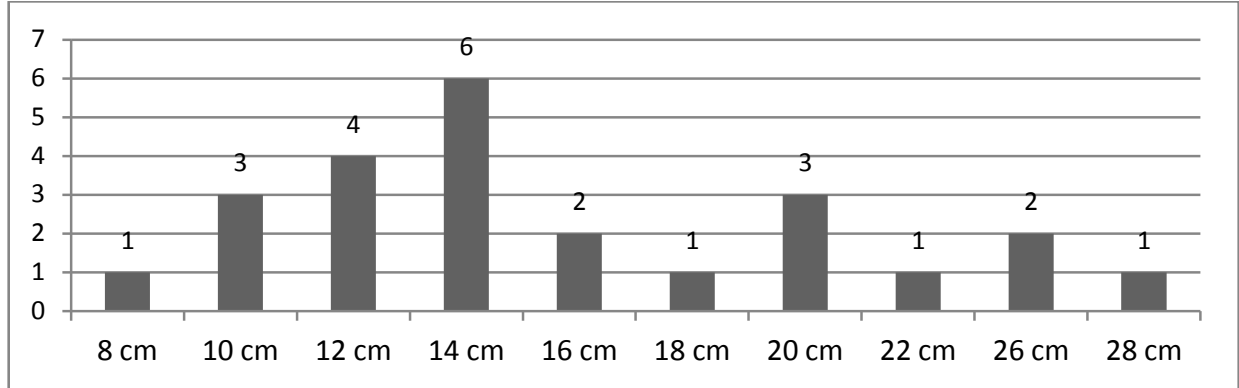

Gráfico 64: diâmetro de abertura das vasilhas.

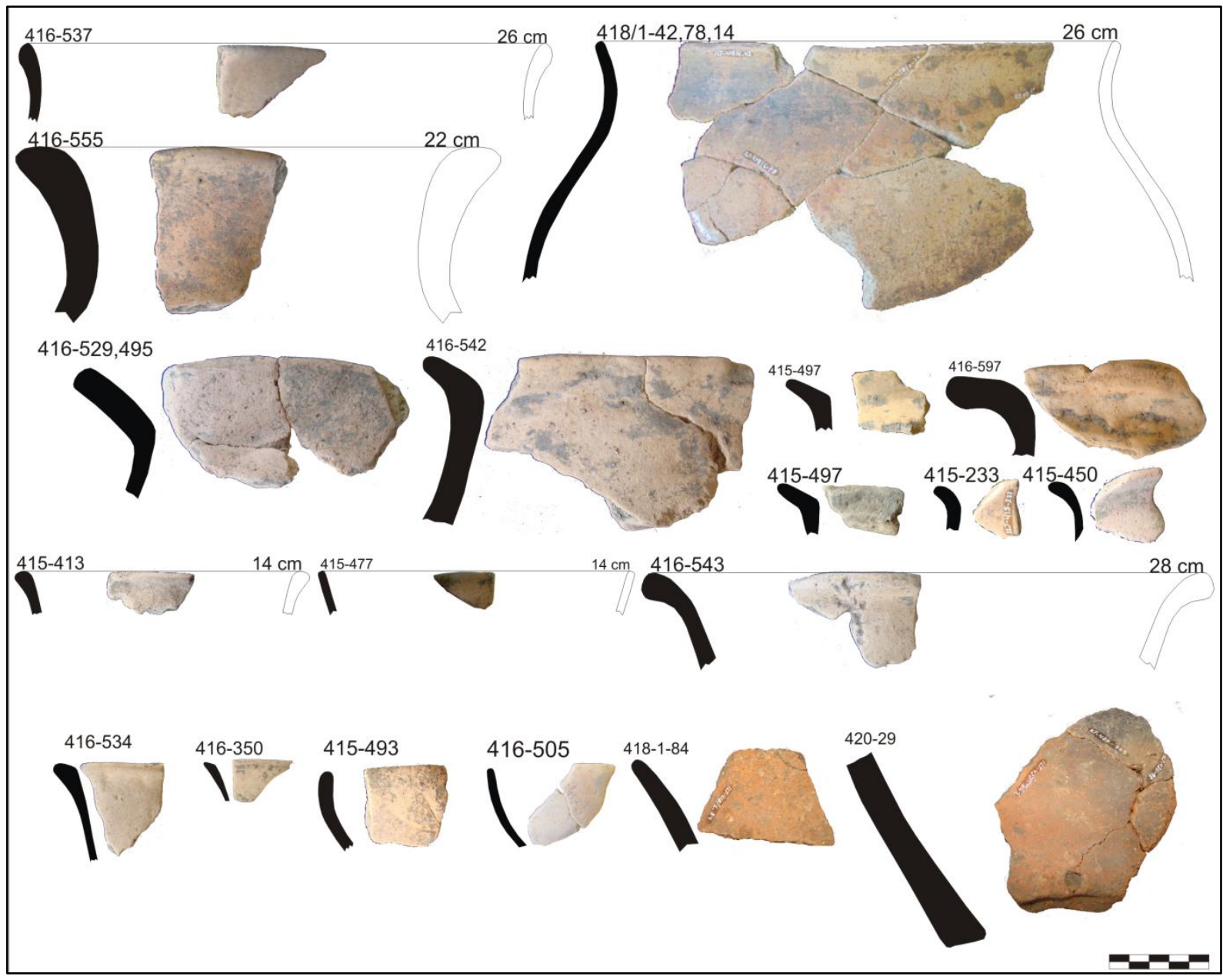

Figura 152: bordas do conjunto tecnológico mais recente 


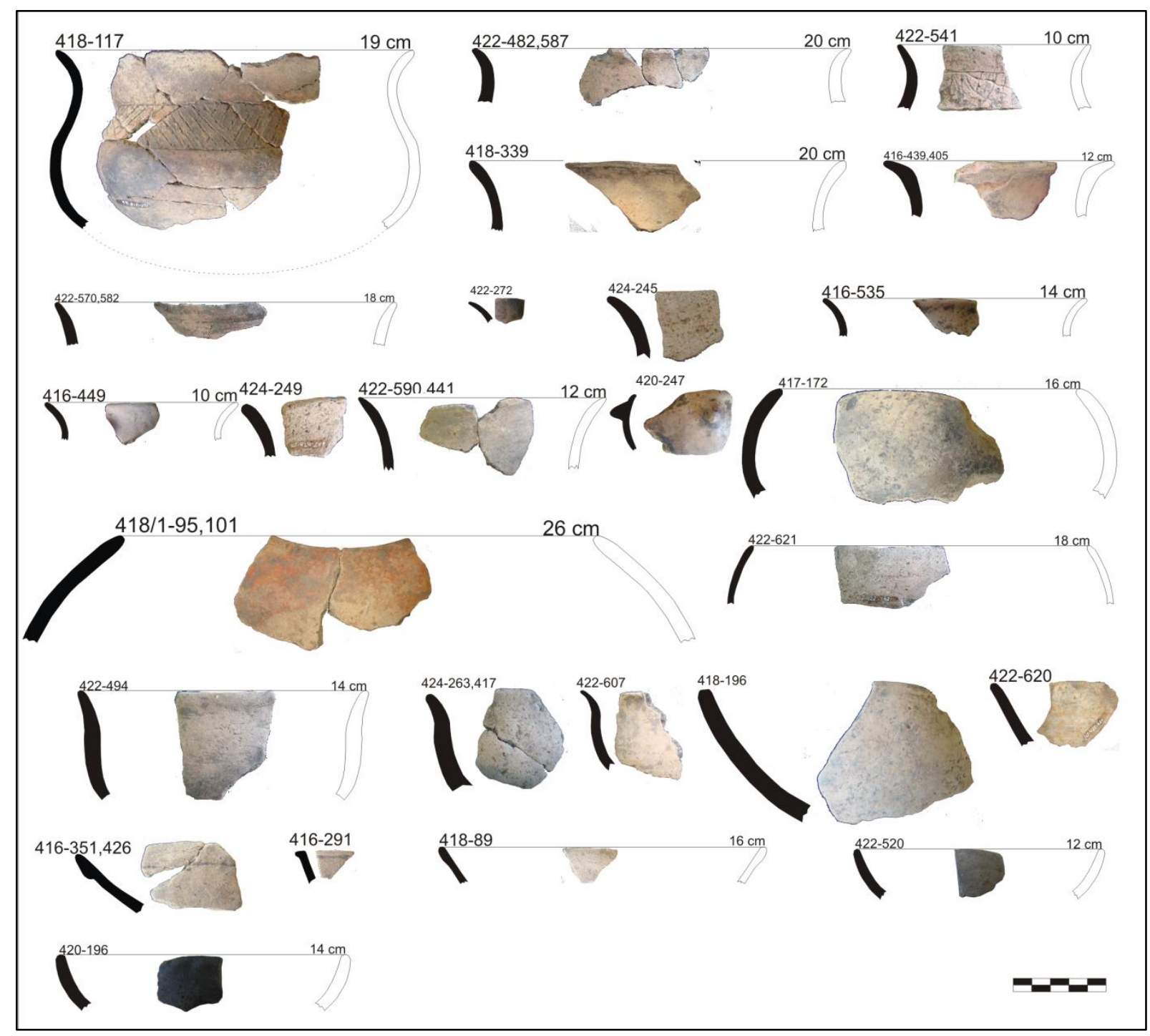

Figura 153: bordas do conjunto tecnológico mais antigo.

A análise conjunta de todos os atributos permitiu separar dois conjuntos tecnológicos diferentes, corroborando com a hipótese de campo. A cerâmica da ocupação mais antiga (50$60 \mathrm{~cm}$ a 80-90 cm, figura 155) é caracterizada pela pasta com adição de caraipé, queima predominantemente reduzida, vasilhas polidas e bem alisadas, tratamentos plásticos como o roletado, inciso (destaca-se uma vasilha com incisões obliquas que não se cruzam, em uma faixa delimitada próxima a borda, semelhante a uma vasilha do sítio Ilha de Santo Antônio), inciso e ponteado, lábio modelado e aplique (zoomorfo), sendo mais frequentes as vasilhas com bordas diretas inclinadas externamente e contraídas (apesar de ocorrer outras inclinações e espessamentos), bem como lábios apontados e irregulares, e as bases plano côncavas e biplanas. Também ocorre um fuso, e conforme já havíamos observado a partir da análise dos dados de campo, eles são frequentes nessa ocupação. Estas características se aproximam 
muito do material cerâmico mais antigo da Ilha das Cobras e Ilha São Francisco, bem como da cerâmica do sítio Ilha de Santo Antônio e Santa Paula, que associamos a tradição Barrancóide.

O conjunto mais recente $(0-10 \mathrm{~cm}$ a $50-60 \mathrm{~cm}$, figura 154) é constituído predominantemente por materiais cuja pasta apresenta cauixí ou somente mineral (apesar de continuar sendo utilizado o caraipé), queima predominantemente oxidante, maior frequência de engobo vermelho (possivelmente preservou-se mais) e raros tratamentos plásticos (incisos), vasilhas com as paredes mais espessas, ocorrência de bordas introvertidas e extrovertidas com ponto angular e bordas expandidas frequentes, e presença de lábios planos que são raros nos níveis mais profundos. Também ocorrem trempes, ausentes na cerâmica mais antiga, e estão ausentes os fusos. Este material assemelha-se aquele mais recente do sítio Ilha das Cobras e Ilha São Francisco, bem como do sítio Ilha Dionísio do qual trataremos em seguida.

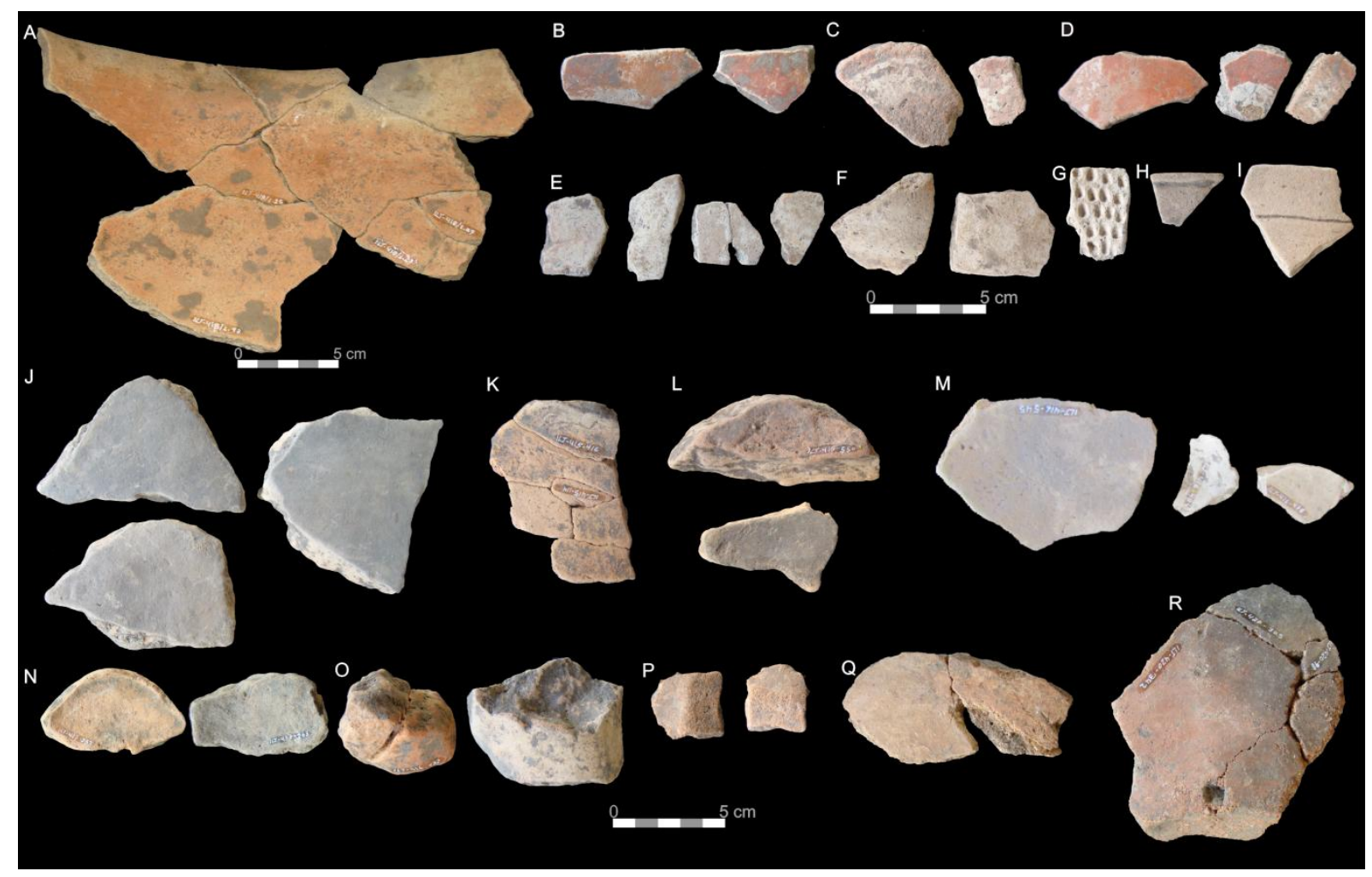

Figura 154: fragmentos da ocupação mais recente: engobo FI (A) e FE (B); pintura vermelha e branca (C, D); engobo branco (E, F); tratamento ponteado (G), e inciso (H, I); paredes (J, K, Q), bases (L, M, N, P); trempes $(O)$, e fragmentos de parede com mineral anguloso na pasta $(Q, R)$ (Fotos: SCIENTIA, 2013). 


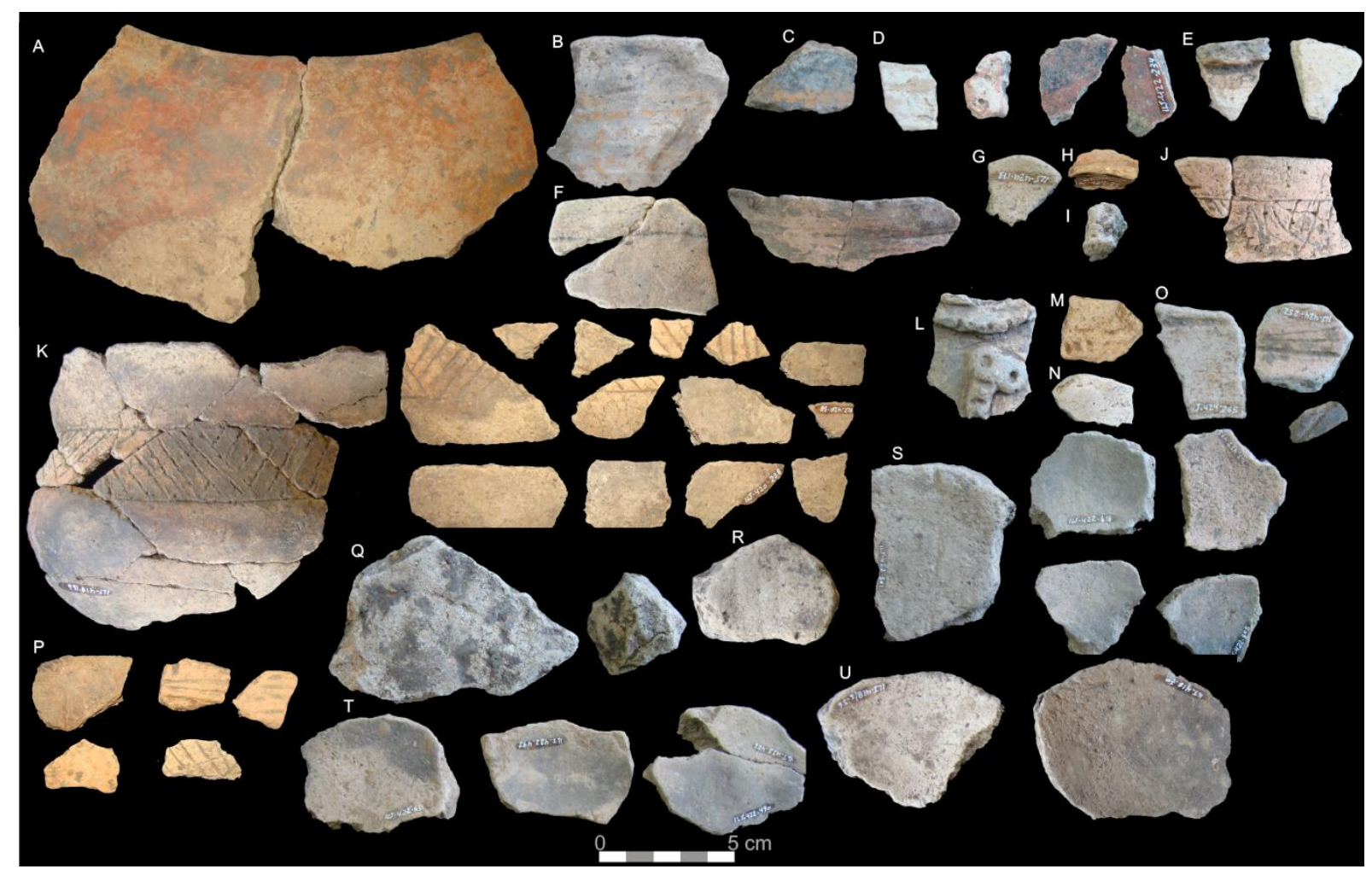

Figura 155: fragmentos da ocupação mais antiga: pintura (A-E); tratamento roletado (F); inciso em linhas oblíquas $(\mathrm{J}, \mathrm{K})$; aplique zoomorfo $(\mathrm{L})$; lábio modelado $(\mathrm{N})$; inciso e ponteado $(\mathrm{M})$, incisos $(\mathrm{O}$, P); possível adorno circular $(\mathbf{G})$, possível asa (H); possível rolete (I); bases (Q- U) (Fotos: SCIENTIA, 2013).

\subsection{Cerâmica do sítio Coração}

No sítio Coração- RO-JP-24, localizado na margem esquerda a jusante da cachoeira de Morrinhos, foram coletados fragmentos de vasilhas cerâmicas na superfície junto a uma cascalheira, logo após o seu impacto por máquinas que retiraram cascalho, e parte de duas vasilhas que ainda estavam in situ. A curadoria, remontagem e analise das vasilhas permitiu que se reconstituísse parte do contexto que foi afetado pela ação de retirada do cascalho. Todos os fragmentos apresentavam uma camada de sedimento avermelhado fortemente adurido em ambas as superfícies, exigindo um cuidadoso processo de limpeza das peças. A remontagem também foi dificultada pela grande fragmentação das vasilhas e dispersão dos fragmentos na área e pela semelhança das características técnicas de todas as vasilhas. A remontagem e análise permitiram verificar que se tratam ao menos de dez vasilhas cerâmicas, sendo cinco tigelas ou tampas e cinco vasilhas maiores carenadas, de contorno composto ou complexo. Nomeamos as vasilhas de acordo com a identificação das diferentes bordas com dígitos (vasilha 1 até vasilha 10), e outros conjuntos de fragmentos, que podem estar associados a alguma das bordas denominadas de vasilhas porém não remontaram a elas, nomeamos com letras (conjunto A ao conjunto D) (Figura 156). 
A vasilha 1é constituída por nove fragmentos de borda de tigela (ou tampa), cuja pasta apresenta quartzo, feldaspato, óxido de ferro, caraipé e carvão, coloração cinza escura (queima reduzida), com ambas as superfícies polidas. A pintura vermelha foi aplicada no lábio e na face externa em linhas finas vermelhas sobre engobo branco espesso, cujos motivos são de difícil identificação devido ao desgaste da peça. A vasilha apresenta borda direta inclinada externamente, espessamento linear, forma simples e estrutura aberta (cuia), o lábio é plano, possui $18 \mathrm{~cm}(25 \%)$ de diâmetro de abertura e $8 \mathrm{~mm}$ de espessura. Fragmentos de parede não remontaram à borda.

A Vasilha 2é constituída por quinze fragmentos de borda de tigela (ou tampa), que remontaram em três partes, com as mesmas características de pasta e queima da vasilha 1 . Possui a superfície interna polida e a externa bem alisada. A pintura vermelha foi aplicada no lábio e na face externa em motivo complexo sobre uma espessa camada de engobo branco, com motivos complexos. A borda é direta inclinada externamente, espessamento linear, lábio arredondado, com $22 \mathrm{~cm}(42,5 \%)$ de diâmetro de abertura. A espessura varia entre $7 \mathrm{~mm}$ (parede) e $9 \mathrm{~mm}$ (borda). Os fragmentos de parede não remontaram à borda.

A vasilha 3 é constituída por onze fragmentos de borda de tigela (ou tampa) que remontaram em duas partes, cuja pasta apresenta a mesma constituição das vasilhas 1 e 2 , queima reduzida interna (cinza escura) e oxidante externa (avermelhada). Ambas as superfícies são polidas e a pintura vermelha foi aplicada no lábio e na face externa em traços finos sobre uma camada espessa de engobo branco, não sendo identificados os motivos devido ao desgaste e fragmentação. A borda é direta inclinada externamente, espessamento linear, lábio plano, possui $24 \mathrm{~cm}(50 \%)$ de diâmetro e espessura de $8 \mathrm{~mm}$. Os fragmentos de parede que podem ser da mesma vasilha não remontaram à borda.

A vasilha 4é constituída por 14 fragmentos de borda e 12 fragmentos de parede que remontaram boa parte de uma tigela (ou tampa), pasta com os mesmos elementos das vasilhas 1,2 e 3, superfícies interna e externa polidas. Possui o lábio pintado de vermelho e na face externa ocorre uma camada espessa de engobo branco sobre o qual foi aplicada pintura vermelha em traços finos e motivo complexo, além de vestígios de pigmentação preta associada. A borda é direta inclinada externamente, levemente contraída, forma simples e estrutura aberta, lábio plano, com $20 \mathrm{~cm}(35 \%)$ de diâmetro de abertura e espessura variando entre $7 \mathrm{~mm}$ próximo ao lábio e $10 \mathrm{~mm}$ na parede. Alguns fragmentos de parede não remontaram. 
A vasilha 5 é constituída por 13 fragmentos de borda e 19 fragmentos de parede que remontaram boa parte de uma de tigela (ou tampa), cuja pasta apresenta os mesmos elementos das vasilhas descritas anteriormente, queima reduzida, ambas as superfícies polidas, pintura vermelha no lábio e vermelha e preta em motivos complexos na face externa, aplicada sobre engobo branco. A borda é direta inclinada externamente, levemente expandida, forma simples e estrutura aberta, lábio plano, com $16 \mathrm{~cm}(62,5 \%)$ de diâmetro de abertura e espessura variando entre $7 \mathrm{~mm}$ próximo ao lábio e $5 \mathrm{~mm}$ na parede. Alguns fragmentos de parede não remontaram.

A vasilha 6 é composta por fragmentos de borda, parede e base, e sua reconstituição parcial permitiu observar a forma composta com carena. Possui pasta com os mesmos elementos das demais, coloração cinza escura, queima reduzida e polimento em ambas as faces. Apresenta pintura vermelha na base até a carena, em ambas as faces. Na face externa apresenta pintura vermelha sobre engobo branco, entre a carena e o lábio, com motivos complexos. O lábio é pintado de vermelho. Possui borda direta inclinada externamente, com reforço externo, lábio biselado, forma complexa e estrutura fechada, com $18 \mathrm{~cm}$ de diâmetro abertura, $17 \mathrm{~cm}$ de diâmetro na carena e $15 \mathrm{~cm}$ de altura. A espessura varia entre $6 \mathrm{~mm}$ na borda, $9 \mathrm{~mm}$ no corpo e $10 \mathrm{~mm}$ na base.

A vasilha 7 é constituída por 4 partes remontadas, sendo duas de borda (18 fragmentos e 2 fragmentos) e duas partes constituídas pela base e carena (uma com 19 fragmentos e a outra com 13 fragmentos). Apresenta pasta com constituição e coloração semelhante às demais vasilhas, queima reduzida, polimento em ambas as faces. $\mathrm{Na}$ face externa, é pintada de vermelho na parte inferior (base até a carena), e na parte superior, acima da carena, apresenta pintura vermelha e preta em traços finos sobre engobo branco, motivos complexos. O lábio é pintado de vermelho. A borda é extrovertida, espessamento linear, lábio plano, com $21 \mathrm{~cm}$ de diâmetro de abertura. A espessura varia entre $8 \mathrm{~mm}$ na borda e $11 \mathrm{~mm}$ no corpo.

Vasilha 8 foi denominada uma borda constituída por 19 fragmentos. Possui pasta com os mesmos elementos das demais, coloração cinza escura, queima reduzida, polimento em ambas as faces. O lábio é pintado de vermelho, e na face externa apresenta pintura vermelha em traços finos sobre engobo branco. É direta vertical, com reforço externo, lábio plano, com $18 \mathrm{~cm}$ de diâmetro de abertura e $8 \mathrm{~mm}$ de espessura. 
A vasilha 9 é constituída por fragmentos de borda e pescoço, sendo que 10 deles remontam uma parte maior. A pasta apresenta os mesmos elementos das demais vasilhas, coloração cinza escura e queima reduzida, com polimento em ambas as faces (na face interna possui estrias de polimento). Possui pintura vermelha no lábio e reforço, e pintura em traços vermelhos e pretos sobre engobo branco na face externa, motivos complexos. É extrovertida, com reforço externo, lábio plano, $22 \mathrm{~cm}$ de diâmetro de abertura (37,5\%), e espessura variando entre $11 \mathrm{~mm}$ na borda e $8 \mathrm{~mm}$ no corpo.

A vasilha 10 é constituída por fragmentos de borda e pescoço. A pasta e coloração é semelhante as demais, queima reduzida e polida em ambas as faces (marcas de polimento na face interna). O lábio e suporte de tampa são pintados de vermelho, e abaixo possui pintura vermelha sobre engobo branco, motivos complexos. A borda é direta inclinada externamente, linear, lábio plano, com $13 \mathrm{~cm}$ de diâmetro de abertura (50\%), e a espessura é de $5 \mathrm{~mm}$.Possui um suporte de tampa logo abaixo do lábio.

Outros fragmentos de vasilhas podem compor alguma destas anteriormente descritas, porém não remontaram a elas, por isso denominamos como conjuntos. O conjunto A é constituído por onze fragmentos de borda de tigela, que possivelmente pertencem a vasilha 3 , pois apresentam as mesmas características de pasta, acabamentos de superfície, queima, forma e diâmetro de abertura. Fragmentos de parede foram associados a este conjunto, apesar de não remontarem.

O conjunto $\mathbf{B}$ é formado por três partes de carena remontadas, com parte da base e do corpo da vasilha. A pasta possui os mesmos elementos das demais e a queima varia entre oxidante e oxidante com núcleo reduzido na base, e reduzida na parte superior acima da carena. Possui alisamento fino na face externa e polimento na face interna, onde as marcas deste processo são fortes. Na face externa apresenta pintura vermelha na parte inferior (base até a carena) e pintura vermelha e preta sobre engobo branco na parte superior, acima da carena. A vasilha possui contorno composto e estrutura fechada. Na face interna, ocorre uma mancha escura na base. A espessura varia entre 7 e $10 \mathrm{~mm}$. Acreditamos que este conjunto de fragmentos possam ser associados às vasilhas 9 e 10, porém não remontaram.

O conjunto Cé composto por 59 fragmentos que remontaram a base, bojo e pescoço de uma vasilha de contorno complexo. A pasta apresenta as mesmas características das demais vasilhas, a queima é reduzida, a superfície interna é polida e na externa foi aplicada pintura. $\mathrm{Na}$ face externa, no centro da base foi pintado um círculo vermelho, e na parte 
contígua abaixo da carena foram pintadas linhas finas paralelas em vermelho sobre engobo branco. No bojo também foi aplicada pintura vermelha em motivos complexos sobre engobo branco, cujo campo é delimitado por duas faixas vermelhas, sendo na parte superior sobre uma área em baixo relevo. O único fragmento de pescoço remontado permite visualizar que nesta parte a vasilha também apresentava pintura vermelha sobre engobo branco. A vasilha possui contorno complexo, com espessura variando entre $12 \mathrm{~mm}$ na base e $8 \mathrm{~mm}$ nas demais partes. Possivelmente este conjunto possa ser associado à vasilha 8 .

O conjunto $\mathbf{D}$ é composto por um pescoço, com mesmas características de pasta das demais, queima reduzida, polimento em ambas as faces e pintura vermelha sobre engobo branco na face externa. Apresenta espessura variando entre 8 e $9 \mathrm{~mm}$. Acreditamos que este conjunto esteja associado à vasilha 7.

A limpeza dos fragmentos, remontagem das vasilhas e análise permitiu identificar ao menos 10 vasilhas cerâmicas. As vasilhas 1, 2, 3, 4 e 5 possuem forma e contorno semelhantes, sendo possíveis tigelas ou tampas, enquanto as vasilhas 6, 7, 8, 9 e 10 possuem contorno composto (apenas uma apresenta contorno complexo). Apesar de o contexto ter sido comprometido, acreditamos que se trata de um contexto simbólico, possivelmente funerário, com presença de cinco urnas e suas respectivas tampas. Um contexto semelhante foi identificado no sítio Morro dos Macacos I, anteriormente apresentado, bem como na área de intervenção da UHE Jirau onde vasilhas e tampas com pinturas elaboradas foram escavadas (MOUTINHO E ROBHRAN-GONZALEZ, 2010), cujas formas apresentadas nas fotos são semelhantes a estas do sítio Coração. Voltaremos a discutir este contexto no próximo capítulo, em conjunto com os outros sítios analisados, porém podemos já adiantar que o vinculamos a Tradição Polícroma da Amazônia. A análise dos demais materiais deste sítio se faz necessária para avançar as interpretações intra-sítio. 

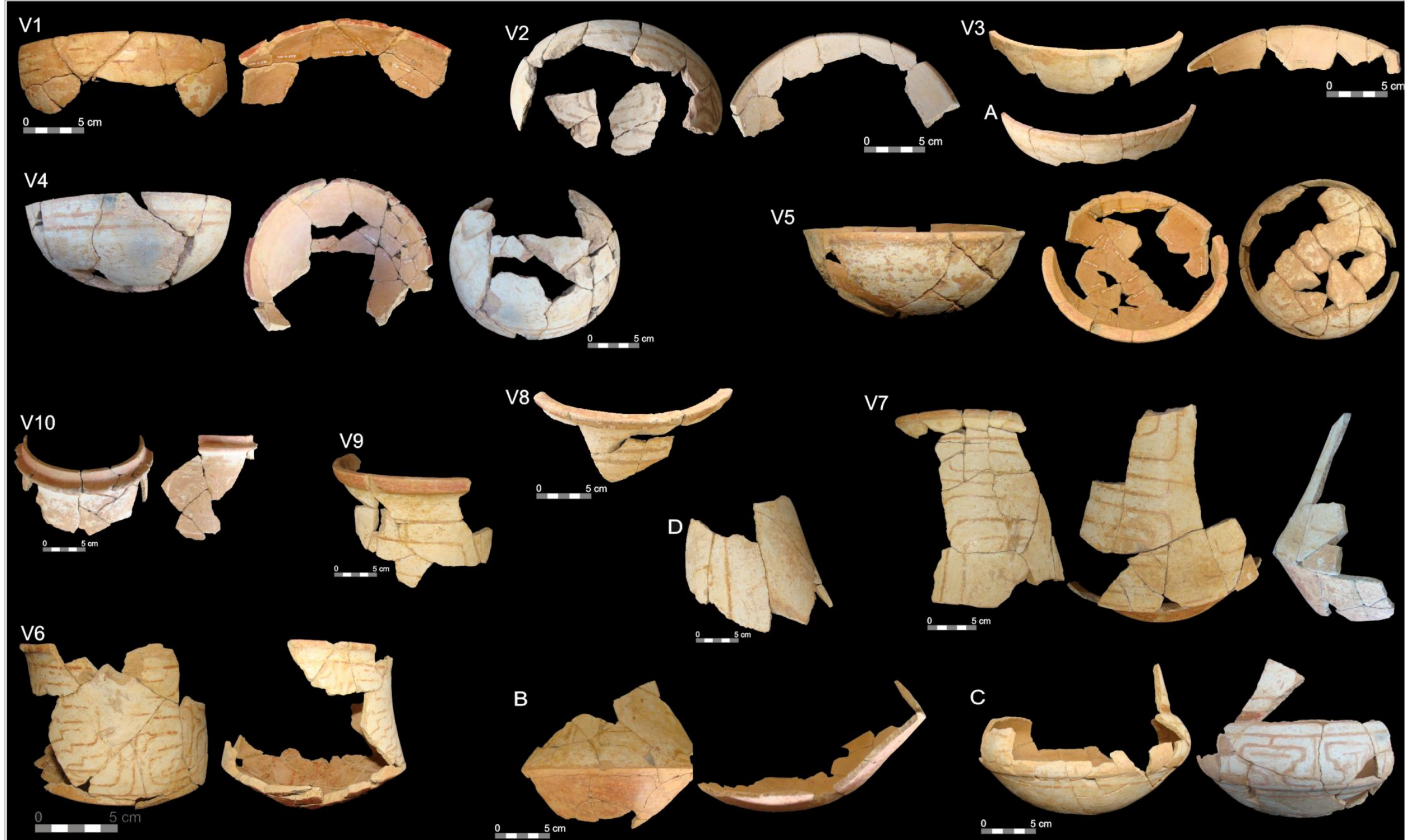

Figura 156: Vasilhas cerâmicas e conjuntos A, B, C e D, sítio Coração (Fotos: SCIENTIA, 2013). 


\subsection{Cerâmica do sítio Ilha Dionísio}

Ao todo foram analisados 2.881 fragmentos diagnósticos, sendo 2.600 de vasilhas (que com as remontagens correspondem a 1.846 fragmentos), 20 de trempe, 256 bolotas de argila e 5 fragmentos não identificados, das unidades E347799 N8984160, E347800 N8984160, E347800 N8984161 e E347805 N8983973. Conforme já mencionamos, foram identificadas duas camadas arqueológicas (camadas A e C) separadas por uma camada estéril (camada B) no setor sul do sítio (gráfico 65). Analisamos separadamente os dados referentes à cerâmica da camada C (187 fragmentos), mais profunda, e da camada A (2.694), mais superficial, para compará-las. As três unidades contíguas foram escavadas na área com urucuris a norte do Setor Sul e a unidade E347805 N8983973 foi escavada na transição para a mata secundária, a sul deste setor e da ilha. Como o contexto de todas as unidades é semelhante, analisaremos as quatro em conjunto. Além disso, foram analisadas 13 vasilhas cerâmicas, bem como fragmentos de tampa e das estruturas, sendo nove vasilhas do setor sul (V1, V2, V3, V4, V5, V6, V7, V8, V9) e quatro vasilhas do setor norte (V16, V 18, V19, V26). As outras vasilhas escavadas nesse sítio não foram restauradas e analisadas.

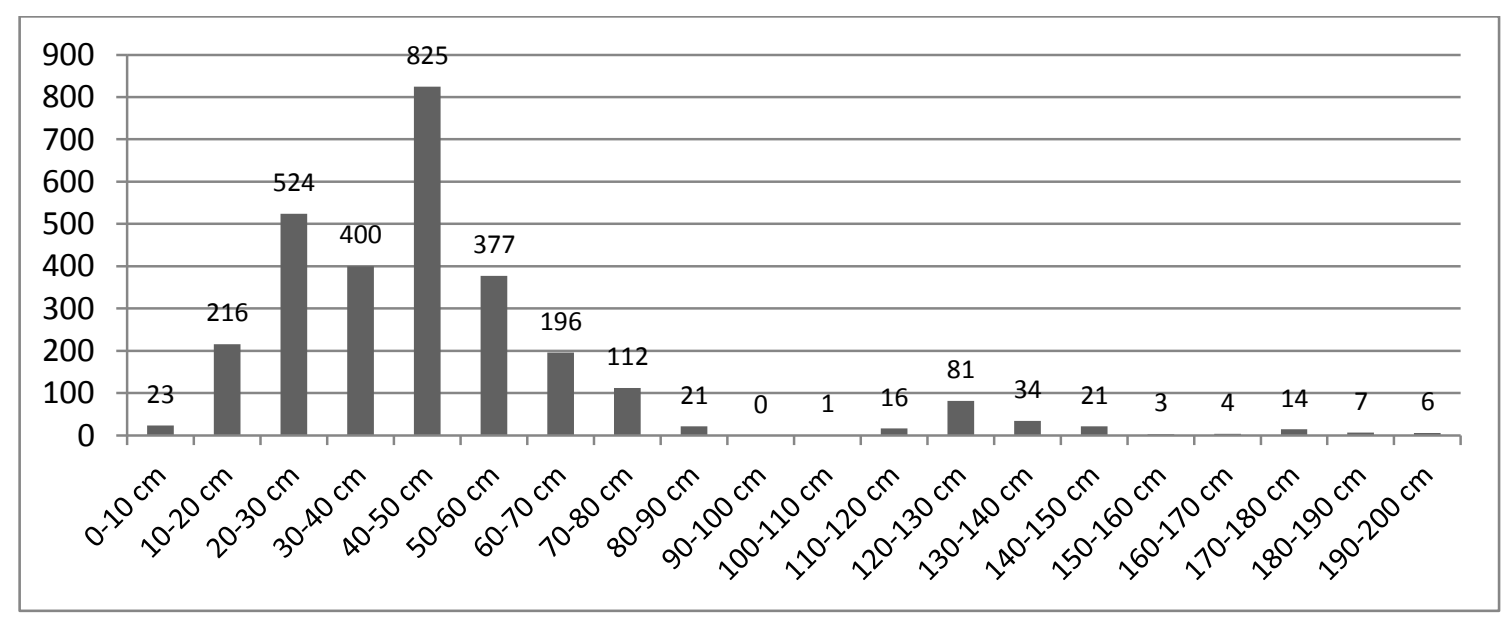

Gráfico 65: cerâmica nos níveis das quatro unidades analisadas- Ilha Dionísio.

\subsubsection{Análise da cerâmica das unidades E347799 N8984160, E347800 N8984160, E347800 N8984161 e E347805 N8983973}

Foram analisados 2.600 fragmentos cerâmicos e quatro fragmentos não identificados (NI) que possivelmente são de vasilhas. Os 2.421 fragmentos cerâmicos da camada A das quatro unidades (com as remontagens correspondem a 1.717 fragmentos de vasilhas) e os 183 da camada $\mathrm{C}$ (com as remontagens correspondem a 134) foram analisados separadamente. Os fragmentos da camada A estão mais bem conservados (74\% dos fragmentos estão bem 
conservados em ambas as faces) do que os da camada $C$ (apenas $25 \%$ dos fragmentos estão bem conservados em ambas as faces e $52 \%$ estão erodidos em ambas as faces).

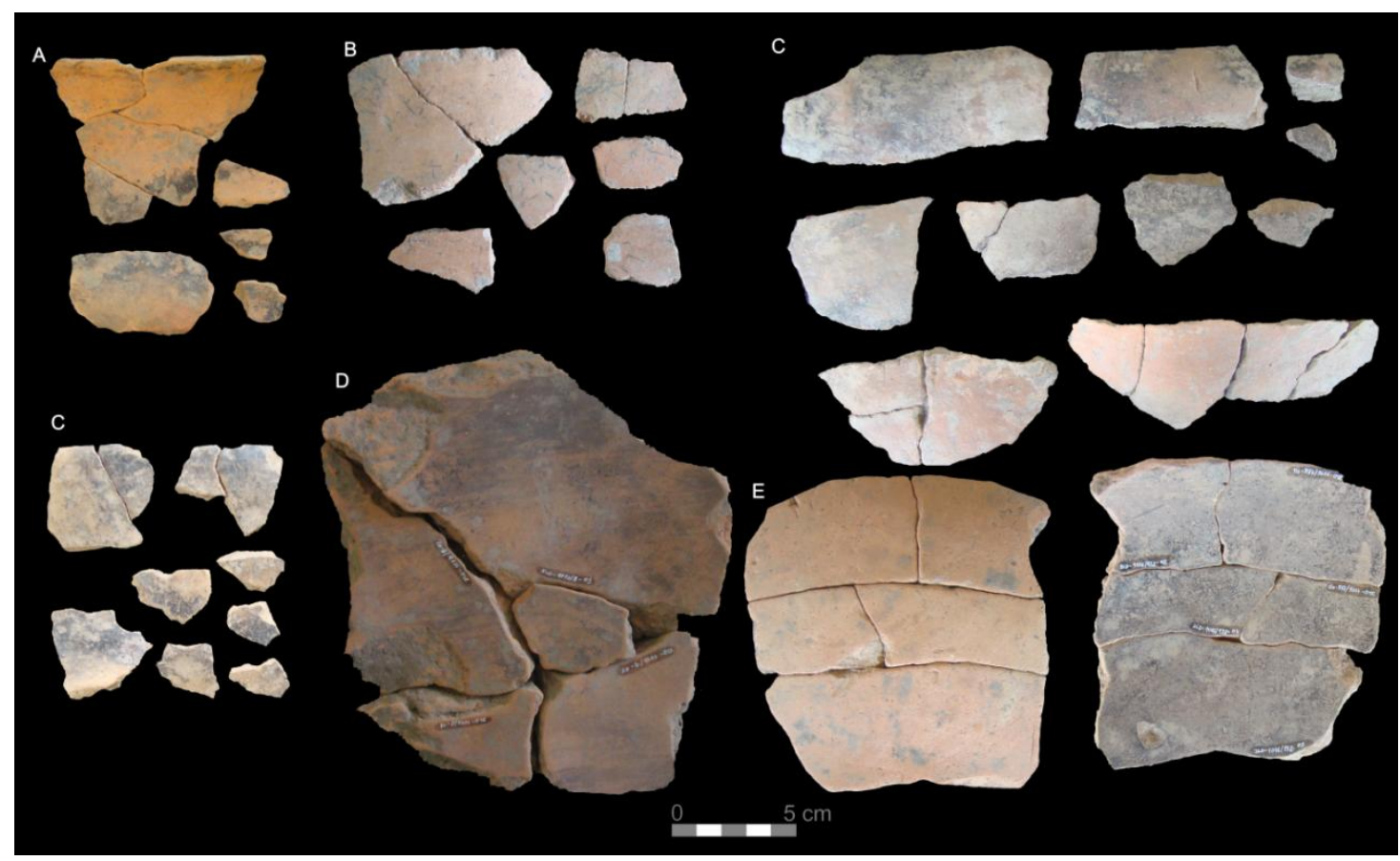

Figura 157: conjuntos de fragmentos da mesma vasilha e remontagens - camada A- sítio Ilha Dionísio (Fotos: SCIENTIA, 2013).

Foram observadas diferenças na escolha da pasta nas duas camadas arqueológicas. Enquanto na camada mais recente (A) predomina a pasta com mineral e cauixí $(45,95 \%)$ e com mineral $(23,30 \%)$ e menor frequência da presença de caraipé e de carvão, na camada mais antiga (C) predomina a pasta com mineral, caraipé e carvão $(57,46 \%)$ e mineral e caraipé $(21,64 \%)$ enquanto a presença de cauixí ou de mineral isolado é menos frequente (gráfico 66 e 67). Na camada A são mais frequentes os fragmentos com presença de óxido de Ferro que na camada $\mathrm{C}$, porém em geral as pastas apresentam os mesmos elementos (quartzo, óxido de ferro, feldspato, mica) associados de diferentes maneiras. Os fragmentos com todos os tipos de pasta estão bastante misturados ao longo dos $90 \mathrm{~cm}$ da camada A, bem como na camada C. Faremos comparações dos tipos de pastas com marcas de uso e formas e inclinação das bordas para verificar se vasilhas com diferentes pastas teriam diferentes usos. 


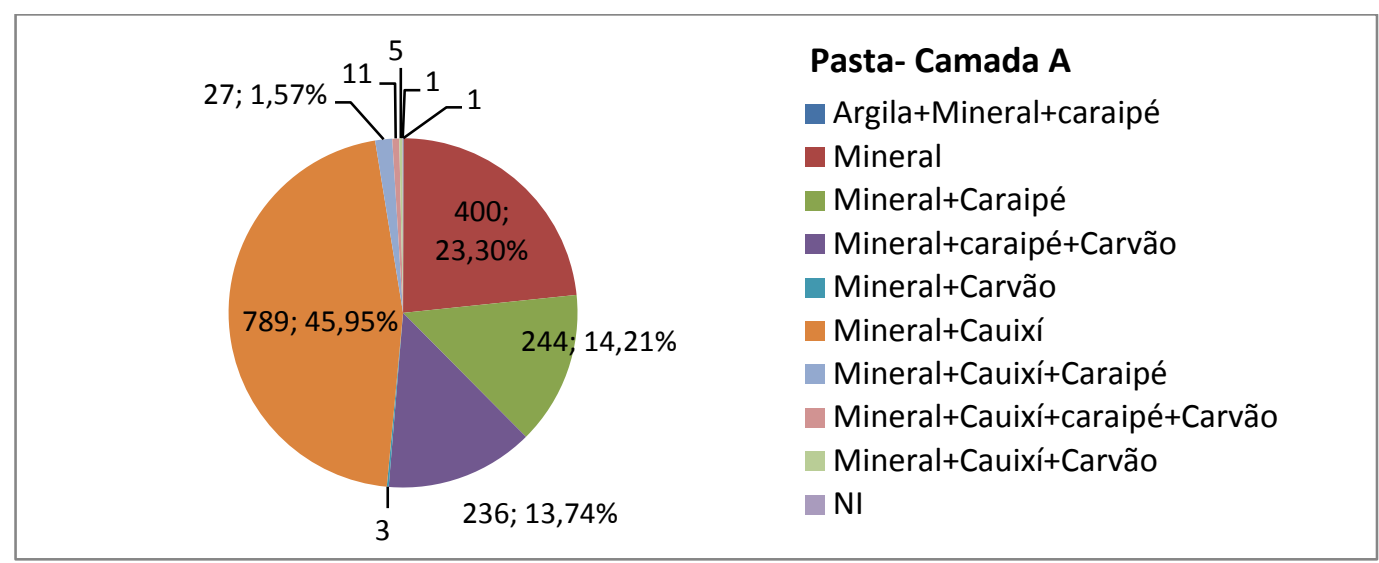

Gráfico 66: análise da pasta da camada A- Ilha Dionísio.

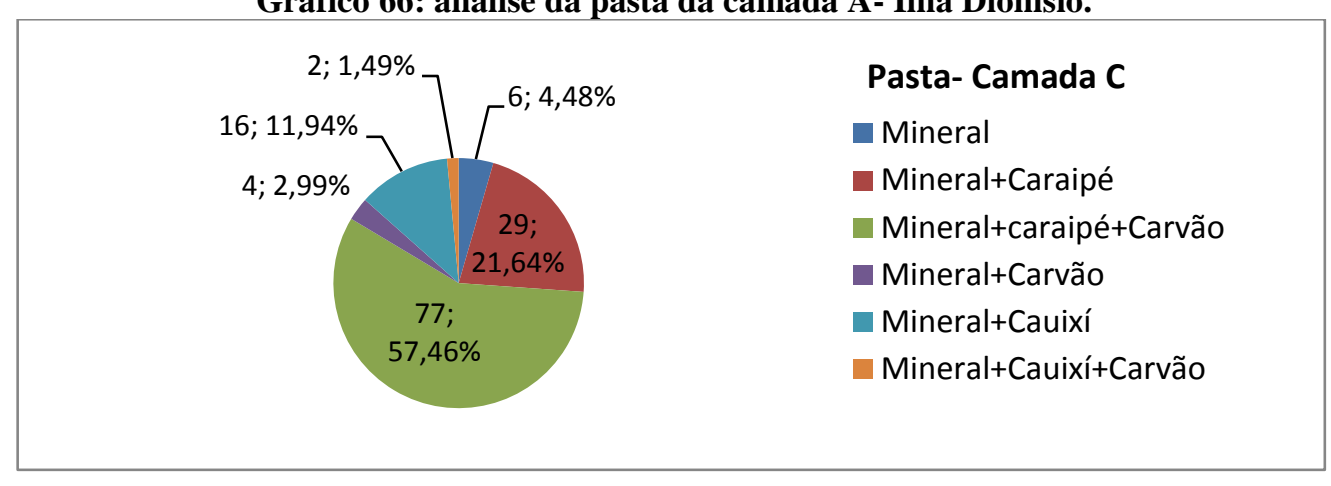

Gráfico 67: análise da pasta da camada C- Ilha Dionísio.

$\mathrm{Na}$ camada A predominam fragmentos com queima oxidante (60,05\% dos fragmentos) em relação à queima reduzida $(32,50 \%)$ enquanto na camada $\mathrm{C}$ é mais frequente a queima reduzida $(78,36 \%)$ em relação a oxidante $(17,16 \%)$, e em ambas as camadas ocorrem poucos fragmentos com variações dequeima das duas superfícies. Em ambas as camadas as vasilhas foram confeccionadas com a técnica acordelada, com exceção das flanges e algumas bases.Em relação ao acabamento de superfície também são observadas diferenças. Enquanto na Camada A sobressai o polimento e a brunidura, na Camada $\mathrm{C}$, apesar de não ter sido identificado em muitos fragmentos devido ao desgaste, predominou o alisamento fino e médio, além da ocorrência de polimento e raros fragmentos com brunidura (gráficos 68 e 69). 


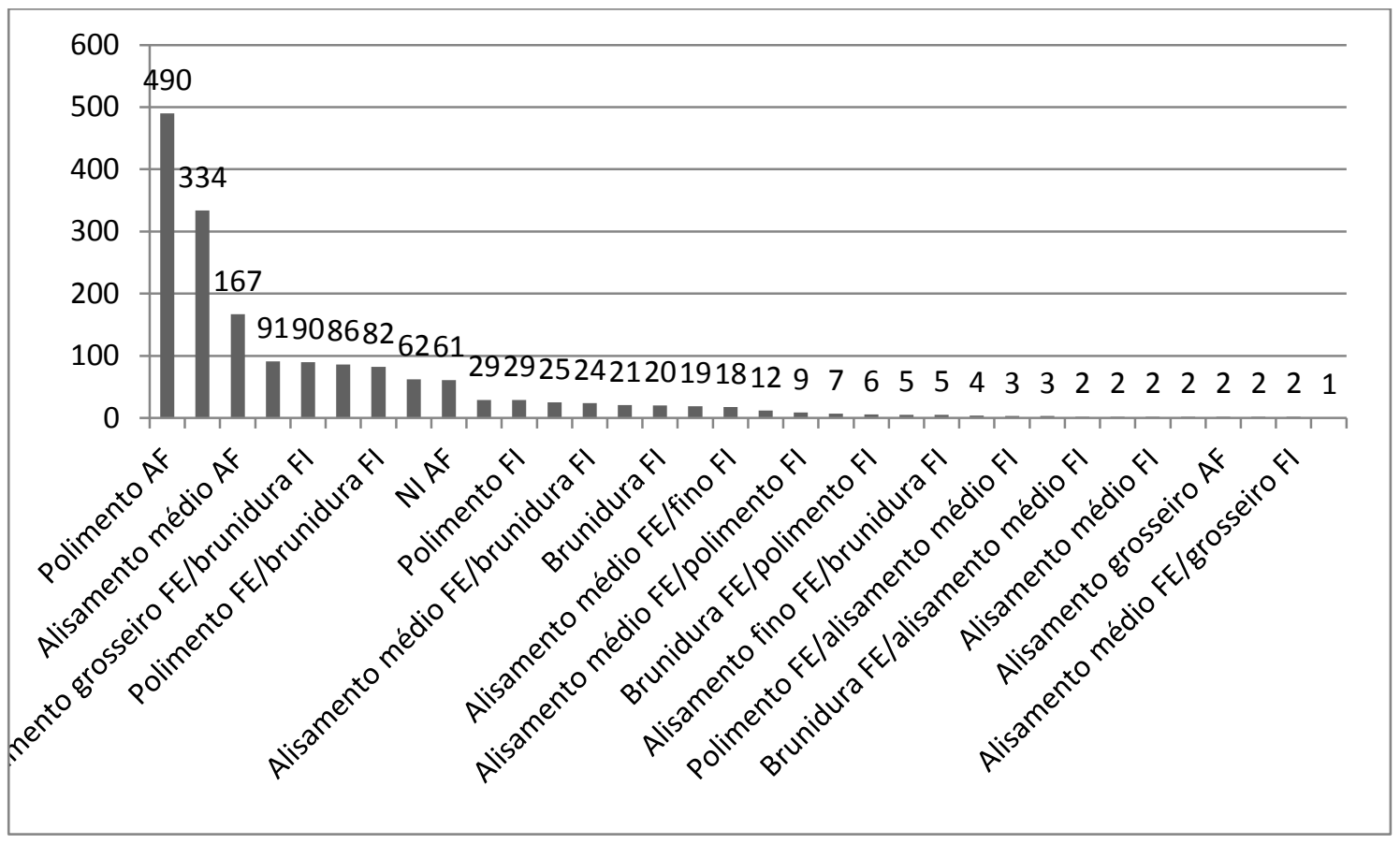

Gráfico 68: acabamentos de superfície - camada A- Ilha Dionísio.

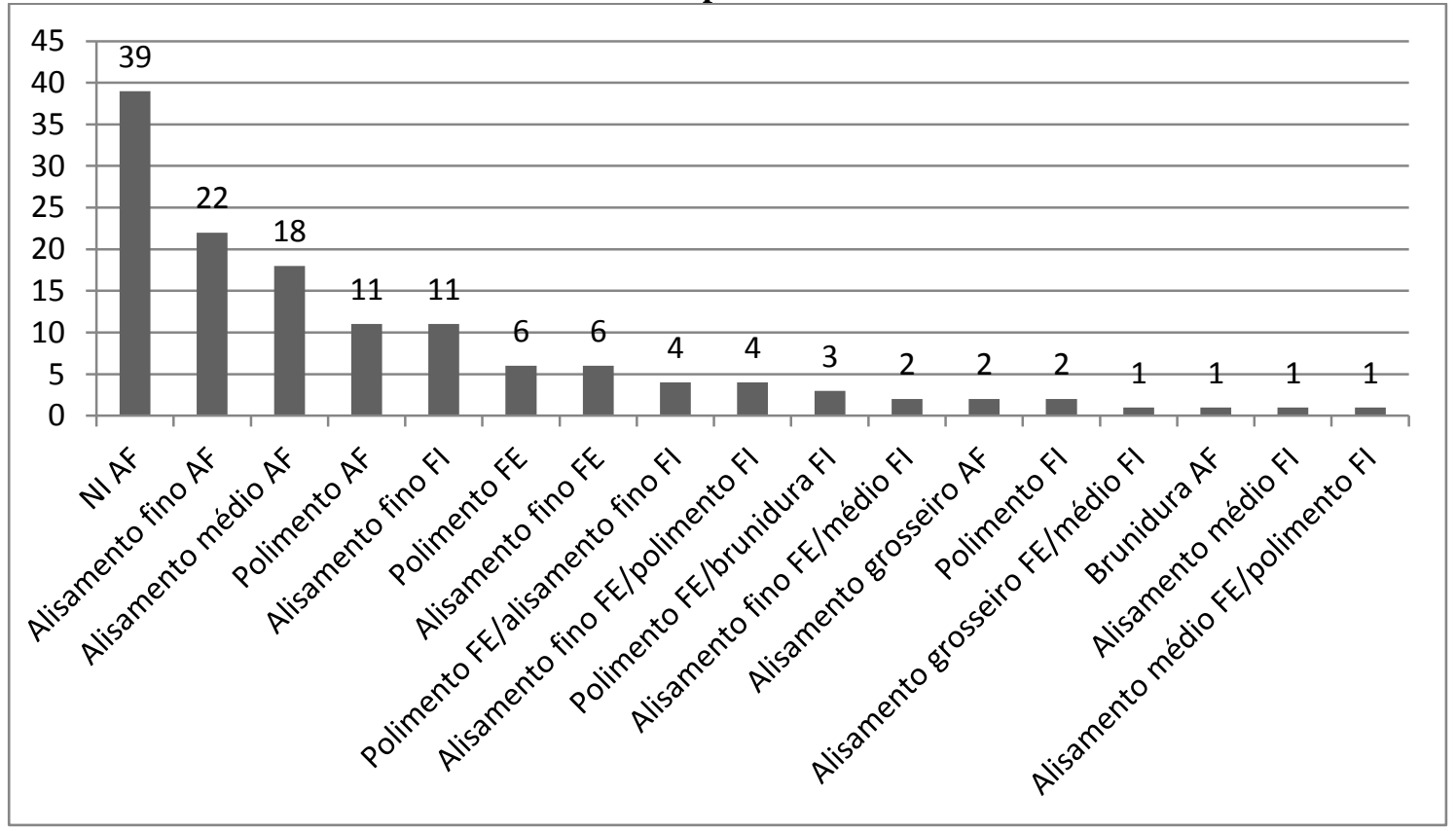

Gráfico 69: acabamentos de superfície - camada C- Ilha Dionísio. 


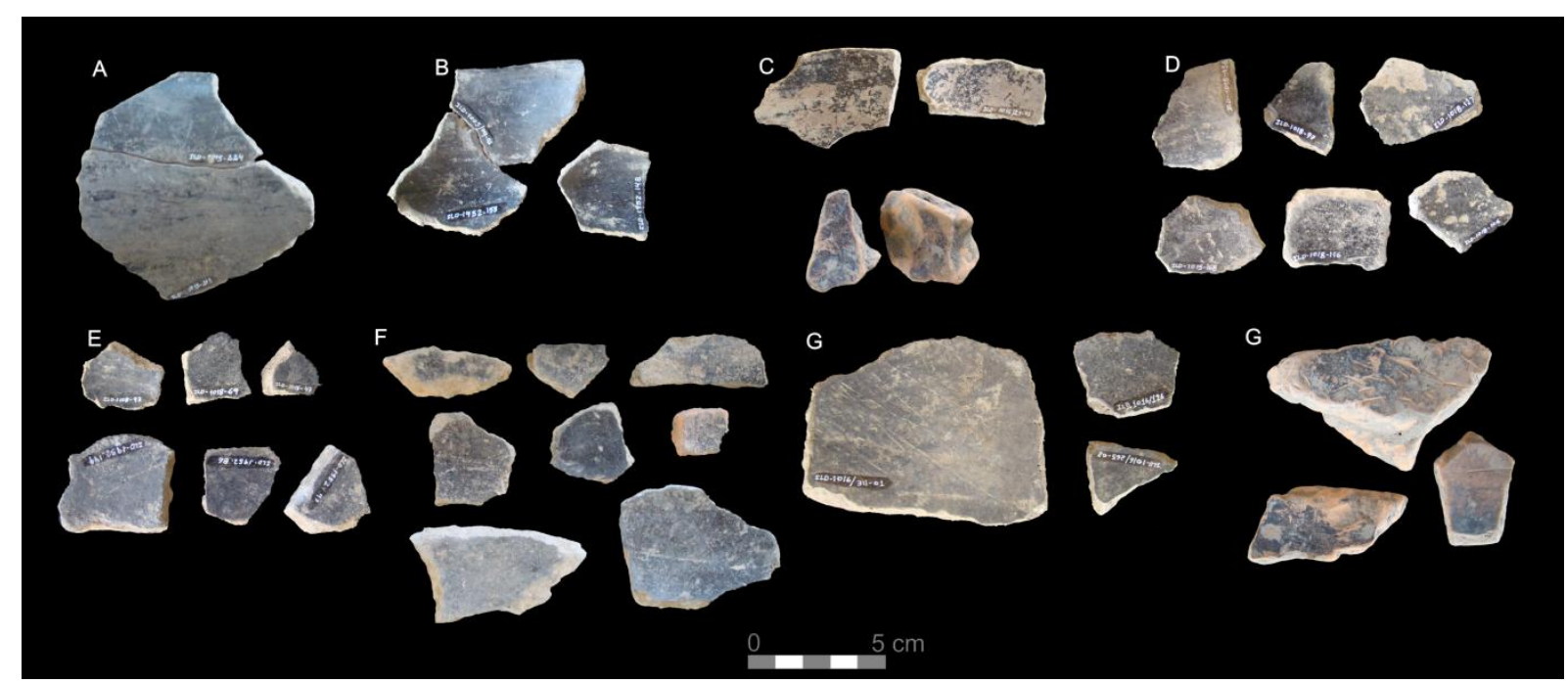

Figura 158: brunidura na face interna de fragmentos- camada A- Ilha Dionísio (Fotos: SCIENTIA, 2013).

Na Camada A ocorrem 98 fragmentos (5,71\%) com engobo, nas seguintes cores: vermelho FE (59), branco FE (15), vermelho AF (8), vermelho FI (6),laranja FI (3), laranja FE (2), laranja AF (1), branco FI (1), vinho FE (3). Na camada C o engobo ocorre em cinco fragmentos $(3,73 \%)$, cor vermelha (2 vermelho AF; 2 vermelho FI; 1 vermelho FE), portanto na ocupação é mais frequente a aplicação de pigmento com cores mais diversificadas, apesar de serem mais bem preservadas que os da camada $\mathrm{C}$.

Na camada A, a pintura está presente em 55 fragmentos (3,20\%), em 28 não foi identificada $(1,63 \%)$ e nos demais está ausente $(1634 ; 95,17 \%)$, nas seguintes cores: vermelha FE (29), branca e vermelha FE (11), branca FE (5), vermelha AF (4), vermelha FI (3), branca FI (1), vermelha FE (1) e preta FE (1), com motivos em linhas horizontais, composto e complexo. Vasilhas que apresentam pintura possuem caraipé na pasta ou cauixí (gráfico 70). Nas vasilhas com cauixí a pintura ocorre diretamente sobre a superfície, em linhas finas ou cobrindo parte da vasilha, sendo a camada de pigmento muito fina e em tons escuros, geralmente com apenas uma cor (vermelho vinho ou preta) (figuras 159 e 160); vasilhas com caraipé na pasta possuem pintura predominantemente em duas cores (vermelha e branca), com traços mais largos (figura 160); as vasilhas que só apresentaram mineral na pasta não foram pintadas. Destaca-se uma vasilha com a base em pedestal e forma de cálice (ILD 1016/2, figura 159) com pintura em motivos complexos em ambas as faces, estando a face interna bastante erodida possivelmente em função do uso (consumo de bebidas fermentadas). Também chama a atenção a associação de pintura vermelha e branca a incisões com motivos 
complexos (incluindo linhas escalonadas), em vasilhas cujas pastas possuem caraipé. $\mathrm{Na}$ camada $\mathrm{C}$ não foram identificados fragmentos com pintura.

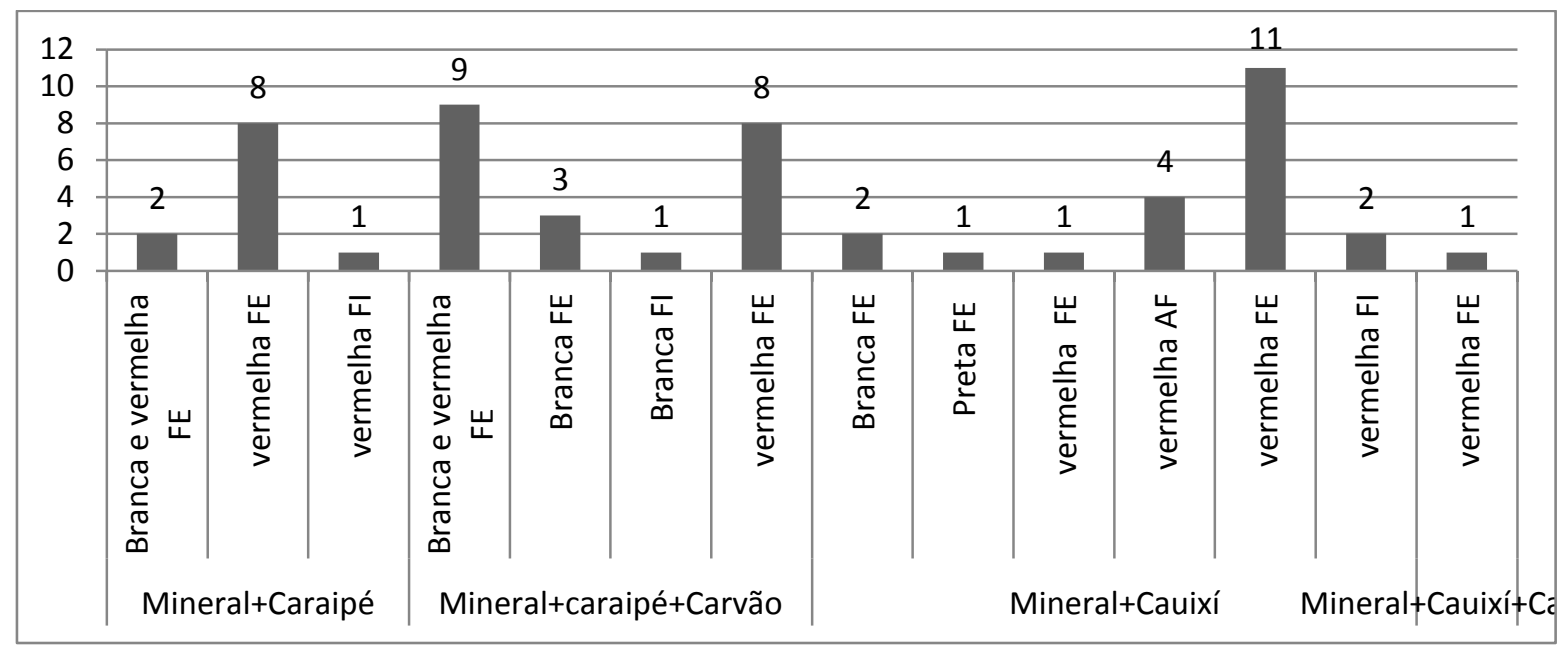

Gráfico 70: relação da ocorrência de pintura com o tipo de pasta (Camada A)- Ilha Dionísio.

Na camada A ocorrem apenas 21 fragmentos com tratamentos plásticos $(1,22 \%)$, enquanto nos demais está ausente (1696; 98,78\%), sendo os seguintes: aplique FE (1), Inciso FE (16), inciso FI (2), modelado FI (1) e ponteado FI (1) (figura 161). Ocorrem na borda, bojo, inflexão e parede, com motivos em linhas horizontais, linhas entrecruzadas, linhas escalonadas, composto e complexo. Na camada C (figura 161) ocorre em sete fragmentos (5, $11 \%)$ e em 130 (94, 89\%) está ausente, sendo os seguintes: modelado FE (1), inciso FE (3), inciso FI (1), inciso AF (1) e escovado FE (1), feitos na borda, lábio e parede, com motivos em linhas horizontais, linhas verticais e compostos.

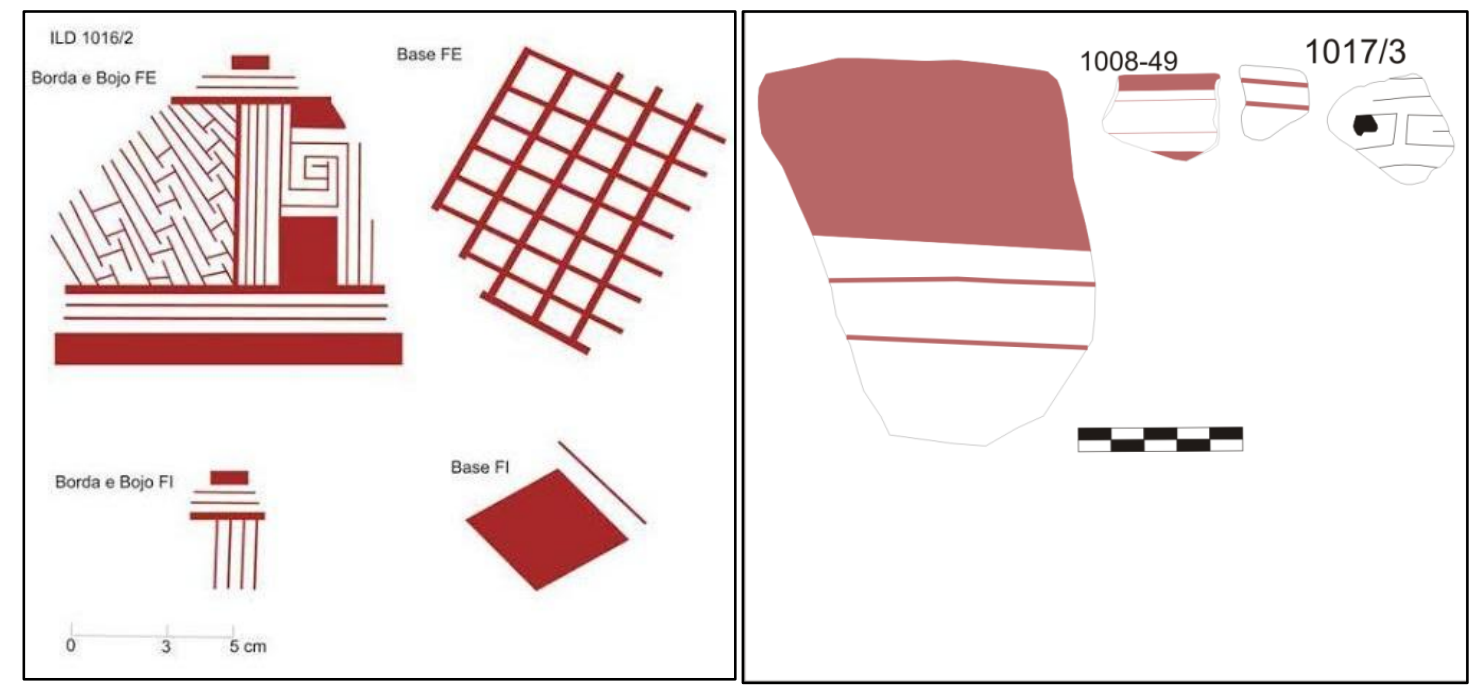

Figura 159: pintura da vasilha em forma de cálice (FE e FI) e de outros fragmentos (FE), respectivamente, todos com cauixí na pasta- Ilha Dionísio (Desenhos: Angislaine F. Costa, 2013). 


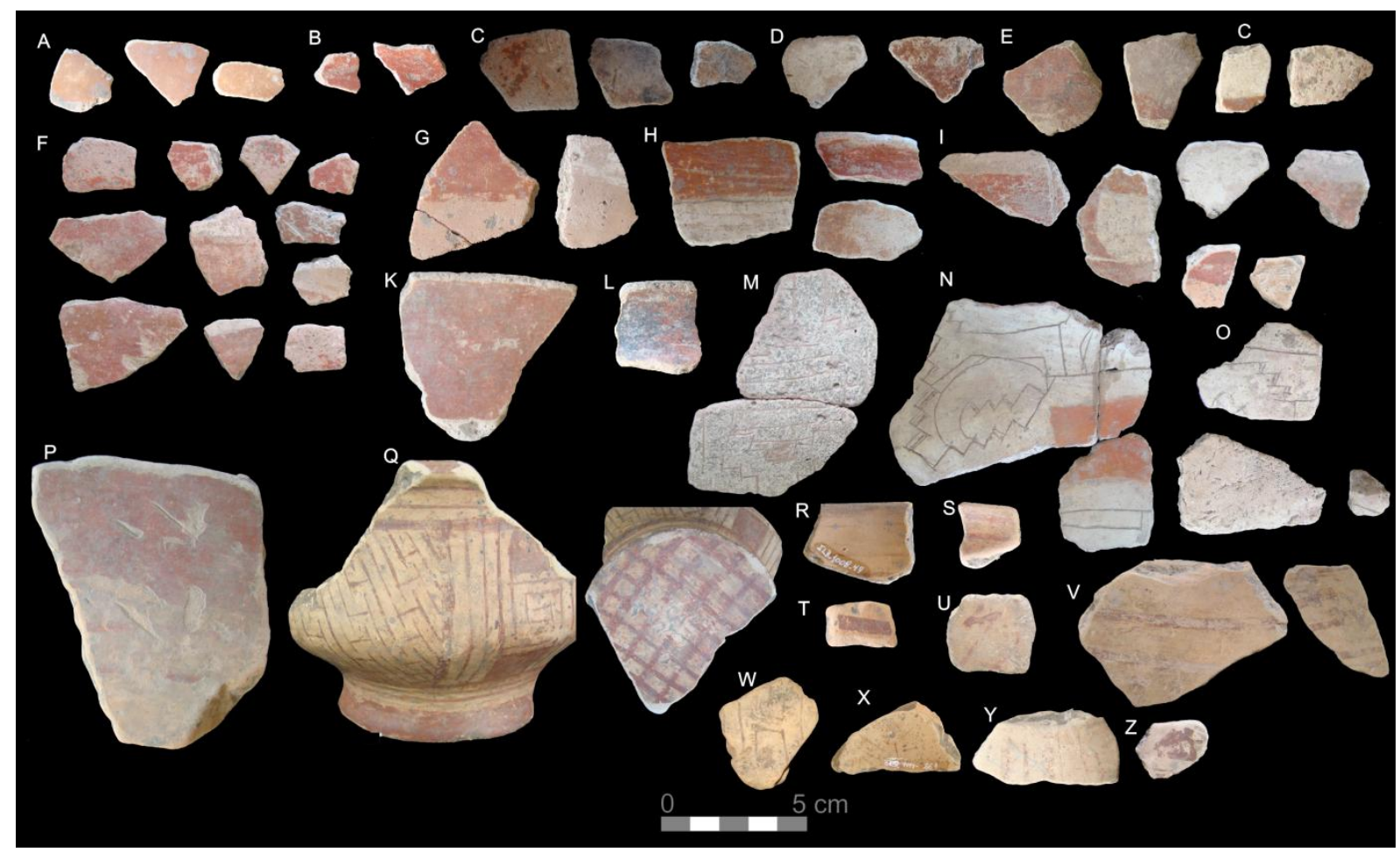

Figura 160: fragmentos da camada A- engobo vermelho ou pintura vermelha e branca na face externa, em vasilhas cuja pasta apresenta mineral ou mineral e caraipé $(\mathbf{A}-\mathbf{O})$; incisões sobre engobo branco $(\mathbf{M}, \mathbf{O})$; incisões sobre pintura vermelha e branca $(N)$; pintura vermelha em fragmentos com cauixí na pasta $(\mathbf{P}$ Z) (Fotos: SCIENTIA, 2013).

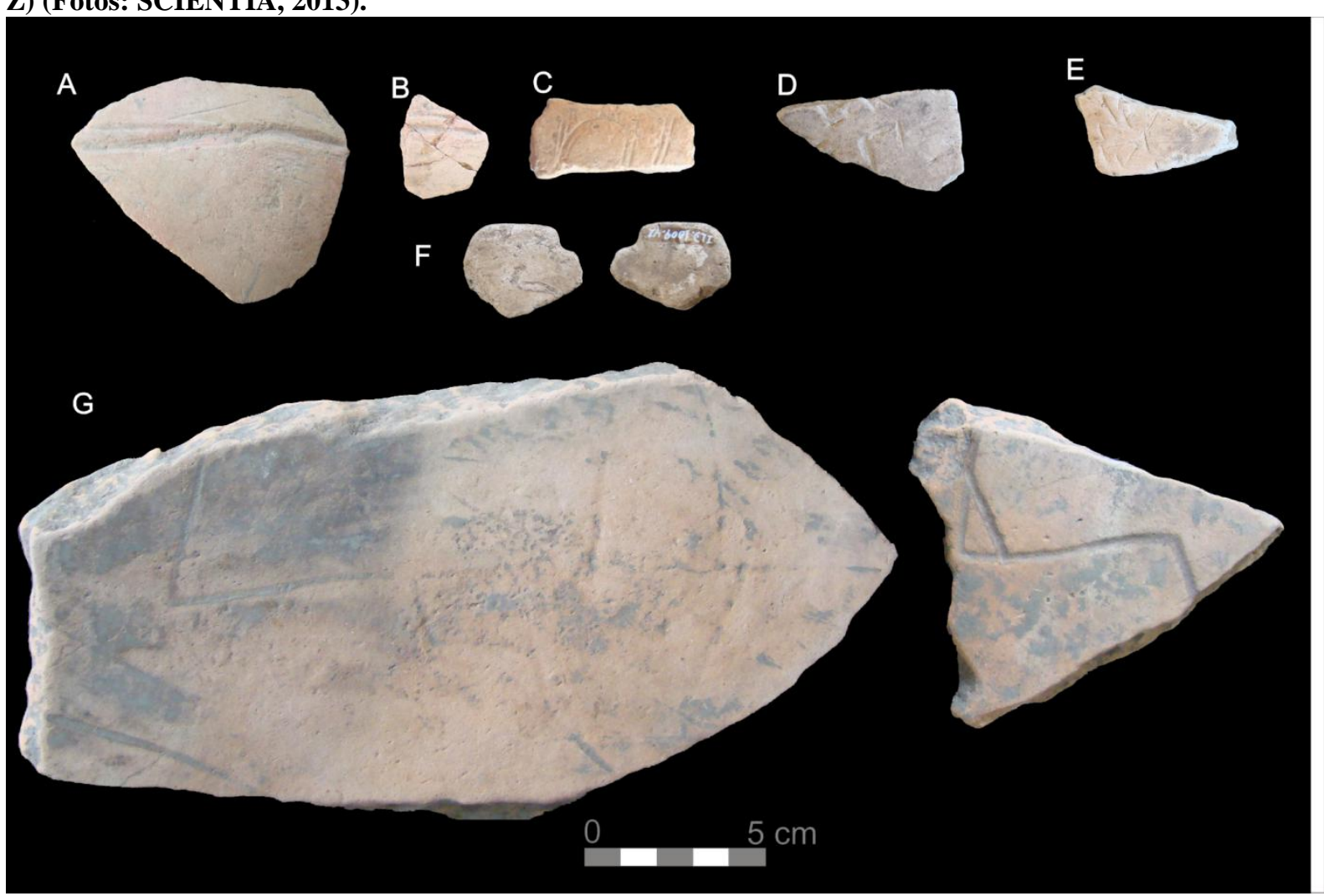

Figura 161: fragmentos da camada A com tratamentos plásticos: incisões (A, B, C, G); ponteado (D, E); borda modelada com incisão FE e engobo branco FI (F) (Fotos: SCIENTIA, 2013). 
Em ambas as camadas predominam fragmentos de parede, inflexão e borda, porém na camada $\mathrm{C}$ ocorrem as flanges que estão ausentes na Camada $\mathrm{A}$. Na camada $\mathrm{C}$ ocorre apenas uma base, devido a fragmentação dos vestígios (ver tabela).

Tabela 5: comparação do atributo parte da vasilha nas duas camadas.

\begin{tabular}{|c|c|c|c|c|}
\hline \multirow{2}{*}{$\begin{array}{l}\text { PARTE DA VASILHA } \\
\text { PAREDE }\end{array}$} & \multicolumn{2}{|c|}{ CAMADA A } & \multicolumn{2}{|c|}{ CAMADA C } \\
\hline & 861 & $50,15 \%$ & 79 & $58,96 \%$ \\
\hline INFLEXÃO & 383 & $22,38 \%$ & 23 & $17,16 \%$ \\
\hline BORDA & 350 & $20,33 \%$ & 19 & $14,18 \%$ \\
\hline BASE & 54 & $3,15 \%$ & 1 & $0,75 \%$ \\
\hline BOJO & 16 & $0,93 \%$ & 2 & $1,49 \%$ \\
\hline FLANGE & 0 & - & 1 & $0,75 \%$ \\
\hline PESCOÇO & 12 & $0,70 \%$ & 1 & $0,75 \%$ \\
\hline LÁBIO & 5 & $0,29 \%$ & 0 & - \\
\hline CARENA & 1 & $0,06 \%$ & 1 & $0,75 \%$ \\
\hline APLIQUE & 1 & $0,06 \%$ & 0 & - \\
\hline BORDA E FLANGE & 0 & - & 4 & $2,99 \%$ \\
\hline BORDA E BOJO & 5 & $0,29 \%$ & 1 & $0,75 \%$ \\
\hline BORDA E PAREDE & 3 & $0,17 \%$ & 1 & $0,75 \%$ \\
\hline BORDA E PESCOÇO & 1 & $0,06 \%$ & 0 & - \\
\hline BORDA E BASE & 3 & $0,17 \%$ & 0 & - \\
\hline PERFIL COMPLETO & 1 & $0,06 \%$ & 0 & - \\
\hline $\mathrm{NI}$ & 21 & $1,22 \%$ & 1 & $0,75 \%$ \\
\hline TOTAL & 1.717 & $100 \%$ & 134 & $100 \%$ \\
\hline
\end{tabular}

A espessura dos fragmentos varia entre 3 e $30 \mathrm{~mm}$ na camada A e entre 3 e $15 \mathrm{~mm}$ na camada $\mathrm{C}$, com maior quantidade entre 5 e $10 \mathrm{~mm}$ em ambas (gráficos 71 e 72). Fragmentos bastante espessos da camada A são de borda, parede e base de vasilhas grandes, cuja pasta apresenta cauixí.

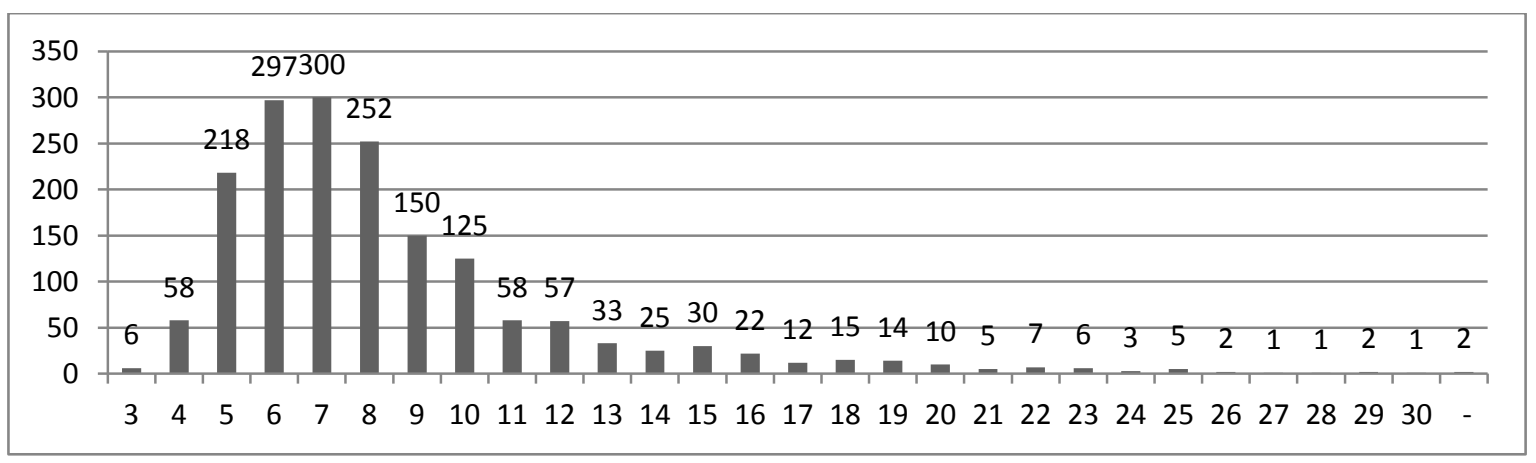

Gráfico 71: espessura dos fragmentos- camada A- Ilha Dionísio. 


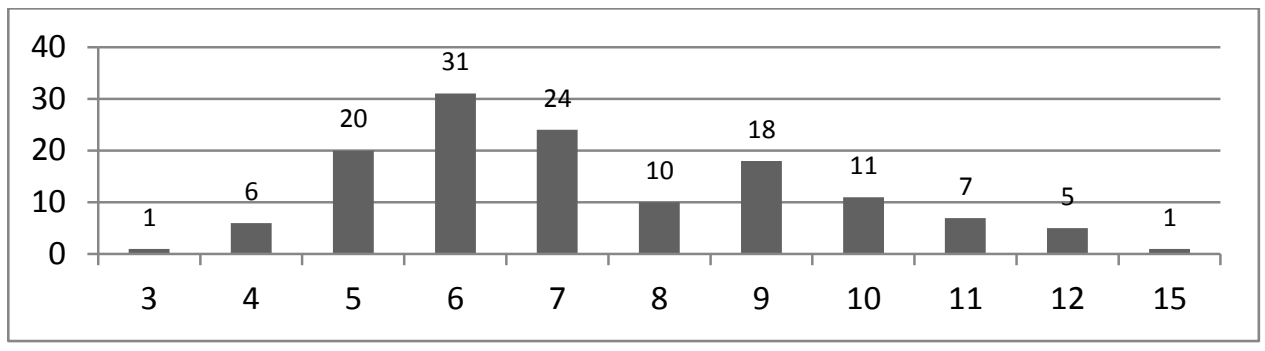

Gráfico 72: espessura dos fragmentos- camada C- Ilha Dionísio.

Na camada A, entre as bordas em que foi possível ver a forma e inclinação, predominam as extrovertidas (96), seguidas pelas diretas inclinadas externamente (37), diretas verticais (27), introvertidas (17), com apenas 10 diretas inclinadas internamente e três extrovertidas com ponto angular. Já na Camada C, não ocorrem às bordas extrovertidas, e predominam as diretas inclinadas externamente (10), com apenas duas diretas inclinadas internamente, duas diretas verticais e uma introvertida. Portanto, bordas extrovertidas e extrovertidas com ponto angular são frequentes na Camada A e ausentes na Camada $\mathrm{C}$, onde as bordas diretas são mais comuns. Na camada A predominam as bordas lineares e contraídas, enquanto na camada $\mathrm{C}$ são mais frequentes as expandidas (gráfico 73). Nas duas camadas predominam lábios arredondados e planos, porém na camada $\mathrm{A}$ os apontados são mais frequentes que na camada $\mathrm{C}$ (gráfico 74). O diâmetro de abertura das vasilhas da camada $\mathrm{A}$ varia entre $4 \mathrm{~cm}$ e $50 \mathrm{~cm}$ (gráfico 75), porém foi possível medi-lo em apenas 42 bordas, e possivelmente ocorriam vasilhas maiores nesta camada, representadas por bordas espessas das quais não foi possível medir o diâmetro. Na camada $\mathrm{C}$ foi possível medir o diâmetro de apenas duas bordas, de $14 \mathrm{~cm}$ e $20 \mathrm{~cm}$.

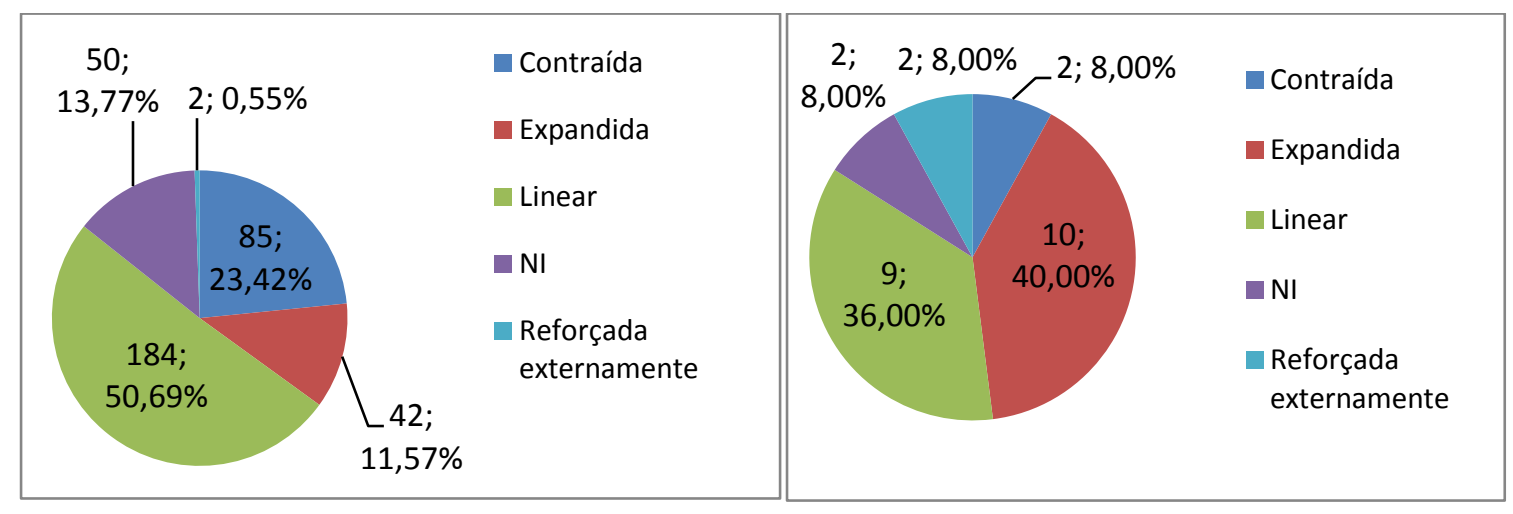

Gráfico 73: comparação do espessamento das bordas das camadas A e C respectivamente. 


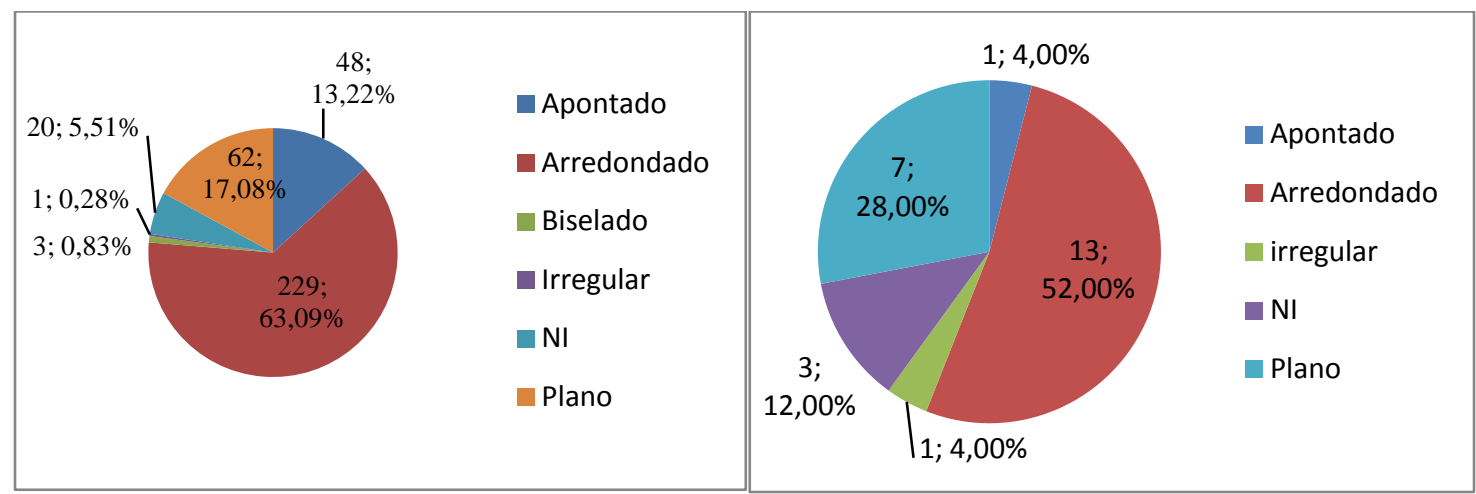

Gráfico 74: comparação dos tipos de lábios das camadas A e C respectivamente.

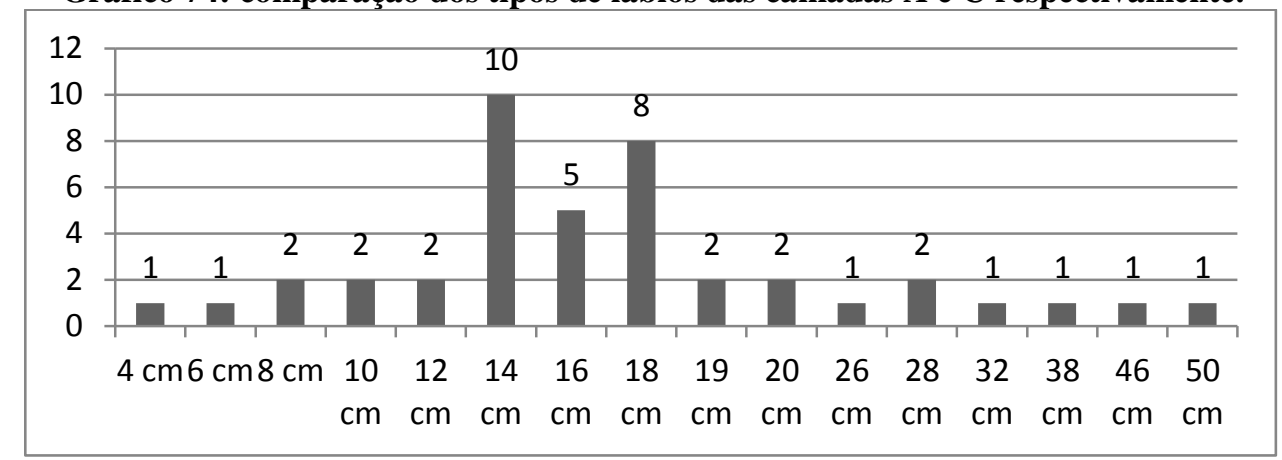

Gráfico 75: diâmetros de abertura- camada A- Ilha Dionísio.

Entre as bases da camada A, ocorrem as convexas côncavas (19), plano côncavas (17), bi-planas (8), em pedestal (2), anelar (1), côncava convexa (1) ou não foram identificadas (9). Nas vasilhas com cauixí na pasta, as bases são predominantemente convexas côncavas (10), bi-planas e em pedestal (figura 166); as vasilhas que apresentam apenas mineral na pasta possuem bases predominantemente plano côncavas, e em menor quantidade as convexas côncavas; vasilhas com caraipé possuem predominantemente bases convexas-côncavas e plano-côncavas e raras bi-planas. 
Bordas extrovertidas
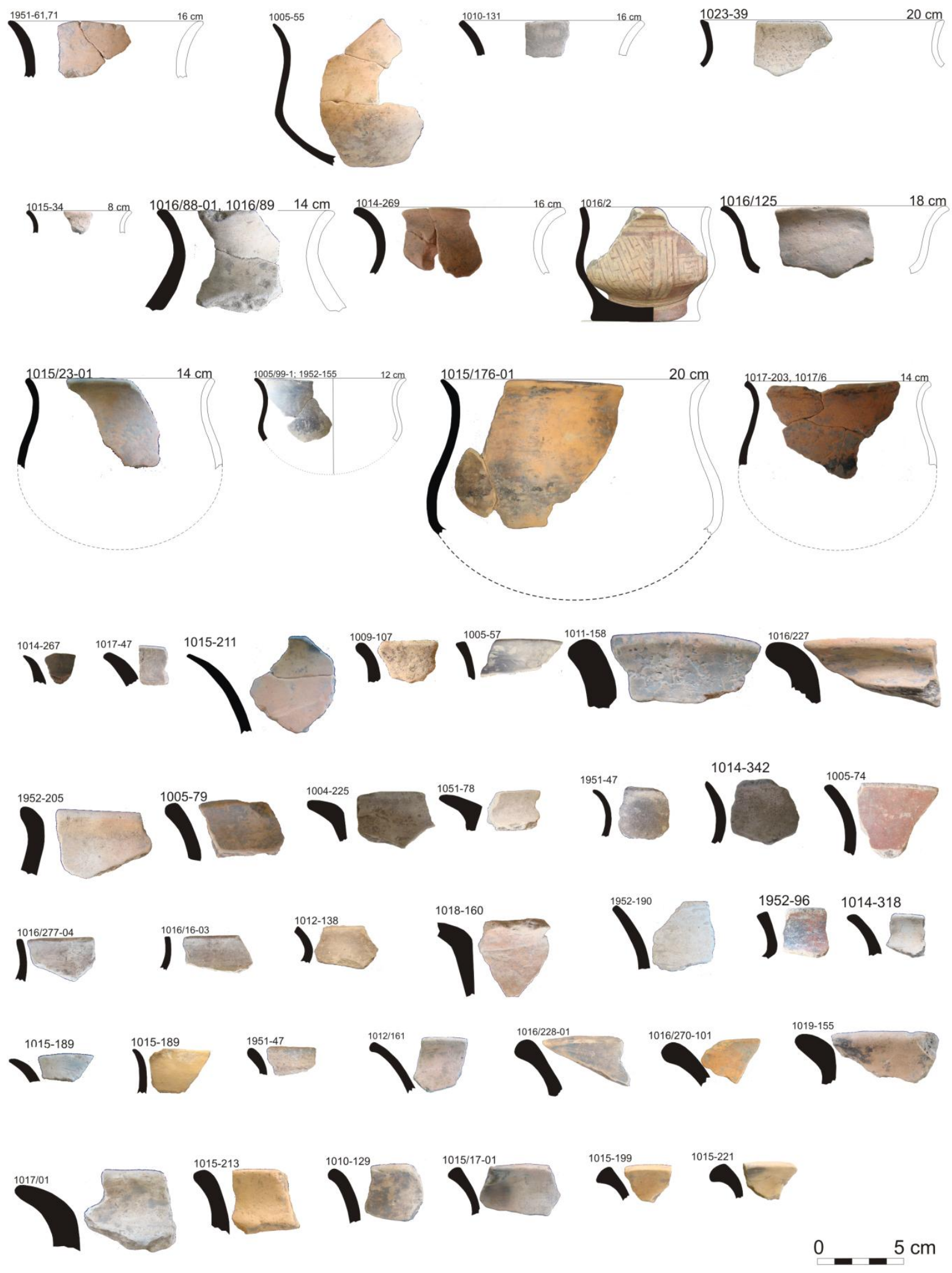

Figura 162: bordas extrovertidas - Camada A- Ilha Dionísio (desenhos: Angislaine F. Costa, 2013). 

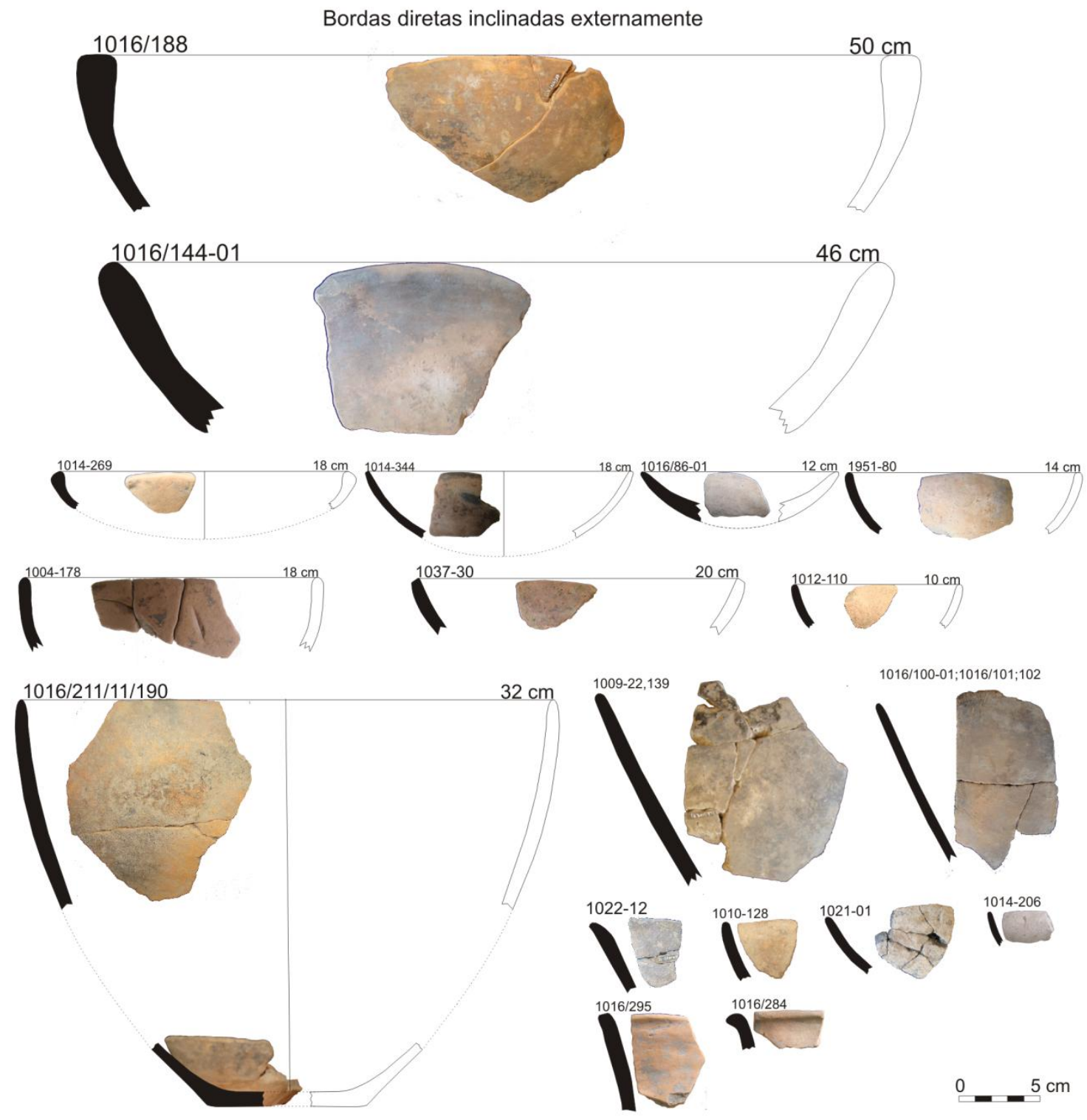

Figura 163: bordas diretas inclinadas externamente - Camada A- Ilha Dionísio.

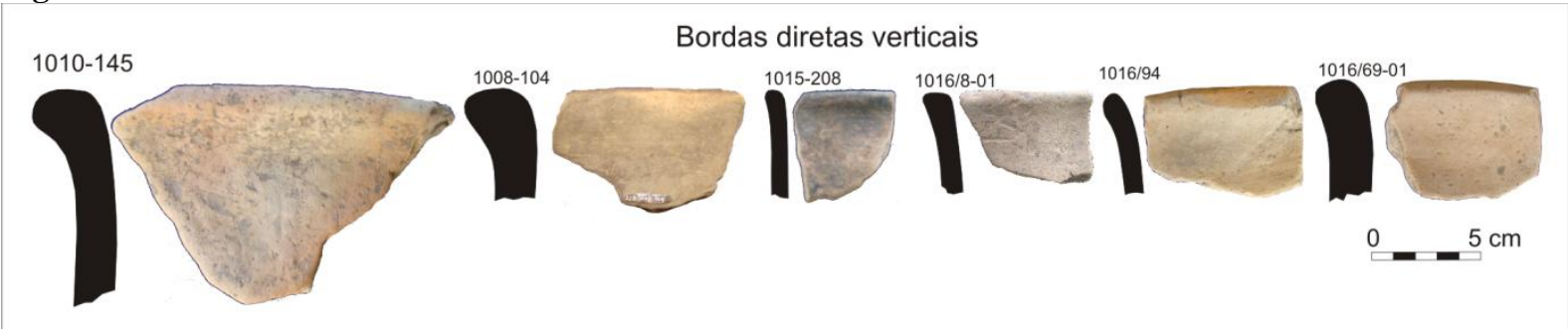

Figura 164: bordas diretas verticais- Camada A- Ilha Dionísio (desenhos: Angislaine F. Costa, 2013). 


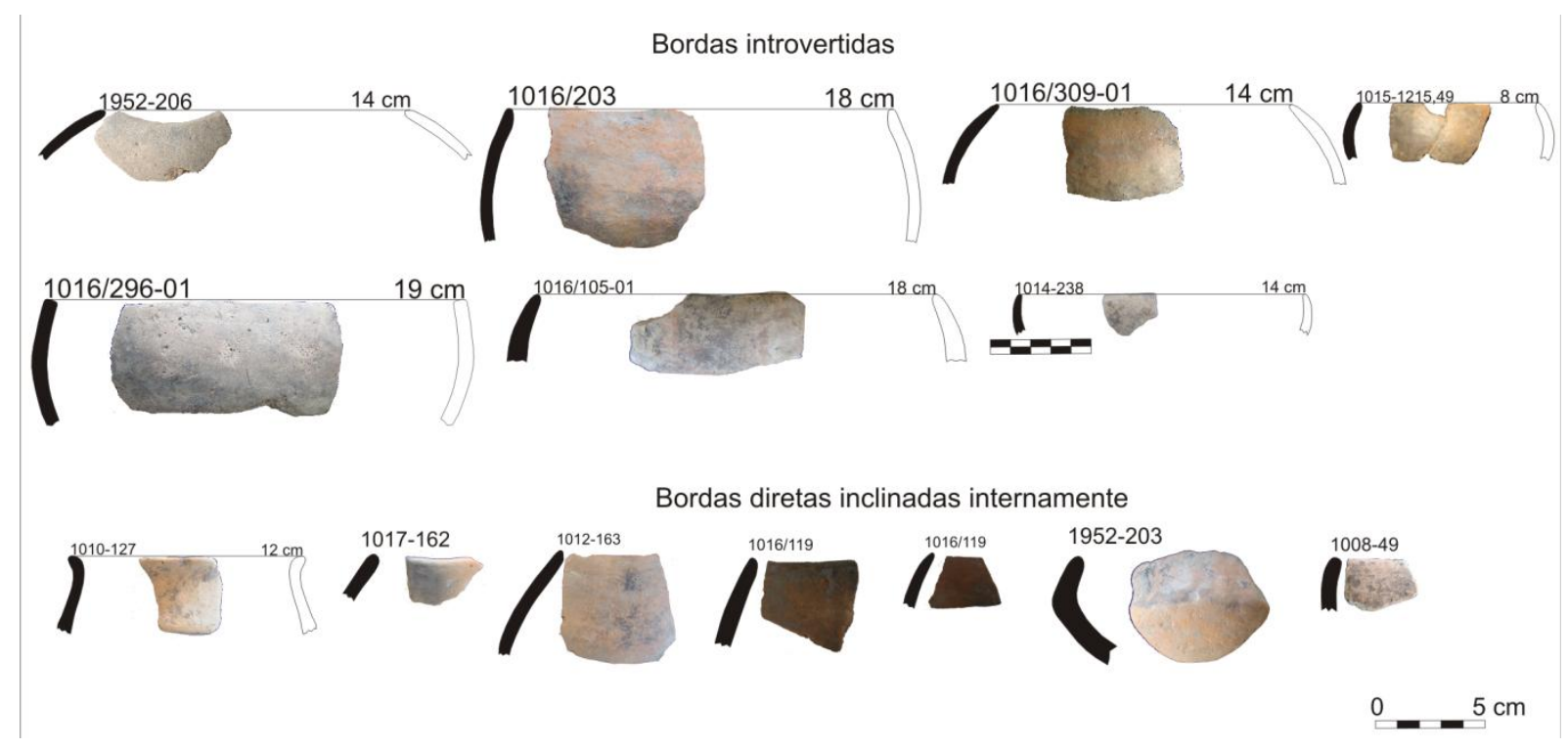

Figura 165: bordas introvertidas e diretas inclinadas internamente - Camada A- Ilha Dionísio (desenhos: Angislaine F. Costa, 2013).

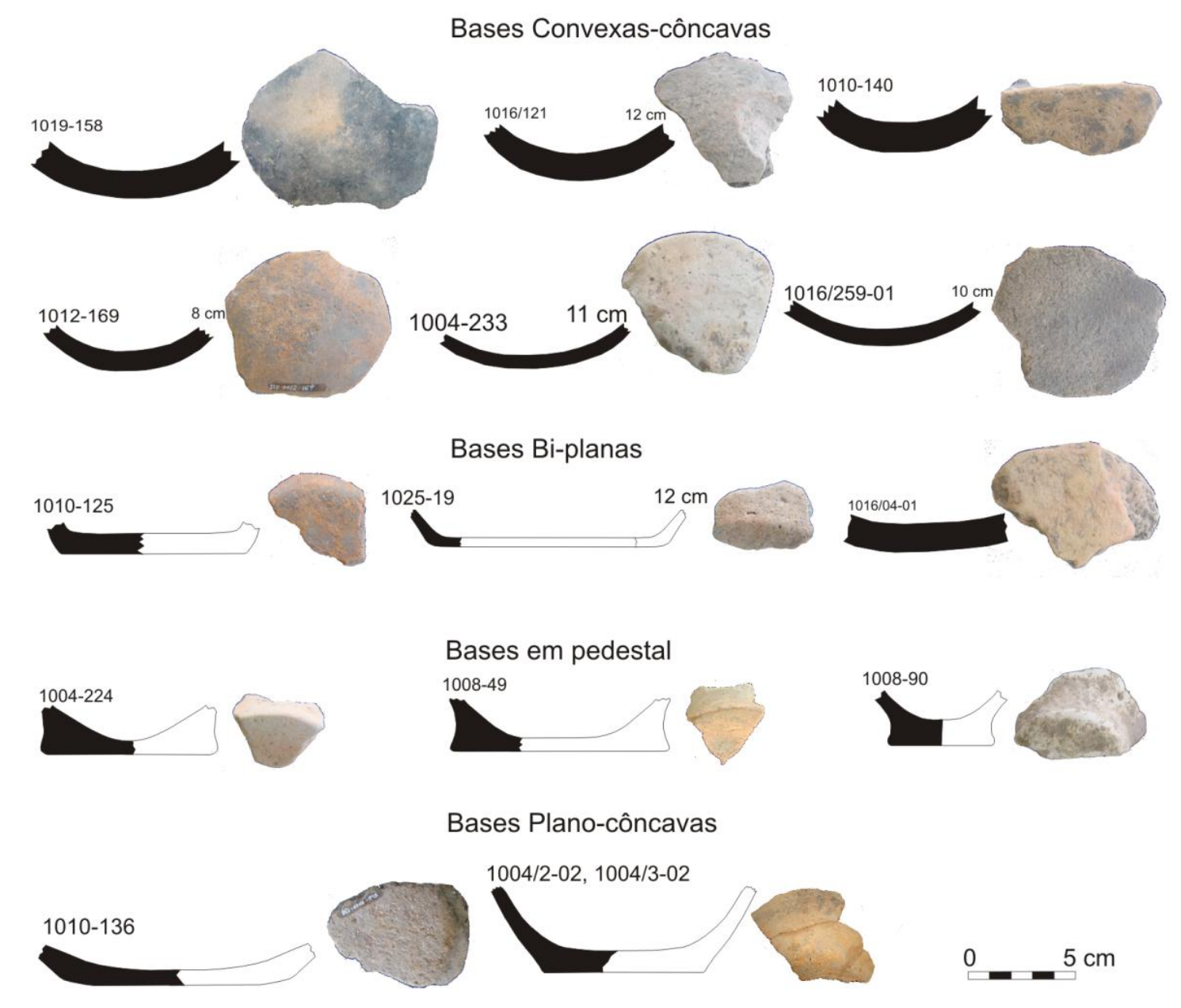

Figura 166: bases- Camada A- Ilha Dionísio (desenhos: Angislaine F. Costa, 2013). 


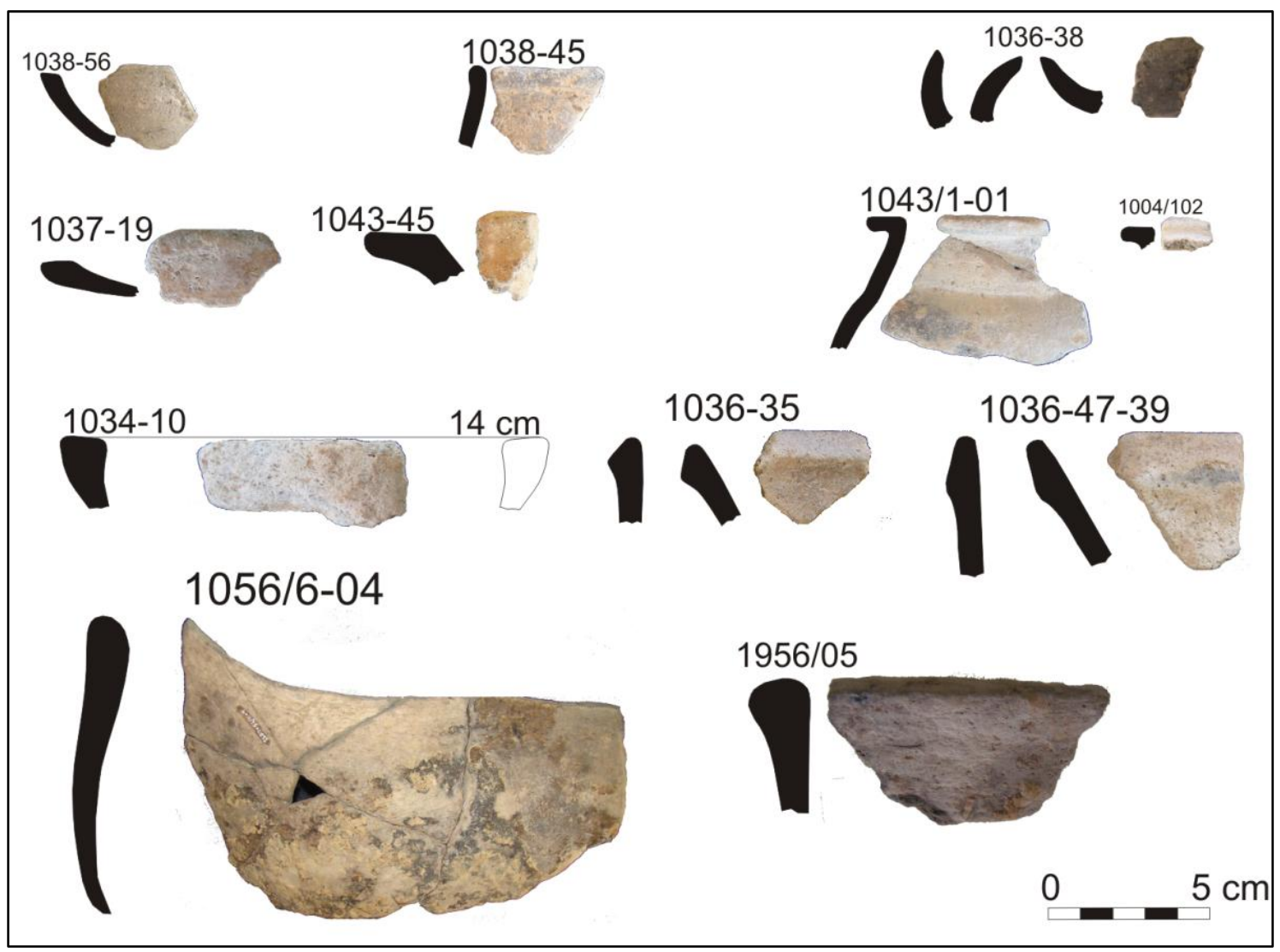

Figura 167: bordas da Camada C- Ilha Dionísio (desenhos: Angislaine F. Costa, 2013).

Marcas de uso foram identificadas em 199 fragmentos da camada A (figura 168), sendo fuligem FE (123), fermentação FI (36), e depósito de carbono FI (30), fuligem FE e depósito FI (7), fuligem FE e fermentação FI (2) e depósito de carbono e fermentação FI (1). $\mathrm{Na}$ camada $\mathrm{C}$ apenas quatro fragmentos apresentam fuligem. Na camada $\mathrm{A}$, observamos que vasilhas com fuligem e depósito de carbono predominantemente possuem apenas mineral na pasta ou mineral e cauixí. Já as vasilhas com marcas de fermentação possuem tanto mineral na pasta, como mineral e caraipé; mineral, caraipé e carvão; e mineral e cauixí.

Os fragmentos de trempe (21) foram encontrados na camada A (figura 169), entre os níveis 10-20 e 60-70 cm das unidades E347799 N8984160 e E347800 N8984161, dezenove com mineral e cauixí e duas com mineral. As 256 bolotas de argila analisadas são das três unidades contíguas, a maioria delas da camada A (0-10 a 80-90 cm) e apenas quatro da camada C (190-200 cm), 167 com mineral e 89 com cauixí.

A análise dos fragmentos das camadas A e C do sítio Ilha Dionísio, separadas por uma camada estéril (camada B), permitiu distinguir dois conjuntos tecnológicos diferentes. A cerâmica da camada A apresenta vasilhas predominantemente com cauixí na pasta, apesar de também serem frequentes vasilhas com mineral e com adição de caraipé; queima oxidante 
mais frequente que a reduzida; superfícies bem alisadas, polidas e brunidas; aplicação de uma camada fina de engobo vermelho; pintura vermelha ou preta em traços finos aplicados diretamente sobre a superfície das vasilhas com cauixí na pasta (motivos em linhas horizontais ou complexos) ou vermelha e branca em traços largos em vasilhas com caraipé (nestas às vezes as incisões estão associadas); raros tratamentos plásticos, destacando-se as linhas incisas isoladas e um modelado escalonado no lábio com engobo branco; estas vasilhas possuem espessuras com grande variação (3 e $30 \mathrm{~mm}$ ), sendo algumas bastante espessas; são frequentes e exclusivas desta camada as bordas extrovertidas e extrovertidas com ponto angular, com espessamentos e lábios de formas variadas; as vasilhas tem grande variação de diâmetro de abertura, entre $4 \mathrm{~cm}$ e $50 \mathrm{~cm}$; vasilhas com bases convexas côncavas (pasta predominantemente com cauixí) possivelmente tinham diferentes usos, incluindo o cozimento de alimentos (panelas), armazenagem e fermentação; vasilhas grandes e espessas com bases plano côncavas possivelmente eram utilizadas para armazenagem; vasilhas pequenas em forma de cálice, com base em pedestal e pintura, seriam utilizadas para consumir líquidos (fermentados). Vasilhas cuja pasta apresenta somente mineral, com bases predominantemente plano côncavas também eram utilizadas como panelas. Marcas de fermentação estão presentes em fragmentos com diferentes pastas e espessuras, e parece que esta prática era bastante frequente entre os portadores desta tecnologia cerâmica. A presença de trempes e bolotas de argila (muitas com cauixí) é característica desta ocupação.

Na camada C (figuras 167 e 170), onde a frequência de fragmentos cerâmicos é muito menor, as vasilhas apresentam pasta predominantemente com adição de caraipé e com queima reduzida. A análise dos acabamentos de superfície ficou prejudicada pelo desgaste das peças, sendo raros os fragmentos com engobo vermelho e a pintura está ausente. Entre os acabamentos plásticos, destaca-se o escovado e o ponteado, bem como uma vasilha com o lábio modelado para dar uma forma alongada (forma de navio ou de bote). As vasilhas possuem paredes menos espessas ( 3 e $15 \mathrm{~mm}$ ), destacando-se as vasilhas com flange labial e as com bordas expandidas ou reforçadas, de tamanho pequeno (de apenas duas bordas foi possível medir o diâmetro, de $14 \mathrm{~cm}$ e $20 \mathrm{~cm}$ ). Apenas uma base foi identificada, portanto possivelmente eram convexas côncavas (bases anelares e plano côncavas modeladas tendem a se conservar melhor). 


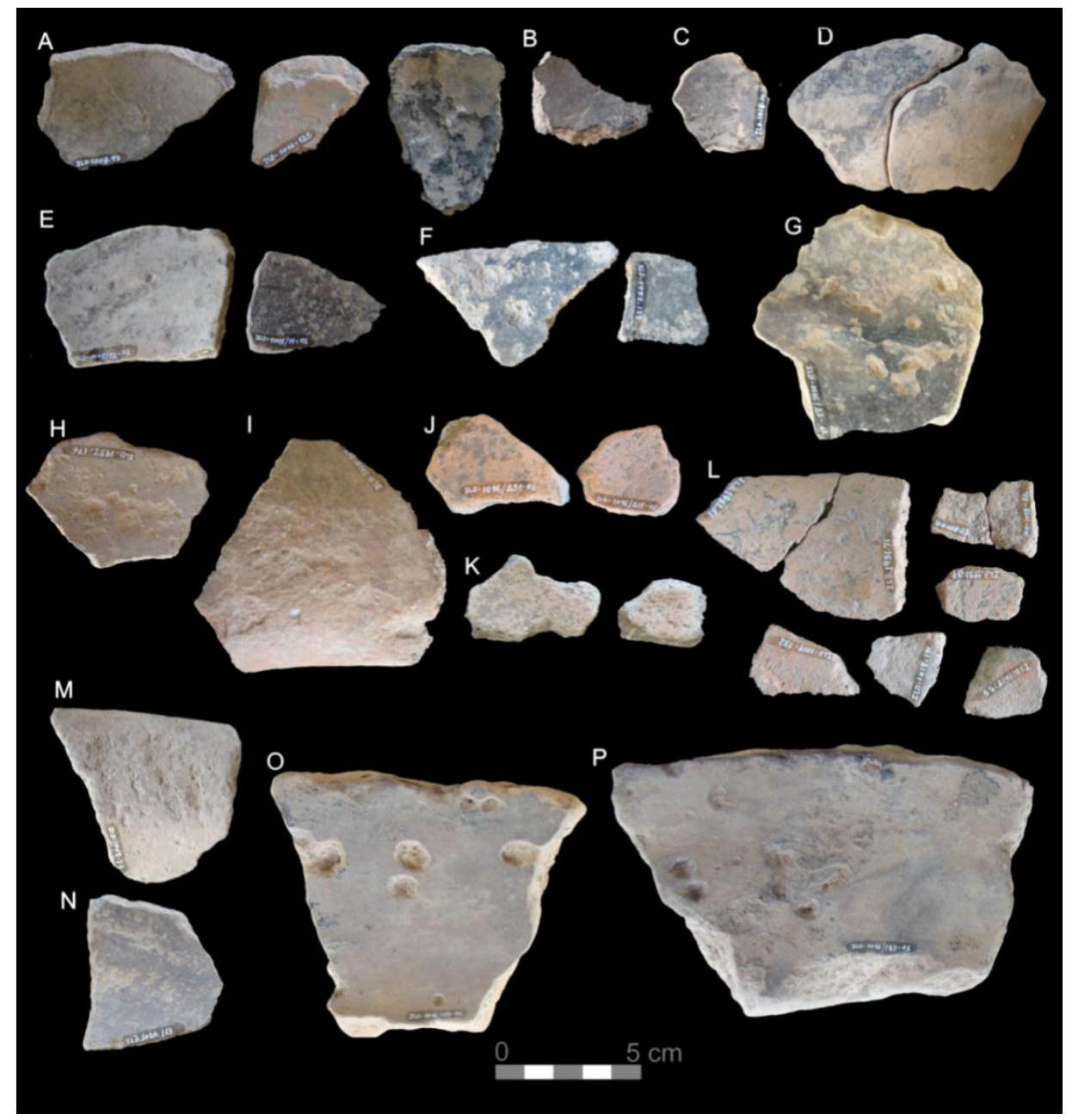

Figura 168: marcas de uso nos fragmentos da camada A: depósito de carbono (A, B, C); fuligem (D); fermentação em fragmentos de diferentes pastas (E- O); fermentação e fuligem (P) (Fotos: SCIENTIA, 2013).

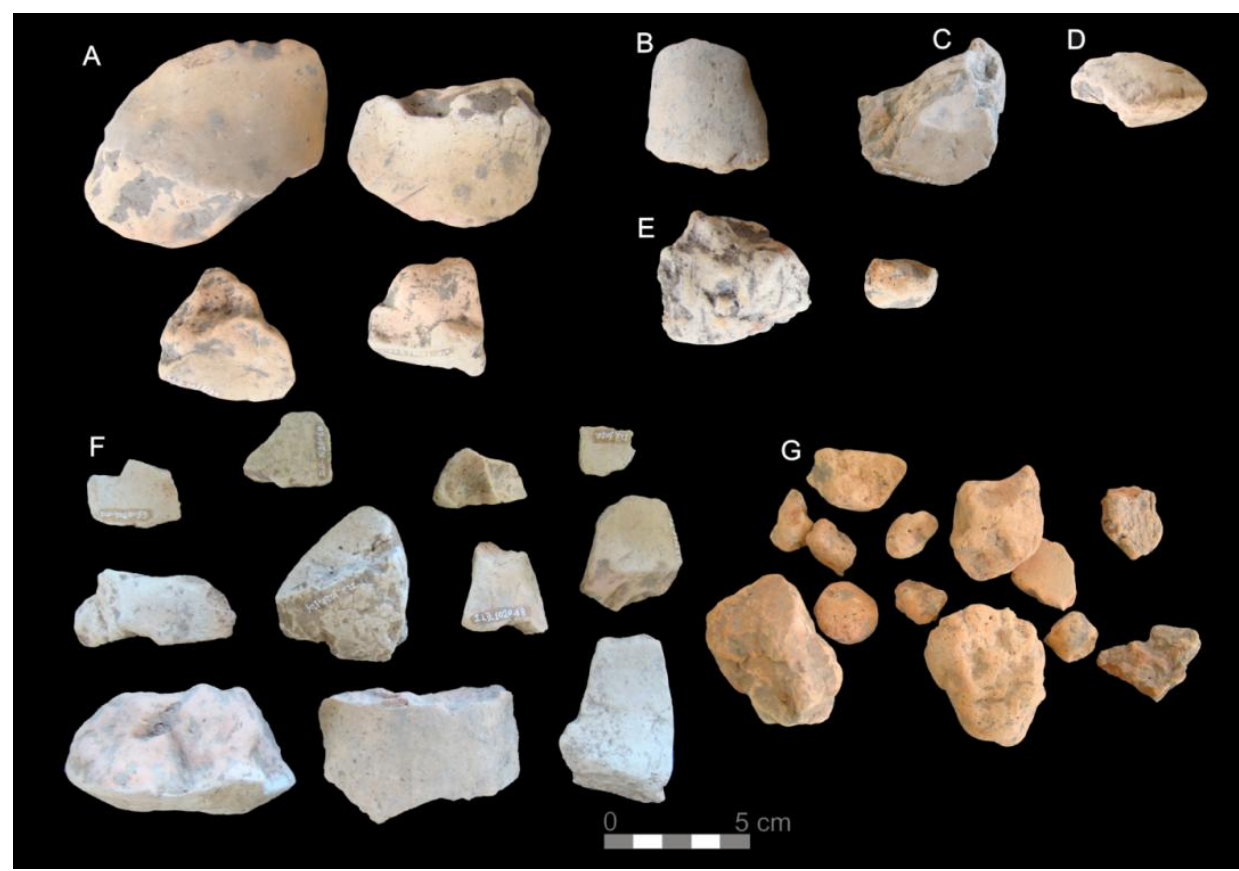

Figura 169: Fragmentos de trempe (A, B, C, D, F) e bolotas de argila (E, G)- Camada A- Ilha Dionísio (Fotos: SCIENTIA, 2013) 


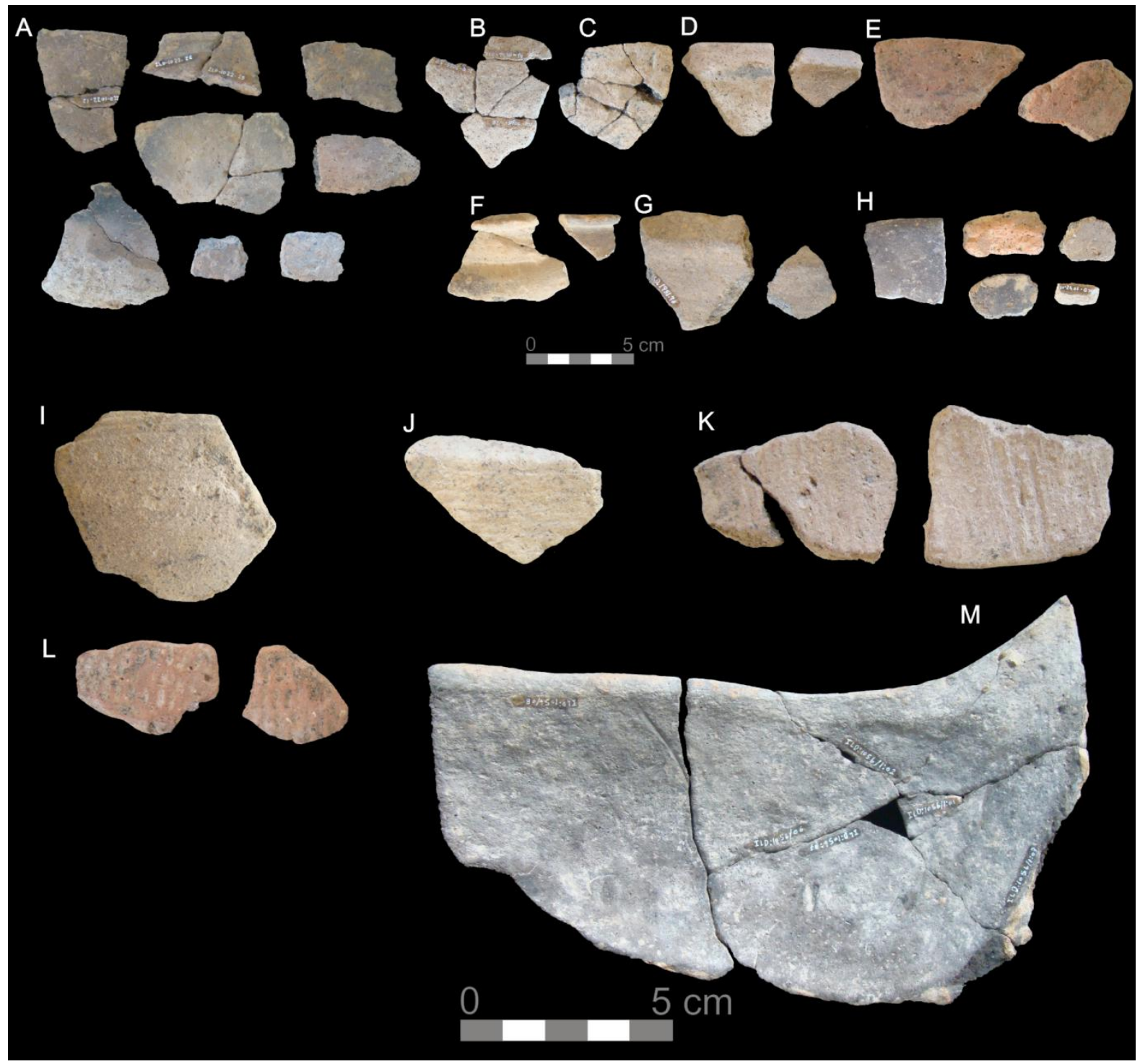

Figura 170: cerâmica da Camada C: parede (A, H), bordas (B-E), flanges labiais (F, G), borda com incisão (I), escovado (J, K), ponteado (L) e vasilha em forma de navio (M) (Fotos: SCIENTIA, 2013).

Concluímos que as escolhas tecnológicas adotadas na confecção das cerâmicas das duas camadas são diferentes, indicando tradições tecnológicas distintas. Voltaremos a esta discussão após a apresentação da análise das vasilhas inteiras e semi-inteiras dos setores sul e norte do sítio.

\subsubsection{Análise das vasilhas cerâmicas e estruturas do sítio Ilha Dionísio}

Analisamos 13 vasilhas cerâmicas, sendo nove do setor sul (V1, V2, V3, V4, V5, V6, V7, V8, V9) e quatro do setor norte (V16, V 18, V19, V26), bem como fragmentos do seu interior, fragmentos de tampa e das estruturas evidenciadas. Do setor Sul, analisamos todas as 
vasilhas e estruturas, porém do setor norte somente aquelas que estão inteiras ou que foram restauradas.

\section{Vasilha 1 e seu contexto ( $\mathbf{E 3 4 7 9 7 3 ~ N 8 9 8 3 9 3 4 / S e t o r ~ S u l )}$}

Conforme vimos no capítulo 3, a vasilha 1 foi escavada na unidade E347973 N8983934, sendo evidenciado no seu interior sedimento com fragmentos cerâmicos, líticos e carvões nos primeiros $20 \mathrm{~cm}$, e abaixo parte de uma segunda vasilha (Vasilha 2), com borda, gargalo e bojo, emborcada dentro da vasilha 1, contendo em seu interior fragmentos estruturados que serviam como tampa, cobrindo um sedimento acinzentado. Foi encontrado apenas um pequeno fragmento pequeno de osso entre 30 e $40 \mathrm{~cm}$, dentro da vasilha 1.
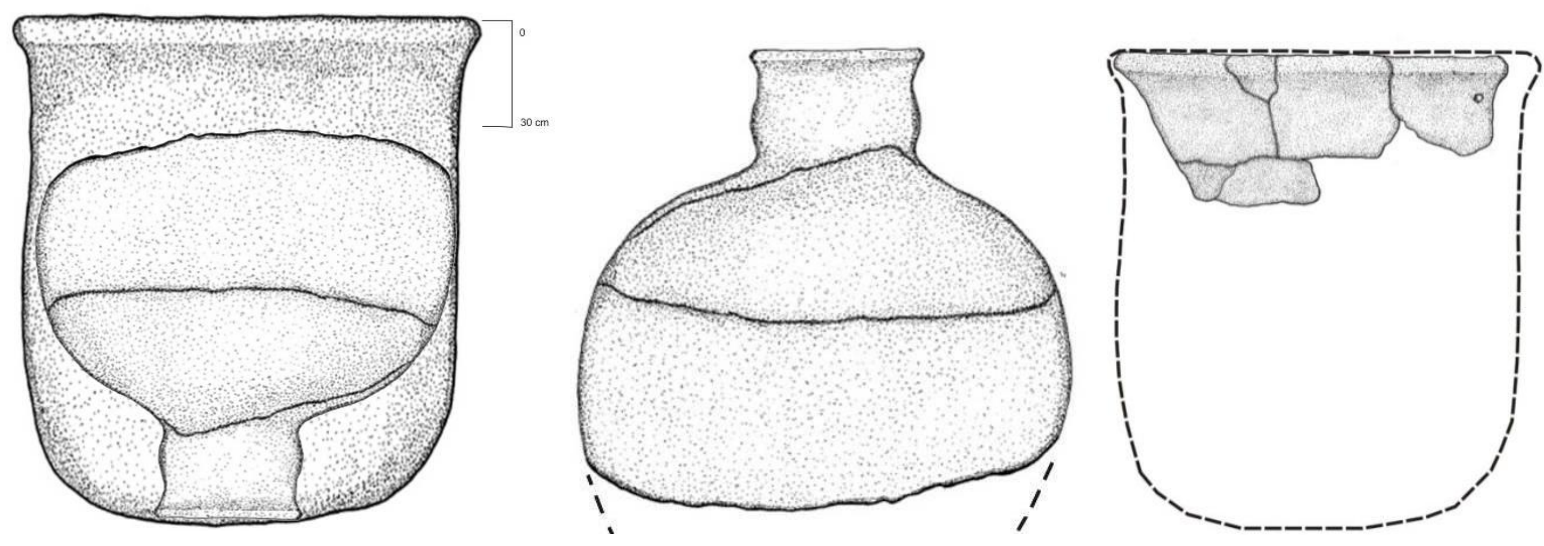

Figura 171: contexto da vasilha 1, vasilha 2 e reconstituição da forma de uma vasilha da tampa (Angislaine F. Costa, 2012).

A vasilha 1 (V1 nas figuras 171 e 173) apresenta pasta com minerais (quartzo e oxido de ferro), cauixí e argila. A coloração da pasta varia entre branca e laranja, em função da queima em ambiente oxidante, e a base apresenta um núcleo levemente acinzentado (reduzido). Foi confeccionada com roletes sobrepostos (em algumas quebras observa-se uma rugosidade, possivelmente uma técnica de união dos roletes) e a base foi modelada; parece ainda terem sido aplicadas porções de argila em algumas partes da vasilha buscando reforçar algumas partes (borda e base) ou corrigir imperfeições (na parede). A superfície interna foi alisada e apresenta descamações de uma fina camada (possível barbotina) e a face externa é polida e apresenta uma fina camada de engobo vermelho que possivelmente recobria toda a peça, porém está evidente em apenas algumas partes devido ao desgaste.

A vasilha apresenta forma aberta com contorno simples, boca circular, parede direta vertical e base convexa plana. A borda é direta, levemente inclinada externamente, expandida 
(é mais espessa pela aplicação de um rolete que reforça o lábio). Possui $59 \mathrm{~cm}$ de diâmetro de abertura e $69 \mathrm{~cm}$ de altura. Na junção da base com o corpo o diâmetro é de $50 \mathrm{~cm}$. A espessura da vasilha varia entre $10 \mathrm{~mm}$ na parede e $38 \mathrm{~mm}$ na base. Na sua face externa, próximo a borda, ocorre um enegrecimento, possivelmente decorrente da queima. O contexto evidenciado no seu interior reforça a ideia de que tenha sido utilizada como urna.

A vasilha 2 (V2 nas figuras 171 e 173) estava emborcada no interior da vasilha 1 e é composta por fragmentos que remontam a borda, gargalo, ombro e parte do corpo, faltando o bojo inferior e a base, que podem ter sido quebradas propositalmente ou a vasilha foi reaproveitada nesse contexto após uma quebra acidental. Encontra-se muito erodida, principalmente na superfície interna no bojo e ombro. A pasta possui cauixí, quartzo e óxido de ferro. A coloração na face interna é mais branca/cinza clara ou escura e na externa é alaranjada, possivelmente decorrente do processo de queima (oxidante incompleta), que propiciou uma maior dureza da superfície externa e consequente maior preservação (cogita-se a hipótese de terem sido utilizadas mais de um tipo de argila na sua confecção, assim como de outras vasilhas, porém essa questão só poderá ser resolvida com analises arqueométricas). Foi confeccionada pela técnica acordelada, porém possivelmente "placas" de argilas foram utilizadas para reforçar as paredes. Tudo indica que o copo da vasilha foi confeccionado com a técnica acordelada e o pescoço com a técnica modelada, porém ainda podem ter sido utilizadas placas para o reforço de algumas partes (desprendimento de placas pode ser decorrente da técnica de produção ou da queima). A superfície externa foi polida e ocorre a aplicação de engobo vermelho no pescoço, onde a peça está mais conservada. Na superfície interna observou-se polimento e engobo vermelho em algumas partes do gargalo, porém a peça encontra-se muito erodida. Ocorre pintura em linhas paralelas (duas) vermelhas no lábio.Trata-se uma vasilha com contorno complexo e estrutura fechada, boca circular, borda extrovertida com lábio arredondado, espessamento linear, e diâmetro de abertura de $16 \mathrm{~cm}$. O gargalo mede $10 \mathrm{~cm}$ de altura. A espessura varia entre 0,8 e $2,1 \mathrm{~cm}$ sendo mais fina no bojo e mais espessa no ombro e na junção do ombro com o pescoço. Na quebra do bojo, o diâmetro mede $45 \mathrm{~cm}$. A erosão acentuada na superfície interna da vasilha pode estar relacionada ao seu uso, à composição da pasta ou ao processo de queima (incompleta). O contexto indica que a vasilha serviu de urna, sendo evidenciado no seu interior sedimento acinzentado com carvão encoberto por fragmentos que serviam como tampa. Ocorrem manchas escuras que podem se tratar de fuligem ou depósito carbônico que se fixou na peça, decorrente do sedimento com muito carvão e cinzas. 
Tudo indica que os fragmentos organizados de forma horizontal, utilizados como tampa na estrutura, pertencem a cinco vasilhas diferentes. Dentre estes, destacam-se 42 fragmentos ( 8 da boca da vasilha e os demais de parede) que pertencem a uma mesma vasilha com características de pasta, queima, técnicas de confecção e forma semelhantes a vasilha 1 (figura $171 ; 173$, letra A). A face externa apresenta alisamento médio e na face interna ocorre brunidura. A borda é inclinada externamente, lábio arredondado e expandido, possivelmente decorrente daaplicação de um rolete para reforçá-lo, a boca é circular com $56 \mathrm{~cm}$ de diâmetro de abertura. Na borda, próximo ao lábio, ocorre um furo confeccionado de dentro pra fora, antes da queima da vasilha.

Outros15 fragmentos (um de borda e os demais de parede) parecem pertencer a uma mesma vasilha, com borda inclinada externamente, espessamento linear, lábio arredondado, boca é circular com diâmetro de $58 \mathrm{~cm}$, e espessura variando entre 1,2 e $2 \mathrm{~cm}$ (figura 173, letra C). Os demais fragmentos são de parede, e apesar de possuírem características semelhantes, parecem pertencer a vasilhas diferentes (um deles possui vestígios de pintura na face externa e depósito de carbono na face interna, enquanto os demais são apenas alisados).

\section{Vasilha 3 e seu contexto (unidade E347952 N8983925/Setor Sul)}

A vasilha 3 (V3, figura 173) foi encontrada no barranco no limite sul do sítio, contendo no seu interior sedimento com cerâmica, lítico, carvão e pequenos farelos de ossos. Fragmentos estavam organizados como tampa e alguns encontrados no seu interior podem ter caído. Analisamos a vasilha 3, os fragmentos da tampa, a cerâmica evidenciada no seu interior e fragmentos diagnósticos escavados no seu entorno, buscando encontrar a sua borda, pois a vasilha está quebrada na parte superior.

A vasilha 3 é composta por 18 fragmentos, com base, bojo e ombro, faltando a borda. A pasta é composta por mineral (quartzo e óxido de Ferro) e cauixí. Tudo indica que foi confeccionada pela técnica de placas. Observa-se que uma camada de $3 \mathrm{~mm}$ se desprende da vasilha na superfície interna. Na parte superior do bojo está mais desgastada na superfície externa, devido à exposição no barranco, e na superfície interna está muito erodida, com sulcos profundos e um furo de diâmetro pequeno. Na face interna ocorre brunidura, que impermeabiliza a vasilha cuja pasta é bastante arenosa e com cauixí, e na face externa ocorre pintura vermelha e polimento. A pintura, aplicada diretamente sobre a superfície, aparece 
apenas em alguns pontos, ora como uma faixa larga e ora em linhas finas, podendo estarem alternadas faixas e linhas.

No interior da Vasilha 3 foram encontrados 33 fragmentos cerâmicos, alguns deles da própria vasilha, outros que compunham a tampa, e os demais devem ter caído com o sedimento (destacando-se uma borda cuja pasta apresenta cauixí; entre os demais, muito fragmentados, apenas 3 fragmentos possuem caraipé na pasta, três com mineral e os demais possuem cauixí). Oito fragmentos possivelmente são da vasilha 3, um deles com a pintura preservada semelhante a da vasilha.

Três fragmentos encontrados no interior da vasilha 3 remontam à tampa, portanto caíram para o seu interior, preservando-se o engobo vermelho. Em uma das extremidades possui a quebra circular, podendo se tratar de um furo propositalmente feito na vasilha antes da quebra, porém é difícil afirmar (figura 173, letra D). Além destes, destaca-se um fragmento de borda que estava na vertical junto à tampa, possivelmente intencionalmente colocada, possuindo pasta com cauixi, técnica acordelada, $7 \mathrm{~mm}$ de espessura, direta inclinada internamente, espessamento linear, lábio arredondado, boca circular de $22 \mathrm{~cm}$ de diâmetro (figura 173, letra E). Do entorno da vasilha 3, na unidade E347952 N8983925, foram analisados 22 fragmentos, os quais apresentam cauixí na pasta, com exceção de um fragmento que possui caraipé (figura 173, letras F, G, H). Destacam-se conjuntos de fragmentos que remontam e podem compor uma única vasilha (poderiam compor a tampa).

Com a análise dos fragmentos da vasilha 3, da tampa, do interior e da unidade, concluímos que a vasilha já encontrava-se quebrada (com ausência da borda) quando foi utilizada nesse contexto. Para cobrir foram utilizados fragmentos de uma vasilha cerâmica com engobo vermelho na face externa. Parte da tampa caiu para o seu interior, preservando-se o pigmento vermelho, bem como uma parte da própria vasilha, com pintura. Parte da tampa pode ter caído para fora da vasilha (fragmento encontrado na unidade). A vasilha foi progressivamente preenchida com sedimento misturado a fragmentos cerâmicos, alguns com cauixí na pasta, outros com caraipé e algumas somente com mineral.

\section{Vasilha 4 e seu contexto (Estrutura 1- unidade E347971 N8983935/Setor Sul)}

A estrutura 1 (figura 173) é composta por uma vasilha cerâmica (vasilha 4) tampada com fragmentos grandes de duas vasilhas diferentes. No interior da vasilha ocorreu sedimento 
com fragmentos cerâmicos e líticos. A vasilha 4 (V4 na figura 173) é composta por 65 fragmentos, sendo 10 da borda, 5 da base e os demais da parede. A pasta apresenta cauixí e minerais (quartzo e óxido de ferro), a queima é oxidante (cores laranja e bege) e a técnica de confecção é a acordelada. Foi polida em ambas as faces, e na superfície interna está enegrecida em algumas porções (possivelmente em função da queima). Possui contorno infletido e estrutura aberta, boca circular,borda extrovertida, lábio arredondado com espessamento expandido, $24 \mathrm{~cm}$ de altura e $42 \mathrm{~cm}$ de diâmetro de abertura. A base é convexa côncava, com um furo no centro ( $9 \mathrm{~cm}$ de diâmetro), feito após a queima da vasilha. A espessura varia entre 0,6 e 1,3 cm, sendo mais espessa próxima à base e a boca.Apresenta desgaste na parte interna, abaixo do bojo, possivelmente decorrente do uso. Na face externa apresenta desplacamento na base, possivelmente em função da queima, mas pode ter sido quebrada intencionalmente, assim como o furo.

A tampa é composta por 32 fragmentos grandes e 37 pequenos. A análise demonstrou que seis fragmentos grandes de duas vasilhas (três de cada uma) foram colocados intercalados sobre a vasilha 4 para encobri-la. Fragmentos de borda e parede são de uma vasilha grande (Conjunto 1A), com pasta, técnicas de confecção, queima e forma semelhante à vasilha 1 , cujas superfícies interna e externa são polidas, a parede é vertical, borda expandida e levemente inclinada externamente, lábio arredondado, com $68 \mathrm{~cm}$ de diâmetro de abertura e espessura variando entre 1,8 e 2,6 cm, sendo mais espessa na borda.

Outros fragmentos de bojo e base são de uma mesma vasilha (Conjunto 1B), cuja pasta também apresenta cauixí e minerais, técnica acordelada, queima variando entre oxidante (laranja) e reduzida (cinza escura) e com polimento em ambas as superfícies. Três fragmentos que estavam no fundo da vasilha remontaram ao fragmento de bojo. Próximo à base a vasilha apresenta-se escurecida na superfície interna, possivelmente pelo uso.

\section{Vasilhas 8 e 9 (coleta de superfície no barranco/Setor Sul)}

No barranco adjacente a esta área foram coletados fragmentos que posteriormente remontaram duas vasilhas (vasilha 8 e vasilha 9). A vasilha 8 (V8, figura 173)possui pasta com mineral e cauixí, queima oxidante, polida em ambas as faces. Possui formainfletida, borda extrovertida, espessamento linear, lábio arredondado, $25 \mathrm{~cm}$ de diâmetro de abertura e $22 \mathrm{~cm}$ de altura, espessura de $10 \mathrm{~mm}$ na borda e $13 \mathrm{~mm}$ no bojo e base. A base é convexa côncava. Possui fuligem na face externa e depósito de carbono na face interna. 
A vasilha 9 (V9, figura 173) possui apenas três fragmentos de bojo e base. A pasta possui mineral e cauixí, queima oxidante, polida em ambas as faces. A base é plano côncava, com aproximadamente $17 \mathrm{~cm}$ de diâmetro. A base possui $7 \mathrm{~mm}$ de espessura no centro e 17 $\mathrm{mm}$ nas extremidades, enquanto o bojo varia entre 11 e $17 \mathrm{~mm}$ em lados opostos na mesma altura (irregular). Apresenta fuligem na face externa do bojo e depósito de carbono na face interna da base.

\section{Estrutura 2 (unidade E347972 N8983936/ Setor Sul)}

A estrutura 2 (figura 174) é composta por fragmentos cerâmicos, carvões, bolotas de argila, líticos e um possível pingente. $\mathrm{Na}$ estrutura ocorrem fragmentos de diversas vasilhas de espessuras e queimas diferenciadas. A análise permitiu a remontagem parcial de três delas (vasilhas 5, 6 e 7), porém ocorrem outras bordas, bases e paredes, destacando-se quatro bordas de vasilhas diferentes, oito fragmentos de base (alguns devem ser da mesma vasilha), e fragmentos que remontam um bojo; os demais estão muito erodidos.

Quinze fragmentos remontaram a vasilha 5 (figura 172; e V5, figura 174). Possui pasta com mineral e cauixí, coloração variando entre laranja e preta, queima oxidante na face externa e reduzida na interna. Parece ter sido confeccionada com a técnica modelada. Apresenta polimento na face externa e alisamento fino na face interna. Possui contorno complexo e estrutura restringida, borda extrovertida, espessamento linear, lábio arredondado boca circular com $8 \mathrm{~cm}$ de diâmetro; mede $13 \mathrm{~cm}$ de altura e a espessura varia entre $4 \mathrm{~mm}$ na boca, $3 \mathrm{~mm}$ no corpo, $10 \mathrm{~mm}$ próximo a base e $3 \mathrm{~mm}$ na base, que é convexa côncava. A superfície interna, na parte da base e bojo apresenta-se reduzida e erodida, porém não é possível saber se é da queima ou do uso.

A vasilha 6 (V6, figura 174) é composta por seis fragmentos de borda, 3 fragmentos de base e 23 fragmentos do corpo. A pasta apresenta alta inclusão de grãos angulosos e subangulosos de quartzo e óxido de ferro. Possui coloração cinza escura e queima reduzida, foi confeccionada com a técnica acordelada e é polida em ambas as faces. Possui contorno simples e estrutura restringida, borda introvertida, espessamento linear e lábio arredondado, boca circular com $8 \mathrm{~cm}$ de diâmetro. A base é plano côncava com $6 \mathrm{~cm}$ de diâmetro e a espessura é de $4 \mathrm{~mm}$ em toda a vasilha. Ocorre fuligem em quase toda a vasilha, principalmente no bojo superior e borda. 
A vasilha 7 (V7, figura 174) é composta por 9 fragmentos de borda e 14 de pescoço. Apresenta quartzo, óxido de ferro e cauixí na pasta, a queima é oxidante e a técnica de confecção é acordelada. Na face externa apresenta engobo vermelho e polimento, e na face interna brunidura. Vasilha com contorno infletido e estrutura fechada, borda extrovertida e expandida e lábio arredondado, boca circular com $22 \mathrm{~cm}$ de diâmetro. Trata-se de uma vasilha com gargalo.

Entre os demais fragmentos da estrutura 2, destaca-se a borda (965/26) extrovertida, linear e com lábio arredondado, com $9 \mathrm{~cm}$ de diâmetro de abertura. Possui cauixí na pasta, queima oxidante e alisamento fino em ambas as faces (figura 174, letra A). Outros 14 fragmentos de bojo possuem características semelhantes e podem compor a mesma vasilha, com forma e tamanho semelhantes à vasilha 5 desta mesma estrutura (figura 174, letra B). Na face externa do bojo ocorrem vestígios de pigmento vermelho, bem como no lábio da borda. Denominamos estes fragmentos de conjunto $2 \mathrm{~A}$.

Quatro bordas de vasilhas diferentes estavam na estrutura (figura 174, letra C). A ILD 955-03, cuja pasta possui caraipé, é extrovertida, linear e com lábio apontado, sem diâmetro identificável, com vestígios de pigmento vermelho em ambas as faces. As bordas ILD 965-25, ILD 968-28 e ILD 956/1 estão bastante fragmentadas, todas com cauixí na pasta e de espessuras bem diferentes (5, 10 e $19 \mathrm{~mm}$ ), sendo que a 968/28 possui vestígios de pigmento vermelho na FE. Destacam-se ainda sete fragmentos de bases convexas côncavas, todas com cauixí na pasta e redução na face interna. Os demais fragmentos são de parede, cujas pastas apresentam mineral, caraipé ou cauixí, alguns com pigmentação vermelha na face externa.

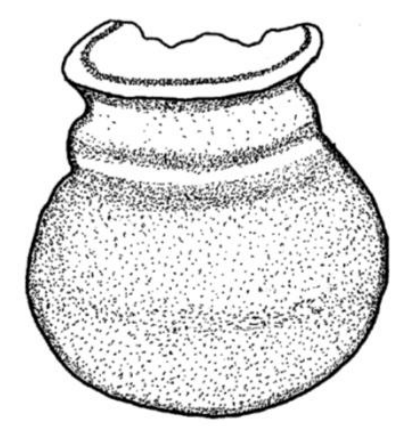

Figura 172: vasilha 5 (Angislaine F. Costa, 2012) 


\section{Estrutura 3 (Unidade E347969 N8983834/Setor Sul)}

A estrutura 3 (figura 174) é caracterizada por fragmentos cerâmicos sobrepostos, constituindo-se de duas camadas de cerâmica cobrindo um possível contexto funerário, pois ocorreram farelos de ossos e um fragmento de dente, bolotas de argila e carvão junto ao sedimento. Estava próxima a estrutura 5 de seixos. Foram identificados fragmentos que compõem duas ou três vasilhas.

Na parte superior estavam 21 fragmentos (4 de borda; 16 de inflexão e parede; uma possível base), cuja pasta apresenta mineral e cauixí, queima variando de oxidante com núcleo escuro a oxidante externa e reduzida interna (laranja e cinza escura) e polimento em ambas as faces. A borda levemente extrovertida, expandida e com lábio arredondado, com $44 \mathrm{~cm}$ de diâmetro de abertura. O bojo é bastante saliente, mas não chega a se constituir um uma carena. A base é bi-plana e possui $14 \mathrm{~cm}$ de diâmetro. A borda apresenta $10 \mathrm{~mm}$ de espessura, a inflexão $12 \mathrm{~mm}$ e a base $10 \mathrm{~mm}$ (figura 174, letra $\mathrm{E}$ ).

Outros 24 fragmentos que estavam na segunda camada da estrutura compõem o bojo inferior de uma vasilha, cuja pasta também apresenta cauixí, queima reduzida e ambas as superfícies são polidas. Na face externa ocorre pintura vermelha, aplicada diretamente sobre a superfície, com traços finos combinados a faixas largas, motivos complexos e de difícil identificação. Possui $18 \mathrm{~mm}$ de espessura. A superfície interna apresenta-se desgastada e queimada com depósito de carbono (figura 174, letra D). 

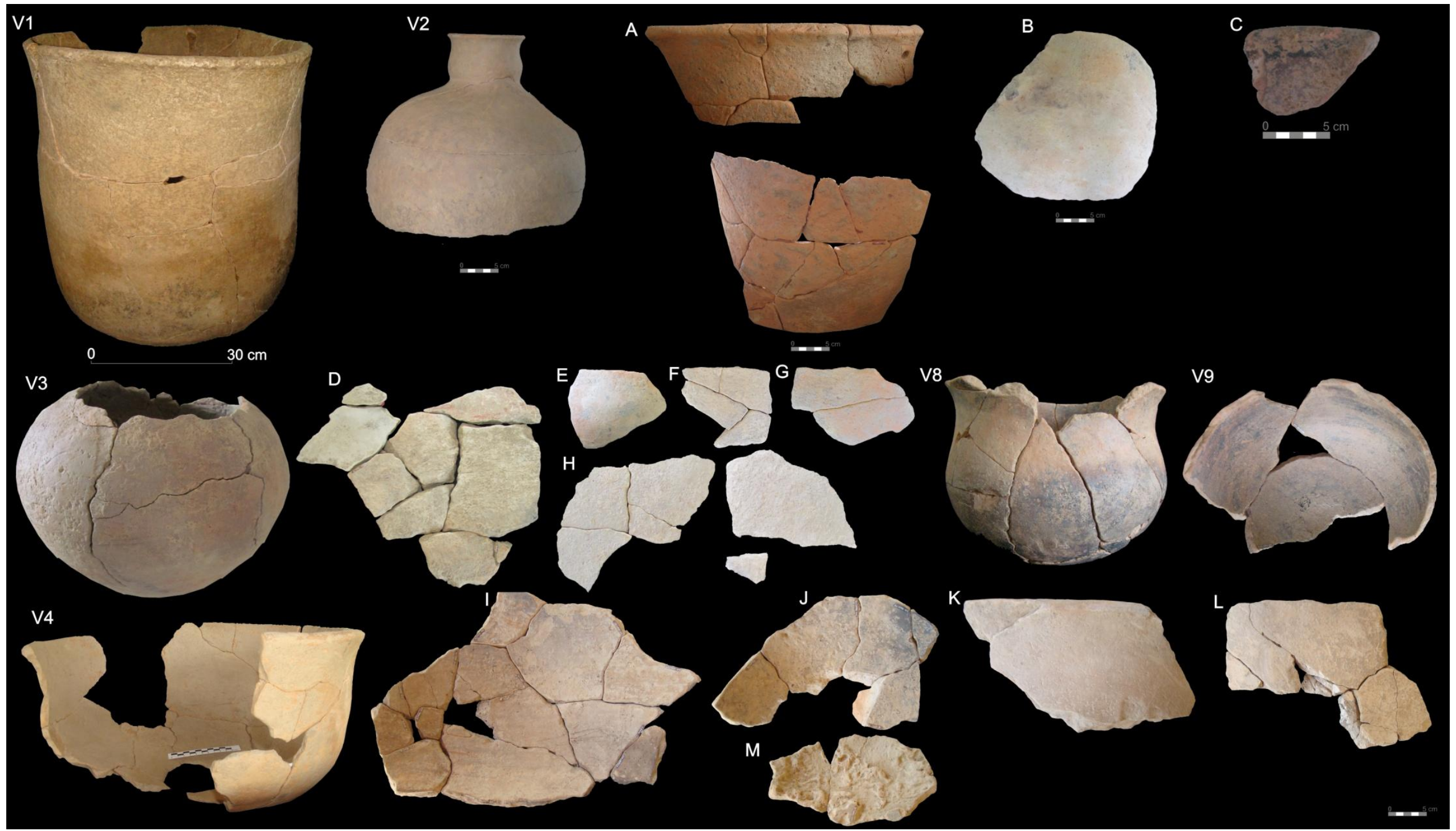

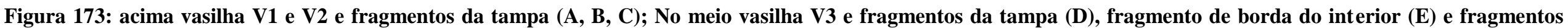
encontrados na unidade (F, G, H); Abaixo V4 e fragmentos de tampa (I, J, L, M); e vasilhas V8 e V9 (Fotos: SCIENTIA, 2012). 


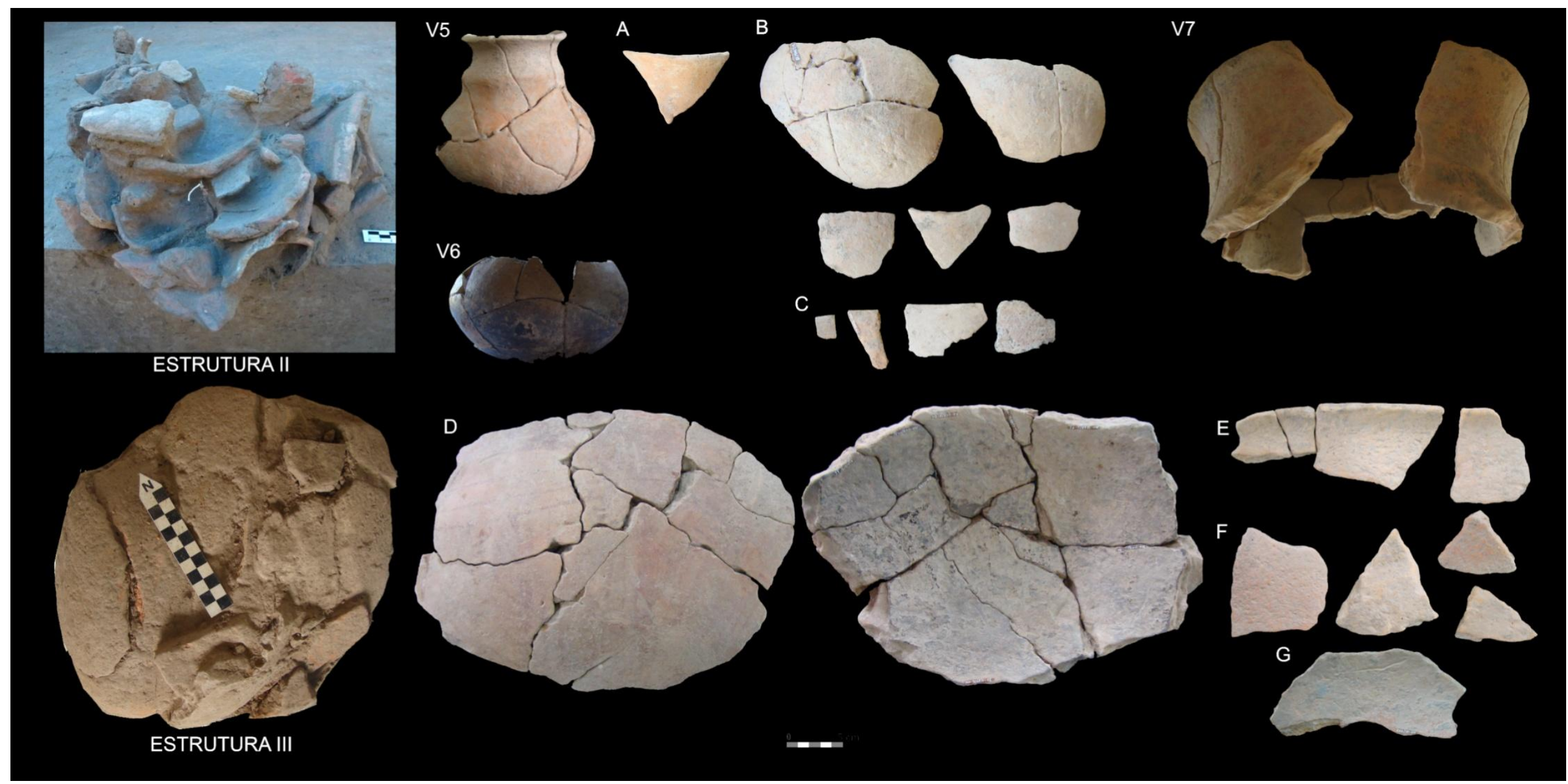

Figura 174: acima estrutura II: vasilha V5, V6 e V7 remontadas; borda (A) e bojo (B), possivelmente da mesma vasilha; e fragmentos de borda (C). Abaixo, estrutura III: Fragmento de bojo com pintura (D), fragmentos de borda (E), de parede (F) e bojo (G) (Fotos: SCIENTIA, 2013) 


\section{Vasilhas 16, 18 e 19 (unidade E347919 N8984459) e da vasilha 26 (E347921 N8984455) do Setor Norte}

As vasilhas 18 e 19 são pequenas, possivelmente miniaturas, e a vasilha 16 é muito semelhante à vasilha 26, escavada na unidade 13 (E347921 N8984455). Na mesma unidade foram escavadas as vasilhas 15 e 17, bastante fragmentadas, bem como duas estruturas: a estrutura 20 composta por carvões associados a uma argila queimada, interpretada como estrutura de combustão, e a estrutura 21 composta por fragmentos cerâmicos e material lítico.

A vasilha 16 (V16, figura 175) também apresenta cauixí na pasta, cuja coloração varia entre marrom clara e laranja, queima oxidante e polimento em ambas as faces. Possui contorno infletido, estrutura restringida, borda extrovertida e expandida, lábio arredondado, boca circular com 34 de diâmetro de abertura, $37 \mathrm{~cm}$ de diâmetro de boje e $32 \mathrm{~cm}$ de altura. A espessura é de $10 \mathrm{~mm}$ na boca, $6 \mathrm{mmno}$ corpo, $23 \mathrm{~mm}$ próximo a base e $19 \mathrm{~m}$ na base. Ocorre fuligem na face externa e depósito de carbono na face interna.

A vasilha 18 (V18, figura 175) possui $4 \mathrm{~cm}$ de altura, boca circular com $8 \mathrm{~cm}$ de diâmetro, $6 \mathrm{~mm}$ de espessura, contorno simples e estrutura não restringida, base convexa côncava. Trata-se de uma miniatura, assim como a vasilha 19 (V19, figura 175), que possui $5,4 \mathrm{~cm}$ de altura, boca circular com 7,5 $\mathrm{cm}$ de diâmetro, $5 \mathrm{~mm}$ de espessura, contorno simples e estrutura não restringida, base plano côncava de $7 \mathrm{~cm}$ de diâmetro.

$\mathrm{Na}$ estrutura 21, escavada na mesma unidade, composta por cerâmica e lítico, destacase uma vasilha em pedestal, estrutura aberta (figura 176, letra A), que possui uma elaborada pintura em ambas as faces (figura 176).

A vasilha 26 (V26, figura 175) continha no seu interior um sedimento acinzentado com cerâmica, lítico, bolotas de argila queimadas e carvões esparsos. Apresenta cauixí na pasta, técnica acordelada, queima oxidante e polida em ambas as faces. Possui contorno infletido, estrutura restringida, borda extrovertida, espessamento expandido, lábio arredondado, boca circular com $33 \mathrm{~cm}$ de diâmetro, $26 \mathrm{~cm}$ de altura e espessura de espessura $12 \mathrm{~mm}$ na boca e $19 \mathrm{~mm}$ na base, que é convexa côncava. Possui fuligem na face externa no bojo e depósito de carbono na face interna da base. Está desgastada na face interna, no bojo inferior e base, possivelmente do uso. 


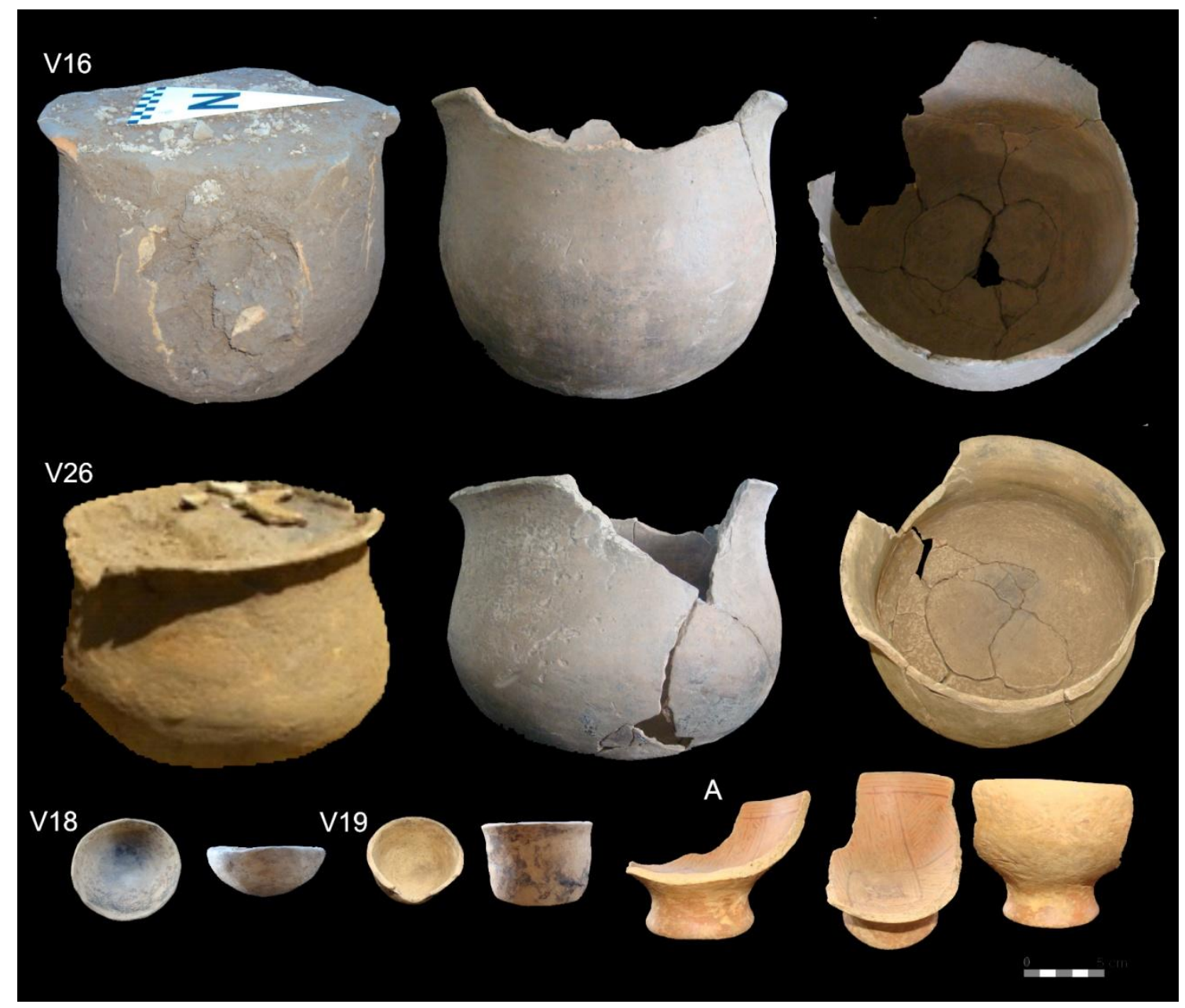

Figura 175: vasilhas V 16, V26, V18, V19 e vasilha da estrutura 21 (A) (Fotos: SCIENTIA, 2013).

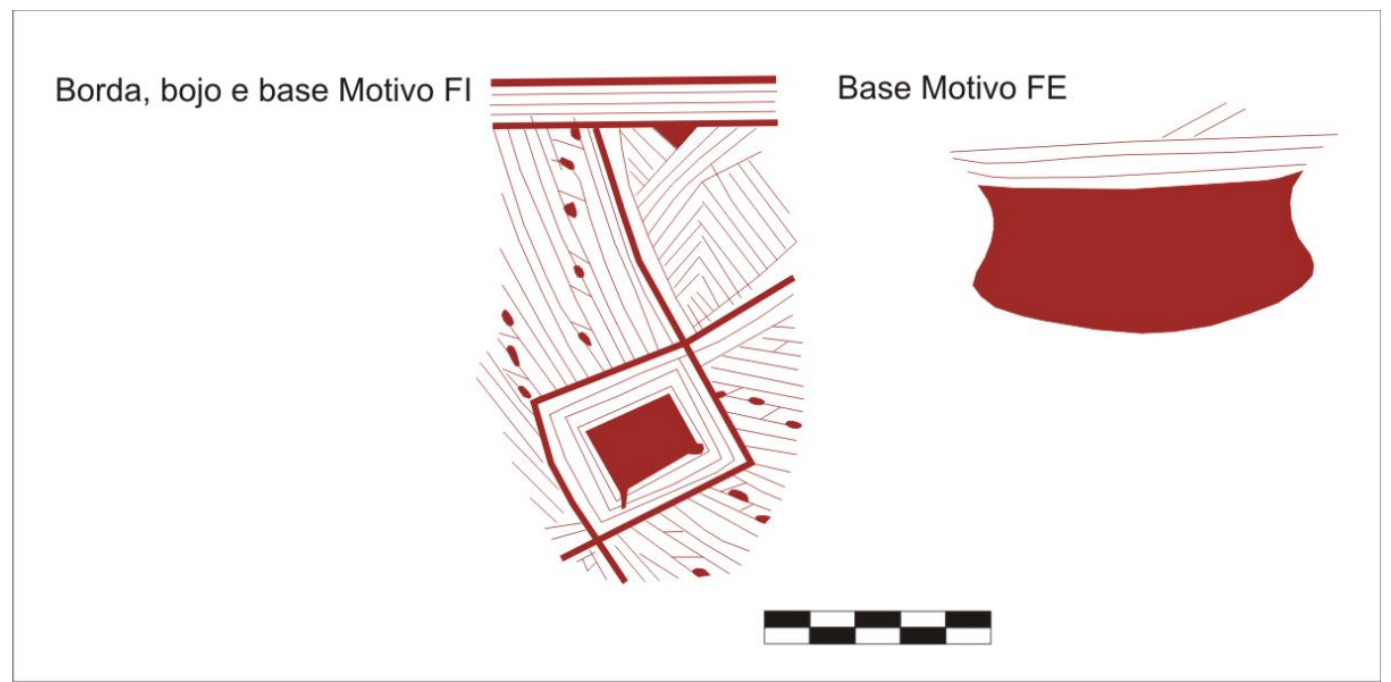

Figura 176: motivo da vasilha em forma de cálice da estrutura 21- setor norte- Ilha Dionísio (Angislaine F. Costa, 2013). 


\subsubsection{Considerações sobre as análises do sítio Ilha Dionísio}

Conforme colocamos anteriormente, com a análise dos fragmentos das unidades foram identificados dois conjuntos tecnológicos diferentes nas duas camadas de ocupação do sítio Ilha Dionísio. A análise das vasilhas cerâmicas escavadas nos setores sul e norte do sítio permitiu ampliar a discussão sobre estas ocupações. Verificou-se que as vasilhas cerâmicas destas duas áreas estão relacionadas à ocupação mais recente (camada A), conforme demonstram as características tecnológicas das vasilhas e tampas.

A ocupação inicial no sítio parece ter sido menos duradoura ou por um grupo com menor densidade populacional, tendo em vista a baixa frequência de material cerâmico, porém este está depositado em $100 \mathrm{~cm}$ da estratigrafia (entre 100 e $200 \mathrm{~cm}$ ) e em uma ampla área, sendo evidenciada em todas as unidades escavadas, incluindo o setor das vasilhas. É necessário aumentar a amostra analisada desta ocupação, porém as características evidenciadas permitem diferenciá-la da cerâmica deixada pela ocupação posterior da Ilha. Vasilhas pequenas, com bordas expandidas e flanges labiais, algumas tratamento escovado, ponteado e inciso, destacando-se uma vasilha com forma de navio (ou bote) são características desta ocupação. Apesar de terem sido identificadas tais características nas cerâmicas antigas do sítio Boa Vista e Vista Alegre, datados em mais de 2.000 anos, não temos elementos suficientes para relacionar esta cerâmica aparentemente bastante antiga do sítio Ilha Dionísio com aqueles conjuntos. Não possuímos datações disponíveis para o sítio Ilha Dionísio.

A ocupação mais recente é caracterizada por grande quantidade de fragmentos de vasilhas cerâmicas, trempes e bolotas de argila, distribuídos entre os níveis 0-10 e 80-90 cm, associados a um sedimento bastante escuro, dispostos em uma área com formato semi-circular no setor Sul e circular no setor Norte, ambos separados por uma área rebaixada que alaga sazonalmente, e com vasilhas cerâmicas e estruturas enterradas em ambos. No setor Sul, as vasilhas e estruturas foram enterradas fora da área de maior densidade de material e terra preta (área de habitação), próximo a margem da ilha e dos pedrais com gravuras rupestres. No lado oposto da ilha (setor norte), uma área semelhante foi evidenciada. As vasilhas foram propositalmente enterradas e tampadas com fragmentos de outras, não sendo evidenciados restos ósseos no seu interior, com exceção de alguns farelos de difícil identificação. Ocorrem ainda estruturas de seixos próximas às vasilhas em ambos os setores, bem como associação de lâminas e adornos polidos e pequenas vasilhas cerâmicas que são miniaturas. Entre estas 
vasilhas pequenas destaca-se uma em formato de cálice encontrada nos setor norte, com forma e pintura semelhantes a uma encontrada na unidade E347799 N8984160, a qual pode ter sido utilizada para o consumo de fermentados. Ocorrem ainda estruturas com fragmentos cerâmicos de diferentes tipos: aquelas compostas por fragmentos grandes sobrepostos, que parecem ter a função de cobrir algo (possível sepultamento), como na estrutura 3 onde apareceram restos ósseos muito pequenos sob os fragmentos. Outras estruturas apresentavam fragmentos de diferentes vasilhas cerâmicas, como a estrutura 2 com fragmentos de três vasilhas mais inteiras além de outras bordas e bases, associadas a lítico e um pingente. No Setor Norte foram evidenciadas estruturas contendo bolotas de argila, possivelmente de combustão. Não analisamos todas as vasilhas, e a gama de formas e tamanhos das vasilhas utilizadas neste contexto deve ser mais diversificada, porém as mais recorrentes utilizadas como possíveis urnas e tampas são as vasilhas de forma infletida (vasilhas 4, 8, 9, 16 e 26), estas com fuligem indicando uso secundário nesse contexto; vasilhas grandes com forma simples (vasilha 1; fragmento de tampa na vasilha 1; fragmentos de tampa da vasilha 4; e fragmentos da estrutura 3); e vasilhas de contorno complexo (vasilha 2). Na estrutura 2 as vasilhas 5, 6 e 7 possuem formas diferenciadas (a vasilha 6 apresenta pasta com mineral, não muito frequente nestes contextos), são pequenas e poderiam ser artefatos pessoais do morto, se relacionados a um sepultamento. A hipótese de estas áreas serem contextos funerários poderá ser investigada em pesquisas futuras, tendo em vista que o sedimento de todas as vasilhas foi coletado. O material lítico da camada de ocupação mais recente é caracterizado pela presença de laminas e adornos polidos, seixos e lâminas com concavidades (bigornas ou contexto simbólico), uma peça com sulco contínuo nas extremidades, e pela alta frequência de seixos, lascas pequenas e núcleos de silexito. Não foi possível relacionar as gravuras com as ocupações do sítio. O material cerâmico da ocupação mais recente é semelhante ao encontrado nos níveis superiores dos sítios Ilha do Japó, Ilha das Cobras e Ilha São Francisco, porém naqueles não foram identificadas áreas com vasilhas inteiras e estruturas. Nestes quatro sítios ocorrem trempes, e nos sítios Ilha do Japó e Dionísio são comuns os adornos polidos e as lâminas. Sugerimos que as quatro ilhas foram ocupadas no período mais recente, e que as ocupações podem ter sido contemporâneas, porém não temos datas disponíveis para estes sítios.

Cerâmicas com características tecnológicas semelhantes encontradas em sítios da jusante, entre as cachoeiras de Teotônio e Santo Antônio, poderiam indicar relações de trocas com os grupos indígenas que ocupavam estas quatro ilhas da montante. No sítio Teotônio 
foram encontradas três vasilhas cerâmicas enterradas, semelhantes a estas do sítio Ilha Dionísio (pasta, acabamentos de superfície, forma), apesar do material encontrado no entorno ser diferente. A análise feita por Almeida (2013) em uma amostra daquele sítio também não evidenciou uma cerâmica com estas características, por isso sugerimos que em um determinado período da ocupação indígena no rio Madeira, relações de trocas poderiam ser bastante frequentes. No sítio Vista Alegre, localizado $4 \mathrm{~km}$ a jusante da cachoeira do Teotônio também foram encontrados fragmentos de vasilhas com pasta com cauixí, sendo as bordas expandidas e a queima oxidante, misturado a um material característico da tradição Polícroma da Amazônia. No sítio do Brejo, localizado junto à cachoeira do Santo Antônio, fragmentos com cauixí na pasta aparecem somente no período mais recente de ocupação do sítio, e não são muito frequentes. Nesse mesmo sítio, uma vasilha com pasta com cauixí e pintura em linhas finas diretamente sobre a superfície (Recipiente R1) foi encontrada junto a fragmentos de uma vasilha da Tradição polícroma (recipiente R2), assim como no sítio Morro dos Macacos I (vasilha 5). Mais uma vez, esta é somente uma hipótese a ser averiguada a aprtir da intensificação das datações e análises dos materiais arqueológicos.

Na ocupação mais recente dos sítios Ilha Dionísio e Ilha do Japó a cerâmica é composta por uma grande variação na escolha da pasta, tamanho e espessura das vasilhas e pintura (vermelha ou preta diretamente sobre a superfície em vasilhas com cauixí na pasta e pintura vermelha e branca em vasilhas com caraipé), diferente dos conjuntos mais antigos nestes e em outros sítios, onde existia uma recorrência maior na escolha da pasta e acabamentos. Essa diversificação encontrada na tecnologia cerâmica pode refletir um contexto onde as relações entre os grupos são mais intensas e flexíveis. Voltaremos a esta discussão a seguir. 


\section{Capítulo 5- Cenários da história indígena no alto rio Madeira: variabilidade cerâmica e diversidade cultural}

A região sul da Amazônia é caracterizada pela grande diversidade ecológica e cultural, incluindo grupos indígenas falantes Tupi, Macro Jê, Arawak, Pano e outras línguas isoladas, conforme indicam os estudos históricos, etnográficos, linguísticos e arqueológicos, sendo o rio Madeira considerado um corredor de expansão dos povos de acordo com os principais modelos arqueológicos (LATHRAP, 1970; BROCHADO 1984, 1989; NOELLI, 1996; HECKENBERGER 2001, 2002, 2005; ERICKSEN, 2011; NEVES, 2012). No Alto rio Madeira e seus afluentes, a história indígena mais recente é caracterizada pela dizimação de parte destas populações através das várias frentes colonialistas empreendidas no estado de Rondônia, bem comoe pela luta dos povos indígenas pela manutenção e retomada de seus territórios. A história indígena de longa duração é ainda pouco explorada através do estudo dos contextos arqueológicos, das fontes históricas e etnográficas.

As pesquisas arqueológicas tiveram início na década de 1970 (MILLER 1983, 1992, 1999, 2009a, 2009b, 2013) e só recentemente começaram a se avolumar e fornecer interpretações alternativas para a história da região (CRUZ, 2008; ZIMPEL, 2009; NEVES, 2012; ALMEIDA, 2013, MORAES, 2013). É cada vez mais evidente que as características climáticas e ecológicas não limitaram a ocupação da região pelos grupos indígenas, conforme sugerido por pesquisas embasadas em preceitos teóricos evolucionistas, deterministas e degeneracionistas da Ecologia Cultural, mas pelo contrário, possui uma longa sequência histórica e cultural abrangendo o final do Pleistoceno e todo o Holoceno, com a formação das terras pretas mais antigas da Amazônia e evidências de manejo e domesticação de plantas.

Partimos do pressuposto de que tamanha diversidade cultural evidenciada no período colonial possui raízes na história mais antiga da região, considerada não somente como o local de origem e dispersão dos povos Tupi (RODRIGUES, 1958, 1964, 1984; NOELLI, 1996; NEVES, 2012), mas também integrando um bloco quase contínuo de povos Arawak da chamada Periferia Meridional da Amazônia (HECKENBERGER, 2001), com uma possível esfera de interações, redes de comércio e comunicação (ERICKSEN, 2011). Nosso principal objetivo foi caracterizar as ocupações indígenas ao longo de um trecho de aproximandamente $80 \mathrm{Km}$ no alto curso do rio Madeira, entre a cachoeira de Santo Antônio e a foz do rio 
Jaciparaná, através do estudo da variabilidade cerâmica de quatorze sítios arqueológicos escavados nesta área.

A seleção das amostras foi orientada para a percepção desta variabilidade não somente em termos verticais, mas também horizontais. Ao mesmo tempo em que alguns sítios arqueológicos, localizados entre as cachoeiras de Santo Antônio e Teotônio, haviam sido datados, evidenciando a presença das populações ceramistas na região há pelo menos 3.000 anos até um período recente (século XVI e XVII), deparávamo-nos com contextos diferentes acima do Teotônio, e era um dos objetivos entender a distribuição das ocupações nesta área mais abrangente, comparando os contextos das primeiras cachoeiras (Santo Antônio e Teotônio), com os sítios à montante, próximos à cachoeira de Morrinhos e acima dela. Não temos datações para estes últimos sítios, o que dificultou a interpretação da variabilidade evidenciada, porém foi possível formular algumas hipóteses a serem aprofundadas no decorrer das pesquisas na região.

Analisamos atributos da cerâmica que caracterizam as escolhas tecnológicas adotadas pelos ceramistas nas diferentes etapas de confecção dos artefatos e, através da análise comparativa, buscamos evidenciar a variabilidade e delimitar os conjuntos artefatuais. Os modos como os artefatos são feitos e utilizados resultam de decisões tomadas por indivíduos em contextos sociais e simbólicos específicos, ou seja, de acordo com as suas trajetórias históricas, e, portanto, são bons indicadores de identidades culturais que compõe uma tradição cultural (LEROI-GOUHAN, 1985; BALFET, 1991; SCHIFFER e SKIBO, 1992, 1997; LEMONNIER, 1992, 1993; DAVID e KRAMER, 2001; DIETLER e HERBICH, 1998; GOSSELAIN, 1998; PIKIRAYI, 2000; CHILION, 1998; DIAS e SILVA, 2001; BOURDIEU, 1977, 2006). Com esta perspectiva, buscamos perceber as permanências e mudanças nos diferentes lugares e temporalidades, evidenciando conjuntos tecnológicos e buscando entender possíveis processos de fronteira e diversidade cultural. Não se trata simplesmente de relacionar de forma direta a cultura material à etnicidade ou língua, mas relacionar as escolhas tecnológicas adotadas por indivíduos às estruturas que caracterizam as diferentes tradições tecnológicas e culturais conhecidas na Amazônia. A própria concepção de etnicidade precisa ser relativizada de acordo com os contextos culturais e históricos específicos, entendida como um fenômeno dinâmico. Conforme vimos anteriormente, no caso dos povos de matriz cultural Arawak, etnicidade é mais bem entendida como um processo de etnogênese, ou seja, de constante refazer e recriar de identidades. 
Também entendemos os sítios arqueológicos como lugares transformados pelos homens através do tempo, cujas marcas deixadas fornecem informações importantes sobre a tradição cultural (ZEDEÑO, 2008; ZEDEÑO e BOWSER, 2009). Alguns lugares foram ocupados e ressignificados de maneiras muito distintas ao longo do tempo, nem sempre facilmente distinguíveis, sendo que a maioria dos sítios estudados foram inicialmente caracterizados como unicomponenciais. A análise da cerâmica e dos demais vestígios auxilia na interpretação das histórias destes sítios arqueológicos, alguns deles relacionados entre si por terem sido ocupados por povos de mesma matriz cultural, concomitantemente ou não. Nosso estudo é menos focado na análise intra- sítio, somente viável através da abordagem de amostras maiores, e mais voltado para o estudo comparativo entre os sítios arqueológicos. Através da comparação das informações do contexto arqueológico e da tecnologia cerâmica com o conhecimento arqueológico e histórico de uma região mais abrangente, buscamos traçar possíveis cenários da história indígena no alto rio Madeira. A história indígena tem uma profundidade temporal ainda maior, que ultrapassa sete mil anos, porém este estudo se limita à abordagem dos povos ceramistas.

\subsection{As ocupações ceramistas antigas no alto rio Madeira}

As ocupações ceramistas mais antigas na área de estudo foram identificadas nos sítios Vista Alegre, Foz do Jatuarana e Boa Vista, em um período entre aproximadamente 3.000 e 1.500 anos atrás, podendo ser ainda mais antigas (uma datação de $4.470 \pm 40$ AP no sítio Boa Vista). Nos sítios Santa Paula, Teotônio e Veneza, apesar de não terem sido datados os estratos mais profundos, acreditamos que tenham sido ocupados no mesmo período, por apresentarem contextos e cerâmica semelhantes, assim o sítio Garbin, que apresenta datações recuadas, e cujos dados contextuais e da triagem da cerâmica o aproxima dos demais sítios citados.

Esta cerâmica antiga era confeccionada com uma pasta com baixa inclusão de grãos de quartzo, arredondados e subangulosos, na qual as ceramistas adicionavam caraipé e carvão, sendo porosa e geralmente de coloração escura em função da queima (reduzida). As superfícies geralmente eram alisadas e com menos frequência polidas e brunidas, sendo que em muitas vasilhas são evidentes as marcas do alisamento feito com a pasta pouco úmida, semelhantes ao escovado. É recorrente a aplicação da barbotina e do engobo vermelho, laranja, vinho e branco, assim como as pinturas em tonalidades semelhantes, feitas no lábio ou 
na face externa das vasilhas, às vezes associadas a incisões. Ocorre uma grande diversidade de tratamentos plásticos, predominando as incisões, mas estão presentes também o escovado, acanalado, ungulado (ou serrungulado), exciso (às vezes associado ao inciso), raros modelados e apliques (zoomorfos), bem como poucos ponteados e incisos e ponteados, todos feitos predominantemente na borda. São características as incisões duplas paralelas feitas no lábio, flange ou parte expandida da borda, porém ocorrem também outros motivos bastante diversificados. Ocorre grande variação na forma das vasilhas, de boca circular e não circular (elipsóide), presença de flange labial e mesial, bordas de diferentes inclinações, espessamentos (destacando-se as expandidas) e formas de lábios, vasilhas com pescoço, vasilhas rasas com a borda bastante inclinada (pratos), destacando-se também a presença de pontos angulares próximos às bordas (contornos compostos e complexos). As bases são predominantemente convexas côncavas, de difícil identificação em função da grande fragmentação, porém também ocorrem algumas plano-côncavas com reforço na junção com o corpo da vasilha. Ocorrem assadores com diâmetros maiores de $50 \mathrm{~cm}$, contudo as demais vasilhas possuem diâmetro variando entre 10 e $28 \mathrm{~cm}$. Ocorre fuligem e depósito de carbono em algumas vasilhas, indicando uso sobre o fogo.

No sítio Vista Alegre, esta ocupação ceramista antiga pôde ser mais bem caracterizada na escavação de $2 \mathrm{~m}^{2}$ do setor 3, área mais elevada do sítio, onde identificamos três conjuntos tecnológicos diferenciados.A cerâmica mais antiga predomina entre $40-50 \mathrm{~cm}$ e $70-80 \mathrm{~cm}$, nas camadas B (coloração 10YR5/3 bruno) e C (de transição para o latossolo), nas quais foi identificada uma estrutura de combustão. Foi obtida a data de 14C $2.080 \pm 30$ AP para o nível 40-50 cm, onde apareceu maior quantidade desta cerâmica. Nossa amostra não permitiu verificar a extensão desta ocupação no sítio, e se ela se estende para os setores 1 e 2, porém no setor 1 foi obtida uma datação de 14C 3.140 \pm 40 AP para o nível 130-140 cm de uma escavação, e em função da fragmentação e erosão do material e das muitas bioturbações nesta área, não conseguimos avançar na sua interpretação, sendo necessário expandir as análises. Mesmo assim, esta datação pode corresponder ao início da ocupação no local pelos povos ceramistas.

No Setor 1 do sítio Boa Vista, em planície de inundação adjacente à margem direita do rio, a ocupação se restringiu a uma área pequena $(40 \times 170 \mathrm{~m})$, com baixa frequência de cerâmica e lítico em uma camada fina de 20 a $30 \mathrm{~cm}$ de profundidade, com exceção da unidade E0392900 N9022302 onde um maior número de fragmentos cerâmicos apareceu entre o nível 0-10 cm e 220-230 cm, caracterizando uma feição em um lugar específico do 
sítio. A camada arqueológica possui coloração 10 YR3/1 bruno amarelado escuro nas quatro unidades com baixa frequência de material, e na E0392900 N9022302 varia entre 10 YR3/1 cinza muito escuro (camada A), 10YR3/3 bruno escuro (camadas B e D), 10YR3/4 bruno (camada C) e 10YR5/8 bruno amarelado (camada E). A ocupação foi datada em $2.010 \pm 30$ AP na camada D $(140-150 \mathrm{~cm})$ e $4.470 \pm 40$ AP na camada E $(220-230 \mathrm{~cm})$. A cerâmica é bastante erodida, caracterizada pela adição de caraipé na pasta, geralmente associado a carvão e queima reduzida predominante. Em poucos fragmentos foi identificada barbotina alaranjada ou engobo vermelho e destacam-se duas flanges labiais decoradas com incisões finas em linhas paralelas, portanto parece se aproximar das características identificadas na cerâmica mais antiga do setor 3 do sítio Vista Alegre.

O sítio Foz do Jatuarana, localizado na planície de inundação da margem esquerda do rio Madeira, se estende paralelamente ao rio, em uma área de 300 x $250 \mathrm{~m}$, com baixa frequência de material arqueológico em uma camada de aproximadamente $80 \mathrm{~cm}$. Também foi ocupado em um período antigo por grupos ceramistas, com datas de $2.780 \pm 40 \mathrm{AP}$ (70-80 cm da unidade E383857 N1022428) e 14C $1890 \pm 30$ AP (30-40 cm da unidade E383934 N902281). A análise do material cerâmico permitiu caracterizar o sítio como multicomponencial, assim como o Vista Alegre e Boa Vista. Nos níveis mais profundos, predomina uma cerâmica com características semelhantes a esta dos outros sítios, porém a fragmentação e erosão dos fragmentos não permitiu avançar nas hipóteses. A cerâmica aparece associada ao sedimento de coloração 7.5YR 3/3 bruno escuro (camada A), 7.5 YR 5/4 bruno (camada B) e 7.5YR 4/6 bruno forte (camada C). Acreditamos que a datação mais recuada, de $2.780 \pm 40$ AP possa ser associada a esta ocupação inicial do sítio.

Os sítios Vista Alegre, Boa Vista e Foz do Jatuarana estão bastante próximos entre si, no trecho entre as cachoeiras de Santo Antônio e Teotônio, porém distantes delas de 2 a 7 km. As ocupações mais antigas localizam-se nas planícies de inundação do rio Madeira, em áreas sazonalmente alagadas, com exceção do sítio Vista Alegre onde se estende até a parte mais alta (facilitando a conservação da cerâmica antiga no setor 3 deste sítio). A cerâmica antiga está associada a pacotes arqueológicos pouco espessos, caracterizados pela coloração marrom clara ou escura, com baixa frequência de material arqueológico e presença frequente de carvão. Nestes sítios, o material lítico é raro, geralmente constituído de fragmentos de quartzo e laterita, e não foram encontradas lâminas polidas e adornos formais relacionados a estas ocupações amis antigas. Foram evidenciadas estruturas de combustão (Vista Alegre) e uma feição com material arqueológico (Boa Vista). 
Os lugares próximos às cachoeiras de Santo Antônio e Teotônio também foram ocupados no período antigo por grupos ceramistas. Junto à cachoeira de Santo Antônio, no sítio Garbin, localizado em um terraço da margem esquerda, foi identificada uma camada com material cerâmico e lítico (camada IV ou B) associado a sedimento de coloração escura (10YR 3/2 bruno acinzentado muito escuro), até a profundidade média de 70 a $100 \mathrm{~cm}$, para a qual se obtiveram as datações de 14C $1.710 \pm 40 \mathrm{AP}(60-70 \mathrm{~cm} / \mathrm{N} 981 \mathrm{E} 941), 1.300 \pm 30 \mathrm{AP}$ (90 cm/Quadra 3m²), $990 \pm 30$ AP $(90 \mathrm{~cm} /$ Quadra 3m²) e $480 \pm 40$ AP (17 cm/N981 E988), sendo a data de $4.910 \pm 100$ AP (50-60 cm/N900 E1017) possivelmente de transição para a camada pré-cerâmica do sítio. A triagem permitiu relacionar o material deste sítio ao do Veneza, localizado na mesma margem e muito próximo. No sítio Veneza, esta cerâmica apareceu associada à camada de $100 \mathrm{~cm}$ de profundidade média, com sedimento de coloração 10YR2/2 (bruno muito escuro) ou 10YR 3/1 (cinzento muito escuro) em uma área de forma elipsoidal e extensão de $204 \mathrm{~m}$ de largura e $340 \mathrm{~m}$ de comprimento, porém a amostra de carvão datada para este sítio estava contaminada sendo necessário datá-lo novamente. Nos níveis mais profundos do sítio Ilha de Santo Antônio, ocorre baixa quantidade de uma cerâmica semelhante a do sítio Veneza, que pode estar relacionada a estas ocupações da margem esquerda, nos sítios Veneza e Garbin. Não temos datações disponíveis para os níveis mais profundos do sítio da ilha. O material lítico associado à cerâmica é abundante nestes três sítios, caracterizado principalmente por lascas e fragmentos de quartzo e por blocos e plaquetas de laterita polidas em uma ou em várias faces, possíveis fontes de pigmentos ou adornos. No sítio Veneza, o único unicomponencial entre os três citados, não foram encontradas lâminas polidas, e nos demais parecem estar associadas a ocupações mais recentes, porém é necessário ampliar as análises dos materiais líticos.

Junto à cachoeira do Teotônio, no sítio Santa Paula, sobre um barranco alto da margem esquerda do rio, nos níveis mais profundos das unidades e sondagens da delimitação, ocorre uma cerâmica com características tecnológicas semelhantes a do sítio Veneza. Este material apareceu nos níveis mais profundos da unidade E382631 N9021469 (120-130 cm a 220-230 cm), misturados a materiais que são mais frequentes na camada superior. A camada III, onde o material está associado, possui coloração 10 YR3/4 bruno, mas as feições evidenciadas são constituídas por sedimentos mais escuros de coloração 10 YR2/2 bruno muito escuro. As datações obtidas para esta unidade são dos níveis 100-110 cm $(1.550 \pm 30$ AP), $180-190 \mathrm{~cm}(1.530 \pm 30$ AP) e $200-210 \mathrm{~cm}(1.520 \pm 40 \mathrm{AP})$, e parecem estar associadas a estas ocupações mais antigas, ou representam um período de transição entre esta ocupação e a 
mais recente, predominante entre os níveis 0-10 cm e 110-120 cm. No entanto, o contexto da unidade (presença de feições) dificulta as interpretações da cronologia, e certamente a continuidade das escavações e análises dos materiais deste sítio irão revelar contextos mais complexos e possivelmente mais antigos. Do sítio Teotônio, localizado na margem oposta, analisamos uma amostra muito pequena e trataremos dele posteriormente por apresentar características específicas. Em ambos os sítios ocorreu pequena quantidade de material lítico, e não é possível afirmar, nesse momento, se os artefatos polidos (lâminas e adornos) são associados a estas ocupações antigas ou às mais recentes.

As comparações entre os sítios permitiram perceber que estas ocupações nos sítios próximos às cachoeiras são caracterizadas pela maior frequência de fragmentos cerâmicos, dispostos em camadas mais espessas (com excessão do sítio Ilha de Santo Antônio) e de coloração mais escura, se comparados com os sítios mais afastados das cachoeiras (Boa Vista, Vista Alegre, Foz do Jatuarana), os quais possuem menor quantidade de material arqueológico em camadas menos espessas e com sedimento um pouco mais claro. Também são observadas diferenças entre os sítios das duas cachoeiras, sendo muito mais frequentes os materiais líticos nos sítios próximos à cachoeira de Santo Antônio do que na cachoeira do Teotônio. São necessárias análises intra-sítio para delimitar melhor tais especificidades nas ocupações dos diferentes lugares, com o refinamento da cronologia. Tais variações podem estar associadas a diferentes áreas de atividades de um mesmo sistema de assentamento, ao tamanho dos grupos que ocuparam estes locais, ao tempo que permaneceram ali ou mesmo a uma dinâmica na ocupação destes diferentes lugares e ao longo do tempo. Como veremos, outra característica que parece diferenciar os sítios das cachoeiras daqueles mais afastados é a sobreposição dos conjuntos cerâmicos a estes mais antigos.

Almeida (2013) já havia relacionado à cerâmica policrômica antiga (ou Inciso Pintada), evidenciada nos níveis mais profundos do sítio Teotônio (especialmente na escavação feita por Eurico Miller, cujo material o autor teve acesso), às cerâmicas Saladóide do Orinoco e Pocó da Amazônia Central, associando à presença dos povos Arawak no rio Madeira, e considerando este sítio como um núcleo na rede de trocas que caracteriza o padrão multi-étnico destes grupos. A cerâmica antiga que analisamos, especialmente a do sítio Veneza e dos níveis mais profundos do sítio Santa Paula, possui características em comum com a cerâmica dos níveis mais profundos da escavação de Eurico Miller no sítio Teotônio, conformedescrição e fotos de Almeida (2013), bem como com as cerâmicas e contextos evidenciados em outras partes da Amazônia, especialmente no Ucayali Central, no Orinoco, 
no baixo Amazonas e no médio Solimões, com os quais comparamos. Como vimos no capítulo 1, Lathrap (1970) evidenciou complexos cerâmicos antigos (Tutishcainyo Inferior e Superior, Shakimu Inferior e Superior), caracterizados por vasilhas com ângulos em várias sessões dos recipientes, decoradas com incisões ou pintura vermelha, entalhes nas bordas e nos ângulos e pontos salientes, bem como decoração modelada e aplicada, os quais o autor comparou às cerâmicas Saladóide da costa da Venezuela e das planícies alagadas do baixo e médio Orinoco e nas Antilhas, aferindo possíveis relações históricas entre os complexos das duas regiões. Na Amazônia Central, as ocupações ceramistas mais antigas da fase Açutuba estão situadas entre aproximadamente 2.250 e 1.350 AP, caracterizadas pela pasta leve e porosa de composição variada, decoração rebuscada e grande variabilidade formal, compondo concentrações (possíveis lixeiras) ou feições com grande quantidade de material decorado (LIMA et al 2006; LIMA, 2008, NEVES, 2012). No Baixo Amazonas, nos rios Nhamundá e Trombetas, nas ocupações associadas à fase Pocó, com datações entre 3.280 e 1.700 AP, a cerâmica apresenta pasta com cauixí, superfícies brilhosas e com uma gama variada de decorações plásticas e crômicas em várias tonalidades, sendo comuns as formas de contorno composto ou complexo (HILBERT e HILBERT, 1980; LIMA 2008, GUAPINDAIA, 2008), as quais Lima (2008) correlacionou às mais antigas da Amazônia Central e do médio Solimões. As semelhanças entre as cerâmicas da fase Açutuba com as da série Saladóide do baixo Orinoco (vasilhas de contorno composto ou complexo com pintura policrômica) e com as cerâmicas Barrancóides da mesma região (formas e decorações plásticas) indicariam o início de uma esfera de interações abrangendo a Amazônia Central, o médio Solimões, o baixo Amazonas e o baixo Orinoco, ao passo que a variabilidade interna seria decorrente da necessidade de afirmação de identidade e status social (Lima, 2008, p. 362). Conforme vimos anteriormente, na Amazônia Central, a cerâmica Açutuba é associada à tradição Borda Incisa, com continuidade nas fases subsequentes (Manacapuru e Paredão) (LIMA, 2008, NEVES, 2012, MORAES 2006, 2013, NEVES, 2012).

No médio Solimões, Costa (2012) identificou cerâmicas bastante antigas, da fase Amanã com datas de $3.320 \pm 30 \mathrm{AP}$ e $2.800 \pm 30 \mathrm{AP}$ e da fase Pocó de $2.690 \pm 30 \mathrm{AP}, 2.500$ \pm 40 AP e $2.410 \pm 40$ AP, com características semelhantes a estes contextos citados. Neves (2012) associou os contextos Açutuba (Amazônia Central), Pocó (baixo Amazonas), de La Pedrera no rio Caquetá (Colômbia) e do sítio Boa Esperança (Tefé) à tradição Pocó (NEVES, 2012, p. 147). Seja como for, estas cerâmicas policrômicas antigas são associadas à ampla expansão dos Arawak pela América do Sul, e às esferas de interações e sistemas multiétnicos 
ou etnogênicos em que estes grupos estavam envolvidos. Entendemos que as cerâmicas antigas do rio Madeira, situadas entre aproximadamente 3.000 e 1.500 anos atrás (podendo ser mais antigas), apresentam características tecnológicas e contextuais semelhantes a estes das outras regiões da Amazônia, as quais possuem tão antigas quanto às obtidas no rio Madeira. Também acreditamos que as datações obtidas por Miller (1992) para o sítio Teotônio

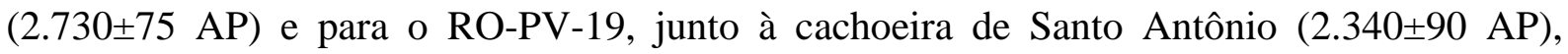
podem corresponder a estas ocupações ceramistas mais antigas, e não à subtradição Jatuarana da Tradição Polícroma da Amazônia, conforme anteriormente havia sido proposto (MILLER 1992, 2013).

No sítio Ilha Dionísio, próximo à foz do rio Jaciparaná, também foi evidenciada uma camada de ocupação profunda (camada C) com baixa frequência de cerâmica e raros líticos, em sedimento mosqueado,bruno amarelado e branco. A cerâmica é bastante erodida, com adição de caraipé na pasta, queima reduzida, raros fragmentos com engobo vermelho e acabamento plástico escovado, ponteado e inciso, destacando-se uma vasilha com o lábio modelado com forma alongada (forma de navio ou bote), bem como as vasilhas com flange labial ou com bordas expandidas ou reforçadas, de tamanho pequeno (em apenas duas bordas foi possível medir o diâmetro, de $14 \mathrm{~cm}$ e $20 \mathrm{~cm}$ ). Não temos datações disponíveis para este sítio, mas acreditamos que seja uma ocupação tão antiga quanto à anteriormente citadas, porém não relacionamos esta cerâmica ao conjunto artefatual identificado nos sítios à jusante em função do tamanho da amostra analisada. Cabe lembrar que no sítio 5 irmãos, localizado em um afluente do rio Jaciparaná, portanto bastante próximo, foi obtida uma datação de 2.450 \pm 30 AP. Este material, entretanto, não analisamos.

\subsection{Ocupações ceramistas em 1.800 AP - sítios Morro dos Macacos I, Vista Alegre e Foz do Jatuarana}

Um segundo conjunto tecnológico foi evidenciado nos sítios Morro dos Macacos I, Vista Alegre e Foz do Jatuarana, afastados das cachoeiras de Santo Antônio e Teotônio entre 2 e 7 km, sobreposto à cerâmica antiga (policrômica antiga ou Inciso Pintada). Esta cerâmica é caracterizada pela pasta com alta inclusão de elementos minerais, compostos principalmente por grãos angulosos e subangulosos de quartzo, médios e grossos, associados a óxido de ferro e feldspato, de coloração avermelhada ou marrom e queima predominantemente oxidante. As superfícies das vasilhas são polidas ou bem alisadas, com ausência de engobo e pinturas, e são 
frequentes os tratamentos plásticos, principalmente incisos, modelados e ponteados, feitos na parte superior das vasilhas. As incisões se diferenciam do conjunto anterior por serem mais largas, com as sessões côncavas (instrumento com a ponta arredondada, diferente das mais antigas que em geral eram feitas com um instrumento mais pontiagudo), feitas quando a vasilha estava com a pasta úmida (diferente da cerâmica mais antiga, decorada quando a pasta estava mais seca), e apresentando uma gama menor de variação dos motivos (predominam as linhas circulares e horizontais) do que a cerâmica antiga; os modelados são abstratos, diferentes de alguns da cerâmica mais antiga que são zoomorfos (Veneza, Garbin e Vista Alegre). Algumas vasilhas possuem flanges labiais (algumas saindo logo abaixo do lábio) ou bordas expandidas, onde preferencialmente são feitas as decorações plásticas. Predominam bordas diretas inclinadas externamente, e estão ausentes os ângulos nas paredes. Não foi possível medir o diâmetro de abertura destas vasilhas, e no sítio Morro dos Macacos, ao menos uma das vasilhas possui boca ovalada.

No sítio Morro dos Macacos I, fragmentos desta cerâmica foram evidenciados em uma escavação feita na planície de inundação, na margem esquerda do rio Madeira, em uma camada de sedimento bruno amarelado claro, com presença de carvão. Estes fragmentos remontaram parcialmente três vasilhas (V6, V7 e V8). O contexto desta escavação indica que a ocupação nessa área do sítio teria sido um evento rápido e possivelmente por um grupo pouco numeroso, porém a amostra precisa ser ampliada para chegar a maiores conclusões. Foi obtida uma datação radiocarbônica de $1.810 \pm 40$ AP na camada C, associada a esta ocupação. Este sítio é multicomponencial, pois foram escavadas cinco vasilhas cerâmicas da tradição Polícroma da Amazônia, nos níveis superiores da mesma área.

Na escavação de $2 \mathrm{~m}^{2}$ do setor 3 do sítio Vista Alegre, acima da cerâmica mais antiga anteriormente descrita, também cerâmica com as características tecnológicas descritas acima, predominante nos níveis $20-30$ e 30-40 cm, na camada A, de coloração 10 YR4/3 bruno. Não possuímos uma datação para estes níveis de ocupação no sítio Vista Alegre, porém como estão sobrepostos à camada datada em 14C 2.080 \pm 30 AP (nível 40-50cm), acreditamos ser de um período mais recente, que possivelmente se aproxima da datação obtida para o Morro dos Macacos I.

No sítio Foz do Jatuarana, a análise permitiu verificar a presença de uma cerâmica semelhante que predomina nos níveis 30-40 e 40-50 da unidade E383857 N9022428 e nos níveis 20-30 e 30-40 cm das unidades E383934 N9022581 e E383935 N9022581, enquanto 
nos níveis mais superficiais e nos mais profundos ocorre uma cerâmica diferente (pasta com caraipé e carvão e núcleos escuros). Apesar da necessidade de ampliação das amostras, acreditamos que a datação de $1.890 \pm 30$ AP (30-40 cm das duas unidades contíguas) esteja relacionada a esta ceramica, caracterizando uma segunda ocupação no sítio, afinal está separada em 1.000 anos da datação mais antiga obtida neste sítio (14C $2.780 \pm 40$ AP). Não analisamos a cerâmica do sítio Morro dos Macacos II, onde foram obtidas as datações de $1.940 \pm 30 \mathrm{AP}^{21}$, para o nível 80-90 cm da unidade E387440 N9022780 e de $920 \pm 30 \mathrm{AP}^{22}$ para o nível 60-70 cm da unidade E387450 N 9022760, porém esta data mais recuada é compatível com estas datações obtidas nos sítios próximos, e a análise deste material poderá auxiliar nesta problemática.

Os três sítios onde esta cerâmica foi evidenciada (Morro dos Macacos I, Vista Alegre e Foz do Jatuarana) estão mais afastados das cachoeiras, e nos três a cerâmica ocorre em uma fina camada, de 10 a $20 \mathrm{~cm}$ de espessura, indicando ocupações pouco duradouras e por grupos pequenos. Acreditamos que as duas datações próximas, de 14C 1.810 440 AP para o Morro dos Macacos I e $1.890 \pm 30$ AP para o Foz do Jatuarana, permitem situar estas ocupações nesse período. As diferenças na escolha da pasta, acabamentos de superfície e formas das vasilhas fornecem subsídios para distinguir esta cerâmica do conjunto tecnológico mais antigo, porém não conseguimos relacionar estes materiais a complexos cerâmicos conhecidos na Amazônia.

\subsection{Ocupações dos portadores da cerâmica Barrancóide no Alto rio Madeira}

Ao passo que os sítios mais afastados das cachoeiras (Morro dos Macacos I, Vista Alegre e Foz do Jatuarana) apresentam a cerâmica que caracteriza uma segunda ocupação em torno de 1.800 anos atrás, sobreposta à antiga cerâmica inciso pintada, nos sítios próximos às cachoeiras de Santo Antônio e Teotônio, encontramos um conjunto tecnológico diferente nos níveis superiores, nos sítios Ilha de Santo Antônio, Santa Paula e Brejo. Esta cerâmica é caracterizada pela escolha de uma pasta com baixa inclusão de elementos minerais (grãos arredondados ou subarredondados de quartzo, às vezes associados a oxido de ferro e feldspato) e com adição de caraipé e de coloração escura (queima reduzida) predominante. As superfícies das vasilhas são bem alisadas, polidas e brunidas, e é comum a aplicação de

\footnotetext{
${ }^{21}$ Datação inédita cedida pela Scientia consultoria científica.

${ }^{22}$ Datação inédita cedida pela Scientia consultoria científica.
} 
barbotina (diversas cores) e engobo vermelho. Ao passo que os fragmentos com pintura são raros, os tratamentos plásticos são frequentes, destacando-se as incisões, às vezes associadas a modelados e apliques (esferas ou zoomorfos produzidos pela aplicação de esferas com um ponteado no centro), inciso e ponteado, roletado (na borda) e modelado (lábio com bicos ou ondulações). A espessura das paredes é fina, com predomínio entre 6 e $10 \mathrm{~mm}$, com exceção dos assadores e das bases anelares e em pedestal que são mais espessas. Estão ausentes fragmentos com pontos angulares (carenas), porém são frequentes as inflexões (pescoço, bojo), indicando o predomínio de vasilhas de contorno infletido e simples. As bordas contraídas são mais frequentes que nos conjuntos mais antigos (e as expandidas são raras) e muitos lábios possuem acabamento irregular (partes planas e partes arredondadas). Além das bases convexas côncavas, as anelares também são características deste conjunto tecnológico. A presença de asas e alças também é específica deste conjunto artefatual, assim como a reciclagem de fragmentos cerâmicos para a confecção de possíveis adornos (polimento das extremidades, dando forma arredondada ou elipsóide) e fusos. Além da fuligem e depósito de carbono, são comuns também as marcas de fermentação, indicando o uso de vasilhas no armazenamento e consumo de bebidas fermentadas. A alta frequência de bolotas de argila e a ocorrência de lâminas e adornos polidos também caracterizam estas ocupações. Os materiais arqueológicos estão associados a espessos pacotes de terra preta, entretanto existem especificidades nos contextos e materiais dos diferentes sítios, que serão apresentadas a seguir. Relacionamos este conjunto artefatual à tradição Borda Incisa, Inciso Modelada ou Barrancóide, e acreditamos que estas ocupações podem ser situadas entre aproximadamente 1.500 e 700 AP no Alto rio Madeira.

Nas proximidades da cachoeira de Santo Antônio, os sítios Ilha de Santo Antônio e do Brejo possuem cerâmicas que associamos a este conjunto, porém com especificidades. Ao passo que no sítio da ilha ocorrem todos os elementos acima citados, com uma grande diversidade de tratamentos plásticos e presença de fusos, no sítio do Brejo foram identificados poucos fragmentos com tratamento roletado, inciso e modelado (lábio) e os fusos não foram encontrados. O que caracteriza a cerâmica do sítio do Brejo é o polimento das superfícies, bem como o alisamento fino e a brunidura, e a grande quantidade de fragmentos com fuligem, características que também estão presentes no material da ilha, e são típicas da tradição Barrancóide, apesar de não muito enfatizadas. As formas das vasilhas também são semelhantes em ambos os sítios, incluindo a inclinação e o espessamento das bordas, os tipos de lábios (com ocorrência dos lábios irregulares), as bases (incluindo as anelares), fragmentos 
de inflexão (pescoço, bojo) e o diâmetro de abertura (varia entre 8 e $42 \mathrm{~cm}$ no Brejo e entre 6 e 36 na ilha, com exceção dos assadores que são maiores). A comparação e relação entre os atributos permitiram relacionar estes sítios, bastante próximos entre si, e com datações do mesmo período.

No sítio Ilha de Santo Antônio, esta cerâmica pôde ser mais bem caracterizada (analisamos os materiais de seis unidades e triamos a cerâmica de todas as demais unidades escavadas no sítio), e apesar de identificarmos uma cerâmica semelhante à do sítio Veneza, em pequena quantidade, nos níveis mais profundos, o conjunto artefatual predominante no sítio é este de um período mais recente, associado a um pacote de terra preta, disposto em uma área com forma circular de aproximadamente 300 x 320 m, no qual estão presentes bolotas de argila, líticos lascados em quartzo, lâminas polidas de rochas ígneas, adornos líticos polidos, lateritas com marcas de polimento (possíveis fontes de pigmento ou adornos), fragmentos de fusos de cerâmica e de vasilhas com as características já citadas. Nesse sítio, em função da maior amostra analisada e, possivelmente, da sua própria especificidade na localização, adjacente à cachoeira, há uma grande diversidade de tratamentos plásticos, de materiais líticos (adornos e lâminas com diferentes formas), e destaca-se um objeto independente zoomorfo. Ocorrem muitos fragmentos erodidos na face interna, alguns caracterizados como marcas de fermentação, principalmente de vasilhas decoradas (pintadas ou com incisões), indicando uso intenso das vasilhas para fermentação e consumo de fermentados. As formas das vasilhas são bastante padronizadas, conforme pode ser observado nos desenhos das bordas e fotos das bases. Nesse sítio, são características as feições de dois tipos: aquelas cônicas de buraco de estaca e feições maiores com fundo côncavo. Temos disponível uma datação para a ocupação ceramista no sítio da Ilha de Santo Antônio, de $990 \pm 40$ AP (42 cm/unidade N990 E849), que relacionamos ao conjunto descrito. Entendemos que as vasilhas encontradas na parte central do sítio (R1, R2, R3 e R4) foram enterradas posteriormente, e não compõem este conjunto artefatual.

O sítio do Brejo, localizado na margem direita, muito próximo ao sítio Ilha de Santo Antônio, possui a cronologia melhor estabelecida. O setor 1, mais próximo ao rio, apresentou cinco camadas arqueológicas com datações $1.120 \pm 40$ AP $(620-630 \mathrm{~cm}), 1.040 \pm 60$ AP (590-600 cm), $1.160 \pm 40$ AP (470-480), $1.040 \pm 40$ AP $(350-360 \mathrm{~cm}), 890 \pm 40$ AP (150160) e $760 \pm 40$ AP (80-90), enquanto o setor 5 , distante $50 \mathrm{~m}$ do rio em elevação

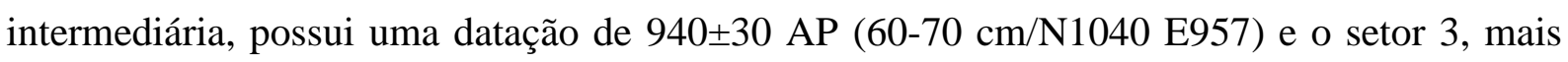
distante do rio na parte mais alta, uma datação de $1.390 \pm 40$ AP $(70$ cm/ N982 - E981). A 
cerâmica foi encontrada em sedimento bruno-escuro a bruno-escuro acinzentado, caracterizado como terra preta. A análise da cerâmica de uma unidade de cada um dos setores datados permitiu compará-los e pensar na ocupação do sítio no decorrer de seis séculos. Comparamos a cerâmica das camadas arqueológicas do setor 1 (separadas pela deposição de sedimento fluvial) e verificamos semelhanças entre os materiais das diferentes camadas, assim como entre os materiais dos demais setores do sítio. No entanto, identificamos mudanças tecnológicas ao longo do tempo: no início da ocupação as vasilhas eram confeccionadas com a adição de caraipé e carvão na pasta, enquanto no período mais recente (a partir de 940 30 AP) a presença de carvão diminuiu (predomina o caraipé) e aparecem vasilhas em cuja pasta ocorre apenas mineral ou mineral e cauixí; os raros fragmentos pintados apareceram também neste último período, porém os tratamentos plásticos estão presentes em todo o período de ocupação, apesar de serem mais frequentes no período mais recente, quando há o aumento da quantidade de cerâmica no sítio (a maior parte dos

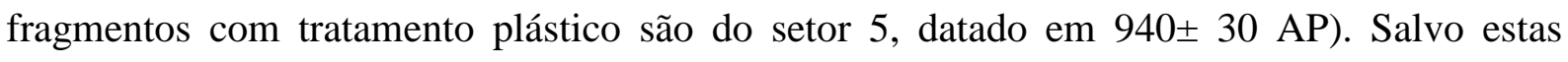
mudanças tecnológicas ocorridas ao longo do tempo, a cerâmica deste sítio é bastante homogênea nos diferentes setores. Conforme dissemos anteriormente, enquanto as características da pasta, queima, acabamento de superfície polido, bem alisado, brunido e engobo vermelho, a pequena quantidade de fragmentos pintados e a forma das vasilhas são características que aproximam esta cerâmica à do sítio da ilha, os elementos que os diferenciam são a menor frequência de tratamentos plásticos $(5,39 \%$ na ilha e 3,39\% no Brejo), entretanto ocorrem os mesmos tipos (roletado, modelado e inciso), bem como a ausência de fusos e possíveis adornos de cerâmica. Acreditamos que estas especificidades possam estar relacionadas a diferentes áreas de atividades. Além disso, parece evidente que a maior variabilidade na escolha da pasta no período final da ocupação no sítio do Brejo (a partir de 940 \pm 30 AP) e a maior diversidade de tratamentos plásticos na Ilha (com data de 14C $990 \pm 40$ AP) representam não somente o adensamento populacional nesse período, mas um maior envolvimento em redes regionais de interações e trocas. A presença de poucas vasilhas cuja pasta apresenta apenas mineral, ou mineral e cauixí, no último período de ocupação do sítio do Brejo, pode ser decorrente da incorporação de inovações tecnológicas, quando a população era maior, ou mesmo da troca de objetos. As vasilhas com estas características (pasta com cauixí; pintura em traços finos diretamente sobre a peça) ocorrem em sítios a montante (Ilha São Francisco, Ilha das Cobras, Ilha Japó e Ilha Dionísio), conforme veremos posteriormente. 
No sítio Santa Paula, além da cerâmica semelhante à do sítio Veneza, encontrada nos níveis mais profundos (120-220 cm), ocorre uma cerâmica semelhante à do sítio Ilha de Santo Antônio, predominante nos níveis superiores $(0-10 \mathrm{~cm}$ a $110-120 \mathrm{~cm})$, destacando-se as superfícies bem alisadas ou polidas, a presença de engobo e a grande quantidade e diversidade de tratamentos plásticos $(15,05 \%$ dos fragmentos da unidade e $8,82 \%$ dos fragmentos da delimitação), predominando os incisos e os incisos e ponteados, porém também ocorrem modelados (lábio ondulado) e apliques, às vezes combinados com incisões e ponteados, além do exciso, escovado, acanalado e roletado, aplicados principalmente na parte superior das vasilhas (borda, lábio, bojo), com motivos variados (linhas horizontais, linhas verticais, em zigue-zague, curvilíneos, linhas retas entrecruzadas, linhas transversais ou obliquas, escalonado, triangular). Destaca-se um aplique zoomorfo e um mamilonar. As vasilhas apresentam predominantemente formas simples e infletidas, bordas diretas e contraídas, e destacam-se os lábios apontados e irregulares; as bases mais frequentes são as convexas côncavas e bi-planas, mas também ocorrem as anelares, plano-côncavas e uma em pedestal. As vasilhas possuem diâmetros entre 6 e $52 \mathrm{~cm}$ (portanto algumas são maiores que nos sítios Ilha de Santo Antônio e Brejo). Ocorre um possível adorno de cerâmica, feito a partir da reciclagem de um fragmento, porém os fusos não foram encontrados nesse sítio até o momento, o que não necessariamente significa que eles não existam no sítio. O lítico é menos frequente que nos sítios do Brejo e Ilha de Santo Antônio, e caracterizado pela presença de blocos de granito, lascas de quartzo, lateritas polidas, adornos polidos e lâminas polidas inteiras ou fragmentadas. Conforme dissemos anteriormente, acreditamos que a datação de $1.550 \pm 30$ AP (103 cm de profundidade) corresponda a ocupação anterior no sítio, ou a período de transição para esta ocupação mais densa. Esta última possivelmente pode ser associada temporalmente ao sítio do Brejo (14C $1.390 \pm 40$ AP a $760 \pm 40$ AP) e Ilha de

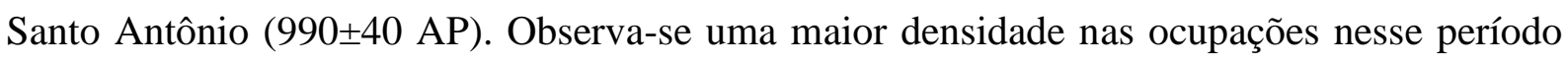
de $990 \pm 40$ AP, com aumento da quantidade de material, bem como no tamanho das vasilhas e na quantidade de vasilhas decoradas com tratamentos plásticos, aparecendo também pastas diferenciadas. Levando em consideração o tamanho deste sítio e sua localização, em frente à cachoeira do Teotônio, a amostra que analisamos não é representativa para a compreensão do seu contexto de ocupação, que certamente é muito complexo; associamos, entretanto, esta cerâmica à tradição Barrancóide. É necessário não somente analisar o material da outra unidade escavada no sítio e das demais sondagens da delimitação, mas também ampliar as áreas escavadas. 
Nos níveis mais profundos das escavações de três sítios à montante, Ilha São Francisco, Ilha das Cobras e Ilha do Japó, ocorre uma cerâmica com características tecnológicas semelhantes aos materiais dos sítios Santa Paula e Ilha de Santo Antônio. Nos sítios Ilha São Francisco e Ilha das Cobras estas semelhanças ocorrem em relação à escolha da pasta, queima, presença de engobo vermelho e tratamentos plásticos (modelado, roletado e apliques zoomorfos), bem como na espessura e forma das vasilhas. Conhecemos uma amostra muito pequena destes dois sítios, e seria necessário fazer a triagem e análise da cerâmica das demais áreas para expandir as interpretações, bem como realizar datações. Este material está associado principalmente a uma camada de sedimento mais escuro (camada $\mathrm{C}$ ), de coloração 10YR 3/2 (bruno acinzentado muito escuro) na Ilha São Francisco e 10 YR3/4(bruno) na Ilha das Cobras. Ocorre lítico lascado e polido (lâminas), porém não foi caracterizado até o momento. Apesar das características tecnológicas permitirem associar esta cerâmica à tradição Barrancóide/Borda incisa, como a presença de apliques zoomorfos modelados e incisões, é necessário aprofundar o estudo destes sítios, que possuem especificidades em relação aos da jusante.

No sítio Ilha do Japó, apesar da amostra analisada ser pequena, as informações de campo sobre os materiais encontrados nas diversas unidades, e as hipóteses levantadas com as escavações, permitiram caracterizar melhor esta ocupação do que nos dois sítios anteriormente citados. A análise do material cerâmico corroborou as informações de que há ao menos dois conjuntos cerâmicos diferentes no sítio. Nos níveis inferiores, ocorreu uma cerâmica com pasta, queima, acabamentos, espessura, formas e tamanho das vasilhas semelhantes a estas anteriormente descritas. As formas infletidas e simples, as bordas com espessamento contraído e lábio apontado, além dos tratamentos plásticos incisos (destacandose as linhas oblíquas que não se cruzam), roletados e aplique (zoomorfo), aproximam este conjunto àqueles das ilhas Santo Antônio, São Francisco e das Cobras, bem como ao sítio Santa Paula e Brejo. A partir da análise dos dados de campo, identificamos a presença de asas semelhantes àquelas do sítio Ilha de Santo Antônio, bem como fusos cerâmicos. A presença de feições de formas arredondadas ou subarredondadas e elípticas (algumas visivelmente buracos de estaca) nas unidades E368030 N9001780 e E368029 N9001780 e a presença de adornos líticos e lâminas polidas são elementos que caracterizam esta ocupação, predominante na camada $\mathrm{C}$, com sedimento de coloração bruno escuro (7.5YR3/3 e 10YR3/3). As características tecnológicas da cerâmica e os contextos evidenciados nos níveis 
mais profundos deste sítio permitem associar esta ocupação aos portadores da tradição Barrancóide, e com a realização de datações será possível avançar na sua compreensão.

Cerâmicas com estas características são encontradas em uma ampla região, associadas à Tradição Borda Incisa/Barrancóide/Inciso Modelada. No Ucayali, Lathrap (1970) evidenciou a cerâmica do complexo Hupa-Iya, cujas vasilhas hemisféricas ou semicontraídas, com apêndices de suspensão abaixo da borda, eram decoradas na parte superior com incisões e esferas aplicadas (alguns zoomorfos nas bordas) ou na face externa, delimitada por uma linha horizontal $2 \mathrm{~cm}$ abaixo da borda, sendo frequentes as incisões em linhas largas que formam motivos espiralados simples. Nesse conjunto, eram também frequentes os assadores, as bolotas de argila e os fusos cerâmicos, e esta cerâmica foi associada pelo autor a tradição Barrancóide ou Inciso-Modelada, encontrada pela primeira vez na planície inundável do Baixo Orenoco (estilo Los Barrancos), e com ampla dispersão na América do Sul, atribuída aos falantes Arawak (LATHRAP, 1970).

Na Amazônia Central, como vimos anteriormente, as cerâmicas das fases Manacapuru e Paredão são associadas à Tradição Borda Incisa/Barrancóide, cujos contextos remetem a ocupações por grupos de matriz cultural Arawak, envolvidos em uma esfera de interações, cujas influências resultariam em mudanças históricas e na diferenciação de grupos culturais que compartilham uma mesma estrutura (LIMA, 2008). Nessa região, haveria um sistema regional multiétnico entre os séculos VII e IX DC, envolvendo grupos relacionados às fases Manacapuru e Paredão, através de relações horizontais e simétricas, incluindo a circulação de cerâmicas e o compartilhamento de uma mesma cosmologia baseada na ocupação de aldeias circulares (NEVES, 2012). No baixo Madeira, as ocupações da fase Axinim, também associada à tradição Barrancóide, estavam presentes entre 1.250 e 800 AP, estando estas populações também envolvidas neste sistema de relações multiétnicas, sendo que a cerâmica possui elementos de diferentes fases e tradições (MORAES, 2013).

Almeida (2013) acredita na existência de um duo Arawak, representado pela cerâmica Inciso Pintada nas cachoeiras de jusante e Inciso Modelada à montante, no rio Guaporé. Nossos dados corroboram com a hipótese da presença Arawak no rio Madeira, e de uma possível rede de interações na qual estes grupos estão envolvidos, porém identificamos a cerâmica Inciso Modelada/Barrancóide nessa mesma região de jusante, sobrepondo a cerâmica Inciso Pintada dos níveis mais profundos. Parece evidente que, se um sistema multiétnico teve início no alto rio Madeira numa data mais recuada, relacionada à cerâmica 
Inciso Pintada ou Saladóide, este se tornou ainda mais evidente no período mais recente, caracterizado pelas ocupações mais densas dos portadores da cerâmica Inciso Modelada ou Barrancóide.

Conforme veremos a seguir, nas quatro ilhas à montante (Ilha São Francisco, Ilha das Cobras, Ilha do Japó e Ilha Dionísio), identificamos um conjunto tecnológico diferente, sobreposto a este que associamos a tradição Borda Incisa ou Barrancóide. A pequena amostra que analisamos do sítio Teotônio corrobora com a hipótese de Almeida (2013) de que o sítio apresenta um contexto complexo e com uma mistura de materiais. Apesar de percebermos diferenças entre os materiais do entorno das vasilhas1, 2 e 3 (sedimento 10YR 5/6 brunoamarelado) e os fragmentos encontrados no seu interior (associados à terra preta), e das próprias vasilhas em relação a estes materiais do entorno e do interior, encontramos dificuldades em associá-los a algum dos conjuntos tecnológicos descritos neste trabalho. Tudo indica que as vasilhas V1, V2 e V3 foram enterradas quando o sítio já era ocupado por grupos ceramistas, ao passo que os fragmentos do interior possuem características tecnológicas mais próximas da Tradição Policromia da Amazônia. As vasilhas V1, V2 e V3 possuem formas e tamanhos diferentes das demais encontradas no entorno e no seu interior, ao passo que se assemelham muito a vasilhas escavadas no sítio Ilha Dionísio, localizado à montante junto à foz do rio Jaciparaná. Não possuímos datações para ambos os sítios, porém acreditamos que ambos os grupos da jusante (entorno das cachoeiras de Santo Antônio e Teotônio) e da montante (em ilhas acima do Teotônio, incluindo a cachoeira de Morrinhos) estariam envolvidos em relações de trocas e intercâmbios, com uma possível fronteira territorial.

A cerâmica Barrancóide evidenciada no alto rio Madeira, nos níveis superiores dos sítios Ilha de Santo Antônio e Santa Paula, assim como nos diferentes níveis e setores do sítio do Brejo, e nos níveis mais profundos das ilhas São Francisco, das Cobras e do Japó, apresentam semelhanças tecnológicas tanto com a cerâmica Manacapuru quanto com a Paredão da Amazônia Central, porém possui especificidades técnicas em função das trajetórias históricas específicas dos povos Arawak nesta região, e dos possíveis contextos etnogênicos em estavam envolvidos.

Além disso, apesar da cerâmica dos sítios Ilha de Santo Antônio e Santa Paula apresentarem semelhanças em relação à cerâmica mais antiga (Inciso Pintada), principalmente na escolha da pasta (adição do caraipé), em algumas decorações plásticas (incisos, modelados), motivos (linhas duplas paralelas, apesar de menos frequentes no último período) 
e local de aplicação das decorações (parte superior das vasilhas), as diferenças são também evidentes: no período mais recente as vasilhas são maiores, estão ausentes flanges e ângulos nas paredes; menor variabilidade formal e decorativa; polimento mais freqüente; raros fragmentos com pintura; presença de bases anelares; ocorrem fusos e possíveis adornos; maior quantidade de lâminas e adornos formais polidos. Portanto, acreditamos que, a exemplo do que ocorre na Amazônia Central e em outras regiões da Amazônia, ambas as cerâmicas mais antigas (relacionadas à Açutuba, Pocó, Saladóide) e as mais recentes (Barrancóide) podem representar identidades sociais ou culturais distintas, ou diferentes identidades étnicas e culturais reformuladas a partir de relações etnogênicas, na qual estavam envolvidos os povos Arawak, portanto portadores de uma mesma matriz cultural, ou seja, um mesmo hábitus, compartilhado e constantemente reformulado nos diferentes campos.

\subsection{As ocupações mais recentes nas ilhas à montante}

Identificamos outro conjunto tecnológico nos níveis superiores das escavações nos sítios Ilha São Francisco, Ilha das Cobras, Ilha do Japó e Ilha Dionísio, diferente daqueles dos sítios a jusante. Nos dois primeiros sítios, verificou-se a diferença desta cerâmica em relação àquela dos níveis mais profundos, principalmente pelas características da pasta (predomínio de cauixí, apesar do caraipé e do mineral isolado também serem utilizados), queima oxidante mais frequente, menor frequência de decorações plásticas e pintadas, fragmentos mais espessos, bordas com espessamento linear e expandido e presença de trempes.

No sítio Ilha do Japó, os dados de campo permitiram detalhar melhor a ocupação, evidenciada entre a superfície e o nível $50-60 \mathrm{~cm}$, em sedimento de coloração variando de bruno (10 YR 3/4) e bruno escuro (7.5YR 3/3), disposto em uma área circular na parte não alagável da ilha. A cerâmica é constituída pela maior quantidade de fragmentos com cauixí ou somente mineral na pasta, apesar de também aparecer o caraipé, queima predominantemente oxidante, raros tratamentos plásticos (incisos) e pintura, presença de engobo vermelho, vasilhas com as paredes mais espessas, ocorrência de bordas introvertidas e extrovertidas com ponto angular e bordas expandidas frequentes. Além das vasilhas cerâmicas, estão presentes as trempes. Os materiais líticos são constituídos por lâminas e adornos polidos, lítico lascado em quartzo e silexito (destacam-se os pequenos seixos lascados), percutores e bigornas. Foram evidenciadas estruturas contendo seixos amontoados, e destaca-se uma estrutura escavada nas unidades E367980 N9001840 e E367981 N9001840 contendo fragmentos de 
vasilhas cerâmicas dispostos na posição horizontal, associados a fragmentos de trempe, carvão e lítico lascado e polido, nos níveis 40-50 e 50-60 cm. É possível que os fragmentos tenham sido intencionalmente organizados, até mesmo para a construção de um aterro nesta parte mais alta da ilha. Nesta ilha, assim como na Ilha das Cobras e Ilha São Francisco, a ocupação está na sua parte oeste, de frente para a montante, e junto aos pedrais com gravuras rupestres e feições de polimento, portanto representa uma escolha semelhante do espaço a ser ocupado.

No sítio Ilha Dionísio, esta ocupação é também caracterizada pela presença de fragmentos de vasilhas cerâmicas e trempes, bolotas de argila, líticos lascados em silexito e quartzo (lascas, núcleos e seixos pequenos) e polidos (lâminas e adornos), distribuídos em uma camada de sedimento de coloração variando entre bruno acinzentado escuro (10YR4/2) e bruno escuro (7.5 YR3/3), dispostos em uma área com forma semicircular ou em ferradura. Também foram evidenciadas estruturas com fragmentos cerâmicos dispostos na posição horizontal em duas áreas escavadas. Nesse sítio, destacam-se ainda os contextos evidenciados nas extremidades norte e sul, com vasilhas inteiras enterradas, algumas com tampa (fragmentos), associadas a estruturas de seixos, de fragmentos cerâmicos e de combustão. No setor Sul, esse contexto aparece fora da área com terra preta e com baixa frequiência de fragmentos cerâmicos, enquanto no setor norte as vasilhas e estruturas foram enterradas em uma área com maior frequência de material arqueológico em uma fina camada de sedimento bruno amarelado escuro. É possível que sejam contextos funerários, apesar da ausência de sepultamentos, ocorrendo apenas raros farelos ósseos.

Neste sítio, existe uma variação maior nas escolhas da pasta (com mineral, com caraipé e com cauixí), não necessariamente relacionadas com o uso das vasilhas. A brunidura, o polimento e as finas camadas de engobo vermelho são características, e ocorrem dois tipos de pintura: em traços finos (vermelho ou preto) feitos diretamente sobre a superfície das vasilhas com cauixí na pasta (motivos em linhas horizontais ou complexos); e a pintura em traços largos (vermelha e branca) em vasilhas com caraipé na pasta (nestas às vezes as incisões estão associadas). São raros os tratamentos plásticos, as vasilhas possuem grande variação de tamanhos e de espessuras, e vasilhas com diferentes formas e pastas possuíam as mesmas funções (cozinhar, fermentar, servir). Destacam-se as vasilhas pequenas em forma de cálice, com base em pedestal e pintura, que seriam utilizadas para consumir líquidos (fermentados). A maioria das vasilhas dos (possíveis) contextos funerários analisadas até o momento, que foram utilizadas como (possíveis) urnas ou tampas, possuem pasta com cauixí, 
muitas delas com fuligem na face externa, tendo uso secundário nesse contexto; além disso, as vasilhas pequenas (V18, V19, e vasilha da estrutura 21) poderiam ser anexos funerários, assim como as lâminas polidas, adornos polidos e outros líticos (peças com concavidades em todas as faces e líticos polidos com sulco). Nas estruturas de fragmentos (próximas às vasilhas enterradas) também predominam vasilhas cuja pasta possui cauixí (apenas a vasilha V6 possui somente mineral), e esta parece ser uma escolha importante para os habitantes da ilha, quando se trata de vasilhas relacionadas a este contexto simbólico.

Não possuímos datações para as ocupações destes quatro sítios arqueológicos. Todos apresentam feições de polimentos e gravuras nos pedrais adjacentes, possivelmente relacionadas a estas ocupações, tendo em vista que nos sítios a jusante não foram encontradas gravuras, porém esta questão merece um estudo à parte. Identificamos semelhanças destes contextos do rio Madeira com os da fase Paredão da Amazônia Central e Axinim do baixo Madeira, bem como com os da tradição Descalvados no Pantanal de Cáceres. Primeiramente, estruturas com fragmentos grandes de vasilhas e de trempes estão presentes nestas ocupações do Madeira (Ilha Dionísio e Japó) assim como nos sítios Paredão da Amazônia Central, onde constituem pisos para a posterior construção de montículos habitacionais ou fogueiras (Moraes, 2013). Nos sítios Descalvados, fragmentos estruturados aparecem em fogueiras ou áreas de armazenagem, porém estão ausentes as trempes, apesar de ocorrerem pisos de argila. Ainda não estão claros os significados destas estruturas no sítio Ilha do Japó e Dionísio, mas o fato é que elas aparecem nos níveis 40-50 e 50-60 cm no primeiro sítio e nos níveis $40-50 \mathrm{~cm}$, 50-60 e 60-70 no segundo, marcando o início da camada arqueológica relacionada a esta segunda ocupação na Ilha do Japó, e à transição para os níveis com maior quantidade de cerâmica na Ilha Dionísio. Em ambos os sítios, estas estruturas aparecem nas áreas com terra preta, com presença de líticos e bolotas de argila juntamente aos fragmentos de vasilhas e trempes. Outra característica que os aproxima dos sítios da fase Paredão é a forma semicircular ou em ferradura do sítio Ilha Dionísio. Além disso, as vasilhas cerâmicas inteiras encontradas nos setores sul e norte do sítio Ilha Dionísio, as quais atribuímos a um possível contexto funerário, lembram o contexto identificado no sítio Vila Gomes, baixo Madeira, cujas vasilhas estavam tampadas com fragmentos cerâmicos e possuíam adornos líticos associados (MORAES, 2013), bem como com os contextos funerários identificados nos sítios Descalvados, onde estavm presentes fogueiras e oferendas funerárias (MIGLIACIO, 2006). Quando comparamos a tecnologia cerâmica desses sítios com a das fases Paredão e Descalvados, a princípio existem poucas semelhanças, restritas à presença de engobo 
vermelho (camada muito fina e frágil) e pintura em motivos geométricos, em linhas muito finas aplicadas diretamente sobre a superfície da vasilha (combinadas com áreas maiores da vasilha cobertas de pigmento), queima predominantemente oxidante (semelhante a fase Paredão), e algumas formas como a da vasilha V2 com gargalo, semelhante a um tipo de cerâmica da fase Paredão. Porém, elementos típicos da fase Paredão, como as cestas com alça, os vasos em forma de canoa ou naviformes, a decoração modelada, as rodas de fuso, alargadores de orelha e as paredes finas que caracterizam aquela cerâmica estão ausentes, alguns deles compondo o conjunto tecnológico mais antigo nesses sítios (Barrancóide). Algumas vasilhas do rio Guaporé, que compõem o acervo do Museu Estadual de Rondônia (MILLER, 1983), bem como da área da UHE Jirau, expostas no Centro Cultural de Nova Mutum Paraná, possuem formas e tratamentos de superfície semelhantes a estas das quatro ilhas.

Enquanto nos sítios próximos às cachoeiras de jusante (Santo Antônio e Teotônio) esses materiais aparecem de forma esporádica ou menos frequente, acima desta última cachoeira eles aparecem em camadas bem definidas nas quatro ilhas. Poderíamos sugerir que as vasilhas com tais características, que ocorrem esporadicamente nos sítios de jusante, sejam provenientes de trocas com os grupos da montante. Somente com a continuidade das pesquisas e com novas datações, poderá ser verificada a existência de uma possível fronteira cultural e territorial no rio Madeira, envolvendo os portadores desta tecnologia cerâmica das ilhas à montante com os portadores da cerâmica Inciso Modelada (Barrancóide) das cachoeiras de jusante. Não somente no sítio Teotônio ocorrem vasilhas com pasta, formas e tratamentos de superfície semelhante (V1, V2 e V3), mas também no sítio do Brejo (R1 e R3) e Morro dos Macacos I (V5), e no sítio Vista Alegre os fragmentos com tais características tecnológicas são mais frequêntes.

Além disso, a diversidade de escolhas tecnológicas nas diferentes etapas da cadeia operatória, evidenciada nas ocupações recentes das ilhas à montante, principalmente na escolha de diferentes pastas com equivalências funcionais e nos tipos de pintura associadas a vasilhas com diferentes pastas, poderiam evidenciar uma maior flexibilidade dessas populações em relação à tecnologia, com uma maior abertura para a aquisição de conhecimentos tecnológicos, trocas de objetos e relações interpessoais com indivíduos de outras identidades culturais, porém esta hipótese está ainda mais longe de ser compreendida. 
Não nos arriscaremos a associar esta tecnologia cerâmica às tradições conhecidas na Amazônia, tendo em vista o tamanho das amostras analisadas e a falta de datações. Porém, podemos afirmar que as análises permitiram diferenciar esta cerâmica daquelas predominantes nas cachoeiras de jusante (Teotônio e Santo Antônio). É possível que a continuidade das pesquisas destes contextos confirme a sua vinculação aos povos de matriz cultural Arawak, assim como nos sítios Paredão e Descalvados, tendo em vista que elementos que compõem o seu padrão cultural regional (HECKENBERGER, 2001; HILL e SANTOS GRANERO, 2002) são evidenciados no tamanho dos sítios e presença de terra preta (sedentarismo), nos possíveis contextos funerários (hierarquia social), bem como na presença de gravuras rupestres.

É esperada uma grande variabilidade na tecnologia cerâmica nestes contextos etnogênicos, em que os falantes Arawak estabeleciam relações históricas com outros povos, resultando em contextos multilinguísticos e culturais, em processos de negociação interétnica, de disputa e incorporação em redes de intercâmbio e comércio, casamentos mistos e interação cerimonial, dos quais resultavam novas identidades sociais através da redescoberta e criativa de componentes tradicionais, incluindo a cultura material (HORNBORG e Hill, 2011; ERIKSEN, 2011; HORNBORG e ERICKSEN, 2011; HILL, 2013).

\subsection{Ocupações dos portadores da Tradição Polícroma da Amazônia no Alto rio Madeira}

Identificamos ainda outro conjunto tecnológico, presente no setor 3 do sítio Boa Vista, bem como em um contexto específico do sítio Morro dos Macacos I e do sítio Coração, assim como nos níveis superficiais do sítio Vista Alegre, e sugeriremos a presença destes materiais nos níveis superiores de alguns sítios como Ilha de Santo Antônio e Santa Paula. Trata-se de uma cerâmica com adição de caraipé na pasta, superfícies bem alisadas e polidas, pintura vermelha e branca (ou preta e branca) na face externa, presença incisões finas em motivos complexos sobre a pintura branca, vasilhas com formas infletidas, compostas ou complexas, com bases convexas côncavas e lábios arredondados, planos ou biselados, a qual associamos à Tradição Polícroma da Amazônia.

O setor 3 do sítio Boa Vista é aparentemente o único contexto unicomponencial que analisamos, associado a esta tradição tecnológica. Em uma parte alta e com ótima visibilidade para o rio, foram encontrados os materiais cerâmico e lítico, em baixa frequência, em superfície e até $60 \mathrm{~cm}$ de profundidade, em sedimento bruno escuro (7.5YR3/4), sobre uma 
base de cascalho laterítico. Foram identificados diferentes tipos de vasilhas neste contexto: aquelas com pintura na face externa e desgaste na face interna, possivelmente utilizadas na fermentação e consumo de bebidas fermentadas (uma delas (V1) possui a forma composta com carena); uma vasilha de forma infletida com fuligem e fragmentos de base com depósito de carbono, indicando uso de vasilhas para cozinhar alimentos; e vasilhas pequenas utilizadas para servir, aparentemente de forma simples. As bases são convexas côncavas, estando ausentes as anelares e em pedestal. $\mathrm{O}$ diâmetro de abertura varia entre 8 e $32 \mathrm{~cm}$. A pintura ocorre predominantemente nas cores preta e branca (apenas um fragmento com pintura vermelha e branca), os traços são largos e os motivos angulares, e destaca-se a aplicação de incisões sobre a pintura branca. Esta cerâmica se diferencia daquela do setor 1, mais antiga. A única datação obtida para o setor 3 é bastante recuada (14C 8.120 \pm 50 AP) e não temos uma referência cronológica para esta ocupação.

No sítio Morro dos Macacos I, junto à planície de inundação, foram evidenciadas vasilhas cerâmicas enterradas nos primeiros $100 \mathrm{~cm}$ (portanto acima da camada com cerâmica datada em $1810 \pm 40$ AP). Trata-se de um contexto com cinco vasilhas cerâmicas, sendo que três (V1, V2 e V3) delas apresentam pintura preta e branca, com traços largos e motivos complexos, sendo que a V2 possui incisões sobre a pintura branca. Outra vasilha pequena com fuligem e depósito de carbono estava associada (V4), assim como uma vasilha com gargalo (pasta com cauixí) e base anelar (V5). Esta última possui características tecnológicas destoantes das demais deste contexto, bem como da cerâmica do sítio Boa Vista. Segundo os moradores que as encontraram, existiam farelos de ossos associados às vasilhas, e acreditamos tratar-se de um contexto funerário. As vasilhas V1, V2, V3 e V4 podem ser associadas à Tradição Polícroma da Amazônia, ao passo que a vasilha V5 não possui as mesmas características tecnológicas.

No sítio Vista Alegre, além dos dois conjuntos tecnológicos identificados no setor 3, ocorreu uma cerâmica diferente nos níveis mais superficiais da escavação de $2 \mathrm{~m}^{2}$ e em diferentes níveis da escavação de 2 x $1 \mathrm{~m}$ (onde o material estava bastante misturado), cuja pasta apresenta predominantemente adição de caraipé (poucos fragmentos com carvão, diferente do material mais antigo), superfícies bem alisadas ou polidas, destacando-se vasilhas com pintura vermelha e branca em traços largos e pintura branca com incisões finas em motivos complexos. Além destas, ocorrem algumas de forma infletida, com fuligem no bojo e borda, indicando uso sobre o fogo, e vasilhas menores de forma simples (possivelmente usadas para servir). As bases são convexas côncavas e ocorrem duas alças, uma delas com 
pintura vermelha e branca. Estes materiais assemelham-se muito àqueles do sítio Boa Vista, onde também foram encontradas vasilhas para diferentes usos, bem como às vasilhas pintadas encontradas no sítio Morro dos Macacos I, e por isso relacionamos esta ocupação mais recente do sítio Vista Alegre à Tradição Polícroma da Amazônia. Não possuímos datações para esta ocupação nesse sítio.

Além disso, no sítio Vista Alegre ocorrem fragmentos de uma cerâmica com cauixí na pasta e presença de pintura vermelha em uma tonalidade mais escura, feita diretamente sobre a superfície da vasilha, que se assemelha àquela do conjunto tecnológico mais recente das quatro ilhas da montante. No sítio Vista Alegre esta cerâmica ocorre entre 0-10 e 10-20 cm da escavação de $2 \mathrm{~m}^{2}$ e em vários níveis da escavação de $2 \times 1 \mathrm{~m}$, portanto, possivelmente, aparece neste sítio em um período brevemente anterior à chegada dos portadores da Tradição Polícroma, ou concomitantemente.

Nas proximidades das cachoeiras, as ocupações dos portadores da Tradição Polícroma da Amazônia são de difícil identificação, possivelmente porque o material misturou-se aos aos fragmentos da cerâmica Barrancóide que predominam nos espessos pacotes de terra preta, semelhante aos contextos evidenciados na Amazônia Central. Na maioria dos sítios analisados, ocorrem fragmentos cerâmicos com pintura misturados aos fragmentos da cerâmica Barrancóide, ou mesmo vasilhas cerâmicas enterradas nesta camada. No sítio Ilha de Santo Antônio e sítio do Brejo, ocorrem fragmentos cerâmicos com pintura vermelha e branca em traços largos (em pequena quantidade) no pacote arqueológico, geralmente com marcas de fermentação na face interna, sendo difícil tanto relacioná-los à ocupação mais duradora do sítio (Barrancóide) quanto separá-los em um conjunto distinto (Tradição Polícroma da Amazônia). O fato é que nos dois sítios ocorrem contextos com vasilhas cerâmicas enterradas, com pintura policrômica vermelha e branca. No sítio da ilha, as vasilhas R1, R2 e R3 possuem formas e motivos que relacionamos à Tradição Polícroma da Amazônia, e nessa mesma área foi encontrada a vasilha $\mathrm{R} 4$, cuja forma, acabamento de superfície e pasta se diferenciam das outras três. No sítio do Brejo, a vasilha R2 possui pasta e pintura semelhante às vasilhas R1, R2 e R3 da ilha, com características tecnológicas da Tradição Polícroma da Amazônia, porém as outras duas vasilhas associadas (R1 e R3) possuem características que destoam desta tradição (cauixí na pasta; pintura em motivos finos diretamente sobre a superfície), semelhantes às vasilhas das ocupações mais recentes das quatro ilhas da montante. Conforme vimos anteriormente, no sítio do Brejo, a frequência de fragmentos com cauixí na pasta aumenta no último período de ocupação do sítio, assim como aqueles com 
mineral (anguloso), e na Ilha de Santo Antônio, estes fragmentos também estão presentes, em pequena quantidade.

Nos sítios próximos à cachoeira do Teotônio, ocorrem contextos semelhantes. No sítio Santa Paula, os únicos fragmentos com pintura vermelha e branca apareceram entre 0-30 cm de profundidade da unidade analisada, e nos níveis 0-20 e 20-40 cm das sondagens da delimitação, com raros fragmentos nos níveis inferiores, todas com marcas de fermentação na face interna. No sítio Teotônio a amostra analisada é muito pequena e reflete um contexto multicomponencial, sendo encontrado um fragmento com pintura vermelha e branca no interior da vasilha 3, juntamente a fragmentos de uma vasilha com fuligem. Não conseguimos avançar na interpretação destes conjuntos cerâmicos no sítio Teotônio, apesar de Almeida (2013) ter identificado um material relacionado a esta tradição tecnológica no local. Também observamos que as vasilhas enterradas possuem características tecnológicas diferentes dos conjuntos artefatuais identificados neste sítio até o momento, mas que se aproximam dos materiais mais recentes das ilhas a montante.

Esta cerâmica com características tecnológicas diferentes (escolha de pasta, acabamentos de superfície e forma), encontrada em pequena quantidade na Ilha de Santo Antônio, Brejo, Morro dos Macacos I e Vista Alegre, e semelhantes ao conjunto tecnológico mais recente identificado nas ilhas à montante, pode resultar das relações entre os grupos de diferentes identidades sociais e culturais. Tratando-se de relações culturais estabelecidas com os portadores da Tradição Polícroma da Amazônia, possivelmente não seriam tão amistosas, conforme indicam as evidências arqueológicas e históricas (MORAES, 2013; NEVES, 2012; MORAES e NEVES, 2012; ALMEIDA, 2013). O que fica mais claro é que, nestes contextos, as vasilhas cerâmicas ou fragmentos da Tradição Polícroma da Amazônia sobrepõem ou se misturam a pacotes arqueológicos da tradição Barrancóide.

No sítio Coração, localizado próximo à cachoeira de Morrinhos, foram encontrados fragmentos de ao menos dez vasilhas cerâmicas, cujo contexto foi comprometido pela retirada de cascalho do local onde estavam enterradas. Porém, é de extrema importância para pensar nas ocupações dos portadores da Tradição Polícroma no Alto rio Madeira, tendo em vista que as formas das vasilhas e as decorações são associadas a esta tradição tecnológica. Nestas, a pintura é vermelha em traços finos sobre engobo branco, com motivos complexos. As formas das vasilhas maiores (possíveis urnas) são compostas e complexas com carena, e os menores (possíveis tampas) possuem forma simples (tigelas), com bases convexas côncavas, lábios 
planos ou arredondados. O diâmetro das tigelas varia entre 16 e $24 \mathrm{~cm}$ e das vasilhas maiores entre 13 e $22 \mathrm{~cm}$, sendo que a vasilha de menor diâmetro possui um suporte para tampa. Relacionamos este contexto a um evidenciado à montante, na área de intervenção da UHE Jirau, onde vasilhas e tampas com pinturas elaboradas foram escavadas, cujas formas apresentadas nas fotos (MOUTINHO e ROBHRAN-GONZALEZ, 2010) são semelhantes a estas do sítio Coração.

Os contextos que analisamos, associados à Tradição Polícroma da Amazônia, não possuem um referencial cronológico em nenhum dos sítios abordados. Porém, a triagem da cerâmica de alguns sítios das proximidades da cachoeira de Santo Antônio fornece parâmetros interessantes para pensar nestas ocupações. O sítio Novo Engenho Velho, implantado em terraço fluvial na margem esquerda do rio Madeira, é caracterizado pela forma circular e presença de montículos dispostos em torno de uma área central, para o qual temos uma datação 14C $490 \pm 50$ AP. A triagem do material apontou características tecnológicas típicas da Tradição Polícroma da Amazônia, entre elas as bordas expandidas, extrovertidas com ponto angular, bases plano côncavas, pintura vermelha e branca, acanalado na face interna da borda, às vezes associado ao engobo, bem como os apliques na face externa associados ao engobo branco (figura 178). No sítio São Domingos, escavado na margem esquerda do rio Madeira, foram obtidas as datações de 14C $500 \pm 30(30-40 \mathrm{~cm})$ e $360 \pm 30(60-70 \mathrm{~cm})$ para a unidade E392674 N9027469, cuja cerâmica (figura 179) possui características de forma (bordas expandidas, bases plano-côncavas) e decorações (pintadas e acanaladas) semelhantes as do sítio Novo Engenho Velho.

Outros sítios das proximidades da cachoeira de Santo Antônio foram escavados e possuem datas mais recentes, como o Campelo (14C $370 \pm 40$ AP), que de acordo com as descrições e registro fotográfico de campo, possui um material com estas características tecnológicas (figura 179). Além destes, no sítio Bom Futuro, localizado a montante da foz do rio Jaciparaná, foram encontrados materiais que relacionamos à Tradição Polícroma da Amazônia, como a vasilha V1 (figura 177), com decoração acanalada na face interna da borda, além de outros materiais com aplique associado à pintura vermelha e branca. Citamos estes contextos para ampliar as hipóteses sobre a ocupação dos portadores desta tradição tecnológica na área pesquisada. Acreditamos que o aprofundamento das análises destes sítios, bem como a realização de datações dos demais anteriormente citados (Boa Vista, Vista Alegre, Ilha de Santo Antônio, Morro dos Macacos I, Coração) permitirá delimitar melhor esta tradição no alto rio Madeira. 


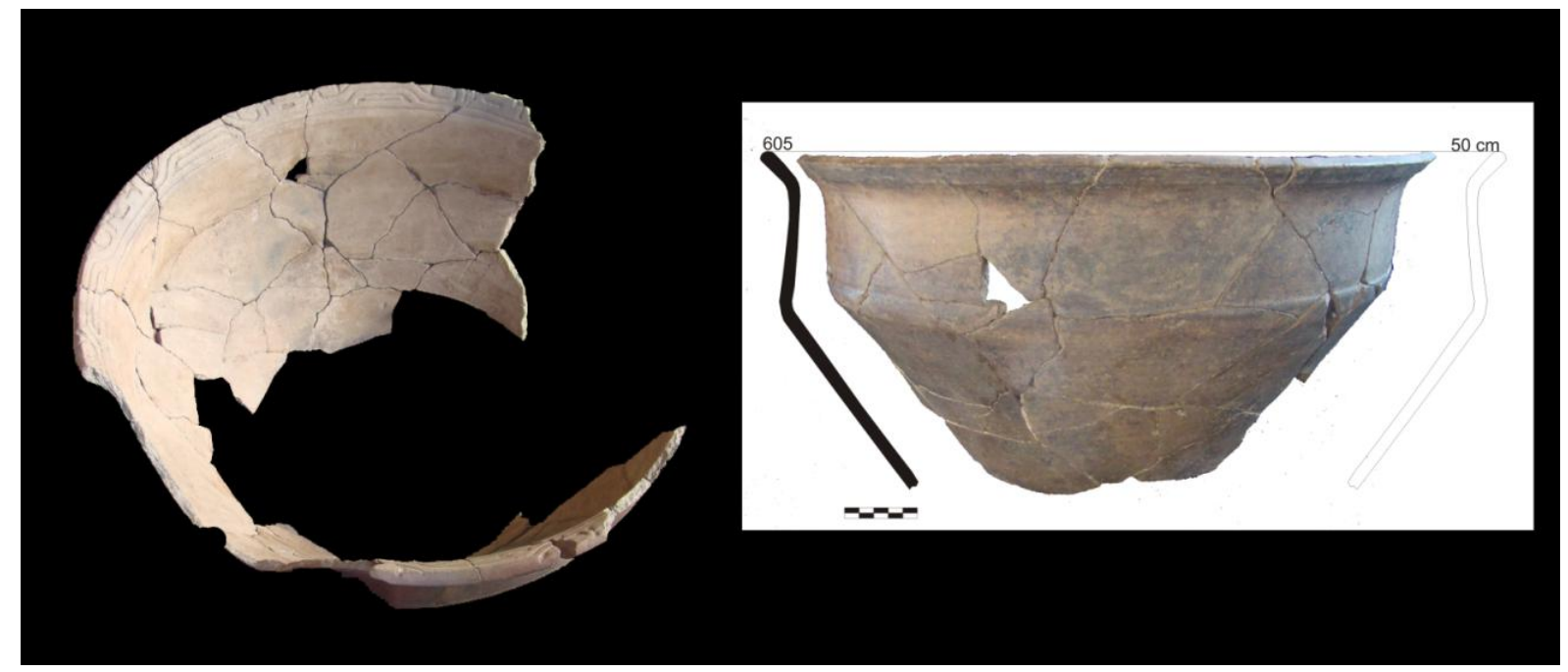

Figura 177:Vasilha cerâmica do sítio Bom Futuro (Fotos: SCIENTIA, 2013).

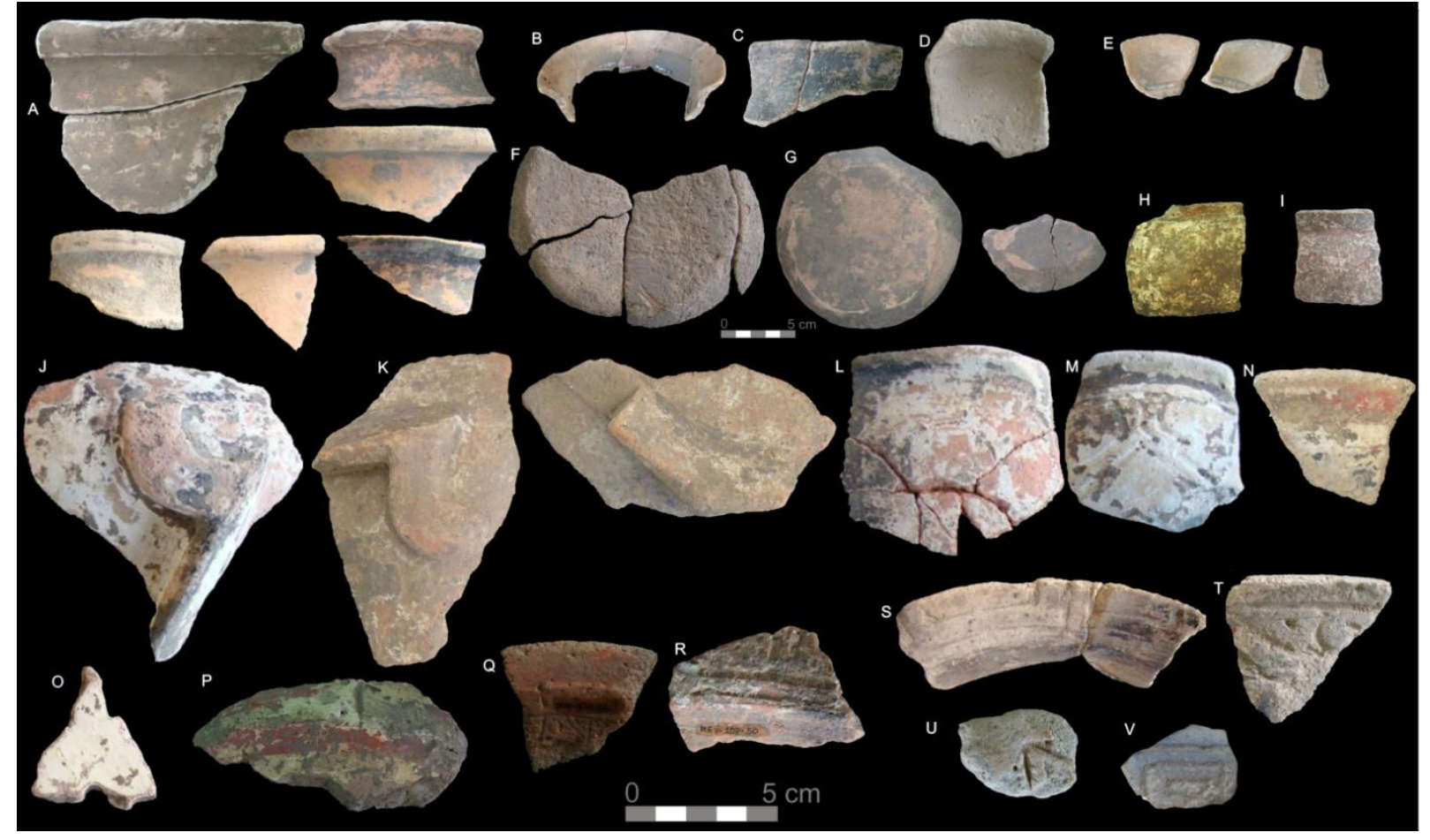

Figura 178: cerâmica do sítio Novo Engenho Velho (Fotos: SCIENTIA, 2011). 


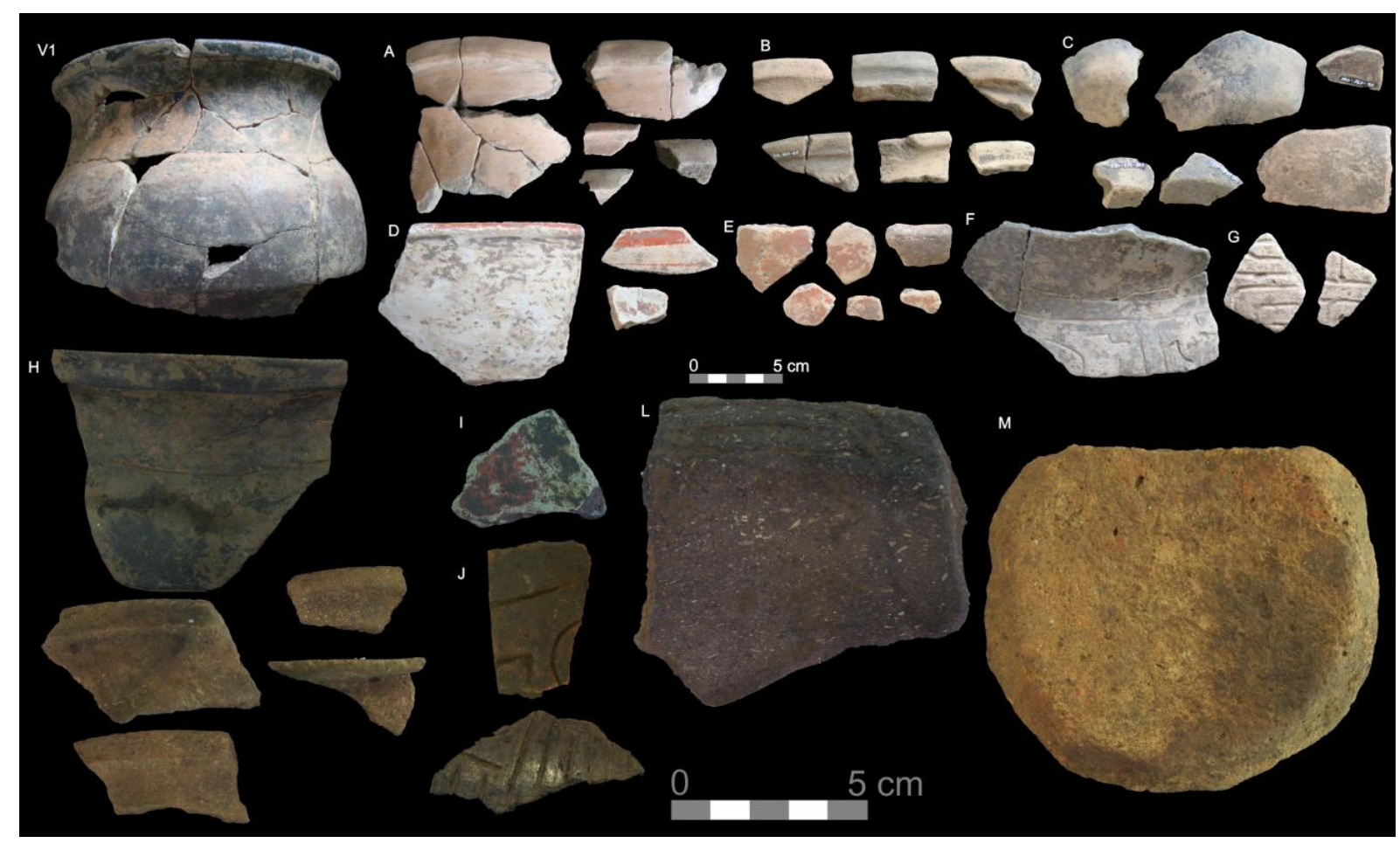

Figura 179: Acima materiais do sítio São Domingos (V1 e peças de A a G) e abaixo do sítio Campelo (H a M) (fotos: SCIENTIA, 2008, 2013).

Identificamos uma grande variabilidade nas formas e decorações das vasilhas da Tradição Polícroma, apesar de apresentarem elementos estruturantes: em alguns sítios predominam as pinturas pretas e brancas (Morro dos Macacos I, Boa Vista), em outros as vermelhas e brancas (Ilha de Santo Antônio, Vista Alegre, Coração); nos sítios da jusante, são comuns os traços largos, enquanto no sítio Coração os traços da pintura são finos; em alguns sítios, é comum a aplicação de incisões em motivos complexos sobre a pintura branca (Morro dos Macacos I, Boa Vista, Vista Alegre); em outros, são frequentes os acanalados e apliques (Novo Engenho Velho); a jusante predominam formas infletidas, enquanto no sítio Coração sobressaem as compostas. A iconografia desta cerâmica está sendo abordada no trabalho de conclusão de curso de Vassoler (2014). A grande variabilidade morfológica e decorativa parece ser uma característica desta tradição, sendo apontada por Lathrap (1970) na cerâmica Caimito do Ucayali Central, assim como por Tamanaha (2012) para a cerâmica Guarita da confluência dos rios Solimões e Negro e médio rio Solimões, onde, segundo o autor, não há uma padronização tecnológica em relação ao preparo da pasta e tecnologia empregada tanto numa escala espacial como temporal. Nessa área, estes grupos teriam ocupado inicialmente os afluentes do rio Solimões (em torno 1.200 AP), e só posteriormente, em torno de 1.000 AP, foram para o rio Solimões e baixo rio Negro, entrando em confronto com os habitantes da fase 
Paredão sem, entretanto abandonar os afluentes (TAMANAHA, 2012). No rio Madeira, esta variabilidade na Tradição Polícroma deve ser investigada, tanto em termos espaciais quanto temporais, tendo em vista que não temos uma cronologia elaborada para estas ocupações, tampouco delimitamos a sua ocorrência ao longo do rio Madeira, e menos ainda nos seus afluentes, apesar de Miller ter identificado esta cerâmica no baixo curso de alguns deles.

Ao passo que é difícil nesse momento, a partir dos dados que obtivemos, delimitar o início das ocupações polícromas na região do Alto Madeira, parece evidente que os portadores desta tradição tecnológica permaneceram na região até os séculos XVI e XVII (sítios Novo Engenho Velho, Campelo e São Domingos), assim como no baixo Madeira (datas de 660AP e 290AP) e na Amazônia Central (data de 180 AP para a ocupação Guarita no sítio Antônio Galo) onde possivelmente grupos menores desta tradição permaneceram na região até o século XVII (MORAES, 2013). No Alto rio Madeira, Almeida (2013) obteve as datações de 540 40 AP, $590 \pm 40$ AP e $620 \pm 60$ AP para a ocupação da Subtradição Jatuarana no sítio Itapirema, portanto datas próximas das que possuímos para a área da cachoeira de Santo Antônio. Já o sítio Associação Calderita, ocupado duas vezes pelo mesmo grupo, possui uma datação de 620 \40 AP para o nível 20-30 cm de uma escavação, e de $940 \pm 40$ AP (40$50 \mathrm{~cm})$ e $980 \pm 40$ AP $(30-40 \mathrm{~cm})$ nos níveis inferiores, indicando uma maior antiguidade desta tradição no Alto rio Madeira. No sítio Teotônio, uma data de 1.250 \30 AP foi associada ao início da ocupação pelos grupos portadores desta tradição (ALMEIDA, 2013). Para Neves (2012), estas datações recuadas da TPA obtidas no Alto rio Madeira indicam que houve uma expansão demográfica destes grupos na região, descendo para o baixo curso desse rio em meados do primeiro milênio DC, até o rio Negro e posteriormente Solimões acima.

É cada vez mais evidente que os portadores da Tradição Polícroma da Amazônia passaram a ocupar a região do Alto rio Madeira quando esta era habitada pelos povos da tradição Barrancóide, acarretando uma série de transformações na história local. Porém, somente o refinamento da cronologia poderá estabelecer a temporalidade deste processo, ao passo que as análises dos contextos arqueológicos poderão detalhar a sua natureza. As datas que temos disponíveis para os contextos que analisamos (1.500 AP no sítio Santa Paula; 900 AP no sítio Ilha de Santo Antônio; e entre 1.300 e 700 AP no sítio do Brejo) estão relacionadas à cerâmica Barrancóide e à presença Arawak na região, enquanto datas do mesmo período (1.250 AP no sítio Teotônio e 980 AP na Associação Caldeita) foram associadas por Almeida (2013) às ocupações da Tradição Polícroma da Amazônia mais antigas na região. Conforme disse o próprio autor, existe "uma série de quebra-cabeças que 
precisam ser encaixados horizontal e verticalmente" para compreender a história indígena no Alto rio Madeira (ALMEIDA, 2013, p 137). Nossa pesquisa permitiu juntar mais algumas peças deste quebra cabeças, ao mesmo tempo em que demonstrou que estamos longe de compreendê-lo. Isto deve ser tomado como um desafio por todos os estudantes da arqueologia e da história indígena no Sudoeste Amazônico e em Rondônia.

No mapa 8 localizamos os cinco conjuntos tecnológicos identificados nesta pesquisa, nos sítios arqueológicos ao longo do rio Madeira, os quais representam a diversidade cultural existente na região em termos temporais e espaciais. 


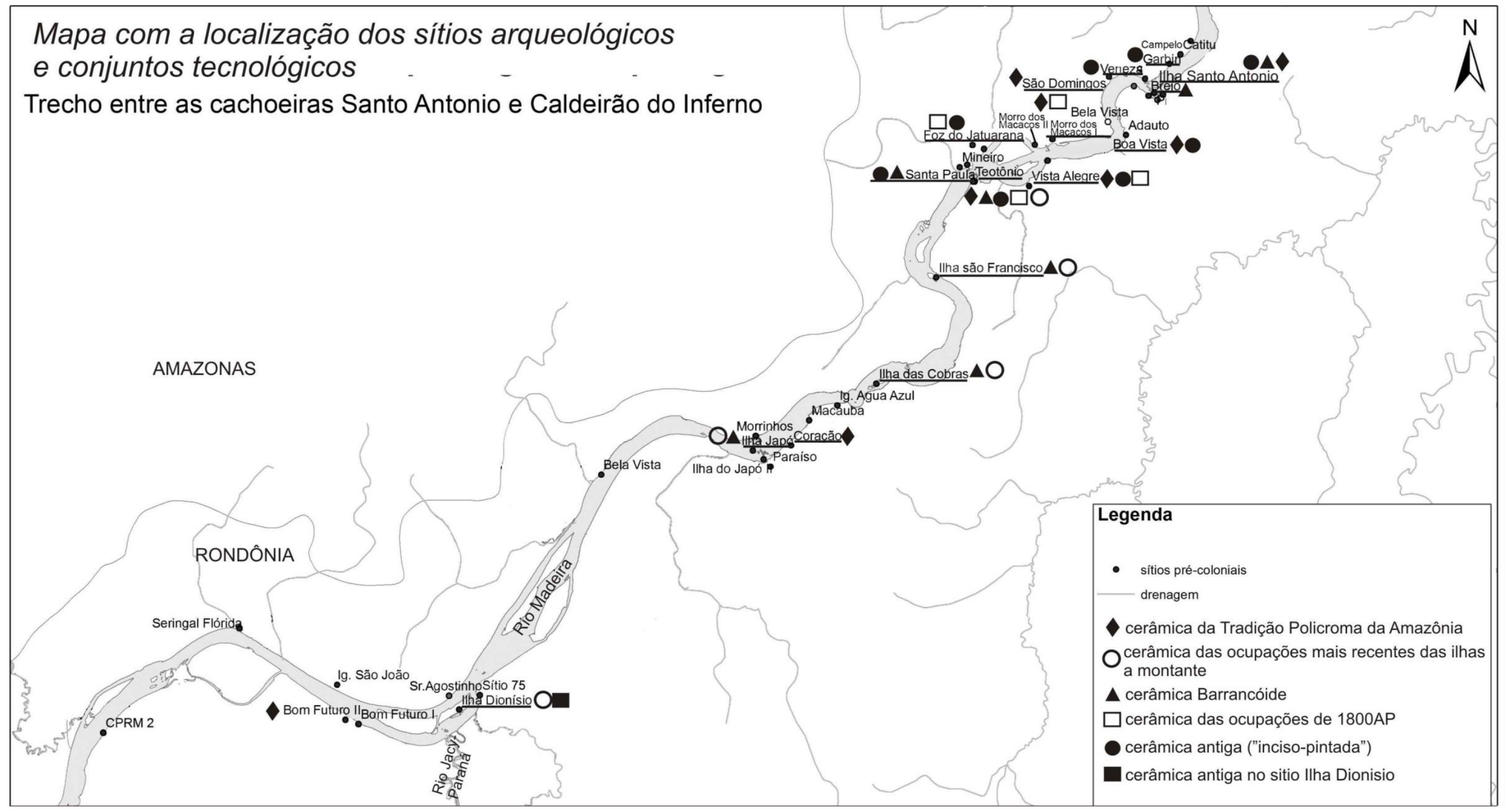

Mapa 8: Localização dos sítios arqueológicos e conjuntos tecnológicos identificados no trabalho (Michelle tizuka, 2014). 


\section{Considerações Finais}

Buscamos demonstrar como estudos voltados para a compreensão da variabilidade artefatual em contextos específicos contribuem para a construção da história indígena de longa duração, quando levados em consideração os dados da linguística histórica, da etnohistória e etnografia. A análise das escolhas tecnológicas, ou seja, dos modos de fazer a cerâmica nos diferentes contextos evidenciados no Alto rio Madeira, entre as proximidades da cachoeira de Santo Antônio e a foz do rio Jaciparaná, permitiu diferenciar cinco conjuntos artefatuais que representam a diversidade cultural existente na região em termos temporais e espaciais. Ao mesmo tempo, a relação com outros contextos da Amazônia e com os modelos para a ocupação da região, construídos com dados interdisciplinares, permite contribuir para a construção de cenários da história cultural desta região.

A maior contribuição do nosso trabalho foi na identificação e caracterização de traços materiais e contextos associados à presença dos povos de matriz cultural Arawak na região, com características específicas, tendo em vista os processos etnogênicos de criação e reformulação de identidades culturais e étnicas nos quais estes grupos estavam envolvidos. No período mais antigo (3.000-1500 AP), estas ocupações foram identificadas nos sítios Boa Vista, Foz do Jatuarana,Veneza, Garbin, Ilha de Santo Antônio, Santa Paula e Vista Alegre, representadas pela cerâmica policrômica antiga, relacionada à Açutuba/Pocó/Saladóide, associada a camadas arqueológicas mais espessas e escuras nas proximidades das cachoeiras do que nos sítios mais afastados. No período subsequente (a partir de $1.500 \mathrm{AP}$ ), as ocupações tornam-se mais densas, conforme pôde ser observado no maior número de fragmentos cerâmicos, em camadas arqueológicas mais espessas de terra preta, e com mudanças tecnológicas visíveis, cujo aumento demográfico teria atingido seu auge em torno de 1.000 AP, representadas pela cerâmica Barrancóide predominante nos sítios Ilha de Santo Antônio, Brejo e Santa Paula, bem como nos níveis mais profundos das ilhas São Francisco, das Cobras e do Japó, para os quais não temos um referencial cronológico até o momento. Entendemos que estes grupos, que forjaram identidades culturais e étnicas específicas, no período mais antigo (3.000-2.000 AP) e mais recente (1.500-700 AP), estabeleceram relações de troca, principalmente no último período, quando as cachoeiras da montante possivelmente passaram a ser ocupadas por grupos distintos, nas ilhas Dionísio, do Japó, das Cobras e São Francisco. Tais relações seriam perceptíveis no último período em função de fragmentos desta cerâmica nos níveis mais superficiais dos sítios do Brejo e Vista Alegre (onde são mais evidentes) e em outros sítios próximos às cachoeiras de jusante (Teotônio). Além disso, a 
grande variação no uso de diferentes pastas e formas das vasilhas na cerâmica das ocupações mais recentes das quatro ilhas da montante poderia refletir esta diversidade e fluidez existente no rio Madeira nesta época, com uma possível fronteira territorial envolvendo redes de trocas de objetos, conhecimentos e pessoas. Tivemos dificuldades em associar estes contextos das ilhas da montante às tradições tecnológicas e culturais conhecidas, apesar de várias características dos contextos, como a forma dos sítios, presença de terra preta, gravuras, possíveis sepultamentos, bem algumas características tecnológicas da cerâmica, indicarem um possível padrão Arawak, como aqueles evidenciados nos sítios da fase Paredão e da fase Descalvados. De qualquer forma, se as cerâmicas antigas dos sítios entre as cachoeiras de Santo Antônio e Teotônio podem ser associadas à presença dos povos Arawak na região, esse processo ocorreu em um período recuado (3.000-2.000 anos), estando as ocupações bastante consolidadas em 1.000 AP.

Sistemas regionais envolvendo a circulação de artefatos, pessoas e conhecimentos são conhecidos em diversas regiões da Amazônia. Além dos exemplos do Alto Xingu (HECKENBERGER, 2001) e no Alto rio Negro (NEVES, 1999), que possuem uma continuidade no período colonial, outros contextos arqueológicos mais antigos possuem tais evidências. Na Amazônia Central, teria existido um sistema regional multiétnico, entre os séculos VII e IX DC, envolvendo os grupos portadores da tecnologia cerâmica Manacapuru e Paredão (NEVES, 2012; MORAES, 2013), cuja esfera de interações possivelmente teria raízes mais profundas, envolvendo os contextos Açutuba, Pocó e Saladóide, entre outros (LIMA, 2008). No baixo rio Madeira, a cerâmica Axinim apresenta uma grande variação de traços estilísticos, com elementos associados a diferentes tradições cerâmicas, o que possivelmente seria resultado de estruturas politico-regionais multiétnicas (MORAES, 20013). No Pantanal de Cáceres, Migliacio (2002, 2006) demonstrou que a complexidade étnica e a diversidade cultural relatada pelos europeus no século XVI estava presente na região desde os séculos X e XI, quando os grupos culturais distintos, das tradições Pantanal e Descalvados, ocuparam a mesma região, com indícios de contatos culturais entre ambos. Estes contextos citados foram associados à presença de grupos da matriz cultural Arawak. No Alto Guaporé, Erig Lima (2012) evidenciou um contexto complexo envolvendo a presença de grupos ceramistas de tradições distintas, entre eles os produtores da cerâmica Córrego Banhado (500 e 1.400 AD) e Capão do Canga (800- 1300 AD), com antigas redes de trocas entre estas duas populações e as portadoras da Tradição Uru (800-1.700 AD), Tradição Una (500 AC-1.200 AD) e Tradição Tupi-Guarani (1.300/1.400-1.700 AD). No Brasil Central, as 
pressões externas teriam causado uma variedade de alianças multiétnicas e integração interegional de diferentes grupos, visível no aumento da complexidade entre sítios de um mesmo assentamento e entre assentamentos (WUST E BARRETO, 1999). Nos Llanos de Mojos, Bolívia, as mudanças graduais identificadas na cerâmica da Loma Salvatirra, ao longo dos 800 anos de ocupação, foram interpretadas como inovações e mudanças no modo de fazer, que poderiam ser decorrentes de influências de outras regiões (JAMES BETANCOURT, 2010).

Entendemos que a grande variabilidade existente entre os materiais mais antigos (cerâmicas antigas relacionadas aos conextos Saladóide/Pocó/Açutuba) e os mais recentes (cerâmica Barrancóide ou Inciso Modelada), e em termos espaciais, entre os sítios das cachoeiras de jusante (cerâmica Barrancóide) e os a montante (ocupações mais recentes das quatro ilhas), associados à presença Arawak na região, pode ser explicada através da própria característica da expansão destes povos, entendida não como uma migração de um grupo delimitado étnica e linguisticamente sobre áreas vazias, mas envolvendo relações históricas com povos de outras famílias linguísticas, resultando em contextos multilinguísticos e culturais com processos de reconstrução de identidades étnicas e sociais, que acarretam em mudanças na cultura material, um dos principais marcadores étnicos e culturais. Encontramos cada vez mais evidências da presença Arawak na chamada Periferia Meridional da Amazônia (HECKENBERGER, 2002), e não seria surpreendente se deparar com contextos diversificados, tendo em vista que possivelmente estas áreas possivelmente eram ocupadas por outros povos, com os quais estabeleceram relações. Anteriormente, apresentamos exemplos etnoarqueológicos de populações que criam estilos distintivos (os microestilos locais), apesar de compartilharem um conjunto similar de ferramentas e técnicas, em função de suas trajetórias históricas específicas (DIETLER e HERBICH, 1998), e que pode haver uma diversidade de expressões estilísticas em diferentes comunidades, porém com características da tradição compartilhada, também entendida como um reservatório simbólico ou sistema de representação social comum (DAVID e KRAMER, 2001).

Este processo de ocupação da região teria sofrido profundas transformações a partir da chegada dos portadores da Tradição Polícroma da Amazônia, da chamada Subtradição Jatuarana. Nosso estudo obteve menos sucesso na caracterização das ocupações desta tradição cultural, principalmente em função da escolha das amostras, que não contemplou os sítios mais característicos desta tradição, ao mesmo tempo em que focou em contextos muito específicos (possíveis contextos funerários) dos sítios, sem considerar a sua totalidade, bem 
como pela falta de uma cronologia para estas ocupações. Além disso, os materiais desta tradição estavam misturados aos de outras tradições tecnológicas. Mesmo assim, percebemos que estes materiais, presentes em toda área de estudo, são caracterizados por uma grande variação formal e decorativa, observada também em outras regiões da Amazônia, porém seguindo escolhas tecnológicas e padrões estruturais bastante peculiares desta tradição. Como enfatizamos anteriormente, apesar de nossos dados não contribuírem para a questão da antiguidade desta tradição na região, na qual Almeida (2013) obteve mais sucesso, tudo indica que estes povos permaneceram aqui até pelo menos o século XVII. E se esta tradição pode ser associada aos falantes do tronco Tupi (LATHRAP, 1970; BROCHADO 1984, 1989, NOELLI, 1996, 2008; NEVES, 2012; ALMEIDA, 2013), é evidente que a expansão destes também envolveu complexas relações interétnicas de assimilação e expulsão dos povos de seus antigos territórios (NOELLI, 1996, 2004), sendo evidenciadas, no baixo Madeira e Amazônia Central, estruturas defensivas construídas pelos povos que os antecederam e que foram expulsos para outras áreas (MORAES e NEVES, 2012; NEVES, 2012; MORAES, 2013).

Conforme dissemos anteriormente, conhecemos muito pouco os contextos ao longo do rio Madeira e menos ainda no curso de seus afluentes, apesar de terem sido evidenciados sítios arqueológicos bastante antigos no Alto Ji-Paraná, com uma cerâmica semelhante à da tradição Tupi-guarani do sudeste e sul do Brasil (MILLER, 2009a, CRUZ, 2008; ZIMPEL, 2009). Ao longo do rio Madeira, não identificamos vasilhas cerâmicas com decoração corrugada e pintada como as evidenciadas naquela área, porém pensamos que estudos futuros devem contemplar a comparação das cerâmicas destes locais. A forma de algumas vasilhas escavadas por Eurico Miller, na bacia do Ji-Paraná, são semelhantes a algumas associadas à Tradição Polícroma da Amazônia no rio Madeira (como a R1 escavada no sítio Ilha de Santo Antônio), ao mesmo tempo em que os tratamentos plásticos entalhado, ungulado, inciso, roletado e a pintura em preto ou vermelho diretamente sobre a superfície ou sobre o engobo, assim como as carenas e as bordas extrovertidas e reforçadas, são características presentes na cerâmica das duas áreas. Certamente que tal comparação deveria abranger outros atributos, e acarretaria em outra discussão.

As pesquisas arqueológicas realizadas até o momento demonstraram que as ocupações ceramistas são bastante antigas na região do atual estado de Rondônia, com 5.000 anos ou mais. No rio Guaporé, a cerâmica aparece em sítios datados entre 4.055 e 700 AP (MILLER, 1983, 2009b, 2013). Nos rios Ji-Paraná, Pimenta Bueno e Comemoração, os sítios das 
diversas fases associadas à tradição Tupi-guarani possuem datas entre 5.000 anos e 400 anos antes do presente (MILLER 2009a, ZIMPEL, 2009). No rio Jamari, a cerâmica da tradição homônima foi datada entre $2.500 \pm 90$ e 420 - $230 \pm 80$ AP (MILLER et al 1999), e no alto curso do rio Madeira, nossos dados indicam que os povos indígenas ceramistas estavam estabelecidos desde pelo menos 3.000 anos atrás.

Entretanto, até o momento, a maior parte das cerâmicas foi apenas classificada em fases e tradições, com base na análise da pasta e das decorações, não correspondendo à variabilidade tecnológica existente nos sítios e na região. Na Bacia do Madeira, a cerâmica foi associada a cinco tradições (Inciso Ponteado, Borda Incisa, Polícroma, Tupiguarani e Jamari), com uma infinidade de fases em cada área pesquisada. No rio Guaporé e seus afluentes, por exemplo, as cerâmicas foram associadas ao menos a quinze fases, poucas delas com descrições dos materiais e contextos (MILLER, 1983, 2009b, 2013).

A extensa discussão sobre o estilo tecnológico e os exemplos etnoarqueológicos e arqueológicos demonstram que não é possível considerar atributos isolados, como a forma e a decoração cerâmica, na caracterização da variabilidade e definição de fronteiras territoriais e culturais do passado, mas somente a análise das escolhas tecnológicas que perpassam a confecção e uso dos artefatos, e que são decisões tomadas por indivíduos em um contexto social e simbólico específico, é que fornece uma base mais sólida para a definição de conjuntos tecnológicos, que representam identidades sociais e culturais (DIAS e SILVA, 2001; DAVID e KRAMER, 2001; DIETLER e HERBICH, 1998; GOSSELAIN, 1998; CHILION, 1998; PIKIRAYI, 2007; SILVA, 2007, 2013; DIAS, 2003, 2007). Em muitos contextos, observou-se que alguns atributos são melhor definidores de identidade étnica, social e individual e de tradições tecnológicas e culturais (SILVA, 2007, 2013), e que nem todas as etapas da cadeia operatória possuem a mesma significância estilística (GOSSELAIN, 1998).

No alto rio Madeira, as classificações das cerâmicas se restringem à Subtradição Jatuarana, da Tradição Polícroma da Amazônia, e mais a montante às fases Jaciparaná, Pederneiras e Ribeirão, não associadas a tradições conhecidas. Nas cachoeiras do Teotônio e Santo Antônio, a associação dos materiais cerâmicos a uma única subtradição mascarou as diferenças tecnológicas entre as cerâmicas mais antigas e as mais recentes, possivelmente porque em ambas ocorrem elementos comuns como a pasta e as decorações plásticas e pintadas. Porém, a análise conjunta dos atributos da pasta, queima, forma, acabamentos de 
superfície e marcas de uso apontam diferentes escolhas tecnológicas importantes na confecção dos materiais deixados pelos grupos indígenas ao longo da história de ocupação destes lugares. Os estudos de Almeida (2013) e os resultados do nosso trabalho demonstraram que as ocupações relacionadas à Tradição Polícroma da Amazônia nessa região são de um período mais recente, e que anteriormente estes locais foram ocupados por outros grupos de tradições distintas. Estudos recentes na Amazônia demonstraram a fragilidade no uso de atributos como a pasta na definição de tradições, sendo identificada uma grande variação na escolha das pastas dentro da Tradição Polícroma da Amazônia em uma mesma região (TAMANAHA, 2012; MORAES, 2013; ALMEIDA, 2013), ao passo que em outros locais as escolhas da pasta são boas definidoras de tradições, como no caso das cerâmicas da tradição Pantanal e Descalvados no Pantanal de Cáceres (MIGLIACIO, 2002, 2006). Somente o estudo da tecnologia cerâmica através da correlação dos atributos, das informações do contexto arqueológico, conjuntamente com os dados etno-históricos, pode fornecer subsídios para perceber a variabilidade no registro arqueológico, histórico e cultural de uma determinada região.

Enquanto no rio Madeira as diferenças na cerâmica (maior popularidade das técnicas plásticas no início da sequência e das técnicas crômicas no final e o aumento da popularidade das urnas funerárias antropomórficas) foram entendidas como uma mudança gradual na tecnologia pertencente a uma mesma tradição (MILLER, 1992), no rio Jamari estas mesmas diferenças (o inciso, ponteado, roletado, escovado, excisos e apliques zoo e antropomorfos são mais frequentes na porção antiga da sequência) foram atribuídas a diferentes fases (Urucuri, Jamari, Cupuí e Matapi) de uma mesma tradição (Jamari), principalmente através da diferença na frequência das decorações (MILLER et al, 1992). Em todas as fases da tradição Jamari, há o uso de areia ou caraipé na pasta, com raros fragmentos com cauixí (o caraipé predomina na base da sequência, decrescendo e sendo suplantado no final pelo tempero de areia), as vasilhas são bem alisadas e as formas são de tigelas ou vasilhas globulares a hemisféricas. Comparando as descrições que inicialmente definiram a subtradição Jatuarana (MILLER, 1992) e a tradição Jamari (MILLER et al, 1992), percebemos que estas possuem semelhanças em relação à pasta (porém na Jatuarana aparece também o carvão associado ao caraipé), acabamentos de superfícies bem elaborados, tratamentos plásticos (excisos, incisos, ponteados, serrungulado, acanalado, apliques zoomórficos e antropomórficos,), engobo, monocromia e policromia. Porém, na Subtradição Jatuarana, aparece uma maior diversidade de tratamentos plásticos, incluindo o exciso raspado, incisoe m linha dupla (e não simples 
como na Jamari), estampado e o carimbado, além de uma maior variedade nas cores da pintura (preta, marrom, magenta, vermelho, laranja, amarelo e creme) e nos motivos das decorações (linhas, faixas e campos curvilíneos, geométricos, zoomórficos e antropomórficos, combinados ou não entre si), bem como as incisões e acanalados retocados ou preenchidos com branco, amarelo, laranja e vermelho; também existe uma maior variação formal, incluindo a presença de vasilhas compostas e complexas, asas, alças e flanges. Interessante é que nas duas regiões o material classificado na subtradição Jatuarana e na tradição Jamari apresentam uma série de elementos que podem corresponder a diferentes tradições tecnológicas, não cabendo em uma única denominação. No rio Madeira, tal variabilidade tecnológica e cultural foi demonstrada. No rio Jamari, as poucas descrições e fotos dos materiais (MILLER et al, 1992) da tradição homônima demonstram a existência de características tecnológicas semelhantes às encontrados em alguns conjuntos do Madeira, como no caso dos incisos e ponteados, modelados, apliques zoomorfos, banho e engobo vermelho, que na área de estudo identificamos como atributos da tradição Barrancóide ou Borda Incisa, assim como os incisos largos ou acanalados na face interna da borda, as bordas expandidas e a pintura vermelha e branca, que no Madeira associamos à Tradição Polícroma da Amazônia. A curadoria e análise desta importante coleção escavada por Eurico Miller, em diversos sítios no rio Jamari, é de extrema urgência (em função de sua conservação) e importância para avançar nas discussões a respeito das ocupações no sudoeste Amazônico.

$\mathrm{Na}$ área de influência da UHE Jirau, acima da cachoeira do Inferno, a montante da nossa área de estudo, as três cerâmicas identificadas (pintada, com decoração plástica e não decorada) por Moutinho e Robhran-Gonzalez (2010) parecem apresentar semelhanças tecnológicas com alguns conjuntos tecnológicos que identificamos à jusante. Apesar de não termos acesso a uma publicação mais detalhada sobre esse material, as fotos publicadas pelos autores citados, bem como a exposição das peças no Centro Cultural de Nova Mutum Paraná (município de Jaciparaná), demonstram a existência de vasilhas pintadas semelhantes às do sítio Coração, associadas à Tradição Polícroma da Amazônia, bem como cerâmicas com formas e pintura (traços finos feitos diretamente sobre a superfície) semelhantes ao conjunto mais recente das ilhas à montante (São Francisco, das Cobras, do Japó e Dionísio), além de fragmentos com decoração plástica semelhante às cerâmicas das ocupações que identificamos nos sítios Morro dos Macacos I, Vista Alegre e Foz do Jatuarana, em torno de 1.800 AP. O estudo dos materiais evidenciados nesta área fornecerá um panorama mais abrangente das ocupações indígenas ao longo do rio Madeira. 
Apesar de nosso objetivo ter sido voltado para a variabilidade no registro arqueológico não somente em temos temporais, mas também espaciais, conseguimos encontrar mais respostas em relação ao segundo, em função da falta de datações para os sítios à montante da cachoeira do Teotônio. Mesmo assim, percebemos que as variações das escolhas nas diferentes etapas da cadeia operatória não foram determinadas por constrangimentos ambientais. Isso fica evidente na adição do caraipé em ao menos uma das ocupações em todos os sítios, mesmo que possivelmente existam grandes variações nas composições das argilas na área abordada. Além disso, as escolhas também não foram sempre determinadas por constrangimentos funcionais, pois, em muitos sítios, todas as categorias de vasilhas, destinadas a usos diversos, possuem uma composição de pasta muito semelhante. Já nas ocupações das ilhas à montante (Ilha São Francisco, das Cobras, do Japó e Dionisio), as diferentes escolhas de pasta não correspondem a diferentes funcionalidades das vasilhas, tendo em vista que depósitos de carbono e fuligem, por exemplo, indicam uso de vasilhas com diferentes pastas e formas no processamento de alimentos sobre o fogo. Como dissemos anteriormente, a maior diversidade de escolhas nas diferentes etapas da cadeia operatória poderia corresponder a uma sociedade mais permeável, menos prescritiva e normativa que outras da região, em termos do conhecimento e aprendizado de tecnologias, e mesmo em relação à troca de objetos. Os estudos da tecnologia cerâmica cada vez mais superam os modelos evolucionistas e deterministas, que dão ênfase aos constrangimentos do meio, das técnicas e das propriedades funcionais dos artefatos, tendo em vista a natureza complexa e fluída das identidades sociais e culturais, estas somente compreendidas através de uma perspectiva contextual e histórica. A tecnologia é entendida como produção social e compondo sistemas culturais e simbólicos, e tal peonto de vista vai ao encontro de uma discussão abrangente nas ciências sociais, da superação da dicotomia entre indivíduo e sociedade (ou estrutura).

Tendo como objetivo principal colaborar para a construção de uma sequência histórica e cultural no alto rio Madeira, ficaram evidentes as dificuldades e limitações que encontramos ao sistematizar, relacionar e interpretar um registro arqueológico complexo, resultante de dinâmicas culturais que caracterizam a história indígena na região. Esperamos que este trabalho seja um incentivo a pesquisa nessa região singular e ainda pouco explorada do ponto de vista arqueológico. 


\section{Referências bibliográficas}

ALMEIDA, F. O. O Complexo Tupi da Amazônica Oriental. Dissertação de Mestrado apresentada no Museu de Arqueologia e Etnologia/USP, 2008.

. A Tradição Polícroma no Alto Rio Madeira. Tese de doutorado apresentada no Museu de Arqueologia e Etnologi/ USP, São Paulo, 2013.

ALVES, M. A. Análise cerâmica: estudo tecnotipológico. Doutorado em Ciências Humanas pela Universidade de São Paulo, 1988.

- Assentamentos e cultura material indígena anteriores ao Contato no Sertão da Farinha Podre, MG, e Monte Alto, SP. Tese de Livre Docência, Museu de Arqueologia e Etnologia da USP, São Paulo, 2009.

AMOROSO, M. R. Corsários no caminho fluvial: Os Mura do rio Madeira. In Manuela Carneiro da Cunha (org). História dos Índios do Brasil. São Paulo: Companhia das Letras, 1992, p. 297-310.

APPOLONI, C. R. et al. Estudo de Cerâmica Arqueológica do Paraná por técnicas nucleares não destrutivas. Revista do Museu de Arqueologia e Etnologia, São Paulo: Suplemento 2, 1997, p. 135-149.

ARAUJO, A. G. M. Teoria e método em Arqueologia regional: um estudo de caso no Alto Paranapanema, Estado de São Paulo.Tese de doutorado, FFLCH-MAE-USP, 2001.

ASHMORE, W. Biographies of Place at Quiriguá, Guatemala. In The Archaeology of Meaningful Places, edited by B. Bowser and M. N. Zedeño, pp. 15-31. University of Utah, Salt Lake City, 2009.

BALEÉ, W. Historical Ecology of Amazonia. In Indigenous Peoples and the Future of Amazonia: an Ecological Anthropology of an Endagered World. SPONSEL, L. (Ed.). Tucson \& London: Tucson Arizona Press, 1995, p. 97-110.

. Sobre a Indigeneidade das paisagens. Revista de Arqueologia, 21, n. 2, 2008, p. 0923.

BALÉE, W.; MOORE, D. Language, Culture, and Environment: Tupi-Guarani Plant Names Over Time. In Amazonian Indians: from prehistory to present. ROOSEVELT, A. (Ed.). Tucson: University of Arizona Press, 1994, p. 363-380. 
BALFET, H. Des chaînes opératoires, pour quoi faire. In: BALFET, H. (Dir.). Observer l'action technique. Des chaînes opératoires, pour quoi faire? Paris: CNRS, 1991, p.11-20.

BARRETO, C. A construção de um passado pré-colonial: uma breve história da Arqueologia Brasileira. Revista USP, São Paulo, n. 44, 1999/2000, p.32-51.

BINFORD, L.R. Archaeology as Anthropology. American Antiquity, 28 (2), 1962, p. $217-$ 225.

Archaeological Systematics and the Study of Culture Process. American Antiquity, vol. 31, n. 2, 1965.

Styles of style; Journal of Anthropological Archaeology, 1989, 8, p. 51-67.

BOURDIEU, P. Outline of a theory of practice.Cambridge: Cambridge University Press, 1977.

A gênese dos conceitos de hábitus e de campo. In: O poder Simbólico. Bertrand Brasil, 2006.

BROCHADO, J. P. An ecological model of the spread of pottery and agriculture into eastern south america.1984. 578f. Tese (doutorado em Filosofia e Antropologia) - University of Illinois at Urbana-Champaign, Carbondale, 1984.

A Expansão dos Tupi e da Cerâmica da Tradição Polícroma Amazônica. Dédalo, São Paulo, 1989, p. 65-82.

BROCHADO, J. P.; MONTICELLI, G. e NEUMANN, E. S. Analogia Etnográfica na reconstrução gráfica das Vasilhas Arqueológicas. Veritas, Porto Alegre, v. 35, n. 140, 1990.

BROCHADO, J. P.; MONTICELLI, G. Regras Práticas na reconstituição gráfica da cerâmica Guarani por comparação com vasilhas inteiras. Estudos Ibero-Americanos, Porto Alegre, 20 (2), 1994.

CARNEIRO, R. A Theory of the Origin of the State. Science 169: 733- 738, 1970. 117-154.

A base ecológica dos cacicados Amazônicos. Revista de Arqueologia, 20, 2007, P. 
CEREZER, J. F. Revendo problemáticas, traçando perspectivas: contributo da arqueologia experimental para a cerâmica guarani. Dissertação de mestrado apresentado Instituto Politécnico de Tomar, 2009.

CHILION, E. S. The cultural Origins of the Technical Choice: Unraveling Algonquian and Iroquian Ceramic Tradictions in the Northeast. In STARK, M. (Ed.). The Archaeology of Social Boundaries. Smithsonian Institution Press. Washington/London. 1998. Pp. 132-160.

CHYMZ, I. Terminologia Arqueológica Brasileira para Cerâmica. Cadernos de Arqueologia, Ano I; $n^{\circ} .1,1976$.

COSTA, A. F. Estudo da Variabilidade da cultura material cerâmica no sítio Veneza. Projeto do Programa Institucional de Bolsas de Iniciação Cientifica - PIBIC, Universidade Federal de Rondônia, 2010.

Entre artefatos e narrativas: a história Indígena do alto rio Madeira a partir dos relatos dos viajantes do século XVIII. Monografia de conclusão de curso, Universidade Federal de Rondônia, 2013a.

Multifuncionalidade das vasilhas cerâmica no sítio Ilha Dionísio. Projeto de mestrado apresentado no Programa de Pós-Gradução em Arqueologia do Museu Nacional, Universidade Federal do Rio de Janeiro, 2013b.

COSTA, B. L. S. Levantamento arqueológico na reserva de desenvolvimento sustentável (RDS) Amanã: Estado do Amazonas. Dissertação de Mestrado, Universidade Federal de São Paulo, 2012.

CPRM. Estudos de Viabilidade UHE Santo Antônio e Jirau - Porto Velho. CPRM -Serviço Geológico do Brasil. 2005.

Geologia e recursos minerais do Estado de Rondônia. Sistema de Informações Geográficas - SIG. Programa Geologia Brasil- Integração, atualização e difusão da Geologia do Brasil. Serviço Geológico do Brasil. 2007.

Geodiversidade do Estado de Rondônia. Programa Geologia Brasil: levantamento da geodiversidade. Serviço Geológico do Brasil. 2010.

CREVELS, M., \& VAN DER VOORT, H. The Guaporé-Mamoré region as a linguistic area, in From linguistic areas to areal linguistics. Editado por P. Muysken. Amsterdam: John Benjamins Publishing Company, 2008, p. 151-179. 
CRUZ, D. G. Lar, doce lar? Arqueologia Tupi na bacia do Ji-Paraná (RO). Dissertação de Mestrado. Universidade de São Paulo, São Paulo. 2008.

CUNHA LIMA, S. Tecnologia Cerâmica Chimu: estudo arqueométrico da coleção $M A E / U S P$. Tese de doutorado. Universidade de São Paulo, São Paulo. 2010.

DANTAS, V. J.\& LIMA, T. A. Pausa para um Banquete: Análise das marcas de uso em vasilhames cerâmicos pré-históricos do Sítio Justino, Canindé de São Francisco, Sergipe.Museu de Arqueologia de Xingó, 2006.

DAVID, N. \& KRAMER, C. Style and the marking of boundaries: contrasting regional studies. In: DAVID, N. e KRAMER, C. (Ed). Etnoarchaeology in action. Cambridge, University Press, 2001, p. 169-224.

DENEVAN, W. The Aboriginal Cultural Geography of the Llanos de Mojos of Bolivia. Ibero Americana, 48. Berkley: University of California Press, 1966.

A Bluff Model of Riverine Settlement in Prehistoric Amazonia. Annals of the Association of American Geographers, vol. 86, n. 4, 1996.

DIAS, A. S. Um projeto para a Arqueologia brasileira: breve histórico da implantação do PRONAPA. Revista do CEPA, 19 (22), 1995, p. 24-39.

Sistemas de Assentamento e Estilo Tecnológico: uma proposta interpretativa para a ocupação pré-colonial do Alto vale do rio dos Sinos, Rio Grande do Sul. Tese de doutorado, Universidade de São Paulo, 2003.

Novas perguntas para um velho problema: escolhas tecnológicas como índices para o estudo de fronteiras e identidades sociais no registro arqueológico. Boletim do Museu Paraense Emilio Goeldi. Ciências Humanas, Belém, v. 2, n. 1, p.59-76, 2007.

DIAS A.S.; SILVA. F. A. Sistema Tecnológico e Estilo: as implicações desta inter-relação no estudo das indústrias líticas do sul do Brasil. Revista do MAE, 11, 2001, p.95-108.

DIETLER, M. \& HERBICH, I. Hábitus, tecniques, style: an integrated approach to the social understanding of material culture and boundaries. In: M. Stark (Ed). The archaeology of Social Boundaries. Smithsonian Institution Press, Washington/London, 1998, pp. 233-263. 
DURAM DA SILVA, E. Ocupação pré-colonial na cachoeira do Teotônio: abordagem tecnológica da cultura material cerâmica dos sítios Santa Paula e Teotônio. Relatório do Programa Institucional de Bolsas de Iniciação Cientifica - PIBIC,Universidade Federal de Rondônia, 2013.

ERIKSEN, L. Nature and Culture in Prehistoric Amazonia. Using G.I.S. to reconstruct ancient ethnogenetic processes from archaeology, linguistics, geography, and ethnohistory. Lund University, Lund 2011.

ERICKSON, C. L. Amazônia: the historical ecology of a domesticated landscape. In: SILVERMAN, H; ISBEL, W. H. Handbook of South American Archaeology. New York: Sprinher, 2008.

ERIG LIMA, L. F. A ocupação pré-colonial na fronteira ocidental: adaptabilidade humana, territorialidade e aspectos geomorfológicos na microrregião do Alto Guaporé, Mato Grosso. Tese de Doutorado, MAE-USP, 2010.

Cerâmica Capão do Canga: uma nova indústria cerâmica na Bacia do Alto Guaporé, Mato Grosso, Brasil. Amazônica -Revista de Antropologia, 4, 2012, pp.187-220.

EVANS, C.; MEGGERS, B.J. Archaeological Investigations on the Rio Napo, Eastern Ecuador. Smithsonian Contributions to Anthropology, vol. 6, 1968.

FAUSTO, C. Os índios antes do Brasil. Rio de Janeiro: Jorge Zahar (3 ed), 2005.

FERREIRA, A. R. Viagem ao Brasil: A expedição philosophica pelas capitanias do Pará, Rio Negro, Mato Grosso e Cuyabá. Volume III. Organizado por J. P M. Soares \& C. Ferrão. Rio de Janeiro: Kapa, 2007.

FERREIRA, L. M. Vestígios de civilização: o Instituto Histórico e Geográfico Brasileiro e a construção da arqueologia imperial (1838-1870). Revista de História Regional, Volume 4, número 1, verão 1999. Universidade Federal de Ponta Grossa, Paraná.

FERREIRA, L. M. Território Primitivo: a institucionalização da Arqueologia no Brasil (1870-1917). Porto Alegre: EDIPUCRS, 2010.

FURNAS, ODEBRECHT \& LEME. Estudo de Impacto Ambiental - Aproveitamento Hidroelétrico Santo Antônio e Jirau, Rio Madeira, RO. Volume III, 2005. 
GARCIA, L. L. W.G. Guias de Análise. São Paulo, 2010.

Arqueologia na região dos interflúvios Xingu-Tocantins a ocupação Tupi no Cateté.

Dissertação de Mestrado. São Paulo: USP, 2012.

GOMES, R. N. Arqueologia e cultura material: uma história contada em cacos de vidros e louças da vila de Santo Antônio (Porto Velho - RO). Dissertação de mestrado, Programa de pós-graduação em Antropologia, Universidade federal do Pará, Belém, 2013.

GOSSELAIN, O. P. Social and technical identity in a clay Crystal Ball. In STARK, M. (Ed.). The Archaeology of Social Boundaries. Smithsonian Institution Press. Washington/London. 1998. Pp.

GOULART, E. P. Técnicas instrumentais para a caracterização mineralógica e Microestrutural de materiais cerâmicos arqueológicos. Revista Canindé, Xingo, nº 4 , dezembro de 2004. Disponível em: http://max.org.br/biblioteca/revistas-ini.asp

GOULDIN, M., SMITH, N. J. \& MAHAR, D. Floods of Fortune: Ecology and economy along the Amazon.Columbia University Press, 2000.

GUAPINDAIA, V. L. Além da margem do rio: as ocupações Konduri e Pocó na região de Porto Trombetas, PA. Tese de Doutorado, Programa de Pós-Graduação em Arqueologia, Museu de Arqueologia e Etnologia, Universidade de São Paulo, 2008.

HECKENBEGER, M. Os Povos do Alto Xingu. História e Cultura. FRANCHETTO, Bruna \& HECKENBERGER, Michael (eds). Rio de Janeiro: Editora da UFRJ, 2001, pp. 21-62.

Rethinking the Arawakan Diapora: Hierarchy, Regionality, and the Amazonian Formative, In: Comparative Arawakan Histories: Rethinking Culture Area and Language Group in Amazonia, J. Hill \& F. Santos-Granero, eds, Urbana: University of Illinois Press, 2002, pp. 179-201.

The ecology of power: culture, place, and personhood in the southern Amazon, AD 1000-2000. New York: Routledge, 2005.

HECKENBERGER, M.; NEVES, E. \& PETERSEN, J. De onde surgem os modelos? As origens e expansões Tupi na Amazônia Central. Revista de Antropologia; USP; v.41; $\mathrm{n}^{\circ}$; 1998; p.69 -96. 
HEGMON, M., KULOW, S. Painting as Agency, Style as Structure: Innovations in Mimbres Poterry Designs From Southwest New Mexico. Journal of Archaeological Method and Theory, Vol 12, No. 4, December 2005.

HILBERT, P.P.; HILBERT, K. Resultados Preliminares da Pesquisa Arqueológica realizada nos rios Nhamundá e Trombetas, baixo Amazonas. Boletim do Museu Paraense Emílio Goeldi, Antropologia, 75, 1980.

HILL, J. Etnicidade na Amazônia Antiga: reconstruindo identidades do passado por meio da arqueologia, da linguística e da etno-história. ILHA v. 15, n. 1, p. 35-69, jan./jun. 2013. DOI: http://dx.doi.org/10.5007/2175-8034.2013v15n1-2p35

HILL, J. \& SANTOS-GRANERO, F. Introduction. In: HILL, J. \& SANTOS-GRANERO, F. (org). Comparative Arawakan Histories: Rethinking Language and Culture Areas in the Amazon, eds., Urbana: University of Illinois Press, 2002, p. 1-22.

HODDER, I. La Arqueología Postprocesual. In: Interpretación em Arqueologia - Corrientes Actuales.Crítica, Barcelona, 1994.

HORNBORG, A. \& HILL, J. Introduction: Ethnicity in Ancient Amazonia. In:HORNBORG, A. \& HILL, J. (org). Ethnicity in Ancient Amazonia: Reconstructing Past Identities from Archaeology, Linguistics, and Ethnohistory. Boulder: University of Colorado Press, 2011, p. $1-30$.

HORNBORG, A. \& ERICKSEN, L. An Attempt to Understand Panoan Ethnogenesis in Relation to Long- Term Patterns and Transformations of Regional Interaction in Western Amazonia. In: HORNBORG, A. \& HILL, J. (org). Ethnicity in Ancient Amazonia: Reconstructing Past Identities from Archaeology, Linguistics, and Ethnohistory. Boulder: University of Colorado Press, 2011, p. 129-154.

HUGO, V. Desbravadores. Volume I. Humaitá: Missão Salesiana, 1959.

JAMES BETANCOURT, C. La cerâmica de la Loma Salvatierra. Inaugural - Dissertation Zur Erlangung der Doktorwürde der Philosophischen Fakultät der Rheinischen Friedrich Wilhelms - niversität zu Bonn, 2010.

KELLER, F. The Amazon and Madeira Rivers: Sketches and Descriptions from the NoteBook of an Explorer. London: Chapman and Hall, 1874. 
KIPNIS, R.; CALDARELLI, S. B.; OLIVEIRA, W. C. Contribuição para a cronologia da colonização amazônica e suas implicações teóricas. Revista de Arqueologia, 18, 2005, p.8193

KIPNIS, R. et al. Aplicação das tecnologias de modelagem 3D conjugada às técnicas tradicionais para o registro das gravuras rupestres do rio Madeira, Rondônia, Brasil. Bol. Mus. Para. Emílio Goeldi. Cienc. Hum., Belém, v. 8, n. 3, p. 605-619, set.-dez. 2013.

LA SALVIA, F. \& BROCHADO, J. P. Cerâmica Guarani.Porto Alegre: Ed. Porsenato Arte e Cultura, 1989, $2^{a}$ edição.

LATHRAP, D. The Upper Amazon. New York, Praeger Publishers, 1970. . El Alto Amazonas. Lima: Chataro Editores, 2010.

LATHRAP, D. \& OLIVER, J. Agüerito: el complejo policromo mas antiguo de America en la confluencia del Apure y Orinoco (Venezuela), Interciencia, Caracas, 12, 1987, p. 274-89.

LEMONNIER, P. Elements for an Anthropology of Technology. Ann Arbor: Michigan, 1992.

Technological choices: transformation in material cultures since the Neolithic.

London: Routledge. 1993. p. 1-35.

LEROI-GOURHAN, A. O Gesto e a palavra, I: Técnica e Linguagem. Lisboa: Edições 70, 1985.

LEVI-STRAUSS, C. Tristes trópicos. Companhia das Letras, 2000.

Introdução à obra de Marcel Mauss. In: Sociologia e Antropologia. São Paulo: Cosac Naify, 2003.

LOWIE, R. The Tropical Forests: An Introduction, In: Handbook of South American Indians, vol. 3, J. Steward, ed. Washington, DC: Bureau of American Ethnology, Smithsonian Institution, Bulletin 143, 1948, pp. 1-56.

LIMA, H. P. História das Caretas: A tradição Borda Incisa na Amazônia Central. Tese de doutorado, Museu de Arqueologia e Etnologia da USP. São Paulo, 2008. 
LIMA, H., NEVES, E. G., e PETERSEN, J. La Fase Açutuba: um novo complexo cerâmico na Amazônia Central. Arqueologia Suramericana, v.2, n. 1, 2006.

MACHADO, J. S. A Formação de Montículos Artificiais na Amazônia Central: um estudo de caso do sítio Hatahara. Dissertação de mestrado. São Paulo: USP, 2005.

MAUSS, M. As Técnicas do Corpo. In: Sociologia e Antropologia. São Paulo: Cosac Naify, 2003.

MEGGERS, B. Environmental Limitation on the Development of Culture. American Anthropologist, 1954.

1987.

Amazônia: a ilusão de um paraíso. São Paulo: Editora da Universidade de São Paulo,

La cerámica temprana en América del Sur: invención independiente o difúsion?

Revista de Arqueologia Americana 13, 1997, p. 7-40.

MEGGERS, B. e EVANS, C. Archaeological Investigations at the Mouth of the Amazon. Washington: Bureau of American Ethnology, Bulletin n. 167, 1957.

An Experimental Formulation of Horizon Styles in the Tropical Forest of South America. In: Essays in Pre-Columbian Art and Archaeology, Samuel Lothrop, ed. Cambridge, Mass: Harvard University Press, 1961, pp.372-388.

MEGGERS, B. J.; EVANS, C.; ESTRADA, E. Early Formative Period of Coastal Ecuador: the Valdivia and Machalilla Phases. Washington, D.C., Smithsonian Contributions to Anthropology, V.1, 234p, 1965.

MEGGERS, B. \& MILLER, E. T. Hunter-Gatheres in Amazônia during the PlaistoceneHolocene Transition. In: Under the Capony: the archaeology of tropical Rainforests (Library Binding). Mercader J. (ed). Rutgers University Press, 2003, p. 291-316.

MENDONÇA DE SOUZA, A. História da Arqueologia Brasileira. Pesquisas, 46 (Antropologia). São Leopoldo, 1991.

MENÉNDEZ, M. A área Madeira-Tapajós: situação de contato e a relação entre colonizador e indígenas. In Manuela Carneiro da Cunha (org). História dos Índios do Brasil. São Paulo: Companhia das Letras, 1992, p. 281-296. 
MIGLIACIO, M. C. A ocupação indígena do Pantanal de Cáceres, Alto Paraguai - do período pré-colonial aos dias atuais. Revista do Museu Antropológico, v.5/6 nº 1. p. 213-250.

2001/2002. UFGO.

O doméstico e o ritual: cotidiano Xaray no Alto Paraguai até o século XVI. Universidade de São Paulo, tese de doutorado, 2006.

MIGLIAZZA, E. C. Linguistic Prehistory and the Refuge Model in Amazonia. In: Biological Diversification in the Tropics. New York, Columbia University Press, 1982, p. 497-519.

MILLER, E.T. História da cultura indígena do Guaporé (Mato Grosso e Rondônia). Dissertação de Mestrado, PUCRS, 1983.

Adaptação agrícola pré-histórica no Alto Rio Madeira In: V. Perspectivas Arqueológicas: Las Tierras Bajas.In: Betty Jane Meggers - Editor. (Org.). Prehistoria Sudamericana. Nuevas Perspectivas. 1 ed. Washington, D.C.,: TARAXACUM, 1992, v. , p. 219-229.

A limitação ambiental como barreira à transposição do período formativo no Brasil. Tecnologia, produção de alimentos e formação de aldeias no sudoeste da Amazônia.In: Ledergerber-Crespo, P.(Ed.) Formativo Sudamericano, una revaluación. Ediciones AbyaYala, Quito-Equador, 1999.

A cultura cerâmica do Tronco Tupi no Alto Ji-Paraná, Rondônia, Brasil: algumas reflexões teóricas, hipotéticas e conclusivas. Revista Brasileira de Lingüística Antropológica, vol. 1, n. 1, 2009a.

Pesquisas Arqueológicas no Pantanal do Guaporé-RO, Brasil: a Sequência Seriada da Cerâmica da Fase Bacabal. In: Meggers B.J. Org., Arqueologia Interpretativa. O Método Quantitativo para o Estabelecimento de Sequências Cerâmicas: Estudos de caso. Marcos A. C. Zimmermann et al. Porto Nacioanl, UNITINS. Pp.103-117, 2009 b.

Algumas Culturas Ceramistas, do Noroeste do Pantanal do Guaporé à Encosta e Altiplano Sudoeste do Chapadão dos Parecis. Origem, Difusão/Migração e Adaptação - do Noroeste da América do Sul ao Brasil. Revista Brasileira de Linguística Antropológica, 2013.

MILLER, E. T. et al.Arqueologia nos Empreendimentos Hidrelétricos da Eletronorte. Brasília, Eletronorte, 1992. 
MONGELÓ, G.Z. O formativo e os modos de produção: ocupações pré-ceramistas no Alto rio Madeira, RO. Projeto de mestrado, MAE-USP, 2012.

MORAES, C.P. Arqueologia na Amazônia Central Vista de uma Perspectiva da Região do Lago do Limão. Dissertação de Mestrado, MAE-USP, São Paulo, 2006.

. Amazônia ano 1000: territorialidade e conflito no tempo das chefias regionais. Tese de Doutorado, MAE-USP, São Paulo, 2013.

MORAES, C.P.; NEVES, E.G. Adensamento Populacional, Interação e Conflito na Amazônia Central. Amazônica -Revista de Antropologia, 4, 2012, pp.122-148.

MOUTINHO, M.; ROBRAHN-GONZÁLEZ, E.M. Memórias de Rondônia. São Paulo: Arte Ensaio, 2010.

MUNITA, C. S. Contribuição da análise por ativação com Nêutrons a estudos arqueométricos: estudo de caso. Canindé, Xingó, n. 6, dezembro de 2005.

NEUMANN, M.A. Ñande Rekó: diferentes jeitos de ser Guarani. Dissertação de Mestrado. Porto Alegre - UFRGS, 2008.

Distribuição das Marcas de Uso e Especificidades Funcionais para a Cerâmica Guarani Pré-Colonial. Revista de Arqueologia, 24(1), 2010, p. 52-65.

NETTO, L. Investigação sobre a arqueologia brasileira. Arquivos do Museu Nacional, 6, 1885. (pp. 257-553).

NEVES, E. G. Arqueologia, História indígena e o registro Etnográfico: exemplos do Alto rio Negro. Revista do Museu de Arqueologia e Etnologia, São Paulo, Suplemento 3, 1999, p. 319-330.

. O Velho e o novo na arqueologia Amazônica. 87-111. Revista USP, São Paulo, n. 44, 1999/2000, p. 32-51.

Arqueologia da Amazônia.Rio de Janeiro: Jorge Zahar Ed., 2006.

Ecology, Ceramic Chronology and Distribution, Long-term History, and Political Change in Amazonian Floodplain. In: Handbook of South American Archaeology. SILVERNAN, H.; ISBELL, W. H. (Eds.). New York: Springer, 2008, p. 359-378. 
. Sob os Tempos do Equinócio: oito mil anos de história na Amazônia Central (6.500 $\overline{A C-1.500} D C$ ). Tese de Livre Docência. MAE, USP, 2012.

NEVES, E.G.; PETERSEN, J.B. Political Economy and Pre-Columbian Landscape Transformation in Central Amazonia. In Time and Complexity in Historical Ecology. BALÉE, W.; ERICKSON, C. (Eds.). NewYork: Columbia University Press, 2006.

NIMUENDAJU, C. Mapa Etno-Histórico. Brasil: IBGE, 1981.

In Pursuit of the Past Amazon. Archaeological Researches in the Brazilian Guyana and in the Amazon Region. Gothenburg: Ethnological Studies, 2004.

NISINGA, L. C. Análise tecnológica da indústria lítica do Sítio Veneza. Fundação Universidade Federal de Rondônia. Relatório do PIBIC, 2013/2014.

NOELLI, F. S. Sem Tekohá não há Tekó: Em busca de um modelo Etnoarqueológico da Aldeia e da Subsistência Guarani e sua Aplicação a uma Área de Domínio no Delta do Rio Jacuí-RS. Dissertação de Mestrado, Porto Alegre: PUC-RS, 1993.

As hipóteses sobre o centro de origem e rotas de expansão dos Tupi. Revista de Antropologia, v. 39, n.2, São Paulo, p. 7-53, 1996.

The Tupi Expansions. In Handbook of South American Archaeology. Handbook of South American Archaeology. SILVERMAN, H.; ISBELL, W.H. (Eds.). Nova York: Springer, 2008, pp. 200-212.

La distribución geográfica de las evidencias arqueológicas guarani. Revista de Indias, 2004, vol. LXIV, núm. 230.

NOELLI, F. S. \& FERREIRA, L. M. A persistência da teoria da degeneração indígena e do colonialismo nos fundamentos da arqueologia brasileira. História, Ciências, Saúde, vol. 14, n. 4, p. 1239-1264. Manguinhos, Rio de Janeiro, 2007.

NOLETO, C. S. Colocando as pedras no caminho: análise tecnológica da indústria lítica do Sítio do Brejo. Relatório final do Projeto PIBIC/UNIR. Porto Velho, 2013. 
NORDENSKIOLD, E. L'archéologie du bassin de l'Amazone. Ars Americana, vol. 1. Paris, 1930.

OLIVEIRA, E.C. Processo de formação do sítio Ilha de Santo Antônio. Projeto do Programa Institucional de Bolsas de Iniciação Cientifica - PIBIC,Universidade Federal de Rondônia, 2012-2013.

OLIVER, J. The Archaeological, linguistic and etnohistorical evidence for the expansion of Arawakan into Northwestern Venezuela and Northeastern Colombia. Ph.D. Dissertation, University of Illinois, 1989.

ORTON, C., TYERS, P.\& VINCE, A.La cerámica en arqueología: Critica (Grijalbo Mondadori, S.A.), Arago, Barcelona, 1997.

PANACHUK, L; CRUZ, D. Documento de Trabalho Scientia. Belém, 2010.

PENA, D. S. F. Apontamentos sobre os cerâmicos do Pará. Arquivos do Museu Nacional, Rio de Janeiro, v.2, 1877, p.47-76.

PETERSEN, J., NEVES, E. \& HECKENBERGER, M. Gift from the Past: Terra Preta and Prehistoric Amerindian Occupation in Amazonia, In: Unknown Amazon, Culture in Nature in Ancient Brazil, C. McEwan, C. Barreto and E. Neves, eds. London: British Museum Press, pp. 86-105, 2001.

PESSOA, C. Fragmentos da história pré-colonial do Alto rio madeira: ocupações na Ilha de Santo Antônio. Trabalho de Conclusão de curso. Departamento de História da Universidade Federal de Rondônia, Porto velho, 2012.

Variabilidade artefatual e os contextos arqueológicos da ocupação Jatuarana no alto rio Madeira. Qualificação de mestrado apresentada ao Programa de Pós-graduação em Antropologia da Universidade Federal do Pará, 2014.

PESSOA, C. \& COSTA, A.F. Um quadro histórico das populações indígenas no Alto rio Madeira durante o século XVIII. Amazônica, Revista Antropologia, 6 (1): 110-139, 2014.

POLITIS, G. Nukak. Bogotá: Instituto Amazónico de Investigaciones científicas/SINCHI, 1996. 
PUGLIESE, F. S. O Sambaqui fluvial Monte Castelo e a operação de sistemas de assentamento na Bacia do Médio Rio Guaporé: 8 mil anos de adaptabilidade humana nos trópicos. Projeto de doutorado, MAE-USP, 2013.

PIKIRAYI, I. Ceramics and group identities: towards a social archaeology in Southern African Iron Age ceramic studies. Jornal of Social Archaeology, v. 7 (3): 286-301, 2007.

RAMIREZ, H. Línguas Indígenas no Alto rio Madeira: Estatuto atual e bibliografia básica. Lingua Viva 1, $2006 \mathrm{~s} / \mathrm{n}$.

Etnônimos e topônimos no rio Madeira (séculos XVI-XX): um sem-número de equívocos. Revista Brasileira de Linguística Antropológica 2, 2010, pp. 13-58.

RICE, P. Pottery analysis, a sourcebook.University of Chicago Press; 1987.

RIZUTTO, M. A. et al. Métodos analíticos não destrutivos para análsie de obras de arte. Revista do Museu de Arqueologia e Etnologia, São Paulo, Anais da primeira Semana de Arqueologia, Suplemento 8: 177-188, 2009.

RODRIGUES, A. D. Classification of Tupí-Guaraní. International Journal of American Linguistics, 1958, 24: 231-4.

A Classificação do Tronco Lingüístico Tupi. Revista de Antropologia (12); USP; Sao Paulo; 1964; p. 99-104.

Relações internas na Família Linguística Tupi-Guarani. Revista de Antropologia, 2728, 1984.

RODRIGUES, J. B. Antiguidades do Amazonas. Ensaios de Ciência, Rio de Janeiro, 1876, v.1, p.93-125.

ROOSEVELT, A. et al. Eighth Millennium Pottery from a Prehistoric Shell Midden in the Brazilian Amazon. Science 254, 1991.

ROOSEVELT, A. Parmana: Prehistoric maize and manioc subsistence along the Amazon and Orinoco. New York: Academic Press, 1980.

Early Pottery in the Amazon: Twenty years of scholarly obscurity. In: Emergence of Pottery. Technology and Innovation in Ancient Societies.Smithsonian Institution Press, 1995. 
ROQUETTE-PINTO, E. Rondônia. São Paulo: Cia. Editora Nacional, 1935.

ROSSETTI, D. F.; TOLEDO, P. M.; GOES, A. M. New geological framework for Western Amazonia (Brazil) and implications for biogeography and evolution, Quaternary Research, v. 64, n. 2, p. 279-280, 2005.

SACKETT, J. R. The meaning of style in Archaeology: a general model. American Antiquity 42: 369-80. 1977

Style and ethnicity in archaeology: the case for isochrestism. In: The uses of style in archaeology. Editado por Margaret W. Conkey e Crhistine A. Hastorf. Cambridge University Press, 1991.

SANTOS, F.C.L. Sítio do Brejo - Análise da cultura material cerâmica. Projeto do Programa Institucional de Bolsas de Iniciação Cientifica - PIBIC, Universidade Federal de Rondônia, 2012-2013.

SCHAAN, D. P.. Investigando Gênero e Organização Social no Espaço Ritual e Funerário Marajoara. In: Livro de Resumos do XII Congresso da Sociedade de Arqueologia Brasileira, São Paulo. 2003.

The Camutins Chiefdom: rise and development of social complexity on Marajó Island, Brasilian Amazon. PHD Dissertation, Pittsburg, 2004.

Uma janela para a história pré-colonial da Amazônia: olhando além - e apesar - das fases e tradições. Bol. Mus. Para. Emílio Goeldi. Ciências Humanas, Belém, v. 2, n. 1, p. $77-$ 89, jan-abr. 2007.

SCIENTIA CONSULTORIA CIENTÍFICA. Projeto de Arqueologia preventiva nas áreas de intervenção do AHE Santo Antônio, RO. São Paulo, 2008.

Relatório Parcial 2 UHE Santo Antônio, 2010.

Arqueologia preventiva nas áreas de intervenção do AHE Santo Antônio, RO:

relatório do resgate arqueológico na área do canteiro. São Paulo, 2011a.

Arqueologia Preventiva nas áreas de intervenção do AHE santo Antônio, RO:

relatório da prospecção arqueológica na área do reservatório. São Paulo, 2011b. 
Arqueologia preventiva nas áreas de intervenção do AHE Santo Antonio, RO: relatório do resgate arqueológico na área do reservatório. São Paulo, 2011c.

Arqueologia preventiva nas áreas de intervenção do AHE Santo Antonio, RO: relatório do registro rupestre e feições de polimento. São Paulo, $2011 \mathrm{~d}$.

SHEPARD, A. O. Ceramic for the archaeologist. Carvigie Institution of Washington Publications; 1995.

SCHIFFER, M.B. Archaeological Context and Systemic Context. In: Michael Schiffer. Behavioral Archaeology. First Principles. Foundations of archaeological Inquiry. 1995. p.2534.

SCHIFFER, M. B.; SKIBO, J. Theory and Experiment in the Study of technical change. In: M.B. Schiffer (Ed.) Technological Perspectives on Behavioral Change. Tucson, University of Arizona Press, p. 40-76, 1992.

The Explanation of Artifact Variability. American Antiquity, v. 62, n. 1, 1997, p. 2750.

SKIBO, J. \& SCHIFFER, M.B., Understanding artifact variability and change: a behavioral framework. In: M.B. Schiffer (Ed.) Anthropological Perspectives ontechnology. Albuquerque, University of New Mexico Press, p. 139-149, 2001

SILVA, F.A. As Tecnologias e seus significados: um estudo da cerâmica dos Assuriní do Xingu e da cestaria dos Kayapó-Xikrin sob uma perspectiva. Tese de Doutoramento; USP; São Paulo; 2000.

Novas perguntas para um velho problema: escolhas tecnológicas como índices para o estudo de fronteiras e identidades sociais no registro arqueológico. Boletim do Museu Paraense Emilio Goeldi. Ciências Humanas, Belém, v. 2, n. 1, p. 91-103, 2007.

Tecnologias em transformação: inovação e (re)produção dos objetos entre os Asurini do Xingu. Bol. Mus. Para. Emílio Goeldi. Cienc. Hum., Belém, v. 8, n. 3, p. 729-744, set.dez. 2013

SILVA, F. A. et al. A Arqueometria e a Análise de Artefatos Cerâmicos: um estudo de fragmentos cerâmicos etnográficos e arqueológicos por fluorescência de Raios X (EDXRF) e transmissão Gama. Revista de Arqueologia, Volume 17, 2004, p. 41-61. 
SILVA. M.A. Pesquisas arqueológicas, museológicas e questões locais no contexto amazônico: desafios para realização de práticas colaborativas. Projeto de mestrado, MAEUSP, 2011.

SIMÕES, M. F. Coletores- pescadores ceramistas do litoral do Salgado, Boletim do Museu Paraense Emílio Goeldi-Nova Série, Belém, n. 78. 1981.

SIMÕES, M.F.; LOPES, D.F. Pesquisas Arqueológicas no baixo/médio Madeira (AM). Revista de Arqueologia, 4(1), P. 117-134, 1987.

STEWARD, J. Culture Areas of the Tropical Forests. In: Handbook of South American Indians, vol. 3, J. Steward, ed. Washington, DC: Bureau of American Ethnology, Smithsonian Institution, Bulletin 143, 1948, p. 883-903.

SOUZA, T.A.S. O inato e o apreendido: a noção de habitus na sociologia de Pierre Bourdieu. Mestrado em Sociologia na Universidade de Brasília, 2007.

SUNER, R. A. Variabilidade arqueológica no Médio Rio Ji-Paraná. Projeto de Doutorado, MAE-USP, 2010.

TAMANAHA, E.K. Ocupação Polícroma no baixo e médio rio Solimões, estado do Amazonas. Dissertação de Mestrado, MAE-USP, 2012.

TIZUKA, M. M. Geoarqueologia e paleohidrologia da planicie aluvial Holocênica do rio Madeira entre Porto Velho e Abunã.Dissertação de Mestrado. Departamento de Geologia, UNESP-Rio Claro, 2013.

TRINDADE, T. Levantamento e prospecção dos sítios com estruturas de terra antrópicas no Sudoeste do Estado de Rondônia. Projeto de Mestrado, MAE-USP, 2012.

URBAN, G. A história da cultura Brasileira segundo as línguas nativas. In: Manuela Carneiro da Cunha (org.). Índios no Brasil. São Paulo, Companhia das Letras, 1992.

VASSOLER, O. J. P. Análise da iconografia das vasilhas cerâmicas da Subtradição Jatuarana no alto rio Madeira em Rondônia. Monografia de Conclusão de Curso de Bacharelado em Arqueologia da Universidade Federal de Rondônia, 2014.

WACQUANT, L. Esclarecer o Habitus. Trad. José Madureira Pinto e Virgílio Borges Pereira. In: Problemas e Práticas, n. 25, Lisboa: Editora Celta, 2004. 
WILLIAMS, D. Early Pottey in the Amazon: a correction. American Antiquity, 62 (2), 1997.

WIESSNER, P. Is there a unity to style? In: M. Conkey; C. Hastorf (Eds). The uses of Styles in Archaeology. Cambridge University Press. 1991. Pp105-112.

WUST, I. Etnicidade e tradições ceramistas: algumas reflexões a partir das antigas aldeias Bororo do Mato Grosso. Revista do Museu de Arqueologia e Etnologia, São Paulo, Suplemento 3: 303-317, 1999.

WUST, I. e BARRETO, C. The ring villages of Central Brazil: a challenge for Amazonian Archaeology. Latin American Antiquity, vol. 10, no. 1, 1999, p. 3-23.

ZEDENO, M. N. The archaeology of territory and territoriality. In The Handbook of Landscape Archaeology, edited by B. David and J. Thomas, pp. 210-217. Left Coast Press, Walnut Creek, California, 2008.

ZEDEÑO, M. N. \& BOWSER, B. J. The Archaeology of Meaningful Places. In The Archaeology of Meaningful Places, edited by B. J. Bowser and M. N. Zedeño, pp. 1-14. University of Utah Press, Salt Lake City, 2009.

ZIMPEL, C. A. Na direção das periferias extremas da Amazônia: arqueologia na bacia do rio Ji-Paraná, Rondônia. Dissertação de Mestrado. Universidade de São Paulo, São Paulo, 2009.

. Arqueologia no Médio e Baixo rio Guaporé e suas implicações para o entendimento dos sítios com construções em terra do sudoeste Amazônico. Projeto de doutorado, MAEUSP, 2013.

ZUSE, S. Os Guarani e a redução Jesuítica: tradição e mudança técnica na cadeia operatória de confecção dos artefatos cerâmicos do sítio Pedra Grande e entorno. Dissertação de Mestrado. Universidade de São Paulo, São Paulo, 2009. 